UNIVERSIDAD COMPLUTENSE DE MADRID

FACULTAD DE GEOGRAFÍA E HISTORIA

Departamento de Musicología
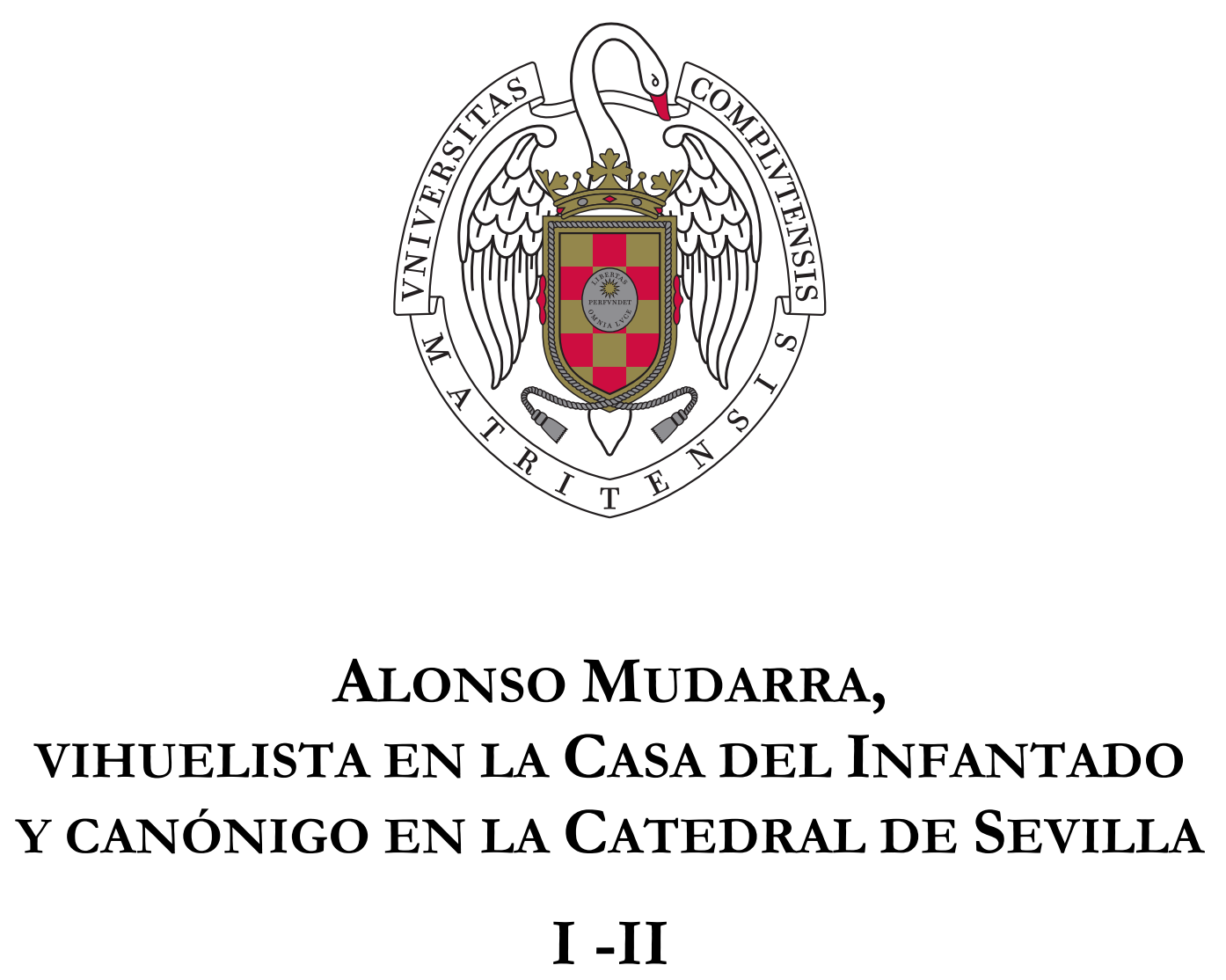

TESIS DOCTORAL PRESENTADA POR:

Francisco Javier Roa Alonso

DIRECTOR:

Dr. Gerardo Arriaga Moreno

Madrid, 2015 

There is no science without fancy, and no art without facts.

(Vladimir Nabokov,

Wisconsin Studies, 1967) 
A Carmen 


\title{
Alonso Mudarra, VIHUELISTA EN LA CASA DEL INFANTADO Y CANÓNIGO EN LA CATEDRAL DE SEVILLA
}

\author{
VOLUMEN 1
}





\section{ÍNDICE GENERAL}

\section{VOLUMEN I}

Lista de figuras

xi

Resumen/Abstract xii

Agradecimientos xvi

Abreviaturas y siglas utilizadas $\quad$ xvii

Criterios de transcripción y edición xix

INTRODUCCIÓN

PARTe 1 - Biografía de Alonso Mudarra 7

VALLADOLID 9

Los otros Mudarra $\quad 11$

La familia de Alonso Mudarra $\quad 23$

$\begin{array}{ll}\text { GUADALAJARA } & 27\end{array}$

La Casa del Infantado $\quad 31$

El linaje Mendoza. Antecedentes $\quad 31$

El III y IV duques del Infantado. El siglo XVI 43

Moneda y salarios en el Antiguo Régimen $\quad 54$

Quitación $\quad 54$

Ración $\quad 55$

Acostamiento $\quad 57$

Merced 58

$\begin{array}{ll}\text { Rentas de la nobleza española } & 59\end{array}$

Casa y Corte. Organización y funcionamiento $\quad 64$

La música en la Casa del Infantado en el siglo XVI 73

$\begin{array}{ll}\text { Capilla } & 74\end{array}$

$\begin{array}{ll}\text { Chantre } & 76\end{array}$

$\begin{array}{ll}\text { Capellanes } & 78\end{array}$

$\begin{array}{lr}\text { Organista } & 80\end{array}$

Mozos de capilla $\quad 81$

$\begin{array}{lr}\text { Cantores } & 88\end{array}$

$\begin{array}{lr}\text { Música } & 101\end{array}$

Ministriles 101

$\begin{array}{ll}\text { Organistas } & 108\end{array}$

Otros músicos 108

Vihuelistas 111

$\begin{array}{ll}\text { Trompetas } & 115\end{array}$

Trompetas 121

Atabaleros 124

Instrumentos musicales en el palacio del Infantado 129

$\begin{array}{ll}\text { Alonso Mudarra, paje y vihuelista } & 134\end{array}$ 
Estructura y organización del cabildo sevillano $\quad 145$

Los músicos de la catedral de Sevilla 154

Cantores 154

Organistas 156

Ministriles 157

Alonso y Francisco Mudarra, canónigos sevillanos 166

El modo de vida de un canónigo sevillano $\quad 182$

Música $\quad 185$

$\begin{array}{ll}\text { Libros } & 187\end{array}$

Joyas 191

Tapices, guadamecíes y pinturas $\quad 192$

Muebles 195

Ropa doméstica $\quad 198$

Vestuario 198

Objetos de coleccionismo y otros 201

Los esclavos en Sevilla. Mudarra y sus esclavos 203

Los testamentos de Mudarra 208

Parte 2 - Obras de Alonso Mudarra 211

LOS TRES LIBROS DE MÚSICA EN CIFRAS PARA VIHUELA 213

El libro 213

La impresión. Juan de León 218

El prólogo y los textos $\quad 222$

Iconografía 236

$\begin{array}{ll}\text { ANÁLISIS DE LAS OBRAS } & 239\end{array}$

$\begin{array}{ll}\text { CONCLUSIONES } & 417\end{array}$

$\begin{array}{ll}\text { AnEXos } & 421\end{array}$

Índices de BNE, Mss/11141 y y Mss/11142 422

Confesiones y absolución de Francisco Mudarra 427

Inventario del III duque del Infantado 429

Tasación de los bienes de Diego Hurtado de Mendoza 430

Inventario de los bienes de Isabel de Aragón, esposa del IV duque 431

Composición del Cabildo de la catedral de Sevilla, 1550

Carta de poder para el cobro de libros 436

Venta de un esclavo 437

Testamento de Alonso Mudarra 438

Inventario del canónigo Mudarra $\quad 440$

Almoneda del canónigo Mudarra 453

Recibo de Miguel de Abrego, criado de Alonso Mudarra 467

Reparto y venta de cebada de Alonso Mudarra 468

$\begin{array}{ll}\text { BibliografíA } & 469\end{array}$ 


\section{VOLUMEN II}

\section{PARTE 3 - Transcripciones}

\section{LIBRO I}

1- Fantasía 1

2- Fantasía 2

3- Fantasía 3

4- Fantasía 4

5- Fantasía 5

6- Fantasía 6

7- Fantasía 7

8- Fantasía 8

9- Fantasía 9

10- Qui tollis

11- Pleni

12- Fantasía 10

13- Conde Claros

14- Romanesca. Guárdame las vacas $1 \quad 48$

15- Pavana 1

16- Pavana de Alexandre $\quad 55$

17- Gallarda

18- Fantasía 11

19- Fantasía 12

20- Fantasía 13

21- Fantasía $14 \quad 68$

22- Pavana 3

23- Romanesca. Guárdame las vacas $2 \quad 74$

LIBRO II

24- Tiento 1

25- Fantasía $15 \quad 78$

26- Kyrie 1

27- Fantasía $16 \quad 87$

28- Tiento $2 \quad 91$

29- Fantasía $17 \quad 92$

30- Fantasía $18 \quad 96$

31- Tiento 3

32- Fantasía $19 \quad 100$

$\begin{array}{lr}33-\text { Kyrie } 2 & 105\end{array}$

34- Tiento $4 \quad 110$

35- Fantasía $20 \quad 111$

36- Benedictus 115

$\begin{array}{lr}37-\text { Tiento } 5 & 118\end{array}$ 
41- Fantasía 23

42- Kyrie $3 \quad 133$

43- Tiento $7 \quad 139$

44- Fantasía $24 \quad 141$

$\begin{array}{ll}\text { 45- Cum sancto spiritu } & 145\end{array}$

46- Tiento $8 \quad 151$

47- Fantasía $25 \quad 152$

48- Fantasía $26 \quad 156$

49- Fantasía $27 \quad 160$

\section{LIBRO III}

50- Pater noster 163

51- Respice in me, Deus 179

52- Clamabat autem mulier. Motete de la cananea 190

53- Durmiendo yva el Señor 201

54- Triste estava el rey David 206

55- Israel, mira tus montes 209

56- Sin dudar. Canción al milagro de la Encarnación 213

57- Recuerde el alma dormida 223

58- Claros y frescos ríos 226

59- ¿Qué llantos son aquestos? 230

60- Si por amar el hombre 235

61- Por ásperos caminos 241

62- Regia qui mesto 246

63- Dulces exuviae 250

64- Beatus ille 256

65- Hanc tua Penelope 257

66- La vita fugge 259

67- Lassato a il Tago 265

$\begin{array}{ll}\text { 68- O gelosia d'amanti } & 270\end{array}$

69- Itene a l' ombra 275

70- Dime adó tienes las mientes $\quad 277$

71- Si me llaman 282

72- Gentil cavallero 288

73- Ysabel, perdiste la tu faxa 295

$\begin{array}{ll}\text { 74- Si viesse e me levasse } & 300\end{array}$

75- Nisi Dominus 302

76- Exurge, quare obdormis 304

77- Tiento $9 \quad 307$ 


\section{LISTA DE FigURAS}

Fig. 1. Valladolid (1574) por Braun y Hogenberg 10

Fig. 2. Descendientes de Juan Sánchez Mudarra (basado en Salazar y Castro) 16

Fig. 3. Casa de los Mudarra en Valladolid 18

Fig. 4. Descendientes de Gerónimo Mudarra 20

Fig. 5. Descendientes de Sebastián Mudarra $\quad 22$

Fig. 6. Familia de Alonso Mudarra 24

Fig. 7. Genealogía del linaje Mendoza 33

Fig. 8. Fachada del Palacio del Infantado de Guadalajara (Jenaro Pérez
Villaamil, 1842)

Fig. 9. Galería alta del Palacio del Infantado de Guadalajara (Angel Lizcano Monedero (1846-1929). Museo Provincial de Bellas Artes, Guadalajara) 42

Fig. 10. Memorial de cosas notables, 1564

Fig. 11. Salón de los Linajes del Palacio del Infantado (Laurent, 1880, BNE.) 76

Fig. 12. Portada de los tratados de Juan de Espinosa 90

Fig. 13. Posible reconstrucción de tres familias de trompetas de la Casa del Infantado

Fig. 14. Posible reconstrucción la familia Gascón 122

Fig. 15. Ministriles negros en la Boda de Santa Úrsula. Museu Nacional de Arte Antiga, Lisboa, c. 1520

Fig. 16. Evolución de la Capilla y los músicos del Infantado 126

Fig. 17. Nómina de 1523 con el nombre de Alonso Mudarra. BNE, Mss/11142, f. 191.

Fig. 18. Nómina de 1542 con el despido de Alonso Mudarra. BNE, Mss/11141, f. $201 \mathrm{v}$.

Fig. 19. Archivo de la Catedral de Sevilla, Libro de Entrada de Prebendados, Sección I. Secretaría. Serie 3. Personal. Sign. 07434, f. 24v.

Fig. 20. MudarRa. Tres libros de música. Ejemplo del prólogo y su transcripción. Libro I, f. A3.

Fig. 21. MudarRA. Tres libros de música. Grabado xilográfico de Mercurio. Libro I, f. A4v.

Fig. 22. MudarRa. Tres libros de música. Grabado xilográfico del profeta Eliseo. Libro III, f. h5.

Fig. 23. MudarRA. Tres libros de música. Emblema de la paz. Libro III, ff. h5v y h8v.

Fig. 24. Mudarra. Tres libros de música. Grabado xilográfico del Rey David. Libro III, f. h7v.

Fig. 25. Esquema de la obra vocal de Mudarra (adaptado de Blecua) 345

Fig. 26. Firma de Alonso Mudarra, $1557 \quad 436$

Fig. 27. Firma de Alonso Mudarra, 1576 


\section{RESUMEN}

La presente tesis doctoral estudia la vida y obra del vihuelista Alonso Mudarra (c. 1509Sevilla, 1 de abril de 1580). A pesar de que ya existe un trabajo previo a cargo de Emilio Pujol, creemos necesario revisitar esta música y a su creador a la luz de las investigaciones realizadas en los dos tercios de siglo transcurridos desde la publicación de dicha monografía.

El estudio está dividido en tres partes y dos volúmenes. En primer lugar abordamos la biografía de Mudarra, enfocándola desde la perspectiva de las tres ciudades que constituyen su itinerario vital: Valladolid, Guadalajara y Sevilla. En la segunda parte se estudia su obra, los Tres libros de música en cifras para vibuela, tanto en lo referente a aspectos bibliográficos como de su contenido. La tercera parte es la edición crítica de la obra musical contenida en los Tres libros.

Los posibles orígenes vallisoletanos de Alonso Mudarra nos han llevado a indagar en la familia Mudarra, miembros del patriciado urbano de Valladolid desde el siglo XIII. Las importantes ramificaciones de la familia en San Martín de Valdeiglesias y en Palencia también son objeto de nuestro estudio. Nuestro propósito ha sido ubicar al Mudarra vihuelista dentro de esta gran familia. Para ello hemos recurrido a diferentes archivos: el Archivo de la Real Chancillería de Valladolid, el Archivo General de Simancas y el Archivo de Protocolos de Valladolid, bien de forma directa o a través de la plataforma Portal de Archivos Españoles (PARES). En otros casos hemos utilizado fuentes indirectas. Hemos podido reconstruir las ramas principales del árbol genealógico para gran parte del siglo XVI y establecer una hipótesis sobre nuestro vihuelista y su familia más cercana, la cual conocemos a través del testamento de Alonso y por la notoriedad de alguno de sus miembros, como es el caso de su hermano Francisco, importante miembro de la curia vaticana.

En la ciudad de Guadalajara, transcurrió el periodo formativo de Alonso Mudarra, quien pasó más de veinte años en el seno de la corte de los duques del Infantado, conviviendo con los mejores músicos del momento. Allí se formó como músico y como 
persona. Podemos documentar su estancia alcarreña mediante unos libros de nóminas conservados en la Biblioteca Nacional de Madrid. Esto nos ha llevado a enfrentarnos a la actividad de una corte de la alta nobleza de gran importancia como es la de los duques del Infantado. Incluimos un estudio bastante exhaustivo sobre los músicos que trabajaron allí a lo largo de cincuenta años por dos razones, primero por la valía de estos músicos, muchos de ellos provenientes de otras cortes, y lo segundo porque creemos que es allí donde se gestó la única obra de Mudarra, los Tres libros de música en cifras. Incluimos algunas aportaciones sobre aspectos musicales como los instrumentos musicales que poseía la familia Mendoza gracias a documentos conservados en el Archivo Histórico Nacional, Sección Nobleza (Toledo).

Sevilla fue el lugar donde Mudarra pasó los últimos treinta y cuatro años de su vida como canónigo de la catedral. Lamentablemente sus ocupaciones y obligaciones en la sede hispalense, muchas de ellas relacionadas con la música, no permitieron que publicara nuevas obras. No obstante, estudiamos a través de las actas capitulares y de documentos civiles del Archivo Histórico de Sevilla, tanto los músicos que allí trabajaron, como el estilo de vida que pudo llevar Alonso como miembro de la «aristocracia» eclesiástica, a la que pertenecían los canónigos sevillanos. Nos centramos en aspectos de la cultura material como son sus posesiones y cómo ello puede afectar en su mentalidad.

La segunda parte aborda un estudio del contenido, aspectos bibliográficos del libro y de producción editorial. Sigue un estudio detallado de todas y cada una de las obras donde figura el aparato crítico, los textos cuando los hay, las concordancias musicales y literarias y un análisis en el que, según el tipo de pieza, se hace más o menos hincapié en aspectos modales, estructurales, etc. Completamos el estudio con las conclusiones, el documentario y la bibliografía.

Las transcripciones de la obra completa constituyen el tercer bloque y el segundo volumen. Las presentamos en edición crítica en doble clave para facilitar la lectura de la marcha polifónica y en tablatura, igualmente en edición crítica, para posibilitar la comparación con la transcripción. Intentamos subsanar la gran cantidad de errores tipográficos que contiene el libro. 


\begin{abstract}
This thesis deals with the life and work of the vihuelist Alonso Mudarra (c. 1509Sevilla, April 1, 1580). Although there is already a previous work by Emilio Pujol about it, we think it is important to revisit Mudarra's music and, therefore, its creator in the light of the researches that were conducted in the two thirds of the century passed after the publication of the monograph by Pujol.
\end{abstract}

The study is divided into three parts and two volumes. Firstly, we approach Mudarra biography, focusing on the perspective given by the three cities that constitute its vital route: Valladolid, Guadalajara and Sevilla. Secondly, his work Tres libros de música en cifras para vihuela (Three Books of Music in Tablature for the Vibuela), is studied with reference to the bibliographic aspects as well as its contents. The third part is the critical edition which is contained in the Three Books.

The likely origins of Alonso Mudarra in Valladolid have led us to investigate the Mudarra family, urban patrician members of Valladolid since the XIII ${ }^{\text {th }}$ century. The major branches of this family that were located in San Martin de Valdeiglesias and Palencia are also faced in our study. Our purpose has been to place the vihuelist Mudarra within this big family. Thus, we have used different files: the «Archivo de la Real Chancillería de Valladolid», the «Archivo General de Simancas» and the «Archivo de Protocolos de Valladolid», either in a direct way or on the «Portal de Archivos Españoles (PARES)». In other cases, we used indirect sources. We could restore the main branches of the family tree in most of the $\mathrm{XVI}^{\text {th }}$ century and establish a hypothesis about our vihuelist and his family which we know by his will and by the reputation of one of its members, such as his brother Francisco, a senior member of the Vatican curia.

In the city of Guadalajara Alonso Mudarra developed his formative period and spent more than twenty years within the court of the Dukes of the Infantado living togehter with the best musicians of the moment. It was there that he was trained as a musician and as a person. We can document his stay in that region by using some payroll books that 
were kept in the «Biblioteca Nacional de Madrid». This fact led us to deal with the activity of a court of great importance consisting of a high nobility such as the Dukes of the Infantado. We also include, for two reasons, a fairly comprehensive study of the musicians who worked there over fifty years. Firstly, because of the value of these musicians, many of them from other courts, and secondly, because we believe that is was there where the only work by Mudarra Tres libros de música en cifras was conceived. Thanks to the «Archivo Histórico Nacional, Sección Nobleza de Toledo» we include some contributions to the musical aspects such as the musical instruments they owned.

Sevilla was the place where he spent the last thirty-four years of his life as a canon in the cathedral. Unfortunately their occupations and obligations in that city, many of them related to music did not allowed him to publish new works. However, looking through the records and civil documents of the «Archivo Histórico de Sevilla», we study both the musicians who worked there and the lifestyle that Alonso had as a member of the ecclesiastical aristocracy, as the Sevillian canons were. We focus on aspects of the material culture, how their possessions were and how them may affect their way of thinking.

The second part deals with a study of content, bibliographic details of the book and publishing issues. A following detailed study of all and every one of the works contains the critical apparatus, the texts when available, musical and literary correspondences and an analysis in which, according to the type of piece, we underline more or less the modal aspects, structural features, etc. We completed the study with conclusions, the documentary and bibliography.

The transcripts of the complete work form the third block and the second volume. They are presented in a critical edition with double clef for an easy reading of the polyphonic process and, in tablature, also in a critical edition, to enable the comparison with the transcription. We also try to fix the large number of typographical errors that the book contains. 


\section{AgRAdeCIMIENTOS}

A la doctora Ana Belén Sánchez Prieto por abrirme las puertas al fascinante mundo de la cultura altonobiliaria.

Al Excmo. Sr. Juan Gil y al profesor José Antonio Ollero Pina por compartir sus trabajos. A los doctores Rosario Álvarez y Javier Marín por su valoración y sus consejos. A Miguel Úbeda, Agurtzane Primo Porras, Inmaculada Matía Polo, Clara Bejarano Pellicer y Hugo Abel Enrique y Cagnolo por su generosidad, apoyo y colaboración.

Al personal del Archivo Histórico Provincial de Sevilla, del Archivo Provincial de Guadalajara y de la Institución Colombina de Sevilla por su inestimable ayuda. A los bibliotecarios y personal de la Biblioteca Nacional de España y de la Real Biblioteca del Monasterio de San Lorenzo de El Escorial por sus facilidades.

A Emilio Pujol por haber dedicado su vida a mostrar al mundo el extraordinario repertorio de nuestros vihuelistas.

A John Griffiths por haber escrito tanto y tan bueno sobre el maravilloso mundo de la vihuela.

A Hopkinson Smith por todo lo que me ha enseñado y deleitado con sus interpretaciones de Mudarra.

Por supuesto, a mi director de tesis, el doctor Gerardo Arriaga, por su paciencia y sus consejos. 


\section{ABREVIATURAS Y SIGLAS UTILIZADAS}

c./cc.

coord.

ed./eds.

f./ff.

facs.

fig.

mrs.

ms.

p./pp.

reed.

s. d.

s. 1.

ss.

$\mathrm{V}$

vol./vols.

AGS

AHPGu

AHPSe

AHN

AHN-SN

ARCHV

BC

$\mathrm{BNE}$

CMP

CSIC

DMEH compás/compases

coordinador

edición o editor/editores

folio/folios

facsímil

figura

maravedís

manuscrito

página/páginas

reedición

sin datos editoriales

sin lugar de edición [sine locus]

siguientes

vuelto

volumen/volúmenes

Archivo General de Simancas

Archivo Histórico Provincial de Guadalajara

Archivo Histórico Provincial de Sevilla

Archivo Histórico Nacional

Archivo Histórico Nacional, Sección Nobleza (Toledo)

Archivo de la Real Chancillería de Valladolid

Biblioteca de Catalunya

Biblioteca Nacional de España (Madrid)

Cancionero Musical de Palacio

Consejo Superior de Investigaciones Científicas

Diccionario de la música española e hispanoamericana 
ICCMU

MME

$\mathrm{RAH}$

RBME

SEdeM

SGAE
Instituto Complutense de Ciencias Musicales

Monumentos de la Música Española

Real Academia de la Historia

Real Biblioteca del Monasterio de San Lorenzo de El Escorial

Sociedad Española de Musicología

Sociedad General de Autores y Editores 


\section{CRITERIOS DE TRANSCRIPCIÓN Y EDICIÓN}

Para la transcripción de textos antiguos utilizamos los siguientes criterios: ${ }^{1}$

- Añadimos las tildes según el criterio actual.

- Respetamos la puntuación original.

- Acentuamos las vocales a y e cuando son sinónimos de ba y be.

- Transcribimos $u / v$ según su valor fonético actual.

- Mantenemos las grafías originales en las alternancias $b / v, c / q, f / h$, respetando la ausencia de $h ; g / j, i / j, i / y$ (consonántica y vocálica), acentuando la $y$ vocálica cuando sea necesario.

- $\mathrm{El}$ signo $\&$ se resuelve por et o por $y$. El signo $\beta$ se resuelve por ss.

- Se desarrollan las abreviaturas sin indicarlo en el texto.

- Utilizamos el paréntesis cuadrado [ ] para indicar que añadimos alguna letra o palabra ausente en el original.

- Cuando reproducimos textos sacados de fuentes secundarias, mantenemos la grafía del transcriptor, incluida la ausencia de tildes.

Para las referencias bibliográficas y algunas citas utilizamos notas a pie de página, apareciendo las referencias completas en su primera mención y abreviadas a continuación de la siguiente manera:

MORPHY, Guillaume. Les Luthistes espagnoles du XVI siècle. Die spanischen Lautenmeister des 16 Jabrbunderts. Leipzig, Breitkopf \& Härtel, 1902, 2 vols.

MORPHY, G. Les Luthistes espagnoles...,

Cuando se trata de obras traducidas la referencia completa se da en el apartado de bibliografía.

\footnotetext{
${ }^{1}$ Aplicamos, en general, las propuestas de BARroso CASTRO, José y SÁnCHEZ DE Bustos, Joaquín. «Propuestas de transcripción para textos del XV y Siglos de Oro», Estado actual de los estudios sobre el Siglo de Oro: actas del II Congreso Internacional de Hispanistas del Siglo de Oro. GARCía MARTín, Manuel (coord.), vol I, 1993, pp. 161-178.
} 
En algunos casos, para obras citadas reiteradas veces, utilizamos referencias abreviadas que indicamos en la bibliografía:

PUjOL. Mudarra.

por

Pujol, Emilio. Alonso Mudarra. Tres libros de música en cifra para vibuela. (Sevilla 1546). MME 7, Barcelona, CSIC, Instituto Español De Musicología, 1949, reed. 1984.

En cuanto a la transcripción musical hemos optado por lo siguiente:

- Presentamos las obras de Mudarra en transcripción a doble clave para facilitar la identificación de la marcha de las voces.

- Añadimos la tablatura en edición crítica, señalando los valores rítmicos originales. $^{2}$

- Mantenemos la división de compases del autor y establecemos la equivalencia de semibreve igual a redonda, sin reducción de valores.

- Elegimos la altura de vihuela (o laúd) en Sol para todas las piezas, aunque en muchos casos implique una armadura con muchas alteraciones.

- Señalamos entre corchetes los añadidos editoriales.

- Incluimos el aparato crítico en el comentario individual de cada pieza, indicando el compás o compases.

- Damos un título y una numeración a cada una de las piezas.

- Incluimos íncipit facsimilar al principio de las transcripciones.

\footnotetext{
${ }^{2}$ Lo que Grier denomina Printed replica. GRIER, James. The Critical Editing of Music. History, Method, and Practice. Cambridge, Cambridge University Press, 1996.
} 


\section{INTRODUCCIÓN}

En 1869 Guillermo Morphy ejecutaba un concierto de piano en la sala Herz de París donde daba a conocer cinco obras de Luis Milán y una de Miguel de Fuenllana, estas tañidas sobre un clave. ${ }^{3}$ Unos años más tarde salía a la luz, de forma póstuma, su trabajo sobre los vihuelistas españoles, bautizados por él como los «laudistas españoles». ${ }^{4} \mathrm{El} \mathrm{libro}$ fue prologado por el musicólogo belga Gevaert y publicado en francés y alemán. Esto favoreció su gran difusión fuera de nuestras fronteras y supuso el pistoletazo de salida para el redescubrimiento del repertorio de vihuela. Poco tiempo después del mencionado concierto, se publicó la primera transcripción moderna de una pieza de vihuela: el romance $A$ las armas, moriscote, contenido en la obra de Fuenllana y que apareció en el Calendario histórico musical para el año 1873. Hacia estos años, es probable que Francisco Asenjo Barbieri ya hubiera adquirido varios de los ejemplares de los libros de vihuela que actualmente posee la Biblioteca Nacional de Madrid. ${ }^{5}$

Con el cambio de siglo y el naciente interés por la música antigua en toda Europa, la música para vihuela llamó la atención de otros musicólogos. Felipe Pedrell, en el tercer tomo de su Cancionero musical popular español, incluyó una selección de piezas de todos los vihuelistas, con la excepción de Daza, principalmente villancicos y romances. ${ }^{6}$ Entre ellas el romance de Mudarra, Triste estaba el rey David. En 1923 Martínez Torner publicó unas cuantas obras de Narváez en versión para piano, incluyendo la tablatura y Jesús Bal y Gay, doce años más tarde, en su selección de romances y villancicos incluía algunos para

${ }^{3}$ El programa y los intérpretes se pueden consultar en REY, Pepe. "Guillermo Morphy: el redescubrimiento de la vihuela en el siglo XIX. I. París, 1868-1870», Roseta, 3 (2009), pp. 26-45.

${ }^{4}$ Morphy, Guillaume. Les Luthistes espagnoles du XVI siècle. Die spanischen Lautenmeister des 16 Jabrbunderts. Leipzig, Breitkopf \& Härtel, 1902, 2 vols.

${ }^{5}$ REY, Pepe. «Guillermo Morphy: el redescubrimiento de la vihuela en el siglo XIX. II. Madrid, 18751899», Roseta, 4 (2010), pp. 46-61; p. 47.

${ }^{6}$ Pedrell, Felipe. Cancionero musical popular español. Valls, Eduardo Castells, 1917-1922, 4 vols. 
vihuela, ninguno de Mudarra. ${ }^{7}$ Fuera de España, en 1925, John Brande Trend publicaba una monografía sobre Luis Milán y los vihuelistas con algunos ejemplos musicales, entre ellos tres de Mudarra, y en 1927 veía la luz la primera transcripción integral de música para este instrumento, El maestro de Luis Milán, a cargo de Leo Schrade. ${ }^{8}$

Pero sin duda alguna, la persona que dedicó su vida al estudio de la vihuela y su música fue Emilio Pujol. Fue el primero en realizar una grabación de música de vihuela, en 1933, y el primero en identificar un instrumento original, la conocida como vihuela JacquemartAndré, en 1936. A partir de 1945 comenzó la serie de publicaciones de vihuelistas con la obra de Luis de Narváez, a la que siguió la de Alonso Mudarra, en 1949 y la parcial de Valderrábano en 1965.

La obra de Fuenllana fue abordada por Charles Jacobs en $1978 .{ }^{10}$ Daza vio la luz de nuevo, primero en forma parcial con la publicación de sus fantasías a cargo de John Griffiths, en 1982 y al año siguiente de forma total en la edición de Rodrigo de Zayas. ${ }^{11}$ El vihuelista faltante, Diego Pisador, fue abordado de forma parcial por nosotros mismos en 2002. ${ }^{12}$ Habría que añadir la labor de la desaparecida editorial Minkoff que, desde el año 1973, inició la publicación de los libros de los vihuelistas en edición facsimilar, aunque sin la cifra colorada. El libro de Mudarra fue el único no publicado por Minkoff, sino que lo hizo la editorial Chanterelle. ${ }^{13}$

${ }^{7}$ MartíneZ TORner, Eduardo. Colección de vihuelistas españoles del siglo XVI. Narváez. El Delphin de Música. 1538. Madrid, Orfeo Tracio, 1923. BAL Y GAY, Jesús. Romances y villancicos españoles del siglo XVI. Dispuestos en edición moderna para canto y piano. México, La Casa de España en México, 1939.

${ }^{8}$ Trend, John Brande. Luis Milan and the Vihuelistas. Oxford, Oxford University Press, Humphrey Milford, 1925 y SCHRADE, Leo. Libro de Música de Vibuela de mano intitulado "El Maestro", compuesto por Luis Milán. Publikationen Älterer Musik, 2. Leipzig, 1927

9 Sobre las grabaciones de música de vihuela puede consultarse GRIFFITHS, John. «Los dos renacimientos de la vihuela», Goldberg, 33 (Abril 2005), pp. 35-43.

${ }^{10}$ JACOBS, Charles. Fuenllana, Orphénica Lyra. Oxford, Oxford University Press, 1978.

11 Griffiths, John. Esteban Daza: The Fantasias for vibuela. Recent Researches in Music of the Renaissance, 54. Madison, A-R Editions, 1982. ZAYAs, Rodrigo de. Los vibuelistas: Esteban Daça. Colección Opera Omnia. Madrid, Alpuerto, 1983.

${ }^{12}$ RoA, Francisco y GÉRTRudix, Felipe. El libro de música de vihuela de Diego Pisador (1552). Madrid, Editorial Pygmalión, 2002.

${ }^{13}$ Damos cumplida cuenta de estas ediciones en la bibliografía. 
Podemos considerar que los estudios teóricos sobre la vihuela comienzan con una obra fundamental de 1953, la tesis de John Ward. Treinta años después, marcará un nuevo hito la de John Griffiths. ${ }^{14}$ Muchos otros investigadores han aportado sus trabajos en las últimas décadas, lo que sería excesivamente prolijo relatar aquí. A ello hay que sumar que hoy en día podemos contar con las ediciones originales de los vihuelistas, y de muchos otros músicos y teóricos, a través de las digitalizaciones de la «Biblioteca Digital Hispana» en internet, lo que posibilita que en los próximos años el número de estudios sobre la vihuela crezca considerablemente.

Nuestra humilde contribución a todo este conjunto de trabajos, que presentamos a continuación y cuyos contenidos hemos expuesto sucintamente en el resumen y el índice, trata sobre Alonso Mudarra. Estudiaremos a este vihuelista y canónigo inserto en los diferentes ambientes en los que le tocó vivir. Para ello, transitaremos enfoques que, si bien no son demasiado frecuentes en la musicología, son bastante usados en historiografía desde hace décadas. Afortunadamente, la ciencia musicológica ha ido abriendo cada vez más puertas a la historia económica y social o la sociohistoria, la historia de las mentalidades, la historia cultural y de la cultura material. Todas ellas nos aportan herramientas que nos ayudan en el objetivo básico de la historia, interpretar y explicar el pasado.

Puede sorprender la cantidad de espacio y esfuerzo que dedicamos a la música en la corte de los duques del Infantado, donde trabajó Mudarra durante largos años. Lo consideramos imprescindible para conocer cómo se gestó su obra y además, creemos que la música en las cortes nobiliarias en la Edad Moderna no ha recibido suficiente atención de la historiografía musical española. ${ }^{15}$ Esta ha focalizado su atención en la música religiosa y en particular en la música de las catedrales, cuyo estudio ha producido

\footnotetext{
${ }^{14}$ WARD, John. The «Vibuela de mano» and its music (1536-1576). Tesis doctoral, New York University, 1953, 2 vols. y GRIfFITHS, John. The Vihuela Fantasia: A comparative study of forms and styles. Tesis doctoral, Monash University, 1983.

${ }^{15}$ Hace casi treinta años María Ester-Sala se lamentaba de esto mismo y presentaba un panorama o estado de la cuestión sobre los estudios sobre el mecenazgo musical en España. EsTER-SALA, María A. «El mecenazgo de la nobleza en la música del siglo XVI», Nassarre: Revista aragonesa de musicología, 4/1-2 (1988), pp. 37-58.
} 
innumerable cantidad de tesis y libros de título «La música en la catedral de...». ${ }^{16}$ Esta tendencia inaugurada por José López Calo en 1963 con su trabajo sobre la catedral de Granada, ${ }^{17}$ fue seguida por muchos otros trabajos, de indudable valor, sobre las distintas catedrales y colegiatas de la geografía española. La música de otras instituciones religiosas, como los monasterios y las órdenes religiosas, también ha sido abordada últimamente por algunos investigadores. ${ }^{18}$

No ocurre lo mismo con la música de la nobleza, aunque existen varios estudios de relevancia sobre la música en las cortes hispanas. En primer lugar, destaca el trabajo de José Subirá sobre la Casa de Alba; ${ }^{19}$ habría que añadir los de Romeu, Moll y Gómez Muntané para la corte del duque de Calabria, el de Russell sobre el III duque de Béjar, o el de Ruiz-Jiménez sobre Medina Sidonia. ${ }^{20}$ Muy sustanciosa es la tesis doctoral de Roberta Freund Schwartz, con una enorme cantidad de datos sobre diferentes cortes nobiliarias, pero, tal vez, con una insuficiente elaboración. ${ }^{21}$ Más recientemente, Juan Pablo Fernández-Cortés ha publicado un extenso estudio, resultado de su tesis doctoral, sobre

${ }^{16}$ CARreras, Juan José. «Música y ciudad: de la historia local a la historia cultural», Música y cultura urbana en la edad moderna. BOMBI, A.; CARreras, J. J. ; MARíN, M. A. (eds.). Valencia, Universitat de València, 2005, pp. 17-51.

${ }^{17}$ LÓPEZ CALO, José. La música en la Catedral de Granada en el siglo XVI. Granada, Fundación RodríguezAcosta, 1963, 2 vols.

${ }^{18}$ Por ejemplo VICENTE DELGADO, Alfonso de. Los cargos musicales y las capillas de música en los monasterios de la orden de san Jerónimo (siglos XVI-XIV). Tesis Doctoral, Universidad Complutense de Madrid, 2010.

${ }^{19}$ Subirá, José. La Música en la Casa de Alba. Estudios Históricos y Biográficos. Madrid, Sucesores de Rivadeneira, 1927. Lamentablemente, según nos comunica personalmente José Manuel Calderón Ortega, director del archivo de la Casa de Alba, de todos los documentos que estudió Subirá la mayoría fueron destruidos en el bombardeo del Palacio de Liria de 1936. No llega a la decena los conservados actualmente.

${ }^{20}$ Romeu Figueras, José. «Mateo Flecha el Viejo, la corte literariomusical del duque de Calabria y el Cancionero llamado de Upsala», Anuario Musical, 13 (1958), pp. 25-101; Moll, Jaime. «Notas para la historia musical de la corte del Duque de Calabria», Anuario Musical, 18 (1963), pp. 123-135 y GómeZ MunTANÉ, Maricarmen. «San Miguel de los Reyes y la capilla musical de don Fernando de Aragón, duque de Calabria (1488-1550)», San Miguel de los Reyes: De Biblioteca Real a Biblioteca Valenciana, Valencia, Generalitat, 2000, pp. 91-111. RussELL, Eleanor. «Music in the House of the Third Duke of Béjar: ca. 1520-1544», Encomium Musicae. Essays in Honor of Robert J. Snow. David Crawford, G. Grayson Wagstaff (eds.), Festschrift Series $n^{\circ}$ 17, Hillsdale, Nueva York, Pendragon Press, 2002, pp. 285-303. RuIZ-JimÉNEZ, Juan. «Power and musical exchange: the Dukes of Medina Sidonia in Renaissance Seville», Early Music, 37/3 (2009), pp. 401-415.

${ }^{21}$ FREUND SCHWARTZ, Roberta. En busca de liberalidad: music and musicians in the courts of the Spanish nobility, 1470-1640. Tesis Doctoral, University of Illinois at Urbana-Champaign, 2001. 
las Casas de Osuna y Benavente que, aunque aborda la música del siglo XVI, se centra en los siglos XVIII y XIX. ${ }^{22}$

Al tratar la música en la corte del Infantado abarcamos un periodo de cerca de cincuenta años, tiempo que supera el de la estancia de Mudarra, pero que consideramos fundamental para conocer la relevancia de la música en dicha corte. Para poder enmarcar las actividades musicales, hemos introducido bastantes aspectos históricos sobre la familia Mendoza que nos ayudan a comprender su papel político y cultural en la Castilla de los siglos XV y XVI. No olvidemos que muchos historiadores consideran a este linaje fundamental para la introducción del Renacimiento en Castilla. También el conocimiento de la estructura administrativa y económica de la Casa mendocina es primordial para entender el encaje de la música dentro de una gran corte. Hemos prestado atención a los espacios donde se desarrollaban estas actividades musicales, los palacios, principalmente; a las ocasiones en que se producían intercambios entre los músicos como visitas regias, bodas ilustres, incluso a los instrumentos musicales que poseían estos grandes nobles y que localizamos en los inventarios de sus bienes.

No hemos olvidado la música de la espléndida catedral de Sevilla la cual, posiblemente, requeriría un trabajo de mayor envergadura. A pesar de lo que decíamos anteriormente, falta una monografía sobre el cabildo sevillano, como sí hay de otras catedrales como Toledo, Santiago, Córdoba y, por supuesto, es imprescindible abordar el estudio en profundidad sobre la música en el siglo XVI en la «Magna hispalensis» continuando trabajos previos de inestimable valor.

A lo largo de este trabajo desfilarán multitud de músicos, hasta hoy muchos de ellos anónimos, que llenaron de música las estancias del palacio del Infantado y las naves de la catedral de Sevilla. Se podría alegar su escasa transcendencia, pero consideramos de gran importancia rescatarlos del olvido por una sencilla razón, ellos estuvieron allí, nosotros no.

\footnotetext{
${ }^{22}$ FernÁNDEZ-Cortés, Juan Pablo. La música en las Casas de Osuna y Benavente (1733-1882). Un estudio sobre el mecenazgo musical de la alta nobleza española. Madrid, SEdeM.
} 



\section{PARTe 1}

\section{Biografía de Alonso MudARRA}





\section{VALLADOLID}

En 1527 nacía en Valladolid quien sería el rey más poderoso del orbe cristiano, el príncipe Felipe. La villa del Esgueva, cruce de caminos entre el norte y el sur de la Península, punto de contacto entre Castilla y León y frontera del Duero, fue residencia de la Corte en multitud de ocasiones, ${ }^{23}$ convirtiéndose en capital de facto en la transición de los siglos XV y XVI. Además, desde 1452, pasó a ser la sede del poder judicial del Reino de Castilla gracias al traslado de la Audiencia o Chancillería Real. ${ }^{24}$ No hay que olvidar la presencia de la Universidad, una de las más importantes de Castilla, con sus cinco cátedras de derecho, donde se formaban muchos de los letrados que trabajaban en dicha Audiencia. ${ }^{25}$ Sin ser sede episcopal, ${ }^{26}$ su abad, nombrado directamente por el Papa, ostentaba un gran poder tanto en lo espiritual como en lo terrenal. Todo ello implicaba que la nobleza que acompañaba a los monarcas en sus desplazamientos, así como una gran cantidad de funcionarios reales y letrados, con frecuencia fijara sus residencias en la villa. ${ }^{27}$ A principios de siglo XVI tenía una población de más de treinta mil habitantes, lo que la convertía en una de las villas más pobladas de la Corona de Castilla. ${ }^{28}$

${ }^{23} \mathrm{La}$ frecuente presencia de la Corte en la villa vallisoletana está documentada desde el siglo XI. RuCQUOI, Adeline. I: Valladolid en la Edad Media. Génesis de un poder (1085-1367). II El mundo abreviado (13671474). 2 vols. Valladolid, Junta de Castilla y León, Consejería de Educación y Cultura, 1997, pp. 167-168.

${ }^{24}$ BenNASSAR, Bartolomé. Valladolid en el Siglo de Oro. Una ciudad de Castilla y su entorno agrario en el siglo ХVI. Valladolid, Ámbito, 1989, p. 116. Este traslado fue sancionado por los Reyes Católicos en 1498, aunque posteriormente sufrió algún desplazamiento.

25 «Ciudad de funcionarios» ha sido denominada Valladolid en más de una ocasión. PÉREZ, Joseph. Los Comuneros. Madrid, Historia 16, 1997, p. 12.

${ }^{26}$ Recordemos que la Colegiata de Santa María fue sufragánea de la Catedral de Palencia hasta 1595, año en que se convirtió en sede obispal.

${ }^{27}$ Muchas de las familias de la alta nobleza levantaron casas, a menudo fortificadas, en el interior de la muralla de Valladolid. Así, los Enríquez, Stúñiga, Guzmán o los Mendoza, erigieron sus palacios-fortaleza en la villa, sin que el rey tuviera ninguna residencia permanente en la misma. RUCQUOI, A. II: Valladolid en la Edad Media. El mundo..., pp. 55 y ss.

${ }^{28}$ Valladolid y Toledo superaban ambas los 30.000 habitantes, seguidas de cerca por Medina del Campo, con unos 20.000. Algo por debajo quedaban Segovia o Salamanca. En Andalucía se concentraban las ciudades más populosas, destacando Sevilla, que pudo llegar a tener 40.000 o incluso 70.000 habitantes. Todas ellas eran posiblemente superadas por Valencia con más de 75.000 habitantes. Una revisión actual de estos datos es la de LADERO QuESADA, Miguel Ángel. «La población de reinos y ciudades en la baja Edad Media española (De finales del siglo XIII a comienzos del XVI)», Boletin de la Real academia de la Historia, 211/1 (Enero-Abril 2014), pp. 37-78. Aunque los datos no siempre coinciden, se pueden consultar también en SOla CASTAÑO, Emilio. Los Reyes Católicos: los reyes que sufragaron la mayor quimera de la historia. Madrid, Anaya, 1988, para Sevilla DomíngueZ OrTiZ, Antonio. Orto y ocaso de Sevilla. Sevilla, Secretariado de Publicaciones 
Esta gran cantidad de habitantes, con gran presencia de las clases privilegiadas y de funcionarios de la Corte y de la Chancillería, consumía muchos bienes suntuarios y la cultura era uno de ellos. Esto provoca un gran desarrollo de las artes y de la música en particular, lo que tiene una gran importancia también para el mundo de la vihuela. ${ }^{29}$ Los inventarios de la época nos muestran una gran cantidad de libros y entre ellos los de música representan un porcentaje no despreciable. ${ }^{30}$ En esta villa se dieron a la imprenta las obras de Luis de Narváez, Enríquez de Valderrábano y Esteban Daza, además del tratado teórico del dominico Fray Tomás de Santa María.

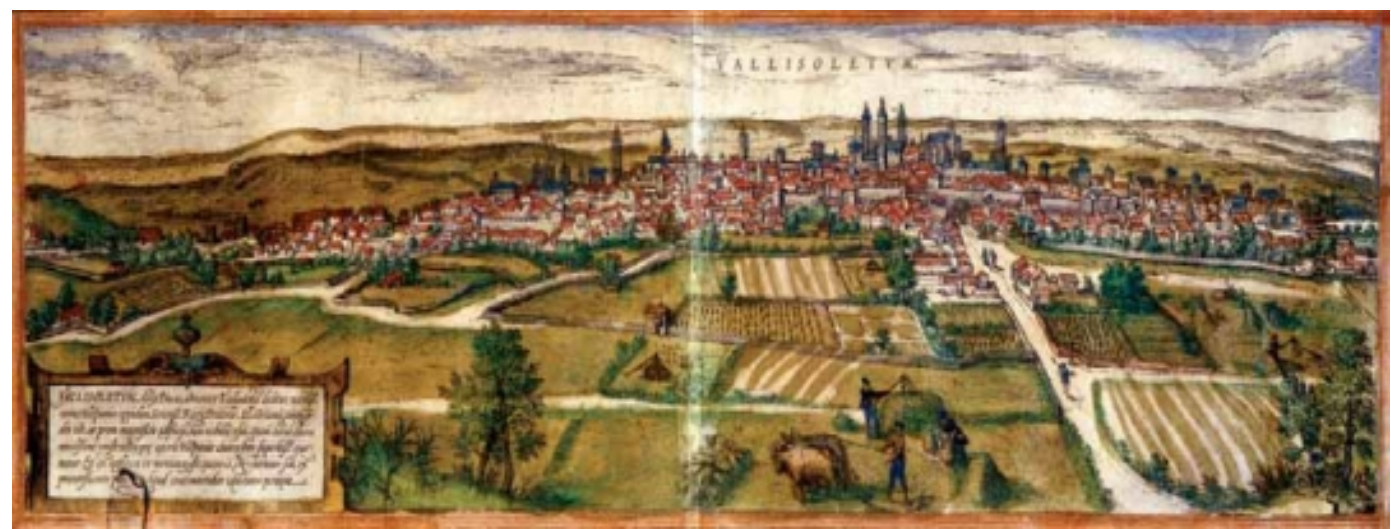

Fig. 1. Valladolid (1574) por Braun y Hogenberg

Un autor anónimo describe la abundante provisión de bienes a finales del siglo XV diciendo que Valladolid

es la mas gentil villa que hay en españa e la mas proveída e más barato de todas cosas ay en ella muchos cavalleros muchos mercaderes de todas formas de tratos muchos oficiales de todos los oficios mecánycos, lábranse en ellas muchas armas e buenas, a esta villa acuden e van todos los cavalleros e las otras gentes que se quyeren vestir o armar porque todo lo que an menester hallan en ella mejor e más barato que en nynguna otra parte. Tiene una plaça la mejor e más rrica que ay en españa y es tal que puesto un onbre en ella, no puede pidir cosa nynguna de las que son nesçesarias a la pollicia umana que no las halle en ella sin que salga del sitio de la plaça e por esto dizen los que hablan en los logares que

de la Universidad de Sevilla, 1981, $3^{\text {a }}$ edición (1 ${ }^{a}$ edición 1946) y una comparativa entre principio y finales de siglo XVI en CARANDE, Ramón. Carlos V y sus banqueros. Barcelona, Crítica, 2000.

${ }^{29}$ En fecha tan temprana como 1448 encontramos en Valladolid al violero Juan de Toledo «que fase las vihuelas», RuCQUOI, A. II: Valladolid en la Edad Media. El mundo..., p. 403.

${ }^{30}$ Rojo VegA, Anastasio. «Libros y bibliotecas en Valladolid», Bulletin Hispanique, 99/1 (1997), pp. 193210. 
Valladolid es el mundo abreviado a causa de las cosas que ay en esta plaça, es logar muy abastecido de pan e vino e carne e frutas tiene muy grande comarca e buena ay en ella estudio general de todas sciencias tiene dos colegios muy singulares e de maravillosos edificios e rentas: es el uno de frayles dominicos teólogos de donde salen grandes sermoneadores y el otro es de seglares. ${ }^{31}$

\section{Los otros Mudarra}

En Valladolid, el apellido Mudarra era muy frecuente en los siglos XV y XVI. La familia Mudarra era una de las diez que se repartían los oficios municipales desde el siglo XIII. Estas diez familias se organizaban en dos linajes de caballeros, el de Reoyo y el de Tovar, perteneciendo la casa de Mudarra, o de los Mudarros, a este último. ${ }^{32}$ A principio de año los dos linajes se repartían los cargos, aunque en ocasiones llegaron a producirse incidentes sangrientos entre ambas facciones que hicieron necesaria la intervención del monarca. $^{33}$

El gobierno de Valladolid desde que el conde Don Pedro Ansurez era señor de ella, fué de las diez casas que se decian de los Linajes, que aun permanecen hoy, y el llamarse asi es porque en ella se

${ }^{31}$ Real Biblioteca del Escorial, M. I. 16, f. 47, de donde tomamos el texto. Citado por RUCQUOI, A. II: Valladolid en la Edad Media. El mundo..., pp. 485-86.

${ }^{32}$ La primera vez que aparecen mencionados los linajes es en 1321, pero parece ser que tiempo atrás ya estaban constituidos. El linaje de Tovar estaba integrado por las casas o familias de Tovar, Gonzalo Díaz, Alonso Díaz, Castellanos y Mudarra y se reunían en la capilla de San Llorente en la Colegiata. El linaje de Reoyo estaba formado por las casas de Reoyo, Corral, Cuadra, Izquierdo y Esteban García y se reunían en el monasterio dominico de San Pablo. Entre los años 1320 y 1332 se vieron obligados a repartir los cargos públicos con otros «hombres buenos» de la villa agrupados en el bando llamado La Voz del Pueblo. Estos linajes con el paso del tiempo se transformaran en auténticos bandos o «partidos». Los caballeros que los dirigían obtendrán la condición de hidalgos desde 1293, lo que les eximía del pago de pechos y otros tributos. Ver RucQuoi, A. I: Valladolid en la Edad Media. Génesis..., pp. 132 y ss. y BENNASSAR, B. Valladolid en el Siglo de Oro... pp. 375 y ss. Más datos sobre los linajes de caballeros en otras ciudades en: DiAGO HERNÁNDEZ, Máximo. «Las corporaciones de caballeros hidalgos en las ciudades castellanas a fines de la Edad Media. Su participación en el ejercicio del poder local», Anuario de Estudios Medievales, 36/2 (2006), pp. 803-838. Una revisión historiográfica sobre el tema en: SORIA MESA, Enrique. «Los estudios sobre las oligarquías municipales en la Castilla moderna. Un balance en claroscuro», Manuscrits, 18 (2000), pp. 185-197 y una aportación bibliográfica en: SÁNCHEZ SAUS, Rafael. «Los patriciados urbanos», El mundo social de Isabel la Católica. Miguel Ángel Ladero Quesada (coord.). Madrid, Dykinson, 2004, pp. 143-155.

${ }^{33}$ Así por ejemplo, Juan II tuvo que intervenir en 1427 porque en Valladolid había «acaescido grandes ruidos entre los vandos, en que habian seydo muertos é feridos algunos hombres, é casas quemadas; y el Rey propuso de ir por su persona á los castigar; y embió á su Relator que era hombre muy diligente é hacia las cosas sin codicia ni parcialidad alguna; y embió con él sus Alcaldes; é mandóles que luego como en la villa entrasen, mandasen cerrar todas las puertas porque no pudiesen salir los malhechores», Crónica de los Reyes de Castilla. Biblioteca de Autores Españoles, Tomo II. Madrid, M. Rivadeneyra, 1877, p. 378.

Algunos datos sobre este tema: ASENJO GONZÁLEZ, María. «Acerca de los linajes urbanos y su conflictividad en las ciudades castellanas a fines de la Edad Media», Clio \& Crimen, 6 (2009), pp. 52-84. 
juntaban toda suerte de vecinos, que de los primeros que se juntaron y congregaron, hoy se reconocen descendientes. El primer dia de año nuevo se juntaban en dos iglesias, que es la Mayor y en el convento de San Pablo. Hay en cada Linaje cinco casas, y de cada Linaje salian los oficios para el gobierno del lugar, como son alcaldes, fieles procuradores de la villa, y procuradores del reino, aposentadores, regidores, escribanos del número, alguaciles; y de los vecinos que no eran de ella, se elegian y nombraban porteros y pregoneros. En cada Linaje se juntaban las cinco casas, y entonces hechas una, echaban suertes de todos los oficios para saber á qué casa le tocaba la eleccion de cada uno: en sacando las suertes se iba cada uno aparte á una de las capillas señaladas para este efecto, donde repartia entre los que eran de ella los oficios que le habian cabido, guardando el órden de preferir en el oficio que se repartia al de mas edad y al que tenia ganada mas antigüedad en las casas, mas esto con atencion de que no hubiese tenido otra vez el oficio dicho, antes de pasar primero el turno por todos los que se hubiesen opuesto á él. Gobiérnase por unas Ordenanzas, que cada una de las casas para si tiene establecidas. Los dos Linajes de ellos se dicen uno de Hernan Sanchez de Tovar, y otro de Reoyo [...] El estilo que estas casas guardaban para asegurar su conservacion es el recibir gente nueva, que es entradiza, y asi la llaman. El precio de la entrada es un yantar, que se reduce a 50 ducados: esto recibe variedad, y queda en aquello que se concierta, lo cual se distribuye entre los que se hallan presentes. ${ }^{34}$

Como vemos, los patricios vallisoletanos se garantizaban el gobierno de la villa con unas exigencias elevadas. Para ser admitidos en el linaje debían ser caballeros, no ser clérigos y ofrecer un banquete (un yantar) por valor de la elevada cantidad de 50 ducados. Además, algunos oficios tenían otras exigencias, como la de ser letrado para ser procurador o alcalde. ${ }^{35}$

Las primeras referencias que conocemos a los Mudarra vallisoletanos se remontan al siglo XIII. El nombre de Don Mudarra, fijo de don Sarracin, aparece en un documento fechado el 3 de junio de $1263 .^{36}$ Este probable fundador de la casa Mudarra era miembro de la oligarquía urbana y poseía viñas en el Carrascal. ${ }^{37}$ Un posible pariente, según

\footnotetext{
34 AnTOLÍnEZ De Burgos, Juan. Historia de Valladolid. Editada y anotada por Juan Ortega Rubio, Valladolid, 1887, pp. 56-58.

${ }^{35}$ Ordenanzas de las cinco casas del linaje de Tovar, en RuCQuOI, A. I: Valladolid en la Edad Media. Génesis..., pp. 354-362.

${ }^{36}$ Mañueco Villalobos, Manuel y Zurita Nieto, José. Documentos de la Iglesia Colegial de Santa María la Mayor (boy Metropolitana) de Valladolid. Siglo XIII. Valladolid, Imprenta Castellana, 1920, Vol. I, p. 338. Citado por RucQuoI, A. I: Valladolid en la Edad Media. Génesis..., p. 241.

${ }^{37}$ Mañueco Villalobos, M. y Zurita Nieto, J. Documentos... Vol. II, p. 12.
} 
Rucquoi, domnus Romanus Sarraceni, miembro del cabildo de la iglesia de Santa María la Mayor, es citado en una carta de $1219 .{ }^{38}$

Un personaje de gran relevancia del patriciado urbano vallisoletano fue Sancho Mudarra, escribano del rey Alfonso XI entre los años 1340 y 1348 como mínimo $^{39}$ y lugarteniente del Notario Mayor de Castilla (teniente de Notario), Fernán Sánchez de Valladolid o de Tovar. Sancho Mudarra, miembro también del linaje de Tovar, recibió la autorización en 1348 para transformar una capilla de la iglesia de San Salvador en sepultura suya y de sus descendientes. ${ }^{40}$

Ya en el siglo XV el número de Mudarras que encontramos en los documentos es abundante. ${ }^{41}$ Dos, o más, Juan Sánchez Mudarra se superponen en el tiempo. Uno de ellos, de profesión mercader y fallecido hacia 1450, es el fundador de la línea principal de los Mudarra, otro, su padre según Salazar y Castro, y un tercero que encontramos como escribano en la Chancillería de Valladolid en $1497 .{ }^{42}$ Frey Pedro Mudarra o frey Pedro Sánchez Mudarra († 1498), hijo de un Juan Sánchez Mudarra y hermano de otro, caballero de la Orden de San Juan de Jerusalén en Valladolid, ${ }^{43}$ lo que necesariamente implicaba

${ }^{38}$ Mañueco Villalobos, M. y Zurita Nieto, J. Documentos... Vol. I, p. 67 y RucQuoi, A. I: Valladolid p. 241. El nombre don Sarracin podría indicar un origen musulmán, pues sarracenos era la forma común en los documentos medievales para denominar a los musulmanes o moros. RUCQUOI, A. I: Valladolid en la Edad Media. Génesis..., p. 124.

${ }^{39}$ GonZalez CRESPO, Esther. «Organización de la cancillería castellana en la primera mitad del siglo XIV», En la España Medieval, 8 (1986), pp. 447-470.

${ }^{40}$ RuCQuOI, A. I: Valladolid en la Edad Media. Génesis..., p. 242.

${ }^{41}$ Podemos reconstruir la genealogía de la línea principal de la familia Mudarra, aunque con muchas lagunas en el siglo XV, gracias a los documentos del llamado «Príncipe de los genealogistas españoles», Luis de Salazar y Castro, conservados en la Real Academia de la Historia (en adelante RAH), Salazar y Castro: Tabla genealógica de la familia Mudarra, vecina de San Martín de Valdeiglesias (Madrid), D-28, f. 162; Papel que trata de la casa de Mudarra, D-58, ff. 128 y 129 y Tabla genealógica de la familia Mudarra, D-58, f. 129v. También contamos con varios pleitos con datos sobre la familia en el Archivo de la Real Chancillería de Valladolid y otros documentos relacionados en el Archivo General de Simancas.

${ }^{42}$ Pino Rebolledo, Fernando. El primer libro de actas del ayuntamiento de Valladolid. Valladolid, Archivo Municipal de Valladolid, 1990, p. 99.

${ }^{43}$ Salazar y Castro los considera dos personas diferentes, sin embargo en algunos documentos aparece indistintamente el nombre de una manera u otra. Como Pedro Sánchez Mudarra en URREA FERnándEZ, Jesús. «Caballeros de la Orden de San Juan de Malta de Valladolid», Boletín del Seminario de Estudios de Arte. 75/2 (2009), pp. 157-168 y como Pedro Mudarra en Álvarez Álvarez, César y Cavero Domínguez, Gregoria. «La encomienda hospitalaria de Puente de Órbigo en la Edad Media (1184-1494)», Lógos hellenikós: homenaje al profesor Gaspar Morocho Gayo, J. María Nieto Ibáñez (coord.), Vol. 2, 2003, pp. 749-762. 
limpieza de sangre y de oficios, ${ }^{44}$ ostentó importantes cargos en la orden sanjuanista: Chanciller, Bailío de Olmos, Comendador de la Puente de Órbigo y Comendador de Wamba. ${ }^{45}$ Dejó la sustanciosa cantidad de 150 ducados al tesoro de Rodas cuando falleció. Una de las condiciones para el ingreso de los caballeros en esta orden era no estar casado, pero Pedro tuvo un hijo natural, de nombre Alonso Mudarra, con mujer soltera, el cual obtuvo su legitimación en Medina del Campo el 5 de febrero de $1504 .^{46}$

Sobrino del anterior fue Diego Mudarra ${ }^{47}$ (†1492), Señor de Santovenia de Pisuerga (Valladolid), ${ }^{48}$ escribano de Valladolid desde 1466, ${ }^{49}$ Alcalde de la Chancillería de Valladolid, ${ }^{50}$ corregidor de Ciudad Rodrigo en los años 1486 y $1487^{51}$ y posteriormente

${ }^{44}$ Una visión diacrónica sobre los estatutos de limpieza de sangre se puede ver en HERNÁNDEZ FRANCO, Juan. Cultura y limpieza de sangre en la España moderna: puritate sanguinis. Murcia, Universidad de Murcia, 1996.

${ }^{45}$ La posesión de encomiendas estaba con frecuencia reservada para la alta nobleza pues, al disfrutar de territorios en usufructo, reportaba grandes beneficios económicos. GARCíA HERNÁN, David. La nobleza en la España moderna. Madrid, Ediciones Istmo, 1992, p. 37.

${ }^{46}$ Legitimación de Alonso Mudarra. Archivo General de Simancas (en adelante AGS), Cámara de Castilla, Libros Registro de Cédulas, Sign. CCA,CED,9,16,7. Sabemos de la existencia de otro hijo del mismo nombre que el padre, Pedro Mudarra, que aparece en las actas municipales en 1497: PiNO REBOLLEDO, F.. Elprimer libro de actas..., p. 91.

${ }^{47}$ Los documentos denominan a este Diego Mudarra el Mozo, hijo del mercader Juan Sanches, diferenciándolo de Diego Mudarra el Viejo, escribano público de Valladolid desde 1430 o antes e hijo del también escribano Sancho Mudarra. Ver Archivo Histórico Nacional (en adelante AHN), Clero SecularRegular, Carpeta 3.498, no 15 y AHN, Clero Secular-Regular, Carpeta 3.461, n 3. Rucquoi supone que el primer Diego es hijo del segundo, lo cual no es posible a la vista de los documentos. RUCQUOI, A. II: Valladolid en la Edad Media. El mundo..., p. 140. Este Diego Mudarra el Mozo, estaría casado con Catalina Ferrer o Santisteban, hija o hermana del ropero Juan Ferrer. RuCQUOI, A. II: Valladolid en la Edad Media. El mundo..., p. 177. También el pleito sobre la ejecutoria de hidalguía de 1572 entre los nietos y bisnieto de Diego deja muy claro que este, el denominado «el Mozo», era hijo de Juan Sánchez Mudarra. Ejecutoria del pleito litigado por Jerónimo de Mudarra y Pedro Mudarra y Antonio Mudarra, sus hijos, vecinos de San Martín de Valdeiglesias (Madrid), con el fiscal del rey y el concejo y pecheros de dicha villa, sobre ejecución de carta ejecutoria de un pleito anterior sobre su bidalguía. Archivo de la Real Chancillería de Valladolid (en adelante ARCHV), Registro de Ejecutorias, Caja 1229, 17.

${ }^{48}$ En 1459 había arrendado del abad de Valladolid, el cardenal Juan de Torquemada, un prado y una «heredad de pan llevar» en Santovenia por 500 maravedís al año y seis cargas y media de pan mitad trigo y mitad cebada. Su mujer, Catalina de Santistevan, figura con el nombre de Catalina Ferrer. AHN, Clero Secular-Regular, Carpeta 3.498, n 15, citado por RUCQUOI, A. II: Valladolid en la Edad Media. El mundo..., p. 222.

${ }^{49}$ Un año antes, en 1465, recibió 5.000 maravedís de juro de heredad (renta situada en los ingresos reales) por sus servicios prestados a la Corona. RuCQUOI, A. II: Valladolid en la Edad Media. El mundo..., p. 159.

${ }^{50}$ En 1475 se le confirmó el nombramiento de Alcalde de la Chancillería a pesar de no haberse graduado en derecho (Alcalde «de capa y espada», según Salazar y Castro, RAH, D-58, ff. 128 y 129). Diego Mudarra alegó que antes de obtener el grado de bachiller en los Estudios de Valladolid falleció su padre y que luego no tuvo tiempo ni oportunidad de obtenerlos. Se le concedió un plazo de dos años para regularizar la situación, pero al año siguiente se le concedió la merced de mantener el oficio. Confirmación del nombramiento de alcalde de la Corte y Chancillería hecho en favor de Diego Mudarra, a pesar de la ley que establece que nadie pueda ejercer el 
corregidor de Molina de Aragón entre 1488 y 1489, donde tuvo serios problemas desde la posesión del cargo, pues intentó, sin éxito, que le sustituyera su hijo Jerónimo. ${ }^{52}$ Sus hermanos también disfrutaban de una buena condición social: Luis Mudarra era caballero de la orden de Calatrava, ${ }^{53}$ alcaide de Cosenza y regidor de Rose (Nápoles), fundó mayorazgo a su sobrino Pedro de Castro Mudarra; Beatriz, abadesa de Santa Isabel de Valladolid y Serrana y Catalina, casadas ambas con ilustres personajes del patriciado vallisoletano.

oficio de alcaldía sin estar graduado. AGS, Registro del Sello de Corte, Sign. RGS,LEG,147501,100 y Merced a Diego Mudarra, alcalde de la Chancillería Real, de seguir usando dicho oficio. AGS, Registro del Sello de Corte, Sign. RGS,LEG,147606,418.

${ }^{51}$ Este año de 1487 había mejorado su sueldo de corregidor a 20.000 maravedís. RUCQUOI, A. II: Valladolid en la Edad Media. El mundo..., p. 231.

${ }^{52}$ Fue acusado de parcialidad hacia algunos de los oficiales CORTÉs RUIZ, M ${ }^{\text {a }}$ Elena. Articulación jurisdiccional y estructura socioeconómica en la comarca de Molina de Aragón a lo largo de la baja edad media. Tesis Doctoral, Universidad Complutense de Madrid, 2000, pp. 1178 y 1185.

${ }^{53}$ En 1493 percibía un salario de 30.000 mrs. por el hábito de Calatrava. Hábito y salario de contino de Frey Luis de Mudarra. AGS, Cámara de Castilla, Libros Registro de Cédulas, Sign. CCA,CED,3-2,8,2. 


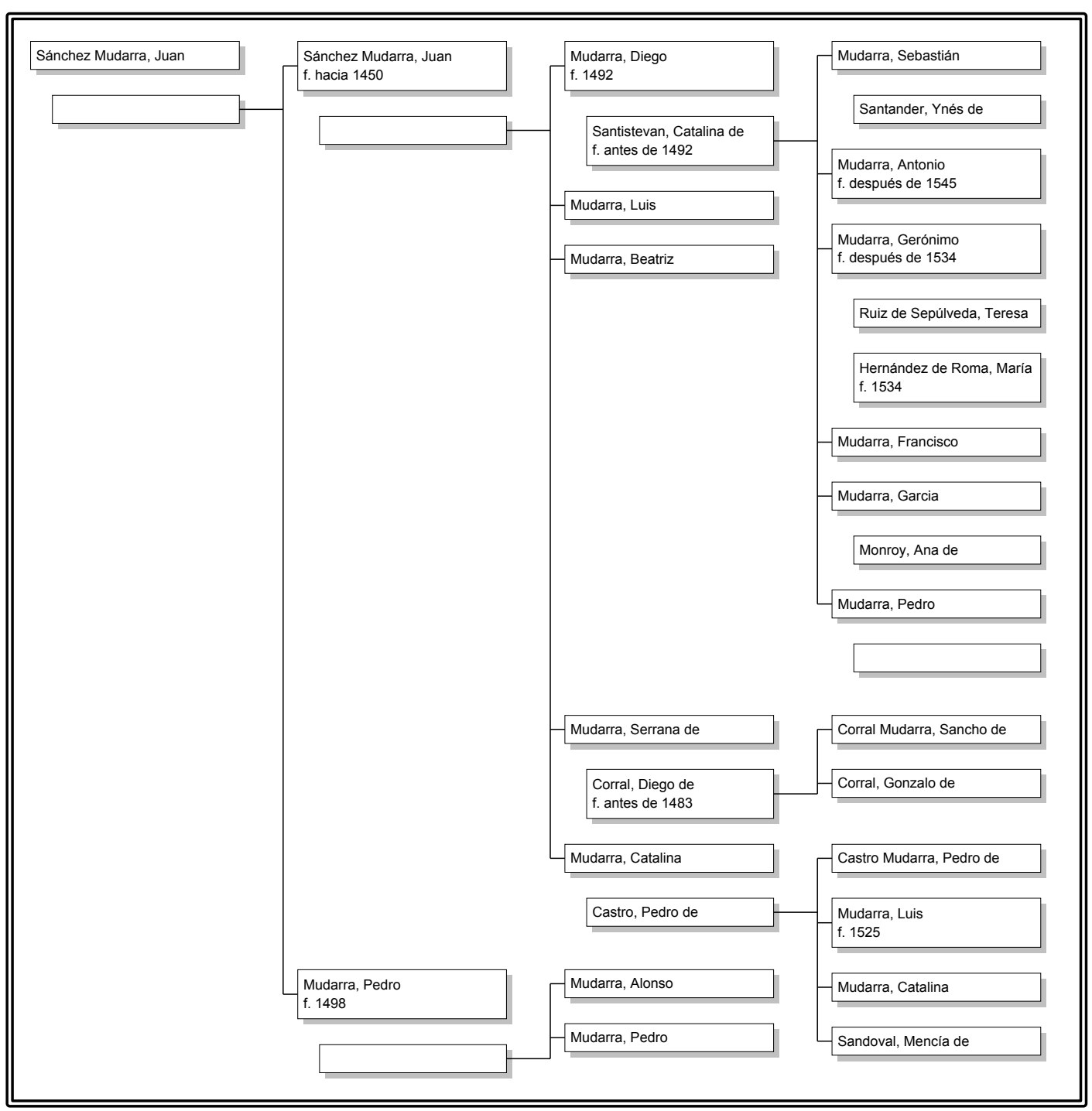

Fig. 2. Descendientes de Juan Sánchez Mudarra (basado en Salazar y Castro)

Se observa una tendencia en la familia Mudarra, que va a ser común a otros miembros de la oligarquía municipal vallisoletana en estos siglos, a intentar imitar el modo de vida noble mediante la constitución de señoríos, creación de mayorazgos, construcción de capillas funerarias, acumulación de rentas como los juros y una política de acumulación de cargos de la administración real.

Por estos años la familia Mudarra padeció la infamante ejecución por parte de la Inquisición de uno de sus miembros, un converso de nombre Francisco Mudarra, quemado en Valladolid en el primer auto de fe celebrado en 1489. Según nos cuenta el Cronicón de Valladolid: 
1489 Junio 19. Fizo la primera justicia la Santa Inquisicion en Valladolid viérnes xviiij de junio del año de lxxxviiij: quemaron xviij personas vivas, é quatro muertas: ninguno de los vivos paresció confesar la sentencia en público: Alonso de Castro, Sancho de Frias, Grabiel de Leon, Diego Cejuela, el Recadador, Gonzalo Gomez de Sevilla, Francisco Pela Ganallo, Simon Herrero, Diego Rivas, Diego de Curiel, platero, Francisco Mudarra $[\ldots]^{54}$

La presencia de conversos en las oligarquías urbanas está comprobada en muchas villas y ciudades en los siglos XV y XVI. ${ }^{55}$ Los cargos municipales ofrecían la posibilidad de ascenso social mediante el contacto con la pequeña aristocracia urbana formada fundamentalmente por caballeros e hidalgos. Así, es frecuente que familias conversas adineradas «limpiaran su sangre» mediante alianzas matrimoniales con miembros de esta pequeña nobleza. Siendo, además, Valladolid una villa de reciente creación, en sus orígenes, allá por el siglo XI, se instalaron gran cantidad de judíos y moros. ${ }^{56}$ Estas minorías religiosas se integraron perfectamente en la población vallisoletana hasta que los sucesos trágicos de las revueltas antijudías de 1391, la instauración de la Inquisición en Valladolid en 1488 y el decreto de expulsión de 1492, forzaron a muchos a convertirse y ocultar sus orígenes. El linaje de Tovar no era ninguna excepción y en su seno había muchos descendientes de conversos. ${ }^{57}$

Hijo primogénito de Diego fue Sebastián Mudarra quien, después de ser capitán del ejército real en las guerras de Italia de 1494, ostentó cargos de corregidor de León entre 1515 y 1520 y de Palencia en 1520 y 1521. Padeció el conflicto de las Comunidades, tanto es así que tras la quema de su casa por los rebeldes, en septiembre de 1520, se vio obligado a huir de la ciudad palentina. Su hermano, Antonio Mudarra fue deán de la catedral de Palencia y consultor del Santo Oficio. Creó un mayorazgo para su sobrina

${ }^{54}$ Doctor De TOledo. Cronicón de Valladolid. 1539, pp. 179-180. Publicado en Colección de documentos inéditos para la historia de España. Madrid, Imprenta de la Viuda de Calero, 1842-1896, Tomo XIII, 1848. Citado por FERNÁNDEZ MARTín, Luis. «Francisco Mudarra, difamador y protegido de San Ignacio 15381555», Archivum bistoricum Societatis Iesu, 62 (1993), pp. 161-173

${ }^{55}$ Para una aproximación al tema: DOMínguEZ ORTIZ, Antonio. La clase social de los conversos en Castilla en la Edad Moderna. Madrid, Instituto Balmes de Sociología, [1955?]. MÁrQuez VillanueVA, Francisco. «Conversos y cargos concejiles en el siglo XV», Revista de Archivos, Bibliotecas y Museos, 63/2 (1957), pp. 503540. Una revisión bibliógrafica más actual RÁBADE OBRADÓ, María del Pilar. «Cristianos nuevos», El mundo social de Isabel la Católica. Madrid, Miguel Ángel Ladero Quesada (coord.) Dykinson, 2004, pp. 275-292.

${ }^{56}$ RuCQuOI, A. I: Valladolid en la Edad Media. Génesis... pp. 64 y 65.

${ }^{57}$ Pertenecientes a una rama colateral del linaje de Tovar, los Torquemada eran descendientes de conversos. RuCQUOI, A. II: Valladolid en la Edad Media. El mundo..., p. 195. 
Catalina y mandó construir una capilla funeraria para la familia Mudarra en la Iglesia de San Juan de Santovenia. También fue responsable de la construcción del Palacio o Casa de los Mudarra de Valladolid (hoy Convento de las Salesas), casa que heredó Diego Mudarra Palacios en 1550.

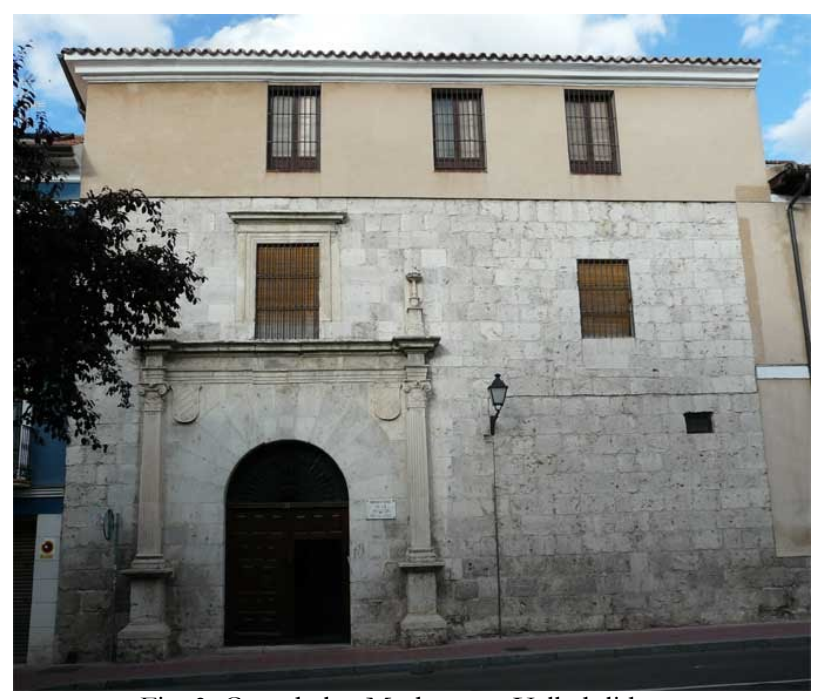

Fig. 3. Casa de los Mudarra en Valladolid

El tercer hermano varón, Gerónimo Mudarra, fundó la rama instalada en San Martín de Valdeiglesias, donde fue alcalde, regidor y donde pleiteó en 1501 y en 1512 por su hidalguía. ${ }^{58}$ Este Gerónimo casó dos veces, primero con Teresa Ruiz de Sepúlveda, hija de Diego Ruiz de Sepúlveda, uno de los hombres más ricos de la villa de San Martín y con quien tuvo a Diego Mudarra Ruiz (†1562), quien heredó el mayorazgo. Fallecida su primera esposa, Teresa, casó con la viuda María Hernández de Roma ${ }^{59}$ teniendo por hijos a Antonio Mudarra (†1573), canónigo de Zamora y deán de la catedral de Palencia, como su tío homónimo; Gerónimo Mudarra quien en 1573 se vio obligado a pleitear para

\footnotetext{
${ }^{58}$ Ver García Garcimartín, Hugo. Articulación jurisdiccional y dinámica socioeconómica de un espacio natural: la cuenca del Alberche (siglos XII - XV). Tesis Doctoral, Universidad Complutense de Madrid, 2002. Los pleitos citados son el de 1501, incluido un traslado en el anteriormente citado ARCHV, Registro de Ejecutorias, Caja 1229, 17 y el de 1512 Ejecutoria del pleito litigado por el concejo, justicia y regimiento de San Martín de Valdeiglesias (Madrid), con Jerónimo de Mudarra, vecino de San Martín de Valdeiglesias, sobre bidalguía. ARCHV, Registro de ejecutorias, Caja 274, 15.

${ }^{59}$ Más datos sobre esta familia en el testamento conjunto de Gerónimo y María Hernández firmado el 2 de noviembre de 1528. Hay copia en RAH, Salazar y Castro: Testamento otorgado por Jerónimo Mudarra y doña María Hernández de Roma, su segunda mujer, vecinos de San Martín de Valdeiglesias. M-159, ff. 58-62.
} 
defender su hidalguía y limpieza de sangre, ${ }^{60}$ (unos años antes, en 1568, sus sobrinos Antonio Mudarra y Bartolomé Frías, hijos de Diego, tuvieron que pleitear con un vecino ante acusaciones similares ${ }^{61}$ ) y Pedro Mudarra, heredero del cargo de deán de Palencia de su hermano Antonio. ${ }^{62}$

Otros hijos y nietos de Juan Sánchez Mudarra tuvieron altos cargos. Luis Mudarra fue caballero de la orden de Calatrava, Frey Sancho de Corral Mudarra fue caballero sanjuanista y bailío de Negroponte. Otro Luis Mudarra, hijo de Catalina y nieto de Juan Sánchez, fue un destacado militar que falleció en la batalla de Pavía en 1525.

${ }^{60}$ Ejecutoria del pleito litigado por Jerónimo Mudarra, hijodalgo, vecino de San Martín de Valdeiglesias (Madrid), con Pedro de Vallejera, alguacil y vecino de San Martín de Valdeiglesias (Madrid), sobre colocación de un líbelo en el Ayuntamiento, con acusaciones al primero de ser judio, no ser hijodalgo y otras cosas. ARCHV, Registro de Ejecutorias, Caja 1256, 9.

${ }^{61}$ Ejecutoria del pleito litigado por Bartolomé Mudarra y Frías Mudarra, hermanos, vecinos de San Martin de $V$ aldeiglesias (Madrid), con Antón de la Sierra, vecino de la misma localidad, preso en Madrid, sobre injurias en torno a la bidalguia de los demandantes y la limpieza de su sangre. ARCHV, Registro de Ejecutorias, Caja 1144, 31. En el título hay un error en los nombres como consecuencia de un error en las primeras líneas de la ejecutoria.

${ }^{62}$ Son numerosos los pleitos que sostuvieron los Mudarra de San Martín por su hidalguía y por la posesión de oficios. Los hijos de Gerónimo y su nieto Bartolomé pleitearon en 1565 con el concejo de San Martín para que les concedieran la mitad de los oficios «honrosos» concejiles (Ejecutoria del pleito litigado por Diego, Bartolomé y Antonio Mudarra, bijosdalgo, y consortes, vecinos de San Martín de Valdeiglesias (Madrid), con el concejo de San Martín de Valdeiglesias (Madrid), sobre solicitud de la mitad de los oficios de alcaldes, regidores, fieles, y procuradores del dicho concejo, y su nombramiento para el estado de los hijosdalgo. ARCHV, Registro de Ejecutorias, Caja 1083, 57). De nuevo en 1572 volvieron a pleitear por su hidalguía (Ejecutoria del pleito litigado por Jerónimo de Mudarra y Pedro Mudarra y Antonio Mudarra, sus hijos, vecinos de San Martín de Valdeiglesias (Madrid), con el fiscal del rey y el concejo y pecheros de dicha villa, sobre ejecución de carta ejecutoria de un pleito anterior sobre su hidalguia. ARCHV, Registro de Ejecutorias, Caja 1129, 17). 


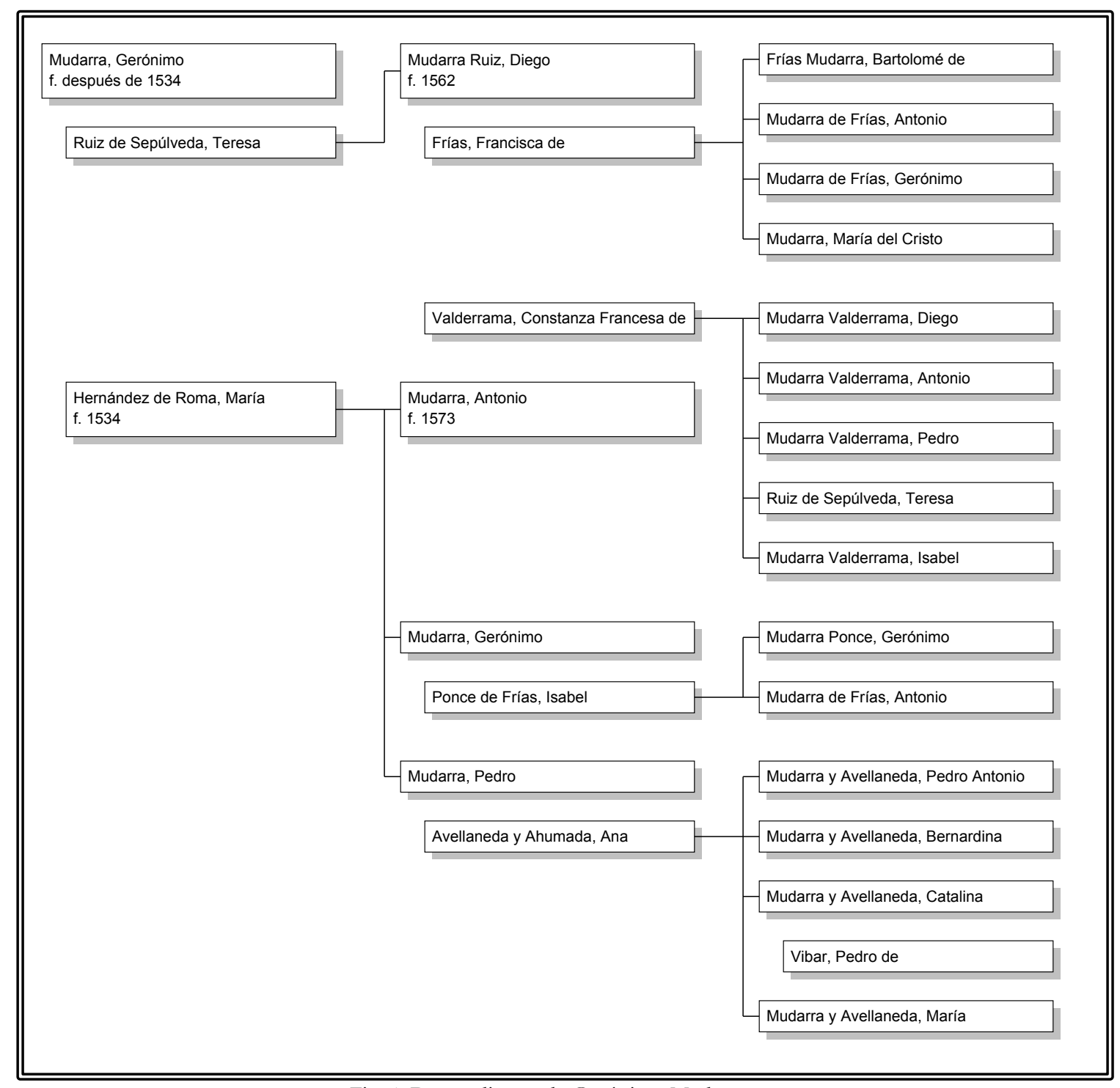

Fig. 4. Descendientes de Gerónimo Mudarra

Sebastián Mudarra, en la línea principal de la familia, tuvo varias hijas y ningún varón. La mayor, Catalina, heredó el mayorazgo de su tío el Deán, casándose con un hijo del doctor Palacios, miembro del Consejo Real, y la siguiente, Ana, se casó con el hijo de un importante militar y cronista de los Reyes Católicos. De esta línea salen Diego Mudarra Palacios $(† 1571)^{63}$ y su hijo Diego Mudarra y Castejón $(† 1609),{ }^{64}$ ambos

${ }^{63}$ Este Diego pleiteó con el linaje Tovar en 1568 para que él y sus hijos fueran aceptados en la dicha casa (Ejecutoria del pleito litigado por Diego Mudarra, vecino y regidor de Valladolid, con la casa de castellanos del linaje de Tobar, sobre aceptación del dicho Diego Mudarra y Diego, Antonio y Felipe, sus hijos, de formar parte de la citada casa de castellanos del linaje de Tobar. ARCHV, Registro de ejecutorias, Caja 1148, 39).

${ }^{64}$ Griffiths identifica a ambos Mudarra, padre e hijo, como una sola persona y le asigna el «oficio» $u$ ocupación de vihuelista, cosa que dudamos pues la presencia de vihuelas en los inventarios es algo frecuente. GRIFFITHS, John. «Mudarra, Diego», DMEH, vol. 7, p. 858. Sin embargo en un trabajo posterior 
regidores de Valladolid, hidalgos reconocidos y cofrades del Hospital de Santa María de Esgueva, ${ }^{65}$ una de las instituciones más prestigiosas en Valladolid, con estatuto de limpieza de sangre para sus veinticuatro cofrades renovados por defunción. Esta cofradía fue fundada en el siglo XI por el conde Pedro Ansúrez, promotor de la villa y primer señor de la misma. Como ya ha sido señalado por otros autores, las cofradías tenían gran importancia para las agrupaciones nobiliarias o bandos pues funcionaban como núcleos de identidad y solidaridad. ${ }^{66}$

Diego Mudarra Palacios poseía una importante biblioteca con más de 500 libros, aunque desconocemos su contenido. ${ }^{67}$ Entre su posesiones aparecen también «dos biuelas con sus caxas» y «una caxa de flautas». Su hijo tenía un «libro de canto de biguela de don luis milan». ${ }^{68}$

Es frecuente la aparición de vihuelas en estos años en los inventarios de los patricios vallisoletanos. Así por ejemplo, el Doctor Tovar en 1587 tenía «una viguela grande de evano» y «una viguela grande quebrada». Ese mismo año fallecía Diego de Tovar y en la tasación de sus bienes figura «una arpa y una biguela quarenta reales», además entre sus libros el «libro de musica de anrriquez quatro reales», es decir el libro de Valderrábano,

los identifica adecuadamente. GRIFFITHS, John. «La vihuela en la época de Felipe II», SuÁREZ-PAJARES, Javier y GRIFFITHS, John (eds.). Políticas y prácticas musicales en el mundo de Felipe II. Madrid, ICCMU, 2004, pp. 415-448; pp. 427-428.

${ }^{65}$ Sobre Diego Mudarra y la Cofradía de Esgueva: Alonso CoRTÉs, Narciso. Los cofrades de Santa María de Esgueva. Miscelánea Vallisoletana, $6^{a}$ serie. Valladolid, Librería Santarén, 194? con la genealogía declarada en 1563 por Diego Mudarra: «Mi padre se llamó pedro de palacios, fue confrade en esta sancta cofradía ... mi aguelo, padre de mi padre, fue el dotor diego de palacios, oydor que fue en esta Real Audiencia ... y mi aguela, madre de mi padre, fue doña beatriz de tobar, que fue hija de hernan sanchez de tobar y hermana de pedro de tobar, Regidor que fue desta villa. «Mi madre se llamó doña catalina mudarra, y mi aguelo, padre de mi madre, se llamó sebastian mudarra, y mi aguela, madre de mi madre, se llamó doña ynes de santander, que todos fueron vecinos desta villa de Valladolid.» De doña Inés de Valladolid dijeron los testigos, que «fue hija legitima del secretario santander, secretario que fue de los Reyes catolicos don fernando e doña ysabel, de los quales rescibio muchas mercedes como criado y oficial suyo hasta que murió» y que fué «sobrina del obispo de palencia don alonso de burgos, que por otro nombre llamaron fray mortero, hija de su hermano mayor, que fue secretario de los Reyes Catolicos.» También Tiedra, José de. El Hospital de Santa María de Esgueva, de Valladolid. Valladolid, Casa Martín, 1937, donde se reproducen las ordenanzas de la cofradía.

${ }^{66}$ GARCía Hernán, D. La nobleza en la España..., p. 27.

${ }^{67}$ Citado por Bennassar, B. Valladolid en el Siglo de Oro... pp. 470 y 484. Sobre la bibliotecas vallisoletanas es imprescindible consultar ROJO VEGA, A. «Libros y bibliotecas...

68 «1571. Testamento e inventario de don Diego Mudarra, regidor» [consulta 21-11-14] y «1610. Inventario de Diego Mudarra, regidor de Valladolid» [consulta 27-7-15] en

$<$ http://www.anastasiorojo.com/\#!/home> 
además de «ocho libros de canto seis reales». ${ }^{69}$ Unos años después, en 1591, en el inventario de Mateo de Tovar encontramos «una biuela y dos guitarras» y en 1596 en el de Pedro Laso de Castilla «dos vihuelas grandes una de seis ordenes y otra de siete». ${ }^{70}$

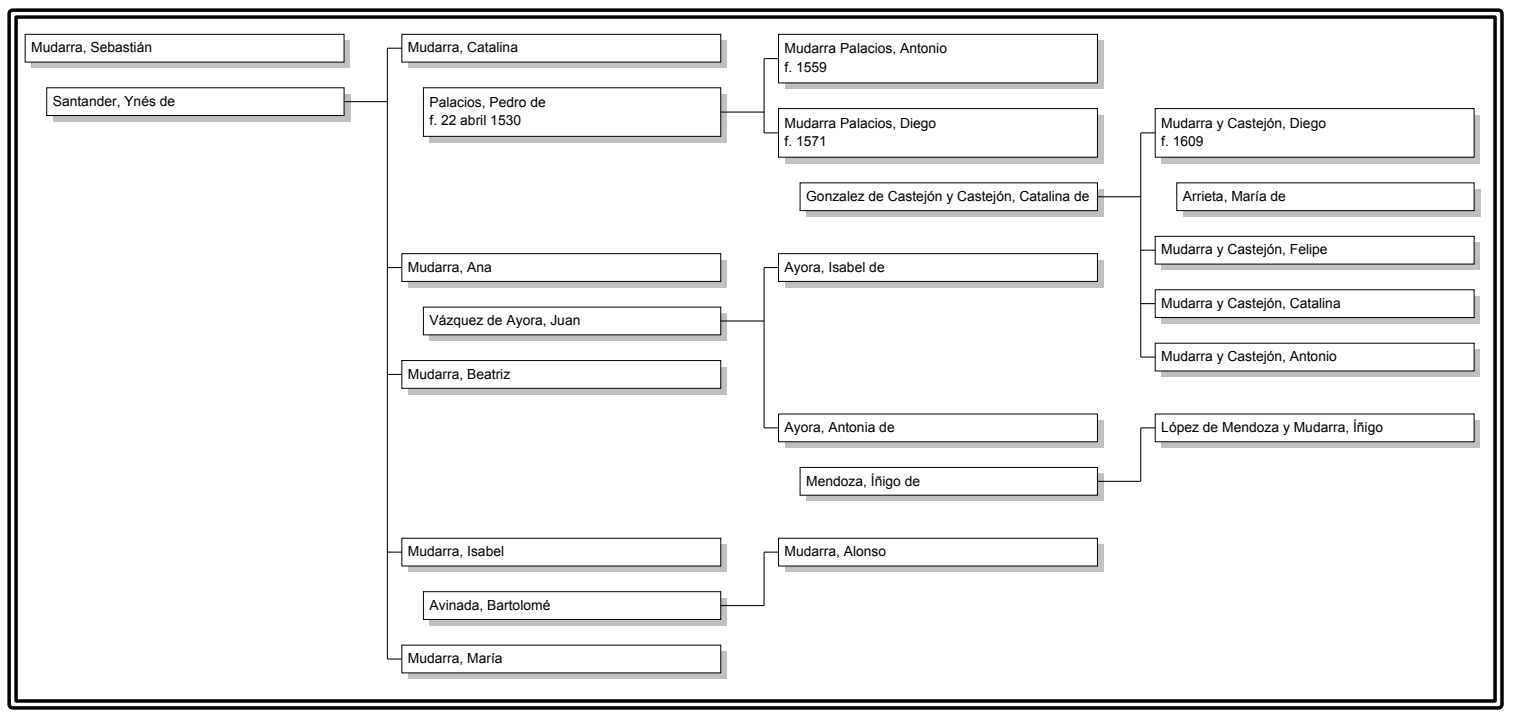

Fig. 5. Descendientes de Sebastián Mudarra

Así pues, numerosos miembros de la familia Mudarra tuvieron cargos en la administración real. Se estima que en estos años un dieciséis por ciento de los miembros de la oligarquía vallisoletana compaginó sus cargos municipales en Valladolid con estos oficios de la administración regia. ${ }^{71}$ En cuanto a los segundones, muchos de ellos ostentaron cargos importantes en el seno de la iglesia. Se observa en esta familia una preferencia por los nombres de Diego o Jerónimo para los primogénitos, que ocupaban cargos administrativos principalmente y Antonio o Luis para los segundogénitos, con cargos religiosos o militares.

${ }^{69}$ Citado por GRIFFITHS, J. «La vihuela en la época..., p. 428 y 1587. «Testamento e inventario de don Diego de Tovar» en <http://www.anastasiorojo.com/\#!/home> [consulta 21-11-14].

${ }^{70}$ «1591. Inventario de don Mateo de Tovar» y «1596. Inventario y biblioteca de don Pedro Laso de Castilla, mayordomo de sus altezas y señor de San Martín de Valbení» en

<http://www.anastasiorojo.com/\#!/home> [consulta 21-11-14].

${ }^{71}$ RuCQUOI, A. II: Valladolid en la Edad Media. El mundo..., p. 231. 


\section{La familia de Alonso Mudarra}

A pesar de la cantidad de personas apellidadas Mudarra en Valladolid, apenas tenemos datos sobre los primeros años del vihuelista Alonso Mudarra. Hemos podido ver que entre los nombres de pila más frecuentes en la línea principal de la familia Mudarra raras veces aparece el nombre de Alonso ni el de Francisco; tal vez este último trajera el recuerdo a la familia del converso relajado por la Inquisición. Tan solo hemos encontrado una rama que podría dar origen a la familia del vihuelista. Nos referimos a Alonso Mudarra, hijo natural de Pedro Mudarra, Comendador de la Orden de San Juan, quien solicitó su legitimación en 1504 para «honras y oficios». Volvemos a encontrar a Alonso Mudarra, vecino de Medina del Campo, en la lista de continos $^{72}$ de la Casa de Castilla que fueron suspendidos de sueldo en 1521 por haber participado en las Comunidades. ${ }^{73}$

No sería imposible que este Alonso fuera el progenitor de la familia del vihuelista. Un argumento que apoya esta hipótesis es que, siendo una rama ilegítima de la familia, no podía acceder al linaje, por lo que tampoco podría ejercer oficios concejiles, quedando la Iglesia como una de las salidas razonables para sus hijos. ${ }^{74}$

Algunos datos tenemos sobre esta familia, así pues, conocemos algunas cosas sobre el hermano mayor, Francisco de Mudarra, clérigo procesado en varias ocasiones en Roma. ${ }^{75}$

\footnotetext{
${ }^{72}$ Las vías normales para los hijos bastardos eran el ejercicio de las armas o la entrada en religión. Un poco más abajo damos una definicion de contino.

${ }^{73}$ El listado se encuentra en MARTíneZ MilláN, José y EZQUERRA REVILLA, Ignacio Javier. «La integración de las élites sociales en las monarquías dinásticas: los continos», Espacios de poder: cortes, ciudades y villas (s. XVI-XVIII), 1 (2002), pp. 339-380; p. 345.

${ }^{74}$ A partir de 1510 el linaje de Tovar prohibirá la admisión de los hijos ilegítimos, por lo que era imposible que accedieran a oficios municipales. RUCQUOI, A. II: Valladolid en la Edad Media. El mundo..., p. 179.

${ }^{75}$ Los datos biográficos fundamentales sobre los dos hermanos Mudarra aparecen en: FERNÁNDEZ MARTín, Luis. «Francisco Mudarra, difamador y protegido de San Ignacio 1538-1555», Archivum historicum Societatis Iesu, 62 (1993), pp. 161-173; GIL, Juan. «Un español ante la Inquisición romana: Francisco Mudarra», Scripturus vitam. Festgabe für W alter Berschin zum 65. Geburtstag, Heidelberg, Mattes Verlag, 2002, pp. 617-625 y Ollero PINA, José Antonio. «Clérigos, universitarios y herejes. La Universidad de Sevilla y la formación académica del cabildo eclesiástico», Universidades hispánicas. Modelos territoriales en la Edad Moderna (I). coord. por Luis Enrique Rodríguez San Pedro Bezares, Juan Luis Polo Rodríguez, Vol. 2, 2007 (Valencia, Valladolid, Oñate, Oviedo y Granada), pp. 107-196. Queremos agradecer la generosidad de los profesores Juan Gil y José Antonio Ollero Pina por habernos facilitado una copia de sus trabajos.
} 
También sabemos de la existencia de tres hermanas Ana, Catalina e Isabel gracias a uno de los testamentos conservados de Alonso, fechado en Sevilla el 23 febrero de $1576 .^{76}$

Desgraciadamente, no se conservan los archivos parroquiales de Valladolid de la primera mitad del siglo XVI, ${ }^{77}$ que nos podrían aportar algo más. Se ha postulado la relación directa entre la familia de nuestro vihuelista y el converso relajado por la Inquisición Francisco Mudarra a finales del siglo XV, sin que exista ninguna prueba veraz de ello ${ }^{78}$. Si nuestra hipótesis es cierta y Alonso Mudarra, el hijo natural del Comendador Pedro Mudarra, es el progenitor, es muy improbable que pertenezcan a una rama «contaminada» por conversos, pues las exigencias de limpieza de sangre eran muy elevadas en las Órdenes Militares.

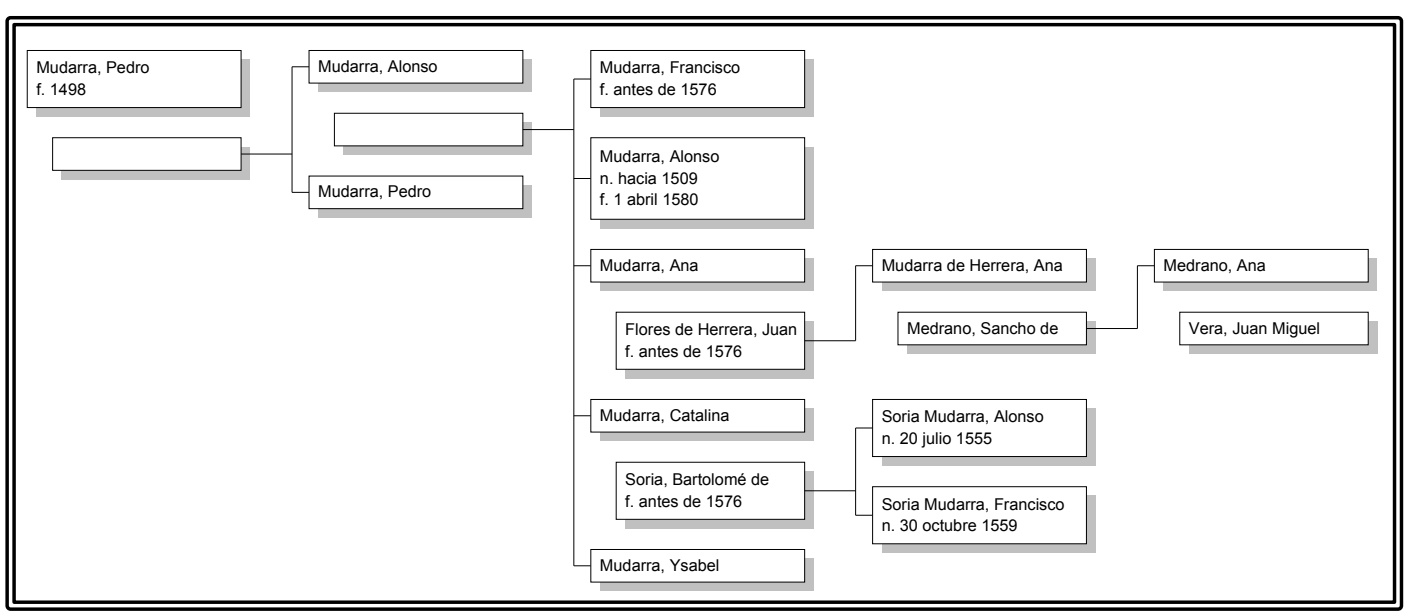

Fig. 6. Familia de Alonso Mudarra

El primero de los hermanos, Francisco Mudarra, fue clérigo de la diócesis de Palencia. ${ }^{79}$ Posiblemente estudiara en la Universidad de Alcalá, donde obtendría el grado

${ }^{76}$ Archivo Histórico Provincial de Sevilla (en adelante AHPSe), Oficio 19, Libro $2^{\mathrm{o}}$ de 1576, Signatura 12432, ff. 439-440v. Reproducimos nuestra transcripción en los anexos.

${ }^{77}$ FERNÁNDEZ MARTíN, L. «Francisco Mudarra..., p. 163.

${ }^{78}$ FERnÁndez MARTín, L. «Francisco Mudarra..., p. 164. Ollero Pina asume esta afirmación, OlLERO PINA, J. A. «Clérigos, universitarios..., p. 173. Ya hemos visto más arriba como la presencia de conversos en las élites urbanas era un hecho y pocas familias podían presumir de no albergar conversos en su seno.

${ }^{79}$ Sacamos la mayor parte de los datos de GIL, J. «Un español ante la Inquisición... 
de doctor en leyes. ${ }^{80}$ Gracias a su amistad con don Alonso Enríquez, abad de la Colegiata de Valladolid ${ }^{81}$ y tal vez compañero de estudios en Alcalá, donde ambos coincidirían con Ignacio de Loyola, ${ }^{82}$ recibió el nombramiento de Maestrescuela de la dicha Colegial de Valladolid en 1527. La colación fue expedida cuando Francisco se encontraba en Roma como representante del propio cabildo vallisoletano, el 2 de diciembre de 1527, sin que pudiera tomar posesión de la plaza, debido a la oposición del Cabildo vallisoletano alegando sus ideas erasmistas.

En 1536 figura en Roma con el cargo de Escritor del Archivo de la Curia romana y el 6 de junio de 1539 era nombrado Procurador de la catedral de Sevilla en la Ciudad Santa, con un salario de 100 ducados anuales, lo que implicaba defender numerosas causas de la catedral hispalense ante la Curia e, incluso, ocuparse de captar voluntades de los cardenales mediante los oportunos regalos. Obtiene dos canonjías en la Catedral de Sevilla en el año 1545 y no fueron estas las últimas. Veremos esto con más detalle al tratar de la catedral de Sevilla.

Fue detenido y acusado de erasmista en 1548, siendo en esta ocasión absuelto gracias a sus contactos y tras confesar sus delitos. ${ }^{83}$ Tras este episodio, Francisco siguió acumulando canonjías en la catedral sevillana consiguiendo otras tres.

${ }^{80}$ Podríamos suponer que Francisco obtuviera su licenciatura en Valladolid y después se trasladara a Alcalá de Henares a obtener su doctorado. Es probable que naciera hacia 1490 o antes, pues la duración de los estudios hasta concluir el doctorado era muy elevada, además del gran desembolso económico que suponía. Klaus Wagner plantea doce años para obtener un título de licenciado en letras en Salamanca, y un coste de 275.500 maravedís hacia 1523. WAGNER, Klaus. «¿Qué costaron los estudios universitarios en Salamanca a principios del siglo XVI?», Archivo Hispalense, 59/180 (1976), pp. 149-151. Rucquoi pone un ejemplo de principios de siglo XV en el que el hijo natural de un clérigo tarda unos veinticinco años en la obtención del título de doctor en leyes en la Universidad de Valladolid. RUCQUOI, A. II: Valladolid en la Edad Media. El mundo..., p. 188. En cualquier caso, la familia de Francisco debía poseer suficiente dinero para costear los estudios de su hijo.

${ }^{81}$ Don Alonso Enríquez era hijo natural del Almirante de Castilla y duque de Medina de Rioseco, don Fernando Enríquez y por tanto de sangre real. Estudió en la Universidad Alcalá de Henares, foco de las ideas erasmistas. Fue un importante teólogo y poderoso abad de la Colegiata de Valladolid durante 62 años. Esta Colegiata poseía grandes rentas y entre sus abades se encuentran personajes ilustres como Juan de Torquemada o Pedro González de Mendoza en el siglo XV. Fernández Martín, Luis. «Don Alonso Enríquez, un abad valisoletano de la época imperial (1497-1577)», Hispania Sacra, 50/102 (1998), pp. 407446.

${ }^{82}$ Francisco promovió, junto a otros españoles residentes en Roma, rumores calumniosos contra Ignacio de Loyola en 1538 diciendo que era un hereje perseguido por la Inquisición española. FERNÁNDEZ MARTín, L. «Francisco Mudarra...

${ }^{83}$ La confesión, en realidad dos confesiones, se produjo en dos días sucesivos, el 13 y 14 de mayo de 1548. Juan Gil incluye estos textos en latín junto con la absolución en GIL, J. «Un español ante la Inquisición..., pp. 621-623. Incluimos traducción en los Anexos, pues las confesiones muestran las ideas erasmistas, en algunas cuestiones coincidentes con Lutero. Hay que recordar que las sentencias absolutorias 
Unos años más tarde, en 1554, fue citado a declarar por la Inquisición romana por lo que huyó a Florencia y posteriormente a Ginebra. Fue declarado hereje y quemado en efigie, todos sus bienes de la Ciudad Eterna confiscados y condenado a la privación de oficios y beneficios. Después de 1555, en que escribe una carta a Ignacio de Loyola en agradecimiento a su intercesión e intenta hacerse con otra canonjía en Sevilla, se pierde su pista.

Francisco y Alonso Mudarra tuvieron tres hermanas: Ana, Catalina, e Ysabel, y las tres parece ser que vivieron en Soria. Ana Mudarra se casó con Juan Flores de Herrera, vecino de dicha ciudad, quien aparece con frecuencia en pleitos de la Chancillería de Valladolid, y tuvieron una hija, Ana Mudarra de Herrera, que casó con Sancho de Medrano. Ambas fueron nombradas herederas universales del canónigo. Catalina Mudarra se casó con Bartolomé de Soria y tuvieron por hijo a Alonso Mudarra, quien fue criado por su tío homónimo en Sevilla. Ysabel Mudarra fue monja en el monasterio de Santa Clara de Soria.

De la infancia de Alonso en Valladolid nada sabemos, únicamente que se debió dedicar al estudio de la vihuela con ahínco, pues en su primera aparición documentada ya ostenta el título de vihuelista. Pero esto ya es en la villa de Guadalajara.

de la Inquisición no implicaban la inocencia del reo. CASTAÑEDA, Paulino. «El proceso inquisitorial», GIL, Juan (ed.) Los conversos y la Inquisición. Sevilla, Fundación El Monte, 2000, pp. 199-222; p. 212. 


\section{GUADALAJARA}

y por saber que me é criado en casa de los Illustríssimos señores Duques del Infantado, mis señores don Diego hurtado de Mendoça, que Dios tiene en su gloria, y don Íñigo lopez, que oy vive y dios nuestro señor guarde, a donde de toda Música auía excelentes hombres, pensarán que en estos mis Libros ay algunas migajas de tanto bueno como é visto en aquella casa y en otras partes de España y en Italia.

Con estas palabras dedicadas al «muy magnífico señor Don Luys çapata» el vihuelista y canónigo Alonso de Mudarra comienza sus Tres libros de música en cifras para vibuela. Hasta ahora poco o nada sabíamos sobre su estancia en Guadalajara. Vamos a ver en los próximos capítulos cuáles eran esos excelentes músicos de los que habla. Intentaremos acercarnos a la rica vida musical de una corte nobiliaria en la primera mitad del siglo XVI.

Gracias a dos manuscritos de la Biblioteca Nacional de Madrid (Nóminas y cuentas de la Casa del Infantado: Mss/11141 y Mss/11142), procedentes del duque de Osuna, que recogen en un tomo facticio las nóminas de gastos de despensa y raciones de caballeros, continos, oficiales y gente de guerra del duque del Infantado, contamos con datos sobre su capilla, los ministriles, los trompetas y atabaleros, además de otros músicos, de un largo periodo, 51 años. ${ }^{84}$ Entre estos músicos y en este periodo encontramos a nuestro vihuelista en su estancia alcarreña durante dos décadas. La primera vez en 1523 como tañedor y paje de cámara. Desde ese año y durante más de veinte, hasta enero de 1543, Alonso Mudarra va a permanecer en la Casa del Infantado ocupando diferentes puestos, pero siempre vinculado a la música. ${ }^{85}$

El cómo llegaron estos libros de nóminas a la Biblioteca Nacional tiene su explicación. Como es bien sabido, una parte importante de los archivos nobiliarios de Castilla se encuentran en la Sección Nobleza del Archivo Histórico Nacional, en Toledo. Los

\footnotetext{
${ }^{84}$ Queremos agradecer encarecidamente a la doctora Ana Belén Sánchez Prieto su generosidad al haber puesto en nuestras manos todos estos preciosos materiales.

${ }^{85}$ Aparte del prólogo de Mudarra, pocos datos teníamos sobre la estancia del vihuelista en la Corte del Infantado, tan solo una pequeña noticia de 1525 sobre su vihuela publicada por Freund Schwartz en FREUND SCHWARTZ, R. En busca de liberalidad..., p. 368.
} 
documentos del Infantado provienen del archivo de la Casa de Osuna. Fueron incautados en 1894 y adquiridos por el Estado español en 1927. Sin embargo, la biblioteca sufrió otra suerte bien distinta. Con la muerte del XIII duque del Infantado sin tener descendencia, los bienes y el título, al igual que el archivo, pasaron al duque de Osuna. En 1884 la Dirección General de Instrucción Pública adquiere la biblioteca completa, donde, entre otras, se incluía la biblioteca del Marqués de Santillana, depositando los manuscritos en la Biblioteca Nacional de Madrid y distribuyendo el resto por otras bibliotecas. ${ }^{86}$ Por azar, tres libros de contaduría encuadernados estaban en la biblioteca ${ }^{87}$ y de aquí acabaron en la Biblioteca Nacional, por lo que han pasado prácticamente desapercibidos para la mayoría de los investigadores.

Somos conscientes de que las presentes nóminas, de donde extraemos los datos, no incluyen la totalidad de los sirvientes de los duques de Infantado, pues se trata únicamente de las nóminas de acostamientos y quitaciones ${ }^{88}$ y no de la despensa y raciones, aunque en algunos casos se cita la parte cobrada en la despensa. Es decir, nos faltan muchos trabajadores de los duques, como la mayoría de los mozos, de menor rango que los oficiales $\mathrm{y}$, por supuesto, los numerosos esclavos que servían en cualquier casa noble en los años que nos ocupan. ${ }^{89}$ Tampoco incluyen, salvo excepciones, los criados de las Casas de otros parientes que vivían en el palacio como son la duquesa, los hijos menores no emancipados a los que muy temprano se les ponía Casa propia, etc. Pero además en la ciudad de Guadalajara residían numerosos parientes de los duques ${ }^{90}$ que también contaban con sus criados y, lo que a nosotros nos interesaría más, sus músicos.

Los libros organizan las nóminas por apartados que suelen llevar un orden similar. De un año para otro hay ligeras variaciones, pero la estructura básica es la que sigue:

${ }^{86}$ SCHIFF, Mario. La Bibliothèque du marquis de Santillane. París, Libraire Émile Bouillon, 1905, pp. XI-XII.

${ }^{87}$ Además de los dos manuscritos citados, hay otro de signatura BNE, Mss/11148 cuyo rango cronológico se escapa a nuestro trabajo.

${ }^{88}$ Veremos estos conceptos un poco más adelante.

${ }^{89}$ Por ejemplo, en la casa del duque de Medina Sidonia había 250 esclavos en 1507. LADERO QUESADA, Miguel Ángel. «El modo de vida noble y su entorno social y cultural en Andalucía a fines de la Edad Media: Guzmanes y Ponces», II Congreso de Academias Iberoamericanas de la Historia. Factores de diferenciación e instancias integradoras en la experiencia del mundo iberoamericano. 1994, pp. 291-318; p. 304.

${ }^{90}$ El conde de Saldaña, primogénito del duque, el conde de Coruña, el conde de Priego, además de la pequeña nobleza alcarreña. 
- Señores

- Caballeros

- Continos

- Consejo

- Oficiales

- Letrados de la corte

- Letrados de Valladolid

- Capilla
- Cantores
- Música (ministriles)
- Trompetas (y atabaleros)

- Caza
- Catarriberas
- Mozos de caza

- Pajes

- Guarda de caballo

- Mozos de espuelas

- Hombres de pie

- Tenencias

- Salarios de receptores

- Gente de guerra

Incluimos en los anexos unos índices con los años y la localización de las nóminas para no ser reiterativos con las notas a pie de página. 



\section{La Casa del Infantado}

\section{El linaje Mendoza. Antecedentes}

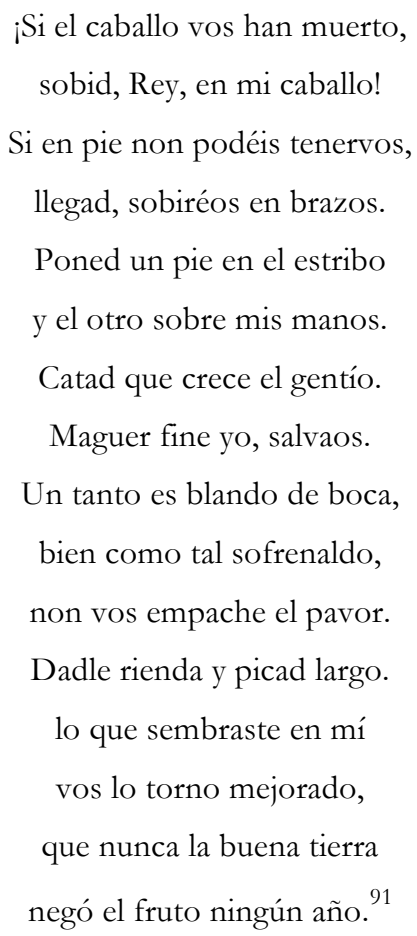

Estos versos de Luis Vélez de Guevara narran la mítica historia de la que la familia Mendoza se enorgullecía y en la que Pero González de Mendoza, señor de Hita y Buitrago, cedía su caballo al maltrecho rey Juan I en la batalla de Aljubarrota (1385), perdiendo su vida en tan heroico lance, junto con lo más granado de la nobleza castellana, y salvando así la del rey. ${ }^{92}$

El linaje Mendoza, de origen alavés, ${ }^{93}$ tomó su apellido de su casa solar llegando a ser

${ }^{91}$ Vélez de GuevarA, Luis. Si el caballo vos han muerto, y blasón de los Mendozas [c. 1625-30]. Edición crítica y anotada de William R. Manson y C. George Peale. Estudios introductorios de Javier J. González y Valerie L. Endres. Newark (Delaware), Juan de la Cuesta-Hispanic Monographs, 2007; vv. 2249-2264.

${ }^{92}$ Este hecho, que fue utilizado por la propaganda mendocina durante siglos, hoy en día está puesto en duda. SÁnChez PRIETO, Ana Belén. La Casa de Mendoza hasta el tercer Duque del Infantado (1350-1531). El ejercicio y alcance del poder señorial en la Castilla bajomedieval. Madrid, Palafox \& Pezuela, 2001, p. 39.

${ }^{93}$ Para todo lo referente a la Casa de Mendoza las obras imprescindibles son: LAYNA SERRANO, Francisco. Historia de Guadalajara y sus Mendozas en los siglos XV y XVI. Guadalajara, Aache, 1993, 4 volúmenes. (reedición de Madrid, Aldus, 1942); Arteaga y Falguera, Cristina de. La casa del Infantado. Cabeza de los Mendoza. 2 vols. Madrid, 1940; NADER, Helen. Los Mendoza y el Renacimiento español. Guadalajara, Institución 
uno de los principales de Castilla con el paso de los siglos. ${ }^{94}$ Podríamos decir que los Mendoza siguieron en estos siglos un auténtico cursus honorum medieval: señor, conde, marqués, duque. ${ }^{95}$ Desde la mitad del siglo XV hasta finales del XVI se constituye en el más importante grupo de poder político y económico formado por una rama principal y numerosas casas subordinadas: Tendilla, Coruña, Priego, Zenete, Mélito, Monteagudo, etc. ${ }^{96}$ Pero además se convierten en los mayores patrocinadores de la élite intelectual castellana, de forma que muchos de los elementos del Renacimiento serían inexplicables sin la participación de los Mendoza.

Desde el siglo XIV, Guadalajara se convirtió en la capital del poder mendocino con su epicentro en el palacio del Infantado. ${ }^{97}$ A pesar de ser una villa de realengo, no de señorío, los Mendoza manejaban todos los resortes de poder: económico, municipal, militar, religioso, cultural y artístico. Controlaban absolutamente, de forma omnímoda, todas las facetas de la vida diaria. No podía ser de otra manera, pues la ya ciudad contaba a principios del siglo XVI con algo más de 4.000 habitantes, de los cuales una gran cantidad

Provincial de Cultura «Marqués de Santillana», 1986. SÁnChez Prieto, A. B. La Casa de Mendoza..., CARrasco, Adolfo. El poder de la sangre. Los duques del Infantado (1601-1841). Madrid, Actas, 2010. Fuentes de muchos de los datos recogidos por estos autores, principalmente por Layna, son las obras manuscritas del jesuita Hernando PeCHA (1567-1659), a saber: Historia de Guadalaxara y cómo la Religión de San Jerónimo en España fue fundada y restaurada por sus ciudadanos, obra anterior a 1632 conservada en la sección de manuscritos de la Biblioteca Nacional de Madrid con la signatura Mss/1756, y copiada casi literalmente por Alonso NÚÑEZ DE CASTRO en su Historia eclesiástica y seglar de la muy noble ciudad de Guadalajara, impresa en Madrid por Pablo de Val en 1653. La segunda de las obras de Pecha es la Historia de las vidas de los Ex[celentísi]mos Señores Duques del Ynfantado y su progenitores desde el Infante Donzuria primer Señor de Vizcaya hasta la Excelentísima señora Duquesa Doña Ana y su Hija Doña Luysa Condesa de Saldaña de 1635, manuscrito conservado en la Biblioteca Provincial de Guadalajara con la signatura Ms. 57 que en muchos aspectos es una copia del anterior, aunque con ligeras variantes. Un reciente trabajo sobre las mujeres Mendoza: ALEGRE CARVAJAL, Esther (ed.). Damas de la Casa de Mendoza. Historias, leyendas y olvidos. Madrid, Ediciones Polifemo, 2014.

${ }^{94}$ El linaje Mendoza fue de los pocos linajes de la nobleza vieja que se mantuvo y consiguió acrecentar su poder y patrimonio durante los Trastámaras, pasando a integrarse en la denominada nobleza nueva. MOXÓ, Salvador de. «De la nobleza vieja a la nobleza nueva. La transformación nobiliaria castellana en la Baja Edad Media», Feudalismo, señorío y nobleza en la Castilla medieval. Madrid, Real Academia de la Historia, 2000, pp. 311-370. Reproducción parcial del publicado en Cuadernos de Historia. Anexos de la revista Hispania, 3 (1969), pp. 1-210.

${ }^{95}$ SuÁREZ FERNÁNDEZ, Luis. Nobleza y Monarquía. Entendimiento y rivalidad. El proceso de construcción de la Corona española. Madrid, RBA, 2007, p. 213.

${ }^{96}$ Ver Alegre Carvajal, E. Damas..., pp. 17-22.

${ }^{97}$ El palacio estaba flanqueado por una lado por una gran plaza, escenario donde se desarrollaban todos los grandes acontecimientos, cerrada por el frente por las caballerizas y por el otro lado por los jardines. Un interesante trabajo sobre las villas ducales: ALEGRE CARVAJAL, Esther. "La configuración de la ciudad nobiliaria en el Renacimiento como proyecto ideológico de una élite de poder», Tiempos modernos: Revista Electrónica de Historia Moderna, 6/16 (2008), pp. 1-19. 
de ellos eran criados del duque, o de sus parientes directos, y el resto dependía económicamente de él. Vamos a ver los antecedentes familiares para poder luego ubicar perfectamente a los Mendoza del siglo XVI.

Dejando fuera oscuros y confusos orígenes, muchas veces inventados por los genealogistas, el primer nombre del linaje que aparece ligado a Guadalajara es el de Gonzalo Yáñez de Mendoza, hijo de Diego Hurtado y de María de Rojas, quien se estableció allí al casar con la alcarreña Juana López de Orozco, hija a su vez de otro alavés, Íñigo López de Orozco. Gonzalo fue montero mayor de Alfonso XI y regidor de Guadalajara.

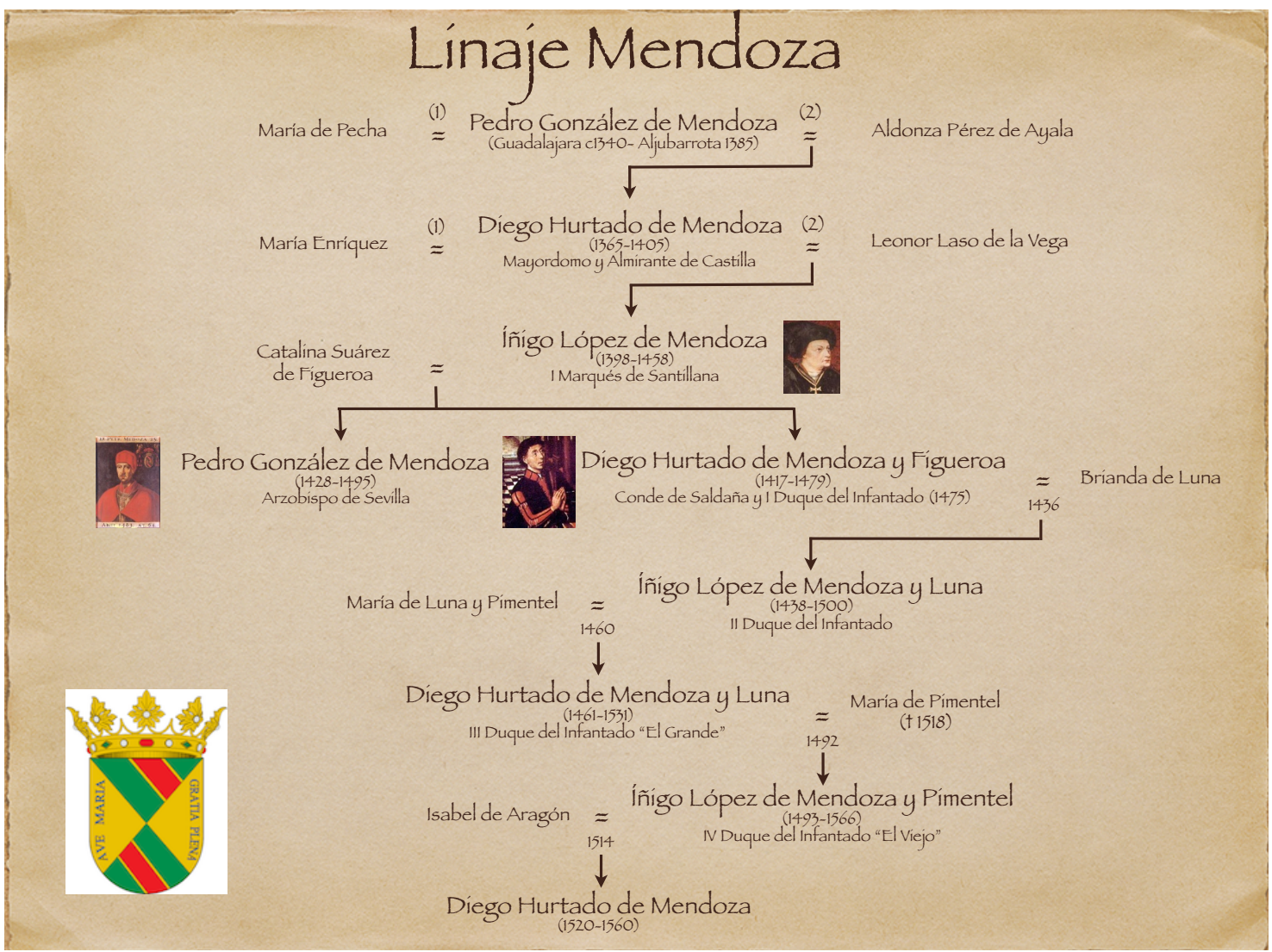

Fig. 7. Genealogía del linaje Mendoza

El hijo de Gonzalo fue Pero o Pedro González de Mendoza (c. 1340-1385), ${ }^{98}$ «el de

${ }^{98}$ A pesar de los años transcurridos la más amplia información sobre este Mendoza se encuentra en ANDrÉS, Alfonso. «Don Pedro González de Mendoza el de Aljubarrota (1340-1385). Ensayo biográfico», 
Aljubarrota», al primer gran Mendoza alcarreño. Partidario de Pedro I el Cruel, cuando la guerra civil empezó a caer hacia el bando contrario, se pasó al de Enrique de Trastámara. Fue hecho prisionero en la decisiva batalla de Nájera (1367) que unió a gran parte de la nobleza castellana a la causa enriqueña. El apoyar a Enrique le supuso recibir numerosas «mercedes enriqueñas», la más importante la concesión del señorío de Hita y Buitrago, y el formar parte del Consejo real, convirtiéndo así a su familia en una de las más ricas y poderosas de Castilla y en uno de los pilares de la dinastía Trastámara. ${ }^{99}$ Además fue nombrado ayo y mayordomo mayor del príncipe Juan, cargo este último que mantuvo cuando este llegó a ser rey con el nombre de Juan I de Castilla. Casó tres veces con damas de la nobleza de Guadalajara, la tercera de ellas fue Aldonza Fernández de Ayala, camarera de la reina, en quien concibió a su primogénito Diego Hurtado de Mendoza, para el que fundó mayorazgo. Fue dado a la literatura y escribió cantigas y dezires amorosos, anticipándose a su nieto el Marqués de Santillana. ${ }^{100}$

Diego Hurtado de Mendoza (1367-1404), II señor de Hita y Buitrago, fue almirante mayor de Castilla. Su cercanía al monarca le permitió incrementar sus posesiones recibiendo el Real de Manzanares. Casó en segundas nupcias con la ricahembra doña Leonor de la Vega, dueña de grandes propiedades en la zona cantábrica, entre las que destacaban Asturias de Santillana, La Vega y la merindad de Liébana. Unió el almirante los dos blasones familiares incorporando el lema Ave María gratia plena que ya nunca faltará en el escudo del linaje Mendoza. Sin llegar a poseer el señorío de Guadalajara, percibía la mayor parte de las rentas de la misma, convirtiéndose de hecho en señor de la ciudad. Además su fastuosa corte atrajo a multitud de hidalgos y plebeyos deseosos de entrar a su servicio. ${ }^{101}$ A su muerte era considerado el más rico hombre de Castilla. ${ }^{102} \mathrm{Al}$ igual que su padre tuvo algunos escarceos con la poesía amatoria.

Boletin de la Real Academia de la Historia, 78/3,4,5,6 (1921), pp. 255-273, 353-376, 415-436, 496-504 y 79/1-2 (1921) pp. 29-42, 144-187.

${ }^{99}$ NADER, H. Los Mendoza y el Renacimiento..., p. 62.

${ }^{100}$ El Cancionero de Baena recopilado a principios del siglo XV para la corte de Juan II contiene varias obras de Pedro González. También en la Biblioteca Nacional de Madrid hay algunas poesías suyas. LAYNA SERrANo, F. Historia de Guadalajara y sus Mendozas..., Tomo I, p. 54.

${ }^{101}$ Decía de él Fernán Pérez de Guzmán: «tenia una gran casa de caballeros y escuderos. En tiempo del no habia caballero en Castilla de tanto estado», citado por SÁnCHEZ PrIETO, A. B. La Casa de Mendoza ..., p. 40.

${ }^{102}$ NADER, H. Los Mendoza y el Renacimiento..., p. 64. 
Íñigo López de Mendoza (1398-1458) «el Marqués de Santillana», fue el primogénito del Almirante. No menos importante que su actividad literaria fue su actividad política, que se desarrolló permanentemente entre la paz y la guerra. ${ }^{103}$ Encarnó el ideal de caballero y poeta que aunaba las armas y las letras, antecedente de su pariente Garcilaso de la Vega. Su vida transcurrió casi en paralelo con la del monarca Juan II, ${ }^{104}$ de quien obtuvo importantes mercedes, entre otras, los títulos de conde del Real y marqués de Santillana.

Nació en Carrión de los Condes y fue criado por su madre doña Leonor. Su padre falleció siendo él muy niño, lo que le acarreó gran perdida de tierras y hacienda, además de perder el título de almirante de Castilla, que pasó a la familia Enríquez, donde se mantuvo por generaciones. Tuvo que recuperar gran parte de sus territorios, muchas veces mediante pleitos y otras por la fuerza de las armas. Reunió una enorme biblioteca que pasó luego a sus sucesores ${ }^{105}$ y juntó una importante corte en sus casas de Guadalajara, ${ }^{106}$ en donde había «dotores e maestros con quien platicaua en las sciencias e lecturas que estudiaua». ${ }^{107}$ Se le puede considerar uno de los precursores del humanismo en Castilla, pues hizo traer de Italia numerosos manuscritos, tanto de clásicos griegos como de autores italianos como Petrarca o Boccaccio; en palabras de su secretario, el poeta Diego de Burgos «oy los de Ytalia se deuen doler e quexar que por lunbre e ynjenio deste señor a ellos sea quitada e trayda a nuestra Castilla». ${ }^{108}$

Cuando contaba con dieciseis años de edad se casó con Catalina de Figueroa y con ella tuvo varios hijos que llegarían a ser fundamentales para conocer la historia de Castilla en la segunda mitad del siglo XV. Diego Hurtado de Mendoza, el primogénito, heredó los

${ }^{103}$ Herrera CaSAdo, Antonio. El marqués de Santillana. Marco, ruta y significados vitales. Guadalajara, Ayuntamiento de Guadalajara, 1998.

${ }^{104}$ Es conocido el importante ambiente cultural y musical de la corte de Juan II de quien Pérez de Guzmán decía que «era músico, tañía e cantaba e trovaba e danzaba muy bien», citado por CAÑAS GÁLVEZ, Francisco de Paula. «La música en la corte de Juan II de Castilla (1406-1454). Nuevas fuentes para su estudio», Revista de Musicología, 23/2 (2000), pp. 367-394; p. 370.

${ }^{105}$ SCHIFF, M. La Bibliothèque....

${ }^{106}$ Una relación de sus criados, incluyendo a Antonillo su trompeta y varios esclavos, puede leerse en el codicilo de su testamento publicado por LAYNA SERrano, F. Historia de Guadalajara y sus Mendozas..., Tomo I, pp. 332-333.

${ }^{107}$ Pulgar, Hernando del. Los claros varones de España. Sevilla, Stanislao Polono, 1500 (Ed. facs Buenos Aires, Barcelona, Salvat, 1970), f. 14.

${ }^{108}$ SCHIFF, M. La Bibliothèque..., p. 462. 
títulos de su padre. El segundo hijo, Íñigo López de Mendoza (1419-1479), fue el primer conde de Tendilla, ${ }^{109}$ pero sin duda el más importante de los hijos del Marqués fue Pedro González de Mendoza. También es destacable la figura de Mencía de Mendoza «la condestablesa», responsable de la construcción de la «Capilla de los condestables» de la catedral de Burgos. ${ }^{110}$

Diego Hurtado de Mendoza (1417-1479) heredó de su padre el marquesado de Santillana y el condado del Real, obteniendo más tarde el título de I duque del Infantado. ${ }^{111}$ Su papel, y el del resto de la familia Mendoza, en la guerra de sucesión castellana fue vital, apoyando primero al rey Enrique IV y posteriormente a los reyes Isabel y Fernando. Este decisivo apoyo le supuso la concesión del título del Infantado por los Reyes Católicos el 22 de julio de 1475.

Unos años antes, en 1461, el rey le había concedido el título de conde de Saldaña, título que quedó desde este momento vinculado a la primogenitura del linaje principal. ${ }^{112} \mathrm{~A}$ pesar de todo, tuvo don Diego algunos enfrentamientos con los monarcas y así en 1459 fue expulsado de la villa de Guadalajara por Enrique IV, instalándose en el castillo del Real de Manzanares, donde permaneció hasta su muerte en 1479. Este castillo fue construido por su padre en sustitución del viejo castillo, pero él lo convirtió en palacio para alojar a toda su corte y sabemos que a partir de 1475 el maestro cantero Juan Guas comenzó a trabajar en la reforma del mismo. ${ }^{113}$

${ }^{109}$ Su hijo fue el conocido como «el Gran Tendilla», capitán general de Granada y gobernador de la Alhambra, de quien Marías dice que fue responsable de la introducción del Renacimiento en España MARÍAS Franco, Fernando. «Los Mendoza y la introducción del Renacimiento en España», Noblez̧a, coleccionismo y mecenazgo. Sevilla, Real Maestranza de Caballería, 1998, pp. 29-44.

${ }^{110}$ Perea Rodríguez, Óscar. «Mencía de Mendoza, condesa de Haro», Alegre Carvajal, Esther (ed.). Damas de la Casa de Mendoza. Historias, leyendas y olvidos. Madrid, Ediciones Polifemo, 2014, pp. 97-132. .

${ }^{111}$ Según Salazar y Acha el funcionamiento de los nombres y apellidos entre los Mendoza, que como observamos se repiten de generación en generación, estaba basado en un «patrimonio onomástico» de los nombres usados previamente por sus antecesores, incluyendo el nombre y el patronímico. Un ejemplo sería el Marqués de Santillana, don Íñigo López de Mendoza, que puso por nombres a sus hijos: Diego Hurtado, Íñigo López, Pedro González, Lorenzo Suárez y Pedro Lasso. Cinco hermanos del mismo padre, se apellidan todos de forma diferente. SALAZAR Y ACHA, Jaime de. Génesis y evolución histórica del apellido en España. Discurso leído el día 26 de mayo de 1991. Madrid, Real Academia Matritense de Heráldica y Genealogía, 1991; pp. 29-30. A esto habría que añadir que, salvo excepciones, los primogénitos de ambos sexos suelen llevar el nombre de los abuelos paternos y los segundogénitos los de los abuelos maternos.

112 CARrasco, Adolfo. El poder de la sangre..., p. 40.

${ }^{113} \mathrm{Al}$ morir en 1479 su hijo prosiguió las obras y parece ser que en estos años se realizo la galería alta. Sobre el castillo: LAmpéreZ y RomeA, Vicente. Los Mendoza del siglo XV y el castillo del Real de Manzanares. 
Se casó en primer lugar con Brianda de $\operatorname{Luna}^{114} \mathrm{y}$, tras el fallecimiento de ésta, en segundas nupcias con Isabel Enríquez de Noronha, teniendo varios hijos con ambas. No contento con esto, dejó varios hijos naturales con otras tantas damas. Fue, en palabras de Hernando del Pulgar «vencido de mugeres e del apetito de los manjares». ${ }^{115}$ Tomó como lema o divisa «dar es señorío, recibir es servidumbre» y como emblema una tolva de molino.

Pedro González de Mendoza (1428-1495) ${ }^{116}$ conocido como «el Gran Cardenal», fue obispo de Calahorra-La Calzada, obispo de Sigüenza, abad de Valladolid, arzobispo de Sevilla, obispo de Osma y arzobispo de Toledo. Acumuló la mayor cantidad de cargos que nunca hubo un prelado castellano, pues tras los sucesivos nombramientos fue conservando las anteriores dignidades y beneficios. Si fue importante su labor eclesiástica, llevando a cabo una profunda reforma en la iglesia, no menos importante fue su labor política, siendo llamado «el tercer Rey Católico». A pesar de su condición, el cardenal tuvo tres hijos con dos mujeres, que fueron legitimados mediante bula papal y posteriormente por los Reyes Católicos ${ }^{117}$ y para los cuales consiguió su padre importantes títulos y

Madrid, Real Academia de la Historia, 1916 y sobre Juan Guas: DomíngueZ CASAS, Rafael. Arte y etiqueta de los Reyes Católico. Artistas, residencias, jardines y bosques. Madrid, Alpuerto, 1993, pp. 29-37 y LóPEZ DíEZ, María. «Juan Guas en la catedral de Segovia», Archivo Español de Arte, 315 (Julio-Septiembre 2006), pp. 299-306. Recordemos que Guas, maestro mayor de las obras reales, fue responsable de la construcción del Palacio del Infantado, del Monasterio de San Juan de los Reyes en Toledo, la Hospedería Real de Guadalupe y de reformas en las catedrales de Segovia y de Ávila, entre otras.

${ }^{114}$ A las bodas entre el hijo del marqués y Brianda de Luna, sobrina del condestable Álvaro de Luna, celebradas en 1436, acudió el rey Juan II con toda su corte, permaneciendo casi un año en Guadalajara. Las fiestas se prolongaron durante varios días con un enorme despliegue de lujo, no faltando ni la música, ni las corridas de toros, ni los juegos de cañas. Layna Serrano, F. Historia de Guadalajara y sus Mendozas..., Tomo II, pp. 215-216.

${ }^{115}$ Pulgar, H. Los claros varones..., f. 26.

${ }^{116}$ Cumplida información sobre el cardenal Pedro González de Mendoza, principalmente sobre su faceta religiosa, en Villalba Ruiz De Toledo, F. Javier. El cardenal Mendoza (1428-1495). Madrid, Rialp, 1988. Como complemento de este trabajo Villalba Ruiz DE TOLEDO, F. Javier. «Colección diplomática del cardenal Mendoza (1454-1503)», Cuadernos de Historia Medieval, Sección Colecciones Documentales, 1 (1999). Durante muchos años se ha considerado al cardenal Mendoza el introductor del renacimiento arquitectónico en Castilla. Veíamos más arriba que Marías atribuía este mérito al conde de Tendilla, mientras que Nader en NADER, H. Los Mendoza y el Renacimiento..., pone al familia Mendoza al completo como los responsables, aunque para ello tenga que ampliar muchos los límites del linaje.

${ }^{117}$ Cuenta Layna, en un relato no por repetido menos entrañable, que cuando el cardenal quiso presentar a sus hijos a la reina Isabel con la excusa de mostrarle sus pecados, la reina al verlos exclamó: «iBellos, muy bellos son vuestros pecados, cardenal!». LAYNA SERRANO, F. Historia de Guadalajara y sus Mendozas..., Tomo II, p. 303. 
beneficios. ${ }^{118}$ Consiguió acumular un gran patrimonio que dejó a sus hijos tras su muerte, ${ }^{119}$ además de grandes riquezas. Fue un activo patrón de las artes, sobre todo de la arquitectura, tanto en Toledo, ${ }^{120}$ como en Guadalajara. ${ }^{121}$ Su casa palacio de la capital alcarreña, construida entre los años 1483 y 1493 como mínimo, ${ }^{122}$ en la colación de Santa María y con la dirección de Lorenzo Vázquez de Segovia, fue descrita por varios viajeros como el humanista, médico y geógrafo alemán Jerónimo Münzer:

La casa del cardenal hállase extramuros de la población y es, sin disputa, una de las más bellas de España. Yo he visto en Roma muchas de cardenales, pero ninguna tan cómoda ni tan bien ordenada como ésta. Tiene un preciosísimo patio de dos galerías con una estancia y pequeñas cámaras en cada uno de sus lados, decoradas con dorados artesones de dibujos y colores diversos; dos salas de verano que dan al jardín, con columnas de mármol y gran cantidad de oro en su aderezo; hermosa capilla, larga, pero no muy ancha, en cuyo altar vese la cruz que fué del cardenal y un retablo con excelentes pinturas representando a San Pedro, San Pablo y la Virgen y, a los lados, San Gregorio y Santa Elena; un frondoso jardín con fuente en medio para regarlo; un inmenso aviarium, cerrado en parte con obra de albañilería, en parte con alambre de cobre, en el que hay tanta variedad de aves, que excede toda ponderación: tórtolas y palomas de España y África; innumerables gallinas africanas de color negro con pintas blancas, que parecían dados, fuerte cresta gris, cola corta y muy zancudas; perdices de varias especies; ánades con plumas de color rojo oscuro y de cola y pico negros; grullas con graciosa cresta blanca y otras infinitas aves que no es posible enumerar. Cuida de ellas un servidor de la casa que no tiene en ella más que esta obligación. Acaso no habrá en el mundo morada más deleitosa, y nada digo de las grandes riquezas del dueño, en cuyo patrimonio reuníanse los beneficios del arzobispado de Toledo, los del obispado de Sigüenza y los de la dignidad de cardenal, sin contar con otros no pequeños. Tenía

${ }^{118}$ El hijo mayor, Rodrigo de Vivar y Mendoza fue marqués del Cenete y conde del Cid, el segundo, Diego Hurtado, fue conde de Mélito y Aniano y el tercero, Juan Hurtado de Mendoza fue destinado a la carrera religiosa, pero prefirió la profesión de caballero, falleciendo en la batalla de Pavía.

${ }^{119}$ Una relación de este patrimonio en FRANCO SILVA, Alfonso. «La herencia patrimonial del gran cardenal de España D. Pedro González de Mendoza», Historia. Instituciones. Documentos, 9 (1982), pp. 453-491. También Franco Silva, Alfonso. «La cámara del Cardenal Mendoza. Lujo, riqueza y poder de un príncipe de la iglesia hispana del siglo XV», Historia. Instituciones. Documentos, 39 (2012), pp. 65-127.

${ }^{120}$ Llamazares RodrígueZ, Fernando. «Mecenazgo artístico del Cardenal Mendoza en Toledo», Los Mendoza y el mundo renacentista. Foro Castellano, ANABAD, Universidad de Castilla la Mancha, 2011, pp. 133159.

${ }^{121}$ Herrera Casado, Antonio. «El Legado arquitectónico de Don Pedro González de Mendoza, Cardenal de España, en la tierra de Guadalajara», Los Mendoza y el mundo renacentista. Foro Castellano, ANABAD, Universidad de Castilla la Mancha, 2011, pp. 187-201.

${ }^{122}$ Esos son los años de los que se conservan los libros de cuentas del Cardenal. SAN Román, Francisco de Borja. «Las obras y los arquitectos del Cardenal Mendoza», Archivo Español de Arte y Arqueología, 7/20 (1931), pp. 153-161. 
mucha mano con el rey y era muy sobrio en el trato de su persona, pero en todo lo demás gastaba sumas considerables. $^{123}$

También Antoine de Lalaing, señor de Montigny, en la crónica del viaje de 1501 en el que acompañó a Felipe el Hermoso, dedica elogios a las casas del cardenal Mendoza:

En la ville a une maison que fist faire le cardinal de Mandos, oncle du duc, et est toute parfaite, ce que n'est la maison duc. et est très-belle de painctures et dorures. Le jardin tout pavé est advironné de galleries, dont l'une est plaine d'oiseauls. ou milieu duquel sourt une belle fontaine. Là se tient la mère du duc. $^{124}$

Íñigo López de Mendoza (1438-1500) fue el II duque del Infantado. Nacido en Guadalajara, se educó con su tío Pedro González de Mendoza. Ambos tuvieron una gran importancia en el ámbito político, pues el apoyo del linaje Mendoza fue decisivo en la guerra civil por la sucesión de Enrique IV y en otros muchos episodios relevantes. ${ }^{125}$

Fue dado a la ostentación y al lujo y también mantuvo una fastuosa corte como, un tanto efusivamente, nos describe Layna:

Por la suntuosidad del edificio, riquísimo ajuar, número de gentiles hombres y damas de honor, así como pajes y otros criados vestidos con lujosas libreas, más el severo y meticuloso ceremonial de régimen casero, con razón pudo decirse y aun criticarse que el segundo duque del Infantado tenía en Guadalajara una Corte, más propia de reyes que de magnates, dada su brillantez; en esto aventajaba el opulento Mendoza a los Católicos Fernando e Isabel, quienes, por tenerla andariega y trashumante, no disponían de un palacio digno de la realeza, montado y organizado en consonancia con su autoridad, prestigio y poderío. $^{126}$

${ }^{123}$ MÜNZER, Jerónimo. «Viaje por España y Portugal en los años 1494 y 1495», Versión del latín por Julio Puyol. Boletín de la Real Academia de la Historia. 84 (1924), pp. 197-279; pp. 266-267.

${ }^{124}$ Lalaing, Antoine. «Voyage de Philippe le Beau en Espagne, en 1501», Collection des voyages des souverains des Pays-Bas. GACHARD, M. (ed.) Bruselas, Hayez, 1876, vol. I, pp. 121-340; p. 229.

${ }^{125}$ No se puede entender el transcurso de la vida política castellana en la segunda mitad del siglo XV y la primera mitad del XVI, o por lo menos, hasta la venida de Carlos V a España, sin la intervención de los Mendoza. Su apoyo era imprescindible para que una determinada opción triunfara y los periodos de incertidumbre política en esos años fueron muchos. Dos obras son fundamentales para entender su papel: SuÁrez FernándeZ, L. Nobleza y Monarquia... y SÁnChez Prieto, A. B. La Casa de Mendoza...

${ }^{126}$ Layna Serrano, Francisco. El Palacio del Infantado en Guadalajara. Guadalajara, Aache, 1997. (reedición de Madrid, 1941); pp. 116-118. 
Para albergar semejante corte mandó construir el palacio del Infantado ${ }^{127}$ en el lugar de las antiguas casas de Guadalajara que hizo demoler, empresa que comenzó hacia $1480^{128}$ y que concluyó hacia 1497. De nuevo el encargado de su construcción fue el francés Juan Guas, en colaboración con el escultor flamenco Egas Cueman ${ }^{129}$ y Lorenzo Vázquez de Segovia, ${ }^{130}$ quienes hicieron converger de forma maravillosa el estilo gótico con el mudéjar.

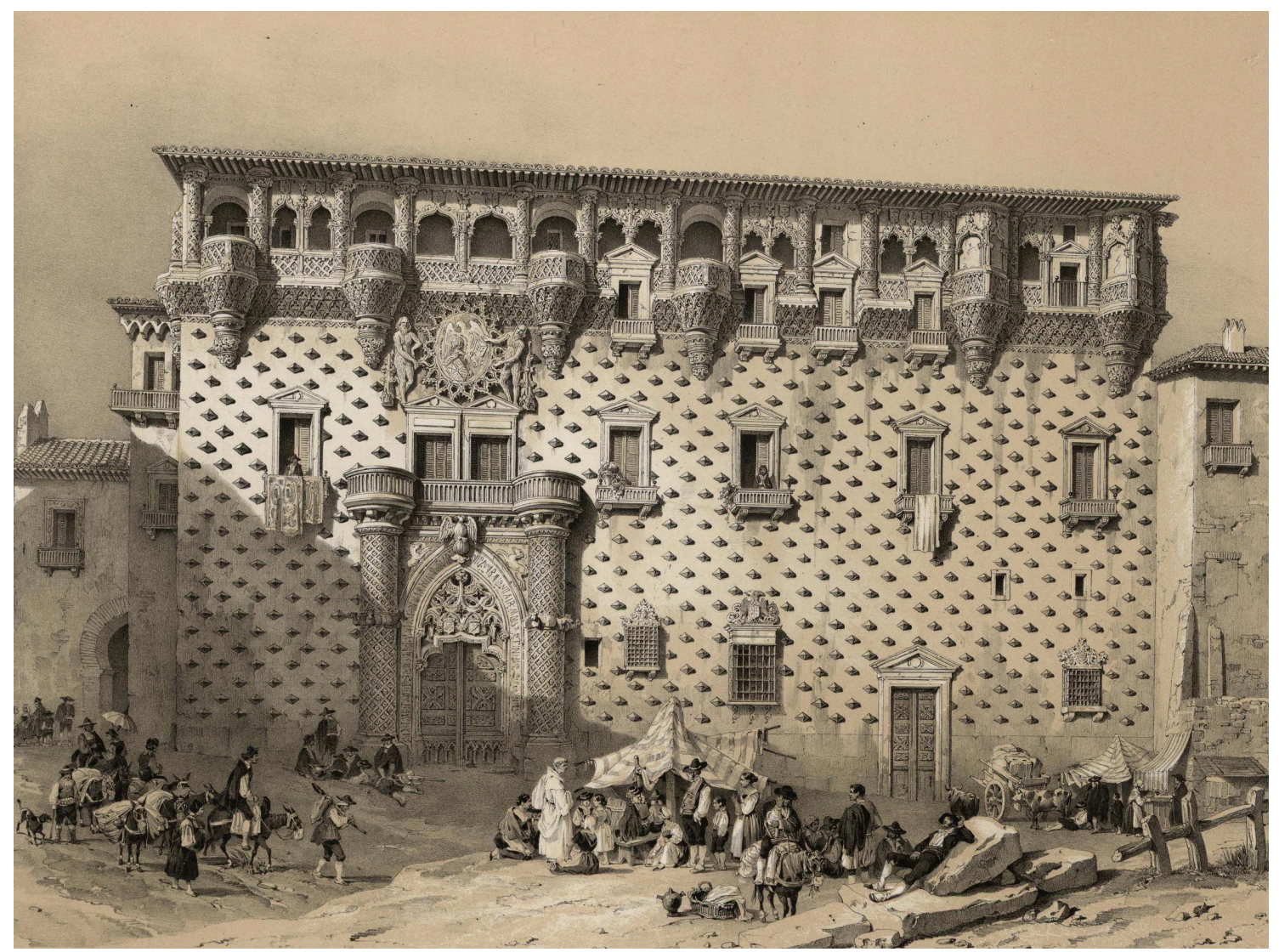

Fig. 8. Fachada del Palacio del Infantado de Guadalajara (Jenaro Pérez Villaamil, 1842)

El palacio fue testigo de numerosas visitas, como la de los Reyes Católicos, que se alojaron allí al menos en dos ocasiones. La primera en 1487 tras la conquista de Málaga y

${ }^{127}$ Sobre el palacio del Infantado las obras de referencia son LAYNA SERRANO, F. El Palacio del Infantado... y HerRera CASADO, Antonio. El palacio del Infantado en Guadalajara. Guadalajara, Aache, 2001

${ }^{128}$ Layna duda de esta fecha para el inicio de la construcción, pero estudios más recientes la confirman. Layna Serrano, F. El Palacio del Infantado..., p. 23 y SANTIAgo Fernández, Javier de y Francisco Olmos, Jose María de. «La inscripción de la fachada del palacio del Infantado en Guadalajara», Documenta \& Instrumenta, 4 (2006), pp. 131-150.

${ }^{129}$ Domínguez CASAs, R. Arte y etiqueta..., pp. 37-41.

${ }^{130}$ A quien ya vimos como maestro de obras del cardenal Mendoza. Sobre su obra ver: ROMERO MedinA, Raúl. «La arquitectura en época de los Reyes Católicos. Lorenzo Vázquez de Segovia introductor del renacimiento en Castilla (c.1450-1515)», Comunicación del Conocimiento. Anuario científico de la Universidad Isabel I, 1 (2012), pp. 479-498. 
camino de Aragón ${ }^{131}$ y la segunda en 1494 cuando acudieron a visitar al enfermo cardenal Mendoza. Veremos, al tratar del III y IV duques, otras ilustres visitas que fueron agasajadas y deslumbradas con el lujo y suntuosidad al que acostumbraban los Mendoza.

De nuevo recurrimos a las palabras de Lalaing al contemplar el palacio del Infantado:

l'hostel du duc encoire non parachevé, oú ils se logèrent: où deux galeries sont, l'une sur l'autre, de blances pierres rices et fort sumptueses. Les pillers sont entretailliés de lyons et griffons enchainnés ensamble, et sont les chambres et salles bien parées et painctes d'or et d'azur. De la plus excellente salle la volsure est de bois et bien entretaillié et fort menuyèrement, et le eut ce duc à ung monastère assés près d'illec, parmy donant III ${ }^{\mathrm{e}}$ florins de rente; aprés le fist dorer tèlement que la dorure a cousté chincq milles ducas. Et ce que les painctures et dorures de làdedens sont toutes diverses les unes aux aultres, est chose de grande estime. En une petite salle en bas sourt une fontaine laquèle furnit d'eaue toute la maison et va tumber en une aultre salle grande oú il y a samblablemente une aultre petitte fontaine, et celles se rendent au jardin en ung vivier grandt et fort profondt, plain de truittes et d'autres poissons. Ceste maison de Goadelagrade est jugiée la plus belle d'Espaigne, sans estre chasteau. ${ }^{132}$

En 1493, sin haber concluido las obras del palacio, el duque comenzó las obras de las caballerizas y las viviendas para los criados, situadas justo enfrente de la fachada principal del palacio. El edificio estaba formado por dos galerías columnadas con arcos de medio punto. De nuevo se utilizó la piedra de Tamajón, pero esta vez se eligió el estilo «al romano», considerado más renacentista frente al gótico mudéjar del palacio. ${ }^{133}$ Tras la muerte del Cardenal en 1595, sus «casas principales» ${ }^{134}$ fueron adquiridas por el duque que en un primer momento las utilizó como armería ${ }^{135}$ y posteriormente fueron habitadas por diferentes miembros de la familia.

${ }^{131}$ Por su situación la ciudad de Guadalajara fue siempre lugar de paso y de encuentro entre los reinos de Castilla y Aragón.

${ }^{132}$ Lalaing, A. «Voyage de Philippe le Beau..., pp. 228-229.

${ }^{133}$ Layna Serrano, F. El Palacio del Infantado... , pp. 84-88. No fue el único edificio a lo Romano que se construía en estas fechas en Guadalajara, pues Antonio de Mendoza estaba levantando el suyo con la dirección de nuevo de Lorenzo Vázquez. Trallero SANZ, Antonio Miguel. «El modelo constructivo del patio del palacio de Antonio Mendoza», Actas del Primer Congreso Nacional de Historia de la Construcción. A. de las Casas, S. Huerta, E. Rabasa (eds.), Madrid, Juan de Herrera, 1996, pp. 499-506 y RodríGuez RebOLLO, Ángel. «El Palacio de don Antonio de Mendoza en Guadalajara. Aspectos decorativos y formales», Archivo Español de Arte. 75/299 (2002), pp. 269-281.

${ }^{134}$ Es la forma común que usan para designar a su palacio.

${ }^{135}$ La armería de los duques del Infantado fue famosa por su enorme colección de armaduras y de todo tipo de armas blancas y de fuego. 
Íñigo López de Mendoza se casó con María de Luna, hija del malogrado condestable don Álvaro de Luna, con lo que la familia Mendoza vio aun más incrementado su patrimonio. Muerto su padre, mantuvo su corte de caballeros y criados sin despedir a ninguno, al contrario de lo acostumbrado, incrementando la corte con otros muchos, siendo tan suntuosa su casa «que más parezía Palacio Real, que cassa de Príncipe Particular» ${ }^{136}$. Además de numerosos caballeros, los hijos de éstos servían al duque en calidad de pajes. También la duquesa doña María mantuvo una casa «como si fuera Reyna [...] con dueñas de honor, con guardas de las damas, con ayudas de Cámara, moças de Retrete y otras criadas que servían a éstas como si fuera Palaçio Real». ${ }^{137}$ Falleció el duque el 14 de julio de 1500, siendo sucedido por su hijo, homónimo de su abuelo, como no podía ser de otra manera.

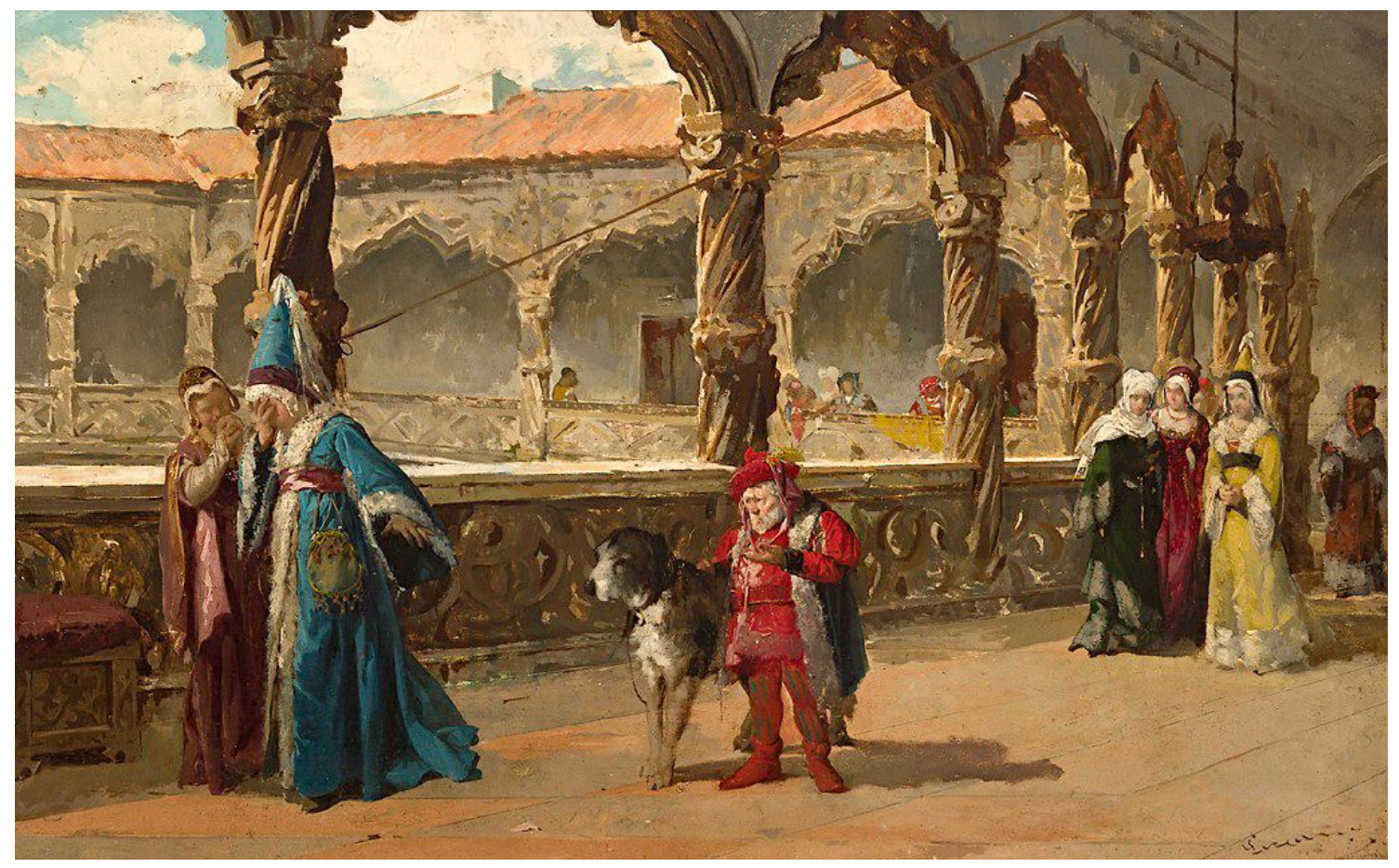

Fig. 9. Galería alta del Palacio del Infantado de Guadalajara

(Angel Lizcano Monedero (1846-1929). Museo Provincial de Bellas Artes, Guadalajara)

\footnotetext{
${ }^{136}$ Pecha. Historia de Guadalaxara..., ff. 199v-200.

${ }^{137}$ Ibidem, f. $200 \mathrm{v}$.
} 


\section{E1 III y IV duques del Infantado. El siglo XVI}

Diego Hurtado de Mendoza (1461-1531) III Duque del Infantado, IV Marqués de Santillana y IV Conde del Real, llamado «el Grande», sumó a todos estos títulos el ser nombrado por Carlos V caballero del Toisón en 1518.

Sucedió a su padre tras su muerte en 1500. Acumuló grandes rentas y fue dado a la ostentación y al lujo. Tenía en su casa una larga nómina de criados, de forma que cada vez que salía de su palacio desplegaba una lujosa comitiva en la que no faltaba su compañía de alabarderos de librea, numerosos caballeros y, por supuesto, sus trompetas, atabales y ministriles. Creó en 1503, a imitación de la realeza, un Consejo formado por juristas con los que administraba la jurisdicción de sus múltiples posesiones. Veremos en el siguiente capítulo de forma más detallada la estructura de su casa.

Se casó varias veces, dejando numerosa descendencia, ${ }^{138}$ pero además tuvo varios hijos ilegítimos con diversas damas alcarreñas e incluso con una bella gitana tuvo a Martín de Mendoza. ${ }^{139}$ Con su esposa María de Pimentel y Pacheco, hija del conde de Benavente, tuvo a su primogénito, de nombre Íñigo. En el último año de su vida, ya anciano y gotoso, se encaprichó de María Maldonado, hija de un criado suyo, Antonio de Proaño, y la hizo tratar como duquesa, casándose con ella el 6 de enero de 1531, lo que produjo fuertes enfrentamientos con sus hijos.

Atesoró una magnífica biblioteca y una lujosa colección de tapices y vajilla de plata. ${ }^{140}$ Le gustaba deslumbrar y ello se manifestó en numerosas ocasiones como las bodas de sus

\footnotetext{
${ }^{138}$ Layna habla de no menos de catorce hijos. LAYNA SERRANO, F. Historia de Guadalajara y sus Mendozas..., Tomo III, p. 131.

${ }^{139}$ Con motivo de las fiestas del Corpus una compañía de gitanos actuó en Guadalajara hacia 1479. El joven conde de Saldaña, futuro III duque, se prendó de la bella María de Cabrera y fruto de su relación nació Martín de Mendoza el Gitano, quien llegó a ser arcediano de Guadalajara y de Talavera, abad de Santillana y de Santander y muchos otros cargos, con lo que acumuló una gran renta. Su padre intentó incluso conseguirle la mitra toledana. La historia lo recuerda también por haber tenido una relación con la hija de Juan de Cervantes, abuelo del escritor y miembro del Consejo del duque del Infantado; fruto de esa relación fue Martina de Mendoza. López DE Meneses, Amada. «Una Prima gitana de Miguel de Cervantes», Estudis Romànics, 14 (1969), pp. 247-250.

${ }^{140}$ Gracias al inventario post mórtem realizado en 1531 conocemos en detalle su colección de bienes suntuarios. GONZÁLEZ RAMOS, Roberto. «Evolución cultural y contraste generacional. Tres generaciones de
} 
hijos y los recibimientos a los numerosos ilustres que le visitaron. Suponemos que estos visitantes, que no olvidemos acudían con su séquito y sus músicos, generarían multitud de situaciones de intercambio y de influencia mutua, de forma que los diferentes estilos musicales nacionales y locales se fecundarían con estos contactos. Como veíamos antes, algunas de estas visitas han dejado testimonio a través de sus acompañantes. Veamos algunos casos.

A finales de 1501 los archiduques Felipe el Hermoso y Juana de Castilla, hija de los Reyes Católicos, preparaban su primer viaje a España. Un enorme cortejo atravesó Francia escoltado por un séquito de nobles flamencos, así como gran cantidad de sirvientes y numerosos carros que contenían muebles, fastuosas vajillas y tapices flamencos. ${ }^{141}$ Junto a ellos gran número de capellanes, cantores (entre lo que podemos destacar a Alexander Agricola y a Pierre de la Rue), nueve trompetas, tres tocadores de «musette», dos tambores de Alemania ${ }^{142}$ y un refuerzo de cuatro sacabuches contratados para la ocasión, todos ellos vestidos con lujosas libreas elaboradas para la ocasión. ${ }^{143}$ En enero llegaron a la frontera española y, tras atravesar Castilla, en marzo arribaron a Madrid. Un mes más tarde se presentó el duque del Infantado con trompetas, atabales y chirimías y con trescientos caballos y decenas de mulas acompañado por sus parientes.

Le merquedi, XXVII ${ }^{\mathrm{e}}$, le duc de l'Infantale, acompaignié de III ${ }^{\mathrm{e}}$ chevauls et de LX à IIIIXX mulets; avoec luy le comte de Concogne (?), le comte de Montagade, le comte de Pleige (?), l'andelental de Crussolle, don Iñigo de la Serde, don Jehan de Mendosse, don Anthoine de Mendosse et aultres; audevant desquels allèrent mons ${ }^{\mathrm{r}}$ de Bezenchon, le comte palatin, le jeune comte de Nassou, mons ${ }^{\mathrm{r}}$ de Veyre et pluseurs aultres gentilshomes. Vint ledict duc, sonnant trompettes, tamburins et chalemeux, descendre à court; fist la révérence à Monsigneur et à Madame; puis remota à cheval, el les prédicts signeurs le convoyèrent à son logis. ${ }^{144}$

la casa del Infantado y cuatro categorías de sus bienes (1531-1566)», Tiempos modernos: Revista Electrónica de Historia Moderna, 7/20 (2010), pp. 1-38.

${ }^{141}$ Calderón Ortega, José Manuel. Felipe el Hermoso. Madrid, Espasa Calpe, 2001.

${ }^{142}$ No queda claro si se trata de dos tambores o de un tambor y una flauta de Alemania. VANDER STRAeTEN, Edmond. La musique aux Pays-Bas avant le XIX siècle. 8 vols. Bruselas, G.-A. van Trigt, 18671888; vol. 7, p. 149 y 152.

${ }^{143}$ Más tarde se unió a la comitiva el corneta y laudista del Archiduque, Augustin Sobinger, quien tocó en Toledo junto a las capillas reales de Castilla, de Aragón y de Flandes el día de Pentecostés. VANDER STRAeTEN, E. La musique aux Pays-Bas..., vol. 7, p. 149.

${ }^{144}$ LALAing, A. «Voyage de Philippe le Beau..., p. 172. Los parientes que acompañaron al duque del Infantado posiblemente fueran Bernardino Suárez, conde de Coruña, Pedro González de Mendoza, conde 
Tras pasar cuatro meses en Toledo, ${ }^{145}$ donde juraron como príncipes de Castilla y asistieron a multitud de ceremonias en las que no faltó la música, ${ }^{146}$ los días 8 y 9 de octubre los archiduques fueron alojados en el palacio del Infantado, de cuya visita solo nos queda la impresión que produjo en Lalaing el magnífico edificio, como ya vimos. El segundo día se celebró una corrida de toros y suponemos que festejos amenizados con música de los que no nos ha llegado ninguna crónica.

Tras la muerte de la Reina Católica en 1504, el duque se mantuvo neutral sin apoyar ni a Fernando ni a Felipe hasta la venida de los príncipes en 1506 cuando se decantó por ellos. ${ }^{147}$

Unos años más tarde en 1510, Germana de Foix, reina de Aragón, pasó por el palacio del duque, donde fue espléndidamente recibida.

La ciudad hizo adobar los caminos, proveyó a los regidores de galas para salir al recibimiento, organizó algunos festejos [...] gozaron de dos días de amenas fiestas populares mientras el real séquito y la gente noble se divertía en grande con los soberbios banquetes, músicas y danzas dadas en los magníficos salones palatinos, o corriendo cañas en la plaza inmediata prolijamente engalanada. ${ }^{148}$

En 1515 se casaron en Madrid Íñigo López de Mendoza, conde de Saldaña, e Isabel de Aragón, sobrina de Fernando el Católico. ${ }^{149}$ A la boda acudieron el rey Fernando y la reina

de Monteagudo, Fernando de Mendoza, conde de Priego, su tío abuelo Pedro Hurtado de Mendoza, adelantado de Cazorla, Íñigo de la Cerda, señor de Miedes y sus tíos Juan y Antonio Hurtado de Mendoza.

${ }^{145}$ El itinerario seguido por los archiduques se puede seguir en CERRO BEX, Victoriano del. «Itinerario seguido por Felipe el Hermoso en sus dos viajes a España», Chronica nova. Revista de historia moderna de la Universidad de Granada, 8 (1973), pp. 59-80.

${ }^{146}$ Knighton, Tess. «Una confluencia de capillas. El caso de Toledo, 1502», La Capilla Real de los Austrias. Música y ritual de corte en la Europa moderna. Madrid, Fundación Carlos de Amberes, 2001, pp. 127149.

${ }^{147}$ NADER, H. Los Mendoza y el Renacimiento..., p. 197. En la Biblioteca Nacional de Madrid se conserva una interesante carta de 1506 en la que Felipe el Hermoso escribe al duque del Infantado contándole el itinerario que pensaba seguir después de su desembarco en Orense, de forma que se pudieran encontrar en el camino. BNE, Mss/020210. En la entrevista que mantuvieron Felipe y Fernando el Católico estuvo presente el duque del Infantado. El apoyo benefició al duque con la promesa de Felipe de la primera sede que quedara vacante, la confirmación de oficios de Guadalajara y la tenencia de su alcázar. SÁNCHEZ Prieto, A. B. La Casa de Mendoza..., p. 152.

${ }^{148}$ Layna Serrano, F. Historia de Guadalajara y sus Mendozas..., Tomo III, p. 60.

${ }^{149}$ En realidad la boda se celebró el año anterior en Guadalajara por poderes, pero hasta este año de 1515 no se reunió la pareja para consumar el matrimonio. 
Germana como padrinos de la boda. El día 12 de diciembre de $1517^{150}$ falleció la duquesa María de Pimentel y Pacheco. Fue enterrada en el panteón familiar de la iglesia del monasterio de San Francisco. ${ }^{151}$ Es muy posible que tras esto la mayoría de los criados de su Casa, y sobre todo los de su cámara, fuesen despedidos y otros pasaran a servir al duque. $\mathrm{Al}$ año siguiente debieron recibir en Guadalajara la visita de la hermana de la princesa Leonor de Austria, hermana de Carlos V.

Durante la guerra civil de las Comunidades (1520-22), ${ }^{152}$ de la misma manera que ocurrió con la sucesión de la reina Isabel, el duque del Infantado mostró una posición ambigua, no tomando partido hasta saber quién saldría ganador. ${ }^{153}$ Sin embargo la revuelta estalló en Guadalajara debido a la traición de los procuradores y fue alentada por un miembro del consejo del duque, el doctor Francisco de Medina, ${ }^{154}$ quien arrastró, parece ser, al primogénito del duque, el conde de Saldaña, a hacerse capitán de los rebeldes. El 5 de junio de 1520 la multitud rodeó el palacio del Infantado con la intención de que el duque castigara a los dos representantes traidores a la ciudad. Este se comprometió a interceder ante el rey garantizándolo con oro, plata y joyas. A pesar de los esfuerzos del duque, la muchedumbre expulsó a los procuradores y destruyó sus casas. Las represalias no se hicieron esperar y don Diego restableció el orden mediante la fuerza de las armas, mandó ahorcar a uno de sus cabecillas, el carpintero Pedro de Coca, y desterró a su hijo, el conde de Saldaña, a la villa de Alcocer. ${ }^{155}$ A finales de 1520, tras la batalla de Tordesillas, Valladolid se había convertido en la tercera capital de los comuneros y Guadalajara se había retirado. Después de la batalla de Villalar (23 de abril de 1521) el movimiento

${ }^{150}$ Layna afirma que ocurrió en 1518, LAYNA SERRANO, F. Historia de Guadalajara y sus Mendozas..., Tomo III, p. 67, pero las nóminas dicen que fue el 12 de diciembre Mss/11142, f. 46.

${ }^{151}$ El monasterio de San Francisco de Guadalajara, cuya obra fue concluida por el Gran Cardenal, cuenta con un panteón a imitación del panteón real del monasterio de Escorial. BonILLA ALMENDROS, Víctor. El monasterio de San Francisco en Guadalajara. Guadalajara, Ayuntamiento de Guadalajara, 1999.

${ }^{152}$ Pérez considera que hasta 1522, con la rendición definitiva de Toledo, no se puede hablar del fin de la revolución de las Comunidades. PÉREZ, Joseph. Los Comuneros...

${ }^{153}$ NAder, H. Los Mendoza y el Renacimiento..., p. 226 y SÁnChez Prieto, A. B. La Casa de Mendoza..., pp. 156-161. Esta postura fue la característica de los Grandes, como el Condestable o el conde de Alba de Liste, además del duque del Infantado. Se ocuparon de mantener el orden en sus respectivas ciudades asumiendo el poder en ellas, a pesar de ser ciudades de realengo. Ver PÉREZ, Joseph. Los Comuneros..., pp. 114-115.

${ }^{154}$ El doctor Medina formó parte del Consejo del duque por lo menos desde 1517 hasta 1522, desde 1525 a 1527 en que fue despedido y desde 1532 a 1549.

${ }^{155}$ Un relato más detallado de todo lo ocurrido en LAYNA SERrano, F. Historia de Guadalajara y sus Mendozas..., Tomo III, pp. 69-84. 
comunero quedó desarmado, pero prosiguió en Toledo, donde otra Mendoza, la hija del II conde de Tendilla, María Pacheco, resistió hasta que huyó a Portugal en febrero de 1522.

No bien habían acabado los sucesos de las Comunidades cuando Guadalajara se vió envuelta en otro episodio que hizo movilizar resortes del poder real y al que la Inquisición se puso con rapidez a atajar. Desde la segunda década del siglo se estaba desarrollando en la ciudad, además de en Toledo y otras poblaciones, la llamada secta de los «alumbrados». Si en el caso de la revolución se vio implicado el conde de Saldaña, en esta ocasión los herejes se concentraron alrededor de condesa Isabel de Aragón. ${ }^{156}$ Veremos más adelante en qué consistió la doctrina de los alumbrados o iluminismo.

El día 5 de junio de 1525 visitó Guadalajara el embajador veneciano Andrea Navagero:

Guadalajara es muy buen pueblo y tiene hermosas casas, entre las cuales hay un palacio que fué del Cardenal Mendoza, Arzobispo de Toledo, y otro del Duque del Infantado, que es el más bello de España. Aquí residen muchos caballeros y personas de cuenta y el Duque del Infantado, que aún cuando la ciudad y la tierra es del Rey, puede considerarse como señor del lugar. Este Duque tiene grandísimos gastos, y si bien sus rentas montan á cincuenta mil ducados, no cubren aquellos; tiene una hueste de doscientos peones y muchos hombres de armas, y una capilla de excelentes músicos, mostrando en todo ser muy liberal. $^{157}$

En ese mismo año de 1525 pasó por Guadalajara el prisionero rey de Francia, Francisco I, tras perder la batalla de Pavía. Fue recibido por el gotoso duque, Diego Hurtado de Mendoza, con grandes celebraciones. Pecha nos relata este acontecimiento:

El Recivimiento que Guadalaxara hiço al Rey de françia, fue solemníssimo; el duque don diego a la saçón estaba malo de la gota, y tan impedido, que no se podía menear, y por esta causa no salió fuera de su cassa a reçibir al Rey, pero enbió al conde de Saldaña su hijo, con sus hermanos, parientes, amigos, y todos los cavalleros de guadalajara a cavallo con muchas galas en sus personas, y luçidas libreas en Pajes, y lacayos: y era tanto el número destos señores, y Cavalleros, que haviéndosse juntado todos en el

\footnotetext{
${ }^{156}$ Incluso el propio duque del Infantado fue sospechoso de mantener ideas luteranas. HAMILTON, Alastair. El proceso de Rodrigo de Bivar (1539). Madrid, Fundación Universitaria Española, 1979, p. 36.

${ }^{157}$ Navagero, Andrea. «Viaje por España del magnífico Micer Andres Navagero, Embajador de Venecia al Emperador Carlos V», FABIÉ, Antonio Maria. Viajes por España de Jorge de Einghen, del Baroón León de Rosmithal de Blatna, de Francisco Guicciardini y de Andrés Navajero. Madrid, 1879, pp. 231-352; p. 250.
} 
Mamparo, Hermita fuera del Arrabal de la ciudad puestos en orden para reunirse con el Rey, las primeras trompetas, y atabales llegaban a la cassa del duque, y los postreros se estaban en la Hermita [...]

Aposentó al Rey en el quarto de los linajes, cuya sala grande y las demás quadras estaban tan adornadas con ricas colgaduras, y los techos hechos una asqua de oro y en toda la familia y criados tanto luçimiento, que le causo admiración al Rey [...]

Al día siguiente hubo toros, y juego de cañas de solo los cavalleros de Guadalajara, sin llamar a ningún otro de fuera: porque estava la çiudad tan poblada de cavalleros [...]

A otro día después de los toros, y cañas, tubo el duque don diego una lid de animales ferozes, para festejar al Rey de françia; y podíalo hazer con façilidad, porque tenía el duque para ostentaçión de su grandeza, una cassa de fieras, donde criaba leones, tigres, onças, y otros fieros animales; híçosse en la Plaça del duque una empaliçada, y hecharon dentro della un león, y un toro, arremetieron el uno al otro, que parezía que al primer ímpetu se havían de despedazar, y no fue assí, que el uno y el otro salieron vivos; acabado este encuentro, se retiraron entrambos, sin volver más acometerse. [...] dexo las músicas, los saraos, los bailes y danças, y los demás regocijos con que festejó al Rey de francia el duque don Diego. 158

La impresión que produjo semejante atención al rey de Francia es recogido por comtemporáneos como Fray Prudencio de Sandoval:

el duque del infantado le hizo tan costoso recibimiento y hospedage, que el francés quedó admirado: y solia despues decir muchas veces que el emperador le hacia injuria en llamarle como á los otros duque, sino que le habia de llamar por escelencia príncipe. ${ }^{159}$

También en estos años Carlos V pasó varias veces por el palacio de Guadalajara, en 1526 y 1528. Pero el hecho más relevante para los Mendoza en estos años fue la coronación como emperador del monarca en Bolonia. El duque no pudo acudir pues estaba viejo y enfermo, pero sí su hijo Íñigo López de Mendoza, quien fue a Toledo a reunirse con el Emperador, junto con lo más selecto de la nobleza alcarreña y una legión de criados que permanecieron varios meses en Italia conviviendo con la corte papal, dedicados a interminables fiestas y demostraciones de riqueza y ostentación. Por fin en 1530 se produjo la ansiada coronación. A la vuelta de tan rumbosa comitiva, los gastos acumulados fueron tales que el Emperador tuvo que solicitar al duque que pagara una deuda contraída por su hijo, el conde de Saldaña, con el mercader Antonio de Zelanda

\footnotetext{
158 PECHA. Historia de Guadalaxara..., , ff. 209v-210.

${ }^{159}$ Sandoval, Prudencio de. Historia del emperador Carlos V, rey de España. Madrid, Madoz y Sagasti, 1846, p. 265.
} 
por valor de 1.600 ducados (600.000 mrs.), cuando estaba en Italia, por mercaderías de lujo como sedas y otras cosas. ${ }^{160}$

El 30 de agosto de 1531 falleció don Diego Hurtado de Mendoza el Grande. Por ironías del destino otros dos grandes fallecerían ese año. El 20 de septiembre don Álvaro de Zuñiga, III duque de Béjar y el 18 de octubre don Fadrique de Toledo, II duque de Alba y rival del duque del Infantado. ${ }^{161}$ Se cerraba una época convulsa e inestable, a partir de este momento muchas familias nobles, como los Mendoza, se refugiaran en sus palacios apartándose en gran medida de la vida política.

Íñigo López de Mendoza (1493-1566) IV duque del Infantado, llamado «el Viejo», asumió el título y todas su deudas, pero también las suyas propias, que eran cuantiosas. ${ }^{162}$ Remodeló totalmente la Casa de su padre despidiendo a muchos criados y manteniendo a otros. Sobre su persona nos dice Pecha:

fue gran músico, tocaba todos los instrumentos, en especial en puntear un laúd era consumado [...] cobró fama de cavallero virtuoso, discreto, cuerdo, sabio, valiente, letrado, diestro en las armas, abentajado en música y gran cazador. ${ }^{163}$

Sin embargo a través de las nóminas de sus criados vemos que gran parte de sus músicos y cazadores, además de muchos pajes, fueron despedidos al poco de asumir la jefatura de la Casa de Mendoza.

A pesar de la reducción de su Casa, y al igual que ocurriera durante los tiempos de su padre «el Grande», el IV duque siguió recibiendo en su palacio ilustres invitados.

${ }^{160}$ Carta de 21 de noviembre de 1530. Layna Serrano, F. Historia de Guadalajara y sus Mendozas..., Tomo III, p. 401.

${ }^{161}$ Elliot ya planteaba hace años la visión de los dos bandos en Castilla, uno partidario de una España abierta y liderado por los cultos y cosmopolitas Mendoza y otro que representaba una visión más conservadora y cerrada, encabezado por el duque de Alba. ElLIOT, John H. La España imperial 1469-1716. Barcelona, RBA, 2006, p. 282. Nader establece también dos bandos, denominándolos el de los caballeros frente al de los letrados, con los Mendoza en el primero de ellos. NADER, H. Los Mendoza y el Renacimiento...

${ }^{162}$ En las nóminas de 1532 hay numerosos pagos correspondientes a deudas contraídas siendo conde de Saldaña, principalmente del año de 1525.

${ }^{163}$ PECHA. Historia de Guadalaxara..., ff. 219v- 220. 
En 1534 vinieron desde Flandes a Guadalajara Mencía de Mendoza, nieta del Gran cardenal y marquesa del Cenete, y su marido el conde de Nassau. ${ }^{164}$ Se instalaron en el castillo de Jadraque, propiedad de la marquesa, con la intención de recibir al Emperador a su paso hacia Túnez. En febrero se firmaron las capitulaciones matrimoniales entre María de Mendoza, hermana menor de Mencía, y Diego Hurtado de Mendoza, heredero del duque.

En 1535, el 3 de marzo, el emperador Carlos V visita de nuevo el palacio camino de Barcelona para la campaña de Túnez. ${ }^{165}$ El duque no acompañó al Emperador en esta campaña, pero puso a su servicio doscientos hombres, junto con otros tantos que puso la ciudad de Guadalajara. Además, muchos de sus parientes, como su hermano el marqués de Montesclaros, el conde de Coruña y su primo, Alonso Suárez de Mendoza, acompañaron a las huestes. ${ }^{166}$

En 1557 Felipe II entrega el señorío de la ciudad de Guadalajara a la infanta Leonor, su tía, disponiendo su alojamiento en el palacio del Infantado, lo que hace que el Duque se traslade a las antiguas casas del cardenal Mendoza, no volviendo a habitar el palacio hasta su muerte en 1566.

No faltaron en la ciudad del IV duque celebraciones de importancia. En 1560 se celebró en Guadalajara la boda entre Felipe II e Isabel de Valois, posiblemente en un

\footnotetext{
${ }^{164}$ A la muerte de su padre, Rodrigo Díaz de Vivar y Mendoza, en 1523, Mencía se había convertido en la mujer más rica de Castilla. Un par de años más tarde, con apenas 16 años, se casó con el conde de Nassau, capitán general de los ejercitos del emperador Carlos y mucho mayor que la condesa. El matrimonio fue concertado por el propio monarca. Tras el fallecimiento del conde, Mencía se volvió a casar, esta vez con Fernando de Aragón, virrey de Aragón y viudo de Germana de Foix, pasando a vivir en Valencia. Ya desde su estancia en Flandes mantuvo contacto con el erasmismo y en España se rodeó de numerosos humanistas, además de ser una importante patrona de las artes y gran coleccionista. Precisamente por ello la corte valenciana fue vigilada muy de cerca por la Inquisición. Datos actualizados sobre Mencía en: MuÑoz, Ferrán. Mencía de Mendoza y la Viuda de Mateo Flecha. Valencia, Institució Alfons el Magnànim, Diputació de València, 2001; GArcía Pérez, Noelia. Mencía de Mendoza. (1508-1554). Madrid, Ediciones del Orto, 2004; GARCía DE PAZ, José Luis. «Las mujeres de los Mendoza», Los Mendoza y el mundo renacentista. Foro Castellano, ANABAD, Universidad de Castilla la Mancha, 2011, pp. 35-49 y HiDALGO OgÁYAR, Juana. «Mencía de Mendoza, marquesa del Zenete, condesa de Nassau y duquesa de Calabria», Alegre Carvajal, Esther (ed.). Damas de la Casa de Mendoza. Historias, leyendas y olvidos. Madrid, Ediciones Polifemo, 2014, pp. 461-482.

165 Layna Serrano, F. El Palacio del Infantado..., pp. 56 y 139. No parece que el pasado comunero del duque fuera ningún impedimento para que las relaciones con el Emperador fueran buenas.

${ }^{166}$ Layna Serrano, F. Historia de Guadalajara y sus Mendozas..., Tomo III, pp. 160-162.
} 
intento de desagraviar a don Íñigo, expulsado de su palacio. Previamente el duque había acudido a Roncesvalles, en compañía del cardenal de Burgos, Francisco de Mendoza y Bobadilla, para recibir y escoltar a la princesa hasta Guadalajara. Para su entrada en la ciudad se fabricó un bosque de encinas con abundancia de animales, conejos, liebres, venados y aves varias, además de abundancia de pan, vino, queso y tocino que se iba repartiendo a todos los de la comitiva ...

Pasaron por todo aquel monte postiço, lleno de Caza y Volarería; llegaron a la puerta mercado, donde havía un arco triunphal grandíssimo, curiosíssimo, lleno de Versos y Jegoríflicos ingeniossos: Allí cerca del arco estava en Ayuntamiento, el Corregidor y Rexidores [...] tenían un rico palio de Brocado con diez y ocho varas doradas para llevar a la Reyna. [...] al entrar la Reyna debaxo del palio, cantaron los cantores de la Capilla real motetes en francés, y castellano, festexando la vienbenida, acompañando a las voces, todo género de instrumentos músicos: Fue la Reyna en su palio con el acompañamiento sobredicho hasta la plaza principal donde havía otro Arco triunfal, que en grandeza, Riqueza y curiosidad, excedía al primero; havía allí trompetas, y atabales, chirimías, música de cantores, danças, bayles, disfrazes y pandorgas; passó de la plaza, y llegó a la iglesia de san Andrés, donde estaban treynta Clérigos del cabildo de curas beneficiados de la dicha ciudad con su cruz, rebestidos con capas de Brocados. Apeose la Reyna y ellos cantaron el te deum Laudamus. ${ }^{167}$

Desgradaciadamente, no todo fueron alegrías tras la boda entre Felipe e Isabel. Pocas semanas después la pareja real se encontraba en Toledo para celebrar Cortes y recibir el juramento del príncipe don Carlos. En representación de la familia Mendoza se hallaba el primogénito del duque, don Diego Hurtado de Mendoza, marqués del Cenete y conde de Saldaña, además de muchos otros familiares y miembros de la nobleza alcarreña. Como era habitual, se celebraron torneos de caballeros, con tan mala suerte que en una justa el conde de Saldaña, que a la sazón contaba con cuarenta años, cayó del caballo, muriendo pocos días después a consecuencia del trágico incidente sin haber llegado a suceder a su padre.

En los últimos años de su vida y tras la muerte de su hijo en 1560 y de la duquesa en 1563, el duque se debió refugiar en concluir la impresión de su libro, ${ }^{168}$ Memorial de cosas

\footnotetext{
${ }^{167}$ PECHA. Historia de Guadalaxara..., f. 224.

${ }^{168}$ Según dice en el colofón el libro se empezó a escribir en 1545 y se concluyó en 1554.
} 
notables, para lo cual montó las prensas en los bajos de su palacio y contrató a Pedro de Robles y Francisco de Cormellas como impresores.

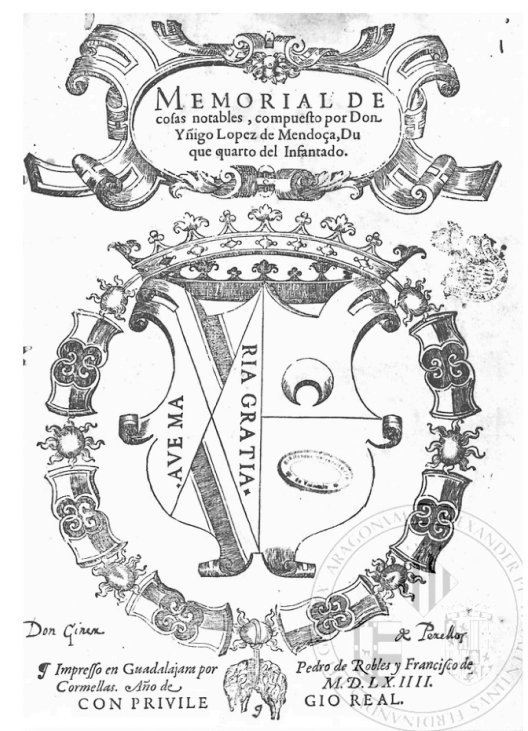

Fig. 10. Memorial de cosas notables, 1564

Tomamos palabras prestadas para describir el libro:

Pintoresca «Summa» de conocimientos mitológicos, histórico-literarios, pasan por sus viejas páginas -inesperado reflejo de lo que era entonces la cultura-: Nemrod, Semíramis, las Sibilas, los egipcios, los asirios, los siete sabios de Grecia, Darío, César, Aníbal y el mismo Nerón, en cuya tertulia palatina alternan los Apóstoles Pedro y Pablo; combinado todo ello en gracioso desorden y con gravedad erudita que confunde muy seriamente lo fabuloso con lo real. Sigue a los hechos una selección de dichos de autores pasados, que dan a conocer las tendencias espirituales del Duque. ${ }^{169}$

El Memorial comienza con una dedicatoria a su hijo Diego, conde de Saldaña y marqués del Cenete:

No es liviana carga (Marqués muy amado hijo) a la que el hombre bien inclinado, ponen los exercicios virtuosos de sus antepassados: especialmente de los que no contentos con la común medida

${ }^{169}$ Arteaga y Falguera, Cristina de. La casa del Infantado. Cabeza de los Mendoza. 2 vols. Madrid, 1940, vol. 1, p. 347. 
de sus yguales, quisieron señalarse más que ellos. [...] Y tened creýdo, que para ningún género de gente, haze tanto al propósito la lectura de buenos libros, como para las personas de vuestra manera: que pocas vezes hallan, quien fielmente les diga las verdades como los libros (que se llaman maestros mudos) se las enseñan. ${ }^{170}$

${ }^{170}$ Prólogo de LÓPeZ De MendozA, Íñigo. Memorial de cosas notables, compuesto por Don Ýñigo López de Mendoca, Duque quarto del Infantado. Guadalajara, 1564. 


\section{Moneda y salarios en el Antiguo Régimen}

Antes de ver las formas de pago en los siglos XV y XVI, veamos de una forma breve los dos sistemas monetarios vigentes que convivían en España en el siglo XVI. ${ }^{152}$ El castellano, de origen árabe, con maravedís, reales de plata (34 mrs.), ducados de oro (375 mrs.) y posteriormente escudos (350 mrs. desde 1535, $400 \mathrm{mrs}$. desde 1566); y el aragonés, común al usado en el resto de Europa desde la época de Carlomagno hasta la Revolución Francesa, basado en dineros, sueldos (12 dineros) y libras (240 dineros). Las equivalencias entre los dos sistemas varían según hablemos de Aragón, Valencia o Barcelona, pero podemos establecer un valor de 15,7 mrs. en Cataluña y $17 \mathrm{mrs}$. en Aragón por cada sueldo. El florín de oro, el denominado dolar bajomedieval, ${ }^{153}$ se introduce en el siglo XIV en Aragón durante el reinado Pedro el Ceremonioso, aunque también se acuñó en Castilla, con una equivalencia de 265 mrs. o 16 sueldos. La moneda de cuenta en Castilla era el maravedí y para cantidades mayores el ducado.

Los pagos por el trabajo en estos siglos se hacían mediante acostamiento, tierras y salario a los oficios militares y en forma de quitación y ración para los continos, oficiales (de los oficios), capellanes, músicos, etc.

\section{Quitación}

Según Covarrubias es: «el salario que se da; y así decimos ración y quitación». ${ }^{154} \mathrm{La}$ quitación sería una parte fija anual del salario que se percibía generalmente en tercios de año. Su nombre proviene de que se descontaba de los ingresos. Era la remuneración que se cobraba por ser nombrado para un puesto u oficio y no todos los empleados de una casa noble la percibían, muchos de ellos, los de menor categoría, solo recibían ración. La quitación más baja en la primera mitad del siglo XVI en las nóminas que estamos

\footnotetext{
${ }^{152}$ El cambio de algunas monedas fue modificado por los Reyes Católicos en la Pragmática de Medina del Campo de 1497. La más significativa fue la del real que se revalorizó de 31 mrs. a 34 mrs. FrANCISCO Olmos, José María de. «La evolución de los cambios monetarios en el reinado de Isabel la Católica según las cuentas del tesorero Gonzalo de Baeza (1477-1504)», En la España Medieval, 21 (1998), pp. 115-142.

${ }^{153}$ El florín antes de 1480 se cambiaba a $240 \mathrm{mrs}$. pero desde este año ya se establece el valor de 265 que, con ligeras variantes se mantendrá. RUEDA SABATER, Mercedes. «El florín: un "dolar” bajomedieval», En la España Medieval, 5 (1984), pp. 865-874.

${ }^{154}$ Covarrubias, Sebastián de. Tesoro de la lengua castellana o española. Madrid, 1611 (Reed. Madrid, Castalia, 1994), p. 846.
} 
estudiando era de unos $2.000 \mathrm{mrs}$. anuales y la más alta de $50.000 \mathrm{mrs}$. con alguna excepción superior. Con frecuencia, además de dinero, cobraban cantidades fijas de trigo como parte del salario. Los criados que tenían montura ${ }^{155}$ podían cobrar una parte de cebada, que solía ser de 45 fanegas anuales por cada animal.

Comprobamos continuamente a través de las nóminas del Infantado como la parte correspondiente a la quitación, y a veces de la ración, la iban cobrando los criados del duque adquiriendo a cuenta diversas mercaderías en casa de los mercaderes de Guadalajara (Diego López Perea, Francisco de Ribera, Antonio y Manuel Meléndez, etc.) los cuales a final de año, o por tercios, presentaban las facturas al contador del duque y cobraban todo junto.

\section{$\underline{\text { Ración }}$}

De nuevo Covarrubias nos dice que es «la parte que se da a cada uno de los criados por cada día». ${ }^{156}$ Es una especie de manutención o mantenimiento diario del criado que se cobra de la despensa. ${ }^{157}$ Esta parte se podía percibir de dos maneras, en dinero, cuando el criado no residía en la casa permanentemente, con lo que comía y dormía fuera de ella, o en forma de alimentos de la botillería cuando residía en la casa, o en las caballerizas, por ejemplo. Es frecuente encontrar en las nóminas después de la quitación la expresión «demás del pan e vino que lleva en mi botillería».

La cantidad percibida dependía mucho del rango del sirviente, así por ejemplo, para los años de entre 1520 y 1540 un paje o un mozo de caza podía cobrar 10 reales al mes, lo que hace $4.080 \mathrm{mrs}$. anuales o mas o menos $11 \mathrm{mrs}$. diarios y un oficial de rango medio entre 15 y 30 reales al mes. (6.120-12.240 mrs. al año). En el nivel superior, continos por ejemplo, podían llegar hasta 30.000 mrs. anuales de ración.

\footnotetext{
${ }^{155}$ Los caballeros y cazadores solían tener caballo, mientras que las mujeres, clérigos, atabaleros o niños, mula. También era muy frecuente el uso de hacaneas para mujeres.

${ }^{156}$ Covarrubias, S. Tesoro..., p. 848.

${ }^{157}$ TORRES SANZ, David. La administración central castellana en la Baja Edad Media. Valladolid, Secretariado de Publicaciones, Universidad de Valladolid, 1982, p. 68.
} 
Conocemos la composición de las raciones sencillas cuando se cobraban «en la mesa» en forma de alimentos, ${ }^{158}$ donde se incluía pan, vino, carne y pescado. A lo largo del año se consumía 200 días de carne y 160 de pescado. Así cada día:

- Dos panes cada día (de media libra cada uno, algo menos de medio kilo).

- Una libra y media de carnero (equivalente a 4,5 mrs.)

- Pescado (equivalente a 3 mrs.)

- Dos cuartillos o un azumbre de vino (aproximadamente un litro diario)

En raciones de mayor nivel se incluía una vela diaria y la cantidad de vino era un azumbre diario (dos litros, más o menos). Los pajes no solían recibir vino. En algunos casos los criados de niveles más altos podían tener derecho a asistencia médica y gastos de botica. ${ }^{159}$

Todo esto, y a a falta de los los documentos de la despensa junto con las nóminas de quitaciones, lo que raramente ocurre, hace tremendamente complicado calcular exactamente cuánto cobraba un criado, pero tenemos datos bastante precisos. Este hecho ya ha sido advertido y lamentado por muchos historiadores.

La remuneración concedida a los civiles se denominaba con frecuencia «sueldo», o «renta»o «quitación». Esta quitación era una retribución fija, anual, que se acompañaba de una «ración»o indemnización por día de servicio. Cuando el criado «servía» de forma continuada, percibía una «quitación y ración» que correspondía exactamente a los días de trabajo efectivo. El total del salario es rara vez conocido. ${ }^{160}$

${ }^{158}$ Los datos provienen de la Casa de Alba hacia mediados de siglo XVI. CALDERÓn OrTEGA, José Manuel. El ducado de Alba. La evolución histórica, el Gobierno y la Hacienda de un Estado señorial (siglos XIV-XVI). Madrid, Dykinson, 2005; p. 366. Coinciden más o menos con lo que se pagaba en la Casa del Infantado; así por ejemplo en 1562 se especifica en el salario de Juan Navarro, mozo de cámara: 6.000 mrs. de acostamiento «demás de un vestido que yo le mando librar e libra y media de carnero e un pan de dos libras e medio açumbre de vino». BNE, Mss/11141, f. 324v.

${ }^{159}$ Aunque sea un poco tardío, en 1642 el mayordomo del duque, Juan Alonso de Nassau, disfrutaba de estos derechos. CARRASCO, Adolfo. El poder de la sangre..., p. 385.

${ }^{160}$ GERBERT, Marie Claude. La nobleza en la Corona de Castilla. Sus estructuras sociales en Extremadura (14541516). Cáceres, Institución cultural «El Brocense», 1989, p. 150. 
No obstante a menudo no está tan clara la diferencia entre los anteriores conceptos y por el mismo oficio uno podía cobrar quitación y otro ración. ${ }^{161}$

Con mucha frecuencia los criados recibían vestuario y calzado o dinero para ello, principalmente los que utilizaban librea, como es el caso de alabarderos, ministriles, trompetas y pajes. ${ }^{162}$

\section{Acostamiento}

Los pagos militares se hacían de varias maneras. En primer lugar los continos, puesto que vivían en la casa del señor o le acompañaban permanentemente, recibían un salario y eran mantenidos por el patrón. Pero además, dentro de las tierras de señorío los caballeros e hidalgos tenían que prestar un servicio militar para lo que el señor les pagaba una pensión, llamada acostamiento, que les obligaba a mantener caballo y armas en buen estado. ${ }^{163}$ Cuando acudían al servicio del patrón, además del acostamiento, cobraban un salario diario, que en 1535 ascendía a dos reales $(68 \mathrm{mrs}.){ }^{164} \mathrm{Un}$ tipo de pago de acostamiento es el denominado tierras en donde los pagos se hacían sobre señoríos o tierras determinadas, de ahí el nombre. Con el tiempo ambos conceptos, acostamiento y tierras, llegaron a confundirse.

Estre sistema, además de permitirle mantener un ejercito dispuesto para actuar en cuanto se le reclamara, permitía fidelizar a determinadas personas en ciudades de realengo y que, por tanto, no eran vasallos del señor sino del rey.

Para obtener allegados era frecuente la entrega de cantidades fijas que permitían al banderizo vivir a costa de su patrono, al menos en parte, a cambio de la prestación de servicio militar a caballo cundo le

161 TORRES SANZ, D. La administración central ..., p. 68.

${ }^{162}$ Vemos con frecuencia en las nóminas que los pajes reciben poco más de $1.000 \mathrm{mrs}$. para el calzado, o que por ejemplo como pasó en 1534 se les retenga su salario de 2.000 mrs. por haber recibido librea. BNE, Mss/11141, f. 10.

${ }^{163}$ Con frecuencia se realizaban alardes para comprobar el estado de las monturas y las armas.

${ }^{164}$ Sobre todo estas cuestiones militares y de forma muy detallada SÁNCHEZ PRIETO, A. B. La Casa de Mendoza..., pp. 213 y ss. 
fuera requerido: esta práctica, denominada acostamiento, guarda semejanza con la inglesa de época lancasteriana bautizada como «bastard feudalism», y sus efectos políticos parecen semejantes. ${ }^{165}$

\section{Merced}

Era frecuente también que los criados recibieran mercedes en dinero por varias razones. Una de ellas y muy frecuente era por motivo de su casamiento. Francisco de Barreda, secretario del duque, recibió 100.000 mrs. para ayuda de su casamiento que recibió en los años 1536, ${ }^{166} 1537,{ }^{167} 1538 .{ }^{168}$ Diego de Reinoso, criado y vecino de Guadalajara, recibió 200.000 mrs. por el mismo concepto desde $1537 .{ }^{169}$ Incluso por el casamiento de sus hijos podían recibir mercedes. Diego López de Orozco, mayordomo mayor, percibió 1.000 ducados por el casamiento de su hijo en $1541 .{ }^{170}$

El traslado y la ayuda para la nueva casa, ${ }^{171}$ cuando alguna hija de un criado ingresaba en un convento, ${ }^{172}$ el vestuario, ${ }^{173}$ eran otras razones posibles para la recepción de mercedes.

Con motivo de determinadas celebraciones también se podían recibir mercedes. Muy frecuente es el aguinaldo de navidad. Por ejemplo los trompetas del Infantado recibieron por este concepto 4.250 mrs. en 1530 y $1531 .{ }^{174}$ Con el fallecimiento del patrón los criados más allegados solían aparecer en los testamentos con donaciones de ciertas cantidades de dinero.

${ }^{165}$ Ladero QueSADA, Miguel Ángel. «Corona y ciudades en la Castilla del siglo XV», En la España Medieval, 8 (1986), pp. 551-574; p. 557.

${ }^{166} \mathrm{BNE}, \mathrm{Mss} / 11141$, f. 64.

${ }^{167}$ BNE, Mss/11141, f. 86v. y 136v.

${ }^{168}$ BNE, Mss/11141, f. 111.

${ }^{169}$ BNE, Mss/11141, f. 86v. y 136v.

${ }^{170} \mathrm{BNE}, \mathrm{Mss} / 11141$, f. 195. En realidad el hijo del mayordomo era pariente del duque, pues Diego López de Orozco estaba casado con María de Mendoza, hija natural de Juan Hurtado de Mendoza, tío del III duque.

${ }^{171}$ Francisco de Labrena recibió en 1536750 mrs. para asentarse en Arenas como redero del duque. BNE, Mss/11141, f. 54v.

${ }^{172}$ En 1542 la sobrina del tesorero recibía una merced anual de $2.000 \mathrm{mrs}$. por permanecer en el convento de la Piedad. BNE, Mss/11141, f. 207.

${ }^{173}$ En 1516 Hurtado, guarda en Espinosa, recibe $4.000 \mathrm{mrs}$. de merced para su vestuario. BNE, Mss/11142, f. 64v.

${ }^{174}$ BNE, Mss/11142, ff. 300v. y 316. 


\section{Rentas de la nobleza española}

Para poder valorar los gastos producidos por el mantenimiento de la Casa y Corte del Infantado, es importante conocer las rentas de la nobleza y para ello contamos con la inestimable ayuda de Lucio Marineo Sículo, quien en su obra De las cosas memorables de España, publicada en 1539, nos da una relación de los ingresos de prelados y títulos de España. Dice así:

Pienso que hare cosa muy agradable si escriviere brevemente de los Perlados/ y Grandes de España: y de las ordenes, y officios que ay en la corte de los Reyes. [...] Entre los Perlados de España que son por cuenta cinquenta y cinco: el Arçobispo de Toledo precede a los otros/ en dignidad/ honrra/ y renta. Porque es Gran Chanciller de Castilla: y tiene por razón de su dignidad el Primado de las Españas. Tiene de renta más de ochenta mil ducados. Arçobispo de Sevilla veynte y quatro mil. [...] Quedanos agora por dezir de los grandes de España: y de la renta que tiene cada uno. La qual aunque no se puede enteramente colligir: lo pornemos sugun nuestro juyzio/ y de otros/ poco más/ o menos: y por ventura daremos no muy lejos del hito. [...] Duque del Infantazgo/ Marques de Santillana, Conde del Real de Mançanares/ y de Saldaña/ de la casa de Mendoça/ y de la Vega/ Cinquenta mil. ${ }^{175}$

RENTAS DE LOS PRELADOS SEGÚN MARINEO SÍCULO ( 1539)

\begin{tabular}{cc}
\hline Dignidad & Renta anual (Ducados) \\
\hline Arzobispo de Toledo & 80.000 \\
Arzobispo de Sevilla & 24.000 \\
Arzobispo de Santiago & 20.000 \\
Arzobispo de Granada & 10.000 \\
Obispo de Burgos & 20.000 \\
Obispo de Sigüenza & 20.000 \\
Obispo de Cuenca & 16.000 \\
\hline
\end{tabular}

Con gran diferencia, las rentas del arzobispo de Toledo, primado de España, superan las de todos los demás. Pero también superan la de cualquier Grande, por lo que, como veremos más adelante, el arzobispo disponía de una corte muy superior a la de algunos miembros de la alta nobleza.

Sabemos por otras fuentes que las rentas del cardenal Mendoza en los años 1491 y 1492 fueron, respectivamente, de cerca de 125.000 ducados y de 108.000 ducados más o

${ }^{175}$ MARineO Sículo, Lucio. De las cosas memorables de España. Alcalá de Henares, Juan de Brocar, 1539. Libro IV, ff. 22v-24. 
menos, elevadísima cantidad que incluso le permitió hacer préstamos a los Reyes Católicos. ${ }^{176}$

Veamos ahora una comparativa entre las rentas de los principales linajes de la alta nobleza, «los Grandes» junto con una enumeración de sus títulos.

RENTAS DE LA GRANDEZA SEGÚN MARINEO SÍCULO ( 1539)

\begin{tabular}{|c|c|c|}
\hline Títulos & Linaje & Renta anual (Ducados) \\
\hline $\begin{array}{l}\text { Duque de Escalona } \\
\text { Marqués de Villena }\end{array}$ & Pacheco & 70.000 \\
\hline $\begin{array}{c}\text { Duque de Sessa y de Terranova } \\
\text { Conde de Cabra }\end{array}$ & Fernández de Córdoba & 60.000 \\
\hline $\begin{array}{l}\text { Condestable de Castilla } \\
\text { Duque de Frías } \\
\text { Conde de Haro } \\
\text { Camarero mayor del Rey }\end{array}$ & Velasco & 60.000 \\
\hline $\begin{array}{c}\text { Duque de Medina Sidonia } \\
\text { Conde de Niebla }\end{array}$ & Guzmán & 55.000 \\
\hline $\begin{array}{c}\text { Almirante de Castilla y de Granada } \\
\text { Duque de Medina de Rioseco } \\
\text { Conde de Modica } \\
\text { Vizconde de Bas }\end{array}$ & Enríquez & 50.000 \\
\hline $\begin{array}{c}\text { Duque del Infantado } \\
\text { Marqués de Santillana } \\
\text { Conde del Real de Manzanares y de Saldaña }\end{array}$ & Mendoza & 50.000 \\
\hline $\begin{array}{l}\text { Duque de Alba } \\
\text { Marqués de Coria } \\
\text { Conde de Salvatierra }\end{array}$ & Toledo & 50.000 \\
\hline $\begin{array}{c}\text { Duque de Béjar } \\
\text { Justicia Mayor de Castilla }\end{array}$ & Zúñiga & 40.000 \\
\hline $\begin{array}{l}\text { Duque de Maqueda } \\
\text { Adelantado de Granada }\end{array}$ & Cárdenas & 30.000 \\
\hline $\begin{array}{l}\text { Duque de Medinaceli } \\
\text { Conde del Puerto }\end{array}$ & Cerda & 30.000 \\
\hline $\begin{array}{l}\text { Duque de Nájera } \\
\text { Conde de Triviño }\end{array}$ & Manrique de Lara & 30.000 \\
\hline $\begin{array}{l}\text { Duque de Alburquerque } \\
\text { Conde de Ledesma }\end{array}$ & Cueva & 25.000 \\
\hline $\begin{array}{l}\text { Duque de Arcos } \\
\text { Señor de Marchena }\end{array}$ & Ponce de León & 25.000 \\
\hline
\end{tabular}

Vemos que el linaje Mendoza solo es superado por los Pacheco, Fernández de Córdoba, Velasco y Guzmán.

${ }^{176}$ SAN ROMÁN, F. «Las obras y los arquitectos..., p. 154. 
Datos comparativos sobre las rentas de los títulos de España a lo largo de un siglo, entre 1520 y 1630, nos los proporcionan Atienza y Simón. ${ }^{177}$ Veamos, por ejemplo, la evolución de las rentas del duque del Infantado: ${ }^{178}$

\section{RENTAS DEL DUQUE DEL INFANTADO, SIGLO XVI}

\begin{tabular}{cccccc}
\hline Año & 1520 & 1539 & 1577 & 1580 & 1597 \\
Renta en ducados & 30.000 & 60.000 & 100.000 & 120.000 & 120.000 \\
\hline
\end{tabular}

De todas estas rentas, que nunca eran suficientes pues la alta nobleza vivía en estado de permanente ruina, gran parte se la llevaba el mantenimiento de su ejército, otra los numerosos pleitos por múltiples motivos que les obligaban a tener procuradores y letrados en la Corte y en las chancillerías. No menos importante era el gasto del mantenimiento de la Casa, la legión de criados que mantenían y que les servían. Aclaremos que la denominación de criado no se aplica solo a los de categoría inferior, sino a cualquiera que cobrara un sueldo del magnate, ostentara algún cargo en la casa e incluso se limitara a acompañar al gran señor. ${ }^{179}$

Este consumo doméstico ha sido estudiado por $\mathrm{M}^{\mathrm{a}}$ Concepción Quintanilla Raso:

El mantenimiento de «casa y corte» en el más amplio sentido -alimentación, vestido, adornoabsorbía una parte considerable de las rentas señoriales. Por lo que se refiere a la propia familia noble, sabemos que a fines de la Edad Media, como consecuencia del aumento de relaciones con Países Bajos e Italia, adquieren cada gustos más exóticos y ricos en cuanto a su indumentaria y al mobiliario y decoración de casas y palacios. Por otro lado, las cortes señoriales de esta época son extraordinariamente amplias y diversificadas: mayordomos, encargados de las caballerizas, acemileros, despenseros, maestresalas, cocheros, pajes, lacayos, criadas, esclavas, y algunos muy especializados y de categoría

${ }^{177}$ ATIENZA HeRnÁnDEZ, Ignacio. Aristocracia, poder y riqueza en la España Moderna: La casa de Osuna siglos XV-XIX. Madrid, Siglo XX de España, 1987 y ATIEnZA HeRnándeZ, Ignacio y Simón LópeZ, Mina. «Patronazgo real, rentas, patrimonio y nobleza en los siglos XVI y XVII: Algunas notas para un análisis político y socioeconómico», Revista internacional de sociología, 45/1 (Enero-Marzo 1987), pp. 25-75.

${ }^{178}$ AtienZa Hernández, I. Aristocracia, poder..., p. 350. También Lalaing nos da unos datos parecidos para los primeros años del siglo XVI: Le duc de l'Infantale [...] tiens XL florins d'or et maison de $V^{c}$ chevauls (el duque del Infantado [...] tiene 40.000 florines de oro y casa de 500 caballos). La equivalencia en ducados sería de más de veintiocho mil ducados. Lalaing, A. «Voyage de Philippe le Beau..., p. 233.

${ }^{179}$ Domínguez OrTiz, Antonio. Las clases privilegiadas en el Antiguo Régimen. Madrid, Akal, 2012 (1 ${ }^{\text {a }}$ edición 1973), p.147. 
superior, como médicos, capellanes o letrados. El mantenimiento de todo ese staff al servicio del señor debía resultar muy gravoso. ${ }^{180}$

Estas cortes tenían la función principal de mantener el estatus o el modo de vida noble.

había que deslumbrar con el lujo para mostrar al mundo entero toda la magnificencia de su poder y superioridad social. La vida en las casas señoriales era como la de una pequeña corte en la que el monarca (el señor) y su familia vivían rodeados de criados de librea, fiestas interminables, partidas de caza, copiosas y suculentas mesas, lujosos mobiliarios, y un largo etcétera de bienes y posesiones que hacen extremadamente difícil, por no decir imposible, su cuantificación exacta por el historiador. ${ }^{181}$

En algunas ocasiones no solo el titular del linaje mantenía casa con criados, también su esposa y su primogénito, llegada una determinada edad, tenían que tener su propia estructura a pequeña escala.

Otra fuente de gastos importante eran los costosos casamientos y en el caso de los duques del Infantado, con sus más que prolíficas familias, tanto las dotes como las celebraciones eran muy gravosas. Así, por ejemplo, en 1513 se firmaron las capitulaciones matrimoniales para el casamiento de Íñigo López de Mendoza e Isabel de Aragón. La dote de la novia, aportada por el rey Fernando y por el padre de ella el infante Enrique Fortuna, duque de Segorbe, fue de doce cuentos (millones) de maravedís, es decir, 32.000 ducados. La parte aportada por el infante, 10.000 ducados, fue en oro, plata, joyas y tapicerías que incrementó el impresionante ajuar de doña Isabel, valorado en 20.000 ducados, donde no faltaron, incluso, tres esclavas negras. El duque aportó en concepto de arras 10.000 ducados, lo que representaba un tercio de sus rentas anuales. ${ }^{182}$

Sin intención de profundizar demasiado en el tema, podemos aportar algunos datos sacados de las nóminas sobre la situación económica en la Casa del Infantado. ${ }^{183}$

${ }^{180}$ QuinTANILla Raso, María Concepción. «Haciendas señoriales nobiliarias en el Reino de Castilla a finales de la Edad Media», Historia de la Hacienda española (épocas antigua y medieval). Homenaje al Profesor García de Valdeavellano. Instituto de Estudios Fiscales, 1982, pp. 767-798; p. 794.

181 GARCía HeRnÁn, D. La nobleza en la España..., p. 48.

${ }^{182}$ Layna Serrano, F. Historia de Guadalajara y sus Mendozas..., Tomo III, pp. 60-61 y 374-375.

${ }^{183}$ Confiamos en poder realizar más adelante un estudio más profundo sobre la estructura y los aspectos económicos en la Casa del Infantado, pero en el momento actual excede los límites de este trabajo. 
En 1511 las rentas de los señoríos del duque del Infantado fueron de 12.378 .491 mrs., es decir, 33.000 ducados más o menos. ${ }^{184} \mathrm{El}$ gasto ordinario de los salarios de la Casa, gobernadores, alcaides y el ejercito fue de $9.557 .022 \mathrm{mrs} .{ }^{185}$ De estos, $1.350 .000 \mathrm{mrs}$. corresponden a la despensa (donde se incluye la alimentación y las raciones), un $14 \%$. La familia directa (la duquesa, el conde de Saldaña y otros ${ }^{186}$ ) percibió un $10 \%$. Los oficiales un $13 \%$. La Capilla, considerando únicamente a los capellanes y mozos de capilla, supuso un gasto de 217.333 mrs., un 2 \%. Los cantores 397.136 mrs., un 4\%. El apartado dedicado a la música en donde se incluyen ministriles (sacabuches y chirimías), músicos de cámara y trompetas y atabales, supuso un gasto en dicho año de 335.333 mrs., un 3,5 \%. Si sumamos Capilla, cantores y música, cerca de un $10 \%$ del gasto ordinario de la Casa iba a parar a este apartado.

Pero como ya dijimos antes, una parte muy importante del presupuesto de las casas de la nobleza se la llevaba el ejercito. Para este año el Infantado destinó 2.659 .433 mrs., un 28 $\%$. Los alcaides de las fortalezas y gobernadores supusieron 333.000 mrs., un 3,5 \%.

Si hiciéramos las cuentas sobre las rentas totales podríamos decir que un quinto del total eran gastos militares. Si sumamos castillos y gobierno de los señoríos llegamos casi al tercio. El mantenimiento de la Casa, de puertas adentro, ${ }^{187}$ supondría más de 13.000 ducados o un $40 \%$ de las rentas percibidas en el dicho año.

\footnotetext{
${ }^{184}$ La cifra coincide bastante bien con lo afirmado por los observadores extranjeros. La sacamos de BNE, Mss/11142, f. 94v. y el desglose por señoríos ff. 93-94v.

${ }^{185}$ Conocemos los datos del duque de Medina Sidonia para 1509 cuyos ingresos fueron de alrededor de 11.000.000 mrs. y los gastos 9.000.000 mrs., cifras muy similares a las del duque del Infantado, si bien fueron años de crisis para el ducado andaluz. NAVARRO SAINZ, José María. «Aproximación a los gastos señoriales de la Casa de los duques de Medina Sidonia a principios del siglo XVI», Huelva en su Historia, 3 (1990), pp. 175-194; p. 175.

${ }^{186}$ La parte más importante es la correspondiente a la duquesa pues mantenía Casa propia con sus dueñas y oficiales. El conde de Saldaña apenas contaba con 17 años por lo que, aunque también poseía Casa propia, era muy reducida.

${ }^{187}$ Continos, oficiales, Capilla y oficios musicales, más la despensa.
} 


\title{
Casa y Corte. Organización y funcionamiento
}

\author{
Si queréys nuevas saber \\ de la corte qué tal es \\ ay en ella haz y envés, \\ ay qué ver y qué no ver; \\ es la corte un gran poder \\ de real ayuntamiento \\ donde está todo el valer, \\ el valer y el merecer \\ de todo merecimiento. ${ }^{188}$
}

El concepto de Corte significa tanto el lugar donde reside el rey o el noble como las personas que le sirven y le acompañan. Esto ya se ve reflejado en las Partidas del Rey Sabio.

Corte es llamado el logar do es el rey, et sus vasallos et sus oficiales con él, que le han cotianamente de consejar et de servir, et los otros del regno que se llegan hi ó por honra dél, ó por alcanzar derecho, o por facer recabdar las otras cosas que han de veer con él: et tomó este nombre de una palabra de latin que dicen cohors, que muestra tanto como ayuntamiento de compañas, ca allí se allegan todos aquellos que han á honrar et guardar al rey et al regno. Et otrosi ha nombre en latin curia. ${ }^{189}$

Esto mismo expresado de una forma más poética de nuevo en palabras del poeta y músico Juan del Encina. ${ }^{190}$

Allí es corte real

donde el rey y reyna fueren, donde ellos estuvieren

Se puede ver una evolución desde el mundo tardorromano, pasando por el bizantino, el andalusí, hasta el mundo cristiano medieval. ${ }^{191}$ La Corte va a ser un espacio jurisdiccional, donde se administra justicia a través de su Consejo; un espacio espiritual

${ }^{188}$ EnCINA, Juan del. Obras completas. II. Poemas jocosos y cultos. Tragedia trovada a la dolorosa muerte del príncipe don Juan. Otros poemas a la muerte. Viaje a Jerusalén. RAmBALDO, Ana M. (ed.). Madrid, Espasa Calpe, 1978, p. 30 .

${ }^{189}$ ALFOnso X Las siete partidas del Rey Don Alfonso el Sabio: cotejadas con varios códices antiguos por la Real Academia de la Historia. Madrid, Real Academia de la Historia, 1807. Reproducción digital en www.cervantes.virtual. (en adelante Partidas) Tomo II, Partida II, Título 9, Ley 27, pp. 82-83.

${ }^{190}$ ENCINA, J. Obras completas. II, p. 30.

${ }^{191}$ Una muy documentada panorámica en FERnÁNDEZ De Córdova Miralles, Álvaro. La Corte de Isabel I. Ritos y ceremonias de una reina (1474-1504). Madrid, Dykinson, 2002, pp. 12 y ss. Fundamental como punto de partida: LADero Quesada, Miguel Ángel. «La Casa Real en la Baja Edad Media», Historia, instituciones, documentos, 25 (1998), pp. 327-350. 
donde se cuida la salud del alma del monarca a través de su Capilla y, por último, un espacio de poder donde tiene lugar la relación con su vasallos y por tanto la fiesta, los banquetes y torneos caballerescos. La nobleza, a imitación de la Corte real, va a crear sus propias cortes con las diferencias consustanciales a su estatus. ${ }^{192}$

Por otra parte, la Casa, que en muchas ocasiones se va a unir al concepto anterior mediante la expresión «casa y corte» incluso confundiéndose, donde no existe una clara diferenciación entre lo público y lo privado, a menudo va a constituir un espacio, físico y funcional, diferenciado donde está el rey, o el noble, con el conjunto de personas que le atienden en su servicio personal y en las funciones politíco-administrativas que dependen directamente de él. ${ }^{193}$ Estas personas son los llamados oficiales, pues son los encargados de los diversos oficios y se organizan de una forma piramidal.

Oficiales deben haber los emperadores et los reyes, et los otros grandes señores, de que se sirvan et se ayuden en las cosas que ellos han de facer. ${ }^{194}$

Con el tiempo «Corte» se va a asociar al lugar donde reside el poder jurídico, las Chancillerías en Castilla y «Casa» donde reside el rey o el noble. Se puede diferenciar, en palabras de Gonzalo Fernández de Oviedo, entre oficios de «governaçión e hazienda» de los de «la puerta adentro del palaçio». ${ }^{195}$

El ceremonial castellano recogido por Fernández de Oviedo fue el sistema por el cual, a imitación de la Casa real, se regían las casas nobles. Este ceremonial castellano se encuentra ya esbozado en las Partidas de Alfonso X y con ligeras variaciones es el que se va a mantener hasta el siglo XVI, cuando, debido al cambio de dinastía, se va a imponer el ceremonial borgoñón, mucho más complicado y con una mayor cantidad de oficios. ${ }^{196}$

\footnotetext{
192 «la Casa del Rey facilita un modelo de organización, en todos sus aspectos, para las diversas Casas de grandes nobles que han de gobernar y administrar sus respectivos estados señoriales, tan incrementados en la tardía Edad Media». Ladero Quesada, M. Á. «La Casa Real..., p. 328.

${ }^{193}$ Ladero Quesada, M. Á. «La Casa Real..., pp. 327-28.

${ }^{194}$ Partidas, II, Título 9, Ley 27, p. 56.

${ }^{195}$ FERNÁNDEZ DE OviEDO, Gonzalo. Libro de la Cámara Real del príncipe don Juan, oficios de su casa y servicio ordinario. Fabregat Barrios, Santiago (ed.). Valencia, Publicacions de la Universitat de València, 2006, p. 82.

${ }^{196}$ Felipe I trajo el ceremonial borgoñón a Castilla manteniendo los usos castellanos, pero su corta vida abortó el intento de imponerlo. Carlos $\mathrm{V}$ mantuvo de forma independiente las Casas borgoñona y
} 
Se da la circunstancia de que varias Casas podían coexistir simultaneamente. Sabemos que al mismo tiempo que el duque del Infantado tenía su Casa, la duquesa mantenía la suya propia, aunque mucho más reducida y el conde de Saldaña, también. ${ }^{197}$

Volviendo a los usos castellanos, los oficios principales de la Casa son el Mayordomo mayor, el Camarero mayor, el Capellán mayor y el Caballerizo mayor. Era frecuente que con la muerte del titular de la Casa los oficios se extinguieran, despidiendo a todos los oficiales, produciéndose a continuación la confirmación de algunos y la sustitución de otros por los de la Casa del heredero u otros nuevos. ${ }^{198}$ La principal razón de esto es que el heredero de un título solía tener su propia Casa montada y cuando fallecía su antecesor incorporaba su propia gente de confianza. Así lo dice la Crónica de Enrique IV:

E la costumbre que en tal caso los Reyes de España guardaron fue, que cuando Rey nuevo avían, los ofiçiales que en el tiempo que era príncipe toviesen los ofiçios; e los ofiçiales del Rey pasado los tales nuevos reyes fiçiesen alguna merced en enmienda de los ofiçios que asy les mandavan dexar. ${ }^{199}$

El Mayordomo era el oficial de mayor rango, de él dependían todos los demás oficios. En las casas reales era un título honorífico y tenía a su cargo a otros mayordomos o tenientes de mayordomo. Según González de Oviedo «cuyo nombre en sí él mismo dize que es el mayor de la casa, entre los ofiçiales della». ${ }^{200}$ Era responsable de la administración hacendística de la casa, los nombramientos de oficiales, la alimentación, lo que implicaba cocina, mesa, despensa y botillería, la caballeriza y la acemilería. Además de su salario, ${ }^{201}$ percibía un porcentaje sobre cada oficial que se asentaba en la casa y un

castellana, pero en 1548 encargó al duque de Alba la sustitución del ceremonial castellano por el de la corte de Borgoña para su hijo el principe Felipe, de forma que el 15 de agosto, día de la Asunción, se impuso el nuevo protocolo.

${ }^{197}$ A partir de cierta edad, que oscilaba entre los 14 y los 18 años, los herederos de la corona o altonobiliarios disfrutaban de su propia Casa. GonzÁlez MArrero, María del Cristo. La Casa de Isabel la Católica. Espacios domésticos y vida cotidiana. Ávila, Institución «Gran Duque de Alba» de la Diputación Provincial de Ávila, 2005, p. 41.

${ }^{198}$ Así ocurrió en la Casa del Infantado a la muerte del III duque, que tengamos constancia y en la de Alba en varias ocasiones. CAlderón OrTega, J. El ducado de Alba..., p. 326.

${ }^{199}$ Citado por: FERNÁNDEZ DE CÓRDOVA, Á. La Corte de Isabel I..., p. 37.

${ }^{200}$ Fernández de Oviedo, G. Libro de la Cámara..., p. 87.

${ }^{201}$ Diego López de Orozco, primero mayordomo mayor del conde de Saldaña con un salario de 50.000 mrs. en 1517, a partir de 1532 figura como mayordomo mayor del ya duque con un salario de $97.000 \mathrm{mrs}$. 
porcentaje de las rentas que estaban a su cargo. Es frecuente la presencia de mayordomos y recaudadores judíos antes de la expulsión de 1492, como Ysaque Adaroque y Abrahem Gamison, mayordomo y recaudador en la Casa del Infantado respectivamente en 1482 y $1483^{202}$ o Daví de la Hija mayordomo en 1486.

Con el tiempo muchas de sus funciones económicas pasaron al Contador mayor $^{203} \mathrm{y}$ al Contador de la despensa y raciones. Este último «Señala los títulos de los ofiçios, e libra las raçiones dela despensa que se dan en dineros, e con su auctoridad e libramiento se dan las raçiones ordinarias a los que las tienen de aver por mandado e merçed del príncipe en su despensa». ${ }^{204}$ Además del salario que se indica en las nóminas, sabemos que los contadores cobraban los derechos de contaduría de 30 maravedís el millar (3\%), ${ }^{205}$ aunque en muchas ocasiones tenían que adelantar el dinero que faltaba en un año para cobrarlo al siguiente. Contaban con la ayuda de dos o tres oficiales de cuentas.

Todo lo relacionado con la despensa y cocina era supervisado por el mayordomo junto con el contador de la despensa. Por debajo de ellos el despensero, el botiller, el veedor, otros oficiales responsables del abastecimiento como el gallinero o el conejero, el aguador, el cerero. En la elaboración de los alimentos un panadero, un pastelero y varios cocineros. Todos ellos siempre asistidos por mozos y por esclavos de los que las nóminas poco o nada nos dicen.

El servicio de la mesa estaba a cargo del Maestresala a cuyo cargo se encontraban los pajes y mozos que la servían. Junto a él el trinchante, quien distribuía y cortaba los alimentos y el copero, oficial encargado de suministrar el vino y de impedir el envenenamiento del patrón.

que subiría en 1535 a 117.000 mrs. Junto a él su teniente de mayordomo Diego Meléndez y después Antonio de Barrionuevo con un salario de $40.000 \mathrm{mrs}$.

202 SÁnChez Prieto, A. B. La Casa de Mendoza..., p. 223.

${ }^{203}$ Alonso de Vallejo desde 1525 con un salario de 30 a 55.000 mrs., sustituido en 1540 por Martín de Cáceres con un salario de 150.000 mrs.

${ }^{204}$ Fernández De Oviedo, G. Libro de la Cámara..., p. 87.

${ }^{205}$ Su salario oscila entre 3000 mrs. y 15.000 mrs., pero el 3\% representaba más de 50.000 mrs. Estos derechos también eran percibidos por los recaudadores de tributos y rentas o receptores. 
este ofiçio deve tenerle ombre de buena casta, e que se presuma de toda limpieza, e lealtad, e buen recabdo, e que ame la vida de su señor e que sea polido; el qual ha de tener muy bien entendido qué vinos ha de tener para la copa, e la mejor agua que aya en la tierra e comarca donde la corte se hallare, e con mucho cuidado e a buen recabdo hazerla traer. E el mayordomo, e el veedor e el mismo copero han de conferir para que se le dé para la copa el mejor vino, e que el despensero lo haga traer, a cuyo cargo es aqueso, e lo ha de entregar al copero, fecha la salva ${ }^{206}$

Para el manejo de la vajilla estaba el repostero de plata y para la preparación de la mesa el repostero de estrados y el de paños.

Otro de los cargos de gran importancia es el de Camarero a cuyo cargo está todo lo que ocurre en la Cámara y que con el paso del tiempo va a ir tomando funciones del mayordomo. Era responsable directo de la atención personal al levantar y acostar del señor, de su vestuario, etc. Un simple ejemplo:

este ofiçio del camarero es muy grande e preeminente en la Casa real [...] al tiempo que el prínçipe se acostaba para reposar la noche, dava su alteza al camarero la orden del vestido que quería traer e vestirse el día siguiente, e el camarero mandava al moço de cámara que tenía las llaves della, como su teniente, que toviese para otro día, de mañana, aparejado todo aquello. [...] Por la mañana el camarero tomava la camisa, e el pañizuelo de nariçes e la cofia con que se devía de tocar la cabeça el prínçipe la noche venidera [...], llevávalo uno de los de la cámara e ivan a vestir al prínçipe. [...] en la noche, cuando el prínçipe se quería retraer, venía el camarero con los de la cámara, según es dicho, e después que se avía desnudado por mano del camarero hasta quedar en calças e jubón e ençima una ropa forrada en martas, o tal como según el tiempo convenía, asentávase en su silla e descalçávale los borzeguís uno de los moços de cámara. Fecho esto, salíanse los de la cámara e un poco antes los reposteros de camas, e guardavan la puerta por de fuera, e quedávase el camarero solo e descalçávale las calças e, quitado el jubón, dávale la camisa de noche e comunicava con su alteza el vestido de la mañana para el día siguiente. $^{207}$

La cámara era un espacio de gran importancia pues es un lugar íntimo, privado, donde la familia se rodea de sus personas de máxima confianza y donde se guardan los objetos de mayor valor. Todo lo relacionado con el vestido, el descanso y gran parte del ocio se

\footnotetext{
${ }^{206}$ FERnÁNDEZ DE Oviedo, G. Libro de la Cámara..., p. 124.

${ }^{207}$ FERNÁNDEZ DE Oviedo, G. Libro de la Cámara..., pp. 95-96.
} 
concentran aquí. Para ello cuentan, además del camarero con reposteros de camas, ${ }^{208}$ guardarropa, mozos y pajes de cámara, lavanderas, porteros que custodian los accesos ${ }^{209} \mathrm{y}$, por supuesto, un grupo de músicos a los que en ocasiones se podían unir los cantores o los ministriles. También tenía el duque varios médicos (físicos) y cirujanos que se ocupaban, junto con el barbero, de su bienestar físico y en algunos casos, como el médico principal, ${ }^{210}$ de supervisar la comida y probarla.

Ya hemos citado antes los pajes, vamos a verlos un poco mas detalladamente. Hacia los siete u ocho años el joven noble salía del entorno femenino y era el momento en que se iniciaba su educación. Los más favorecidos tendrían desde este momento casa propia con un ayo, un maestro y un mayordomo. Los de menos recursos entrarían en una casa noble a servir como pajes ${ }^{211}$ allí aprenderían a servir, el ejercicio de las armas y de las letras incluyendo la práctica de la música y la danza, porque la Corte:

\author{
es una escuela ecelente \\ de criança y cortesía \\ y es un bivir diligente \\ y un saber que al más prudente \\ da mayor sabiduría. ${ }^{212}$
}

Entre ellos se establecían dos categorías, siendo los más importantes los pajes de cámara, pues algunos de ellos optaban a diferentes cargos de oficiales como camarero, maestresala o reposteros. No está claro cuántos años podía servir un paje como tal, pues

208 «entoldan la cámara e hazen la cama en que duerme el prínçipe, e guardan la puerta más próxima al prínçipe». FERnÁndez DE Oviedo, G. Libro de la Cámara..., p. 116. Estos reposteros de camas, junto con los de plata, tenían salarios bastante altos, lo cual es lógico teniendo en cuenta que custodiaban el cuerpo y las riquezas del patrón.

209 «los porteros de sala guardan la puerta primera, e en casa del prínçipe conviene que sean ombres de bien, porque tienen cargo importante e no han de dar lugar ni dexar entrar a los que no se deven admitir de aquella puerta adentro, ni a personas sospechosas». FernÁnDEZ DE OviEDO, G. Libro de la Cámara..., p. 122.

${ }^{210}$ El mejor pagado de todos, por lo que pensamos que era el médico personal del duque, era el doctor Fabricio con un salario de 80.000 mrs. entre 1520 y 1530.

${ }^{211}$ Ver GONZALO SÁNCHEZ-MOLERO, José Luis. El aprendizaje cortesano de Felipe II (1527-1546). La formación de un príncipe del Renacimiento. Madrid, Sociedad Estatal para la Conmemoración de los Centenarios de Felipe II y Carlos V, 1999 y DíAz GiTO, Manuel Antonio. «La labor docente del maestro de pajes y de latín de Felipe II», Calamvs Renascens, 1 (2000), pp. 81-100. También existe la posibilidad de que ocurran ambas cosas. Sabemos que don Enrique, hijo del IV duque del Infantado, sirvió entre los pajes del príncipe Felipe antes de que le pusieran casa propia en 1535.

${ }^{212}$ ENCINA, J. Obras completas. II, p. 32. 
nosotros hemos visto en las nóminas del Infantado desde pajes que servían un par de años hasta otros que permanecían hasta 15 o 16 años, ${ }^{213}$ lo que quiere decir que entrarían muy jóvenes. ${ }^{214}$

Diego de Hermosilla dice que los pajes:

allende de ser hijos de buenos padres lo fueran por sí, á lo menos que tuvieran muestra dello conforme á sus años, porque de los que se sirven cuando niños, se fian y confian más comunmente cuando hombres por la afición que con la niñez se cobran; que en aquella edad más son compañeros que criados; y si estos aciertan á ser ruines y de malas costumbres, no puede dejar de pegársele algo al niño con quien tratan por razón de familiaridad é igualdad de los años, aunque el uno sea señor y el otro criado, de manera que no siendo virtuosos y bien inclinados cuando chicos, no le podrán ser provechosos, ántes le dañarán para entonces y para después. ${ }^{215}$

Otro espacio de gran importancia era la Capilla que trataremos con mucho más detalle en el capítulo siguiente junto a los músicos que servían en ella. También hay que destacar el Consejo que se encargaba de la jurisdicción, a imitación del Consejo real y del que el duque dispuso desde 1503. Estaba formado por letrados y presidido por el conde de Priego. Había también otros letrados ${ }^{216}$ que actuaban como procuradores del duque y que residían en Valladolid, sede de la chancillería.

Para concluir con los diferentes espacio nos queda hablar de la Caballeriza. A cargo de un Caballerizo mayor debe contar con grandes instalaciones, ${ }^{217}$ pues allí residen,

${ }^{213}$ Los hermanos Sancho y Francisco Cimbrón estuvieron al servicio del duque, constando como pajes, 15 y 16 años respectivamente.

${ }^{214}$ Gerbert afirma que entrarían sobre los 14 años, nosotros pensamos que en algunos casos mucho antes, principalmente los hijos de los oficiales y continos de la Casa. GERBERT, M. C.. La nobleza en la Corona de Castilla..., p. 144.

${ }^{215}$ Hermosilla, Diego de. Diálogo de los pajes. Rodríguez Villa, A. (ed.). Madrid, Imprenta de la Revista Española, 1901, p. 135. Sin embargo, también se queja Hermosilla del maltrato que reciben los pajes en la corte, el hambre que pasan y lo mal que los visten.

${ }^{216}$ Entre ellos estaba el licenciado Juan de Cervantes, abuelo del escritor, quien figura entre 1527 y 1531 cuando fue despedido, el 15 de febrero. En 1527 entre los pajes también aparece el «hijo de Cervantes», no podemos saber cuál. Sobre la relación con los Mendoza ver SERRANO y SANZ, Manuel. «El licenciado Juan de Cervantes y don Íñigo López de Mendoza, cuarto duque del Infantado», Boletín de la Real Academia Española, 13/41 (1926), pp. 18-43.

${ }^{217}$ Enfrente del palacio del Infantado, donde luego estuvo el palacio de Montesclaros, como ya vimos. 
además de los caballos, hacaneas y mulas, ${ }^{218}$ los mozos de espuelas, y los oficios cinegéticos, con sus cazadores, halconeros, mozos, lebreles, etc. Ya dijimos anteriormente que el duque tenía además una casa de fieras con leones, tigres y otros animales. También cuenta la Casa con el oficio de Acemilero mayor, responsable de los traslados y suministros.

No hay que olvidar el personal relativo a la seguridad. A imitación de la guardia fundada por Fernando el Católico en $1504,{ }^{219}$ el duque del Infantado contaba con una compañía de alabarderos, en número de $100,{ }^{220}$ entre 1520 y hasta enero de 1530, todos ellos vestidos de librea ${ }^{221}$ y dirigidos por el capitán Alonso Yáñez Campuzano.

Además de los oficiales en las nóminas vemos otros criados del duque. En primer lugar y tras la familia aparecen los continos, con muy altos salarios ${ }^{222}$ y algunos de ellos con otros oficios como mayordomo, maestresala, caballerizo, corregidor, letrado, gobernador, etc. Entre los apellidos vemos parientes de los Mendoza y muchos apellidos que se corresponden con el patriciado alcarreño ${ }^{223}$ que, en muchas ocasiones, ostentaba cargos municipales, por lo que también era una forma de controlar los oficios concejiles y fidelizar a la nobleza local en una ciudad, recordemos, que no era de señorío sino de

\footnotetext{
${ }^{218}$ Para el año de 1536 el caballerizo Vitores de Moraza tenía a su cargo dieciseis caballos, dos del duque y el resto de caza, tres mulas de la duquesa y cuatro mulas de carro y el acemilero Eugenio de Madrid cinco acémilas para la litera, una para el agua y doce más de servicio. BNE, Mss/11141, f. 55.

${ }^{219}$ Formada por un capitán, un teniente, un alférez, un abanderado, dos sargentos, dos cabos de escuadra, un tambor, un pífano y 100 alabarderos.

${ }^{220}$ Layna afirma que contaba con 40 alabarderos lo cual, según las nóminas, es incorrecto. LAYNA Serrano, F. Historia de Guadalajara y sus Mendozas..., Tomo III, p. 33. Sánchez Prieto aporta el dato correcto. SÁnchez Prieto, A. B. La Casa de Mendoza..., p. 225. Como dato curioso decir que cada uno cobraba un florín, 252 mrs., tal vez el mismo salario que daba a los suyos Fernando el Católico. Para la gente de las guarda, çient ombres a florín cada uno. BNE, Mss/11142, f. 167v.

${ }^{221} \mathrm{El}$ sastre les confeccionaba las libreas y residían de forma permanente en la casa ducal. Entre ellos había algunos negros, esclavos o liberados, cosa que ocurría en otras casas nobles. LADERO QUESADA, M. Á. «El modo de vida noble..., p. 304. También en otros grupos vemos criados negros cuyo único salario era el vestuario, y la manutención, claro. Es el caso de los mozos de espuelas Cristóbal de Luján y Miguel a los que se les da de vestir en 1527. BNE, Mss/11142, f. 282v. o de Diego del Jardín (podría tratarse también de un esclavo musulmán) liberado por el duque Diego Hurtado en su testamento y que luego vemos como mozo de espuelas en 1530 y 1531 y como hombre de pie entre 1534 y 1541. También Luis Sycon mozo de caballos en 1517 que recibe 1.000 mrs. BNE, Mss/11142, f. 55v.

${ }^{222}$ Hasta 100.000 mrs.

${ }^{223}$ Arellano, Arias Dávila, Bastida, Castilla, Loaysa, Morales, Paez de Sotomayor, etc. Apellidos que también encontramos entre los pajes.
} 
realengo. ${ }^{224}$ Este tipo particular de servidores palaciegos, y que también aparecen en las casas reales, aunque en algunas ocasiones no tendrían una función determinada, sí tendrían la de acompañar al duque en sus desplazamientos formando una especie de guardia personal de honor y entre ellos estarían los cargos superiores de los oficiales, como mayordomo mayor o caballerizo mayor, sin embargo los contadores consideraron innecesario consignar sus oficios en las nóminas, pues eran perfectamente conocidos en la Corte.

Las Casas nobiliarias no andaban muy alejadas de las Casas reales en cuanto a su grandeza y boato. La Casa de Isabel la Católica contaba con un personal de entre $400 \mathrm{y}$ 500 personas, cifra similar a la del rey de Inglaterra a mediados del siglo XV. ${ }^{225} \mathrm{El}$ III duque del Infantado disponía de entre 300 a 500 miembros en su Casa, ${ }^{226}$ contando únicamente continos, oficiales, capilla, músicos, caballeriza y caza, sin que sepamos cuántos mozos y esclavos les asistían.

Podemos intentar imaginar el efecto que produciría en la gente de Guadalajara, o de otros lugares, cuando el duque saliera acompañado por todo su séquito, por ejemplo en el año de 1527, con casi 600 criados en su casa: ${ }^{227}$ abriendo el cortejo sus cien alabarderos, con su capitán, su pífano y su atambor, seguidos tal vez por sus catorce trompetas ${ }^{228}$ y sus cuatro pares de atabales, tal vez después de éstos, o mezclados con ellos, cuatro sacabuches y otros tantos chirimías, todos ellos de librea, después y tras el rey de armas, veinte guardias a caballo, los cincuenta caballeros, entre la familia y continos, que acompañaban al duque, posiblemente además de algunas damas, tras ellos los catorce cazadores con sus pajes de caza y los cerca de ochenta pajes de su Casa. No debía pasar desapercibido semejante despliegue humano sonoro y visual.

${ }^{224}$ MARTínez Millán, J. y EZQuerra Revilla, I. J. «La integración de las élites sociales ...

${ }^{225}$ Fernández de CóRdova Miralles, Á. La Corte de Isabel I..., p. 138.

${ }^{226}$ A los que habría que añadir los 100 alabarderos.

${ }^{227} \mathrm{La}$ descripción es totalmente inventada por nosotros, no así el número de participantes cuyos datos sacamos de las nóminas. Nos inspiramos en la descripción dada por Robledo en ROBLEDo EsTAIRE, Luis. «La música en la Casa del Rey», Aspectos de la cultura musical en la Corte de Felipe II. Madrid, Alpuerto, Fundación Caja Madrid, 2000, pp. 99-193; p. 172.

${ }^{228}$ Posiblemente, los trompetas desfilaran distribuidos en varios grupos, como ocurría en la Casa real, teniendo en cuenta su elevado número. 


\section{La música en la Casa del Infantado en el siglo XVI}

A lo largo del Renacimiento la música juega un triple papel en el entorno cortesano [...] En primer lugar forma parte esencial del entretenimiento. En segundo lugar interviene en los servicios litúrgicos que se desarrollan en las capillas privadas. Y, en último lugar, aunque no el menos importante, figura su papel heráldico. ${ }^{229}$

En las nóminas del Infantado la parte musical, en la mayoría de los años, se organiza en: Capilla, Cantores, Música y Trompetas. Para su estudio a continuación usaremos esta división, pues, además, el orden refleja la relación de unos con otros. La capilla y los cantores intervienen a menudo juntos en la parte cultual, los cantores con los músicos en la parte lúdica y los músicos, específicamente los ministriles, junto con los trompetas en la parte representativa.

Por cuestiones prácticas, nos hemos visto obligados, debido a su enorme cantidad, a homogeneizar los nombres, ya que una misma persona puede aparecer a lo largo de los años con modificaciones sustanciales en su nombre o apellido. Pensemos que en el periodo que nos ocupa fueron muchos los secretarios y contadores que se ocuparon de redactar esas nóminas y las diferencias ortográficas son abundantes, además de que en muchos casos los criados son únicamente nombrados por su nombre de pila. Elegimos casi siempre la más frecuente o la forma actualizada cuando se trata de nombres de uso habitual, a menos que se trate de un nombre reconocido históricamente. Así Pedro por Pero, Fernando o Hernando, Luis por Luys, Mendoza por Mendoça, San Pedro por Sant Pedro y así una innumerable cantidad de casos que no podemos señalar cada vez, pues harían inmanejables las notas.

${ }^{229}$ GÓMEZ, Maricarmen (ed.). Historia de la música en España e Hispanoamérica. Vol. 2. De los Reyes Católicos a Felipe II. Madrid, Fondo de Cultura Económica, 2012, p. 21. 


\section{Capilla}

Desde muy temprano los duques del Infantado contaron con una Capilla bien surtida que se ubicó en el salón de linajes. ${ }^{230}$ Dice Pecha del III duque en su Historia de Guadalaxara:

Desde su tierna edad se mostró Nuestro don diego Hurtado de Mendoza, Pío, deboto y christianíssimo, y tubo tan grande afiçión a los offiçios y çeremonias de la iglessia, que hizo su cassa una iglesia, o Capilla Real, donde tenía sus Capellanes, Cantores, Menestriles, Órgano y otros instrumentos músicos conçernientes al officio divino.

Dedicó por Capilla suya la sala grande de los linajes, cuyo techo con Artesones dorados (que entonces estaba casi nuebo) hecho un asqua de oro, en el testero de la mano derecha un altar con un Retablo de figuras pequeñas de talla entera y media talla a la usança de aquel tiempo, que después cuando se deshizo la Capilla, se lo dieron al Combento de sant françisco de la dha çiudad donde sirbió de retablo en el Altar mayor, hasta que la duquessa sería Ana de Mendoza les hiço el que oy tienen, por los años de 1630 [...] decíansse cada día muchas missas en la Capilla, y assistiendo el algunas dellas, y todos los días de fiesta se decía una missa cantada a canto de órgano, y a esta siempre se hallaba presente el duque don diego.

La fiesta de corpus Christi la celebraba solemníssimamente, todo el octavario estava descubierto el sanctíssimo sacramento en su Capilla, y se cantaban missas, y Vísperas a canto de órgano; el primero día de la octaba hacia una proçessión muy solemne alrededor de los corredores altos de su cassa, que los tenía adereçados con ricas colgaduras, y quadros, con quatro altares a las quatro esquinas adornados con imágines, Reliquias, y piezas de oro y plata, y estos días havía muchas danças, comedias, máscaras, toros y juegos de cañas por deboçión y [...] del sanctíssimo sacramento y todos los ocho días desta octava no salía de cassa y cessaba de negociar [...]. ${ }^{231}$

La primera relación que conservamos de la Capilla del Infantado es de 1511. En ella vemos once capellanes entre los cuales hay un capellán mayor, un chantre y un capellán organista. Lamentablemente, no podemos precisar cuáles de los otros capellanes eran

${ }^{230}$ Este salón se utilizaba, además de para las ceremonias religiosas diarias y semanales, para otros actos relevantes de la Casa ducal. Por ejemplo, el día de Pascua de Resurrección de 1535 se celebró allí la boda entre María de Mendoza y Fonseca, hermana de la marquesa del Cenete, y Diego Hurtado de Mendoza, conde de Saldaña, y el 20 de enero de 1542, la boda entre María de Mendoza y Aragón, hija mayor de los IV duques, e Íñigo López de Mendoza, III marqués de Mondéjar y IV conde de Tendilla. No contamos con descripciones de las bodas, pero en ellas debió de haber gran despliegue de lujo y derroche.

${ }^{231}$ PECHA. Historia de Guadalaxara..., ff. 203v- 204. 
capellanes de coro y cuáles no. ${ }^{232}$ Aparece un segundo organista, pero recibió una merced, no salario, por lo que posiblemente estuviera jubilado. Además un sacristán y cuatro mozos de capilla. No encontramos reposteros, como sería lo habitual, porque, o bien son los que aparecen entre los oficiales designados únicamente como reposteros o los mozos de capilla se ocuparían de todo lo concerniente al aderezo y preparación de la capilla junto con el sacristán.

CAPILLA DEL III DUQUE DEL INFANTADO 1511

\begin{tabular}{lll}
\hline & Oficio & Salario $\mathbf{( M =}$ miles de maravedís $)$ \\
\hline GUZMÁN, Pedro de & Capellán Mayor & $23,333 \mathrm{M}^{1}$ \\
CÉSPEDES, Juan de & Chantre & $30 \mathrm{M}$ \\
TORRES, Alonso de & Organista y capellán & $30 \mathrm{M}$ \\
TORRES, Diego de & Organista y capellán & $10,5 \mathrm{M}$ merced \\
CASTILLO, Alonso del & Capellán & $15 \mathrm{M}$ \\
DÍAZ, Fernando & Capellán & $15 \mathrm{M}$ \\
FRÍAS, Pedro de & Capellán & $15 \mathrm{M}+4 \mathrm{M}$ merced \\
IZQUIERDO, Alonso & Capellán & $15 \mathrm{M}$ \\
LÓPEZ, Antonio & Capellán & $15 \mathrm{M}$ \\
MARTÍNEZ, Cristóbal & Capellán & $15 \mathrm{M}$ \\
MARTíNEZ, Jerónimo & Capellán & $15 \mathrm{M}$ \\
SÁNCHEZ, Sebastián & Capellán Capellanía Sr. D. Bernaldino & $15 \mathrm{M}$ \\
RIBERA & Sacristán & $6 \mathrm{M}$ \\
CLAVIJO, Gracián de & Mozo de capilla & $2 \mathrm{M}$ \\
CÓRDOBA, Pedro de & Mozo de capilla & $2 \mathrm{M}$ \\
PORTILLO & Mozo de capilla & $2 \mathrm{M}$ \\
SANTOS, Pedro de los & Mozo de capilla & $2 \mathrm{M}$ \\
\hline
\end{tabular}

TOTAL

11 capellanes (1 chantre y 1 organista), 1 sacristán, 4 mozos de capilla

${ }^{1}$ Desde $1^{\circ}$ junio por lo que su salario anual era de $40 \mathrm{M}$

\footnotetext{
${ }^{232}$ Alonso del Castillo figura en 1525 entre los cantores, por lo que no es improbable que fuera capellán y cantor.
} 


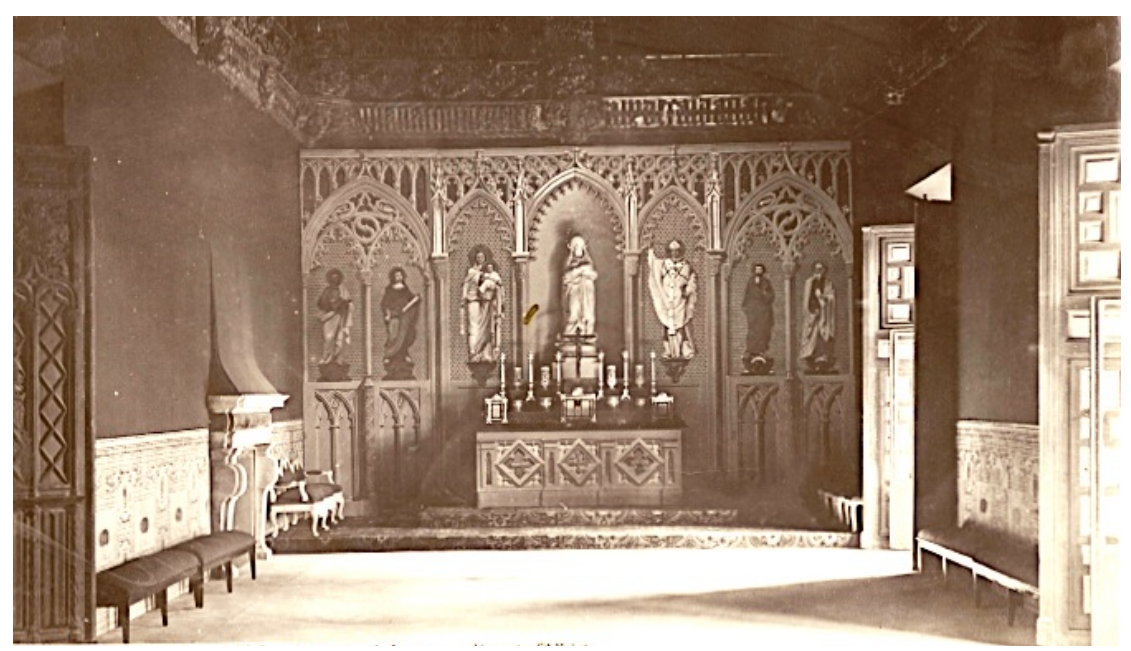

Fig. 11. Salón de los Linajes del Palacio del Infantado (Laurent, 1880, BNE.)

\section{Chantre}

Chantre tanto quiere decir como cantor, et pertenesce á su oficio de comenzar los responsos, et los himnos et los otros cantos que hobieren á cantar tambien en las procesiones que fecieren como en el coro: et él debe mandar et ordenar quien lea et cante las cosas que fueren menester de leer ó de cantar: et á él deben obedecer los acólitos, et los leedores et los salmistas. Et algunas eglesias catedrales son en que ha capiscoles que han ese mesmo oficio que los chantres. ${ }^{233}$

Efectivamente, el chantre es el capellán encargado de coordinar todos los aspectos litúrgicos tanto en el altar, misas y oficios, como en el exterior, las procesiones, por ejemplo. Además de entonar los cantos litúrgicos debía organizar los cantos y lecturas, vigilar a los que cantaban o leían y corregir sus fallos. La organización semanal era otra de sus responsabilidades y a él le tocaba imponer las penas, generalmente pecuniarias, de los desobedientes o negligentes. También le correspondía decidir sobre las intervenciones en canto llano o polifónicas, fueran vocales, organísticas o con la presencia de ministriles altos. El cuidado de los libros litúrgicos, así como de los relacionados con la organización de la capilla, la educación y vigilancia de los mozos de capilla, su selección y mantenimiento, formaba parte de su trabajo. También participaba en la selección de los

${ }^{233}$ Partidas. Partida I, Título VI, Ley V, p. 254. 
cantores y miembros del coro. Incluso el vestuario de los celebrantes y la cera que se usaba le competían. ${ }^{234}$

Uno de los salarios más elevados es el del chantre y capellán Juan de Céspedes, quien encontramos manteniendo su puesto y su salario durante 22 años, desde 1511 hasta 1532, con 30.000 mrs. anuales y 30 fanegas de trigo. Puede tratarse del capellán y cantor que sirvió a la reina Isabel desde 1495 hasta el fallecimiento de ésta en 1504 y que acompañó su féretro hasta Granada. ${ }^{235}$ Antes de servir en la casa de los Reyes Católicos había servido al cardenal Mendoza hasta su muerte y posteriormente desde 1505 a 1511 y desde 1514 a 1516 en la capilla aragonesa de Fernando, hasta que este último falleció en enero de ese año. ${ }^{236}$ Si esto fuera así habría empezado con el cardenal Mendoza, seguido en la corte de Isabel, pasando por la de Fernando, contratado en la del duque del Infantado, vuelto a asentar en Aragón y concluyendo de nuevo en Guadalajara. Por lo que se ve no tuvo nunca ninguna dificultad en conseguir un nuevo empleo tras el fallecimiento de sus ilustrísimos patrones.

\footnotetext{
${ }^{234}$ No conocemos ningún documento de la Casa del Infantado que detalle las competencias de cada uno de sus miembros así que tenemos que ver sus atribuciones en organismos similares o cercanos. Teniendo en cuenta que el cardenal Pedro González de Mendoza fue arzobispo de la catedral hispalense y después de la catedral primada, podemos extrapolar las funciones en la capilla del Infantado viendo lo que ocurría en las catedrales de Sevilla y de Toledo. Para la primera: GonZÁlez BARRIOnUeVO, Herminio. Francisco Guerrero (1528-1599) Vida y obra. La música en la catedral de Sevilla a finales del siglo XVI. Sevilla, Cabildo Metropolitano de la Catedral de Sevilla, 2000. Para la segunda: LOP OTín, María José. El cabildo catedralicio de Toledo en el siglo XV: aspectos institucionales y sociológicos. Tesis Doctoral, Universidad Complutense de Madrid, 2002.

${ }^{235}$ Juan de Céspedes fue asentado como cantor de la reina el 15 de enero de 1495 con un salario en ración de 20.000 mrs. TORRE, Antonio de la. La Casa de Isabel la Católica. Madrid, CSIC, 1954, p. 38. En 1497 ya consta como capellán y cantor. En 1499 recibe, junto con su hermano Fernando de Aguilera, 5.000 mrs. para vestuario. Al año siguiente otro tanto, así como en 1502, 1503 y 1504. En 150110.500 mrs. como ayuda de costa y 1504 otros 17.000 mrs. para una mula. TORRE, Antonio de la y Torre, E. A. de la. Cuentas de Gonzalo de Baeza tesorero de Isabel la Católica. 2 vols. Madrid, CSIC, 1956, pp. 350, 428, 505, 540-541, 567, 620, 628 y 649. En enero de 1505 recibe 5.750 mrs. en concepto de ayuda de costa por el desplazamiento desde Medina del Campo a Granada. LLORENS CISTERÓ; José Ma. Francisco Guerrero. Opera Omnia. Tomo X. Magnificats per omnes tono. Barcelona, CSIC, 1999, p. 40. Estos datos sobre Céspedes han sido recogidos también en KNIGHTON, Tess. Música y músicos en la corte de Fernando el Católico, 1474-1516. Zaragoza, Institución «Fernando el Católico» (CSIC), Sección de Música Antigua, Excma. Diputación Provincial, 2001. Además de su salario, y lo que percibiera de más en la capilla de la reina, sabemos que disfrutaba de un beneficio en Brihuega. FERNÁNDEZ DE CÓRDOVA, Á. La Corte de Isabel I..., p. 179.

${ }^{236}$ Son varios los cantores que provenientes de la casa del Cardenal de España fueron asentados por los Reyes Carólicos: Juan Ruiz de Madrid en 1493, Juan de las Heras, Juan Román y Pedro de la Puebla, además de Juan de Céspedes. KNIGHTON, T. Música y músicos..., pp. 105, 182-88 y 191-195.
} 


\section{Capellanes}

A ellos les corresponde el cuidado espiritual del duque, de su familia y de todos los criados que le sirven. Misas, oficios divinos, sacramentos, procesiones, pero además otro sinfín de funciones. Podemos ver en la casa de Alba cuáles eran sus atribuciones:

cuidar de que todos los criados confesarn y comulgasen al menos una vez al año, cobrándoles cédula de confesión y comunión por Pascua de Resurrección [...] siempre debería estar el capellán o un semanero para bendecir la mesa del duque [...] procurar que los criados vivan honestamente, cumpliendo con sus deberes religiosos, amonestándolos en su caso [..] repartir la carne que se sirviera en la mesa del duque los días de cuaresma o de pescado, entre pobres y necesitados [...] visitar semanalmente la enfermería y al resto de los criados enfermos ${ }^{237}$

De todos los capellanes el de superior salario es Pedro de Guzmán (40.000 mrs. anuales, aunque fue asentado a primeros de junio, por lo que cobró la parte proporcional), por lo que podríamos pensar que ostentara desde los primeros momentos el cargo de Capellán Mayor ${ }^{238}$ y tal vez confesor del duque. ${ }^{239}$ No lo volvemos a ver con ese nombre en las cuentas del Infantado, pero sí aparece hasta 1531, año de la muerte del III duque, mosén $^{240}$ Pedro con un salario de 30.000 mrs. anuales. La identificación de una persona con otra es bastante plausible.

También Francisco Ramírez percibía un salario alto, 25.000 mrs., pues era, además de capellán, sacristán mayor. ${ }^{241}$ Pedro de Frías, capellán y vicario del arcediano de Guadalajara, era otro de los capellanes que se mantuvo desde 1511 hasta su fallecimiento en 1534 con un salario de 19.000 mrs. ${ }^{242}$ El resto de los capellanes perciben un salario de 15.000 mrs. anuales.

${ }^{237}$ Calderón Ortega, J. El ducado de Alba..., p. 265.

${ }^{238}$ Así consta en las nóminas de 1542 hasta 1546.

${ }^{239}$ En 1531 fue uno de los testigos en el testamento del III duque, don Diego Hurtado de Mendoza y Luna. Reproducido en LAYNa Serrano, F. Historia de Guadalajara y sus Mendozas..., Tomo III, pp. 402 y 403.

${ }^{240}$ El título de mosen se utilizaba con frecuencia en Castilla, no solo para los clérigos y nobles provenientes del reino de Aragón, sino también a los de más allá de los Pirineos. RUCQUOI, A. II: Valladolid en la Edad Media. El mundo..., pp. 99-100.

${ }^{241}$ Además de sacristán mayor, había un sacristán menor que no debía ser capellán, pues su salario era muy inferior, tan solo 6.000 mrs., como algunos mozos de capilla.

${ }^{242}$ A partir de 1532 cobraba 22.400 mrs. porque las 40 fanegas de trigo se las pagaban en moneda a razón de 85 mrs. por fanega. Sabemos que Frías, a pesar de ser cura, mantenía en su casa una moza con la 
Junto a mosén Pedro y Pedro de Frías uno de los capellanes que más tiempo permaneció al servicio del duque fue Hernando de Espinosa (c. 1485), a pesar de que su ortodoxia católica fue puesta en duda por la propia Inquisición. ${ }^{243}$

\section{CAPILLA DEL DUQUE DEL INFANTADO 1517}

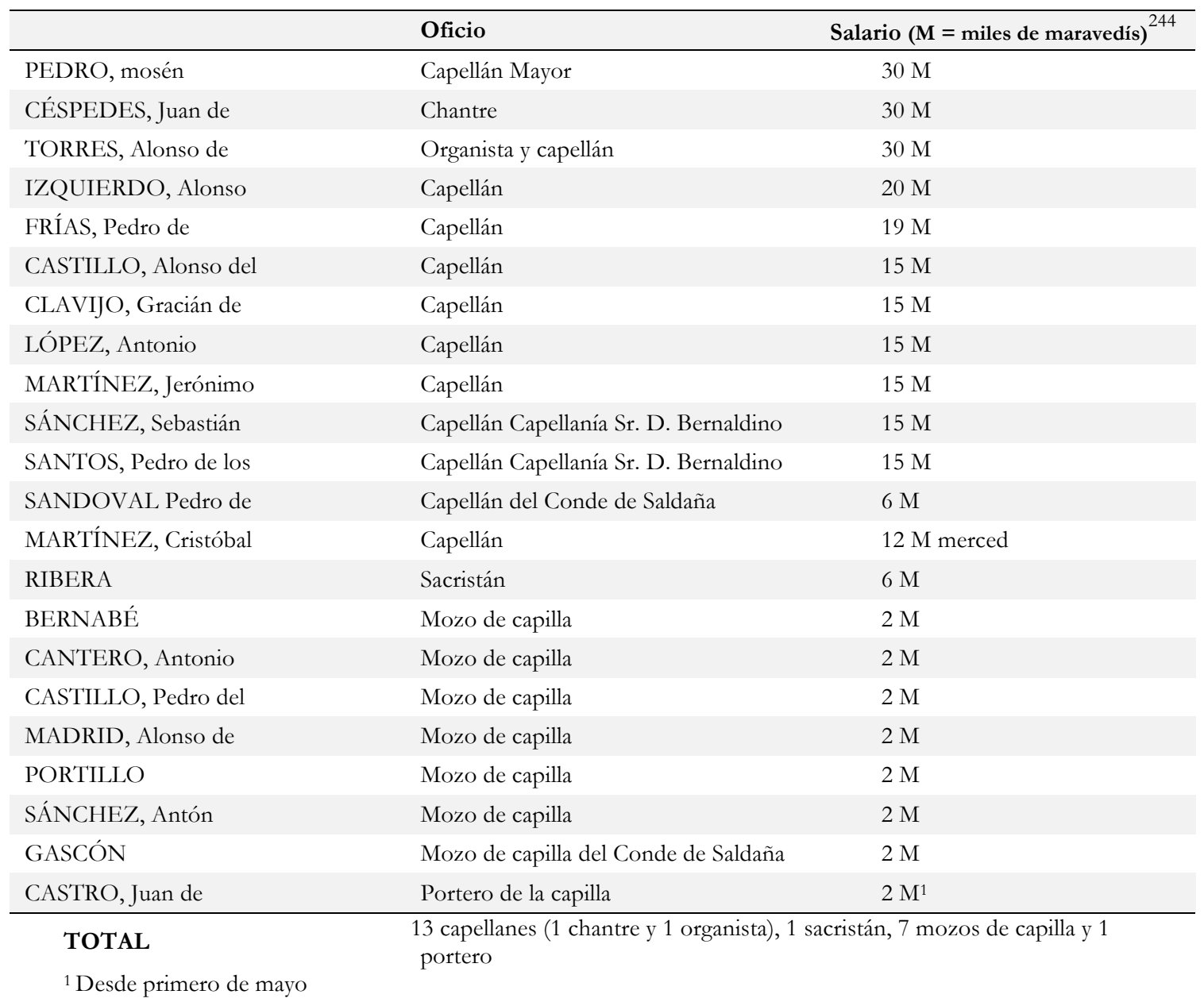

En 1517 volvemos a ver once capellanes en la capilla del Infantado, más uno, Cristóbal Martínez, que recibió una merced y, además, en este año de 1517 encontramos a un

que vivía amancebado desde antes de 1518 y que en 1538 ya había fallecido el dicho vicario. HAMILTON, Alastair. El proceso..., p. 69 y 94.

${ }^{243}$ En el proceso contra María de Cazalla, acusada de iluminada, Hernando de Espinosa fue requerido como testigo por la propia acusada, pero fue recusado por el fiscal por haber sido denunciado por iluminismo unos años antes. BATAILLON, Marcel. Erasmo y España. Estudios sobre la historia espiritual del siglo XVI. México, Buenos Aires, Fondo de Cultura Económica, 1966, p. 473.

${ }^{244}$ A partir de aquí utilizamos M para referirnos a miles de maravedís sin que lo volvamos a indicar. 
capellán y un mozo de capilla exclusivos del Conde de Saldaña, Íñigo López de Mendoza, que a la sazón contaba con 23 años. De nuevo un sacristán y seis mozos de capilla.

En los años siguientes el número de capellanes oscilará entre trece y dieciocho y a partir de 1522 tendremos dos sacristanes, un sacristán mayor, capellán y un sacristán menor. Desde 1532, con la muerte del III duque, habrá una reducción drástica que no se detendrá hasta que no queden más que dos capellanes.

\section{Organista}

La capilla del duque tenía sus propios organistas, independientemente de la cámara, donde había otros, como veremos un poco más adelante, con un sueldo muy inferior. Su función sería, casi con seguridad litúrgica o paralitúrgica.

El capellán organista ${ }^{245}$ Alonso de Torres (c. 1480), con salario de 30.000 mrs. anuales, estuvo al servicio del duque durante veinte años y percibía el salario de su hermano, del que desconocemos el nombre, que recibía 14.092 mrs. anuales en concepto de ración. Al año siguiente de abandonar su puesto, en 1531, encontramos un organista homónimo en la catedral de Segovia y que falleció el 15 de marzo de 1531, lo que hace factible la identificación de ambos. ${ }^{246}$ En este mismo año de 1511 tenemos el nombre de Diego de Torres, capellán y organista al que el duque otorga una merced de 10.500 mrs. (en realidad le regala la casa en la que habitaba en Buitrago) y una sobrepelliz, por lo que no sería descabellado pensar que Alonso sustituyera al jubilado Diego (su padre o su tío) o que se tratara de su anónimo hermano. Alonso de Torres consta como capellán entre 1522 y 1526 en otros archivos. ${ }^{247}$

${ }^{245}$ Alonso de Torres figura como músico de tecla, capellán organista.

246 Aguirre Rincón, Soterraña. «Torres, Alonso de (I)», DMEH, vol. 10, p. 398.

${ }^{247}$ En el Archivo Histórico Provincial de Guadalajara (en adelante AHPGu), citado por FREUND SCHWARTZ, R. En busca de liberalidad..., p. 364. 
El organista Alonso de Torres compartió desde 1523 su puesto con Baltasar Chacón. ${ }^{248}$ Este último, de quien no sabemos si además de organista era capellán, aunque creemos que no, permaneció al servicio del Infantado con un buen salario, superior incluso al de Torres, 50.000 mrs., hasta 1534. En algunos años, junto al salario en dinero, percibía 40 fanegas de trigo y 45 fanegas de cebada (cantidad que recibían todos aquellos que disponían de montura, fuese mula o caballo). Es posible que las habilidades del capellán Torres no fueran suficientes para el duque, pues el salario de Chacón era de los más elevados, solo superado por el maestro de capilla y superior al del capellán mayor o el chantre, incluso por encima de los oficiales de más alto rango de la Casa, ${ }^{249}$ lo que nos hace pensar que sus habilidades como tañedor debían de ser bastante apreciables. Desde 1538 no encontramos organista en la capilla.

\section{Mozos de capilla}

En este caso podemos suponer que, además de otros cometidos como ejercer de monaguillos, su obligación fundamental era cantar en las misas y oficios:

Al igual que los niños de coro de las catedrales, estaban destinados desde el principio a la carrera eclesiástica y, dentro de esa orientación general, eran elegidos por sus voces, pues, como declara el monarca lusitano don Duarte a propósito del personal de su capilla, deben ser «de boa disposiçâo em uozes e entender e sotileza e de bom asesego porque taes como estes som Razom e uem a ser bons clerigos e bons cantores». 250

Es muy probable que, como ocurría en las catedrales españolas ingresaran con siete u ocho años de edad y permanecieran hasta el cambio de voz de la pubertad. De hecho, algunos de ellos llegarán a ser capellanes del Infantado como Pedro del Castillo o incluso

\footnotetext{
${ }^{248}$ Sabemos de la existencia de F. Chacón, organista desde 1531 hasta 1545 de la catedral de Córdoba y autor de una ensalada, El molino, publicada en Praga junto con las de Flecha. Ver PÉREZ GuTiÉRREZ, Mariano. «Chacón, F.», DMEH, vol. 3, p. 523.

${ }^{249}$ Para este año el caballerizo mayor cobraba 35.300 mrs. para él y tres mozos, el camarero mayor 30.000 mrs.. Incluso el presidente del Consejo ducal, el conde de Priego, cobraba 40.000 mrs. Tan solo el médico personal del duque, el doctor maese Fabricio, con un salario de 80.000 mrs., superaba al de Chacón.

${ }^{250}$ BECEIRO PITA, Isabel. «La educación: un derecho y un deber del cortesano», La enseñanza en la Edad Media. [X Semana de Estudios Medievales, Najera 1999]. Logroño, Instituto de Estudios Riojanos, 2000, pp. 175-206; p. 182.
} 
cantores como Antonio Sánchez de Azañón. ${ }^{251}$ Caso parecido sería el de don Cristóbal de Maldonado que pasa de ser mozo a capellán, pero probablemente se trate de un pariente de la duquesa María Maldonado, última esposa del III duque, pues incluso aparece precedido del «don». Se podría pensar también que Bernabé, mozo de capilla, es posteriormente Bernabé de Santistevan, sacristán menor.

Casos extraños son los de Portillo que se mantuvo como mozo de capilla durante veintiún años, entre 1511 y 1531 o Alonso de Madrid once años, por lo que podríamos pensar que se tratara de falsetistas o castrados.

En 1511 tenemos cuatro mozos de capilla, pero luego irán aumentando en número hasta llegar a seis en 1523, para luego disminuir con el IV duque, de forma que a partir de 1536 solo queda un mozo de capilla (excepto en 1548, cuando volvemos a ver dos).

En los años 1517 a 1527 también hay un portero de la capilla, subiendo a dos en 1530 y 1531 para luego desaparecer de las nóminas. ${ }^{252}$

${ }^{251}$ Antón o Antonio Sánchez de Azañón figura al principio como Antón Sánchez, luego como Antonio Sánchez, lo que nos indica que se trata de una misma persona. Este tipo de confusiones debe ser más común de lo que pensamos ya que, como dijimos más arriba, cambian los secretarios, los contadores, etc. y la nómina de un año no tiene porque ser igual que la del siguiente. Creemos que muchas personas que hemos identificado como dos diferentes son la misma, pero a día de hoy no podemos resolver todos los casos.

${ }^{252}$ Insistimos una vez más en el hecho de que la ausencia de las nóminas de quitación no implica necesariamente la ausencia como servidor, ya que pueden cobrar únicamente ración. 
CAPILLA DE LA CASA DEL INFANTADO DURANTE EL III DUQUE

\begin{tabular}{|c|c|c|c|c|c|c|c|c|c|c|}
\hline & Oficio & 1520 & 1522 & 1523 & 1524 & 1525 & 1526 & 1527 & 1530 & 1531 \\
\hline PEDRO, mosén & Capellán Mayor & $30 \mathrm{M}^{1}$ & $30 \mathrm{M}^{1}$ & $30 \mathrm{M}$ & $30 \mathrm{M}$ & $30 \mathrm{M}$ & $30 \mathrm{M}$ & $30 \mathrm{M}$ & $30 \mathrm{M}$ & $30 \mathrm{M}$ \\
\hline CÉSPEDES, Juan de & Chantre & $30 \mathrm{M}$ & $30 \mathrm{M}^{2}$ & $30 \mathrm{M}$ & $30 \mathrm{M}$ & $30 \mathrm{M}$ & $30 \mathrm{M}$ & $30 \mathrm{M}$ & $30 \mathrm{M}$ & $30 \mathrm{M}$ \\
\hline TORRES, Alonso de & Organista y capellán & $44,092 \mathrm{M}^{3}$ & $44,092 \mathrm{M}^{2}$ & $44,092 \mathrm{M}$ & $44,092 \mathrm{M}$ & $44,092 \mathrm{M}$ & $44,092 \mathrm{M}$ & $44,092 \mathrm{M}$ & $30 \mathrm{M}$ & \\
\hline CHACÓN, Baltasar & Organista & & & $50 \mathrm{M}$ & $50 \mathrm{M}$ & $50 \mathrm{M}$ & $50 \mathrm{M}^{4}$ & $50 \mathrm{M}$ & $50 \mathrm{M}$ & $50 \mathrm{M}$ \\
\hline CABRERA, Gutierre & Capellán & & & & $15 \mathrm{M}$ & & & & & \\
\hline CÁRDENAS, Antonio de & Capellán & & & & $15 \mathrm{M}^{5}$ & $30 \mathrm{M}$ & & & & \\
\hline CASTILLO, Alonso del & Capellán & $27,240 \mathrm{M}^{6}$ & $27,240 \mathrm{M}$ & $27,240 \mathrm{M}$ & $27,240 \mathrm{M}$ & $27,240 \mathrm{M}^{6}$ & & & & \\
\hline CETINA, Mosén & Capellán & & & & & & & & $30 \mathrm{M}$ & $30 \mathrm{M}$ \\
\hline CLAVIJO, Gracián de & Capellán & $15 \mathrm{M}$ & & & & & & & & \\
\hline DUAREZ, Martín & Capellán & $0,75 \mathrm{M}$ & $0,75 \mathrm{M}$ & $0,75 \mathrm{M}$ & $0,75 \mathrm{M}$ & & $10 \mathrm{M}$ & $10 \mathrm{M}$ & $10 \mathrm{M}$ & $10 \mathrm{M}$ \\
\hline ESPINOSA, Hernando de & Capellán & & & $10 \mathrm{M}^{7}$ & $15 \mathrm{M}$ & $15 \mathrm{M}$ & $15 \mathrm{M}$ & $15 \mathrm{M}$ & $15 \mathrm{M}$ & $15 \mathrm{M}$ \\
\hline FRÍAS, Pedro de & Capellán & $19 \mathrm{M}$ & $19 \mathrm{M}^{8}$ & $19 \mathrm{M}$ & $19 \mathrm{M}$ & $19 \mathrm{M}$ & $19 \mathrm{M}$ & $19 \mathrm{M}$ & $19 \mathrm{M}$ & $19 \mathrm{M}$ \\
\hline $\begin{array}{l}\text { GARCÍA de ÉCIJA } \\
\text { (cura de Santiago) }\end{array}$ & Capellán & $2 \mathrm{M}$ & $2 \mathrm{M}$ & $2 \mathrm{M}$ & $8 \mathrm{M}$ & $8 \mathrm{M}$ & $8 \mathrm{M}$ & $8 \mathrm{M}$ & $8 \mathrm{M}$ & $8 \mathrm{M}$ \\
\hline GUERRERO, Francisco & Capellán & & & & & & & $18 \mathrm{M}$ & & \\
\hline $\begin{array}{l}\text { GUTIÉRREZ } \\
\text { ALTAMIRANO, Francisco }\end{array}$ & Capellán & & $20 \mathrm{M}$ & & & & & & & \\
\hline HERRERA, Francisco & Capellán & & & & & & $20 \mathrm{M}$ & $20 \mathrm{M}$ & $20 \mathrm{M}$ & $20 \mathrm{M}$ \\
\hline IZQUIERDO, Alonso & Capellán & $20 \mathrm{M}$ & $20 \mathrm{M}^{9}$ & & & & & & & \\
\hline LÓPEZ, Antonio & Capellán & $15 \mathrm{M}$ & $15 \mathrm{M}$ & $15 \mathrm{M}$ & $15 \mathrm{M}$ & $15 \mathrm{M}$ & $15 \mathrm{M}$ & $15 \mathrm{M}$ & & \\
\hline MARTÍNEZ, Alonso & Capellán & & & & & & & & $15 \mathrm{M}$ & $15 \mathrm{M}$ \\
\hline MARTÍNEZ, Jerónimo & Capellán & $15 \mathrm{M}$ & $15 \mathrm{M}$ & $15 \mathrm{M}$ & $15 \mathrm{M}$ & $15 \mathrm{M}$ & $15 \mathrm{M}$ & $15 \mathrm{M}$ & & \\
\hline MENDOZA, Pedro de & Capellán & & & & & & $30 \mathrm{M}$ & $30 \mathrm{M}$ & & \\
\hline SÁNCHEZ, Bernabé & Capellán & & & & $12,5 \mathrm{M}^{10}$ & $15 \mathrm{M}$ & $15 \mathrm{M}$ & $15 \mathrm{M}$ & $15 \mathrm{M}$ & $15 \mathrm{M}$ \\
\hline SANDOVAL, Francisco de & Capellán & & & & & $15 \mathrm{M}$ & & & & \\
\hline SÁNCHEZ, Sebastián & $\begin{array}{l}\text { Capellán Capellanía } \\
\text { Bernaldino de Mendoza }\end{array}$ & $15 \mathrm{M}$ & $15 \mathrm{M}$ & $15 \mathrm{M}$ & $15 \mathrm{M}$ & & & & & \\
\hline SANTOS, Pedro de los & $\begin{array}{l}\text { Capellán Capellanía } \\
\text { Bernaldino Mendoza }\end{array}$ & $15 \mathrm{M}$ & & $15 \mathrm{M}$ & $15 \mathrm{M}$ & & & & & \\
\hline DÍAZ, Antonio & Capellán Da Elvira & & & & $4 \mathrm{M}^{11}$ & & & & & \\
\hline
\end{tabular}


CAPILLA DE LA CASA DEL INFANTADO DURANTE EL III DUQUE

\begin{tabular}{|c|c|c|c|c|c|c|c|c|c|c|}
\hline & Oficio & 1520 & 1522 & 1523 & 1524 & 1525 & 1526 & 1527 & 1530 & 1531 \\
\hline MARTÍNEZ, Francisco & Capellán en Madrid & $11,88 \mathrm{M}$ & $15 \mathrm{M}$ & & & & & & & \\
\hline SOSA & Capellán en valenciano & & & & & & $15 \mathrm{M}$ & $15 \mathrm{M}$ & $15 \mathrm{M}$ & $15 \mathrm{M}$ \\
\hline PÉREZ, Francisco & Capellán S Ana & & & & & $12 \mathrm{M}$ & $12 \mathrm{M}$ & $15 \mathrm{M}$ & & \\
\hline RAMÍREZ, Francisco & $\begin{array}{l}\text { Capellán y sacristán } \\
\text { mayor }\end{array}$ & & 25 M Alonso & $25 \mathrm{M}$ & $25 \mathrm{M}$ & $25 \mathrm{M}$ & $25 \mathrm{M}$ & $25 \mathrm{M}$ & $25 \mathrm{M}$ & $25 \mathrm{M}$ \\
\hline RIBERA & Sacristán menor & $6 \mathrm{M}$ & $6 \mathrm{M}$ & & & & & & & \\
\hline SANTISTEBAN, Bernabé de & Sacristán menor & & & & $6 \mathrm{M}$ & $6 \mathrm{M}$ & $6 \mathrm{M}$ & $6 \mathrm{M}$ & $6 \mathrm{M}$ & $6 \mathrm{M}$ \\
\hline CASTILLO, Pedro del & Mozo de capilla/Capellán & $2 \mathrm{M}$ & & & $27,240 \mathrm{M}^{12}$ & & & & & \\
\hline MALDONADO, Cristóbal & Mozo de capilla/Capellán & & & & & & & $1,833^{13}$ & $2 \mathrm{M}$ & $20 \mathrm{M}^{14}$ \\
\hline BERLANGA & Mozo de capilla & & & & & & & & $2 \mathrm{M}$ & $2 \mathrm{M}$ \\
\hline BERNABÉ & Mozo de capilla & $2 \mathrm{M}$ & $2 \mathrm{M}$ & $6 \mathrm{M}$ & & & & & & \\
\hline CASTILLO, Cristóbal del & Mozo de capilla & & & & $6,092 \mathrm{M}$ & $6,092 \mathrm{M}$ & $6,092 \mathrm{M}$ & 6,092 M & & \\
\hline CASTRO, Hijo de & Mozo de capilla & & & & & & $6,092 \mathrm{M}$ & & & \\
\hline DÍAZ, Pedro & Mozo de capilla & & & & & & $2 \mathrm{M}^{15}$ & $2 \mathrm{M}^{16}$ & & \\
\hline FRANCOLÍN & Mozo de capilla & & & & & & & & $2 \mathrm{M}$ & \\
\hline LEÓN, Diego de & Mozo de capilla & & & & & & & & $1,333 \mathrm{M}^{17}$ & $2 \mathrm{M}$ \\
\hline LIÉBANA & Mozo de capilla & & & & & & & & $2 \mathrm{M}$ & \\
\hline LÓPEZ, Juan & Mozo de capilla & & $2 \mathrm{M}$ & & & & & & & \\
\hline MADRID, Alonso de & Mozo de capilla & $2 \mathrm{M}$ & $2 \mathrm{M}$ & $2 \mathrm{M}$ & $2 \mathrm{M}$ & $2 \mathrm{M}$ & $2 \mathrm{M}^{15}$ & $2 \mathrm{M}$ & & \\
\hline MONTALBAN & Mozo de capilla & & & & & & 6,092 M & & & \\
\hline MONTALVO & Mozo de capilla & & & & & & $2 \mathrm{M}$ & $2 \mathrm{M}$ & & \\
\hline PAZ, Alonso de la & Mozo de capilla & & & & & & & & & $1,6665^{18}$ \\
\hline PÉREZ, Juan & Mozo de capilla & & & $2 \mathrm{M}$ & $2 \mathrm{M}$ & $2 \mathrm{M}$ & & & & \\
\hline PORTILLO & Mozo de capilla & $2 \mathrm{M}$ & $2 \mathrm{M}$ & $2 \mathrm{M}$ & $2 \mathrm{M}$ & $2 \mathrm{M}$ & $2 \mathrm{M}$ & $2 \mathrm{M}$ & $2 \mathrm{M}$ & $2 \mathrm{M}$ \\
\hline RIBERA & Mozo de capilla & & & $6 \mathrm{M}$ & $6 \mathrm{M}$ & $6 \mathrm{M}$ & $6 \mathrm{M}$ & $6 \mathrm{M}$ & & \\
\hline $\begin{array}{l}\text { SÁNCHEZ DE AZAÑON, } \\
\text { Antonio }\end{array}$ & Mozo de capilla & $2 \mathrm{M}$ & $2 \mathrm{M}$ & $2 \mathrm{M}$ & $4 \mathrm{M}$ & $4 \mathrm{M}$ & $8 \mathrm{M}$ & $8 \mathrm{M}$ & & $10 \mathrm{M}^{19}$ \\
\hline TORICES & Mozo de capilla & & & & & & & & $2 \mathrm{M}$ & $2 \mathrm{M}$ \\
\hline ZARZOSA & Mozo de capilla & & & & & & & & $2 \mathrm{M}$ & $2 \mathrm{M}$ \\
\hline
\end{tabular}


CAPILLA DE LA CASA DEL INFANTADO DURANTE EL III DUQUE

\begin{tabular}{|c|c|c|c|c|c|c|c|c|c|c|}
\hline & Oficio & 1520 & 1522 & 1523 & 1524 & 1525 & 1526 & 1527 & 1530 & 1531 \\
\hline GASCÓN & $\begin{array}{l}\text { Mozo de capilla del } \\
\text { Conde de Saldaña }\end{array}$ & & & & & & & & & $2 \mathrm{M}$ \\
\hline CASTRO, Juan de & Portero de la capilla & $10,092 \mathrm{M}$ & $10,092 \mathrm{M}$ & $10,092 \mathrm{M}$ & $10,092 \mathrm{M}$ & $10,092 \mathrm{M}$ & $10,092 \mathrm{M}$ & $10,092 \mathrm{M}$ & $10,092 \mathrm{M}$ & $10,092 \mathrm{M}$ \\
\hline ORO, Juan de & Portero de la capilla & & & & & & & & $10 \mathrm{M}$ & $10 \mathrm{M}$ \\
\hline PAEZ & Racionero de Toledo & & & & & & & & & $12 \mathrm{M}$ \\
\hline
\end{tabular}

${ }^{1}$ Mosén Pedro percibía 30.000 mrs. más la ración y quitación de su sobrino que era de 6.092 mrs. entre 1520 y 1523. Además recibía 30 fanegas de trigo anuales desde 1522 . Fue despedido el 14 de febrero de 1531. ${ }^{2}$ Desde 1522 recibía también 30 fanegas de trigo.

${ }^{3}$ Hasta 1527 Alonso de Torres percibirá, además de su salario, la ración de su hermano.

${ }^{4}$ Desde 1526 además 40 fanegas de trigo y desde 1530 otras 45 fanegas de cebada.

Aparece entre los cantores por lo que podemos suponer que era capellán y cantor.

'Percibía 15.000 mrs. de quitación más 12.240 mrs. de ración (un real al día). Desde 1522 también 100 fanegas de trigo. Falleció el 8 de mayo de 1525.

7 Desde primero de mayo.

Más 40 fanegas de trigo desde 1522

${ }^{9}$ Despedido a finales de mayo.

${ }^{10}$ Desde primero de marzo.

${ }^{11}$ Despedido.

${ }^{12}$ Capellán. Recibe también 100 fanegas de trigo.

${ }_{13}^{13}$ Desde primeros de febrero.

${ }^{14}$ Aparece como capellán don Crsitóbal Maldonado.

${ }^{15}$ Desde primeros de mayo.

${ }^{16}$ Despedido el 30 de enero por lo que no lo incluimos en la cuenta general.

${ }^{17}$ Más ración.

${ }^{18}$ Desde primeros de marzo.

${ }^{19}$ Aparece como cantor. 
CAPILLA DE LA CASA DEL INFANTADO DURANTE EL IV DUQUE

\begin{tabular}{|c|c|c|c|c|c|c|c|c|c|c|c|c|c|c|c|}
\hline CAPILLA & Oficio & 1532 & 1534 & 1535 & 1536 & 1537 & 1538 & 1540 & 1541 & 1542 & 1544 & 1545 & 1546 & 1548 & 1549 \\
\hline PEDRO, mosén & Capellán Mayor & $42 \mathrm{M}^{1}$ & $42 \mathrm{M}^{1}$ & $42 \mathrm{M}$ & $42 \mathrm{M}$ & $42 \mathrm{M}$ & $42 \mathrm{M}$ & $42 \mathrm{M}$ & $42 \mathrm{M}$ & $42 \mathrm{M}$ & $42 \mathrm{M}$ & $42 \mathrm{M}$ & $42 \mathrm{M}$ & & \\
\hline CÉSPEDES, Juan de & Chantre & $\begin{array}{c}32,550 \\
\mathrm{M}^{2}\end{array}$ & & & & & & & & & & & & & \\
\hline CHACÓN, Baltasar & Organista & $50 \mathrm{M}^{3}$ & $50 \mathrm{M}$ & $50 \mathrm{M}$ & $\begin{array}{c}25,694 \\
\mathrm{M}^{4}\end{array}$ & $\begin{array}{c}11,457 \\
\mathrm{M}^{5}\end{array}$ & & & & & & & & & \\
\hline CETINA, Mosén & Capellán y tenor & $30 \mathrm{M}$ & & & & & & & & & & & & & \\
\hline $\begin{array}{l}\text { CIFUENTES, } \\
\text { Bartolomé de }\end{array}$ & Capellán & $20 \mathrm{M}$ & $25 \mathrm{M}$ & $25 \mathrm{M}$ & $25 \mathrm{M}$ & $25 \mathrm{M}$ & $25 \mathrm{M}$ & & & & & & & & \\
\hline $\begin{array}{l}\text { ESPINOSA, Hernando } \\
\text { de }\end{array}$ & Capellán & $15 \mathrm{M}$ & $20 \mathrm{M}$ & $20 \mathrm{M}$ & $20 \mathrm{M}$ & $20 \mathrm{M}$ & $20 \mathrm{M}$ & $20 \mathrm{M}$ & $20 \mathrm{M}$ & $20 \mathrm{M}$ & $20 \mathrm{M}$ & $20 \mathrm{M}$ & $20 \mathrm{M}$ & $20 \mathrm{M}$ & $20 \mathrm{M}$ \\
\hline FRÍAS, Pedro de & Capellán y Vicario & $22,4 \mathrm{M}$ & $5,6 \mathrm{M}^{6}$ & & & & & & & & & & & & \\
\hline HERRERA, Francisco & Capellán & $20 \mathrm{M}$ & & & & & & & & & & & & & \\
\hline IRUESTE, bachiller & Capellán & & $\begin{array}{c}15,920 \\
\mathrm{M}^{7}\end{array}$ & $4,44 \mathrm{M}$ & & & & & & & & & & & \\
\hline ESTRADA, Rodrigo de & Capellán & & & & & & & & & & & & & & $15 \mathrm{M}$ \\
\hline $\begin{array}{l}\text { LÓPEZ DE } \\
\text { MORATILLA, Juan }\end{array}$ & Capellán & & & $10 \mathrm{M}^{8}$ & $15 \mathrm{M}$ & $15 \mathrm{M}$ & $15 \mathrm{M}$ & $15 \mathrm{M}$ & $15 \mathrm{M}$ & $15 \mathrm{M}$ & $15 \mathrm{M}$ & $15 \mathrm{M}$ & $15 \mathrm{M}$ & $15 \mathrm{M}$ & $15 \mathrm{M}$ \\
\hline $\begin{array}{l}\text { SANTISTEBAN, } \\
\text { Bernabé de }\end{array}$ & Sacristán mayor & $6 \mathrm{M}^{9}$ & $6 \mathrm{M}^{9}$ & $6 \mathrm{M}^{9}$ & $6 \mathrm{M}^{9}$ & $10 \mathrm{M}^{9}$ & $10 \mathrm{M}^{9}$ & $10 \mathrm{M}^{9}$ & $\begin{array}{c}7,333 \\
\mathrm{M}^{9}\end{array}$ & $6 \mathrm{M}^{9}$ & $6 \mathrm{M}^{9}$ & $6 \mathrm{M}^{9}$ & $6 \mathrm{M}^{9}$ & $6 \mathrm{M}^{9}$ & $6 \mathrm{M}^{9}$ \\
\hline CHERINO & Mozo de capilla & $2 \mathrm{M}^{9}$ & $2 \mathrm{M}^{9}$ & $\begin{array}{c}0,416 \\
\mathrm{M}^{10}\end{array}$ & & & & & & & & & & & \\
\hline GAZPE, Sebastián de & Mozo de capilla & & & $1,5 \mathrm{M}^{11}$ & $2 \mathrm{M}^{8}$ & $2 \mathrm{M}^{8}$ & $2 \mathrm{M}^{8}$ & $2 \mathrm{M}^{8}$ & & & & & & & \\
\hline HERNÁNDEZ, Alonso & Mozo de capilla & & & & & & & & $2 \mathrm{M}^{8}$ & $2 \mathrm{M}^{8}$ & $2 \mathrm{M}^{8}$ & $6,08 \mathrm{M}$ & $6 \mathrm{M}$ & $\begin{array}{l}6,08 \\
M^{12}\end{array}$ & \\
\hline YANGUAS, Pedro de & Mozo de capilla & & & & & & & & & & & & & $\begin{array}{l}6,08 \\
\mathrm{M}^{12} \\
\end{array}$ & $\begin{array}{l}6,08 \\
M^{12}\end{array}$ \\
\hline
\end{tabular}

${ }^{1}$ Además percibía 18.000 mrs. de ración, en total 60.000 mrs.

${ }^{2}$ Correspondientes a los $30.000 \mathrm{mrs.}$, y las 30 fanegas de trigo que se le pagaban en dinero.

3 Además de 40 fanegas de trigo y 45 de cebada.

${ }^{4}$ Fue asentado de nuevo el 25 de junio, por lo que solo recibió la parte proporcional de su salario y del trigo y cebada (20 fanegas y 6 celemines de trigo y 23 fanegas y 1,5 celemines de cebada).

5 Despedido el 23 de marzo por lo que cobró la parte proporcional. ( 9 fanegas y 2 celemines de trigo

y 10 fanegas y 3,5 celemines de cebada).
${ }^{6}$ Falleció a finales de marzo de 1534.

Figura entre los oficiales en lugar de en la capilla. Además recibía 10 fanegas de trigo. Fue despedido el 13 de abril de 1535 .

Desde primeros de mayo.

Mas 10 reales al mes de ración en la despensa ( 4.080 mrs. anuales).

${ }^{10}$ Despedido mediado marzo.

${ }^{11}$ Más una ración. Desde primeros de abril.

${ }^{12}$ Con la ración. 
CAPILLA DE LA CASA DEL INFANTADO 1562

\begin{tabular}{llr}
\hline Nombre & Oficio & Salario \\
\hline MONTALVO, Alonso de & Capellán y limosnero & $25 \mathrm{M}$ \\
LÓPEZ DE MORATILLA, Diego & Capellán & $15 \mathrm{M}$ \\
MONHIERRO, Alonso de & Sacristán mayor & $10,08 \mathrm{M}$ \\
LÓPEZ, Gaspar & Sacristán & $4 \mathrm{M}$ \\
MONTALVO, Agustín de & Mozo de capilla & $8 \mathrm{M}$ \\
\hline
\end{tabular}

Conservamos la nómina de 1564 reproducida por Layna. ${ }^{253}$ En ella solo encontramos al capellán, Hernán Rodríguez, con 12.000 mrs anuales de ración y un mozo de capilla, Francisco de la Cruz, con 6.000 mrs de ración anuales.

Relacionado con la capilla y los usos religiosos está el libro conocido como Misal del Infantado o Misal del Cardenal Mendoza de la Biblioteca Nacional de Madrid (BNE Mss Vitr. 18/5), datado hacia los años que nos ocupan. En su interior, además de varios bellos escudos de los Mendoza, aparece el lema «Pves este fin a de aver la mas svbida ventvra, de bvscar en lo que dura».

${ }^{253}$ Layna Serrano, F. Historia de Guadalajara y sus Mendozas..., Tomo III, pp. 421-25. Hay que pensar que al ser una nómina de raciones y despensa no aparecen las quitaciones. 


\section{Cantores}

En el año de 1511 aparecen veinticinco cantores en la nómina, pero dos fueron sustituidos por otros y se incrementó en otros dos, en total tendríamos veintitrés cantores simultáneos. Entre ellos tenemos dos cantores con sueldo ligeramente más elevado, diez con un sueldo medio y nueve con un sueldo bajo, posiblemente niños cantores. El siguiente año del que tenemos datos, 1517, aparecen veintidós cantores, pero Francisco de Tapia fue despedido en agosto y Pedro Bermúdez fue asentado a finales de ese mes, por lo que el total sería veintiuno. Desgraciadamente desconocemos el registro de ellos excepto en muy pocos casos por otras fuentes, lo que señalamos en la tabla.

Sabemos que el número de cantores adultos en las cortes europeas oscilaba en los años 1500 a 1510 entre los doce de la corte de Maximiliano I de Austria, los veinte de la Inglaterra de los Tudor o los cuarenta y seis de la capilla aragonesa de Fernando el Católico. ${ }^{254}$ El número de doce cantores era muy común. ${ }^{255}$

CANTORES DEL DUQUE DEL INFANTADO 1511 y 1517

\begin{tabular}{|c|c|c|}
\hline CANTORES & 1511 & 1517 \\
\hline ESPINOSA, Pedro de & & $80 \mathrm{M}$ \\
\hline BERMÚDEZ, Pedro & & $16,666 \mathrm{M}^{1}$ \\
\hline MÉNDEZ, Bernardino & & $50 \mathrm{M}$ \\
\hline VALDEOLIVAS, Francisco de & \multicolumn{2}{|c|}{$35 \mathrm{M}+3 \mathrm{M}$ merced } \\
\hline SANTANGELO, Diego de & & $35 \mathrm{M}$ \\
\hline BIVAR, Rodrigo de & & $30 \mathrm{M}$ \\
\hline GARCÍA, mosén & \multicolumn{2}{|l|}{$30 \mathrm{M}$} \\
\hline TAPIA, Francisco de & $27,5 \mathrm{M}^{2}$ & $20 \mathrm{M}^{3}$ \\
\hline BARRIONUEVO, Francisco de & $25 \mathrm{M}$ & $30 \mathrm{M}$ \\
\hline FRESNEDA, Álvaro de & & $30 \mathrm{M}$ \\
\hline HAMUSCO, Pedro de & \multicolumn{2}{|l|}{$25 \mathrm{M}$} \\
\hline LORCA, Juan de & $25 \mathrm{M}$ & $25 \mathrm{M}$ \\
\hline VILLADA, Pedro de & $25 \mathrm{M}$ & $25 \mathrm{M}$ \\
\hline MIÑO, Antonio de & \multicolumn{2}{|l|}{20,8334} \\
\hline MUÑOZ & \multicolumn{2}{|l|}{$25 \mathrm{M}$} \\
\hline VIANA, Pedro de & $11,803 \mathrm{M}^{5}$ & $25 \mathrm{M}$ \\
\hline \multicolumn{3}{|c|}{$\begin{array}{l}{ }^{254} \text { KNIGHTON, T. Música y músicos..., p. } 94 . \\
{ }^{255} \text { En 1526, cuando la emperatriz Isabel llegó a España y quiso reorganizar su Casa, pidió consejo al } \\
\text { ispo de Porto, su confesor y capellán mayor y este le recomendó «se deven reçebir fasta cumplimiento de } \\
\text { ze cantores [...] y que este número de doze deve aver siempre». Citado por ANGLÉs, Higinio. La Música en } \\
\text { Corte de Carlos V, con la transcripción del «Libro de cifra nueva, para tecla arpa y vihuela» de Luys Venegas de } \\
\text { mestrosa (Alcalá de Henares, 1557). MME 2, , } 2 \text { vols. Barcelona, CSIC, Instituto Español de Musicología, } \\
\text { 44, reed. 1984; vol 1, p. } 31 \text {. }\end{array}$} \\
\hline
\end{tabular}




\begin{tabular}{lll} 
ORGAZ, Fernando de & $25 \mathrm{M}+4 \mathrm{M}$ merced & $10 \mathrm{M}$ \\
GARIJO, Pedro & $8,333 \mathrm{M}^{6}$ & \\
ORGAZ, Cristóbal de & $8,333 \mathrm{M}^{6}$ & $18 \mathrm{M}$ \\
CALVO, Francisco & $15 \mathrm{M}$ & $15 \mathrm{M}$ \\
PALACIOS, Andrés de & $15 \mathrm{M}$ & \\
RAMÍREZ, Alonso & $10 \mathrm{M} 1^{\circ}$ mayo & $15 \mathrm{M}$ \\
CUERVA, Juan de la & $6 \mathrm{M}$ & $20 \mathrm{M}$ \\
LÓPEZ, Juan & $6 \mathrm{M}$ & $15 \mathrm{M}$ \\
NÚNEZ & & $12 \mathrm{M}$ \\
BARRIONUEVO, Juan de & & $6 \mathrm{M}$ \\
GARCíA, Gregorio, (hijo de mosén García) & & \\
BASURTO, García & $4 \mathrm{M}$ & \\
FIGUEROA, Andrés de & $4 \mathrm{M}$ & \\
PASTRANA, Pablo de & $4 \mathrm{M}$ & $4 \mathrm{M}$ \\
VALDEARENAS, Andrés de & $4 \mathrm{M}$ & \\
ARÉVALO, Lorenzo de & $2 \mathrm{M}$ & $2 \mathrm{M}$ \\
AVENDANO, Gaspar de (hijo mosén Pedro) & & $4 \mathrm{M}$ \\
\hline MANZANARES, Ludovica de & $2 \mathrm{M}$ & $\mathbf{2 2}$ \\
POLANCO, Juan de & $2 \mathrm{M}$ & $\mathbf{2 5}$ \\
\hline TOTAL & & \\
\hline
\end{tabular}

${ }^{1}$ Desde finales de agosto por lo que su salario era de $50.000 \mathrm{mrs}$.

${ }^{2}$ Desde febrero a razón de $30.000 \mathrm{mrs}$. anuales.

${ }^{3}$ Fue despedido en agosto cobrando solo 20.000 de sus $30.000 \mathrm{mrs}$.

${ }^{4}$ Desde marzo a razón de $25.000 \mathrm{mrs}$. al año.

${ }^{5}$ Desde 20 de julio a razón de $15.000 \mathrm{mrs}$. al año.

${ }^{6}$ Despedido en abril a razón de 25.000 mrs. al año.

El cantor mejor pagado es Pedro de Espinosa, que a partir de 1525 figura como arcediano de Almazán. Su salario de 80.000 mrs., desde 1517, es muy superior al de cualquier otro cantor, e incluso el doble del sueldo del presidente del Consejo del duque, el conde de Priego. Tan solo el organista Baltasar Chacón, con un salario de 50.000 mrs. se acerca. ${ }^{256}$ Esto nos hace pensar que Espinosa tal vez ejercería de maestro de capilla y fuera responsable de todos los oficios musicales de la capilla y la cámara. Entre los años 1511 y 1516 está documentada su presencia como cantor en la Capilla Real aragonesa con un salario de 30.000 mrs. Además, en los años 1513 a 1516 recibió 7.500 mrs. anuales para su librea. ${ }^{257}$ Estuvo al servicio del duque durante quince años, entre 1517 y 1531.

${ }^{256}$ El salario de los cantores en Castilla y Aragón era hacia 1526 de entre 30 o 40.000 mrs., mientras que en Portugal apenas superaba los 20.000 mrs. Ver Anglés, H. La Música en la Corte de Carlos V..., vol. 1, p. 30.

${ }^{257}$ Knighton, T. Música y músicos..., p. 72 y 188-192. Recordemos que este año de 1516 fue el del fallecimiento de Fernando el Católico, por lo que Espinosa no pasó demasiado tiempo sin trabajo. 
No sabemos la relación que podría tener con el teórico Juan de Espinosa, arcipreste de Santa Olaya y racionero de la catedral de Toledo, del que conocemos pocos datos biográficos. ${ }^{258}$ Lo que sí es clara la relación del teórico con la Casa del Infantado, ya que dos de sus libros ${ }^{259}$ están dedicados a Martín de Mendoza el Gitano, Arcediano de Talavera y Guadalajara e hijo natural del duque con María Cabrera. Además en la portada de ambos libros aparece el escudo del Infantado.

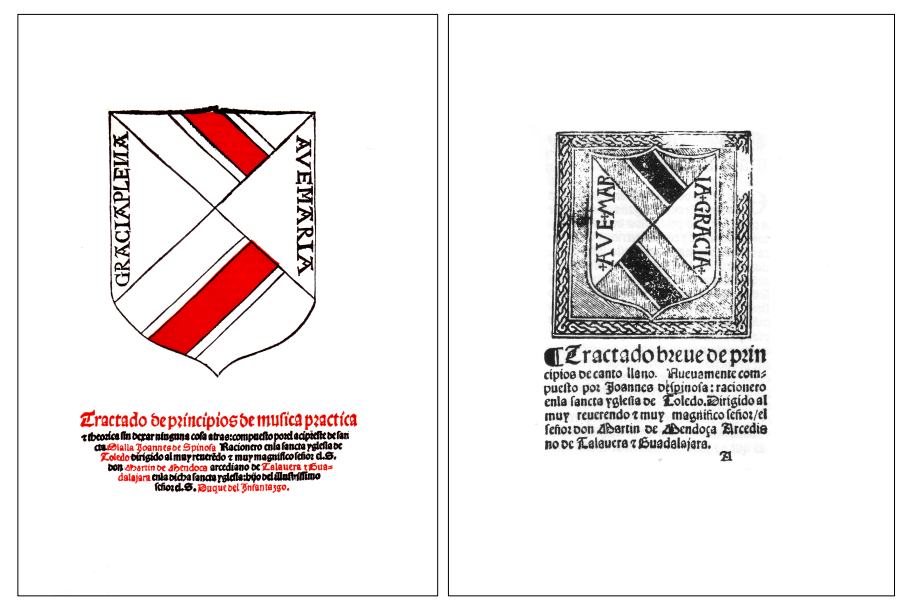

Fig. 12. Portada de los tratados de Juan de Espinosa

Caso parecido es el de Pedro Bermúdez, cantor con un alto salario (50.000 mrs.) fue asentado a finales de agosto de 1517, por lo que solo cobró la parte proporcional, 16.666 mrs. Provenía de la Capilla Real aragonesa donde está presente en los años 1514 y $1515{ }^{260}$ Sin embargo, al contrario que Espinosa, no lo volvemos a encontrar en las nóminas del Infantado después de 1517.

Nos encontramos pues con dos cantores provenientes de la capilla musical del Fernando el Católico. Cuando el monarca falleció en 1516, la capilla quedó disuelta. Un año después los ministriles, trompetas y atabaleros cobraron sus atrasos y quedaron

${ }^{258}$ Un breve esbozo en MARTín GALÁN, Jesús. «Espinosa, Juan de», DMEH, vol. 4, pp. 781-782.

${ }^{259}$ EsPINOSA, Juan de. Tractado de principios de música práctica y teórica sin dejar ninguna cosa atrás. Toledo, Guillem de Brocar, 1520. (Ed. facs. Viejos Libros de Música, 13, Madrid, Joyas Bibliográficas, 1978). Tratado Breve de principios de canto llano. c1520. (Ed. facs. Viejos Libros de Música, 10, Madrid, Joyas Bibliográficas, 1978).

${ }^{260}$ KNighton, T. Música y músicos..., pp 191-192. 
asimilados por la Casa real de Castilla, pero de los cantores nada sabíamos, hecho de lo que se lamentaba Higinio Anglés:

Hasta hoy no hemos encontrado ningún documento que nos aclare lo sucedido con los cantores de su capilla; más no sería extraño que también ellos hubieran quedado adscritos a la Casa Real de Castilla $^{261}$

Anteriormente la capilla de Fernando el Católico se había nutrido de algún cantor proveniente de los Mendoza. Cuando el cardenal Pedro González de Mendoza falleció en Guadalajara el 11 de enero de 1495, cuatro de sus cantores pasaron al servicio del monarca en un breve lapso de tiempo. ${ }^{262}$ Es razonable pensar que algunos otros cantores y músicos del cardenal Mendoza fueran contratados por el duque del Infantado o por algún otro pariente de este.

También vamos a ver el movimiento contrario: cantores del duque del Infantado que posteriormente pasan a servir a una capilla real. Es el caso de Francisco de Barrionuevo, quien en 1511 y 1517 está al servicio del duque con un salario de 25 y 30.000 mrs. respectivamente y varios años después, si se trata de la misma persona, en 1539 acompañando el cadáver de la emperatriz Isabel de Portugal en Granada. ${ }^{263}$

Destaca también el nombre de García Basurto (en el original Vasurto), únicamente en la nómina de 1511, con un salario de tan solo $4.000 \mathrm{mrs}$. frente a otros salarios de cantores de 25 o 30.000 mrs. lo que nos hace suponer que sería muy joven y que formaría parte del grupo de los mozos de coro. No es improbable que se trate de Juan García de Basurto (c. 1480-1547), maestro de capilla del príncipe Felipe desde 1543, pues anteriormente a 1517 no sabíamos nada de él, pero los datos de su nacimiento aportados hasta ahora no coinciden con esta afirmación.

\footnotetext{
261 ANGLÉs, H. La Música en la Corte de Carlos V ..., vol. 1, p. 6.

${ }^{262}$ Juan de Céspedes, Juan de las Heras, Juan Román y Pedro de la Puebla fueron asentados el 15 de enero de 1495, tan solo cuatro días después del fallecimiento del cardenal, en la capilla del Rey Católico. KNIGHTON, T. Música y músicos..., p. 105.

263 ANGLÉs, H. La Música en la Corte de Carlos V..., vol. 1, p. 54.
} 
Juan García de Basurto era natural de la diócesis de Calahorra, en la Rioja. Parece descartarse su pertenencia a la capilla musical del cardenal Francisco Jiménez de Cisneros, por lo que su primer empleo conocido fue como cantor de la catedral de Tarazona, donde ingresó en 1517 y en la que obtuvo el magisterio de coro en $1518 .^{264}$

Caso similar es el de Pedro de Salazar, quien desde 1543 figura como cantor contrabajo en la capilla del príncipe Felipe, ${ }^{265}$ después de haber servido, junto con García de Basurto, en la capilla del cardenal Tavera. ${ }^{266}$ Salazar sirvió en la capilla del III duque en los años 1530 y 1531 con un salario de 25 y 30.000 mrs. respectivamente.

Francisco Rodríguez, hijo de Marchamalo, entra al servicio del duque en mayo de 1524, permaneciendo en su puesto hasta 1527 con un salario muy bajo, 6.092 de ración y quitación, lo que nos hace pensar que sería muy joven, tal vez un niño. Desde 1542 hasta 1551 sirve como tenor en la capilla de los duques de Calabria con un salario de alrededor de 40.000 mrs. $^{267}$

Más dudoso es Pedro Muñoz al ser un nombre muy común, pero tras estar cuatro años al servicio del duque, entre 1524 y 1527, desaparece. No es improbable que sea el mismo que estaba al servicio de las Infantas en 1539 y 1546 con un salario de 40.000 mrs. ${ }^{268}$

${ }^{264}$ RUIZ-JiMÉNEZ, Juan. «Música sacra el esplendor de la tradición», GÓMEZ, Maricarmen (ed.). Historia de la música en España e Hispanoamérica. Vol. 2. De los Reyes Católicos a Felipe II. Madrid, Fondo de Cultura Económica, 2012, pp. 291-395. Ver también Llorens Cisteró, José Ma . «García de Basurto, Juan», DMEH, vol. 5, p. 438.

${ }^{265}$ Entró en la Casa de Castilla en diciembre de 1543, en 1554 pasó a la de Borgoña y aquí permaneció desde 1556 hasta 1574. ANGLÉs, H. La Música en la Corte de Carlos V ..., vol. 1, pp. 93, 95 y ss. y MARTÍNEZ Millán, José y FERnÁndeZ Conti, Santiago (coords.). La monarquía de Felipe II: la Casa del Rey. Madrid, Fundación Mapfre Tavera, 2005, 2 vols, vol. II, p. 410.

${ }^{266}$ Sirvió al cardenal Tavera desde enero de 1542 hasta octubre de 1543 cuando pasó a la capilla del príncipe. Su salario era de $40.000 \mathrm{mrs}$. de ración y quitación. MoLL, Jaime. «Músicos en la Corte del Cardenal Juan Tavera (1523-1545): Luis Venegas de Henestrosa», Anuario Musical, 6 (1951), pp. 155-178; pp. 168-169.

${ }^{267}$ Freund SCHWARTz, R. En busca de liberalidad... pp. 295, 323 y 538. Posiblemente sea el mismo que sirvió en la capilla de la Casa de Borgoña del príncipe y luego rey Felipe entre 1554 y 1559. MARTíNEZ MiLlÁN, J. y FERNÁNDEZ CONTI, S. La monarquía de Felipe II..., vol. II, p. 391.

${ }^{268}$ ANGLÉs, H. La Música en la Corte de Carlos V ..., vol. 1, pp. 62 y 75. La fecha de 1545 es dudosa pues el documento que copia Anglés carece de ella. 
Pedro de Villada sirve al duque entre 1511 y 1531. No sabemos si existe relación con Pedro de Villada Alarcón organista y racionero de la catedral de Sevilla desde 1540 hasta su fallecimiento en $1573 .^{269}$

Junto con el anterior encontramos el nombre de una mujer o niña cantora, Ludovica de Manzanares, con un salario de solo $2.000 \mathrm{mrs}$. La presencia de mujeres entre los cantores es inhabitual, pero no imposible. En la Casa de Alba Ana la Cantora percibe 3.000 mrs. en $1500 .^{270}$

A partir de 1532 los pocos cantores que quedan son incluidos en la nómina en el apartado capilla. No sabemos si se les concedió una capellanía, pues por lo menos dos de ellos (Rodrigo de Bivar y Pedro de Espinosa) habían sido ordenados como sacerdotes. Además, mosén Cetina, que era capellán sin más, en 1532 consta como capellán y tenor. Algunos cantores pueden no estar incluidos en la lista como es el caso del paje de cámara Soto al que se añade en la nómina de cantores de 1530 sin salario, porque ya lo llevaba entre los pajes.

Con frecuencia vemos padres e hijos en las listas de cantores: Gaspar de Avendaño, hijo de mosén Pedro, ${ }^{271}$ Gregorio García, hijo de mosén García o Francisco Rodríguez, hijo de Marchamalo.

Nos detendremos un poco más en el cantor tiple Rodrigo de Bivar del que tenemos muchos más datos, pues fue procesado por alumbrado por la Inquisición en 1539.

Antes de nada intentaremos explicar el complejo fenómeno de los alumbrados castellanos que tuvo de cabeza a la Inquisición.

Las denuncias contra los alumbrados o dexados comienzan en 1519 en Guadalajara, ${ }^{272}$ pero son años muy convulsos por la revuelta de las Comunidades y las Germanías y no se

\footnotetext{
${ }^{269}$ PÉrez GutiÉrRez, Mariano. «Villada Alarcón, Pedro de.», DMEH, vol. 10, p. 908.

${ }^{270}$ CAlderón OrTega, J. El ducado de Alba..., p. 277.

${ }^{271}$ Lo más lógico es que se refiera a Pedro de Espinosa más que a mosén Pedro capellán mayor.

${ }^{272}$ La predicación tal vez comenzara hacia 1512. HAmilton, A. El proceso..., p. 9.
} 
hace nada. Hasta finales de 1523, cuando es nombrado Inquisidor General Alonso Manrique, no se da curso a las denuncias. En los dos años siguientes los inquisidores visitan Toledo, Escalona, Pastrana y Guadalajara recogiendo las testificaciones y produciéndose las primeras detenciones, como las de Pedro Ruiz de Alcaraz ${ }^{273}$ e Isabel de la Cruz. El 24 de septiembre de 1525 se publica el llamado Edicto de los alumbrados de Toledo que recoge cuarenta y ocho proposiciones heréticas y que debe ser leído en todas la iglesias todos los años. Las personas que tras la lectura del edicto se acogieran a confesar no serían castigados ni sus bienes confiscados. Los procesos se suceden uno tras otro: Alcaraz, Isabel de la Cruz y Gaspar de Bedoya (condenados en 1529), ${ }^{274}$ Juan López de Celain (condenado a muerte en 1530), ${ }^{275}$ María de Cazalla (1531-1535), ${ }^{276}$ Juan de Vergara (1531-1537) y Rodrigo de Bivar (condenado en 1539).

Pero ¿qué son los alumbrados o el iluminismo?. Si cogemos y mezclamos ciertos judeoconversos de clase media urbana, con elementos comuneros, un poco de erasmismo, unas gotas de luteranismo y algo de franciscanismo reformado y esto le añadimos algunos personajes de la alta nobleza castellana, como el duque del Infantado y su familia, o el marqués de Villena y el Almirante de Castilla, obtenemos la respuesta.

La mayoría de las personas denunciadas [...] procedían de un mismo medio: el de los judíos conversos; era la primera generación postinquisitorial; simpatizaban con una abolición de las excesivas ceremonias litúrgicas y sacramentales; se inclinaban [por] la Biblia y la oración mental más que a las prácticas externas de la Iglesia; practicaban, con ligeras variantes, un método peculiar de contemplación,

${ }^{273}$ Alcaraz había sido criado del conde de Priego, presidente del Consejo ducal. SELKE DE SÁNCHEZ, Ángela. «Algunos datos nuevos sobre los primeros alumbrados. El Edicto de 1525 y su relación con el proceso de Alcaraz», Bulletin Hispanique, 54/2 (1952), pp. 125-152.

${ }^{274}$ El castigo que se les impuso fue, a Alcaraz de cien azotes y a Isabel de la Cruz a ser expuesta a la verguenza pública en los lugares de su predicación y después cadena perpetua de cárcel. HAMILTON, A. El proceso..., p. 11.

${ }^{275}$ Juan López de Celain (1488-1530) había estado al servicio de Alonso del Castillo capellán del duque del Infantado en Guadalajara hacia 1523. Desde 1527 era capellán de la Capilla Real de Granada y en 1530 fue torturado, sentenciado a muerte por la Inquisición y quemado en Granada. SELKE DE SÁNCHEZ, Ángela. «Vida y muerte de Juan López de Celain, alumbrado vizcaíno», Bulletin Hispanique, 62/2 (1960), pp. 136-162.

${ }^{276}$ María fue acusada no solo de alumbrada, sino también de luterana, aunque también sería correcto definirla como erasmista. Había sido maestra de los alumbrados de Pastrana y era una mujer de una gran inteligencia. y cultura. Sufrió un duro tormento de manos de los verdugos de la Inquisición. GIORDANO, María Laura. María de Cazalla (1487-?). Madrid, Ediciones del Orto, 1998 y CASTRO SÁNCHEZ, Álvaro. Las noches oscuras de María de Cazalla. Mujer, herejía y gobierno en el siglo XVI. Madrid, La Linterna Sorda, 2011. 
el dexamiento [...]. En la misma línea de oposición está la ética libertaria, utópica y pacifista de los alumbrados. $^{277}$

Entre los alumbrados y los testigos de los procesos encontramos multitud de criados del duque del Infantado, incluidos capellanes y músicos. Diego de Espinosa, chirimía, declaró como testigo en 1524, acusando a su vez a varios criados del duque, ${ }^{278}$ Pedro de Sandoval, capellán del conde de Saldaña, fue acusado por otro testigo; los capellanes Alonso del Castillo, Alonso de Torres, organista, y Pedro de Frías también declararon contra Bivar. Incluso el mayordomo mayor y casado con una prima del del duque, Diego López de Orozco, declaró ante la Inquisición. ${ }^{279}$

La familia Mendoza, en particular algunas mujeres de la familia, formó parte, o fue sospechosa de serlo, de este grupo de alumbrados. La condesa de Saldaña, Isabel de Aragón, ${ }^{280}$ lectora de Erasmo, ${ }^{281}$ se relacionaba espiritualmente con el obispo Cazalla, hermano de María de Cazalla, y parece ser que juntos escribieron un libro del que incluso se llegó a alabar en la Dieta de Aubsburgo. ${ }^{282}$ Brianda de Mendoza y Luna ${ }^{283}$ y su prima

${ }^{277}$ MÁRQUeZ, Antonio. Los alumbrados. Orígenes y filosofía (1525-1559). Madrid, Taurus, 1980 (2a ed. corregida y aumentada); pp. 66-67.

${ }^{278} \mathrm{Al}$ propio Rodrigo de Bivar, a Gabriel de Vega despensero del conde de Saldaña y después del duque; a Albadán, hijo del caballerizo mayor y sobrino de Pedro Ruiz de Alcaraz; a Campuzano el Mozo, hijo del contino Diego de Campuzano; a las mujeres de algunos de los criados: la del trompeta Gascón (posiblemente Alonso), la de Cifuentes escribano de la ciudad, etc. HAMILTON, A. El proceso..., p. 17. Elvira de Arteaga, doncella del Infantado relacionada con Isabel de la Cruz e hija del tesorero García de Buitrago y María Falconi, tenía dos hermanos entre los pajes del duque: Juan de Arteaga y Pedro Falconi, paje ente 1520 y 1531. Sobre Elvira LEÓN DE LA VEGA, Manuel de. Los protestantes y la espiritualidad evangélica en la España del siglo ХVI. 2 volúmenes, El autor, 2011, vol. 2, p. 183.

${ }^{279}$ Rodríguez Posilio, Montserrat. «Brianda de Mendoza y Luna», Alegre CARVAjAl, Esther (ed.) Damas de la Casa de Mendoza. Historias, leyendas y olvidos. Madrid, Ediciones Polifemo, 2014, pp. 219-241; p. 233.

${ }^{280}$ Ya su marido, como vimos más arriba, estuvo implicado en la causa de los Comuneros, incluso liderando militarmente la revuelta en Guadalajara.

${ }^{281}$ María de Cazalla encargó una traducción castellana de los Coloquios de Erasmo para la condesa. Giordano, M. L. María de Cazalla..., p. 21.

282 BATAillon, M. Erasmo y España..., p. 211.

${ }^{283}$ Brianda de Mendoza (c. 1470-1534) era hermana del III duque y permaneció soltera toda su vida. Su madre, la duquesa María de Luna, le había dejado una cuantiosa fortuna. Vivía junto a su tío el solterón Antonio de Mendoza, hasta que este falleció en 1510 donándole su palacio. Se dedicó a comprar casas de las manzanas adyacentes con la intención de fundar un beaterio de la orden terciaria de San Francisco y un colegio de doncellas, cosa que consiguió en 1524 tras obtener las correspondientes bulas pontificias. LAYNA SERrAno, F. Historia de Guadalajara y sus Mendozas..., Tomo III, pp. 42-45. 
María de Mendoza ${ }^{284}$ declararon como testigos de abonos en el proceso contra María de Cazalla en marzo de 1533 . $^{285}$

Las proposiciones que defendían los alumbrados o dexados se pueden ver en el edicto de Toledo. Negaban la existencia del infierno, rechazaban las imágenes sagradas, tanto de los santos como el propio crucifijo, negaban el sacramento de la confesión y la presencia real de Jesucristo en la hostia consagrada, defendían la oración mental frente a la vocal, despreciaban las jerarquías eclesiásticas, condenaban el ritualismo de los gestos y las señales externas de los fieles durante la celebración de la misa, practicaban el dejamiento, estado místico en el cual decían que no podían pecar, leían y comentaban la Biblia en romance y afirmaban que en el matrimonio durante el acto conyugal estaban más unidos a Dios que en la oración. ${ }^{286}$

Rodrigo de Bivar, cristiano viejo e hidalgo, ${ }^{287}$ habría nacido hacia 1486 en Guadalajara. Desde 1517 lo encontramos en la corte mendocina con uno de los mejores salarios de los cantores, 30.000 mrs., hasta finales de 1531 o principios de 1532 cuando fue despedido. Sabemos que en 1525, o antes, ya era clérigo presbítero ${ }^{288}$ y posiblemente capellán. En marzo de este año declaró voluntariamente, acogiéndose a un edicto de gracia publicado un mes antes, suplicando clemencia, ${ }^{289}$ una vez que Alcaraz e Isabel de la Cruz se encontraban en las cárceles de la Inquisición. Reconoció reunirse en los conventículos con su vecina Isabel de la Cruz y haber hablado con Alcaraz y con Bedoya. Al año siguiente, en noviembre, fue citado como testigo en el proceso de Alcaraz. En 1530 fue denunciado por varios testigos por lo que tuvo que volver a declarar ante los inquisidores. Tras salir de Guadalajara se instaló en Alcalá donde entró en contacto con los círculos erasmistas que

\footnotetext{
${ }^{284}$ Rodríguez Posilio, M. «Brianda de Mendoza..., p. 233.

${ }^{285}$ En su beaterio parece ser que fue visitado por muchos alumbrados, además de que algunos de sus criados fueran sospechosos, pues Brianda no renunció a la vida seglar ni a relacionarse con multitud de

${ }^{286}$ Esta proposición parte de María de Cazalla quien afirmaba «que estando ella en el acto carnal con su marido estava más allegada a Dios que si estuviesse en la más alta oración del mundo e [...] que quando pagaba la debda marital estava toda divina», CASTRO SÁNCHEZ, Á. Las noches oscuras..., p. 127.

${ }^{287}$ De todos los acusados Bivar es uno de los pocos que no tiene orígenes judeoconversos, eso tal vez justifique que su condena no fuera tan severa como la de otros procesados.

${ }^{288}$ En 1539 parece ser que llevaba veinticinco años siendo clérigo de misa según sus acusadores, por lo que en toda su estancia en el palacio del Infantado lo habría sido. HAmiLton, A. El proceso..., p. 93.

${ }^{289}$ Si se presentaba en un plazo de treinta días se podía librar del castigo y de la confiscación de sus
} personas. bienes. 
en estos años estaban siendo acosados por el Santo Oficio. ${ }^{290}$ Finalmente en 1538 los inquisidores volvieron contra él y en 1539 fue procesado y acusado, ${ }^{291}$ aunque su condena se saldó con una multa. En estos años Bivar disfrutaba de un beneficio en la iglesia de Santiago del Arrabal de Toledo. Posteriormente nada sabemos de Rodrigo, tan solo que tuvo varios hijos, uno de ellos Rodrigo, clérigo beneficiado como su padre, fue también procesado por la Inquisición en $1554 .^{292}$

Como vemos en las tablas, los cantores tuvieron la misma evolución que los capellanes, aunque partían de un alto número en 1511 y 1517 . A partir de 1520 se estabilizan más o menos en la docena, con algún pico como el de 1524. Tras la muerte del III duque su número desciende bruscamente para desaparecer poco después.

${ }^{290}$ En los primeros momentos residió en la casa del impresor Miguel de Eguía

${ }^{291}$ En esta ocasión presentó como testigos de su parte los ministriles de la catedral de Toledo, Diego de Espinosa, chirimía y Juan de Morales y Sotomayor, sacabuches. Los delitos fueron, de una forma resumida, defender la confesión y la oración mental, no reverenciar a los santos, despreciar los signos externos de los fieles cristianos y reunirse con personas que posteriormente fueron condenadas por la Inquisición. También fue acusado de hacer gestos extremos y llorar mientras decía misa.

${ }^{292}$ Hamilton, A. Elproceso..., p. 7. 
CANTORES DE LA CASA DEL INFANTADO

\begin{tabular}{|c|c|c|c|c|c|c|c|c|c|c|c|c|c|c|}
\hline CANTORES & Voz & 1511 & 1517 & 1520 & 1522 & 1523 & 1524 & 1525 & 1526 & 1527 & 1530 & 1531 & 1532 & 1534 \\
\hline ANTÓN, mosén & & & & & & & $35 \mathrm{M}$ & & & & & & & \\
\hline $\begin{array}{l}\text { ARÉVALO, Lorenzo } \\
\text { de }\end{array}$ & & $2 \mathrm{M}$ & & & & & & & & & & & & \\
\hline ATIENZA, Pedro de & & & & & $2 \mathrm{M}$ & $2 \mathrm{M}$ & $2 \mathrm{M}$ & $7,808 \mathrm{M}^{1}$ & $20 \mathrm{M}$ & $20 \mathrm{M}$ & $30 \mathrm{M}$ & $30 \mathrm{M}$ & & \\
\hline $\begin{array}{l}\text { AVENDAÑO, Gaspar } \\
\text { de [hijo de mosén } \\
\text { Pedro] }\end{array}$ & & & $2 \mathrm{M}$ & & & & & & & & & & & \\
\hline $\begin{array}{l}\text { BARRIONUEVO, } \\
\text { Francisco de }\end{array}$ & & $25 \mathrm{M}$ & $30 \mathrm{M}$ & & & & & & & & & & & \\
\hline $\begin{array}{l}\text { BARRIONUEVO, } \\
\text { Juan de }\end{array}$ & & & $12 \mathrm{M}$ & & & & & & & & & & & \\
\hline BASURTO, García & & $4 \mathrm{M}$ & & & & & & & & & & & & \\
\hline BERMÚDEZ, Pedro & & & $\begin{array}{c}16,666 \\
\mathrm{M}^{2}\end{array}$ & & & & & & & & & & & \\
\hline $\begin{array}{l}\text { BIVAR, Rodrigo de } \\
\text { (c. 1486) }\end{array}$ & Tiple & & $30 \mathrm{M}$ & $30 \mathrm{M}$ & $30 \mathrm{M}$ & $30 \mathrm{M}$ & $30 \mathrm{M}$ & $30 \mathrm{M}^{1}$ & $30 \mathrm{M}$ & $30 \mathrm{M}$ & $30 \mathrm{M}$ & $30 \mathrm{M}$ & & \\
\hline CALVO, Francisco & & $15 \mathrm{M}$ & $18 \mathrm{M}$ & & $25 \mathrm{M}$ & $25 \mathrm{M}$ & & & & & & & & \\
\hline CASTILLO, Juan del & & & & & & & & & & & $35 \mathrm{M}$ & $35 \mathrm{M}$ & $35 \mathrm{M}^{3}$ & \\
\hline CUERVA, Juan de la & & $6 \mathrm{M}$ & $15 \mathrm{M}$ & & & & & & & & & & & \\
\hline ESPINOSA, Pedro de & & & $80 \mathrm{M}$ & $80 \mathrm{M}$ & $80 \mathrm{M}$ & $80 \mathrm{M}$ & $80 \mathrm{M}$ & $80 \mathrm{M}^{1}$ & $80 \mathrm{M}^{4}$ & $80 \mathrm{M}$ & $80 \mathrm{M}$ & $80 \mathrm{M}$ & $80 \mathrm{M}$ & $\begin{array}{c}34,0655 \\
\mathrm{M}^{5}\end{array}$ \\
\hline $\begin{array}{l}\text { FIGUEROA, Andrés } \\
\text { de }\end{array}$ & & $4 \mathrm{M}$ & & & & & & & & & & & & \\
\hline $\begin{array}{l}\text { FRESNEDA, Álvaro } \\
\text { de }\end{array}$ & & & $30 \mathrm{M}$ & $30 \mathrm{M}$ & $30 \mathrm{M}$ & $30 \mathrm{M}$ & $35 \mathrm{M}$ & & & & & & & \\
\hline $\begin{array}{l}\text { GARCÍA, Gregorio } \\
\text { [hijo de mosén García] }\end{array}$ & & & $6 \mathrm{M}$ & $6 \mathrm{M}$ & $6 \mathrm{M}$ & $6 \mathrm{M}$ & $6 \mathrm{M}$ & $6 \mathrm{M}^{1}$ & & & & & & \\
\hline GARCÍA, mosén & & $30 \mathrm{M}$ & & & & & & & & & & & & \\
\hline GARIJO, Pedro & & $8,333 \mathrm{M}^{6}$ & & & & & & & & & & & & \\
\hline HAMUSCO, Pedro de & & $25 \mathrm{M}$ & & & & & & & & & & & & \\
\hline JUAN, mosén & & & & & $21,840 \mathrm{M}$ & $30 \mathrm{M}^{7}$ & $21,840 \mathrm{M}$ & & & & $21,816 \mathrm{M}$ & $\begin{array}{c}21,816 \\
\mathrm{M}^{8}\end{array}$ & & \\
\hline LÓPEZ, Juan & & $6 \mathrm{M}$ & $20 \mathrm{M}$ & $\begin{array}{c}31,532 \\
\mathrm{M}^{9}\end{array}$ & $\begin{array}{c}35,826 \\
\mathrm{M}^{10}\end{array}$ & $\begin{array}{c}35,826 \\
\mathrm{M}^{11}\end{array}$ & $\begin{array}{c}35,826 \\
\mathrm{M}^{11}\end{array}$ & $\begin{array}{c}35,826 \\
\mathrm{M}^{1,11}\end{array}$ & $\begin{array}{c}35,826 \\
\mathrm{M}^{11}\end{array}$ & $\begin{array}{c}35,826 \\
\mathrm{M}^{11}\end{array}$ & $\begin{array}{c}35,826 \\
\mathrm{M}^{11}\end{array}$ & $\begin{array}{c}35,826 \\
\mathrm{M}^{11}\end{array}$ & $\begin{array}{c}35,826 \\
\mathrm{M}^{11}\end{array}$ & \\
\hline LORCA, Juan de & & $25 \mathrm{M}$ & $25 \mathrm{M}$ & & & & & & & & & & & \\
\hline
\end{tabular}


CANTORES DE LA CASA DEL INFANTADO

\begin{tabular}{|c|c|c|c|c|c|c|c|c|c|c|c|c|c|c|}
\hline CANTORES & Voz & 1511 & 1517 & 1520 & 1522 & 1523 & 1524 & 1525 & 1526 & 1527 & 1530 & 1531 & 1532 & 1534 \\
\hline LOSCOS, Juan de & & & & & & & & $70 \mathrm{M}^{1,12}$ & $70 \mathrm{M}$ & $70 \mathrm{M}$ & & $80 \mathrm{M}^{13}$ & & \\
\hline MACHUCA & & & & & & & & $27 \mathrm{M}^{1,14}$ & & & & & & \\
\hline $\begin{array}{l}\text { MANZANARES, } \\
\text { Ludovica de }\end{array}$ & & $2 \mathrm{M}$ & & & & & & & & & & & & \\
\hline MARCHAMALO & & & & & & & $25 \mathrm{M}$ & $25 \mathrm{M}^{1}$ & $25 \mathrm{M}$ & $25 \mathrm{M}$ & $25 \mathrm{M}$ & $25 \mathrm{M}$ & & \\
\hline MÉNDEZ, Bernardino & & & $50 \mathrm{M}$ & & & & & & & & & & & \\
\hline MIÑO, Antonio de & & $\begin{array}{c}20,833 \\
\mathrm{M}^{15}\end{array}$ & & & & & & & & & & & & \\
\hline MUÑOZ & & $25 \mathrm{M}$ & & $15 \mathrm{M}$ & $15 \mathrm{M}$ & $15 \mathrm{M}$ & $10 \mathrm{M}$ & $10 \mathrm{M}^{1}$ & $10 \mathrm{M}$ & $10 \mathrm{M}$ & & & & \\
\hline MUÑOZ, Pedro & & & & & & & $\begin{array}{c}19,167 \\
\mathrm{M}^{16}\end{array}$ & $30 \mathrm{M}^{17}$ & $30 \mathrm{M}^{17}$ & $30 \mathrm{M}^{17}$ & & & & \\
\hline NÚÑEZ & & & $15 \mathrm{M}$ & & & & & & & & & & & \\
\hline ORGAZ, Cristóbal de & & $8,333 \mathrm{M}^{6}$ & & & & & & & & & & & & \\
\hline ORGAZ, Fernando de & & $25 \mathrm{M}^{18}$ & $10 \mathrm{M}$ & $10 \mathrm{M}$ & $10 \mathrm{M}$ & $10 \mathrm{M}$ & $10 \mathrm{M}$ & $10 \mathrm{M}^{1}$ & $10 \mathrm{M}$ & $10 \mathrm{M}^{6}$ & $10 \mathrm{M}$ & $10 \mathrm{M}$ & & \\
\hline ORTIZ, Juan & & & & & & & $10 \mathrm{M}$ & & $30 \mathrm{M}$ & $30 \mathrm{M}$ & & & & \\
\hline PALACIOS, Andrés de & & $15 \mathrm{M}$ & $15 \mathrm{M}$ & $15 \mathrm{M}$ & $15 \mathrm{M}$ & $15 \mathrm{M}$ & $15 \mathrm{M}$ & & & & & & & \\
\hline PASTRANA, Pablo de & & $4 \mathrm{M}$ & & & & & & & & & & & & \\
\hline POLANCO, Juan de & & $2 \mathrm{M}$ & $4 \mathrm{M}$ & $4 \mathrm{M}$ & $4 \mathrm{M}$ & & & & & & & & & \\
\hline RAMÍREZ, Alonso & & $10 \mathrm{M}^{15}$ & & & & & & & & & & & & \\
\hline REJÓN, Miguel & & & & & & & & & & $35 \mathrm{M}$ & & & & \\
\hline ROBREDO & & & & & & & & & & & $50 \mathrm{M}$ & & & \\
\hline $\begin{array}{l}\text { RODRÍGUEZ, } \\
\text { Francisco [hijo de } \\
\text { Marchamalo] }\end{array}$ & Tenor & & & & & & $\begin{array}{c}4,059 \\
\mathrm{M}^{19}\end{array}$ & $6,092 \mathrm{M}^{1}$ & 6,092 M & 6,092 M & & & & \\
\hline RUIZ, Cristóbal & & & & $30 \mathrm{M}$ & $30 \mathrm{M}$ & $30 \mathrm{M}$ & $30 \mathrm{M}$ & $35 \mathrm{M}^{1}$ & $35 \mathrm{M}$ & $35 \mathrm{M}$ & $35 \mathrm{M}^{20}$ & & & \\
\hline SALAZAR, Pedro de & Contrabajo & & & & & & & & & & $25 \mathrm{M}$ & $30 \mathrm{M}^{12}$ & & \\
\hline $\begin{array}{l}\text { SÁNCHEZ DE } \\
\text { AZAÑÓN, Antonio }\end{array}$ & & & & & & & & & & & & $10 \mathrm{M}$ & & \\
\hline $\begin{array}{l}\text { SANTANGELO, } \\
\text { Diego de }\end{array}$ & & & $35 \mathrm{M}$ & & & & & & & & & & & \\
\hline TAPIA, Francisco de & & $27,5 \mathrm{M}^{21}$ & $20 \mathrm{M}^{22}$ & & & & & & & & & & & \\
\hline
\end{tabular}




\section{CANTORES DE LA CASA DEL INFANTADO}

\begin{tabular}{|c|c|c|c|c|c|c|c|c|c|c|c|c|c|c|}
\hline CANTORES & Voz & 1511 & 1517 & 1520 & 1522 & 1523 & 1524 & 1525 & 1526 & 1527 & 1530 & 1531 & 1532 & 1534 \\
\hline $\begin{array}{l}\text { TOLEDO, Sebastián } \\
\text { de }\end{array}$ & & & & & & & & & $35 \mathrm{M}$ & $35 \mathrm{M}$ & & & & \\
\hline TORREJÓN & & & & & & & & & & & $25 \mathrm{M}$ & $25 \mathrm{M}$ & & \\
\hline TUERBA, Juan de & & & & $15 \mathrm{M}$ & & & & & & & & & & \\
\hline $\begin{array}{l}\text { VALDEARENAS, } \\
\text { Andrés de }\end{array}$ & & $4 \mathrm{M}$ & $4 \mathrm{M}$ & & & & & & & & & & & \\
\hline $\begin{array}{l}\text { VALDEOLIVAS, } \\
\text { Francisco de }\end{array}$ & & $35 \mathrm{M}^{23}$ & & & & & & & & & & & & \\
\hline VIANA, Pedro de & Contrabajo & $\begin{array}{c}11,803 \\
M^{24}\end{array}$ & $25 \mathrm{M}$ & $25 \mathrm{M}$ & $25 \mathrm{M}$ & $25 \mathrm{M}$ & $25 \mathrm{M}$ & $25 \mathrm{M}^{1}$ & $25 \mathrm{M}$ & $25 \mathrm{M}$ & & & & \\
\hline VILLADA, Pedro de & & $25 \mathrm{M}$ & $25 \mathrm{M}$ & $25 \mathrm{M}$ & $25 \mathrm{M}^{17}$ & $25 \mathrm{M}^{17}$ & $25 \mathrm{M}$ & $25 \mathrm{M}^{1,17}$ & $25 \mathrm{M}^{17}$ & $25 \mathrm{M}$ & $25 \mathrm{M}^{17}$ & $25 \mathrm{M}^{17}$ & & \\
\hline TOTAL & & 25 & $21^{25}$ & 13 & 15 & 14 & 18 & 15 & 15 & 16 & 13 & 13 & 3 & 1 \\
\hline \multicolumn{7}{|c|}{$\begin{array}{l}\text { A partir de } 1525 \text { los cantores aparecen incluidos en la capilla. Rodrigo de Bivar consta como clérigo. } \\
2 \text { Desde finales de agosto por lo que solo cobró la parte proporcional de sus } 50.000 \mathrm{mrs} . \\
3 \text { Además percibía } 30 \text { fanegas de trigo y } 4.080 \mathrm{mrs} \text {. de ración. } \\
{ }^{4} \text { Desde } 1526 \text { figura como Arcediano. El año anterior había sido despedido en abril. } \\
{ }^{5} \text { Despedido el } 6 \text { de junio. } \\
{ }^{6} \text { Despedido en abril. } \\
{ }^{7} \text { Con la ración. } \\
{ }^{8} \text { Además percibía } 40 \text { fanegas de trigo. } \\
{ }^{9} \text { Con la ración. } \\
{ }^{10} \text { Además percibía } 20 \text { fanegas de trigo. } \\
{ }^{11} \text { Además percibía } 20 \text { fanegas de trigo, } 101 \text { fanegas y } 8 \text { celemines de cebada. } \\
{ }^{12} \text { Desde primero de mayo. } \\
{ }^{13} \text { Desde } 15 \text { de febrero, además percibía } 30 \text { fanegas de trigo y } 50 \text { fanegas de cebada. }\end{array}$} & \multicolumn{7}{|c|}{$\begin{array}{l}{ }^{14} \text { Desde } 5 \text { de abril. } \\
{ }^{15} \text { Desde primero de marzo. } \\
{ }^{16} \text { Desde el } 10 \text { de mayo. } \\
{ }^{17} \text { Además percibía } 30 \text { fanegas de trigo. } \\
{ }^{18} \text { Más } 4.000 \text { mrs. de merced. } \\
{ }^{19} \text { Desde primero de mayo. } \\
{ }^{20} \text { Despedido el } 15 \text { de junio. } \\
{ }^{21} \text { Desde primero de febrero. } \\
{ }^{22} \text { Despedido a finales de agosto por lo que solo cobró } 20.000 \mathrm{n} \\
{ }^{23} \text { Más } 3.000 \text { mrs. de merced. } \\
{ }^{24} \text { Desde el } 20 \text { de julio. }\end{array}$} & \\
\hline
\end{tabular}




\section{Música}

En este apartado se incluyen todos los ministriles, sacabuches y chirimías, además de otros músicos de la cámara de los que, lamentablemente, raras veces se indica el instrumento que tañían, con suerte nos identifican algunos tañedores de tecla, aunque en el caso de los organistas sí se suele indicar.

Una interesante relación de músicos de corte nos la da el cronista del condestable Lucas de Iranzo, cuando este último contraía matrimonio con Teresa de Torres en 1461 en Jaén:

Pues tronpetas, ministreles de duçaynas e cherimías, atabaleros, tanborinos e pandereteros, e locos e truhanes, tañedores de cuerda e otras personas de más actoridad, así como trobadores e otros que en tales fiestas e de semejantes señores de estado acostunbran e suelen reçebir, que en las dichas fiestas avían concurrido ¿quien podría enumerar las merçedes e dádiuas de jubones de seda e ropas de finos paños, e dineros e otras cosas que les mandó dar? ${ }^{293}$

\section{Ministriles}

Los ministriles altos, chirimías y sacabuches de una forma genérica, lo que no indica que no tañeran otros muchos instrumentos, eran los músicos mejor pagados de la Corte del duque. Ello a causa de que su trabajo podía llegar a ser agotador debido a su participación tanto en los actos religiosos como en los civiles, así dentro como fuera del palacio. No había ocasión en la que no se les necesitara, participaban de los actos religiosos en la capilla y fuera de ella en las procesiones, intervenían en la cámara para disfrute de la familia o en los salones en las muchas ocasiones de fiestas cortesanas, acompañaban a sus señores en sus desplazamientos, eran imprescindibles en justas y juegos de cañas, etc. De nuevo el cronista del condestable nos dice:

${ }^{293}$ Mata Carriazo, Juan de. Hechos del Condestable don Miguel Lucas de Iranzo (Crónica del siglo XV). Madrid, Espasa-Calpe, 1940 (Edición facsímil con estudio preliminar de Michel García, Granada, Universidad de Granada-Marcial Pons, 2009), p. 60. 
Y después de que los dichos señores y otras gentes ouieron çenado, luego los ministriles tocaron las duçaynas; los quales de aquellas fiestas, segúnd lo que trabajaron, no me pasmó sino cómo no perdieron el seso. $^{294}$

Si bien los documentos denominan a los ministriles como chirimías y sacabuches sabemos por un inventario realizado a la muerte de don Diego, III duque, ${ }^{295}$ que los músicos tenían en su poder ciertos instrumentos posesión del duque y que por tanto fueron inventariados. Vemos varios juegos de cornetas, tanto negras como blancas o mudas, en manos de los sacabuches; flautas a cargo de los chirimías y bajones a cargo tanto de unos como de otros. ${ }^{296}$

Como ya vimos con los cantores, de nuevo encontramos músicos que provienen o van a la Capilla real o a la catedral de Toledo (o a la corte del cardenal Tavera, lo que venía a ser lo mismo).

El chirimía Juan de Saravia está incluido en una nómina de 1518 de los ministriles que residen en la corte real. ${ }^{297}$ En 1520 lo vemos en la corte del Infantado con el salario más alto de los chirimías, 40.000 mrs., vuelve a la Casa de Castilla del Emperador y la reina Juana desde el 30 de agosto de 1522 hasta el 23 de agosto de 1527, cuando es despedido, ${ }^{298}$ con un salario menor que el cobrado en el Infantado, 30.000 mrs. De nuevo lo volvemos a ver en 1530 en Guadalajara, recuperando su sueldo, para ser despedido al año siguiente.

Un caso interesante es el del sacabuche de origen posiblemente flamenco Jos Denis $(\dagger$ 25 de mayo de 1527). ${ }^{299}$ La primera información sobre él procede de un pleito sobre unas

\footnotetext{
${ }^{294}$ Mata Carriazo, J. Hechos del Condestable..., p. 47.

${ }^{295}$ Archivo Histórico Nacional, Sección Nobleza (Toledo) (en adelante AHN-SN) Osuna, C. 1835, doc. 15 (sin foliar).

${ }^{296} \mathrm{La}$ asignación de las flautas a los chirimías es algo que debía ser bastante común. Así ocurría en la catedral de Sevilla. STEvenson, Robert. La música en las catedrales españolas del Siglo de Oro. Madrid, Alianza, 1993 , p. 177.

${ }^{297}$ ANGLÉs, H. La Música en la Corte de Carlos V..., vol 1, p. 9.

298 Martínez Millán, José (dir.). La Corte de Carlos V. Madrid, Sociedad Estatal para la Conmemoración de los Centenarios de Felipe II y Carlos V, 2000, vol. 4, p. 342.

${ }^{299}$ Pudiera ser que a este ministril se refiera el bufón Don Francés de Zuñiga cuando hace afirmar al condestable de Castilla «Señores y cavalleros, oy es nuestro día. Y demás desto, parezco ministril alto
} 
viñas de 1495 , en donde figura como sacabuche del duque del Infantado. ${ }^{300}$ Años más tarde, aparece acompañando a Felipe el Hermoso, en su viaje a España de 1502-1503, ${ }^{301}$ en el grupo de los cuatro sacabuches contratados para la ocasión. ${ }^{302}$ Existe la posibilidad de que el duque le «prestara» a su músico o, tal vez, con la muerte del II duque del Infantado en 1500 fuese despedido, junto con el resto de los miembros de la Casa y anduviera contratado en otro lugar. Creemos que después de esta jornada se debió mantener al servicio del Archiduque, pues en el segundo viaje que este realizó en 1506 para tomar posesión de la corona de Castilla junto a Juana, volvemos a encontrar una lista de diez ministriles (joueulx d'instrumens) encabezada por Joosse d'Ems, Pierre Jourdan y Hans Naglel. ${ }^{303}$ Pensamos que este Joosse d'Ems no es otro que Joose Denis que encabezaba la lista del primer viaje, seguido de Jourdan y del famoso Nagel. Tras el fallecimiento en 1506 de Felipe el Hermoso, es probable que se incorporara de nuevo a la Casa del Infantado ya que en la pública almoneda de los bienes de Felipe, los Mendoza adquirieron la mayoría de los tapices y parte de la vajilla de plata, ${ }^{304}$ lo que no hace imposible que se quedaran con algunos sirvientes. Jos Denis, posiblemente tras haber servido en años anteriores, volvería a Guadalajara, quedándose con un salario muy elevado hasta su muerte.

No es infrecuente la presencia de ministriles extranjeros en las casas de la nobleza española, así ya hacia 1480 figuran dos sacabuches foráneos en la casa del duque de Alba,

estranjero que bivo con el duque del Ynfantazgo». ZúÑIGA, Don Francés. Crónica burlesca del emperador Carlos $V$. (Edición, introducción y notas de José Antonio Sánchez Paso), Salamanca, Universidad de Salamanca, 1989; p. 81.

${ }^{300}$ Incitativa, a petición de Diego Jurado, vecino de Guadalajara, sobre que Jos Denys, sacabuche del duque del Infantado, le ha tomado unos pedazos de viñas. AGS, Registro del Sello de Corte, Sign. RGS,LEG,149502,118.

301 A finales de 1501 Felipe el Hermoso y la princesa Juana visitaron España para jurar como príncipes en Toledo. VAnder STRAeten, E. La musique aux Pays-Bas..., vol. 7, p. 149.

${ }^{302}$ Los nombres son Josse Denis, Pierre Jourdan, Jennnin de Calus y Michel de Chastreul. VANDER STRAETEN, E. La musique aux Pays-Bas..., vol. 7, p. 149.

${ }^{303}$ VAnder Straeten, E. La musique aux Pays-Bas..., vol. 7, p. 163 y GACHARD, E. (ed.) Collection des voyages des souverains des Pays-Bas. Bruselas, Hayez, 1876, vol. I, p. 531.

${ }^{304}$ Layna Serrano, F. Historia de Guadalajara y sus Mendozas..., Tomo III, p. 32. Sin embargo el 2 de febrero de 1504 asentó en la Casa de Isabel la Católica en Medina del Campo el ministril alto Jos de Bruselas con un salario de 30.000 mrs. TORRE, A. La Casa de Isabel..., pp. 96, 167 y 226. Parece ser que había llegado a finales de 1503 sin que lo asentaran, percibiendo otros $10.000 \mathrm{mrs}$. por los cuatro meses que le adeudaban. TOrRe, A. Cuentas de Gonzalo de Baeza..., p. 630 y 650. También conocemos la existencia de otro sacabuche de nombre Jos, sin que conozcamos su apellido, en la Casa del conde de Benavente en 1499. FREUND SCHWARTZ, R. En busca de liberalidad..., p. 469. 
Hanequin de Colonia y Cristóbal de León Cataneo y a finales de siglo eran cuatro los sacabuches flamencos. ${ }^{305}$

Este número de cuatro sacabuches es el que vemos en las nóminas del Infantado desde 1511, oscilando entre tres y cuatro desde 1520 hasta 1535, cuando desaparecen todos al ser despedidos los dos últimos que quedaban. El caso de los ministriles de chirimía es diferente, en 1511 solo hay uno, Diego de Espinosa, pero a partir de 1517 se consolida un grupo de cuatro, llegando hasta cinco desde 1530 para ser despedidos todos, al igual que los sacabuches, en 1535. ${ }^{306}$ Algo parecido vemos en la Casa del marqués del Cenete en donde solo figuran un chirimía, Diego de Madrigal y un sacabuche, Sebastián Figueroa en $1515 .^{307}$

Pero no solo con la Casa real se producían intercambios, también ocurría entre las casas nobles e incluso con las grandes catedrales como la de Toledo. ${ }^{308}$

Gerónimo de Cuéllar fue uno de los tres ministriles que en 1531 firmaron un contrato en exclusividad por 20 años con la catedral de Toledo, con la obligación de constituir un grupo de seis ministriles, con un salario de 32.500 mrs., inferior al de 35.000

\footnotetext{
${ }^{305}$ Juan, Pedro, Diego y Francisco de Flandes. CAlderón OrTEGA, J. El ducado de Alba..., p. 278.

${ }^{306}$ En 1546 el duque de Calabria contaba con tres sacabuches y cinco chirimías, la misma cantidad que el Infantado en 1534; en el caso de los cantores y trompetas y atabales también hay coincidencia en cuanto a su número. No sería de extrañar que la capilla musical del duque del Infantado hubiera servido de modelo para la valenciana. No hay que perder de vista que la marquesa del Cenete y futura duquesa de Calabria, Mencía de Mendoza, volvió a España desde Breda en el año de 1534 visitando el palacio del Infantado y estableciéndose en el castillo de Jadraque. Una relación de músicos en la corte de Mencía en MoLL, J. «Notas para la historia musical..., pp. 123-135. Es una verdad a medias la afirmación de Gómez Muntané de que la capilla del duque de Calabria solo era comparable con la del Emperador o la de su hijo. En esos años, tal vez, pero una década antes la del Infantado era igual o superior en plantilla. GómeZ MuNTANÉ, M. «San Miguel de los Reyes ..., p. 98.

${ }^{307}$ El salario del chirimía fue de 10.000 mrs. y el del sacabuche 8.500 mrs. Además en la nómina vemos un atabalero, Francisco Dueñas, con 3.000 mrs. de salario y un trompeta, Jorge Martínez, con 1.500 mrs. Gómez Lorente, Manuel. El marquesado del Cenete (1490-1523). Tesis Doctoral, Universidad de Granada, 1990, p. 556.

${ }^{308}$ En la catedral de Toledo los ministriles estaban obligados a servir a la iglesia, pero también al arzobispo. Según su contrato «aveis de ser obligados de tañer en la dicha yglesia con vuestros ystrumentos en todas las fiestas principales que oviere porçesión entera en la dicha yglesia e en las otras fiestas quel rreverendisimo señor arçobispo de toeledo [sic] mandare e fuere servido». El contrato entero está reproducido en Perales De la CAL, Ramón. Papeles Barbieri. Madrid, Alpuerto, 1985, pp. 47-51.
} 
mrs. que cobrara en 1531 en Guadalajara. ${ }^{309}$ Tras servir al duque del Infantado entre 1522 y 1524, marcha a la Casa de Castilla entre 1524 y $1526^{310}$ y posteriormente en 1531 pasa a Toledo, pero en 1541 ya no está en la nómina. Junto a él fueron contratados en Toledo Gaspar Maynete, chirimía tiple y Bartolomé de Medrano, ${ }^{311}$ chirimía contralto, este último con un salario inferior a Maynete y Cuéllar.

Garçi (o García) González (c. 1511), sacabuche al servicio del Infantado entre 1530 y 1535, cobraba un salario primero de $30.000 \mathrm{mrs}$. y después de $35.000 \mathrm{mrs}$. Se conserva un contrato de aprendizaje entre González y el bachiller Gonzalo Muñoz para que González enseñara el «arte de sacabuche o chirimía a lo que más se inclinare destos dos artes» al sobrino del bachiller por un periodo de cinco años. ${ }^{312}$ Tras ser despedido en Guadalajara, lo encontramos sirviendo al conde de Benavente en 1535 y $1536^{313}$ y en la Corte del duque de Calabria en 1542 y en 1546 con un salario de 120 ducados (45.000 mrs.), el más alto de entre los sacabuches y teniendo a su cargo un mozo que se ocupa de los libros de los ministriles, por lo que percibía otros 12 ducados (4.500 mrs.). ${ }^{314}$ En 1548 y hasta 1554, y de 1569 (el año antes su salario subió a 58.000 mrs.) a 1575 o 1579 (él o su hijo) sirve en la

${ }^{309}$ La catedral de Toledo fue después de Sevilla (1526) y Córdoba (1528) pionera en asalariar un grupo de ministriles para el culto divino. Un estudio sobre los grupos de ministriles en las catedrales españolas es RUIZ-JimÉNEZ, Juan. «Ministriles y extravagantes en la celebración religiosa», Políticas y prácticas musicales en el mundo de Felipe II. Madrid, ICCMU, 2004, pp. 199-239.

${ }^{310}$ Asentado el 15 de junio de 1524. Martínez Millán, J. La Corte de Carlos V..., vol. 4, p. 132.

${ }^{311}$ Bartolomé de Medrano es famoso, entre otras cosas, por haber acompañado a Hernán Cortés a Honduras y ser partícipe de un famoso caso de canibalismo relatado por el obispo Pedraza: «vno que se dize medrano cheremia que es al presente de la iglesia de toledo natural de ... que se hallo en este naufragio dixo a mi el obispo y a otras muchas personas que auia comido de los sesos de un montesinos sacabuche natural de la cibdad de seuilla y de las assaduras y sesos de bernardo Caldera [...] que auian ydo de la dicha seuilla a seruir al dicho marques del valle de menestriles». PEDRAZA, Cristóbal. «Relación de Honduras é Higueras por el obispo D. Cristobal Pedraza», Relaciones de Yucatán, Colección de Documentos Inéditos de Ultramar, Tomo 11, Madrid, Sucesores de Rivadeneyra, 1898, p. 413.

${ }^{312}$ FrEUND SCHWARTZ, R. En busca de liberalidad..., p. 627-28. El pago sería de 30.000 mrs. al concluir el aprendizaje y sería a cuenta del tío los gastos de calzado y vestido y la de la alimentación se ocuparía Garçi, pero recibiría 6.000 mrs. más al año para ello. Además el sobrino estaba obligado a servir «en todas la cosas que fueren lícitas e onestas» durante estos cinco años. Este tipo de contratos es el denominado de servicio y es diferente del contrato de concierto donde se abona una cantidad al principio. Sobre este asunto ver: REYNAud, François. «Música y músicos toledanos: grupos e individuos fuera de la catedral», Políticas y prácticas musicales en el mundo de Felipe II. Madrid, ICCMU, 2004, pp. 241-252; p. 248.

${ }^{313}$ FREUND SCHWARTZ, R. En busca de liberalidad..., pp. 471 y 524.

${ }^{314}$ Para el año 1542, con un salario de 47.256 mrs., donde suponemos se incluiría la ración, en FREUND SCHWARTZ, R. En busca de liberalidad..., p. 296 y para el resto de años MOLL, J. «Notas para la historia musical..., p. 126. 
catedral de Toledo como sacabuche contrabajo. ${ }^{315}$ El 7 de marzo de 1560 la catedral de Sevilla contrata al sacabuche García Gonsales con un salario de 55.000 mrs. y cinco cahizes de trigo. ${ }^{316}$

Diego de Espinosa (c. 1498), a quien ya vimos como testigo en el proceso de Rodrigo de Bivar y él mismo implicado en el movimiento alumbrado de Guadalajara, ${ }^{317}$ sirvió al duque del Infantado como chirimía desde 1511 a 1535, año en que fue despedido tras 25 años de servicio. Su salario se incrementó varias veces, en 1526 subió a 35.000 mrs. y en 1531 a 40.000 mrs. Fue contratado el 29 de mayo de 1535 como chirimía tiple en la catedral de Toledo, donde estuvo hasta $1546 .{ }^{318}$ Junto a él, y también proveniente de la capilla de Guadalajara, fue asentado el sacabuche Juan de Morales, testigo también del pleito de Bivar, que había servido al duque desde 1526 hasta 1535.

Caso particular es el del chirimía Diego de Foz que siendo asentado a mediados de agosto se fue a finales de ese mismo mes por lo que solo cobró 1.250 mrs. Otros destacan por permanecer largo tiempo al servicio del duque, incluso pasando de una generación a otra en la casa ducal. Miguel Pujol aparece con el nombre cambiado varias veces, unas como Puchol, otras como Bunchol, a pesar de haber permanecido mucho tiempo al servicio del Infantado.

Hay otros casos como el de Hierónimo de Sotomayor, sacabuche de la catedral de Toledo en 1539, que afirma haber sido criado del duque del Infantado catorce o quince años antes, ${ }^{319}$ pero al que no encontramos en las nóminas.

\footnotetext{
${ }^{315}$ NoOnE, Michael. «Los ministriles en la catedral de Toledo en la segunda mitad del siglo XVI», Los instrumentos musicales en el siglo XVI. Ávila, Fundación cultural Sta. Teresa, 1993, pp. 125-133; pp. 127-28. Los años intermedios entre 1554 y 1569 no se han conservado. Sabemos también por el trabajo del profesor Noone que en 1561 Garci González, o su hijo, llevó a su mujer ciega y a su familia a Toledo gracias a una ayuda de 15.000 mrs. otorgada por el cabildo catedralicio. Además, el 2 de diciembre de 1564 prestó declaración en el proceso inquisitorial contra Isabel Ortiz y dice ser de edad de «cinquenta y tres años poco más o menos» por lo que debió nacer hacia 1511, ver MAZUELA-ANGUITA, A. «Mujeres músicas y ...

${ }^{316}$ STEvenson, Robert. La Música en la Catedral de Sevilla. 1478-1606. Documentos para su estudio. Madrid, SEdeM, 1985, p. 46.

${ }^{317}$ Fue interrogado por lo menos tres veces por la Inquisición. HAMILTON, A. El proceso..., p. 17.

${ }^{318}$ NoONE, Michael. «Los ministriles en la catedral..., p. 127. Es posible que Espinosa fuese uno de los dos ministriles que se presentaron en abril de 1535 después de haber sido asentados otros seis. MoLL, Jaime. «Documentos para la historia de la música de la catedral de Toledo», Anuario musical, 13 (1958), pp. 159-166.

${ }^{319}$ Igualmente en el proceso de Bivar. HAMILTON, A. Elproceso..., p. 94 y 100.
} 
El chirimía Lope del Castillo sirvió al III y IV duques entre 1530 y 1535, previamente en 1529 había presentado una demanda para recuperar el importe de un instrumento por él siguiendo las órdenes del duque. ${ }^{320}$ Luego lo encontramos en la casa del duque de Calabria entre 1550 y 1552 al servicio de la duquesa doña Mencía de Mendoza. ${ }^{321}$ De aquí pasó a la catedral de Valencia donde en 1560 se creó una capilla de ministriles formada por Lope del Castillo, Antoni del Castillo, Lope del Castillo minor y Diego de Miranda, posiblemente padre e hijos, además de un cuarto. ${ }^{322}$

Varios de los ministriles al ser despedidos en 1535 fueron contratados por el conde de Benavente, Garçi González, como ya vimos antes, y posiblemente Juan de Robredo. Además los dos Diego Vázquez, padre e hijo, que desaparecen en 1534, los vemos en la casa del conde de Benavente. ${ }^{323}$ Tal vez ellos sirvieran de puente para buscar contrato a sus antiguos compañeros.

Vemos varias relaciones de parentesco en la lista como Diego Vázquez, padre e hijo, chirimía y sacabuche respectivamente. Posiblemente Juan de Robredo también fuera pariente de los Vázquez. ${ }^{324}$ Además gracias a un documento ${ }^{325}$ sobre unas rentas sabemos que el tañedor Juan de Morales Baylin el Viejo, fallecido en 1531 el mismo año que el III duque, tras haberle servido por lo menos veintiún años, era padre de Diego de Morales, también tañedor y de Juan de Morales el Mozo, sacabuche. Además Miguel Pujol, también sacabuche, estaba casado con María de Morales hija de Juan de Morales Baylin. Sabemos que Pedro de Morales, sacabuche, no era hijo de Morales el Viejo, pero es más que probable que sea también pariente.

Connocemos un caso incluso de maestro y discípulo entre los ministriles. En 1525 Juan de Úbeda y Diego Vázquez firmaron un contrato para que este último enseñara al

\footnotetext{
${ }^{320}$ FreUnd SCHWARTZ, R. En busca de liberalidad..., p. 510.

${ }^{321}$ FREUND SCHWARTZ, R. En busca de liberalidad..., pp. 324 y 510.

322 CLIMENT; «La capilla de música de la catedral de Valencia», Anuario Musical, 37 (1982), pp. 55-69; p.

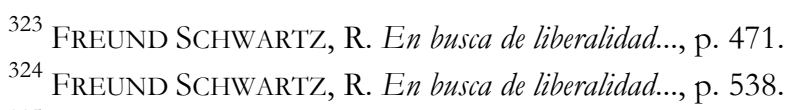
65. 
hijo del primero, de nombre también Juan, el oficio de chirimía. El pago sería de 40.000 mrs. en cuatro plazos, además de una fanega de trigo cada mes y sus vestidos y calzado todo el tiempo que durara el aprendizaje. ${ }^{326}$ En 1530 vemos a Juan de Úbeda al servicio del duque como chirimía con un salario de 20.000 mrs., pero fue despedido en agosto de este mismo año.

\section{Organistas}

Desde 1520 tenemos un organista entre los músicos de la cámara. Gil Martínez hasta 1523 con un salario muy bajo, 2.000 mrs. (compárese con los 30 o 50.000 mrs. de Torres y Chacón). Desde 1523 hasta, por lo menos, hasta 1527, Juan Ordóñez con un salario de 6.000 mrs. y de 1530, como mínimo, a 1531, Juan de Caravaño. Todos ellos figuran como organistas, pero podemos suponer que se encargarían también de los múltiples instrumentos de tecla que aparecen en los inventarios de la Casa como claviórganos, «clavizínbanos» y clavicordios.

\section{Otros músicos}

Para el año 1522 conocemos el nombre de dos músicos al servicio del conde de Saldaña, pues percibieron sus salarios cuando este llegó a duque del Infantado en 1532. Se trata de Diego de Morales, hijo de Juan Morales Baylin, y de Íñigo de Talavera, sin que conozcamos qué instrumentos tocaban, aunque el primero consta como tañedor. Diego de Morales había servido en la casa del duque entre 1511 y 1520, al menos, y luego vuelve a aparecer en 1525 , pero ya no una vez que el conde de Saldaña llega a duque.

Marco de Madrid debió ser responsable de la música de la cámara, pues es el que más tiempo permaneció en ella, desde 1511 hasta su fallecimiento el 14 de marzo de 1535, y el que mayor salario tenía en los primeros años, 30.000 mrs. Otro músico que permaneció mucho tiempo fue Juan de Morales Baylin el Viejo, de quien ya comentabamos sus relaciones familiares un poco más arriba. También sirvió en el palacio ducal desde 1511 hasta 1535, pero en este caso fue despedido junto con la mayoría de los músicos. A ambos

\footnotetext{
${ }^{326}$ El pago se haría de la siguiente manera: 12.000 mrs. cuando supiera tañer algunas obras, $12.000 \mathrm{mrs}$. cuando entrara a servir a algún señor y los otros $16.000 \mathrm{mrs}$. cuando fuera cobrando el primer y segundo año. Reproducido en Freund SCHWARTZ, R. En busca de liberalidad..., p. 626.
} 
se les bajó el salario en 1527 de 15.000 a 10.000 mrs., aunque al primero ya se le había bajado después de 1517. Podemos pensar que eran demasiado viejos y sus habilidades musicales ya estaban muy menguadas, pero se les mantenía un salario al igual que a muchos criados jubilados. ${ }^{327}$

En 1540 y 1541 encontramos un nombre conocido entre los oficiales, Jos Denis. Evidentemente se debe tratar del hijo, pues el padre había fallecido en 1527. A diferencia de su homónimo no figura como sacabuche sino como músico.

Como músico de arpa solo aparece Diego de Rivas en 1545 y 1546 con un buen salario, 40.000 mrs., lo cual es extraño porque en otras familias nobles los arpistas figuran a lo largo de todo el siglo. Tal vez alguno de nuestros músicos sin instrumento encomendado fuera tañedor de arpa.

En 1562 solo encontramos entre los oficiales a Agustín de Alcaraz como músico de tecla y con un salario de 20.000 mrs. En la nómina de $1564^{328}$ aparece Marcos de Solís, músico de vihuela del duque con un salario de 3.333,5 mrs de ración cada mes, a razón de 40.000 mrs anuales. En los salarios acrecentados de 1565 tenemos a Francisco Páez, maestro de danzar del señor don Enrique, un ducado al mes de ración. A Hernando Bejarano y a su hijo, músicos de vihuela de arco, $25.000 \mathrm{mrs}$ de acostamiento desde el 14 de abril, pagados de la despensa. A Blas Serrano, músico de vihuela de arco, $15.000 \mathrm{mrs}$ de acostamiento de un año desde el 15 de abril, pagados en ración.

Hemos incluido en nuestra lista, aunque no aparecen entre los músicos sino entre los oficiales, a Alonso de Guadalupe y a Diego de Bejarano, debido a su condición de violeros, aunque no consten como tales.

El primero de ellos, Alonso de Guadalupe, por el interés que tiene este apellido para el mundo de la vihuela. Como es conocido, uno de los pocos ejemplares de vihuela conservados actualmente es la llamada vihuela Jacquemart-André. Este instrumento

\footnotetext{
${ }^{327}$ El pago de una pensión de jubilación era frecuente entre los militares del Infantado, como indican las nóminas.

${ }^{328}$ Layna Serrano, F. Historia de Guadalajara y sus Mendozas..., Tomo III, pp. 421-25.
} 
presenta una inscripción a fuego en el clavijero con el nombre Guadalupe, que ha sido identificado con el violero toledano Johan de Guadalupe. ${ }^{329}$ Creemos que Alonso de Guadalupe, maestro de vihuelas que figura entre los oficiales del Infantado, se ocuparía de fabricación y restauración de las vihuelas de arco y las de mano. Es bastante probable que ambos Guadalupe sean familiares.

El segundo de ellos, Diego Bejarano, ${ }^{330}$ posiblemente pariente de los músicos de vihuela de arco Hernando Bejarano y su hijo, figura como maestro de atarceas (=taraceas) entre los años 1540 y 1549 con un salario de $20.000 \mathrm{mrs}$. Varios de los instrumentos musicales inventariados en 1564 tras la muerte de Isabel de Aragón, esposa del IV duque del Infantado, fueron fabricados por él. Se trata de dos arpas y una vihuela. ${ }^{331}$

- «arpa que hizo vexarano con una caxa de madera que está forrada en palmylla azul»

- «otra arpa que hizo vexarano con caxa de madera»

- «otra vigüela de hechura de tunba que hizo vejarano con su caxa de madera teñyda de negro».

También aparecen entre los oficiales, con un salario de 3.000 mrs., Tomás Francés, pífano y Antonio Testa, atambor, cuyas funciones, obviamente, eran de tipo militar. El atambor (posiblemente una caja) solo consta el año de 1527, pero en 1531 y 1531 el capitán de los escopeteros recibió 3.000 mrs para un atambor.

${ }^{329}$ REYNAUD, François. La polyphonie tolédane et son milieu. Des premiers témoignages aux environs de 1600. París y Turnhout, CNRS y Brepols, 1996, p. 406. Información reciente sobre esta vihuela en DugOT, Joël. «La vihuela del Musée Jacquemart-André», Aux origines de la guitare: La vihuela de mano. París, Cité de la musique, Musée de la musique, 2004, pp. 50-61. La bibliografía sobre este instrumento es abundante, se puede encontrar en: GONZÁLEZ, Carlos (ed.). Estudios sobre la vihuela. Madrid, Sociedad de la Vihuela, 2007.

${ }^{330}$ Los Bejarano son una familia de violeros y ministriles ROBLEDO ESTAIRE, Luis. «La música en la Casa de la Reina, Príncipe e Infantas», Aspectos de la cultura musical en la Corte de Felipe II. Madrid, Alpuerto, Fundación Caja Madrid, 2000, pp. 195-212; p. 207 y RomANILlos VEGA, José Luis y HARRIS WiNSPEAR, Marian. The vihuela de mano and the Spanish Guitar. A dictionary of the makers of plucked and bowed musical instruments of Spain (1200-2002). Guijosa, The Sanguino Press, 2002; pp. 34-35. Este Diego Bejarano es tal vez el mismo que formó parte de la Junta de violeros que en 1584 reformaron las ordenanzas de violeros como se refleja en el documento reproducido en Romanillos VEGA, J. L. y HARRIS WinsPEAR, M. The vihuela de mano..., p. 474. Entre 1522 y 1531 tenemos otro Diego Bejarano con el oficio de mesero; podemos pensar que era el encargado de las mesas de taracea que aparecen en el inventario. No sabemos si se trata de la misma persona o de padre e hijo.

${ }^{331}$ AHN-SN, Osuna, C. 1834, doc. 2. 
$\underline{\text { Vihuelistas }}$

Conocemos los nombres de los vihuelistas de algunas casas nobles: ${ }^{332}$

- Duque de Medina Sidonia: Antonio Toledano, vihuelista de la casa de la reina Juana en $1506^{333}$ y en la casa del duque de Medina Sidonia en 1509 con un salario de 9.400 mrs. ${ }^{334}$ Rodrigo de Illescas y Maestre Pedro en $1508 .{ }^{335}$

- Duque de Alba: Álvaro de Miranda y Pedro de Illescas en la década de 1470, el primero con salario de 9.000 mrs. En 1495 Juan de Illescas y Alonso Guillén con 10.000 mrs. de quitación. ${ }^{336}$

- Duque de Arcos: Antonio Ramos en 1513 y Hernán López en 1547-50. ${ }^{337}$

En las nóminas del Infantado solo encontramos a Mudarra durante muchos años como vihuelista y en 1534 Marcos de Solís, lo que no quiere decir que alguno de los otros designados como músico también pudiera ser vihuelista. Dedicaremos un capítulo posterior a Mudarra.

\footnotetext{
${ }^{332}$ Siempre nos queda la duda en las nóminas si se refieren a vihuela de mano o de arco.

${ }^{333}$ Martínez Millán, J. La Corte de Carlos V..., vol. 4, p. 363.

${ }^{334}$ NAVARro SAINZ, J. «Aproximación a los gastos..., p. 191.

${ }^{335}$ FrEUND SCHWARTZ, R. En busca de liberalidad..., p. 474.

${ }^{336}$ CAlderón OrTEGA, J. El ducado de Alba..., p. 278-79.

${ }^{337}$ FREUND SCHWARTZ, R. En busca de liberalidad..., pp. 420, y 426.
} 
MÚSICOS DE LA CASA DEL INFANTADO DURANTE EL III DUQUE

\begin{tabular}{|c|c|c|c|c|c|c|c|c|c|c|c|c|}
\hline MÚSICOS Y MINISTRILES & Oficio & 1511 & 1517 & 1520 & 1522 & 1523 & 1524 & 1525 & 1526 & 1527 & 1530 & 1531 \\
\hline CASTILLO, Lope del & Chirimía & & & & & & & & & & $30 \mathrm{M}$ & $30 \mathrm{M}$ \\
\hline ESPINOSA, Diego de & Chirimía & $15 \mathrm{M}$ & $9,375 \mathrm{M}^{1}$ & $23 \mathrm{M}$ & $30 \mathrm{M}$ & $30 \mathrm{M}$ & $30 \mathrm{M}$ & $30 \mathrm{M}$ & $35 \mathrm{M}$ & $35 \mathrm{M}$ & $35 \mathrm{M}$ & $40 \mathrm{M}$ \\
\hline FOZ, Pedro de & Chirimía & & $1,25 \mathrm{M}^{2}$ & & & & & & & & & \\
\hline ROBREDO, Juan de & Chirimía & & & & $20 \mathrm{M}$ & $20 \mathrm{M}$ & $20 \mathrm{M}$ & $20 \mathrm{M}$ & & & & $30 \mathrm{M}^{3}$ \\
\hline SACEDO, Pedro de & Chirimía & & & $23 \mathrm{M}$ & $25 \mathrm{M}$ & $25 \mathrm{M}$ & $25 \mathrm{M}$ & $25 \mathrm{M}$ & $30 \mathrm{M}$ & $30 \mathrm{M}$ & $30 \mathrm{M}$ & $30 \mathrm{M}$ \\
\hline SARAVIA, Juan de & Chirimía & & & $40 \mathrm{M}$ & & & & & & & $40 \mathrm{M}$ & $40 \mathrm{M}^{4}$ \\
\hline ÚBEDA, Juan de & Chirimía & & & & & & & & & & $20 \mathrm{M}^{5}$ & \\
\hline VÁZQUEZ el Viejo, Diego & Chirimía & & $15 \mathrm{M}$ & $30 \mathrm{M}$ & $30 \mathrm{M}$ & $30 \mathrm{M}$ & $30 \mathrm{M}$ & $30 \mathrm{M}$ & $35 \mathrm{M}$ & $35 \mathrm{M}$ & & $40 \mathrm{M}$ \\
\hline ZAMORA, Francisco de & Chirimía & & $23 \mathrm{M}$ & & & & & & & & & \\
\hline CAMPUZANO, Juan & Sacabuche & $\begin{array}{c}13,333 \\
\mathrm{M}^{6}\end{array}$ & $20 \mathrm{M}$ & & & & & & & & & \\
\hline CUELLAR, Gerónimo de & Sacabuche & & & & $22,05 \mathrm{M}^{7}$ & $26 \mathrm{M}$ & $28 \mathrm{M}^{8}$ & & & & $35 \mathrm{M}$ & \\
\hline DENIS, Jos & Sacabuche & $40 \mathrm{M}$ & $40 \mathrm{M}$ & $40 \mathrm{M}$ & $40 \mathrm{M}$ & $40 \mathrm{M}$ & $40 \mathrm{M}$ & $40 \mathrm{M}$ & $40 \mathrm{M}$ & $40 \mathrm{M}^{9}$ & & \\
\hline GODIÑO, Miguel & Sacabuche & $10 \mathrm{M}^{10}$ & $5 \mathrm{M}^{1}$ & & & & & & & & & \\
\hline GONZÁLEZ, Garçi & Sacabuche & & & & & & & & & & $30 \mathrm{M}$ & $30 \mathrm{M}$ \\
\hline MORALES el Mozo, Juan de & Sacabuche & & & & & & & & $20 \mathrm{M}^{11}$ & $20 \mathrm{M}$ & $30 \mathrm{M}$ & $30 \mathrm{M}$ \\
\hline MORALES, Pedro de & Sacabuche & & & & & $20 \mathrm{M}$ & $20 \mathrm{M}$ & $20 \mathrm{M}$ & $25 \mathrm{M}$ & $25 \mathrm{M}$ & & \\
\hline MORATILLA, & Sacabuche & & & & & & & & & & $10 \mathrm{M}^{5}$ & \\
\hline PUJOL/PUCHOL, Miguel & Sacabuche & $23 \mathrm{M}$ & $26 \mathrm{M}$ & $26 \mathrm{M}$ & $26 \mathrm{M}$ & $26 \mathrm{M}$ & $26 \mathrm{M}$ & $26 \mathrm{M}$ & $26 \mathrm{M}$ & $26 \mathrm{M}$ & $26 \mathrm{M}$ & $10 \mathrm{M}$ \\
\hline VALERA, Diego de & Sacabuche & & & $25 \mathrm{M}$ & & & & & & & & \\
\hline VÁZQUEZ, Diego el Mozo & Sacabuche & & & & & & & & & & & $10 \mathrm{M}$ \\
\hline CARAVAÑO, Juan de & Organista & & & & & & & & & & $6 \mathrm{M}$ & $6 \mathrm{M}$ \\
\hline MARTÍNEZ, Gil & Organista & & & $2 \mathrm{M}$ & $2 \mathrm{M}$ & & & & & & & \\
\hline ORDÓÑEZ, Juan & Organista & & & & & $6 \mathrm{M}$ & $6 \mathrm{M}$ & $6 \mathrm{M}$ & $6 \mathrm{M}$ & $6 \mathrm{M}$ & & \\
\hline LEZCANO, Martín de & Tañedor/Músico & & & $2 \mathrm{M}$ & $2 \mathrm{M}$ & $2 \mathrm{M}$ & $2 \mathrm{M}$ & $2 \mathrm{M}$ & $2 \mathrm{M}$ & $2 \mathrm{M}$ & $2 \mathrm{M}$ & $2 \mathrm{M}$ \\
\hline $\begin{array}{l}\text { MORALES BAYLIN el Viejo, } \\
\text { Juan de }\end{array}$ & Tañedor/Músico & $15 \mathrm{M}$ & $15 \mathrm{M}$ & $15 \mathrm{M}$ & $15 \mathrm{M}$ & $15 \mathrm{M}$ & $15 \mathrm{M}$ & $15 \mathrm{M}$ & $15 \mathrm{M}$ & $10 \mathrm{M}^{12}$ & $10 \mathrm{M}$ & $2,92 \mathrm{M}^{13}$ \\
\hline $\begin{array}{l}\text { MORALES, Diego de (hijo de } \\
\text { Juan) }\end{array}$ & Tañedor/Músico & $2 \mathrm{M}$ & $11 \mathrm{M}^{14}$ & $12 \mathrm{M}$ & & & & $2 \mathrm{M}^{15}$ & & & & \\
\hline
\end{tabular}


MÚSICOS DE LA CASA DEL INFANTADO DURANTE EL III DUQUE

\begin{tabular}{|c|c|c|c|c|c|c|c|c|c|c|c|c|}
\hline MÚSICOS Y MINISTRILES & Oficio & 1511 & 1517 & 1520 & 1522 & 1523 & 1524 & 1525 & 1526 & 1527 & 1530 & 1531 \\
\hline Domenico & Músico & $24 \mathrm{M}$ & & & & & & & & & & \\
\hline MADRID, Marco de & Músico & $30 \mathrm{M}$ & $30 \mathrm{M}$ & $15 \mathrm{M}$ & $15 \mathrm{M}$ & $15 \mathrm{M}$ & $15 \mathrm{M}$ & $15 \mathrm{M}$ & $15 \mathrm{M}$ & $10 \mathrm{M}^{12}$ & $10 \mathrm{M}$ & $10 \mathrm{M}$ \\
\hline RODRÍGUEZ, Diego & Músico & $10 \mathrm{M}$ & $10 \mathrm{M}$ & & & & & & & & & \\
\hline MUDARRA, Alonso de & Vihuelista & & & & & $10 \mathrm{M}^{16}$ & $10 \mathrm{M}^{16}$ & $10 \mathrm{M}^{16}$ & $10 \mathrm{M}^{16}$ & $10 \mathrm{M}^{16}$ & $10 \mathrm{M}^{16}$ & $10 \mathrm{M}^{16}$ \\
\hline SEGOVIA, Diego de & Tamborino & $6 \mathrm{M}$ & & & & & & & & & & \\
\hline TESTA, Antonio & Atambor ${ }^{17}$ & & & & & & & & & $3 \mathrm{M}^{18}$ & & \\
\hline FRANCÉS, Tomás & Pífano ${ }^{18}$ & & & & & & & & & $3 \mathrm{M}$ & $3 \mathrm{M}$ & \\
\hline YANGUAS, Juan de & Pífano & & & & $1,5 \mathrm{M}^{19}$ & & & & & $1,5 \mathrm{M}^{19}$ & & \\
\hline GUADALUPE, Alonso de & Maestro de vihuelas ${ }^{18}$ & & $10 \mathrm{M}$ & $10 \mathrm{M}^{20}$ & & & & & & & & \\
\hline
\end{tabular}

${ }^{1}$ Fue asentado a mediados de agosto.

${ }^{2}$ Fue asentado a mediados de agosto y se fue a finales de ese mes.

${ }^{3}$ Desde primero de marzo.

${ }^{4}$ Fue despedido en enero y sustituido por Diego Vázquez.

${ }^{5}$ Despedido en agosto de 1530.

${ }^{6}$ Desde primero de mayo.

${ }_{7}^{7}$ Desde el 11 de febrero.

${ }^{8}$ Se fue en agosto.

${ }^{9} \dagger$ el 25 de mayo de 1527.

${ }^{10}$ Desde primero de agosto.

${ }^{11}$ Desde febrero.

2 Le bajaron el sueldo.

${ }^{13} \dagger$ el 17 de abril de 1531 .

${ }_{15}^{14}$ Desde febrero.

${ }^{5}$ Al servicio del Conde de Saldaña. El duque pago la deuda que había adquirido con el mercader Juan de Perea en 1532.

${ }^{17}$ En 1530 y 1531 Rodrigo de Campuzano, capitán de los escopeteros de Hita, cobró 3.000 mrs. por un atambor del que desconocemos el nombre.

${ }^{8}$ Entre los oficiales.

${ }^{19}$ Entre los hombres de pie. En realidad aparece entre 1517 y 1527, pero solo indica pífano en los años 1522 y 1527, lo que no quiere decir que no ejerciera de tal durante 11 años.

${ }^{20}$ Los $10.000 \mathrm{mrs}$. son de merced, fue despedido a finales de 1521 
MÚSICOS DE LA CASA DEL INFANTADO DURANTE EL IV DUQUE

\begin{tabular}{|c|c|c|c|c|c|c|c|c|c|c|c|c|}
\hline MÚSICOS Y MINISTRILES & Oficio & $1532^{1}$ & 1534 & 1535 & 1536 & 1537 & 1538 & 1540 & 1541 & 1542 & 1545 & 1546 \\
\hline CASTILLO, Lope del & Chirimía & $30 \mathrm{M}$ & $30 \mathrm{M}$ & $7,5 \mathrm{M}^{2}$ & & & & & & & & \\
\hline ESPINOSA, Diego de & Chirimía & $40 \mathrm{M}$ & $40 \mathrm{M}$ & $10 \mathrm{M}^{2}$ & & & & & & & & \\
\hline LÓPEZ, Antonio & Chirimía & $18,55 \mathrm{M}^{3}$ & $20 \mathrm{M}$ & $5 \mathrm{M}^{2}$ & & & & & & & & \\
\hline ROBREDO, Juan de & Chirimía & $30 \mathrm{M}$ & $30 \mathrm{M}$ & $7,5 \mathrm{M}^{2}$ & & & & & & & & \\
\hline SACEDO, Pedro de & Chirimía & $1,450 \mathrm{M}^{4}$ & $14,250 \mathrm{M}$ & & & & & & & & & \\
\hline VÁZQUEZ el Viejo, Diego & Chirimía & $40 \mathrm{M}$ & $40 \mathrm{M}$ & & & & & & & & & \\
\hline GONZÁLEZ, Garçi & Sacabuche & $35 \mathrm{M}$ & $35 \mathrm{M}$ & $8,75 \mathrm{M}^{2}$ & & & & & & & & \\
\hline MORALES el Mozo, Juan de & Sacabuche & $35 \mathrm{M}$ & $35 \mathrm{M}$ & $8,75 \mathrm{M}^{2}$ & & & & & & & & \\
\hline VÁZQUEZ el Mozo, Diego & Sacabuche & $10 \mathrm{M}$ & $20 \mathrm{M}$ & & & & & & & & & \\
\hline DENIS, Jos & Músico & & & & & & & $21 \mathrm{M}^{5}$ & $21 \mathrm{M}^{5}$ & & & \\
\hline MADRID, Marco de & Músico & $10 \mathrm{M}$ & $10 \mathrm{M}$ & $2 \mathrm{M}^{6}$ & & & & & & & & \\
\hline RAMÍREZ, Martín & Músico & & $\begin{array}{c}11,920 \\
\mathrm{M}^{7}\end{array}$ & & & & & & & & & \\
\hline RIVAS, Diego de & Músico de Arpa & & & & & & & & & & $40 \mathrm{M}^{8}$ & $44 \mathrm{M}^{8}$ \\
\hline MUDARRA, Alonso de & Vihuelista & $\begin{array}{c}22,775 \\
\mathrm{M}^{9}\end{array}$ & $\begin{array}{c}23,920 \\
\mathrm{M}^{9}\end{array}$ & & & $\begin{array}{c}19,933 \\
\mathrm{M}^{10}\end{array}$ & $40 \mathrm{M}^{11}$ & $40 \mathrm{M}^{11}$ & $40 \mathrm{M}^{11}$ & $40 \mathrm{M}^{11}$ & & \\
\hline BEJARANO, Diego de & Maestro de atarceas ${ }^{12}$ & & & & & & & $1,772 \mathrm{M}$ & $20 \mathrm{M}$ & $20 \mathrm{M}$ & $20 \mathrm{M}$ & $20 \mathrm{M}$ \\
\hline
\end{tabular}

${ }^{1}$ En los años de 1532 y 1535 los músicos aparecen incluidos en la capilla. No es así en 1534.

${ }^{2}$ Despedido a finales de marzo. Hay errores en las quitaciones.

3 Desde el 29 de enero. Sustituyó a Pedro de Sacedo que fue despedido el día anterior.

${ }^{4}$ Despedido 28 enero. Sustituido por Antonio López.

5 Es muy probable que se trate del hijo del Jos Denis sacabuche. Aparece entre los oficiales con el título de músico. Cobraba 9.000 mrs. de quitación y 12.000 mrs. de ración.

'† el 14 de marzo de 1535.

${ }^{7}$ Más 10 reales al mes de ración. En total 16.000 mrs. Fue despedido a finales de mayo.

${ }^{8}$ Aparece entre los oficiales. Además cobraba 24 fanegas de trigo, 45 fanegas de cebada y la posada. Fue despedido el 23 de agosto de 1546.

9 Además recibía 90 fanegas de cebada y ración.

${ }^{10}$ Desde primero de marzo. Además 37 fanegas de cebada.

${ }^{11}$ De quitación y ración y 90 fanegas de cebada.

${ }^{12}$ Entre los oficiales. Todavía cobró en 1548 y 1549. 


\section{Trompetas}

Pasamos ahora a ver los «músicos ruidosos», que decía Menéndez Pidal. ${ }^{338}$ Incluimos en este apartado, tal y como viene consignado en las nóminas, a trompetas y atabales. Ya hemos señalado su carácter heráldico.

Iban antes e despues gente ynfinita de la çibdat e de la su corte; el sonido era grande de las tronpetas e atabales e gentes, con alegria, que pareçia que los çielos e la tierra destellauan en aquella ora alegria de coraçon, que dezir nose puede; ca el coraçon de grande ynfuso gozo, dulçes por los ojos destila gotas: ffue tan trihunfal rreçebimiento, qual nunca Roma fizo a los sus priçipes. ${ }^{339}$

El ruido representa el poder, ${ }^{340}$ el rey y los grandes nobles siempre aparecen precedidos del intenso ruido provocado por trompetas y atabales. Con frecuencia se contrapone la brutalidad de este ruido con la dulzura de chirimías o dulzainas.

Delante de los ya dichos pajes yua tan grand moltitud e ruydo de atabales, tronpetas bastardas e italianas, chirimías, tanborinos, panderos e locos, e vallesteros de maça, e otros ofiçiales de diuersas maneras, que no avíe persona que vna a otra oyr se pudiesen, por çerca e alto que en vno fablasen. Y entre los otros, yua vna copla de tres ministreles de duçaynas, que muy dulçe e acordadamente sonauan [...] E dicha la misa, boluiéronse a su posada [...] con tanta gente y estruendo de tantas tronpetas y atabales, e los otros estormentos, que no paresçía sinó que se viníe el mundo abaxo. ${ }^{341}$

El número de trompetas y atabales fue aumentando en los siglos XV y XVI. Fernando el Católico contaba con cuatro trompetas y un atabalero en 1475, subiendo en la década de 1480 a ocho trompetas y cuatro atabaleros, número que se mantuvo hasta su muerte. Una cantidad similar se encontraba en la casa de Isabel de Castilla. ${ }^{342}$ En 1504 Felipe el Hermoso se presenta en España con nueve trompetas, pero en 1506, en su segundo viaje,

\footnotetext{
338 MENÉndez PIDAL, Ramón. Poesía juglaresca y orígenes de las literaturas románicas. Madrid, Instituto de Estudios Políticos, 1957, 6a ed., p. 45.

${ }^{339}$ Recibimiento que hicieron en Toledo a los reyes Isabel y Fernando en 1477. Citado por FERNÁNDEZ DE Córdova Miralles, Á. La Corte de Isabel I..., p. 387.

340 «Qui détient le bruit détient le pouvoir». CLARE, Lucien. «Le connétable, la musique et le pouvoir (d'après Los hechos del Condestable Miguel Lucas de Iranzo)», Bulletin Hispanique, 90/1-2 (1988), pp. 27-57;

${ }^{341}$ La descripción corresponde con la boda del Condestable Lucas de Iranzo cuando la pareja se dirige a la iglesia. Mata Carriazo, J. Hechos del Condestable..., pp. 43-45.

${ }^{342}$ KNighton, T. Música y músicos..., p. 146.
} p. 28. 
ya son doce. ${ }^{343}$ Carlos V tenía en la Casa de Castilla entre seis y nueve trompetas y cuatro atabaleros. Felipe II contaba con dieciocho trompetas de la escuela italiana, acompañados por dos atabaleros y doce trompetas, más cinco atabaleros, de la escuela española. ${ }^{344}$

Entre la alta nobleza el duque de Alba contaba con un elenco de siete trompetas y un atabalero en las décadas de 1470 y $1480^{345}$. El conde-duque de Benavente en 1499, siete trompetas y dos atabales. ${ }^{346} \mathrm{El}$ duque de Medina Sidonia en 1508 también siete trompetas y dos atabaleros, ${ }^{347}$ en 1516 seis trompetas y un atabalero y en 1535 nueve trompetas (más una trompeta italiana) y dos atabaleros. ${ }^{348}$ El duque de Arcos contaba con seis trompetas en 1510 y las mismas entre 1547 y 1548, en 1549 cinco y en 1550 cuatro. ${ }^{349}$ El duque de Calabria ocho trompetas y dos atabaleros en $1546 .{ }^{350} \mathrm{El}$ duque de Béjar posiblemente tenía también siete trompetas y cuatro atabaleros a mediados del siglo XVI. ${ }^{351}$

El duque del Infantado cuenta con nueve trompetas en 1511 y doce desde 1517, oscilando entre once y quince hasta 1534, siendo despedidos todos entre junio de 1534 y marzo de 1535 (en este año todos los músicos figuran en la Capilla). Como veremos después el número de atabaleros se estabiliza en cuatro desde 1520, manteniendo uno hasta 1538.

${ }^{343}$ VAnder Straeten, E. La musique aux Pays-Bas..., vol. 7, p. 157 y 163-34. En 1474 Carlos el Temerario, duque de Borgoña, tenía a su servicio doce trompetas de guerra, seis ministriles y cuatro tañedores de instrumentos bajos. ROBLEDO ESTAIRE, Luis. «La música en la corte madrileña de los Austrias. Antecedentes: las casas reales hasta 1556», Revista de Musicología, $10 / 3$ (1987), pp. 753-796,; p. 759.

${ }^{344}$ Un estudio detallado en ROBLEDO ESTAIRE, L. «La música en la Casa del Rey...

345 CAlderón Ortega, J. El ducado de Alba..., p. 278-79.

${ }^{346}$ FERnÁNDEZ-CORTÉs, J. La música en las Casas de ..., p. 113-14.

${ }^{347}$ FreUnd SCHWARTZ, R. En busca de liberalidad..., p. 474.

${ }^{348}$ RUIZ-JIMÉNEZ, J. «Power and musical exchange..., pp. 410-411.

${ }^{349}$ FREUND SCHWARTZ, R. En busca de liberalidad..., p. 426.

${ }^{350}$ MoLL, J. «Notas para la historia musical..., pp. 127-28.

${ }^{351}$ Extrapolamos los datos del inventario de 1544 del Castillo de Belalcázar donde figuran siete paños y siete cordones de trompetas y ocho atabales de cobre (cuatro pares). Citado por RUSSELL, E. «Music in the House..., pp. 285-303. 
TROMPETAS Y ATABALES EN LAS CASAS NOBLES

\begin{tabular}{cccc}
\hline CASA & AÑO & TROMPETAS & ATABALEROS \\
\hline Duque de Alba & $1470-1480$ & 7 & 1 \\
Conde-duque de Benavente & 1499 & 7 & 2 \\
Duque de Medina Sidonia & 1508 & 7 & 2 \\
Duque de Arcos & 1510 & 6 & $?$ \\
Duque de Medina Sidonia & 1516 & $9+1$ & 2 \\
Duque de Medina Sidonia & 1535 & 8 & 2 \\
Duque de Calabria & 1546 & 6 & $?$ \\
Duque de Arcos & $1547-1548$ & 7 & 4
\end{tabular}


TROMPETAS DE LA CASA DEL INFANTADO

\begin{tabular}{|c|c|c|c|c|c|c|c|c|c|c|c|c|c|c|c|}
\hline & Nota & 1511 & 1517 & 1520 & 1522 & 1523 & 1524 & 1525 & 1526 & 1527 & 1530 & 1531 & 1532 & 1534 & 1535 \\
\hline $\begin{array}{l}\text { CAMARGO, Fernando } \\
\text { de }\end{array}$ & & & $14 \mathrm{M}$ & $14 \mathrm{M}$ & $14 \mathrm{M}$ & $14 \mathrm{M}$ & $14 \mathrm{M}$ & $14 \mathrm{M}$ & $18 \mathrm{M}$ & $18 \mathrm{M}$ & $18 \mathrm{M}$ & $18 \mathrm{M}$ & $18 \mathrm{M}$ & $18 \mathrm{M}$ & \\
\hline CASTILLO, Alonso del & & $18 \mathrm{M}$ & & & & & & & & & & & & & \\
\hline CASTILLO, Andrés del & & $18 \mathrm{M}$ & $18 \mathrm{M}$ & & & & & & & $18 \mathrm{M}$ & $18 \mathrm{M}$ & $18 \mathrm{M}$ & $18 \mathrm{M}$ & $7,8 \mathrm{M}^{1}$ & \\
\hline CASTILLO, Antón del & & $14 \mathrm{M}$ & $14 \mathrm{M}$ & & & & $14 \mathrm{M}$ & $14 \mathrm{M}$ & $14 \mathrm{M}$ & $14 \mathrm{M}$ & $14 \mathrm{M}$ & $14 \mathrm{M}$ & $14 \mathrm{M}$ & $14 \mathrm{M}$ & $3,5 \mathrm{M}^{2}$ \\
\hline CASTILLO, Cebrián del & $\begin{array}{l}\text { Hijo de Juan } \\
\text { del Castillo }\end{array}$ & & & & & & & & & & & & $8 \mathrm{M}$ & $\begin{array}{c}3,466 \\
\mathrm{M}^{1}\end{array}$ & \\
\hline $\begin{array}{l}\text { CASTILLO, Francisco } \\
\text { del }\end{array}$ & el Mozo & & $16 \mathrm{M}$ & $16 \mathrm{M}$ & $16 \mathrm{M}$ & $16 \mathrm{M}$ & $16 \mathrm{M}$ & $16 \mathrm{M}$ & $16 \mathrm{M}$ & $16 \mathrm{M}$ & $16 \mathrm{M}$ & $16 \mathrm{M}$ & $16 \mathrm{M}$ & $\begin{array}{c}6,932 \\
\mathrm{M}^{1}\end{array}$ & \\
\hline $\begin{array}{l}\text { CASTILLO, Francisco } \\
\text { del }\end{array}$ & el Viejo & $18 \mathrm{M}$ & $18 \mathrm{M}$ & $18 \mathrm{M}$ & $18 \mathrm{M}$ & $18 \mathrm{M}$ & $18 \mathrm{M}$ & $18 \mathrm{M}$ & $18 \mathrm{M}^{3}$ & & & & & & \\
\hline CASTILLO, Juan del & $\begin{array}{l}\text { Hijo de } \\
\text { Antón del } \\
\text { Castillo }\end{array}$ & & & & & & & & & $14 \mathrm{M}^{4}$ & $14 \mathrm{M}$ & $6 \mathrm{M}^{5}$ & $14 \mathrm{M}$ & $\begin{array}{c}6,065 \\
\mathrm{M}^{1}\end{array}$ & \\
\hline CASTROVERDE & & $6 \mathrm{M}$ & $6 \mathrm{M}$ & & & & & & & & & & & & \\
\hline GARCÍA, Juan & & $14 \mathrm{M}$ & $18 \mathrm{M}$ & $18 \mathrm{M}$ & $18 \mathrm{M}$ & $18 \mathrm{M}$ & $18 \mathrm{M}$ & $18 \mathrm{M}$ & $18 \mathrm{M}$ & $18 \mathrm{M}$ & $18 \mathrm{M}$ & $18 \mathrm{M}$ & $18 \mathrm{M}$ & $18 \mathrm{M}$ & $4,5 \mathrm{M}^{2}$ \\
\hline GASCÓN, Alonso & & $18 \mathrm{M}$ & $18 \mathrm{M}$ & $18 \mathrm{M}$ & $18 \mathrm{M}$ & $18 \mathrm{M}$ & $18 \mathrm{M}$ & $18 \mathrm{M}$ & $18 \mathrm{M}$ & $18 \mathrm{M}^{6}$ & $18 \mathrm{M}$ & $18 \mathrm{M}$ & $18 \mathrm{M}$ & $18 \mathrm{M}$ & \\
\hline GASCÓN, Bernabé & & & & $14 \mathrm{M}$ & $14 \mathrm{M}$ & $14 \mathrm{M}$ & $14 \mathrm{M}$ & $14 \mathrm{M}$ & $14 \mathrm{M}$ & & & & & & \\
\hline $\begin{array}{l}\text { HONTAÑÓN, } \\
\text { Francisco de }\end{array}$ & & & & & & & & & & & $20 \mathrm{M}$ & $20 \mathrm{M}$ & & & \\
\hline LÓPEZ, Pero & & & & $12 \mathrm{M}$ & $12 \mathrm{M}$ & $12 \mathrm{M}$ & $12 \mathrm{M}$ & $12 \mathrm{M}$ & $12 \mathrm{M}$ & $12 \mathrm{M}$ & & & & & \\
\hline MADRID, Diego de & & $10 \mathrm{M}$ & & & & & & & & & & & & & \\
\hline PAREDES, Rodrigo de & & & & & & & & $8,166 \mathrm{M}^{7}$ & $14 \mathrm{M}$ & $14 \mathrm{M}$ & $14 \mathrm{M}$ & $14 \mathrm{M}$ & & & \\
\hline QUIRÓS, Diego de & $\begin{array}{l}\text { Hijo de Juan } \\
\text { de San Pedro }\end{array}$ & & & & & & & & & & & & & $4 \mathrm{M}^{8}$ & $1 \mathrm{M}^{2}$ \\
\hline $\begin{array}{l}\text { SAN PEDRO, Fernando } \\
\text { de }\end{array}$ & $\begin{array}{l}\text { Hijo de Juan } \\
\text { de San Pedro }\end{array}$ & & $14 \mathrm{M}$ & $14 \mathrm{M}$ & $18 \mathrm{M}$ & $18 \mathrm{M}$ & $18 \mathrm{M}$ & $18 \mathrm{M}$ & $18 \mathrm{M}$ & $18 \mathrm{M}$ & $18 \mathrm{M}$ & $18 \mathrm{M}$ & & $18 \mathrm{M}$ & \\
\hline SAN PEDRO, Juan de & & $18 \mathrm{M}^{9}$ & $23 \mathrm{M}^{9}$ & $23 \mathrm{M}$ & $23 \mathrm{M}^{10}$ & $23 \mathrm{M}^{10}$ & $23 \mathrm{M}$ & $23 \mathrm{M}^{10}$ & $23 \mathrm{M}^{10}$ & $23 \mathrm{M}^{10}$ & & & & $23 \mathrm{M}^{10}$ & $5,75 \mathrm{M}^{2}$ \\
\hline SAN PEDRO, Juan de & $\begin{array}{l}\text { Hijo de Juan } \\
\text { de San Pedro }\end{array}$ & & & & & & & & & & & & & $4 \mathrm{M}^{8}$ & $1 \mathrm{M}^{2}$ \\
\hline SAN PEDRO, Pedro de & & & & & & & & & & & & & & $18 \mathrm{M}$ & \\
\hline TOLOSA, Antonio de, & $\begin{array}{l}\text { Hermano de } \\
\text { Fernando }\end{array}$ & & & $12 \mathrm{M}$ & $12 \mathrm{M}$ & $12 \mathrm{M}$ & $12 \mathrm{M}$ & $12 \mathrm{M}$ & $12 \mathrm{M}$ & $12 \mathrm{M}$ & & & & & \\
\hline TOLOSA, Bernardo de & & & & & & & & & & $14 \mathrm{M}^{4}$ & $14 \mathrm{M}$ & $14 \mathrm{M}$ & 8,166 & $14 \mathrm{M}$ & $3,5 \mathrm{M}^{2}$ \\
\hline
\end{tabular}


$\mathrm{M}^{7}$

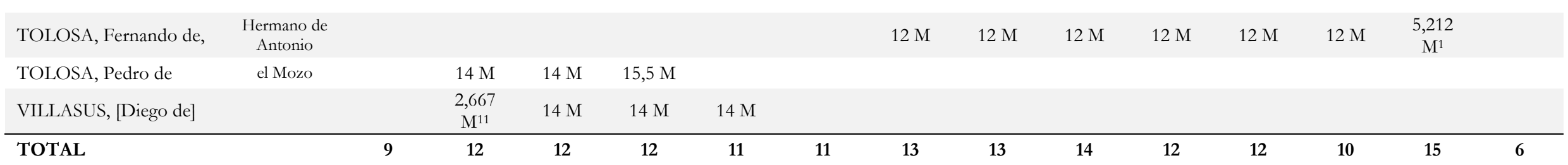

${ }^{1}$ Despedido 6 junio de 1534.

2 Despedido fin marzo. Aparece en la Capilla.

${ }^{3}$ Falleció a finales de abril de 1526.

${ }^{4}$ Desde febrero de 1527.

Despedido en abril.

Despedido aunque cobró todo su salario.

${ }^{7}$ Desde primero de junio.

\$ Más $6.000 \mathrm{mrs}$. de ración.
En

${ }^{9}$ En 1511 percibe $5.000 \mathrm{mrs}$. de merced y en $1517,3.000 \mathrm{mrs}$.

${ }^{10}$ Además percibía 40 fanegas de trigo.

${ }_{11}$ Fue despedido a finales de agosto por lo que solo cobró la parte proporcional de los $4.000 \mathrm{mrs}$. de salario. 
ATABALEROS DE LA CASA DEL INFANTADO

\begin{tabular}{|c|c|c|c|c|c|c|c|c|c|c|c|c|c|c|c|c|c|}
\hline & 1511 & 1517 & 1520 & 1522 & 1523 & 1524 & 1525 & 1526 & 1527 & 1530 & 1531 & 1532 & 1534 & 1535 & 1536 & 1537 & 1538 \\
\hline BARBA, Garci & & $3 \mathrm{M}$ & $6,72 \mathrm{M}^{1}$ & $7,092 \mathrm{M}$ & 7,092 M & $7,092 \mathrm{M}$ & 7,092 M & 7,092 M & $7,092 \mathrm{M}^{2}$ & $10 \mathrm{M}$ & $10 \mathrm{M}$ & $10 \mathrm{M}$ & $12 \mathrm{M}^{1}$ & $1,98 \mathrm{M}^{3}$ & & & \\
\hline Cristóbal & $7 \mathrm{M}$ & & & & & & & & & & & & & & & & \\
\hline Diego, maestre & $3 \mathrm{M}$ & $3 \mathrm{M}$ & $7,092 \mathrm{M}^{1}$ & $7,092 \mathrm{M}$ & $7,092 \mathrm{M}$ & $7,092 \mathrm{M}$ & 7,092 M & $7,092 \mathrm{M}$ & $7,092 \mathrm{M}$ & $7,092 \mathrm{M}$ & 7,092 M & $11,160 \mathrm{M}$ & $11,172 \mathrm{M}^{1}$ & $4,713 \mathrm{M}^{4}$ & $8 \mathrm{M}^{1}$ & $8 \mathrm{M}^{1}$ & $8 \mathrm{M}^{1}$ \\
\hline LAGUNA, Diego de & & & & & & & & $21 \mathrm{M}^{5}$ & $9 \mathrm{M}^{6}$ & & & & & & & & \\
\hline LUIS el Negro & & & $2 \mathrm{M}$ & $2 \mathrm{M}$ & & & & & & & & & & & & & \\
\hline MENDOZA, Luis de & & & & & $2 \mathrm{M}$ & $2 \mathrm{M}^{7}$ & $2 \mathrm{M}$ & & & & & & & & & & \\
\hline MORALES, Juan de & & & 6,092 M $\mathrm{M}^{1}$ & 6,092 M & 6,092 M & & & & & & & & & & & & \\
\hline Pedro, hijo de Diego & & & & & & & & {$[4,092 \mathrm{M}]^{8}$} & $?$ & {$[4,092 \mathrm{M}]^{8}[$} & $4,092 \mathrm{M}]^{8}$ & $4,08 \mathrm{M}$ & $6,08 \mathrm{M}^{1}$ & $0,5 \mathrm{M}^{3}$ & & & \\
\hline PORTILLO & & & & & & & & & & & & & $10 \mathrm{M}^{1}$ & $1,48 \mathrm{M}^{3}$ & & & \\
\hline SUÁREZ, Bernardino & & & & & & & & & & $10 \mathrm{M}^{9}$ & $15 \mathrm{M}^{9}$ & $21 \mathrm{M}^{10}$ & & & & & \\
\hline ZAYAS, Antonio de & $3 \mathrm{M}$ & & & & & & & & & & & & & & & & \\
\hline TOTAL & 3 & 2 & 4 & 4 & 4 & 3 & 3 & 4 & $4 ?$ & 4 & 4 & 4 & 4 & 4 & 1 & 1 & 1 \\
\hline \multicolumn{18}{|c|}{$\begin{array}{l}{ }^{1} \text { Con la ración. } \\
2 \text { A finales de julio se le acrecentó hasta } 10.000 \text { mrs. } \\
3 \text { Despedido a finales de marzo de } 1535 . \\
{ }^{4} \text { Despedido fin marzo y vuelto a asentar en abril. } \\
59.000 \text { de quitación y } 12.000 \text { mrs. de ración en la despensa. } \\
6 \text { Suponemos que además percibió los } 12.000 \text { mrs. de ración. } \\
{ }^{7} \text { Despedido. } \\
{ }^{8} \text { Lo cobró su padre el maestre Diego. } \\
{ }^{2} \text { Cobró } 2.250 \text { mrs. para cueros. } \\
10\end{array}$} \\
\hline
\end{tabular}




\section{$\underline{\text { Trompetas }}$}

En el siguiente esquema intentamos mostrar las relaciones de los tres clanes principales de trompetas de la Casa del Infantado, Castillo, San Pedro y Tolosa. Marcamos con línea discontinua cuando la relación no es segura. Entre paréntesis los años en los que estuvieron sirviendo en Guadalajara.

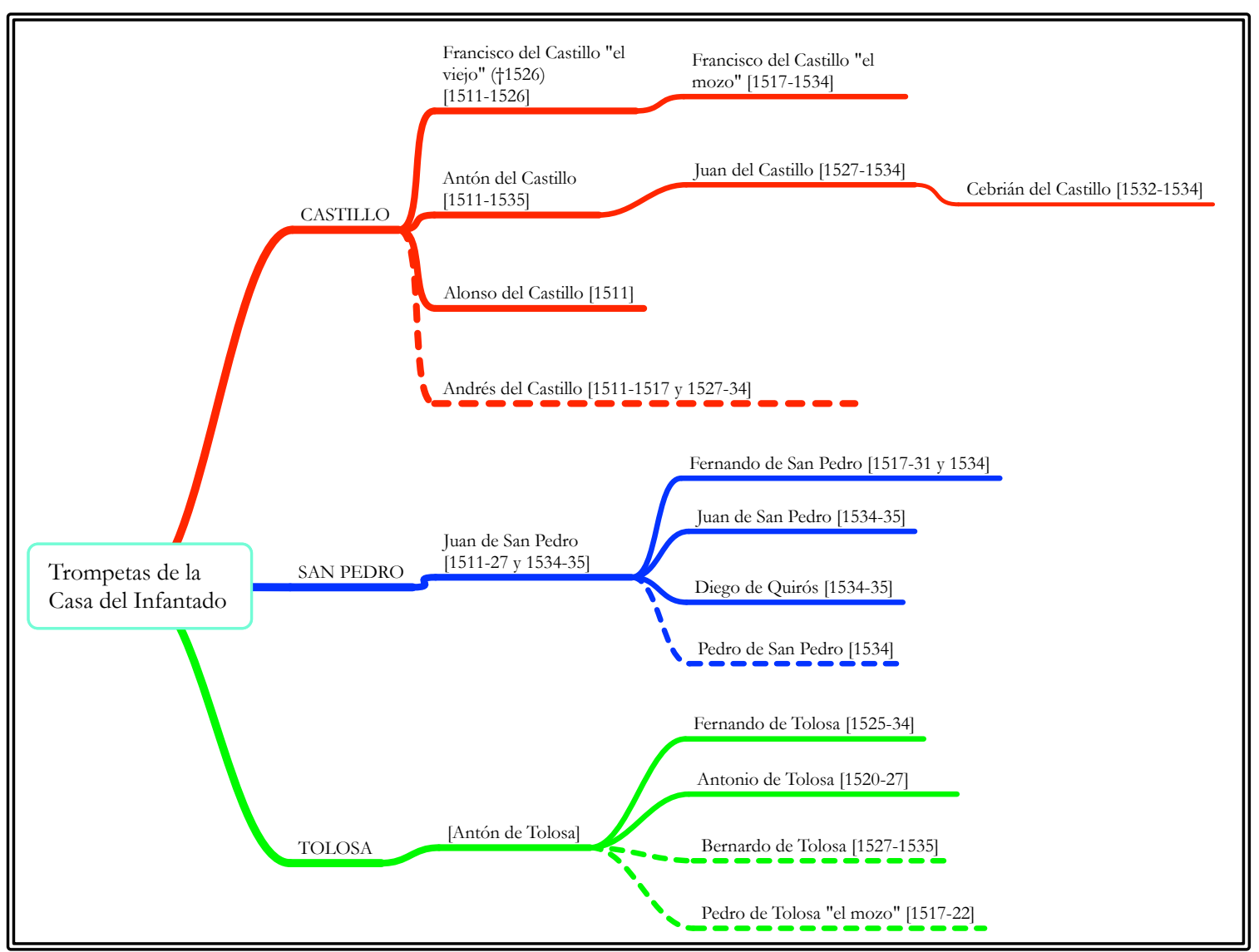

Fig. 13. Posible reconstrucción de tres familias de trompetas de la Casa del Infantado

Como podemos ver es frecuente la presencia de padres e hijos, e incluso nietos, simultáneamente. En el caso de los Castillo, contamos con siete miembros, llegando a superponerse hasta cinco. 
En los años de 1530 y 1531, los trompetas reciben 4.250 mrs. en concepto de aguinaldo navideño. A mediados de 1534 fueron despedidos la mayoría ${ }^{352}$ y el resto el año siguiente. De la mayoría nada sabemos posteriormente, pero algunos de ellos aparecen en otras cortes. Veamos los casos más sobresalientes.

Bernabé Gascón († 28 de febrero de 1557) sirvió al duque entre 1520 y 1526 junto con Alonso Gascón (que ya aparece en 1511 y tal vez fuera su padre). Entró al servicio del Emperador en la Casa de Castilla el 17 de agosto de 1528, prosiguiendo al servicio de Felipe II hasta su muerte en 1557. Cuando falleció dejó, al menos, dos hijos menores de edad, Gaspar y Antonio, que le sucedieron en el cargo uno tras otro. ${ }^{353}$ Añadimos una posible reconstrucción de la familia Gascón (con líneas punteadas señalamos las relaciones dudosas).

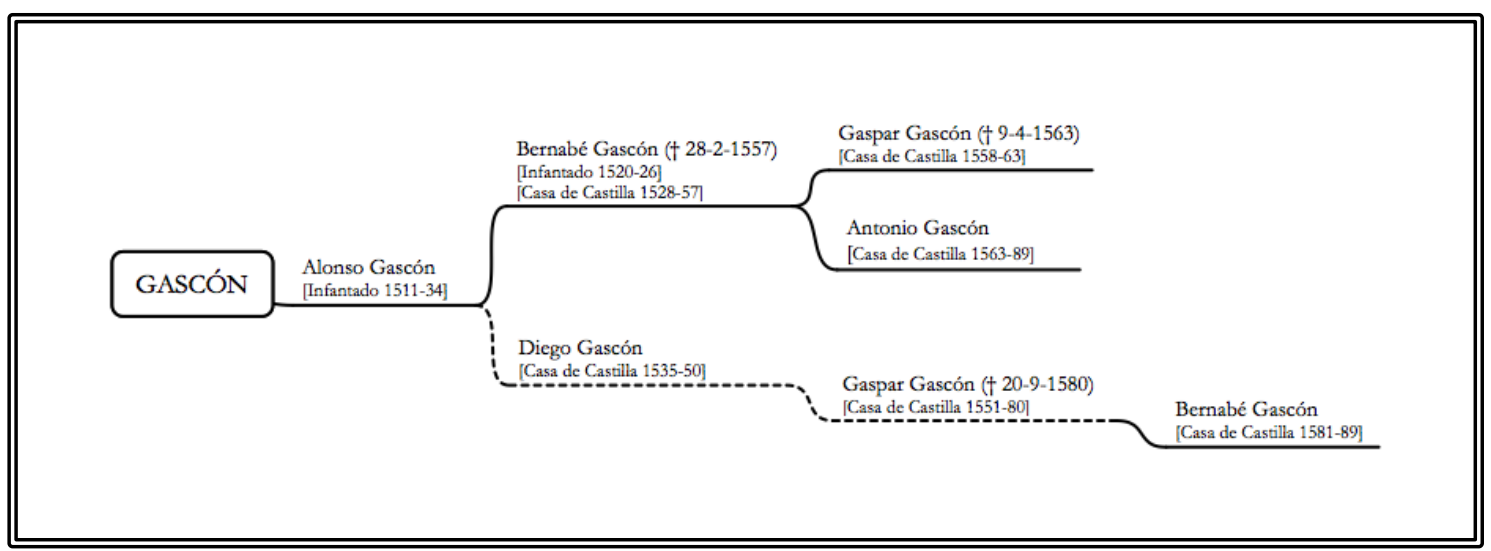

Fig. 14. Posible reconstrucción la familia Gascón

A Cebrián del Castillo († 24 de abril de 1560), trompeta de tercera generación como mínimo, tras tres años en la Casa del Infantado (1532 a 1534), lo encontramos al servicio del Emperador, en la Casa de Castilla en 1539, con un salario de 25.000 mrs. ${ }^{354}$ Unos años

\footnotetext{
${ }^{352}$ En la nómina encontramos quince nombres, pero considerando que fueron despedidos cinco y que otors cinco o son nuevos o vuelven a aparecer tras algunos años ausentes, podríamos considerar el número de diez trompetas lo correcto para ese año de 1534.

${ }^{353}$ Anglés, H. La Música en la Corte de Carlos V..., vol 1, pp. 38-39, 63 y 117 y MARTíneZ MiLlán, J. y FERNÁndez CONTI, S. La monarquía de Felipe II..., vol. II, p. 182. Entre 1539 y 1550 también aparece en las nóminas de la Casa de Castilla Diego Gascón, tal vez su hermano. MARTínez Millán, J. La Corte de Carlos V..., vol. 4, p. 176.

${ }^{354}$ ANGLÉs, H. La Música en la Corte de Carlos V..., vol 1, p. 63. Fue asentado el 13 de diciembre de 1538., vid. Martínez Millán, J. y Fernández Conti, S. La monarquía de Felipe II..., vol. II, p. 98. También en Knighton, Tess. «La música en la casa y capilla del Príncipe Felipe (1543-1556): modelos y contextos»,
} 
más tarde, en 1552, servía a la infanta Juana que partía desde Toro hacia Portugal. ${ }^{355}$ Desde 1556 hasta su muerte en 1560 está en la nómina de la Casa de Castilla del primero príncipe y después rey, Felipe II.

Juan de San Pedro sirvió en la Casa de Castilla desde el 15 de julio de 1524 hasta enero de $1528 .{ }^{356}$ Se debe tratar del hijo, que sirvió al duque del Infantado entre 1534 y 1535, porque el padre en ese año estaba en Guadalajara. También encontramos entre 1530 y 1553 a un Juan de Quirós en la Capilla castellana. ${ }^{357}$ No es improbable que se trate de otro miembro de la familia San Pedro, pues uno de sus integrantes se llamaba Diego de Quirós. ${ }^{358}$

Junto a él Diego de Villasus († 13 de octubre de 1559). Sirvió en el Infantado desde 1517, aunque en este año fue despedido, hasta 1523. El 15 de julio de 1524 pasó a la Casa de Castilla permaneciendo al menos hasta 1533. De nuevo vuelve a ser asentado en 1556 quedándose hasta su muerte. ${ }^{359}$ Su hijo Pedro le sucedió en la Corte hasta que huyó por haber matado a su mujer en $1585 .^{360}$

Fernando de Camargo, trompeta en el Infantado entre 1517 y 1534, pudiera tener relación con la familia de ministriles Camargo, ${ }^{361}$ pues los orígenes de esta familia son alcarreños.

Aspectos de la cultura musical en la Corte de Felipe II. Madrid, Alpuerto, Fundación Caja Madrid, 2000, pp. 35-97; p. 48.

${ }^{355}$ AngLés, H. La Música en la Corte de Carlos V..., vol 1, p. 117.

${ }^{356}$ Martínez Millán, J. La Corte de Carlos V..., vol. 4, p. 335 y Anglés, H. La Música en la Corte de Carlos V..., vol 1, p. 23.

${ }^{357}$ Martínez Millán, J. La Corte de Carlos V..., vol. 4, p. 311.

${ }^{358}$ ANGLÉs, H. La Música en la Corte de Carlos V ..., vol 1, p. 63.

359 MArtínez Millán, J. y Fernández CONTI, S. La monarquia de Felipe II..., vol. II, p. 499 y AngLÉS, H. La Música en la Corte de Carlos V..., vol 1, pp. 23, 43, 63 y 117.

360 SOLAR-QuiNTES, Nicolás A. «Nuevos documentos sobre ministriles, trompetas, cantorcicos, organistas y capilla real de Felipe II», Miscelánea en homenaje a Monseñor Higinio Anglés. Barcelona, CSIC, 195861, vol. 2, pp. 851-888; pp. 858-859.

${ }^{361}$ Esta familia ya llamó la atención de Vander Straeten quien les dedicó varias líneas. VANDER Straeten, E. La musique aux Pays-Bas..., vol. 7, pp. 105-106. Solar-Quintes transcribió varios documentos, planteó su origen alcarreño. SOlAR-QuiNTES, N. A. «Nuevos documentos..., pp. 851-53 y Robledo ha propuesto una posible reconstrucción genealógica. ROBLEDO ESTAIRE, L. «La música en la Casa del Rey... , p. 156. 
En la corte del duque de Calabria entre los años 1550 y 1552 aparece un trompeta de nombre Luis Tolosa. ${ }^{362}$ No sería descabellado que perteneciera al clan Tolosa que hemos visto en el Infantado.

\section{$\underline{\text { Atabaleros }}$}

Acompañando siempre a los trompetas están los atabales, de forma que como vimos se incluyen en el grupo genérico de las primeros. A lomos de mulas, pues son menos asustadizas que los caballos ante el estruendo, los atabales solían ir por pares ${ }^{363}$ y estaban fabricados en cobre con parche de piel tensado por correas.

Diego de Laguna († enero de 1562), atabalero, sirvió al duque en 1526 y parte de 1527 con un salario muy elevado de 21.000 mrs. (9.000 mrs. de quitación y 12.000 mrs. de ración), lo que es prueba de su gran valía. Tras abandonar Guadalajara, entró en la Casa de Castilla en agosto de 1527, sirviendo hasta 1531. En 1535 sirve al duque de Medina Sidonia. ${ }^{364}$ Vuelve a la Casa Real en 1539, permaneciendo al servicio de Felipe II hasta su muerte en 1562 y siendo sustituido por su hijo Juan de Laguna. ${ }^{365}$

Tras la marcha de Laguna del Infantado entró Bernardino Suárez, también con un elevado salario de 21.000 mrs., aunque en un par de años, 1530 y 1531, desconocemos si cobró la ración de 6.000 mrs. Podemos pensar que tanto Laguna como Suárez ostentarían la jefatura de los atabaleros, prueba de ello es que en 1530 y 1531 Bernardino Suárez recibe 2.250 mrs. para los cueros de los atabales, lo cual indica que era el responsable de los instrumentos.

\footnotetext{
${ }^{362}$ FREUND SCHWARTZ, R. En busca de liberalidad..., p. 324.

${ }^{363}$ Según Robledo los atabaleros españoles de Felipe II llevarían los atabales organizados por voces y por registros homogéneos: un par de tiples, un par de contraltos, un par de tenores y un par de bajos en el caso de contar con cuatro pares. Robledo EstAire, L. «La música en la Casa del Rey... , p. 174.

${ }^{364}$ Su salario en este caso era inferior al percibido en Guadalajara: 16.000 mrs. RUIZ-JIMÉNEZ, J. «Power and musical exchange..., p. 411.

${ }^{365}$ Martínez Millán, J. y Fernández Conti, S. La monarquía de Felipe II..., vol. II, p. 237. También en Anglés, H. La Música en la Corte de Carlos V..., vol 1, p. 64 y Knighton, T. «La música en la casa..., p.
} 49. 
El maestre Diego sirvió al duque entre 1511 y 1538, su hijo Pedro por lo menos entre 1526 y 1535, aunque en varias ocasiones el salario, en ración, lo cobraba el padre, por lo que no podemos estar seguros de los años que sirvió.

El número de atabaleros va a oscilar, a partir de 1520, entre tres y cuatro para quedar a partir de 1535, como ya ocurría con otros músicos, reducidos a uno solo. Uno de ellos posiblemente negro, Luis el Negro, y que tal vez sea el que se encontramos a partir de 1525 como Luis de Mendoza, pues con frecuencia los esclavos liberados adquirían los apellidos de sus amos. Además la presencia de atabaleros «exóticos» no es algo fuera de los común, conocemos la existencia de tres atabaleros moros, uno de ellos de nombre Fratix, en la corte de Juan II de Castilla en $1453^{366}$ y en 1472 el cardenal Mendoza hizo su entrada en Valencia para entrevistarse con el legado pontificio precedido de dos atabaleros negros. ${ }^{367}$ En la casa real aragonesa el atabalero Cristóbal el Negro figura entre $1476 \mathrm{y}$ 1500. ${ }^{368}$ También otras casas nobles poseían músicos negros como el VI conde de Benavente, quien en 1554 compró un grupo de seis esclavos ministriles. ${ }^{369}$

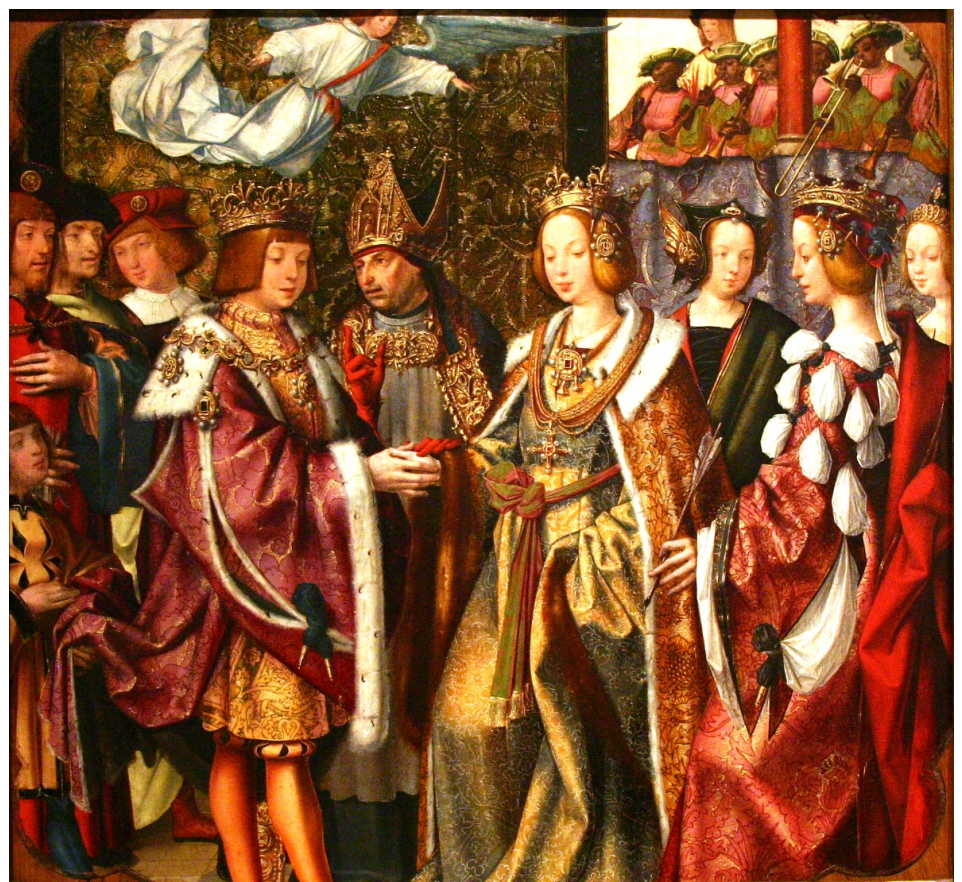

Fig. 15. Ministriles negros en la Boda de Santa Úrsula. Museu Nacional de Arte Antiga, Lisboa, c. 1520

\footnotetext{
${ }^{366}$ CAÑAs GÁlveZ, F. «La música en la corte de Juan II..., pp. 378, 381, 388 y 390.

367 Citado por Fernández de Córdova Miralles, Á. La Corte de Isabel I..., p. 316.

${ }^{368}$ KNIGHTON, T. Música y músicos..., pp. 197-205.

${ }^{369}$ FERNÁNDEZ-CORTÉs, J. La música en las Casas de ..., p. 114.
} 
Entre los atabaleros encontramos a Diego de Segovia, tamborino en 1511 con un salario de 6.000 mrs., alto en relación con sus compañeros de los atabales. Esto es debido a que posiblemente debiera compaginar sus funciones heráldicas con las de acompañamiento de las danzas y espectáculos de la corte. Así nos dice Covarrubias que los tamborinos son «atambores pequeños para regocijos y fiestas». ${ }^{370} \mathrm{La}$ presencia de tamborinos en las cortes está bien documentada. La emperatriz Isabel tenía en 1539 entre sus «oficiales de manos» a Juan Sánchez, tamborino, ${ }^{371}$ que en una nómina posterior de la Casa de las infantas se señala junto con tres maestros de danzar y con un salario de 15.000 mrs. $^{372}$

Como resumen de la evolución de los oficios musicales en el palacio del Infantado veamos el siguiente esquema:

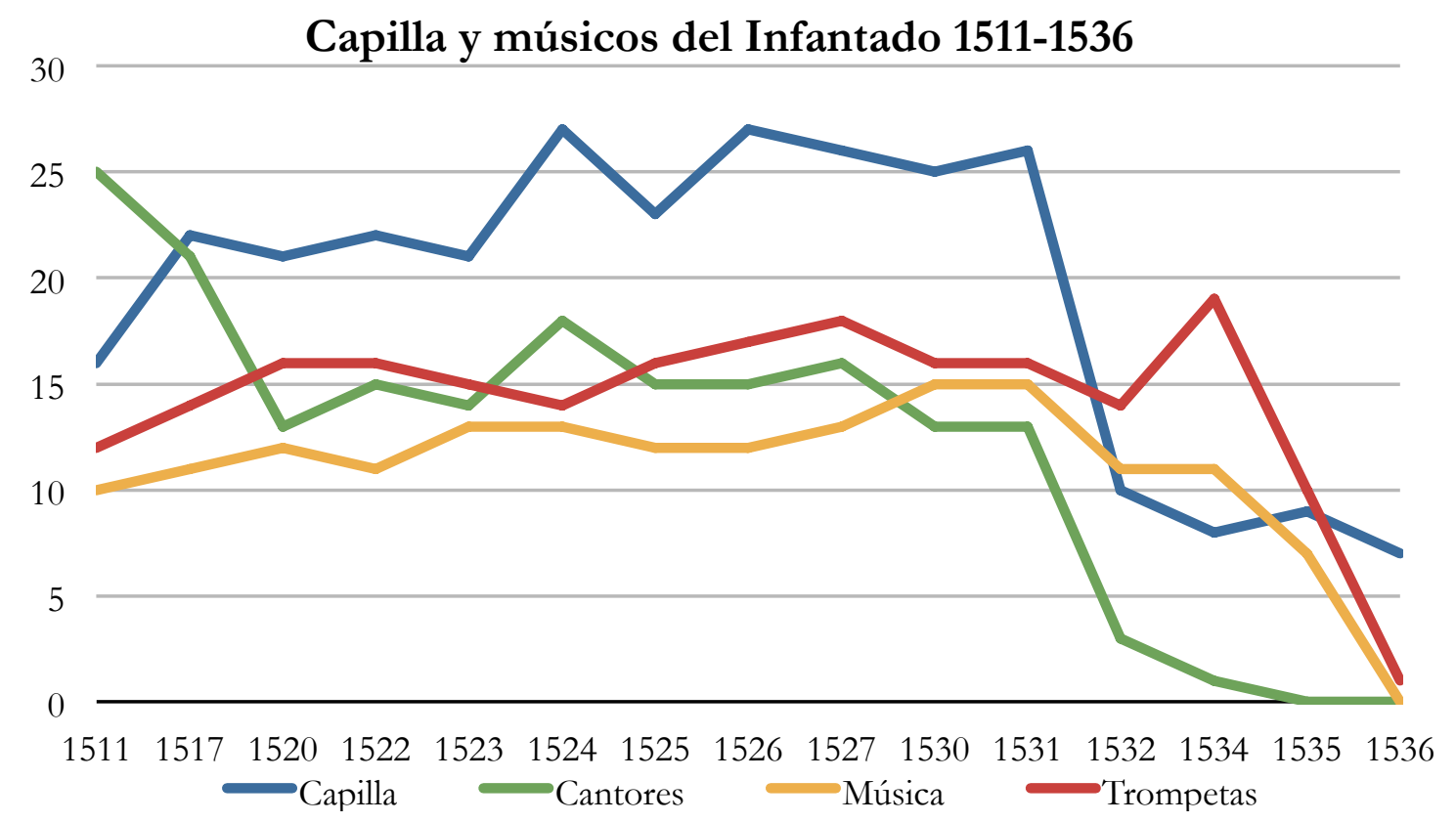

Fig. 16. Evolución de la Capilla y los músicos del Infantado

\footnotetext{
${ }^{370}$ Covarrubias, S. Tesoro...., p. 911.

${ }^{371}$ ANGLÉs, H. La Música en la Corte de Carlos V..., vol 1, pp. 54-55.

${ }^{372}$ ANGLÉs, H. La Música en la Corte de Carlos V..., vol 1, p. 62.
} 
Podemos ver que el número de cantores disminuyó drásticamente en 1520, para mantenerse y desaparecer prácticamente en 1531 con la muerte del III duque. Los capellanes aumentaron hasta 1527, quedando reducidos a ocho desde 1534. Los ministriles, músicos de la cámara y trompetas sufrieron un fuerte descenso en 1531 para desaparecer totalmente en 1536. Posteriormente encontraremos únicamente uno o dos músicos.

Creemos que es posible que el duque y su familia hicieran uso de los músicos municipales que empezamos a encontrar en las actas del ayuntamiento de Guadalajara desde 1545, cuando se citan trompeteros, atabales y ministriles para festejar el nacimiento del príncipe Carlos. Veamos una breve relación de la intervención de los músicos municipales en Guadalajara. En 1559 para el casamiento de Felipe II con Isabel de Valois se vistió a dos atambores y dos pífanos y en 1571 para celebrar el nacimiento del príncipe Fernando se vistió a los cuatro trompetas y los tres atabales municipales, así como a sus mulas, con «bayeta colorada y verde». En 1585 Felipe II pasa por la ciudad, por lo que se contratan ministriles y otros músicos y se viste de librea a el «atambor y trompetas y atabales». Al año siguiente para celebrar el parto de la hermana del rey, Catalina Micaela, tañeron chirimías en el corredor del ayuntamiento y después hubo «trompetas e atabales e música de canto de órgano». En 1592 volvió a pasar por allí Felipe II y «se acordó que se enbie por la música de menestriles a madrid [...] En lo que toca a trompetas, se bea si ay bastante número en la ciudad que baste, y si no hubiere lo busquen en alcalá de manera que esté todo cumplido». En 1593 se acuerda un concierto con el ministril Miguel de Baldés y su compañía para que sirvieran a la ciudad cuatro ministriles con un salario total de 56.000 mrs. cada año, para ello se les adelantaría doscientos reales para traer su casa, además de abonarles una ayuda de costa por el viaje. Unos meses después se les exige además que enseñen su arte al cantor y vecino de la ciudad Lázaro Gallardo. Todavía en 1598 la ciudad contaba con trompetas y atabales además de chirimías y ministriles. ${ }^{373}$

Otra cuestión que habría que considerar, y que es un fenómeno no exclusivo de la nobleza castellana, es el cambio de gusto y la saturación ante algo, los grupos de

\footnotetext{
${ }^{373}$ Layna Serrano, F. Historia de Guadalajara y sus Mendozas..., Tomo III, pp. 447, 453, 458, 464-65, $467,475,477-78,484-85$
} 
ministriles y trompetas, que antaño era signo de distinción y que va a ser omnipresente en el siglo XVI en catedrales, colegiatas, ayuntamientos en gran parte de Europa. En palabras mejor dichas que las nuestras:

After the middle of the sixteenth century, the aristocratic preference slowly began to move toward the mixed ensemble of strings and winds, the so-called, «broken-consort». Considering the fact that the wind band had been dominant for more than a century in aristocratic circles, perhaps part of the explanation for the move to adopt strings into their «consorts» can be found simply in the need for the noble to distinguish himself from the mere citizen. Thus with the development of very successful civic wind bands during the fifteenth and early sixteenth century, affording the middle-classes the opportunity to imitate the entertainments of the aristocracy, the aristocracy moved on to something else - as they would have placed little value on anything available to everyone. ${ }^{374}$

${ }^{374}$ Whitwell, David. The Renaissance Wind Band and Wind Ensemble. The History and Literature of the Wind Band and Wind Ensemble, volume 2. Austin, Texas, Whitwell Books, 2011, (2 ed.), p. 4. 


\section{Instrumentos musicales en el palacio del Infantado}

Tenemos la suerte de contar con los inventarios y tasaciones post mórtem de los bienes $^{375}$ del III y IV duques del Infantado y del malogrado Diego Hurtado de Mendoza, conde de Saldaña y marqués del Cenete, fallecido antes de heredar el ducado. ${ }^{376}$ En ellos, entre otros objetos, se consignan instrumentos musicales y en algunos con los precios pagados en almoneda. ${ }^{377}$

A la muerte de don Diego Hurtado de Mendoza, III duque, se hizo inventario. ${ }^{378}$ Entre los múltiples objetos de todo tipo encontramos varios instrumentos musicales:

[f.30v.] Una vyhuela grande en su caxa de paño amarillo e verde ...

Otra caxa vazía

Un laúd con la caxa ensayalada de colorado

Otra caxa de vyhuela ensayalada colorada vazía

Otra caxa de vyhuela vazía

[f. 35] Una vyhuela de arco

Una bozina grande de marfil

Un atanbor

Una corneta de monte guarneçida de terçiopelo

[f. 35v.] Unos órganos de palo con sus fuelles e pesos

En un documento incluido un poco más adelante encontramos la tasación de estos mismos bienes: $:^{379}$

${ }^{375}$ La función de estos inventarios era separar los objetos que podían estar ligados a un mayorazgo de los que no. Estos últimos se vendían en pública almoneda para con lo obtenido pagar las deudas y las múltiples mandas, en forma de misas fundamentalmente, del finado. Estos inventarios y tasaciones son en la mayor parte de los casos de un tamaño tal que su estudio en profundidad excede en mucho las pretensiones de este estudio, por lo que solo ofrecemos una aproximación.

${ }^{376}$ Han sido estudiados entre otros por Roberto González Ramos en GONZÁLEZ Ramos, Roberto. «Imágenes, libros y armas. Tipología y significado de los bienes de Diego Hurtado de Mendoza, conde de Saldaña y marqués del Cenete (1520-1560)», Anuario del Departamento de Historia y Teoría del Arte, 21 (2009), pp. 31-46. y GONZÁLEZ RAMOS, Roberto. «Evolución cultural...

${ }^{377}$ Estudiado parcialmente, aunque con algunos errores, en FREUND SCHWARTZ, R. En busca de liberalidad... En un reciente artículo, Ascensión Mazuela-Anguita ha reproducido también el listado de instrumentos musicales de Isabel de Aragón IV duquesa. MAZUELA-ANGUiTA, Ascensión. «Mujeres músicas y documentos de la Inquisición en el mundo ibérico del siglo XVI: Isabel de Plazaola y la IV Duquesa del Infantado», Revista de Musicología, 36/1-2 (2013), pp. 15-55. Incluimos nuestra transcripción de estos documentos en los anexos.

${ }^{378}$ Hemos revisado el extensísimo inventario sin llegar a profundizar en él. Inventario post mortem de Diego Hurtado de Mendoza, III duque del Infantado, 31 de agosto de 1531. AHN-SN, Osuna, C. 1832, doc. 1. 
Una vihuela de arco medio ducado

Un atanbor medio ducado

Una corneta de caza guarneçida de terçiopelo

Unos órganos de palo con sus fuelles y pesos doze ducados

\section{//}

Un órgano que estava en la [...] diez y seys ducados

Un claveçínbano diez y seys ducados

Una vyhuela grande en su caxa que tiene las espaldas la vihuela

tunbada en dos ducados y medio

Yten otra caxa vazía de vyhuela en tres reales

Yten un laúd en una caxa forrada de colorado en dos ducados

y medio

Otra caxa de vyhuela ensayalada

Otra caxa de vyhuela quatro reales
937,5 [mrs.]

102 [mrs.]

937,5 [mrs.]

187,5 [mrs.]

187,5 [mrs.]

265 [mrs.]

4.500 [mrs.]

6.000 [mrs.]

6.000 [mrs.]

250 [mrs.]

136 [mrs.]

Vemos pues muchas cajas de vihuela, una vihuela grande, un laúd y una vihuela de arco, además de varios instrumentos de tecla como órganos y un clave.

Varios instrumentos de viento vamos encontrar en otro inventario, ${ }^{380}$ en donde nos indica los instrumentos y quién los tiene. Se trata de los músicos del Infantado y algún otro que no hemos visto en nuestras nóminas.

Garçi González tiene en su poder un sacabuche de plata y una corneta negra, ${ }^{381}$ Diego Vázquez el Viejo un bajón de boj y una caja con once flautas, su hijo, Diego Vázquez el Mozo, dos cornetas y otro bajón de boj. Baltasar Vázquez va a tener cuatro cornetas una blanca, una negra, una muta y otra negra con brocal de plata. Francisco González otras dos

${ }^{379}$ Inventario-tasación de los bienes del III duque del Infantado, enero de 1532. AHN-SN, Osuna, C. 1832, doc. 4. Lamentablemente, el documento está sin foliar.

${ }^{380}$ En realidad un traslado de este inventario. AHN-SN, Osuna, C. 1835, doc. 15. Lo reproducimos parcialmente en los anexos.

${ }^{381}$ En este inventario se detallan diferentes tipos de cornetas, en algún caso las define como cornetas de música para diferenciarlas de las cornetas de caza o de monte, que también aparecen en el inventario. Las cornetas negras o curvas, llamadas así por estar forradas de cuero negro. Un tipo particular de estas es la tuerta que vendría a ser el bajo. Las blancas o mudas, rectas y de madera de boj, frutales o de marfil y de un sonido más dulce, con la boquilla tallada en el cuerpo. Otro tipo sería la corneta recta, con boquilla independiente. ANDRÉs, Ramón. Diccionario de instrumentos musicales. De Píndaro a Bach. Barcelona, Bibliograf, 1995, pp. 124-128. 
cornetas. Juan de Robredo una caja con seis flautas y un libro de canto. Melchor Torres un sacabuche grande y por último Lorenzo de Alentisque dos cornetas y siete pífanos. De este último sabemos que era morisco y vecino de Guadalajara. ${ }^{382}$ Resulta que, además de los músicos que ya conocíamos, nos encontramos unos nuevos de los que desconocemos la relación con el duque, pero no debe ser muy alejada si disponían de los instrumentos propiedad de don Diego. Este inventario nos muestra dos cosas: lo primero es que los ministriles tenían que tañer una gran cantidad de instrumentos y en general los chirimías se ocupaban de las flautas y los sacabuches de las cornetas. El bajón, instrumento que estaba reemplazando al sacabuche a mediados de siglo, lo vemos en manos de ambos. Lo segundo que aprendemos es que, por muchos documentos que tengamos, nunca podremos abarcar la cantidad de músicos que trabajaban para las casas nobles, pues aunque algunos estaban en nómina, otros eran contratados para las diversas ocasiones.

Siguiendo de forma cronológica, ${ }^{383}$ tenemos el inventario y tasación de los bienes del conde de Saldaña, Diego Hurtado de Mendoza, fallecido sin haber heredado el ducado en 1560. ${ }^{384}$ En la tasación hay un apartado denominado «arpas y bigüelas» donde encontramos varias arpas de muy rica factura: un arpa dorada, tasada en cuatro ducados (1.500 mrs.), un arpa de nogal con molduras y taraceas por 3.000 mrs., otra arpa labrada y con taraceas con un precio superior a las otras, doce ducados o $4.500 \mathrm{mrs}$. y por último otra arpa también labrada y con taraceas por la mitad que la anterior, seis ducados. También aparecen dos clavicordios (tal vez claves) uno grande tasado en el elevado precio de 15.000 mrs. y uno pequeño en 6.000 mrs. A continuacion dos vihuelas grandes, una de ella de ciprés y tumbada (con forma de tumba) valoradas ambas en cuatro ducados $(1.500$ mrs.) y por último un laúd un poco más caro, cinco ducados.

En el inventario de los bienes de Isabel de Aragón (1491-1563), ${ }^{385}$ IV duquesa del Infantado, realizado tras su fallecimiento, en el capítulo «arpas, vigüelas y claviórganos» aparecen muchos instrumentos que podemos suponer pertenecían a la cámara de la

\footnotetext{
${ }^{382}$ Layna Serrano, F. Historia de Guadalajara y sus Mendozas..., Tomo III, p. 217.

${ }^{383}$ Nos referimos a la cronología de los originales, pues se trata de traslados sacados a veces cincuenta años después.

384 AHN-SN, Osuna, C. 1835 doc. 2.

385 AHN-SN, Osuna, C. 1834 doc. 2. Lo reproducimos parcialmente en los anexos.
} 
duquesa. Los más abundantes son las arpas, hasta siete, varias de ellas de muy rica hechura destacando una de ébano con taraceas y medallones de marfil. Dos de ellas fueron construidas por Bejarano, al que veíamos como maestro de taraceas. Hay otra que perteneció a la marquesa del Cenete y fue regalada a la duquesa, posiblemente en 1534 cuando pasó por Guadalajara a concertar la boda de su hermana. Este arpa se remodeló y de una grande se hizo una pequeña.

Los siguientes instrumentos en número son los «clavizínbanos», o claves, cuatro exactamente y de diferentes tamaños. Uno de ellos fue un regalo del doctor Laguna, ${ }^{386}$ otro se lo compraron a un fraile. También un par de claviórganos, «con sus fuelles y pesas de plomo», uno de ellos comprado en Toledo. La representación de instrumentos con mástil también es alta: tres laúdes, dos de ellos de Flandes, dos vihuelas, una «de hechura de tumba» hecha por Bejarano y otra grande muy rica hecha de costera de Brasil, suponemos palosanto, y con taraceas, «pinturas de atarazes», según el documento. También dos vihuelas de arco, una grande y una pequeña por último una guitarra común.

Los instrumentos de viento que figuran son: una caja con siete flautas, seis de Flandes y una Axabeba («jabeva»), una caja con tres dulzainas, una caja con ocho orlos de madera en mal estado, un pífano rematado en hueso y dos flautas pegadas entre sí.

En estos dos inventarios se observa una abundancia de arpas, cosa que no ocurría en los anteriores. Tampoco encontramos músicos de arpa en las nóminas del Infantado hasta 1545 y 1546, años en que figura Diego de Rivas. ${ }^{387} \mathrm{El}$ arpa es un instrumento muy de moda en el siglo XV y que a principios del siglo XVI fue dejada de lado por su dificultad para entonar notas alteradas, hasta el punto de que Bermudo se lamenta en 1555: «Muy pocos tañedores ay de harpa». ${ }^{388} \mathrm{~A}$ mediados de siglo recupera su prestigio con la aparición de las arpas de dos órdenes y en el siglo XVII será omnipresente. ${ }^{389}$ No sabemos

\footnotetext{
${ }^{386}$ Imaginamos que se refiere a Andrés Laguna (1499-1559), médico judeoconverso y erasmista, por lo que no es extraño su relación con la «alumbrada» Isabel de Aragón.

${ }^{387}$ No debe ser casualidad que la primera pieza de arpa impresa que conozcamos sea el Tiento para barpa u órgano que aparece al final de la obra de Mudarra y del que hablaremos más adelante.

${ }^{388}$ Bermudo, Fray Juan. Declaración de instrumentos musicales. Osuna, Juan de León, 1555 (en adelante BERMUDO. Declaración), f. 112.

${ }^{389}$ El nombre de arpa de dos órdenes no aparecerá hasta principios de siglo XVII, pero ya Bermudo habla de ellas. BORDAS, Cristina. "The double harp in Spain from the 16th to the 18th centuries», Early Music. 15/2, 1987, pp. 148-163.
} 
si las arpas de estos inventarios son dobles o no, pero una de ellas sí fue transformada, la regalada por la marquesa del Cenete.

Casi todos los instrumentos que aparecen en el inventario, al igual que en los anteriores, están provistos de una caja o de una funda, imaginamos que para protegerlos de los numerosos desplazamientos.

El último documento al que nos vamos a referir es la tasación del IV duque. ${ }^{390}$ No hemos podido localizar instrumentos por ahora, aparte de unas cuantas cornetas que posiblemente sean de caza, pues figuran en el apartado «Cornetas y collares de lebreles y otras cosas de perros». Sí vemos en el apartado «Libros de música y reloges de alemania» varios libros de música y su tasación. Son los siguientes:

$\begin{array}{llc}\text { iij libros grandes de músicas } & \text { Yten tasó tres libros grandes de música encorados y guarneçidos } \\ \text { libro de tablas coloradas } & \text { de tablas y cuero blanco en ocho ducados } & 3.000 \text { [mrs.] } \\ & \text { Yten tasó el suso dicho otro libro grande guarneçido de tablas e } \\ & \text { cuero colorado que es de las misas de Jusquin y otros auctores } \\ & \text { en veinte reales } & 680 \text { [mrs.] } \\ \text { vj libros pequeños vendidos } & \text { Yten tassó el suso dicho otros seis libros de música guarneçidos } \\ \text { los tres pequeños } & \text { guarneçidos [sic] con tablas y cuero negro los tres medianos } \\ \text { iij libros de música } & \text { otros tres chicos en seis reales a real cada uno } 204 \text { [mrs.] } \\ & \text { Yten tasó el susodicho otros tres libros de música medianos los } \\ & \text { dos guarneçidos de pergamino y el otro de tablas El de tablas en } \\ & \text { quatro reales y uno de los de pergamino que es teñydo en tres } \\ & \text { reales y el otro pequeño en medio que son todos siete reales y } \\ & \text { medio } & 255 \text { [mrs.] }\end{array}$

De todos los libros de música únicamente se refiere al contenido de uno de ellos «misas de Jusquin y otros auctores». ${ }^{391}$ Podemos pensar que los libros grandes de tablas serían libros manuscritos en pergamino y los medianos y pequeños, impresos en papel, pero no tenemos ninguna certeza.

${ }^{390}$ AHN-SN, Osuna, C. 1834 doc. 1.

${ }^{391}$ Es más que probable que se trate del conocido como «libro de las quince misas de Josquin» Liber quindecim missarum electarum quae per excellentissimos musicos compositae fuerunt. Roma, A. Antico, 1516 (RISM B/1 $\left.1516^{1}\right)$. 


\section{Alonso Mudarra, paje y vihuelista}

En 1523 un jovencísimo Alonso Mudarra llega a Guadalajara desde Valladolid, o tal vez desde Medina del Campo. El cambio entre una gran ciudad con más de treinta mil habitantes, o con cerca de veinte mil, a una provinciana con poco más de cuatro mil ${ }^{392}$ debió ser un choque bastante brusco para el joven Mudarra. Hacía tan solo un año que el Emperador había concedido el perdón a los sublevados en la rebelión de las Comunidades, por lo que la resaca comunera todavía se percibiría en el ambiente de la ciudad. Su padre, Alonso como él, también había sido castigado por haber simpatizado con la revuelta. En estos momentos en la ciudad una nueva rebelión, esta vez más pacífica, se estaba fraguando. Un exacerbado misticismo recorría las casas y los palacios, afectando tanto a amos como a criados, a religiosos como laicos. Se trataba de la secta de los alumbrados.

Allí es contratado por el duque del Infantado como paje de cámara y vihuelista con un salario de 10.000 mrs., muy superior al de la mayoría de los pajes ${ }^{393}$ y cercano al de cualquier músico de la Casa. ${ }^{394}$ Sin embargo, no era el suyo el salario más elevado de los pajes de cámara, pues ese mismo año varios de ellos habían visto cómo su salario se acrecentaba, pero se trataba en muchos casos de parientes del duque. Este elevado sueldo nos hace pensar que las habilidades musicales de Alonso debían ser muchas, además de que su padre, o algún pariente muy cercano, mantenía una relación estrecha con el duque, por lo que nos inclinamos a creer, a pesar de que no contamos con datos que lo confirmen, que nuestro vihuelista debía contar con unos catorce años, habiendo nacido hacia $1509 . .^{395}$

392 LADERO QUeSADA, M. Á. «La población de reinos..., p. 68.

${ }^{393}$ Recordemos que en estos años los pajes que no pertenecían a la cámara recibían 2.000 mrs. de quitación y 4.092 mrs. de ración anuales. Además nueve de ellos percibían para sus monturas 45 fanegas de cebada o 60, en el caso de que tuvieran un mozo a su servicio, lo que indica que acompañarían al duque en sus salidas del palacio junto con continos, alabarderos, trompetas y ministriles. Posiblemente Mudarra también recibiera la ración de 4.092 mrs.

${ }^{394}$ Superior incluso al del organista de cámara Juan Ordóñez.

${ }^{395}$ Pujol sugiere para el nacimiento de Mudarra un intervalo entre 1506 y 1510, mientras que Ward retrasa la fecha hasta 1520. PUJOL. Mudarra..., p. 26 y WARD, John. The «Vibuela de mano» and its music (15361576). Tesis doctoral, New York University, 1953, 2 vols.; p. 375. 
La primera anotación en las nóminas de la Casa del Infantado dice únicamente: «A mudarra tañedor paje de cámara». ${ }^{396}$

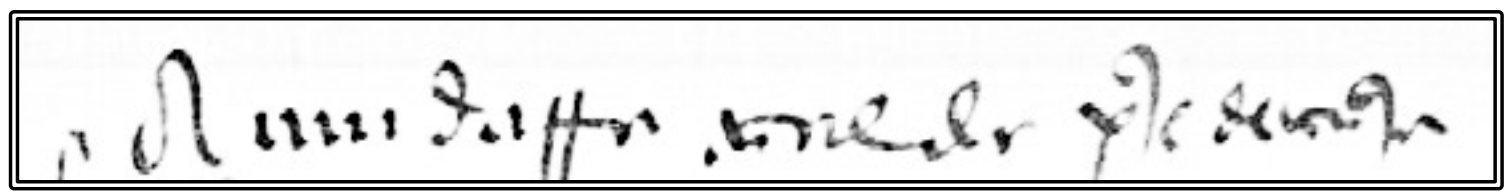

Fig. 17. Nómina de 1523 con el nombre de Alonso Mudarra. BNE, Mss/11142, f. 191.

Para este año de 1523, la Casa del Infantado contaba con cincuenta y seis pajes, seis de ellos de cámara. Entre ellos encontramos los nombres de familiares de los Mendoza, los de muchos antiguos linajes alcarreños como los Sotomayor, los Morales, los Arellano, los Cimbrón, ${ }^{397}$ cuyos nombres encontramos también entre los continos de los duques del Infantado. El ambiente del palacio debió ser nuevo para Alonso, pues no en vano se trataba de un extraordinario edificio que albergaba una Casa y Corte de alrededor de cuatrocientos criados, además de una innumerable cantidad de mozos y esclavos. Este contraste entre una pequeña ciudad y una corte «casi» regia debió impactar en Alonso que, además, se vió rodeado de los mejores músicos que pudiera soñar: trompetas, chirimías y sacabuches sonando en cada ocasión, además de la magnífica capilla musical con excelentes cantores y organistas. Recordemos que esta decada de los años veinte es el periodo en el que el duque del Infantado contaba con el mayor elenco musical y cultual: alrededor de catorce capellanes con sus dos organistas ${ }^{398}$ y seis mozos de capilla, un sacristán y un portero. Cerca de quince cantores, cuatro chirimías, cuatro sacabuches, once trompetas y tres o cuatro atabaleros; en la cámara un organista y otros tres músicos, además de Mudarra como vihuelista.

En los años siguientes, 1524 a 1527, volvemos a encontrar a Alonso Mudarra con el mismo salario entre los pajes y únicamente con la designación de paje de cámara. Debió

${ }^{396}$ BNE, Mss/11142, f. 191.

${ }^{397}$ Hay varios hermanos pajes Cimbrón descritos por NúÑEZ DE CASTRO, A. Historia eclesiástica y..., f. 332. Uno de ellos, Diego Suárez Cimbrón, mató a Alonso de Arellano por lo que fue ejecutado en la plaza de Guadalajara en 1542.

${ }^{398}$ A partir de 1524. 
ser testigo y actor en estos años del fastuoso recibimiento que se hizo a Francisco I. Posiblemente el duque le hiciera tañer delante de su ilustre invitado, pues hizo exhibición de todo lo que pudiera impresionarle. También las varias visitas de Carlos V, que sin duda acudiría acompañado de sus músicos, ${ }^{399}$ serían una oportunidad de intercambio para un joven deseoso de aprender.

Lamentablemente no contamos con las nóminas de 1528 y 1529, años cruciales, pues en 1529 partió la comitiva del emperador Carlos con destino a Bolonia y, como ya vimos, el conde de Saldaña con muchos de sus criados le acompañó en la coronación de 1530, no regresando hasta otoño de este año. Se ha postulado en varias ocasiones que Mudarra pudo acompañar al séquito imperial hasta Italia, ${ }^{400}$ nosotros creemos que tal vez no fuera así y que se quedara amenizando al senil III duque, que en los años 1530 y 1531 estaba muy encandilado con su última conquista, la joven María Maldonado. ${ }^{401}$ La nómina de 1530 dice que a Mudarra se le acrecentó el salario en 15.000 mrs. llegando a 30.000 mrs., ${ }^{402}$ sin embargo el último salario del que teníamos noticia era de 10.000 mrs., por lo tuvieron que subírselo en 1528 y 1529.

En 1531, año del fallecimiento del III duque la nómina de Mudarra se mantiene en 30.000 mrs. En 1532 la nómina de Mudarra es como sigue:

A alonso de mudarra my músico de vigüela 22.775,5 y 90 fanegas de çebada a conplymyento de pago de 34.165,5 que le montaron aver desde primero de enero hasta mediado abril, a rrasón de 24.080 con una raçión para un moço en my despensa, porque hasta allý comýa del plato y desde el dicho día mediado abril salyó de la cámara a conplymyento de quarenta myll mrs. que le mandé acreçentar y las dichas noventa fanegas de çevada para dos bestias, porque demás de los dichos 22.775,5 lleva 1.340 de

${ }^{399}$ En estos años, entre 1513 y 1547, formaba parte de la Casa del Emperador el «tañedor de la vihuela» Martín Sánchez, aunque no queda claro qué tipo de vihuela tañía, si de mano o de arco. MARTínEZ MiLLÁN, J. La Corte de Carlos V..., vol. 4, p. 336.

${ }^{400}$ Así lo sugieren por ejemplo Pujol. Mudarra, p. 31; Stevenson, Robert. «Mudarra Alonso», The New Grove Dictionary of music and musicians, vol. 12, Londres: Macmillan, 1980, pp. 757-58.

${ }^{401}$ Como dato curioso apuntaremos la presencia de Rodrigo de Proaño, posiblemente hermano de «la Maldonada», como era conocida en palacio, entre los pajes en estos dos años y con un salario normal en 1530, 10.000 mrs. y de 40.000 mrs. al año siguiente cuando ya su hermana era duquesa.

${ }^{402}$ A lo que habría que añadir la ración. 
raçión en my despensa que es complymyento lo uno y lo otra a los dichos 34.165,5 que le montaron aver hasta fin de dizienbre del dicho año demás de la dicha çevada. ${ }^{403}$

Sin embargo contamos con una segunda nómina de este año prácticamente coincidente pero con pequeñas diferencias y que dice:

A alonso de mudarra 20.000 por la dicha rrazón demás de una rraçión de 4.080 que lleva en despensa.

[al margen] Mediado abril de 1532 años mandó [su señoría] que le diesen en rraçión cada mes 1.000, demás la rraçión de su moço 20.000 en quitación [90] fanegas de cebada. ${ }^{404}$

Esta complicada nómina nos viene a decir en primer lugar que en dicho año de 1532 Mudarra había abandonado la cámara y posiblemente se hubiera instalado fuera del palacio en Guadalajara. Recordemos que el año anterior había fallecido el III duque, lo que implicaba la remodelación total de las Casas, pues el heredero ya contaba con la suya propia. Llama la atención que Mudarra no fuera despedido, lo que indica el aprecio que le tenían.

Este año deja de aparecer entre los pajes y lo encontramos en un lugar inusual (entre los pagos por tierras, es decir acostamientos militares) en la primera de las nóminas y en la capilla en la segunda, después de los capellanes y el camarero, sin que sepamos si tiene algo que ver o simplemente es un error. Lo más probable es que una vez fuera de la cámara no quedara claro cuál era su nueva ubicación. Intentaremos a continuación explicar el galimatías del salario de Mudarra para este año.

Hasta mitad de abril Mudarra reside en palacio con una quitación de 20.000 mrs. y una ración de 4.080 mrs. (10 reales mensuales), por lo que con la muerte del duque le habrían bajado el salario, pues veíamos que en 1530 y 1531 era de 30.000 mrs. Este mes sale de la cámara y debió instalarse en alguna vivienda cercana junto con su mozo, cuyo salario hasta ahora corría a cuenta del duque en forma de ración en alimentos, «comía del plato». Su nuevo salario es en total de 40.000 mrs. y 90 fanegas de cebada para su caballo y la

\footnotetext{
${ }^{403}$ BNE, Mss/11141, f. 337.

${ }^{404}$ En la segunda nómina de este año aparece bajo el epígrafe de capilla. BNE, Mss/11142, f. 361.
} 
montura de su mozo. Aquí se incluye una quitación de 23.920 mrs. y una ración de 1.340 mrs mensuales (16.080 mrs. anuales), 1.000 mrs. le corresponden a él de su ración y 340 mrs. (10 reales, la ración básica) para su mozo. Por lo tanto tiene que cobrar tres meses y medio del antiguo salario y ocho y medio del nuevo, en total $34.165,5 \mathrm{mrs}$. Una parte se le paga en esta nómina, la quitación de los tres meses y medio (la ración ya la habría cobrado de la despensa), es decir 5.832,5 mrs. ${ }^{405}$ más la nueva quitación de los ocho meses y medio restantes, 16.943 mrs. en total 22.775,5 mrs. y el resto, 11.390 mrs. lo cobraría en la despensa.

No debió ser ajeno Mudarra a lo que ocurría con el movimiento alumbrado, pues como hemos visto, entre 1529 y 1539 las condenas se sucedieron y toda Guadalajara se vio sacudida por las delaciones y los castigos, algunos de ellos públicos como las infligidos a Alcaraz y a Isabel de la Cruz en 1529 y que tal vez Mudarra presenciara. La noticia de la ejecución de Juan López de Celain debió causar gran terror también en la ciudad y en la casa del duque, no solo entre los criados, sino también entre los señores. Muchos de ellos fueron llamados a declarar. Alonso, hermano de un condenado por luterano años después, debió conocer de primera mano todo lo ocurrido, pues tenía tan cerca a Rodrigo de Bivar o al chirimía Espinosa y no nos extrañaría que simpatizara de alguna manera con semejante credo. En cualquier caso, que sepamos, nunca fue llamado a testificar, aunque hay varios procesos que a día de hoy se encuentran perdidos.

No disponemos de la nómina de 1533, aunque podemos suponer que Mudarra seguía al servicio del duque con el mismo salario, ya que en 1534 vuelve a aparecer con las mismas condiciones. Sin embargo, hay una diferencia que tampoco podemos afirmar que no se trate de un error del contador o de algo relevante. Mudarra figura entre los continos, lo que entre otras cosas querría decir que ostentaba el título de caballero.

$\mathrm{Al}$ año siguiente, 1535, y también en 1536, Mudarra ha desaparecido de las nóminas y no volverá a aparecer hasta marzo de 1537 en que es asentado de nuevo. Hay dos posibilidades, o bien son los años en los que aprovecho para viajar a Italia, en particular a

\footnotetext{
${ }^{405}$ Los decimales en las nóminas no existen pues se trara de numeración romana, lo único que escriben son los medios mrs. El sistema que usan en cantidades como $1.000 \mathrm{~ms}$. al dividir en tercios es asignar al primero y segundo tercios 333 mrs. y al tercero 334 mrs. y así en los mútiplos.
} 
Roma, donde residía su hermano Francisco o son los años que empleó en sus estudios universitarios, ${ }^{406}$ tal vez en las cercanas universidades de Sigüenza o de Alcalá. Nos inclinamos más por esta segunda opción pues debía contar con 26 o 27 años, edad más que adecuada para esta labor.

A primeros de marzo de 1537 vuelve a ser asentado como músico y con su salario anterior, con la única diferencia de que ahora recibe únicamente 45 fanegas de cebada en lugar de las 90 de antaño. Cobra la parte proporcional de sus 40.000 mrs. es decir, 33.334 mrs. En 1538 figura entre los miembros de la Capilla y de nuevo entre los años 1540 y 1542, con el mismo salario, entre los continos.

Hecho relevante es que en 1537, cuando vuelve, todos los músicos habían sido despedidos, con la excepción del maestre Diego, atabalero y el organista de la capilla Baltasar Chacón que es despedido inmediatamente cuando se incorpora Mudarra. ¿Quiere esto decir que a nuestro vihuelista le tocó encargarse de la música de los órganos de la capilla? Es una posibilidad, pues como ya hemos señalado en alguna ocasión muchos músicos en esta época podían ser considerados multinstrumentistas. ${ }^{407}$ En 1540 es contratado Jos Denis hijo con lo que únicamente quedan dos músicos en las nóminas.

La última nómina que tenemos con su nombre, la de 1542, figura entre los continos con el texto:

A alonso de mudarra mi músico veynte e tres myll e nueveçientos y veinte mrs demás de 1.340 que lleva de rraçión cada mes en mi despensa a cunplimiento de 40.000 y 45 fanegas de çevada

Es el mismo texto de todos los últimos años, pero al margen hay varias anotaciones superpuestas de difícil lectura:

a pastrana en arenas

\footnotetext{
${ }^{406}$ No sabemos qué estudios podía tener Alonso Mudarra, pero es fácil suponer que los tuvo, pues no en vano su hermano era doctor, tal vez por la Universidad de Alcalá y lo lógico es que el hermano menor siguiera sus pasos de alguna manera estudiando derecho canónico o algo similar.

${ }^{407}$ ROA AlONSO, Francisco Javier. «Tecla, arpa y vihuela: aspectos de la cultura material en la época de Cabezón», Revista de Musicología, 34/2 (2011), pp. 109-132.
} 
Se refiere a quién hay que hacerle el pago, el mercader alcarreño Juan Pérez de Pastrana y de qué rentas se saca, de las de Arenas de San Pedro.

no se le libre la cebada

Esta anotación debajo de los 45 fanegas de cebada tachada nos indica que no cobró la cebada del año de 1542.

fue despedido a 4 de henero de 543 y mandó su señoría que gozase de todo el mes hasta que buscase señor? y que le librasen en la despensa deste año del tiempo que finó cavallo. Entró en su lugar diego de rribas

Este último párrafo nos da los siguientes datos, el día en que fue despedido, pero que sin embargo se le mantuvo el salario todo el mes hasta que encontrara nuevo acomodo. También nos dice que a Mudarra se le había muerto el caballo, parecería un dato insignificante, pero nos indica que en 1542 Mudarra era caballero, por eso figura entre los continos y no clérigo, si lo fuera utilizaría la montura habitual de estos, la mula. Por último un dato muy importante, fue sustituido por Diego de Rivas, músico de arpa que veíamos más arriba con el mismo salario de 40.000 mrs. en 1545 y 1546. Esto nos dice, primero que Rivas entró dos años antes de aparecer en nuestras nóminas y segundo, creo que es lo más importante, que tanto el papel de Mudarra como de Rivas no era exclusivamente de tañedores sino, tal vez, de responsables musicales de la Casa.

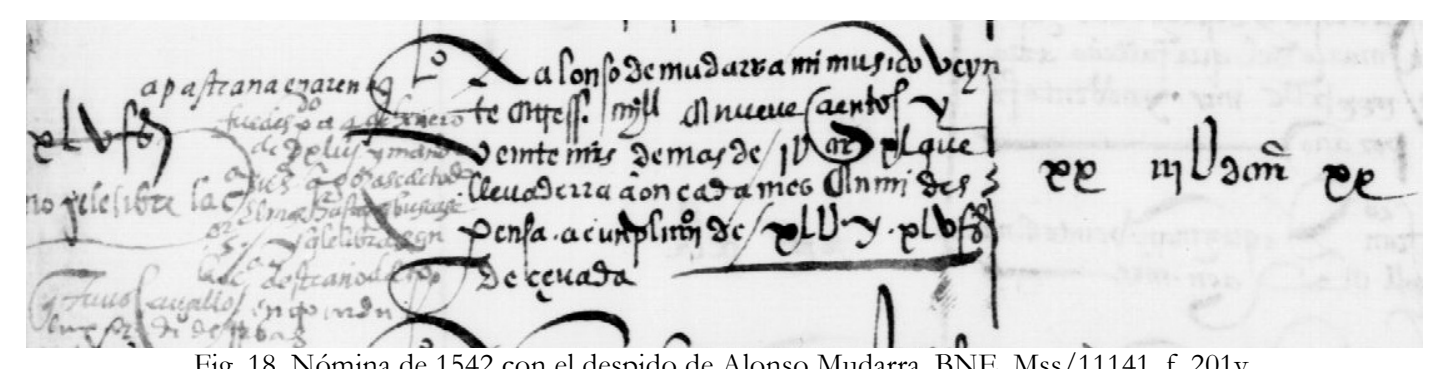

Fig. 18. Nómina de 1542 con el despido de Alonso Mudarra. BNE, Mss/11141, f. 201v.

Después de esta anotación no volvemos a saber nada de Alonso hasta finales de 1546, cuando publica su libro de vihuela. Creemos posible que en estos tres o cuatro años que 
se nos quedan en blanco, tal vez aprovechara para visitar a su hermano en Roma, quien todavía no había empezado a tener problemas con la Inquisición romana, más bien disfrutaba de una situación excepcional dentro de la Curia vaticana, ocupándose de incrementar su beneficios eclesiásticos y su fortuna.

En fin, ese día 4 de enero de 1543, Alonso Mudarra, con cerca de treinta y cuatro años de edad, abandona el palacio del Infantado y tal vez poco después Guadalajara, tras más de veinte años de servicio a dos generaciones de duques del Infantado y de estar rodeado de «excelentes hombres de toda música», los mejores de Castilla, sin duda. Su nuevo destino una gran ciudad, Sevilla, «la nueva Roma» o «la nueva Babilonia», según los ojos que la observaran. 



\section{SEVILLA}

estoy en Sevilla, ciudad asentada toda en una llanura á la márgen izquierda del Bétis, que ahora llaman Guadalquivir [...] se parece más á las ciudades de Italia que á las demas de España; sus calles son anchas y hermosas, pero la mayor parte de las casas no son muy buenas, si bien hay algunos palacios que no los tienen mejores ni más bellos en toda España; hay dentro bastantes jardines y no pocos solares, como ciudad que está poco poblada; tiene algunas buenas iglesias, especialmente la mayor, que es bellísima y más grande que la de Toledo, pero no tan rica en adornos de arquitectura. Los canónigos gozan cada uno de cuatrocientos ó quinientos ducados de renta al año [...] alrededor de toda la fábrica del templo hay una ancha lonja de mármoles, cerrada con cadenas, de la cual se baja por escalones al andar de la calle; en esta lonja hay todo el dia muchos hidalgos y mercaderes y paseantes, y es el sitio más bello de Sevilla, al cual llaman las Gradas; en la calle y plaza, que están junto, asiste también mucha gente, se hacen allí muchos engaños y es una especie de mercado $[. . .]^{408}$

Estas palabras fueron escritas por el embajador veneciano Andrea Navagero tras su llegada a la ciudad el 8 de marzo de 1526. El motivo de su visita: acudir a lo que se presumía iba a ser el acontecimiento más importante en mucho tiempo, no solo en Sevilla, también en Castilla e incluso más allá; la imperial boda entre su majestad Carlos y su prima Isabel de Portugal. Toda la ciudad bullía de actividad, se preparaban las galas, ornamentos, arcos triunfales, músicas, etc. ${ }^{409}$ Una muchedumbre de arquitecturas efímeras convertían la vieja ciudad, con sus características construcciones mezcla de cristianas e islámicas, en la Nueva Roma. Con la celebración de la cesárea boda, Sevilla le ganaba la partida de la capitalidad del imperio a su rival más inmediata, Toledo. Tras estos grandes festejos ya nada sería igual en la capital hispalense.

Veinte años antes, en 1506, se había puesto la última piedra del cimborrio del mayor templo de la cristiandad, la Catedral de Santa María de Sevilla. En tan solo un siglo la ciudad experimentó un enorme crecimiento y pasó de 60 o 70.000 habitantes en 1500 a

\footnotetext{
${ }^{408}$ Cuarta carta de Andrea Navagero, Navagero, Andrea. «Cartas de Micer Andrés Navajero, gentilhombre veneciano, á M. Juan Bautista Raumusio», FABIÉ, Antonio María. Viajes por España de Jorge de Einghen, del Baroón León de Rosmithal de Blatna, de Francisco Guicciardini y de Andrés Navajero. Madrid, Librería de los Bibliófilos, 1879, pp. 353-413; pp. 381-382.

${ }^{409}$ Una detallada descripción de la ciudad y sus preparativos en GÓMEZ-SALVAGO SÁNCHEZ, Mónica. Fastos de una boda real en la Sevilla del Quinientos (Estudio y documentos). Sevilla, Universidad de Sevilla, 1998.
} 
100.000 en 1565, hasta llegar a los 150.000 habitantes en 1588, lo que la convertía en una de las urbes mayores de Europa. ${ }^{410}$

Veinte años después de la boda del emperador, en 1546, llegaba a la ciudad un joven cortesano y excelente vihuelista con la firme intención de sacar adelante el proyecto de sus libros de cifra y, claro está, de hacerse con el canonicato de la catedral hispalense que su hermano Francisco le había cedido.

${ }^{410}$ Únicamente era superada en número de habitantes por París, con más de 200.000 en el último tercio del siglo, o Nápoles, con 212.000 habitantes en 1547. DomíngueZ OrTIZ, A. Orto y ocaso..., pp. 71 y ss. 


\section{Estructura y organización del cabildo sevillano}

Veamos de forma breve las características básicas del cabildo de la Catedral de Sevilla. Empecemos por una definición de cabildo catedralicio: «es una persona jurídica, bajo la jurisdicción episcopal, encabezada por el deán, que contiene diferente número de dignidades o personas (deán, prior, arcedianos, maestrescuela, tesorero, chantre, abades, etc.), canónigos, racioneros o porcionarios y medio-racioneros». ${ }^{411}$

En el caso del cabildo sevillano, desde las constituciones del siglo XIII, tras la reconquista de la ciudad, el número de capitulares, prebendados o beneficiados era de ochenta, cuarenta de ellos canónigos, veinte racioneros y otros veinte medio racioneros. Los cuarenta canónigos percibían la prebenda íntegra, los racioneros dos tercios y los medio racioneros un tercio. De entre los canónigos había diez dignidades, ${ }^{412}$ que ordenados según prelación eran: Deán, Arcediano de Sevilla, Chantre, Tesorero, Maestrescuela y Arcedianos de Écija, Jerez, Niebla, Reina y Carmona. También dentro de los canónigos había cuatro que se denominaban canónigos de oficio, cuyo nombramiento se realizaba mediante oposición y a los que se les exigía una formación académica superior. Eran los canónigos magistral, doctoral, lectoral y penitenciario. ${ }^{413}$ Además, en el siglo XVI, una canonjía estaba ligada a la Inquisición y otra, desde 1560, estaba dividida en tres medias raciones para los cantores, ${ }^{414}$ pasando a cuatro los cantores racioneros en 1574. ${ }^{415}$ Hay que añadir que el Maestro de Capilla cobraba una ración entera y el organista

${ }^{411}$ NiETo Soria, José Manuel y SANZ SANCHO, Iluminado. Historia de España. La época medieval: Iglesia y cultura. Madrid, Istmo, 2011, p. 170.

${ }^{412}$ En realidad había once dignidades, pero una de ellas, el Prior de Sevilla, no pertenecía a los canónigos por lo que no tenía voto ni percibía beneficios de la mesa capitular. No era obligatorio que las dignidades fueran canónigos, podían ser racioneros o medio racioneros, con lo cual esto es una simplificación.

${ }^{413}$ La canonjía magistral y doctoral, creadas en 1474, eran ocupadas por un teólogo y un canonista respectivamente. El primero era el predicador oficial de la catedral y el segundo el encargado de los pleitos judiciales del cabildo. Las canonjías lectoral y penitenciaria fueron creadas a partir de Trento, aunque sus funciones ya fueran ejecutadas con anterioridad. La lectoral era encomendada a un biblista que se encargaba de enseñar publicamente la doctrina y la penitenciaria a un teólogo que hacía de confesor oficial de la catedral.

${ }^{414}$ Las tres medias raciones, para tiple, tenor y bajo, se crearon por bula pontificia el 12 de diciembre del dicho año al dividir la ración del doctor Hernán Ramírez. GONZÁLEz BARRIONUEVO, Herminio. Francisco Guerrero (1528-1599) Vida y obra. La música en la catedral de Sevilla a finales del siglo XVI. Sevilla, Cabildo Metropolitano de la Catedral de Sevilla, 2000, pp. 124-125.

${ }^{415}$ Se creó una media ración para contralto. BejARANO PELLICER, Clara. El mercado de la música en la Sevilla del Siglo de Oro. Sevilla, Universidad de Sevilla-Fundación Focus-Abengoa, 2013, p. 197. 
media. ${ }^{416}$ Además de estos ochenta prebendados, la catedral hispalense contaba con numeroso personal subalterno como los capellanes, clérigos de la veintena, mozos de coro, sacristanes, cantores y músicos, etc. En total, alrededor de trescientas personas, sin contar con criados y otros servidores laicos. Esta enorme y complicada estructura religiosa permitía la celebración de hasta quinientas misas diarias. ${ }^{417}$

Evidentemente, la catedral de Sevilla era un caso excepcional, no tanto en el elevado número como en la calidad de las prebendas. Era superada en número por las de Santiago y Toledo, esta última, por ejemplo, contaba con catorce dignidades, cuarenta canónigos prebendados, veinte canónigos extravagantes, cincuenta racioneros, más de cien capellanes y cuarenta mozos de coro o clerizones. ${ }^{418}$ Por comparación, un cabildo medio como el de Jaén contaba con siete dignidades, veintiuna canonjías y veinticuatro raciones y uno pequeño como el de Santo Domingo de la Calzada tres dignidades, diez canónigos y seis medio racioneros. ${ }^{419}$

Las obligaciones de cada uno de los miembros del cabildo, su organización y las remuneraciones recibidas en cada caso estaban recogidas en los estatutos. Por sorprendente que parezca, en Sevilla no había un corpus definido sino más bien un «desordenado conjunto de reglas y leyes» ${ }^{420}$ recogido en varios libros, tanto manuscritos como impresos:

los estatutos por los que se ha regido la sede hispalense han sido desde siempre un conjunto de reglamentos repartido entre documentos originales y copias hechas en diferentes libros, unas veces duplicadas y otras sometidas a distintos tratamientos en los que se han resumido, aumentado o corregido sus contenidos. En fin, una información que nunca se llegó a organizar del todo, ni poner en limpio,

\footnotetext{
${ }^{416}$ El Maestro de Capilla estaría incluido entre los racioneros y el organista entre los medios racioneros.

${ }^{417}$ HernándeZ Borreguero, José Julián. La Catedral de Sevilla. Economía y Esplendor. (Siglos XVI y XVII). Sevilla, Ayuntamiento de Sevilla-ICAS, 2010, p. 30.

${ }^{418}$ Lop Otín, M. J. El cabildo catedralicio de Toledo... , p. 266. La de Palencia también era de las grandes catedrales con catorce dignidades y cerca de cincuenta canónigos, pero cuyas prebendas apenas superaban los 700 ducados. Cabeza Rodríguez, Antonio. Clérigos y señores. Política y Religión en Palencia en el Siglo de Oro. Palencia, Diputación Provincial, 1996, p. 155 y 196.

${ }^{419}$ Domínguez ORTIZ, A. Las clases privilegiadas..., p. 237. Muy parecido al de Jaén era el de la vecina Córdoba con ocho dignidades, veinte canónigos y veinte racioneros. SANZ SANCHO, Iluminado. «El cabildo catedralicio de Córdoba en la Edad Media», En la España Medieval, 23 (2000), pp. 189-264.

${ }^{420}$ Belmonte FERnÁNDEZ, Diego. «Borradores, originales, copias y recopilaciones: los Libros de Estatutos del cabildo catedralicio sevillano», Historia. Instituciones. Documentos, 41 (2014), pp. 45-74; p. 45.
} 
pese a los intentos, muchas veces repetidos, de los diferentes personajes que a lo largo de los siglos han intentado dar orden a este complicado grupo de normas. ${ }^{421}$

De toda esta cantidad de copias utilizaremos las vigentes al periodo que nos interesa, de 1546 a $1580 .{ }^{422}$ Hay que señalar que era práctica común en el cabildo sevillano disponer las normas en lo que llamaban tablas del cabildo, que consistían en pizarras o maderas en las que se pegaban pergaminos, con texto en gran tamaño, con los juramentos y normas básicas y que se distribuían en zonas visibles, de forma que los beneficiados no pudieran alegar desconocimiento de sus obligaciones. ${ }^{423}$

De una forma resumida podemos explicar, con la ayuda de los estatutos, las funciones básicas de cada uno de los prebendados. Veamos las del deán, el chantre, el tesorero y el maestrescuela, pues son los que tienen jurisdicción sobre los otros miembros de la catedral y atribuciones muy concretas:

El Deán ha de tener cuydado del choro, cómo se haga e diga el Oficio muy honestamente, e ordenadamente [...] puede pugnir a los Beneficiados que en el choro no estuvieren honestamente [...] puede e deve encomendar los oficios del choro, assí la Missa, e el Evangelio, e Epístola [...] deve dezir la Missa en los días solemnes, quando el perlado no la dixere [...] puede hazer llamar a Cabildo [...] deve conocer e juzgar los pleytos civiles que fueren entre los beneficiados [...] ha de tener la una llave de las reliquias [...] pertenece proponer los negocios en Cabildo... ${ }^{424}$

${ }^{421}$ Belmonte FernándeZ, D. «Borradores..., p. 46. No es exclusivo este desorden de la catedral hispalense, pues en la catedral de Palencia ocurría algo similar. Los estatutos no estaban recopilados adecuadamente y había muchas versiones que podían, incluso, contradecirse, por lo que los canónigos usaban, según la situación, el códice que les interesara más. CABEZA RODRíGUEZ, A. Clérigos y señores..., p. 284. Hubo en Palencia muchos intentos de recopilarlos y llevarlos a la imprenta, para que cada beneficiado tuviera un ejemplar, pues se daba la paradoja de que los prebendados juraban unos estatutos que no conocían. Se realizaron varias recopilaciones, aunque nunca llegaron a las prensas. CABEZA, Antonio. La vida en una catedral del Antiguo Régimen. Palencia, Junta de Castilla y León: Consejería de Educación y Cultura, 1997, pp. 55-62.

${ }^{422}$ Contamos con varias con copias digitales de los Estatutos en la web que utilizaremos. La primera es impresa y fue recopilada por mandato del arzobispo Alonso Manrique entre los años 1523 y 1538 siendo impresa varias décadas después. La denominaremos Estatutos Manrique. Se conservan tres copias en el Fondo Antiguo de la Universidad de Sevilla, pudiendo ser consultada en la web la de signatura A Res. 74/2/05 en $<$ http://fondosdigitales.us.es/fondos/libros/1322/8/estatutos-y-constituciones-de-la-santa-iglesia-deseuilla/> [consulta 16-6-15]. La segunda copia, recopilada por mandato del arzobispo Fernando de Valdés, manuscrita en latín y castellano y con certificación fechada el 8 de agosto de 1550, está depositada en la Biblioteca de la Universidad de Valladolid con signatura Rms 73 y es consultable en <http://uvadoc.uva.es/handle/10324/231> [consulta 16-6-15] a la que denominaremos Estatutos Valdés.

${ }^{423}$ BeLmonte FernÁNDEZ, D. «Borradores..., p. 68.

${ }^{424}$ Estatutos Manrique, f. 9. 
El Chantre ha de començar todos los cantos, e regir los clérigos de la veintena por sí, o por un Sochantre [...] e él lo ha de pagar de sus dineros, e el dicho Sochantre ha de tener cura de enseñar los moços todo aquello que han de dezir en el choro, e el Cabildo paga el salario desto al dicho Sochantre [...] al Chantre pertenece dar las veyntenas, e poner los moços en el choro [...] conogce de los pleytos civiles que fueren entre los clérigos de la veyntena, e entre los criados del choro. ${ }^{425}$

El Thesorero ha de tener cura, e guardar toda la Iglesia, por lo qual a él pertenece poner dos sacristanes que sean hombres de buena fama, e si puede ser dever ser de Missa [...] Págalos la obra de la Iglesia, según el salario que fuese ordenado por el Deán e Cabildo [...] el Thesorero ha de distribuyr las candelas [...] ha de dar quenta al Deán e Cabildo de todas las cosas que estuvieren en el sagrario [...] ha de poner un hombre que guarde la Iglesia de día e de noche [...] ha de poner un hombre en cada una de las torres de las campanas... ${ }^{426}$

El Maestrescuela pertenece por sí o por otro corregir todos los libros de la Iglesia, assí de canto, como los otros que son menester para qualquier officio de la Iglesia, e esto a su costa [...] a él pertenece escrevir por sí o por otrie a su costa todas las letras mensageras del Cabildo, o responsiones de las letras que fueren embiadas al Cabildo [...] ha de tener la una llave del sello del Cabildo [...] ha de poner el Maestro de la Gramática, pero el Cabildo paga el salario... ${ }^{427}$

Por supuesto, todo este despliegue humano requería un despliegue económico acorde. Ya vimos anteriormente que las rentas del arzobispo de Sevilla habían sido hacia 1539 de unos 24.000 ducados anuales, seguido de cerca por el arzobispo de Santiago y bastante lejos de las elevadísimas rentas de la primada toledana. Las rentas totales del arzobispado hispalense hacia 1580 eran de unos 85.000 ducados, ${ }^{428}$ fundamentalmente provenientes de los diezmos ${ }^{429}$ y los arrendamientos. ${ }^{430} \mathrm{La}$ estructura administrativa necesaria era muy

${ }^{425}$ Estatutos Manrique, f. 9v.

${ }^{426}$ Estatutos Manrique, ff. 9v-10.

${ }^{427}$ Estatutos Manrique, f. 10v.

${ }^{428}$ Domínguez OrTiz, Antonio. «Un informe sobre el estado de la sede hispalense en 1581», Hispania Sacra, 6/1 (1953), pp. 181-195; p. 183.

${ }^{429}$ Un ejemplo de la complejidad del sistema lo muestra el reparto del diezmo entre el arzobispo y el cabildo. De un tercio de lo recaudado se repartían la mitad cada uno, pero de la parte del arzobispo el cabildo restaba un décimo para los gastos de administración. De esta forma el arzobispo percibía nueve sesentavos y el cabildo once sesentavos del total: «la tercera parte es para el Arçobispo y Cabildo por mitad, aunque de la mitad del Arçobispo diezma el Cabildo por causa de la administración» DomínGUEZ ORTIZ, A. «Un informe..., p. 4.

${ }^{430}$ Se calcula que la iglesia sevillana poseía una décima parte de la riqueza urbana, bien en propiedad, bien con gravámenes a su favor. MORALeS PADrón, Francisco. Historia de Sevilla. La ciudad del Quinientos. Sevilla, Universidad de Sevilla, 1989, p. 280. 
compleja, había dos mayordomos, canónigos ordenados, uno encargado de la «mesa capitular» dividida a su vez en pitancería y comunal y otro de la «mayordomía de la fábrica», ambos asistidos por contadores, también clérigos (racioneros o veinteneros) y numerosos oficiales. ${ }^{431}$

En cuanto a la remuneración, cada canonigo sevillano percibía unos 1.900 ducados (712.500 mrs.) anuales mientras que el deán percibía 6.000 ducados (2.250.000 mrs.) hacia $1581 .^{432}$ Se pueden considerar salarios muy altos, no equiparables a los de otras canonjías de Castilla, con excepción de Toledo; lo normal eran los canonicatos de entre 50 y 1.000 ducados anuales (18.750 a 375.000 mrs.). ${ }^{433}$ De este salario había una parte fija, la prebenda o grosa, que se cobraba simplemente acudiendo cinco días al mes a los actos litúrgicos. La parte variable se denominaba pitanza y era una especie de incentivo que se cobraba cuando los capitulares acudían a los cultos diarios que se celebraban en la catedral. Había otros complementos como son las gallinas ${ }^{434}$ y las misadas. Parte de estos pagos se entregaban en forma de trigo y cebada. ${ }^{435}$ En cualquier caso en cada partida la proporción siempre era la misma, la dignidad cobraba seis, el canónigo tres, el racionero dos y el medio racionero uno.

Estos elevados beneficios permitían a los canónigos hispalenses un alto nivel de vida, la denominada «vida de canónigo», con pocas obligaciones, exceptuando la asistencia a los diversos actos religiosos de la catedral, casa proporcionada por el cabildo, en la que no faltaban tres o cuatro criados, un ama y, cómo no, algún esclavo. Estaban obligados, eso sí, a salir a la calle con el suficiente boato y ostentación; así lo mandaban las constituciones

\footnotetext{
${ }^{431}$ Hasta 26 personas entre contadores y oficiales. Hernández Borreguero, J. J. La Catedral de Sevilla..., pp. 31-35.

${ }^{432}$ Domínguez OrTiz, A. «Un informe..., p. 185. En esta época los canónigos palentinos cobraban de su prebenda entre 4.000 y 8.000 reales (136.000 a 272.000 mrs.). CABEZA, A. La vida en una catedral..., p. 74.

${ }^{433}$ DOMíngueZ ORTIZ, A. Las clases privilegiadas..., p. 237.

${ }^{434}$ El cobro en gallinas era un procedimiento medieval que protegía los pagos de la inflación, principalmente los arrendamientos perpetuos. Estos pagos se valoraban parte en moneda y parte en gallinas; llegado el momento del cobro se utilizaba el precio de mercado de las gallinas para hacer la conversión a maravedís. Hernández Borreguero, J. J. La Catedral de Sevilla..., pp. 105-107.

${ }^{435}$ A mediados del siglo XVII la retribución en grano representaba un $40 \%$ del total y aproximadamente el 60\% del salario era fijo y el resto variable, según incentivos. HERnÁNDEZ BorreguERo, J. J. La Catedral de Sevilla..., pp. 109-110.
} 
dictadas por el cardenal Mendoza, que preveían duras penas para los que no las cumpliesen:

Por otro acto Capitular, de nueve dias de el mes de Iulio, de el año de mil y quinientos y diez, se mandò que cada Dignidad tuviesse en su casa tres cavalgaduras, una para su persona, y las dos para dos criados que le acompañen. El Canonigo dos, una para el, y otra para un criado. Que el que dentro de dos meses no tuviesse las dichas cavalgaduras, no ubiesse la cevada que se le da cada año. Que si pasado otro mes, no las tuviesse, pierda el trigo de un año. Que si despues de aquellos tres meses, passasen otros tres sin tenellas, no le apuntassen ni le escriviessen en el Coro, hasta que tuviesse las dichas cavalgaduras. ${ }^{436}$

Además, como veremos después, el consumo de objetos suntuarios por parte de los canónigos era muy elevado. Gran parte de ellos tenían estudios universitarios, ${ }^{437}$ por lo que era frecuente que poseyeran buenas bibliotecas.

Otros miembros de la iglesia sevillana percibían salarios mucho menores, pero en absoluto exiguos. Los clérigos veinteneros cobraban 100.000 mrs., lo mismo que los cinco curas que administraban los sacramentos. Los capellanes de coro más o menos 100 ducados (37.500 mrs.) y el resto de capellanes entre 30.000 y $45.000 \mathrm{mrs} .{ }^{438}$ En cuanto a los salarios de los músicos, nos ocupamos de ellos en el siguiente epígrafe. ${ }^{439}$

Las condiciones de acceso a los beneficios eclesiásticos dependían de la clase de este beneficio. Para acceder a uno simple sin cura de almas, bastaba haber cumplido los catorce años y ser clérigo, como mínimo tonsurado. Para un beneficio en un cabildo, fuera canonigo o dignidad, había que tener veintidós años y la tonsura. Para un beneficio

${ }^{436}$ Salazar De Mendoza, Pedro. Crónica de el Gran Cardenal de España, don Pedro Gonçalez de Mendoça. Toledo, Imprenta de doña María Ortiz de Saravia, 1625, p. 414. Copia digital en:

$<$ http://bibliotecadigital.jcyl.es/i18n/consulta/registro.cmd?id=13377> [consulta 11-4-15]. Algo parecido ocurría en Palencia donde desde 1440 los prebendados juraban el estatuto de los hombres y mulas, según el cual estaban obligados a tener, las dignidades cuatro criados, los canónigos dos y los racioneros uno. CABEZA RODRÍGUEZ, A. Clérigos y señores..., p. 58.

${ }^{437}$ Más de la mitad de los canónigos sevillanos de las dos últimas décadas del siglo XVI poseían estudios universitarios, principalmente licenciaturas y doctorados. Las universidades en las que habían estudiado eran Salamanca, Alcalá de Henares, Osuna y Sevilla. PIKE, Ruth. Aristócratas y comerciantes. La sociedad sevillana en el siglo XVI. Barcelona, Ariel, 1978, p. 67.

${ }^{438}$ DOMíngueZ OrTiZ, A. «Un informe..., pp. 185-86.

${ }^{439}$ Nos fijaremos principalmente en los salarios hasta 1580, año de la muerte del canónigo Mudarra. Para salarios en la catedral de Sevilla a principios del siglo XVII se puede consultar: CÁRDENAS SERVÁN, Inmaculada. Elpolifonista Alonso Lobo y su entorno. Santiago de Compostela, Universidad, 1987. 
con cura de almas, veinticinco años y estar ordenado de presbítero. ${ }^{440}$ Condición necesaria también era la residencia. ${ }^{441}$ Las formas de acceso eran variadas y complejas, pero se pueden simplificar así. En general los beneficios capitulares solo podían concederse cuando quedaban vacantes, ${ }^{442}$ aunque había sistemas para soslayar este impedimento. Estos beneficios, principalmente las dignidades y canonicatos, eran de libre provisión, lo que quería decir que correspondía a la Santa Sede la colación cuando la vacante se producía en los ocho meses apostólicos (los dos primeros de cada trimestre, enero, febrero, abril, mayo, julio, agosto, octubre, noviembre) y al cabildo junto con el obispo cuando la vacante se producía en los cuatro meses ordinarios. ${ }^{443}$ Así era también en la catedral de Sevilla:

quando alguno requiriere o demandare ser admitido a la possessión de alguno de los Beneficios desta santa Iglesia de qualquier condición que el Beneficio sea, agora sea avido por provissión papal, agora por ordinaria, la qual se ha de hazer por el perlado juntamente con su Cabildo... ${ }^{444}$

Ocurría con demasiada frecuencia que cuando alguna canonjía quedaba vacante las presiones por parte de los poderosos para conseguirla, para ellos o para algún pariente, eran muy fuertes, de forma que

algunos señores de estado, e otros de mucha autoridad e poder molestan e importunan a las personas deste Cabildo y a las vezes amenazan e pone temores porque den la possessión, o provean del beneficio que vaca a las personas que a ellos plaze [...] por lo qual acaece que muchas vezes dan sus votos contra su voluntad, y en peligro de sus conciencias, e daño de la Iglesia... ${ }^{445}$

Por no hablar de los frecuentes casos de compra de votos.

${ }^{440}$ Esto es lo que se dispone en el Concilio de Trento, precisamente para evitar los abusos cometidos con anterioridad. BARrio GOZALO, Maximiliano. «El sistema beneficial en la España del siglo XVIII. Pervivencias y cambios», Cuadernos Dieciochistas, 2 (2001), pp. 73-107; p. 87.

441 «Se entiende por residencia la permanencia continua del beneficiado en el lugar del beneficio. La residencia no ha de ser material, sino laboriosa, bastante para poder cumplir las cargas del beneficio». GOLMAYO, Pedro Benito. Instituciones del Derecho canónico. Madrid, Librería de Gabriel Sánchez, 1896, Tomo II, cap. 23, 276. Consultable en <www.cervantesvirtual.com> [consulta 27-6-15]

${ }^{442}$ Los beneficios quedaban vacantes por muerte del titular, por renuncia o por desposesión, por ejemplo, tras sentencia de la Inquisición.

${ }^{443}$ Había muchas excepciones en este asunto, que principalmente afectaban a la provisión regia que fue aumentando con el paso de los siglos tras la caída de Granada y la conquista de América. BARRIO GOZALO, M. «el sistema beneficial..., p. 96.

${ }^{444}$ Estatutos Manrique, f. $11 \mathrm{v}$.

${ }^{445}$ Estatutos Manrique, f. 12. 
Además de este tipo de nombramientos por libre provisión había otros tres muy comunes: la permuta, la resigna y la coadjutoría. La primera consistía en el intercambio de beneficios entre dos beneficiados; ${ }^{446}$ correspondía al obispo, o a los obispos cuando se trataba de obispados diferentes, aceptarla o no. La resigna in favorem era la transmisión de un beneficio a otra persona, supervisada y autorizada por las bulas pontificias pertinentes para evitar toda sospecha de simonía. ${ }^{447}$ La coadjutoría era la cesión de la prebenda fundamentalmente por motivo de vejez o enfermedad. ${ }^{448}$ El tipo más común era la coadjutoría perpetua con derecho a sucesión.

Estos tipos de acceso a los beneficios capitulares fueron puestos en duda y la propia Curia pontificia emitió numerosas disposiciones para evitar lo que de hecho ocurría, que numerosas familias coparan los cabildos como si de verdaderas dinastías catedralicias ${ }^{449}$ se tratara. Puesto que las prebendas, en teoría, no se podían heredar ni vincular a mayorazgos, la resigna y la coadjutoría permitían la cesión de tíos a «sobrinos» u otros familiares cercanos, ${ }^{450}$ lo que representa un caso evidente de nepotismo. ${ }^{451}$ Este fenómeno, que se daba en la catedral sevillana, también ocurría en otras muchas catedrales y colegiatas. ${ }^{452}$

${ }^{446}$ «La permuta es una renuncia que hacen dos beneficiados con la condición de que se confiera al uno el beneficio del otro». Golmayo, P. B. Instituciones del Derecho..., Tomo II, cap. 23, 278.

447 «La resignación o renuncia in favorem es aquella por la cual el párroco, canónigo u otro beneficiado, hace dimisión de su beneficio con la expresa condición de que se le confiera a determinada persona que él designa». Golmayo, P. B. Instituciones del Derecho..., Tomo II, cap. 23, 276. Evidentemente, excepto en los casos en que la resigna se produjera entre parientes, siempre había una compensación económica para el que cedía el beneficio, que en muchos casos era una parte de los frutos de la prebenda.

448 «Facultad obtenidad por bulas pontificias para servir y asistir a una dignidad o prebenda eclesiástica en vida del propietario de la misma, con derecho fijo a sucederlo en ella tras su muerte». MARTíNEZ RUIZ, Enrique (dir.). Diccionario de Historia Moderna de España. I. La Iglesia. Madrid, Istmo, 1998, p. 76.

${ }^{449}$ Díaz Rodríguez, Antonio J. «el precio del nepotismo. Coadjutoría y resigna en las catedrales andaluzas (SS. XVI-XVIII)», Chronica nova. Revista de historia moderna de la Universidad de Granada, 35 (2009), pp. 287-309; p. 290.

${ }^{450}$ En teoría, desde 1528 en Castilla no estaban permitidas las coadjutorías de padres a hijos a menos que las examinara el Consejo Real. CABEZA RoDríGUEZ, A. Clérigos y señores..., p. 254.

${ }^{451}$ El Concilio de Trento intentó poner freno a estas fórmulas de cesión de prebendas y así lo hizo, pero a partir del siglo XVII volvieron a ponerse en práctica. DíAZ RODRíGUEZ, A. J. «el precio del nepotismo..., pp. 293-294.

${ }^{452}$ El fenómeno, estudiado para Córdoba, Sevilla y Cádiz en DíAz RoDRíGueZ, A. J. «el precio del nepotismo..., era común a otros lugares. Destacamos el caso de la catedral de Palencia donde, por ejemplo, los Mudarra se hicieron con el deanato durante prácticamente todo el siglo XVI y, además, se formaron verdaderas redes clientelares de canónigos y racioneros. CABEZA RODRÍGUEZ, A. Clérigos y señores... 
Todo el proceso de obtención de bulas tenía un elevado coste económico, pues eran muchos los eslabones que obtenían ingresos por su expedición. ${ }^{453}$ Las bulas eran necesarias para la cesión de prebendas, pero también para las dispensas matrimoniales por consanguinidad, para el reconocimiento de hijos ilegítimos, etc. Primeramente había que contar con un contacto (un canónigo, por ejemplo) o un intermediario profesional que a su vez dispusiera de una persona en Roma. Mucho mejor si se contaba con alguien que fuera miembro de la Curia vaticana (un protonotario, un escritor apostólico, etc.), un pariente o un procurador profesional. De hecho, las catedrales y colegiatas contaban con procuradores en Roma para que se ocuparan de estos asuntos. El organismo encargado de las bulas de resigna y coadjutoría era la Dataría Apostólica, donde conocían perfectamente las rentas de cualquier beneficio, por lo que tasaban las bulas según el valor de la prebenda, fijando el precio en lo percibido en un año o más. Además, los beneficios capitulares estaban gravados con la annata y la media annata (el importe de un año de la renta o de medio año, respectivamente), la primera para los beneficios mayores y la segunda para los menores. Por supuesto, todos los intermediarios que actuaban cobraban su parte. Para garantizarse el pago de las importantes cantidades que podían representar las bulas estas solían llegar a España empeñadas, es decir, en Roma se ponían en manos de un banquero, quien las hacía llegar hasta sus representantes en Sevilla, por ejemplo. Para recibir la bula el interesado debía abonar las cantidades pertinentes de la expedición y gestión y, cómo no, el consiguiente interés para los banqueros. Al final de todo el proceso el precio alcanzado superaba con mucho, e incluso multiplicaba, la renta anual de cualquier prebenda. Se ha comparado a estos intermediarios con los alquimistas pues eran capaces de convertir el plomo (del sello de las bulas) en oro. ${ }^{454}$

\footnotetext{
${ }^{453}$ Tomamos el procedimiento de DíAz RodrígueZ, A. J. «el precio del nepotismo... y de CABEZA RODRíGuEZ, A. Clérigos y señores...

${ }^{454}$ DíAz RodrígueZ, A. J. «el precio del nepotismo..., p. 298.
} 


\section{Los músicos de la Catedral de Sevilla}

Evidentemente, el mundo musical de la Catedral en la segunda mitad del siglo XVI está dominado por la personalidad artística de Francisco Guerrero. Mucho se ha escrito sobre su vida y obra, ${ }^{455}$ por lo que no vamos a incidir en ello. Nos fijaremos un poco más en lo que consideramos la cotidianidad de la vida musical y en personajes como los ministriles, ${ }^{456}$ tal vez no tan afamados, pero fundamentales para conocer el día a día de una catedral.

\section{$\underline{\text { Cantores }}$}

Como era de esperar, la catedral hispalense contaba con un elenco musical muy relevante. Bajo la dirección y supervisión del Chantre, auxiliado por el Sochantre, funcionaban el coro de canto llano, los cantores de polifonía, organistas y ministriles. Sus atribuciones más concretas según los estatutos ya las vimos anteriormente. El canto llano estaba a cargo de los «veinteneros», los capellanes de coro y los mozos de coro, divididos todos ellos en dos coros, el coro del Deán y el coro del Arcediano de Sevilla.

El canto de órgano o polifonía estaba a cargo de los cantores dirigidos por el Maestro de capilla, cargo regentado por Alonso de $\mathrm{Alba}^{457}$ desde 1503 y sucedido por Juan Valera, ${ }^{458}$ Pedro de Escobar ${ }^{459}$ y Pedro Fernández de Castilleja. Pero sin duda el nombre

\footnotetext{
${ }^{455}$ Fundamentales para el acercamiento a Guerrero y a la vida musical de la catedral son: STEVENSON, R. La música en las catedrales... y GONZÁLEZ BARRIONUEVO, H. Francisco Guerrero...

${ }^{456}$ Un excelente trabajo sobre estos músicos, muchas veces entre la catedral y el mundo civil municipal, es Bejarano Pellicer, C. El mercado de la música...

${ }^{457}$ Recibido el 25 de enero de 1503, el día 1 de febrero recibió una casa en alquiler con una renta de 3.400 mrs. anuales. El día 6 de septiembre de 1504 se hace cargo de los mozos de coro (o de los seises) el sochantre Andrés de Hojeda, pues Alonso de Alba había fallecido. El lunes 23 de septiembre el cabildo ordena comprar unos libros de canto de órgano en la almoneda de los bienes del fallecido maestro. STEVenson, Robert. La Música en la Catedral de Sevilla. 1478-1606. Documentos para su estudio. Madrid, SEdeM, 1985. [En adelante citamos solo tanto en notas como en el cuerpo del texto como ACS seguidas de la numeración dada por Stevenson] ACS 49, 50, 59 y 60.

${ }^{458}$ El día 15 de enero de 1505 el cabildo el concede la casa que tenía arrendada Alonso de Alba con la misma renta, casa que, al ser grande, le permitía vivir con los cantorcicos (los muchachos). Al igual que su antecesor debió fallecer pronto, ya que el 17 de mayo de 1507 el cabildo hacía llamar a Pedro de Escobar como su sucesor. Debió ocuparse también de tañer los órganos pues el 7 de junio de 1507 Francisco de Troya, clérigo, se hace cargo de los del coro y de la capilla de la Antigua. ACS 68, 81 y 82.

${ }^{459}$ El 19 de mayo de 1507 el cabildo mandó un mensajero a Portugal para llamar a Pedro Escobar como maestro de capilla. En enero de 1508 ya está asentado, pues solicita un adelanto y en mayo reclama el
} 
fundamental en este cargo es el de Francisco Guerrero que, tras ejercer de cantor contralto, pasó a ser ayudante del maestro de capilla Pedro Fernández, con garantía de sucesión, mediante bula papal conseguida gracias a las gestiones realizadas en Roma por el procurador Francisco de Mudarra. Tras la muerte de Pedro Fernández, en 1574, Guerrero asumió el cargo al completo hasta su fallecimiento en 1599.

Pasamos de largo sobre la nómina de cantores que sirvieron en la catedral, por ser demasiado prolija y fuera de nuestros objetivos. Veamos únicamente el número de ellos con el paso de los años. En 1545 y 1546 había doce cantores, además de cuatro ministriles y un organista. En los años 1564 y 1565 había subido a trece cantores y cinco ministriles. A finales de siglo debían ser muchos más, pues sabemos de la presencia de cinco tiples. ${ }^{460}$ En cuanto a los salarios, sabemos que en 1478 se pagaba 1.200 mrs. por una cantoría. ${ }^{461}$ En 1488 había subido a 3.000 mrs. ${ }^{462}$ En 1504 oscila entre los 2.000 mrs. a Bernal y Ulloa recién asentados, los $5.000 \mathrm{mrs}$. de Martín de Montoya, y los 6.000 mrs. recién aumentados de Villafranca. ${ }^{463}$ En 1518 el tenor y presbítero Juan de la Parra ya fue contratado por la cantidad de 12.000 mrs. y dos cahíces de trigo y el también presbítero, el contrabajo Bernaldino de Navarrete, por 10.000 mrs. ${ }^{464}$ En 1526 se producen muchos cambios en lo musical, pues, aparte de plantearse la contratación de ministriles, son varios los nuevos cantores y los aumentos de salario que figuran en las actas, siendo el salario más alto de 12.000 mrs. El primer cantor que encontramos con un salario elevado es Álvaro de Cervantes, cantor tiple, asentado en 1535 con 50.000 mrs. y cuatro cahíces de trigo, salario que podemos considerar en estos años correspondiente a un cantor virtuoso. Sin embargo, el intento les duró poco, pues al año siguiente Cervantes se había ido a la catedral de Cádiz, suponemos que con una oferta más generosa aún. ${ }^{465}$

importe del vestuario de los cantorcicos que le habían cargado a él, correspondiéndole al fallecido Valera. En los años siguientes acumula varias capellanías, con sus consiguientes rentas. ACS 81, 87, 88, 90, 91 y 92.

${ }^{460}$ GonzÁlez BARrionuevo, H. Francisco Guerrero..., p. 121.

${ }^{461} \operatorname{ACS} 7$ y 10.

462 ACS 47.

${ }^{463}$ ACS 64, 66 y 67.

${ }^{464}$ ACS 127 y 128.

${ }^{465}$ ACS 183 y 188. Unos años antes la catedral había tenido mala suerte con otro cantor tiple. Martín de Navarrete fue confirmado por el cabildo el 14 de diciembre de 1532. El 18 de agosto del año siguiente fue despedido. Al mes siguiente solicitó de nuevo su ingreso y despedido de nuevo en noviembre. ACS 170 , 174,176 y 181. 
En 1553 el cabildo se lamenta de la falta de contrabajos y del mucho dinero que se han gastado en buscar uno bueno. Deciden contratar a Miguel Castaño con el salario de 40.000 mrs. y cinco cahíces de trigo, con la promesa de concederle la primera vacante de clérigo de la veintena que hubiere, lo que implicaba un salario mucho más alto, cosa que así hicieron al año siguiente. ${ }^{466}$

Observamos que en los años siguientes se hace un mayor esfuerzo en pagar mejores salarios a los nuevos cantores, tal vez por exigencia de Guerrero, incluso apoyado por Mudarra, para elevar el nivel de la Capilla con buenos cantores y, como veremos luego, buenos ministriles. Además, se van a renovar los libros de canto de órgano porque «son muy antiguos y las obras dellas muy antiguas», encargando el trabajo de copia a Rodrigo de Ceballos. ${ }^{467}$

\section{Organistas}

No vamos a detenernos sobre los órganos de la catedral de Sevilla que eran varios y estaban colocados en diversos lugares, como el altar mayor, el coro y la capilla de la Antigua. Prestaremos un poco más de atención a los organistas. Como vimos, la plaza de organista titular estaba provista de una media ración de la mesa capitular. Los primeros nombres que encontramos ya constan como racioneros: ${ }^{468}$ Álvaro de Zamora entre 1478 y 1480; ${ }^{469}$ Juan Bernal entre 1480 y 1507, a quien le correspondía un salario de 5.000 mrs. en 1481; ${ }^{470}$ Diego Hernández entre 1507 y 1540; $;^{471}$ Pedro de Villada y Alarcón entre 1540 y 1572 y fallecido este sucedido por Jerónimo de Peraza y Sotomayor entre 1573 y 1580 o 1581. Este año, el cabildo solicitó a Roma la eliminación de la prebenda de organista, que tras la pertinente bula pasó a ser músico asalariado sin presencia ni voto en el cabildo.

\footnotetext{
${ }^{466}$ ACS 280 y 286.

${ }^{467}$ ACS 278.

${ }^{468}$ Tomamos los datos, además de ACS, de GonZÁLEZ BARRIOnUEVO, H. Francisco Guerrero..., pp. $262-$ 271.

${ }^{469}$ ACS 17, 19, 20 y más. Fue sustituido por ausencia en varias ocasiones por Luis de Astorga y por Bernal que se quedó con la prebenda.

${ }^{470}$ Entró como sustituto de Zamora pero luego quedó como organista titular con la media ración. ACS 29, 32 y más.

${ }^{471}$ En 1507 se creó la ración de organista asignándole el mismo salario que al maestro de capilla. ACS
} 82. 
Además del organista titular las actas reflejan desde el primer momento la presencia de un segundo organista contratado, alguno de ellos bastante bien pagado como es el caso de Rodrigo de Morales, asentado en 1540 con un salario de 30.000 mrs. y cuatro cahíces de trigo. ${ }^{472} \mathrm{La}$ función de estos organistas era suplir las ausencias de los titulares y ocuparse de los órganos de la capilla de la Antigua y del altar mayor.

\section{Ministriles}

Sabido es, que desde 1526 la «Magna hispalensis» contó con un grupo de ministriles contratados permanentemente, siendo pionera en esto y seguida por Córdoba en 1528 y por Toledo en $1531 .{ }^{473}$

Hasta 1526 el cabildo venía contratando a los ministriles del duque de Medina Sidonia y, posiblemente, a otros. ${ }^{474}$ Así el 10 de noviembre de 1507 se pagó 1.000 mrs. a los ministriles del duque por haber asistido a la procesión del día de Santa María. ${ }^{475}$ El 24 de abril de 1514 los ministriles cobraron 12 ducados (4.500 mrs.) por tañer en la vigilia de Pascua de Resurrección. ${ }^{476} \mathrm{El} 1$ de junio de 1517 los ministriles, trompetas y atabaleros cobraron 20 ducados (7.500 mrs.) por su intervención en la procesión del Corpus y el día 26 del mismo mes se ordenó pago a los ministriles por haber participado en la procesión de la octava del Corpus. ${ }^{477}$ Pocos meses más tarde, el 13 de noviembre, los ministriles, trompetas y atabales, esta vez acompañados de los tamborinos, lo que nos hace suponer la inclusión de danzas, recibieron todos juntos 10 ducados (3.750 mrs.) por su trabajo en la fiesta de San Martín. ${ }^{478} \mathrm{Al}$ año siguiente fueron llamados los ministriles (sacabuches y chirimías), trompetas y atabaleros para la Pascua de Resurrección, abonándoseles un salario de 11 ducados $^{479}$ (4.125 mrs.), un ducado menos de lo que pagaron en 1514.

472 ACS 230 y 231.

${ }^{473}$ Un estudio detallado sobre la cronología de contratación de ministriles en la catedrales españolas en RUIZ-JiMÉNEZ, Juan. «Ministriles y extravagantes...

${ }^{474}$ También mantenía relación el cabildo con el duque de Arcos prestándole cantores (como hacía con el de Medina Sidonia) para su palacio de Marchena. ACS 194 y 217.

475 ACS 85.

${ }^{476}$ ACS 99.

477 ACS 107 y 108.

478 ACS 109.

${ }^{479}$ ACS 114. 
Volvemos a encontrar ministriles contratados en varias ocasiones, en muchas de ellas solo se indica que se les pague «lo que otras vezes suele dalles por cada venida» o «lo que se les suele dar otras vezes»». ${ }^{480}$ El 2 de julio de 1518, el cabildo ordena pagar 20 ducados (7.500 mrs.) a ministriles, trompetas, atabales y tamborinos por las Vísperas de San Pedro ${ }^{481}$ y el 20 de agosto, 13 ducados (4.875 mrs.) por la Asunción. ${ }^{482}$ El 11 de mayo de 1524 trompetas y atabaleros recibieron 2 ducados $(750 \mathrm{mrs}$.) por la procesión de la Virgen.

Por fin el cabildo decide tener ministriles propios para no depender de su disponibilidad. La decisión se tomó en cabildo el lunes 9 de julio de 1526:

ACS 149. /f. 151 v./ Lunes 9 de julio de 1526

[...] tener salariados e por suyos algunos menestriles altos sacabuches e chirimias para que tengan en algunas fiestas principales e procesiones que faze esta santa iglesia lo qual se podria hazer con salario honesto e tal que no fuese mucho mas que lo que se les da en vezes e que servirian mucho mejor y mas vezes e veniendo a votos verbales e aviendo sobre ello algunos tratados determinaron e mandaron que se resciban çinco menestriles altos en esta santa iglesia tres chirimias que sean tiple e tenor e contra e dos sacabuches personas habiles en su arte para que sirvan en esta santa iglesia [...] el salario que contraten con ellos fasta contia de dozientos ducados cada año a todos çinco y menos si menos ser pudiere.

No parece que el grupo de ministriles reclamado en $1526^{483}$ permaneciera ya de continuo, pues en 1532 el cabildo contrata a Pedro de San Pedro, chirimía tiple, ${ }^{484}$ con un salario de 10.000 maravedís y un cahíz de trigo (12 fanegas); en 1533 examinan al chirimía tiple Francisco de Flandes ${ }^{485}$ y valoran que el sacabuche Andrés de Deça pueda tañer como contralto (chirimía?). No debió ser de su agrado Francisco, ${ }^{486}$ o se marchó, pues el 7 de noviembre del mismo año el cabildo comisiona al maestro de capilla y dos racioneros

${ }^{480}$ ACS 119, 121.

${ }^{481}$ ACS 122. Durante la víspera de la festividad de San Pedro y San Pablo se tocaba desde la giralda las llamadas «Lágrimas de San Pedro».

482 ACS 129.

${ }^{483}$ Dos años tardaron en aplicar la decisión, pues hasta 1528 no se llegaron a asentar según se deduce de los libros de fábrica. Bejarano Pellicer, C. El mercado de la música..., p. 206.

${ }^{484}$ Aunque las actas solo dicen tiple presuponemos chirimía, pues la agrupación frecuente era de chirimías tiple, contralto y tenor y sacabuches contralto o tenor y bajo. No sabemos si este San Pedro tiene algo que ver con la familia de trompetas San Pedro que veíamos en Guadalajara.

${ }^{485}$ Desconocemos qué relación puede tener con el homónimo que ya vimos en la Casa de Alba a finales del siglo XV.

${ }^{486}$ Lo volvemos a ver en la catedral de Jaén en 1540. ACS 799. 
para que busquen «algund buen ministril cheremia que sea contra altos tenor o tiple». ${ }^{487}$ Este movimiento de los ministriles puede indicar que hubo renovación entre 1526 y 1532 , bien porque el cabildo los despidiera, como ocurrió en Córdoba al año siguiente de ser asentados, o porque los ministriles se marcharan. Creemos que esta última opción es razonable considerando que el salario que percibían era bastante escaso. Doscientos ducados al año son 75.000 mrs., que a repartir entre cinco son 15.000 mrs. para cada ministril, cantidad por debajo de lo que se pagaba en ese mismo año de 1526, por ejemplo, en la Casa del Infantado, donde los chirimías cobraban entre 30.000 y 35.000 mrs. y los sacabuches entre 20.000 y 40.000 mrs. De hecho, el salario de Pedro de San Pedro es más bajo todavía, a pesar de haber transcurrido seis años, pero incluye un cahíz de trigo (12 fanegas) que estaría valorado en cerca de 1.300 maravedís. ${ }^{488}$ Podemos comparar también el salario ofrecido a los ministriles en 1531 por la catedral de Toledo. En el contrato ${ }^{489}$ se estipula que entre los seis cobren 150.000 mrs. repartidos de la siguiente manera: Gaspar Maynete y Gerónimo de Cuéllar, chirimía tiple y sacabuche respectivamente, cobrarían 32.500 mrs. cada uno y su compañero o criado 20.000 mrs., mientras que Bartolomé de Medrano, chirimía contralto y su hijo, u otro compañero, 45.000 mrs. a repartir. Observamos que estos salarios se ajustan más a los pagados por las casas altonobiliarias en los mismo años. Si consideramos que, además, Sevilla era una de las ciudades con un coste de vida más elevado de Castilla en el siglo XVI, es fácil pensar que los ministriles hispalenses abandonarían la catedral, no solo por falta de disciplina, ${ }^{490}$ ni por discrepancias dentro del cabildo sobre su utilidad, ${ }^{491}$ sino principalmente por algo mucho más prosaico: la catedral sevillana pagaba poco, queriendo pagar aun menos e incluso, tarde. ${ }^{492}$ Era, además, su intención que tañeran en más ocasiones por lo mismo que se les daba extraordinariamente «que no fuese mucho mas de lo que se les da en vezes

\footnotetext{
487 ACS 179.
}

${ }^{488}$ Calculamos el trigo a tasa (precio máximo al que se podía vender un producto, so pena de fuertes sanciones económicas), a pesar de que en estos años no había sido actualizada por lo que se aplicaba la de 1502, cuando en Castilla se tasaba a $110 \mathrm{mrs}$. la fanega de trigo, 60 la de cebada y 70 la de centeno. HAMILTON, Earl J. El tesoro americano y la revolución de los precios en España, 1501-1650. Barcelona, Crítica, 2000, p. 258.

489 Como veíamos está reproducido en Perales de la Cal, R. Papeles Barbieri..., pp. 47-51.

${ }^{490}$ Sí hubo casos de indisciplina de los ministriles, como en 1538 cuando se les restó de su salario de los días que se ausentaron sin permiso. Se decidió que se les apuntara, como a los cantores y a los prebendados, cuándo acudían y cuándo se ausentaban de su obligación. ACS 216.

491 Así lo analiza RuIZ-JiMÉNEZ, Juan. «Ministriles y extravagantes..., pp. 201-202.

492 «que los cantores y ministriles canten y tangan y les libren sus nominas segun se les suele librar y sy el mayordomo no les pagare que esperen asy en lo pasado como en lo por venir», ACS 175. 
e que servirian mucho mejor e mas vezes». Tal vez los ministriles no estuvieran muy de acuerdo con este contrato que, muy probablemente, les obligaría a la exclusividad, con lo que sus beneficios se verían muy menguados.

En 1538 se hace llamar al chirimía Luis de Medrano para que vuelva a servir en la catedral donde ya había estado anteriormente y Pedro de San Pedro sigue todavía al servicio de la catedral. ${ }^{493}$ De repente, el 23 de noviembre de 1545 , el cabildo decide despedir a todos los ministriles alegando lo caros que le resultan:

Este dicho día los dichos señores platicando en razón de la mucha necesidad que padese la fábrica por los muchos salarios eçesivos que paga los dichos señores, botando por botos bervales por mayor parte, mandaron que se dé licencia a los ministriles de esta santa Iglesia y se tengan por despedidos y les paguen todo de lo que se les debe y que se notifique al mayordomo y contadores ${ }^{494}$.

No duró mucho esta situación, ya que en marzo de 1546 se vuelve a contratar al chirimía tenor Luis de Medrano por 20.000 mrs. y dos cahíces de trigo, ${ }^{495}$ al sacabuche Andrés de Deça por 25.000 mrs. y tres cahíces y a Pedro de San Pedro. ${ }^{496}$ Además, entran Calderón con el mismo salario que Deça y posiblemente también sacabuche y Mora y Montoya $^{497}$ con 15.000 mrs. y de los que desconocemos el instrumento, lo que hace un total de seis músicos. También se espera recibir a una pareja de ministriles, chirimías tiple y contralto, que vienen de Valencia y a los que se les asigna un salario de $30.000 \mathrm{mrs}$. y cuatro cahíces a cada uno. ${ }^{498}$ En noviembre de ese año todavía esperan, esta vez a tres

\footnotetext{
${ }^{493}$ ACS 218 y 220.

494 Actas Capitulares, libro 22, f. 261v. Copiamos la cita de BejArano PelliCer, C. El mercado de la música..., p. 206.

${ }^{495}$ No se debió incorporar inmediatamente, pues si se trata del mismo Luis de Medrano que en este año trabajaba en la corte de los duques de Calabria con un salario similar, 22.500 mrs., abandonó Valencia en el útimo tercio del año, según las nóminas, que es cuando se debió incorporar en Sevilla. Hay otro Medrano en Valencia, Diego, que sí permaneció e incluso en ese tercer tercio se le incrementó el salario a 120 ducados (45.000 mrs.), el doble de lo que cobraba Luis. MoLL, J. «Notas para la historia musical..., p. 126. Podríamos también pensar en relación con el chirimía de la catedral toledana Bartolomé de Medrano, tal vez se trate del padre. Unos años más tarde, desde 1563, Luis de Medrano y su hijo homónimo se encuentran al servicio de la catedral de Toledo. DABrio GonZÁLEZ, María Teresa. «La capilla musical de don Cristóbal de Rojas en la Catedral de Córdoba», Laboratorio de Arte, 4 (1991), pp. 101-118.

${ }^{496}$ No podemos afirmar rotundamente que se trate de Pedro, pues se le cita por el apellido.

${ }^{497}$ Podría tratarse de Joan Montoya, también al servicio de los duques de Calabria ese año. MoLL, J. «Notas para la historia musical..., p. 126.

${ }^{498}$ Creemos que, por alguna razón que desconocemos, en 1546 parte de los ministriles de la corte del duque de Calabria fueron despedidos y acabaron en la catedral hispalense.
} 
ministriles valencianos habiendo sido encargado Deça del concierto (el contrato) con ellos, lo que nos indica que Deça sería el encargado de los tañedores.

Parece que volvió a haber problemas con la estabilidad de los músicos, pues en 1551 se contratan chirimías, sacabuches, trompetas y atabales para la noche de San Pedro. En 1553 el cabildo se plantea la necesidad de volver a contar con una plantilla estable de ministriles $^{499}$

pareçio a todos que /f. 57/ era cosa muy decente y conforme a la divina escritura que la dicha sancta yglesia fuese servida y con todo genero de musica onesta como son los dichos menestriles por que siendo tan ynsigne y grande templo como lo es tiene muncha necesidad de la dicha musica por su sonorosidad pues los tienen todas las yglesias catredales despaña de muncho menos posibilidad mayormente que saliendo como salen todos los benefiçiados y clerigos desta sancta yglesia en prosiçion munchos dias solenes del año a el rededor de la dicha yglesia y para yr a las yglesias parrochiales y monesterios desta dicha çibdad de muy largos trechos y conviene muncho la dicha musica par yr mas honrradas y autorizadas y devotas las dichas prosiçiones y para que con mas devoçion y afeçion se muevan e ynçite el pueblo a las acompañar y venir a los divinos ofiçios a la sancta yglesia ${ }^{500}$

En septiembre se fija el número y salario de los ministriles de la siguiente manera: Juan Peraça, ${ }^{501}$ chirimía tiple, 55.000 mrs. y cinco cahíces de trigo; Andrés Deça, sacabuche, 30.000 mrs. y cuatro cahíces; Luis de Medrano, chirimía tenor, 25.000 mrs. y dos cahíces; Juan Baptista, sacabuche, 25.000 mrs. y dos cahíces; Antonio de San Pedro, chirimía

${ }^{499}$ No sabemos cuánto pudieron influir en esta decisión Francisco Guerrero, ayudante de maestro de capilla y el canónigo Mudarra, pero la busqueda le correspondió a tres canónigos y al organista racionero Villada.

${ }^{500}$ ACS 274.

${ }^{501}$ Se trata del progenitor de la familia Peraza. Al igual que Montoya había servido en la corte valenciana de los duques de Calabria en 1546. Desde allí se trasladó con su familia a Toledo y de aquí a Sevilla, donde fue contratado en 1553. Se escapó de Sevilla, sirviendo en Toledo y posteriormente, desde el 24 de noviembre de 1567, con un salario de 100.000 mrs., en la catedral de Salamanca. Falleció en Toledo el 15 de julio de 1575. Su hijo mayor, Jerónimo de Peraza (Sevilla c. 1550-1617) sucederá a Villada en la ración de organista en 1573 pasando en el mismo puesto a Toledo en 1579 donde quedará hasta su muerte. En 1578 entra como ministril otro hijo, Juan de Peraza y ya en 1584 el elogiado Francisco Peraza († Sevilla 1598), el menor de los hermanos, ocupa el banco del órgano hasta su muerte. MoLL, J. «Notas para la historia musical..., p. 127. RuiZ-JiméneZ, Juan. «La dinastía de los Peraza. Nuevos datos para la biografía de Jerónimo Peraza II», Cuadernos de Arte. 46 (1995), Universidad de Granada, pp. 53-63. LÓPEZ-CaLO, José. «Peraza [Pedraza]», DMEH, vol. 8, pp. 603-605. 
tenor, 30.000 mrs. y cuatro cahíces; Martín de San Pedro, ${ }^{502}$ sacabuche, 12.000 mrs. y dos cahíces de trigo. En total una chirimía tiple, dos tenores y tres sacabuches. ${ }^{503}$

$\mathrm{Al}$ año siguiente de nuevo están buscando ministriles, uno de los contratados era el hermano de Medrano. ${ }^{504}$ En 1556 se aumenta el salario de este último y a Juan Baptista a 30.000 mrs. y dos cahíces y Deça se encuentra enfermo. ${ }^{505}$

En 1557 asientan al chirimía tiple Gaspar Maynete, al que ya vimos en la catedral de Toledo, con un salario de 50.000 mrs. y tres cahíces de trigo y a San Pedro, ${ }^{506}$ sacabuche, con 30.000 mrs. y dos cahíces. ${ }^{507}$ Para las plazas restantes se debió convocar oposición, pues se presentan Mora, que ya había estado en 1546, su padre y dos hermanos. Debieron ser aceptados con un salario de 100 ducados (3.750 mrs.) y un cahíz de trigo a cada uno. Otros tres ministriles que habían llegado para la selección no fueron recibidos y se les dió a cada uno cuatro ducados (1.500 mrs.) para el regreso a su casa.

Por fin, en 1560 el cabildo debió decidir subir el nivel de los ministriles contratando a los mejores, aunque les resultara más gravoso. Es llamado el sacabuche Garçi González, ${ }^{508}$ como ya vimos anteriormente, que debía tener ya cerca de cincuenta años y había pasado por las cortes del Infantado, Benavente y Calabria, y también dos miembros de la afamada familia Camargo ${ }^{509}$ provenientes de la Casa Real, pues se les exigía licencia del rey. Eran Melchor de Camargo, chirimía tiple, con el generoso salario de 300 ducados (112.500 mrs.) y diez cahíces de trigo y Gaspar, sacabuche, con 150 ducados (56.250 mrs.) y seis cahíces

atento a las abilidades y calidades y la necesidad que esta santa yglesia tiene de buenas vozes y otras causas que a ello les mueve que se reçiban y resçibieron a los dichos cheremia y sacabuche para el servicio desta dicha santa yglesia y les davan y dieron de partido a melchior de camargo tiple trezientos ducados y dies cahizes de pan trgo [sic] y al dicho gaspar de camargo sacabuche çiento y cinquenta ducados y seis cahizes de pan trigo y con condicion que no sirviendo a vos se se tenga por despedidos a

\footnotetext{
502 Posiblemente Antonio fuera el padre de Martín ya que la diferencia de salarios puede indicar diferencia de edades. Es muy probable que fuesen parientes de Pedro de San Pedro.

503 ACS 277.

504 ACS 288.

${ }^{505}$ ACS 306 y 308.

${ }^{506}$ Posiblemente Martín.

${ }^{507}$ ACS 315, 316, 317, 318 y 319.

508 ACS 342.

${ }^{509}$ Muy relacionados con la Casa Real como se puede ver en ROBLEDO ESTAIRE, L. «La música en la Casa del Rey..., p. 156-158.
} 
vos y que todo lo suso dicho se les dava y diera con condicion que traigan licencia de su magestad [...] syendo los menestriles suso dichos buenos como dis que lo son que se resçiban ${ }^{510}$

En agosto de 1563 se acrecenta el salario de todos los ministriles de la siguiente manera: ${ }^{511}$ a los chirimías tiple Diego de Andrada y Juan de Rojas a 50.000 mrs. y cinco cahíces de trigo, lo mismo al sacabuche Juan Baptista y los otros dos sacabuches Diego López y Gaspar de las Cuevas $(† 1580)^{512} 37.500$ mrs. y cuatro cahíces. Luis de Medrano se había ido el mes anterior a Córdoba. ${ }^{513}$ En 1565 se recibe a Gerónimo de Medina, sacabuche, con un salario de 30.000 mrs. y tres cahíces y al año siguiente se le sube el salario a 100 ducados, pero sin el trigo. ${ }^{514}$ Poco a poco el grupo de ministriles sevillano se ha ido haciendo estable gracias a una subida de los salarios hasta hacerlos apetecibles y también al empeño del cabildo por firmar contratos en exclusividad de larga duración, obligando a los ministriles a traerse a sus familias a la ciudad, incluso pagándoles una ayuda de costa para instalarse. ${ }^{515}$

Las relaciones familiares también fueron importantes para ser recibidos como ministriles en la catedral. Ya hemos visto los casos de la familia San Pedro, los Mora o los Medrano. Pero el caso más significativo es el de la familia Peraça o Peraza. El primero en acceder fue Juan Peraça, chirimía tiple, padre de los organistas y racioneros Jerónimo y Francisco de Peraza. El último es el ministril Juan Peraza, hermano de los organistas e hijo por tanto del homónimo, recibido en 1578.

Los lazos de solidaridad con los enfermos también existían y de hecho estaba regulado por el cabildo que cuando un cantor o ministril faltara a alguna fiesta fuera de la catedral por estar enfermo se le pagara su parte como si hubiera acudido. ${ }^{516}$

${ }^{510}$ ACS 346.

511 ACS 381.

512 Este ministril fue acusado de la muerte de un hombre y el cabildo solicitó en 1566 un perdón al rey por medio de su procurador en la corte. ACS 425.

${ }^{513}$ ACS 378.

514 ACS 392 y 418.

${ }^{515}$ En principio no era así como pasó con un ministril de Murcia en 1554 o a Garçi González al que no pagaron su venida en 1560. ACS 288 y 342. Sí se la pagan en 1583 a un menestril del que no nos dicen el nombre. ACS 578. Gerónimo de Medina permaneció al servicio del cabildo sevillano durante 48 años según Bejarano Pellicer, C. El mercado de la música..., p. 139.

${ }^{516}$ ACS 429. 
En cuanto al número de ministriles, vimos que en 1526 se contrató a cinco, sin que sepamos los nombres: tres chirimías, tiple, alto y tenor y dos sacabuches. Recordemos que en este mismo año el duque del Infantado contaba con tres chirimías y cuatro sacabuches, pero un par de años antes tenía cuatro de cada instrumento. En Toledo en 1531 fueron seis los asentados. En 1553 las plazas en Sevilla fueron seis, tres chirimías y tres sacabuches. En 1563 volvemos a encontrar el mismo elenco y es posible que se mantuviera unos años. En 1581 son cinco, pero a principios del siglo XVII pasaron a ocho, después a diez, para quedar cinco a finales del siglo. ${ }^{517}$

También las actas capitulares nos hablan de los instrumentos de los ministriles. En enero de 1565 se comisiona al canónigo Luis Carrillo para que repare una caja de flautas y si no es posible, que compre otra. ${ }^{518}$ En enero del año siguiente se apremia al canónigo para que compre las flautas con urgencia. ${ }^{519}$ No sabemos si estas se llegaron a comprar porque en 1571 se decide adquirir un juego que se entrega a Juan Baptista (posiblemente el líder del grupo al ser de mayor antigüedad). ${ }^{520}$

Sobre los libros usados por los ministriles ${ }^{521}$ tenemos varias referencias. En 1560 se resuelve comprar un libro de canto para los chirimías. ${ }^{522}$ En 1572 se compra un libro de misas de Guerrero a los ministriles. ${ }^{523}$

No quisieramos dejar los ministriles sin decir algunas palabras sobre la interpretación. Es de suponer que los grupos de instrumentistas acostumbrados a tocar juntos durante muchos años, muchos de ellos eran incluso parientes, tendrían unas prácticas interpretativas generadas por la convivencia y por la tradición. Sin embargo, Francisco Guerrero sintió la necesidad de poner por escrito una serie de reglas para la ejecución. Tal

\footnotetext{
${ }^{517}$ Bejarano PeLlicer, C. El mercado de la música..., p. 209.

518 ACS 390.

519 ACS 419.

${ }^{520}$ De hecho en 1566 era el único ministril que tenía la llave de los instrumentos y de los libros de música. GonZÁLEZ BARRIONUEvo, H. Francisco Guerrero..., p. 221.

${ }^{521}$ Sobre el repertorio de ministriles conservado ver KREITNER, Kenneth. «The repertory of the Spanish cathedral bands», Early Music, 37/2 (2009), pp. 267-286.

522 ACS 343.

523 ACS 487.
} 
vez la abundancia de músicos de primer nivel, y con el ego quizás muy crecido, provocaba situaciones en las que se producía confusión. A este respecto las actas del 11 de julio de 1586 recogen el siguiente «horden que han de tener los Ministriles en el tañar [sic]». ${ }^{524}$

Este dicho dia llamados para ello mandaron que los ministriles guarden el horden que el Maestro francisco Guerrero ha dado por escripto [...] el cual horden es el que se sigue:

primeramente que Rojas y lopes tañan siempre los tiples de las chirimias y que guarden con mucho cuydado horden en el glosar en sus lugares y tiempos de manera que cuando el uno glosare el otro vaya con llaneza aguardandose el uno al otro porque glosando juntos se haçen disparates para tapar los oydos.

Ytem que los mismos Rojas y lopez quando uviere cosa de cornetas las tañan ellos Guardando el mesmo horden cada uno de moderarse en las glosas esperandose el uno al otro porque como ya es dicho glosar juntos es disonançia ynsufrible. Que juan de medina taña de hordinario el contralto y de lugar a los tiples no turbandolos con exceder de la glosa que debe a contralto y que quando el dicho Juan de medina tañere solo el contralto por tiple con los sacabuches se le dexa el campo abierto para hacer las galas y glosas que quisiere que en este ynstrumento las sabe bien hacer. /f. 47/ que Alvanches taña tenores y el baxon.

\section{ACS 617}

Que en las fiestas del choro aya siempre un berso de flautas.

que en las salves los tres versos que tañen el uno sea con chirimias y el otro con cornetas y el otro con flautas porque siempre un instrumento enfada y ansi lo proveyeron

${ }^{524}$ ACS 616 y 617. Somos conscientes de que estos textos han sido reproducidos en multitud de ocasiones, pero no nos sustraemos a la repetición debido a su interés. González Barrionuevo recoje un texto del libro de fábrica con instrucciones parecidas. GonZÁLEZ BARRIONUEVO, H. Francisco Guerrero..., p. 249. 


\section{Alonso y Francisco Mudarra, canónigos sevillanos}

La relación de los Mudarra con la catedral hispalense comienza, como veíamos anteriormente, con el nombramiento de Francisco Mudarra como procurador de la catedral en Roma, el 6 de junio de 1539, con un salario de 100 ducados (37.500 mrs.) anuales. ${ }^{525}$ Unos meses más tarde, Francisco escribe una carta al cabildo sevillano en donde relata las noticias de Roma, ${ }^{526}$ sus gestiones y, posiblemente, los gastos ocasionados por ellas (la comisión está formada por el doctor Francisco Ramírez y los contadores) para su aprobación y liquidación.

ACS 225. /f. 288 v./ Viernes veynte e seys de setiembre de 1539

En este cometio su señoria a los señores por dotor ramirez con contadores que vean una carta de francisco de mudarra procurador del cabildo en Roma y hagan una memoria de lo que se le deve responder y en cada negocio escrivan su paresçer e lo trayan a cabildo fecho vt supra.

Tras unos meses, en los que parece que fue sustituido de su cargo de procurador, vuelve a él el 31 de julio de $1545 .{ }^{527}$ Lo encontramos de nuevo en las actas capitulares rindiendo cuentas en enero del año siguiente:

\section{ACS 233. /f. 16/ Lunes 10 de enero de 1546}

Este dicho dia los dichos señores disputaron a los señores el maestro escuela y arcediano de niebla y al doctor gasco y a don hieronimo manrique y racionero rodrigo tamariz y pedro de villagarcia y licenciado luzero juntamente con los señores contadores para que mañana de mañana honze de enero se junten en casa de cuentas y vean las cuentas de francisco de mudarra todos o la mayor parte y vistas traigan relaçion dellas a cabildo

En cuanto a Alonso, nada sabemos entre el 4 de enero de 1543, cuando abandona el palacio del Infantado, y este año de 1546. Con una edad entre 34 y 36 años Alonso

${ }^{525}$ GIL, J. «Un español ante la Inquisición..., p. 617. Unos años antes, en 1518, Francisco de Peñalosa canónigo sevillano y cantor de la capilla pontificia en Roma, había servido al cabildo sevillano también como procurador y solicitador suyo con un salario de 120 ducados (45.000 mrs.), lo que nos induce a pensar que tal vez Peñalosa tuviera estudios en derecho canónico. ACS 116. Más datos sobre el compositor en KNIGHTON, Tess. «Peñalosa, Francisco de», DMEH, vol. 8, pp. 586-589.

${ }^{526}$ Suponemos que fue así, ya que era frecuente que los agentes de los cabildos catedralicios o colegiales en Roma escribieran cartas con las noticias más importantes acontecidas sobre cuestiones eclesiásticas, pero también de actualidad. CABEZA, A. La vida en una catedral..., pp. 112-113.

${ }^{527}$ GIL, J. «Un español ante la Inquisición..., p. 617. Los datos siguientes sobre la biografía de Francisco también van sacados del trabajo del profesor Gil por lo que, a menos que no sea así, no seguimos indicándolo. 
necesitaba algún sustento adecuado a su estatus. Es probable que recurriera a su hermano y que incluso fuera a visitarle a Roma, donde Francisco contaba con excelentes relaciones entre los curiales. Evidentemente, para una persona sin ningún título de nobleza la carrera eclesiástica era la mejor salida. Además, en su familia tenía el precedente de los Mudarra palentinos, los homónimos Antonio Mudarra, tío y sobrino, que acapararon el deanato de la catedral durante casi un siglo. Qué mejor que tener un hermano trabajando al lado del Papa para acceder a uno de los cabildos más deseados de Castilla, el de la catedral hispalense, y de paso ahorrarse un montón de ducados en la expedición de las bulas pertinentes.

Por fin, imaginamos que tras numerosas gestiones y esperando el momento adecuado, el 23 de abril de 1545 Francisco consigue una canonjía en el cabildo sevillano mediante bula del Papa Paulo III. ${ }^{528}$ La documentación la presentó Francisco de Urueña el 22 de julio de 1546 y el propio Urueña, en nombre de Francisco Mudarra, tomó posesión de la prebenda el 26 de julio. Llama la atención que el antecesor de la plaza, Francisco de Acuesta, falleció el 21 de julio de 1546, por lo que solo tardaron un día en presentar la documentación y también es significativo que un año antes Francisco se hubiera hecho con ella.

El proceso de presentación de bulas y de la toma de posesión está definido por los estatutos:

Primeramente presente sus bulas e processo fulminado sobre ellas, e qualquier otro título o colación del tal beneficio en Cabildo, y el Cabildo lo vea todo y examine diligentemente [...] entonce [sic] mande que su pertiguero llame para el día siguiente a los Canónigos ordenados para ver las bulas o processos o provissión, e si necessario fuere dar la possesión, los quales ayuntados el siguiente día, y avida suficiente práctica y tratado, vengan a votos verbales: e si la maior parte votaren que sea recebido, luego le sea tomado juramento por el Deán, o por el Presidente que en su ausencia ende se hallare, segun la forma en el siguiente estatuto escripta, e fecho el tal juramento, sean deputados dos Beneficiados que le vayan a consignar el estalo o silla en el choro 529

\footnotetext{
${ }^{528}$ Se trata de la canonjía número 2 que vacó por fallecimiento de Francisco de Acuesta.

${ }^{529}$ Estatutos Manrique, f. 11.
} 
No debía ser intención de Francisco disfrutar del canonicato personalmente, ya que esto le obligaría volver a Castilla apartándole de sus negocios romanos, por lo que resignó la canonjía en su hermano Alonso (no hay que descartar que estuviera pensada para este último), lo cual fue sancionado por bula de 23 de agosto de 1546. El día 18 de octubre el medio racionero Francisco Ponce, actuando como procurador de Alonso de Mudarra, presentaba las bulas ante el cabildo, además de un poder firmado el día anterior ante el notario apostólico Antonio Ramos. ${ }^{530}$

ACS 238. /f. 101 v./ Lunes 18 de octubre de 1546

In dei nomyne amen. por el thenor deste presente publico instrumento sea notorio e magnifico a los que la presente vyeren como en la muy noble e muy leal çibdad de sevilla lunes diez y ocho dias del mes de otubre año del naçimiento de nuestro salvador Jhesuchristo de mill y quinientos e quarenta e seis años este dia estando los muy magnificos y muy reverendos señores al [sic] dean y cabildo de la santa yglesia de la dicha çibdad de sevilla ayuntados capitularmente en la sacristia nueva de los calices y presidiendo el muy magnifico señor don diego de carmona dean de la dicha santa yglesia en presençia de my alonso desquivel canonigo notario apostolico por la apostolica autorydad e de los testigos de yuso escritos paresçio ende presente en el dicho cabildo el señor francisco ponçe medio raçionero de la dicha santa yglesia en nombre e como procurador que se mostro ser del señor alonso de mudarra clerigo de la dioçesis de palencia por virtud del poder que del presento fecho en sevilla a los diez y siete dias del mes de otubre del año de mill y quinientos e quarenta e seis años signado e subscrito del sino e subscriçion de antonio ramos notario apostolico y en el dicho nonbre a los dichos señores unas bulas apostolicas de nuestro muy santo padre paulo papa tercio de provision e canonica institucion que le fue fecha al dicho alonso de mudarra de la canongia e prebenda /f. 111 [sic]/ que en esta dicha santa yglesia tuvo e posee el reverendo señor francisco mudarra canonigo que fue desta dicha santa yglesia que vaco por libre resignacion que en manos de su santidad hizo el dicho señor francisco mudarra en favor del dicho señor alonso mudarra. la una graçiosa sellada con el verdadero sello de plomo pendiente en cordon de juego amaryllo y colorado segund costumbre de corte romana e otra executoria asimesmo escrita en pergamino con el dicho sello de plomo pendiente en cordon de cañamo enteras las dichas bulas no rotas ny chançeladas antes sanas e de toda sospecha e viçio careçientes sygund que por ellas paresçia la data de las quales es rome apud santum marcum anno incarnationis divi nri millmo quinquagesimo quadragesimo sesto decimo Kl. septenbres pontificatus nri. ano duodecimo. e asi mesmo presento vn proçeso sobre las dichas letras fulminado por el muy reverendo in christo padre juan campegio obispo palentino juez ececutor en la dicha vula rigurosa e proçeso principalmente nombrado fecho en roma sub anno a natiuitate divi nri jhesu christo millmo quinquagesimo quadragesimo sexto in dictione quarta die

${ }^{530}$ Antonio Ramos figura años más tarde, en 1580, como albacea del propio Alonso Mudarra. Esto indicaría que Alonso Mudarra se encontraba en Sevilla en esa día, pues suponemos imprescindible su presencia física para firmar un poder. 
vero decima sexta mensis septenvros pontificatus prelibali santissimi divi nri pauli divina providentia pape tertii ano eius duodecimo signado e subscrito del signo e subscriçion del onrrado varon blas de casaruvia escritor del archivo de la corte romana e sellado con el sello del archivio de la corte romana impreso en caxa de madera en çera colorada pendiente en cordon de cañamo colorado e asi presentadas las dichas bulas e proçeso como dicho es luego el dicho señor francisco ponçe procurador suso dicho en el dicho nombre pidio e requirio a los dichos señores vean las dichas bulas e proçeso sobrellas fulminado e las guarden obedezcan e cumplan como en ellas se qontiene e le mande admitir a la corporal real actual posesion vel quasi de los dichos canonicato e prebenda que en esta dicha santa yglesia / $\mathrm{f}$. 111v./ tuvo e poseo el dicho señor francisco mudarra canonigo que fue de la dicha santa yglesia e le manden acudir e acudan con todos los frutos e rentas derecho e ovençiones a los dichos canonicato e prebenda anexos e pertenesçientes e le den silla en el coro e lugar e boz en el cabildo segund costumbre de semejantes posesiones. e luego los dichos señores respondieron que veran las dichas bulas e proçeso e haran lo que fuere justicia testigos diego lopez e pedro gudiel de palacios rodrigues de la dicha santa yglesia, llamados e rogados.

ACS 239.

E luego incontinenti los dichos señores cometieron las dichas bulas e proçeso sobre ellas fulminado al señor dotor valtasar desquivel su concanonigo para que las vea e haga dellas relaçion e que des que las aya visto haga llamar para oyr la dicha relacion e dar posesion si fuere menester, testigos los dichos.

Como era prescriptivo, las bulas fueron examinadas por un experto, el canónigo y doctor Baltasar de Esquivel, que presentó dos días después al cabildo, reunido al efecto tras ser convocado por el pertiguero, un informe sobre ellas. Tras discutirlas se votó a viva VOZ y por unanimidad (unanimiti nemine discrepante) fueron aceptadas. A continuación el concanónigo elegido para ello, Hernando de la Torre, acompañó al procurador hasta el coro y le hizo sentarse en la silla que tenía asignada, desde donde el electo debía lanzar un puñado de monedas, las arras, a la multitud de personas allí congregadas para la ocasión. Poco después venían los juramentos, de nuevo en la sala del cabildo y, puesto de rodillas, ante el deán.

Por cada uno de los pasos, el beneficiado nuevo debía pagar unos derechos: al pertiguero por convocar a cabildo y al notario por expedir el beneficio firmado, $600 \mathrm{mrs}$. a cada uno. Además, debía pagar a la fábrica 9.000 mrs. en concepto de «capa y broncha».

ACS 240

E despues de lo suso dicho miercoles veynte dias del mes de otubre del dicho año estando los dichos señores dean e cabildo conviene a saber dean y canonigos ordenados in sacris ayuntados capitularmente 
en su lugar capitular acostumbrado e llamados de ante dia por diego de solis farfan su pertiguero para oyr la dicha relaçion de las dichas bulas e dar la posesion si fuere menester luego el dicho señor dotor valtasar desquivel hizo relaçion de lo que contenian dichas bulas e aviendo los dichos señores platicado en ello vinieron a votos vervales e todos vnanimiti nemine discrepante respondieron e dixeron quellos obedeçieron las dichas bulas e proçeso sobre ellas fulminado segund e como en ellas se qontiene y que en cumplimiento de lo que por ellas su santidad manda, dixeron que admitian e admitieron a la posesion real corporal actual vel quasi al dicho alonso de mudarra e al dicho señor francisco ponçe su procurador en su nombre de la canongia e prebenda que en esta dicha santa yglesia tuvo e poseo el dicho señor francisco mudarra /f. 112/ e le avian e obieron por canonigo e que cometian e cometieron al reverendo señor licenciado de la torre su concanonigo que vaya con el dicho señor francisco ponce procurador suso dicho al coro de la dicha santa yglesia e le de e señale en el dicho coro a la parte e coro del dean una silla alta e le de lugar en su cavildo e haga todas las otras cosas que se suelen hazer en semejantes posesiones e reçebçiones para lo qual dixeron que le davan e dieron su poder cumplido e cometieron sus vezes. e luego el dicho señor hernando de la torre açeptando la dicha comision fue al coro de la dicha santa yglesia con el dicho francisco ponçe en el dicho nonbre e le dio e señalo una silla alta en el dicho coro a la parte e coro del dean e le hizo asentar en ella e le dio çierta moneda usual la qual el dicho francisco ponçe tomo en sus manos e la lanço entre mucha jente que ende estava en señal de verdadera e paçifica posesion e recevçion de frutos e rentas de los dichos canonicatos e prevenda. e luego el dicho señor canonigo hernando de la torre comisario suso dicho bolvio con el dicho francisco ponçe al cabildo de los dichos señores dean y canonigo ordenados in sacris quedavan ayuntados como dicho es. e luego el dicho francisco ponçe en el dicho nombre fincadas las rodillas antel dicho señor dean presidente en el dicho cabildo juro a los santos evangelios de dios e sobre la señal de la cruz donde corporalmente puso su manos de tener e guardar los estatutos y loables costumbres de la dicha santa yglesia sygund e de la manera que se contiene el dicho juramento en una tabla para esto diputada y espeçialmente juro el estatuto de la media grosa y el de los beneficiados desta santa yglesia no ordenados y el de los hijos y nietos de los reconçiliados e condenados por la heretica pravedad segund que en los dichos estatutos y en cada uno dellos mas /f. 112v./ largamente se qontiene los quales dio por leydos. e hecho el dicho juramento, el dicho señor canonigo hernando de la torre comisario suso dicho hizo asentar al dicho señor francisco ponce en el dicho nombre en el dicho su cabildo a la parte e coro del dean do se asientan los otros señores canonigos e le dio lugar e boz en cabildo e luego los dichos señores lo mandaron escrivir y asentar en los libros quadernos e matriculas do se asientan e escriven los otros señores dignidades canonigos racioneros e medios racioneros de la dicha santa yglesia e mandaron que le sean dado e acudido con todos los frutos e rentas a la dicha su calongia tocantes e pertenecientes sigund que entre los dichos señores es costumbre e de todo esto en como paso el dicho francisco ponce en el dicho nombre pidio e requirio a mi el dicho notario de un instrumento o dos o mas los que menester sean para guarda e conservaçion de su derecho testigos geronimo de godoy e venito de varahona clerigos de la dicha santa yglesia rogados. E yo el dicho notario le di este segund e de la manera que dicha es e paso, firmado de mi nombre e signado con mi signo que fue fecho e paso en la dicha çibdad de sevilla dia mes e año suso dichos, testigos los dichos. 
Hechos los juramentos, el beneficiado ya tenía voz en el cabildo y era asentado en los libros de la catedral, pero si la posesión había sido realizada a través de procurador, el canónigo tenía que volver a jurar cuando se incorporara en persona. No sabemos cuándo ocurrió esto en el caso de Alonso Mudarra, ni tampoco cuándo tomó las órdenes sacras, ${ }^{531}$ lo cual posiblemente ocurrió en el obispado de Palencia, pues como clérigo palentino se le presenta.

El Libro de Entrada de Prebendados del Archivo de la Catedral de Sevilla registra las tomas de posesión y los fallecimientos. En el caso de la canonjía 2, que es la recibió Alonso, señala que Francisco tomó posesión de ella en agosto de 1546, ${ }^{532}$ sin indicar el día (deja un espacio en blanco) lo que contradice ligeramente el dato de las Actas capitulares. También deja claro que la posesión de la canonjía se realizó el día antes citado, 20 de octubre de 1546.

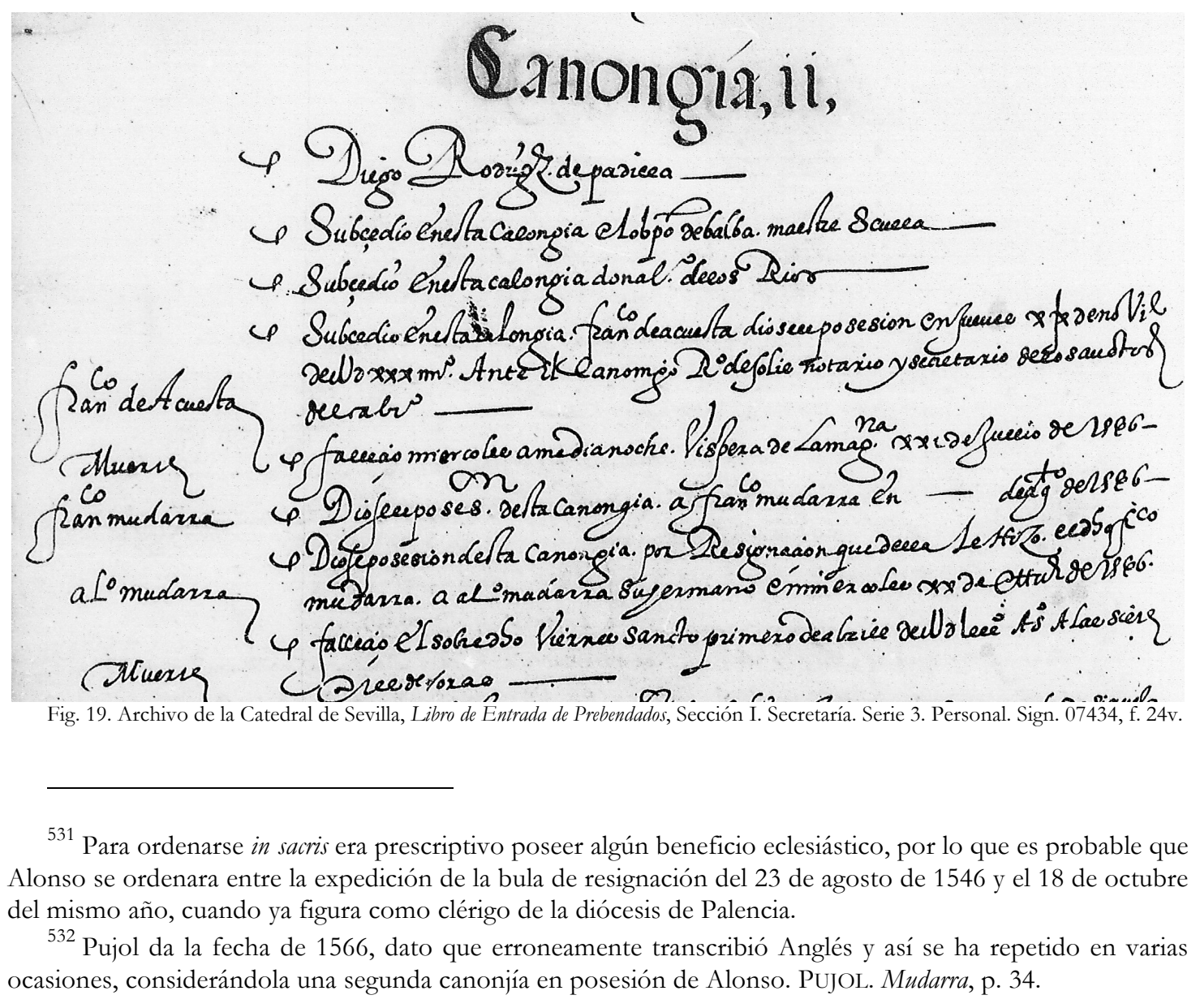


No se detuvo aquí Francisco Mudarra y el 22 de mayo de 1545 consiguió una segunda canonjía, la de Alonso de Esquivel, mediante bula pontificia. Una vez fallecido Esquivel, de nuevo Francisco de Urueña presentó la documentación pertinente el 30 de noviembre de 1546, tomando posesión de la canonjía en nombre de Francisco el 3 de diciembre de $1546 .^{533}$

ACS 242 /f. 118 v./ Viernes tres dias de diziembre del dicho año de 1.DXLVI años

Posesion al Señor Francisco Mudarra de la calongia que vaco por muerte del señor Alonso de Esquivel.../f. 119/

\section{ACS 243.}

que admitian e admitieron al dicho señor raçionero francisco de ureña alias de trillo en nombre del dicho señor francisco mudarra su parte a la poseçion real actual vel casy de los dichos canonicatos y prebenda que vaco por fin y muerte del dicho canonigo alonso desquivel y le mandavan y mandaron acudir al dicho señor canonigo francisco mudarra con todos los frutos y rentas al dicho canonicato y prebenda anexas...

De esta manera, en poco menos de dos meses, quedaban proveídos los dos hermanos de su correspondiente canonicato. Poco le duró a Francisco esta nueva canonjía, pues el 21 de noviembre del año siguiente Francisco Ximénez presentó las bulas de resignación sobre la misma.

ACS 248. /f. 125 v./Lunes 21 dias del mes de noviembre 1547

Bullas del Canonicato que tenia el Señor Francisco Mudarra. [...] por las quales parece, por la graciosa y simple resignación que el dicho Francisco Mudarra hizo en manos de Su Santidad, el favor de el dicho Francisco Ximénez de la canonjía que el dicho Francisco Mudarra tenía y posseía en esta dicha sancta iglesia ${ }^{534}$

Volvemos a tener noticias de Francisco en 1548 cuando es detenido por la Inquisición romana acusado de herejía y encerrado en la Torre Nona, en Roma. Aquí firmará sus dos

\footnotetext{
${ }^{533}$ La concesión de la canonjía a Francisco fue protestada por la familia Jerez, de origen converso, por lo que el cabildo tomó medidas protegiendo a Mudarra e investigando a los Jerez. GIL, J. «Un español ante la Inquisición..., pp. 623-624.

${ }^{534}$ Tomamos el principio de la cita de Stevenson y la continuación de PUJOL. Mudarra, p. 34.
} 
confesiones $^{535}$ en las que reconoce «errores», en realidad ideas erasmistas y luteranas. Fue absuelto, debido a su amistad con el Papa Paulo III, el 31 de agosto de 1548.

Tras ello volvió Francisco a su actividad habitual, el comercio de canonjías. El 22 de febrero de 1549 conseguía una bula de regreso de la canonjía perteneciente a Pedro Suárez de Robreda. ${ }^{536}$ Una vez fallecido este, el 28 de agosto del mismo año, fue Alonso quien tomó posesión de la prebenda, pues Francisco la había resignado en él, el 30 de agosto de 1549. Sin embargo Francisco tenía otros planes y el 29 de marzo de 1550 la canonjía pasó a manos de Juan Álvarez de Arce quien debía pagar a Francisco una pensión anual de 200 ducados. Fallecido Juan Álvarez el 3 de marzo de 1554, de nuevo Alonso presentó ante el cabildo sevillano las bulas de absolución de su hermano y tres días más tarde la bula de regreso a favor de Francisco. Esta vez hubo un cierto revuelo en la reunión del cabildo, ya que algunos canónigos se negaban a dar el beneficio a Francisco por el hecho de haber sido juzgado por la Inquisición. Al final le fue concedida, pues así lo determinaban las bulas presentadas. Más tarde la vemos en manos de Gonzalo Pérez.

Sorprendemente Francisco siguió en su imparable carrera de acumulación de prebendas y tras la muerte del canónigo Domingo de Zorzona consiguió un cuarto canonicato resignándolo en el Arcediano de Sevilla, Rodrigo Jiménez, pero reservándose la percepción de sus frutos. Esto fue denunciado por Alonso de Saelices quien se hizo con la canonjía el 4 de abril de 1555.

Tres meses después se producía el fallecimiento del racionero Tomás de Lucio y de nuevo Alonso, actuando como procurador de su hermano presentó las bulas de regreso a la canonjía, pero en esta ocasión Alonso de Saelices se opuso alegando que Francisco Mudarra había sido condenado por la Inquisición y privado de todo beneficio. Como prueba presentó las dos confesiones de Mudarra que ya hemos citado anteriormente.

ACS 295. /f. 62 v./ Viernes 26 de julio de 1555

En el dicho dia ante los dichos señores el señor licenciado luzero hizo relacion de las bullas del Regresso que el cabildo antes le fueron cometida sobre la raçion de thomas de luzio raçionero que fue

\footnotetext{
${ }^{535}$ Como dijimos, incluimos la traducción en los Anexos.

${ }^{536}$ La canonjía número 23.
} 
desta dicha santa iglesia y hecha la dicha relaçion luego yncontinenti el señor canonigo alonso de saelizes presento ante los dichos señores el requerimiento siguiente y cierto transumpto de declaraçion diz que hecho por françisco mudarra estante en roma ante los señores ynquisidores della y cierta sentencia dada contra el dicho francisco mudarra y çierto monitorio todo lo qual dize en esta guisa:

\section{ACS 296.}

Muy magnificos y muy reverendos señores alonso de saelizes canonigo en esta sancta iglesia de sevilla digo que he entendido que por parte de francisco /f. 63/ mudarra por alonso mudarra su hermano y como su procurador de que han sido presentadas ante vuestra señoria unas bulas diz que de regresso a la raçion que en esta santa iglesia tuvo thomas de luzio difuncto en fabor del dicho francisco de mudarra el qual alonso mudarra como procurador le requirio a vuestra señoria se las viese y admitiese y cunpliese como en ellas se contiene por ende yo el dicho alonso de saelizes canonigo en los mejores via y modo que de derecho aya lugar y puedo premisas [sic] las solenidades del digo que vuestra señoria no deve admitir al dicho alonso mudarra por procurador ni mandar ver las dichas bullas por ser como son de un honbre yncapaz y ynabil y condenado por la sancta ynquisiçion privado de tener benefiçios y ofiçios y de toda su renta y por tal es avido y publicamente reputado en esta sancta iglesia y arzobispado de sevilla y en todas las otras partes y lugares que le conocen y han conoçido la qual reputacion publica basta que vuestra señoria en este lugar a el ni a su procurador no le admitan ni baste decir el dicho alonso mudarra quel dicho su hermano se salvara pues es cosa futura y por esto que fuese libre no basta para admitir cosa suya en este lugar sino mostrase reabilitaçion para tener benefiçios especialmente para en esta sancta iglesia constandole el estatuto della por aver sido ereje pues como dicho tengo fue privado dellos y de todos sus beneficios y ofiçios y bienes por la sancta ynquisicion por ende suplico a vuestra señoria y si necessario es otra vez le requiero si es verdad que las dichas bullas son pre- /f. 63 v./ sentadas o presentaren no admitillas no cometerlas a ninguno de v. sa. y puesto que de facto fuese hecho manden no se pase adelante hasta tanto queste nuestro requirimiento sea satisfecho y se trate desta exepcion que es perentoria y conforme a derecho lo qual suspende el negoçio principal y hasta que sea declarado sera abilitado por la sancta sede apostolica v. s. lo mande suspender donde no protesto contra v. s. y cada uno de v. s. ansi de todo lo que puedo protestar y quexarme donde y con derecho deva e de todos los daños e yntereses y me ofrezco siendo necessario mostrar a v. s. el monitorio discernido por los ilustrisimos ynquisidores en Roma y las confesiones hechas tenidas y perpetradas de eregia contra la sancta fee catholica por el dicho francisco mudarra con mas la sentençia privatoria y condenatoria contra el por los dichos ilustrisimos ynquisidores en Roma dada y promulgada para que v. s. pareçiendole lo mande ver y leer y para corroboraçion de todo lo sobre dicho mandandome restituyr los originales y pido por testimonio y al presente notario me lo de en publica forma y a los presentes que dello sean testigos presente alonso de saelizes canonigo.

Primera confesion ...

Segunda confesion ... 
ACS 297.

/f. 74/ ... llamados para ello de ante dia y votando sobre ello por ava y atramuz y que una ava negra lo contradiga y que los señores luys de lezana y antonio de la peña sus concanonigos traten de los hazer amigos y este voto se llegaron los señores benefiçiado siguientes:

ACS 298.

Don alonso de porra hermano de reyna

diego rodriguez luzero

doctor balthasar desquibel

almaçan

alonso mudarra

melchior maldonado

Después de 1555, Francisco Mudarra desaparece de la vida pública, aunque parece ser que se instaló en Ginebra.

Volviendo a Alonso, sabemos que durante estos años su nombre aparece en las actas capitulares en varias ocasiones con alguna relación con la música o con la liturgia. Por ejemplo, en 1547 se le comisiona para revisar y adquirir nuevos libros para maitines.

ACS 247. /f. 118 v./Miercoles 19 dias de octubre 1547

Este dicho dia los muy reverendos y muy magnificos señores el cabildo de la santa yglesia de sevilla capitularmente ayuntados segun lo an de uso y costumbre presidiendo el señor arcediano de sevilla cometieron a los señores canonigos sebastian de minçon y alonso mudarra juntamente con los señores contadores para que provean lo que conviene en los libros que faltan para los maitines y saber si tienen dineros de mas los escriptores.

Diez años más tarde, en 1557, se está ocupando de sus negocios editoriales reclamando una deuda pendiente por la venta de sus libros, como veremos más adelante.

$\mathrm{Al}$ año siguiente solicitó el permiso reglamentario para realizar obras de acondicionamiento de su casa («labrar su casa», que en realidad sería posesión del cabildo, como la de todos los canónigos). ${ }^{537}$

\footnotetext{
${ }^{537}$ Suárez Martos da información sobre unas casas que tenía Mudarra en la calle Real. No creemos que se trate de su vivienda principal, pues lo normal es que los canónigos residieran en la collación de Santa María, al lado de la catedral. Se debe tratar de la calle Real de la Cestería, actualmente calle Almansa, en los
} 
ACS 334. /f. 42 v./ Lunes 27 de junio de 1558

En este dia estando los dichos señores segund dicho es en su cabildo y presidiendo el señor doctor don martin gasco maestre escuela y canonigo en la dicha santa yglesia dieron quinze dias para labrar su casa al señor canonigo alonso mudarra conforme al estatuto.

Poco más sabemos del día a día de Alonso. En 1559 fue nombrado presidente de la capilla más importante y suntuosa de la catedral de Sevilla: la capilla de Nuestra Señora de la Antigua. ${ }^{538}$ Este cargo lo ejerció de forma intermitente, además de en 1559, en 1562, 1563 y en $1566,{ }^{539}$ cuando se encargó de renovar los cálices de plata, fundiendo los antiguos para hacer unos nuevos.

\section{ACS 420. /f. 211 v./ Miercoles 20 de febrero de 1566}

En este dicho dia los dichos señores cometieron a los señores alonso mudarra canonigo presidente de la capilla de nuestra señora del antigua y antonio de corral canonigo y mayordomo de fabrica [del antigua] que de siete calices viejos que ay en la capilla de los calices hagan quatro que sean buenos para que sirvan en la dicha capilla de los calices.

Pero sobre todo va a figurar el nombre de Alonso en relación al órgano grande realizado por el flamenco maese Jorge cuya construcción se dilató mucho, entre los años 1567 y 1579. Mudarra fue comisionado, junto al organista Villada y otros prebendados, para la supervisión de los trabajos y tuvo, en primer lugar, que recabar información sobre las aptitudes del organero un año antes de comenzar.

arrabales. «en la cestrería frontero del río que lindan de la una parte con casas de [en blanco] y de la otra parte con casas de [en blanco] y por delante la dicha calle Real, las quales tiene de por vida el señor canónigo Alonso de Mudarra» en SuÁrez MarTos, Juan María. El rito de la Salve en la catedral de Sevilla durante el siglo xvi. Estudio del repertorio musical contenido en los manuscritos 5-5-20 de la Biblioteca Colombina y el Libro de Polifonía $n^{\circ}$ 1 de la catedral de Sevilla. Granada, Centro de Documentación Musical de Andalucía, Junta de Andalucía, 2010, p. 104.

${ }^{538}$ En esta capilla, además del monumental sepulcro de Diego Hurtado de Mendoza, arzobispo de Sevilla, se encuentran las lápidas de dos insignes músicos sevillanos: Francisco Guerrero y el organista Francisco Peraza. González Barrionuevo, H. Francisco Guerrero..., pp. 103-108. Durante varios siglos fue la capilla más importante de la catedral hispalense, celebrándose cerca de catorce mil misas anuales y todos los sábados la Salve con canto de órgano con voces y ministriles. Su interior estaba adornado con cuarenta lámparas de plata, lo que da prueba de su riqueza. Medianero Hernández, José María. Nuesta Señora de la Antigua. La Virgen «decana» de Sevilla. Sevilla, Diputación de Sevilla, 2008, p. 31.

${ }^{539}$ SuÁrez Martos, J. M.. El rito de la Salve..., pp. 104-105. 
ACS 423. /f. 218/ Sabado 16 de marzo de 1566

En este dia los muy ilustres señores dean y cabildo de la santa iglesia de sevilla congregados ... cometieron a los señores don geronimo manrrique arcediano de ecija y alonso mudarra canonigo y pedro de villada racionero que se ynformen de la abilidad de maestre jox flamenco si sera qual convenga para que se le pueda encargar que haga un organo principal de que en esta iglesia ay falta y refieran en cabildo.

Tan importante fue el proyecto que incluso el deán, Cristóbal de Padilla, estuvo directamente involucrado en la comisión responsable

\section{ACS 433. /f. 29/ Miercoles 9 de abril de 1567}

En este dia los dichos señores cometieron a los señores don christoval de padilla dean alonso mudarra y doctor Ramirez canonigos y racionero villada que tracten con maestre Juan flamenco maestro de hazer organos lo que toca al organo que se pretende hazer para esta sancta iglesia y de la forma y manera del y del lugar donde a de estar y de todo hagan Relación en cabildo.

\section{ACS 436. /f. 39/ Miercoles 21 de mayo de 1567}

En este dia los dichos señores don christoval de padilla dean alonso mudarra doctor hernan ramirez canonigos y pedro de villada racionero diputados para el organo que se a de hazer para esta santa iglesia que manden acabar y efectuar el dicho organo conforme a como lo tienen tractado y a la Relacion que acerca dello hizieron este dia en cabildo y lo concierten en el precio que mas les paresciere que conviene sin que de el dicho organo se labre y despues de acabado se aciente y para lo assi hazer y efectuar les dieron poder cumplido y les cometieron sus vezes y mandaron que los señores contadores libren lo que para esto fuere menester fray antonio de corral.

En este mismo año de 1567 hizo dejamiento de unas casas propiedad del cabildo y que había estado arrendadas al mercader Pedro López. Puede tratarse de las casas de la Cestería y que al abandonarlas el inquilino Mudarra tuviera que repararlas. De esta manera se desentendía de su mantenimiento y volvían a manos del cabildo para volverlas a arrendar.

\section{ACS 437. /f. 68/ Miercoles 20 de agosto de 1567}

En este dia estando los dichos señores congregados como dicho es e siendo ende presente el señor canonigo alonso mudarra dixo que el hazia e hizo dexamiento en manos de su señoria de las casas que en el se avian rematado que avia tenido pedro lopez de toledo mercader que son de la fabrica desta santa iglesia a daño suyo y pro de la dicha fabrica que por tanto su señoria admitiesse el dicho su dexamiento como es costumbre lo qual oydo por los dichos señores del cabildo dixeron que ellos admitian e 
admitieron el dicho dexamiento no apartando mano del dicho señor canonigo mudarra hasta que las dichas casas esten rematadas e afiançadas e mandaron poner cedulas para arrendarlas como es costumbre.

ACS 438. /f. 70 v./ Lunes 25 de agosto de 1567

En este dicho dia el señor canonigo Alonso mudarra dixo que suplicava a su señoria mandassen rematar la casa de la fabrica sobre que se traxo pleyto con pedro lopez de toledo de que el avia hecho dexamiento a daño suyo y pro de la dicha casa oviese alguna quiebra el se allanava y obligava de estar por lo que la mayor parte del cabildo en ello detreminase como fuesse regla general testigos los señores racioneros juan ramirez corthegana y benito diaz.

Poco después, en 1568, Mudarra fue nombrador mayordomo de fábrica de la catedral hispalense. ${ }^{540}$

ACS 449. /f. 142/ Sabado 20 de marzo de 1568

En este dicho dia los dichos señores llamados para ello y votandolo por cedulas secretas eligieron por mayordomo de la fabrica al señor canonigo alonso mudarra.

Esto, por supuesto, implicaba mayor responsabilidad con respecto a la construcción del órgano, pues a la Fábrica le correspondía el pago del mismo. La marcha del deán hizo que fuera el chantre, Juan de Medina, el máximo responsable de la comisión.

\section{ACS 450. /f. 39/ Miércoles 5 de mayo de 1568}

En este dia los dichos señores mandaron que se le de lo necessario a maestre jors organista que haze el organo grande para esta santa iglesia y mandaron que en el no haga mas de lo que esta obligado a hazer y atento a que el señor dean era diputado para ello y se va aora nombraron en su lugar a los señores don juan de medina chantre y don geronimo manrrique arcediano de ecija con el mayoromo de fabrica los quales con los demas señores diputados que para esto ay den lugar al dicho maestre jors donde este y haga el organo y vean el lugar donde assimesmo sera bien que se ponga este organo tomando para ello paresçer de personas que lo entiendan y tracten alla lo que convendra hacerse.

\section{Poco después también el doctor Hernán Ramírez se apartó de la comisión.}

${ }^{540}$ La Mayordomía de fabrica era independiente de la mesa capitular y movía una gran cantidad de recursos pues era responsable de todos los aspectos materiales del templo (obras) y de los cultuales (lo relacionado con la liturgia, incluidos los salarios de capellanes, clérigos de la veintena, sacristanes, músicos, etc. y el mantenimiento del edificio). Sus ingresos se originaban principalmente por el arrendamiento de las numerosas propiedades inmobiliarias, más de 450 en estos años. HERnÁNDEZ Borreguero, J. J. La Catedral de Sevilla... 
ACS 464. /f. 194/ Lunes 6 de septiembre de 1568

En este dicho dia los dichos señores aviendo visto todo lo que ay escrito acerca de la obra del organo grande que se avia mandado hazer y oydo el Requerimiento del señor doctor Ramirez canonigo del qual dicho Requerimiento y apelacion que es la que presento el cabildo proximo passado dixo el dicho señor doctor Ramirez que el se apartava y aparto y que lo dava todo por ninguno testigos los señores racionero bravo y velasco luego el señor canonigo mudarra presento cierto escrito de Requerimiento sobre el dicho negocio del thenor siguiente.

Aqui el Requerimiento

En muchas otras ocasiones vemos el nombre de Mudarra, una vez nombrado mayordomo, relacionado con reparaciones y asuntos cotidianos

ACS 466. /f. 203/ Miercoles 20 de octubre de 1568

En este dia los dichos señores mandaron que la casilla del muelle se repare atento a que no esta obligado a ello el que lo tiene arrendado y cometieronlo al señor canonigo mudarra mayordomo de fabrica.

... con la adquisición de vestuario para los mozos de coro

ACS 467. /f. 209 v./ Viernes 12 de noviembre de 1568

En este dicho dia los dichos señores cometieron al señor canonigo alonso Mudarra mayordomo de la fabrica que mando hazer dos dozenas de opas y otras dos de sobrepellizes para los moços de choro desta santa iglesia y que las opas que ay viejas que no estan para servir se den para mantillas a los niños de la cuna.

Incluso en alguna ocasión, como la muerte del racionero organista Villada, el arzobispo delegó su voto en Mudarra, pues se le suponía persona competente en cuestiones musicales.

ACS 493. /f. 16/ Miercoles 4 de marzo [de] 1573

En este dicho dia estando los dichos señores congregados para proveer la media raçion del organo que vaco por fin y muerte del arcediano pedro de villada y tratando sobre lo que se devia de hazer por no estar presente el ylustrisimo señor arçobispo de sevilla, los dichos señores mandaron que yo el infraescrito secretario, fuese a saber de su señoria ilustrisima que mandava se hiziese en esto, al qual recado su señoria ilustrisima me respondio que el cabildo mirase en hazer lo que mas conviniese en 
servicio de Dios y desta santa iglesia y que si quisiesen proveer dava e dio su voto al señor canonigo alonso mudarra. e luego de comun consentimiento dieron por cumplidos y çerrados los editos.

También los gastos ocasionados por los autos de fe, al cual tenían que acudir los cantores, repercutían en la catedral sevillana. Incluso los doseles para el duque.

ACS 497. /f. 22 v./ Miercoles 4 dias del mes de noviembre de 1573

En este dia los dichos señores mandaron se haga el solito tablado que se suele hazer en la plaça de sant francisco para la asistençia del aucto de la fee lo qual se comettio al señor canonigo mudarra mayordomo de la fabrica.

ACS 498. /f. 26/ Miercoles 11 de noviembre de 1573

Este dicho dia los señores mandaron que los cantores asistan como suelen en el aucto de la fee que se celebrara domingo quince dias deste presente mes.

ACS 499.

Este dicho dia los dichos señores comettieron al señor canonigo Mudarra de diez doseles para la jornada del duque tomando recaudo.

Además del órgano principal, que seguía construyéndose, los otros instrumentos también necesitaban ser reparados.

ACS 500./f. 30/ Lunes 23 de noviembre de 1573

Este dicho dia los dichos señores comettieron a los señores Alonso mudarra y hernando Mohedano canonigos hagan adreçar la caxa del organo de nuestra señora del Antigua y que los señores contadores libren lo necesario para el dicho adreço el qual sea bueno.

ACS 505./f. 84/ Martes 30 de marzo de 1574

Este dicho dia los dichos señores congregados como dicho es cometieron a los señores obispo desquilache Alonso Mudarra Antonio del Corro canonigos y Jeronimo peraça de sotomayor racionero den orden con el maestro flamenco que haze el organo le haga con toda brebedad haziendole prober de lo necessario y le manden no se ocuppe de hazer mas talla hasta que asiente cañuria y demuestra de si, en lo cual le soliciten encargandoselo mucho.

ACS 506./f. 124 v./ Miercoles 23 de junio de 1574

Este dicho dia los dichos señores cometieron a los señores Alonso mudarra Antonio del Corro canonigos Geronimo de Peraça y Diego Bejarano racionero vean y comuniquen officiales tocantes al organo y refieran. 
Es bastante llamativo que también Mudarra fuera el encargado de ver la idoneidad y decencia de las letras compuestas por Francisco Guerrero para la Navidad.

ACS 516./f. 279 v./ Viernes 11 de noviembre de 1575

E luego todos los dichos señores congregados como dicho es mandaron quel maestro francisco Guerrero no componga letra ninguna para las fiestas de navidad sin començallas con el señor maiordomo de fabrica el qual dicho señor las vea y confiera y vean si son decentes para se decir.

Las últimas noticias que encontramos en las actas capitulares sobre Mudarra son posteriores a su muerte y se refieren a la almoneda de sus bienes y a sus últimas voluntades. Las veremos más adelante. 


\section{E1 modo de vida de un canónigo sevillano}

Una manera de acercarse a la vida cotidiana y al nivel socioeconómico de una persona o un colectivo es a través de los inventarios post mórtem.

Para el historiador, este tipo de fuente representa una mina excepcional de datos sobre la vida cotidiana y las estructuras económicas y sociales del pasado, pues permite entrar en contacto directo con las precariedades vitales y la miseria de unos, así como con el confort y la opulencia de otros ${ }^{541}$

Hace más de tres décadas, Bartolomé Bennassar establecía las aportaciones principales de los inventarios post mórtem. Según él, estos nos proporcionan muchos datos del fallecido: la fuerza de la moda en el difunto y su familia, su riqueza y su comportamiento hacia el consumo, el grado de religiosidad y las devociones particulares, sus gustos artísticos y por último, su cultura escrita. ${ }^{542}$ Para ello hacía falta estudiar respectivamente: el vestido, los tipos de telas y su estado (nuevo o traído); las joyas, el oro y la plata, los tapices y alfombras, los juros y censos; las imágenes y retablos sagrados, así como los libros religiosos y las mandas piadosas; las pinturas, esculturas, de nuevo los tapices y los objetos preciosos y para lo último, su biblioteca.

Además, los inventarios, en función de su tipología, pueden informarnos sobre las viviendas. En este sentido, encontramos los siguientes tipos: inventarios que siguen un orden lógico en sus descripciones, agrupando los objetos similares; inventarios que describen los objetos estancia por estancia; inventarios que, como los anteriores, describen cada estancia, pero agrupando los objetos, y, por último, inventarios que no siguen ningún orden lógico. ${ }^{543}$

Para conocer las estancias debemos conocer algo de las casas de la época que nos ocupa. La vivienda típica sevillana de las clases acomodadas, designada habitualmente

\footnotetext{
${ }^{541}$ SOBRADO CORREA, Hortensio. «Los inventarios post-mortem como fuente privilegiada para el estudio de la historia de la cultura material en la Edad Moderna», Hispania: Revista española de historia, 63/215 (2003), pp. 825-862.

${ }^{542}$ BENNASSAR, Bartolomé. «Los inventarios post-mortem y la historia de las mentalidades», La documentación notarial y la Historia: Actas del II Coloquio de Metodología Histórica Aplicada. Santiago de Compostela, 1984, vol. II, pp. 139-146; pp. 140-41.

${ }^{543}$ SOBRADO CORREA, H. «Los inventarios post-mortem ..., p. 832.
} 
como «casa de morada», solía ser unifamiliar y bastante amplia. El tipo más común era la casa patio, muy común en el mundo mediterráneo. Varias son las características destacadas de esta casa. ${ }^{544}$ En primer lugar la sobriedad de la fachada, con escasas ventanas y poca ornamentación, rasgo que pertenece a la herencia andalusí. Solían constar de dos plantas, llamándose «medias casas» a la de una sola planta. Era costumbre, sobre todo en las casas acomodadas, que los inquilinos pasaran el invierno en la planta alta, más soleada y menos húmeda y el verano en la planta baja, más fresca. Podían tener también zaquizamí o sobrado, azotea y mirador. El material más común para su construcción era el ladrillo; raras son las casas sevillanas de piedra. Pero la característica más relevante de estas viviendas es la presencia del patio, alrededor del cual se construyen los corredores de ambas plantas, generalmente abiertos y con balaustrada. Hay que destacar que la palabra corral en esta época designa al patio. No obstante, además del patio contaban con un corral, en el sentido actual, donde se criaban las gallinas y, con frecuencia, un huerto. Se accedía a la casa por un zaguán, que en ocasiones no permitía ver el patio, de donde partían las escaleras. En la planta superior, la planta noble, se ubicaba la cámara o alcoba y alguna habitación más pequeña, denominada recámara. En la planta inferior estaba la cocina y algunas salas, incluida la cámara para dormir en verano. Los criados y esclavos podían dormir en esta planta o en el sobrado, cuando lo había. Pero volvamos a los inventarios.

El estudio de los inventarios sevillanos muestra que los clérigos, y entre ellos como clase alta los canónigos, dedicaban un alto porcentaje de sus bienes a ropa, ajuar y joyas. En sus casas se daba bastante importancia al lujo, la comodidad, el arte y la cultura, por encima de otros grupos sociales, incluida la nobleza. Una explicación es que, puesto que no solían tener casa propia, pues pertenecía a la catedral, podían dedicar gran parte de sus rentas a estos bienes suntuarios. Hay que añadir el hecho de que muchos de los canónigos sevillanos contaban con estudios superiores, como veíamos más arriba, por lo que la inversión en arte y cultura era importante para ellos. ${ }^{545}$

\footnotetext{
${ }^{544}$ HaZAÑAS, Joaquín. Algunas consideraciones sobre la casa sevillana. Sevilla, Padilla Libros, 1989.

${ }^{545}$ Rodríguez VÁzQueZ, Antonio L. Ricos y pobres. Propiedad y vida privada en la Sevilla del siglo XVI. Sevilla, Servicio de Publicaciones del Ayuntamiento de Sevilla, 1995, p. 77.
} 
Tenemos la suerte de contar con el inventario post mórtem de Alonso Mudarra, así como del registro de la almoneda celebrada después, con los precios pagados por los diferentes objetos por los pujadores. ${ }^{546} \mathrm{El}$ descubridor y el primero en estudiarlos, Klaus Wagner, ${ }^{547}$ ya llamó la atención sobre varios hechos importantes: la escasez de instrumentos musicales y de libros de música, el desorden del inventario y la modestia de su biblioteca. Trataremos estos temas más extensamente. También contamos con un testamento de Alonso, pero lamentablemente no se trata del último, sino del fechado el 23 de febrero de 1576. Sabemos por el inventario que hubo un segundo testamento, firmado el 24 de marzo de 1580, unos pocos días antes de fallecer.

También las actas capitulares se refieren a este inventario y a la posterior almoneda. El albacea nombrado por Mudarra fue el presbítero Antonio Ramos, quien ya veíamos como notario apostólico.

ACS 543./f. 16/ Viernes 8 de abril de 1580

Este dia comettieron a los señores mayordomo de fabrica y Racionero bartolome Ruiz y a cualquier dellos se hallen presentes a hazer del inventario de los bienes del canonigo Mudarra que aya gloria que dexo a la fabrica y los Reciban de mano de Antonio Ramos su Albacea y los vendan y Rematen en publica Almoneda a las personas que mas por ellos dieron para hazer dellos la voluntad del testados para lo qual les comettieron sus vezes ansimismo mandaron que en lo que toca al trigo que quedo en grano del dicho canonigo en su casa se de a las hermanas y parientes del dicho canonigo pagandolo a la tassa.

Mes y medio después el cabildo apremia a los prebendados para que paguen lo que deban de la almoneda de Mudarra.

ACS 570./f. 28/ Viernes 25 de mayo de 1582

... que sus señores qontadores hagan poner en sus casillas a los que tuvieren los señores beneficiados que deven dineros de lo que sacaron del Almoneda del señor canonigo mudarra y que si no tuvieren casillas los cobren de los manuales y que el señor mayordomo del comunal los de por mandado de los dichos señores contadores.

546 AHPSe, Oficio 19, de Gaspar de León Garabito, Libro $3^{\circ}$ de 1580, Signatura 12459, ff. 250v-260v. y 728-740. Reproducimos nuestra transcripción en los anexos.

${ }^{547}$ WAGNER, Klaus. «Los libros del canónigo y vihuelista Alonso Mudarra», Bulletin Hispanique, 92/1 (1990), pp. 655-675. 
El inventario de Mudarra parece pertenecer al tipo tercero de los que anteriormente señalábamos. Va estancia por estancia y a veces agrupa los objetos, si bien, como hemos dicho, está ciertamente desordenado. Encontramos muebles, tapicerías, cuadros, vestidos, menaje, joyas y plata, armas y algunos objetos de colección. No conocemos sus posesiones inmobilarias o en juros y censos, aunque el en el inventario indica «un cofrete pequeño de flandes con unas scripturas dentro». Sí figura una cierta cantidad de dinero en metálico que tenía en un cofre de hierro en su casa: 222 escudos de oro «de a quatro y de a dos y senzillos» (88.800 mrs.) y además en otra parte 3.388 reales (115.192 mrs.), en total 203.999 mrs.

Lo más valioso de su inventario son su esclava negra Esperanza de 16 o 17 años, ${ }^{548}$ que alcanzó un precio de 92 ducados (34.500 mrs.) y su mula negra con sus guarniciones, vendida en 82,5 ducados (30.937,5 mrs.).

Mudarra como hombre rico, o por lo menos de clase media alta, del Renacimiento sevillano tenía: una buena casa en la collación de Santa María la Mayor, es decir, al lado de la catedral, propietaria de la vivienda; varios criados y esclavos, una buena librería, tapices, joyas y servicios de plata, además de una buena cama y buenos ropajes. ${ }^{549}$

Veamos algunos apartados más atentamente.

\section{Música}

Como ya ha sido señalado, resulta sorprendente la escasez de instrumentos y libros de música en manos del canónigo y vihuelista Mudarra. ${ }^{550}$ Únicamente figuran dos vihuelas en el inventario: «Una bigüela con su caxa de madera» y «Una bigüela mediana». La primera fue adquirida en almoneda por el racionero Cristóbal de Mesa en 38 reales (1.292 mrs.) y la segunda por el canónigo Antonio González en 36 reales (1.224 mrs.). Podríamos considerar estos precios como de instrumentos de una cierta calidad, pues si

\footnotetext{
${ }^{548}$ Como veremos había otra esclava, Madalena, que debió ser ahorrada (liberada), pues adquirió una de las cajas del inventario.

${ }^{549}$ Estos eran algunos de los atributos de los hombres ricos. LlEÓ CANAL, Vicente. Nueva Roma. Mitología y humanismo en el Renacimiento sevillano. Madrid, Centro de Estudios Europa Hispánica, 2012.

${ }^{550}$ WAGNER, K. «Los libros del canónigo...
} 
los comparamos con otros inventarios vemos que, por ejemplo, las dos vihuelas grandes que figuraban en el inventario de 1560 de Diego Hurtado de Mendoza, conde de Saldaña y marqués del Cenete, ${ }^{551}$ se tasaron en cuatro ducados (1.500 mrs.) cada una con su funda, mientras que un laúd se tasó en cinco ducados (1.875 mrs.). Es fácil suponer que los instrumentos pertenecientes al primogénito del duque del Infantado serían de elaborada y costosa factura. Por otra parte, conocemos los precios de almoneda y tasación de algunas vihuelas sevillanas en manos de propietarios de diferente extracción social. ${ }^{552}$ El presbítero Juan Buzón de Escalante poseía al fallecer, en 1595, una vihuela valorada en 5 reales (170 mrs). Juan del Carpio, capellán de la catedral, en 1570, otra vihuela valorada en 12 reales (408 mrs.). El jurado y contino de la Casa Real, Juan de la Fuente, tenía en 1543 una vihuela «buena» valorada en un ducado (375 mrs.). Además de los citados, solo encontramos precios tan elevados como los de Mudarra para vihuelas en modelos de ébano con lazo, lo que podríamos denominar de lujo. ${ }^{53}$ Podemos pensar que los dos instrumentos que poseía Alonso Mudarra eran de muy alta calidad, lo que parece lógico atendiendo a su también alto nivel como instrumentista.

Ningún otro instrumento consta en la casa del canónigo vihuelista, mientras que en otros inventarios de clérigos sevillanos como el del inquisidor Andrés Gasco aparece: «vn clavicordio, vn monocordio, una caxa de viguelas que tiene una viguela grande de seys órdenes y un discante de seys hórdenes, otro discante de cinco órdenes, vna gitarra [sic], vna harpa», además de varios libros de música, entre los que se incluye un libro de misas de Guerrero y el Orphénica lyra de Fuenllana. ${ }^{554}$ Más cercano en cuanto a nivel económico, el canónigo y arcediano de Écija, Jerónimo Manrique, fallecido el mismo año que Mudarra, tenía en su casa «una guitarra de cinco órdenes de évano», «siete bigüelas de arco, cinco grandes y dos pequeñas, con sus arquillos metidas en tres caxas», además de

\footnotetext{
${ }^{551}$ AHN-SN, Osuna, C. 1835 doc. 2.

552 Bejarano Pellicer, C. El mercado de la música..., pp. 542-543.

${ }^{553}$ Romanillos y Harris recojen varios casos de vihuelas de ébano de entre $932 \mathrm{mrs}$. y cinco ducados (1.870 mrs.) para los años de 1575 en Toledo y 1588 en Madrid. Romanillos VeGA, J. L. y HarRis WINSPEAR, M. The vibuela de mano..., p. 481-484.

${ }^{554}$ WAGNER; Klaus. «Lecturas y otras aficiones del inquisidor Andrés Gasco (†1566)», Boletín de la Real academia de la Historia, 171/1 (1979), pp. 149-181; p. 174.
} 
varios libros de música de motetes, villanescas y estrambotes, tanto manuscritos como de imprenta, entre los que aparecen los nombres de Francisco Guerrero o Juan Vázquez. ${ }^{555}$

Al lado de una de las vihuelas de Mudarra se hallaron dos atriles, uno pequeño con bisagra y otro con peana y cerca de la otra un atril de madera de goncel. En cuanto a los libros de música de Alonso, hablaremos de ellos en el siguiente epígrafe.

\section{Libros}

Este aspecto ya fue estudiado por Klaus Wagner, ${ }^{556}$ quien identificó los títulos existentes en la biblioteca de Mudarra. Tan solo 117 títulos formaban su biblioteca, cantidad suficiente para una persona de su calidad y cultura, pero no excesiva. ${ }^{557}$

Abundan los libros litúrgicos: misales, diurnales, breviarios, lo cual no es extraño, debido a la condición clerical de Mudarra, y a que, además, entre ellos los hay pretridentinos (antiguos o viejos, según el inventario) y postridentinos (nuevos), por lo que muchos están duplicados. ${ }^{558}$ Junto a estos libros también hay una Biblia en cinco volúmenes, vendida en 17 reales (578 mrs.), varios libros de carácter doctrinal, libros de sermones, comentarios de los salmos, vocabularios eclesiásticos, etc. Algunos libros sobre cuestiones teológicas, como el tratado contra Lutero del escolástico germano Johann Eck, un par de obras del prolífico escritor Dionisio Cartujano o del teólogo y consejero real Alfonso de Castro. ${ }^{559}$ En la frontera con el erasmismo está el manual de Johann Gropper, Inchiridion. ${ }^{500}$ No falta entre ellos la Guía de pecadores y el Memorial de la vida cristiana de Fray

\footnotetext{
${ }^{555}$ AHPSe, Oficio 19, de Gaspar de León Garabito, Libro $3^{\circ}$ de 1580, Signatura 12459, ff. 88-99v.

${ }^{556}$ WAgNeR, K. «Los libros del canónigo... Para la identificación de los títulos remitimos a este trabajo.

${ }^{557}$ Recordemos, por ejemplo, la biblioteca de 500 libros del regidor vallisoletano Diego Mudarra Palacios. El inquisidor Gasco que veíamos más arriba tenía 300 volúmenes de libros. WAGNER; K. «Lecturas y otras aficiones..., p. 156. Wagner registra 116 libros, pero omite un diurnal, por lo que hay que sumar uno

${ }^{558}$ De hecho en la almoneda se vendieron por mucho menor precio los antiguos que los nuevos. Por ejemplo, los diurnales viejos se vendieron cada uno por medio real (17 mrs.), mientras que los nuevos diez veces más caros, por 5 reales $(170 \mathrm{mrs}$.). Los misales romanos antiguos por 2 reales (68 mrs.), pero uno nuevo por 25 reales $(850 \mathrm{mrs}$.).

559 Enchiridion locorum communium aduersus Luterum de Eck, Liber de quatuor hominis nouissimis y Commentariorum opus in Psalmos omnes Davidicos de Cartujano y Adversus omnes haereses de Castro.

${ }^{560}$ En el inventario de Mudarra aparece como Incridion christiane institutionis.
} más. 
Luis de Granada. Completa esta colección un catálogo de libros prohibidos. Para la ayuda en la lectura de estos libros latinos Mudarra contaba con el Vocabulario español-latino de Antonio de Nebrija.

Con relación a los libros religiosos, debemos señalar que Alonso Mudarra, como algunos otros canónigos, racioneros y conventos sevillanos, tuvo en su poder una Biblia editada en Lyon que fue secuestrada por la Inquisición. ${ }^{561}$ En 1552 el Santo Oficio decidió recoger todas las Biblias impresas fuera de Castilla, para examinarlas y ver si contenían notas e interpretaciones que no se ajustaran exactamente al dogma o que tuvieran elementos luteranos. Una vez examinadas y tachados los pasajes sospechosos eran, en la mayoría de los casos, devueltas a sus dueños. La mayor parte de ellas correspondieron a las publicadas en Lyon. Precisamente, Mudarra tenía una de estas impresa en 1540, aunque no sabemos si le fue devuelta y si se corresponde con la del inventario. También obraba en su poder una edición parisina del mismo año de Acta Apostolorum que igualmente fue secuestrada y que no figura en su inventario post mórtem.

En cuanto a las inquietudes históricas de Mudarra vemos, junto a una relación de vidas de pontífices, y una historia de la Iglesia, ${ }^{562}$ la Historia Ymperial y Cesárea del sevillano Pedro Mexía, alguna historia bélica como la Historia en la qual se cuentan muchas guerras sucedidas entre Christianos y infieles de Pedro de Salazar (sobre las guerras en Berbería), la Historia en la qual se trata de la origen y guerras que han tenido los Turcos de Juan Navarro o la Crónica del Perú de Pedro Cieza de León. Podemos incluir en este apartado la primera y segunda parte de las Repúblicas del mundo de Jerónimo Román ${ }^{563}$ y las obras de Flavio Josefo. ${ }^{564}$

Las ciencias estarían representadas por la Chronografía o Reportorio de los tiempos de Jerónimo de Chaves, la medicina por los libros de Nicolás Monardes, Sánchez Ciruelo o

561 Tellechea Idígoras, J. Ignacio. «Biblias publicadas fuera de España secuestradas por la Inquisición de Sevilla en 1552», Bulletin Hispanique, 64/3-4 (1962), pp. 236-247.

${ }^{562}$ Historia pontifical de Gonzalo de Illescas y La historia de la Yglesia que llaman ecclesiástica y tripartita de Eusebio de Cesarea.

${ }^{563}$ No figuran entre los libros vendidos en almoneda.

${ }^{564}$ Antiquitatum Judaicarum libri XX [...] De bello judaico. 
Alfonso López de Corella. ${ }^{565}$ También aquí el Libro de los secretos de Alejo Piamontés, del que Mudarra tenía dos ejemplares y la Suma de filosofía natural del sevillano Alonso de Fuentes. ${ }^{566}$

Dentro del género de las misceláneas se encontraba en la biblioteca de Mudarra el Jardín de flores curiosas de Antonio de Torquemada y la Silva de varia lección de Pedro Mexía.

Hay varios libros de dichos o decires curiosos como son el Alivio de caminantes de Juan de Timoneda, la Floresta española de apogtemas de Melchor de Santa Cruz. ${ }^{567}$ Asimismo, los Proverbios del Marqués de Santillana o Las quatrocientas respuestas de Luis de Escobar. También de carácter moralizante y en forma de diálogo, La Torre de David de Fray Jerónimo de Lemos.

No abunda la literatura de ficción. Entre los autores clásicos, a pesar de que viendo los textos de sus piezas vocales podríamos pensar que Mudarra tuviera una buena colección, solo aparecen: la Historia Etiópica de Heliodoro, unas Fábulas de Esopo y una Eneida en romance de Virgilio. La poesía está representada por el Carlo Famoso de Luis Zapata de Chaves, ${ }^{568}$ algunos romances como los Romances nuevamente sacados de historias antiguas de la crónica de España de Lorenzo de Sepulveda y «Un librito con ciertos Romançes de mano».

El autor más representado en la biblioteca de Mudarra es Antonio de Guevara con cuatro títulos: Menosprecio de corte y alabanza de aldea, Epistolas familiares, Aviso de privados y doctrina de cortesanos y el Arte del Mareary de los inventores de ella.

\footnotetext{
${ }^{565}$ Primera y segunda y tercera partes de la Historia medicinal de las cosas que se traen de nuestras Indias Occidentales de Nicolás de Monardes, Hexameron theologal sobre el regimiento Medicinal contra la pestilencia de Pedro Sánchez Ciruelo y Trescientas preguntas de cosas naturales y sus respuestas de Alfonso López de Corella.

${ }^{566}$ Curioso libro en verso en forma de diálogo en donde un personaje, Etrusco, usa el verso suelto italiano y el otro, Vandalio, el verso castellano. Para el primer personaje el impresor, Juan de León, emplea tipografía romana, mientras que para el segundo, gótica. Se puede consultar la obra en la Biblioteca Digital Hispana. <http://bdh-rd.bne.es>

${ }^{567}$ Wagner también incluye aquí el Jardín de flores curiosas de Torquemada.

${ }^{568}$ Por su contenido se podría incluir también entre los libros históricos o crónicas. Fue vendido por la elevada cantidad de 15 reales (510 mrs.).
} 
Debido a su oficio, y posiblemente a sus negocios, Mudarra poseía algún libro de economía como el Tratado en que a la clara se ponen y determinan las materias de los préstamos que se vsan entre los que tractan y negocian de Luis de Alcalá y relacionado con ello el Tratado de las rentas de los beneficios ecclesiásticos para saber en qué se han de gastar de Martín de Azpilcueta.

Muy pocos libros de música figuran en el inventario. Destaca el Arte ingeniosa de música de Melchor de Torres. ${ }^{569}$ Primeramente publicado en Alcalá de Henares en 1544, fue reimpreso en 1559, por Atanasio de Salzedo, con quien Mudarra tuvo relación comercial. No hemos encontrado ninguna relación entre la obra de vihuela de Mudarra y este libro, cuyo contenido es bastante básico, un poco de canto llano y algo de canto de órgano.

De los otros libros de música que obraban en poder de Mudarra, solo uno es impreso, el «libro de çifra de vigüela ympresso». Podríamos pensar que se trataba de su propia obra o tal vez un libro de otro autor. También aparece un manuscrito, lamentablemente perdido, llamado «un libro de çifras de música de mano» y varios cuadernillos de música tanto encuadernados: «Ocho quadernicos de cifra música enquadernados de pergamino blanco», como sueltos: «otros quadernos sueltos de música». Ninguno de los libros de música fue vendido en almoneda, lo que hace probable que fuera legado en su testamento a algún pariente o amigo cercano.

Podemos conjeturar mediante el inventario dónde se encontraban los libros, puesto que suponemos que se realizó habitación por habitación. Cerca de la cama tenía un escritorio en donde se encontraban «dos libros cubiertos de pergamino blanco de quentas de los fructos de la canongía del dicho señor Canónigo». No muy lejos, Mudarra tenía su Biblia, muchos pares de anteojos, algunos rotos, y el libro de vihuela. Como decíamos antes, podría ser un libro de otro autor que estuviera leyendo, no obstante sus dos vihuelas no se encontraban cerca. La mayor parte de los libros religiosos se hallaron en la

${ }^{569}$ El libro se titula Arte ingeniosa de música, con nueva manera de avisos breves y compendiosos sobre toda la facultad della. Hay reproducción digital de la edición de 1566 en la Biblioteca Universitaria de Zaragoza. De su autor prácticamente nada sabemos, excepto que fue maestro de capilla en Alcalá de Henares y autor de una ensalada de título El sueño. SANHUESA FONSECA, María. «Torres, Melchor de», DMEH, vol. 10, p. 405 y RoS FÁBREgAS, Emilio. «Libros de música en bibliotecas españolas en el siglo XVI (y III)», Pliegos de bibliofilia, 17 (2002), pp. 17-54. Podríamos pensar que Melchor de Torres tuviera relación con los organistas del Infantado Alonso y Diego de Torres, por lo que Mudarra podría haber recibido el libro de Melchor como regalo. 
misma habitación principal o cámara de la planta alta, mientras que las misceláneas y literatura parecen estar en la planta baja.

Joyas

Mudarra tenía algunas joyas, no demasiadas, de las que lamentablemente no sabemos su valor, pues no se vendieron en la almoneda, sino por otro lado que desconocemos, o fueron legadas en el testamento como los libros de música.

En la misma habitación donde se encontraba su cama, posiblemente en el interior de su bufete, tenía varios objetos de gran valor. En un garniel de terciopelo había una moneda o medalla de plata de unos tres reales de peso la cual «la una faz tiene a Cristo nuestro salvador y en la otra tiene al mismo Cristo y una figura hincado de Rodillas». El garniel contenía también once medallas o monedas de oro antiguas dentro de un papel que decía: «monedas del maestro Maeda». Posiblemente se refiera a Asensio de Maeda, maestro mayor de la catedral de Sevilla, encargado de restaurar la capilla de la Antigua, con quien Mudarra tuvo bastante relación. ${ }^{570}$ Junto a lo anterior, una medalla dorada guarnecida de ébano con la imagen de Pío V (1566-1572) y aparte, otra medalla de cobre. Entre las joyas destacan «un agnus dei de oro con su crucifixo y nuestra señora y sant Juan de pasta de olor, con una cinta de seda de grana de que colgava», del que hablaremos más adelante, un «anillo de oro esmaltado con una piedra grande con un Rostro para sello. Como naranjada» y otro anillo de plata dorada. Como curiosidad, Mudarra tenía un mondadientes de oro y uno de plata, este último quebrado. ${ }^{571}$ Completan las joyas algunos otros objetos religiosos como rosarios y cruces. Podríamos incluir una hebilla o guarnición de pretina ${ }^{572}$ de plata de la que tampoco sabemos el valor.

${ }^{570}$ Asensio de Maeda fue el responsable de trasladar la imagen de la Virgen de la Antigua a su actual emplazamiento. La imagen estaba pintada sobre un pilar de la mezquita almohade, por lo que hubo que cortar el muro y cambiarlo de sitio. El proceso debió ser supervisado por Alonso Mudarra por su condición de mayordomo de fábrica ya que en estos años no era presidente de la capilla de la Antigua. MEDiANERO HeRnÁndeZ, J. M.. Nuesta Señora de la Antigua..., p. 37.

${ }^{571}$ El mondadientes de oro, o en su defecto de plata, que incluso se llevaba colgado del cuello, se utilizaba para combatir la halitosis, pues se pensaba que estos materiales tenían propiedades que eliminaban el mal olor. Ruiz Somavilla, María José. «El cuerpo limpio». Análisis de las prácticas higiénicas en la España del mundo moderno. Málaga, Universidad de Málaga, 1993, pp. 109 y 111.

572 «Estrecho cinturón que ceñía la sotana de clérigos, licenciados, letrados, etc.» SOUSA CONGOSTO, Francisco de. Introducción a la historia de la indumentaria en España. Madrid, Istmo, 2007, p. 467. 
Por supuesto, Mudarra contaba con un completo «servicio de plata»: salero, cubiletes, naranjera, escudilla, salseros pequeños y grandes, cucharas y tenedores, jarro, azucarero. Todo ello estaba expuesto en un aparador, junto a algunas piezas del menaje de cerámica.

Para poder pesar sus metales preciosos, Mudarra tenía «un peso con su marco entero de pesar oro metido todo en una caxa», vendido en 9 reales (306 mrs.).

\section{Tapices, guadamecíes y pinturas}

La presencia de tapices en las casas tenía varias funciones: aislar del frío y la humedad, decorar los muros y compartimentar las estancias, pero además de esto eran «elementos transmisores de ideas como la magnificencia, la posición social o el poder económico de sus propietarios». ${ }^{573}$ Las casas de la nobleza estaban profusamente adornadas de este tipo de objetos, generalmente flamencos. El duque del Infantado poseía una fabulosa colección de ellos, ${ }^{574}$ hecho que fue perfectamente conocido por Mudarra en su juventud. También los canónigos sevillanos tenían en sus aposentos varios tapices. ${ }^{575}$

No sabemos mucho sobre los que tenía Mudarra pues el inventario es parco: «çinco Paños de corte que estavan colgados en una sala alta de las dichas sus casas todos de figuras traýdos» $\mathrm{y}$ «dos paños de corte que estavan colgados dentro de una recámara de la dicha sala alta el uno de figuras y el otro de verduras y montería traýdo». Podemos pensar que los de figuras podrían corresponderse con escenas bíblicas o mitológicas y el de verduras y montería con escenas de caza. Los precios alcanzados fueron de entre 4,25 reales $\left(144,5\right.$ mrs.) y 7 reales $\left(238\right.$ mrs.) el ana cuadrada. ${ }^{576}$ Los de la sala alta suponían unos 48 metros cuadrados en total, siendo el más grande de ellos de más de 11 metros

\footnotetext{
${ }^{573}$ RAMíREZ RUIZ, Victoria. Las tapicerías en las colecciones de la nobleza española del siglo XVII. Tesis Doctoral, Universidad Complutense de Madrid, 2013, p. 64.

${ }^{574}$ RAmírez Ruiz, V. Las tapicerías en las colecciones... y SuÁREz DE ArCos, Fernando y HerrerA CASADO, Antonio. «Tapicerías en la Casa de Mendoza», Wad-al-ayara, 14 (1987). Guadalajara, Institución provincial de cultura «Marqués de Santillana», pp 213-247.

${ }^{575}$ En el inventario de Jerónimo Manrique figura una buena colección de tapices. AHPSe, Oficio 19, de Gaspar de León Garabito, Libro $3^{\circ}$ de 1580, Signatura 12459, ff. 250v-260v.

${ }^{576}$ Las tapicerías se medían en anas, medida utilizada en Flandes y con la equivalencia de un ana igual a 0,695 metros, aunque existían variantes según fuera el ana de Brabante $(0,695$ m.), de Gante (0,698 m.) o de Brujas $(0,700 \mathrm{~m}$.). Para realizar la conversión de anas cuadradas a metros cuadrados debemos multiplicar por 0,483. SuÁrez de Arcos, F. y Herrera Casado, A. «Tapicerías en la Casa ..., p. 216.
} 
cuadrados. Los de la recámara tendrían también unos 11 metros cuadrados cada uno. En total los siete tapices fueron vendidos en almoneda por 752 reales $(25.568 \mathrm{mrs}$.) cifra que se acerca a la pagada por su esclava Esperanza o por su mula.

También incluimos entre los tapices varias cortinas: «Una antepuerta de terçiopelo de tripa azul con su vara de hierro en que está colgada», valorada en 20,5 reales (697 mrs.)y las alfombras «Una alfombra vieja pequeña» valorada en 33 reales (1.122 mrs.) y «Una alfombrita pequeña verde y colorada» en 25 reales (850 mrs.).

No menos lujosos y valiosos que los tapices eran los guadamecíes cordobeses que se usaban para recubrir las paredes o como sobremesa. Mudarra poseía once de ellos, por una parte «Nueve guadameçíes y una sobremesa de lo proprio» sin especificar nada más. La almoneda es algo más generosa en detalles: «quatro guadamesíes dorados en el dicho señor raçionero tamayo en diez ducados» y «seis guadamesíes colorados con sus cenefas verdes En el dicho señor raçionero pedro mexía en doze ducados». En total alcanzaron el precio de 22 ducados (8.250 mrs.). En otra parte localizamos otro guadamecí de mucho menor valor y usado para recubrir algún mueble «una sobremesa de guadamesí colorada en el dicho racionero pedro mexía en ocho reales».

Mudarra tenía varias pinturas en su casa, casi todas ellas de temática religiosa. La mayoría de ellas no alcanzaron un gran valor en la almoneda, entre 4 y 12 reales (136 a 408 mrs.) cada una. Tan solo el retablo de la Magdalena con el crucifijo alcanzó un valor de 38 reales (1.292 mrs.), pero es muy probable que se debiera a la riqueza de la guarnición más que a la calidad de la pintura, asunto sobre el que los tasadores no solían opinar. ${ }^{577}$ La relación de ellas es la que sigue:

Una ymagen de nuestro salvador con la cruz a questas pequeño de pintura

Una ymagen de la salutaçión de pintura pequeña

Una ymagen de quando la magdalena llegó del conbite del phariseo de pintura pequeña

Otra ymagen de nuestro salvador quando le presentaron la mujer adúltera de pincel pequeña

Otra ymagen de nuestra señora con el niño Jesús al pecho de pintura

${ }^{577}$ Un precio medio de 400 mrs. es bastante común en los inventarios sevillanos de el último tercio del siglo XVI. RODRígueZ VÁZQUEZ, A. L. Ricos y pobres..., p. 127. 
Un lienço con su bastidor de quando aparesçió dios a moyses en la çarça

Un retablito con su guarniçión con la madalena y crucifijo en la mano

Otros dos lienços con sus bastidor uno de batallas y otro de unas figuras de ovejas y camellos

Otro lienço con su bastidor de la oraçión del huerto

Otro retablo de cristo nuestro señor con los ladrones cruçificado

Era cosa frecuente coleccionar estampas o papeles con imágenes diversas. Así en casa de Mudarra se hallaron: «nueve papeles de estanpas viejos» que se vendieron en 2 reales (68 mrs.) y «un papel de mapamundi aforrado en lienço» vendido en 9 reales (306 mrs.).

Algunas esculturas o figuras «de bulto» se hallan también en el inventario, como una imagen de San Sebastián (santo invocado contra la peste) metida en una caja dorada y que fue vendida en 22 reales (748 mrs.). Mudarra poseía, además, una vidriera con tres figuras de la historia de Tobías, que se vendió en 16 reales (544 mrs.). Podemos considerar todos estos cuadros y esculturas, más que como obras de arte, como objetos de devoción.

También vemos en el inventario un «agnus dei de çera grande». Los «Agnusdei» eran «unas pequeñas tablillas de cera, de forma oval o circular, que generalmente llevan impresa en relieve la imagen del cordero místico». ${ }^{578}$ Solían elaborarse de cera pura, blanca y virgen que posteriormente se sumergía en aceite consagrado y agua bendita. El proceso concluía con la bendición papal en el propio Vaticano, en el primer año del pontificado o en años de Jubileo, el sábado in albis. Se distribuían entre los miembros de la curia, obispos y fieles selectos el mismo día. Lo más curioso es que estas piezas se consideraban, además de reliquias, amuletos frente a múltiples adversidades. Entre sus poderes taumatúrgicos estaban: ahuyentar los malos espíritus y demonios, conjurar las tormentas, terremotos, incendios, proteger frente a la peste y otras enfermedades, etc. Debido a todo esto eran muy cotizados y codiciados. Es probable que el que tenía Alonso llegara a su poder a través de su hermano Francisco, quien sí tenía gran influencia en el Vaticano (por lo menos hasta caer en desgracia). Lamentablemente, este Agnusdei no fue vendido en la almoneda, por lo que no podemos saber su precio. Veíamos entre las joyas la presencia de un Agnus Dei de oro, pero en este caso creemos que tiene otro significado.

\footnotetext{
${ }^{578}$ Herradón Figueroa, María Antonia. «Cera y devoción. Los agnusdei en la colección del Museo Nacional de Antropología», Revista de Dialectología y Tradiciones Populares, 54/1 (1999), pp. 207-237; p. 209.
} 


\section{Muebles}

Las casas del siglo XVI no solían estar muy provistas de muebles. Lo más abundante eran las arcas y los cofres donde se guardaba todo tipo de objetos. Las primeras se utilizaban para guardar los enseres de la casa, incluidos los libros, siendo los tipos más comunes las «ensayaladas» y las «encoradas». ${ }^{579} \mathrm{Al}$ lado de la cama de Mudarra se encontraba «Una caxa de madera pequeña en que está mucha desta ropa de lienço ynventariada» con sábanas, manteles y camisas. Además de esta caja, figuran varias arcas y cofres, algunos de ellos con cerraduras. Destaca, por el alto precio, un cofre de hierro con su pie de madera, vendido en 20 ducados $(7.500 \mathrm{mrs}$.), utilizado como caja fuerte por Mudarra, pues dentro estaba su dinero. También un par de cofres grandes de Flandes ${ }^{580}$ tumbados con su cerradura doble que fueron rematados en 3 ducados (1.125 mrs.) y en 38 reales (1.292 mrs.). Subrayamos que la esclava Madalena adquirió «una caxa de madera vieja» en tres reales, lo que nos hace suponer que había sido liberada en el testamento. ${ }^{581} \mathrm{~A}$ veces las arcas tenían, además, otras funciones como por ejemplo, de asiento, así «un escaño que tanbién sirve de arca con su çerradura en quarenta y seys reales en el señor doctor sanct miguel». Junto a estas arcas o cajas vemos un número elevado de cofrecitos, varios de ellos de Flandes, cuyo precio no superaba el real.

Otro tipo de muebles son los escritorios y bufetes de los que Mudarra tenía varios. En la cámara tenía un escritorio de nogal con su cajonera baja, vendido en seis ducados y un real (6.034 mrs.), donde suponemos que trabajaba y un bufete viejo, vendido en 36 reales (1.156 mrs.), donde guardaba los objetos de más valor como sus joyas. En la sala baja tenía otros dos escritorios pequeños por los que se pagó 20 y 46 reales (680 y 1.564 mrs.).

\footnotetext{
${ }^{579}$ Las arcas ensayaladas estaban forradas de telas variadas, desde lienzos bastos hasta ricas sedas. Las encoradas se forraban de piel de bovino, cabra o caballo. GonZÁlez MARrero, M del C. La Casa de Isabel la Católica..., p. 207.

${ }^{580}$ Los cofres de Flandes eran importados desde allí y se refiere a «los construidos con el sistema de bastidores [...] compartimentados en panelados múltiples; los de marquetería de elemento por elemento», Rodríguez Bernis, Sofía. Diccionario de mobiliario. Madrid, Ministerio de Cultura, 2006. Publicación electrónica en:

<http://www.mcu.es/museos/MC/Tesauros/Mobiliario/Capitulos.html> [consulta 16-8-2015], p. 113.

${ }^{581}$ Los esclavos no podían tener posesiones de ningún tipo mientras no fueran libres. FraNCO SILVA, Alfonso. La esclavitud en Andalucía 1450-1550. Granada, Universidad de Granada, 1992, p. 110.
} 
Había otro tipo de mesas en la casa de Mudarra, siendo las más características las varias mesas plegables. Era frecuente que las mesas se montaran y desmontaran para modificar la habitación o para trasladarlas de sitio. ${ }^{582}$ En la planta alta tenía una mesa pequeña de bancos y cadena, donde posiblemente comería estando solo, valorada en 6 reales (204 mrs.) y en la planta baja otras dos mesas del mismo tipo; una de roble (borne, dice el inventario) por la que se pagó el doble que por la anterior, 12 reales (408 mrs.) y es la que suponemos que utilizaría cuando comiera con más comensales. La tercera estaba en la cocina junto a otra auxiliar.

Otro tipo particular de mesa, que no podía faltar en una casa de una cierta categoria, era el aparador. Acompañando a la mesa de comedor, su función era la de contener y exhibir la vajilla, principalmente la de plata, así como servir de mesa auxiliar en la comida. Mudarra tenía un aparador en la habitación principal donde estaba toda su plata, que a pesar de estar incompleto, «sin el cumplimiento de arriba» dice el inventario, fue vendido en 40 reales (1.360 mrs.).

Las sillas eran también abundantes, con varios tipos fundamentales, la silla de caderas, plegable, con brazos de madera, asiento y respaldo de piel o tela; la silla de espaldas que tenía el respaldo más alto y sin brazos y la silla de descanso, más cómoda con respaldo alto abatible y asiento bajo. ${ }^{583}$ Mudarra tenía tres sillas de descanso y una de espaldas, creemos que en la planta superior. Podemos fantasear y pensar que estas tres sillas, que se vendieron cada una en 13,5 reales (459 mrs.) serían las de lectura y trabajo del anciano Mudarra y la de espaldas la que usaría para tañer sus vihuelas. En la baja dos sillas de espaldas viejas, dos medias sillas de espaldas, una silla de caderas, una silla de cuero rasa y una silla de trozos de Flandes. ${ }^{584}$ Esta última estaba al lado de un atril y una vihuela, por lo que podemos suponer que era la que él, o su sobrino, usaban para tocar en la planta baja.

\footnotetext{
${ }^{582}$ Las mesas de banco y cadena eran mesas sostenidas sobre borriquetas «el banco» que se graduaban en altura mediante la cadena. GonzÁlez MArrero, M del C. La Casa de Isabel la Católica..., p. 151.

${ }^{583}$ GonzÁlez Marrero, M del C. La Casa de Isabel la Católica..., pp. 147-148. La silla de descanso «Hace su aparición al mismo tiempo que la silla de brazos, en el reinado de Felipe II», RoDRíGUEZ BERNIS, S. Diccionario de mobiliario..., p. 305. Sin embargo, la almoneda contradice al inventario en algunas ocasiones, denominando a unas por otras.

${ }^{584}$ Por cuatro de estas sillas se pagó 16 reales $(544 \mathrm{mrs}$.), lo que muestra la diferencia con las de descanso.
} 
Pero sin duda alguna, el mueble de mayor valor y del que más orgullosos se sentían sus propietarios era la cama, la cual a menudo presidía la habitación principal o cámara, ${ }^{585}$ como creemos que ocurría en el caso de Mudarra. El inventario la describe como «una cama de paño colorado estamenete ${ }^{586}$ que tiene siete pieças con el cobertor con su armadura de madera con quatro remates a las esquinas de vidros de colores». Es decir, se trataba de la característica cama con dosel y, en este caso, adornada con cristales coloreados, que alcanzó en la almoneda el alto precio de 33 ducados (12.375 mrs.), eso sin contar con sus colchones y sábanas. ${ }^{587} \mathrm{La}$ cama tenía cuatro colchones rellenos de lana que fueron vendidos individualmente a precios que oscilaban entre 23 y 36 reales (782 a 1.224 mrs.). En la misma estancia, o en otra estancia cercana a ella, encontramos una segunda cama que podría pertenecer al sobrino de Mudarra. Se trata de una cama de red blanca labrada, de cuatro paños y cielo que se vendió en 61 reales (2.074 mrs.). Junto a la cama principal se inventariaron dos colchones de los criados los cuales, como era costumbre, dormirían en la misma habitación que el señor, pero con los colchones en el suelo. En la planta baja había otras dos camas, una de ellas una cama de viento, ${ }^{588}$ valorada en 35 reales $(1.190$ mrs.) y una media cama, con «sus varandas» y «sus tornillos y su llave», lo que indica que era desmontable, valorada en 27 reales (918 mrs.). Es posible que una de ellas fuera de Alonso Mudarra, para pasar el caluroso verano, como veíamos más arriba. Sin embargo, la otra, tal y como nos indica el testamento, debía ser en la que dormían el ama Marigarcía y su marido Castillo, criados ambos del canónigo.

Podemos resumir lo relacionado al mobiliario afirmando que Mudarra vivía rodeado del confort y las comodidades adecuadas a su categoría. Las casas sevillanas no solían contar con una gran cantidad de muebles y se puede considerar que tan solo las clases

\footnotetext{
${ }^{585}$ De la importancia de esta cama da fe el testamento de 1576, en que la cama es legada a su sobrino Alonso, pero el hecho de venderse en la almoneda indica que en el testamento posterior esta disposición fue modificada, por alguna razón que desconocemos.

${ }^{586} \mathrm{El}$ estamenete o estameñete era un tejido de lana de calidad superior a la estameña y con una urdimbre similar. GonzÁlez MARrero, M del C. La Casa de Isabel la Católica..., p. 374.

${ }^{587}$ Los inventarios diferencian entre cama completa con cabecero, dosel, cielo y cortinas de la media cama que no contaba con estos tapices y que sería como una cama sencilla actual. El modelo más valorado sería la cama de paño. RoDRígueZ VÁZQUEZ, A. L. Ricos y pobres..., p. 123.

${ }^{588}$ La cama de viento era una «cama compuesta por un lienzo tendido en un bastidor que a veces es de tijera», RODRíGuez BERnIS, S. Diccionario de mobiliario..., pp. 83 y 87.
} 
adineradas podían tener un mobiliario de alrededor de $50.000 \mathrm{mrs} .{ }^{589}$ que es, más o menos, el valor del de Mudarra según podemos calcular con los precios de la almoneda.

\section{$\underline{\text { Ropa doméstica }}$}

La cama de dosel colorada se completaba con varias almohadas y cojines: «Una almohada de lienço labrada de grana» vendida en 9,5 reales (323 mrs.), «Dos almohadas pequeñas una labrada de grana y otra de azul llenas de lana» en 18 reales (612 mrs.). Además de la ropa de cama, la casa contaba con una gran cantidad de manteles, toallas, paños y lienzos varios que podemos englobar dentro de la ropa doméstica. Las colchas eran lo más costoso, pues las dos que poseía Mudarra eran de tejido de holanda, el más valioso de todos. ${ }^{590}$ Se pagó 6 ducados (2.250 mrs.) por una usada y 11 ducados (4.125 mrs.) por una nueva. En este tejido también tenía un par de sábanas que se vendieron en 30 reales $(1.020 \mathrm{mrs}$.$) , mientras que otras más comunes lo hicieron por debajo de 10$ reales (340 mrs.) cada una. Además, tenía múltiples frazadas, mantas, manteles «alimaniscos», pañuelos de mesa, paños de rostro, etc, que sería excesivamente prolijo detallar.

\section{$\underline{\text { Vestuario }}$}

Como ya ha sido señalado, el Renacimiento, con su culto al individualismo, al lujo y la ostentación, «ha sido una de las épocas que mayor importancia ha concedido al traje.» ${ }^{591}$ La posición social quedaba claramente definida mediante el vestuario, tanto es así que fueron numerosas las pragmáticas reales que intentaron reglamentar su uso. Desde los Reyes Católicos hasta fines del siglo XVI se intentó regular, sin mucho éxito, el uso de los tejidos más caros como los brocados bordados de oro y plata y de las sedas, en principio

${ }^{589}$ Rodríguez VÁzQuez, A. L. Ricos y pobres..., p. 125.

${ }^{590}$ Este tejido de importación se utilizaba tanto para vestido como para el ajuar doméstico y era muy apreciado por las clases altas e incluso por la realeza, por lo que era un símbolo de distinción. Una vara de holanda se tasó en 204 mrs., mientras que el ruan, también muy cotizado, entre 95 y 125 mrs. El lienzo presilla en $68 \mathrm{mrs}$. y el lienzo francés en $26 \mathrm{mrs}$. la vara.

${ }^{591}$ Bernis, Carmen. Indumentaria española en tiempos de Carlos V. Madrid, Instituto Diego Velázquez (CSIC), 1962, p. 7. Sacamos la mayor parte de nuestros datos sobre el vestido de aquí y de SouSA CONGOSTO, F. Introducción a la bistoria... 
reservados únicamente a las personas reales los primeros y a personas y situaciones selectas las segundas. ${ }^{592}$

Sin intención de ser exhaustivos vamos a ver qué tipo de elementos constituían el vestuario de un canónigo sevillano de la segunda mitad del siglo XVI.

La camisa era la prenda básica, se colocaba sobre la piel haciendo las funciones de ropa interior. ${ }^{593}$ Algunas partes, como las mangas y el cuello, podían ser vistas, por lo que se cuidaba su confección con frecuentes bordados. También el tejido era importante, siendo de nuevo la holanda el más valorado. Mudarra poseía varias camisas de holanda, tres camisas nuevas, por las que se pagó en total 64 reales $(2.176 \mathrm{mrs}$.) y otras tres usadas, tasadas en 18 reales (612 mrs.) Además encontramos una camisa de ruan, valorada en 7,5 reales (255 mrs.). Es decir, las de holanda era tres veces más caras que las de ruan.

Sobre la camisa se disponía el jubón, pero en el inventario de Mudarra solo figuran dos, uno de lienzo y otro de estameña colorado, vendidos ambos en 8 reales (272 mrs.), ${ }^{594}$ aunque también tenía una «almilla de punto de seda blanca». ${ }^{595}$ Las piernas se cubrían con las calzas desde la cintura hasta los pies, pero en el siglo XVI se pusieron de moda las medias calzas y los griguiescos. ${ }^{596}$ Mudarra tenía tres pares de medias calzas de estameña y de lana viejas cuyo precio más alto fue de 4 reales $(136 \mathrm{mrs}$.) un par. Además tenía cuatro griguiescos usados de diferentes tejidos por los que se pagó entre 10 y 13 reales (340 a 442 mrs.). También poseía cinco pares de calcetas, que solían ir debajo de las calzas y otros diez pares de escarpines (a medio real cada par), que hacían la función de los calcetines actuales, colocándose también debajo de las calzas.

\footnotetext{
592 Se permitía que los grandes y caballeros pudieran llevar brocados cuando fueran a la guerra, pero la realidad es que los usaban con frecuencia en justas y juegos de cañas. BERNIS, C. Indumentaria española ..., pp. $12-15$.

${ }^{593}$ La norma higiénica establecía que la camisa se debía cambiar una vez a la semana, por lo que era común que la gente con recursos dispusiera como mínimo de dos. Mudarra tenía siete. Ruiz SomaVILLA, M. J. «El cuerpo limpio..., pp. 122 y ss.

${ }^{594}$ Podemos pensar que, en la calurosa Sevilla, Mudarra vestía la sotana directamente sobre la camisa.

${ }^{595}$ La almilla era una "prenda interior de abrigo que se vestía sobre la camisa y sobre el jubón», su función era de abrigo. BERNIS, C. Indumentaria española..., p. 76.

${ }^{596}$ No queda claro si los greguescos del siglo XVI son lo mismo que los del XVII, pero por el inventario podemos deducir que se refiere a la parte de arriba de las calzas.
} 
Ataviado con camisa, jubón y calzas el hombre se consideraba que estaba en ropa semiinterior o semidesnudo, por lo que para ir completamente vestido por encima se colocaba el sayo y al avanzar el siglo una prenda más corta como la ropilla, la ropeta o el coleto. ${ }^{597}$ Mudarra, como hombre a la moda que era, tenía varias ropillas, así por ejemplo tenía una ropilla de paño negro por la que se pagó 27 reales (918 mrs.), una ropilla de pelo de camello en 15 reales (510 mrs.), además de un coleto de cuero o cordobán por el que apenas se pagó 2 reales (68 mrs.).

Encima de sayos, ropillas y demás se utilizaba la ropa de cubrir o sobretodo, que se podía denominar simplemente ropa cuando tenía mangas, o diferentes tipos de capas. Mudarra tenía algunas muy lujosas, atendiendo a lo pagado por ellas como «una ropa de trama de seda» por la que se pagó 50 reales $(1.700 \mathrm{mrs}$.), también un herreruelo de paño negro ${ }^{598}$ por el que se pagó la importante cantidad de 90 reales (3.060 mrs.).

Como es lógico, en el inventario figura una gran cantidad de ropa característica del oficio de canónigo. Tres sotanas de burato y carisea, a 12 y 48 reales (408 y 1632 mrs), respectivamente. Dos sobrepellices, una de seda labrada, valorada en 60 reales $(2.040$ mrs.) y otra lisa, 36 reales (1.224 mrs.). Una beca de tafetán, en 9 reales (306 mrs.).

Una prenda muy particular era la denominada «ropa de levantar» que era un traje de una sola pieza con mangas anchas utilizado para estar en casa. Solia ser típica de la gente adinerada y Mudarra tenía dos muy valiosas: una de paño morisco, valorada en 42 reales (1.428 mrs.) y otra de fusteda ${ }^{599}$ negra forrada de pelo de conejo, valorada en 50 reales (1.700 mrs.).

El calzado de Mudarra estaba compuesto por unos borceguíes y unas botas enceradas vendidas en 12 reales (408 mrs.). Varios guantes, un par de ellos adobados por los que se pagó 6,5 reales (221 mrs.), frente al real pagado por cada uno de los pares viejos.

\footnotetext{
${ }^{597}$ Se diferenciaban en que la ropilla y la ropeta tenían mangas largas y el coleto era como un chaleco sin mangas. BERNIS, C. Indumentaria española..., p. 16.

598 «Sobretodo corto masculino, sin mangas, presente en el traje en la segunda mitad del siglo XVI, de forma semicircular con el escote ribeteado», SOUSA CONGOSTO, F. Introducción..., p. 459.

${ }^{599} \mathrm{La}$ fusteda o fustán era una tela con pelo por uno de los lados, por lo que en la almoneda se la denomina de pelo de camello.
} 
Como sombreros en el inventario de Mudarra abundan los bonetes acolchados, lo cual es razonable siendo el tocado característico de los clérigos. Tenía cuatro bonetes blancos, uno escarlata y otros seis de tafetán o burato ${ }^{600}$ de los que desconocemos el color. Para ir más engalanado contaba con un «sombrero con sus cordones con la copa forrada de tafetán» valorado en 10,5 reales (357 mrs.).

Apreciamos que Mudarra vestía a la moda, lo cual atestigua la presencia de griguiescos y herreruelos, prendas ambas de actualidad en la segunda mitad del siglo XVI. También el uso de ropa de levantar es signo de su categoría, además de los tejidos caros, como las holandas o sedas labradas, que figuran en su inventario.

Para completar este apartado podemos conjeturar sobre el aspecto físico de Mudarra. Es más que probable que, siguiendo la moda imperante durante el reinado de Felipe II entre la gente de calidad, ${ }^{601}$ llevara la barba cuidada. ${ }^{602}$ No hemos encontrado ningún peine entre sus pertenencias, ${ }^{603}$ lo que nos hace suponer una carencia de pelo y que fuera, tal vez, cubierto siempre con bonete de clérigo, dada la elevada cantidad de ellos que figuran en el inventario. Es fácil suponer la permanente presencia de sus anteojos, lo cuales también son abundantes en su casa, algunos incluso con montura de plata.

\section{Objetos de coleccionismo y otros}

Era bastante común que las personas adineradas contaran con algunas armas como objeto de colección. En la casa de Mudarra había pocas, apenas un alfanje, una rodela, una alabarda, un lanzón, un cuchillo de monte y un par de ballestas, una de ellas para cazar pájaros (ballesta de bodoques).

${ }^{600}$ El tafetán era un tejido de seda y el burato de lana.

${ }^{601}$ BERNIS, C. Indumentaria española..., p. 34 y RuIZ SOMAVILLA, M. J. «El cuerpo limpio..., pp. 115-117.

${ }^{602}$ En la almoneda figura «Una baçía para hazer la barva con dos paños grandes y dos pequeños para los mesmo con una taleguita en que están estos paños al señor canónigo mohedano en veynte y çinco reales»,

${ }^{603}$ El peinarse se consideraba una práctica higiénica que había que realizar varias veces al día para abrir los poros y expulsar los elementos nocivos acumulados en el cuerpo durante el sueño. RUIZ SOMAVILLA, M. J. «El cuerpo limpio..., pp. 122 y ss. 
Tenía varios relojes, dos de ellos de marfil y otro de arena metido en una caja de ébano. Muchos objetos de cerámica, posiblemente de uso doméstico. También dentro del coleccionismo se pueden considerar las estampas anteriormente vistas, los mapamundis y el globo terráqueo con su pie que fue comprado en 3 reales (102 mrs.). Algunos objetos de los que desconocemos su utilidad podían tener una función ornamental como «Dos pomas de vidrio de colores una grande y otra pequeña con sus pies de madera en diez reales».

Además de la mula y varias gallinas con sus pollitos, Mudarra tenía algunos animales exóticos: un papagayo, que fue vendido en 70 reales $(2.380 \mathrm{mrs}),.{ }^{604}$ un canario y un xamarín (un chamarin o verdecillo). De estos dos últimos desconocemos su precio.

Como curiosidad, decir que en la almoneda se vendieron algunos alimentos de la casa de Mudarra como «una sera con unas pasas de Almuñecar» un «jarro con miel» y lo más cotizado «tres tocinos con su espalda y su pernil», vendidos los tres a $56 \mathrm{mrs}$. la libra $(0,46$ $\mathrm{kg}$ ) resultando un total de $2.423 \mathrm{mrs}$. También en el corral de la casa tenía un gallo, tres gallinas y veintisiete pollitos, de los que no sabemos dónde acabaron. Además, el canónigo Mohedano le cuidaba dos gallinas y veinte pollitos.

En total la almoneda recaudó 92.000 mrs., como nos indican las actas capitulares, que se utilizaron para satisfacer las mandas testamentarias del canónigo vihuelista.

ACS 573./f. 30/ Viernes primero de junio de 1582

En este dia mandaron que los noventa y dos mill maravedises de los bienes de mudarra que estan en poder del Receptor de la fabrica los cobre juan de villalan y los tenga en su Poder hasta que mande otra cosa el cabildo y que el señor bartolome ruiz se informe adonde mando mudarra repartir esta limosna y refiera.

Sabemos de la existencia de varios criados de Mudarra. Uno de ellos Miguel de Abrego, además de su ama Marigarcía y su marido Castillo. Las personas a su servicio se completarían con los esclavos que veremos a continuación.

\footnotetext{
${ }^{604}$ El precio alcanzado por el papagayo prácticamente duplicaba el de cada una de las vihuelas.
} 


\section{Los esclavos en Sevilla. Mudarra y sus esclavos}

Es conocida la sentencia del toledano Melchor de Santa Cruz que, en 1574, decía que Sevilla "parecía a los trebejos del ajedrez, tantos prietos como blancos, por los muchos esclavos que hay en aquella ciudad». ${ }^{605}$ Sin llegar a una proporción tan exagerada, la realidad es que hacia estos años, en que Sevilla debía contar con más de 100.000 habitantes incluyendo la población flotante, el número de esclavos rebasaba la cifra de 6.000 y para todo el arzobispado de Sevilla (que incluía Sevilla, Huelva y parte de Cádiz y Málaga) rondaba los 15.000. ${ }^{606}$ Ninguna otra ciudad de Castilla se acercaba a esa proporción y ello se debía a que la capital hispalense, junto con Lisboa, era el mayor mercado de esclavos negros de toda Europa, situación que se acrecentó a partir del descubrimiento del Nuevo Mundo. ${ }^{607}$

No todos los esclavos de Sevilla eran negros, había también musulmanes provenientes de la conquista de Granada y de las guerras mediterráneas contra los turcos y los piratas berberiscos. La esclavitud de canarios e indios, en principio tolerada, fue prohibida por los Reyes Católicos. ${ }^{608} \mathrm{~A}$ los musulmanes se los denomina esclavos blancos en los documentos que también hablan de esclavos loros, refiriéndose a los mulatos, que eran abundantes, pudiendo ser mulatos de negro y moro o canario o cristiano. Entre los negros se diferenciaba entre bozales y ladinos. Los primeros eran los que acababan de llegar de Africa, por lo que desconocían todo, incluido el idioma de sus amos. Los ladinos eran los que, habiendo nacido en Península, habían asimilado las costumbres y la lengua (que podía ser el portugués). A lo largo del siglo XVI los esclavos canarios e indios fueron desapareciendo completamente, los moriscos y berberiscos disminuyendo y los negros

\footnotetext{
${ }^{605}$ Santa Cruz de Dueñas, Melchor. Floresta española. Buenos Aires, México, Espasa Calpe, 1947, p.158.

${ }^{606}$ Domínguez ORTIZ, Antonio. La esclavitud en Castilla en la Edad Moderna y otros estudios de marginados. Granada, Comares, 2003, p. 9.

${ }^{607}$ En realidad la mayoría de los esclavos negros que se vendían en Sevilla provenían de Lisboa u otros puntos de Portugal, pues esta reino tenía el monopolio de las mercancías del Africa Negra desde la paz de Alcaçovas de 1479 y el Tratado de Tordesillas de 1494. Domínguez OrTIZ, A. La esclavitud en Castilla..., p. 5 y CORTÉS LÓPEZ, José Luis. La esclavitud negra en la España peninsular del siglo XVI. Salamanca, Universidad de Salamanca, 1989, p. 155.

${ }^{608}$ Los monarcas prohibieron la venta de los canarios convertidos al cristianismo. FRANCO SILVA, Alfonso. La esclavitud en Sevilla y su tierra a fines de la Edad Media. Sevilla, Diputación Provincial, 1979, p. 147
} 
aumentando, de forma que a finales de siglo esclavo era prácticamente sinónimo de negro. ${ }^{609}$

La justificación moral a la esclavitud se basaba principalmente en que eran prisioneros de guerra. ${ }^{610}$ Se podía ser esclavo por guerra o por nacimiento, «de buena guerra y no de paz» era el formulismo en los contratos de compraventa. Esto que podía ser cierto para musulmanes granadinos, en el siglo XV, o para turcos o berberiscos en el XVI, no debía ser válido para los esclavos negros, excepto los berberiscos, pues Castilla en ningún momento estuvo en guerra con pueblos africanos negros.

Los precios de los esclavos variaban en función de su color, sexo, edad, estado de salud, etc. Los moriscos y después los berberiscos eran los más cotizados, aunque tenían fama de astutos y taimados, después venían los negros, los cuales se pensaba que eran cariñosos e ingenuos. En general, por una hembra se pagaba más que por un varón ya que, entre otras razones, las esclavas podían aportar a su dueño lo que se ha denominado «el salario del placer». ${ }^{611}$ No olvidemos que los hijos de las esclavas pasaban a ser propiedad de su amo y podían ser incluso vendidos proporcionando pingües beneficios. Por edades, las mujeres entre quince y veinticinco años eran las más valiosas y los hombres entre doce y veniticinco años. A partir de los treinta años su precio comenzaba a disminuir. Por los niños pequeños se pagaba poco porque la mortandad infantil era muy elevada. Con todos estos condicionantes, podemos fijar el precio medio de un esclavo en el último tercio de siglo entre 70 y 85 ducados (26.250 a 31.875 mrs.). ${ }^{612}$

En 1565 un maestro (albañil, cantero o carpintero) y un peón que trabajaban en la ciudad de Sevilla cobraban 3,5 y 2 reales diarios, respectivamente. ${ }^{613}$ Si consideramos unos 300 días trabajados, pues los domingos y festivos no trabajados no se cobraban, el salario anual sería de 35.700 y 20.400 mrs., más o menos el precio de un esclavo, lo que hacía

\footnotetext{
${ }^{609}$ Hay que destacar que algunos de los negros capturados en Berbería eran también musulmanes.

${ }^{610}$ La justificación ideológica y jurídica estaba basada en Aristóteles y Santo Tomás, además de en Las Partidas.

${ }^{611}$ BenNAsSAR, Bartolomé. Los españoles. Actitudes y mentalidad. Barcelona, Argos, 1978, p. 108.

${ }^{612}$ CORTÉs LÓPEZ, J. L.. La esclavitud negra ..., p. 136.

${ }^{613}$ Morales Padrón, F. Historia de Sevilla..., p. 98.
} 
prácticamente improbable que un trabajador a jornal pudiera emplear el salario de un año en adquirir uno.

El esclavo sevillano era, en primer lugar, un bien suntuario, lo que no quiere decir que sus amos no estuvieran presentes en las diversas capas de la sociedad, con la diferencia clara del número de ellos. La Corona poseía una gran cantidad, fundamentalmente como galeotes. Pero la nobleza y los eclesiásticos eran los que mayor cantidad de esclavos poseían. Entre los primeros ya vimos que los incluían entre los músicos, o en su guardia de alabarderos como forma de ornato. ${ }^{614}$ Lógicamente, la nobleza sevillana acaparaba gran número de ellos. En poder de los clérigos seran también muy frecuentes, con un claro predominio entre el clero catedralicio. Desde el arzobispo, pasando por arcedianos, canónigos, racioneros, capellanes y otros empleados de la catedral, todos compraban y vendían esclavos. En principio, los clérigos no podían vender esclavos, por lo que hacían uso casi siempre de un procurador. ${ }^{615}$ Un caso particular era el de los canónigos, pues todos poseían esclavos, algunos debido a su constante compra y venta parecen más bien mercaderes. Entre los capellanes e incluso algún cantor se da un fenómeno similar. ${ }^{616}$ Son muy frecuentes entre los artesanos sevillanos los poseedores de esclavos, pero en este caso se trataba de una inversión porque eran utilizados como aprendices en los talleres, llegando algún esclavo a adquirir la condición de oficial. Ni que decir tiene que los mercaderes sevillanos acaparaban una gran cantidad de ellos.

El destino de muchos de estos esclavos era el trabajo doméstico y, parece ser, que el trato no era demasiado duro pues solían integrarse en la familia. Esto no quita para que no se les aplicaran castigos e incluso se les marcara en la cara, o en otras partes del cuerpo, con una $\mathrm{S}$ y un clavo o con el nombre del dueño. No era esta, sin embargo, una práctica común; se solía marcar con más frecuencia a los esclavos blancos (musulmanes) y, sobre todo a los huidores. ${ }^{617}$ Con frecuencia se les colocaban argollas de hierro para evitar su fuga. Tampoco hay que despreciar la cantidad de ellos que morían en el trayecto a la Península. No obstante, los esclavos bautizados podían aspirar a su liberación o su

\footnotetext{
${ }^{614}$ Ya vimos que los duques de Medina Sidonia poseían 250 esclavos hacia 1507.

${ }^{615}$ CORTÉs LÓPEZ, J. L.. La esclavitud negra ..., p. 129.

${ }^{616}$ Franco Silva, A. La esclavitud en Sevilla ... , pp. 152-154.

${ }^{617}$ PIKE, R. Aristócratas y comerciantes..., p. 187.
} 
«ahorramiento», en terminología de la época. En muchos casos eran liberados en los testamentos tras una vida de servicio fiel, en otros se les permitía trabajar en talleres de artesanos ahorrando una pequeña parte (de ahí el término ahorrar), pues la mayor iba a los bolsillos del amo, para comprar su liberación.

El mayor mercado europeo de esclavos lo constituían las Gradas de la Catedral de Sevilla, donde se realizaban ventas y subastas de todo tipo. Las Gradas, delimitadas por columnas de granito y cadenas, pertenecían a la jurisdicción eclesiástica, por lo que el cabildo catedralicio tenían mucho que decir y, de hecho, algunos canónigos participaban de los negocios que allí se gestaban.

Hace ya años fue dado a la luz un documento proveniente de la parroquia del Sagrario de la catedral sevillana, en el que se mostraba que Alonso Mudarra poseía al menos tres esclavas. ${ }^{618}$ El documento es un acta bautismal fechada el 18 de junio de 1570 en donde se bautiza a Francisca «esclava de señor canónigo Mudarra» y a Juana, «hija de María». ${ }^{619}$ Es decir se trata de dos adultas y una niña. Los padrinos fueron Andrés de Aguilar, clérigo y sacristán mayor de la catedral y Maria Jesús, vecina de la collación de San Miguel. En el artículo de Preciado parece insinuarse la paternidad de Mudarra sobre la niña esclava. Podría ser posible, pero no lo creemos. Era frecuente que los dueños de las esclavas tuvieran hijos con ellas y que en el caso de los clérigos se intentara silenciar el nombre del padre, pero con frecuencia los hijos son reconocidos y en muchos casos son liberados en los testamentos de sus amos, incluso dejándoles todos su bienes. ${ }^{620}$ Raro sería que un clérigo vendiera a su propio hijo y a su concubina a extraños. En este caso creemos probable que hubiera vendido a las tres esclavas, porque no queda ninguna de ellas en poder de Mudarra en el momento de su fallecimiento.

\footnotetext{
${ }^{618}$ PRECIADO, Dionisio. «Las esclavas del canónigo vihuelista Alonso Mudarra (†1580)», Revista de Musicología, 2 (1979), pp. 132-135.

${ }^{619}$ Entre las razones que llevaban a una persona a bautizar a sus esclavos había dos principales: la liberación o la venta. Muchos traficantes bautizaban a sus esclavos antes de embarcarlos hacia América o antes de venderlos en las Gradas, de ahí la gran cantidad de partidas bautismales de la parroquia del Sagrario. Franco SiLVA, A. La esclavitud en Sevilla... , pp. 231-242.

${ }^{620}$ Franco Silva, A. La esclavitud en Andalucía..., p. 126.
} 
En el momento de su muerte, Alonso tenía en su poder a otras dos esclavas distintas a las anteriores: Madalena, que debió ser liberada, pues pudo pujar en la almoneda y Esperanza, de 16 o 17 años, que fue vendida por 92 ducados (34.500 mrs.).

Encontramos, de momento, a cinco esclavas en poder de Mudarra, pero para nuestra sorpresa todavía hubo más.

El 4 de noviembre de 1560, el canónigo Alonso Mudarra firmaba personalmente ante el escribano Diego Ramos la venta de un esclavo negro de nombre Juan. ${ }^{621}$ Decimos personalmente porque, como veíamos antes, los clérigos no podían actuar como vendedores directamente, por lo que usaban procuradores. El esclavo fue vendido a Beatriz de Morales, viuda de Alonso de Molina, por importe de 95 ducados (35.625 mrs.). Escasos datos nos aporta el documento sobre las características de Juan, edad de veinticinco años «poco más o menos» y los típicos formulismos de los documentos de compraventa de esclavos. Ser «de buena guerra e no de paz», no ser enfermo, ni borracho, ni ladrón, ni huidor, ni herético, ni endemoniado. Es decir, perfecta salud corporal y de alma. Mudarra se compromete a devolver el importe del esclavo si tuviera alguna enfermedad «secreta». Podemos considerar un precio alto el pagado por Beatriz, considerando, como veíamos antes, que se trata de un varón y de que 20 años después la esclava Esperanza, del mismo canónigo, fue vendida por 92 ducados. Digamos que Mudarra hizo un buen negocio.

No sabemos qué trato dispensaría Mudarra a sus esclavos, lo que es cierto es que en el inventario figura «Una argolla de hierro para esclavo», lo que hace posible que Mudarra actuara como intermediario comprando y vendiendo esclavos para obtener buenos beneficios.

${ }^{621}$ AHPSe, Oficio 5, de Diego Ramos, Libro $3^{\circ}$ de 1560, Signatura 3407, f. 482. Reproducimos nuestra transcripción en los anexos. 


\section{Los testamentos de Mudarra}

Como ya indicábamos antes, tenemos un testamento de Alonso Mudarra, pero no es el último, fechado el 24 de marzo de 1580, sino el del 23 de febrero de $1576 .{ }^{622}$ Aun así, nos ha permitido conocer varios datos sobre la familia de Alonso y algunas otras cuestiones.

Tras una presentación formularia que nos dice dónde vivía, en la collación de Santa María la Mayor, comienzan las mandas testamentarias. Solicita ser enterrado en la iglesia catedral, pero no quiere que se le hagan honras fúnebres. Pide que se le haga la vigilia y la misa que le corresponde como beneficiado, dotándolas de lo necesario para cera y para los capellanes de la veintena que han de llevar su cuerpo. Para estos últimos concede 2 reales (68 mrs.) extra para cada uno. En la capilla de la Antigua pide 22 misas en las nueve fiestas de la Virgen y en las trece de la Luz, para lo que provee la limosna acostumbrada y 3 ducados (1.125 mrs.) para cera.

Para el día de su defunción, y si no se puede, otro día, solicita una misa de réquiem con su vigilia en la catedral, para lo que reserva 6 ducados ( 2.250 mrs.), además de otras treinta misas en el mismo sitio a 3 reales $(102$ mrs.) cada una.

Dona a la fábrica de la catedral 6 ducados $(2.250 \mathrm{mrs}$.), a las obras pías 2 reales (68 mrs.) a cada una y a los niños huérfanos 4 ducados (1.500 mrs.).

Después de ocuparse de su alma, pasa a ocuparse de sus familiares y criados. En primer lugar de su hermana Ysabel, monja en el monasterio de Santa Clara de Soria. Para el monasterio dona 6 ducados (2.250 mrs.) y para su hermana, si estuviera viva en el momento del fallecimiento del canónigo, 100 ducados (37.500 mrs.), con la condición de que se le vayan dando poco a poco según sus necesidades. Inmediatamente después se ocupa de sus criados a los que se les debe liquidar lo que constara en su libro de cuentas, además de dos ducados a cada uno. A su ama Marigarcía y a su marido Castillo lega la ropa de cama en la que duermen. A continuación prosigue con su familia. A su sobrino homónimo, hijo de su hermana Catalina Mudarra y el difunto Bartolomé de Soria, que vivía con él, le dona 100 ducados (37.500 mrs.) además de los otros 100 que le había dado

\footnotetext{
${ }^{622}$ AHPSe, Oficio 19, de Luis Sánchez Guerrero, Libro $2^{\circ}$ de 1576, Signatura 12432, ff. 439-440v. Reproducimos nuestra transcripción en los anexos.
} 
ya para sus estudios. También le da toda su ropa, su cama con todos sus complementos, colchones, cortinas, etc. A su madre, Catalina, otros 100 ducados. Llama la atención que en la almoneda posterior al fallecimiento de nuestro vihuelista se vendiera la ropa y la cama colorada, lo que nos hace pensar en que en el último testamento, el de 1580, su sobrino no heredaba estas cosas, tal vez porque hubiera fallecido. Por último, nombra como herederos universales de todos sus bienes, que no especifica, a su hermana Ana, viuda de Juan de Flores de Herrera y a su sobrina Ana de Herrera, casada con Sancho de Medrano, vecinos todos de la ciudad de Soria.

Para la ejecución del testamento nombra por albaceas a los dos curas del Sagrario de la catedral de Sevilla más antiguos, y a los cinco curas les dona veinte fanegas de trigo para que se las repartan. No fueron estos los albaceas definitivos, sino Antonio Ramos.

Otras varias cosas debieron cambiar en el testamento que firmó antes de fallecer y que, desdichadamente, no hemos podido localizar. Sabemos que se realizó el 24 de marzo de 1580. Ya vimos que en el primer testamento Mudarra legaba dos ducados a cada uno de sus criados, sabemos por otro documento fechado el 9 de mayo de $1580^{623}$ que, por lo menos, uno de sus criados, Miguel de Abrego, recibió 6 ducados (2.250 mrs.) además de los atrasos correspondientes de dos meses: 24 reales $(816 \mathrm{mrs}$.), lo que nos aporta el dato de que el salario de Abrego era de 144 reales (4.896 mrs.) anuales. Suponemos que más la manutención.

El último documento que conservamos, fechado el 18 de mayo de 1580, se refiere a la venta de la cebada y del trigo que se le debía al canónigo Mudarra. ${ }^{624}$ La cebada, 20 fanegas y 11 almudes, se vendió a miembros del cabildo al precio de la tasa (5,5 reales) y el trigo, 42 fanegas y media, a las hermanas y sobrinas de Mudarra, también a tasa (11 reales). ${ }^{625}$ Del sobrino Alonso nada sabemos.

${ }^{623}$ AHPSe, Oficio 19, de Gaspar de León Garabito, Libro $3^{\circ}$ de 1580, Signatura 12459, f. 285. Reproducimos nuestra transcripción en los anexos.

${ }^{624}$ AHPSe, Oficio 19, de Gaspar de León Garabito, Libro $3^{\circ}$ de 1580, Signatura 12459, f. 386. Reproducimos nuestra transcripción en los anexos.

${ }^{625}$ Que el vender el trigo y la cebada fuera algo beneficioso para los compradores indica que se debía vender en Sevilla a un precio superior. Por otra parte vemos como las tasas que se usaron fueron las fijadas 
También tuvo Mudarra en sus últimas disposiciones sensibilidad hacia los pobres vergonzantes de la collación de Santa María. ${ }^{626}$

ACS 574./f. 30 v./ Miercoles 6 de junio de 1582

En este dicho dia nombraron para dar la limosna en esta collacion que ordeno el señor canonigo mudarra que aya gloria a los señores mohedano y bartolome ruiz la qual den conforme a la disposicion del dicho mudarra a los pobres vergonçantes desta dicha collaçion.

Mudarra fallecía el Viernes santo 1 de abril de 1580 a las siete horas de la mañana. ${ }^{627}$

por Felipe II en 1566 para la cebada y en 1571 para el trigo. HAMILTON, Earl J. El tesoro americano..., pp. 262263.

${ }^{626}$ Lo cual no quiere decir que se diera a los pobres los $92.000 \mathrm{mrs}$. como se ha afirmado en varias ocasiones.

${ }^{627}$ «Falleçió el sobredicho Viernes sancto primero de abrill del U dLxxx ${ }^{\circ}$ años a las siete antes de oras». Archivo de la Catedral de Sevilla, Libro de Entrada de Prebendados, Sección I. Secretaría. Serie 3. Personal. Sign. 07434, f. 24v. 


\section{PARTe II}

\section{ObRas de Alonso MUdARRA}





\section{LOS TRES LIBROS DE MÚSICA EN CIFRAS PARA VIHUELA}

\section{E1 libro}

Tan sólo dos ejemplares del libro de Mudarra han llegado hasta nuestro días, uno está en la Biblioteca Nacional de Madrid (R. 14630) y el otro en la Real Biblioteca del Monasterio de San Lorenzo de El Escorial (15-VI-43).

Se trata de un volumen en $4^{\circ}$ apaisado, en el que cada uno de los tres libros que contiene lleva su propia portada y foliación independiente. Las tres portadas están «enmarcadas por la misma orla xilográfica con motivos vegetales y dos angelotes sosteniendo la imagen de la cruz en el Calvario rodeada por el lema: "Soli Deo honor et gloria"»». ${ }^{628}$

El papel utilizado es el mismo en los tres libros, papel con la filigrana «de la mano» o guante con una flor de cinco pétalos saliendo del dedo corazón, ${ }^{629}$ mientras que en las hojas de guarda se utiliza papel diferente.

La estructura de los cuadernillos es algo irregular, principalmente en el libro tercero y creemos que las fórmulas de colación de cuadernillos que se manejan en ambos ejemplares son incorrectas. Proponemos la siguiente:

$$
\text { 4. }{ }^{\circ} \text {; A4, A-C8, A-C8, D4, A6, b-h8, []8, []8 }
$$

Además, en este libro tercero no se numeraron los folios excepto los cuatro primeros e incorrectamente, pues se repite el f. 3, por lo que el índice se refiere a las obras y no a los folios.

Los dos ejemplares presentan algunas diferencias que veremos a continuación.

\footnotetext{
${ }^{628}$ Tomamos parte de la descripción del catálogo de la BNE.

${ }^{629}$ Lamentablemente esta filigrana aparece en toda Europa desde el siglo XV al XVII por lo que no nos aporta ningún dato sobre su origen o fecha, lo único, nos permite saber que todo el libro se hizo con la misma partida. Montaner Frutos, Alberto. Prontuario de bibliografía. Pautas para la realización de descripciones, citas y repertorios. Gijón, Ediciones Trea, 1999, p. 87.
} 
BNE R. 14630 (E: Mn R/14630)

Dimensiones $141 \times 200 \mathrm{~mm}$. Procedente del fondo Barbieri. ${ }^{630}$

Según la descripción de Anglés/Subirá: ${ }^{631}$

Encuadernación en piel blanca. Título envuelto en una orla decorativa; en el centro de la parte superior, una cruz encuadrada en un círculo con una inscripción latina que ha quedado incompleta al recortar los bordes para encuadernar la obra.

Ejemplar mutilado, pues en el Libro tercero faltan varios fols. s. n. Además, en los últimos pliegos está rota la parte superior del ángulo derecho y deja incompletos los textos literario y musical, así como parte de los folios finales de erratas.

Posteriormente a la descripción de Anglés y Subirá, ha sido nuevamente encuadernado y restaurado, en 1974, según consta en el tejuelo del interior de la tapa y en la descripción bibliográfica. La encuadernación actual es en «pergamino sobre cartón con filetes dorados en las tapas».

La portada presenta un dibujo a pluma, de no muy buena factura, de un laudista y en el f. A4v de los preliminares hay una rúbrica, Dominguos Romano, y varios fragmentos de notación mensural blanca. Hay numerosas correcciones en su interior, muchas de ellas coincidentes con las indicadas en la fe de erratas, lo que puede indicar que el libro fue usado.

La descripción bibliográfica es la siguiente:

[4], XXIV, [1], XXVII, [1], III [i.e. IV], [50] h., [16] h. en bl. il.

El libro se encuentra en muy mal estado desde su origen, pues fue incorrectamente encuadernado e impaginado, por lo que faltan muchas hojas y otras se encuentran

\footnotetext{
${ }^{630}$ Pujol erróneamente dice que el ejemplar de el Escorial es el que procede del fondo Barbieri. PujOL. Mudarra, p. 37. Otro importante desliz de Pujol es haber cambiado el título de la obra de Mudarra. Donde dice «música en cifra» debería decir «música en cifras». Este error se ha ido arrastrando posteriormente.

${ }^{631}$ ANGLÉs, Higinio y SuBIRÁ, José. Catálogo Musical de la Biblioteca Nacional de Madrid. III Impresos: Música práctica. Barcelona, CSIC, Instituto Español de Musicología, 1951, n 101, pp. 89-90.
} 
indebidamente situadas principalmente en el Libro III. La colación de cuadernillos dada por la BNE es:

$$
\text { 4. }{ }^{\circ} \text {; A4, A -C8, A -C8, D4, a -c6, d8, e6, f8? }{ }^{1}, \mathrm{~g}-\mathrm{h} 8,[] 8,[] 8
$$

Errores de signatura: aparte de múltiples errores en la numeración, en el cuadernillo D4 figura G1 por D1y C3 por D3.

Creemos que hay un error, pues en el tercer libro los cuadernillos b, c y e constan de 8 hojas. La fórmula que incluyen en su descripción Anglés y Subirá es la misma incorrecta de la BNE.

Si bien detallamos en cada una de las obras la distribución de los folios o su ausencia cuando ello ocurre, vamos a incluir la secuencia del tercer libro que presenta este ejemplar. ${ }^{632}$

III Libro: A1-6, b1-6, b8 $, \mathrm{b} 7^{\mathrm{b}}, \mathrm{c} 3^{\mathrm{a}}, \mathrm{b} 8^{\mathrm{b}}, \mathrm{c} 4^{\mathrm{a}}, \mathrm{c} 3^{\mathrm{b}}, \mathrm{c} 5^{\mathrm{a}}, \mathrm{c} 4^{\mathrm{b}}, \mathrm{c} 6^{\mathrm{a}}, \mathrm{c} 5^{\mathrm{b}}, \mathrm{d} 1^{\mathrm{a}}, \mathrm{c} 6^{\mathrm{b}}, \mathrm{d} 2^{\mathrm{a}}, \mathrm{d} 1^{\mathrm{b}}, \mathrm{d} 3^{\mathrm{a}}$, $\mathrm{d} 2^{\mathrm{b}}, \mathrm{d} 4^{\mathrm{a}}, \mathrm{d} 3^{\mathrm{b}}, \mathrm{d} 5^{\mathrm{a}}, \mathrm{d} 4^{\mathrm{b}}, \mathrm{d} 6^{\mathrm{a}}, \mathrm{d} 5^{\mathrm{b}}, \mathrm{d} 7^{\mathrm{a}}, \mathrm{d} 6^{\mathrm{b}}, \mathrm{d} 8^{\mathrm{a}}, \mathrm{d} 7^{\mathrm{b}}, \mathrm{e} 1^{\mathrm{a}}, \mathrm{d} 8^{\mathrm{b}}, \mathrm{e} 2^{\mathrm{a}}, \mathrm{e} 1^{\mathrm{b}}, \mathrm{e} 3^{\mathrm{a}}, \mathrm{e} 2^{\mathrm{b}}, \mathrm{e} 4^{\mathrm{a}}, \mathrm{e} 3^{\mathrm{b}}, \mathrm{e} 5^{\mathrm{a}}, \mathrm{e} 4^{\mathrm{b}}$, $\mathrm{e} 7 \mathrm{a}, \mathrm{e} 5^{\mathrm{b}}, \mathrm{e} 8^{\mathrm{a}}, \mathrm{e} 7^{\mathrm{b}}, \mathrm{f} 1^{\mathrm{a}}, \mathrm{e} 8^{\mathrm{b}}, \mathrm{f} 3^{\mathrm{a}}, \mathrm{f} 1^{\mathrm{b}}, \mathrm{f} 4^{\mathrm{a}}, \mathrm{f} 3^{\mathrm{b}}, \mathrm{f} 5^{\mathrm{a}}, \mathrm{f} 4^{\mathrm{b}}, \mathrm{f} 6^{\mathrm{a}}, \mathrm{f} 5^{\mathrm{b}}, \mathrm{f} 8^{\mathrm{a}}, \mathrm{f} 6^{\mathrm{b}}, \mathrm{g} 1^{\mathrm{a}}, \mathrm{f} 8^{\mathrm{b}}, \mathrm{g} 2^{\mathrm{a}}, \mathrm{g} 1^{\mathrm{b}}, \mathrm{g} 3^{\mathrm{a}}, \mathrm{g} 2^{\mathrm{b}}$, $\mathrm{g} 4^{\mathrm{a}}, \mathrm{g} 3^{\mathrm{b}}, \mathrm{g} 5^{\mathrm{a}}, \mathrm{g} 4^{\mathrm{b}}, \mathrm{g} 6^{\mathrm{a}}, \mathrm{g} 5^{\mathrm{b}}, \mathrm{g} 7^{\mathrm{a}}, \mathrm{g} 6^{\mathrm{b}}, \mathrm{g} 8^{\mathrm{a}}, \mathrm{g} 7^{\mathrm{b}}, \mathrm{h} 1^{\mathrm{a}}, \mathrm{g} 8^{\mathrm{b}}, \mathrm{h} 2^{\mathrm{a}}, \mathrm{h} 1^{\mathrm{b}}, \mathrm{h} 3^{\mathrm{a}}, \mathrm{h} 2^{\mathrm{b}}, \mathrm{h} 4^{\mathrm{a}}, \mathrm{h} 3^{\mathrm{b}}, \mathrm{h} 5^{\mathrm{a}}, \mathrm{h} 4^{\mathrm{b}}$, h6 $6^{\mathrm{a}}, \mathrm{h} 5^{\mathrm{b}}, \mathrm{h} 7^{\mathrm{a}}, \mathrm{h} 6^{\mathrm{b}}, \mathrm{h} 8^{\mathrm{a}}, \mathrm{h} 7^{\mathrm{b}}, i 1^{\mathrm{a}}, \mathrm{h} 8^{\mathrm{b}} \ldots$

Faltarían las páginas: $\mathrm{b} 7^{\mathrm{a}}, \mathrm{c} 1^{\mathrm{a}}, \mathrm{c} 1^{\mathrm{b}}, \mathrm{c} 2^{\mathrm{a}}, \mathrm{c} 2^{\mathrm{b}}, \mathrm{c} 7^{\mathrm{a}}, \mathrm{c} 7^{\mathrm{b}}, \mathrm{c} 8^{\mathrm{a}}, \mathrm{c} 8^{\mathrm{b}}, \mathrm{e} 6^{\mathrm{a}}, \mathrm{e} 6^{\mathrm{b}}, \mathrm{f} 2^{\mathrm{a}}, \mathrm{f2} 2^{\mathrm{b}}, \mathrm{f} 7^{\mathrm{a}}, \mathrm{f} 7^{\mathrm{b}}$.

En resumen, podemos decir que este ejemplar sufrió varios incidentes y en diferentes ocasiones. En el taller de impresión hubo algún problema con los cuadernillos b y c y puede que en algún otro punto. Después de que el libro se vendiera y pasara por manos de su propietario, quien escribió una serie de piezas manuscritas al final, perdió algunas hojas y fue encuadernado de nuevo, con tan mala suerte que desde el cuadernillo c en adelante todas las hojas están volteadas. ${ }^{633}$

${ }^{632}$ Indicamos con el superíndice a y b el recto y verso respectivamente.

${ }^{633} \mathrm{La}$ «maldición» de este libro no acaba aquí ya que incluso la edición facsimilar de Tyler comete el error de trastocar los ff. e5 y e6. TYLER, James (ed.). Complete facsimile edition with an introduction by James Tyler. Mónaco, Chanterelle, 1980. 
En este ejemplar se encuentran dieciséis hojas añadidas al final con música manuscrita en tablatura. Son seis obras de Fuenllana (dúos y obras a tres) copiadas por la misma mano y una Basa e alta copiadas por otra mano diferente. El contenido detallado es (indicamos con la abreviatura $\mathrm{Fu}$, el número de pieza según la edición de Jacobs ${ }^{634}$ con la que se corresponde cada una):

f. 1. «dúo de flecha que dis, se amores me ao de matan». «Volta» $\left(\mathrm{Fu} \mathrm{n}^{\circ} 4\right)$

f. 1v. «comtrapomto sobre este vilancete» «Volta» $\left(\mathrm{Fu} \mathrm{n}^{\circ} 5\right)$

f. 2v. «Dúo de folhana» (Fu no 9)

f. 4. «dúo de morales susepi disrael» $\left(\mathrm{Fu} \mathrm{n}^{\circ} 3\right)$

f. 5. «beneditus a tres da misa de guaude barbara de morales» (Fu n $\left.{ }^{\circ} 13\right)$

f. 6. «beneditus a quatro da misa dave Regina celorum de morales» ( $\mathrm{Fu} \mathrm{n}^{\circ} 53$ )

f. $7 \mathrm{v}$. «et acemdi im celum a tres da misa dave Regina celorum» (Fu n ${ }^{\circ} 11$, sólo dos compases)

f. 8. en blanco

f. $8 \mathrm{v}$. «basa e alta» Se trata de una obra anónima aunque con algunas coincidencias con Il ballarino de Caroso. ${ }^{635}$

f. 9v. «alta»

f. 10. fragmento en cifra

f. $10 \mathrm{v}$. blanco

ff. 11-16. blancos con pauta de seis.

Las figuras rítmicas no fueron copiadas en todas las piezas y su ausencia hace imposible su ejecución correcta, tal vez debían ser añadidas posteriormente. El autor del manuscrito pudo ser el dueño del libro, Dominguos Romano, lo que es apoyado por la presencia de palabras en portugués (vilancete por villancico o Folhana por Fuenllana). Podemos decir que las obras de Fuenllana fueron copiadas por una mano portuguesa y que no terminó con su labor.

\footnotetext{
${ }^{634}$ JACOBS, Charles (ed.). Fuenllana, Orphénica Lyra. Oxford, Oxford University Press, 1978.

${ }^{635}$ CAROSO, Fabritio. Il ballarino. Venecia, Francesco Ziletti, 1581.
} 
RBME 15-VI-43 (E: E 15-VI-43)

Encuadernación del siglo XVI de la biblioteca del Monasterio en cuero leonado o castaño. Cantos dorados, como es característico en los libros de esta biblioteca, marcado en el lado corto «44 MVDARRA», es decir, la antigua signatura y la identificación. Las primeras páginas están muy deterioradas y todo el libro tiene una mancha de humedad en la zona inferior.

Sus dimensiones son 145 × $200 \mathrm{~mm}$. (exteriores 154 × $204 \mathrm{~mm}$.), lo que indica que ha sido menos mutilado que el ejemplar de la BNE, ya que mantiene la encuadernación original. No procede de la «Librería rica» de Felipe. ${ }^{636}$

No presenta todas las correcciones que aparecen en el otro ejemplar, sin embargo las correcciones de los titulillos de los ff. 21 y $22 \mathrm{v}$ son coincidentes incluso en la letra, lo que nos indica que fueron hechas en el mismo proceso de impresión. Solamente hay correcciones a mano y señaladas al margen en dos obras Durmiendo yva el Señor y Claros y frescos ríos, lo que más bien parece obra de algún investigador o lector posterior. Creemos que el libro pasó directamente a la biblioteca del monasterio y no fue usado.

La fórmula de colación dada por la ficha de la biblioteca es también errónea, pues asigna al cuadernillo A del libro tercero 8 hojas en lugar de 6 .

${ }^{636}$ Colección formada entre 1535 y 1559. GONZALO SÁnCHEZ-MOLERO, José Luis. La "Librería rica” de Felipe II. Estudio histórico y catalogación. San Lorenzo de El Escorial, Estudios Superiores del Escorial, 1998. 


\section{La impresión. Juan de León}

La impresión de los Tres libros de música corrió a cargo de Juan de León. Ya hemos visto que debió ser bastante problemática, lo que produjo una gran cantidad de erratas, superando en número incluso al libro de Pisador. Esto se puede deber a la inexperiencia del impresor en libros de música o a la situación del autor, que, al mismo tiempo que se ocupaba del libro, estaba en pleno nombramiento como canónigo, lo que posiblemente dificultó las correcciones. En los libros de cifra era común que las correciones en el taller las llevara a cabo el propio autor, o alguien de su confianza, pues no sería muy común que los impresores españoles conocieran el sistema de cifra tan a fondo.

Mudarra eligió un formato como el de Narváez y muy común en Italia y Francia, el cuarto apaisado, y además prescindió de la cifra colorada que disparaba los costes de impresión. En su lugar utilizó rasguitos o sacó la voz que se cantaba en figuras de canto de órgano de manera que se podía imprimir su libro en una sola tirada. Vamos a repasar los sistemas de impresión utilizados por los vihuelistas. Denominaremos método italiano al empleado por Petrucci (doble impresión: primero se imprimían las pautas y después las figuras y las cifras, lo que implicaba una muy cuidadosa alineación.) y método francés al de Attaingnant (tipos con pauta y signo y una única impresión: se combinaba cada nota o símbolo (letra) con su propio segmento de pentagrama en un sólo tipo de imprenta, este sistema era más económico que el de la doble impresión, pero menos bello a la vista, puesto que se aprecian en muchos casos los huecos en el pautado). El libro de Milán fue impreso por posiblemente con el método francés, mediante una doble tirada, primero las cifras en rojo y en una segunda impresión el resto en negro. Narváez usó probablemente el método italiano, con tres tiradas: primero el rojo, luego la pauta y por último la tirada de negro. Mudarra utilizó el método francés con una sola tirada. Valderrábano, Pisador y Fuenllana comparten, además del formato en folio, el método francés y el uso del color rojo, con dos impresiones, primero rojo y después negro. Por último el libro de Daza recupera el formato en cuarto apaisado que ya usaron Narváez y Mudarra y los rasguitos para la línea vocal, por lo que de nuevo una tirada bastaría. 
En la primera mitad del siglo XVI, Sevilla se había convertido en el mayor centro productor de libros y naipes de Castilla, muchos de los cuales estaban destinados al comercio con las Indias. ${ }^{637}$ Juan de León comenzó su actividad sevillana como naipero y en 1545 inició la impresión de libros con la Historia Imperial y Cesárea, de Pedro Mejía y el Tratado de la Sphera, de Juan de Sacrobusto en traducción de Jerónimo de Chaves.

En estas primeras impresiones aparece una marca de impresor, el emblema de Hércules con el lema «Labor omnia vincit», que no aparece en la obra de Mudarra, pero sí más tarde en la de Fuenllana. En 1547, León imprimió la Summa de Philosophia natural, de Alonso de Fuentes. ${ }^{638}$ Desde 1549 a 1555 desarrolló su actividad en Osuna, tras ser nombrado impresor de la universidad fundada el año anterior por don Juan Téllez de Girón, IV conde de Ureña. Allí imprimió los tres libros de Bermudo ${ }^{639}$ y los Villancicos y canciones de Juan Vázquez. ${ }^{640}$

La marca tipográfica que Juan de León usa en las tres portadas del libro de Mudarra, el emblema del Gólgota con los tres clavos, le fue traspasada por el impresor sevillano Gaspar Zapata en 1545, quien también le cedió la letrería, capitulares decoradas y tabernáculos (orlas completas). ${ }^{641} \mathrm{La}$ inscripción que figura en dicha marca, «Soli Deo honor et gloria», aparece relacionada en otros libros (como las dos primeras obras de Bermudo y los villancicos de Vázquez) con la frase «Sola fides sufficit», ambas con connotaciones luteranas. En estos años el círculo luterano sevillano estaba en pleno auge, por lo que no es descartable algún significado que relacione a Juan de León, o a Mudarra, con estas heterodoxias. ${ }^{642}$

${ }^{637}$ MORALes Padrón, F. Historia de Sevilla..., p. 164.

${ }^{638}$ Escudero y Perosso, Francisco. Tipografía hispalense. Anales bibliográficos de la ciudad de Sevilla desde el establecimiento de la imprenta hasta finales del siglo XVII. Madrid, Sucesores de Rivadeneyra, 1894. Nótese que tanto el libro de Mejía como el de Fuentes figuran en el inventario de libros de Mudarra, posiblemente como regalo del propio impresor.

${ }^{639}$ Bermudo, Fray Juan. Comiença el libro primero de la declaración de instrumentos. Osuna, Juan de León, 1549, Bermudo, Fray Juan. Arte Tripharia. Osuna, Juan de León, 1550 y Bermudo. Declaración.

${ }^{640}$ VÁZQUEZ, Juan. Villancicos $i$ canciones de Inan V asqueza a tres y a cuatro. Osuna, Juan de León, 1551.

${ }^{641}$ Zapata había impreso varios libros en 1543 y 1544. En 1550 figura como criado de Fadrique Enríquez, hermano del marqués de Tarifa, en 1559 fue reclamado por la Inquisición y al encontrarse en Nápoles fue quemado en estatua por luterano en 1562. MoLL, Jaime. «Gaspar Zapata, impresor sevillano condenado por la Inquisición en 1562», Pliegos de Bibliofilia, 7 (1999), pp. 5-10.

${ }^{642}$ Son varios los impresores sospechosos y condenados por luteranos o erasmistas. Además de Zapata, ya citado, es conocido el caso del alcalaíno Miguel de Eguía. 
Tras la marcha de Juan de León a Osuna, debió vender las letras iniciales y los ornamentos tipográficos a Martín de Montesdoca, ${ }^{643}$ quien tomó el relevo en las impresiones musicales en Sevilla. Recordemos que de su taller salió la Orphénica lyra de Fuenllana, las Sacrae Cantiones de Francisco Guerrero y la Agenda defunctorum de Juan Vázquez. La pregunta que se nos plantea es, si Juan de León cedió sus materiales tipográficos a Montesdoca, por qué no hizo lo mismo con las tipografías de la cifra y canto de órgano que utilizó con Mudarra. En el libro de Bermudo de 1555 hay algún ejemplo de cifra de vihuela (f. 101, por ejemplo), pero aunque se parecen bastante las cifras de vihuela no pasa lo mismo con el canto de órgano. Hay una explicación posible, al igual que ocurrió años más tarde con Cabezón, ${ }^{644}$ Mudarra se quedó tras la impresión con la tipografía. Tampoco sabemos si Juan de León se ocupó de la fundición de los tipos originales o Mudarra los había conseguido previamente en otro sitio, tal vez Alcalá de Henares.

Queda saber cómo costeó Mudarra la impresión de su obra ya que en esta época debía andar un poco ajustado económicamente y las impresiones eran caras. Mediante un documento de 1557 sabemos que tuvo que reclamar a Atanasio de Salzedo, librero de Alcalá de Henares, 250 reales (8.500 mrs.) que le debía por 150 ejemplares de su libro que le había dejado para vender. ${ }^{65}$ Para la reclamación dió poderes al arcipreste de Maqueda, Antonio de Torres y a su criado, Alonso García, para que lo hicieran en su nombre.

Atanasio de Salzedo, «librero vecino de la villa dalcalá de Henares», figura en 1529, junto a el impresor Cristóbal Francés, en una escritura de concierto para imprimir un Amadís de Grecia. ${ }^{646}$ En 1534 consta en un documento junto a Francisco de Navascues, impresor, relacionados con la venta de unos misales y breviarios. En 1536 participa con Miguel de Eguía, con el que ya había tenido relación anteriormente, en la impresión de los Parthenice septem de Juan Bautista de Mantua. En 1544 adquiere la tirada íntegra, 1.000

\footnotetext{
${ }^{643}$ WAGNER, Klaus. Martín de Montesdoca y su prensa. Contribución al estudio de la imprenta y de la bibliografía sevillanas del siglo xvi. Sevilla, Universidad de Sevilla, 1982.

${ }^{644}$ PÉREZ PASTOR, Cristóbal. «Escrituras de concierto para imprimir libros», Revista de Archivos, Bibliotecas y Museos, 26 (1897), pp. 363-371; p. 367.

${ }^{645}$ Lo que implica que habían fijado un precio por libro de unos $57 \mathrm{mrs}$. a lo que habría que añadir el beneficio del librero.

${ }^{646}$ MARTín ABAD, Julián. La imprenta en Alcalá de Henares (1502-1600). Madrid, Arco Libros, 1991, 3 vols. Vol 1, pp. 84-87.
} 
ejemplares, del Codex de poenitentia de Juan de Medina, impreso por Juan de Brocar. Por ello pagó la cantidad de 238.000 mrs., dejando una buena cantidad de bienes hipotecados en garantía. Tras fallecer Brocar en 1552, Salzedo se dedicó a la impresión de pragmáticas cuyas licencias adquiría de Francisco del Castillo, Domingo de Zabala y Blas de Saavedra. Esté último, en 1558, le puso un pleito por impago de la cesión de uno de estos privilegios para imprimir y vender pragmáticas. ${ }^{647}$

En definitiva, no está demasiado claro por qué acabó Mudarra imprimiendo con Juan de León, si fue su primera elección o antes había tanteado a los impresores de Alcalá de Henares, a los que tal vez conocía. Tal vez quiso costear los gastos a medias con Salzedo, pero este acumulaba tantas deudas que una más no le debió importar demasiado.

${ }^{647}$ Ejecutoria del pleito litigado por Blas de Saavedra, escribano de cámara, con Atanasio de Salcedo, vecino de Alcalá de Henares (Madrid), sobre impago por la cesión y traspaso de la merced y privilegio para imprimir y vender pragmáticas. ARCHV, Registro de Ejecutorias, Caja 916, 6. 


\section{El prólogo y los textos}

A continuación damos los textos contenidos en el prólogo y cuerpo del libro de Mudarra en transcripción paleográfica simplificada.

[Libro 1, f. A1]

sey AlONSO

Sov MUDARRA

\section{s\% TRES LIBROS DE MÚSICA EN CI}

FRAS PARA VIHUELA. EN EL PRIMERO AY MÚSICA FÁCIL Y DIFÍ

cil en fantasías: y ComPosturas: y Pavanas: y Gallardas: y AlGunas fantasías pora guitarra. El segu[n]do trata de los ocho tonos (o modos) tiene muchas fantasías Por diversas partes: y Com-

posturas glosadas. El tercero es de música

para cantada y tañida. Tiene mo-

tetes. Psalmos. Romances.

canciones, Sonettos en

castellano: y Italiano.

Versos e[n] latín. Villa[n]zicos. Di-

rigidos al muy magní-

fico señor el se-

ñor do[n] Luys

çapata.

$\mathbb{C}$ Fue impresso el presente libro en la muy noble y leal ciudad de Sevilla en casa de Iuan de Leó[n]. 1546. 
[f. A1v]

\section{\&ov EPÍSTOLA AL MUY}

magnífico señor Don Luys çapata.

NOTORIA COSA ES MUY MAGNÍFICO SENNOR AVER SIDO TENIDO EN | mucho: entre los: Antiguos griegos, todo género de Música. Y principalmente el de la|Vihuela, porque Segú[n] cuenta Plutarco de Epaminundas príncipe de grecia aver sido muy|loado porque en un banquete tañó y cantó excelentemente. Y por el contrario: Themís-| tocles avido por indocto porque no lo supo hazer. En otra parte dize que Alcibiades solía|dezir que tenía por mejor la música de la vihuela que la de las flautas: porque con la vihue- | la no se pierde la habla: ni la figura del rostro, Como en las flautas la pierden los que las tañen: y esto en $\mathrm{ta}[\mathrm{n}] \mid$ ta manera que apenas son de sus amigos quando están tañendo conocidos. Marco Tullio Cicerón en | el primero de las Tusculanas: toca también lo de Epaminondas: y Themistocles; iuntamente con dezir q[ue]|los griegos pensavan estar en los cantos de las bozes; y sonido de las cuerdas la suma erudición. De ma-| nera que pues la música de los antiguos era tenida en gran veneración preciándose della grandes Ca-|pitanes: ansí Romanos como Griegos no devría en nuestros tiempos ser tenida en menos pues ay áni| mos y ingenios no menos osados y entendidos que en los passados. De lo qual estoy bien satisfecho|de v[uest] ra merced no avelle agraviado naturaleza En nada pues le dotó en todas las gracias y abilidades que pu|do. Y si de todos la música y todas las otras Artes fuesen tan favorecidas y entendidas como de vuestra|merced: no sólamente serían tenidas en algo las obras de muy excellentes Hombres: que el día de oy se |emprime[n]: mas las de los que medianamente lo hazen: las muy subidas para sacar fruto dellas y las que|han Principiado a subir para animar a los que las hazen a que osen passar adelante trabajando hasta llegar $\mid$ a entender lo que los que perfectamente lo hazen entienden. Y pues yo soy de los que no perfecta ni|medianame[n]te entienden, no dexaré de ampararme con su favor en esta mi obra la qual no sacara a luz|si no fuera por su mandado; y por tener alguna confiança de los que me conocen y saben los días que ha|que trabajo en el estudio de la vihuela los quales por esto, Y por saber que me é criado en casa de los Ilus | tríssimos señores Duques del Infantado mis señores do[n] Diego hurtado de mendoça que Dios tiene en | su gloria y don Íñigo lópez que oy vive y dios nuestro señor guarde a donde de toda Música avía ex-|celentes hombres pensaran que en estos mis Libros ay algunas 
migajas de tanto bueno como é visto en|aquella casa y en otras partes de España y en Italia. Las quales dos cosas me han hecho tener atrevim[i]ento / de querer sacar a luz esta mi obra la qual ofrezco a vuestra merced Suplicándole no mire al pequeño ser|[vi]cio sino a la voluntad con que se ofresce; la qual excede a todo lo que se le pudiera ofrescer.

[f. A2]

sov TABLA DEL LIBRO PRIMERO

C Fantasías a tres bozes
y a quatro.
C Fantasías de passos des enbueltos
C Otra fantasía de passos-
C Otra para desembolver las manos-_
C Otra de passos de contado -
C Otra fantasía fácil
$\mathbb{C}$ Otra fácil -
C Otra fantasía fácil
$\mathbb{C}$ Otra fantasía
C Otra fantasía
$\mathbb{C}$ Otra fantasía q[ue] co[n]tra haze la harpa
en la manera de luduvico -
Composturas de Iosquin
C La postrera parte de la gloria de la mis
sa de faysan regres

$\mathbb{C}$ Pleni de la mesma missa a tres Obras menudas

$\mathbb{C}$ Condeclaros en doze maneras-

C Romanesca o guárdame las vacas de cinco maneras-

$\mathbb{C}$ Una pavana

C Otra pavana de Alexandre Una gallarda

$\mathbb{C}$ Una fantasía a quatro bozes al tem ple viejo

\section{[f. A2v]}

$\mathbb{C}$ De cómo se an de entender estos libros.

AUNQUE EN OTROS DOS LIBROS DE CIFRAS PARA VIHUELA | que ay impressos en españa de dos excele[n]tes músicos en los quales ay obras de|muy buena música ansí suyas como de otros grandes componedores: ay da- $\mid$ da larga cue[n]ta de la orden de la Vihuela y de las 
cifras della. No por esto d[e]xaré|de dezir lo q[ue] en los dichos libros está dicho acerca de la declaración de las ci|fras co[n] declarar algu[n]as cosas que de mi cosecha pongo. Las cifras Son en cue[n]ta $\mid$ de alguarismo y son estas. $\theta 123456789$. C La primera se llama |zero en la cuerda que la tal estuviere se á de tocar en vazío sin poner el dedo|en ella. En todas las otras se an de poner los dedos. $\mathbb{C}$ La segunda cifra es|número de uno y es el Primer traste. $\mathbb{C}$ Y la tercera es dos y es a dos tras $\mid$ tes. $\mathbb{C}$ Y la quarta es tres y es a tres trastes y procediendo por las que res $\mid$ tan hasta la postrera que es nueve y señala al noveno traste. Y cuando passare la compostura o fantasía del|noveno traste y llegare al dezeno estará con esta cifra $*$ Y si al onzeno con esta. Ej. Estas cifras toman|la cantidad o valor de cinco figuras de canto de órgano las quales son estas. =odł.

|Van guiadas a las cifras con unos puntillos los quales no sirven de más que| de guiar. En todas las cifras no se ponen figuras de canto de órgano y las que no las tuvieren tomarán | el valor o cantidad de la figura que atrás quedare hasta que venga otra que prive aquella.

| Para saber a qué co[m]pás se an de tañer estas cifras se ponen tres tiempos diferentes $y$ son estos. $\notin \in$. I Los quales van puestos al principio de cada obra. La diferencia que ay de uno a otro es que|por el primero á de yr el compás apriessa. Y por el segundo ni muy apriessa ni muy a espacio. Por el tercero |á de yr despacio porque por este entran dobladas cifras en un compás que por los otros. Por los dos pri-|meros tantas cifras entran en un compás por el uno como por el otro. Solo ay la difere[n]cia di| cha. $\mathbb{C}$ La primera figura del canto de órgano de las arriba dichas por estos dos tiempos $\notin €$ vale $\mid$ dos compases. ${ }^{648}$ La qual no toparan en el primero ni segundo libros. En el tercero sí. Y tendrá un ras|go por encima desta manera $\cap$. El qual da a ente[n]der que pasa la mitad de aquella figura a otro compás.|Y lo mesmo se á de entender de las otras figuras quando tuvieren el dicho rasgo. Por el tercero t[iem]po que |es este. $\$$ la dicha primera figura vale un co[m]pás como en un exemplo que aquí pongo verán: desta | figura: y de todas las otras.

\footnotetext{
${ }^{648}$ Evidentemente se trata de un error, debe ser el signo de compás apriessa en lugar del de despacio.
} 
C Exemplo de todo lo dicho y de las rayas q[u]é cuerdas sean.
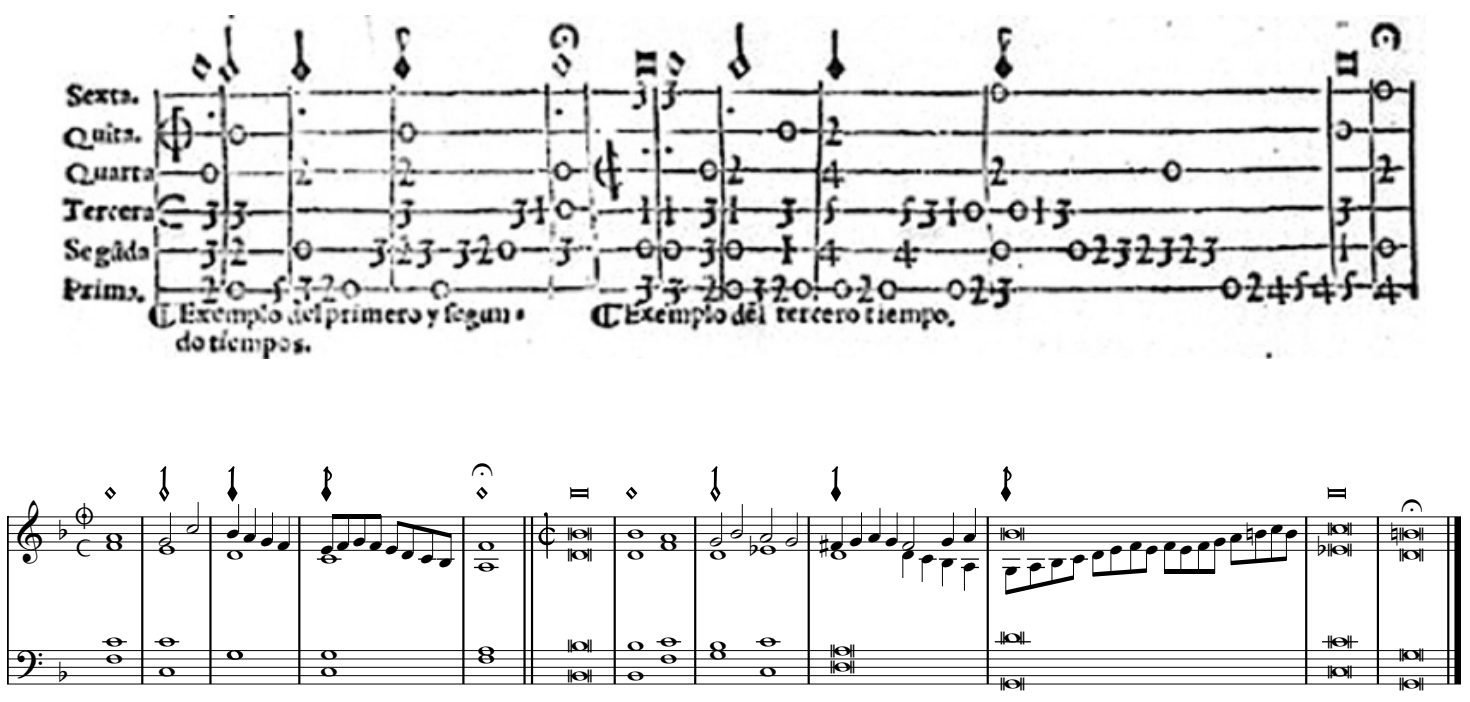

Fig. 20. MudArRA. Tres libros de música. Ejemplo del prólogo y su transcripción. Libro I, f. A3.

Todas las cifras q[ue] estuvieren un[as] en derecho de otras estando guiadas con $\mathrm{pu}[\mathrm{n}]$ tillos o sin ellos es un|golpe y se an de tocar aquellas cuerdas iuntas: y las q[ue] estuvieren salidas unas de otras se an de tocar|cada una por sí.

|C Las rayas que atraviessan de la sexta a al prima sirven de dividir los compases en los quales se vee|bien claro de cada figura exemplo de las que entran en un compás.

|C Esta diferencia de tiempos (o compases) con otros q[ue] no pongo aq[uí] no sin causa los Antiguos los usa-| ron y segú[n] mi parecer fue para conformar la música (o el movimiento della) con el sentido de la letra. Por|que si una letra es de materia alegre y regozijada de necessidad el compás á de yr regozijado y apriessa.|Y si otra ni del todo es alegre ni del todo triste también tendrá esta necessidad de otro compás que ni va| ya muy apriessa ni muy despatio. Y ni más ni menos la que del todo es triste querrá el compás despacio.

|C Acerca del redoble quiero dezir mi parecer. Y es q[ue] tengo por bueno el de dos dedos: y que quien qui- | siere tañer bien de mi consejo dévelo; usar porque es redoble más cierto: y que da mejor ayre a los pas-|sos. Del dedillo no digo mal quien pudiere tener 
entra[m]bas ma[n]eras de redoblar no se hallará mal co[n] ellas porque entrambas son menester a tie[m]pos. El dedillo para passos que se haze[n] de la prima hazia la sexta q[ue]|son de arriba para abaxo y el de dos dedos para los que se hazen de abaxo pa[ra] arriba y para el clausular|Todos los passos que fueren del valor de esta figura \$ Serán redoblados desto verán espirie[n]cia en tres fantasías q[ue] pongo al principio del primer libro y señalada cada manera de redoble deste arte adó dixere|

[f. A3v]

dos de. Será redoble de dos dedos. Y adó dedi. Será de dedillo.Todos los otros passos yrán sin redoble| no siendo del valor de la figura arriba dicha. Entié[n]dese llevándose este tie[m]po $€$ que si lleva este otro $\oiint$ | en el qual va más apresurado el co[m]pás bie[n] puede yr de redoble los que fueren del valor desta figura Como verán en la quarta fantasía del primer libro. Los passos que llevaren este tiempo $\notin$ Por la unal figura y por la otra de las aquí arriba dichas de necesidad abrán de yr redoblados porque por este ti-|empo como está dicho entra[n] dobladas figuras en un compás que por los otros.

|C Encima de algunas cifras toparán esta señal $\wedge$ la qual se pone para que sepan q[ue] no an de alçar el dedo|de la cuerda durante aquel compás, si estuviere al principio dél. Y si al fin hasta la mitad del que se sigue.

$\mathbb{C}$ En el tercero libro de las obras pa[ra] cantadas y tañidas topará[n] delante de algu[na]s cifras un rasguito des- $\mid$ ta manera. $\mathbf{f}^{\prime}$. El qual da a entender que la cifra q[ue] le tubiere delante será la vox que se puede ca[n]tar si q[ui]| sieren la qual á de yr también tañida. En el dicho libro toparán tanbién sobre algunas Figuras del|Canto de Órgano En la box que va sacada en canto de órgano para cantada una estrellica|desta manera pónese para q[ue] sepan que la figura q[ue] encima la tuviere se á de dividir en dos partes | Si fuere semibreve partirse en dos mínimas si mínima en dos semínimas si semínima en dos corcheas | esto se á de entender a la segu[n]da buelta o e[n] la tercera porq[ue] en tal lugar la buelta segunda o tercera no tra|en los pies la misma cantidad ni sílavas que en la primera porq[ue] trae más o menos. Qua[n]do hallaren la tal|asonada tener debajo dos renglones o tres, y para entender q[ue] la dicha asonada se á de tornar a dezir dos o|tres vezes según la letra que debaxo tubiere lo demuestra ay ta[m]bién unas dos pausas con quatro|puntillos desta manera : ||: los quales dizen q[ue] llegados allí torne[n] a dezirla ta[n]tas vezes qua[n]tas re[n]glo|nes tubiere debaxo y después passar adelante. 
[Libro 2, f. A1]

\title{
sथ LIBRO SEGUNDO DE MÚSICA
}

\author{
EN CIFRAS PARA VIHUELA. EN EL QUAL AY MUCHAS \\ fantasías y algunas ComPosturas Glosadas \\ por los ocho tonos que por otro \\ no[m]bre más propio \\ Se llama[n] mo \\ dos
}

$\mathbb{C}$ Fue impresso el presente libro en la muy noble y leal ciudad de Sevilla en casa de Iuan de Leó[n].

1546.

\section{[f. A1v]}

$\mathbb{C}$ Primer tono.

$\mathbb{C}$ Un tiento y una fantasía

$\mathbb{C}$ El primer Kirie de la missa de b[ea]ta virgine de Iosquin glosado

$\mathbb{C}$ Una fantasía

$$
\text { Segundo tono. }
$$

$\mathbb{C}$ Un tiento y una fantasía

$\mathbb{C}$ Una fantasía sobre fa.mi.ut.re.

Tercero tono.

$\mathbb{C}$ Un tiento y una fantasía

$\mathbb{C}$ Un Kirie de una missa de Iosquin que va sobre pange lingua glosado

$$
\text { Quarto tono. }
$$

$\mathbb{C}$ Un tiento y una fantasía

$\mathbb{C}$ Un benedictus de la missa de la sol fa.re.mi de Iosquin glosado

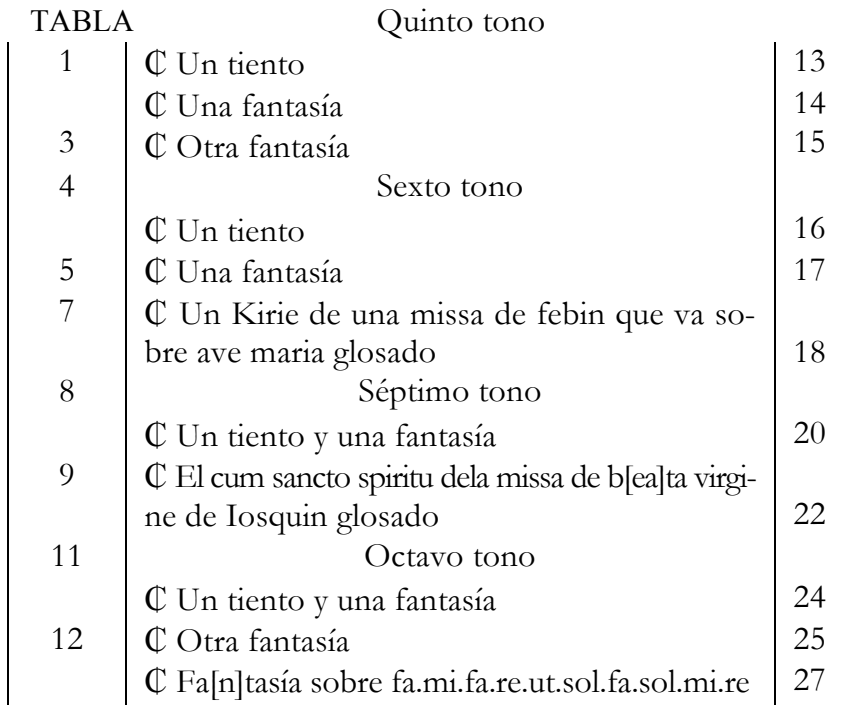


[Libro 3, f. A1]

\title{
s\% LIBRO TERCERO
}

\author{
DE MÚSICA EN CIFRAS Y CANTO
}

de órgano para tañer y cantar con la Vihuela,; en el

qual ay Motetes, Psalmos, Romances, Cancio

nes. Sonetos, Versos en latín, Villan-

cicos, como veran en la tabla que

a la buelta desta hoja está

\section{0}

$\mathbb{C}$ Fue impresso el presente libro en la muy noble y muy

leal ciudad de Sevilla en casa de Iuan de León.

[f. A1v]

\begin{tabular}{|c|c|c|}
\hline & IAE & \\
\hline MOTETES. & & C La vita fugge. Letra de Petracha. \\
\hline $\mathbb{C}$ Pater noster a quatro de Adrian Vuillart & $\mathrm{i}$ & $\mathbb{C}$ Lassato a il tago \\
\hline $\mathbb{C}$ Respice in me deus de Gomberth. & ii & $\mathbb{C}$ O gelosia di amanti. Letra de Sanazaro. \\
\hline $\mathbb{C}$ Clamabat autem. & iii & C Ytene al hombra. Letra de Sanazaro. \\
\hline ROMANCES. & & VERSOS EN LATÍN \\
\hline $\mathbb{C}$ Durmiendo yva el Señor, con segunda di- & & C Regia qui mesto. \\
\hline ferencia. & iiii & $\mathbb{C}$ Dulces exuvie del quarto de Vergilio. \\
\hline $\mathbb{C}$ Triste estava el rey David. & $\mathrm{v}$ & $\mathbb{C}$ Beatus ille qui procul negociis. de hora[cio] \\
\hline $\mathbb{C}$ Israel mira tus montes. & vi & $\mathbb{C}$ Hanc tua Penelope. de ovidio. \\
\hline CANCIONES & & VILLANCICOS \\
\hline $\mathbb{C}$ Sin dubdar, con segunda parte. & vii & $\mathbb{C}$ Dime adó tienes las mientes. \\
\hline $\mathbb{C}$ Recuerde el alma dormida. & viii & $\mathbb{C}$ Si me llama a mí llaman. \\
\hline C Claros y frescos ríos. letra de Boscán & ix & $\mathbb{C}$ Gentil cavallero. \\
\hline SONETOS EN CASTELLANO & & $\begin{array}{l}\mathbb{C} \text { Ysabel perdiste la tu faxa. } \\
\mathbb{C} \text { Si viesse e me levasse. }\end{array}$ \\
\hline C Qué llantos son aquestos. & $\mathrm{x}$ & $\mathbb{C}$ PSALMOS \\
\hline C Si por amar el hombre. & $\mathrm{xi}$ & $\mathbb{C}$ Nisi dominus edificaverit domum, \\
\hline $\mathbb{C}$ Por ásperos caminos. Letra de Garcilaso. & xii & $\mathbb{C}$ Exurge quare obdormis domine. \\
\hline SONETOS EN YTALIANO & & $\mathbb{C}$ Fines tabule, \\
\hline $\begin{array}{l}\text { \&) } \mathrm{La} \mathrm{cu} \\
\text { las ol }\end{array}$ & 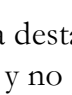 & $\begin{array}{l}\text { bla va por } \\
\text { las hojas }\end{array}$ \\
\hline
\end{tabular}


[Libro 3, f. h6]

C CORECIÓN. Por la qual se podrán emmendar algunos herrores que en estos libros ay | PRIMER LIBRO

|C En la declaración destas cifras en una regla q[ue] está debaxo del exemplo en el primer renglón falta una a $\mid$ y una ese adonde dize un, á de dezir unas,

|C En la primera plana de la quarta foja a los quatro Compasses un zero y un dos que están en la segunda|á de estar primero el dos y después el zero mudando el uno en el lugar del otro.

|C En la quinta foja en la primera plana está una fantasía la qual passa de allí a la primera plana de la sesta fo|ja. Y otra fantasía que enpieça en la buelta de la dicha quinta foja passa de allí a la buelta de la dicha sesta| foja.

|C En una fantasía que enpieça en la séptima foja a los sesenta y ocho compasses falta una cifra en la segu[n] | da de número uno á de estar al fin del compás.

|C En una fantasía que comie[n]ça en la novena foja a los ochenta, y quatro compasses falta un zero en la quin|ta á de estar antes del dos. En esta mesma fantasía tres co[m]passes más adela[n]te de los arriba dichos un seys | que está en la quinta y un dos que está en la tercera, an de estar el seys en la sexta y el dos en la quarta.

|C En una fantasía que contra haze la harpa y comiença en la trezena foja al cabo della en el penúltimo co[m] $\mid$ pás está una mínima blanca sobre un cinco á de ser corchea.

|C En la segunda parte de la gloria de la missa de faysan regres a los treinta y dos co[m]passes falta una semíni|ma que á de estar sobre un tres que está en la tercera.|

\section{SEGUNDO LIBRO}

|C En una fantasía que comiença en la primera foja a los veinte y siete compasses un nueve que está en la segunda á de estar en la prima.

|C En un Kirie que comiença e[n] la quarta foja. A los diez y seys co[m]passes un diez que está en la tercera. Á de|ser tres. Más adelante a los sesenta y siete compasses una semínima q[ue] está sobre un zero á de ser corchea|Más adela[n]te e[n] la plana q[ue] acaba este Kirie en la cabeça dize segundo tono á de dezir primero.

|C En la séptima foja en una fantasía a los quarenta y quatro co[m]passes falta una semínima sobre un dos q[ue]| está en la quinta. 
|C En un Kirie que comiença en la novena foja a los setenta compasses está una semínima sobre un zero á|de ser mínima.

|C En la trezena foja en un Benedictus glosado a los sesenta y un compasses un tres que está en la prima á|de estar en derecho de un quatro que está en la tercera, [f. h6v]

\section{TERCERO LIBRO}

IC En el motete de la Cananea al dezeno compás al prencipio dél en la prima falta un cinco á de estar en $\mid$ derecho del uno que está en la segu[n]da. Más adelan[t]e a los quarenta y dos co[m]passes un dos que está en la ter|cera á de ser tres.

$\mid \mathbb{C}$ En un roma[n]ce que dize durmiendo yva el señor e[n] la primera parte a los veinte y cinco co[m]passes un dos $\mid$ que está en la prima en derecho de un tres y uno, á de ser tres. $\mathbb{C}$ Más adelante en el mesmo roma[n]ce e[n] la|segu[n]da buelta a los diez y nueve compasses un tres que está en la quarta á de estar e[n] derecho del cinco que | está en la prima.

|C En una canción que dize sin dudar a los quare[n]ta y tres co[m]passes un cinco que está al cabo del compás | solo á de ser tres.

|C En un soneto que dize la vita fuge e[n] la vox de canto de órga[n]o a los diez y siete co[m]passes está la clave en | la primera raya á de estar en la segunda como las de atrás.

$\mid \mathbb{C}$ En un soneto que dize lassato a il tago al tercero co[m]pás un dos que está en la quarta á de ser tres, Más a|delante a los veinte y siete co[m]passes un zero que está en la prima á de ser cinco.

$\mid \mathbb{C}$ En un villancico q[ue] dize gentil Cavallero a los diez y nueve co[m]passes un tres q[ue] está en la prima á de ser| siete.

| Fin de la coreción.

[f. h7]

De esta otra parte se pone un principio de un Libro que tenía hecho pa[ra] Imprimir, en el qual avía mu-|chas, Fantasías, y Composturas en una nueva manera de cifras para Harpa. y Órgano, el qual acordé| poner aquí (Pues mis ocupaciones no me dieron lugar a que imprimiese el dicho libro) para $\mathrm{q}[\mathrm{u}] \mathrm{e}$ si a alguno|le pareciere bien la invención destas cifras se pueda aprovechar della, sacando en ellas composturas como|se sacan en las de la Vihuela porque en todo llevan la mesma orden, salvo que estas cifras no tienen núme- | ro 
de uno, ni de dos, ni de nada todas son de una manera no hazen más de señalar las cuerdas en que an $\mid$ de tocar.

[f. h8]

se Las rayas y los espacios so[n] las cuerdas de la Harpa: y el Iuego del Órgano: El espacio primero de aquí abaxo|es la cuerda más gruesa, y más baxa. Y allí es fe faut, Y en la raya primera que se sigue gamaut. \&c. Las claves|y los bemoles muestran bien que si[g]no sea cada cuerda. Y el tono que á de tener, El temple que aquí tiene es el común|para tañer por el sexto tono. Y si alguna cuerda o cuerdas eran menester mudar $\mathrm{pa}[\mathrm{ra}]$ tañer por por otras partes señalávalas | en el libro que dicho tengo con una mano, o manos poniéndolas en derecho de cada cuerda para que con un dedo la|señalaren y dezía allí súbases a áb[a]xese. Para formar los semitonos se ponen estas dos señales b \# en la cuerda que qual-|quiera de ellas estubiere se á de poner el dedo acerca de las clavijas.

[f. h8v]

Acabose la presente obra e[n] la muy noble y leal Ciudad de Sevilla por Juan de Leó[n] impressor a sancta Marina en la calle real a siete días d[e]l mes de Deziembre. 1546.

El prólogo de Mudarra, de tipo epistolar como él mismo indica, es el prólogo característico de los vihuelistas con alusiones clásicas y cierto sabor humanístico. Como ha sido señalado al hablar de estos prólogos: «Su erudición es de segunda mano. [...] Sin embargo, su humanismo fue auténtico». ${ }^{649}$ Comienza hablando de la valoración de la vihuela entre los antiguos griegos, pues es cosa común la identificación de su instrumento con la lira clásica entre los vihuelistas, como demuestra el propio título de la obra de Fuenllana: Orphénica lyra. Cita la anécdota recogida por Pseudo Plutarco en Sobre la música, relativa a la habilidad de Epaminondas para tañer y cantar y el respeto adquirido por ello y la carencia de Temístocles por no saber hacerlo. Sigue con las Vidas paralelas de Plutarco y

${ }^{649}$ Pope, Isabel. «La vihuela y su música en el ambiente humanístico», Nueva Revista de Filología Hispánica, 12 (1961), pp. 364-376; p. 366. 
la opinión negativa de Alcibiades sobre la flauta y positiva sobre la lira. A continuación, cita a Cicerón en su Tusculanas, de nuevo con el episodio sobre los generales tebano y ateniense y la valoración de la música en la erudición (o instrucción).

Tras esta alabanza a la música de canto y vihuela pasa a ensalzar al destinatario, Luis Zapata, y sus habilidades musicales y artísticas. La falsa modestia de todo prólogo también está presente «pues yo soy de los que no perfecta ni medianamente entienden» para luego exponer el mucho tiempo dedicado al estudio de la vihuela y sus años de servicio a los duques del Infantado, así como su viaje a Italia.

Mudarra dedica su obra al «muy magnífico señor don Luys Çapata» y lo primero que debemos preguntarnos es ¿quién es este Luys Çapata? Pujol, sin dudarlo, lo identifica con el licenciado Luys Zapata ${ }^{650}$ abuelo del autor de Carlo famoso, Luis Zapata de Chaves. El primero de ellos fue un importante jurista miembro del Consejo de los Reyes Católicos, letrado de las Cortes de Castilla, encargado de la redacción de las Leyes de Toro, además de muchos otros cargos de un larguísimo currículo que llega hasta el reinado de Carlos V. ${ }^{651}$ Tuvo relación con Sevilla, pues fue el encargado del establecimiento y regulación de la Casa de Contratación de Sevilla, además de ejercer de Alcalde Mayor en la dicha ciudad. Todo esto le hizo acumular una inmensa fortuna y levantar un palacio en Llerena, «la mejor casa de caballero de España», según su nieto homónimo. Pues bien, aunque desconocemos la fecha exacta de su muerte, no debió ser mucho más tarde de 1522, cuando redactó su testamento. No parece ser el mejor candidato a receptor del prólogo de Mudarra.

El primogénito de don Luys, Francisco Zapata, heredó el mayorazgo y sus riquezas. ${ }^{652}$ Recibió muchas mercedes del Emperador, siendo nombrado Comendador de Hornachos,

${ }^{650}$ PUjOL. Mudarra, pp. 31-32.

${ }^{651}$ Tomamos los datos de MALdonAdo FernándeZ, Manuel. «Don Luis Zapata, consejero real, letrado de las Cortes y fundador del mayorazgo y señorío de Çehel de las Alpujarras», Actas de la II Jornada de Historia de Llerena. Llerena, Junta de Extremadura, Consejería de Educación, Ciencia y Tecnología, Dirección General de Ordenación, Renovación y Centros, 2001, pp. 95-116.

${ }^{652}$ Tomamos los datos de MALdonAdo FERNÁnDEZ, Manuel. «Don Luis Zapata de Chaves, III Señor del Estado de Çehel de las Alpujarras y de las Villas de Jubrecelada (Llerena), Ulela y Ulula», Revista de Estudios Extremeños, 58/3 (2002), pp. 991-1029 y de RODRíGUEZ CACHÓN, Irene. El «Libro de cetrería» (1583) de Luis de Zapata: estudio y edición crítica. Tesis Doctoral, Universidad de Valladolid, 2013. 
villa poblada por moriscos y perteneciente a la Orden de Santiago. Don Francisco falleció en 1544, no sin antes haberse casado cuatro veces. Fruto de su tercer matrimonio fue Luis Zapata de Chaves, el insigne escritor autor de una traducción de Horacio, de Carlo famoso, poema épico sobre la vida de Carlos $\mathrm{V}$ y de varios manuscritos que no vieron las prensas en vida del autor, el Libro de Cetrería y la Miscelánea; esta última obra muy conocida en el mundo de la vihuela por la cita sobre Luys de Narváez tantas veces repetida. Creemos que este Zapata es el destinatario de la dedicatoria de Mudarra.

Luis Zapata de Chaves nació en 1526 en Llerena y con nueve años, en 1535, entró en la Corte como paje, primero de la Emperatriz y después del príncipe Felipe. En 1539 Carlos V le concede el hábito de Santiago. Cuando unos pocos años después fallece su padre, hereda el mayorazgo y una inmensa fortuna. Acompañó al príncipe Felipe en su viaje por Europa entre 1548 y 1551. Posteriormente se trasladó a Llerena y tras enviudar, en 1558, marchó a Sevilla donde se entregó a la vida disoluta dilapidando la fortuna heredada. Entre 1566 y 1590 o 1591 estuvo encarcelado, primero en prisión y luego entre Hornachos y Valencia de la Torre. Los motivos de su encierro no están claros, pero se ha apuntado incluso sus afinidades erasmistas. Falleció hacia 1595.

No sabemos qué relación pudo tener Mudarra con tan ilustre y curioso personaje, tampoco cuándo escribió el prólogo, lo cierto es que en 1546 Zapata era un hombre poderosísimo que contaba con el favor del príncipe y del Emperador, y tan sólo tres años antes Mudarra andaba a la busca de un nuevo patrón, tras abandonar el palacio del Infantado. La posible afinidad ideológica tampoco es descartable.

Sólo unas breves palabras con respecto a la declaración de la cifra. ${ }^{653}$ Mudarra no se extiende demasiado en las explicaciones, justificándose en que las dos publicaciones anteriores a la suya, Milán y Narváez, sin duda, ya dan suficiente cuenta de ello. Expone brevemente los rudimentos de la cifra. No dice ni una palabra sobre la forma de templar el instrumento, como sí hiciera Milán. No define el compás, pero sin embargo utiliza tres signos para diferenciar el tempo:

\footnotetext{
${ }^{653}$ Cumplida información sobre el contenido de los prólogos de los vihuelistas y su comparación en RoA, F. y GÉRTRudix, F. El libro de música..., Estudio y transcripción, no 1, pp. 23-31 y OHLSEN V., Oscar. Aspectos Técnicos Esenciales en la Ejecución del Laúd. Madrid. Ópera tres, 1992.
} 


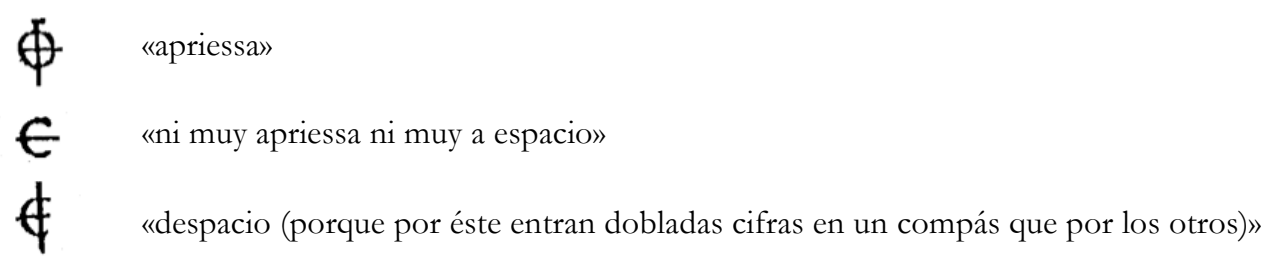

Hay que destacar que Mudarra diferencia el uso de los tres tiempos según el carácter de la pieza, reservando el tiempo lento para las piezas tristes y el rápido para las alegres.

Tampoco habla de las proporciones, aunque en las instrucciones que añade al principio de sus dos Romanescas pide proporción de tres semibreves al compás. Sí es más prolijo al hablar de la digitación de la mano derecha y el redoble de dos dedos (la figueta) y el dedillo a los que dedica las primeras fantasías. Tampoco utiliza ningún tipo de signo para dividir las obras según su dificultad, aunque emplea la palabra «fácil» en algunas de sus primeras fantasías y en los tres libros se ve claramente como va pasando de lo fácil a lo difícil. Para indicar la voz que se ha de cantar, utiliza el rasguito o la saca en canto de órgano.

Utiliza dos tipos de signos para la ligadura, uno para el canto de órgano y otro para la cifra de vihuela, además de signos especiales como la estrellita para dividir las notas en las repeticiones de texto y el signo de repetición «unas dos pausas con quatro puntillos», explicándonos que hay que repetir tantas veces como líneas de texto tenga. 


\section{Iconografía}

En el libro de Mudarra hay varios grabados xilográficos. El primero de ellos, situado tras los preliminares y antes de la música del primer libro, representa a Mercurio tañendo la lira que acaba de fabricar con el caparazón de una tortuga. La intención, posiblemente, es resaltar el origen divino de la música y la identificación de la lira con la vihuela. Acompaña a la imagen un dístico de la Oda X del libro I de los Carmina de Horacio. ${ }^{654}$

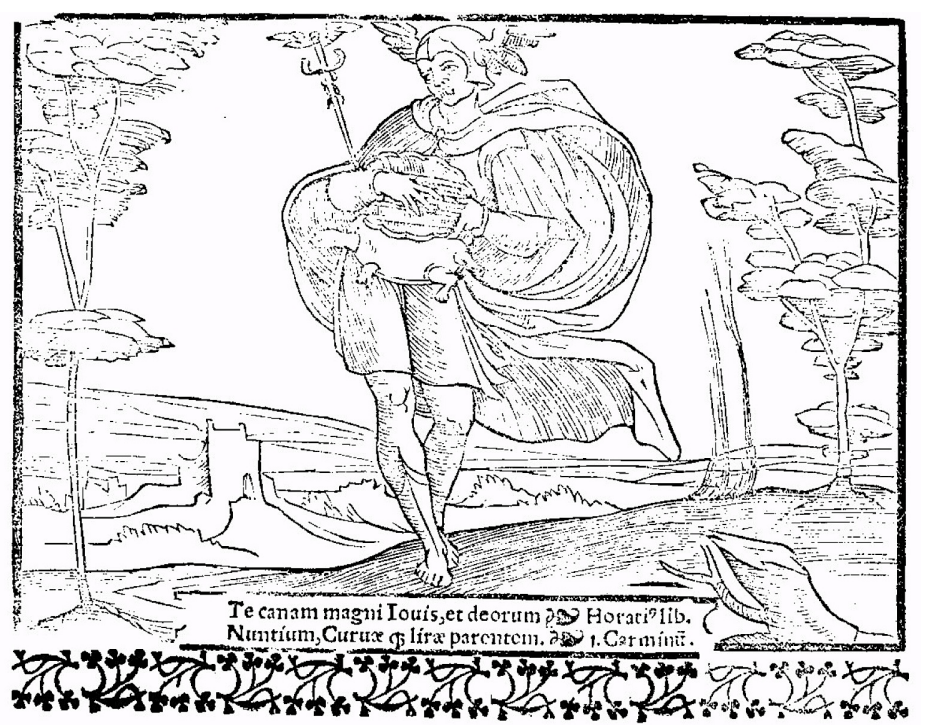

Fig. 21. MudarRa. Tres libros de música. Grabado xilográfico de Mercurio. Libro I, f. A4v.

«Te cana magni lovis, et deorum Nuntium; curvaquae lirae parentem»

[«A ti cantaré mensajero del gran Júpiter y de los dioses, y padre de la curvada lira»]

Horatio, Lib. 1 Carminum

El segundo de los grandes grabados xilográficos representa al profeta Eliseo acompañado de un vihuelista mientras Dios le tiende la mano. El arpa bíblica ha sido sustituida por un vihuelista zurdo. En este caso cierra la parte musical del tercer libro, tras los salmos. Puede representar el cómo mediante la música se puede elevar el alma a Dios. Un grabado similar incluyó Montesdeoca en la obra de Fuenllana, pero con la inscripción «Laudate Deum in cithara: laudate Deum chordis , et organo». ${ }^{65}$

\footnotetext{
${ }^{654}$ Nos basamos en OTAOLA, Paloma. «Aspectos iconográficos en los libros de música para vihuela», Hispanica Lyra, 4 (2006), pp 12-19.

${ }^{655}$ FuENLLANA. Orphénica lyra, f. 59.
} 


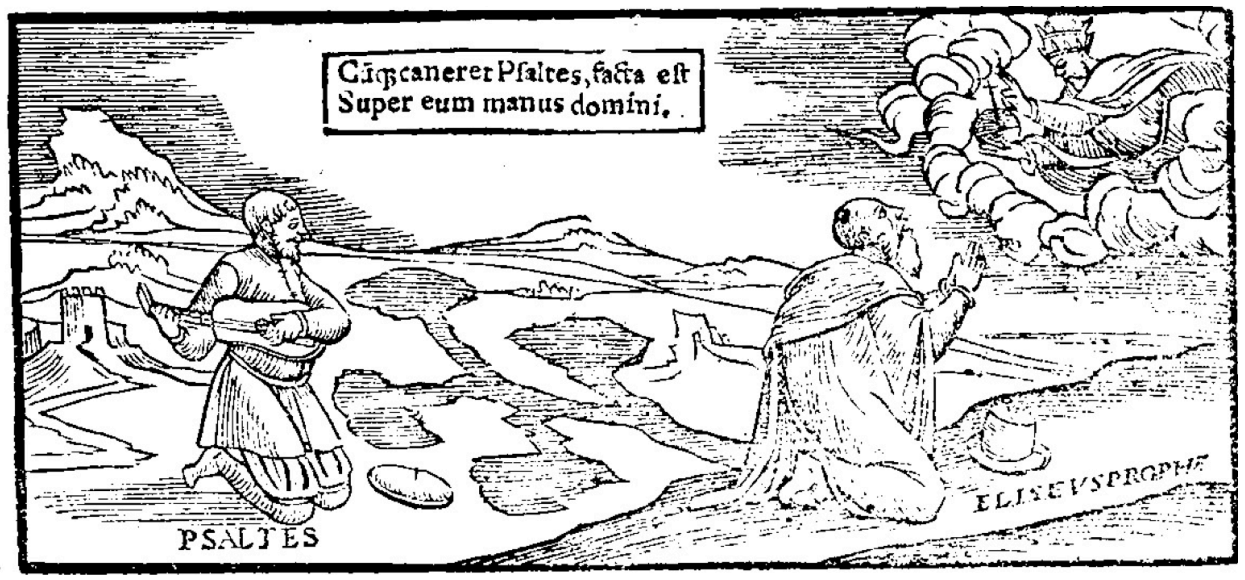

Fig. 22. MudARRA. Tres libros de música. Grabado xilográfico del profeta Eliseo. Libro III, f. h5.

«Cumque caneret psaltes, facta est super eum manus Domini»

[«Y sucedió que mientras el tañedor tocaba, la mano del Señor vino sobre él»]

iiii. Reg. caput iii (2 Reyes, 3, 15-16)

El siguiente grabado es el Emblema de la paz, que repite dos veces una vez después de la fe de erratas y la segunda en el colofón. Este emblema aparece en Alciato con la inscripción «Ex bello pax». ${ }^{656}$ Curiosamente, el grabado que más se parece al de Mudarra es el de la edición de Lyon de 1550.

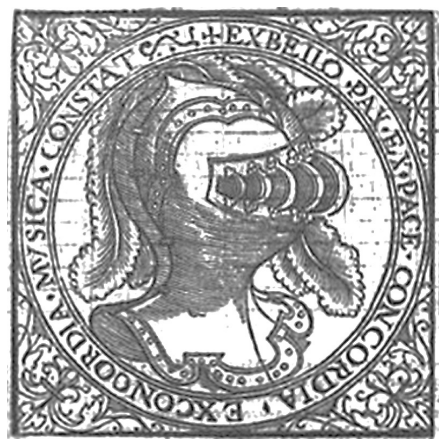

Fig. 23. MudArRA. Tres libros de música. Emblema de la paz. Libro III, ff. h5v y h8v.

«Ex bello pax, ex pace concordia, ex concordia musica constat»

[«De la guerra la paz, de la paz la concordia, de la concordia la música consta»]

656 Se pueden consultar las diferentes ediciones de los Emblemas de Alciato en la web <http://www.emblems.arts.gla.ac.uk/alciato/index.php> [consulta 10-09-2015] 
Pudiera haber una intención de relacionar la concordia de la música con la «música mundana» de los pitagóricos.

El último grabado aparece antes de la cifra de arpa y se trata del rey David, protagonista de varias piezas de Mudarra, con su arpa y un texto de la Biblia en el que cuenta cómo David aliviaba a Saúl con la música de su cítara.

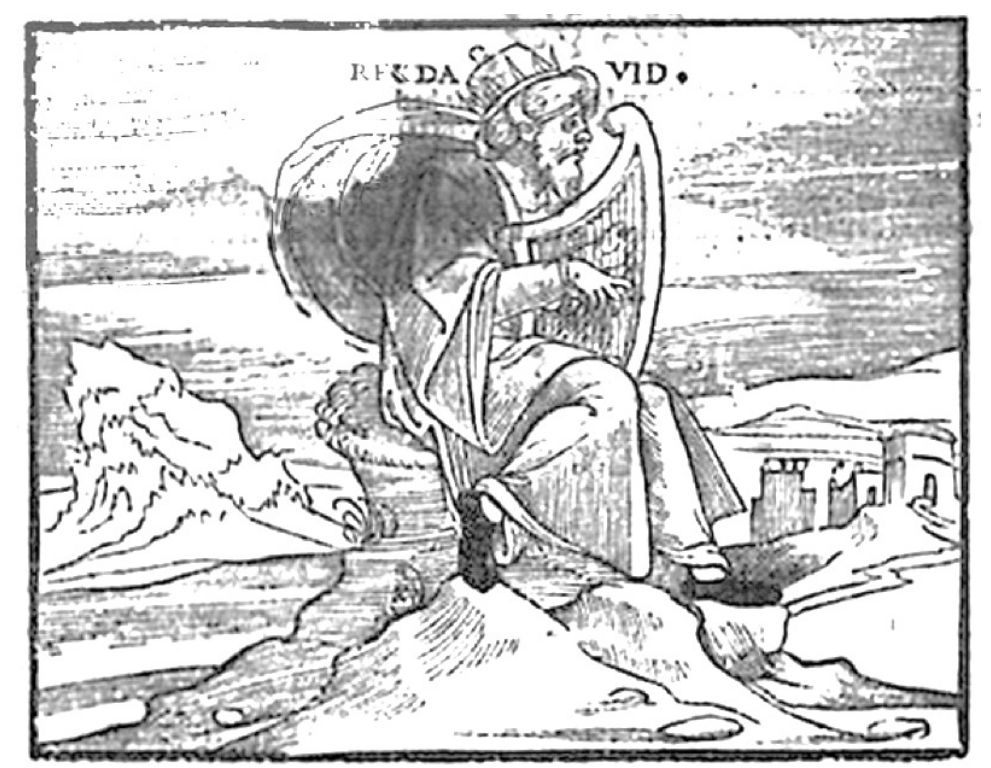

Fig. 24. MudARRA. Tres libros de música. Grabado xilográfico del Rey David. Libro III, f. h7v.

«Quandocumque spiritus domini malus arripiebat Saul, David tollebat citharam et percutiebat manu sua \& refocillabatur Saul; \& levius habebat. Recedebat enim ab eo spiritus malus»

[«Y así cuando el mal espíritu asaltaba a Saúl, David tomaba la cítara y tocaba: Saúl se aliviaba y se sentía mejor, y el mal espíritu se alejaba de él»]

I. Regum, Caput XVI (1 Samuel I, 16, 23)

Podríamos buscar explicaciones simbólicas, autobiográficas o lo que queramos, pues tenemos la sospecha de que el libro de Mudarra contiene muchas sorpresas de este tipo, pero de momento lo dejamos aquí. 


\section{ANÁLISIS DE LAS OBRAS}

Abordamos ahora el análisis individual de todas las obras contenidas en el libro de Mudarra. Para cada una de ellas seguimos la misma ordenación. Tras el número y el título, damos una descripción sintética donde se incluye: género, modo, posición, número de voces, tempo y notas móviles. A continuación van las notas críticas referentes a las transcripciones. Sigue el texto en las piezas vocales. En algunas obras incluimos una introducción relativa a cuestiones que tienen que ver con el género y otros aspectos. Continuamos con la estructura posible y un análisis breve. Un comentario final puede incluir conclusiones sobre la pieza y asuntos relacionados. Damos un resumen con los criterios principales que hemos utilizado.

1. Para describir acordes y cadencias utilizamos los siguientes signos: ${ }^{67}$

- Números romanos en mayúscula, acorde mayor

- Números romanos en minúscula, acorde menor

- Números romanos en mayúscula tachada, acorde sin tercera y a veces sin quinta

- Números romanos con ${ }^{\circ}$, acorde disminuido

- Superíndices ${ }^{4-3}$ o ${ }^{4 . \# 3}$ retardo de tercera por la cuarta sin alteración de la $3^{\text {a }}$ o con alteración, respectivamente

- Acordes sobre grados ascendidos o descendidos \# y b

- Llamaremos cadencia tonal a la que ocurre por salto de cuarta o quinta en el bajo y retardo 43 y modal a la que el bajo desciende de grado y retardo 7 6

2. Utilizamos c. y cc. como abreviaturas de compás y compases.

3. Usaremos los términos tono y modo indistintamente como así hacían en la época.

${ }^{657}$ Tomo lo fundamental de ArRiAGA, Gerardo. «La obra instrumental de Luis Milán», Roseta, 4 (2010), pp. 6-45; p. 9. 
4. Indicamos las notas alteradas como notas móviles con el grado de la escala entre paréntesis.

5. Para referirnos a las voces empleamos la forma actual debido a la variedad de nombres que se usaban en la época:

- Soprano: superius, tiple o cantus

- Contralto: alto, contralto o contraalto

- Tenor: lo mismo

- Bajo: bassus, contrabajo

6. Cuando hablamos de posiciones nos referimos a disposiciones de los acordes de tónica usados en vihuela o laúd en Sol (si quisieramos saber las de la guitarra, con la tercera cuerda afinada un semitono más baja, bastaría con calcular una tercera menor inferior con respecto a la vihuela). Es lo que Milán y Fuenllana llaman términos y partes y Narváez y Pisador partes. ${ }^{658}$ En el caso de las piezas para guitarra de cuatro órdenes nos referimos a la afinación común usada hoy en día: g-c-e-a.

7. Cuando decimos vihuela e Sol o en La, por ejemplo, nos referimos al instrumento que se requeriría para obtener la altura teórica del modo y está relacionado con la posición. Son las vihuelas que el vihuelista «imagina», en palabras de Bermudo. En varios casos indicamos G/D aplicado al I y II modo, lo que quiere decir que nos da lo mismo pensar en ellos por Gsolreut, con un bemol en la armadura, o en posición de Re menor.

8. En los esquemas explicativos de la estructura, intentamos que el compás que inicia la sección sea el que inicia el nuevo motivo o la textura diferente. Debido a las características de esta música, permanentemente imbricada, es muy común que un compás sea principio de sección y final de la anterior y la cadencia concluya en él. No obstante la consideramos de la sección anterior.

\footnotetext{
${ }^{658}$ Sobre este asunto se puede ver ARRIAGA, G. «La obra instrumental..., pp. 23-25.
} 


\section{OBRAS DE MUDARRA}

\begin{tabular}{|c|c|c|c|c|c|c|c|c|c|c|}
\hline $\mathbf{N}^{o}$ & Título & Género & Modo & Posición & Vihuela & Armadura & Tempo & Voces & Longitud & Textura \\
\hline \multicolumn{11}{|c|}{ LIBRO I } \\
\hline 1 & Fantasía 1 & F1 & I & $\mathrm{c}$ & A & $2 b$ & $\mathrm{M}$ & 4 & 57 & Id \\
\hline 2 & Fantasía 2 & F2 & I & $\mathrm{g}$ & $G / D$ & $1 b$ & $\mathrm{M}$ & 4 & 54 & Id \\
\hline 3 & Fantasía 3 & F3 & $\mathrm{V}(\mathrm{VII})$ & $\mathrm{F}$ & A & - & $\mathrm{M}$ & 4 & 53 & Id \\
\hline 4 & Fantasía 4 & $\mathrm{~F} 4$ & $\mathrm{~V}$ & $\mathrm{~F}$ & G & - & $\mathrm{R}$ & 4 & 72 & Id \\
\hline 5 & Fantasía 5 & F5 & VI & $\mathrm{F}$ & G & - & $\mathrm{M}$ & 3 & 73 & $\operatorname{ImP}$ \\
\hline 6 & Fantasía 6 & F6 & VI & $\mathrm{F}$ & $G$ & - & $\mathrm{R}$ & 4 & 76 & $\operatorname{ImP}$ \\
\hline 7 & Fantasía 7 & F7 & I & $\mathrm{c}$ & $\mathrm{A}$ & $2 b$ & $\mathrm{M}$ & 4 & 85 & $\operatorname{ImP}$ \\
\hline 8 & Fantasía 8 & F8 & I & $\mathrm{c}$ & $\mathrm{A}$ & $2 b$ & $\mathrm{M}$ & 4 & 70 & $\operatorname{ImP}$ \\
\hline 9 & Fantasía 9 & F9 & I & $\mathrm{g}$ & G/D & $1 b$ & $\mathrm{R}$ & 4 & 106 & $\operatorname{ImP}$ \\
\hline 10 & Qui tollis & Compostura 1 & II & $\mathrm{g}$ & $G / D$ & $1 b$ & $\mathrm{M}$ & 4 & 101 & $\operatorname{ImP}$ \\
\hline 11 & Pleni & Compostura 2 & II & $\mathrm{g}$ & G/D & $1 b$ & $\mathrm{M}$ & 3 & 88 & $\operatorname{ImP}$ \\
\hline 12 & Fantasía & F10 & II & $\mathrm{g}$ & $\mathrm{G} / \mathrm{D}$ & $1 b$ & $\mathrm{R}$ & 4 & 157 & Id \\
\hline 13 & Conde Claros & D1 & $\mathrm{V}$ & $\mathrm{F}$ & G & $1 b$ & $\mathrm{M}$ & 3 & 79 & \\
\hline 14 & $\begin{array}{c}\text { Romanesca. Guárdame las } \\
\text { vacas } 1\end{array}$ & D2 & I & $\mathrm{f}$ & $\mathrm{E}$ & $3 b$ & $\mathrm{~L}$ & 4 & 50 & \\
\hline 15 & Pavana 1 & P1 & $\mathrm{I}$ & $\mathrm{g}$ & G/D & $1 b$ & $\mathrm{M}$ & 4 & 79 & \\
\hline 16 & Pavana de Alexandre & $\mathrm{P} 2$ & VIII & $\mathrm{F}$ & A & $2 b$ & $\mathrm{~L}$ & 4 & 24 & \\
\hline 17 & Gallarda & G1 & VIII & $\mathrm{F}$ & A & $2 b$ & $\mathrm{R}$ & 4 & 18 & \\
\hline 18 & Fantasía 11 & F11 & $\mathrm{I}$ & $\mathrm{f}$ & gt & $2 b$ & $\mathrm{M}$ & 4 & 71 & Id \\
\hline 19 & Fantasía 12 & F12 & IV & $\mathrm{g}$ & $\mathrm{gt}$ & $3 b$ & $\mathrm{M}$ & 4 & 67 & $\operatorname{ImP}$ \\
\hline 20 & Fantasía 13 & F13 & $\mathrm{V}$ & G & $\mathrm{gt}$ & $2 \#$ & $\mathrm{R}$ & 4 & 62 & $\operatorname{ImP}$ \\
\hline 21 & Fantasía 14 & F14 & I & $\mathrm{g}$ & $\mathrm{gt}$ & $1 \mathrm{v}$ & $\mathrm{M}$ & 4 & 58 & $\operatorname{ImP}$ \\
\hline
\end{tabular}




\begin{tabular}{|c|c|c|c|c|c|c|c|c|c|c|}
\hline 22 & Pavana 3 & P3 & $\mathrm{I}$ & c & gt & $2 b$ & $\mathrm{M}$ & 4 & 49 & \\
\hline 23 & $\begin{array}{c}\text { Romanesca. Guárdame las } \\
\text { vacas } 2\end{array}$ & D3 & I & $g$ & $\mathrm{gt}$ & $1 b$ & $\mathrm{~L}$ & 3 & 30 & \\
\hline \multicolumn{11}{|c|}{ LIBRO II } \\
\hline 24 & Tiento 1 & $\mathrm{~T} 1$ & I & $\mathrm{f}$ & $\mathrm{E}$ & $3 b$ & $\mathrm{R}$ & 4 & 23 & \\
\hline 25 & Fantasía 15 & F15 & I & $\mathrm{f}$ & $\mathrm{E}$ & $3 b$ & $\mathrm{M}$ & 4 & 109 & $\operatorname{ImP}$ \\
\hline 26 & Kyrie 1 & Glosado 1 & I & $\mathrm{f}$ & $E$ & $3 b$ & $\mathrm{M}$ & 4 & 100 & \\
\hline 27 & Fantasía 16 & F16 & $\mathrm{I}$ & $\mathrm{f}$ & $\mathrm{E}$ & $3 b$ & $\mathrm{R}$ & 4 & 94 & $\operatorname{ImP}$ \\
\hline 28 & Tiento 2 & $\mathrm{~T} 2$ & II & $\mathrm{g}$ & G/D & $1 b$ & $\mathrm{R}$ & 4 & 21 & \\
\hline 29 & Fantasía 17 & F17 & II & $\mathrm{g}$ & $\mathrm{G} / \mathrm{D}$ & $1 b$ & $\mathrm{M}$ & 4 & 83 & $\operatorname{ImP}$ \\
\hline 30 & Fantasía 18 & F18 & II & $\mathrm{g}$ & $G / D$ & $1 b$ & $\mathrm{R}$ & 4 & 63 & Ost \\
\hline 31 & Tiento 3 & T3 & III & $\mathrm{g}$ & $E$ & $3 b$ & $\mathrm{R}$ & 4 & 21 & \\
\hline 32 & Fantasía 19 & F19 & III & $\mathrm{g}$ & $\mathrm{E}$ & $3 b$ & $\mathrm{M}$ & 4 & 109 & $\operatorname{ImP}$ \\
\hline 33 & Kyrie 2 & G2 & III & $\mathrm{g}$ & $\mathrm{E}$ & $3 b$ & M & 4 & 102 & \\
\hline 34 & Tiento 4 & T4 & IV & $\mathrm{f}$ & $\mathrm{F} \#$ & $5 b$ & $\mathrm{R}$ & 4 & 23 & \\
\hline 35 & Fantasía 20 & F20 & IV & $\mathrm{f}$ & $\mathrm{F} \#$ & $5 b$ & $\mathrm{M}$ & 4 & 87 & $\mathrm{Im}$ \\
\hline 36 & Benedictus & G3 & IV & $\mathrm{f}$ & $\mathrm{F} \#$ & $5 b$ & $\mathrm{R}$ & 4 & 69 & \\
\hline 37 & Tiento 5 & T5 & $\mathrm{V}$ & G & $\mathrm{F}$ & $2 \#$ & $\mathrm{R}$ & 4 & 40 & \\
\hline 38 & Fantasía 21 & F21 & $\mathrm{V}$ & G & $\mathrm{F}$ & $2 \#$ & $\mathrm{M}$ & 4 & 63 & $\operatorname{ImP}$ \\
\hline 39 & Fantasía 22 & F22 & $\mathrm{V}$ & G & $\mathrm{F}$ & $2 \#$ & $\mathrm{R}$ & 4 & 106 & $\operatorname{ImP}$ \\
\hline 40 & Tiento 6 & T6 & VI & $A b$ & $\mathrm{E}$ & $3 b$ & $\mathrm{R}$ & 4 & 30 & \\
\hline 41 & Fantasía 23 & F23 & VI & $A b$ & $\mathrm{E}$ & $3 b$ & $\mathrm{M}$ & 4 & 67 & $\mathrm{Id}$ \\
\hline 42 & Kyrie 3 & G4 & VI & $A b$ & $\mathrm{E}$ & $3 b$ & $\mathrm{R}$ & 4 & 141 & \\
\hline 43 & Tiento 7 & $\mathrm{~T} 7$ & VII & $\mathrm{F}$ & A & $2 b$ & $\mathrm{R}$ & 4 & 29 & \\
\hline 44 & Fantasía 24 & F24 & VII & $\mathrm{F}$ & $\mathrm{A}$ & $2 b$ & $\mathrm{R}$ & 4 & 86 & $\operatorname{ImP}$ \\
\hline 45 & Cum sancto spiritu & G5 & VII & $\mathrm{F}$ & A & $2 b$ & $\mathrm{R}$ & 4 & 124 & \\
\hline 46 & Tiento 8 & T8 & VIII & G & G & - & $\mathrm{R}$ & 4 & 24 & $\mathrm{Im}$ \\
\hline 47 & Fantasía 25 & F25 & VIII & G & G & - & $\mathrm{M}$ & 4 & 95 & $\operatorname{ImP}$ \\
\hline 48 & Fantasía 26 & F26 & VIII & G & G & - & $\mathrm{R}$ & 4 & 85 & $\operatorname{ImP}$ \\
\hline 49 & Fantasía 27 & F27 & VIII & $G$ & $G$ & - & $\mathrm{R}$ & 4 & 60 & $\mathrm{Im} / \mathrm{Ost}$ \\
\hline
\end{tabular}




\section{LIBRO III}

\begin{tabular}{|c|c|c|c|c|c|c|c|c|c|}
\hline 50 & Pater noster & Motete 1 & $\mathrm{~V}$ & $A b$ & $\mathrm{E}$ & $3 b$ & M & 4 & 219 \\
\hline 51 & Respice in me, Deus & Motete 2 & I & e b & G\# & $5 b$ & $\mathrm{M}$ & 5 & 154 \\
\hline 52 & $\begin{array}{c}\text { Clamabat autem mulier. } \\
\text { Motete de la cananea }\end{array}$ & Motete 3 & $\mathrm{~V}$ & $A b$ & $\mathrm{E}$ & $4 b$ & $\mathrm{M}$ & $3+1$ & 182 \\
\hline 53 & Durmiendo yva el Señor & Romance 1 & $\mathrm{I}$ & $\mathrm{B} b$ & $\mathrm{~B}$ & $4 b$ & $\mathrm{M}$ & $3+1$ & 68 \\
\hline 54 & Triste estava el rey David & Romance 2 & IV & $\mathrm{f}$ & $\mathrm{F} \#$ & $5 b$ & $\mathrm{M}$ & $3+1$ & 44 \\
\hline 55 & Israel, mira tus montes & Romance 3 & $\mathrm{I}$ & $\mathrm{c}$ & A & $3 b$ & $\mathrm{M}$ & $3+1$ & 52 \\
\hline 56 & $\begin{array}{c}\text { Sin dudar. Canción al } \\
\text { milagro de la Encarnación }\end{array}$ & Canción 1 & VIII & G & G & - & M y R & 4 & 139 \\
\hline 57 & Recuerde el alma dormida & Canción 2 & II & $\mathrm{f}$ & $\mathrm{E}$ & $3 b$ & $\mathrm{M}$ & $3+1$ & 38 \\
\hline 58 & Claros y frescos ríos & Canción 3 & II & $\mathrm{g}$ & G/D & $1 b$ & $\mathrm{M}$ & $3+1$ & 63 \\
\hline 59 & ¿Qué llantos son aquestos? & Soneto en castellano 1 & IV & $\mathrm{f}$ & $\mathrm{F} \#$ & $5 b$ & $\mathrm{My} \mathrm{L}$ & $3+1$ & 68 \\
\hline 60 & Si por amar el hombre & Soneto en castellano 2 & II & $\mathrm{g}$ & G & $1 b$ & $\mathrm{M}$ & $3+1$ & 86 \\
\hline 61 & Por ásperos caminos. & Soneto en castellano 3 & VIII & $\mathrm{F}$ & A & $2 b$ & $\mathrm{M}$ & $3+1$ & 81 \\
\hline 62 & Regia qui mesto & Versos en latín 1 & II & $\mathrm{f}$ & $\mathrm{E}$ & $3 b$ & M & $3+1$ & 62 \\
\hline 63 & Dulces exuviae & Versos en latín 2 & II & $\mathrm{g}$ & G & $1 b$ & $\mathrm{M}$ & $3+1$ & 90 \\
\hline 64 & Beatus ille & Versos en latín 3 & $\mathrm{~V}$ & $\mathrm{~F}$ & G & - & $\mathrm{L}$ & $3+1$ & 16 \\
\hline 65 & Hanc tua Penelope & Versos en latín 4 & II & $\mathrm{g}$ & G & $1 b$ & $\mathrm{M}$ & $3+1$ & 25 \\
\hline 66 & La vita fugge & Soneto en italiano 1 & III & $\mathrm{g}$ & $\mathrm{E}$ & $3 b$ & M y L & $3+1$ & 104 \\
\hline 67 & Lassato a il Tago & Soneto en italiano 2 & $\mathrm{I}$ & $\mathrm{f}$ & $\mathrm{E}$ & $4 b$ & $\mathrm{M}$ & $3+1$ & 83 \\
\hline 68 & O gelosia d'amanti & Soneto en italiano 3 & VIII & G & G & - & $\mathrm{M}$ & $3+1$ & 84 \\
\hline 69 & Itene a l'ombra & Soneto en italiano 4 & VIII & $\mathrm{E}$ & $\mathrm{B}$ & $4 b$ & $\mathrm{M}$ & $3+1$ & 23 \\
\hline 70 & Dime adó tienes las mientes & Villancico 1 & $\mathrm{I}$ & $\mathrm{B} b$ & $\mathrm{~F} \#$ & $4 b$ & $\mathrm{M}$ & $3+1$ & 84 \\
\hline 71 & Si me llaman & Villancico 2 & I & $\mathrm{c}$ & A & $2 b$ & $\mathrm{M}$ & $3+1$ & 84 \\
\hline 72 & Gentil cavallero & Villancico 3 & I & $\mathrm{c}$ & A & $2 b$ & $\mathrm{M}$ & $3+1$ & 96 \\
\hline 73 & Ysabel, perdiste la tu faxa & Villancico 4 & $\mathrm{I}$ & $g$ & G & $1 b$ & $\mathrm{M}$ & $4+1$ & 69 \\
\hline 74 & Si viesse e me levasse & Villancico 5 & $\mathrm{I}$ & $\mathrm{c}$ & $\mathrm{A}$ & $2 b$ & $\mathrm{M}$ & $3+1$ & 24 \\
\hline 75 & Nisi Dominus & Salmo 1 & $\mathrm{I}$ & $\mathrm{g}$ & $\mathrm{A}$ & $2 b$ & $\mathrm{M}$ & $4+1$ & 19 \\
\hline 76 & Exurge, quare obdormis & Salmo 2 & VII & $\mathrm{f}$ & $\mathrm{E}$ & $4 b$ & $\mathrm{M}$ & $3+1$ & 41 \\
\hline 77 & Tiento 9 & Tiento 9 & VII & - & - & $2 b$ & $\mathrm{M}$ & 4 & 16 \\
\hline
\end{tabular}


En la columna "Textura" incluimos las siguientes abreviaturas, únicamente en el caso de las fantasías y tientos:

- ImP: imitativa politemática

- Im: imtitativa

- Ost: ostinato

- Id: idiomática 


\section{LIBRO I}

«Tres libros de música en cifras para vihuela. En el primero ay música fácil y difícil en fantasías: y Composturas: y Pavanas: y Gallardas: y algunas fantasías para guitarra.»

El libro I, tal y como nos indica Mudarra en su índice, consta de veintitrés obras divididas de la siguiente manera:

- Fantasías a tres y cuatro voces (10)

- Fantasías de pasos (4)

- Fantasías de pasos largos (3)

- Fantasía de pasos de contado (1)

- Fantasías fáciles (3)

- Otras fantasías (3)

- Composturas de Josquin (2)

- Obras menudas (5)

○ Diferencias (2)

- Danzas (3)

- Obras para guitarra (6)

- Fantasías (4)

- Danza (1)

- Diferencias (1) 


\section{1- Fantasía 1}

Fantasía de pasos largos. I modo. Posición c (vihuela en La). 4 voces. Tempo medio («ni muy apriessa ni muy a espacio»). Notas móviles: Mi Ł (III), Fa\# (IV), Lab (VI), Si ๒ (VII).

\section{NOTAS CRÍTICAS}

1. c. 50. Añadimos la nota que figura entre corchetes.

\section{ESTRUCTURA}

$\begin{array}{ccccc}\text { Secciones } & \text { Compases } & \text { Cadencia final } & \text { Longitud } & \text { Textura } \\ 1 & 1-18 & \mathrm{v} & 18 \mathrm{cc} . & \text { Imitativa } \\ 2 & 19-35 & \mathrm{~V} & 17 \mathrm{cc} . & \text { Idiomática } \\ 3 & 36-57 & \mathrm{I} & 22 \mathrm{cc} . & \text { Imitativa } \\ & & & \text { Idiomática }\end{array}$

\section{ANÁLISIS}

Sección 1: comienzo en bicinum en soprano y contralto, cadencia modal (7 6) en I grado sin quinta ni tercera. Repetición exacta en tenor y bajo. Entrada en bicinium con el motivo cuarta baja de nuevo en tenor y bajo a distancia de medio compás. Cadencia sobre el v grado. El motivo es muy similar en los tres bicinia y se podría considerar variaciones del mismo con ligeras modificaciones rítmicas en su cabeza.

Sección 2: pasos largos o redobles. Cadencia rota (c. 21) sobre III grado y cadencias sobre I grado, primero modal (cc. 26-27) y después tonal (cc. 30-31). ${ }^{661}$ Durante toda la sección alterna pasajes de redobles ascendentes donde indica «dos de[dos]» y descendentes para tañer con «dedi[llo]».

Sección 3: comienza de nuevo con la cabeza del motivo de la sección 1 por movimiento directo y movimiento contrario. Cadencia rota y cadencia modal remisa sobre el V grado (cc. 40-43) para volver a los redobles. Cadencia rota sobre el III grado, concluyendo sobre episodio plagal sobre el ii y I grado. Final en acorde mayor completo.

\footnotetext{
${ }^{661}$ Como vimos más arriba, denominamos cadencia tonal a la que consta de salto de cuarta o quinta en el bajo y retardo 4-3 en una voz superior y cadencia modal la que el bajo procede por descenso de segunda y suele llevar retardo 7-6 en voz superior (o su inversión).
} 


\section{COMENTARIO}

Las tres primeras fantasías de Mudarra son denominadas por el autor «fantasías de pasos largos para desenvolver las manos». Esta primera también figura en el índice como «fantasía de passos des enbueltos». Se trata de tres piezas de carácter idiomático con procedimientos escalísticos: pasos o redobles, alternando con secciones o episodios de carácter imitativo. En el prólogo se ocupa de estos procedimientos, explicando las formas de redoblar, como ya veíamos anteriormente. Esteban Daza, treinta años después, volverá a utilizar esta misma terminología, incluyendo cuatro fantasías de este tipo, ${ }^{662}$ con la diferencia de que este último las incluye entre las piezas difíciles y Mudarra entre las fáciles. Podríamos clasificarlas en tonos mixtos como hace Milán con sus fantasías de consonancias y redobles. ${ }^{663}$

\section{2- Fantasía 2}

Fantasía de pasos largos. I modo por Gsolreut. Posición g (vihuela en Sol). 4 voces. Tempo medio. Notas móviles: Si ఢ (II), Do\# (IV), Mi b (VI), Fa\# (VII).

\section{NOTAS CRÍTICAS}

1. c. 5 . Añadimos la semimínima que figura entre corchetes.

2. c. 17. Ponemos 8 en $3^{\circ}$ orden en lugar de 3 .

\section{ESTRUCTURA}

$\begin{array}{ccccc}\text { Secciones } & \text { Compases } & \text { Cadencia final } & \text { Longitud } & \text { Textura } \\ 1 & 1-21 & \mathrm{~V} & 21 \mathrm{cc} . & \text { Idiomática } \\ 2 & 22-37 & \mathrm{~V} & 15 \mathrm{cc} . & \text { Imitativa } \\ 3 & 38-54 & \mathrm{I} & 18 \mathrm{cc} . & \text { Idiomática }\end{array}$

\footnotetext{
${ }^{662}$ Las obras número 19 a 22 según numeración de BROWN, Howard Mayer. Instrumental music printed before 1600. A Bibliography. Cambridge Massachusetts, Harvard University Press, 1979. En adelante BROWN.

663 «La razón porque en esta arte de música se nombra alguna fantasía de dos tonos es porque en esta arte de tañer de gala con estos redobles largos: parece bien que las fantasías se estrañen passando por los términos de sus tonos maestros y discípulos». MiLÁN. El maestro. f. E5v [p. 56].
} 


\section{ANÁLISIS}

Sección 1: comienzo con redobles en dedillo y dos dedos. Cadencia modal en I grado (cc. 5-6) para comenzar un pasaje con un motivo rítmico en el bajo que responde imitándose en el contralto. Doble cadencia modal con \#IV ${ }^{\circ}$ con retardo 7 \#6 seguida de cadencia tonal con 4 \#3. De nuevo la cabeza del motivo rítmico para concluir con cadencia modal sobre el $\forall$.

Sección 2: bicinium en soprano y contralto, cadencia tonal sobre $V$ grado. Bicinium en tenor y bajo con los mismos motivos que el anterior y misma cadencia. Nuevo bicinium entre tenor y soprano concluyendo en cadencia tonal sobre $\mathrm{I}$.

Sección 3: de nuevo redobles y el motivo rítmico de la sección 1 simultáneamente consigo mismo por aumentación. Cadencia sobre i grado para concluir con cadencia tonal sobre el $¥$ seguido de una pequeña coda.

\section{COMENTARIO}

La estructura se parece a la de la fantasía anterior pero cambiando el orden de las secciones.

Griffiths dice sobre esta pieza:

In this fantasia, and the others of the same type, Mudarra allows his music to be governed by the free flow of spontaneous melodic ideas. Even in such circunstances, he is careful not to allow the idiomatic inspiration to override his sense of linear integrity. In some instances, he creates lines whose compass is too wide to be sung, but it is infrequent for lines to complete phrases as a different voice to that as which they began. [...] It demonstrates that idiomatic passages are not conceived in a truly independent spirit, but generally subject to the same polyphonic controls as passages of imitation or free counterpoint. Mudarra's sense of idiom operates with conformity to conceptual forces. ${ }^{664}$

\footnotetext{
${ }^{664}$ Griffiths, J. The Vibuela Fantasia..., pp. 222-223.
} 


\section{3- Fantasía 3}

Fantasía de pasos largos. V modo. Posición F (vihuela en Sol). 4 voces. Tempo medio. Notas móviles: Fa\# (I), Si b (IV), Mi b (VII).

\section{NOTAS CRÍTICAS}

1. c. 42 . Ponemos 2 en $5^{\circ}$ orden en lugar de 3 .

2. c. 53 . Ponemos 3 en $2^{\circ}$ orden en lugar de 2 .

\section{ESTRUCTURA}

$\begin{array}{ccccc}\text { Secciones } & \text { Compases } & \text { Cadencia final } & \text { Longitud } & \text { Textura } \\ 1 & 1-29 & \text { I } & 29 \mathrm{cc} . & \text { Idiomática } \\ 2 & 30-53 & \text { I } & 24 \mathrm{cc} . & \text { Idiomática }\end{array}$

\section{ANÁLISIS}

Sección 1: la cabeza del motivo inicial es la inversión del inicio de la fantasía anterior. Comienzo a tres voces con el motivo de redobles en el soprano, cadencia sobre el I grado con retardo en el bajo. Para este pasaje indica dedillo, cuando debería ser dos dedos siendo coherente con lo explicado en el prólogo, pues se trata de una escala ascendente. Repetición del fragmento con el motivo en el bajo, con la diferencia de que en el descenso el VII grado es natural en lugar de bemol. En el c. 12 se producen dos séptimas paralelas. Cadencia rota en los cc. 22-23. Concluye la sección con cadencia sobre el I, de nuevo con el retardo en el bajo.

Sección 2: tras un nuevo comienzo con redobles se da paso a un fragmento modulante. Partiendo del $\mathrm{V}$ grado presenta una serie de notas alteradas atípicas del modo V, empezado por un Fa\# primero de paso y después como resolución de un retardo 4 \#3 en una cadencia modal sobre el II grado (cc. 36-37). Esta cadencia asimismo sobre un VII grado rebajado (típico del VII modo, no del V). Concluye este fragmento con cadencia sobre el II grado en posición de sexta. Vuelven los redobles culminando en un breve episodio con imitación entre tenor y bajo y cadencias finales a 4 voces con cadencia modal con retardo 76 y tonal con retardo 43 . Final sin tercera. 


\section{COMENTARio}

A pesar de estar en $\mathrm{V}$ modo, la presencia abundante del séptimo grado con bemol (Mi $b$ en nuestra transcripción) nos haría pensar en un VII modo. De hecho el primer motivo podría pertenecer a este tono.

\section{4- Fantasía 4}

Fantasía de pasos de contado. V modo. Posición F (vihuela en Sol). 4 voces. Tempo rápido (apriessa). Notas móviles: Sib (IV), Mib (VII).

\section{NOTAS CRÍTICAS}

1. c. 4.20 en $2^{\circ}$ orden en lugar de 0 2. Corregido a mano en el original e indicado en la fe de erratas del final.

2. c. 58. Añadimos la semimínima que figura entre corchetes.

\section{ANÁLISIS}

La estructura de esta pieza es particular, pues fluye de forma continua en valores de semimínimas (negras en nuestra versión) solo interrumpido este flujo por cadencias en el I, IV y V grados. Únicamente en los cc. 16-27 ocurre un pequeño episodio imitativo que concluye en cadencia tonal sobre el $\mathrm{V}$ grado para retomar el frenético movimiento de semímínimas. En los cc. 36-37, 38-39, 40-41 y 42 se produce una progresión de un motivo sacado del motivo inicial, que va descendiendo por grados desde el I hasta el V. Este tipo de progresiones son frecuentes en Luis Milán y en los laudistas italianos de una generación anterior como Spinacino y algo más raras en vihuelistas posteriores. ${ }^{665}$ Concluye la fantasía con cadencias tonales sobre I grado.

${ }^{665}$ GÁsSER, Luis. Luis Milán on Sixteenth-Century Performance Practice. Bloomington \& Indianapolis, Indiana University Press, 1996, pp. 116-117. 


\section{COMENTARIO}

Además de la indicación de tempo al principio de la obra escribe «Á de yr el compás muy apriesa». La mayor parte de la pieza, debido a su velocidad, discurre a dos voces, con algunos fragmentos a tres voces y cuatro en las cadencias.

Griffiths dice de esta fantasía: «is unique among his work, and the only fantasia in the repertory of the vihuelists to use its particular method of constructions. ${ }^{666}$ De hecho, es la única fantasía que se conoce con este título. Tal vez se refiera al cantus firmus que fluye de forma casi continua por toda la pieza, algo parecido a las fantasías de «passos remedados» de Diego Pisador.

\section{5- Fantasía 5}

Fantasía fácil. VI modo. Posición F (vihuela en Sol). 3 voces. Tempo medio. Notas móviles: Si b (IV), Do\# (V).

\section{INTRODUCCIÓN}

Tras las cuatro fantasías de pasos, Mudarra continua con tres fantasías fáciles. La facilidad de esta primera radica en ser a tres voces y con una textura transparente. Los pasajes imitativos suelen ser a dos voces y los de tres voces son homófonos. Además no sobrepasa el traste 5 de la vihuela, lo que hace que digitalmente sea sencilla.

\section{ESTRUCTURA}

$\begin{array}{ccccc}\text { Secciones } & \text { Compases } & \text { Cadencia final } & \text { Longitud } & \text { Textura } \\ 1 & 1-24 & \text { VI } & 24 \mathrm{cc} . & \text { Imitativa } \\ 2 & 25-53 & \text { III } & 29 \mathrm{cc} . & \text { Imitativa } \\ 3 & 54-73 & \text { I } & 20 \mathrm{cc} . & \text { Imitativa }\end{array}$

${ }^{666}$ GrifFithS, J. The Vibuela Fantasia..., p. 216. 


\section{ANÁLISIS}

Sección 1: comienzo imitativo entre soprano, tenor y bajo con un motivo de quinta ascendente que luego desciende. Solo el soprano presenta el tema íntegro, con un ámbito de un tritus plagal. Tras una cadencia modal sobre el $\mathrm{V}$ grado sigue un pasaje homofónico con leves imitaciones. De nuevo vuelven a aparecer las séptimas paralelas (c. 15), aunque Mudarra intente disimularlas con la resolución del retardo. Concluye la sección con cadencia tonal sobre el VI grado.

Sección 2: comienzo imitativo con un breve motivo descendente. Tras una cadencia modal sobre el IV grado, pasaje a tres voces casi homofónico y contrapunto libre. Cadencia modal (frigia) sobre el $\mathrm{HI}$.

Sección 3: nuevo comienzo imitativo con un tercer motivo descendente, primero a diferentes alturas, para luego solo hacerlo sobre el V grado y, casi como un ostinato, desembocar en una cadencia modal sobre el $\mathrm{I}$ grado.

\section{6- Fantasía 6}

Fantasía fácil. VI modo. Posición F (vihuela en Sol). 4 voces. Tempo rápido. Notas móviles: Si b (IV), Do\# (V), Mi b (VII).

\section{ESTRUCTURA}

$\begin{array}{ccccc}\text { Secciones } & \text { Compases } & \text { Cadencia final } & \text { Longitud } & \text { Textura } \\ 1 & 1-19 & \text { I } & 19 \text { cc. } & \text { Imitativa } \\ 2 & 20-38 & \text { I } & 19 \mathrm{cc} . & \text { Imitativa } \\ 3 & 39-56 & \text { I } & 18 \mathrm{cc} . & \text { Imitativa } \\ 4 & 57-76 & \text { I } & 20 \mathrm{cc} . & \text { Imitativa }\end{array}$

\section{ANÁLISIS}

Sección 1: bicinium entre soprano (motivo 1) y contralto (motivo 2) que cadencia en I grado. Respuesta casi literal en tenor y bajo. Episodio imitativo sobre el tema de la voz superior (motivo 1). Cadencia tonal completa a cuatro voces $v^{7}-\# I V^{6}-V^{4-3}-I$ (cc. 16-17). Se 
producen un par de quintas paralelas entre contralto y soprano, pero la segunda es disminuida. Enlace con escala ascendente.

Sección 2: contrapunto libre a tres voces con muchas apariciones del la subtónica (Mi $b$ en nuestra transcripción) lo que nos haría pensar en una modulación al VII u VIII modos. Cadencia modal al I grado.

Sección 3: nuevos bicinia sobre un fragmento del motivo 2 (motivo 3) y un nuevo motivo. La imitación pareada ocurre dos veces entre soprano y contralto y es respondida en tenor y bajo. Estrecho con la cabeza del motivo 3 y cadencia sobre el I.

Sección 4: similar a la sección 2. Contrapunto libre a tres voces con alguna cita del motivo 3. De nuevo nos movemos en una zona de ambigüedad modal, con frecuentes apariciones del Mi b y el Do\#. Tras la cadencia tonal sobre el I hay una breve coda plagal.

Creemos que esta fantasía tan absolutamente simétrica con tantos recursos contrapuntísticos como el uso frecuente de las voces pareadas, frecuentes estrechos, está muy cerca del estilo francoflamenco, en particular de Josquin, que tan bien conocía Mudarra, pues transcribe y glosa varias piezas suyas, como veremos más adelante.

\section{COMENTARIO}

De nuevo una fantasía fácil, pero en esta ocasión a cuatro voces y bastante más compleja que la anterior y además en tempo apriessa. Alcanza en una sola ocasión el traste 7 de la prima de la vihuela. Textura politemática imitativa y estructura perfectamente regular.

Griffiths transcribe y analiza esta pieza destacando su proporción arquitectónica. ${ }^{667}$

\footnotetext{
${ }^{667}$ Griffiths, J. The Vibuela Fantasia..., pp. 192-196.
} 


\section{7- Fantasía 7}

Fantasía fácil. I modo. Posición c (vihuela en La). 4 voces. Tempo medio. Notas móviles: Mi ต (III), Fa\# (IV), La b (VI), Si ต (VII).

\section{ESTRUCTURA}

$\begin{array}{ccccc}\text { Secciones } & \text { Compases } & \text { Cadencia final } & \text { Longitud } & \text { Textura } \\ 1 & 1-24 & \mathrm{~V} & 24 \mathrm{cc} . & \text { Libre e imitativa } \\ 2 & 25-40 & \mathrm{v} & 16 \mathrm{cc} . & \text { Imitativa } \\ 3 & 41-65 & \mathrm{I} & 25 \mathrm{cc} . & \text { Imitativa } \\ 4 & 66-85 & \mathrm{I} & 20 \mathrm{cc} . & \text { Imitativa }\end{array}$

\section{ANÁLISIS}

Sección 1: comienzo donde apenas se puede distinguir ningún tema, únicamente el motivo rítmico inicial de mínima con puntillo seguida de semimínima y que será recurrente a lo largo de toda la pieza, tanto en su forma ascendente como descendente. Podríamos ver los diez primeros compases como una introducción para definir el modo, con su cadencia tonal sobre $\mathrm{I}$, cadencia rota sobre el III, para concluir con cadencia tonal sobre el i grado. En el c. 11 comienzan una serie de imitaciones con un motivo, derivado del inicio, un poco más elaborado. Concluye con cadencia tonal sobre el $¥$.

Sección 2: motivo derivado del primero, por movimiento contrario imitándose en todas las voces. Cadencia tonal sobre I grado, breve episodio y semicadencia sobre el v.

Sección 3: mientras las voces inferiores terminan una cadencia sobre aparentemente sobre el I grado (en realidad sobre el $b \mathrm{VI}^{\circ}$ ), la voz superior entona un motivo algo más largo que los anteriores, siendo respondido por el bajo hasta unirse en una serie de sextas paralelas que concluye en cadencia modal sobre el $\mathrm{I}$. Tras una serie de acordes cadenciales, llegamos a una especie de pedal de $\mathrm{V}$ grado de cuatro compases que culmina en varias cadencias sobre el I grado.

Sección 4: comienza con un motivo en contralto que ya apareció anteriormente, en los cc. 11-12 y que no llegó a aprovechar, pues rápidamente mutó a otro diseño. Tras una cadencia rota sobre el bVI, el motivo vuelve a aparecer en el contralto doblado en 
décimas paralelas en el bajo. Nueva cadencia rota sobre el bVI (c. 75) para concluir con una coda plagal de diez compases.

\section{COMENTARIO}

La dificultad va en aumento, pues frecuenta los trastes 7 y 8 de la vihuela. Es muy diferente a la anterior debido a los pocos elementos contrapuntísticos que contiene.

\section{8- Fantasía 8}

Fantasía. I modo. Posición c (vihuela en La). 4 voces. Tempo medio. Notas móviles: Mi $\nleftarrow$ (III), Fa\# (IV), La b (VI), Si

\section{NOTAS CRÍTICAS}

1. c. 69. Los dos 9 del $2^{\circ}$ orden están invertidos.

\section{ESTRUCTURA}

$\begin{array}{ccccc}\text { Secciones } & \text { Compases } & \text { Cadencia final } & \text { Longitud } & \text { Textura } \\ 1 & \text { cc. } 1-16 & \text { i } & 16 & \text { Imitativa } \\ 2 & \text { cc. } 17-28 & \text { I } & 12 & \text { Imitativa } \\ 3 & \text { cc. } 29-40 & \text { i } & 12 & \text { Libre } \\ 4 & \text { cc. } 41-54 & \text { i } & 14 & \text { Libre } \\ 5 & \text { cc. } 55-70 & \text { I } & 16 & \text { Libre }\end{array}$

\section{ANÁLISIS}

Sección 1: breve motivo ascendente imitándose y voces libres en una textura a tres voces, cadencia sobre el i grado, nueva entrada y cadencia frigia sobre el V. Pasaje de enlace hacia el i grado. En el c. 13 vemos ya una particularidad, de tantas que tiene Mudarra, se trata de una escapada o floreo sin resolución. ${ }^{668}$

${ }^{668}$ Este tipo de disonancias es frecuente en Josquin, por ejemplo en la Missa Pangue Lingua. MotTE, Diether de la. Contrapunto. Madrid, Labor, 1991, p. 104. 
Sección 2: nuevo motivo breve derivado del anterior con imitaciones cada vez más estrechas, textura a cuatro voces. En el c. 19 vemos una apoyatura en sustitución del retardo 4 3. Cadencia tonal sobre el $I$ sin quinta ni tercera.

Sección 3: de nuevo a tres voces con escasas imitaciones sobre la cabeza del motivo inicial. Desde posiciones muy graves de la vihuela, va ascendiendo poco a poco hasta cadenciar en el tiple sobre el i grado.

Sección 4: contrapunto libre, con algunos acordes extraños a la modalidad, como el bII del punto más agudo de la pieza (c. 44), seguido de un par de quintas paralelas en los dos compases siguiente. Cadencia tonal a cuatro voces sobre el I grado.

Sección 5: de nuevo contrapunto libre a tres voces para concluir a cuatro voces con cadencia final en $\mathrm{I}$.

\section{9- Fantasía 9}

Fantasía. II modo. Posición g (vihuela en Sol). 4 voces. Tempo rápido. Notas móviles: Si $\vdash$ (III), Do\# (IV), Mi b (VI), Fa\# (VII).

\section{NOTAS CRÍTICAS}

1. c. 35 . Añadimos la nota que figura entre corchetes.

2. c. 55 . Ponemos 2 en $4^{\circ}$ orden en lugar de 3.

3. c. 68.2 en $1^{\circ}$ orden invertido.

4. c. 80 . Ponemos 7 en $3^{\circ}$ orden en lugar de 5 .

5. c. 81 . Ponemos 10 en $3^{\circ}$ orden en lugar de 8 .

6. c. 85 . Añadimos 0 en $5^{\circ}$ orden. Corregido a mano en el original y mal indicado en la fe de erratas del final que indica compás 84 .

7. c. 88. Ponemos 6 en $6^{\circ}$ orden en lugar de $5^{\circ}$ y 2 en $4^{\circ}$ orden en lugar de $3^{\circ}$. Corregido a mano en el original e indicado en la fe de erratas del final.

8. c. 106. Ponemos 2 en $4^{\circ}$ orden en lugar de 3.

\section{ESTRUCTURA}

$\begin{array}{ccccc}\text { Secciones } & \text { Compases } & \text { Cadencia final } & \text { Longitud } & \text { Textura } \\ 1 & \text { cc. } 1-22 & \mathrm{~V} & 22 & \text { Imitativa }\end{array}$




$\begin{array}{llllc}2 & \text { cc. } 23-44 & \text { I } & 22 & \text { Libre } \\ 3 & \text { cc. } 45-73 & \text { i } & 29 & \text { Libre } \\ 4 & \text { cc. } 74-105 & \text { I } & 33 & \text { Imitativa }\end{array}$

\section{ANÁLISIS}

Sección 1: comienza con un largo tema que recorre toda la octava y todas las voces en el orden contralto, soprano, tenor y bajo. Entre medias, cadencia rota sobre el vi grado, tonal sobre el i y modal sobre el V. El pasaje final (cc. 20-24) es desconcertante por sus armonías:

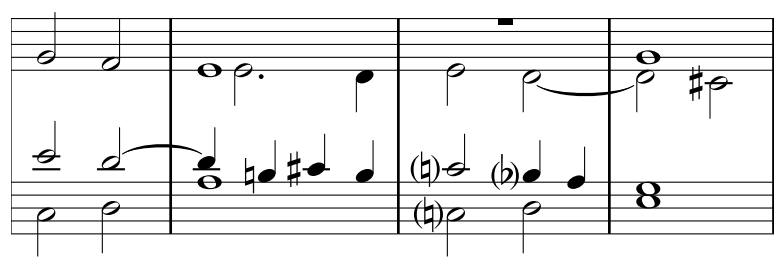

Ejemplo 1. Fantasía 9. Mudarra (cc. 20-24)

Comienza una cadencia hacia el $\mathrm{V}$ grado, con un retardo 4 \#3 sobre el II grado ornamentado en el tenor, que en lugar de resolver en el $\mathrm{V}$ intercala un IV grado sin alterar, seguido de un $\mathrm{III}^{6}$ (o un $\mathrm{V}$ con la sexta como apoyatura) para luego seguir con una cadencia modal con 7 \#6 hacia el V.

Sección 2: en medio de la cadencia anterior comienza un nuevo motivo, mucho más sencillo que el anterior. En realidad se trata de la figura rímica de mínima con puntillo y semimínima que veíamos en fantasías anteriores. La sección discurre a tres voces y prácticamente en contrapunto libre con leves apariciones del motivo rítmico citado antes.

Sección 3: fragmento en contrapunto libre con frecuente aparición de las cuatro voces y muchas cadencias sobre el I grado.

Sección 4: nuevo pasaje imitativo con textura más transparente que los anteriores y armonías más características del modo. Comienza un motivo (emparentado con el motivo principal de la sección 2) en contralto, acompañado por melodías libres en bajo y soprano, hace una cadencia rota sobre el II grado. El motivo pasa al soprano y cadencia en el $¥$. Exposición del mismo en el bajo acompañado por tenor, motivo en el tenor, después en 
contralto y en soprano acumulando voces hasta las cuatro. Los últimos nueve compases conforman una coda, con una especie de pedal sobre el $\mathrm{V}$ y cadencia tonal a cuatro voces sobre el $\mathrm{I}$.

\section{COMENTARIO}

Podemos considerar esta fantasía como la pieza más compleja de ejecución de todo el libro primero, con notas hasta el traste 10, gran longitud (106 compases) y tempo rápido. Pero además incluye algunas audacias armónicas difíciles de explicar. También es la pieza con mayor cantidad de erratas hasta ahora, lo que nos impide saber si las audacias son tales o errores de imprenta.

\section{0- Qui tollis}

Compostura de Josquin sacada de la segunda parte del Gloria de la Missa Faysant regret\%: II modo por Gsolrent. Posición g (vihuela en Sol). 4 voces. Tempo medio. Notas móviles: Si

\section{NOTAS CRÍTICAS}

1. c. 18. Añadimos la nota que figura entre corchetes.

2. c. 32. Añadimos la nota que figura entre corchetes. Indicado en la fe de erratas del final.

3. c. 48.3 en $1^{\circ}$ orden invertido.

4. c. 81. Error rítmico.

\section{ANÁLISIS}

Esta pieza y la siguiente son fragmentos de la misma misa, sin apenas intervención por parte de Mudarra. Este utiliza la palabra «compostura» en el mismo sentido que Fuenllana unos pocos años más tarde, quien diferencia en su libro entre composturas y fantasías, siendo las primeras obras ajenas y las segundas propias. 
Únicamente en las cadencias, como Fuenllana, ${ }^{669}$ introduce las glosas características del instrumento y las notas largas las divide para manterner el sonido, el resto es literal. ${ }^{670}$ Utilizamos para la comparación la transcripción de Smijers ${ }^{671}$ y las ediciones de época como son el Missarum Josquin liber tertius publicado por Petrucci en $1514^{672}$ y el Liber quindecim missarum editado por Antico en 1516 y conocido en España como «las quince misas de Josquin». ${ }^{673}$

Un ejemplo de cláusula glosada:

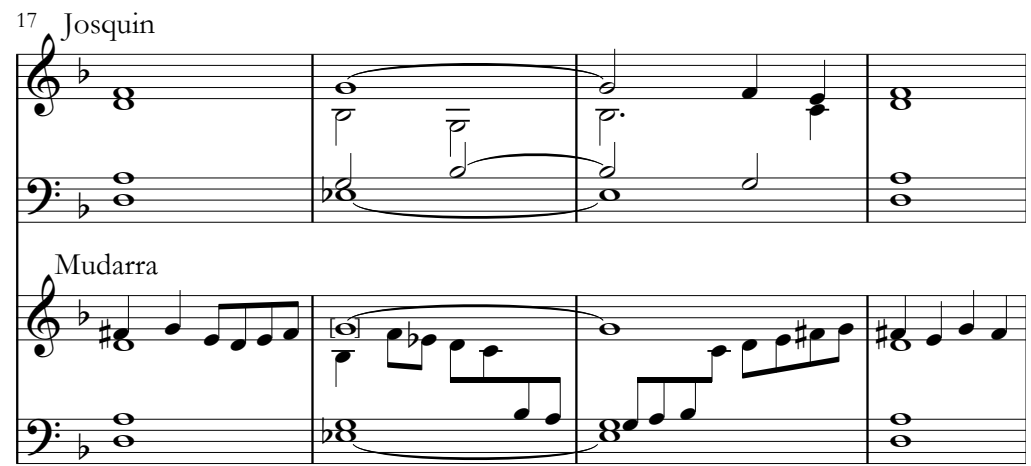

Ejemplo 2. Qui tollis (cc. 17-20)

La pieza consiste en varios dúos entre los que se intercalan pasajes homofónicos a cuatro voces, culminando con un pasaje ternario (según Mudarra el Cum sancto spiritu).

\section{COMENTARIO}

Creemos que Mudarra no debió utilizar una fuente impresa sino algún manuscrito que circulara en manos de los músicos, pues hay algunas variantes, algunas mayores y otras de

${ }^{669}$ Dice Fuenllana «si no fuere offreciéndose cláusula, o en tiempo que la misma compostura diere lugar no se deve en otra manera defraudar la compostura con las semejantes glosas o redobles». FUENLLANA. Orphénica lyra, f. v.

${ }^{670}$ Pujol afirma que «El canto llano en la versión de Mudarra difiere, en determinados pasajes, del tenor del original de Josquin, y, en consecuencia, de las demás voces también», sin que esta afirmación tenga ningún fundamento real. PUJOL. Mudarra, p. 64.

${ }^{671}$ Smijers, A. (ed.). Werken van Josquin des Prez. Vol 27. Missen XIII. Missa Faisant Regretz. Amsterdam, G. Alsbach \& Co., 1951. El original parece ser el de Petrucci.

${ }^{672}$ Missarum Josquin liber tertius. Fossombrone, Ottaviano Petrucci, 1514 (RISM A/I J 673).

${ }^{673}$ Liber quindecim missarum ... Ya lo encontramos en el inventario post mórtem del IV duque del Infantado tasado en 20 reales. 
menor importancia. Después del c. 39 de nuestra transcripción debería haber otros tres compases que han desaparecido. Cuatro compases (dos de la edición de Smijers) se han transformado en un diseño cadencial a una voz. Los cc. 52-54 son muy distintos al original. Aparte de estas ausencias, el resto de las voces son prácticamente literales, con leves modificaciones cuando es complicado "digitalmente" dar todas las voces.

\section{1- Pleni}

Compostura de Josquin del Sanctus de la Missa Faysant regretz. II modo por Gsolreut. Posición g (vihuela en Sol). 3 voces. Tempo medio. Notas móviles: Si Ł (III), Mi b (VI), $\mathrm{Fa \#}$ (VII).

\section{NOTAS CRÍTICAS}

1. c. 15. Añadimos la nota que figura entre corchetes.

2. c. 81. Eliminamos una figura rítmica redundante.

3. c. 86. Añadimos la mínima que figura entre corchetes.

\section{INTRODUCCIÓN}

Esta miniatura de Josquin es una obra a tres voces (el tenor calla) con una textura permanentemente imitativa, llegando al canon en muchas ocasiones. El tratamiento que le da Mudarra es similar a la de la pieza anterior: fidelidad máxima al original y ornamentación de las cláusulas. Utilizaremos para la comparación las mismas fuentes y transcripción que antes.

\section{ESTRUCTURA}

$\begin{array}{ccccc}\text { Secciones } & \text { Compases } & \text { Cadencia final } & \text { Longitud } & \text { Textura } \\ 1 & \text { cc. } 1-26 & \mathrm{~V} & 26 & \text { Imitativa } \\ 2 & \text { cc. } 28-52 & \mathrm{i} & 26 & \text { Imitativa } \\ 3 & \text { cc. } 53-88 & \mathrm{~V} & 36 & \text { Imitativa }\end{array}$




\section{ANÁLISIS}

Sección 1: comienza el bajo con el primer motivo imitado en canon al unísono por el contralto y a la octava por el soprano. El segundo motivo nace en el contralto antes de concluir el soprano con el primero y es respondido al unísono por el bajo y a la quinta por soprano. Tras un pasaje libre, Mudarra omite un compás después del c. 24, provocando, entre otras cosas, en el c. 26 una disonancia de séptima en parte fuerte.

Sección 2: este fragmento está basado en un diseño de síncopa, resolución y floreo entre bajo y contralto frente a soprano, donde Mudarra introduce algunas leves modificaciones que hacen el ritmo más uniforme, y más sencilla su ejecución. Los cc. 3641 se repiten prácticamente en los cc. 42-48. Sin que en ningún momento se haya producido una cadencia o cláusula conclusiva, termina en una especie de semicadencia.

Sección 3: un bicinium en las voces superiores es respondido en las inferiores. Mudarra introduce algún cambio rítmico para hacer que el motivo de mínima con puntillo semimínima predomine. Nueva imitación en el c. 67 entre soprano y bajo mientras el contralto acompaña libremente. El c. 76 es un añadido de Mudarra y a partir de aquí se podría considera como una coda. En el c. 87 vemos el floreo sin resolución o escapada (también en Josquin) que vimos en la Fantasía 8.

\section{2- Fantasía 10}

Fantasía. II modo por Gsolreut. Posición g (vihuela en Sol). 4 voces (en los acordes a veces refuerza hasta cinco voces). Tempo rápido. Notas móviles: Mi b (VI), Fa\# (VII).

\section{NOTAS CRÍTICAS}

1. c. 14 . Añadimos rasguito sobre el 4 en $2^{\circ}$ orden.

2. c. 51 . Mal numerado el folio. Donde dice XIII debe decir XIV.

3. c. 59. Añadimos la mínima que figura entre corchetes y la línea divisoria de compases.

4. c. 70 . Añadimos rasguito sobre el 2 en $4^{\circ}$ orden.

5. c. 72. Añadimos la semimínima que figura entre corchetes.

6. c. 154. Añadimos la mínima que figura entre corchetes.

7. c. 156. Corchea en lugar de semimínima. Indicado en la fe de erratas del final. 


\section{INTRODUCCIÓN}

Es tal vez la obra más conocida de Mudarra, la más interpretada y la más estudiada. Ya llamó la atención de Morphy, siendo la única fantasía de Mudarra que transcribió, lo que representa la primera transcripción de ella que conocemos. ${ }^{674}$ Posteriormente, Griffiths la analizó en su tesis doctoral y escribió tres años más tarde un artículo monográfico que, a día de hoy, sigue siendo el análisis más certero y completo de la obra. ${ }^{675}$ Recientemente Fiorentino se ha ocupado de ella en su tesis sobre la folía. ${ }^{676}$ Para nuestro análisis seguiremos en lo fundamental a Griffiths, incluyendo alguna de las aportaciones de Fiorentino. Según Griffiths, la Fantasía X estaría formada por tres variaciones sobre el esquema de la folía de diferente longitud y con algunas particularidades.

\section{ESTRUCTURA}

$\begin{array}{cccc}\text { Secciones } & \text { Compases } & \text { Cadencia final } & \text { Longitud } \\ 1 & 1-95 & \text { IV } & 95 \mathrm{cc} . \\ 2 & 96-124 & \text { III } & 29 \mathrm{cc} . \\ 3 & 125-157 & \text { I } & 33 \mathrm{cc} .\end{array}$

\section{ANÁLISIS}

Sección 1: construida con únicamente tres motivos, una tercera menor descendente con un ritmo dactílico $\left(1^{\circ}\right)$ sirve de anacrusa a un arpegio descendente $\left(2^{\circ}\right)$ que concluye con unos redobles sobre las notas del acorde $\left(3^{\circ}\right)$ y que conducen a la siguiente armonía. El arpegio puede repetirse dos, tres veces o ninguna. Los redobles se agrupan con frecuencia en grupos de tres notas, lo que produce una interesante ambigüedad rítmica. Los diseños de tercera parten de la nota tónica modal en el tiple (armonizada con un IV grado), suben diatónicamente hasta alcanzar el V (armonizado con un acorde de III

${ }^{674}$ MorpHy, G. Les Luthistes espagnoles..., vol. II, pp. 103-105.

${ }^{675}$ GRIFFITHS, J. The Vibuela Fantasia..., pp. 223-229 y GrIFFITHS, John. «La «Fantasía que contrahaze la Harpa» de Alonso Mudarra; estudio histórico analítico», Revista de Musicología, 9 (1986), pp. 29-40. Sin ánimo de restar un ápice del mérito a estos dos magníficos trabajos, simplemente advertimos que en el análisis de la fantasía en su tesis Griffiths comete un error en la numeración de los compases, añadiendo uno más. Este error queda perfectamente subsanado en el posterior artículo.

${ }^{676}$ FIORENTINO, Giuseppe. Música española del Renacimiento entre tradición oral y transmisión escrita: el esquema de folía en procesos de composición e improvisación. Tesis Doctoral, Universidad de Granada, 2009, pp. 379-383. 
grado) y luego vuelven a descender al mismo acorde de IV. En cada subida se van afirmando las armonías características de la folía con alguna modificación. Los módulos de la progresión ascendente no son iguales. Además de ir alcanzando notas más agudas, en la primera mitad cada módulo es más corto que el anterior. El primero y el segundo son casi iguales con 13 y 12 cc. respectivamente y dos repeticiones del arpegio. El tercero solo tiene 8 cc. y una presentación del arpegio. De esta forma se consigue un incremento paulatino de la tensión. El punto culminante se consigue en el c. 48 (exactamente la mitad con 47 cc. a cada lado), insistiendo en la nota más aguda, la V, durante 7 cc.. Tras esto comienza el descenso.

En el c. 91 se produce una ruptura de la progresión, parece como si faltara un compás y de hecho Pujol lo interpreta así. ${ }^{677}$ Añade un compás para que se mantenga la progresión. Nosotros estamos de acuerdo con Griffiths cuando afirma:

La conversión del compás 91 del original en dos compases no parece correcta; la brusquedad anormal del compás 91 parece intencionada. Es la señal que nos da Mudarra para indicar el enlace de las dos primeras variaciones. La adición de un compás, además, desequilibra la simetría de la primera variación, aunque mantiene la consistencia de los arpegios anteriores. ${ }^{678}$

Durante toda la sección las únicas notas móviles que aparecen son las características del II modo: el VII grado elevado y el VI rebajado (Fa\# y Mib respectivamente). El ámbito también se respeta escrupulosamente en el tiple.

Sección 2: el c. 95 se puede considerar último de la anterior sección y primero de esta. La misma célula del principio, pero ahora con un cambio de dirección, se repite cuatro veces. A partir del c. 111 vuelven los redobles con un diseño que seguirá hasta el final y en el c. 115 se introducen unas interesantes síncopas mediante un desplazamiento de la nota del bajo. Estas síncopas también fueron consideradas por Pujol como un error. Griffiths no lo piensa así y nosotros tampoco.

Sección 3: es la que ha hecho tan famosa a esta obra. De su particularidad da cuenta Mudarra al advertir «de aquí fasta açerca del final ay algunas falsas, tañiéndose bien no pareçen mal». Lo más llamativo son esas falsas o disonancias que se producen, por

\footnotetext{
${ }^{677}$ Pujol añade un compás en la transcripción y afirma en la crítica de la edición: «Lógicamente falta un compás». Pujol Mudarra, pp. 17 y 91. Sin embargo, en la transcripción de Morphy no se corrige el compás y una gran parte de los intérpretes actuales de vihuela lo tañen tal y como indica la tablatura.

${ }^{678}$ GRIFFITHS, J. «La «Fantasía que contrahaze..., p. 35.
} 
ejemplo, ente el Fa\# de la voz superior y el Fa natural del bajo, además de cuartas, séptimas y novenas de golpe en parte fuerte. La explicación de esta falsa relación entre Fa\#\# y Fa natural nos la da Bermudo cuando explica las formas de tañer las cláusulas y sus semitonos en el arpa. ${ }^{679}$ Una de ellas, la más común, era preafinar las cuerdas correspondientes a la nota del VII grado, subiéndolas un semitono en las dos octavas superiores, mientras que en la octava baja quedaba el sonido natural. Algo parecido podría ocurrir en los instrumentos de tecla que tuvieran octava corta.

\section{COMENTARIO}

Algunas palabras sobre la duración de las notas. Hemos preferido en nuestra transcripción no prolongar los valores de las notas mucho más de lo que indica el propio autor. Hemos visto que Mudarra dice «Encima de algunas cifras toparán esta señal $\wedge$ la qual se pone para que sepan que no an de alçar el dedo de la cuerda durante aquel compás, si estuviere al principio del. Y si al fin hasta la mitad del que se sigue». Aun así, como dicta el sentido común y la práctica interpretativa, en los diseños iniciales de cada acorde prolongamos las notas hasta que se dan las cuatro o cinco notas del acorde, pues creemos que los rasguitos indican en este caso precisamente esto. Sin embargo, no prolongamos más allá de la semibreve las notas y dejamos al interprete la posibilidad de mantenerlas hasta su extinción natural, lo que dependerá del tempo, del tipo de cuerdas y del instrumento. ${ }^{680}$

El título de la pieza sería un homenaje a un famoso arpista de la corte de Fernando de Aragón, duque de Calabria. Sirvió al rey Fadrique de Nápoles, padre del duque, y cuando este último fue traído a España desde Nápoles vino con él. ${ }^{681}$ Bermudo se refiere a el arpista en los siguientes términos:

\footnotetext{
${ }^{679}$ Bermudo. Declaración, f. 110v.

${ }^{680}$ Se puede observar en las grabaciones discográficas como algunos intérpretes de vihuela prefieren mantener los sonidos de los acordes, mientras que otros optan por cortarlos.

${ }^{681}$ BERMúDEZ, Egberto. «Sobre la identidad de Ludovico», Nassarre: Revista aragonesa de musicología, 10/1 (1994), pp. 9-16.
} 
Dizen, que el nombrado Ludovico quando venía a clausular: poniendo el dedo debaxo de la cuerda, la semitonava, y hazía cláusula de sustentado. Gran destreza y certidumbre era menester para esto. ${ }^{62}$

De hecho cuando Mudarra habla de la cifra de arpa en la explicación del tiento para arpa y órgano explica la forma de semitonar «Para formar los semitonos se ponen estas dos señales $b$ \# en la cuerda que qualquiera de ellas estubiere se á de poner el dedo acerca de las clavijas».

Mudarra debió oir hablar de Ludovico, pues no debemos olvidar la relación entre las capillas del Infantado y de los duques de Calabria. No sería descabellado pensar que en su juventud Mudarra hubiera tenido ocasión de escucharlo.

\section{3- Conde Claros}

Diferencias. V modo. Posición F (vihuela en Sol). 4 voces. Tempo lento. Notas móviles: Si b (IV), Mi b (VII).

\section{NOTAS CRÍTICAS}

1. c. 12. Añadimos doble barra final de diferencia.

2. c. 19. Ponemos 3 en $2^{\circ}$ orden en lugar de 2 .

3. c. 21. Ponemos 3 en $3^{\circ}$ orden en lugar de 2. Corregido a mano en el original.

4. c. 24. Ponemos 3 en $3^{\circ}$ orden en lugar de 2 .

5. c. 26. Sobra una doble barra de final de diferencia.

6. c. 30. Añadimos doble barra final de diferencia.

7. c. 35 . Ponemos 3 en $6^{\circ}$ orden en lugar de en $5^{\circ}$.

\section{INTRODUCCIÓN}

Con esta pieza comienza las que Mudarra denomina en su índice Obras menudas, donde se incluyen dos series de diferencias y tres danzas. ${ }^{683}$ Las cinco piezas, en relación al resto de las obras, son de baja dificultad.

${ }^{682}$ BERMudo. Declaración, f. $110 \mathrm{v}$.

${ }^{683}$ Las cinco piezas fueron transcritas por el conde Morphy. MORPHY, G. Les Luthistes espagnoles..., vol. II, pp. 96-102. 
El Conde Claros es, junto con el Guárdame las vacas, el ostinato armónico o ground favorito de los vihuelistas españoles para la creación de diferencias o variaciones. El texto se corresponde con el «Romance del Conde Claros de Montalbán» y tanto este como la música gozaron de gran popularidad en el siglo XVI. ${ }^{684}$ Sobre el texto se tiene noticias desde el siglo anterior, pues era muy conocido en los círculos cortesanos de los Reyes Católicos. En el Cancionero de Palacio hay una obra de Juan del Encina sobre el fragmento de la escena de la prisión que comienza Pésame de vos, el conde (CMP 131, ff. 77v-78). La melodía utilizada en este caso poco tiene que ver con la que se hará famosa en el siglo XVI. Sin embargo, en el mismo cancionero se encuentra el villancico Alza la voz, pregonero (CMP 152, f. 88), que en cancioneros posteriores aparecerá como desecha del romance citado. Algunos autores han visto relación musical entre este villancico y la melodía común del siglo XVI. ${ }^{685}$

Francisco de Salinas, en su De musica libri septem, utiliza esta melodía como ejemplo del metro denominado tetrámetro cataléctico, formado por un pie moloso y una dipodia trocaica que se repiten con la segunda dipodia incompleta. Nos dice que con esta música cantaban los españoles los romances resolviendo el moloso (en un jónico mayor o dos largas y dos breves). La misma melodía se adapta al texto Retraýda está la infanta, dejando la segunda dipodia completa. ${ }^{686}$

Musicalmente la forma es sencilla: tres acordes en el V modo de I, IV y V grados en estado fundamental. El ritmo característico de hemiolia o alternancia de tres por cuatro y seis por ocho es ampliamente conocido en la música española; en la música vocal es fácilmente reconocible a través del ennegrecimiento, pero en las tablaturas de vihuela no hay ningún signo especial que lo identifique y los vihuelistas suelen escribirlo en compás binario, de forma que es preciso adivinarlo. Si reducimos un cuarto los valores dados por

\footnotetext{
${ }^{684}$ Un estudio clásico sobre la musica de este romance en POPE, Isabel. «Notas sobre la melodía del Conde Claron», Nueva Revista de Filología Hispánica, 7 (1953), pp. 395-402.

${ }^{685}$ LAwrenCE, Deborah. «Spain's “Conde Claros”: From Popular Song to Harmonic Formula», Journal of Musicological Research, 30 (2011), pp. 46-65.

${ }^{686}$ SALinAs, Francisco. De Musica libri Septem. Salamanca, Mathias Gastius, 1577, pp. 342 y 346.
} 
Salinas y los vihuelistas, unimos melodía y esquema armónico y añadimos el texto del primer verso, tenemos:

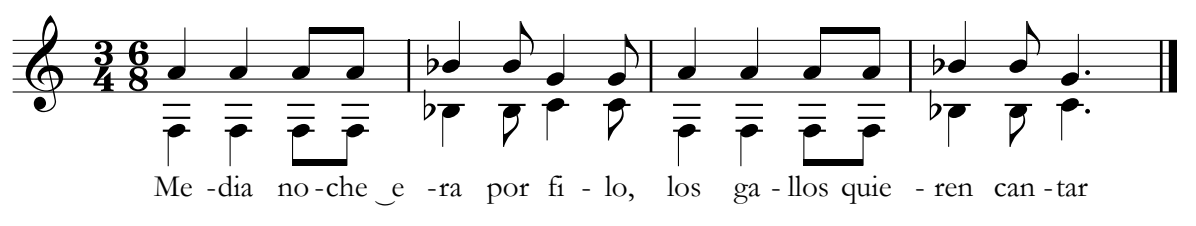

Ejemplo 3. Esquema del Conde Claros

Los vihuelistas elaboran sus diferencias sobre la mitad de este breve esquema ocupando, por lo general, seis compases binarios. Estas transcurren de forma continua, en muchos casos enlazándose unas con otras. Esto no quiere decir que todas ellas necesariamente se deban interpretar seguidas, sino seleccionándolas a voluntad; como afirma Valderrábano: «que cada uno taña la diferencia que meior le agradare». ${ }^{687}$

Del éxito de este tema da cuenta la cantidad de versiones impresas, la mayoría de ellas en muy pocos años y muchas fuera de España. Incluimos una lista de las ediciones que tuvo esta pieza en el siglo XVI. Indicamos el número de variaciones totales ya que no todos los autores lo consideran igual. Narváez llama diferencia desde la primera presentación del tema, Mudarra desde la segunda, Valderrábano no dice nada, Pisador desde la segunda pero se olvida de otra, Venegas desde la segunda. Ponemos el título del Índice del autor y del cuerpo del libro cuando difieren.

1. Narváez (1538), Conde claros del sesto tono. Veynte y dos diferencias de Conde claros para discantar. (22 variaciones) f. $82-86 .{ }^{688}$

2. Mudarra (1546), Conde claros. Conde claros en doze maneras. (13 variaciones) ff. 15v$16 \mathrm{v}$.

${ }^{687}$ Tal vez diga esto debido al enorme número de variaciones que incluye. VALDERRÁBANO. Silva de sirenas, f. $97 \mathrm{v}$.

${ }^{688}$ La paginación del sexto libro es errónea, por lo que los números corresponden con la numeración que debería tener. Hay transcripción moderna en PujoL, E. Luys de Narváez..., pp. 82-85. 
3. Valderrábano (1547), Esta música que se sigue va sobre el canto llano del conde Claros. Sobre el tenor del conde claros en tercera menor a cinco Anrríquez: (13 variaciones) f. 48v-50. Para dos vihuelas afinadas a distancia de tercera menor. ${ }^{689}$

4. Valderrábano (1547), Diferencias sobre el tenor del conde claros por dos partes. (49 variaciones) ff. $97 \mathrm{v}-99 \mathrm{v} .{ }^{690}$

5. Valderrábano (1547), Diferencias sobre el tenor del conde claros por dos partes. (74 variaciones) ff. $99 \mathrm{v}-103 .{ }^{691}$

6. Pisador (1552), Conde claros con ciertas differencias para los principiantes y para los que más saben. Conde claros, con treynta y siete differencias. (38 o 39 variaciones), ff. 1-2. ${ }^{692}$

7. Morlaye, Guillaume. Le Premier livre de Chansons... París (1552), Conte clare, (12 variaciones) f. 24v-25v. Para guitarra renacentista.

8. Morlaye, Guillaume. Quatriesme livre contenant plusieurs Fantasies... París (1552), Contreclare a corde avallée, (6 variaciones) f. 18v-19. Para guitarra renacentista.

9. Morlaye, Guillaume. Quatriesme livre contenant plusieurs Fantasies... París (1552), Contreclare, (2 variaciones) f. 27v. Para cítara (cistre).

10. Phalèse, Pierre. Hortus Musarum... Lovaina (1552), Conde claros, pp. 102-103. Para dos laúdes. Copiado de Valderrábano, $1547 .{ }^{693}$

11. Morlaye, Guillaume. Le Second livre de Chansons... París (1553), Conte clare, (3 variaciones) f. 29. Para guitarra renacentista.

12. Morlaye, Guillaume. Le Second livre de Chansons... París (1553), Conte clare, (7 variaciones) f. 29v-30. Para guitarra renacentista. ${ }^{694}$

${ }^{689}$ Esta pieza difiere del resto en que únicamente la voz superior de una de las vihuelas lleva el canto llano o melodía del Conde Claros mientras que el resto funcionan contrapuntísticamente sin que las armonías se correspondan con el esquema básico. Hay transcripción moderna en PUjOL, E. Enríquez de Valderrábano..., vol 1, pp. 54-56 y en GRIFFITHS, John. Tañer vihuela según Juan Bermudo. Polifonía Vocal y Tablaturas Instrumentales. Zaragoza, Institución «Fernando el Católico» (C.S.I.C.), Sección de Música Antigua, Excma. Diputación Provincial, 2003, pp. 98-99.

${ }^{690}$ Hay transcripción moderna en PUjOL, E. Enríquez de Valderrábano..., vol 2, pp. 75-81.

${ }^{691}$ Hay transcripción moderna en PUjOL, E. Enríquez de V alderrábano..., vol 2, pp. 82-91.

${ }^{692}$ En el índice indica treinta y siete diferencias, más el tema inicial, pero una de ellas, la sexta, es doble, no sabemos si es error de imprenta o premeditado. Hay transcripción moderna en ROA, F. y GÉRTRUDIX, F. El libro de música..., Estudio y transcripción, no 1, pp. 139-140.

${ }^{693}$ Phalèse se limita a copiar las dos series de diferencias para vihuela sola e indicar que se toquen en vihuelas a distancia de cuarta, ya que una está en posición de Fa y otra de Do. Tan burda es la copia que toma parcialmente las variaciones más fáciles, es decir, las primeras, pero sin que coincidan los compases, por lo que una vihuela termina antes de la otra.

${ }^{694}$ Una particularidad de esta versión es que cada módulo de variación consta de cinco compases, es decir, elimina el primer compás de los seis que son habituales. Hay transcripción moderna en HEARTZ, 
13. Venegas de Henestrosa (1557), Conde Claros, (6 variaciones) f. 65v. Para tecla, arpa y vihuela. ${ }^{695}$

Además de en los impresos, se han conservado algunos manuscritos con diferencias sobre este tema, como son el denominado Manuscrito de Simancas y algunos manuscritos para laúd del siglo XVI y principios del XVII, aunque estos últimos Conde Claros parecen ser todos copias de los de Morlaye: ${ }^{696}$

- AGS, Casas y Sitios Reales, Legajo 394, f. 130. Manuscrito de Simancas, Contrapunto sobre el conde claros, f. 1v. (4 variaciones). ${ }^{697}$

- EIRE-Dublin, Trinity College Library, Ms.408/2 (c1605), A galliard caled philida. Philida Galliard/Conde Claro, pp. 108/2-109 (=Guillaume Morlaye).

- GB-Cambridge University Library, Ms.Dd.5.78.3 (c1595-1600), Conde Claro by Guillaume Morlaye/Hornpipe, ff. 73v-74.

- EIRE-Dublin, Library of Archbishop Narcissus Marsh, Marsh Ms.Z3.2.13 (c1595), Gally: Queen Scottes. Queen of Scots Galliard/Conde Claro, p. 61/2 (=Guillaume Morlaye) y Conde claro/Hornpipe, pp. 232-233 (=Guillaume Morlaye).

- GB-Nottingham University Library, Willoughby Mi LM 16 (c1560-1585), Quande charo. Qande claro. Conde claro by Guillaume Morlaye, ff. 38-39v.

Vemos que la pieza tuvo gran difusión en Francia hacia mitad de siglo, lo que coincide con gran número de publicaciones para guitarra de cuatro órdenes, y aparece a finales de siglo en Inglaterra. La guitarra llegó a Francia durante el reinado del malogrado Enrique II, tal vez como consecuencia de su estancia como prisionero en Castilla del emperador

Daniel. «Parisian Music Publishing under Henry II: A Propos of Four Recently Discovered Guitar Books», The Musical Quarterly, 46/4 (1960), pp. 448-467; p. 464.

${ }^{695}$ Hay transcripción moderna en ANGLÉs, H. La Música en la Corte de Carlos V..., vol. 2, p. 185.

${ }^{696}$ Tomamos las referencias de CRAIG-MCFEELY, Julia. English Lute Manuscripts and Scribes, 1530-1630. An examination of the place of the lute in 16th-and 17th-century English Society through a study of the English Lute Manuscripts of the so-called 'Golden Age', including a detailed catalogue of the sources. Oxford, 2000. Publicación electrónica en: <http://www.ramesescats.co.uk/thesis/> [consulta 28-10-14]. Los títulos los tomamos directamente de dicho trabajo.

${ }^{697}$ CoronA-AlCALDE, Antonio. «A vihuela manuscript in the archivo de Simancas», The Lute, 26/1, 1986, pp. 3-20. 
Carlos V entre 1526 y 1530. ${ }^{698}$ Llegó a alcanzar tal éxito que en 1556 el anónimo autor de Discours non plus melancoliques se lamenta, un tanto exageradamente:

despuis douze ou quinze ans en ça, tout nostre monde s'est mis a Guiterner, le Luc presque mis en obly, [...] en maniere que trouverés aujourdui plus de Guiterneurs en France, qu'en Espagne. ${ }^{699}$

Es muy probable que cuando la guitarra llegó a Francia llevara consigo un repertorio agregado en el que se incluiría el Conde Claros y algunas otras piezas hispanas. Muchas de estas piezas se mantuvieron en el repertorio francés simplemente cambiándoles el texto.

La relación del Conde Claros con la guitarra de cuatro órdenes se ve apoyada por el hecho de que Narváez en sus diferencias sobre este tema incluye una que «contrahaze la guitarra», para lo que usa únicamente las cuatro cuerdas interiores de la vihuela. También relaciona el instrumento y la tonada Bermudo, quien no tenía esta música en muy alta consideración, cuando afirma: «Pues no se, si es más sabio: el que pretende contentar oýdos, o por mejor dezir orejas de pueblo: al qual contentan con el canto de Conde claros, tañido en guitarra, aunque sea destemplada». ${ }^{700}$

\section{ANÁLISIS}

Aunque los primeros compases, donde presenta el tema, son a cuatro voces, desde la siguiente diferencia transcurre a tres voces y luego al final vuelve a las cuatro. Mudarra considera tema y diferencias, de hecho en el índice titula Conde claros en doze maneras, a pesar de ser trece las variaciones. Mudarra, como Narváez, Valderrábano, Pisador y Venegas, utiliza seis compases para cada variación. Denominaremos las diferencias tal y como quería el autor.

Tras la presentación del tema, en la primera diferencia las dos voces superiores se imitan y el bajo mantiene su diseño hasta el c. 11 donde sustituye un acorde del IV grado por el I grado quedando la secuencia I-IV-I-V. Esto vuelve a ocurrir en la siguiente diferencia donde las voces superiores siguen haciendo pequeñas imitaciones. En la tercera

\footnotetext{
${ }^{698}$ TYLER, James. The early guitar. A History and Handbook. Londres, Oxford University Press, 1980, p. 26.

${ }^{699}$ Citado por VACCARO, Jean-Michel. La musique de luth en France au XVIe siècle. París, Centre National de la Recherche Scientifique, 1981, p. 459.

${ }^{700}$ Bermudo. Declaración, f. 3v.
} 
diferencia vuelve al diseño armónico inicial e introduce redobles en todas las voces. Parecida es la siguiente con una cierta ambigüedad en el acorde del c. 29. En la quinta mantiene parte de la melodía original en la voz superior. En la sexta de nuevo la armonía no se corresponde, pues los dos últimos compases oscilan entre un II y un $\mathrm{V}$ grado, aunque la melodía está fielmente representada en la voz superior. La siguiente variación mantiene la melodía prácticamente en la voz superior mientras las otras dos se mueven con lentos redobles. La octava diferencia transcurre a dos voces con la inferior manteniendo la armonía y la superior en rápidas glosas. Estas glosas pasan a la siguiente variación repartiéndose entre las dos voces superiores mientras el bajo sostiene la estructura. La diferencia décima busca la parte aguda del diapasón alcanzando el décimo traste y funciona además a cuatro voces. En el c. 65 en lugar de un retardo introduce una apoyatura. La undécima variación introduce una sorpresa armónica en el c. 70 donde sustituye un acorde IV grado por uno sobre el VII rebajado. La última variación comienza con unas décimas paralelas y mediante rápidos redobles nos lleva de nuevo al bVII para descender hacia el V grado y cadenciar en el I.

\section{4- Romanesca. Guárdame las vacas 1}

Diferencias. I modo. Posición f (vihuela en Mi). 4 voces. Tempo lento. Notas móviles: La

\section{NOTAS CRÍTICAS}

1. c. 49.6 en $1^{\circ}$ orden invertido.

\section{INTRODUCCIÓN}

De nuevo otra serie de diferencias sobre un tema omnipresente en el repertorio de vihuela. En lugar del texto de un romance tomado como título o motivo se trata ahora de un villancico, Guárdame las vacas, ${ }^{701}$ cuyo texto dice así:

\footnotetext{
${ }^{701}$ En numerosas ocasiones, incluso en grabaciones recientes, se titula a esta pieza O guárdame la vacas, confundiendo la conjunción "o" que pone Mudarra Romanesca o Guárdame... con el título. Creemos que este
} 
Guárdame las vacas, carillo, y besart[e] é

Bésame tú a mí, que yo te las guardaré. ${ }^{702}$

Covarrubias en 1611, en su Tesoro de la lengua castellana o española, nos da una definición con una variante del texto:

Las vacas, es una cierta sonada entre músicos, y sobre ella han hecho grandes diferencias de contrapunto y pasos forzados; y díjose así por empezar el villancico con estas palabras: «Guárdame las vacas, carillejo, por tu fe». ${ }^{703}$

El esquema melódico-armónico, muy posiblemente derivado del de folía, es el siguiente:

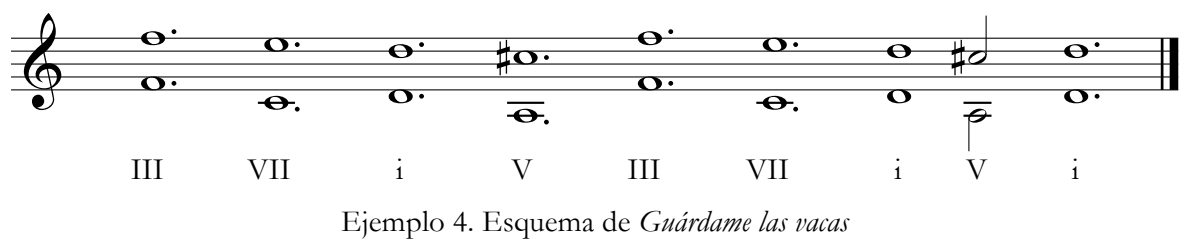

Vemos que se ajusta a un I modo con una melodía basada en una cuarta disminuída descendente que se repite. La relación con este modo para Correa de Arauxo es indudable cuando titula a una obra suya Dies y seis glosas sobre el canto llano Guárdame las vacas, o por mejor dezir sobre el seculorum del primero tono de canto llano que uno y otro cabe sobre el contrabajo del dicho discante. $^{704}$

error proviene de la primera edición de esta pieza, la del conde Morphy, quien ya llamó a la obra así y seguido por Pujol que contribuyó al error.

${ }^{702}$ Frenk, Margit. Nuevo Corpus de la Antigua Lírica Popular Hispánica (siglos XV a XVII). 2 vols., México, D. F., Facultad de Filosofía y Letras UNAM, El Colegio de México, Fondo de Cultura Económica, 2003., p. 1200, no 1683 A (en adelante FRENK. Nuevo Corpus). Al ser tan grande su difusión, el número de variantes también lo es.

${ }^{703}$ Covarrubias, S. Tesoro..., p. 947.

${ }^{704}$ Correa de ArauXo, Francisco. Libro de Tientos y Discursos de Música práctica y Theórica de órgano, intitulado Facultad orgánica. Alcalá de Henares, Antonio Arnao, 1626. Edición de Miguel Bernal Ripoll, Madrid, SEdeM, 2013, vol. 3, p. 140. 
Una vez más Salinas nos informa sobre los ritmos y advierte sobre la distinta manera de ejecutarse este canto en Italia, llamado Stantia romanescha, donde se usa el ritmo de hemiolia ajustado a la proporción mayor, y en España, el canto de Las vacas, en el que se usa el metro trocaico en proporción menor. Sin embargo un poco más adelante nos advierte que para el discanto de Las vacas se prefiere el ritmo formado por molosos (.os) o jónicos (oه 1 4 ) «debido a la gravedad del compás de seis tiempos, más excelente que la ligereza del de tres», es decir, para las diferencias se aplicaría el ritmo de romanesca al canto de Las vacas. ${ }^{705}$

Canto de Las vacas

Romanesca

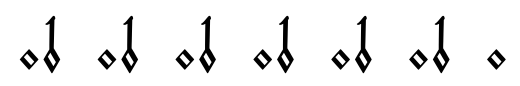

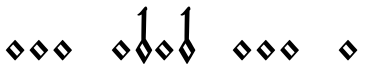

Hay que decir que este esquema métrico, como ya ha sido señalado, en el caso de Las vacas abarca dos versos hexasílabos y en la Romanesca un endecasílabo. ${ }^{706}$

No vamos a abordar la cuestión de los orígenes y las relaciones con la folía y otros ostinati o grounds y que ha sido largamente discutida el siglo pasado y el presente. ${ }^{707}$

De los siete vihuelistas, cuatro de ellos utilizan este esquema o tema para la creación de diferencias. También aparece en los libros de Cabezón y Venegas, además de en algunos manuscritos. Su presencia en obras fuera de España es tan grande y prolongada que excede nuestas intenciones realizar una lista completa. ${ }^{708}$ Añadimos algunos manuscritos españoles donde también figuran diferencias de vacas:

${ }^{705}$ SALINAS, F. De Musica..., p. 348.

${ }^{706}$ FiorentinO, Giuseppe. Música española..., p. 407.

${ }^{707}$ Un buen resumen de las diferentes opiniones y datos sobre ello a lo largo de la historia, se puede ver en Fiorentino, Giuseppe. Música española... Por supuesto, el autor de la tesis aporta sus propias conclusiones.

${ }^{708}$ Incluso a día de hoy, parece ser que pervive entre la música popular en la llamada zona de las cuadrillas, que abarca la región murciana y alrededores. BERLANGA FERNÁNDEZ, Miguel Ángel. «El bajo Guárdame las vacas y las músicas tradicionales en el sureste español», Revista de Musicología, 28/1 (2005), pp. 501-513. 
- Narváez (1538), Quatro diferencias sobre Guárdame las vacas, son del primer tono. Y un segundo juego Otras tres diferencias hechas por otra parte, ff. 92-96. (7 variaciones). ${ }^{709}$

- Mudarra (1546), Romanesca o guárdame las vacas en cinco maneras. Romanesca: o guárdame las vacas, proporción tres semibreves al compás, ff. 17-18, para vihuela (5 variaciones) y La romanesca en tres maneras, f. 24 , para guitarra de cuatro órdenes (3 variaciones).

- Valderrábano (1547), fols. 96-97. Siete diferencias sobre guárdame las vacas del primero y segundo grados. Siete diferencias fáciles, sobre guárdame las vacas (7 variaciones). ${ }^{710}$

- Pisador (1552), Las vacas con doze diferencias. Las bacas con sus diferencias para discantar, ff. $2 \mathrm{v}-4$ (13 variaciones). ${ }^{711}$

- Venegas (1557), Otras tantas sobre las vacas. Otras cinco sobre las vacas. Tres mínimas al compás, ff. 65v-66v. (6 variaciones). Para tecla. ${ }^{712}$

- Antonio de Cabezón (1578), Differencias sobre las vacas (7 variaciones) y Otras diferencias de vacas (4 variaciones), ff. 197-200. Para tecla. ${ }^{713}$

- En el manuscrito Ramillete de Flores encontramos dos juegos de Francisco Páez: Seis diferencias de bacas, ff. 273v-275 y Seis diferencias sobre bacas, ff. 278v-280v, (12 variaciones en total), además de una copia de las tres primeras de Narváez, f. $278 .^{714}$

- En el Manuscrito de Simancas figura un juego de dos diferencias, la segunda de ellas copia de Narváez. ${ }^{715}$

${ }^{709}$ Hay transcripción moderna en PUJOL, E. Luys de Narváez..., pp. 85-89.

${ }^{710}$ Hay transcripción moderna en PUJOL, E. Enriquez de Valderrábano..., vol 2, pp. 72-74.

${ }^{711}$ Hay transcripción moderna en ROA, F. y GÉRTRUDIX, F. El libro de música... Estudio y transcripción, $\mathrm{n}^{\circ}$ 2pp. 141-143.

${ }^{712}$ Hay transcripción moderna en ANGLÉs, H. La Música en la Corte de Carlos V..., vol. 2, p. 186-188.

${ }^{713}$ Hay transcripción moderna en Antonio de Cabezón (*1510c; †1566) Obras de música para tecla, arpa y vihuela. Nueva edición crítica completa. Javier Artigas Pina et alii (eds.). 4 vols. Zaragoza, CSIC, Institución «Fernando el Católico», Sección de Música Antigua, Excma. Diputación Provincial, 2010, vol. III, pp. 192206.

${ }^{714}$ BNE, Mss/6001, ff. 263v-283. REY, Juan José (ed.). Ramillete de flores: colección inédita de piezas para vibuela (1593). Madrid, Alpuerto, 1982 (2 ed.), con transcripción moderna en pp. 89-92, 102-105 y 100-101 respectivamente.

${ }^{715}$ CORONA-AlCALDE, A. «A vihuela manuscript... 


\section{ANÁLISIS}

Al contrario que en la pieza anterior, Mudarra llama diferencias desde la primera presentación del ostinato. Utiliza por primera vez en su libro la proporción mayor, una breve o tres semibreves al compás y, por consiguiente, el signo de tempo «despacio». En contraste con las diferencias de Narváez, apenas hay indicios de hemiolia. Todas las variaciones concluyen con una pequeña ripresa de dos compases con la secuencia acordal IV-V (casi siempre $\mathrm{V}^{4-3}$ ).

La primera diferencia es a tres voces, las dos superiores presentan la melodía base en terceras en la primera mitad, mientras que el bajo se mueve un poco y en la segunda mitad se invierten los papeles.

La segunda diferencia es similar a la anterior, tres voces y la presencia de tres quintas paralelas en los cc. 12-14. El acorde del i grado es sustituido por uno de bVI.

La tercera utiliza cuatro voces e introduce algunos acordes intermedios que incrementan la tensión armónica. Alcanza la nota mas aguda en el traste diez de la cuerda prima.

La cuarta diferencia es a dos voces, lo que permite un movimiento más rápido de los redobles.

La quinta vuelve a ser a cuatro voces y la ripresa final es plagal pues solo hace uso del IV grado.

\section{COMENTARIO}

Aunque en alguna ocasión se ha afirmado que en la obra de Mudarra es la primera vez que se usa en la literatura musical el término "Romanesca" ${ }^{716}$ debemos decir que Mudarra comparte el honor con el prolífico y polémico editor, y posteriormente impresor, Pierre Phalèse, quien en el mes de diciembre de 1546 (el mismo mes y año que Mudarra) dio a la luz en Lovaina su Carminum pro Testudinum IIII. La pieza que cierra el libro se denomina Romanescha y tiene muchas similitudes con la de Mudarra, además del título. Si tomamos la pieza completa del editor flamenco y la primera diferencia, o el tema, de Mudarra,

\footnotetext{
${ }^{716}$ Así ocurre en GrifFiths, John. «Guárdame las vacas», DMEH, vol. 5, p. 937-938 y en FiorentinO, Giuseppe. Música española..., p. 401.
} 
reducimos valores para incluirlas en el mismo compás y las transportamos a la misma altura nos sale lo siguiente:
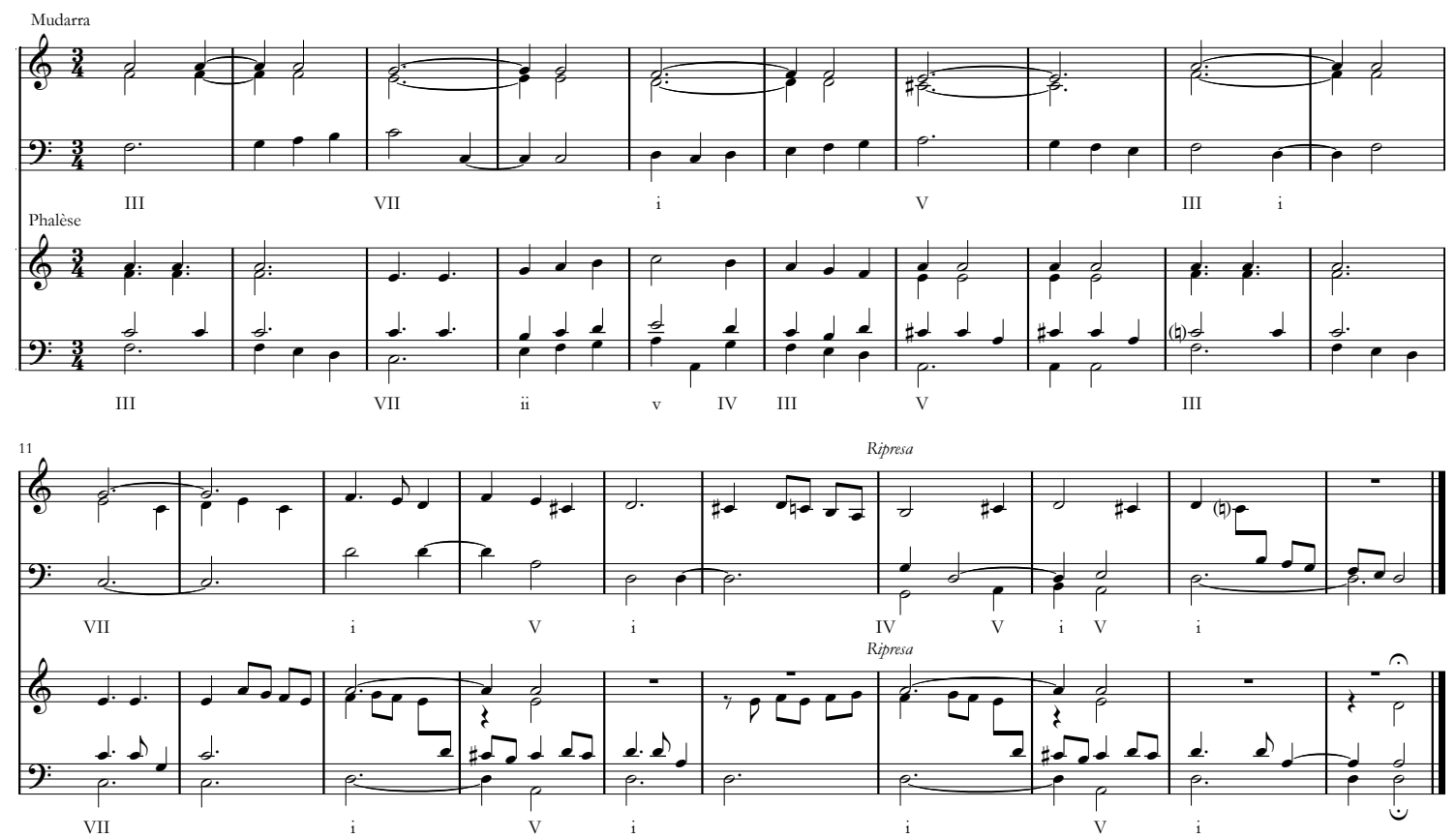

Ejemplo 5. Comparación Romanescas Mudarra y Phalèse

Podemos apreciar que la estructura armónica es muy similar, aunque Phalèse introduce mayor cantidad de acordes de paso, no importándole las tres quintas paralelas del c. 4 o las dos del c. 6. Los apoyos armónicos fundamentales caen exactamente en el mismo sitio. Hay ambigüedad en los cc. 5-6, mientras Mudarra mantiene una armonía sobre el i grado con floreo y notas de paso, Phalèse opta por una encadenación de acordes v-IV-III-(ii-i). También hay que valorar que, en función de la escritura, la pieza de Mudarra se debe tañer despacio, pues así lo indica y la de Phalèse parece más apresurada, aunque también tenga mayor movimiento de las voces. Coinciden ambas en la presencia de una ripresa de cuatro compases, pero mientras en Mudarra es la repetición literal de los cuatro anteriores con la serie i-V-i, Phalèse opta por un IV grado intercalado lo que produce la secuencia IV-V-iV-i. Desconocemos de dónde sacó Phalèse esta pieza, pero todo el resto del libro es de origen italiano, son fantasías, pavanas y gallardas (se trata de saltarellos a los que ha cambiado el nombre), sacadas de Francesco da Milano y de Pietro Paulo Borrono da Milano, suponemos que sin su autorización. Habría que considerar también que en el 
ambiente de Lovaina la presencia española era bastante fuerte, de hecho a unos cuantos kilómetros de allí hasta unos pocos años antes se encontraba la corte de los condes de Nassau: Enrique y Mencía de Mendoza.

\section{5- Pavana 1}

Pavana. I modo. Posición g (vihuela en Sol). 4 voces. Tempo medio. Notas móviles: Si

\section{NOTAS CRÍTICAS}

1. c. 72 . Añadimos la mínima que figura entre corchetes.

\section{INTRODUCCIÓN}

Con la pavana volvemos a las mismas cuestiones que antes, pues se trata de una danza sobre cuyos orígenes se discute si son españoles e italianos, asunto que trataremos someramente al final.

Thomas Morley nos da una buena definición de ella en 1597. Aunque es un poco tardía, nos sirve para ver su estructura.

danza solemne y generalmente compuesta por tres partes, cada una de las cuales se toca dos veces; cada parte suele contener ocho, doce o dieciséis semibreves ... menos de ocho no he visto en ninguna Pavana. En ésta no hace falta insistir en la imitación como en la Fantasía. ${ }^{717}$

Nos interesa un tipo particular de pavanas con una estructura acordal derivada o emparentada con la de la folía que se publicaron en España principalmente. Entre ellas se diferencian pavanas ternarias, denominadas también pavanas-folía y pavanas binarias o pavanillas. ${ }^{718}$ Por supuesto que en España hubo pavanas binarias con otra estructura

${ }^{717}$ Plaine and Easie Introduction, citado en ATLAS, Allan W. La música del Renacimiento. La música en la Europa occidental, 1400-1600. Madrid, Akal, 2002, p. 564.

${ }^{718}$ REY, Juan José. Danzas cantadas en el Renacimiento español. SEdeM, 1978. 
acordal, como son las de Luis Milán, la Pavana de Alexandre del propio Mudarra o la Pavana real de Valderrábano.

La pavanilla como esquema melódico-armónico va a aparecer por primera vez precisamente en la obra de Mudarra y no una, sino dos veces, pues la Pavana para guitarra de cuatro órdenes, que veremos más adelante, comparte la estructura con esta que vamos a analizar a continuación. Sin embargo, la primera obra con ese nombre no va a ver la luz hasta 1581 en el tratado de danza de Fabritio Caroso Il ballarino. ${ }^{719}$ En España la primera aparición va a ocurrir en el manuscrito Ramillete de flores. Entre medias está la obra de Antonio de Cabezón Discante sobre la pavana italiana o Pavana italiana (ff. 186v-187).

La diferencia fundamental entre la pavana de Mudarra y las posteriores es que la primera está dividida en tres secciones mientras que las otras únicamente utilizan la primera sección de Mudarra, que es lo que acabará llamándose pavana italiana, en el caso de Cabezón y pavanilla después. Su estructura acordal se corresponde perfectamente con la de la folía cuya estructura podría ser así: ${ }^{720}$

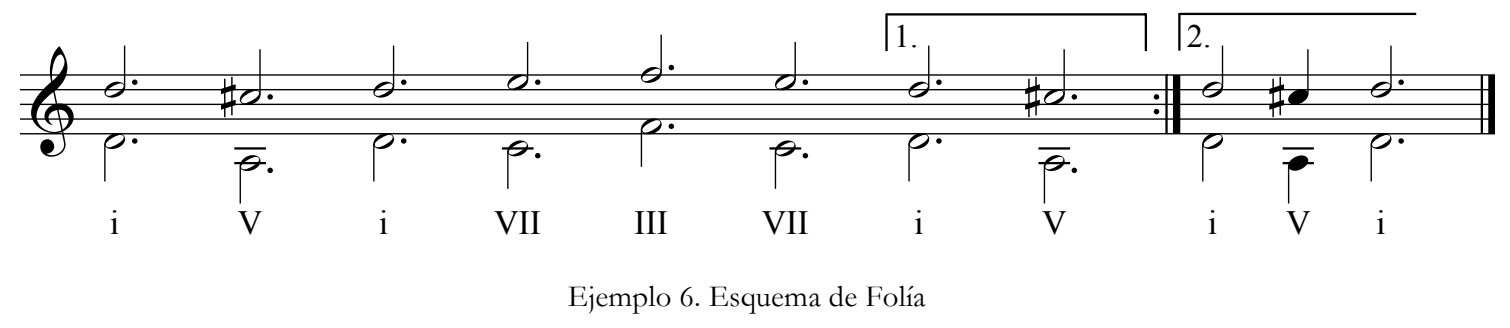

ESTRUCTURA

$\begin{array}{ccccc}\text { Secciones } & \text { Forma } & \text { Compases } & \text { Cadencia final } & \text { Longitud } \\ 1 & \text { a a' } & 1-32 & \text { i } & 32 \text { cc. }(16+16) \\ 2 & \text { b b' } & 33-50 & \text { V } & 18 \text { cc. }(9+9) \\ 3 & \text { c c' } & 51-79 & \text { I } & 29 \text { cc. }(15+14)\end{array}$

${ }^{719}$ CAROso, F. Il ballarino, f. 39v.

${ }^{720}$ Simplificamos el esquema ajustándolo a una folía temprana sin atender demasiado a cuestiones rítmicas, aunque incluimos una subdivisión ternaria. Para ver diferentes variantes FIORENTINO, Giuseppe. Música española..., pp. 10-14. 


\section{ANÁLISIS}

Sección 1: como señalamos anteriormente, es la que posteriormente se va a denominar pavanilla. Consta de dos subsecciones simétricas a y a', cada una de ellas de exactamente dieciséis compases. Las alteraciones que aparecen son las características del I y II modo.

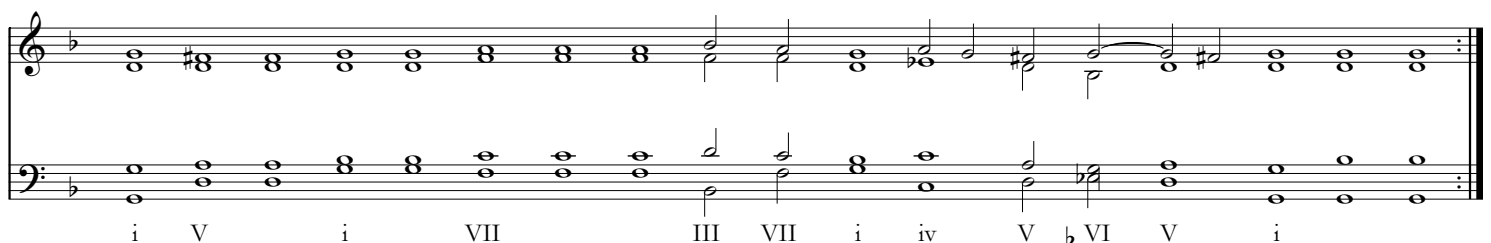

Ejemplo 7. Esquema de pavanilla. Sección 1 de la Pavana 1 de Mudarra (cc. 1-32)

Sección 2: de nuevo se divide en dos subsecciones b y b', aunque en esta ocasión ambas de nueve compases. Esta irregularidad también ocurre en las pavanas de Luis Milán. ${ }^{721}$ El esquema acordal de esta sección también está relacionado con la folía, de hecho se trata del esquema de Guárdame las vacas en compás binario. Esta sección es más movida que la anterior con redobles más frecuentes y más largos.

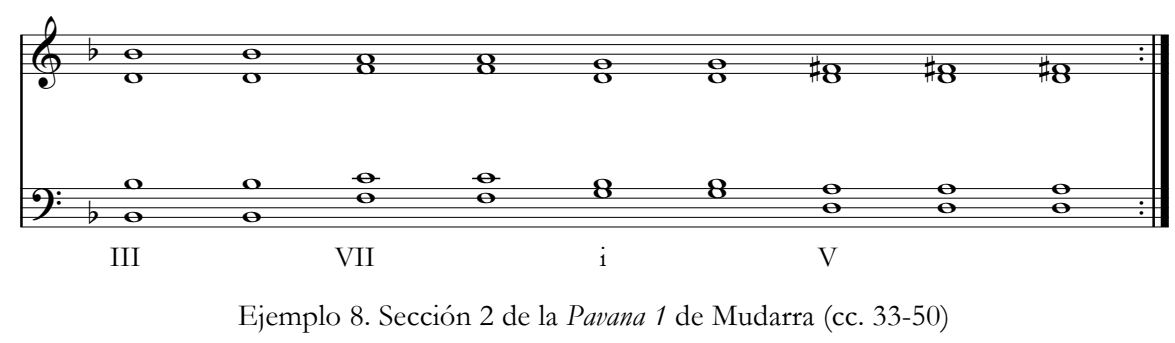

Sección 3: dos subsecciones, c y c', de quince y catorce compases respectivamente. Aquí la asimetría es mayor, no solo no se respeta la cuadratura (lo lógico sería que fueran dos subsecciones de dieciséis compases), sino que parece como si faltara un compás

${ }^{721}$ REY, Juan José. Danæas cantadas..., p. 50 y ARRIAGA, G. «La obra instrumental..., pp. 9-10. 
después del c. 76. Fiorentino lo piensa así y sugiere una posible reconstrucción del compás faltante. ${ }^{722}$ En ese caso la estructura de la sección quedaría así:

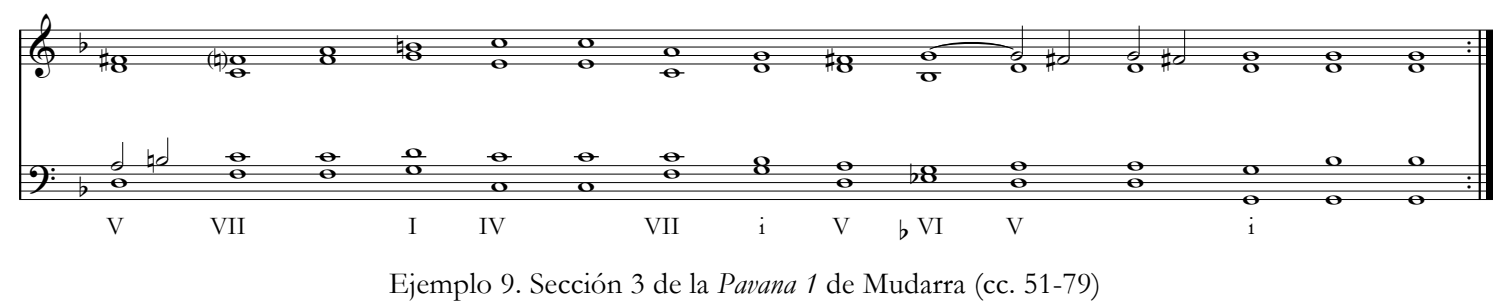

En realidad lo más lógico hubiera sido que las tres secciones tuvieran una forma cuadrada, $32+16+32$ compases, por ejemplo. Se podría aducir que la asimetría tanto en Mudarra como en Milán, se podía deber al ser piezas abstractas, no para ser danzadas o que los compositores se despistaran y tomaran de oído algo que hubieran escuchado en el pasado. Yo no lo creo así. Tanto Mudarra como Milán son músicos criados en dos de las cortes más importantes del momento, la del duque del Infantado y la del duque de Calabria. A ellas llegó todo lo novedoso de Italia, se imitó, se recreó, se cantó, se danzó, se glosó. Ambos vihuelistas debieron participar en cientos y cientos de danzas, era parte de su oficio. En el caso de la Pavana de Mudarra la primera sección cumple con el canon de dieciséis compases y termina con un calderón, la segunda se prolonga un compás, pero no lleva calderón y la tercera podría ser de catorce compases prolongados, si aceptamos la errata de faltar uno después del c. 76.

\section{COMENTARIO}

Fiorentino realiza un profundo e interesante estudio sobre la pavanilla en todas sus fuentes europeas y plantea la hipótesis de que Mudarra tal vez copiara para su pavana un tema de origen italiano conocido como la Pavana del Duca. Posteriormente, Cabezón tomaría la primera parte de Mudarra para sus glosas sobre la Pavana italiana. Al ser una versión reducida de la pavana, se introduce el nombre de pavanilla que se exporta a Italia como pavaniglia. $^{723}$

\footnotetext{
${ }^{722}$ Fiorentino, Giuseppe. Música española..., pp. 316-317.

${ }^{723}$ Fiorentino, Giuseppe. Música española..., pp. 350-353.
} 


\section{6- Pavana de Alexandre}

Pavana. VIII modo. Posición F (vihuela en La). 4 voces. Tempo lento. Notas móviles: Si

\section{INTRODUCCIÓN}

De nuevo una danza y también una pavana, sin que tenga ninguna relación con las pavanillas ni con las pavanas-folía. En este caso sí presenta una estructura perfectamente regular y tempo pausado, lo que junto al compás binario hace que no tengamos ninguna duda en cuanto a su adscripción al género de pavana.

\section{ESTRUCTURA}

$\begin{array}{ccccc}\text { Secciones } & \text { Forma } & \text { Compases } & \text { Cadencia final } & \text { Longitud } \\ 1 & \text { a } & 1-12 & \text { V } & 12 \mathrm{cc} . \\ 2 & \text { a } & 13-24 & \text { I } & 12 \mathrm{cc} .\end{array}$

\section{ANÁLISIS}

Consta de dos secciones a y a' de doce compases cada una, que a su vez se pueden subdividir de seis en seis compases.

La estructura acordal es: a: I-VII-I-V y a': I-VII-IV-V-I, ocupando cada armonía tres compases, excepto en la cadencia final.

\section{COMENTARIO}

Más problemático resulta saber quién era el Alexander al que alude el título. En las nóminas de la Casa del Infantado que, entre unas cosas y otras, abarcan más de 50 años, no hemos encontrado ningún servidor, no ya músico, que responda a ese nombre. Pujol planteaba la posibilidad de que se tratara de Alexander Agricola, ${ }^{724}$ compositor flamenco que falleció en Valladolid en 1506, cuando acompañaba a Felipe el Hermoso en su

\footnotetext{
${ }^{724}$ Pujol. Mudarra, p. 67.
} 
segundo viaje por España. No es imposible este hecho, teniendo en cuenta la posible relación entre la capilla de Felipe y la del duque del Infantado. Hay otros candidatos, tal vez menos probables. En las nóminas de la Casa de Borgoña del emperador figura un Alexandro, tañedor de arpa, en $1534 .^{725}$ Un segundo Alexandre era «maestro de tañer y dançar» de los pajes en 1554 de la Casa del rey Felipe II. ${ }^{726}$ Las fechas hacen probable tanto a uno como a otro, aunque este segundo sea un poco más tardío.

Para Griffiths esta pavana sería una versión en tono mayor del passamezzo antico, cuya secuencia característica comienza $\mathrm{i}-\mathrm{VII}-\mathrm{i}^{727}$ Salinas nos da la pista cuando identifica pavana milanesa y passamezæo.: «Pavana Milanesa, sive Passoemezo vulgo vocatur». ${ }^{728}$ Efectivamente, si tomamos la Pavana chiamata la Milanesa de Pietro Paulo Borrono da Milano, publicada por Casteliono en $1536,{ }^{729}$ vemos que la secuencia acordal es I-VII-I-V para cada ocho compases y coincide con la usada por Mudarra para cada doce.

\section{7- Gallarda}

Gallarda. VIII modo. Posición F (vihuela en La). 4 voces. Tempo rápido. Notas móviles: La b (III), Si Ł (IV), Mi Ł (VII).

\section{NOTAS CRÍTICAS}

1. c. 17. Mal colocada la mínima.

\section{INTRODUCCIÓN}

Se trata de la única pieza titulada gallarda en todo el repertorio de vihuela o la primera si consideramos el libro de Cabezón también válido para este instrumento, donde figuran

${ }^{725}$ Martínez Millán, J. La Corte de Carlos V..., vol. 4, p. 56.

${ }^{726}$ ROBLEDO ESTAIRE, L. «La música en la Casa del Rey..., p. 187.

${ }^{727}$ GRIFFITHS, John. «Pavana», DMEH, vol. 8, pp. 523-524.

${ }^{728}$ Salinas, F. De Musica..., p. 356.

${ }^{729}$ CASTEliono, Giovanni Antonio. Intabolatura de leuto de diversi autori novamente stampata... Milán, Casteliono, 1536, f. 9. Sería interesante conocer la relación entre este libro y los de los vihuelistas, pues utiliza el mismo sistema mensural para representar el ritmo que se usó en España a partir de Narváez. Hay que recordar que en 1535 se produjo la anexión del Ducado de Milán a la Corona española. 
unas Differencias sobre la Gallarda Milanesa (ff. 188-189), ${ }^{730}$ si bien la sexta de las pavanas de Luis Milán puede ser considerada como tal. ${ }^{731}$ En cualquier caso, dos piezas denominadas gallardas en todo el repertorio hispano instrumental no es demasiado.

Morley nos dice:

Después de cada Pavana suele seguir una Gallarda (un tipo de música hecha a partir de la Pavana). Se trata de un tipo de danza más ligero y movido que la pavana, pero formada por el mismo número de partes. $^{732}$

Así ocurre en el caso de Mudarra, la gallarda sigue a la pavana, con la que se podría ver algún tipo de relación melódica y, además, ambas constan de dos secciones. También comparten modo o tono. A pesar de estar escrita en un compás binario, el ritmo de la gallarda es claramente ternario.

\section{ESTRUCTURA}

$\begin{array}{ccccc}\text { Secciones } & \text { Forma } & \text { Compases } & \text { Cadencia final } & \text { Longitud } \\ 1 & \text { a } & 1-18 & \text { I } & 36 \text { cc. }(18+18) \\ 2 & \text { a' } & 19-36 & \text { I } & 36 \text { cc. }(18+18)\end{array}$

\section{ANÁLISIS}

Llama la atención la economía de medios con la que Mudarra construye esta gallarda. Tan solo dos elementos, a los que llamaremos $\alpha$ y $\beta$, le sirven para elaborar toda la pieza. El motivo $\alpha$ consiste en tres notas repetidas, un enlace y cuatro notas descendentes en un intervalo de cuarta. El motivo $\beta$ tiene cuatro notas ascendentes en un intervalo de cuarta, y luego desciende hacia una cadencia. Este último recuerda mucho al de la segunda sección de una pavana-folía o pavana ternaria. ${ }^{733}$ La primera sección presenta el material $\alpha$ con el acorde del I grado y con la melodía en la quinta de este y le añade dos

\footnotetext{
${ }^{730}$ Hay transcripción moderna en Antonio de Cabezón (*1510c; †1566) Obras..., vol. III, pp. 157-161.

731 FiorentinO, Giuseppe. «La pavana ternaria de Luis Milán», Roseta, 0 (2007), pp. 36-43.

${ }^{732}$ Plaine and Easie Introduction, citado en ATLAS, A. W. La música del Renacimiento..., p. 565.

${ }^{733}$ Y que según Fiorentino esta pavana ternaria sería en realidad una gallarda. FIORENTINO, Giuseppe. Música española..., p. 432.
} 
presentaciones de $\beta$ a las que llamamos $\beta$ y $\beta$, algunos redobles sirven para unir los elementos, se repite toda la sección. La sección 2 presenta el motivo $\alpha$ una segunda por debajo y sobre el acorde del VII grado, a lo que llamamos $\alpha$ ' y dos nuevas presentaciones de $\beta$ : $\beta$ ", y $\beta$ ", '. También hace uso de redobles para unir un motivo con otro. Esta sencilla manera de composición estaría muy cerca del procedimiento llamado de centonización. La pieza quedaría de la siguiente manera:

Sección 1: $\left\|: \quad \alpha \quad \beta \quad \beta^{\prime}:\right\|$

Sección 2: $\left\|: \quad \alpha^{\prime} \quad \beta^{\prime \prime} \beta^{\prime \prime}:\right\|$

Incluimos una transcripción en compás ternario con los motivos indicados:
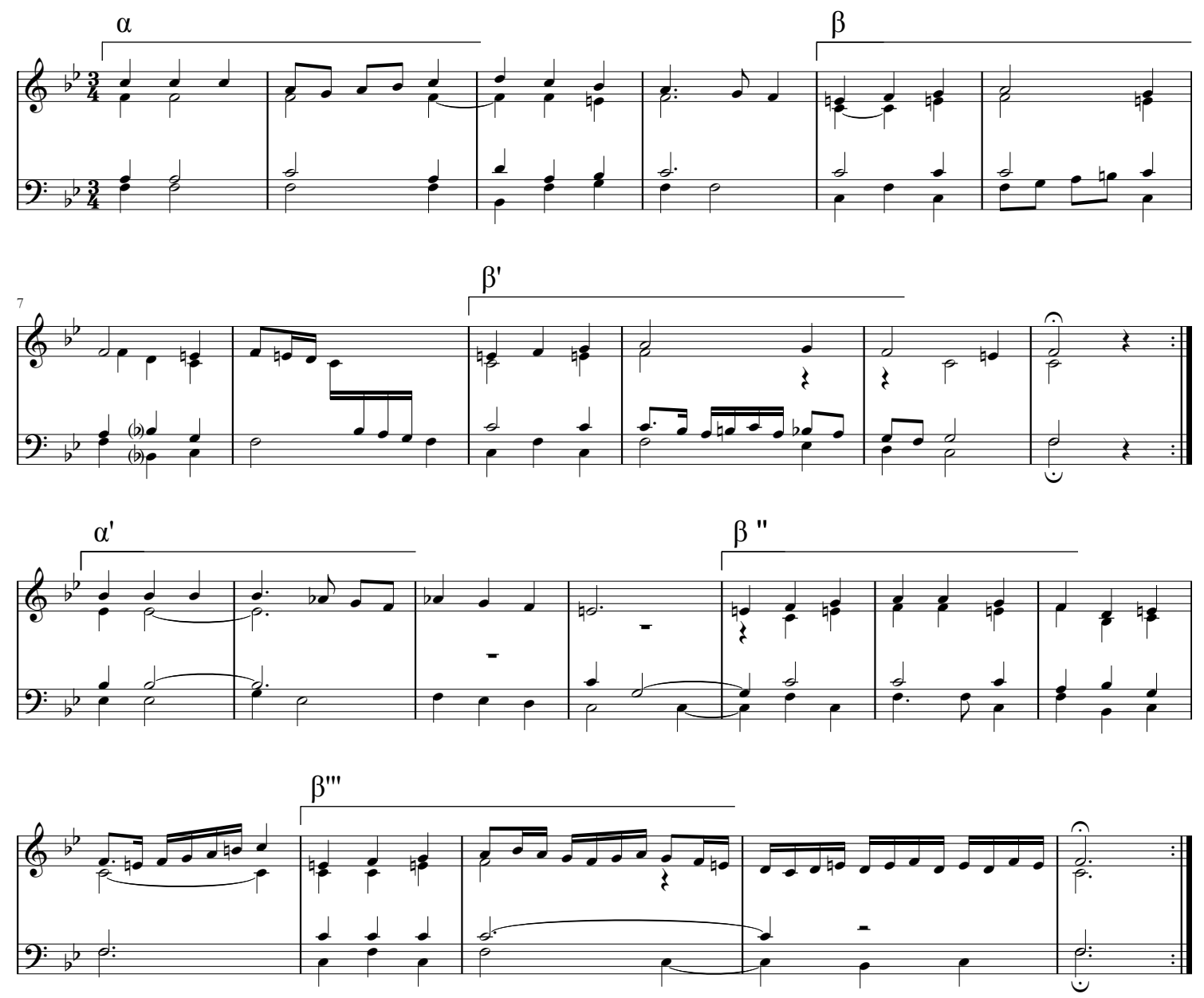

Ejemplo 10. Análisis de la Gallarda de Mudarra escrita en compás ternario 


\section{8- Fantasía 11}

Fantasía. I modo. Posición $\mathrm{f}$ (guitarra de cuatro órdenes afinada «al temple viejo»). 4

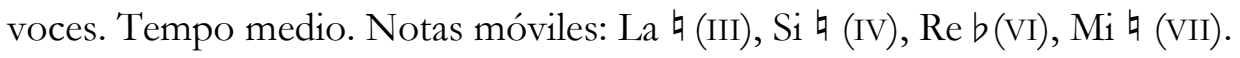

\section{NOTAS CRÍTICAS}

1. Guitarra al temple viejo. Corregido a mano en el original.

\section{INTRODUCCIÓN}

Con esta pieza comienzan las obras para guitarra de cuatro órdenes, conocida hoy en día como guitarra renacentista. ${ }^{734}$ Son las primeras obras publicadas para este instrumento en toda Europa. Una vez más Mudarra es pionero en el marco de la música instrumental europea adelantándose en tres años a Barberiis, quien en 1549 publica en Venecia su décimo libro de tablatura de laúd, ${ }^{735}$ en cuyo final incluye cuatro Fantasie per sonar sopra la Chitarra da sette corde (ff. Gg 4v-Hh 1v). En realidad no son tales fantasías sino sencillas danzas, la primera de ellas aparecerá como branle en 1553 en uno de los libros de guitarra publicado por Morlaye. ${ }^{736}$ Tras esto vendrían varios libros exclusivos para guitarra, los cuatro publicados por Morlaye y los cinco de Le Roy en París a partir de $1550 .{ }^{737}$ Podemos incluir también a Valderrábano que, al año siguiente del libro de Mudarra, incluye al final de su Silva de sirenas una obra titulada Música para discantar sobre un punto en la que el canto llano, consistente en un único acorde, se puede tañer en «vihuela templada en unísonus con la que á de discantar, o en guitarra su tercera en vazío a los vieios con tercera en lleno de la vihuela en unísonus». ${ }^{738}$

\footnotetext{
${ }^{734}$ Un reciente trabajo con abundante iconografía de este insrumento ALONSO YLLANA, Jesús. Contribución de la arqueología subacuática al conocimiento de la evolución de la guitarra. Tesis Doctoral, Universidad Complutense de Madrid, 2014.

${ }^{735}$ BARBERIIS, Melchiore de. Opera intitolata Contina... Venecia, G Scotto, 1549.

${ }^{736}$ MORLAYe, Guillaume. Le Second livre de ...., París, Michel Fezandat, 1553, f. 24v.

${ }^{737}$ Cumplida información sobre el repertorio para guitarra de cuatro órdenes en TYLER, James y SPARKS, Paul. The Guitar and its Music from the Renaissance to the Classical Era. Nueva York, Oxford University Press, 2007.

${ }^{738}$ VALDERRÁBANO. Silva de sirenas, f. 103v-104.
} 
Pero además, la primera fuente sobre la afinación de la guitarra renacentista también aparece en un impreso español, la obra de Fray Juan Bermudo. En la Declaración nos informa de las afinaciones que se usan, ${ }^{739}$ además de otras imaginarias o propuestas por él. En dos ocasiones explica estas afinaciones, ${ }^{740}$ en el capítulo 32 del libro segundo titulado De la distancia que tiene la guitarra y la bandurria y en el 65 del libro cuarto De las guitarras que se usan ahora:

La guitarra común tiene quatro órdenes de cuerdas: las quales cuerdas se pueden llamar quarta, tercera, segunda y prima. Esta guitarra tiene comúnmente dos temples. Uno se llama a los nuevos: y otro a los viejos. [...] El temple de la guitarra a los viejos no diffiere de esta a los nuevos: sino que la quarta cuerda suelen abaxar un tono. [...] Este temple más es para romances viejos, y Música golpeada: que para Música de el tiempo. El que uviere de cifrar para guitarra buena Música: sea en el temple de los nuevos. $^{741}$

De mayor abilidad se puede mostrar un tañedor con la intelligencia, y uso de la guitarra: que con el de la vihuela, por ser instrumento más corto. Por lo qual es de saber, que se usan dos maneras de guitarra: y son la que dizen a los nuevos y a los viejos, a los altos y a los baxos: de las quales dos differencias tractaré en el presente capítulo. Las guitarras tienen comúnmente quatro cuerdas. [...] Pongan se en la guitarra diez trastes: como en la vihuela. Los cortos o abreviados en Música no le ponen más de cinco o seys. ${ }^{742}$

Continúa explicando las alturas de las diferentes afinaciones, que son las que usamos nosotros para nuestras transcripciones. ${ }^{743}$

Mudarra va a usar estos dos tipos de afinaciones en sus obras para guitarra, denominándolas «guitarra al temple viejo» y «guitarra al temple nuevo». En Francia la primera será conocida como a corde avallée en varios de los libros de Morlaye. Sin embargo,

${ }^{739}$ Sobre las afinaciones de la guitarra renacentista: TYLER, James. «The renaissance guitar 1500-1650», Early Music, 3 (1975), pp. 341-347 y ARriAgA, Gerardo. «La Guitarra de cuatro órdenes en el siglo XVI. Conveniencia de su inclusión en los programas actuales de los Conservatorios», Música y Educación, 1/2 (1988), pp. 369-406.

${ }^{740}$ Bermudo reutilizó sus anteriores libros para confección del de 1555 y en muchas ocasiones se repite. FREIS, Wolfgang. «Becoming a theorist: The growth of the Bermudo's Declaración de instrumentos musicales», Revista de Musicología, 18/1-2 (1995), pp. 27-112.

${ }^{741}$ BERMUdO. Declaración, f. 28v.

${ }^{742}$ BERMUDO. Declaración, f. 96.

${ }^{743}$ Somos plenamente conscientes de que se trata de alturas teóricas, no absolutas, al igual que las de la vihuela, pero se han estandarizado hoy en día en la interpretación de la música antigua. 
no hay diferencia de repertorio, aparentemente, tal y como afirma Bermudo, pues Mudarra usa el temple viejo para una fantasía y el nuevo para tres fantasías, una pavana y una romanesca. De todas formas, creemos que las piezas que incluye en sus Tres libros no son excesivamente representativas del repertorio de guitarra, si las comparamos con las que figuran en los libros franceses de Morlaye y Le Roy, sino que están dentro del estilo general de las piezas de vihuela del primer libro.

En otra cosa coincide Mudarra con Bermudo, en la exigencia de llevar la guitarra diez trastes «Á de estar entrastada como vihuela con diez trastes» y también pide «á de tener bordón en la cuarta», lo que quiere decir que posiblemente en esta época ya existía la que hoy llamamos afinación recurrente. ${ }^{744}$

\section{ESTRUCTURA}

$\begin{array}{ccccc}\text { Secciones } & \text { Compases } & \text { Cadencia final } & \text { Longitud } & \text { Textura } \\ 1 & \text { cc. } 1-32 & \text { i } & 32 & \text { Libre } \\ 2 & \text { cc. } 33-71 & \text { I } & 39 & \text { Imitativa }\end{array}$

\section{ANÁLISIS}

Sección 1: comienza alrededor del v grado, con una especie de cantus firmus en el bajo y a tres voces. Hasta el c. 8 no alcanza el i grado, al que llega con una cadencia modal con retardo 76 y afirmándolo con tres acordes plenos a cuatro voces seguidos de tres compases del acorde de V grado. El cantus firmus anterior se presenta en la voz intermedia y una cuarta alta (sobre el i grado), mientras las otras voces discurren libremente. Se llega a una cadencia rota (c. 21) y tras otro pasaje libre, en el que podemos encontrar incluso la secuencia acordal de las Vacas (cc. 30-31), tal vez como recuerdo de un estilo pretérito, llega al acorde de i grado.

Sección 2: mediante un pasaje a dos voces introduce en la voz superior un largo tema de diez compases de duración (cc. 34-43) y que le va a servir luego como reserva de motivos que irán apareciendo en esta sección. Sigue un breve canon al unísono a distancia de mínima, que produce una secuencia de séptimas paralelas, pero sin ninguna

\footnotetext{
${ }^{744}$ Término acuñado por ARRIAGA, G. «La Guitarra de cuatro órdenes..., p. 391.
} 
transgresión contrapuntística. Un nuevo pasaje de redobles rápidos utilizando material del tema largo, conduce a una nueva presentación del tema sin la cabeza (o con esta glosada). Un pasaje homofónico con algunos retardos nos conduce a la cadencia final tonal, rematada por tres compases plagales y final sobre el I grado a cuatro voces.

\section{COMENTARio}

Esta pieza podría recordar a los ricercares de las publicaciones venecianas tempranas para laúd, las de Spinacino, Dalza, y Bossinensis. Griffiths los define como piezas de corta duración, estructura libre y fuertemente idiomáticas. ${ }^{745}$ Tal vez esto justifique la afinación «a los viejos», pues así Mudarra nos muestra no solo una afinación de la guitarra, sino también una forma de componer anterior, distinta a la polifonía más puramente imitativa de su tiempo.

\section{9- Fantasía 12}

Fantasía. IV modo. Posición g (guitarra de cuatro órdenes). 4 voces. Tempo medio. Notas móviles: La

\section{NOTAS CRÍTICAS}

1. c. 8. Sobra el rasguito.

2. c. 15 . Ponemos 2 en $1^{\circ}$ orden en lugar de 8 .

3. c. 26.6 en $1^{\circ}$ orden invertido.

\section{INTRODUCCIÓN}

A partir de aquí todas las piezas son para afinación «al temple nuevo». Creemos que esto tiene implicaciones también en cuanto al estilo compositivo. Griffiths se ha ocupado también de esta fantasía, si bien sus conclusiones difieren ligeramente de las nuestras. ${ }^{746}$

\footnotetext{
${ }^{745}$ GRIFFITHS, John. «Spinacino's Twelve-tone Experiment», Journal of the Lute Society of America, 40 (2011), pp. 47-76; p. 48.

${ }^{746}$ Griffiths, J. The Vibuela Fantasia..., pp. 200-204.
} 


\section{ESTRUCTURA}

$\begin{array}{ccccc}\text { Secciones } & \text { Compases } & \text { Cadencia final } & \text { Longitud } & \text { Textura } \\ 1 & \text { cc. } 1-22 & \text { I } & 22 & \text { Imitativa } \\ 2 & \text { cc. } 23-47 & \text { iv } & 25 & \text { Libre } \\ 3 & \text { cc. } 48-67 & \text { I } & 20 & \text { Imitativa }\end{array}$

\section{ANÁLISIS}

Sección 1: comienzo claramente imitativo con un tema de cinco compases en la voz superior, respondido por el bajo a la octava y una tercera entrada en la voz intermedia al unísono de la primera con la que se cruza. Prácticamente, podemos hablar de un canon. Desde el punto de vista modal, llama la atención que esta melodía, aparentemente, no esté en un cuarto modo, pues las primeras notas corresponden a un modo mayor, un séptimo por ejemplo, aunque luego se delata con el VI grado rebajado. Esto produce que los acordes que se van formando sean el I y el iv. Digamos, en sentido figurado, que Mudarra está enseñando sus cartas, pues para enseñarnos una afinación moderna usa recursos contrapuntísticos modernos (imitación estricta, al estilo de Narváez o Francesco da Milano) y un modo IV evolucionado. Tras una cadencia rota (cc. 17-18), el tema levemente modificado vuelve a la voz intermedia, acompañado en sextas por la inferior. Se produce la primera cadencia frigia en los cc. 22-23. Nótese que en 22 compases el Si b solo ha aparecido tres veces, frente a once presentaciones del Si ఢ.

Sección 2: a partir de aquí hay mayor movimiento armónico, con algunos recuerdos del tema inicial. Tras una larga cadencia primero rota sobre el iv grado, luego sobre el III grado, para concluir en una frigia sobre el I grado, Mudarra busca la zona aguda de la guitarra con un pasaje homofónico con armonía estática que concluye en el iv grado.

Sección 3: la voz superior adquiere un gran protagonismo melódico presentando un diseño en corcheas en el c. 48 que será utilizado en progresión estricta, tanto melódica como acordal, en los cc. 54-57. Entre tanto en el bajo se ha producido una presentación parcial del tema inicial, concluyendo en cadencia sobre el iv grado que inicia la progresión. Una nueva cadencia frigia (c. 61) nos conduce suavemente hasta el final, culminando la obra con otra cadencia característica del modo. 


\section{0- Fantasía 13}

Fantasía. V modo. Posición G (guitarra de cuatro órdenes). 4 voces. Tempo rápido. Notas móviles: Do

\section{NOTAS CRÍTICAS}

1. c. 13. Añadimos la mínima que figura entre corchetes. Ponemos 3 en $1^{\circ}$ orden en lugar de 2 .

\section{ESTRUCTURA}

$\begin{array}{ccccc}\text { Secciones } & \text { Compases } & \text { Cadencia final } & \text { Longitud } & \text { Textura } \\ 1 & \text { cc. } 1-39 & \text { V } & 22 & \text { Libre } \\ 2 & \text { cc. } 40-62 & \text { I } & 23 & \text { Imitativa }\end{array}$

\section{ANÁLISIS}

Sección 1: comienzo a una voz con motivo ascendente que recorre una duodécima (gd'), por lo que tal vez se debería hablar de tono mixto, que concluye en cadencia rota sobre el iii grado (cc. 5-6). Unos cuantos compases en contrapunto libre nos llevan a una cadencia modal sobre el I grado, donde de nuevo se inicia el motivo primero una octava más arriba, aunque se trunca a las cinco notas. Un pasaje descendente y luego ascendente conduce a la nota más aguda, desde donde desciende insistiendo en una cadencia sobre el $\mathrm{V}$ grado y comienza el motivo inicial por movimiento contrario, mientras la voz superior vuelve a alcanzar el registro más agudo del instrumento, donde permanece unos cuantos compases. En total, son catorce compases en la zona por encima del traste cinco, lo que incrementa la dificultad técnica. Un pasaje homofónico rematado por un redoble ascendente de octava cierra la sección.

Sección 2.: una secuencia de acordes casi tonal nos lleva a otra progresión, primero en las voces superiores (cc. 42-45), para después unirse el bajo, siendo respondido por la voz superior y luego por la intermedia. En total cinco presentaciones del motivo. Una cadencia modal sobre el I grado, sobre la que se insinúa la cabeza del motivo inicial, conduce a un pasaje estático, al que podríamos considerar coda, sobre el I grado con una imitación entre la voz superior y la intermedia cierra la pieza. 


\section{1- Fantasía 14}

Fantasía. I modo. Posición g (guitarra de cuatro órdenes). 4 voces. Tempo medio. Notas móviles: Si 4 (III), Do\# (IV), Mi b (VI), Fa\# (VII).

\section{NOTAS CRÍTICAS}

1. c. 36. Ponemos 4 en $3^{\circ}$ orden en lugar de 5 .

2. c. 58 . Ponemos 3 en $2^{\circ}$ orden en lugar de 1 .

\section{ESTRUCTURA}

$\begin{array}{ccccc}\text { Secciones } & \text { Compases } & \text { Cadencia final } & \text { Longitud } & \text { Textura } \\ 1 & \text { cc. } 1-39 & \text { V } & 39 & \text { Imitativa } \\ 2 & \text { cc. } 40-58 & \text { I } & 19 & \text { Libre }\end{array}$

\section{ANÁLISIS}

Sección 1: la voz superior presenta el tema, cuya cabeza es el verdadero motivo de toda fantasía, un semitono ascendente que aparece continuamente con las mismas notas (Re Mi b) y que dota a la pieza de un pathos particular. Las otras dos voces acompañan con notas largas con una armonía estática sobre el i grado. El tema pasa a la voz intermedia (c. 4) y de nuevo a la superior (c. 10) con el bajo haciéndole un eco. Un pasaje con redobles y sextas paralelas nos lleva de nuevo a la cabeza del tema (cc. 17-18) que se repite insistentemente en la vOz superior para abordar una progresión descendente (cc. 19-23). En el c. 23 el motivo ascendente de mínima con puntillo y semimínima, que utilizó en anteriores fantasías y una nueva progresión en la voz superior, que llega a la zona aguda de la guitarra, volviendo a aparecer el semitono en el bajo, pero descendiendo (cc. 30-31). Una cadencia rota nos lleva a otra cadencia modal sobre el i grado.

Sección 2: desde las notas más agudas del instrumento va descendiendo en un fragmento, donde el tenaz e insistente semitono ascendente se mezcla con el motivo de mínima con puntillo y semimínima por movimiento contrario. Cierra la pieza una cadencia modal sobre el I grado rematada por una coda plagal de dos compases. 


\section{2- Pavana 3}

Pavana. I modo. Posición c (guitarra de cuatro órdenes). 4 voces. Tempo medio. Notas móviles: Mi 4 (III), Fa\# (IV), La b (VI), Si 4 (VII).

\section{NOTAS CRÍTICAS}

1. c. 35 . Añadimos la doble barra.

2. c. 49. Añadimos la breve que figura entre corchetes.

\section{INTRODUCCIÓN}

El esquema armónico de esta pieza es exactamente el mismo que el de la Pavana 1 para vihuela. No obstante, varía la forma de escribir las secciones. En la Pavana 1 no había barras de repetición, en esta sí, además de un signo de repetición (tres puntos). De esta forma los 49 compases escritos se convierten en 80 o en 113 compases según lo entendamos. Si consideramos que la barra de repetición del final afecta solo a la sección 3, sería la primera cifra, pero si tomamos la repetición desde el principio de la sección 2 nos saldrían los 113 compases, si bien contradice la estructura de la Pavana 1 para vihuela. En el primer caso tendríamos una estructura: a a b b' c c y en el segundo: a a b b' c b b' c c. ${ }^{74}$ Nosotros vamos a considerar la estructura estandarizada, sin desechar totalmente la segunda opción, aunque en la transcripción ponemos la música tal y como se presenta en la tablatura. Lo que sí queda confirmado es la extraña longitud de cada una de las secciones en ambas pavanas.

\section{ESTRUCTURA}

$\begin{array}{ccccc}\text { Secciones } & \text { Forma } & \text { Compases } & \text { Cadencia final } & \text { Longitud } \\ 1 & \text { a a } & 1-16 & \text { i } & 32 \text { cc. }(16 \times 2) \\ 2 & \text { b b' } & 17-34 & \text { V } & 18 \text { cc. }(9+9) \\ 3 & \text { c c } & 35-49 & \text { I } & 30 \text { cc. }(15 \times 2)\end{array}$

${ }^{747}$ Entre los intérpretes hay diversidad de opiniones. Unos, como Hopkinson Smith, interpretan los 113 compases, otros, como Jacob Heringman, interpretan 80. Alonso Mudarra. Tres libros de música en cifras para vihuela. Sévile 1546. Hopkinson Smith (vihuela de mano). CD. Astrée Audivis E 8740, 1992. Alonso Mudarra. Songs \& solos for vibuela \& guitar. Catherine King (mezzosoprano), Jacob Heringman (vihuela y guitarra renacentista). CD. Londres, ASV Gaudeamus GAU 162, 1997. 


\section{ANÁLISIS}

Sección 1: practicamente igual que la de la pavana para vihuela, Mudarra reutiliza algunos motivos melódicos, aunque en general es bastante «llana» ${ }^{78}$. En este caso opta por hacer una repetición literal.

Sección 2: la primera presentación de b, con la estructura acordal de Las vacas, apenas lleva glosa. En la repetición de b va incrementando la tensión con pasajes rápidos hasta alcanzar el la nota más aguda del instrumento, el traste 10 de la prima.

Sección 3: al igual que en la primera, la repetición es literal no hay el exceso de glosas y redobles de la segunda.

\section{3- Romanesca. Guárdame las vacas 2}

Diferencias. I modo. Posición g (guitarra de cuatro órdenes). 3 voces. Tempo lento. Notas móviles: Si Ł (III), Mi Ł (VI), Fa\# (VII).

\section{NOTAS CRÍTICAS}

1. c. 14 . Ponemos 0 en $1^{\circ}$ orden en lugar de 9.

2. c. 20. Añadimos la doble barra.

\section{ANÁLISIS}

Son tres diferencias sobre el mismo esquema que las anteriores Vacas, tanto es así que las posiciones digitales que usa en uno y otro caso son prácticamente las mismas, considerando la diferencia de relación interválica del tercer orden en ambos instrumentos. Sin embargo, hay mayor contraste en estas que en el caso de las pavanas.

La primera diferencia mantiene el bajo con las notas básicas mientras las dos voces superiores se alternan en líneas más glosadas. Sustituye el tercer acorde, que debería ser un

\footnotetext{
${ }^{748}$ En el sentido que utilizan Milán y Pisador, sin glosas.
} 
i grado por un acorde del VI grado, pero únicamente en el primer hemistiquio. Concluye con la consabida ripresa de dos compases y con acorde menor.

La segunda diferencia funciona prácticamente a dos voces en la primera mitad, que respeta el esquema acordal de Vacas, y a tres en la segunda mitad. Concluye con el acorde mayorizado.

La tercera y última diferencia es a tres voces. Busca la nota más aguda de la guitarra, alcanzándola en dos ocasiones. Concluye con la ripresa, pero esta vez con una cadencia modal, descendiendo en el bajo y con sexta mayor que resuelve en octava. 


\section{LIBRO II}

«Libro segundo de música en cifras para vihuela. En el qual ay muchas fantasías y algunas Composturas Glosadas por los ocho tonos que por otro nombre más propio se llaman modos».

El libro II, consta de veintiséis obras agrupadas por tonos o modos: ${ }^{79}$

- Primer tono (4)
○ Tiento
- Fantasía
- Glosado sobre un Kyrie
- Fantasía

- Segundo tono (3)
○ Tiento
- Fantasía
- Fantasía

- Tercer tono (3)
○ Tiento
- Fantasía
- Glosado sobre un Kyrie

- Cuarto tono (3)
○ Tiento
- Fantasía
- Glosado sobre un Benedictus

- Quinto tono (3)
○ Tiento

\footnotetext{
${ }^{749}$ Hasta ahora, las únicas obras instrumentales agrupadas eran danzas como la pavana, saltarello y piva de los laudistas en Italia y la pavana y gallarda en Francia, aunque también se emparejan tastar de corde con recercar en la obra de Dalza. DALZA, Joan Ambrosio. Intabulatura de Lauto. Libro Quarto. Venecia, Petrucci, 1508.
} 

- Fantasía
- Fantasía

- Sexto tono (3)
○ Tiento
- Fantasía
- Glosado sobre un Kyrie

- Séptimo tono (3)
○ Tiento
- Fantasía
- Glosado sobre un Cum sancto spiritu

- Octavo tono (4)
$\circ$ Tiento
- Fantasía
- Fantasía
- Fantasía

Una tendencia observada por algunos autores, ${ }^{750}$ es el enorme interés suscitado por los modos en el siglo XVI. Muchos compositores de música vocal o instrumental agruparon sus obras en ciclos modales. Magnificats, fabordones, chansons, fantasías, tientos, ricercares, etc. se editan en grupos de ocho o doce «tonos». En la música religiosa la necesidad de conjugar el canto llano con la polifonía hacía necesario que se respetaran los tonos por una cuestión práctica y litúrgica. Sin embargo, en la música instrumental profana tal vez se unieron estas piezas, en muchas ocasiones breves, en un intento de producir formas musicales de mayor envergadura. Algunos podrán objetar que estos ciclos del siglo XVI vendrían a ser «el canto del cisne» de la modalidad, para adentrarnos en los modernos mundos de la tonalidad ya presente en el siglo siguiente. En realidad, el mundo modal va a persistir en el marco de la música religiosa, tanto vocal como de órgano, por lo menos hasta dos siglos después, de forma que en las obras de los

\footnotetext{
${ }^{750}$ Un estudio sobre estos ciclos modales en WIERING, Frans. The Language of the Modes. Studies in the History of Polyphonic Music. Nueva York y Londres, Routledge, 2001.
} 
organistas de los siglos XVI a XVIII se puede apreciar como los ocho tonos o modos van a asimilarse con diferentes tonalidades con el paso de los años. ${ }^{751}$

- $1^{\circ}$ tono Re menor

- $2^{\circ}$ tono Sol menor (debido a la costumbre de escribirlo por gesolreut con un bemol)

- $\quad 3^{\circ}$ tono La menor

- $4^{\circ}$ tono La menor concluyendo sobre la dominante

- $5^{\circ}$ tono Do mayor (o Re mayor)

- $6^{\circ}$ tono $\quad$ Fa mayor

- $7^{\circ}$ tono Re mayor

- $8^{\circ}$ tono Sol mayor (haciendo sentir el tono de Do)

Tal vez la música instrumental profana abandonara más tempranamente el mundo modal, debido al auge de la melodía acompañada. En el caso de la vihuela es evidente que el cambio de repertorio y el empuje arrollador de la guitarra, primero de cuatro órdenes y después de cinco, propició la paulatina desaparición del instrumento y su repertorio. ${ }^{752}$

Los vihuelistas van a caer también en esta «moda» de los modos. Desde Luis Milán a Esteban Daza, todos los vihuelistas van a dar especial importancia a los ciclos de fantasías o tientos recorriendo los ocho tonos (modos). ${ }^{753}$ Excepto Mudarra y Daza, todos ellos van a incluir una breve explicación en el prólogo o declaración sobre los modos.

Mudarra, a pesar de todo, no nos da ninguna indicación teórica sobre los modos, por lo que vamos a tomar la explicación de Luis Milán para ver las características de los diferentes modos: ${ }^{754}$

Los tonos se han de conoscer en tres cosas. Primeramente en el término. Secundariamente en las cláusulas. Terceramente en la cláusula final que es donde fenecen: y quanto a lo primero que es conoscer el tono en el término: es de saber que el tono se ha de conoscer en solo en tiple en las composturas de

751 CHAilley, Jacques. L'imbroglio des modes. París, Alphonse Leduc, 1977, p. 83.

${ }^{752}$ El laúd fue capaz de adaptarse a los nuevos tiempos principalmente ampliando su tamaño y su registro mediante la adición de nuevos órdenes de cuerdas, lo que le permitió sobrevivir hasta finales del barroco, como mínimo.

${ }^{753}$ Una relación de estos ciclos modales en WIERING, F. The Language of the Modes...

${ }^{754}$ En realidad Milán no es totalmente original en su descripción de los modos, pues toma casi literalmente del teórico Martínez de Bizcargui su exposición de las cláusulas. MARTínEZ DE BIZCARGUI, Gonzalo. Arte de canto llano y contrapunto y canto de órgano con proporciones y modos. Burgos, Fadrique Alemán de Basilea, 1511, ff. b5v-b6. 
música al qual los inventores de los tonos dieron diez puntos de término: de manera que el tiple donde se ha de conoscer el tono ha de tener diez puntos de término contado que ha de subir nueve puntos encima de su cláusula final y abaxar uno debaxo de su cláusula final que son diez. Esto se entiende en los quatro tonos maestros: que son el primero/ y el tercero/ y el quinto/ y el séptimo tonos porque los otros quatro tonos discípulos / que son el segundo/ y el quarto / y el sexto / y el octavo / tienen el dicho término de diez puntos: la meytad por arriba que contaréys seys puntos encima de su cláusula final: y la meytad por abaxo que contaréys cinco puntos debaxo la cláusula final.

El tono o modo queda definido fundamentalmente por el ámbito, la cadencia final y las cadencias intermedias, donde lo importante es la altura a la que se producen, pues esto es a veces casi lo único que distingue un modo auténtico del plagal.

El ámbito, y en esto coinciden casi todos los teóricos, debe ser de diez puntos (ocho de arte y dos de licencia), de forma que los modos auténticos pueden subir una novena y bajar una segunda desde su final y los plagales subir una sexta y bajar una quinta. En los modos polifónicos esto se debe observar en el tiple.

La cadencia final suele ser, en la inmensa mayoría de los casos, sobre la final del modo. La cláusulas o cadencias intermedias, fundamentalmente, están sacadas de las del canto llano.

Como resumen del texto de Milán incluimos el siguiente cuadro: ${ }^{755}$

\begin{tabular}{|c|c|c|c|c|}
\hline Tono & Final & Ámbito & Cláusulas generales & Cláusulas voluntarias \\
\hline I & d' & $c^{\prime}-e^{\prime \prime}$ & $d^{\prime}, g^{\prime}, a^{\prime}, d^{\prime \prime}$ & $f^{\prime}, c^{\prime}$ \\
\hline II & $\mathrm{d}^{\prime}$ & $g-b^{\prime}$ & $a, d^{\prime}, g^{\prime}, a^{\prime}$ & $f^{\prime}$ \\
\hline III & $e^{\prime}$ & $d^{\prime}-f$ “ & $e^{\prime}, a^{\prime}, b^{\prime}, e^{\prime \prime}$ & g' \\
\hline IV & $e^{\prime}$ & $a-c "$ & $b, e^{\prime}, a^{\prime}, b^{\prime}$ & $g^{\prime}$ \\
\hline $\mathrm{V}$ & $f^{\prime}$ & e'-g"' & $f^{\prime}, b^{\prime}, c^{\prime \prime}, f^{\prime \prime}$ & $a^{\prime}$ \\
\hline VI & $f^{\prime}$ & b-d" & $c^{\prime}, f^{\prime}, b^{\prime}, c^{\prime \prime}$ & $a^{\prime}$ \\
\hline VII & g' & $f^{\prime}-a ”$ & g', c", d", g" & $b^{\prime}$ \\
\hline VIII & $g^{\prime}$ & $c^{\prime}-b^{\prime \prime}$ & d', g', c', d" & $b^{\prime}$ \\
\hline
\end{tabular}

\footnotetext{
${ }^{755}$ Utilizamos en este caso la notación alfabética con la correspondencia de c’ para el Do4.
} 


\section{4- Tiento 1}

Tiento. I modo. Posición f (vihuela en Mi). 4 voces. Tempo rápido. Notas móviles: $\mathrm{La} \mapsto$ (III), Si

\section{INTRODUCCIÓN}

Dice Covarrubias que tiento es:

El floreo del músico de vihuela, o de otro instrumento, antes de tañer de propósito; y esto se hace para tentar y experimentar si está templado, pasando por todas las consonancias del tono. ${ }^{756}$

La primera noticia que tenemos del término tentar, en el sentido de ejecutar un tiento instrumental, aparece a mediados del siglo XV en la obra Batalla campal entre perros y lobos de Alfonso de Palencia:

Esto mayormente vemos mucho usar a los músicos, los cuales, después de temprado el laúd o salterio, o órgano o chirimía u otro cualquier suave instrumento, tientan agudamente con los dedos algunos deleitables y breves pasos, por causa que den y pongan entero y cobdicioso el oído a los que desean oír suavidades. ${ }^{757}$

Ya en la época era conocida la relación entre el tiento ( y sus equivalentes italianos, los recercari o los tastar de corde de Dalza ${ }^{758}$ ) y el exordio del discurso retórico, pues su función sería equivalente, preparar al oyente captando su atención y predisponiéndole para lo que viene a continuación. ${ }^{759}$ Es posible que los tientos de Milán estén lejos de este cometido ya que se trata en realidad de fantasías de gran dificultal, pero en los de Mudarra la identificación es unívoca. Presentan las progresiones, cadencias y alteraciones, es decir,

${ }^{756}$ Covarrubias, S. Tesoro..., p 919.

${ }^{757}$ Citado por RoBledo EstAire, Luis. «La música en el pensamiento humanista español», Revista de Musicología, 21/2, (1998), pp. 385-429.

${ }^{758}$ DALZA, J. A.. Intabulatura de Lauto..., ff. 3v-6v.

${ }^{759}$ KIRKENDALE, Warren. «Ciceronians versus Aristotelians on the Ricercar as Exordium, from Bembo to Bach», Journal of the American Musicological Society, 32/1 (Spring 1979), pp. 1-44. Un reciente y excelente trabajo sobre la retórica aplicada al repertorio de vihuela es Griffiths, John. «Arquitectural en Rethoric in Music of the Age of Victoria», SuÁreZ-PajARes, Javier y SOL, Manuel del (eds.). Tomás Luis de Victoria: Estudios, Studies., Madrid, ICCMU, 2013, pp. 231-245. 
todas las características modales, o consonancias del tono, como dice Covarrubias, que luego veremos en las fantasías subsiguientes. También Fuenllana incluye ocho tientos y, además, nos da una explicación en su prólogo cuando dice:

me pareció cosa razonable poner al fin deste libro ocho tientos: dentro de cada uno de los quales se incluyen las cláusulas naturales y acidentales, que en cada uno de los ocho tonos ordinariamente se suelen usar. Tuve por provechoso este documento: porque el que quisiere tañer una obra compuesta, o fantasía del primero tono, o de qualquiera de los ocho, haziendo principio con un tiento destos, podrá yr entrando en el tono sin dar dessabrimiento al oýdo, como vemos que se recibe quando de un instante se passa de un tono a otro. La compostura destos tientos es de consonancias y no más porque como dicho tengo, mi intinción es, que se reconozcan los términos del tono, usando de las cláusulas que en el ay. ${ }^{760}$

Parece como si Fuenllana estuviera describiendo los tientos de Mudarra, los cuales debía conocer con toda seguridad. Ambos comparten características como la brevedad y la ausencia de glosas, es decir, estar construidos principalmente a base de consonancias. ${ }^{761}$

\section{ESTRUCTURA}

$\begin{array}{ccccc}\text { Secciones } & \text { Compases } & \text { Cadencia final } & \text { Longitud } & \text { Textura } \\ 1 & 1-6 & \text { i } & 6 \mathrm{cc} . & \text { Homofónica } \\ 2 & 7-15 & \text { i } & 9 \mathrm{cc} . & \text { Imitativa } \\ 3 & 16-23 & \text { I } & 8 \mathrm{cc} . & \text { No imitativa }\end{array}$

\section{ANÁLISIS}

Sección 1: si bien es muy difícil en una obra de esta brevedad establecer secciones, podemos ver que Mudarra utiliza los seis primeros compases para establecer el modo, recorriendo todo el diapente por encima de la final con un motivo descendente y cadenciar en el i grado. La secuencia resultante es:

$$
\mathrm{i}-\mathrm{iv}-\mathrm{VII}-\mathrm{i}-\mathrm{iv}^{7-6-5}-\mathrm{V}^{4-\natural^{3}}-\mathrm{i}
$$

Sección 2: estos nueve compases giran alrededor del $\mathrm{v}$ grado con cadencia tonal $\left(\mathrm{II}^{4-\natural^{3}}\right.$ v), y cadencia modal y tonal hacia el i grado ( vii $\left.^{7-\natural^{6}}-\mathrm{V}^{4-\natural^{3}}-\mathrm{i}\right)$.

\footnotetext{
${ }^{760}$ FuenllanA. Orphénica lyra, f. vii.
}

${ }^{761}$ Son muchas las coincidencias entre los tientos de ambos autores. Por ejemplo, el primer tiento de ambos está escrito por los mismo términos (posición de f o vihuela en Mi que diríamos nosotros). 
Sección 3: un episodio a base de redobles nos lleva a una cadencia al I grado (cc. 1819), concluyendo en la parte más aguda del instrumento con una coda plagal.

\section{5- Fantasía 15}

Fantasía. I modo. Posición f (vihuela en Mi). 4 voces. Tempo medio. Notas móviles: $\mathrm{La} \nleftarrow$ (III), Si $\nleftarrow$ (IV), Reb(VI), Mi $\nleftarrow$ (VII).

\section{NOTAS CRITICAS}

1. La foliación es incorrecta, donde dice Fol. III debería decir Fol. II.

2. c. 7 . Ponemos 6 en $3^{\circ}$ orden en lugar de 8 .

3. c. 16 . Mal colocada la mínima.

4. cc. 17-18. Añadimos la línea divisoria de compás.

5. c. 28 . Ponemos 9 en $1^{\circ}$ orden en lugar de en $2^{\circ}$. Corregido a mano en el original e indicado en la fe de erratas del final. Al añadir la línea divisoria de los cc. 17-18 no es correcto el número de compás, por lo que queda la duda abierta de si hay que añadirla o no.

6. c. 52. Ponemos mínima en lugar de semimínima.

7. c. 66. Mal colocada la mínima.

8. c. 79. Añadimos la mínima que figura entre corchetes.

9. c. 81. Primer tono en el titulillo en lugar de segundo. Corregido a mano en el original.

\section{ESTRUCTURA}

$\begin{array}{ccccc}\text { Secciones } & \text { Compases } & \text { Cadencia final } & \text { Longitud } & \text { Textura } \\ 1 & 1-35 & \mathrm{~V} & 35 \mathrm{cc} . & \text { Imitativa politemática } \\ 2 & 36-71 & \mathrm{~V} & 36 \mathrm{cc} . & \text { Imitativa politemática } \\ 3 & 72-109 & \mathrm{I} & 38 \mathrm{cc} . & \text { Imitativa politemática }\end{array}$

\section{ANÁLISIS}

Sección 1: comienza a cuatro voces con una melodía en el soprano que ya ha utilizado en anteriores ocasiones: en el inicio de la Fantasía 1 y de las Fantasías 7, 8, 12 y 13 parcialmente. En realidad, es un gesto inicial bastante común, por ejemplo, Tomás de Santa María lo usa en varias ocasiones en las fantasías que incluye como ejemplos 
musicales asociado al primero y segundo tono. ${ }^{762}$ También Narváez en su Fantasía 1, de primer tono por Gsolreut, utiliza ese motivo como segundo tema (cc. 14-17) y Fuenllana al principio del Tiento del primero tono, aunque sin ligar las dos primeras notas. ${ }^{763}$ Lo sorprendente de Mudarra es que una vez iniciada la fantasía con ese motivo, al que llamaremos a, en el segundo compás presenta el que será el verdadero protagonista de toda esta sección (b). Similar al primero, pero por movimiento contrario, se inicia en el bajo, repitiéndose en la misma voz tras una cadencia modal sobre el V grado (cc. 3-4) que se repite también (cc. 6-7). En este punto se inicia un canon (con una mutación en una nota) entre las voces superiores. ${ }^{764}$ Recoge el tema el bajo ligeramente modificado (c. 11), nueva cadencia y de nuevo el tema casi en canon entre las dos voces inferiores (cc. 14-15). Surge un nuevo motivo de cuarta ascendente (c) en soprano, responde contralto y bajo. El soprano inicia el tema a, para cerrar en la primera cadencia sobre el i grado de toda la pieza (cc. 23-24), si no consideramos la del c. 4 que no cumple las condiciones para serlo (ausencia de retardo, por ejemplo). Siguen unas cadencias sobre el iv grado, alcanzándose la nota más aguda del la vihuela donde cadencia. Tras un pasaje de transición, donde incluso aparecen unas notorias séptimas paralelas, concluye en un $\mathrm{V}$ grado.

Sección 2: en el soprano el tema c que concluye en cadencia rota, entra el bajo con el tema a y el soprano toma el tema b. De nuevo varias séptimas paralelas (c. 41). El tema a y b (en realidad uno es inversión de otro) simultáneamente en soprano y bajo en un pasaje a base de terceras y sextas paralelas. Encadena varias cadencias rotas sobre el sexto grado descendido con continuas intervenciones de los tres temas, hasta llegar a una cadencia modal sobre el V grado (cc. 71-72).

Sección 3: a pesar de la gran densidad de las secciones anteriores, Mudarra introduce nuevos elementos en esta. En este caso se trata de un motivo polifónico a cuatro voces de apenas tres compases basado en los acordes del $\mathrm{V}$ ybVI grados, con un semitono que asciende y desciende recordándonos a la Fantasía 14 para guitarra (cc. 72-74). Este motivo se imita intercambiando las voces y, lo más sorprendente en Mudarra, se repite

\footnotetext{
762 SANTA María, Fray Tomás de. Libro llamado Arte de tañer fantasía. Valladolid, Francisco Fernández de Córdova, 1565: Primero tono (ff. 67v), Segundo tono (f. 68), Primero por gesolreut (f. 72v).

${ }^{763}$ NARVÁEZ. El delphin, ff. 1-3 y FuENLLANA. Orphénica lyra, f. 170v.

${ }^{764}$ Este fragmento será utilizado por Venegas de Henestrosa para la Fantasía o Tiento del primer tono (f. 34), Fantasía II en la edición de Anglés (pp. 78-80), construida a partir de la Fantasía 1 de Narváez. Los compases coincidentes en Venegas son los cc. 129-138. VENEGAS DE HENESTROSA, Luys. Libro de cifra nueva para tecla, harpa y vihuela. Alcalá de Henares, Joan de Brocar, 1557.
} 
completamente con ligeras modificaciones, de forma que los cc. 74-77 son prácticamente iguales a los cc. 79-82. Este recurso de repetir fragmentos cuando llega el final de la obra lo podemos ver en Milán (por ejemplo en las Fantasías 5 y 7 ) y algo también en Narváez (Fantasía 11). Derivado del motivo anterior, surge uno nuevo a dos voces basado en el semitono y la progresión $\mathrm{V}$ - bVI - iv - V que va pasando por varias voces y repitiéndose como un ostinato hasta culminar en una ornamentada cadencia sobre el i grado (cc. 101102), seguida de una coda plagal de siete compases.

\section{COMENTARIO}

Como conclusión de este extenso análisis, podemos decir que se trata de una gran obra en todos los sentidos, en dificultad técnica, en complejidad, en extensión, en belleza. Mudarra despliega todos sus recursos contrapuntísticos y su imaginación con una gran cantidad de temas que nos recuerdan en muchos casos los escuchados en las fantasías del primer libro.

\section{6- Kyrie 1}

Glosado. I modo. Posición f (vihuela en Mi). 4 voces. Tempo medio. Notas móviles: $\mathrm{La} \curvearrowleft$ (III), Si $\sqsubset$ (IV), Reb(VI), Mi

\section{NOTAS CRÍTICAS}

1. La foliación es incorrecta, donde dice Fol. IIII debería decir Fol. III.

2. c. 6. Añadimos la semibreve que figura entre corchetes.

3. c. 16 . Ponemos 3 en $3^{\circ}$ orden en lugar de 10 . Corregido a mano en el original e indicado en la fe de erratas del final.

4. c. 33. Añadimos la indicación que figura entre corchetes.

5. c. 34. Ponemos 0 en $1^{\circ}$ orden en lugar de 2 .

6. c. 67. Ponemos corchea en lugar de semimínima. Corregido a mano en el original e indicado en la fe de erratas del final. 


\section{INTRODUCCIÓN}

Si en el primer libro Mudarra tomaba un par de composturas de Josquin y las presentaba casi literalmente, con apenas unas glosas en las cadencias, ahora coge una pieza de Josquin, un Kyrie de la Missa de Beata Virgine, y la transforma completamente. ${ }^{765}$ Mudarra no se limita a glosar la pieza de Josquin en el sentido de ornamentarla, sino que la amplifica, de forma que cuarenta y ocho semibreves de Josquin se convierten en cien de Mudarra. Estamos aquí muy cerca de los procedimientos magistralmente descritos por Margit Frenk para las glosas literarias de los villancicos, la cuales la autora clasifica en: ${ }^{766}$

- Glosa como versión ampliada

$$
\begin{aligned}
\circ \quad \text { Despliegue } \\
\text { - Despliegue total } \\
\text { - Despliegue parcial }
\end{aligned}
$$

○ Desarrollo

- Glosa como entidad aparte

Los glosados de Mudarra estarían dentro del procedimiento del desarrollo, ya que toma fragmentos y motivos del original, los acompaña de su propias glosas y utiliza su temática para las glosas añadidas. ${ }^{767}$

\section{ESTRUCTURA}

$\begin{array}{ccccc}\text { Secciones } & \text { Compases } & \text { Cadencia final } & \text { Longitud } & \text { Tipo } \\ 1 & 1-32 & \text { i } & 32 \mathrm{cc} . & \text { Glosa } \\ 2 & 33-44 & \text { V } & 12 \mathrm{cc} . & \text { Josquin } \\ 3 & 45-56 & \text { v } & 12 \mathrm{cc} . & \text { Glosa } \\ 4 & 57-74 & \text { v } & 18 \mathrm{cc} . & \text { Josquin } \\ 5 & 75-91 & \text { i } & 17 \mathrm{cc} . & \text { Glosa } \\ 6 & 92-100 & \text { I } & 9 \mathrm{cc} & \text { Josquin }\end{array}$

${ }^{765}$ Tomamos el original de Missarum Josquin liber tertius... y Liber quindecim missarum... de donde está sacada la edición Josquin des Prés. Missa de Beata virgine. Das Chorwerk 42, Wolfenbüttel, Möseler Verlag, 1936.

${ }^{766}$ FRENK, Margit. «Glosas de tipo popular en el antigua lírica», Estudios sobre la lírica antigua. Madrid, Castalia, 1978, pp. 267-308.

${ }^{767}$ Como ya señaló John Ward, las glosas de Mudarra son las primeras obras de este género impresas en España, ya que las obras ajenas contenidas en el libro de Narváez son intabulaciones literales. WARD, J. The "Vibuela de mano..., p. 226. 


\section{ANÁLISIS}

La fórmula utilizada por Mudarra consiste en dividir el original en varias secciones y anteponer un comentario a cada una de ellas. ${ }^{768}$

Sección 1: toma el motivo inicial de Josquin y realiza imitaciones en todas las voces, cambiando el orden del original y añadiendo voces. Usa el tema inicial como una especie de cantus firmus u ostinato. Para la comparación entre ambas piezas transportamos la de Mudarra un tono alto para que coincida con el original y señalamos el motivo original.
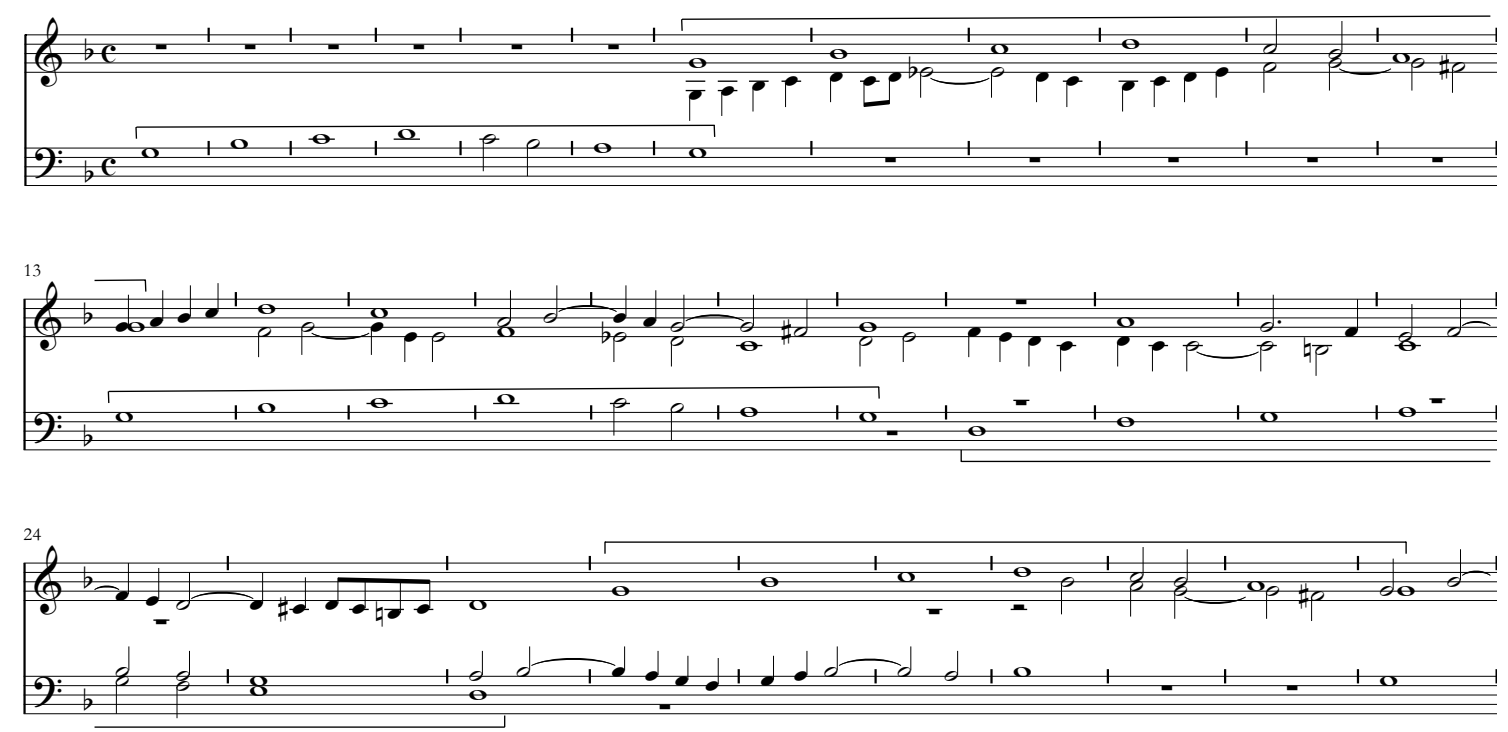

Ejemplo 11. Sección 1 del Kyrie 1 de Mudarra (cc. 1-33)

Sección 2: es prácticamente literal con el original de Josquin desde la cuarta breve hasta la novena (seis breves de Josquin se corresponden con doce compases de Mudarra).

${ }^{768}$ Un somero estudio sobre estas glosas de Mudarra en LAWRENCE, Deborah. «Mudarra’s Instrumental Glosas: Imitation and Homage in a Spanish Style», Encomium Musicae. Essays in Honor of Robert J. Snow. David Crawford, G. Grayson Wagstaff (eds.), Festschrift Series no 17, Hillsdale, Nueva York, Pendragon Press, 2002, pp. 305-319. Hay que tomar con cierta cautela este trabajo, pues la autora debió realizar sus análisis a partir de las transcripciones de Pujol, con los inconvenientes que ello genera. 


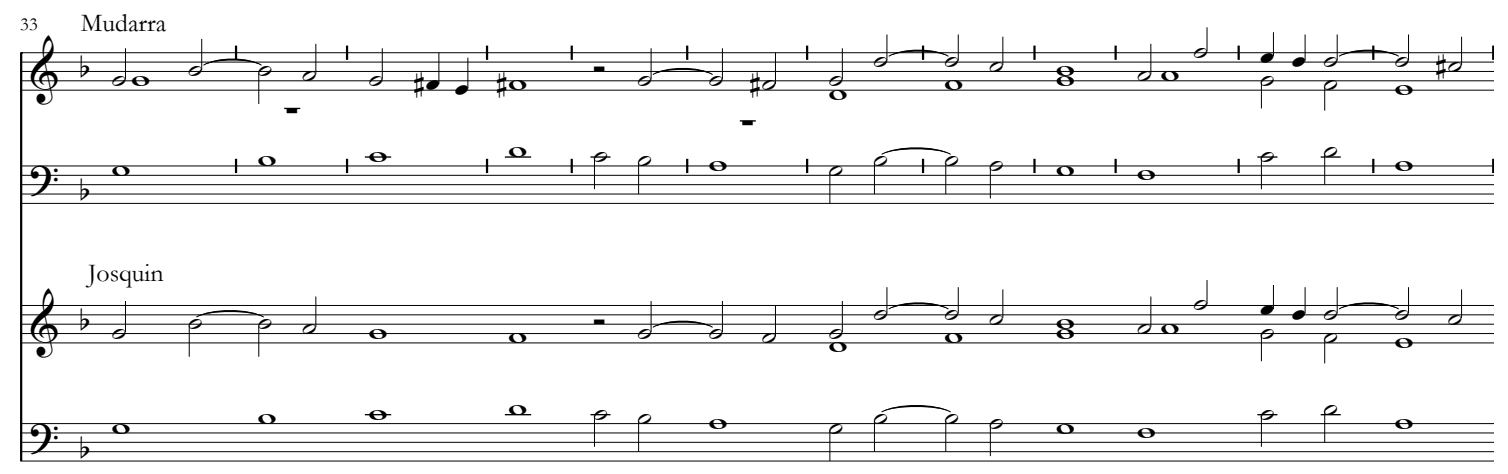

Ejemplo 12. Sección 2 del Kyrie 1 de Mudarra, comparación con Josquin (cc. 33-44)

Sección 3: realiza la glosa sobre el motivo que vendrá después, es decir, se anticipa, acompañándolo con voces libres que en muchos casos derivan del motivo inicial.

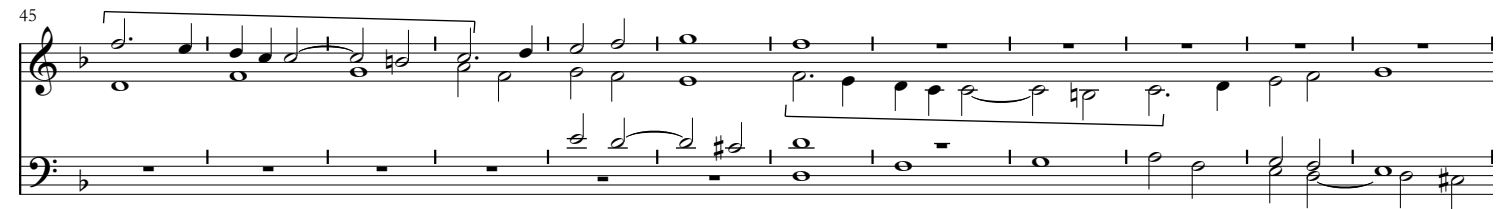

Ejemplo 13. Sección 3 del Kyrie 1 de Mudarra (cc. 45-56)

Sección 4: literal con respecto a los compases originales de Josquin.

Sección 5: Mudarra se aleja más del modelo de Josquin, aunque sí toma algunos elementos melódicos, escribiendo un episodio a base de redobles continuos que claramente nos indican que estamos llegando al final.
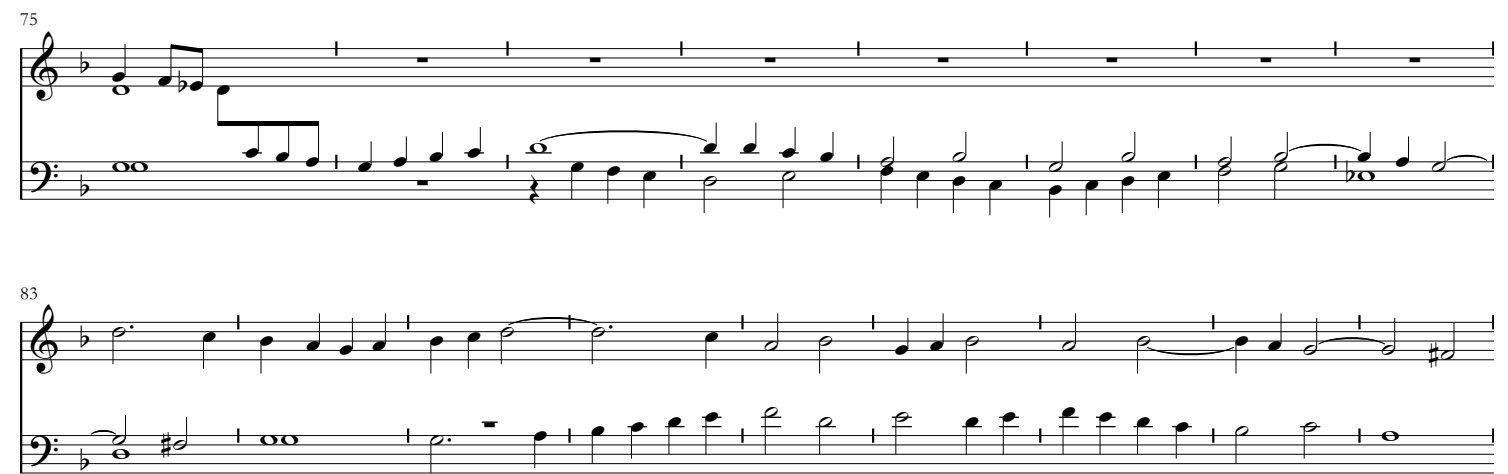

Ejemplo 14. Sección 5 del Kyrie 1 de Mudarra (cc. 75-91) 
Sección 6: de nuevo sigue el modelo aunque en esta ocasión introduce un enlace escalístico al principio y ornamenta la cadencia final, además de modificarla y modernizarla, pues la de Josquin es una cadencia Landino.

\section{COMENTARIO}

John Ward analiza esta glosa en su tesis sobre la vihuela, destacando la habilidad de Mudarra para combinar la música de Josquin con la suya propia dando como resultado «neither pure Josquin nor Mudarra, but a pleasing fusion». ${ }^{769}$

\section{7- Fantasía 16}

Fantasía. I modo. Posición f (vihuela en Mi). 4 voces. Tempo rápido. Notas móviles: La ต (III), Si ต (IV), Reb (VI), Mi ต (VII).

\section{NOTAS CRÍTICAS}

1. La foliación es incorrecta, donde dice Fol. V debería decir Fol. IV.

2. Primer tono en el titulillo en lugar de segundo. Corregido a mano en el original e indicado en la fe de erratas del final.

3. cc. 3-4. Añadimos la línea divisoria de compás.

4. c. 16. Mal colocada la semimínima.

5. c. 24 . Ponemos 3 en $3^{\circ}$ orden en lugar de en $4^{\circ}$ orden.

6. c. 48 . Ponemos 3 en $1^{\circ}$ orden en lugar de 2 .

7. c. 86. Ponemos una mínima en lugar de una semimínima.

\section{ESTRUCTURA}

$\begin{array}{ccccc}\text { Secciones } & \text { Compases } & \text { Cadencia final } & \text { Longitud } & \text { Textura } \\ 1 & 1-33 & \mathrm{~V} & 33 \mathrm{cc} . & \text { Imitativa politemática } \\ 2 & 34-71 & \mathrm{~V} & 38 \mathrm{cc} . & \text { Imitativa politemática } \\ 3 & 72-96 & \mathrm{I} & 23 \mathrm{cc} . & \text { Imitativa politemática }\end{array}$

${ }^{769}$ WARD, J. The «Vibuela de mano..., pp. 228-229. 


\section{ANÁLISIS}

Sección 1: comienzo imitativo en cascada ascendente $(\mathrm{B}, \mathrm{T}, \mathrm{A}, \mathrm{S})$ basado en un breve motivo cadencial y descendente en el ámbito de una cuarta. Tras una cadencia modal sobre el $\forall$ grado (cc. 13-14), un nuevo motivo en bicinium en el tenor en estrecho con el bajo con un variante de sí mismo, respuesta en tenor y contralto, tercera entrada de voces pareadas entre contralto y soprano y nueva respuesta de tenor y bajo concluyendo con cadencia tonal sobre el $\forall$ grado. Tras esta, se repite la presentación en el agudo añadiendo una tercera voz. Hay ligeras modificaciones de la cabeza del motivo en las diversas imitaciones, pero siempre se distingue por su diseño. Es también característico de toda esta sección que las imitaciones van desde el grave poco a poco subiendo hasta alcanzar la zona aguda del instrumento, lo que garantiza también un incremento de la tensión. Concluye el fragmento en un reposo o semicadencia sobre el $\mathrm{V}$ grado.

Sección 2: tras un enlace ascendente surge un nuevo motivo en el bajo caracterizado por una cuarta ascendente (cc. 36-37), respondido en soprano y de nuevo en bajo una segunda inferior. Desde el primer momento, es patente la presencia del sexto grado rebajado, que prácticamente había estado ausente en la primera sección, generando continuas cadencias rotas de semitono ascendente. Surgen nuevos temas de tipo ascendente alcanzando la zona aguda y reincidiendo en las cadencias rotas. Se alcanza el V grado mediante una cadencia frigia incompleta.

Sección 3: un motivo ya usado en la sección anterior se repite tres veces a diferentes octavas, se le une un segundo motivo derivado de motivos ya escuchados mientras el bajo insiste en el la secuencia V - bVI. Cadencia modal sobre el i grado seguida de una coda plagal y un acorde sobre el I grado.

\section{COMENTARIO}

Griffiths también se ocupa de esta fantasía en su tesis, aunque su análisis difiere ligeramente del nuestro, pero no en lo fundamental. ${ }^{770}$

\footnotetext{
${ }^{770}$ GriffithS, J. The Vibuela Fantasia..., pp. 196-200.
} 


\section{8- Tiento 2}

Tiento. II modo por Gsolreut. Posición g (vihuela en Sol). 4 voces. Tempo rápido. Notas móviles: Mi b (VI), Fa\# (VII).

\section{NOTAS CRÍTICAS}

1. La foliación es incorrecta, donde dice Fol. VI debería decir Fol. V.

\section{ESTRUCTURA}

$\begin{array}{ccccc}\text { Secciones } & \text { Compases } & \text { Cadencia final } & \text { Longitud } & \text { Textura } \\ 1 & 1-6 & \text { III } & 6 \text { cc. } & \text { Homofónica } \\ 2 & 7-13 & \text { i } & 7 \text { cc. } & \text { No imitativa } \\ 3 & 14-21 & \text { I } & 8 \text { cc. } & \text { No imitativa }\end{array}$

\section{ANÁLISIS}

$\mathrm{Al}$ igual que el anterior tiento está basado en consonancias, aunque introduce algunos redobles. La estructura también es paralela con el Tiento 1. En los primeros siete compases establece los acordes fundamentales del modo, pero llama la atención que no figure entre ellos el acorde sobre el I grado. El centro de gravedad oscila entre el III y el VII grados, produciendo la secuencia siguiente: ${ }^{771}$

$$
\text { III - bVI - VII - ii - III - bVI - VII }{ }^{4-3}-\text { III }
$$

A partir del c. 7 comienzan los redobles y se asienta el acorde del i grado durante tres compases. A partir de aquí (c. 14) avanza hacia un par de cadencias sobre el i grado, la primera un tanto particular $\left(\right.$ iv $^{9-8}$ - i) y la segunda característica de los modos I y II (V - b $\left.\mathrm{VI}-\mathrm{V}^{4-\# 3}-\mathrm{I}\right)$.

\footnotetext{
${ }^{771}$ No hay que perder de vista que el II grado es la nota dominante modal del II tono.
} 


\section{9- Fantasía 17}

Fantasía. II modo por Gsolreut. Posición g (vihuela en Sol). 4 voces. Tempo medio. Notas móviles: Si ต (III), Do\# (VII), Mi b (VI), Fa\# (VII).

\section{NOTAS CRÍTICAS}

1. c. 58 . Ponemos 2 en $4^{\circ}$ orden en lugar de 3.

\section{ESTRUCTURA}

$\begin{array}{ccccc}\text { Secciones } & \text { Compases } & \text { Cadencia final } & \text { Longitud } & \text { Textura } \\ 1 & 1-24 & \text { i } & 24 \mathrm{cc} . & \text { Imitativa politemática } \\ 2 & 25-44 & \text { III } & 20 \mathrm{cc} . & \text { Imitativa } \\ 3 & 45-62 & \mathrm{~V} & 18 \mathrm{cc} . & \text { Imitativa } \\ 4 & 63-83 & \text { I } & 21 \mathrm{cc} & \text { Homofónica }\end{array}$

\section{ANÁLISIS}

Sección 1: comienza en el tenor el primer motivo, respondido por soprano y después por bajo, a continuación polifonía libre, más bien homofónica y cadencia sobre el III grado. Estos primeros doce compases se mueven entre el III y VII grado, al igual que ocurría al principio del tiento anterior. Un segundo motivo basado en un «quiebro reiterado», en terminología de Santa María, ${ }^{772}$ se expone en el soprano y responde en contralto y en bajo. Esta exposición se mueve sobre el V y i grados. De nuevo un pasaje en polifonía libre nos lleva a una cadencia modal sobre el i grado (ii ${ }^{7 \# 6}-$ i).

Sección 2: un nuevo motivo, aunque muy parecido al primero, se expone en soprano y bajo, cadencias sobre i grado y rota sobre II. Motivo en el tenor, polifonía libre y motivo en el bajo que nos lleva a un pasaje basado en retardos y que culmina en el III grado.

Sección 3: episodio basado en redobles ascendentes y descendentes generados por un motivo descendente en un ámbito de quinta. Cadencia tonal sobre el i grado (cc. 59-60), motivo ascendente en décimas que llega a un $\mathrm{V}$ grado.

Sección 4: comienza una serie de retardos ascendentes en la voz central mientras las voces extremas marchan en décimas ascendentes. A partir del c. 66 la pieza se mueve

\footnotetext{
${ }^{772}$ Santa María, T. Libro llamado Arte..., f. 46v-47.
} 
homofónicamente a cuatro voces, hasta llegar al c. 78 donde unos redobles nos llevan a la cadencia final tonal y plagal con acordes de cinco y seis voces.

\section{COMENTARIO}

Once años después de publicarse los libros de Mudarra, se publicaba en Alcalá de Henares el Libro de cifra nueva para tecla, harpa y vibuela de Luys Venegas de Henestrosa donde, como él mismo dice en su prólogo, recogió «muchas obras de diversos autores, assí de tecla como de vihuela». ${ }^{73}$ Entre ellas figuran los Tientos de los ocho tonos de vibuela según el índice (ff. 34-43), a los que luego llama fantasías, cuya autoría corresponde en trece ocasiones a Mudarra, en cinco a Narváez y en una a Valderrábano. A continuación van dos fabordones, uno de Mudarra y otro de Pisador. ${ }^{774}$ Al estudiar la Fantasía 15 de Mudarra, veíamos como Venegas utilizaba algunos de sus compases para una de sus obras, juntándolos con una fantasía de Narváez. En el caso de la Fantasía $I I I^{775}$ por el segundo tono, Venegas «reutiliza» casi completamente esta Fantasía 17 de Mudarra, cortando donde cree conveniente y añadiendo por otro lado. Para ver el procedimiento incluimos transcripción de la fantasía de Venegas/Mudarra transportada a la altura de nuestra transcripción de Mudarra, si bien la original de Venegas está en la altura de Re. ${ }^{776}$

Venegas utiliza literalmente los primeros 27 compases de Mudarra añadiendo algunas glosas en algunos puntos (cc. 4-5, 10, 12, 14, etc.), incluso modificando algunos diseños (cc. 15-18). Llegado al c. 27 salta a los cc. 61-80 añadiendo también glosas. A partir del c. 48 toma los cc. 12-17 del Tiento 2 de Mudarra y desde el c. 54 al final toma de nuevo el c. 61 de la fantasía y cadencia sobre el I grado.

\footnotetext{
${ }^{773}$ VENEGAS DE HENESTROSA. Libro de cifra nueva..., f. 1.

${ }^{774}$ Este hecho ya fue estudiado por WARD, John. "The Editorial Methods of Venegas de Henestrosa», Musica Disciplina, 6 (1952), pp. 105-113.

${ }^{775}$ Según la numeración de ANGLÉs, H. La Música en la Corte de Carlos V ..., vol. 2, p. 81. VENEGAS DE HeNESTROSA. Libro de cifra nueva..., ff. 34v-35.

${ }^{776}$ Venegas de Henestrosa incluye para el segundo modo una armadura con un bemol, al hacer el transporte serían dos. Respetamos su elección, si bien no es nada común. Corregimos varias notas alteradas de los cc. 46-47 que, obviamente, son errores tipográficos.
} 


\section{Segundo tono}
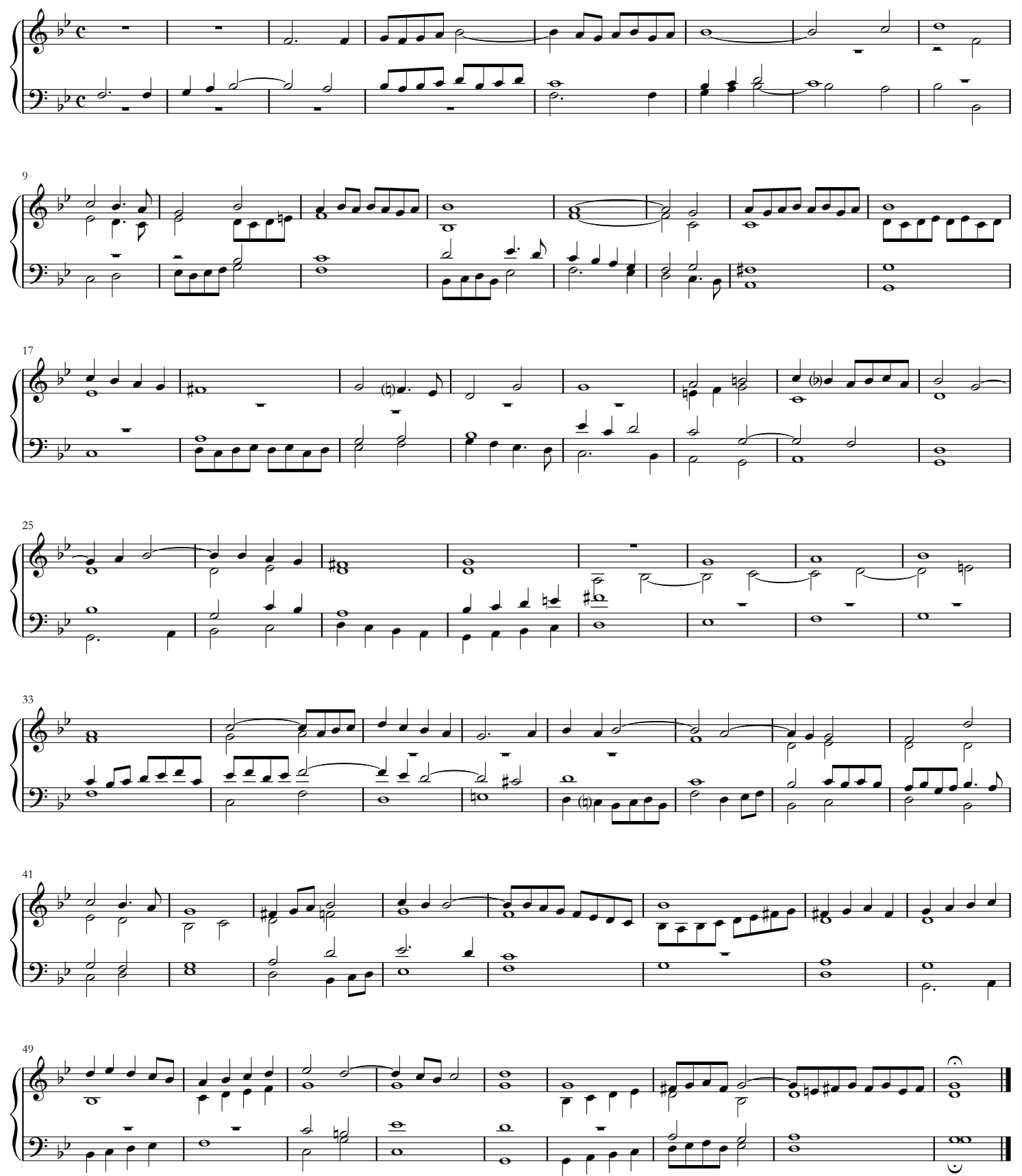

Ejemplo 15. Fantasía III de Venegas de Henestrosa/Mudarra 


\section{0- Fantasía 18}

Fantasía. II modo por Gsolreut. Posición g (vihuela en Sol). 4 voces. Tempo rápido. Notas móviles: Si ต (III), Do\# (VII), Mi b (VI), Fa\# (VII).

\section{NOTAS CRÍTICAS}

1. c. 30.3 en $2^{\circ}$ orden invertido.

\section{ESTRUCTURA}

$\begin{array}{ccccc}\text { Secciones } & \text { Compases } & \text { Cadencia final } & \text { Longitud } & \text { Textura } \\ 1 & 1-19 & \text { i } & 19 \mathrm{cc} . & \text { Ostinato } \\ 2 & 20-41 & \text { i } & 22 \mathrm{cc} . & \text { Ostinato } \\ 3 & 42-63 & \text { I } & 22 \mathrm{cc} . & \text { Ostinato }\end{array}$

\section{ANÁLISIS}

El motivo está formado por las sílabas de solmisación fa, mi, ut, re (con el ut o do sostenido) y va a aparecer durante toda la obra, y en todas las voces, un total de dieciocho veces, doce a la misma altura (en nuestra transcripción si, la, fa\#, sol) y seis transportada. Recuerda mucho en su textura a la Fantasía de pasos de contado del propio Mudarra. Este procedimiento de usar un ostinato para las fantasías es utilizado profusamente en las doce fantasías con passos remedados de Diego Pisador. ${ }^{777}$

Sección 1: el cantus firmus se expone en soprano acompañado por un movimiento constante de semimínimas en el tenor que recoge el tema a continuación. Se repite la alternancia, ahora a tres voces, hasta llegar a la primera cadencia clara en los cc. 12-13. El ostinato hace que las armonías que se generan sean muy repetitivas, porque, además, en esta sección se presenta seis veces sin transportar. Tras la cadencia se une una voz más y así a cuatro voces con diálogo constante entre ellas se alcanza la nota más aguda (la quinta del modo II) y una nueva cadencia sobre el i grado.

\footnotetext{
${ }^{777}$ Ver ROA, F. y GÉRTRUDIX, F. El libro de música... Estudio y transcripción.
} 
Sección 2: bicinium entre las dos voces superiores y las inferiores con un diseño rítmico más variado y con el ostinato transportado a la quinta y luego a la cuarta, obligando este segundo transporte a una mutación en el diseño para no salirse del modo, siendo el tercer intervalo de segunda mayor en lugar de menor. En los cc. 36-36 el ostinato se presenta con los valores rítmicos disminuidos dentro de un pasaje homofónico, concluyendo en cadencia sobre el i grado.

Sección 3: con una textura más ligera a dos y tres voces y con el ostinato sin transportar, excepto en una ocasión, y un motivo rítmico ya conocido (mínima con puntillo y semimínimas) y su versión invertida, avanza hacia la últimas cadencias donde encadena una cadencia modal sin retardo (ii ${ }^{\# 6}$ - i), una breve pedal sobre el $\mathrm{V}$ grado y cadencia conclusiva con todos los elementos $\left(i-V-b V I^{4-3}-i v-V^{4-\# 3}-~ f\right)$.

\section{COMENTARIO}

Esta fantasía también fue utilizada por Venegas de Henestrosa titulándola Otra fantesía [sic] del segundo tono, sobre fa. mi. ut. re. ${ }^{778}$ En esta ocasión la versión de Venegas reproduce literalmente la de Mudarra, únicamente ligerísimos cambios en algunas figuraciones rítmicas.

Griffiths analiza esta fantasía incluyéndola en el grupo de las fantasías ostinato o basadas en un cantus firmus. ${ }^{779}$

\section{1- Tiento 3}

Tiento. III modo. Posición g (vihuela en Mi). 4 voces. Tempo rápido. Notas móviles: La ต (II), Si Ł (III).

\section{NOTAS CRÍTICAS}

1. c. 5. Sobra la semimínima.

\footnotetext{
${ }^{778}$ Venegas de HeneStrosa. Libro de cifra nueva..., f. 35. Fantasía IV de vihuela según ANGLÉs, H. La Música en la Corte de Carlos V..., vol. 2, p. 82.

${ }^{779}$ Tomamos muchos elementos de su análisis. GRIFFITHS, J. The Vihuela Fantasia..., pp. 211-216.
} 


\section{ESTRUCTURA}

$\begin{array}{ccccc}\text { Secciones } & \text { Compases } & \text { Cadencia final } & \text { Longitud } & \text { Textura } \\ 1 & 1-12 & \text { iv } & 12 \mathrm{cc} . & \text { Imitativa politemática } \\ 2 & 13-21 & \text { I } & 9 \mathrm{cc} . & \text { No imitativa }\end{array}$

\section{ANÁLISIS}

A diferencia de los anteriores tientos, de carácter homofónico, este presenta una textura imitativa.

Sección 1: comienzo en imitación pareada con dos temas distintos (en contrapunto invertible), aunque muy emparentados entre sí, pues se puede considerar el uno inversion del otro. Primero tenor y bajo, se añade contralto y posteriormente soprano. Los centros modales son, en primer lugar el VI grado sobre el que cadencia tres veces (cc. 3-4, 5-6 y 910) y el iv grado con el que termina la sección. El tercer acorde en importancia es el III grado. Se puede resumir la sección como: III - VI - iv

Sección 2: redobles que recorren todo el diapasón nos anuncian la cadencia final, una cadencia frigia II - I sin cláusula de retardo en ninguna voz.

\section{2- Fantasía 19}

Fantasía. III modo. Posición g (vihuela en Mi). 4 voces. Tempo medio. Notas móviles: Solb (I), La

\section{NOTAS CRÍTICAS}

1. c. 3. Añadimos el puntillo de la mínima.

ESTRUCTURA

$\begin{array}{ccccc}\text { Secciones } & \text { Compases } & \text { Cadencia final } & \text { Longitud } & \text { Textura } \\ 1 & 1-28 & \text { iv } & 28 \mathrm{cc} . & \text { Imitativa politemática } \\ 2 & 29-61 & \text { iv } & 33 \mathrm{cc} . & \text { Imitativa politemática } \\ 3 & 62-109 & \text { I } & 48 \mathrm{cc} . & \text { Imitativa politemática }\end{array}$




\section{ANÁLISIS}

Sección 1: al igual que ocurría con el tiento precedente, Mudarra utiliza dos temas distintos en imitación pareada. Primero bajo y contralto y después tenor y soprano, manteniéndose el contralto una variante de uno de los temas. De igual manera el centro modal va a ser el VI grado sobre el que se producen dos cadencias tonales III $^{4-3}$ - VI (cc. 5-6 y 10-11). Un episodio en las dos voces superiores en polifonía libre es respondido por las dos inferiores. El centro de gravedad modal se ha desplazado al iv grado sobre el que cadencia. Tenemos que destacar, que uno de los temas con los que se abre esta sección (y que se mantiene en contralto) está íntimamente relacionado con el tema principal con el que se inicia el glosado siguiente basado en un Kyrie de Josquin. Un pasaje homofónico a cuatro voces, con especial relevancia del iv grado, que continúa con unos redobles, nos lleva a a una cadencia tonal sobre el iv grado.

Sección 2: comienza un episodio imitativo a tres voces con dos motivos que nos recuerdan a los del tiento tercero. Primero bajo y tenor (cc. 26-27) y luego soprano. Nueva cadencia sobre el iv grado (cc. 35-36). Entradas sucesivas en imitación nos conducen a una nueva cadencia tonal sobre el iv grado, donde se produce una detención, continuando a cuatro voces con intervenciones de los motivos que iniciaban esta sección, concluyendo en cadencia sobre el iv grado.

Sección 3: principalmente a dos voces, recuerda a la fantasía cuarta «de pasos de contado» y la anterior sobre un cantus firmus, la número 18. La particularidad es que el cantus firmus que va a utilizar ahora está relacionado con el tema inicial del contralto, ya que en realidad se trara del motivo inicial de la pieza siguiente, el Kyrie. Se inicia en el bajo y pasa por tenor y soprano. Sin dejar de sonar el cantus firmus, comienza un nuevo motivo en el contralto en el c. 73. Este tema consiste en un diseño que asciende una tercera y desciende una quinta. La segunda presentación es literal en los intervalos lo que produce una nota excesivamente extraña al modo el I grado bemolizado. Multiples repeticiones del motivo nos conducen a una cadencia frigia sobre el I grado, seguida de una coda plagal con nueva cadencia modal, concluyendo con el I grado mayorizado. 


\section{COMENTARIO}

Venegas incluye esta fantasía en su libro con el título Primera fantesía del tercero tono. ${ }^{780}$ Coincide de forma casi literal con el original de Mudarra, únicamente incluyendo alguna glosa (cc. 79-80 por ejemplo) y llegando al final se salta un compás (el c. 98).

Griffiths analiza esta fantasía ${ }^{781}$ de la que afirma que:

demonstrates the manner in which Mudarra incorporated his lyrical melodic style into an imitative framework to create a charming idiomatic work. [...] employs Mudarra's characteristic techniques of dissimilar duos, free contapuntal extensions and unequally distributed textures. Textures and processes in the opening and closing parts recall those used by Milán.

\section{3- Kyrie 2}

Glosado. III modo. Posición g (vihuela en Mi). 4 voces. Tempo medio. Notas móviles:

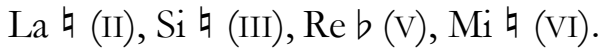

\section{NOTAS CRÍTICAS}

1. cc. 22-23. Añadimos la línea divisoria de compás.

2. c. 38. Añadimos la nota que figura entre corchetes.

\section{INTRODUCCIÓN}

El segundo de los glosados de Mudarra está basado en el Kyrie I de la Missa Pangue lingua de Josquin ${ }^{782}$. Los procedimientos que utiliza son similares a los del anterior, con algunas particularidades.

${ }^{780}$ Venegas De Henestrosa. Libro de cifra nueva..., ff. 35v-36. Transcripción en Anglés, H. La Música en la Corte de Carlos V..., vol. 2, pp. 83-84, como Fantasía $V$ de vibuela.

${ }^{781}$ GriffiTHS, J. The Vihuela Fantasia..., pp. 204-207.

${ }^{782}$ Tomamos el original de Josquin de Missae tredecim quatuor vocum a praestantis: artificib: compositae. Nuremberg, Grapheus, 1539 y de la edición Josquin des Prés. Missa Pangue lingua. Das Chorwerk 1, Wolfenbüttel y Zurich, Möseler Verlag, 1929. 


\section{ESTRUCTURA}

$\begin{array}{ccccc}\text { Secciones } & \text { Compases } & \text { Cadencia final } & \text { Longitud } & \text { Tipo } \\ 1 & 1-25 & \text { VI } & 25 \mathrm{cc} . & \text { Glosa } \\ 2 & 26-50 & \text { III } & 24 \mathrm{cc} . & \text { Josquin } \\ 3 & 51-87 & \text { III } & 38 \mathrm{cc} . & \text { Glosa } \\ 4 & 88-102 & \text { I } & 15 \mathrm{cc} . & \text { Josquin }\end{array}$

ANÁLISIS

Sección 1: Mudarra toma el motivo inicial del Kyrie I de la misma misa y lo mezcla con el motivo del Kyrie II, obteniendo un tema propio con el que comienza una serie de imitaciones desde el contralto, seguido por el soprano en canon, que se trunca en el c. 12. Todos estos compases mantienen una armonía estática. Se inicia el motivo en el bajo y es respondido por tenor con el tema variado. La entrada del tenor es anunciada por una cadencia rota $\mathrm{I}^{4-\natural^{3}}$ - II. El bajo introduce un breve motivo saltarín que conduce a una cadencia modal sobre el VI grado.

Sección 2: coincide casi literalmente con el original de Josquin, pero introduce algunas glosas, fundamentalmente al principio para acompañar los valores largos. 

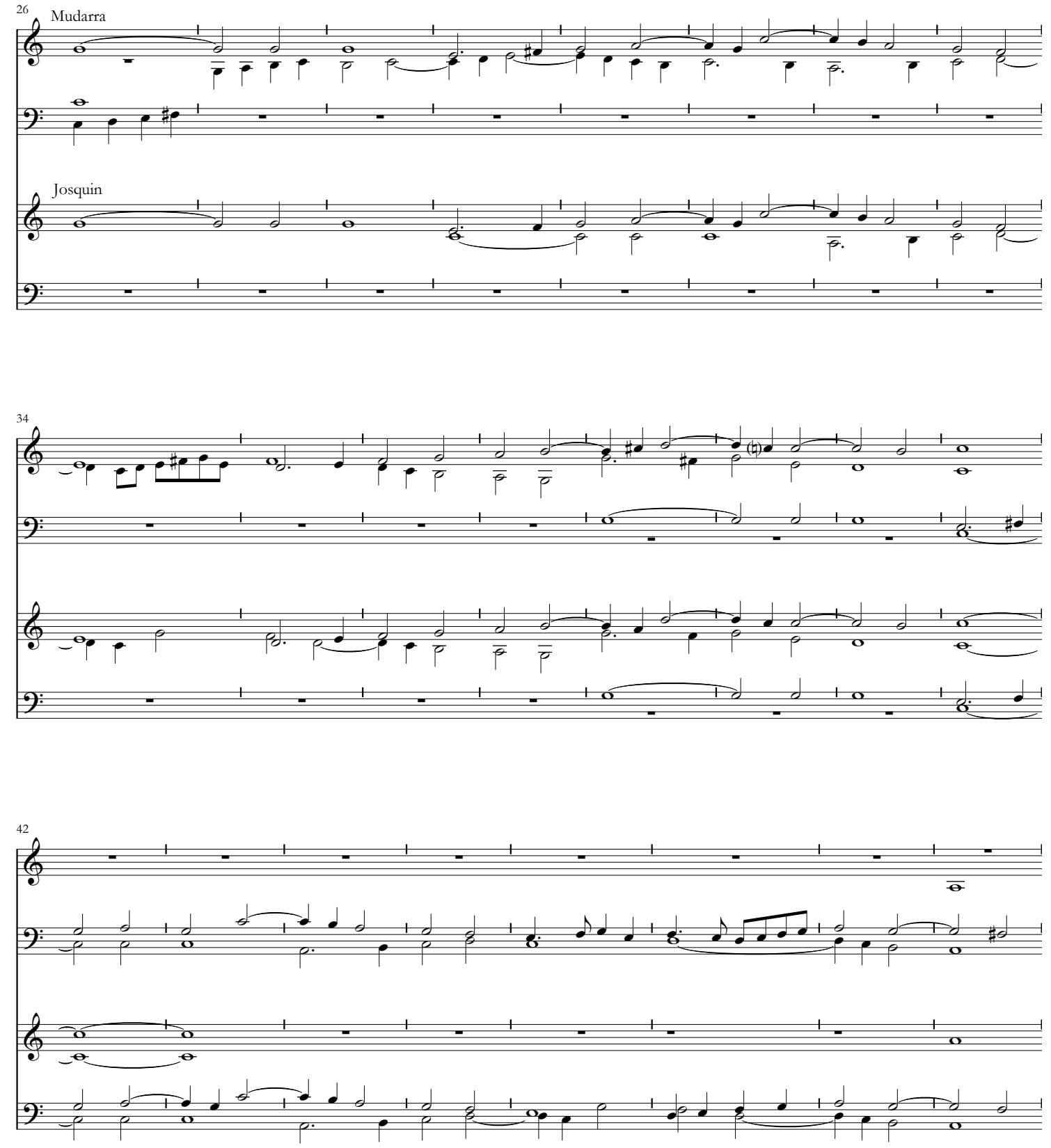

Ejemplo 16. Sección 2 del Kyrie 2 de Mudarra, comparación con Josquin (cc. 26-49)

Sección 3: un pasaje homofónico lleva a un acorde sobre el bV grado, nota totalmente ajena al modo. Cadencia sobre el II grado, donde comienza una breve progresión (cc. 5962) que nos devuelve al área tonal del III y VI grados. Un grupo ascendente de corcheas nos lleva a una nueva progresión (cc. 67-74). Todos los motivos que van surgiendo están inspirados en lo hasta ahora escuchado, aunque podríamos hablar de polifonía libre. 
Desde un acorde de VII grado pasando por un pasaje sobre el i grado con repeticiones se llega a la última sección.

Sección 4: nuevo pasaje literal sobre el último fragmento del Kyrie de Josquin, al que añade una cadencia plagal propia (cc. 98-102).

\section{COMENTARio}

Venegas reutiliza esta pieza en su Segunda fantesía del tercero tono ${ }^{783}$ En este caso su método de "corta y pega" es el siguiente. Toma los dieciséis primeros compases del Kyrie literalmente transportados una cuarta según nuestra transcripción, añade cinco y pega otros catorce de Mudarra (cc. 51-64). A continuación coloca el Tiento 3 completo, pero transportado una segunda con relación a nuestra transcripción y termina la obra.

Estas tres piezas del modo III se pueden considerar perfectamente como una obra en tres partes, pues no solo comparten el tono o modo, sino que están ligadas temáticamente, de forma que en la fantasía Mudarra usa tanto temas o motivos del Kyrie como del tiento. No es común esta unidad temática en el repertorio de vihuela.

\section{4- Tiento 4}

Tiento. IV modo. Posición f (vihuela en Fa\#). 4 voces. Tempo rápido. Notas móviles: Sol ต (II), La ต (III), Re ต (VI).

\section{NOTAS CRÍTICAS}

1. c. 21. Añadimos la mínima que figura entre corchetes.

\section{ESTRUCTURA}

$\begin{array}{ccccc}\text { Secciones } & \text { Compases } & \text { Cadencia final } & \text { Longitud } & \text { Textura } \\ 1 & 1-7 & \text { iv } & 7 \mathrm{cc} . & \text { Homofónica }\end{array}$

${ }^{783}$ Venegas de Henestrosa. Libro de cifra nueva..., f. 36. Transcripción en ANGLÉs, H. La Música en la Corte de Carlos V..., vol. 2, p. 85, como Fantasía VI de vibuela. 


$\begin{array}{lcccc}2 & 8-15 & \text { I } & 8 \mathrm{cc} . & \text { No imitativa } \\ 3 & 16-23 & \text { I } & 8 \mathrm{cc} . & \text { No imitativa }\end{array}$

\section{ANÁLISIS}

Sección 1: casi homofónica a cuatro voces, con movimiento de la voz aguda delimitando claramente su ámbito superior (una quinta más la nota de licencia). Oscila entre el iv y el i grado.

Sección 2: la textura pasa a tres voces con movimientos más continuados. Finaliza con cadencia frigia sobre el I grado.

Sección 3: coda plagal a cuatro voces en la que alcanza las posiciones más agudas del instrumento para volver a realizar una cadencia frigia.

\section{5- Fantasía 20}

Fantasía. IV modo. Posición $\mathrm{f}$ (vihuela en Fa\#). 4 voces. Tempo medio. Notas móviles: Sol Ł (II), La ' (III), Dob (V), Re

\section{NOTAS CRÍTICAS}

1. c. 27 . Ponemos 0 en $4^{\circ}$ orden en lugar de en $3^{\circ}$ orden.

\section{ESTRUCTURA}

$\begin{array}{ccccc}\text { Secciones } & \text { Compases } & \text { Cadencia final } & \text { Longitud } & \text { Textura } \\ 1 & 1-28 & \text { iv } & 28 \mathrm{cc} . & \text { Imitativa } \\ 2 & 29-56 & \text { iv } & 28 \mathrm{cc} . & \text { Imitativa } \\ 3 & 57-87 & \text { I } & 31 \mathrm{cc} . & \text { Imitativa politemática }\end{array}$

\section{ANÁLISIS}

Sección 1: comienzo homofónico a cuatro voces afirmándose los acordes de I y iv grado. A partir del c. 8 se inicia un sencillo motivo de cuatro notas (una nota y sus inmediatas superior en inferior) que se va a convertir en el tema o lema de toda la sección. 
Surge en el soprano, pasa a contralto y luego al tenor. Entre medias se van intercalando cadencias sobre el iv grado en una textura permanente a dos y tres voces.

Sección 2: un nuevo motivo, también breve, basado en una nota repetida y derivado del anterior provoca varias apoyaturas. Continúa en polifonía libre a tres y cuatro voces hasta una cadencia sobre el III grado (cc. 40-41), a partir de la cual el movimiento de las voces se anima concluyendo en una rotunda cadencia, primero frigia sobre el I grado y luego tres veces sobre el iv (cc. 45-51). Una coda de seis compases a dos voces nos lleva a una cadencia sobre el $¥$ grado

Sección 3: nuevo motivo en el soprano que es respondido en el contralto con una variante. Desemboca en una progresión (cc. 65-77) en la que se modifica la cabeza del motivo en las respuestas sucesivas, manteniéndose en los antecedentes. Se llega a la parte aguda del instrumento con un par de notas (f " y e") fuera del ámbito modal, también extraña la presencia del Do $b$, nota también ajena al modo. De nuevo una cadencia frigia nos lleva al acorde del I grado.

\section{COMENTARIO}

Venegas incluye esta pieza como Primera fantesía del quarto tono. ${ }^{784}$ De nuevo es una transcripción literal con ligeras variantes (por ejemplo cambia el c. 49 y ornamenta el c. $50)$.

\section{6- Benedictus}

Glosado. IV modo. Posición f (vihuela en Fa\#). 4 voces. Tempo rápido. Notas móviles: Sol ฤ (II), La ' (III), Dob (V), Re

\section{NOTAS CRÍTICAS}

1. c. 58.6 en $1^{\circ}$ orden invertido.

\footnotetext{
${ }^{784}$ Venegas De HeneStrosa. Libro de cifra nueva..., ff. 36v-37. Transcripción en ANGLÉs, H. La Música en la Corte de Carlos V..., vol. 2, pp. 86-87, como Fantasía VII de vihuela.
} 


\section{INTRODUCCIÓN}

El tercero de los glosados de Mudarra está basado en el Benedictus de la Missa La sol fa re $m i$ de Josquin. ${ }^{785}$ Los Benedictus fueron muy apreciados por los vihuelistas, pues suelen ser piezas a dos o tres voces. ${ }^{786}$ Esta de Mudarra es una obra mucho más breve que los anteriores glosados y en tiempo rápido.

\section{ESTRUCTURA}

$\begin{array}{ccccc}\text { Secciones } & \text { Compases } & \text { Cadencia final } & \text { Longitud } & \text { Tipo } \\ 1 & 1-20 & \text { I } & 20 \mathrm{cc} . & \text { Glosa } \\ 2 & 21-32 & \text { iv } & 12 \mathrm{cc} . & \text { Josquin } \\ 3 & 33-40 & \text { iv } & 8 \mathrm{cc} . & \text { Glosa } \\ 4 & 41-69 & \text { I } & 29 \mathrm{cc} . & \text { Josquin }\end{array}$

\section{ANÁLISIS}

Mudarra divide la pieza en dos partes desiguales, tomando seis breves para la primera y dieciséis para la segunda.

Sección 1: como ya hizo en los glosados anteriores, Mudarra toma el tema inicial y construye un episodio imitativo a dos voces sobre él, añadiendo un contramotivo. El motivo se expone cuatro veces a diferentes alturas.

Sección 2: se corresponde literalmente con las seis primeras breves de Josquin, añadiendo únicamente unas ligeras glosas al final.

Sección 3: brevísima glosa sobre el tema de Josquin levemente transformado.

Sección 4: también literal con el original de Josquin con un breve añadido plagal en los últimos compases.

\footnotetext{
${ }^{785}$ Tomamos el original de Josquin de Liber primus Missarum Josquin. Fossombrone, Ottaviano Petrucci, 1502 y de la edición SMIJERS (ed.) Missa La sol fa re mi. Vol. 11. Missen II Amsterdam, G. Alsbach \& Co., 1926.

${ }^{786}$ Valderrábano incluye dos Benedictus (f. 2 y 86v), Pisador cinco (ff. 35, 40, 44, 52, y 56), Fuenllana cuatro (f. 7, 40v, 55 y 108). Griffiths analiza varios de ellos en GRIFFITHS, J. Tañer vibuela...
} 


\section{7- Tiento 5}

Tiento. V modo. Posición G (vihuela en Fa). 4 voces. Tempo rápido. Notas móviles: Sol\# (I), Do

\section{ESTRUCTURA}

$\begin{array}{ccccc}\text { Secciones } & \text { Compases } & \text { Cadencia final } & \text { Longitud } & \text { Textura } \\ 1 & 1-28 & \text { I } & 28 \mathrm{cc} . & \text { Imitativa monotemática } \\ 2 & 29-40 & \text { I } & 12 \mathrm{cc} . & \text { No imitativa }\end{array}$

\section{ANÁLISIS}

Sección 1: este tiento está basado en el tema que veíamos en la Fantasía 15 y que parecía asociado al primer y segundo modo. Comienza el motivo en el tenor, mientras el resto de las voces lo acompañan, responde contralto. Cadencia tonal en el I grado (cc 910) exponiéndose el tema en soprano con una modificación en la cabeza, en lugar de alcanzar la quinta por grados conjuntos lo hace por salto, pero el descenso es el mismo. Cadencia modal sobre el V grado, aparece el tema de nuevo en contralto. Cadencia sobre el ii grado con Sol\# y nueva entrada con una nueva mutación en la cabeza, en lugar de una quinta, ahora es una sexta de salto (c. 21). Llama la atención que el ámbito del soprano pertenece más bien al sexto modo que al quinto. Nuevas cadencias hasta llegar al I grado.

Sección 2: polifonía libre y estrecho sobre la cabeza del tema inicial para concluir con cadencia tonal sobre el I grado.

\section{8- Fantasía 21}

Fantasía. V modo. Posición G (vihuela en Fa). 4 voces. Tempo medio. Notas móviles: Sol\# (I), Do Ł (IV), Fa Ł (VII).

\section{NOTAS CRÍTICAS}

1. c. 48. Añadimos la semimínima que figura entre corchetes. 
2. c. 53. Añadimos la mínima que figura entre corchetes.

\section{ESTRUCTURA}

$\begin{array}{ccccc}\text { Secciones } & \text { Compases } & \text { Cadencia final } & \text { Longitud } & \text { Textura } \\ 1 & 1-27 & \text { I } & 27 \mathrm{cc} . & \text { Imitativa politemática } \\ 2 & 28-45 & \text { I } & 18 \mathrm{cc} . & \text { Imitativa } \\ 3 & 57-87 & \text { I } & 18 \mathrm{cc} . & \text { Imitativa }\end{array}$

\section{ANÁLISIS}

Sección 1: comienzo muy similar al del tiento anterior, con un motivo derivado que se expone en tenor $\mathrm{y}$ en soprano, mientras que el resto de las voces acompañan homofónicamente, polifonía libre y cadencia modal sobre el V grado (cc. 12-13). De cuatro o tres voces pasamos a dos con un gesto ascendente de segunda, al que no podemos llamar ni siquiera motivo, que va pasando por todas las voces generando una textura transparente y estática, matizada por alguna cadencia intermedia, que va acumulando voces hasta una cadencia tonal sobre el I grado.

Seccción 2: nuevo tema ascendente en soprano respondido por el contralto. Unas décimas paralelas nos llevan a la nota más aguda, para la que ni siquiera hay traste según recomienda Mudarra, el «traste» 11. Una cadencia modal nos deja en el I grado.

Sección 3: un nuevo tema ascendente con semínima con puntillo en bajo y soprano, polifonía libre y cadencia modal sobre el I grado. Pasaje cadencial en décimas paralelas y cadencia tonal final sobre el I grado.

\section{COMENTARIO}

Venegas también incluye esta pieza como Segunda fantesía del quinto tono. ${ }^{787}$ Los primeros compases son iguales (cc. 1-18), se salta siete compases y vuelve a retomar desde el c. 25 de Mudarra hasta el c. 39 donde se salta otros dos compases (cc. 40-41). Retoma el c. 42 de Mudarra hasta el c. 59, se salta el c. 60. A continuación le pega el Tiento 5 desde el principio, cambia los cc. 19-20 y continúa con su copia de los cc. 21-40 de Mudarra.

\footnotetext{
${ }^{787}$ Venegas de Henestrosa. Libro de cifra nueva..., f. 38. Transcripción en AnglÉs, H. La Música en la Corte de Carlos V..., vol. 2, pp. 92-93, como Fantasía XI de vihuela.
} 


\section{9- Fantasía 22}

Fantasía. V modo. Posición G (vihuela en Fa). 4 voces. Tempo rápido. Notas móviles: Sol\# (I), Do

\section{ESTRUCTURA}

$\begin{array}{ccccc}\text { Secciones } & \text { Compases } & \text { Cadencia final } & \text { Longitud } & \text { Textura } \\ 1 & 1-49 & \text { I } & 49 \mathrm{cc} . & \text { Imitativa politemática } \\ 2 & 50-106 & \text { I } & 57 \mathrm{cc} . & \text { Imitativa politemática }\end{array}$

\section{ANÁLISIS}

Sección 1: de nuevo el tema ascendente en este caso de ámbito de una octava en lugar de una quinta. Se expone en el bajo siendo respondido por el soprano con una falsa entrada y por el contralto, mientras el tenor hace un contramotivo. De nuevo entrada en el bajo con contramotivo en tenor. Cadencia sobre el $\mathrm{V}$ grado. El tema inicial por movimiento contrario con ligeras variaciones en soprano y bajo, pasaje homofónico y cadencia modal sobre el I grado. Un motivo ascendente de cuatro notas en mínimas alterna con la cabeza del tema inicial. Largo episodio de redobles en corcheas y cadencia modal en I grado.

Sección 2: Mudarra toma el motivo de la Fantasía 20 del cuarto tono y lo reutiliza en esta sección de la misma manera, con una textura a dos o tres voces y pasando continuamente de una voz a otra e incluso en décimas paralelas. Tras una cadencia tonal sobre el I grado, une este pequeño motivo con las cuatro mínimas ascendentes para fabricarse un nuevo tema, con el que juega en bicinium en contrapunto invertible y a tres voces hasta llegar a una nueva cadencia sobre el I grado. A partir de aquí, el movimiento perpetuo de semimínimas ya casi no abandona la obra, hasta llegar a una cadencia completa (modal y tonal) sobre el I grado. 


\section{COMENTARIO}

Venegas incluye esta pieza como Primera fantesía del quinto tono. ${ }^{788}$ Toma desde el c. 1, pero omite la entrada del soprano de los cc. 4-5. En los cc. 20-21 (el c. 20 es anómalo en Mudarra) añade unas sextas por encima. En el c. 21 se inventa una entrada en el tiple y continúa hasta el c. 91 donde corta, cadencia y termina.

Una vez más, Mudarra consigue una gran unidad a base de reutilizar temas escuchados anteriormente, utilizar el mismo modo y además enlazar tres piezas rápido-lento-rápido, como ha ido haciendo en casi todos los modos (únicamente el tercer modo concluye con una pieza lenta). Es indudable el deseo del autor de que las piezas se interpreten una a continuación de otra, diferenciándose de lo que ocurre con las series de danzas italianas pavana, saltarello y piva, intercalando una o dos piezas lentas entre dos más rápidas, lo cual será común desde el siglo siguiente.

\section{0- Tiento 6}

Tiento. VI modo. Posición A b (vihuela en Mi). 4 voces. Tempo rápido. Notas móviles: La $\vdash$ (I), Re b (IV), Sol b (VII).

\section{ESTRUCTURA}

$\begin{array}{ccccc}\text { Secciones } & \text { Compases } & \text { Cadencia final } & \text { Longitud } & \text { Textura } \\ 1 & 1-15 & \text { I } & 15 \mathrm{cc} . & \text { Imitativa monotemática } \\ 2 & 16-30 & \text { I } & 15 \mathrm{cc} . & \text { Imitativa monotemática }\end{array}$

\section{ANÁLISIS}

Sección 1: comienzo homofónico y un tema ascendente desde el c. 3 en soprano que cadencia en el iii grado (la dominante del VI modo). Responde el motivo ascendente

${ }^{788}$ Venegas de Henestrosa. Libro de cifra nueva..., ff. 37v-38. Transcripción en ANGLÉs, H. La Música en la Corte de Carlos V..., vol. 2, p. 91, como Fantasía X de vihuela. 
modificado en el contralto, cadenciando en el V grado. Nueva variante en soprano y cadencia sobre el I grado.

Sección 2: similar al inicio, pero ahora el tema se presenta sobre el I grado en soprano, cadenciando primero sobre el V grado, después en el bajo para cadenciar en el I grado, cerrando con unos redobles de dos octavas.

\section{1- Fantasía 23}

Fantasía. VI modo. Posición A b (vihuela en Mi). 4 voces. Tempo medio. Notas móviles: La $\natural$ (I), Re b (IV), Mi $\nleftarrow$ (V), Sol b (VII).

\section{NOTAS CRÍTICAS}

1. c. 23. Añadimos la semimínima que figura entre corchetes.

\section{ESTRUCTURA}

$\begin{array}{ccccc}\text { Secciones } & \text { Compases } & \text { Cadencia final } & \text { Longitud } & \text { Textura } \\ 1 & 1-41 & \text { I } & 41 \mathrm{cc} . & \text { Imitativa politemática } \\ 2 & 42-67 & \text { I } & 26 \mathrm{cc} . & \text { No imitativa }\end{array}$

\section{ANÁLISIS}

Sección 1: comienzo en polifonía libre a tres voces hasta llegar a una cadencia modal sobre el I grado (c. 10-11) donde vuelve a aparecer un motivo del primer compás. Una cadencia modal nos lleva al iii grado con un nuevo (o el primero realmente) tema en el soprano, que es respondido en el tenor cadenciando de nuevo en iii grado (cc. 22-23). Pasaje en polifonía libre que se va acelerando hasta una progresión de dos compases (cc. 30-31) y una cadencia sobre el I grado, donde un motivo usado cinco compases antes se convierte en el motor de una progresión que nos deja en el I grado.

Sección 2: nuevo motivo a dos voces que cadencia en el ii grado donde va a permanecer estático durante seis compases, con la única interrupción de un ii grado. En los siguientes seis compases (cc. 52-58) el movimiento armónico también es escaso. 
Durante toda esta sección el bajo se comporta como un cantus firmus. Los últimos ocho compases son completamente homofónicos.

\section{COMENTARIO}

Venegas incluye esta pieza como Segunda fantasía del sexto tono. ${ }^{789}$ Literal desde el c. 1 hasta el final de la obra de Mudarra. Superpone el último compás de la fantasía de Mudarra con el Tiento 6 que añade literalmente hasta el final. Mismo procedimiento que ya había usado en anteriores ocasiones.

Griffiths analiza esta fantasía clasificándola entre las no imitativas dividiéndola en tres secciones en lugar de en dos. ${ }^{790}$

\section{2- Kyrie 3}

Glosado. VI modo. Posición A b (vihuela en Mi). 4 voces. Tempo rápido. Notas móviles: La

\section{NOTAS CRÍTICAS}

1. c. 23. Añadimos la mínima que figura entre corchetes.

2. c. 30. desplazamos el texto "févin" un compás antes por estar mal situado.

3. c. 44. Añadimos la mínima que figura entre corchetes.

4. c. 45 . Añadimos la semimínima que figura entre corchetes.

5. c. 58. Añadimos el texto que figura entre corchetes.

6. c. 74. Añadimos el texto que figura entre corchetes.

\section{INTRODUCCIÓN}

El cuarto de los glosados de Mudarra está sacado de el Kyrie de la Missa Ave Maria de Antonie de Févin ${ }^{791}$, la cual a su vez está basada en el Ave María ... virgo serena de Josquin.

${ }^{789}$ Venegas de Henestrosa. Libro de cifra nueva..., ff. 40 (erróneamente foliado como f. 29). Transcripción en ANGLÉs, H. La Música en la Corte de Carlos V..., vol. 2, pp. 98-99, como Fantasía XIV de vibuela.

${ }^{790}$ GrifFITHS, J. The Vihuela Fantasia..., pp. 208-211.

${ }^{791}$ Tomamos el original de Févin de Liber quindecim missarum... 


\section{ESTRUCTURA}

$\begin{array}{ccccc}\text { Secciones } & \text { Compases } & \text { Cadencia final } & \text { Longitud } & \text { Tipo } \\ 1 & 1-29 & \text { V } & 29 \mathrm{cc} . & \text { Glosa } \\ 2 & 30-56 & \text { I } & 27 \mathrm{cc} . & \text { Févin } \\ 3 & 57-73 & \text { I } & 17 \mathrm{cc} . & \text { Glosa } \\ 4 & 74-87 & \text { iii } & 14 \mathrm{cc} . & \text { Févin } \\ 5 & 88-102 & \text { iii } & 15 \mathrm{cc} . & \text { Glosa } \\ 6 & 103-114 & \text { I } & 12 \mathrm{cc} & \text { Févin } \\ 7 & 115-127 & \text { I } & 13 \mathrm{cc} . & \text { Glosa } \\ 8 & 128-141 & \text { I } & 14 \mathrm{cc} . & \text { Févin }\end{array}$

ANÁLISIS

Sección 1: Mudarra toma la cabeza del tema de Josquin/Févin y realiza un episodio imitativo con entradas en soprano con respuesta en contralto a la quinta inferior. Se suma el tenor a la altura inicial, con una cadencia tonal sobre el I grado (cc. 12-13). Calla el contralto y entra el bajo de nuevo quinta inferior. Mediante polifonía libre a tres voces se llega al V grado.

Sección 2: como ocurría con el Kyrie 2, Mudarra utiliza el principio de la obra que emula, pero añade glosas continuamente para rellenar los compases. Utiliza las catorce breves primeras de Févin. 

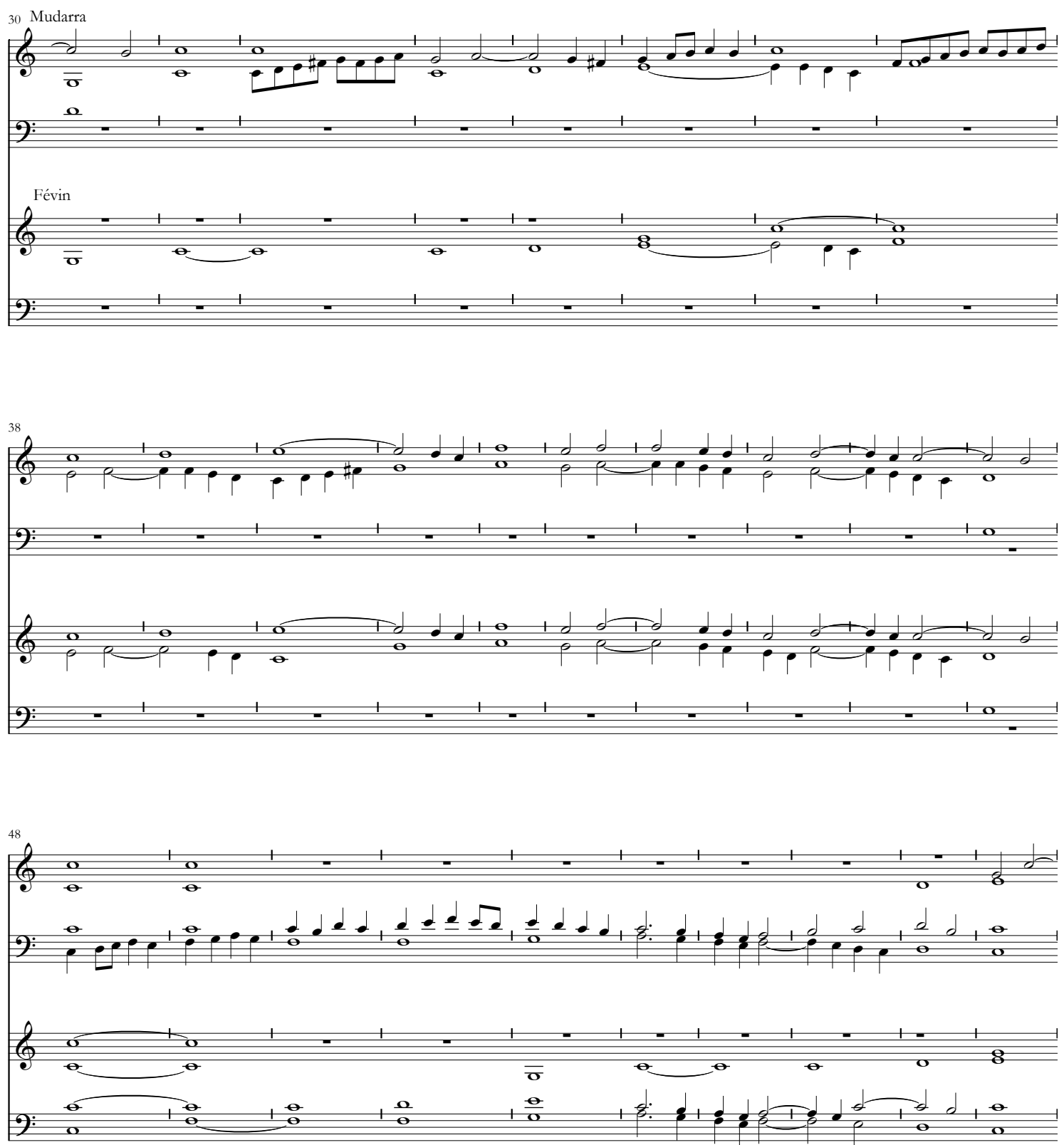

Ejemplo 17. Sección 2 del Kyrie 3 de Mudarra, comparación con Févin (cc. 30-56)

Sección 3: aunque no está indicado en la tablatura, uno más de los errores tipográficos de la obra de Mudarra, comienza una nueva sección de glosa basada en motivos relacionados con lo escuchado hasta ahora. Podríamos hablar de una melodía acompañada, ya que únicamente el soprano lleva un motivo, que en realidad recuerda mucho el perfil del tema original, pero glosado. El resto de las voces definen unos acordes, principalmente de iii grado (dominante modal, como decíamos antes) hasta llegar 
a un pasaje más movido sobre el $\mathrm{V}$ grado que concluye en cadencia modal sobre el iii grado y pasar de golpe al I grado.

Sección 4: al igual que en la sección anterior, falta la indicación de nueva parte. Obviamente otro error. Toma las siete breves siguientes aunque en este caso no añade glosas excepto en la cadencia final de sección, es totalmente fiel al original.

Sección 5: de nuevo glosado. Mudarra construye un dúo con las voces superiores que va descendiendo continuamente. En realidad está construyendo un antecedente del dúo de Févin que viene a continuación.

Sección 6: literal con el original y como decíamos antes, dúo entre bajo y contralto primero y bajo y tenor a continuación.

Sección 7: glosado que se anticipa al fragmento que viene después. Mudarra elige el motivo del contralto y fabrica un episodio en estrecho sobre la misma nota, a diferentes octavas, a tres voces consiguiendo, además, mayor incremento de la tensión al ir subiendo hacia la zona aguda.

Sección 8: de nuevo literal sobre las nueve últimas breves de Févin, sonando como perfecto consecuente de la glosa elaborada por Mudarra.

\section{ANÁLISIS}

Después de la Fantasía 10, es la obra más larga de las hasta ahora vista. Pensamos también que se trata de una obra magistral y de gran belleza. Para su elaboración toma la pieza de Févin y la trocea en cuatro fragmentos ${ }^{792}$ a los que antecede comentarios que exceden muchas veces técnicamente al original.

Podríamos aventurar la hipótesis de que esta gran obra, en la que el tema de Josquin está continuamente presente, pudiera tener un significado alegórico o metafórico. Ya veíamos que en el escudo de la familia Mendoza figuraba el lema de la salutación angélica Ave Maria, gratia plena desde la época del almirante don Diego Hurtado de Mendoza. Esta divisa familiar omnipresente era, por supuesto, conocida por Mudarra quien creemos que debió escribir la mayoría de sus obras durante su larga estancia en el palacio del Infantado.

\footnotetext{
${ }^{792}$ La profesora Lawrence realiza un análisis muy superficial y no se percata de que el número de secciones es mayor de lo que aparentemente indica Mudarra. LAWRENCE, Deborah. «Mudarra's Instrumental Glosas...
} 
No sería de extrañar que la melodía de Josquin, tan conocida en su época, fuera usada en el palacio de los Mendoza con un significado simbólico y que Mudarra quisiera halagar a sus patronos con estas glosas sobre una parodia del famoso motete.

\section{3- Tiento 7}

Tiento. VII modo. Posición F (vihuela en A). 4 voces. Tempo rápido. Notas móviles: Fa\# (I), La b (III), Si ต (IV), Mi ต (VII).

\section{NOTAS CRÍTICAS}

1. c. 13. Añadimos la mínima que figura entre corchetes.

\section{ESTRUCTURA}

$\begin{array}{ccccc}\text { Secciones } & \text { Compases } & \text { Cadencia final } & \text { Longitud } & \text { Textura } \\ 1 & 1-14 & \text { I } & 14 \mathrm{cc} . & \text { Homofónica } \\ 2 & 15-29 & \text { I } & 15 \mathrm{cc} . & \text { Homofónica }\end{array}$

\section{ANÁLISIS}

Sección 1: tras una afirmación de los grados I y IV, enseguida se presenta una cadencia sobre el ii grado (incluso con el I grado alterado), pero a continuación se dirige al I grado que asienta con una cadencia tonal con retardo. Este fragmento presenta una estructura paralela: los seis primeros compases (cc. 1-6) son gemelos de los seis últimos de la sección (cc. 9-14), estando unidos por una línea melódica cadencial de dos compases.

Sección 2: similar a la anterior, incluso si contamos el c. 14 hay paralelismo casi total en la estructura rítmica inicial y en la melodía superior. Se le da gran importancia al ii grado al que se llega mediante una cadencia frigia con el III grado rebajado. Tras esto, se vuelve al V grado que cadencia en $¥$ grado. 


\section{4- Fantasía 24}

Fantasía. VII modo. Posición F (vihuela en A). 4 voces. Tempo rápido. Notas móviles: Fa\# (I), La b (III), Si ต (IV), Mi ต (VII).

\section{NOTAS CRÍTICAS}

1. c. 15. Añadimos la semimínima que figura entre corchetes.

2. c. 16. Añadimos la mínima que figura entre corchetes.

3. c. 19. Añadimos la mínima que figura entre corchetes.

\section{ESTRUCTURA}

$\begin{array}{ccccc}\text { Secciones } & \text { Compases } & \text { Cadencia final } & \text { Longitud } & \text { Textura } \\ 1 & 1-24 & \mathrm{~V} & 24 \mathrm{cc} . & \text { Imitativa } \\ 2 & 25-44 & \text { IV } & 20 \mathrm{cc} . & \text { Imitativa } \\ 3 & 45-67 & \mathrm{I} & 23 \mathrm{cc} . & \text { Imitativa } \\ 4 & 68-86 & \mathrm{I} & 19 \mathrm{cc} . & \text { Imitativa }\end{array}$

\section{ANÁLISIS}

Sección 1: una melodía de amplio vuelo, una novena de ámbito y seis compases de duración, se expone en el contralto mientras el soprano le acompaña con notas tenidas. Es respondido por el tenor una cuarta por debajo y después por el bajo otra cuarta baja (sobre el ii grado). Un fragmento modulante en el registro agudo nos conduce a una cadencia modal sobre el V grado.

Sección 2: comienza un nuevo tema en el soprano acompañado por el contralto en dúo. Tras una cadencia sobre el VI grado vuelve el soprano con el bajo con el mismo motivo, aunque enseguida lo abandona concluyendo en un episodio de redobles a dos voces y una cadencia sobre el IV grado.

Sección 3: polifonía libre con alusiones a la cabeza del motivo inicial. Llegamos a una cadencia tonal sobre el I grado donde comienza otro episodio de redobles hasta una nueva cadencia sobre el I grado.

Sección 4: nuevo motivo en soprano y después en bajo en dúo con el tenor. El motivo se repite varias veces en el bajo hasta alcanzar la cadencia final plagal sobre el I grado. 


\section{COMENTARIO}

Venegas incluye esta pieza como Segunda fantasía del séptimo tono. ${ }^{793}$ Omite los siete primeros compases de Mudarra y continúa literal desde el c. 8 hasta el final de la obra original. Superpone el último compás de la fantasía de Mudarra con el Tiento 7 que añade literalmente hasta el final. Mismo procedimiento que ya había usado en anteriores ocasiones.

\section{5- Cum sancto spiritu}

Glosado. VII modo. Posición F (vihuela en A). 4 voces. Tempo rápido. Notas móviles: Fa\# (I), La b (III), Si ‡ (IV), Mi Ł (VII).

\section{NOTAS CRÍTICAS}

1. c. 40. Añadimos la mínima que figura entre corchetes.

2. c. 52. Añadimos la semimínima que figura entre corchetes.

\section{INTRODUCCIÓN}

El quinto y último de los glosados de Mudarra está sacado del Cum sancto spiritu del Gloria de la Missa de Beata Virgine de Josquin ${ }^{794}$, de la que ya había utilizado el Kyrie.

\section{ESTRUCTURA}

$\begin{array}{ccccc}\text { Secciones } & \text { Compases } & \text { Cadencia final } & \text { Longitud } & \text { Tipo } \\ 1 & 1-15 & \text { VI } & 15 \mathrm{cc} . & \text { Glosa } \\ 2 & 16-33 & \text { I } & 18 \mathrm{cc} . & \text { Josquin } \\ 3 & 34-54 & \text { I } & 21 \mathrm{cc} . & \text { Glosa } \\ 4 & 55-78 & \text { V } & 24 \mathrm{cc} . & \text { Josquin } \\ 5 & 79-87 & \text { V } & 9 \mathrm{cc} . & \text { Glosa } \\ 6 & 88-124 & \text { I } & 37 \mathrm{cc} & \text { Josquin }\end{array}$

\footnotetext{
${ }^{793}$ Venegas de Henestrosa. Libro de cifra nueva..., ff. 41v-42. Transcripción en ANGLÉs, H. La Música en la Corte de Carlos V..., vol. 2, pp. 103-104, como Fantasía XVI de vibuela.

${ }^{794}$ Tomamos el original de Missarum Josquin liber tertius... y Liber quindecim missarum... y de la edición Josquin des Prés. Missa de Beata virgine. Das Chorwerk 42, Wolfenbüttel, Möseler Verlag, 1936.
} 


\section{ANÁLISIS}

Sección 1: Mudarra vuelve a utilizar la misma técnica que ya usó en el Kyrie 1, toma el motivo inicial de Josquin y le añade una voz o contramotivo que va glosando. Comienza con un bicinium entre contralto y soprano y entre bajo y tenor. Soprano y tenor se ocupan del tema de Josquin y contralto y bajo del contramotivo.

Sección 2: con excepción de una glosa cadencial en el punto de enlace, el resto es literal con el original de Josquin.

Sección 3: se trata de una glosa sobre la cabeza del motivo inicial, prácticamente irreconocible, primero en dúo en las voces superiores, luego a tres voces y vuelta al dúo en las inferiores.

Sección 4: al principio literal, aunque Mudarra adelanta una nota con respecto al original (por lo que añadimos un compás en el ejemplo), pero pasados doce compases comienza a introducir glosas que enlazan perfectamente con la siguiente sección. 

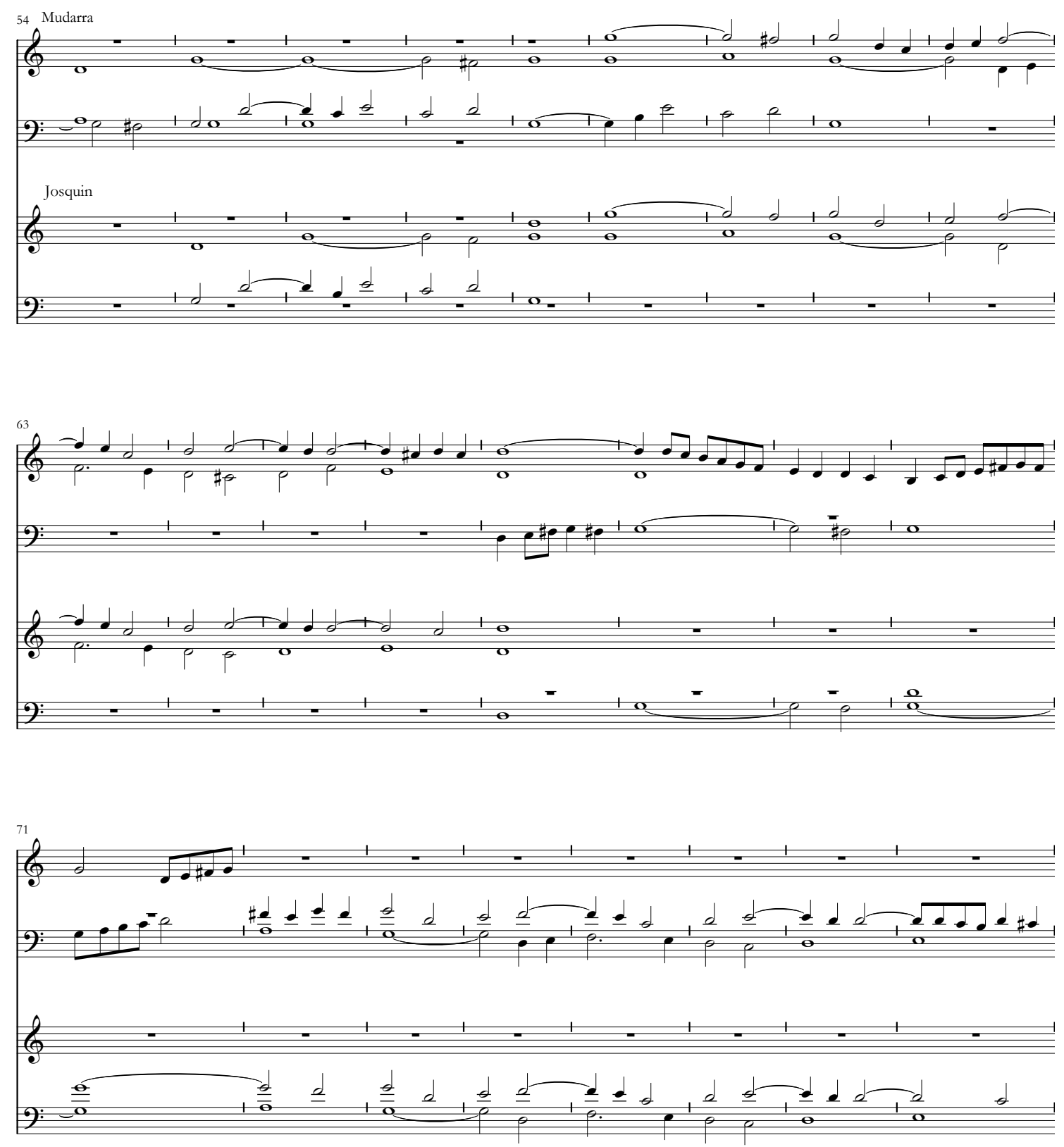

Ejemplo 18. Sección 4 del Cum sancto spiritu de Mudarra, comparación con Josquin (cc. 54-78)

Sección 5: un inocente motivo surgido en el c. 48 genera un tema que construye esta sección. Primero en el tenor que es respondido por contralto y por soprano.

Sección 6: la gran actividad rítmica provocada no se puede detener de golpe, por lo que Mudarra ornamenta profusamente los quince primeros compases de esta sección, para luego dejar el original de Josquin, con muy pocas modificaciones, hasta el final. Incluimos la comparación solamente de la primera parte más ornamentada. 

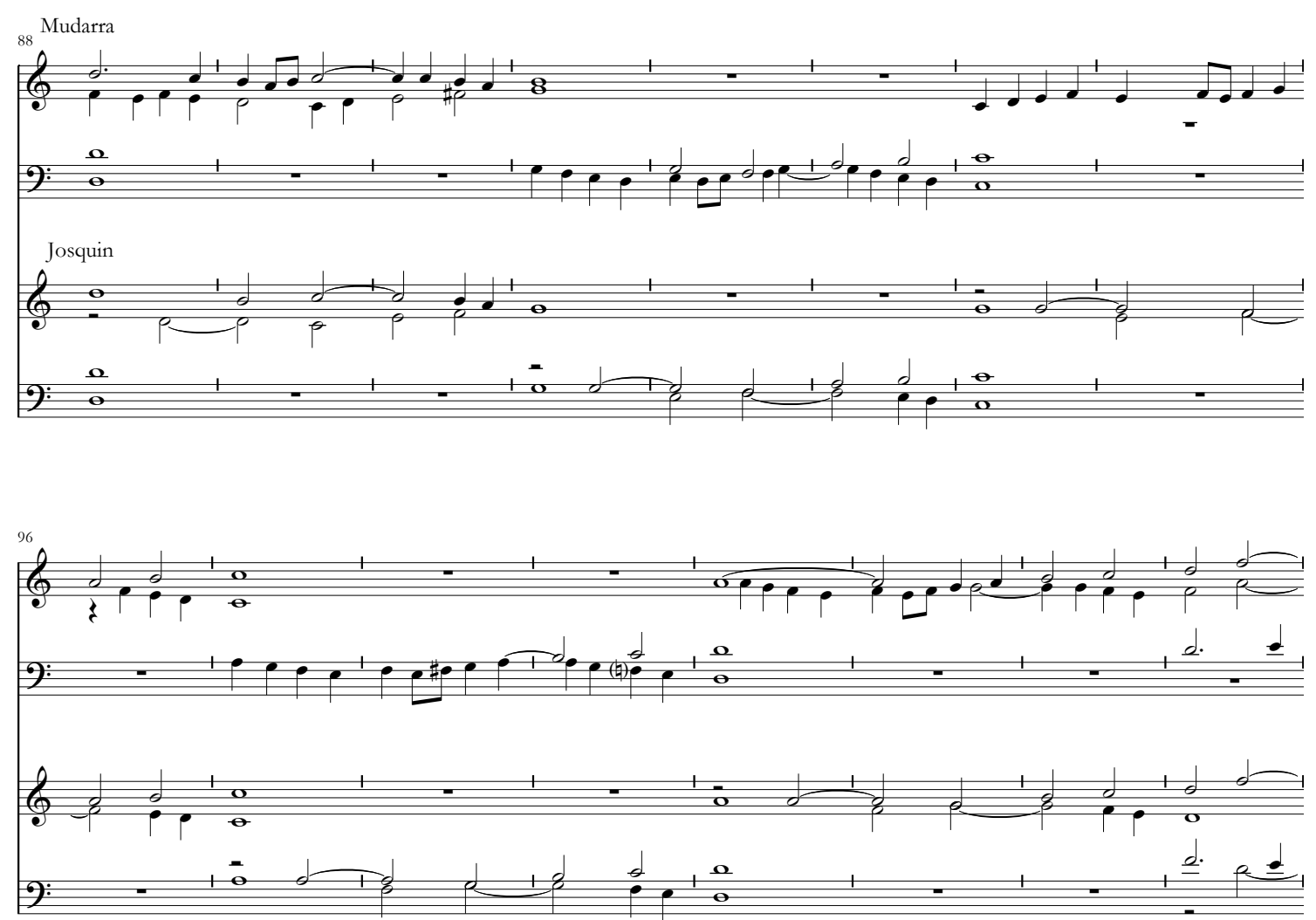

Ejemplo 19. Primera parte de la Sección 6 del Cum sancto spiritu de Mudarra, comparación con Josquin (cc. 88-103)

\section{Comentario}

Esta pieza de Josquin fue una de las más intabuladas tanto para vihuela o laúd, como para tecla. ${ }^{795}$ Además de Mudarra, Valderrábano ${ }^{796}$ y Pisador $^{797}$ la incluyeron, sin apenas cambios en sus libros. Cabezón también la incluye, pero con profusión de glosas. ${ }^{798}$ Fuera de nuestras fronteras: Newsidler, Ochsenkhun y Phalèse. ${ }^{799}$

${ }^{795}$ Una relación de intabulaciones y un análisis de la misma en WARD, John. «The Use of Borrowed Material in 16th-Century Instrumental Music». Journal of the American Musicological Society, 5/2, (Summer 1952), pp. 88-98.

${ }^{796}$ VALDERRÁBANO. Silva de sirenas, f. 85.

${ }^{797}$ PISADOR. Libro de música de vihuela, f. $70 \mathrm{v}$.

${ }^{798}$ CABEZÓn. Obras, ff. 103-104. Hay transcripción moderna en Antonio de Cabezón (*1510c; †1566) Obras..., vol. III, pp. 139-143.

${ }^{799}$ Ver WARD, J. «The Use of Borrowed..., p. 90. 


\section{6- Tiento 8}

Tiento. VIII modo. Posición G (vihuela en G). 4 voces. Tempo rápido. Notas móviles: Fa\# (VII).

\section{ESTRUCTURA}

$\begin{array}{ccccc}\text { Secciones } & \text { Compases } & \text { Cadencia final } & \text { Longitud } & \text { Textura } \\ 1 & 1-10 & \text { I } & 10 \mathrm{cc} . & \text { No imitativa } \\ 2 & 11-24 & \text { I } & 14 \mathrm{cc} . & \text { Imitativa }\end{array}$

\section{ANÁLISIS}

Sección 1: en los seis primeros compases se afirma un acorde de IV grado, de forma que casi parecería que estamos en un Do mayor. ${ }^{800}$ A partir del c. 7 se hace notar la tónica modal con la presencia del VII grado alterado y cadencia tonal sobre el I grado.

Sección 2: se enuncia en el tenor el motivo preferido por Mudarra, usado recientemente en las obras de VII modo, en dúo con el bajo. Desde el c. 16 la pieza funciona a cuatro voces cadenciando en I grado y seguido de una coda plagal donde aparece el motivo citado en el soprano.

Si consideramos la coda aparte, la estructura sería: 10 cc. +10 cc. +4 cc.

\section{7- Fantasía 25}

Fantasía. VIII modo. Posición G (vihuela en G). 4 voces. Tempo medio. Notas móviles: Do\# (IV), Fa\# (VII).

\section{NOTAS CRÍTICAS}

1. c. 53 . Ponemos 6 en $4^{\circ}$ orden en lugar de 5 .

2. c. 81 . Ponemos 6 en $4^{\circ}$ orden en lugar de 7 .

${ }^{800}$ Como decía Chailley el octavo tono se corresponde con un sol mayor "haciendo sentir el tono de do". Chailley, J. L'imbroglio..., p. 83. 


\section{ESTRUCTURA}

$\begin{array}{ccccc}\text { Secciones } & \text { Compases } & \text { Cadencia final } & \text { Longitud } & \text { Textura } \\ 1 & 1-24 & \text { IV } & 24 \mathrm{cc} . & \text { Imitativa politemática } \\ 2 & 25-54 & \text { I } & 30 \mathrm{cc} . & \text { Imitativa } \\ 3 & 55-95 & \text { I } & 41 \mathrm{cc} . & \text { Imitativa politemática }\end{array}$

\section{ANÁLISIS}

Sección 1: comienzo imitativo desde el contralto respondido por soprano, tenor y bajo. Hay ligeras diferencias en el motivo entre una entrada y otra. Cadencia modal sobre el I grado y tonal sobre el IV (cc. 13-15), aunque con dos octavas paralelas (por mucho que intentemos cruzar las voces). Un nuevo motivo en el soprano respondido en contralto. Concluye la sección sobre el IV grado.

Sección 2: un motivo ascendente en el bajo, acompañado por un cantus firmus en el contralto, es respondido por el motivo en contralto en dúo con soprano. Vuelve el dúo, ahora entre tenor y contralto, con modificaciones en el motivo. Tras una cadencia sobre el IV grado (cc. 38-39), las tres voces inferiores marchan homofónicamente en semibreves mientras la voz superior realiza glosas. Cierra la sección una cadencia modal sobre el I grado.

Sección 3: el mismo motivo que abría la sección anterior en estrecho entre tenor y bajo abren este episodio a tres voces, fuertemente polarizado hacia el I grado, con frecuente presencia del VII grado alterado. Se alcanza la nota más aguda y desde aquí utilizando variantes de la cabeza del motivo, también por movimiento contrario, se llega a una cadencia sobre el v grado. En el c. 71 se repiten casi literalmente los cc. 55-58, cambia únicamente la voz superior. Una cadencia sobre el I grado en el c. 75 inicia un episodio fuertemente imitativo sobre el motivo por movimiento contrario, llegando a la zona grave para luego volver a atacar el agudo y con glosas rápidas y décimas paralelas cadenciar sobre I grado. Una coda plagal de siete compases cierra la pieza. 


\section{COMENTARIO}

Venegas incluye esta pieza como Segunda fantesía del octavo tono. ${ }^{801}$ Literal desde el principio, introduce una glosa en el c. 23, añade un compás entre los cc. 32 y 33, elimina notas de los cc. 55-57 de Mudarra, cambia figuraciones rítmicas, elimina glosas de Mudarra y al acabar la pieza, una vez más, añade el tiento correspondiente al modo, el Tiento 8, que añade literalmente hasta el final, aunque olvida un compás, el de la cadencia correspondiente al c. 19, por lo que el final queda un tanto extraño.

\section{8- Fantasía 26}

Fantasía. VIII modo. Posición G (vihuela en G). 4 voces. Tempo rápido. Notas móviles: Fa\# (VII).

\section{NOTAS CRÍTICAS}

1. c. 16. Añadimos la semimínima que figura entre corchetes.

\section{ESTRUCTURA}

$\begin{array}{ccccc}\text { Secciones } & \text { Compases } & \text { Cadencia final } & \text { Longitud } & \text { Textura } \\ 1 & 1-23 & \text { I } & 23 & \text { Imitativa politemática } \\ 2 & 24-42 & \text { IV } & 19 & \text { Imitativa/Idiomática } \\ 3 & 43-58 & \text { I } & 16 & \text { Imitativa } \\ 4 & 59-85 & \text { I } & 27 & \text { Imitativa }\end{array}$

\section{ANÁLISIS}

Sección 1: comienzo en bicinium entre contralto y soprano y tenor y bajo, alcanzando la zona aguda del instrumento. El fragmento se mueve sobre el IV grado donde cadencia en cc. 9-10. En ese punto se inicia un nuevo tema ascendente, el tercero, basado en el ya conocido diseño de mínima con puntillo y semimínima que recorre un intervalo de quinta.

${ }^{801}$ Venegas de Henestrosa. Libro de cifra nueva..., ff. 42v-43. Transcripción en ANGLÉs, H. La Música en la Corte de Carlos V..., vol. 2, pp. 106-108, como Fantasía XVIII de vibuela, quien «corrige» el último acorde para evitar dos octavas y dos quintas paralelas. 
Surge en soprano, responde el bajo dos veces, primero a la octava y luego a la undécima inferior. De nuevo el motivo en soprano y en forma descendente hasta un pasaje con cadencias modales sobre el I grado a diferentes octavas.

Sección 2: pasaje a dos voces con la misma técnica de la Fantasía 4 de pasos de contado, en una voz una especie de cantus firmus mientras que otra se mueve rápidamente en semimínimas. Primero en soprano y contralto y respondido literalmente en tenor y bajo (c. 30), cadenciando siempre en el I grado. Con este mismo impulso contralto y bajo concluyen en una cadencia sobre el IV grado.

Sección 3: se inicia en el bajo un nuevo tema, también ascendente y relacionado con los anteriores, responde soprano a la octava superior y soprano y contralto a la quinta y su octava, respondiendo el bajo a la doble octava y con cadencia tonal sobre el I grado.

Sección 4: un motivo de cuatro notas ya escuchado en otras fantasías (en la Fantasía 20, por ejemplo) se presenta en bicinium en las voces superiores y luego en las inferiores. $\mathrm{Al}$ ser simétrico, muchas veces no se sabe dónde comienza, por lo que genera fragmentos muy direccionales. Se añade una tercera voz y cadencia en I grado. A partir del c. 76 repite literalmente los cc. 69-72. Concluye con un episodio cadencial a cuatro voces sobre el mismo motivo.

\section{COMENTARio}

Venegas incluye esta pieza como Primera fantesía del octavo tono. ${ }^{802}$ Literal desde el principio hasta el final.

${ }^{802}$ Venegas de Henestrosa. Libro de cifra nueva..., f. 42. Transcripción en AngLés, H. La Música en la Corte de Carlos V..., vol. 2, pp. 105-106, como Fantasía XVII de vibuela. Hay un error en el c. 11 de la transcripción. 


\section{9- Fantasía 27}

Fantasía. VIII modo. Posición G (vihuela en G). 4 voces. Tempo rápido. Notas móviles: Fa\# (VII).

\section{NOTAS CRÍTICAS}

1. c. 36 . La semimínima es innecesaria.

\section{ESTRUCTURA}

$\begin{array}{ccccr}\text { Secciones } & \text { Compases } & \text { Cadencia final } & \text { Longitud } & \text { Textura } \\ 1 & 1-27 & \text { I } & 27 & \text { Imitativa } \\ 2 & 28-60 & \text { I } & 33 & \text { Ostinato }\end{array}$

\section{ANÁLISIS}

Sección 1: el motivo fa, mi, fa, re, ut se utiliza temáticamente, no como ostinato. Primero se expone en orden contralto, soprano, bajo y tenor, a continuación en estrecho. Continuamente está presente el IV grado. Concluye la sección sobre un I grado con calderón, cosa nada usual en Mudarra, excepto en danzas y diferencias.

Sección 2: el tema ahora como cantus firmus sobre otra voz en semimínimas, al igual que en la fantasía anterior. Primero soprano y contralto y respuesta casi literal en tenor y bajo. De nuevo en contralto y tenor y así sucesivamente va pasando el ostinato de una voz a otra, animándose en algunos momentos con corcheas

\section{COMENTARio}

Venegas incluye esta pieza como Tercera fantesía del octavo tono. ${ }^{803}$ Como la anterior, literal desde el principio hasta el final.

${ }^{803}$ Venegas de Henestrosa. Libro de cifra nueva..., f. 43. Transcripción en Anglés, H. La Música en la Corte de Carlos V..., vol. 2, p. 109, como Fantasía XIX de vibuela. 


\section{LIBRO III}

El tercer libro de los Tres libros de música en cifra para vihuela lleva el título «Libro tercero de música, en cifras y canto de órgano para tañer y cantar con la Vihuela, en el qual ay Motetes, Psalmos, Romances, Canciones, Sonetos, Versos en latín, Villancicos, como rezan en la tabla que a la buelta desta hoja está».

Este libro está completamente dedicado a la música vocal y contiene veintisiete piezas distribuidas de la siguiente manera:

- 3 motetes

- 3 romances

- 3 canciones

- 3 sonetos en castellano

- 4 versos en latín

- 4 sonetos en italiano

- 5 villancicos

- 2 salmos

Hace más de cuarenta años, el ya fallecido José Manuel Blecua escribía un imprescindible artículo titulado «Mudarra y la poesía del Renacimiento: una lección sencilla». ${ }^{804}$ En él llamaba la atención sobre el carácter de magisterio de la obra de Mudarra para el estudio de la poesía del Renacimiento. Según él, en los Tres libros se contendrían todas las tendencias poéticas que coexistieron en plena mitad del siglo XVI y que explican toda la evolución ulterior de la poesía hispánica. Partimos de un sustrato tradicional, y de gran éxito en las cortes en esa época, representado por los romances y villancicos, de los que Mudarra incluye tres de cada género. A su lado una poesía culta, ejemplificada por las canciones Recuerde el alma dormida, sobre texto de Jorge Manrique y otra de texto anónimo, Sin dudar. La introducción de las formas italianas estaría representada por las obras con

${ }^{804}$ BLECUA, José Manuel. «Mudarra y la poesía del Renacimiento: una lección sencilla». Studia Hispanica in honorem R. Lapesa, I. Madrid, Cátedra Seminario Menéndez Pidal - Gredos, 1972, pp. 173-179. 
texto de Boscán (Claros y frescos ríos) y Garcilaso (Por ásperos caminos) ${ }^{805}$, además de por un soneto elegíaco (¿Qué llantos son aquestos?) y uno amoroso (Si por amar el hombre). Las influencias italianas se manifestarían a traves de los textos de Petrarca (La vita fugge), Sannazaro (O gelosia di amanti e Itene a l'ombra) y el autor anónimo de Lassato a il Tago. Los clásicos también tendrían cabida con la presencia de Virgilio (Dulces exuviae), Horacio (Beatus ille) y Ovidio (Hanc tua, Penelope), además de otro soneto elegíaco, esta vez en latín, Regia qui mesto. Junto a esto, la Biblia también se vería reflejada por los dos salmos que cierran el libro.

No nos podemos sustraer a incluir el esquema que cierra el artículo del profesor Blecua, aunque modificando el orden de los elementos.

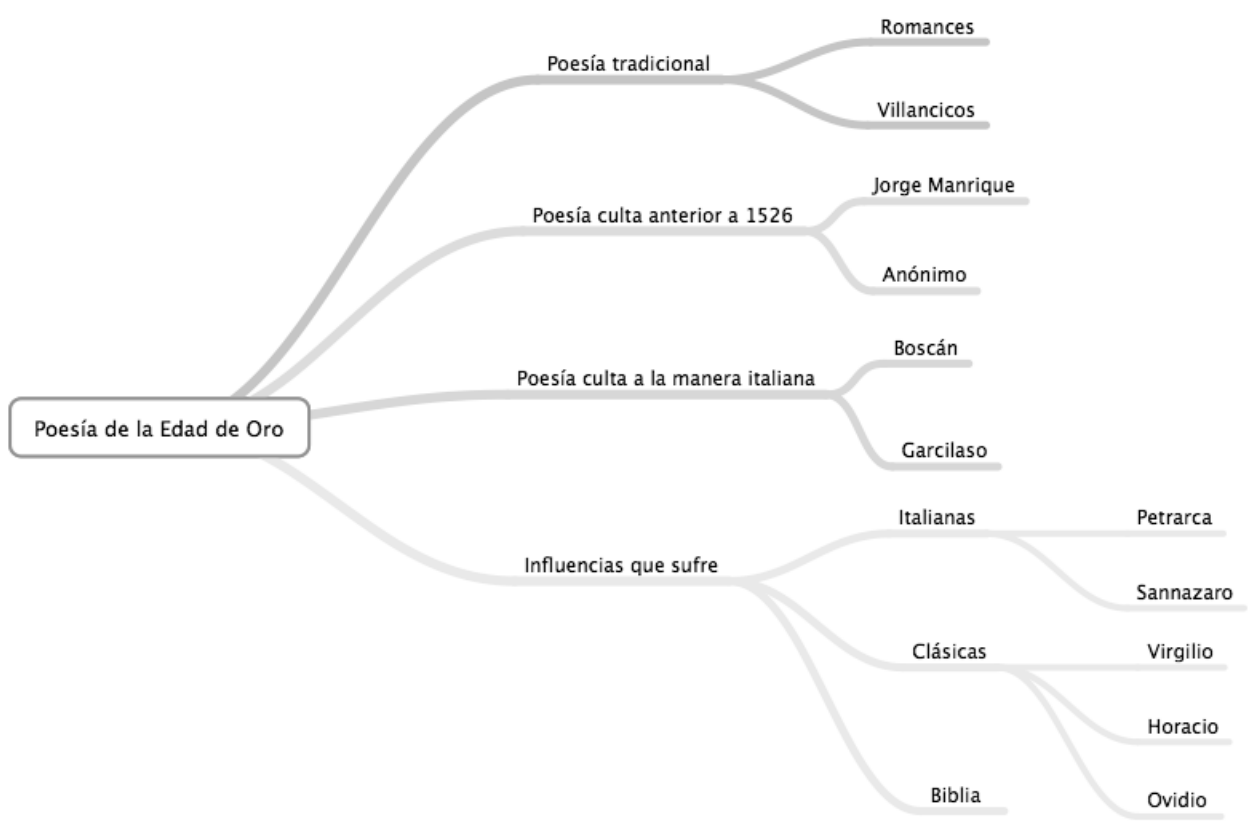

Fig. 25. Esquema de la obra vocal de Mudarra (adaptado de Blecua)

No podríamos añadir ni una coma a la también magistral clase del profesor Blecua.

${ }^{805}$ Mudarra señala en el índice del tercer libro la autoría de la letra de la mayoría de las piezas, lo cual es significativo de su intención; no es muy común la indicación del nombre del autor del texto en otros vihuelistas. 
Queremos destacar que todo este repertorio vocal (y el instrumental de los dos libros anteriores) es representativo de una corte castellana como la del Infantado en Guadalajara. Es muy probable que no fuera muy diferente al de otras cortes, pues las influencias eran continuas. Con lo que no podemos estar de acuerdo es con la excesiva identificación de esta música con el «humanismo sevillano», o con la llamada «escuela sevillana» representada por Morales y Guerrero, entre otros. Con demasiada frecuencia oímos hablar, o leemos, sobre los vihuelistas andaluces, la escuela andaluza de vihuela o sobre el sevillano Mudarra. ${ }^{806}$ Nosotros estamos convencidos que de todo este repertorio, o la mayor parte de él, se concibió, tañió, glosó y cantó en el palacio alcarreño durante la larga estancia de Alonso, palacio que abandonó tres o cuatro años antes de la publicación de su libro y de la toma de posesión de su canonjía.

Para hacernos una idea del papel que desempeña la música vocal entre los vihuelistas incluimos un cuadro con los géneros utilizados por ellos:

\begin{tabular}{|c|c|c|c|c|c|c|c|c|c|c|c|c|c|c|c|c|c|c|}
\hline $\begin{array}{l}\text { Géneros } \\
\text { vocales }\end{array}$ & 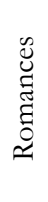 & 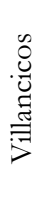 & 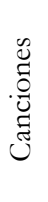 & 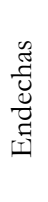 & 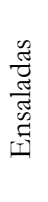 & $\begin{array}{l}0 \\
0 \\
0 \\
0 \\
0 \\
\tilde{D}\end{array}$ & 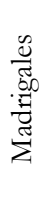 & 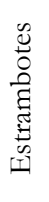 & 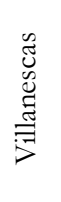 & $\begin{array}{l}\mathbb{J}_{0}^{0} \\
\stackrel{ \pm}{0} \\
\sum\end{array}$ & 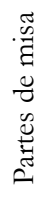 & 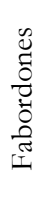 & 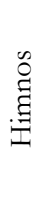 & $\begin{array}{l}0 \\
0 \\
0 \\
0 \\
0 \\
>\end{array}$ & $\begin{array}{l}0 \\
0 \\
0 \\
0 \\
0 \\
0 \\
0 \\
0\end{array}$ & 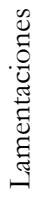 & 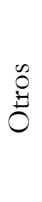 & సే \\
\hline Milán & 4 & 12 & & & & 6 & & & & & & & & & & & & 22 \\
\hline Narváez & 2 & 5 & & & & & & & & & & & & & & & & 7 \\
\hline Mudarra & 3 & 5 & 3 & & & 7 & & & & 3 & & 2 & & 4 & & & & 27 \\
\hline Valderrábano & 8 & 9 & 16 & & & 5 & & & & 25 & 5 & & & & 1 & 1 & & 70 \\
\hline Pisador & 5 & 15 & 2 & 1 & & 2 & 1 & & 11 & 13 & 2 & 3 & 2 & & & & & 57 \\
\hline Fuenllana & 3 & 18 & & 1 & 3 & 6 & 1 & 14 & 3 & 29 & 21 & 9 & 6 & & & 1 & 2 & 117 \\
\hline Daza & 1 & 11 & 1 & & & 3 & & & 9 & 13 & & & & & & & & 38 \\
\hline $\begin{array}{l}\text { Total por } \\
\text { género }\end{array}$ & 26 & 75 & 22 & 2 & 3 & 29 & 2 & 14 & 23 & 83 & 28 & 14 & 8 & 4 & 1 & 2 & 2 & 338 \\
\hline
\end{tabular}

${ }^{806}$ Por ejemplo en Martín MOREnO, Antonio. Historia de la música andaluza. Sevilla, Editoriales Andaluzas Unidas, 1985, que incluye un capítulo titulado Los vihuelistas andaluces Alonso de Mudarra y Luis de Narváez, pp. 164-170. 
Si calculamos la proporción de obras vocales con respecto al total de cada autor nos salen los siguientes datos:

- Milán

- Narváez

- Mudarra

- Valderrábano

- Pisador ${ }^{807}$

- Fuenllana

- Daza
$22 / 72 \quad 30,6 \%$

$7 / 33 \quad 21,2 \%$

$27 / 77 \quad 35,1 \%$

$70 / 170 \quad 41,2 \%$

$57 / 95 \quad 60 \%$

$117 / 188 \quad 62,2 \%$

$38 / 62 \quad 61,3 \%$

A simple vista, observamos un interés creciente por el repertorio vocal en los libros de vihuela, de forma que, descontando la obra de Narváez, vemos cómo en 40 años se duplica el porcentaje de obras vocales, lo que evidencia un mayor interés de los consumidores de estos libros (fundamentalmente clases medias) por la música doméstica para voz y vihuela.

${ }^{807}$ No consideramos las fantasías con cifra colorada como música vocal y las dos misas con una voz señalada las consideramos como dos obras. 


\section{0- Pater noster}

Motete. V modo. Posición A b (vihuela en E). 4 voces. Tempo medio. Notas móviles:

$\mathrm{La} \curvearrowleft(\mathrm{I}), \operatorname{Re} b(\mathrm{IV}), \mathrm{Mi}$ ต (V), Sol b (VII). Voz canto: tenor.

\section{NOTAS CRÍTICAS}

1. c. 9. Ponemos 3 en $2^{\circ}$ orden en lugar de 4 .

2. c. 16. Ponemos 1 en $3^{\circ}$ orden en lugar de 5 .

3. c. 42. Añadimos rasguito en 3 y 1 en $3^{\circ}$ orden.

4. c. 57. Añadimos rasguito en 4 y 3 en $3^{\circ}$ orden y 5 en $4^{\circ}$ orden.

5. c. 60 . Añadimos rasguito en 3 en $3^{\circ}$ orden.

6. c. 89 . Añadimos rasguito en 4 y 5 en $4^{\circ}$ orden.

7. c. 111. Ponemos 2 en $2^{\circ}$ orden en lugar de 1 .

8. c. 137. Añadimos la nota que figura entre corchetes.

9. c. 154 . Sobra el 1 en $2^{\circ}$ orden.

10. c. 165. Añadimos la nota que figura entre corchetes.

11. c. 190. La semimínima es innecesaria.

12. c. 209. Añadimos la semibreve que figura entre corchetes.

13. c. 212. Añadimos rasguito en 3 en $3^{\circ}$ orden.

14. c. 213. Ponemos 3 en $6^{\circ}$ orden en lugar de 5 .

15. c. 215. Añadimos la semibreve que figura entre corchetes.

16. c. 217. Ponemos mínima en lugar de semibreve y añadimos rasguito en 5 en $4^{\circ}$ orden en las dos ocasiones.

17. c. 278. Añadimos rasguito en 5 en $4^{\circ}$ orden.

\section{TEXTO}

Pater noster, qui es in coelis, sanctificetur nomen tuum, adveniat regnum tuum, fiat voluntas tua, sicut in coelo, et in terra. Panem nostrum quotidianum da nobis hodie, et dimitte nobis debita nostra, sicut et nos dimittimus debitoribus nostris, et ne nos inducas in tentationem. 
Sed libera nos a malo.

Amen.

VARIANTES: Mudarra: 1 «celis», 2 «santificetur», 5 «celo», 6 «cuotidianum», 7 «odie», 8 «dimite», 9 «dimitimus», 11 «set». ${ }^{808}$

\section{INTRODUCCIÓN}

La primera de las piezas del libro tercero es una intabulación sobre el motete Ave Maria de Adrian Willaert. ${ }^{809}$ Figura entre las obras vocales religiosas del siglo XVI con mayor éxito y, posiblemente, la más exitosa de este autor. De ello da prueba la cantidad de veces que se imprimió a mediados de siglo ${ }^{810}$ :

- 1532, Lyon, Jacques Moderne, Primus liber cum quatuor vocibus. "Motteti del fiore". [RISM $\left.1532^{10}\right]$

- 1534, París, Pierre Attaingnant, Liber secundus quatuor et viginti musicales quatuor vocum motetos. [RISM 15344]

- $\quad$ 1538, Nuremberg, Johann Petreius, Modulationes aliquot quatuor vocum... [RISM 15387]

- 1539, Venecia, Antonio Gardano, Primus liber cum quatuor vocibus. Fior de mottetti tratti dalli mottetti del fiore. [RISM 153912]

- $\quad$ 1545, Venecia, Antonio Gardano, Adriani Willaert musici celeberrimi. musica quatuor vocum. Liber secundus. [RISM 1545c - W 1109]

- $\quad$ 1545, Venecia, Antonio Gardano, Flos florum primus liber quatuor vocibus. Motteti del fior. [RISM $\left.1545^{4}\right]$

- $\quad$ 1553, París, Nicolas du Chemin y Claude Goudimel, Liber primus collectorum modulorum... [RISM 15532]

- $\quad$ 1554, Amberes, Tielman Susato, Liber quartus ecclesiasticarum cantionum...[RISM 15548]

- 1564, Venecia, Rampazetto, Mottetti del Fiore a quattro voci, novamente ristampati, et con somma diligentia revisti et corretti. Libro primo. [RISM 15646]

${ }^{808}$ Indicamos con la cifra el número de verso o de línea.

${ }^{809}$ Mudarra lo denomina Adrian Vuillart al igual que Pisador (Adrianus de Villart). Villart es el nombre alternativo que aparece en varias fuentes, como las colecciones de Moderne de 1532 y Attaingnant de 1534.

${ }^{810}$ Muchas de estas ediciones son reediciones de los Motteti del fiore. Una transcripción clásica en: ZENCK, H.-Gerstemberg, W. (ed). Adriani Willaert, Opera Omnia. II: Motteta IV vocum, Liber secundus 1539 et 1545. CMM: Corpus Mensurabilis Musicae 3, Roma: American Institute of Musicology, 1950. Sacamos la lista de la web de la Fundación Adriaen Willaert:

$<$ http://www.adriaenwillaert.be/index.html $>$ [consulta 22-4-15]. 
También entre los vihuelistas y laudistas gozó de gran predicamento pues, además de Mudarra, intabularon esta obra Giulio Abondante ${ }^{811}$ y Diego Pisador. ${ }^{812}$ Este último se limitó a transcribir la obra tal cual sin añadidos, incluso, si consideramos una vihuela en Sol, la altura elegida coincide con la del original de Willaert, aunque omite algunos compases. Abondante utiliza los mismos «términos», pero introduce glosas decorativas en algunos momentos. ${ }^{813} \mathrm{La}$ segunda parte de este motete, el Ave Maria, también fue intabulado por Pisador. ${ }^{814}$ Fuenllana igualmente transcribe el Ave María y añade una fantasía parodia sobre esta obra. ${ }^{815}$

Otras obras de Willaert relacionadas figuran en el repertorio de vihuela. Valderrábano ${ }^{816}$ transcribe un Pater noster de Willaert para dos vihuelas de forma literal, pero se trata de la pieza homónima a seis voces publicada por Gardano en $1542 .{ }^{817}$

\section{COMENTARIO}

Mudarra, como ya hizo con otras composturas en anteriores libros, toma el original de Willaert $\mathrm{y}$, respetando la estructura, introduce abundantes glosas en todas las voces. Además, cambia la altura y usa los términos de A b, lo que complica mucho la digitación. Esto, unido a su gran longitud (219 compases, la obra más larga de los tres libros), hace de ella una obra de gran complejidad.

Es relevante que omite algunos compases, lo que nos hace pensar en alguna fuente manuscrita, pues las impresas suelen ser bastante homogéneas.

La pieza está escrita para voz y vihuela, siendo la voz de tenor la elegida para cantar, si bien no desde el principio, sino desde la segunda enunciación del Pater noster (c. 13). Mudarra utiliza un rasguito sobre la cifra para indicar esta voz, como ya veíamos más arriba, únicamente en esta pieza y en la siguiente. Advierte que la voz señalada puede ser

${ }^{811}$ Abondante, Julio [Giulio]. Intabolatura di lautto libro secondo... Venecia, Hieronimo Scotto, 1548, f. E4v-F1. Una transcripción con un breve comentario en: CHILESOTTI, Oscar. «Il Pater noster di Adriano Willaert», Sammelbände der Internationalen Musikgesellschaft, 3 (1902), pp. 468-472.

812 PISADOR. Libro de música de vibuela, ff. 77-78.

${ }^{813}$ Sorprendentemente, Pujol afirma que los motetes transcritos por Pisador y Mudarra son obras diferentes. PUJOL. Mudarra, p. 74.

${ }^{814}$ PISADOR. Libro de música de vibuela, ff. 76-77.

815 Ave Maria y Fantasía del autor remedando esta ave maria. FUENLLANA. Orphénica lyra, f. 35-36.

${ }^{816}$ VALDERRÁBANO. Silva de sirenas, ff. 53v-55.

${ }^{817}$ Musicorum Sex vocum, que vulgo Motecta dicuntur..., Venecia, Gardano, 1542. 
cantada si se quiere, pero siempre debe ser tañida: «El qual da a entender que la cifra que le tubiere delante será la vox que se puede cantar si quisieren la qual a de yr también tañida.» ${ }^{818}$ Ya vimos que este sistema representaba un considerable ahorro de costes de impresión.

Como ejemplo de la forma de trabajar de Mudarra, comparándola con la de su contemporáneo italiano Giulio Abondante, incluimos los primeros compases de la pieza junto con los de Willaert. Es evidente que las glosas de Mudarra son de tipo estructural y tienen un carácter imitativo en muchos casos, mientras que las de Abondante se limitan a adornar las cadencias.

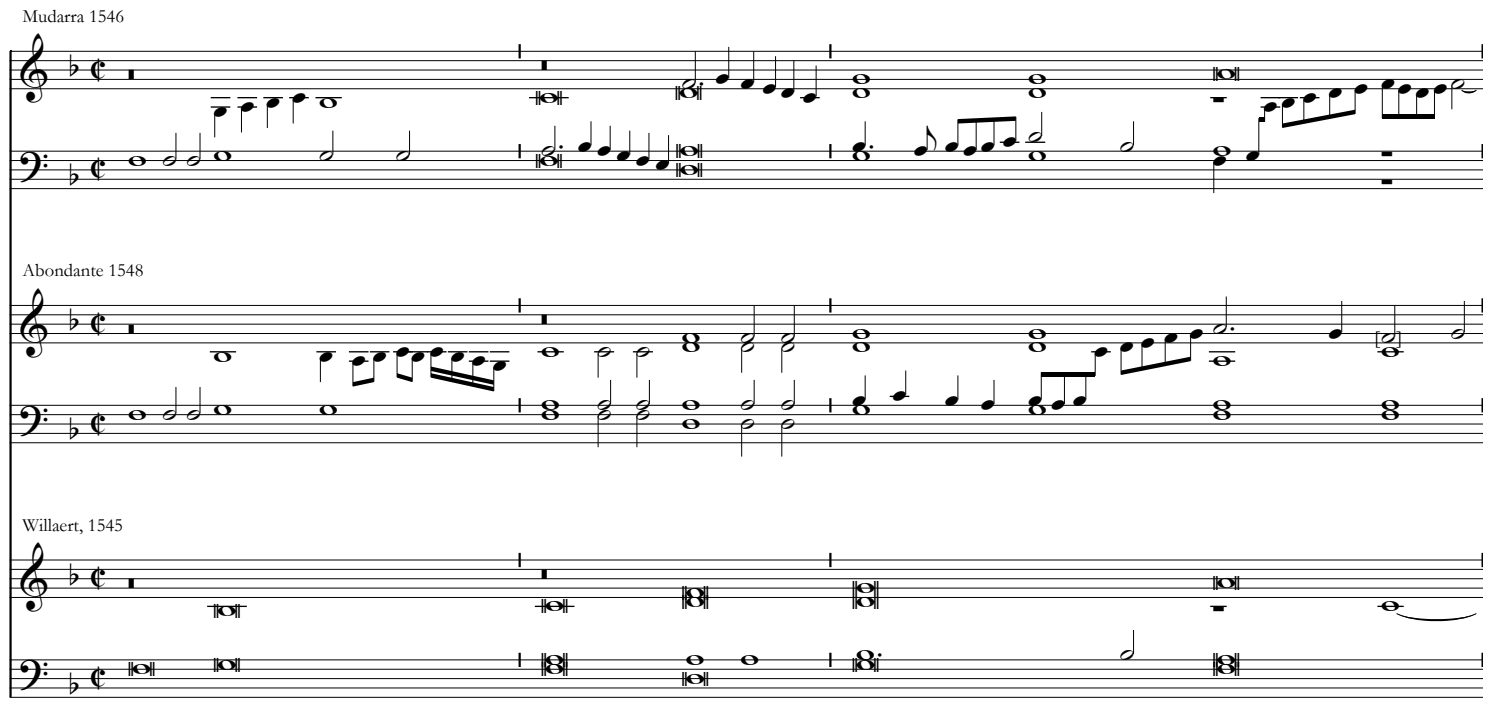

Ejemplo 20. Comparación de los primeros compases del Pater noster de Mudarra, Abondante y Willaert.

${ }^{818}$ MUDARRA. Tres libros de música, Libro I, f. A3v de los preliminares. 


\section{1- Respice in me, Deus}

Motete. I modo. Posición e b (vihuela en G\# ). 5 voces. Tempo medio. Notas móviles: Sol ต (III), La

\section{NOTAS CRÍTICAS}

1. c. 12. Añadimos la nota que figura entre corchetes.

2. c. 14. Lo correcto sería «me-i».

3. c. 33. Ponemos 4 en $2^{\circ}$ orden en lugar de 5 .

4. c. 37. Lo correcto sería «ti-o».

5. c. 41 . Lo correcto sería «me-i»».

6. c. 52. Lo correcto sería «me-is».

7. c. 53. Lo correcto sería «e-ru-e».

8. c. 80 . Ponemos el rasguito en 5 en $5^{\circ}$ orden en lugar de en $4^{\circ}$ orden.

9. c. 113. Añadimos rasguito en 6 e $5^{\circ}$ orden.

10. c. 118 . Ponemos 1 en $1^{\circ}$ orden en lugar de 0 en $2^{\circ}$ orden.

11. c. 129. Añadimos rasguito en 3 en $5^{\circ}$ orden.

\section{TEXTO}

El texto se corresponde con el Introito del III domingo post Pentecostes y pertenece a el Salmo 24: Ad te, Domine, levavi anima meam, versículos 16-20. ${ }^{819}$

Respice in me et miserere mei: quia unicus et pauper sum ego.

Tribulationes cordis mei multiplicatae sunt: de necessitatibus meis erue me.

Vide humilitatem meam et laborem meum: et dimitte universa delicta mea.

Respice inimicos meos, quoniam multiplicati sunt: et odio iniquo oderunt me.

Custodi animam meam et erue me: non erubescam quoniam speravi in te.

VARIANTES: Mudarra: 1 «Respice in me, Deus», 1 «e», 1 omite «ego», 2 «multiplicate», 3 añade «et vide», 4 «oderant», 5 «esperavi»

${ }^{819}$ Tomamos el texto de Breviarium Toletanae, p. 206 


\section{INTRODUCCIÓN}

Si bien esta pieza es atribuida a Gombert por Mudarra, en realidad se trata de un contrafactum de una pieza de Josquin. Esta identificación en tiempos actuales ocurrió por casualidad, el hecho lo cuenta el propio musicólogo Charles Van den Borren. Se encontraba leyendo al piano la transcripción de Pujol cuando su yerno, Safford Cape, a la sazón director del grupo Pro Musica Antiqua, reconoció la pieza, pues formaba parte de repertorio de su grupo. ${ }^{820}$

La pieza de Josquin es la chanson Je ne me puis tenir d'aimer, cuyo texto no puede estar más lejos del utilizado en la pieza de Mudarra, si bien se trata de un lamento en ambos casos. Esta obra de Josquin recuerda en muchos momentos a la conocida Mille regretz intabulada por Narváez. Sin embargo, la primera publicación de la chanson de Josquin no ocurre hasta cuatro años después de la de Mudarra. ${ }^{821}$

También en Fuenllana se encuentra un motete atribuido a Gombert y que se corresponde con la misma chanson, se trata de la obra a cinco voces Lauda Syon. ${ }^{822}$ Bermudo recomendaba poner en la vihuela música de Gombert después de la de Josquin, aunque advertía de su dificultad:

Entre la música estrangera que hallaréys buena para poner: no olvidéys la de el gran músico Iusquin que començó la música. Lo último que avéys de poner sea Música del excelente Gomberth. Por la dificultad que tiene para poner en la vihuela, por ser derramada: la pongo en el último lugar. ${ }^{823}$

El cómo pudo pasar una obra profana a convertirse en modelo de dos contrafacta es explicado por Blackburn en un artículo, donde expone el posible proceso de transmisión de esta pieza, que tuvo todavía otras versiones alemanas y del este de Europa ${ }^{824}$ Existiría

820 BORREN, Charles Van den. «Publications musicologiques espagnoles», Revue Belge de Musicologie/Belgisch Tijdschrift voor Muziekwetenschap, 7/2-4 (1953), pp. 146-164, p. 156.

${ }^{821}$ Trente sixiesme livre contenant XXX... París, Pierre Attaingnant, 1549. En el Odhecaton $C$ hay una pieza a cuatro voces atribuida a Josquin con el mismo texto, pero distinta música.

${ }^{822}$ FuenLlanA. Orphénica lyra, ff. 65v-66.

${ }^{823}$ Bermudo. Declaración, f. 99v. Nótese que Bermudo escribe Gomberth como Mudarra.

${ }^{824}$ BlackBurn, Bonnie J. «Josquin's Chansons: Ignored and Lost Sources», Journal of the American Musicological Society, 29/1 (Spring, 1976), pp. 30-76. 
un modelo vocal que desconocemos y que sería el que derivó en las composiciones de Mudarra y Fuenllana.

\section{COMENTARIO}

Mudarra utiliza unas posiciones o términos difíciles de ejecutar y difíciles de explicar, pues la pieza de Fuenllana se mueve por los términos de re (vihuela en $\mathrm{G}$ ), lo que permite muchas cuerdas al aire, y de hecho, Fuenllana la califica como fácil, mientras que la obra de Mudarra se mueve sobre mi bemol (vihuela en G\#), con muy pocas cuerdas al aire, sin que sea necesario, ya que la nota más grave es un primer traste del sexto orden.

A pesar de esto y a diferencia del motete anterior, apenas encontramos variación con respecto a la pieza de Josquin: mismo número de compases, alguna voz ausente en algún momento por imposibilidad del instrumento y ciertas variaciones rítmicas, posiblemente derivadas de la adaptación del nuevo texto. Tan solo glosas cadenciales que nos recuerdan a las composturas del primer libro.

\section{2- Clamabat autem mulier. Motete de la cananea}

Motete. V modo. Posición A b (vihuela en E). $3+1$ voces. Tempo medio. Notas móviles: Re b (IV), Mi Ł (V), Sol b (VII). Voz canto: contralto y soprano.

\section{NOTAS CRÍTICAS}

1. c. 1. Mudarra escribe un bemol en la armadura, por lo que lo respetamos.

2. c. 10 . Añadimos 5 en $1^{\circ}$ orden. Corregido a mano en el original e indicado en la fe de erratas del final.

3. c. 40. Hay un error en el custos de pentagrama superior y faltan los bemoles.

4. c. 42 . Ponemos 3 en $3^{\circ}$ orden en lugar de 2 . Corregido a mano en el original e indicado en la fe de erratas del final.

5. c. 120 . Ponemos 3 en $4^{\circ}$ orden en lugar de 5. Corregido a mano en el original.

6. c. 129. Añadimos la mínima que figura entre corchetes.

7. c. 142. Ponemos el rasguito sobre el 3 en $4^{\circ}$ orden en lugar de sobre el 1 en $3^{\circ}$.

8. c. 178. Añadimos la mínima que figura entre corchetes. 
El texto es una paráfrasis del evangelio de San Mateo (15, 22-28).

Clamabat autem mulier chananea ad Dominum Iesum, dicens:

«Domine, adiuva me, fili David, adiuva me; filia mea male a demonio vexatur».

Respondens Iesus ait illi: «non sum missus nisi ad oves quae perierunt domus Israel»;

at illa venit et adoravit eum: «Domine, adiuva me».

Respondens Iesus ait illi: «mulier, magna est fides tua; fiat tibi sicut vis».

VARIANTES: Mudarra: 1 «cananea», «Ihesum», 3 «misus», «que», «domo Isrrael ad», 5 «Iesum».

\section{INTRODUCCIÓN}

El autor de la pieza en la que se basa Mudarra es Pedro de Escobar, probablemente cantor de la Capilla Real castellana y posteriormente maestro de capilla de la catedral de Sevilla, como vimos más arriba. ${ }^{825}$

El motete Clamabat autem mulier fue su obra más conocida. Está basado a su vez en un auto de Gil Vicente, el Auto da Cananea fechado en 1534. Tuvo una gran difusión, pues figura en nueve manuscritos y en el libro de tecla de Gonzalo de Baena ${ }^{826}$, además de esta adaptación de Mudarra que nos ocupa. Uno de los manuscritos que lo contiene es el Manuscrito 2 de la catedral de Tarazona (Tarazona, ms. 2, ff. 94v-95) ${ }^{827}$ y en esta versión basaremos nuestra comparación.

\footnotetext{
${ }^{825}$ No vamos a entrar en la polémica sobre la identficación de Pedro de Escobar con Pedro del Puerto, nos remitimos a varios trabajos con opiniones opuestas. Por un lado: STEVENSON, Robert. «Escobar, Pedro de [Pedro del Puerto; Pedro do Porto]", The New Grove Dictionary of music and musicians, vol. 6, Londres: Macmillan, 1980, pp. 243-244 y KNighton, Tess. «Escobar, Pedro de [Pedro del Puerto, Pedro do Oporto]», DMEH, vol. 4, pp. 721-724 y por el otro: ViLLANueVa SERRANO, Francesc. «La identificación de Pedro de Escobar con Pedro de Porto: una revisión definitiva a la luz de nuevos datos», Revista de Musicología, 34/1 (2011), pp. 37-58. Sacamos los datos biográficos y sobre su obra del trabajo de Knighton.

${ }^{826}$ BAENA, Gonçalo de. Arte novamente inventada pera aprender a tanger. Lisboa, German Galharde, 1540, ff. 50-52. Hay transcripción moderna en ForsT, Bruno (ed.) Gonzalo de Baena .... Lisboa, 1540. Madrid, Dairea, 2012, pp. 144-148.

${ }^{827}$ Hay edición moderna en CALAhORRA, Pedro (ed.). Autores hispanos de los siglos xv-xvi de los ms. 2 y 5 de la catedral de Tarazona. Polifonía aragonesa, IX. Zaragoza, Institución «Fernando el Católico», Sección de Música Antigua, Excma. Diputación Provincial, 1995.
} 
El motete consiste en un diálogo dramático entre Jesús de Nazaret y una mujer cananea, a los que hay que añadir la figura del narrador.

\section{COMENTARIO}

Con esta pieza comienzan las obras con una voz para cantar, que en general no está incluida en la tablatura, escrita en pentagrama aparte en figuras de canto de órgano. La altura está indicada con una frase: «entónase la boz en la tercera al tercero traste». Mudarra vuelve a utilizar posiciones o términos correspondientes a vihuela en Mi, como en el Pater noster, aunque en este caso, al tratarse de una obra a tres voces más la cantada, la dificultad técnica es menor.

Mudarra manipula el material original como en los glosados del segundo libro. Desconocemos la fuente que usó, evidentemente manuscrita, por lo que no podemos saber si las manipulaciones mayores son de su mano o previas. Por ejemplo, en muchas partes se añaden compases, pero en otras faltan. Además, el texto no coincide completamente con el de Tarazona. Si nos fijamos en las frases literarias y las numeramos del 1 al 8, podemos comparar el número de compases (contamos semibreves en el caso de Tarazona) que ocupa cada una de las frases en la versión de Mudarra y en la de Tarazona:

$\begin{array}{ccc}\text { Frase } & \text { Mudarra } & \text { Tarazona } \\ 1 & \text { cc. } 1-39=39 \mathrm{cc} . & 31 \mathrm{sb} \\ 2 & \text { cc. } 40-79=40 \mathrm{cc} . & 28 \mathrm{sb} \\ 3 & \text { cc. } 80-88=9 \mathrm{cc} . & 10 \mathrm{sb} \\ 4 & \text { cc. } 89-115=27 \mathrm{cc} . & 27 \mathrm{sb} \\ 5 & \text { cc. } 116-128=13 \mathrm{cc} . & 20 \mathrm{sb} \\ 6 & \text { cc. } 129-140=12 \mathrm{cc} . & 13 \mathrm{sb} \\ 7 & \text { cc. } 141-149=9 \mathrm{cc} & 9 \mathrm{sb} \\ 8 & \text { cc. } 150-182=33 \mathrm{cc} . & 42 \mathrm{sb}\end{array}$

Podemos apreciar que las diferencias son bastante significativas en algunas frases. En las dos primeras Mudarra añade música, las dos siguientes son muy similares, la 5 y la 8 son mucho más largas en Tarazona y la 6 y 7 son de casi igual longitud. 
También en el número de voces hay cambios. Ponemos como ejemplo los primeros compases de Mudarra y de Escobar, en la versión de Tarazona para que se aprecie.
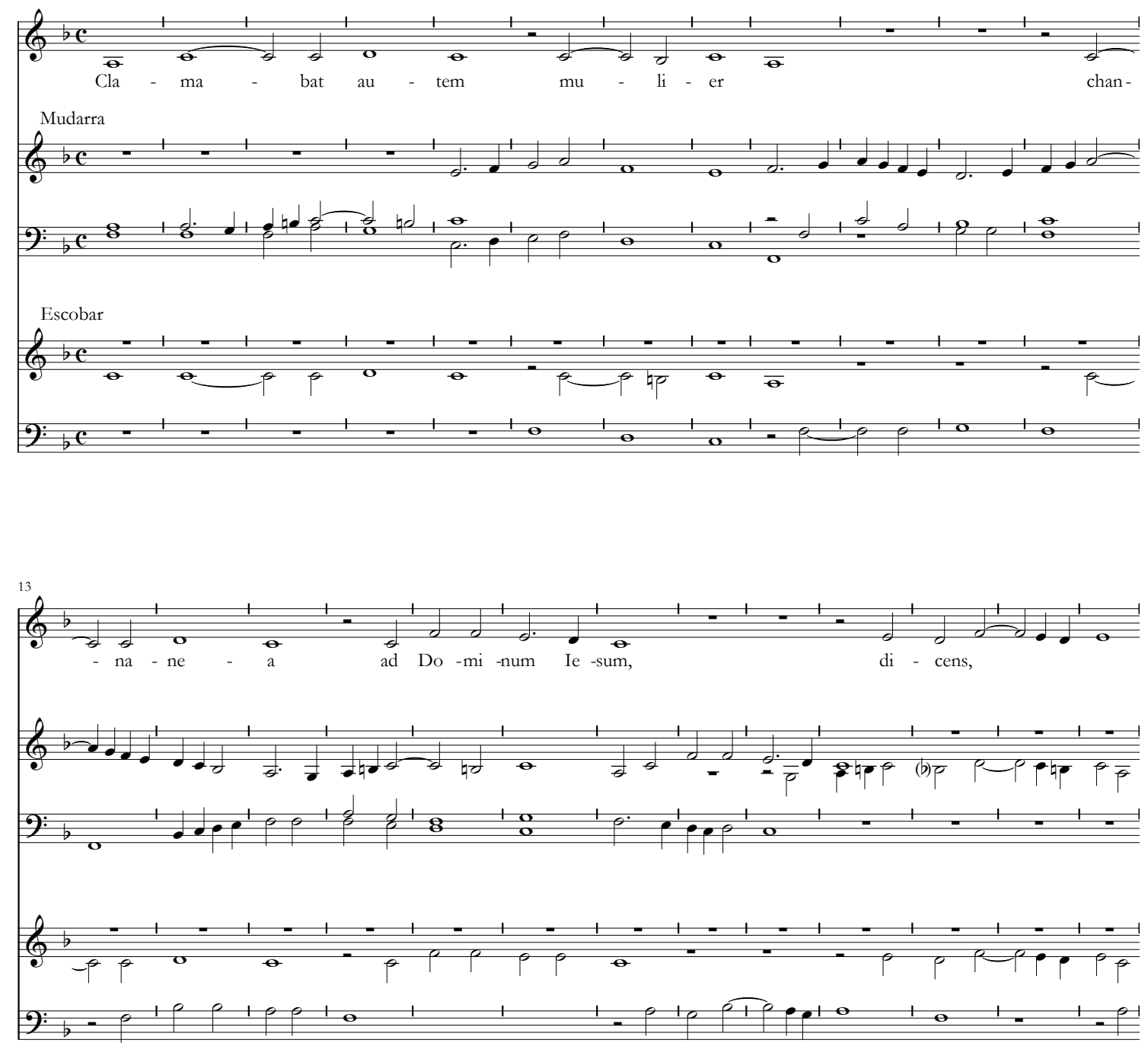

Ejemplo 21. Comparación de los primeros compases del Motete de la cananea en Mudarra y Escobar.

Desde el primer compás observamos lo que será común en toda la pieza, pasamos de una voz en la versión en Tarazona, a tres en la de Mudarra, que además van generando un contrapunto imitativo a lo largo de toda la pieza. De nuevo, no se trata de glosas decorativas sino estructurales. 


\section{3- Durmiendo yva el Señor}

Romance. I modo. Posición B b (vihuela en B). ${ }^{828} 3+1$ voces. Tempo medio. Notas móviles: Sol b (VI), La ต (VII). Voz canto: contralto.

\section{NOTAS CRÍTICAS}

1. c. 3. Añadimos el texto que figura entre corchetes.

2. c. 5 . Ponemos 1 en $6^{\circ}$ orden en lugar de 0 .

3. c. 25. Ponemos 3 en $1^{\circ}$ orden en lugar de 2 . Corregido a mano en el original e indicado en la fe de erratas del final.

4. c. 28. Añadimos el calderón.

5. c. 33. Ponemos 4 en $3^{\circ}$ orden en lugar de 3 .

6. cc. 39-54. En el ejemplar de la BNE falta la página completa, siendo sustituida por la que corresponde al f. 12r.

7. c. 41. Añadimos la semibreve que figura entre corchetes. Añadida a mano en el ejemplar del Escorial.

8. c. 47. Ponemos el 3 del $3^{\circ}$ orden alineado sobre el 5. Corregido a mano en el original del Escorial e indicado en la fe de erratas del final.

9. c. 68. Añadimos la doble barra de repetición.

\section{TEXTO}

El texto, inspirado en el evangelio de San Mateo (8, 23-27), figura en el Cancionero general a partir de la segunda edición entre las obras de devoción y bajo el título Romance de otro cavallero. ${ }^{829}$ Añadimos los diez versos del Cancionero a la versión de Mudarra, que presenta pocas variantes con respecto a la impresa.

\footnotetext{
Durmiendo yva el Señor

en una nave en la mar,

sus discípulos con él,
}

${ }^{828}$ El transporte que usa Mudarra para esta pieza, vihuela en Si, podría resultar extraño, aunque si consideraramos que está en un I modo por Gsolreut, nos volvemos a encontrar con una vihuela en Mi, como el Pater noster y Clamabat autem mulier.

${ }^{829}$ Tomamos la versión del Cancionero general... Toledo, Ramón de Petras, 1527, f. 14v. Seguimos la puntuación de BINKLEY, Thomas y FrENK Margit Spanish Romances of de sixteenth century. Bloomington \& Indianapolis: Indiana University Press, 1995, p. 115. 
que no l'osan recordar.

El agua, con la tormenta,

començos'a levantar,

las olas cubren la nave,

que la quieren anegar.

Los discípulos con miedo

començaron de llamar.

diziendo: «Señor, Señor,

quiérasnos presto librar».

Y despierto el buen Jesú,

començóles de hablar:

«O hombres de poca fe,

qué teméys quered pensar,

quán gran ofensa es a dios,

de su gran poder dubdar».

Y levantóse mandando

a los vientos y a la mar

gran espanto puso entrellos

y muy más maravillar,

diziendo «quién es aquel,

que el tiempo haze mudar».

VARIANTES: Cancionero general: 4 y 6 sin elisión, 12 «salvar» por «librar».

\section{INTRODUCCIÓN}

Comienzan aquí los tres romances bíblicos con los que abre Mudarra las piezas en castellano. ${ }^{830}$ Todos los vihuelistas incluyen romances en sus libros, siendo Mudarra y Valderrábano los únicos que se decantan por este género bíblico. ${ }^{831}$

El romance es un género que pasó de ser despreciado por los poetas cultos, como prueba la famosa sentencia del Marqués de Santillana quien en el Proemio al Condestable afirmaba: «Ínfimos son aquellos que sin ningund orden, regla nin cuento fazen estos

${ }^{830}$ Los tres fueron transcritos por MORPHY, G. Les Luthistes espagnoles..., vol. II, pp. 106-111.

${ }^{831}$ Una visión general sobre el asunto en OTAOLA, Paloma. «Los romances para vihuela del siglo XVI», Actas del XIV Congreso de ll Asociación International de Hispanistas. LERNER, Isaías, NIVAL, Robert y ALONSO, Alejandro (eds.). Newark (Delaware), Juan de la Cuesta, 2004, vol. II, pp. 435-446. 
romançes e cantares de que las gentes de baxa e servil condiçión se alegran», ${ }^{832}$ a estar de moda en los palacios: «en el transcurso de la segunda mitad del siglo XV, la afición a estos romances tradicionales subió desde el pueblo bajo hasta las clases ilustradas». ${ }^{833}$ En el siglo XVI con la ayuda de la imprenta su difusión llegó a ser mucho mayor, sin que se abandonara la fundamental transmisión manuscrita. ${ }^{834}$

El tratamiento que dan los vihuelistas a los romances es variable, pero en general hay una cierta tendencia a agrupar los textos por estrofas o cuartetas, siendo el procedimiento más común que la misma música se repita cada cuatro versos, como nos indica Narváez: «Por ser la letra destos romances muy conocida no se pone aquí sino los quatro pies primeros del romance porque de quatro en quatro pies se an de cantan». ${ }^{835} \mathrm{Ya}$ en la época de Juan del Encina se daba la tendencia de agrupar los versos en cuartetas: «los romances suelen yr de cuatro en cuatro pies aunque no van en consonante sino el segundo y el cuarto pie». ${ }^{836}$

Suelen utilizar una melodía para cada octosílabo repitiendo con frecuencia el cuarto verso con la misma música o variante de ella (esta repetición se hará común en el siglo siguiente).

$$
\begin{array}{llllll}
\text { Música } & \mathrm{a} & \mathrm{b} & \mathrm{c} & \mathrm{d} & \mathrm{d} \\
\text { Texto } & \mathrm{a} & \mathrm{b} & \mathrm{c} & \mathrm{d} & \mathrm{d}
\end{array}
$$

Excepciones a esta forma de musicar los romances las encontramos en Luis Milán, quien utiliza diferente música para dos $\operatorname{cuartetas}^{837}$ y en Mudarra, como veremos a continuación.

${ }^{832}$ Marqués de Santillana. Poesías completas. Kerkhof, Maxim P A. M y Gómez Moreno, Ángel (eds.). Madrid, Castalia, 2003, p. 649.

${ }^{833}$ MenÉndez Pidal, R. Poesía juglaresca..., p. 322.

${ }^{834}$ Dumanoir calcula que frente a novecientos cincuenta romances conservados sin música, solo conservamos con música unos ochenta. Dumanoir, Virginie. «Melodía y texto. El caso de los romances viejos», Música y literatura en la España de la Edad Media y del Renacimiento. Madrid, Casa de Velázquez, 2003, pp. 107-116; p. 112.

${ }^{835}$ NARVÁEZ. El delphín, f. 66.

${ }^{836}$ ENCINA, Juan del. Cancionero de las obras de Juan del Enzina. Salamanca, 1496. (Ed. facsímil Madrid, Real Academia Española, 1989), fol. V.

${ }^{837}$ Pone la misma música a las cuartetas de dos en dos. Una exposición en ARRIAGA, Gerardo. «La obra vocal de Luis Milán», Roseta, 1 (2008), pp. 6-43 y sobre su interpretación en GÁsSER, L. Luis Milán..., p. 171. 


\section{ESTRUCTURA}

$\begin{array}{ccccc}\text { Secciones } & \text { Compases } & \text { Cadencia final } & \text { Longitud } & \text { Motivos } \\ 1 & 1-28 & \text { i } & 28 \mathrm{cc} .(\mathrm{x} 2) & \mathrm{a}, \mathrm{b}, \mathrm{c}, \mathrm{d} \\ 2 & 29-68 & \text { I } & 40 \mathrm{cc} .(\mathrm{x} 2) & \mathrm{a}, \mathrm{b}, \mathrm{c}, \mathrm{d}\end{array}$

\section{ANÁLISIS}

Más que de secciones deberíamos de hablar de versiones, pues el propio autor nos dice al principio de la segunda «Síguese otra vez el mismo romance de otra manera». Es similar a lo que hace Milán con diez de sus obras, que presenta también en doble versión, aunque con una importante diferencia: Milán vuelve a poner el mismo texto para la segunda versión, mientras que Mudarra continúa el texto como si quisiera que se fueran intercalando una y otra. Además la primera estaría en un estilo homofónico, «música golpeada», que diría Bermudo y la segunda tiene un carácter más imitativo, más «moderno», además de ser más compleja de ejecución.

Sección 1: Mudarra utiliza una frase musical para cada verso, pero de una forma particular, pues aunque su unidad es también la cuarteta, utiliza el procedimiento denominado lexaprén. Pone música a la primera cuarteta mediante cuatro frases musicales y a continuación repite la misma música, pero repitiendo los dos últimos versos de la primera cuarteta y continuando con los dos primeros de la segunda cuarteta y así sucesivamente.

\begin{tabular}{clc} 
Verso & \multicolumn{1}{c}{ Texto } & Música \\
1 & Durmiendo yva el Señor & $\mathrm{a}$ \\
2 & en una nave en la mar, & $\mathrm{b}$ \\
3 & sus discípulos con él, & $\mathrm{c}$ \\
4 & que no l'osan recordar, & $\mathrm{d}$ \\
3 & sus discípulos con él, & $\mathrm{a}$ \\
4 & que no l'osan recordar. & $\mathrm{b}$ \\
5 & El agua, con la tormenta, & $\mathrm{c}$ \\
6 & començos'a levantar, & $\mathrm{d}$
\end{tabular}


Los temas que utiliza Mudarra están muy cerca de un estilo declamatorio, con un ámbito muy reducido. Hay que destacar la asimetría entre ellos, pues a pesar de estar contruidos sobre octosílabos, la duración en compases es 8-5-6-9 para los motivos a, b, c $\mathrm{yd}$, respectivamente.
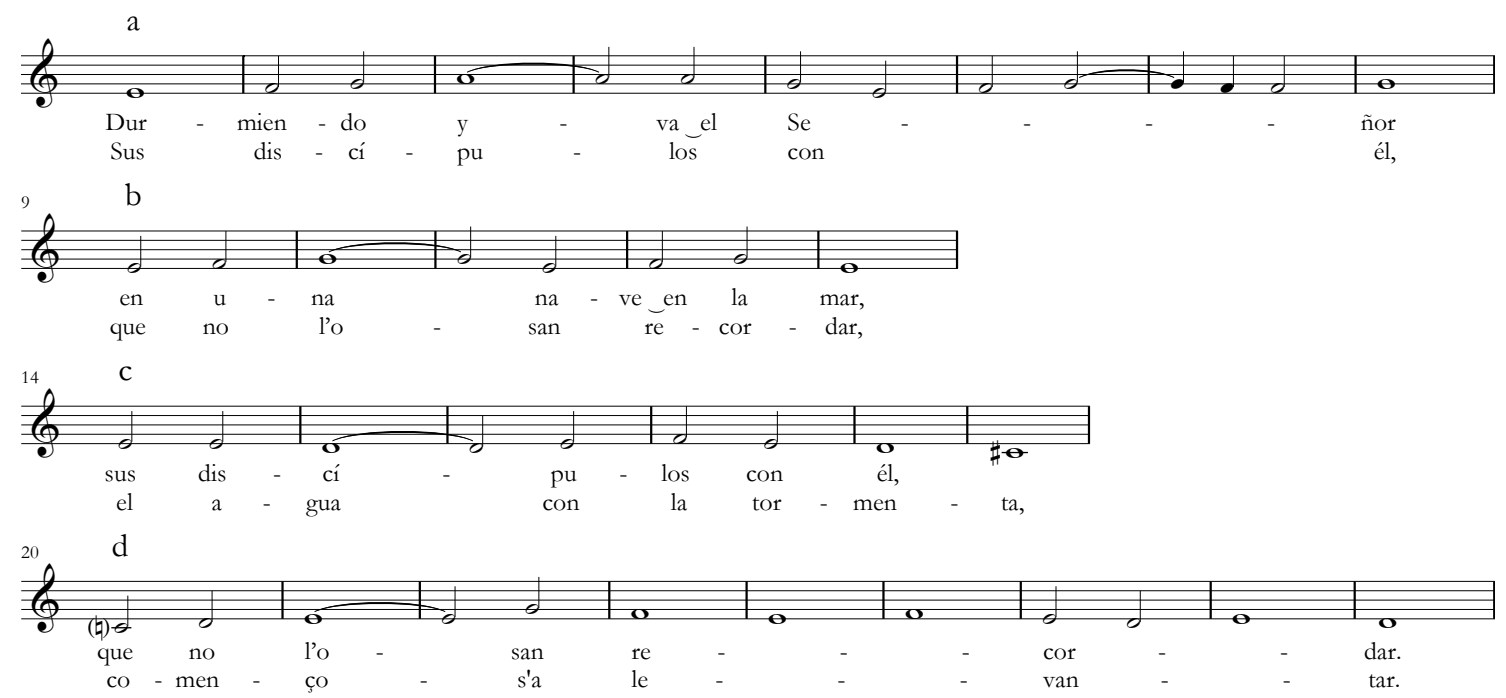

Ejemplo 22. Temas del romance Durmiendo iba el Señor.

Otro hecho significativo que tenemos que resaltar es que, como ya había notado Griffiths para el romance Triste estaba el rey David, ${ }^{838}$ los primeros acordes de la pieza son V - i - VII - III - VII - i, justamente el esquema armónico de la pavana-folía, directamente emparentado con el de pavanilla que veíamos más arriba. Esto, se pregunta Griffiths, «ies un estilo original de Mudarra o puede reflejar algo de las tradiciones orales o populares de recitado musical?». ${ }^{839}$

Sección 2: comienza con un breve pasaje instrumental imitativo. Hay más abundancia de redobles que en la versión anterior. Concluye con una coda plagal.

${ }^{838}$ GrifFiTHS, John. «Luis Milán, Alonso Mudarra y la canción acompañada», Edad de Oro, 22 (2003), pp. 7-28; p. 25.

${ }^{839}$ GRIfFiths, J. «Luis Milán, Alonso Mudarra..., p. 24. 


\section{COMENTARIO}

Esta forma particular de presentar los romances, repitiendo dos versos cada vez, hace que dos cuartetas necesiten tres presentaciones completas de la música. Esto nos lleva a preguntarnos sobre la viabilidad de ejecutar largos poemas, como son los romances generalmente, mediante este sistema. Si como plantea Gásser, las ejecuciones de romances, y de otros géneros, podían superar la hora de duración, ${ }^{840}$ repitiendo dos versos de cada cuatro la duración sería mayor de hora y media. Por supuesto, este sistema se aplica a romances bíblicos de corta duración, lo que no quiere decir que pueda ser extrapolable a otros tipos de romances.

\section{4- Triste estava el rey David}

Romance. IV modo. Posición f (vihuela en G\#). $3+1$ voces. Tempo medio. Notas móviles: Sol $\pitchfork$ (II), La

\section{NOTAS CRÍTICAS}

1. cc. 1-18. En el ejemplar de la BNE la página correspondiente al f. 13r está situada en el f. 12r.

2. cc. 39-44. En el ejemplar de la BNE falta la tercera página, la que correspondería al f. 14r.

3. c. 44. Añadimos la doble barra de repetición.

\section{TEXTO}

No aparece en ninguna otra fuente. ${ }^{841}$ Está inspirado en Libro segundo de Samuel (19, $1-9)$.

Triste estava el rey David, triste y con gran passión, quando le vinieron nuevas,

${ }^{840}$ GÁsSER, L. Luis Milán..., pp. 25-28.

${ }^{841}$ Tomamos la versión de Mudarra, que es la misma que toman BINKLEY, T. y Frenk M. Spanish Romances..., p. 116, con ligerísimas variantes. Existe entre los sefarditas de Israel una versión musical con muchas diferencias musicales y textuales. Citado en GÓMEZ, Maricarmen. «El renacer del repertorio lírico español», GÓMEZ, Maricarmen (ed.). Historia de la música en España e Hispanoamérica. Vol. 2. De los Reyes Católicos a Felipe II. Madrid, Fondo de Cultura Económica, 2012, pp. 21-161; pp. 107-108. 


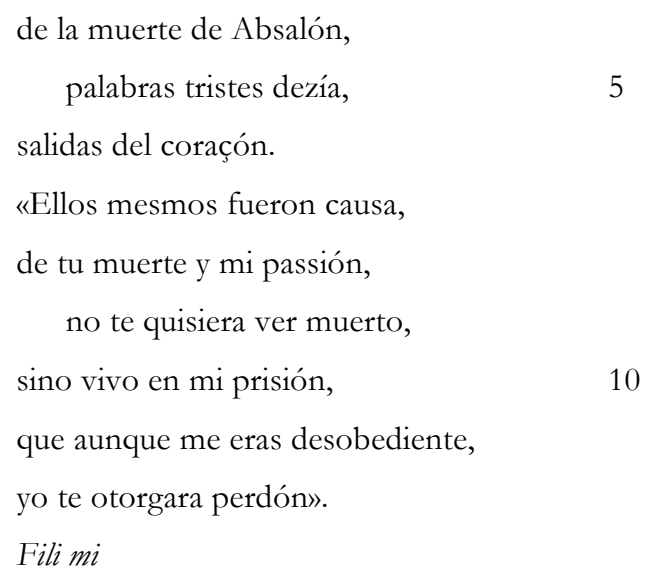

VARIANTES: Mudarra: 11 «aunque me sera desobediente».

\section{ESTRUCTURA}

$\begin{array}{ccccc}\text { Secciones } & \text { Compases } & \text { Cadencia final } & \text { Longitud } & \text { Motivos } \\ 1 & 1-44 & \text { I } & 44 \mathrm{cc} . & \mathrm{a}, \mathrm{b}, \mathrm{c}, \mathrm{d}, \mathrm{e}\end{array}$

\section{ANÁLISIS}

Mudarra vuelve a utilizar el sistema del lexaprén, aunque ahora con la particularidad de que repite la mitad del último verso, «de Absalón», tres veces más y en la segunda cuarteta lo sustituye por «Fili mi», algo que nos podría recordar las exclamaciones finales del romance Paseábase el rey moro.

Como en el romance anterior, la distribución de los versos por compases es asimétrica: 10-7-9-8-10 compases para los motivos a, b, c, d y e, respectivamente, por lo que el cuarto verso toma 18 compases.

La textura general es homofónica, si bien a partir del segundo verso se apuntan algunas desarrollos horizontales y en la tercera hay un comienzo imitativo. A diferencia del anterior romance, los diferentes versos están marcados por cláusulas completas. Al final de la cuarta frase hay un sorpresivo cambio de un acorde mayor sobre el VII grado a uno menor que enlaza con un I grado. Tras un expresivo silencio, comienza una coda con las repeticiones textuales, concluyendo con una cadencia frigia. ${ }^{842}$

${ }^{842}$ Griffiths realiza un interesante análisis de esta pieza. GRIFFITHS, J. «Luis Milán, Alonso Mudarra..., pp. 24-26 


\section{5- Israel, mira tus montes}

Romance. I modo. Posición c (vihuela en A). $3+1$ voces. Tempo medio. Notas móviles: Mi Ł (III), La b (VI), Si Ł (VII). Voz canto: contralto.

\section{NOTAS CRÍTICAS}

1. cc. 1-8. En el ejemplar de la BNE falta la primera página, la que correspondería al f. 14r.

2. En el titulillo donde pone «Entónase la boz en segundo traste» debería decir «Entónase la boz en primer traste».

3. c. 45. Error en el custos del pentagrama superior.

4. c. 52. Añadimos la doble barra de repetición.

\section{TEXTO}

Aparece en otras fuentes como son un pliego suelto de la Biblioteca Nacional (BNE R.

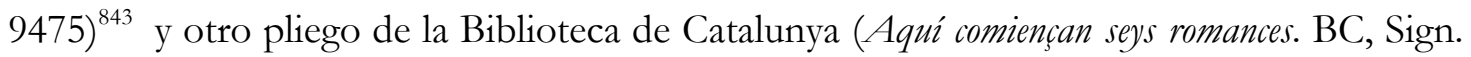
R 261850, fol. 2r-2v), de donde tomamos la continuación del de Mudarra. ${ }^{844}$

Israel mira tus montes

cómo estan ensangrentados

de la sangre de tus nobles,

de tus nobles y esforçados.

¡Ay dolor cómo cayeron

varones tan estimados!

No sepan en Philistea

de casos tan desdichados

ni se alegren las mugeres

de los incircuncidados

llorad hijas de Israel

y teñid vuestros tocados

pues es muerto el rey Saúl

${ }^{843}$ FrenK, Margit. «Sobre los textos poéticos en Juan Vásquez, Mudarra y Narváez». Estudios sobre la lírica antigua. Madrid, Castalia, 1978, pp. 175-203; p. 201.

${ }^{844}$ Tomamos la edición de Brown y García-San Román, aunque le añadimos la acentuación y algún cambio gráfico («v» por «u» consonántica) para ser coherentes con el resto de los textos. BROWN, Kennneth y GARCíA-SAN ROMÁN, Gemma. «Un cuaderno de versos manuscritos en español de ca. 1550 en el Archivo Histórico de Protocolos de Barcelona», Studia Aurea, 8 (2014), pp. 477-608; pp. 594-595. 


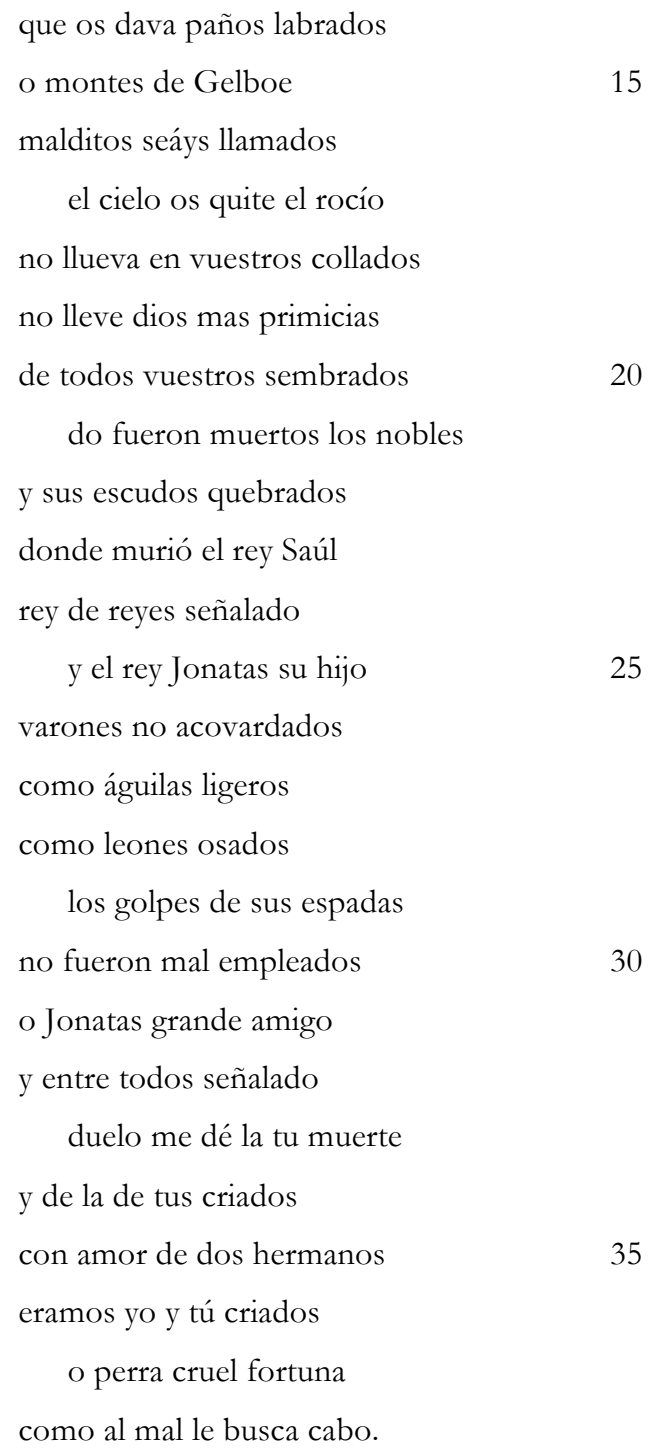

VARIANTES: BC, R 261850: 4 «cavalleros» por «de tus nobles y», 6 «señalados» por «estimados».

\section{ESTRUCTURA}

$\begin{array}{ccccc}\text { Secciones } & \text { Compases } & \text { Cadencia final } & \text { Longitud } & \text { Motivos } \\ 1 & 1-52 & \text { I } & 52 \mathrm{cc} . & \mathrm{a}, \mathrm{b}, \mathrm{c}, \mathrm{d}, \mathrm{e}\end{array}$

\section{ANÁLISIS}

La realización de este tercer romance bíblico es similar a la de los dos anteriores: uso de lexaprén y repetición de las últimas palabras del cuarto verso con distinta música, como en el anterior. Pero ahora incluye un nuevo elemento que nos recuerda mucho a los 
romances de Milán: al final del segundo y del cuarto verso añade unos redobles rápidos, sobre una nota tenida de la voz, que enlazan con el siguiente verso.

La distribución de compases por verso es 8-12-10-13-9; se puede considerar que hay una cierta simetría.

El comienzo es muy estático desde el punto de vista armónico y la melodía que se canta es prácticamente una recitación. A partir del segundo verso (c. 9) hay un poco de imitación, cerrando con una cadencia modal y un pasaje de redobles. El tercero y el cuarto funcionan en contrapunto libre, concluyendo el tercero con cadencia plagal sobre el I grado y el cuarto con redobles. El último cierra con cadencia incompleta sobre el i grado, sin retardo y coda plagal.

\section{COMENTARIO}

Tanto en la edición de Morphy como en la de Pujol, debido a la errata en el titulillo, se opta por poner un sostenido a la primera nota (en nuestro caso sería un becuadro) y, por consiguiente, a las siguientes. Morphy lo pone directamente y Pujol lo sugiere. En terminología de la época están sustituyendo «faes» por «mies». Esto ha provocado que en varias grabaciones discográficas se cante así, alterado. Nosotros no lo vemos necesario, ya que si el titulillo fuera correcto no lo sería la parte escrita en canto de órgano y viceversa. Cierto que en el quinto sistema también hay un error en el custos, pero no deja de ser una errata más de las muchas que contiene el libro de Mudarra y que, como se puede comprobar, se acumulan en algunas piezas.

La pieza se ajusta perfectamente a un I modo, tanto en ámbito como en alteraciones y concuerda con ese estilo recitado improvisado usado para los romances que tan magistralmente nos explica Griffiths en el artículo ya citado. ${ }^{845}$

${ }^{845}$ GRIFFITHS, J. «Luis Milán, Alonso Mudarra... 


\title{
56- Sin dudar. Canción al milagro de la Encarnación
}

Canción. VIII modo. Posición G (vihuela en G). 4 voces. Tempo medio. Notas móviles: Do\# (IV), Fa\# (VII). Voz canto: contralto.

\section{NOTAS CRÍTICAS}

1. cc. 1-7. En el ejemplar de la BNE falta la primera página, la correspondiente al f. 15v.

2. cc. 8-25. En el ejemplar de la BNE la página correspondiente al f. 16r está situada en el $13 \mathrm{r}$.

3. cc. 25-43. En el ejemplar de la BNE la página correspondiente al f. 16v está situada en el 14v.

4. c. 34.. Añadimos la mínima que figura entre corchetes.

5. c. 43. Ponemos 2 en $1^{\circ}$ orden en lugar de 5. Indicado en la fe de erratas del final, aunque incorrectamente, pues pide un 3 en $1^{\circ}$ orden.

6. cc. 44-61. En el ejemplar de la BNE la página correspondiente al f. 17r está situada en el 14r.

7. c. 54 . Ponemos 3 en $3^{\circ}$ orden en lugar de 2 .

8. c. 61. Añadimos la nota que figura entre corchetes.

9. c. 81. La nota del canto debe ser Sol en lugar de La.

10. c. 81 . Ponemos 2 en $4^{\circ}$ orden en lugar de 3 .

11. c. 108 . Mal colocado el 2 del $6^{\circ}$ orden.

12. c. 113. Ponemos 2 en $2^{\circ}$ orden en lugar de 0 .

\section{TEXTO}

Aparece también en el Segundo Cancionero espiritual de Montemayor seguido de una glosa y en un manuscrito de la Biblioteca Nacional de Madrid. ${ }^{846}$

\author{
Sin dudar \\ nunca en gota cupo mar; \\ ni en centella \\ el fuego de do sale ella. \\ Lo mayor \\ nunca cupo en lo menor, \\ sino Dios en la donzella. \\ ¿Por qué arte \\ el todo cupo en la parte?
} 5

No se sabe,

${ }^{846}$ Jorge de Montemayor. Segundo Cancionero espiritual. Amberes, 1558, f. 46v. y A nuestra señora, BNE Mss/3902, f. 139v. 
que'l que en el mundo no cabe

quepa allí.

No basta razón aquí

si la fe no nos desparte.

VARIANTES: BNE Mss/3902: 4 «el fuego do sale», 12 «quepa aquí».

\section{INTRODUCCIÓN}

En los años en los que Mudarra estaba viviendo en el palacio del Infantado y posiblemente escribiendo su libro, la poesía castellana estaba sufriendo una transformación fundamental con la llegada de las nuevas formas italianizantes. Por un lado se seguía cantando la vieja poesía tradicional castellana, representada entre otras por la canción manriqueña o la de Juan del Encina, con sus octosílabos y su temática gobernada por los conceptos del amor cortés; por otro llegaba el influjo petrarquista con sus versos endecasílabos que fluyen libremente, con sus ecos pastoriles y su reflejo de la belleza femenina. La transición de la poesía tradicional a la nueva debió ocurrir entre 1526 y 1533, de la mano, principalmente, de dos amigos, Garcilaso y Boscán. ${ }^{847}$ Tampoco hay que olvidar los «sonetos fechos al itálico modo» que escribió el Marqués de Santillana y que debieron ser recitados o cantados en el palacio de Guadalajara.

Si bien Milán va a ser el primero en publicar canciones para voz e instrumento, antecedentes de la monodía acompañada, ${ }^{848}$ Mudarra va a ser el primero en España en publicar canciones propiamente dichas y formas italianas como el el soneto.

\section{ESTRUCTURA}

$\begin{array}{ccccc}\text { Verso } & \text { Rima } & \text { Motivo } & \text { Compases } & \text { Longitud } \\ 1 & 4 \mathrm{a} & \mathrm{a} & \text { cc. } 1-8 & 8 \mathrm{cc} . \\ 2 & 8 \mathrm{a} & \mathrm{b} & \text { cc. } 9-34 & 26 \mathrm{cc} . \\ 3 & 4 \mathrm{~b} & \text { c } & \text { cc. } 35-45 & 10 \mathrm{cc} . \\ 4 & 8 \mathrm{~b} & \text { d } & \text { cc. } 46-51 & 6 \mathrm{cc} .\end{array}$

${ }^{847}$ RIVERS, Elías L. Boscán y Garcilaso: su amistad y el Renacimiento en España. Sevilla, Sibilina-Fundación BBVA, 2010, pp. 20-23.

${ }^{848}$ Según Griffiths, únicamente una frottola de Bossinensis es la única canción creada para voz e instrumento anterior a las de Milán y Mudarra. GRIFFITHS, J. «Luis Milán, Alonso Mudarra..., p. 7. 


$\begin{array}{lllll}5 & 4 \mathrm{c} & \mathrm{e} & \text { cc. } 52-54 & 3 \mathrm{cc} . \\ 6 & 8 \mathrm{c} & \mathrm{f} & \text { cc. } 55-64 & 10 \mathrm{cc} . \\ 7 & 8 \mathrm{~b} & \mathrm{~g} & \text { cc. } 65-81 & 23 \mathrm{cc} . \\ 1 & 4 \mathrm{~d} & \mathrm{~h} & \text { cc. } 82-87 & 6 \mathrm{cc} . \\ 2 & 8 \mathrm{~d} & \mathrm{i} & \text { cc. } 88-103 & 16 \mathrm{cc} . \\ 3 & 4 \mathrm{e} & \mathrm{j} & \text { cc. } 104-114 & 11 \mathrm{cc} \\ 4 & 8 \mathrm{e} & \mathrm{k} & \text { cc. } 115-121 & 7 \mathrm{cc} . \\ 5 & 4 \mathrm{f} & 1 & \text { cc. } 122-123 & 2 \mathrm{cc} . \\ 6 & 8 \mathrm{f} & \mathrm{m} & \text { cc. } 124-132 & 9 \mathrm{cc} . \\ 7 & 8 \mathrm{~d} & \mathrm{n} & \text { cc. } 133-139 & 7 \mathrm{cc} .\end{array}$

ANÁLISIS

Esta canción dedicada a la Virgen todavía está anclada en la métrica antigua, con octosílabos y pies quebrados. Está muy cerca de la copla manriqueña, aunque con una estructura particular, pues se trata de pareados agrupados en estrofas de siete versos, rematados con un verso que rima con el inicio. No se mantiene totalmente la rima entre una estrofa y otra, ya que en la primera el séptimo verso rima con el tercero y el cuarto y en la segunda con el primero y segundo.

La música que se aplica al texto, que además va tañida en la vihuela, es mucho más asimétrica que en los romances antes vistos. En sus 145 compases (si contamos la repetición) el texto se reparte sin aparente estructura y con una gran cantidad de repeticiones textuales y en algunos casos melódicas. La melodía se libera del corsé de la rima y vuela libremente en un ámbito muy grande, de décima, con un carácter fuertemente lírico. ${ }^{849}$

${ }^{849}$ Pocas grabaciones hay de esta pieza debido a su gran dificultad para los cantantes. 


\section{7- Recuerde el alma dormida}

Canción. II modo. Posición f (vihuela en E). $3+1$ voces. Tempo medio. Notas

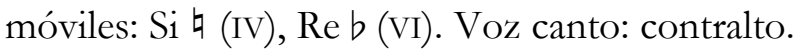

\section{NOTAS CRÍTICAS}

1. cc. 1-38. Falta toda la canción en el ejemplar de la BNE.

2. c. 38. Añadimos la breve que figura entre corchetes.

\section{TEXTO}

Se trata de las Coplas a la muerte de su padre de Jorge Manrique. ${ }^{850}$

Recuerde el alma dormida, abive el seso [y] despierte

contemplando

cómo se pasa la vida,

cómo se viene la muerte

tan callando.

Quán presto se va el placer, cómo, después de acordado, da dolor;

cómo, a nuestro parescer,

qualquier[a] tiempo pasado

fue mejor.

Pues si vemos lo presente cómo en un punto se es ido y acabado,

si juzgamos sabiamente, daremos lo no venido por pasado.

No se engañe nadie, no, pensando que ha de durar

lo que espera

más que duró lo que vio,

${ }^{850}$ Tomamos el inicio de Mudarra y algunos versos más de JORGE MANRIQUE. Obra completa. Edición de Augusto Cortina. Madrid, Espasa Calpe, 1979, pp. 115-116. 


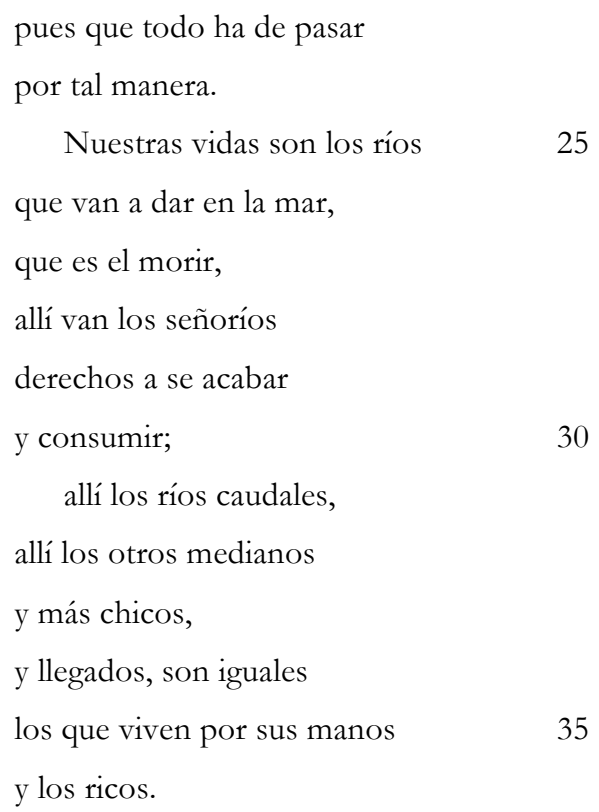

VARIANTES: Mudarra: 2 falta «y», 11 «qualquier».

\section{ESTRUCTURA}

$\begin{array}{ccccc}\text { Verso } & \text { Rima } & \text { Motivo } & \text { Compases } & \text { Longitud } \\ 1 & 8 \mathrm{a} & \mathrm{a} & \text { cc. } 1-6 & 6 \mathrm{cc} . \\ 2 & 8 \mathrm{~b} & \mathrm{~b} & \text { cc. } 7-13 & 7 \mathrm{cc} . \\ 3 & 4 \mathrm{c} & \text { c } & \text { cc. } 14-18 & 5 \mathrm{cc} . \\ 4 & 8 \mathrm{a} & \text { a' } & \text { cc. } 19-24 & 6 \mathrm{cc} . \\ 5 & 8 \mathrm{~b} & \text { b' } & \text { cc. } 25-31 & 7 \mathrm{cc} . \\ 6 & 8 \mathrm{c} & \text { d } & \text { cc. } 32-38 & 7 \mathrm{cc} .\end{array}$

\section{ANÁLISIS}

Muy diferente a la canción anterior y más cercana a los romances en cuanto a la realización musical. La estructura es completamente estrófica, las frases simétricas y el ámbito más reducido, casi un recitado. Mudarra nos muestra cómo es capaz de componer en muy diversos estilos, según la poesía que quiera poner en música. 


\section{COMENTARIO}

El texto de Mudarra es muy fiel al de Manrique. Morphy transcribe esta obra y la siguiente. ${ }^{851}$

\section{8- Claros y frescos ríos}

Canción. II modo. Posición g (vihuela en G). $3+1$ voces. Tempo medio. Notas móviles: La b (II), Mi b (VI), Fa\# (VII). Voz canto: soprano.

\section{NOTAS CRÍTICAS}

1. cc. 1-17. Falta el primer folio en el ejemplar de la BNE.

2. c. 10. Añadimos la mínima que figura entre corchetes.

3. c. 14 . Ponemos 2 en $4^{\circ}$ orden en lugar de 3 .

4. c. 17. Ponemos 2 en $4^{\circ}$ orden en lugar de 3 .

5. c. 27. Sobra una figura de semimínima.

6. c. 33. Ponemos 3 en $2^{\circ}$ orden en lugar de 2 .

7. c. 37. Ponemos mínima con puntillo y semimínima en lugar de mínima con puntillo y mínima.

8. c. 40 . Ponemos 2 en $5^{\circ}$ orden en lugar de 3 .

9. c. 41. Añadimos el puntillo a al mínima.

\section{TEXTO}

El texto de Juan Boscán dice así: ${ }^{852}$

\section{Claros y frescos ríos}

que mansamente vays

siguiendo vuestro natural camino;

desiertos montes míos,

que en un estado estáys

de soledad muy triste de contino;

aves, en quien ai tino

${ }^{851}$ MORPHY, G. Les Luthistes espagnoles..., vol. II, pp. 113-115.

852 Tomamos el inicio de Mudarra y añadimos otra estrofa tomada de la edición de 1543. BosCán, Juan. Las obras de Boscán y algunas de Garcilasso de la vega repartidas en quatro libros. Barcelona, Carles Amoros, 1543, ff. 30-33v. 
de estar sienpre cantando,

árboles que vivís,

y al fin también morís,

perdiendo a vezes tiempos y ganando;

oýdme iuntamente

mi box amarga, ronca y tan doliente.

Pues quiso mi ventura,

que uviesse d'apartarme

de quien jamás osé pensar partirme;

en tanta desventura

conviene consolarme,

que no es agora tiempo de morirme.

El alma a de estar firme,

que'n un tan baxo'stado

vergonçosa es la muerte

si acabo en mal tan fuerte,

todos dirán, que voy desesperado;

y quien tan bien amó

no es bien que digan, que tan mal murió.

VARIANTES: Boscán: 5 «que’n», 8 «de descansar cantando», 10 «y en fin», 12 «juntamente», 13 «boz».

\section{ESTRUCTURA}

$\begin{array}{ccccc}\text { Verso } & \text { Rima } & \text { Motivo } & \text { Compases } & \text { Longitud } \\ 1 & 7 \mathrm{a} & \mathrm{a} & \text { cc. } 1-5 & 5 \mathrm{cc} . \\ 2 & 7 \mathrm{~b} & \text { a' } & \text { cc. } 6-9 & 4 \mathrm{cc} . \\ 3 & 11 \mathrm{C} & \mathrm{b} & \text { cc. } 10-17 & 8 \mathrm{cc} . \\ 4 & 7 \mathrm{a} & \mathrm{a} & \text { cc. } 1-5 & 5 \mathrm{cc} . \\ 5 & 7 \mathrm{~b} & \text { a' } & \text { cc. } 6-9 & 4 \mathrm{cc} . \\ 6 & 11 \mathrm{C} & \text { b } & \text { cc. } 10-17 & 8 \mathrm{cc} . \\ 7 & 7 \mathrm{c} & \text { a } & \text { cc. } 18-22 & 5 \mathrm{cc} . \\ 8 & 7 \mathrm{~d} & \text { a' } & \text { cc. } 23-27 & 5 \mathrm{cc} . \\ 9 & 7 \mathrm{e} & \text { a" } & \text { cc. } 28-31 & 4 \mathrm{cc} . \\ 10 & 7 \mathrm{e} & \text { a' } & \text { cc. } 32-35 & 4 \mathrm{cc} . \\ 11 & 11 \mathrm{D} & \text { c } & \text { cc. } 36-41 & 6 \mathrm{cc} . \\ 12 & 7 \mathrm{f} & \text { d } & \text { cc. } 42-53 & 12 \mathrm{cc} . \\ 13 & 11 \mathrm{~F} & \text { e } & \text { cc. } 54-63 & 10 \mathrm{cc} .\end{array}$




\section{ANÁLISIS}

Métricamente se trata de una estancia o canción petrarquista. Mudarra se plantea cómo resolver la estructura. Lo que hace es utilizar la forma poética como modelo para la forma musical. Comparemos la estructura métrica y la forma con los motivos melódicos (a la derecha).

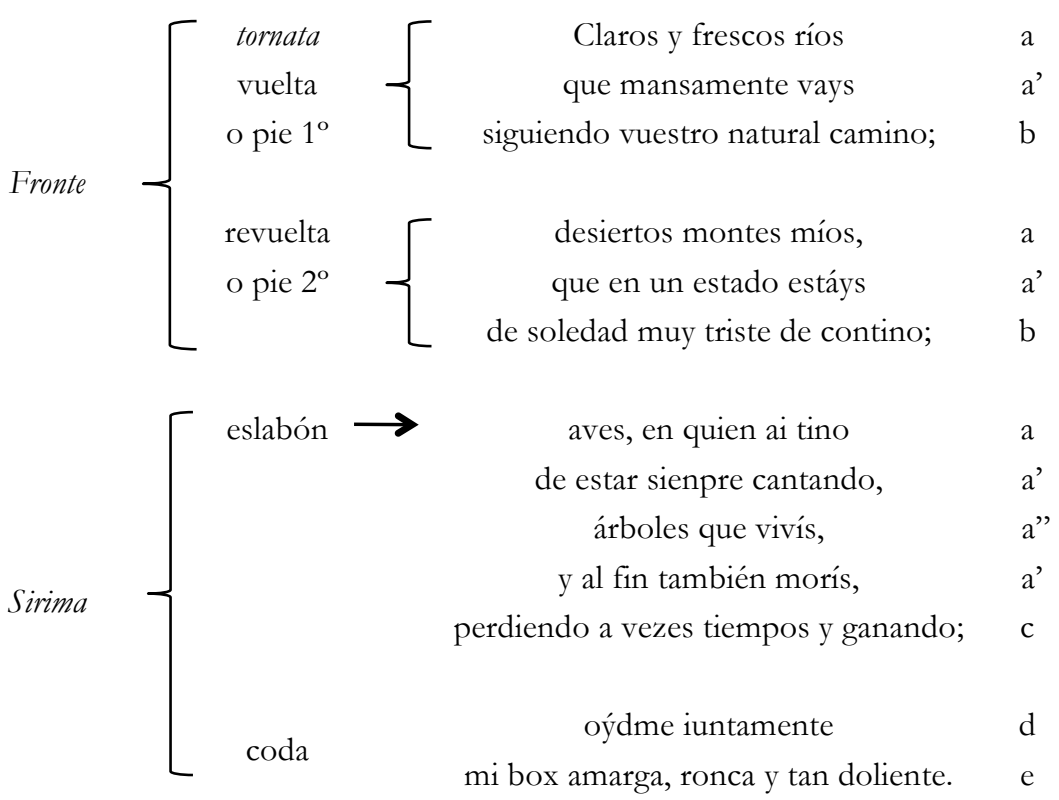

Mudarra repite la misma música para los dos pies, siendo la primera y segunda frase muy parecidas y, de nuevo, casi un recitado. Para el verso eslabón y el siguiente repite el inicio. Abandona el estilo recitado únicamente en los tres últimos versos, particularmente en los dos que forman la coda. La textura es permanentemente homofónica, sin ningún momento imitativo.

\section{COMENTARIO}

Hay una versión de la canción a tres voces en el cancionero de Medinaceli. ${ }^{853}$

${ }^{853}$ Cancionero musical de la Casa de Medinaceli (Siglo XVI) I. Polifonía profana. Transcripción y estudio por Miguel Querol Gavaldá. MME VIII-IX, 2 vols. Barcelona, CSIC, Instituto Español de Musicología, 1949, vol. 1, pp. 9-10. Querol atribuye la versión de Mudarra a Guerrero. 


\section{9- ¿Qué llantos son aquestos?}

Soneto. IV modo. Posición $\mathrm{f}$ (vihuela en F\#). $3+1$ voces. Tempo medio y lento.

Notas móviles: Sol Ł (II), La

\section{NOTAS CRÍTICAS}

1. cc. 8-23. Mal colocado en el ejemplar de la BNE. En el lugar del f. 24v.

2. c. 11. Falta el puntillo en la mínima de canto de órgano.

3. c. 17. Mal colocada la breve, debe ser Si en lugar de La (Do en lugar de Si en nuestra transcrición).

4. c. 23. Añadimos la nota que figura entre corchetes.

5. cc. 24-55. En el ejmplar de la BNE invertidos f. 24 y f. 24v.

6. c. 42. Mal colocada la semimínima.

7. c. 49 . Ponemos 5 en $3^{\circ}$ orden en $4^{\circ}$ orden y 4 en $2^{\circ}$ orden en $3^{\circ}$ orden.

TEXTo

Se trata de un soneto escrito en forma de diálogo.

¿Qué llantos son aquestos? ¿Qué fatiga

es esta? ¿Qué tristeza es la que veo?

-Murió nuestra princesa, la qual, creo

que fue más de virtud que nadie amiga.

_ ¿Cómo en los mesmos dioses, la enemiga

del hombre, así esecuta su deseo?

—Sí que la muerte puede, según beo,

hazer que lo mortal el alma siga.

—Pues ¿qué es de su poder? ¿dó su grandeza?

-Agora todo le es sin fruto y vano;

desanparóle todo al paso fuerte.

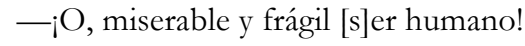

$¡ \mathrm{O}$, quán poca zeniza en tal tristeza

la llama y resplandor claro convierte! 


\section{INTRODUCCIÓN}

Comienzan tres sonetos castellanos puestos en música. De nuevo Mudarra es pionero ya que se trata de los primeros publicados en España. No sin ciertas reservas, podríamos pensar en estas piezas como los primeros balbuceos del madrigal castellano.

\section{ESTRUCTURA}

\begin{tabular}{|c|c|c|c|c|c|}
\hline Verso & Rima & Motivo & Voz & Compases & Longitud \\
\hline 1 & $11 \mathrm{~A}$ & \multirow{2}{*}{$\mathrm{a} 1, \mathrm{a} 2, \mathrm{a} 3$} & \multirow{2}{*}{ contralto } & \multirow{2}{*}{ cc. $1-16$} & \multirow{2}{*}{$16 \mathrm{cc}$} \\
\hline 2 & $11 \mathrm{~B}$ & & & & \\
\hline 3 & $11 \mathrm{~B}$ & \multirow{2}{*}{ b1, b2 } & \multirow{2}{*}{ tenor } & \multirow[b]{2}{*}{ cc. $17-25$} & \multirow[b]{2}{*}{$9 \mathrm{cc}}$. \\
\hline 4 & $11 \mathrm{~A}$ & & & & \\
\hline 5 & $11 \mathrm{~A}$ & \multirow{2}{*}{$\mathrm{a} 1, \mathrm{a} 2, \mathrm{a} 3$} & \multirow{2}{*}{ contralto } & \multirow{2}{*}{ cc. $1-16$} & \multirow{2}{*}{$16 \mathrm{cc}}$. \\
\hline 6 & 11B & & & & \\
\hline 7 & 11B & \multirow{2}{*}{ b1, b2 } & \multirow{2}{*}{ tenor } & \multirow{2}{*}{ cc. $17-25$} & \multirow{2}{*}{$9 \mathrm{cc}}$. \\
\hline 8 & $11 \mathrm{~A}$ & & & & \\
\hline 9 & $11 \mathrm{C}$ & a1, a2' & contralto & cc. $27-34$ & $9 \mathrm{cc}$. \\
\hline 10 & $11 \mathrm{D}$ & \multirow{2}{*}{ b1, b2' } & \multirow{2}{*}{ tenor } & \multirow{2}{*}{ cc. $35-44$} & \multirow{2}{*}{$10 \mathrm{cc}}$. \\
\hline 11 & $11 \mathrm{E}$ & & & & \\
\hline 12 & $11 \mathrm{D}$ & a1 & \multirow{3}{*}{ contralto } & \multirow{3}{*}{ cc. $45-68$} & \multirow{3}{*}{$24 \mathrm{cc}}$. \\
\hline 13 & $11 \mathrm{C}$ & a1 & & & \\
\hline 14 & $11 \mathrm{E}$ & $\mathrm{c}$ & & & \\
\hline
\end{tabular}

\section{ANÁLISIS}

Los versos 1 y 2 van seguidos, sin pausa, por lo que el motivo a2 pertenece a los dos. Lo mismo ocurre con los versos 3 y 4, repitiéndose en el segundo cuarteto. No hay que perder de vista que los compases del tenor son dobles que los del contralto. Podríamos hablar, mutatis mutandis, de un encabalgamiento melódico.

Con muy poco material melódico, Mudarra es capaz de resolver el cómo adaptar la nueva métrica italiana a la música, sin tener ningún modelo previo en España. Quedaría por ver las influencias externas que conoció y que le pudieron servir de guía, pero ello excede este análisis, por lo que lo dejamos para posteriores trabajos. 


\section{COMENTARio}

La obra es un soneto elegíaco o epitafio dedicado a la muerte de María Manuela de Portugal, primera esposa del príncipe Felipe, quien falleció el 12 de julio de 1545, a los pocos días de dar a luz al príncipe Carlos. Este dato hace obligatorio que la composición sea posterior y que, por lo menos, el tercer libro fuera concluido después de esa fecha.

En cuanto a la autoría del texto, Pujol plantea la posibilidad de que sea Jorge de Montemayor o Gregorio Silvestre. ${ }^{854}$ Blecua se decanta más por Montemayor. ${ }^{855}$ No sería descartable que el autor fuera el propio Mudarra, habida cuenta que en la mayoría de las piezas vocales indica el autor del texto.

Los epitafios dialogados con preguntas y respuestas fueron bastante comunes en círculos alcalaínos o sevillanos y entre poetas del siglo XVI como Diego Hurtado de Mendoza, Jorge de Montemayor o Gutierre de Cetina. ${ }^{856}$

Esta obra fue publicada por Jacobs. ${ }^{857}$

${ }^{854}$ Pujol Mudarra, p. 79.

${ }^{855}$ BLECUA, J. M. «Mudarra y la poesía..., p. 175.

${ }^{856}$ PONCE CÁRDENAS, Jesús. «El epitafio hispánico en el Renacimiento: textos y contextos», La mort des grands; arts, textes et rites (XIe-XVIIIe siècle). e-Spania, 17 (2014). Revista electrónica en <http://espania.revues.org> [consulta 10-6-2015]

${ }^{857}$ JACOBS, Charles. Tempo Notation in Renaissance Spain. Musicological Studies, 8. Brooklyn Nueva York, Institute of Medieaeval Music, 1964, pp. 82-84. 


\section{0- Si por amar el hombre}

Soneto. II modo. Posición g (vihuela en G). $3+1$ voces. Tempo medio. Notas móviles: Si 4 (III), Do\# (IV), Mi b (VI), Fa\# (VII). Voz canto: soprano.

\section{NOTAS CRÍTICAS}

1. En el ejemplar de la BNE están invertidos los folios y está intercalada la primera página de la siguiente pieza.

2. c. 68. La semibreve es innecesaria.

3. c. 77 . La semimínima es innecesaria.

TEXTO

Si por amar el hombre ser amado

merece, y por querer bien, ser querido, no sé yo por qué soy aborrecido,

mas sé que siempre duro en este estado.

Si un coraçón senzillo y no doblado

merece un amor cierto y no fingido,

quán desdichado devo de aver sido,

pues lo que se me deve aún no me an dado.

Y si por servir siempre a porfía

se alcança galardón destos officios,

10

sin que más me repliques ni me alegues,

ámame, pues que te amo, ánima mía;

quiéreme, pues te adoro, y no me niegues

el galardón devido a mis servicios.

El texto es anónimo, aunque se encuentra reproducido en un cancionero sevillano tardío junto a sonetos de Diego Hurtado de Mendoza (el poeta). ${ }^{858}$

${ }^{858}$ El cancionero estaría fechado en 1560-1570. Cancionero sevillano de Toledo. Manuscrito 506 (fondo BorbónLorenzana) Biblioteca de Castilla-La Mancha. LABrador Herraiz, José L.; DiFranCO, Ralph A.; Montero, Juan (eds.). Sevilla, Universidad de Sevilla, 2006, p. 353. 


\section{ANÁLISIS}

Al igual que en el soneto anterior, Mudarra utiliza la misma música para los dos primeros cuartetos, encadenando los motivos melódicos con los versos (hecho que será característico de los madrigales). Utiliza el mismo motivo para los dos primeros versos del primer terceto y nuevas melodías para los siguientes versos, retomando el cuarto motivo de los cuartetos para el último verso del soneto. En realidad, todos los motivos utilizados están estrechamente emparentados, pues se trata de notas repetidas comenzando a diferentes alturas.

Aunque la textura es predominantemente homofónica, hay un cierto movimiento de las voces de la vihuela, tal vez para compensar el estatismo de la voz cantante.

\section{COMENTARio}

Morphy transcribe este soneto y el siguiente. ${ }^{859}$

\section{1- Por ásperos caminos}

Soneto. VIII modo. Posición f (vihuela en A). $3+1$ voces. Tempo medio. Notas móviles: Si Ł (IV), Do\# (V), Mi Ł (VII). Voz canto: soprano.

\section{NOTAS CRÍTICAS}

1. En el ejemplar de la BNE todos los folios están invertidos e intercalados algunos de la anterior pieza.

2. c. 18. Añadimos la semibreve que figura entre corchetes.

3. c. 22. Añadimos la nota que figura entre corchetes.

4. cc. 42-48. Sustituimos el texto, pues es muy probable que se trate de un error.

5. c. 60 . La semimínima es innecesaria.

6. c. 78.3 en $6^{\circ}$ orden invertido.

\section{Texto}

Se trata del Soneto VI de Garcilaso de la Vega. ${ }^{860}$

${ }^{859}$ MORPHY, G. Les Luthistes espagnoles..., vol. II, pp. 116-119. 
Por ásperos caminos soy llevado

a parte que de miedo no me muevo,

y si a mudarme a dar un paso pruevo

allí por los cabellos soy tornado;

mas tal estoy que con la muerte al lado

busco de mi vivir consejo nuevo,

[y] conozco el mejor y el peor apruevo

o por costumbre mala o por mi hado.

De la otra parte, el breve tiempo mío

y el errado proceso de mis años,

en su primer principio y en su medio,

mi inclinación, con quien ya no porfío

la cierta muerte, fin de tantos daños,

me hacen descuidar de mi remedio.

VARIANTES: Garcilaso: 1 «he llegado», Mudarra: 7 falta «y» y se produce dialefa, Garcilaso: 9 «por otra parte», Mudarra: 10 «herrado», 11 repite «y el herrado proceso de mis años», 13 «la ciertamente».

Comparando con la versión de Barcelona de 1543, podemos afirmar que Mudarra no usó esta fuente, sino otra, posiblemente manuscrita.

\section{ESTRUCTURA}

$\begin{array}{ccccc}\text { Verso } & \text { Rima } & \text { Motivo } & \text { Compases } & \text { Longitud } \\ 1 & 11 \mathrm{~A} & \mathrm{a} & \text { cc. } 1-10 & 10 \mathrm{cc} . \\ 2 & 11 \mathrm{~B} & \mathrm{~b} & \text { cc. } 11-18 & 8 \mathrm{cc} . \\ 3 & 11 \mathrm{~B} & \text { c } & \text { cc. } 19-24 & 6 \mathrm{cc} . \\ 4 & 11 \mathrm{~A} & \mathrm{~d} & \text { cc. } 25-31 & 7 \mathrm{cc} . \\ 5 & 11 \mathrm{~A} & \mathrm{a} & \text { cc. } 1-10 & 10 \mathrm{cc} . \\ 6 & 11 \mathrm{~B} & \text { b } & \text { cc. } 11-18 & 8 \mathrm{cc} . \\ 7 & 11 \mathrm{~B} & \text { c } & \text { cc. } 19-24 & 6 \mathrm{cc} . \\ 8 & 11 \mathrm{~A} & \mathrm{~d} & \text { cc. } 25-31 & 7 \mathrm{cc} . \\ 9 & 11 \mathrm{C} & \text { e } & \text { cc. } 32-41 & 10 \mathrm{cc} . \\ 10 & 11 \mathrm{D} & \mathrm{f} & \text { cc. } 42-48 & 7 \mathrm{cc} .\end{array}$

${ }^{860}$ Tomamos el texto de Mudarra, excepto en las erratas evidentes y lo contrastamos con GARCILASO DE LA VEGA. Poesías castellanas completas. Rivers, Elías L. (ed.). Madrid, Castalia, 2003, 3ª ed., p. 48. 


$\begin{array}{lllll}11 & 11 \mathrm{E} & \mathrm{f}^{\prime} & \text { cc. } 49-55 & 7 \mathrm{cc} . \\ 12 & 11 \mathrm{C} & \mathrm{g} & \text { cc. } 56-62 & 7 \mathrm{cc} . \\ 13 & 11 \mathrm{D} & \text { g' } & \text { cc. } 63-70 & 8 \mathrm{cc} . \\ 14 & 11 \mathrm{E} & \text { h } & \text { cc. } 71-81 & 11 \mathrm{cc} .\end{array}$

ANÁLISIS

Se repite el tratamiento dado a los anteriores sonetos, los dos primeros cuartetos reciben la misma música, y los tercetos varían. Notamos varias diferencias fundamentales: cada verso tiene asignado un motivo melódico, que concluye en una cadencia o un reposo armónico. Las melodías son mucho más cantables, lejos de los recitado previos. A pesar de la homofonía dominante, hay una cierta imitación en las voces de la vihuela. Hay un breve interludio contrapuntístico al inicio del primer terceto con imitación entre la vihuela y la voz. En este mismo terceto se produce una progresión. El último es bastante melismático.

Creemos que la realización musical de este soneto es previa a la de los sonetos anteriores e incluso a las canciones. Mudarra se muestra mucho más conservador y pone música al texto de Garcilaso como si se tratara de un romance.

\section{2- Regia qui mesto}

Versos en latín. II modo. Posición f (vihuela en E). $3+1$ voces. Tempo medio. Notas móviles: Si $\sqsubset$ (IV), Re b (VI), Mi $\nleftarrow$ (VII). Voz canto: contralto.

\section{NOTAS CRÍTICAS}

1. En el ejemplar de la BNE están desordenadas las páginas. El f. 31 (cc. 16-33) está antes que el f. 30v (cc. 1-15). Lo mismo para f. 31v (cc. 34-50) y el f. 32 (cc. 35-62).

2. c. 14. Añadimos la semimínima que figura entre corchetes.

3. c. 34. Añadimos la nota que figura entre corchetes. 
Epitafio latino. De nuevo se trata de un lamento por la muerte de la princesa María Manuela de Portugal, al igual que el soneto ¿Qué llantos son aquestos?, en esta ocasión en latín. $^{861}$

Regia qui mesto spectas cenotaphia vultu, quid stas? quin largo perluis imbre genas? Occidit, occideret princeps, sed qualem nulla dederunt tempora, sed qualem tempora nulla dabunt.

Corripit accipiter meliorem examine praedam. 5 Mors, o crudelis, o rimaque qui rapis Philipum. Philipus in terris mihi sponsus in aethere Christus, si fors plus posset plura datura fuit.

Nil mihi vobiscum, iam mors et vita.

Valete nam vivo felix non moritura deo. 10

Haec mihi sit vita, haec requies aeterna laborum.

Cetera nam semper sors violenta rapit.

VARIANTES: Mudarra: 6 «Philipus»», 8 «poset», 10 «faelix».

Tú que miras con rostro triste este túmulo real, ¿qué haces ahí parado? ¿Por qué no riegas tus mejillas con larga lluvia? Murió ella, y habría muerto el príncipe, pero a unos se les acaba el tiempo, mientras a otros aún les queda.

El águila arrebató la mejor presa del rebaño. 5 ¡Oh!, cruel muerte. ¡Oh!, sima que atrapas a Felipe. Felipe fue en la tierra mi esposo y Cristo en el cielo. Si acaso hubiese podido, más le habría entregado.

Nada tengo ya con vosotros, solo la muerte y la vida. Quedaos en paz, porque vivo feliz y no moriré para Dios. 10

Esta será mi vida y el descanso eterno de mis trabajos.

Pues la suerte violenta arrebata siempre lo demás.

${ }^{861}$ Tomamos el texto de Mudarra y la traducción de REY, Pepe. Músicas para Felipe II. Programa de mano del Ciclo celebrado en el Auditorio Municipal de Logroño, Febrero 1998, p. 45. 


\section{ESTRUCTURA}

$\begin{array}{ccccc}\text { Secciones } & \text { Compases } & \text { Cadencia final } & \text { Longitud } & \text { Motivos } \\ 1 & 1-23 & \text { V } & 23 \mathrm{cc} . & \mathrm{a} \\ 2 & 24-36 & \text { V } & 13 \mathrm{cc} . & \mathrm{b} \\ 3 & 37-51 & \text { III } & 15 \mathrm{cc} . & \mathrm{c} \\ 4 & 52-62 & \text { I } & 11 \mathrm{cc} . & \mathrm{d}\end{array}$

ANÁLISIS

A diferencia de los primeros sonetos, cada frase del texto se corresponde más o menos con una frase musical. Sin embargo, podemos apreciar desde el primer motivo una cierta homofonía y un predominio de valores largos y breves.

Sección 1: Comienza con una introducción en la vihuela basada en un motivo que va pasando de voz en voz hasta ser recogido por el canto con el primer verso. Cadencia de forma notoria en el $\mathrm{V}$ grado añadiendo unas glosas finales de remate.

Sección 2: la vihuela recoge un motivo ascendente escuchado antes, mientras que la voz entona una melodía descendente. Cadencia de forma clara de nuevo sobre el V grado.

Sección 3: pasaje homofónico sobre las palabras « Occidit, occideret princeps». Toma parte del siguiente verso.

Sección 4: nuevamente la vihuela anuncia un tema en imitación que es recogido por la vOZ cantante.

No queda muy claro el registro de la voz que canta: unas veces ocupa la tesitura de contralto, otras de tenor y otras de soprano, lo cual es inusual en las piezas vocales de Mudarra, que suele ser bastante riguroso en el número de voces y sus ámbitos.

\section{COMENTARIO}

Esta elegía de autor anónimo abre el grupo de los versos en latín en la obra de Mudarra, las únicas piezas profanas latinas de todo el repertorio vihuelístico. Posiblemente Mudarra conoció los experimentos de Petrus Tritonius quien puso en música odas de Horacio, publicadas en 1507 y algunas de ellas recogidas por el laudista Hans Judenkünig. Sí parece claro que Mudarra conoció, como veremos después, a los imitadores de 
Tritonius, Paul Hofhaimer y Ludwig Senfl. Tal vez intentó con esta pieza imitar el verso latino mediante la combinación de sílabas largas y cortas y el uso de la homofonía. ${ }^{862}$

\section{3- Dulces exuviae}

Versos en latín. II modo. Posición g (vihuela en G). 3 + 1 voces. Tempo medio. Notas móviles: Si $\sqsubset$ (III), Do\# (IV), Mi b (VI), Fa\# (VII). Voz canto: soprano.

\section{NOTAS CRÍTICAS}

1. En el ejemplar de la BNE están desordenadas las páginas. El f. 33 (cc. 17-34) está antes que el 32v (cc. 1-16). También el f. 33v (cc. 35-52) y f. 34 (cc. 53-70). También f. 34v (cc. 71-90) está desplazado.

2. c. 18 . Ponemos 2 en $5^{\circ}$ orden en lugar de 3 .

3. c. 15 . Dividimos la mínima para ajustar «moe-ni-a».

4. c. 25. Añadimos la semibreve que figura entre corchetes.

5. c. 57. Dividimos la mínima para ajustar «me-i».

6. c. 60 . Ponemos 3 en $3^{\circ}$ orden en lugar de 2 .

7. c. 69. Añadimos la semibreve que figura entre corchetes.

8. c. 69. Dividimos la mínima para ajustar «ta-li-a».

9. c. 70. Añadimos el puntillo de la mínima.

10. c. 72 . Ponemos 2 en $4^{\circ}$ orden en lugar de 3 .

\section{TEXTO}

Se trata del monólogo final de Dido del libro IV de la Eneida de Virgilio (651-665). ${ }^{863}$

«Dulces exuviae, dum fata deusque sinebat, accipite hanc animam meque his exsolvite curis.

Vixi et quem dederat cursum Fortuna peregi, et nunc magna mei sub terras ibit imago.

${ }^{862}$ Atlas, A. W. La música del Renacimiento..., pp. 696-697. Bergua CAVero, Jorge. La música de los clásicos. Versiones de la poesía antigua de la Edad Media al Renacimiento. Valencia, Pre-textos, 2012, pp. 85-97.

${ }^{863}$ Tomamos el texto y la traducción de VIRGILIO. Eneida. (Introducción y traducción de Rafael Fontán Barreiro). Madrid, Alianza, 1990, p. 63. 
ulta virum poenas inimico a fratre recepi,

felix, heu nimium felix, si litora tantum

numquam Dardaniae tetigissent nostra carinae.»

dixit, et os impressa toro «moriemur inultae,

sed moriamur» ait. «Sic, sic iuvat ire sub umbras,

hauriat hunc oculis ignem crudelis ab alto

Dardanus, et nostrae secum ferat omina mortis».

Dixerat, atque illam media inter talia ferro

conlapsam aspiciunt comites, ensemque cruore

spumantem sparsasque manus.

VARIANTES: Mudarra (utilizamos la numeración de los versos estandarizada de la Eneida): 651

«sinebant», 656 «penas», «frare», 657 «faelix» una vez, «tamtum», 658 «tetegisent», «carine», 659 «inpressa», «inulte», 662 «nostre».

«Dulces prendas, mientras los hados y el dios lo permitían, acoged a esta alma y libradme de estas angustias.

He vivido, y he cumplido el curso que Fortuna me había marcado, y es hora de que marche bajo tierra mi gran imagen.

He fundado una ciudad ilustre, he visto mis propias murallas, castigo impuse a un hermano enemigo tras vengar a mi esposo: feliz, jah!, demasiado feliz habría sido si solo nuestra costa nunca hubiesen tocado los barcos dardanios.»

Dijo, y, la boca pegada al lecho: «Moriremos sin venganza, mas muramos», añade. «Así, así me place bajar a las sombras, que devore este fuego con sus ojos desde alta mar el troyano cruel y se lleve consigo la maldición de mi muerte.»

Había dicho, y entre tales palabras la ven las siervas vencida por la espada, y el hierro espumante de sangre y las manos salpicadas.

\section{COMENTARIO}

Desde principios del siglo XVI, muchos compositores pusieron en música este texto. Ocurre un hecho bastante común en la literatura y que consiste en que de un poema épico 
se desgaje un fragmento lírico y cobre vida propia. ${ }^{864}$ Tal vez el primero, o uno de los primeros, en escribir sobre este lamento fuera Josquin, seguido de Mouton, Willaert, Arcadelt, Lasso y muchos otros compositores de menor categoría. ${ }^{865}$ Como es bien sabido, el suidicio de la abandonada reina Dido traspasó los umbrales del siglo XVII de la mano de ilustres compositores de ópera. Es también conocida la historia, versificada por Castiglione, sobre Isabella Gonzaga y su órgano de alabastro en el que tañía Dulces exuviae. ${ }^{866}$ En general, los autores citados ponen en música los primeros versos (651-658). Mudarra añade los relativos al suicidio de Dido (659-665) y además, con distinta música.

El uso de la vihuela para acompañar versos de Virgilio está documentado por ejemplo en un pasaje de los Diálogos sobre la educación de Juan Luis Vives:

«Lupiano.-Coge la vihuela y cántanos algo. Tamayo.—¿Qué queréis que cante? Lupiano.cualquier cosa sobre el juego. Tamayo._¿Un poema de Virgilio? Lupiano.—Sí, eso mismo. O si prefieres, alguno de nuestro Vives; ${ }^{867}$

\section{ANÁLISIS}

Mudarra pone la misma música a los cuatro primeros versos repitiéndola tres veces. Los tres últimos versos los divide en dos frases musicales. La primera de ellas es casi un recitado sobre una nota, que sube una sexta gradualmente, alcanzando un climax que se disuelve en la siguente frase.

Al lo largo de la obra hay un uso sistemático del semitono, tal y como bastantes años después prescribiría Zarlino, quien recomendaba su uso para expresar sentimientos de dolor. La textura es predominantemente homofónica, aunque Mudarra echa mano de la imitación en algunos momentos. El ritmo de la voz es una permanente combinación de dáctilos y espondeos, en un intento de imitar la métrica griega.

John Griffiths en el artículo anteriormente citado realiza un análisis de esta pieza. ${ }^{868}$

\footnotetext{
${ }^{864}$ VegA, María José. Poética y música en el Renacimiento. La invención del paradigma clásico. Madrid, Caronte, 2011, p. 71.

${ }^{865}$ GuentNer, Francis J. «Dulces exuviae in Sixteenth Century Music», The Classical Journal 68/1 (1972), pp. $62-67$

${ }^{866}$ El comienzo del poema de Castiglione en Bergua Cavero, J. La música de los clásicos..., p. 106.

${ }^{867}$ Citado por Robledo Estaire, L. «La música..., p. 406.
} 


\section{4- Beatus ille}

Versos en latín. V modo. Posición F (vihuela en G). 3 + 1 voces. Tempo lento. Notas móviles: Si Ł (IV), Mi b (VII). Voz canto: soprano.

\section{NOTAS CRÍTICAS}

1. Falta toda la obra en el ejemplar de la BNE.

\section{TEXTO}

Se trata del comienzo del Epodo II de Horacio. ${ }^{869}$

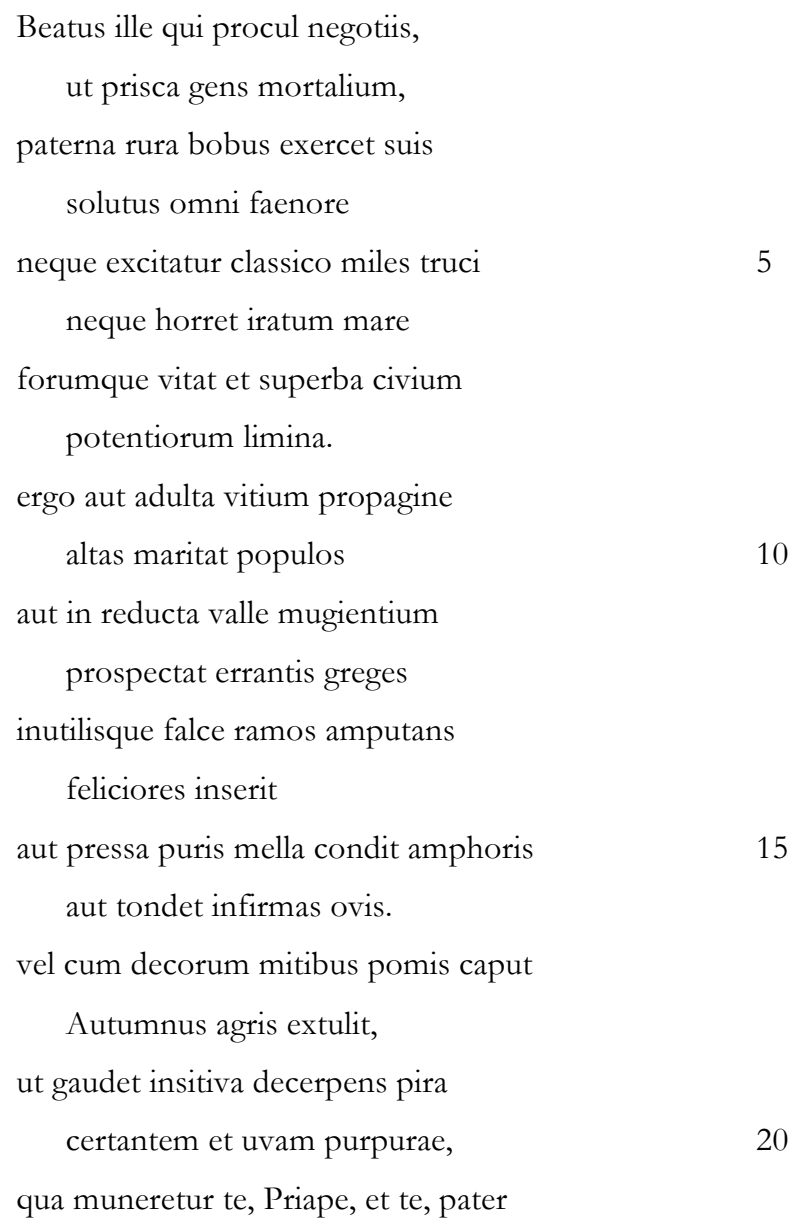

${ }^{868}$ Griffiths, J. «Luis Milán, Alonso Mudarra..., pp. 26-28.

${ }^{869}$ Tomamos el texto y la traducción de TORRE, Esteban. «La traducción del epodo II de Horacio (Beatus ille)», Hermēneus. Revista de Traducción e Interpretación, 1 (1999), pp. 1-14. Añadimos algunos versos más a los de Mudarra. 
Silvane, tutor finium.

libet iacere modo sub antiqua ilice, modo in tenaci gramine:

labuntur altis interim ripis aquae, queruntur in silvis aves

fontesque lymphis obstrepunt manantibus, somnos quod invitet levis.

VARIANTES: Mudarra: 1 «negociis», 3 «exgercet», 4 «fenore».

Dichoso aquél que vive, lejos de los negocios, como la antigua grey de los mortales;

y, con sus propios bueyes, labra el campo paterno, libre del interés y de la usura.

No le despierta el fiero toque de la trompeta, ni le aterra la mar embravecida;

y esquiva el foro público, y el umbral altanero de las aristocráticas mansiones.

Enlaza, sabiamente, los elevados álamos con el pujante brote de las vides;

o, en apartado valle, vigila los rebaños de las reses que mugen y campean;

o poda con su hoz las inútiles ramas, trasplantando las más reverdecidas;

o pone en limpios cántaros las estrujadas mieles,

o trasquila a las tímidas ovejas.

Y cuando alza el otoño su cabeza en los campos, ornada con los frutos más suaves, ¡cómo goza cogiendo las injertadas peras y unas uvas más rojas que la púrpura para obsequiarte a ti, Príapo, y a ti, Padre

Silvano, protector de sus linderos! Le gusta descansar bajo la vieja encina, o en el tupido césped de algún prado; mientras, las aguas corren por sus cauces profundos, 25 los pájaros se quejan en los bosques y las fuentes murmuran en sus manantiales, invitando a una leve somnolencia. 


\section{COMENTARio}

Parece ser que muchos de los poemas líricos (odas y epodos) de Horacio fueron compuestos para ser cantados. Se conservan también algunos manuscritos medievales con textos suyos y con anotaciones musicales, lo que no parece probable es que estas melodías sean originales. En realidad, la obra de Horacio se usaba con un fin pedagógico, ya que en sus odas y epodos utiliza una gran cantidad de métricas distintas. ${ }^{870}$

Lo cierto es que Horacio siempre estuvo presente en las escuelas de latinidad. Sin embargo, a principios del siglo XVI se empezó a experimentar con melodías sobre sus textos, como vimos anteriormente. El caso de Hofhaimer ${ }^{871}$ es particularmente interesante, pues sirvió de modelo a Mudarra para esta obra, Beatus ille, y la siguiente.

Además de Mudarra otros autores, como Orlando di Lasso hicieron uso de este epodo.

\section{ANÁLISIS}

Desde el punto de vista métrico se trata de un dístico de trímetro y dímetro yámbico o, lo que es lo mismo, un yambico senario o de seis pies y otro de cuatro.

La versión de Mudarra es literal con respecto a la Hofhaimer en las voces del bajo y soprano y con leves diferencias en tenor y alto. Hofhaimer presenta la obra sin compás, pero Mudarra la somete a un compás binario, donde obviamente no funciona adecuadamente. El primer verso es poco problemático, pues si lo consideramos ternario y con comienzo anacrúsico, ${ }^{872}$ encaja perfectamente. Más complejo es el segundo, que aunque debería constar de cuatro pies yámbicos, las sustituciones lo hacen de muy difícil encaje tanto en un compás binario como ternario.

Dimetro yámbico regular:

Dimetro yámbico con sustituciones:

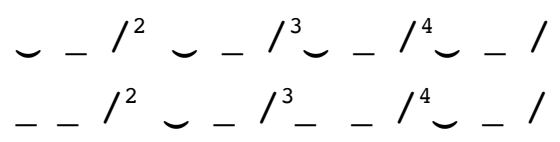

Esta última forma es la que usan tanto Mudarra como su modelo.

\footnotetext{
${ }^{870}$ Bergua Cavero, J. La música de los clásicos..., pp. 37 y ss.

${ }^{871}$ HofHaimer, Paul y SENFl, Ludwig. Poeticae Pauli Hofheimeri, niri equestri dignitate insigni, ac Musici excellentis, quales sub ipsam mortem cecinit, qualesq[ue] ante hac nunquàm uisae..., Nuremberg, Johan Petreium, 1539, ff. c5v [=p.78, Media vox], cc5v [=p. 142, Alta vox], C5v [=206, Infima vox], CC5v[=270, Suprema vox]. Esta obra debió tener gran difusión en España. Calvete de Estrella la compró en Salamanca en 1543 para el príncipe Felipe. Citaremos por el primer autor.

${ }^{872}$ Salinas dice que el Beatus ille comienza en el alzar. SALINAS, F. De Musica..., p. 542.
} 

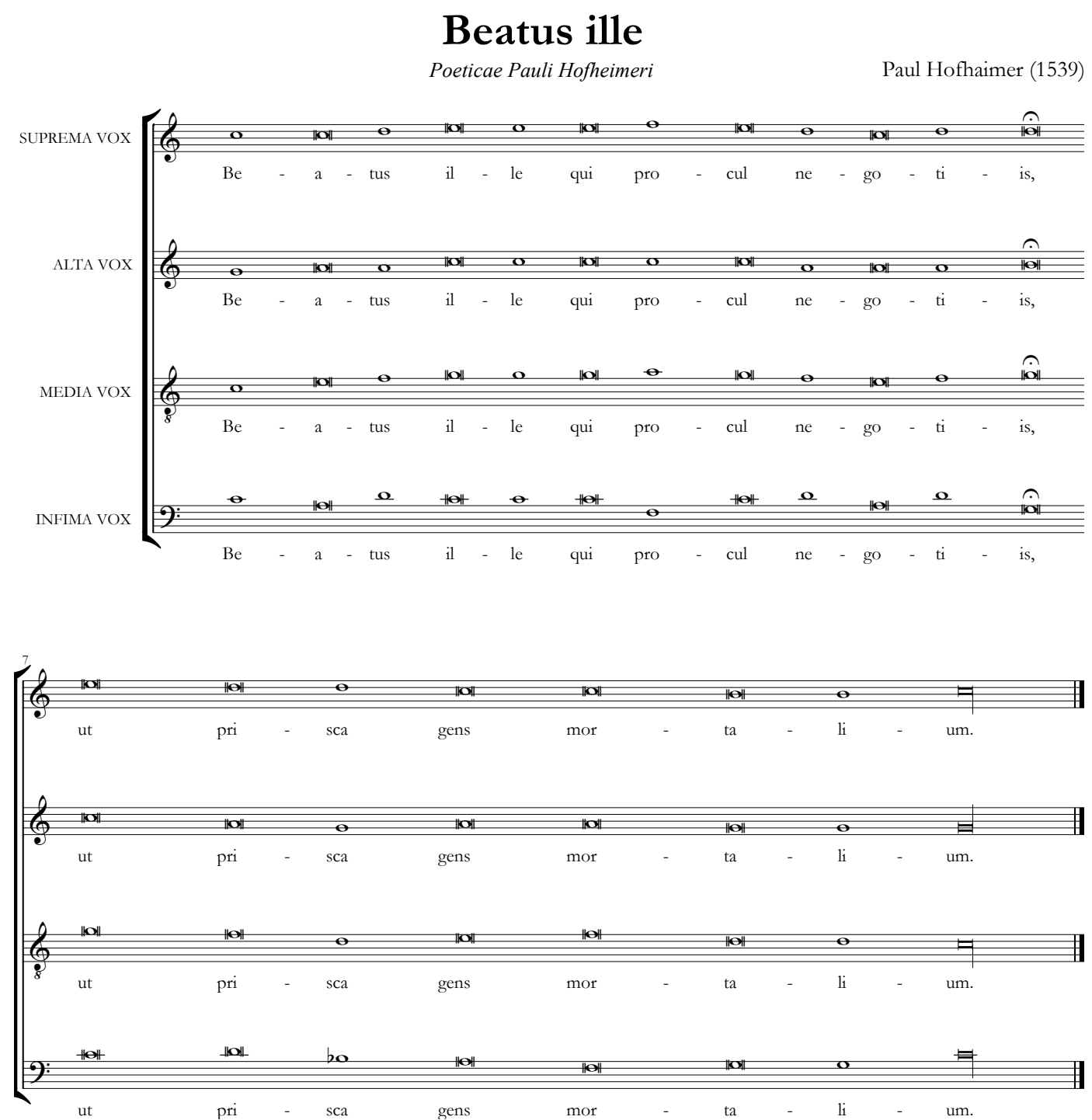

Ejemplo 23. Beatus ille, Hofhaimer.

Como curiosidad decir que, tal y como ha calculado Gásser, la interpretación del epodo completo con la música de Mudarra llevaría unos de doce minutos. ${ }^{873}$

${ }^{873}$ GÁsser, L. Luis Milán..., p. 27. 


\section{5- Hanc tua Penelope}

Versos en latín. II modo. Posición g (vihuela en G). $3+1$ voces. Tempo medio. Notas móviles: Si 4 (III), Do\# (IV), Mi b (VI), Fa\# (VII). Voz canto: soprano.

\section{NOTAS CRÍTICAS}

1. Falta la primera página (cc. 1-16) en el ejemplar de la BNE.

\section{TEXTO}

Se trata de la primera epístola de las Heroidas de Ovidio: ${ }^{874}$

Hanc tua Penelope lento tibi mittit, Ulixe;

Nil mihi rescribas; attamen ipse veni.

Troia iacet, certe Danais invisa puellis;

Vix Priamus tanti totaque Troia fuit.

O utinam tum, cum Lacedaemona classe petebat,

Obrutus insanis esset adulter aquis!

Non ego deserto iacuissem frigida lecto;

Non quererer tardos ire relicta dies

Nec mihi quaerenti spatiosam fallere noctem

Lassaret viduas pendula tela manus.

Quando ego non timui graviora pericula veris?

Res est solliciti plena timoris amor.

VARIANTES: Mudarra: 1 «Ulyses».

Esta carta, Ulises, la envía Penélope a tu tardanza.

No me contestes; sino mejor, ven en persona.

Yace en ruinas Troya, aborrecida, con razón, de las mujeres dánaas;

no mereció tanto Príamo ni Troya entera.

¡Ay! Ojalá entonces, cuando navegaba a Lacedemonia, $\quad 5$

se hubieran tragado las enfurecidas olas al adúltero.

${ }^{874}$ Tomamos el texto y la traducción de Ovidio. Heroidas. E MOYA CORTINES, Francisca (ed. bilingüe). Madrid, CSIC, 1986, cambiamos «u» por «V», y viceversa, según el criterio que utilizamos a lo largo de todo el trabajo. Disponemos la traducción en forma de verso aunque sea en prosa. Añadimos algunos versos más a los de Mudarra. 


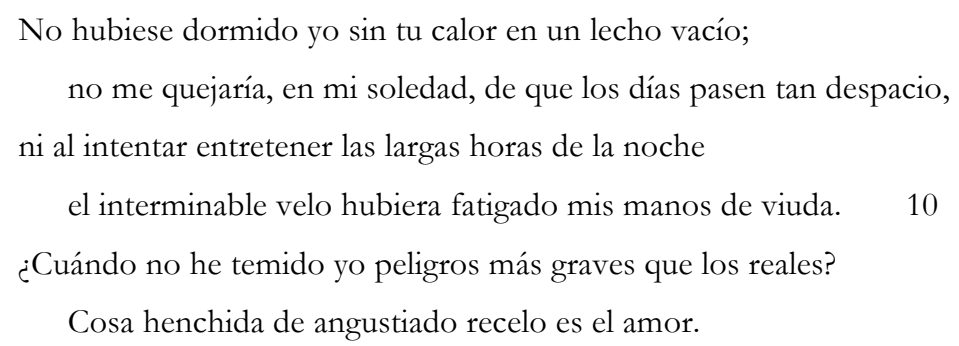

\section{ANÁLISIS}

Mudarra, tomando el modelo de Hofhaimer, ${ }^{875}$ escribe una nueva pieza basándose en el dístico elegiaco. Si bien la melodía no se corresponde con la de aquel, rítmicamente son copia uno de otro. Es posible incluso que Mudarra utilizara el texto del austriaco ya que las coincidencias textuales son muchas (todas las variantes se dan en los dos autores).

El dístico elegiaco está formado por un hexámetro más pentametro, combinando dáctilos y espondeos:

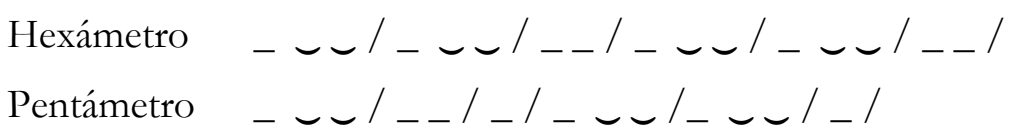

Esto trasladado a música nos da exactamente el ritmo utilizado por Mudarra. El hexámetro correspondería con los cc. 1-12 y el pentametro con los cc. 13-25.

${ }^{875}$ Hofhaimer, P. y Senfl, L. Poeticae Pauli Hofheimeri..., ff. d5v [=p.94, Media vox], dd5v [=p. 158, Alta vox], D5v [=222, Infima vox], DD5v[=286, Suprema vox]. 


\section{6- La vita fugge}

Soneto en italiano. III modo. Posición g (vihuela en E). $3+1$ voces. Tempo medio y lento. Notas móviles: La

\section{NOTAS CRÍTICAS}

1. En el ejemplar de la BNE la primera página está mal colocada todas las demás invertidas.

2. c. 8. Sobra el bemol de la armadura.

3. c. 17. Error de clave, debe ser Do en $2^{a}$ línea en lugar de Do en $1^{a}$. Indicado en la fe de erratas del final.

4. c. 23. Ponemos 2 en $4^{\circ}$ orden en lugar de 3 .

5. c. 36. La barra de repetición está invertida.

6. c. 88. Añadimos la semibreve que figura entre corchetes.

\section{TEXTO}

El texto pertenece al Canzoniere de Petrarca (Rime, In morte di Madonna Laura, 272). ${ }^{876}$

La vita fugge, et non s'arresta una hora,

et la morte vien dietro a gran giornate,

et le cose presenti et le passate

mi dànno guerra, et le future anchora;

e 'l rimembrare et l'aspettar m'accora,

or quinci or quindi, sí che ' $\mathrm{n}$ veritate,

se non ch'i' ò di me stesso pietate,

i' sarei già di questi pensier' fora.

Tornami avanti, s'alcun dolce mai

ebbe 'l cor tristo; et poi da l'altra parte

10

veggio al mio navigar turbati i vènti;

veggio fortuna in porto, et stanco omai

il mio nocchier, et rotte arbore et sarte,

e i lumi bei che mirar seglio, spenti.

${ }^{876}$ Tomamos el texto en italiano y la traducción de PETRARCA, Francesco. Cancionero. Cortines, Јасово (ed. bilingüe). (Texto italiano establecido por Gianfranco Contini). Madrid, Cátedra, 2012, $5^{\text {a }}$ ed., 2 vols.; vol. II, pp. 810-811. 
VARIANTES: Mudarra: 1 «se arresta un», 2 «ven dietro», 3 «presente», 5 «el rimembrar et la aspetar machora», 6 «horquinci, horquindi», 7 «non chi hodi me», 9 «se alcun», 10 «hebel cor», 12 «stancho homai», 16 «soglio».

Huye la vida sin pararse un punto

y le sigue la muerte a grandes pasos,

y las cosas presentes y pasadas

me dan guerra, e incluso las futuras;

recuerdos y esperanzas me atormentan

5

de la misma manera, y bien es cierto

que, si no me apiadase de mí mismo,

en cosas semejantes no pensara.

Del corazón evoco la dulzura,

si alguna vez la tuvo, y de otra parte

preveo mi navegar tempestuoso;

veo la suerte en el puerto, y ya cansado

mi piloto, y los mástiles deshechos,

y las hermosas luces, apagadas.

\section{COMENTARIO}

Tras las cuatro piezas sobre textos latinos, Mudarra, fiel a su esquematismo, incluye cuatro sonetos en italiano, uno de un clásico, Petrarca, un anónimo y dos de un contemporáneo, aunque de una o dos generaciones antes, Sannazaro.

\section{ESTRUCTURA}

$\begin{array}{ccccc}\text { Verso } & \text { Rima } & \text { Motivo } & \text { Compases } & \text { Longitud } \\ 1 & 11 \mathrm{~A} & \text { a } & \text { cc. } 1-9 & 9 \mathrm{cc} . \\ 2 & 11 \mathrm{~B} & \text { b } & \text { cc. } 10-16 & 7 \mathrm{cc} . \\ 3 & 11 \mathrm{~B} & \text { c } & \text { cc. } 17-26 & 10 \mathrm{cc} . \\ 4 & 11 \mathrm{~A} & \text { d } & \text { cc. } 27-36 & 10 \mathrm{cc} . \\ 5 & 11 \mathrm{~A} & \text { a } & \text { cc. } 1-9 & 9 \mathrm{cc} . \\ 6 & 11 \mathrm{~B} & \text { b } & \text { cc. } 10-16 & 7 \mathrm{cc} . \\ 7 & 11 \mathrm{~B} & \text { c } & \text { cc. } 17-26 & 10 \mathrm{cc} . \\ 8 & 11 \mathrm{~A} & \text { d } & \text { cc. } 27-36 & 10 \mathrm{cc} . \\ 9 & 11 \mathrm{C} & \text { a } & \text { cc. } 37-56 & 20 \mathrm{cc} . \\ 10 & 11 \mathrm{D} & \text { b' } & \text { cc. } 57-65 & 9 \mathrm{cc} .\end{array}$




$\begin{array}{lllll}11 & 11 \mathrm{E} & \text { c' } & \text { cc. } 66-75 & 10 \mathrm{cc} . \\ 12 & 11 \mathrm{C} & \text { a” } & \text { cc. } 76-84 & 9 \mathrm{cc} . \\ 13 & 11 \mathrm{D} & \text { b” } & \text { cc. } 85-93 & 9 \mathrm{cc} . \\ 14 & 11 \mathrm{E} & \text { a"” } & \text { cc. } 94-104 & 11 \mathrm{cc} .\end{array}$

ANÁLISIS

Se repite el tratamiento dado a los anteriores sonetos, los dos primeros cuartetos reciben la misma música, y los tercetos varían. Hay un breve interludio instrumental, con imitaciones, al principio de los tercetos cuya música deriva de los temas escuchados en los cuartetos. Termina con un cambio de compás sobre la palabra «spenti» sobre unas glosas. La textura de toda la pieza es predominantemente homofónica.

\section{7- Lassato a il Tago}

Soneto en italiano. I modo. Posición $\mathrm{f}$ (vihuela en E). 4 voces. Tempo medio. Notas móviles: La ต (III), Re b (VI), Mi ต (VII). Voz canto: contralto.

\section{NOTAS CRÍTICAS}

1. cc. 1-25. Falta la primera y segunda páginas en el ejemplar de la BNE.

2. c. 3. La fe de erratas indica un error que no existe.

3. c. 8. Sobra el bemol de la armadura.

4. c. 21. La mínima mal colocada.

5. c. 25. Ponemos 3 en $4^{\circ}$ orden en lugar de 2 .

6. c. 41 . Ponemos 5 en $1^{\circ}$ orden en lugar de 0 . Indicado en la fe de erratas del final.

7. c. 78. Añadimos la mínima que figura entre corchetes.

\section{TEXTO}

Nuevamente un texto anónimo que, además, desgraciadamente está incompleto, pues, aunque se anuncia como soneto, solo se incluye un cuarteto. Como señala Pujol, puede tratarse de una obra elegiaca dedicada a la muerte de la emperatriz Isabel de Portugal. ${ }^{877}$

\footnotetext{
${ }^{877}$ PujOL. Mudarra, p. 83.
} 
Lassato a il Tago su dorate arene;

Ne più qual pria vol andar lucente;

Poscia privato si a de la excelente

Alma per che l'orbe tutto geme.

Dejado a la arena dorada del Tajo;

No quiere andar más lúcido;

Pues se le ha privado de la excelente

Alma por la que todo el orbe gime.

\section{ESTRUCTURA}

$\begin{array}{ccccc}\text { Verso } & \text { Rima } & \text { Motivo } & \text { Compases } & \text { Longitud } \\ 1 & 11 \mathrm{~A} & \text { a } & \text { cc. } 1-18 & 18 \mathrm{cc} . \\ 2 & 11 \mathrm{~B} & \text { b } & \text { cc. } 19-35 & 17 \mathrm{cc} . \\ 3 & 11 \mathrm{~B} & \text { c } & \text { cc. } 36-43 & 8 \mathrm{cc} . \\ 4 & 11 \mathrm{~A} & \text { d } & \text { cc. } 44-36 & 10 \mathrm{cc} .\end{array}$

\section{ANÁLISIS}

Se trata de una pieza extraña por el lugar que ocupa ya que su estilo compositivo está más cerca de las fantasías que de las piezas vocales. Tiene un comienzo imitativo a cuatro voces, una de ellas, la contralto, es la que se canta y además va doblada en la vihuela como ocurría, además de en los dos primeros motetes, en la canción Sin dudar. Hay continuas cadencias con sus retardos característicos.

Tras enunciar el verso 2 se produce un bicinium entre bajo y tenor y contralto y soprano (cc. 22-31). Sin embargo, el tercero es acompañado homofónicamente. El último verso es repetido parcialmente seis veces con nuevo bicinium (cc. 50-58) con un motivo insistente que por fin resuelve en la palabra «geme», que también se repite.

\section{COMENTARIO}

Podríamos aventurar que se trata de una pieza anterior a las otras italianas y a los experimentos latinos. Creemos bastante probable que Mudarra viajara a Italia a reunirse con su hermano cuando este aun no había caído en desgracia y cuando Alonso fue despedido del palacio del Infantado. Es decir, entre 1543 y 1546. No sabemos si las piezas 
latinas e italianas son resultado de este viaje, pero parece claro que en el libro de Mudarra conviven dos estilos.

\section{8- O gelosia d'amanti}

Soneto en italiano. VIII modo. Posición G (vihuela en G). $3+1$ voces. Tempo medio. Notas móviles: Si b (III), Do\# (IV), Fa\# (VII). Voz canto: soprano.

\section{NOTAS CRÍTICAS}

1. c. 30. Añadimos la semibreve que figura entre corchetes.

2. c. 32. Mudarra escribe «le em-pia».

3. c. 80. Sobra una figura de mínima.

\section{TEXTO}

Se trata del Soneto 23 de las Rime de Sannazaro. ${ }^{878}$

O gelosia, d'amanti orribil freno, che in un pùnto mi tiri et tien sì forte, o sorella di l'empia et cruda morte che con tua vista turbi 'l ciel sereno;

o serpente nascosto in dolce seno

che con tue voglie mie speranze hai morte, tra felici successi adversa sorte, tra soavi vivande aspro beneno.

Di qual boca infernal nel mondo uscisti, o crudel mostro, o peste de' mortali, 10 per far gli giorni miei sì oscuri e tristi?

Tornati in giù, non aumentar miei mali; infelice paura, ad quid venisti?

Hor non bastaba Amor con li suoi strali?

${ }^{878}$ Usamos el texto de Mudarra aquí y en la versión musical, pues las diferencias son tan importantes que cambian frases enteras. Comparamos con el texto de la edición veneciana: SANNAZARO, Jacopo. Le rime di M. Giacobo Sannazaro Nobile Napolitano. Venecia, Nicolo d'Aristotile detto Zoppino, 1532. Tomamos la traducción de Artieda incluida en Alatorre, Antonio. «Fama española de un soneto de Sannazaro», Nueva Revista de Filología Hispánica, 36/2 (1988), pp. 955-973. 
VARIANTES: Sannazaro: 2 «che'n un pùnto mi volgi e tien sì forte », Mudarra: 4 «turbi il ciel», 5 «serpenti», Sannazaro: 6 «D'eletti fior, che mie speranze hay morte», 7 «Tra prosperi successi», 9 «Da qual cava infernal», 11 « che fai li giorni», 12 «Tornati giù». 879

¡Celos, que a los que amáys servís de freno, y dándome mil bueltas me assís fuerte!

¡O furia y sombra, hermana de la muerte, que anublas con tu vista el sol sereno!

Sierpe escondida en un jardín ameno,

do muere mi esperança en solo verte;

en la prosperidad contraria suerte

y en el dulce manjar me das veneno.

Dime ¿de qué infernal prisión saliste, que los mortales pechos inquietas

y esta vida me das amarga y triste?

¡Buélvete allá, que el coraçón me aprietas!

Infelice temor, ¿a qué viniste?

Di, ¿no bastava Amor con sus saetas?

\section{ESTRUCTURA}

$\begin{array}{ccccc}\text { Verso } & \text { Rima } & \text { Motivo } & \text { Compases } & \text { Longitud } \\ 1-2 & 11 \mathrm{~A}-11 \mathrm{~B} & \mathrm{a} & \text { cc. } 1-29 & 29 \mathrm{cc} . \\ 3-4 & 11 \mathrm{~B}-11 \mathrm{~A} & \mathrm{~b} & \text { cc. } 30-49 & 20 \mathrm{cc} . \\ 5-6 & 11 \mathrm{~A}-11 \mathrm{~B} & \mathrm{a} & \text { cc. } 1-29 & 29 \mathrm{cc} . \\ 7-8 & 11 \mathrm{~B}-11 \mathrm{~A} & \text { b } & \text { cc. } 30-49 & 20 \mathrm{cc} . \\ 9-10 * & 11 \mathrm{C}-11 \mathrm{D} * & \text { c } & \text { cc. } 50-65 & 16 \mathrm{cc} . \\ 10 *-11 & 11 \mathrm{C} *-11 \mathrm{D} & \text { a' } & \text { cc. } 66-84 & 19 \mathrm{cc} . \\ 12-13 * & 11 \mathrm{C}-11 \mathrm{D} * & \text { c } & \text { cc. } 50-65 & 16 \mathrm{cc} . \\ 13 *-14 & 11 \mathrm{D} *-11 \mathrm{C} & \text { a' } & \text { cc. } 66-84 & 19 \mathrm{cc} .\end{array}$

\section{ANÁLISIS}

Aunque la obra empieza con un episodio instrumental imitativo, volvemos al estilo homofónico predominante en la mayoría de los sonetos. En esta ocasión, Mudarra utiliza dos motivos por cada cuarteto, agrupando los versos de dos en dos. En los tercetos divide

${ }^{879} \mathrm{Al}$ contratar estos textos, se puede apreciar que hay mayor concordancia que con otras fuentes, por lo que es probable que a Mudarra llegara copia de esta edición veneciana. 
el segundo de cada uno de ellos por la mitad (lo que indicamos con *) asignando a cada verso y medio un motivo.

\section{COMENTARIO}

Este mismo soneto también fue puesto en música por Luis Milán. ${ }^{880}$ La distribución de los versos es diferente a la de Mudarra, pero melódicamente hay muchas similitudes. El texto, sin embargo, no procede de la misma fuente.

\section{9- Itene a l'ombra}

Soneto italiano. VIII modo. Posición E (vihuela en B). $3+1$ voces. Tempo medio. Notas móviles: Re $\vdash$ (VII). Voz canto: soprano.

\section{TEXTO}

Se trata de la égloga segunda de la Arcadia de Sannazaro. ${ }^{881}$

Itene all'ombra degli ameni faggi,

pasciute pecorelle, omai che 'l sole

sul mezzo giorno indrizza i caldi raggi.

Ivi udirete l'alte mie parole

lodar gli occhi sereni e trecce bionde,

le mani e le bellezze al mondo sole;

mentre il mio canto e'l murmurar de l'onde

s'accorderanno, e voi di passo in passo

ite pascendo fiori, erbette e fronde.

Io veggio un uom, se non è sterpo o sasso;

egli è pur uom che dorme in quella valle,

disteso in terra fatigoso e lasso.

Ai panni, a la statura et a le spalle,

\footnotetext{
${ }^{880}$ MiLÁN. El maestro. ff. R2v-R3 [pp. 194-196].
}

${ }^{881}$ Tomamos el texto de SANNAZARO, Iacopo. Opere Volgari. MAURO, Alfredo (ed.). Bari, Laterza, 1961, p. 7. Añadimos algunos versos más a los de Mudarra. La traducción es de Julio Martínez Mesanza en Sannazaro, Jacopo. Arcadia. Tateo, Francesco (ed.) Madrid, Cátedra, 1993. Al ser una traducción en prosa, se producen algunos desajustes al disponerla en forma de verso. 
et a quel can che è bianco, el par che sia

Uranio, se 'l giudicio mio non falle.

Egli è Uranio, il qual tanta armonia

ha ne la lira, et un dir sì leggiadro,

che ben s'agguaglia a la sampogna mia.

VARIANTES: Mudarra: 2 «ormai».

Marchad a la sombra de las amenas hayas, saciadas ovejas, ahora que el sol del medio día lanza sus calurosos rayos.

Allí oiréis cómo mis elevadas palabras los ojos calmados alaban y las trenzas rubias,

las manos y la belleza única en el mundo.

Se armonizará mi canto con el murmurar de las ondas, mientras vosotras vais pastando flores, hierbecillas y hojas.

Yo veo un hombre, si no es tronco o piedra es entonces un hombre que duerme en este valle, echado en tierra, fatigado y laso.

Por la vestimenta, la estatura y las espaldas, y por ese perro, que es blanco, diría que es Uranio, si mi juicio no me engaña.

Él es Uranio, de un decir elegante, de tanta armonía con la lira que bien se iguala a mi zampoña.

ESTRUCTURA

$\begin{array}{ccccc}\text { Verso } & \text { Rima } & \text { Motivo } & \text { Compases } & \text { Longitud } \\ 1 & 11 \mathrm{~A} & \mathrm{a} & \text { cc. } 1-10 & 10 \mathrm{cc} . \\ 2 & 11 \mathrm{~B} & \text { b } & \text { cc. } 11-17 & 7 \mathrm{cc} . \\ 3 & 11 \mathrm{~A} & \text { b } & \text { cc. } 18-23 & 6 \mathrm{cc} .\end{array}$

\section{ANÁLISIS}

A pesar de que Mudarra lo denomine así, no es un soneto. Se trata de tercetos encadenados o en terza rima, metro característico de las églogas bucólicas y que también 
usó Garcilaso para las suyas. Se forma con endecasílabos con rima consonante y forma ABA BCB CDC DED... Mudarra, a pesar de nombrarlo inadecuadamente, es perfectamente consciente de la forma, pues pone música únicamente a tres versos. La textura es predominantemente homofónica. Morphy transcribe esta pieza. ${ }^{882}$

\section{0- Dime adó tienes las mientes}

Villancico. I modo. Posición B b (vihuela en F\#). $3+1$ voces. Tempo medio. Notas

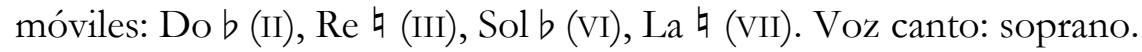

\section{NOTAS CRÍTICAS}

1. c. 43. Ponemos 3 en $3^{\circ}$ orden en lugar de 5 .

2. cc. 69-70. Añadimos la barra de compás.

TEXTO

El texto es el que sigue. ${ }^{883}$

\footnotetext{
Díme adó tienes las mientes

pastorcico descuydado,

que se te pierde el ganado. y ansí como con fatigas,

Nunca duermo, siempre afano,

${ }^{882}$ Morphy, G. Les Luthistes espagnoles..., vol. II, pp. 120-128.

${ }^{883}$ Para las concordancias literarias y las variantes remitimos a FRENK. Nuevo Corpus, p. 790, no 1154 bis. En el Cancionero de Palacio, CMP 291, hay una versión anónima que difiere totalmente en la música, pero coincide textualmente y añade varias coplas más. 


\section{INTRODUCCIÓN}

No es fácil dar una definición precisa del villancico del siglo XVI debido a la gran variedad de esquemas, pero podemos tomar prestada la definición que nos da Margit Frenk: «composición poético-musical formada por un estribillo inicial y estrofas que rematan con la repetición musical y parcialmente textual del estribillo». ${ }^{884}$

$\mathrm{Al}$ igual que ocurrió con los romances, como veíamos más arriba, los villancicos se pusieron de moda en las cortes castellanas en los siglos XV y XVI. Tanto los poetas como los músicos, tratándose en muchos casos de la misma persona, tomaron el cantarcillo popular y lo amplificaron y comentaron con sus glosas. De nuevo recurrimos a Frenk para la explicación:

Adoptar es adaptar. Cuando la poesía cortesana, hacia fines del siglo XV, abrió sus puertas a la canción rústica y callejera, no quiso dejarla entrar desaliñada como venía: le puso un vestido decente y a la moda, dejándole sólo la cabeza al descubierto. Con su nuevo ropaje (glosa al estilo cortesano), la intrusa pudo ya figurar dignamente al lado de damas y caballeros. Los músicos hicieron otro tanto: aceptaron la sencilla melodía, pero la revistieron de galas polifónicas. ${ }^{885}$

La forma poética va a condicionar la forma musical que utilizan los vihuelistas, la cual de una forma general podríamos describir así: a partir de un estribillo o cabeza de número variable de versos y melodías, basado en un cantar-núcleo, se desarrolla la copla, formada por la mudanza, que utiliza música diferente y la vuelta que retoma la música y la rima del estribillo. ${ }^{886}$ La repetición del estribillo al final no suele estar escrita, pero es probable que ocurriera.

Estos cinco villancicos de Mudarra que se siguen fueron transcritos por Morphy. ${ }^{887}$

${ }^{884}$ FrenK, Margit. «Los romances-villancico», Poesía popular bispánica. 44 estudios. México, Fondo de Cultura Económica, 2006, pp. 621-631; p. 621.

${ }^{885}$ Frenk, Margit. "Glosas de tipo popular en la antigua lírica», Poesía popular hispánica. 44 estudios. México, Fondo de Cultura Económica, 2006, pp. 413-447; p. 417.

${ }^{886}$ Utilizamos letra cursiva para el estribillo y los versos de vuelta, que llevan la música del estribillo.

${ }^{887}$ Morphy, G. Les Luthistes espagnoles..., vol. II, pp. 113-115. 


\section{ESTRUCTURA}

\begin{tabular}{|c|c|c|c|c|}
\hline Verso & Rima & Melodía & Compases & Longitud \\
\hline 1 & $8 a$ & a & cc. $1-8$ & 8 cc. \\
\hline 2 & $8 b$ & b & cc. $9-15$ & 7 cc. \\
\hline 3 & $8 b$ & $\mathrm{c}, \mathrm{c}$ & cc. $16-35$ & 20 cc. \\
\hline 4 & $8 c$ & $a^{\prime}$ & cc. $36-43$ & 8 cc. \\
\hline 5 & $8 \mathrm{~d}$ & b' & cc. $44-49$ & $6 \mathrm{cc}$. \\
\hline 6 & $8 \mathrm{~d}$ & $a^{\prime}$ & cc. $50-55$ & $6 \mathrm{cc}$ \\
\hline 7 & $8 c$ & b' & cc. 56-61 & $6 \mathrm{cc}$ \\
\hline 8 & $8 c$ & $a^{\prime}$ & cc. $62-67$ & $6 \mathrm{cc}$. \\
\hline 9 & $8 \mathrm{~b}$ & b & cc. $68-74$ & 7 cc. \\
\hline 10 & $8 b$ & c & cc. $75-84$ & $10 \mathrm{cc}$. \\
\hline
\end{tabular}

ANÁLISIS

Se puede apreciar en el esquema anterior como con muy pocos elementos, provenientes todos de la cabeza del villancico o cantar-núcleo, Mudarra construye toda la pieza. Si asignamos mayúsculas para los versos del estribillo y de la vuelta el esquema resultante sería: ABCC a'b'a'b'a' BC.

Todas las melodías tienen forma de arco y el ámbito total de la pieza es de una octava. La vihuela va realizando un acompañamiento en contrapunto libre, muchas veces doblando a la tercera, la sexta o la décima a la melodía que se canta.

\section{COMENTARIO}

Hace ya setenta años Marius Schneider localizó este villancico en la localidad granadina de Gor en boca de pastores y lugareños. ${ }^{888}$ Las tres versiones que recogió coinciden bastante bien en cuanto al contenido literario, pero, lo más sorprendente, es que las coincidencias musicales son muy significativas. Las hipótesis que planteaba el musicólogo alemán era que, o bien Mudarra había tomado la cancioncilla del repertorio popular o que la realización de Mudarra se hubiera popularizado. Schneider se decanta por la primera opción; nosotros también.

\footnotetext{
888 SCHNEIDER, Marius. «Un villancico de Alonso de Mudarra procedente de la música popular granadina», Anuario Musical, 10 (1955), pp. 79-83.
} 
Según Frenk, este villancico está muy cerca del estilo pastoril creado por Juan del Encina. ${ }^{889}$

Además de la versión de Mudarra y la del Cancionero de Palacio, hay otra versión en el Cancionero musical Masson, f. $16^{890}$

\section{1- Si me llaman}

Villancico. I modo. Posición c (vihuela en A). $3+1$ voces. Tempo medio. Notas móviles: La b (VI), Si ॄ (VII). Voz canto: soprano.

\section{NOTAS CRÍTICAS}

1. c. 52. Añadimos la barra de repetición.

2. c. 56 . Ponemos 3 y 5 en $3^{\circ}$ orden en lugar de 5 y 3 .

3. c. 56. Eliminamos el bemol de la pauta de la voz, pues carece de sentido.

4. c. 57. Mudarra señala una repetición de texto. La eliminamos por innecesaria.

5. c. 65. El signo de repetición es incorrecto, solo debe afectar a los cc. 52-65.

\section{TeXto}

Aparece en numerosas fuentes. ${ }^{891}$

Si me llaman, a mí llaman, que cuido que me llaman a mí.

$\mathrm{Y}$ en aquella sierra erguida cuido que me llaman a mí.

Llaman a la más ga[r]rida, que cuido que me llaman a mí.

${ }^{889}$ Frenk, Margit. «El cancionero oral en el Siglo de Oro», Poesía popular hispánica. 44 estudios. México, Fondo de Cultura Económica, 2006, pp. 159-175; p. 166.

${ }^{890}$ Se trata de una pieza a una voz que coincide únicamente con la de Mudarra en el texto de la cabeza del villancico. Hay transcripción moderna en MorAis, Manuel (ed.): Vilancetes, cantigas e romances do século XVI. Transcripción de Manuel Morais. Portugaliae Musica; XLVII. Lisboa, Fundaçao Calouste Gulbenkian, 1986, p. 94.

${ }^{891}$ Para las concordancias literarias y las variantes remitimos a FRENK. Nuevo Corpus, pp. 167-168, $\mathrm{n}^{\circ}$ $190 \mathrm{C}$. 


\section{ESTRUCTURA}

$\begin{array}{ccccc}\text { Verso } & \text { Rima } & \text { Melodía } & \text { Compases } & \text { Longitud } \\ 1 & 8 \mathrm{a} & \mathrm{a} & \text { cc. } 1-13 & 13 \mathrm{cc} . \\ 2 & 9 \mathrm{~b} & \text { b, b, b, b', b } & \text { cc. } 14-51 & 38 \mathrm{cc} . \\ 3-4 & 8 \mathrm{c}-8 \mathrm{~b} & \text { c, c } & \text { cc. } 52-65 & 14 \mathrm{cc} . \\ 5 & 8 \mathrm{c} & \mathrm{a} & \text { cc. } 66-70 & 5 \mathrm{cc} . \\ 6 & 9 \mathrm{~b} & \text { b', b } & \text { cc. } 71-55 & 6 \mathrm{cc} .\end{array}$

\section{ANÁLISIS}

Comienza con el tema a en imitación para luego seguir en contrapunto libre, mientras el tema b se repite cinco veces con un interludio instrumental por medio. La copla comienza también con imitación sobre un nuevo tema, repitiéndose todo antes de pasar a la vuelta donde se retoma el tema a y el b otras dos veces.

$\mathrm{El}$ esquema resultante queda: $\mathrm{ABB}{ }^{*} \mathrm{BB} \mathrm{B}^{\prime} \mathrm{cc} \mathrm{AB} \mathrm{B}^{\prime} \mathrm{Btilizamos} *$ para indicar un episodio instrumental de una cierta duración)

\section{COMENTARIO}

Está basado en la mismas melodías que la versión de Juan Vázquez publicada en $1560,{ }^{892}$ pero la realización musical difiere, aunque ambas están construidas mediante contrapunto imitativo. No obstante, Mudarra no es tan sistemático en la imitación como Vázquez. También Pisador utilizó este villancico, pero en este caso coincide con la versión de Vázquez. ${ }^{893}$

${ }^{892}$ ANGLÉS, Higinio. Juan Vásquez «Recopilación de Sonetos y Villancicos a quatro y a cinco» (Sevilla, 1560). MME 4, Barcelona, CSIC, Instituto Español de Musicología, 1946, nº 31, pp. 198-199.

${ }^{893}$ PISADOR. Libro de música de vihuela, ff. 11v-12. Hay transcripción moderna en ROA, F. y GÉRTRUDIX, F. El libro de música... Estudio y transcripción, $\mathrm{n}^{\circ} 22$, p. 160. 


\section{2- Gentil cavallero}

Villancico. I modo. Posición c (vihuela en A). $3+1$ voces. Tempo medio. Notas móviles: Mi Ł (III), Fa\# (IV). La b (VI), Si Ł (VII). Voz canto: soprano.

\section{NOTAS CRÍTICAS}

1. c. 17. Añadimos la mínima que figura entre corchetes.

2. c. 19. Ponemos 7 en $1^{\circ}$ orden en lugar de 3 . Indicado en la fe de erratas del final.

3. c. 54 . Ponemos 2 en $4^{\circ}$ orden en lugar de 3 .

\section{TEXTO}

Aparece en numerosas fuentes. ${ }^{894}$

«Gentil cavallero
dédesme hora un beso:
siquiera por el daño
que me avéys hecho».
Venía el cavallero,
venía de Sevilla,
en huerta de monjas
limones cogía,
y la prioresa
prenda le pedía:
«siquiera por el daño,
que me avéys hecho».

\section{ESTRUCTURA}

$\begin{array}{ccccc}\text { Verso } & \text { Rima } & \text { Melodía } & \text { Compases } & \text { Longitud } \\ 1 & 6 \mathrm{a} & \mathrm{a} & \text { cc. } 1-5 & 5 \mathrm{cc} . \\ 2 & 7 \mathrm{a} & \mathrm{b} & \text { cc. } 6-10 & 5 \mathrm{cc} . \\ 3-4 & 7 \mathrm{~b}-5 \mathrm{a} & \text { c, c } & \text { cc. } 11-38 & 28 \mathrm{cc} . \\ 5 & 7 \mathrm{a} & \mathrm{a} & \text { cc. } 39-43 & 5 \mathrm{cc} .\end{array}$

${ }^{894}$ Para las concordancias literarias y las variantes remitimos a FRENK. Nuevo Corpus, pp. 1199-1200, $\mathrm{n}^{\circ}$ 1682. 


$\begin{array}{ccccc}6 & 7 c & \text { b } & \text { cc. } 44-48 & 5 \text { cc. } \\ 7 & \text { 6d } & \text { a } & \text { cc. } 49-53 & 5 \text { cc. } \\ 8 & \text { 6c } & \text { b } & \text { cc. } 54-58 & 5 \text { cc. } \\ 9 & 6 e & \text { a } & \text { cc. } 59-63 & 5 \text { cc. } \\ 10 & \text { 6c } & \text { b } & \text { cc. } 64-68 & 5 \text { cc. } \\ 11-12 & 7 b-5 a & \text { c, c } & \text { cc. } 69-96 & 28 \text { cc. }\end{array}$

\section{ANÁLISIS}

Tras la rápida exposición de los dos primeros temas, a y b, y antes de que acabe el segundo, se inicia el tema c en imitación en la vihuela y luego en la voz, donde se repite dos veces mientras las voces instrumentales insisten en la cabeza de este tema que incluye dos versos. La copla repite las dos melodías iniciales para los seis versos, mientras la vihuela acompaña en contrapunto libre. En la vuelta se repite la misma situación que en los dos últimos versos del estribillo, intercalando un episodio instrumental imitativo sobre c. El esquema resultante quedaría así: ABCC ababab *CC

\section{COMENTARIO}

Del mismo villancico hay una versión de Pisador $^{895}$ y también en el Cançoner de Barcelona. ${ }^{896}$ En ambos casos coinciden los temas con los de Mudarra, pero la realización es diferente.

\section{3- Ysabel, perdiste la tu faxa}

Villancico. I modo. Posición g (vihuela en G). $4+1$ voces. Tempo medio. Notas móviles: Si 4 (III), Do\# (IV), Mi b (VI), Fa\# (VII). Voz canto: tenor o soprano.

\section{NOTAS CRÍTICAS}

1. c. 10. El rasguito carece de sentido.

2. c. 14. La mínima es innecesaria.

${ }^{895}$ PISADOR. Libro de música de vibuela, f. 13. Hay transcripción moderna en ROA, F. y GÉRTRUDIX, F. El libro de música... Estudio y transcripción, no 26, p. 164.

${ }^{896}$ Cançoner de Barcelona, Biblioteca de Catalunya, M 454, f. $185 \mathrm{v}$. 
TEXTO

El texto es el siguiente. ${ }^{897}$

$$
\begin{gathered}
\text { Ysabel, Ysabel } \\
\text { perdiste la tu faxa: } \\
\text { ¡éla por do va } \\
\text { nadando por el agua! } \\
\text { Ysabel, la tan garrida }
\end{gathered}
$$

\section{5}

\section{ESTRUCTURA}

$\begin{array}{ccccc}\text { Verso } & \text { Rima } & \text { Melodía } & \text { Compases } & \text { Longitud } \\ 1-2 & \text { 6a-7b } & \text { a } & \text { cc. } 1-28 & 28 \text { cc. } \\ 3-4 & 5 \mathrm{c}-7 \mathrm{~b} & \text { b, b } & \text { cc. } 29-51 & 23 \text { cc. } \\ 5 & 8 \mathrm{~d} & \text { a', a' } & \text { cc. } 52-69 & 18 \mathrm{cc} .\end{array}$

\section{ANÁLISIS}

Es el único villancico a cinco voces, aunque solo en determinados momentos. Comienzo imitativo sobre el tema a en todas las voces. El motivo b está basado en una nota repetida que imprime un movimiento rápido a toda la sección. El quinto verso retoma el motivo a sin que podamos hablar de una auténtica vuelta debido a la ausencia de rima. El esquema resultante queda: AbbA'A'

Mudarra indica que se puede cantar también octava arriba.

${ }^{897}$ Para las concordancias literarias y las variantes remitimos a FRENK. Nuevo Corpus, p. 1209, no 1694. 


\section{4- Si viesse e me levasse}

Villancico. I modo. Posición c (vihuela en A). $3+1$ voces. Tempo medio. Notas móviles: La b (VI), Si 4 (VII). Voz canto: soprano.

\section{NOTAS CRÍTICAS}

1. c. Añadimos Fine y doble barra final.

2. c. 19. Mínima añadida a mano en el original.

3. c. 24. Añadimos D. C. al Fine.

\section{TEXTO}

El texto es el siguiente. ${ }^{898}$

\section{Si viesse e me levasse,}

por miña vida, que no gridase!

Meu amigo atán garrido

si viesse o domingo,

por miña vida, que no gridasse!

\section{ESTRUCTURA}

$\begin{array}{ccccc}\text { Verso } & \text { Rima } & \text { Melodía } & \text { Compases } & \text { Longitud } \\ 1 & 8 \mathrm{a} & \mathrm{a} & \text { cc. } 1-6 & 6 \mathrm{cc} . \\ 2 & 10 \mathrm{a} & \text { b, b' } & \text { cc. } 7-18 & 12 \mathrm{cc} . \\ 3 & 8 \mathrm{~b} & \mathrm{a} & \text { cc. } 19-24 & 6 \mathrm{cc} . \\ 4 & 8 \mathrm{~b} & \mathrm{a} & \text { cc. } 1-6 & 6 \mathrm{cc} . \\ 5 & 10 \mathrm{a} & \text { b, b' } & \text { cc. } 7-18 & 12 \mathrm{cc} .\end{array}$

\section{ANÁLISIS}

Un sencillo acompañamiento homofónico con muy pocos acordes, principalmente i y V grado, sirven para acompañar este sencillo y breve villancico.

\footnotetext{
${ }^{898}$ Para las concordancias literarias y las variantes remitimos a FRENK. Nuevo Corpus, p. 408, no 584.
} 


\title{
75- Nisi Dominus
}

Salmo. VII modo. Posición g (vihuela en A). $4+1$ voces. Tempo medio. Notas móviles: La b (II), Si ต (III), Mi b (VI), Fa\# (VII). Voz canto: tenor.

\section{NOTAS CRÍTICAS}

1. c. 4. Mudarra escribe «edificaverit».

2. c. 7. Desdoblamos la semibreve para el segundo texto.

3. cc. 10-12. Desplazamos la palabra «frustra».

4. c. 15. Mudarra escribe «edificant».

5. c. 19. Añadimos barra de repetición.

\section{TEXTO}

Se trata del Salmo 126.

\author{
Nisi Dominus aedificaverit domum \\ in vanum laboraverunt qui aedificant eam. \\ Nisi Dominus custodierit civitatem \\ frustra vigilat qui custodit eam. \\ Si el Señor no edifica la casa, \\ en vano trabajan los que la edifican. \\ Si el Señor no custodia la ciudad, \\ inutilmente vigila quien la custodia.
}

\section{INTRODUCCIÓN}

Dice Santa María a propósito de los tonos: «los tonos se tañen de dos maneras. La una es conforme a la propriedad y naturaleza que cada tono tiene [...] La otra manera es conforme al seculorum, que cada tono tiene, lo qual sirve solamente para tañer en la yglesia, Psalmos, hymnos y cánticos». ${ }^{899}$

Así hace Mudarra para los dos salmos que incluye en su libro, toma dos tonos del seculorum y sobre ellos compone sendos fabordones. El sencillo procedimiento es descrito

${ }^{899}$ SANTA María, T. Libro llamado Arte..., f. 62v. 
por Monachus a finales del siglo XV, ${ }^{900}$ se toma la melodía del seculorum como soprano y se le añade un tenor que comienza y termina a la octava, con terceras y sextas paralelas. Se añade el bajo comenzando a octava y unísono del tenor y rellenando con terceras y quintas; posteriormente se añade el contralto. Se mantiene en los fabordones la división en hemistiquios del salmo o Magnificat original. Al estar basados en una cuerda de recitación sobre la dominante del tono, la armonía que se genera es muy estática y además la final de la pieza no coincide con la final del modal.

Los salmos de Mudarra serían los primeros fabordones instrumentales, o para voz e instrumento, conocidos, aunque el autor no los denomine así. Otros vihuelistas posteriores que publicaron fabordones para voz y vihuela en sus libros son: Pisador con dos, Fuenllana con nueve de Guerrero por todos los tonos y Venegas que toma prestados un par de ellos. Podemos añadir los dos tientos de Cabezón sobre tonos del Magnificat.$^{901}$

\section{ANÁLISIS}

La pieza se divide en dos partes de nueve y diez compases, la primera concluye en la cadencia media y la segunda en la cadencia final. Se puede observar como Mudarra utiliza, en general, las notas largas para los acentos prosódicos. Hay que destacar que se trata de una pieza a cinco voces.
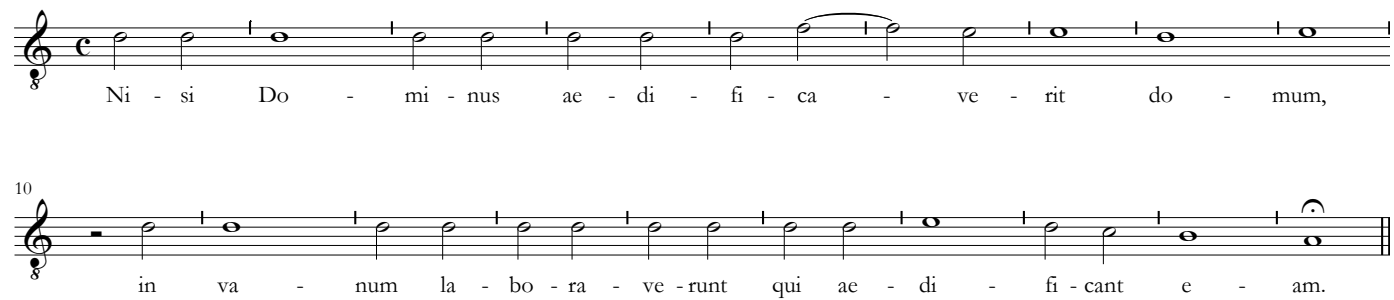

Ejemplo 24. Melodía del salmo Nisi Dominus.

Venegas incluye esta pieza como Favordones de vihuela. Séptimo tono. ${ }^{902}$

${ }^{900}$ Descrito por Hudson, Richard. «The Folia, Fedele and Falsobordone», The Musical Quarterly, 58 (1972), pp. 398-411; p. 403.

${ }^{901}$ Roig-Francolí, Miguel A. «Dos tientos de Cabezón basados en tonos de Magnificat», Revista de Musicologia, 21/2 (1998), pp. 477-495.

${ }^{902}$ Venegas de HenESTROSA. Libro de cifra nueva..., f. $43 \mathrm{v}$. 


\section{6- Exurge, quare obdormis}

Salmo. I modo. Posición f (vihuela en E). $3+1$ voces. Tempo medio. Notas móviles: Sol b (II), La $\nleftarrow$ (III), Re b (VI), Mi $\pitchfork$ (VII). Voz canto: soprano o tenor.

\section{NOTAS CRÍTICAS}

1. Respetamos la grafía «Exurge» en lugar de «Exsurge», pues la primera es frecuente en el siglo XVI.

2. cc. 27-28. Mudarra escribe «inopie».

3. cc. 29-30 Mudarra escribe «nostre».

4. c. 34. La semimínima está invertida.

5. c. 34-35. Reajustamos el texto. Mudarra escribe «tribulationes nostre».

TEXTO

Se corresponde con el Introito del domingo de Sexagésima y está extraído del Salmo 43: Deus, auribus nostris (versículos 23-24).

\footnotetext{
Exurge, quare obdormis, Domine?

exurge, et ne repellas in finem.

Quare faciem tuam avertis, oblivisceris

inopiae nostrae et tribulationis nostrae?

Levántate, ¿por qué duermes, Señor?

levántate y no te alejes para siempre.

¿por qué apartas tu rostro, olvidando

nuestra necesidad y nuestra tribulación?
}

\section{ANÁLISIS}

Similar al anterior, aunque en esta ocasión Mudarra pone música a los dos versos completos, dividiendo el segundo en tres secciones.

Hudson reproduce esta pieza y cree encontrar una relación entre su secuencia acordal y el esquema de folía. ${ }^{903}$

${ }^{903}$ Hudson, Richard. «The Folia..., 
El texto que cierra los tres libros presenta un cierto tono trágico de súplica, pero, como ya ha sido destacado, hay un cierto carácter grave en toda la obra vocal de Mudarra. Escasean las obras alegres, que son más frecuentes en otros vihuelistas. ${ }^{904}$

\section{7- Tiento 9}

Tiento. VII modo. 4 voces. Tempo medio. Notas móviles: Sił (IV), Mi Ł (VII).

\section{NOTAS CRÍTICAS}

1. c. 8. Añadimos la mínima que figura entre corchetes.

\section{COMENTARIO}

Esta brevísima obra de Mudarra es un experimento de un nuevo tipo de notación para arpa u órgano. Una vez más Mudarra es pionero, pues se trata de la primera pieza de arpa publicada. Tal y como defiende Andrés Cea, ${ }^{905}$ parece ser que el instrumento destinatario de esta cifra es el arpa más que el órgano, pues carece de los signos para las pausas, necesarios en las tablaturas de órgano, y alude continuamente a las cuerdas, más que al juego del órgano. Podría existir una relación entre esta cifra de Mudarra y las tabula compositoria o los keyboard scores.

Antes de la pieza pone el siguiente texto:

De esta otra parte se pone un principio de un Libro que tenía hecho para Imprimir, en el qual avía muchas Fantasías y Composturas en una nueva manera de cifras para Harpa y Órgano, el qual acordé poner aquí (Pues mis ocupaciones no me dieron lugar a que imprimiese el dicho libro) para que si a alguno le paresciere bien la invención destas cifras se pueda aprovechar della, sacando en ellas composturas como se sacan en las de la Vihuela porque en todo llevan la mesma orden, salvo que estas

${ }^{904}$ SUÁREZ-PAJARES, Javier. «La música instrumental: vihuelas, arpa y tecla», GÓMEZ, Maricarmen (ed.). Historia de la música en España e Hispanoamérica. Vol. 2. De los Reyes Católicos a Felipe II. Madrid, Fondo de Cultura Económica, 2012, pp. 215-290; p. 250.

905 CEA GALÁN, Andrés. La cifra hispana: música, tañedores e instrumentos (siglos XVI-XVIII). Tesis Doctoral, Universidad Complutense de Madrid, 2014. Seguimos sus aportaciones para los párrafos siguientes. Los posibles modelos de la cifra de Mudarra son estudiados exhaustivamente en dicho trabajo. 
cifras no tienen número de uno, ni de dos, ni de nada. Todas son de una manera, no hazen más de señalar las cuerdas en que an de tocar.

Lamentablemente el libro prometido nunca vió la luz, si es que existió. Esta aclaración recuerda mucho a la de Venegas de Henestrosa cuando nos promete sacar otros seis libros, «que aunque está hechos, no saldrán, hasta ver el provecho que haze el primero». ${ }^{906}$ Pura estrategia comercial.

${ }^{906}$ Venegas De Henestrosa. Libro de cifra nueva..., f. 1v. 



\section{CONCLUSIONES}

El trabajo que aquí concluye nos ha permitido explicar no sólo la figura y la obra de Alonso Mudarra, sino también su contexto. Esa era nuestra intención original, pues estamos firmemente convencidos de que el conocimiento de la parte es muy difícil sin analizar el todo.

El objeto de nuestro estudio, el vihuelista y canónigo Alonso de Mudarra, es representativo de una sociedad en permanente ebullición y cambio: la sociedad castellana renacentista del siglo XVI. Hemos intentado indagar en el universo intelectual y espiritual de un individuo inmerso en un convulso mundo social marcado por un cambio de dinastía, revoluciones sociales truncadas y una fuerte espiritualidad, no siempre lo suficientemente ortodoxa. Culturalmente, Castilla se convirtió en el crisol donde se fusionaron los elementos autóctonos, con fuerte presencia del pasado mudéjar, los nuevos usos francoflamencos traídos por los Habsburgo y la novedosa y resplandeciente cultura italiana que causaba furor en las cortes hispanas.

Alonso Mudarra debió nacer hacia 1509 en Valladolid, o tal vez en Medina del Campo, en el seno de una familia de esas que se han denominado el «patriciado urbano», que eran parte fundamental del poder municipal durante los siglos XIII a XVI y en las que la sospecha de contaminación «conversa» era permanente. En una rama lateral de esta familia, estaría el comendador Frey Pedro Mudarra, de la Orden de San Juan de Jerusalén. Su condición de caballero sanjuanista y su juramento de celibato no le impidieron tener al menos un par de hijos de mujer soltera, Alonso y Pedro Mudarra. Alonso perteneció al selecto cuerpo de «continos» de la Casa de Castilla, cayendo en desgracia por su implicación en la revolución de las Comunidades. Creemos que este Alonso sería el padre de nuestro vihuelista. Datos ciertos son los de los hermanos Francisco, Ana, Catalina e Ysabel. El mayor, Francisco, fue un conspicuo curial vaticano que acabó siendo condenado por la Inquisición debido a sus afinidades erasmistas y luteranas. Reservados para Francisco los estudios universitarios y, a priori, la carrera eclesiástica, Alonso ingresó 
en la rutilante corte alcarreña de los duques del Infantado. Sus méritos, una extremada pericia como vihuelista que le convirtió desde su tierna mocedad en vihuelista de cámara del duque. Allí, en Guadalajara, pasó dos décadas de su vida en compañía de «excelentes hombres», lo más granado de la música española del momento. Tras un repaso por las decenas de nombres de los músicos que trabajaron en Guadalajara y después de contrastar los datos con los de otras cortes y catedrales españolas, tenemos la certeza de que el palacio del Infantado fue destino codiciado por los mejores músicos de Castilla y aun de fuera de ella. Hemos podido documentar numerosos capellanes, cantores, varias dinastías de ministriles y trompetas, tañedores de cámara que, dentro de la particular carrera de un músico renacentista, pasaron por las ilustres cortes de la monarquía, de la alta nobleza o de las más importantes catedrales.

Cuando en 1543 Alonso fue despedido, su futuro posiblemente fuera incierto. Tenía la posibilidad de buscar un nuevo patrón y continuar con su carrera de vihuelista. En estas fechas es probable que ya tuviera la determinación de sacar en cifra de molde sus músicas, tantos años practicadas. Un posible viaje a Roma y los contactos de su hermano Francisco hicieron que su vida diera un vuelco inesperado. En 1546, al mismo tiempo que publicaba sus Tres libros de música en cifras para vibuela, obtenía una sustanciosa canonjía en la catedral de Santa María de Sevilla. Desde este año, hasta su muerte el 1 de abril 1580, Viernes Santo, lamentablemente para nosotros la música pasó a un segundo plano en su vida. El prometido «Libro que tenía hecho para imprimir, en el qual avía muchas fantasías y composturas en una nueva manera de cifras para harpa y órgano» tal vez sea el que figura en su inventario como «un libro de çifras de música de mano», tristemente perdido. En la catedral hispalense los dos hermanos Mudarra dedicaron todo su empeño en comerciar con canonicatos, hasta que Francisco cayó en desgracia. Fuera de los muros de la catedral no conocemos ninguna actividad de Alonso, descontando algunos pleitos y negocios. Sabemos que en su casa de la collación de Santa María vivía en compañía de su sobrino homónimo y de sus criados y esclavos llevando una «vida de canónigo».

Mudarra tuvo la suerte de contar con un poderoso invento gracias al cual pudo trascender y alcanzar la gloria y la fama, nos referimos, claro está, a la imprenta. Sin ella, posiblemente, no estaríamos hoy aquí escribiendo sobre él. La música que nos hizo llegar 
al presente constituye uno de los monumentos artísticos de los siglos dorados hispanos y a ella hemos dedicado otra gran parte de este trabajo.

Sus Tres libros es el tercero cronológicamente entre los siete magníficos libros de vihuela que vieron la luz en las prensas españolas. Puede que no sea tan bello en su factura como los que incluyen la cifra colorada y el gran formato en folio, puede también que esté trufado de erratas tipográficas, pero su contenido compensa cualquier defecto. Todo en él está perfectamente planificado y ordenado según un criterio pedagógico y, tal vez, retórico. Además, está lleno de novedades, pues Alonso Mudarra fue pionero desde el punto de vista musical en muchos aspectos, tanto en lo instrumental como en lo vocal.

El primero de los tres libros en que se divide su obra está dedicado al aprendizaje del vihuelista, con fantasías en las que le indica la técnica para redoblar, otras denominadas fáciles que le introducen en el contrapunto, seguidas de un par de composturas del gran Josquin. Una deslumbrante fantasía imitando el arpa constituye el primer ejemplo conocido del esquema de folía en el repertorio instrumental y no es el único en la obra de Mudarra, pues poco más adelante incluye un par de pavanillas, esquema emparentado o derivado de la folía. También aquí aparece por primera vez en España una pieza con el nombre de gallarda y comparte con Phalèse la primera presentación del termino romanesca. Por si esto fuera poco, encontramos la primera música impresa para guitarra de cuatro órdenes, la que hoy llamamos guitarra renacentista.

El segundo libro está estructurado sobre los primeros ciclos modales formados por varias piezas seguidas que aparecen en Europa y entre ellos los primeros glosados sobre composturas impresos en España. La idea de unidad de cada grupo de piezas sobre un modo está corroborada por una unidad motívica y una alternancia de piezas rápidas y lentas que será característica de las suites del siglo siguiente.

El tercer libro está dedicado en exclusiva a la música vocal. Destaca en él su carácter magistral en cuanto a su contenido textual, pues alberga todas las tendencias poéticas que coexistieron en la Castilla de principios del siglo XVI. Tradición y modernidad conviven sin fricciones, como así ocurriría en las cortes hispanas. La tradición estaría constituida 
por romances, villancicos y la poesía culta castellana de corte manriqueño. La modernidad por las nuevas formas italianas, cuyos representantes abarcarían desde Petrarca a Sannazaro y sus émulos castellanos, Garcilaso y Boscán. Aunque pudiera parecer paradójico, a esta modernidad habría que sumar los clásicos latinos, como Horacio, Ovidio y Virgilio, pues para esta generación de artistas avanzar significaba retroceder y emular a los mejores.

Muchas de estas piezas vocales se pueden considerar antecedentes de la monodía acompañada, pues Mudarra es de los precursores en componer música específica para voz y acompañamiento instrumental. Entre ellas encontramos las primeras canciones y sonetos en castellano puestos en música. Concluye su tercer libro con los primeros fabordones instrumentales en Europa y, para rematar, cierra su obra la primera tablatura para arpa conocida, y primera para órgano en España.

En definitiva, Mudarra es el vihuelista más innovador y, posiblemente, el que mejor representa las tendencias más avanzadas en la música hispana de la primera mitad del siglo XVI. Su posición dentro de la música europea debe ser reivindicada, pues figura entre los compositores vanguardistas de su generación. Se le podría considerar muy cercano a Luis Milán, ambos vihuelistas cortesanos en lugares estratégicos por donde circulaban todas las novedades artísticas, Guadalajara y Valencia. También lo podemos comparar con Luis de Narváez, pero mientras que en este la influencia del mundo francoflamenco, con su contrapunto lógico y racional, es más evidente, el mundo espiritual de Mudarra está más próximo a lo emocional, a lo lírico o lo retórico, en definitiva al humanismo. 


\section{Anexos}

Anex

Contenido

Página

I Índices de BNE, Mss/11141 y y Mss/11142

422

II Confesiones y absolución de Francisco Mudarra $\quad 427$

III Inventario del III duque del Infantado 429

IV Tasación de los bienes de Diego Hurtado de Mendoza 430

V Inventario de los bienes de Isabel de Aragón, esposa del IV duque 431

VI Composición del Cabildo de la catedral de Sevilla, 1550

VII Carta de poder para el cobro de libros 436

$\begin{array}{lll}\text { VIII } & \text { Venta de un esclavo } & 437\end{array}$

IX Testamento de Alonso Mudarra 438

$\begin{array}{lll}\text { X Inventario del canónigo Mudarra } & 440\end{array}$

XI Almoneda del canónigo Mudarra 453

XII Recibo de Miguel de Abrego, criado de Alonso Mudarra 467

XIII Reparto y venta de cebada de Alonso Mudarra $\quad 468$ 
ANEXo I

ÍNDICES DE BNE, Mss/11141 y BNE, Mss/11142

BNE, Mss/11141

\begin{tabular}{lll}
\hline Año & Descripción & Folios \\
\hline
\end{tabular}

1534 Nómina de los maravedís, pan, trigo y cevada que Alonso de Vallejo Contador de

ff. $1-11$

D. Íñigo López de Mendoza 4º Duque del Infantado, avía de librar el año de 1534 para el gasto de su despensa y raciones y a los cavalleros y continos oficiales y gente de guerra y desquentos acostumbrados y otras cosas como en dicha nómina se contiene.

Blanco.

1535 Nómina original firmada de Don Íñigo López de Mendoza $4^{\circ}$ Duque del Infantado; de los maravedís, pan, trigo y cevada que Alonso de Vallejo su Contador avía de librar para el gasto de su despensa y raciones y a los Cavalleros y Continos y oficiales y gente de guerra y desquentos acostumbrados y otras cosas, el año de 1535, en la conformidad que en dicha nómina se declara. Blanco.

1536 Nómina original firmada de Don Íñigo López de Mendoza $4^{\circ}$ Duque del Infantado, de los maravedís, pan, trigo y cevada gallinas y vino, que Alonso de Vallejo su Contador avía de librar el año de 1536 para el gasto de su despensa y raciones, y a los Cavalleros y Continos oficiales y gente de guerra, y desquentos acostumbrados y otras cosas como en dicha nómina se contiene.

Blanco.

1537 Nómina de los maravedís, pan, trigo y cevada gallinas y vino que Alonso de Vallejo Contador de Don Íñigo López de Mendoza $4^{\circ}$ Duque del Infantado, avía de librar el año de 1537 para el gasto de su despensa y raciones, y a los Cavalleros y Continos de su Casa y oficiales y gente de guerra, y desquentos acostumbrados y otras cosas ordinarias y extraordinarias de la Casa de dicho Duque, como en dicha nómina se contiene.

Blanco.

1537 Nómina original firmada de Don Íñigo López de Mendoza $4^{\circ}$ Duque del Infantado su firma en 23 de julio de 1537, por la qual manda a Bartolomé Gallego su criado que de las 646D990 mrs. que le libró en sus rentas y hacienda el dicho año, para la paga de los cavalleros y escuderos que con dicho Duque vivían en los partidos de Tordehumos, Arévalo y Ontiveros y sus tierras y comarcas, diese y pagase a las personas en dicha nómina contenidas las cantidades de mrs. en ella espresadas que avían de aver de sus acostamientos el dicho año de 1537.

Blanco.

1538 Nómina original firmada de Don Íñigo López de Mendoza $4^{\circ}$ Duque del Infantado, de los maravedís, pan, trigo, cevada, gallinas y vino que Alonso de Vallejo su Contador avía de librar el año de 1538 para el gasto de la despensa y raciones de dicho Duque, y a los Cavalleros y Continos y oficiales y desquentos acostumbrados y otras cosas como en dicha nómina se contiene.

Blanco.

1537 Nómina de los maravedís, pan, trigo, cevada, gallinas y vino que Alonso de Vallejo Contador de Don Íñigo López de Mendoza $4^{\circ}$ Duque del Infantado, avía de librar el año de 1537 para el gasto de la despensa y raciones, y a los Cavalleros y Continos y oficiales y gente de guerra y desquentos acostumbrados de su Casa y otras cosas ordinarias y extraordinarias de su Casa, como en dicha nómina se contiene.

Blanco.

ff. $14-20$

ff. 21-42

ff. 43-44

ff. $45-68$

ff. $69-70$

ff. $71-87$

ff. 88-91

ff. $92-95$

ff. $96-97$

ff. $98-115$

ff. $116-118$

ff. $119-140$ 
1538 Nómina de los maravedís, pan, trigo, cevada, gallinas y vino que Alonso de Vallejo Contador de Don Íñigo López de Mendoza $4^{\circ}$ Duque del Infantado avía de librar el año de 1538 para el gasto de su despensa y raciones, y a los Cavalleros y Continos y oficiales y gente de guerra y desquentos acostumbrados de su Casa y otras cosas según se contiene en dicha nómina.

Blanco.

1540 Nómina original firmada de D. Íñigo López de Mendoza $4^{\circ}$ Duque del Infantado fecha el año de 1540 por la qual manda a Martín de Cáceres su contador maior, librase a la Duquesa su muger y al Conde de Saldaña su hijo y a su despensa y a las otras personas en la dicha nómina contenidas. los maravedís, pan, trigo, cevada, gallinas y vino que en ella se declaran que lo avían de aver el dicho año así en acostamiento como en ración.

Blanco.

Nómina de los maravedís, pan, trigo, cevada, gallinas y vino que Martín de Cáceres Contador maior de D. Íñigo López de Mendoza $4^{\circ}$ Duque del Infantado, avía de librar el año de 1541 para su despensa y a la Duquesa su muger y Conde de Saldaña su hijo y a las otras personas en dicha nómina contenidas, que lo avían de aver el dicho año así en acostamiento como en ración.

Blanco.

Cuentas totales.

Blanco.

ff. $156-161$

ff. $162-180$

Nómina original firmada de D. Íñigo López de Mendoza $4^{\circ}$ Duque del Infantado fecha el año de 1542 por la qual manda a Martín de Cáceres su contador maior, que librase a la Duquesa su muger y al Conde de Saldaña su hijo, y a su despensa y las otras personas contenidas en dicha nómina, los maravedís, pan, trigo, cevada, gallinas y vino que en ella se declaran, lo qual avían de aver el dicho año así en acostamiento como en ración.

Blanco

1544 Apuntamiento de libranza de la Casa de Don Íñigo López de Mendoza $4^{\circ}$ Duque del Infantado del año de mil y quinientos y quarenta y quatro.

Blanco.

1546 Nómina original firmada de D. Íñigo López de Mendoza $4^{\circ}$ Duque del Infantado fecha el año de 1546 por la qual manda a Martín de Cáceres su contador maior, que librase a la Duquesa su muger y Conde de Saldaña su hijo y a su despensa y raciones y a los otros sus hijos y personas de su Casa en dicha nómina contenidas, los maravedís, pan, trigo, cevada, gallinas que en ella se expresan, que avían de aver el dicho año por su acostamiento y raciones.

Blanco

1545 Nómina original firmada de D. Íñigo López de Mendoza $4^{\circ}$ Duque del Infantado, fecha el año de 1545, por la qual manda a Martín de Cáceres su contador maior, que librase a la Duquesa su muger y Conde de Saldaña su hijo y a los demás sus hijos y personas de su casa contenidas en dicha nómina, los maravedís, pan, trigo, cevada y gallinas que en ella se refieren, que lo avían de aver el dicho año por sus acostamientos y ración.

Blanco.

Apuntamiento de la librança de la Casa de Don Íñigo López de Mendoza $4^{\circ}$ Duque del Infantado del año de mil quinientos y quarenta y seis.

Blanco.

1548 Nómina original firmada de D. Íñigo López de Mendoza $4^{\circ}$ Duque del Infantado fecha el año de 1548 por la qual manda a Rodrigo de Quiroga su Contador maior, que librase a la Duquesa su muger y Conde de Saldaña su hijo y a su despensa y demás sus hijos y personas de su casa contenidas en dicha nómina, los maravedís, pan y gallinas y otras cosas que avían de aver en el dicho año.

Blanco.

1549 Nómina original firmada de D. Íñigo López de Mendoza $4^{\circ}$ Duque del Infantado fecha el año de 1549 por la qual manda a los oficiales de su contaduría que librasen a la Duquesa su muger y al Conde de Saldaña su hijo, y a su despensa y raciones y a los otros sus hijos y criados de su casa que en dicha nómina se contienen, los 
maravedís, pan y gallinas que en ella se declaran, que los avían de aver el dicho año por sus acostamientos y raciones.

Blanco.

1562 Nómina de los maravedís, trigo, centeno, cevada y gallinas que Pedro de Alcocer y Diego Gil Contadores de Don Íñigo López de Mendoza Duque del Infantado, avían de librar el año de 1562 a la Duquesa su muger y al Marqués del Zenete y Don Íñigo de Mendoza sus hijos y al Conde de Tendilla y a los Cavalleros y continos y gente de guerra de su casa y otras cosas contenidas en dicha nómina, que los avían de aver el dicho año.

Blanco.

1603 Relación firmada de Antonio de Villacis Contador de Don Juan Hurtado de Mendoza Marqués del Zenete y Duque del Infantado fecha el año de 1603, de los criados que se avían de despedir luego quel dicho Duque partiese de Guadalajara a Valladolid.

Blanco.

Nómina original firmada de don Juan Hurtado de Mendoza Marques del Zenete y Duque del Infantado su fecha en la ciudad de Guadalajara a 5 de Abril de 1603 por la qual manda al Licenciado Diego de Albornoz y sotomaior su Contador que en el interin que el dicho Duque y la Duquesa $\mathrm{D}^{\mathrm{a}}$ Ana su muger estubieren fuera de la ciudad de quales quier maarvedís de su cargo diese y pagase en ella a las personas sus criados contenidas en dicha nómina, los maravedís que en la partida se declaran que avían de aver en el dicho año, esto demás de las raciones que avía de pagar cada día a las personas contenidas en un memorial firmado de Antonio de Villacis Contador del dicho Duque.

Blanco.

1603 Relación original firmada de Antonio de Villacis Contador de Don Juan Hurtado de Mendoza Duque del Infantado fecha en Valladolid a 12 de Octubre de 1603, de las personas a quien dicho Duque mandó que se les borrase o quitase las raciones de que les hacía merced y salarios que les dava.

Blanco. 
1486 Relación simple de los maravedís que el señor Valverde avía para pagar ff. I, 1-2 acostamientos y sueldos a la gente de Ontiveros Blanco.

1486 Libramiento original dado por Don Íñigo López de Mendoza Duque del Infantado su fecha en 15 de Marzo de 1486 por el qual manda a Don Daví de la Hija su Mayordomo que los mrs. que avía recivido de Diego Francés, diese a las personas en él contenidas las quantías de mrs. que avían de aver de sus acostamientos que de dicho Duque tenían, y se los mandava pagar adelantados por quanto avían de ir con él a la guerra de los moros.

Blanco.

1534 Nómina original firmada de Don Íñigo López de Mendoza $4^{\circ}$ Duque del Infantado, de los mrs. pan trigo y çevada que Alonso Vallejo su Contador avía de librar, para el gasto de su despensa y raciones y a los cavalleros y continos y oficiales y gente de guerra y desquentos acostumbrados y otras cosas ordinarias y extraordinarias el año de 1534 en la conformidad que en dicha nómina se contiene.

Blanco y cuentas.

1486 Un libramiento original dado por Don Íñigo López de Mendoza Duque del Infantado su fecha en 20 de Enero de 1487 por el qual manda a Don Daví de la Hija su Mayordomo en la Villa de Buitrago y su tierra, que del cargo de su arrendamiento del año pasado de 1586 diere y pague a las personas en dicho libramiento contenidas, los maravedís en él espresados que los avían de aver a cumplimiento de sus acostamientos que de dicho Duque tenían y ubieron de aver el dicho año de 1486.

Blanco.

1517 Relación del cargo y data de las rentas y hacienda de Don Diego Hurtado de Mendoza $3^{\circ}$ Duque del Infantado año de 1517 con los servicios de la Duquesa su muger, y con las ratas que le pertenecieron en dicho año y con los derechos de Contaduría de 30 maravedís el millar que se cargan por cuerpo de renta, sin el pan gallinas y otras cosas que el dicho Duque tenía.

Blanco.

1511 Relación del cargo y data de la hacienda de Don Diego Hurtado de Mendoza $3^{\circ}$ Duque del Infantado del año de 1511 con los servicios de la Duquesa su muger y rentas pertenecientes a dicho Duque y derechos de Contaduría y otras cosas en ella contenidas.

Blanco.

1517 Nómina original de la gente contina de Don Íñigo López de Mendoza Conde de Saldaña su fecha en 28 de mayo de 1517 por la que la manda a Diego López de Orozco su mayordomo maior diese y pagase a las personas en ella contenidas las cantidades de mrs. que en ellas se refieren por razón de sus acostamientos y otras cosas. Y a continuación van los recivos originales.

Blanco

1520 Nómina de la gente Contina y de tierra de la Casa de Don Diego Hurtado de Mendoza $3^{\circ}$ Duque del Infantado, de el año de 1520, en que se les manda pagar sus acostamientos y salarios.

Blanco.

1522 Nómina de la gente contina y de tierra de la Casa de Don Diego Hurtado de Mendoza $3^{\circ}$ Duque del Infantado, del año de 1522 por la qual se les manda pagar sus acostamientos y salarios.

Blanco.

1555 Nómina original firmada de Don Íñigo López de Mendoza $4^{\circ}$ Duque del Infantado y refrendada de Valverde su Secretario fecha en 29 de Julio de 1555 por la qual manda a Pero Ximénez su Mayordomo de las rentas de la villa de Hita y su partido,

ff. $4-7$

ff. 6-7

ff. $8-36$

ff. $37-38$

ff. $39-40$

ff. 41-42

ff. $43-86$

ff. $87-88$

ff. $134-136$

ff. $137-141$ 
que de los maravedís de su cargo diese y pagase a la gente de armas de la dicha villa contenidas en dicha nómina, los maravedís que en ella se declaran que los avían de aver el dicho año por sus acostamientos y a su continuación van las cartas de pago originales.

Blanco.

1523 Nómina de la gente Contina y de tierra de la Casa de Don Diego Hurtado de Mendoza $3^{\circ}$ Duque del Infantado del año de 1523 por la qual se les manda pagar sus acostamientos y salarios.

Blanco

1524 Nómina de la gente Contina y de tierra de la Casa de Don Diego Hurtado de Mendoza $3^{\circ}$ Duque del Infantado del año de 1524 por la qual se les manda pagar sus acostamientos y salarios.

1524 Nómina de la gente contina y de tierra de la Casa de Don Diego Hurtado de Mendoza $3^{\circ}$ Duque del Infantado del dicho año de 1524 por la qual se les manda pagar sus acostamientos y salarios.

\section{Blanco.}

1525 Nómina de la gente contina y de tierra de la Casa de Don Diego Hurtado de Mendoza $3^{\circ}$ Duque del Infantado del año de 1525 por la qual se les manda pagar sus acostamientos y salarios.

Blanco.

1526 Nómina de la gente contina y de tierra de la Casa de Don Diego Hurtado de Mendoza $3^{\circ}$ Duque del Infantado del año de 1526 por la qual se les manda pagar sus acostamientos y salarios.

Blanco.

f. 182

ff. 182 bis-

194

ff. $195-197$

ff. $198-210$

ff. $211-223$

ff. $224-226$

ff. $227-238$

ff. $239-240$

ff. $241-255$

1526 Nómina de la gente contina y de tierra de la Casa de Don Diego Hurtado de Mendoza $3^{\circ}$ Duque del Infantado del dicho año de 1526 en que se les manda pagar sus acostamientos y salarios.

Blanco

1527 Nómina de la gente contina y de tierra de la Casa de Don Diego Hurtado de Mendoza $3^{\circ}$ Duque del Infantado del año de 1527 por la qual se les manda pagar los acostamientos y salarios que tenían en cada un año.

Blanco.

1529 Nómina de la gente de caza del año de 1529 que tenía Don Diego Hurtado de Mendoza $3^{\circ}$ Duque del Infantado en que se manda a Francisco Tabaldillo que los 258D242 maravedís que se le avían librado el dicho año, los entregue al Cazador maior y Cazadores y mozos de caza y otras personas contenidas en dicha nómina, a cada uno los maravedís que en cada partida se refieren que lo avían de aver por sus acostamientos. Y con ello está el poder original que dichos cazadores dieron al dicho Francisco Tabladillo para que librase dichos maravedías y fianza que dél hicieron.

1530 Nómina de la gente contina y de tierra de la Casa de Don Diego Hurtado de Mendoza Duque $3^{\circ}$ del Infantado del año de 1530 en que se les manda pagar los acostamientos y salarios que cada uno tenía.

Blanco.

1531 Nómina de la gente contina y de tierra de la Casa del Duque del Infantado del año de 1531 en que se les manda pagar los acostamientos y salarios que cada uno tenía.

Blanco.

1532 Nómina original firmada de Don Íñigo López de Mendoza $4^{\circ}$ Duque del Infantado, de los maravedís y pan trigo y Cevada que Alonso de Ballejo su Contador avía de librar a la Duquesa su muger y para el gasto de su despensa y raciones, y a los cavalleros y continos y oficiales y gente de guerra y desquentos acostumbrados otras cosas del año de 1532 en la conformidad que en ella se declara.

1532 Nómina de la gente continua y de guerra y tierra y oficiales y otras personas criados de Don Íñigo López de Mendoza $4^{\circ}$ Duque del Infantado, a quienes se les avía de librar sus acostamientos y quitaciones desde primero de Enero del año de 1532 en adelante. 


\section{ANEXO II \\ CONFESIONES Y ABSOLUCIÓN DE FRANCISCO MUdARRA}

Texto original en GIL, Juan. «Un español ante la Inquisición romana: Francisco Mudarra», Scripturus vitam. Festgabe für Walter Berschin zum 65. Geburtstag, Heidelberg, Mattes Verlag, 2002, pp. 617-625; pp. 621-623.

Primera confesión [Roma, 13 de mayo de 1548]

Reverendísimo e ilustrísimo señor. Situado en estas preocupaciones, con las que Nuestro Señor se ha dignado en alcanzarme y afectarme, deseando más estar confundido en este mundo que en el venidero, confieso lo siguiente, de este modo:

Recuerdo que yo, al hablar de la persona del Pontífice, he dicho que el Pontífice ***, viviendo en pecado mortal, no tiene ninguna autoridad. Sobre los votos por los muertos creo que he dicho al reverendísimo [obispo] compostelano que sabía qué valían las misas por los difuntos; aunque encontraba algunas dudas sobre ellas, sin embargo no recuerdo haber pecado, por Cristo. Así mismo, he hablado sobre las religiones de los hermanos y también sobre el Pontífice romano. De esta manera confieso que comparto el sentimiento con los Luteranos en muchas cosas, tanto en lo que se refiere a la imágenes de los santos como a su veneración, y en otros errores y afirmaciones a causa de esto mismo, sobre todo en torno al matrimonio de los sacerdotes, las indulgencias y la invocación de los santos.

También he leído Paschinum in estasi, y una respuesta a los abusos, y cierta carta que respondía a otra del cardenal Carpentras, que después quemé, las cuáles de dónde las saqué no lo recuerdo. De todas estas cosas me avergüenzo en gran medida, porque reniego y abjuro de todos esos errores, y pido un castigo y misericordia.

Por lo tanto yo, Francisco Mudarra Español, suplico a vuestra señoría reverendísima, por las entrañas de nuestro señor Jesucristo, que se digne a compadecerse de mí, pues estoy dispuesto a soportar todo castigo, prometiendo no repetir los errores anteriormente mencionados, -que he escrito que cometí a través del reverendísimo maestro don Teófilo, sustituto de vuestra reverendísima señoría-, en lo sucesivo, prometiendo confesar ante vuestra señoría reverendísima algún otro error si lo recordara.

Francisco Mudarra, humilde servidor de vuestra Ilustrísima señoría.

[Por detrás de la confesión anterior, con palabras así está escrito: «Al ilustrísimo y reverendísimo señor cardenal Juan Pedro, inquisidor Teatino, muy digno benefactor mío».]

Segunda confesión [Roma, 14 de mayo de 1548]

Ilustrísimo y reverendísimo señor. A través del maestro don Teófilo he comprendido con cuánta misericordia y caridad vuestra reverendísima señoría ha seguido mi causa y me ha abrazado a mí, desgraciado y nefando pecador, por la cual le doy a él un inmortal agradecimiento, y se lo daría, si pudiera, a vuestra señoría. Que Jesucristo se digne a recompensarle por mí. Suplico a vuestra reverendísima señoría, por su acostumbrada clemencia y humanidad, que se digne a velar por mi honor y mi fortuna, y a utilizar conmigo esa misericordia que utiliza nuestro señor Jesucristo con todos los pecadores que reconocen y contemplan sus propios pecados. Además de estas cosas que habrá, de las que he dado testimonio en mis cartas, recuerdo que, al leer a Erasmo, sobre la elección de los alimentos fui en otro tiempo de la misma opinión, porque era excesiva, y también de las peregrinaciones, errores que al mismo tiempo que los anteriores maldigo y detesto, abjuro y me retracto. Sobre los cómplices de estos errores de momento solo me viene a la mente Egidio, aquél hermano Carmelita, que fue el autor y el origen de la subversión vuestra y mía. Charlé también además*** con cierto milanés, cuyo nombre [queda] para Dios, pues esas cosas son antiguas y más que pasadas. Pero si después me viniera a la mente, prometo revelárselo rápidamente a vuestra reverendísima señoría. Y condeno las blasfemias, me retracto y con mucha vehemencia abjuro ante vuestra reverendísima señoría, ante Dios, Jesucristo y sus santos ángeles de todas las herejes blasfemias y de los malditos errores que he seguido o dicho: en primer lugar sobre el matrimonio de los sacerdotes, sobre las indulgencias, sobre la invocación a los santos, sobre la veneración de las imágenes, sobre la autoridad del Pontífice que vive en pecado mortal, y todas las demás herejías similares y errores, que yo quizá haya 
mantenido entre mis premisas como enemigo de la iglesia y que haya dicho, y pido la indulgencia y la absolución humildemente de vuestra señoría reverendísima, que Dios guarde hasta que Él quiera.

Desde las cárceles de la torre de Nona, el día catorce de marzo de 1548. Del puño y letra de Francisco Mudarra, humilde servidor de vuestra ilustrísima y reverendísima señoría. Por detrás de la anterior confesión había escritas estas palabras: «Al ilustrísimo y reverendísimo don Juan Pedro, cardenal teatino, señor mío santísimo y mi principal benefactor. La presente copia fue collacionada por mí, el notario abajo firmante, con los originales.

\section{Absolución de Francisco Mudarra [Roma, 31 de agosto de 1548]}

Tras invocar el nombre de Cristo ante el tribunal, sentados y solo teniendo ante los ojos a Dios, a través de esta nuestra sentencia definitiva, que hemos hecho conforme al consejo de los expertos en derecho, en estos escritos pronunciamos, sentenciamos, juzgamos y declaramos en la causa y las causas que primero se dieron ante los reverendísimos señores Juan Pedro, obispo Sabino, y Juan de San Sixto Beguense, cardenales de la Santa Iglesia Romana, junto con nosotros, y, después de la solicitud por parte de aquel del poder de una comisión especial de nuestro santísimo señor, que también se dieron ante nosotros, entre el magnífico señor Nicolás Farfaro, procurador fiscal, por una parte, y el reverendo señor Francisco Mudarra por otra, clérigo de la diócesis palentina, escritor de cartas apostólicas, encontrado culpable e interrogado sobre los crímenes alegados y sobre los excesos de herejía y apostasía atribuidos a él, y sobre las confesiones y delitos de otra [persona], expresados y desarrollados ampliamente de este modo en las partes de la causa, y sobre sus partidarios con ocasión de aquellos asuntos; en primera instancia le fueron contrarias y se cambian.

[Declaramos]que dicho señor Francisco tenía que ser absuelto y estarlo, y debía ser absuelto y ser liberado de las molestias, inquietudes, perturbaciones e impedimentos ocasionados a él por el mencionado señor procurador fiscal con motivo de las cosas anteriormente mencionadas, anunciadas y reveladas y conminadas a ser efectuadas; en cuanto que lo absolvemos y lo liberamos, y lo declaramos absuelto [declaramos] que todos y cada uno de los procesos e investigaciones a propósito de lo anteriormente mencionado contra el propio señor Francisco, hechos por cualquier medio, aún no conformados, y cualesquiera obligaciones, precauciones o garantías [presentadas] tanto por el mencionado don Francisco como por cualesquiera otras personas en su nombre, acerca tanto de su comparecencia como de su permanencia en la ciudad, y estancia conforme a derecho y de su liberación una vez juzgado, o bien otras [obligaciones, precauciones o garantías] también presentadas y hechas, deben ser revocadas, no ratificadas y anuladas, y deben ser invalidados, no ratificados, y ser anulados tanto el propio don Francisco como sus mediadores, y que con la precaución contenida en las mismas obligaciones sea liberado al momento, en cuanto que lo invalidamos, no ratificamos y anulamos y mandamos que sea invalidado, no ratificado y anulado, y además declaramos que no ha incurrido el citado don Francisco en ninguna acción infamante, o de incapacidad conocida.

Es más, que las molestias, humillaciones, perturbaciones, preocupaciones y cualesquiera prohibiciones impuestas, hechas y provocadas por el mencionado señor procurador fiscal al propio señor don Francisco, que hayan sido provocadas y llevadas a cabo también son temerarias, ilícitas, desiguales, indebidas e injustas y de hecho mal asumidas, y que haberlas hecho y hacerlas no le estaba permitido al propio señor procurador fiscal ni le convenían por derecho, y a propósito de aquellas le tenía que ser impuesto un silencio perpetuo, y se lo imponemos, imponiéndole además la condena de los gastos derivados de la causa.

En efecto, esta sentencia había sido escrita de tal manera: así la pronunciamos, Filipo el vicario y yo, el comisario. Así la pronuncié yo, Sebastiano Pigino, obispo Ferentino y comisario. Así la pronuncié yo, Máximo Delfino, canónigo mantuano y subdelegado. Fue leída, entregada y promulgada por escrito la anteriormente dicha sentencia definitiva por los mismos reverendos padres señores obispos Salutiario y Ferentino y por el reverendo señor don Máximo Delfino, el subdelegado, tanto sus documentos como los escritos del puño y letra de cualquiera de ellos en Roma, en la casa del mismo obispo Salutiaro, reunidos él mismo y el reverendo señor obispo Ferentino y avisado como juez subdelegado don Máximo, tanto para dictar su sentencia como para escuchar las causas, sentados ante el tribunal, en el año mil quinientos cuarenta y ocho del nacimiento del señor, en el sexto de la indicción, el último día del mes de Agosto, bajo el pontificado del santísimo padre en Cristo y señor nuestro don Paulo Tercero, por la divina providencia Papa en su año decimocuarto, estando presentes también los venerables hombres Francisco, en otro tiempo del Bugio de Juan Pedro, lego Milanés, Fernando de Medina, clérigo de la diócesis palentina, y Rodrigo de Valdés, clérigo ovetense, como testigos de todas las premisas, llamados e interrogados especialmente sobre cada una de ellas. 


\section{ANEXO III}

\section{INVENTARIO DEL III DUQUE DEL INFANTADO}

Guadalajara, 28 de agosto de 1581

AHN-SN, Osuna, C. 1835, doc. 15. (documento sin foliar)

Imbentarios Cajón 11 Legajo $4^{\circ}$ Número 15

Imbentario de los bienes que quedaron por fin y muerte del señor Duque del Infantado Don Diego, el qual fue sacado en la Ciudad de Guadalajara con authoridad de Justicia en 28 de agosto de 1581 a pedimento del Señor Don Íñigo López de Mendoza Duque del Infantado hijo del dicho Duque Don Diego Está authorizado de Diego de Cisneros escrivano del Número de dicha Ciudad.

$$
\text { // }
$$

$\checkmark$ Un sabuche [sic] de plata en su caxa cubierta de cuero negro y cerradura plateada el qual tiene garçi gonçález a su conosçimyento

$\checkmark$ Un baxón de box y en su funda de baqueta con su candado pequeño de alemaña con su llave tiénelo bázquez el viejo a su conosçimyento

$$
\text { // }
$$

$\checkmark$ Ocho cornetas de música las quatro cubiertas de cuero negro y las quatro blancas de madera tiénelas diego bázquez el moço y baltasar bázquez y francisco gonçález y alentisque a su conosçimyento

$\checkmark$ Seys flautas en su caxa con su llave tiénelas Jhoan de robredo a su conosçimyento

$\checkmark$ Un baxón de box con su funda de baqueta y su candado tiénelo diego bázquez el moço a su conosçimyento

$\checkmark$ Diez flautas en una caxa digo onçe flautas entre grandes y pequeñas están en dos caxas tiénelas diego bázquez el viejo a su conosçimyento

$\checkmark \quad$ Un libro de canto tiénelo juan de rrobredo a su conosçimyento

$\checkmark$ Dos cornetas la una muta y la otra negra con su brocal de plata tiénelas baltasar bázquez a su conosçimyento

$\checkmark$ Una corneta negra con sus brocales de plata tiénela garçi gonçález a su conosçimyento

$\checkmark$ Un sacabuche grande tiénele melchior de torres a su conosçimyento

$\checkmark$ Una caxa en que ay siete pífanos los çinco pequeños y los dos grandes es la caxa de madera cubierta de cuero tiénelos lorenço de alentisco a su conosçimyento 


\section{ANEXO IV}

\section{Tasación de los bienes de Diego Hurtado de Mendoza, Conde DE SAldaña y MARQuÉS del CENETE}

Guadalajara, 1560

AHN-SN, Osuna, C. 1835, doc. 2. (documento sin foliar)

$$
/ /
$$

Imbentarios Cajón 11 Legajo $4^{\circ}$ Número 2

Tasación que en la Ciudad de Guadalajara se hizo ante Diego de Cisneros escrivano del Número de ella el año de 1560 de los bienes que se expresan en en imventario del número primero deste legajo el qual fue sacado con authoridad de la Justicia de la dicha ciudad en 28 de agosto de 1581 a pedimento del Señor Don Íñigo López de Mendoza Marqués del Cenete y Duque del Infantado

$$
\text { Arpas y bigüelas }
$$

Una arpa dorada con su caja negra barreada de oja de lata e funda de cuero se tassó con la caja y funda En quatro ducados

Otra arpa de nogal labrada de moldura e de tarazes en su funda de badana y caxa de pino se tassó en tres myll maravedís

$3.000[\mathrm{mrs}]$

Otra arpa labrada de tarasces con una funda de cuero naranjado se tassó en doze ducados.

Otra arpa de tarasces con molduras con su caja se tassó en seis ducados

Un clavicordio guarnesçido de terciopelo verde la caxa con clabazón dorada y el pie de nogal y una cubierta de cuero se tassó en quynze myll mrs.

$15.000[\mathrm{mrs}]$

Otro clavicordio pequeño

con su caja de pino y pie de pino se tassó en seis myll mrs

$6.000[\mathrm{mrs}]$

Una bigüela grande con su caja de pino aforrada de cuero negro se tassó en quatro ducados

Otra bigüela grande de çiprés tunbada con su caja de pino se tassó en quatro ducados

Un laúd con su caja de cuero negro se tassó en çinco ducados 


\section{ANEXo V \\ INVENTARIO DE LOS BIENES DE ISABEL DE ARAGÓN, ESPOSA DEL IV DUQUE DEL INFANTADO}

Guadalajara, 1564

AHN-SN, Osuna, C. 1834, doc. 2. (ff. 13-14)

Imbentarios Cajón 11 Legajo 3 Número 2

Imbentario que se hizo por la justicia de Guadalajara el año de 1564 ante Diego de Cisneros escribano, de los bienes que quedaron por fin y muerte de Doña Isabel de Aragón a pedimento de Don Iñigo López de Mendoza Duque del Infantado su marido

arpas vigüelas y claviórganos

clavi/órgano Yten un clavi/órgano con sus fuelles y pesas de plomo metido en una caxa de madera

clavizínbano Yten un clavizínbano grande metido en una caxa de madera encorada de cuero negro

clavizínbano Yten otro clavizínbano más pequeño que está metido en una caxa de madera blanca

clavi/órgano Yten otro clavi/órgano que se

[f. 13v.]

compró en Toledo que tiene sus pesas de plomo y fuelles metido en una caja de madera encorada

clavizínbano

clavizínbano

arpa de çiprés

arpa de noguera

arpa de çiprés

$\operatorname{arpa}$

arpa
Yten otro clavizínbano que dio el dotor Laguna a su señoría metido en una caxa de madera color verde

Yten otro clavizínbano pequeño que se compró de un frayle metido en una caxa de madera teñyda de negro

Yten una arpa de çiprés que se hizo de otra grande que avía dado a su señora la señora marquesa del zenete con su caxa

Yten otra arpa grande de noguera labrada de atarazes con caxa de madera e funda de paño verde

Yten otra arpa más pequeña de çiprés con caxa de madera e funda de cuero

Yten otra arpa que hizo vexarano con una caxa de madera que está forrada en palmylla azul

Yten otra arpa más pequeña con caxa de madera 
Arca [sic] de hévano Yten otra arpa de hévano de muy rrica labor de atarazes con medallas de marfil con su caxa de madera blanca

Arpa Yten otra arpa que hizo vexarano con caxa de madera

Laúd Yten un laúd grande con caxa aforrada en paño colorado

Laúdes Yten otros dos laúdes de flandes con caxas de madera forradas en cuero negro

Vigüela Yten vigüela grande con costera de brasil e algunas pinturas de atarazes con caxa de madera que está aforrada con un pelo de paño colorado por dedentro

Vigüela de arco Yten una vigüela de arco grande

Vigüela de arco Yten otra vigüela de arco pequeña

Vigüela tunvada Yten otra vigüela de hechura de tunba que hizo vejarano con su caxa de madera teñyda de negro

Guitarra

Yten una guitarra común con una funda de fuseta parda vieja

caxa de flautas

Yten una caxa de flautas de flandes con syete piezas que es de madera aforradas en cuero negro y la una flauta

\section{[f. $14 \mathrm{v}$.}

dellas es pequeña que se dize jabeva

caxa de duzaynas

Yten otra caxa de duzaynas de madera guarneçida de cuero negro vieja e quebrada que tiene tres piezas que la mayor está desconzertada

caxa de orlos

Yten otra caxa de madera vieja quebrada que tiene ocho piezas de orlos de palo amarillo a lazos chicos en grandes que están carcomidos que el uno grande dellos está quebrado

pífano Yten un pífano con dos cabos de hueso en dos rremates

flautas $\quad$ Yten dos flautas pegadas una otra 
ANEXo Vi

Composición del CABILdo SEVILlano, EN ÉPOCA DEL ARZobispo Don FERnANDo de VALDÉs, 1550

Constituciones de la iglesia de Sevilla. Biblioteca de la Universidad de Valladolid, Signatura Rms 73, ff. 18-21.

Dignidades

\begin{tabular}{lll}
\hline Don Juan Manuel & Deán & Canónigo \\
Don Rodrigo Ximénez & Arcediano de Sevilla & Canónigo y Medio racionero \\
Don Juan de Medina & Chantre & \\
Don Antonio de la Peña & Tesorero & Canónigo \\
Doctor Don Martín Gasco & Maestrescuela & Medio racionero \\
Don Hierónimo Manrique & Arcediano de Écija & Canónigo y Medio racionero \\
Don Melchior Maldonado & Arcediano de Jerez & Canónigo \\
Don Fernando de Sauzedo & Arcediano de Niebla & Canónigo \\
Don Alonso de Porras & Arcediano de Reina & Medio racionero \\
Don Hierónimo Manrique & Arcediano de Carmona & Canónigo y Medio racionero \\
& & \\
& Canónigos &
\end{tabular}

Licenciado Francisco Tello de Sandoval

Diego Rodríguez Luzero [licenciado]

Pedro de Almaçán

Juan de Urbina

Alonso de Mudarra

Luis Deliçana

Luis Carrillo de Castilla

Doctor Fernando Ramírez

Alonso de Çamora

Andrés Méndez

Juan Martínez Alvarado

Antonio del Corral

Antonio del Corro

Fernando Mohedano

Licenciado Juan de Ovando

Santo Oficio de la Inquisición

Luçiano Denegrón

Don Juan de Median

Doctor don Martín Gasco

[Maestrescuela]

Don Melchior Maldonado

[Arcediano de Jerez]

Fernán Ruiz de Hojeda

Doctor Baltasar de Esquivel

Diego Godomexía

Gonçalo de Brizeño 
Antonio de Eraso

Alonso de Sahelizes

Antonio Gonçalez

Gonçalo Pérez

Diego de Ribera Ponçe

Melchior de Matamoros

Antonio de Pamones

Juan Bautista Montoya

Fernán López

Maestro Álvaro de Medina

Don Hierónimo Manrique

[Arcediano de Carmona]

Don Fernando de Sauzedo

[Arcediano de Niebla]

Don Antonio de la Peña

[Tesorero]

Don Juan Manuel

[Deán]

Don Rodrigo Ximénez

[Arcediano de Sevilla]

\section{Racioneros}

Andrés de Sauzedo

Juan Pérez Bejarano

Amador de Jacomar

Pedro Pablo

Fernán Pérez de Sauzedo

Diego de Valdés

Doctor Juan de Escobar

Licenciado Andrés Gasco

Bernandino de Ysla

Doctor Egidio de Çevadilla

Juan de Solís

Pedro Venegas

Luis de Armijo

Andrés de Segura

Isidro de la Cueva

Gabriel de Liñán

Rodrigo Gudiel de Palaçios i Morán

La cámara

Hierónimo Brizeño

Magister Puerorum

Bernardino de Valdevieso

Juan Pérez de Espina

Pedro de Guzmán

Licenciado Cristóbal de Bustamante

Alonso Marín

Francisco Díaz Bravo 
Alonso Ternero

Licenciado Diego Amado

Alonso Gasco

Don Pedro Vélez de Guevara

Don Rodrigo Ximénez

[Arcediano de Sevilla]

Don Martín Gasco

[Maestrescuela]

Don Hierónimo Manrique

[Arcediano de Écija]

Don Alonso de Porras

[Arcediano de Reina]

Don Pedro Vélez de Guevara

Diego López de Cortegana

Francisco Vanegas

Pedro de Villada

Bartolomé de Segura

Juan Rodríguez de Cortegana

Alexo de Velasco

Hierónimo Gómez

Pedro López de Verastegui

Juan de Arziniega

Don Luis Ponçe 


\section{ANEXO VII}

\section{CARTA DE PODER PARA EL COBRO DE LIBROS}

Sevilla, 25 de mayo de 1557

AHPSe, Oficio 5, de Diego Ramos, Libro $2^{\circ}$ de 1557, Signatura 3395, f. 174.

\section{[f. 174]}

Sepan quantos esta carta bieren como yo Alonso Mudarra canónigo en la sancta yglesia de sevylla e vezino della otorgo e conozco que doy todo my poder cumplido e bastante segun que lo yo tengo y de derecho se requyere al señor antonyo de torres arcipreste de la yglesia de la ȩila de maqueda y a alonso garçía criado del dicho señor arcypreste ambos a dos juntamente a cada uno dellos por sy in solydum especialmente para que puedan y en mi nombre e como yo mesmo puedan pedir y demandar y resçebir y cobrar en juicio y fuera dél de atanasio de Saucedo mercader de libros vecino de la villa de Alcalá de Henares y de sus bienes y de quien con derecho deban dozientos y çinquenta reales de plata que me deve de çiento y çinquenta libros de çifras de música de biguela que yo le di que vendiese por mí e que los pueda resçebir e resçiban espyder resçibo dellos dar y dellas cartas de pago e defender quanto que convengan e balan y sean firmes como si yo mesmo las diese y otorgase sy a ello presente fuese e sy oviere razon de la cobrança de lo susodicho fuere nesçesario entrar en contienda de juicio puedan paresçer e parescan ante qualesquier juezes y justicias que en derecho deban y hazer e hagan todas las demandas e pedimyentos e requerimyentos e protestaçiones y enplazamyentos e çitaçiones y entregas e prisiones y embargos e secrestos e bendydas e remate de bienes y los juramentos que conbengan y responder y responder [sic] e responda a los contra alegados [...]

[174v] e contra de los que contra mý fueren dados e presentados asý en dichos como en presonas y concluyr e pedir y oyr sentencia o sentencias asý interlocutorias como definitibas y consentir y apelar y suplicar della o dellas e de qualquier modo e agravyo que en my perjuicio se fiziere e seguir e fenesçer [...] apelaçión y suplicaçion para allý donde con derecho de quienes hazer e hagan juicio e fuera dél todos los otros autos e diligençias judiçiales y estrajudiçiales que convengan e menester se mande de hazer y que yo haría seyendo presente en persona [...] de derecho se requiere en facultad de lo sustituyr en quyen quysieren y los rebocar y con sus ynçidençias y dependençias anexidades y conexidades y los reliebo según derecho e prometo aver por lo que me obligo mi persona y bienes avidos e por aver fecha la carta en sevilla en el dicho año de myll [...] años yusoescriptos martes veynte e çinco días del mes de mayo [...] y el dicho señor canónigo alonso mudarra que yo diego ramos escribano público de sevilla doy fee que conozco lo firmó de su nombre testigos que fueron presentes diego fernandes y el [...]de torres arcipreste

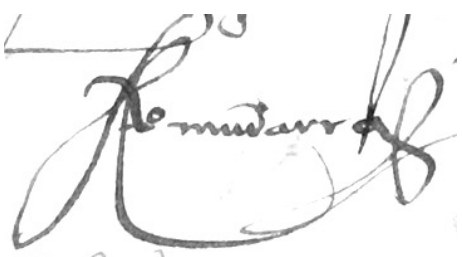

Fig. 26. Firma de Alonso Mudarra, 1557 


\section{ANEXO VIII}

\section{VENTA DE UN ESCLAVO}

Sevilla, 4 de noviembre de 1560

AHPSe, Oficio 5, de Diego Ramos, Libro $3^{\circ}$ de 1560, Signatura 3407, f. 482.

[f. 482]

Sepan quantos esta carta vieren como yo Alonso Mudarra canónigo en la sancta yglesia de Sevilla e vecino della otorgo e conozco e vendo a vos beatris de morales biuda muger de alonso de Molina dicho vecino de la dicha çybdad de Sevilla en la collación de san bartolomé que está presente un esclavo negro mýo e de nombre Juan de hedad de veynte e çinco años poco más o menos e vos lo bendo por de buena guerra e no de paz e por sano e que no es enfermo de ninguna enfermedad e vos lo aseguro que no es borracho ni ladrón ni huydor ni hetico ni endemonyado ni tiene gota coral ni ojos claros e no vee ni tiene otra tacha ni enfermedad pública ni secreta ny qualquiera de la dichas tachas e alguna dellas paresciere aver tenydo que me lo podeys bolver e yo me obligo a lo resçebir en vos bolver el precio pagado en el dicho e vendo e vendo bos lo por precio e contía de noventa e çinco ducados de la moneda que sea por aver los quales de vos resçebí realmente en un efeto en reales de plata en presençia del escribano público e yusoescriptos e son en my $[\ldots]$

E si el dicho esclavo que vos ansý vendo mas vale o valer puede del precio sobredicho que de vos rresçebí como dicho es la demasya sy alguna ay o oviere quier sea es poca o es muncha cantidad vos la doy de donación porques mi voluntad de vos la dar e donar aunque no aya causa para ello e la ynsigno y es por ynsignada e serca dello rrenuncio la ysignación de los quinientos sueldos de la ley de alcalá de henares como en sevilla e otros quallesquiera leyes que en su favor sean e desde oy questa carta es fecha en adelante para syempre jamás otorgo que me desapodero dél? e desysto e parto? e abro mano del dicho esclavo e de todo quanto poder e derecho e propiedad e señorío dél tengo y entrego él y que la tenencia e propiedad e señorío de la vos la dicha beatris de morales para que desde oy en adelante sea vuestro e de vuestros herederos e susecores e de quien vos o ellos quisierdes e por bien tuvierdes e los ayades e ayan para lo dar e vender empeñar e donar e tomar e trocar e cambiar y enagenar e para que fagades e podades fazer dél y él y con él todo lo que quisierdes e por bien tuvierdes como cosa vuestra misma propia avida e conprada por vuestros propios dineros e yo vos soy fiador e me obligo de vos rredrar e anparar e defender e vos [...] çierto [...] e el dicho esclavo que vos ansý vendo de todas e qualesquier personas que vos lo pidan e demanden embargen y contra [...] e qualquier [...] o por qualquier rrazón que sea e de tomar e rresçebir [...] la voz e autoría e definsyón de qualesquier pleytos e demandas por razón del dicho esclavo de vos sean fechas e movidas e los seguiremos a nuestras

[f. 482v] propias costas e misiones [...] del derecho e de vos sacar a pas y a salvo de todo ello por manera? como gozéys del dicho esclavo syn pleyto e syn contradición de persona alguna [...] la dicha pena e sy ansy no lo hiziere que sea obligado e me obligo de vos lo dar e pagar e tornar e bolver el preçio sobredicho de los dichos noventa çinco ducados que de vos rresçebí con el doblo e pena o por nonbre de ynterese con más las costas que sobrello se vos recresçieren y la dicha pena pagada e no pagada que todo valga e sea firme lo que esta carta com[...] e todo e por todo según dicho es so la dicha pena e por esta carta doy poder cumplido e baste a todos e qualesquier juezes e jurados de qualquier fuero e juridición que sean ante quien esta carta paresçiere para que por todos los rremedios e rrigores del derecho me conpelan y apremien a lo asy tener e cumplir según dicho es so la dicha pena e sobre la qual rrenuncio toda apelaçión e suplycaçión e qualesquier leyes e otras que en mi favor sean e la ley del derecho que diz que general rrenunciasyón de leyes fecha non vala bien asý como si lo sy lo susodicho fuese cosa juzgada e pasada que pleyto e por demanda e respuesta que fuese sobrello dada sentencia definitiva e la sentencia fuese consentida de las partes que juyzio que para lo asý pagar e cumplir como dicho es obligo mi persona e bienes avidos e por aver fecha la carta en sevylla [...] ante mí diego reinosa escribano público della en el quatro días del mes de noviembre de myll e quinientos e sesenta años y el dicho alonso mudarra que yo el dicho escribano público doy fee que conosco lo firmó de su mano testigos que fueron presentes diego [..] e yo el dicho escribano público doy fee della paga y entrega de los dichos noventa y çinco ducados de reales? 


\section{ANEXO IX}

\section{Testamento de Alonso Mudarra}

Sevilla, 23 febrero de 1576

AHPSe, Oficio 19, de Luis Sánchez Guerrero, Libro $2^{\circ}$ de 1576, Signatura 12432, ff. 439-440v.

[f. 439]

En el nonbre de la Sanctíssima trinidad padre y hijo y espíritu sancto tres personas y un solo dios verdadero que vive e reyna para siempre sin fin Amen. Sepan qua[n]tos esta carta de testamento vieren como Alonso mudarra Canónigo de la santa yglesia de sevilla y vezino de la dicha ciudad de sevilla de la colaçión de sancta maría la mayor estando sano de salud corporal y en mi seso y entendimiento y juyzio natural tal qual dios nuestro señor tubo por bien de me dar y creyendo y confesando como creo tengo y confieso todo aquello que tiene y cree y confiesa la sancta yglesia Cathólica Romana y protestando como protesto de vivir y morir debaxo desta santa fe y creençia otorgo y conozco que hago y ordeno mi testamento y última voluntad en la manera siguiente

$\checkmark$ primeramente encomiendo mi ánima a dios nuestro señor que la crió y redimió por el preçio de su santíssima sangre Al qual suplico por los méritos de su sacratíssima pasión y por los méritos y yntercesión de la gloriossí[si]ma virgen sancta maría madre suya y Señora nuestra y de todos los Santos perdone mi ánima y la lleve consigo a la gloria para que fue criada y quando de mí acaeciere fallescimiento siendo en esta çiudad de sevilla quiero que mi cuerpo sea sepultado en la dicha sancta yglesia en la sepultura que me fuere señalada por los Ilustres señores deán y cabildo

[f. 439v] de la dicha santa yglesia mi[s] señores y que el cuerpo presente se me diga una vigilia y missa que los dichos señores acostumbran dezir por sus conbenefiçiados y dese la çera que se suele dar en los entierros de los señores beneficiados desta santa yglesia y a los veynteneros de la dicha santa yglesia se les dé a dos reales a cada uno el día del entierro por el trabajo de llevar mi cuerpo y esto de más de lo que se les suele dar

$\checkmark$ Yten digo y declaro y quiero que no me sean hechas onrras

$\checkmark$ Yten digo que se me digan en la capilla de nuestra Señora del antigua por mi ánima nueve missas de las nueve fiestas de nuestra señora y las treze de la luz y dese la limosna acostumbrada y dense a la dicha capilla tres ducados para çera

$\checkmark$ Yten digo que me digan en el sagrario de la dicha santa yglesia treynta missas por mi ánima y de mis defuntos del día que ocurriere y pido por mí a los señores curas del dicho sagrario las digan ellos y déseles de limosna a tres rreales por cada missa y más se les den seys ducados porque me digan una missa de rrequien con su vigilia cantada con sus ministros y si pudiere ser el día de mi entierro si no sea quando pudieren

$\checkmark \quad$ Yten mando a la fábrica de la dicha santa yglesia seys ducados

$\checkmark$ Yten mando a la obras pías y acostumbradas desta ciudad a cada una dos reales y a los niños expósitos quatro ducados

$\checkmark \quad$ Yten mando al monesterio de santa Clara de soria seys ducados y si al tiempo que falleciere fuere viva

[f. 440]

ysabel mudarra mi hermana monja en el dicho monesterio mando que de mis bienes den mis herederos a la dicha mi hermana monja çien ducados los quales le vayan dando poco a poco para las cosas que uviere menester y tubier neçesidad fasta cumplir el dicho número de los dichos çien ducados 
$\checkmark \quad$ Yten mando que a mis criados se les pague lo que pareciere por mi libro devérseles y de mas desto se les dé a dos ducados a cada uno y a la ama marigarçía y su marido castillo se les dexe la ropa de la cama en que duermen

$\checkmark$ Yten digo que mando que a mi sobrino Alonso mudarra que en mi casa tengo hijo de catalina mudarra mi herma [sic] muger que fue de bartolomé de soria su padre dozientos ducados de oro o su valor y más le hago gracia de otros dozientos ducados que le tengo dados para que con ellos tratase y se aprovechase para ayuda de su estudio y mando también se dé a la dicha su madre si fuera viva çien ducados para ayuda su costa

$\checkmark$ Yten mando mas al dicho mi sobrino todas las ropas de mi bestir y la cama colchones y cortinas de grana en que yo duermo

$\checkmark \quad$ E para cumplir e pagar este mi testamento y todo lo en él contenido nombro por mis albaçeas a dos señores de los curas del sagrario de la dicha santa yglesia de sevilla digo los dos mas antig[u]os a los quales y cada uno dellos yn solidun doy todo mi poder cumplido para que por su propia autoridad y sin liçençia ni autoridad de juez ni de otra persona alguna puedan entrar y tomar de mis bienes y de su balor cunplir e pagar este mi testamento e todo lo que en él se contiene a los quales suplico açeten por mí este trabajo / y digo más y es mi boluntad que tomen del trigo que tubiere en mi casa / o se me deviere por rrazón de mi prevenda veynte fanegas de trigo las quales rrepartan entre ellos y sus compañeros que todos suelen ser çinco por partes yguales /

[f. 440v] y para todo y cunplido este mi testamento quiero que todo el rremaniente de mis bienes derechos y açiones que yo he y tengo y me perteneçen y pueden perteneçer lo ayan y hereden doña ana mudarra mi hermana muger que fue de Juan flores de herrera vezinos de la ciudad de soria y su hija doña ana mudarra de herrera muger de sancho de medrano vecinos de la dicha çiudad de soria por yguales partes a las quales yo nombro e ynstituyo por mis universales herederos de todo el rremaniente de mis bienes derechos y açiones y si al tiempo de mi muerte la dicha mi hermana y heredera fuere muerta quiero que la dicha su hija mi heredera aya y herede todo el dicho remaniente de mis bienes y açiones enteramente para ella y sus hijos y si no fuese viva ayanlo sus hijos

$\checkmark$ Y por esta presente carta yo rreboco y doy por ningunos y de ningún valor y efeto todos qualesquier testamentos e codeçillos que yo antes deste aya hecho y otorgado por escrito y de palabra o en otra manera los q[u]ales qui[e]ro que no valan ni hagan fe en juyzio ni fu[e]ra del salvo este mi testamento en ques cunplida mi húltima voluntad el qual quiero que valga por testamento y si no valiere por testamento valga por codiçillo y en aquella vía y forma que mejor de derecho aya lugar en testimonio de lo qual otorgue la presente carta firmada en sevilla en la Yglesia della jueves veynte y tres días del mes de febrero de myll e quinientos e setenta y seis años y el dicho señor canónigo alonso mudarra lo firmó de su nombre al qual yo luis sánchez guerrero escribano público de la çibdad de sevilla doy fee quel [ilegible] e un entre renglones así mesmo do dize dos vala.

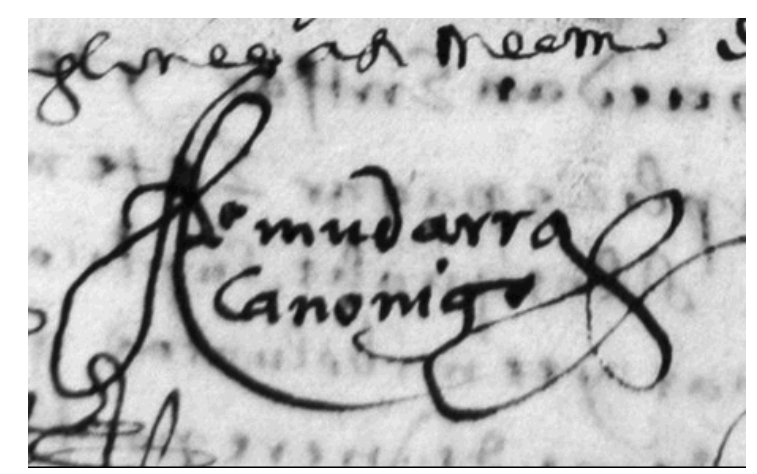

Fig. 27. Firma de Alonso Mudarra, 1576 


\section{ANEXo X}

\section{INVENTARIO DEL CANÓNIGO MUDARRA}

Sevilla, 14 de abril de 1580

AHPSe, Oficio 19, de Gaspar de León Garabito, Libro $3^{\circ}$ de 1580, Signatura 12459, ff. 250v-260v.

$$
\text { [f. 250v.] }
$$

En la muy noble e muy leal çiudad de sevilla jueves catorze días en el mes de abril de myll y quinientos y ochenta años ante mí gaspar de leon garavito escribano público de sevilla e testigos yusoscriptos paresçió el señor antonio rramos clérigo presvítero vecino de la çiudad de sevilla al qual yo escribano público doy fee que conozco e dixo que por quanto El señor Alonso Mudarra canónigo que fue della santa iglesia desta çiudad de sevilla es fallesçido de la presente vida y antes que fallesziese fizo e otorgó su testamento y última voluntad que pasó ante el dicho antonio ramos como notario apostólico en veintiquatro días del mes de março próximo pasado deste presente año en que esta de myll quinientos e ochenta años lo dexó y nombró por su albaçea como en el dicho testamento se contiene a que dixo que se rrefería e rrefirió del qual dicho señor canónigo alonso mudarra quedaron a estos bienes e para que sean sabidos y conosidos e quáles y quántos son los quería escrevir e poner por ynventario y los bienes de que ansí dixo que hazía e hizo el ynventario son los siguientes

\section{[f. 251]}

Inventario De los Bienes que quedaron del señor Alonso mudarra Canónigo de la sancta yglesia de sevilla que sea en gloria que hizo Antonio Ramos clérigo albaçea del dicho señor Canónigo en presençia de los señores fernan almohedano de saavedra canónigo y bartolome Ruiz Racionero de la dicha sancta yglesia, como Comissarios de los señores Deán y Cabildo de la dicha sancta yglesia perpetuos administradores de la fábrica della a la qual el dicho señor Canónigo Alonso mudarra por su testamento mandó sus bienes muebles y semovientes según por su testamento paresçe y los bienes que se hallaron dentro de la dicha su casa e que se ynventariaron son los siguientes.

$\checkmark$ Primeramente çinco Paños de corte que estavan colgados en una sala alta de las dichas sus casas todos de figuras traýdos

$\checkmark$ Yten dos paños de corte que estavan colgados dentro de una recámara de la dicha sala alta el uno de figuras y el otro de verduras y montería traýdos

$\checkmark$ Yten una cama de paño colorado estamenete que tiene siete pieças con el cobertor con su armadura de madera con quatro remates a las esquinas de vidros de colores

$\checkmark$ Una antepuerta de terçiopelo de tripa azul con su vara de hierro en que está colgada

$\checkmark$ Seys colchones de lienço presilla llenos de lana los quatro de la persona del dicho señor canónigo y los dos de criados de su casa

$\checkmark$ Una almohada de lienço labrada de grana bazía

$\checkmark$ Dos almohadas pequeñas una labrada de grana y otra de azul llenas de lana

$\checkmark$ Un coxinito de lienço blanco con una banda por medio lleno de lana

$\checkmark$ Dos sábanas de olanda

$\checkmark$ Otras tres sábanas de Ruan

\footnotetext{
$\checkmark$ Siete sábanas de lienço basto para moços

$\checkmark$ Dos boneticos blancos colchados

$\checkmark$ Ocho pañuelos de mesa caseros bastos

$\checkmark$ dos pañuelos de mesa alimaniscos viejos

$\checkmark$ quatro tablas de manteles caseros bastos

$\checkmark$ Una tabla de manteles alimaniscos viejos
} 
$\checkmark \quad$ Una camissa de Ruan del dicho señor canónigo

$\checkmark$ Un caxa de madera pequeña en que está mucha desta ropa de lienço ynventariada

$\checkmark \quad$ Un bufete de madera traýdo

$\checkmark$ Una messa pequeña con sus bancos y cadena de hierro

$\checkmark$ Dos libros cubiertos de pergamino blanco de quentas de los fructos de la canongía del dicho señor Canónigo y de otras cosas que estavan en un escriptorio

$\checkmark \quad$ Un garniel de terçiopelo negro y dentro della una pieça como moneda de plata que puede pesar hasta tres reales que la una faz tiene a Cristo nuestro salvador y en la otra tiene al mismo Cristo y una figura hincado de Rodillas

$\checkmark$ Yten tenía dentro el dicho garniel honze monedas de / oro en un papel yntitulado de letra del dicho señor Canónigo que dize / monedas de oro antiguas del maestro maeda.

$\checkmark$ Yten un agnus dei de / oro con su crucifixo y nuestra señora y sant Juan de pasta de / olor con una cinta de seda de grana de que colgava

$\checkmark \quad$ Iten un ceñidor de colonia prieta de vara y quarta

$\checkmark$ Un anillo de / oro esmaltado con una piedra grande con un Rostro para sello. Como naranjada

$\checkmark \quad$ Un anillo de plata dorado de uña liso

$\checkmark$ Una medalla Redonda guarneçida de Évano en que está la ymagen de la feliçe Recordaçión de Pío papa quinto dorada

$\checkmark$ Un mondadientes de / oro

$\checkmark$ Honze quentas de palo leonado con su Cruz de lo proprio y un estremo de Évano negro

$\checkmark$ Dos Rosarios pequeños de quentas negras y estas metidas en una caxita de flandes pequeña

$\checkmark$ Un mondadientes de plata pequeño quebrado en dos pedaços

$\checkmark$ Otra caxita de flandes con una medallita de cobre dentro

$\checkmark$ Otra caxita de flandes bazía

$\checkmark$ Dos boneticos colchados blancos

$\checkmark$ Un par de guantes adobados

$\checkmark$ Un pañuelo de narizes con su guarniçión a la Redonda

$\checkmark \quad$ Otro pañuelo de narizes traýdo con su guarniçión

$\checkmark$ Una toballita de lienço pequeña de Ruan labrada de seda negra

$\checkmark \quad$ Çinco cordones de seda negra de atacar

$\checkmark \quad$ Un agnus Dei de çera grande

$\checkmark$ Una cruz de madera Leonada

$\checkmark$ Un cuchillo de monte largo con su bayna verde y otro cuchillo mediano y otro punçón y lima con la propia bayna

$\checkmark \quad$ Un cubilete de plata dorado de bevedero y pie dél

$\checkmark$ Un salerito de plata de tres pieças dorado

$\checkmark$ Una naranjera de plara pequeña delgada

$\checkmark \quad$ Una escudilla de plara de dos orejas

$\checkmark$ Dos salseritos de plata

$\checkmark$ Un salsero grande de plata

$\checkmark$ Çinco cucharas de plata de uña

$\checkmark$ Dos tenedorcitos de plata

$\checkmark$ Un jarro de plata mediano a partes dorado

$\checkmark$ Un açucarero de plata con su tapadero

$\checkmark$ Una caxa de hoja de milán redonda

$\checkmark \quad$ Un pichelico de barro de flandes

$\checkmark \quad$ Tres platos de génova azules

$\checkmark$ Un jarrito pequeño de lo mismo

$\checkmark$ Un aparador de madera sin el cumplimiento de arriba

$\checkmark \quad$ Una xelosía de madera para tener vidros 
$\checkmark \quad$ Una porçelanita de barro pequeña

$\checkmark$ Un escriptorio de madera de nogal con su cuerpo baxo

$\checkmark$ Una bayna con dos cuchillos y un tenedor

$\checkmark$ Unas tixeras de hierro de platero

$\checkmark$ Diez y seis çintas de hiladillo prietas

$\checkmark$ Una blibia [sic] en çinco cuerpos cubiertos de cuero leonado

$\checkmark$ Otra bayna de dos cuchillos

$\checkmark$ Otro cuchillo suelto de cachas prietas

$\checkmark$ Dos reloxitos uno de marfil y otro como libro sin lumbre

$\checkmark$ Dos formonçillos sin cabos y una pauta de hierro

$\checkmark$ Un velito pequeño de volante

$\checkmark$ Una caxita de madera verde

$\checkmark$ Un rosario suelto dentro con la dicha caxita

$\checkmark$ Unos antojos de camino con su cuero colorado asido

$\checkmark$ Una caxa con dos antojos

$\checkmark$ Otros antojos de camino de cristal con cuero negro

$\checkmark \quad$ Unos antojos quebrados guarnecidos de plata.

$\checkmark$ Quatro pares de antojos sueltos.

$\checkmark \quad$ Unas cuentecitas de ámbar y unos coralicos redondos con ellos en un papel metidos

$\checkmark$ Un libro de çifra de vigüela ympresso

$\checkmark$ Otro par de antojos sueltos

$\checkmark$ Un / obillo de hilo de cartas

$\checkmark \quad$ Una moneda de plata como un Real de peso

$\checkmark$ Un bonete de paño nuevo aforrado en escarlatín

$\checkmark$ Un pesico pequeño y un marco de media libra pequeño metidos todos en una caxita de madera

$\checkmark$ Un candelero de açofar de tres lumbres

$\checkmark \quad$ Un breviario romano de media cámara con sus registros

$\checkmark$ Un missal romano pequeño nuevo con sus registros de seda

$\checkmark$ La historia ymperial de pedro mexía cubierto de cuero leonado

\section{[f. 253]}

$\checkmark$ Baptista platino de Vita et moribus sumorum pontificum cubierto de cuero viejo

$\checkmark$ La historia pontifical en dos cuerpos cubiertos de pergamino blanco

$\checkmark \quad$ La historia de la Yglesia que llaman ecclesiástica y tripartita cubierto de cuero blanco vieja

$\checkmark \quad$ La segunda parte de las Repúblicas del mundo nueva cubierta de pergamino blanco

$\checkmark \quad$ Un breviario Romano pequeño de ympresión de burgos cubierto de tablas negras

$\checkmark$ Un missal Romano de los antiguos de cuerpo pequeño

$\checkmark$ Opus aureum viejo cubierto de cuero leonado

$\checkmark$ Incridion christiane institutionis cubierto de cuero leonado

$\checkmark$ Un missal sevillano de los antiguos cubierto de cuero leonado

$\checkmark$ Dionisio Cartuxano sobre los psalmos cubierto de cuero de bezerro

$\checkmark$ Alonso de castro adversus omnes hereses cubierto con tablas de madera con cuero de bezerro

$\checkmark$ Suma omnium conciliorum cubierto con cuero leonado

$\checkmark \quad$ Manuale sacramentorum según el uso de sevilla cubierto de bezerro negro

$\checkmark$ Los sermones de Joan Justo cartoxano cubierto de pergamino blanco

$\checkmark$ Bocabulario ecclesiástico de Rodrigo de Santaella cubierto de cuero leonado

$\checkmark$ Razionale divinorum officiorum de guillermo durando cubierto de cuero de bezerro

$\checkmark$ Diego Ximénez arias alcántara Intitulado lexicon ecclesiástico cubierto de cuero blanco

$\checkmark$ Dionisio Cartuxano de quatuor hominis novissimis cubierto de cuero leonado

$\checkmark$ Paráfrase sobre Job de Fray francisco Titelmagno

$\checkmark$ Enchiridion locorum comunium adversus luterum

$\checkmark$ Guillermo parisiense cubierto de negro

$\checkmark \quad$ Diurno Romano de los antiguos 
$\checkmark$ Officio de la semana sancta

$\checkmark$ Diurno Romano de los nuevos viejo

[f. 253v.]

$\checkmark$ Pandetalegis evangelice

$\checkmark$ Enchiridion de oratione et horis canonicis de martín azpilqueta cubierto de blanco

$\checkmark$ Exposiçión del canon de la missa

$\checkmark \quad$ Guía de pecadores de fray luis de granada

$\checkmark$ Dos salmos de david propheta de Joan fero

$\checkmark$ Diurnal sevillano de los viejos

$\checkmark$ Ordo secundit celebrandi missas

$\checkmark \quad$ Alexio et de montani de secretos cubierto de cuero negro

$\checkmark$ Calendario perpetuo del Rezado Romano

$\checkmark$ Breviario sevillano pequeño viejo

$\checkmark$ Catecismo de pio papa quinto

$\checkmark$ Manual de confesores del doctor navarro cubierto de pergamino blanco

$\checkmark$ Menosprecio de corte y alabança de aldea

$\checkmark$ Aviso de privados y doctrina de cortesanos

$\checkmark$ Tratado de superstiçiones de martín de arles

$\checkmark$ Trabajo de galeras pequeño

$\checkmark$ Primera y segunda parte de las epístolas de Antonio de guevara en dos cuerpos

$\checkmark$ Purificador de la conçiençia del maestro fray agustín de esbarroya

$\checkmark$ Titelmano sobre los psalmos de david cubierto de cuero leonado

$\checkmark \quad$ Catálogo de los libros prohibidos

$\checkmark \quad$ Un quaderno de la propriedad de los sanctos de españa

$\checkmark$ Una ymagen de nuestro salvador con la cruz a questas pequeño de pintura

$\checkmark \quad$ Una ymagen de la salutaçión de pintura pequeña

$\checkmark$ Una ymagen de quando la magdalena llegó del conbite del phariseo de pintura pequeña

$\checkmark$ Otra ymagen de nuestro salvador quando le presentaron la mujer adúltera de pincel pequeña

$\checkmark$ Otra ymagen de nuestra señora con el niño Jesús al pecho de pintura

$\checkmark$ Un velo de red blanco una guarniçión de orilla colorada

$\checkmark$ Un cofreçito pequeño con sus barrotes de hierro

$\checkmark$ Yten otro salsero grande / de plata

$\checkmark$ Yten otro cubilete de plata de la misma forma del de arriba

$\checkmark$ Yten en la dicha sala alta está una caxa blanca de madera con su cerradura pestillera hazia arriba

$\checkmark$ Un cofre tumbado de flandes con dos cerraduras en el qual estavan las cosas siguientes

$\checkmark$ Una bazía de barvero

$\checkmark$ Dos paños de hacer la barba

$\checkmark$ Dos pañytos bastos de limpiar la cabeça todo esto metidos en una taleguita de lienço

$\checkmark$ Un pedaço de lienço Ruan nuevo en que puede aver tres varas

$\checkmark \quad$ Unas tobasuelas de lienço basto viejas

$\checkmark$ Un bavadero de lienço colchado nuevo

$\checkmark$ Una almohada de lienço traýda bazía

$\checkmark$ Tres camissas de olanda traýdas

$\checkmark$ Una almilla de punto vieja

$\checkmark$ Un paño de rostro blanco labrado de red

$\checkmark$ Otro paño de rostro viejo remendado

$\checkmark$ Una cama de red / de quatro paños y su çielo vieja blanca

$\checkmark \quad$ Una colcha blanca traýda

$\checkmark \quad$ El lienço de un colchón de presilla nuevo

$\checkmark$ Un coxinito blanco de lienço viejo

$\checkmark \quad$ Un pañuelo de narizes blanco 
$\checkmark \quad$ Quatro escofietas viejas

$\checkmark \quad$ Seys pares de escarpines viejos

$\checkmark$ Çinco calçetas de lienço traýdas <hasta aquí>

$\checkmark$ Una caxa ensayalada vieja con su çerradura y llave en que está metido lo siguiente

$\checkmark$ Un garniel de cuero negro

$\checkmark$ Tres pedaçuelo de estamenete escarlatín

$\checkmark \quad$ Un regalillo de raso negro forrado en pellejos negros

$\checkmark$ Una carpeta forrada de lienço blanco

$\checkmark \quad$ Un manteo de burato traýdo

$\checkmark$ Unas mangas de anascote sueltas

$\checkmark \quad$ Una ropeta de carisea vieja

$\checkmark$ Unas medias calças de estameña viejas

$\checkmark$ Unos griguiescos de paño negro rraído forrados de lienço blanco

$\checkmark$ Una sotana de burato o gorvarán traída

$\checkmark$ Otra sotana de burato vieja rota

$\checkmark$ Una sonata de carisea negra traýda

$\checkmark \quad$ Una ropilla corta de carisea traída

$\checkmark$ Otros griguiescos de paño viejos forradosde lienço blanco

$\checkmark$ Una ropilla de tafetán forrada en vayeta negra

$\checkmark$ Unas medias de lana negras de punto traýdas

$\checkmark$ Una manguilla de estamenete suelta

$\checkmark$ Un çeñidor de colonia negro

$\checkmark$ Tres bonetillos de tafetán

$\checkmark$ Una escobilla de limpiar ropa

$\checkmark$ Un almariete de una gaveta caýda de madera

$\checkmark \quad$ Una caxa de madera blanca nueva en que está lo siguiente con sus tres bisagras nuevas y cerradura pestillera hazia arriba y con sus cantoneras de hierro por de / dentro

$\checkmark$ Dos sávanas de Ruan buenas

$\checkmark$ Dos coxinitos de lienço uno labrado de grana y otro de azul

$\checkmark$ Dos almohadas medianas de lienço guarneçidas de red blanca

$\checkmark \quad$ Un coxinito lleno de lana labrado de grana

$\checkmark \quad$ Tres paños blancos con sus guarniçiones de red blanca

$\checkmark$ Otro paño de rostro labrado de seda azul

$\checkmark$ Tres camissas de olanda

$\checkmark$ Una colcha blanca

$\checkmark$ Dos pares de medias calçetas blancas de lienço

$\checkmark$ Una escofieta acolchada blanca

$\checkmark$ Una solletica como jarrito de plata para bever $<$ hasta aquí $>$

\section{[f. 255]}

$\checkmark \quad$ Un cofre de hierro con su pie de madera y dentro del un cofreçito de flandes pequeño en el qual estava una bolsa de seda de punto vieja parda y dentro della, Dozientos y veynte y dos escudos en / oro de a quatro y de a dos / y senzillos

$\checkmark$ Otro cofreçillo de flandes de color naranjado

$\checkmark$ Una piedra como çarçillo de dos piezas una azul y otra verde la verde guarneçida de / oro / o plata dorada pendientes una de otra

$\checkmark$ Una piedra como leonado guarneçida de / oro / o plata dorada

$\checkmark$ Un pedaçito de uña guarneçida de plata

$\checkmark \quad$ La guarniçión de unos antojos de plata

$\checkmark$ Una guarniçión de plata de pretina entera y otro pedaçito [...]

$\checkmark$ Una quenta larga de sangre y leche

$\checkmark$ Otra quenta de sangre pequeña 
$\checkmark \quad$ Un anillo de piedra de sangre

$\checkmark$ Quatro sillas la una de espalda y las tres de descanso

$\checkmark$ Un escalentador de cobre con su asta de hierro

$\checkmark$ Una bazía de açofar pequeña

$\checkmark$ Un cantaro de cobre traýdo

$\checkmark$ Otro cántaro de cobre mediano

$\checkmark$ Una ballesta con sus gafas

$\checkmark$ Una romana de hierro pequeña

$\checkmark$ Una cadena delgada de hierro

$\checkmark$ Una xaula de hierro y palo de calandria

$\checkmark$ Media cama de madera con sus varandas

$\checkmark$ Una silla de mula vieja

$\checkmark$ Un platelillo de estaño viejo

$\checkmark$ Un barrilete de hoja de milán

$\checkmark$ Otro barrilete de vidro guarnesçido en verga

$\checkmark$ Una guarniçión de lampara de hoja de milán

$\checkmark$ Un candil de hoja de milán

$\checkmark$ Una vela de lienço basta para el patio

$\checkmark \quad$ Una caxa de madera encorada para el serviçio

$\checkmark$ Una sillita de cuero rasa vieja

$\checkmark$ Dos bastidores de madera de ventana con su lienço

$\checkmark$ Quatro barrenas metidas en un taleguillo

$\checkmark$ Dos espuelas de pico labradas

$\checkmark$ Una ratonera

$\checkmark$ Una argolla de hierro para esclavo

$\checkmark \quad$ Una hoz de hierro vieja

$\checkmark$ Una bota de tener vino de cuero

$\checkmark \quad$ Una porçelana labrada grande / de colores

$\checkmark \quad$ Una caxeta de cuero para un cubilete

$\checkmark$ Un breviario romano de tres liçiones viejo

$\checkmark$ Un libro officio della semana sancta

$\checkmark$ Otro breviario de tres liçiones viejo

$\checkmark \quad$ Un diurnal de lo proprio [falta en Wagner]

$\checkmark$ Un diurno romano de los nuevos viejo

$\checkmark$ Unas fábulas de Ysopo rotas

$\checkmark$ Un diurno de tres liçiones viejo

$\checkmark$ Unos quadernicos de diversas cosas por enquadernar

$\checkmark$ Un libro de çifras de música de mano viejo

$\checkmark$ Ocho quadernicos de eifra música enquadernados de pergamino blanco

$\checkmark$ Otros quadernos sueltos de música

$\checkmark$ Quatro papeles de estampas

$\checkmark$ Una redoma de vidro bazía con su bajera

$\checkmark \quad$ Otra redoma de vidro con su bajera

$\checkmark \quad$ Una poma de vidro grande bazía

$\checkmark$ Una copa de vidro larga

$\checkmark \quad$ Una limeta de vidrio con un cuello largo

$\checkmark$ Un boteçillo de vidro

$\checkmark$ Otros quatro papeles de estampa viejos

$\checkmark$ Una alcarraça y un cantarillo y un jarro vedriado de amara

$\checkmark$ Una linterna de vidro

$\checkmark \quad$ Siete esteras de esparto la una dellas pequeña 
$\checkmark \quad$ Seys cubiletes de vidrio

$\checkmark$ Catorze taças de vidrio de diversas suertes

$\checkmark$ Una limetica de vidrio dorada a partes

$\checkmark$ Otra limetica de vidrio de enfriar

$\checkmark$ Siete vasos de vidro los çinco con sus tapaderas y el uno es dorado

$\checkmark$ Un vasito verde de vidrio con su tapadera

$\checkmark$ Una taça de vidrio de dos asas

$\checkmark$ Dos pomitos de vidrio el uno de pico

$\checkmark$ Una porçelana alta pequeña de colores

$\checkmark$ Otra porçelana con castillos y leones por armas

$\checkmark$ Ocho platos de beneçia de colores azules

$\checkmark$ Tres escudillas con figuras

$\checkmark$ Una escudilla de la Yndia dorada por defuera

$\checkmark$ Un jarro pequeño de Talavera con su tapadera azul

$\checkmark$ Un salserico azul

$\checkmark$ Un salero de barro azul

$\checkmark$ Quatro porcelanas pequeñas de diversas suertes

$\checkmark$ Un jarro de barro azul

$\checkmark$ Otro jarro de barro blanco de pico pintado de azul a partes

$\checkmark$ Dos jarritos de barro colorado

$\checkmark$ Una taça de calabaça

$\checkmark$ Dos platicos de peltre y otros quatro platicos más pequeños y dos salseritos de lo mismo todos nuevos

$\checkmark$ Una força grande / pa tener pan vedriada de verde

$\checkmark$ Dos escabelos viejos

$\checkmark$ Una banquilla pequeña de madera vieja

$\checkmark$ Dos sillas de espaldas viejas

$\checkmark \quad$ Una media silla de espaldas

$\checkmark$ Dos pichelitos de peltre uno con tapadera y otro sin ella viejos

$\checkmark$ Una alabarda con su hierro

$\checkmark$ Un lançón con su hierro

$\checkmark$ Dos candeleros de açofar

$\checkmark \quad$ Un crucifixo con una cruz de évano

$\checkmark$ Un harnero de cuero y un medio almud y un quartillo de madera y una espuela de correón dentro dél

$\checkmark$ Una fuenteçica de hoja de milán

$\checkmark$ Una alfombra vieja pequeña

$\checkmark$ Un guadameçil de cuero colorado y dorado traýdo

$\checkmark$ Una almilla de estameñete colorado vieja

$\checkmark \quad$ Una canasta de mynbre con ciertas guarniciones viejas de mula

$\checkmark$ Una prensa de bonetes

$\checkmark \quad$ Tres toçinos cada uno con su espalda y pernil

$\checkmark$ Dos medias fanegas de madera con un rasero

$\checkmark$ Dos pies de caxas de hierro y son de madera

$\checkmark$ Una puerta de madera pequeña con su cerradura

$\checkmark$ Una fraçada blanca

$\checkmark$ Otras dos fraçacas blancas la una vieja y la otra traýda

$\checkmark$ Dos mantas de cama de los sayaleros

$\checkmark$ La madera de una cama de viento

$\checkmark$ Un lienço con su bastidor de quando aparesçió dios a moyses en la çarça

$\checkmark$ Un retablito con su guarniçión con la madalena y crucifijo en la mano

$\checkmark$ Otros dos lienços con sus bastidor uno de batallas y otro de unas figuras de ovejas y camellos

$\checkmark$ Otro lienço con su bastidor de la oraçión del huerto 
$\checkmark$ Otro retablo de cristo nuestro señor con los ladrones cruçificado

$\checkmark$ Una mesa de borne con su cadena de hierro y sus tablas

$\checkmark \quad$ Una silla de caderas y otra media silla vieja

$\checkmark$ Un brasero de copa con su copa dentro y sus tenaças

$\checkmark$ Dos candados con sus llaves

$\checkmark$ Unas tenaças

$\checkmark \quad$ Unos morillos de hierro para el fuego

$\checkmark$ Una baçía pequeña con asas

$\checkmark$ Una calderetica de açofar pequeña

$\checkmark$ Una caldera grande de cobre

$\checkmark$ Otras tres calderas pequeñas de cobre

$\checkmark$ Dos caços de cobre uno grande y otro pequeño

$\checkmark$ Dos sartenes de hierro una grande y otra pequeña

$\checkmark \quad$ Un vadil de hierro y unas parrillas un cuchillo

$\checkmark \quad$ Un morillo de hierro

$\checkmark \quad$ Nueve platos de peltre viejos grandes y pequeños

$\checkmark$ Un almirez de açofar con su mano

$\checkmark$ Quatro asadores de hierro

$\checkmark$ Una palanca de hierro

$\checkmark$ Unos grillos y una cuchara de hierro

$\checkmark$ Dos xaulas para pájaros

$\checkmark$ Un fuelleçito para blasero

$\checkmark \quad$ Una arquita pequeña de cedro y dentro della está lo siguiente

$\checkmark$ Dos sobrepellizes blancas una labrada de seda y otra blanca

$\checkmark$ Un par de guantes viejos

$\checkmark \quad$ Otro par de guantes viejos

$\checkmark \quad$ Una veca de tafetán negro vieja

$\checkmark$ Un candelerico de açofar de tres lumbres

$\checkmark$ Dos pomas de vidro la una grande con sus pies de madera

$\checkmark$ Un candelero de açofar con sus tixeras de despavilar

$\checkmark$ Una vela de çera labrada vieja

$\checkmark$ Un alfanje con un cuchillo y un punçón

$\checkmark$ Una calabaça labrada con su cubierta

$\checkmark$ Un martillo y un çerrojo pequeño y otros objetos

$\checkmark$ Un palustre pequeño

$\checkmark \quad$ Una mesita rredonda de madera con su pie

$\checkmark$ Una rodela

$\checkmark \quad$ Una ymagen del san sebastián con una caxa dorada

$\checkmark \quad$ Un atrilito de madera pequeño

$\checkmark \quad$ Una redoma grande con su bajera

$\checkmark$ Un calvario con un tabernáculo pequeño de pasta viejo

$\checkmark$ Un quitasol de bocaçi verde

$\checkmark$ Un atrilito de madera

$\checkmark \quad$ Una bigüela con su caxa de madera

$\checkmark$ Una sillita de troços de flandes

$\checkmark$ Una cobertera de / olla de cobre

$\checkmark$ Dos ymágenes pequeñas de yeso

$\checkmark$ Una caxa con tres cuchillos y un tenedor

$\checkmark$ Otra caxa con dos cuchillos pequeños y un tenedor 
$\checkmark$ Un estuche con unas tixeras y tres instrumentos de hierro chiquitos

$\checkmark$ Dos salvaderas de madera

$\checkmark$ Quatro tinteros de vidrio

$\checkmark$ Unas tenacillas y unos alicates de platero

$\checkmark$ Una escrivanía de oja de milán dorado

$\checkmark \quad$ Libro de quatroçientas Respuestas del almirante de Castilla

$\checkmark \quad$ Los proverbios de don Ýñigo López

$\checkmark$ Otro volumen de las quatrocientas Respuestas

$\checkmark$ Los doze libros de la neira en Romançe

$\checkmark$ Romançes de la crónica de españa

$\checkmark \quad$ Primera parte de la crónica del perú

$\checkmark$ Un librito de hojas prietas

$\checkmark$ Un librito con ciertos Romançes de mano

$\checkmark$ Suma de la conquista del Reyno de nápoles

$\checkmark$ Dos bonetes de burato uno nuevo y otro viejo

$\checkmark$ Un escriptorio de madera con sus caxonçitos traceados

$\checkmark$ Otro con su llave

$\checkmark$ Un lienço del Rico avariento

$\checkmark$ Una plancha de hierro para defensa del fuego

$\checkmark$ Un mapamundi forrado en lienço

$\checkmark \quad$ Un cofrete pequeño de flandes con unas scripturas dentro

$\checkmark$ Un hornillo baxo de hierro viejo

$\checkmark$ Una escrivanía de madera verde con unas tijeras y un cuchillo y un punçón y salvaderas

$\checkmark$ Un sobrero con sus cordones con la copa forrada de tafetán

$\checkmark$ Un manteo de carisea

$\checkmark \quad$ Un manteo de burato traýdo

$\checkmark \quad$ Un herreruelo de paño negro

$\checkmark \quad$ Un manto de anascote viejo

$\checkmark \quad$ Una Ropa de levantar de paño morisco

$\checkmark$ Otra Ropa de levantar de fusteda negra forrada de pelo de conejo

$\checkmark$ Una alfombrita pequeña verde y colorada

$\checkmark \quad$ Una sobremesa de paño azul

$\checkmark$ Unos mantelicos pequeños alimaniscos

$\checkmark$ Una vedriera con tres figuras

$\checkmark$ Dos Retablitos chiquitos

$\checkmark \quad$ Nueve guadameçíes y una sobremesa de lo proprio

$\checkmark$ Un reloxito de arena con su caxita de évano

$\checkmark$ Un jubón de lienço viejo

$\checkmark$ Tres costales los dos nuevos

$\checkmark$ Dos freçadas viejas

$\checkmark$ Una antepuerta de corte vieja

$\checkmark$ Una almohada de tripa azul llena de lana

$\checkmark \quad$ Un coleto de cordován viejos

$\checkmark \quad$ Un sayito de paño azul de un escolano

$\checkmark$ Otra escrivanía de madera pintada

$\checkmark$ Un lienço pequeño de los quatro evangelistas

$\checkmark$ Dos retablitos uno del juizio del oýdo?

$\checkmark$ Un atrilico de madera de gonçel

$\checkmark$ El lienço de la cama de viento

$\checkmark$ Otro pedaço de lienço viejo

$\checkmark$ Dos lienços de corredor con sus cuerdas 
$\checkmark$ Otro pedaço de lienço basto viejo

$\checkmark \quad$ Una ymagen de san sebastián con su bastidor

$\checkmark \quad$ Una ballesta con sus gafas y una alxava con dos tiros

$\checkmark \quad$ Una sera con unas pasas de almuñecar

$\checkmark \quad$ Un jarro con miel

$\checkmark$ Una xeringa de açofar

$\checkmark$ Una redoma de vidro

$\checkmark$ Una sierra pequeñita

$\checkmark$ Una caxeta de madera blanca vieja

$\checkmark$ Unos pañetes de lienço

$\checkmark$ Un pedaço de lienço casero basto

$\checkmark$ Un bonetero colchado viejo

$\checkmark$ Un pedaço de Ruan en que abrá vara y media

$\checkmark$ Ocho pañuelos alimaniscos

$\checkmark$ Dos pares de manteles alimaniscos

$\checkmark$ Un pedaço de Ruan en que puede aver hasta ocho varas

$\checkmark$ Un pedaço de olanda en que puede aver ocho varas

$\checkmark$ Dos escofietas colchadas

\section{[f. 258v.]}

$\checkmark \quad$ Un pedaço de lienço Ruan de hasta una vara

$\checkmark$ Unos griguiescos de pelo de camello viejos

$\checkmark$ Unas botas de cuero

$\checkmark$ Unos borceguíes de cuero viejos

$\checkmark \quad$ Unas medias de punto de lana grandes y otras pequeñas

$\checkmark$ Otras medias de carisea negras y otras coloradas viejas

$\checkmark$ Una ropilla de pelo de camello viejo

$\checkmark \quad$ Unos griguiescos de carisea viejos

$\checkmark$ Un cobertor de cama tinto de grana

$\checkmark$ Dos candeleros de açofar

$\checkmark$ Un cerrojo con su cerradura y llave

$\checkmark$ Un candadito de flandes

$\checkmark \quad$ Una bigüela mediana.

$\checkmark$ Una caxa de madera con su çerradura pestillera hazia arriba

$\checkmark$ Una pieça de presilla que terná doze o catorze varas

$\checkmark \quad$ Una pieça de pañuelos caseros bastos en que ay nueve pañuelos

$\checkmark$ Dos pedaços de lienço bastos

$\checkmark$ Otro pedaço de Ruan en que abrá quatro o çinco baras

$\checkmark$ Unos manteles y quatro pañuelos viejos alimaniscos

$\checkmark$ Quatro pares de escarpines nuevos

$\checkmark$ Quatro rematicos de cama pintados

$\checkmark$ Una media freçada blanca

$\checkmark$ Un cofre de flandes tumbado grande

$\checkmark$ Una estera de esparto

$\checkmark$ Un escabelito de madera viejo

$\checkmark \quad$ Un libro de las Repúblicas del mundo cubierto con pergamino blanco

$\checkmark$ Un libro de propietatibus Rebus

$\checkmark$ Historia etiopía

$\checkmark$ Un libro copilaçión de leyes del Rey don fernando

$\checkmark$ Josep de antiquitatibus et vero Judaico

$\checkmark$ Breviario romano de los nuevos ympreso en burgos

$\checkmark$ Historia de la origen y guerra de los turcos

$\checkmark$ Historia de guerras entre cristianos e ynfieles

$\checkmark$ Libro de abricultura

$\checkmark$ Vocabulario de antonio de lebrixa 


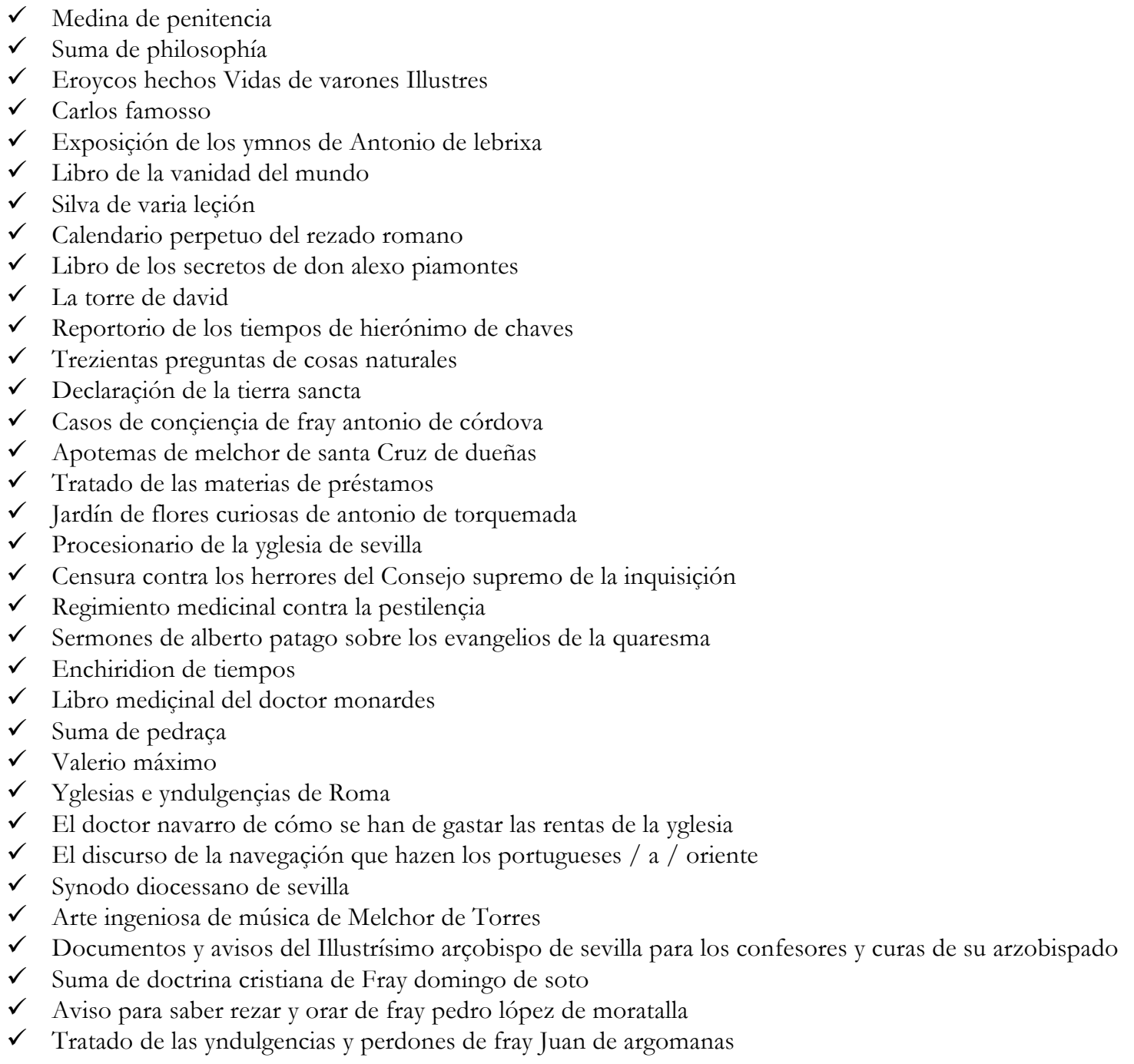

$\checkmark$ Alivio de caminantes de Juan de timoneda

$\checkmark$ Memorial de la vida cristiana de fray luis de granada

$\checkmark$ Un anafre de hierro

$\checkmark$ Unas trévedes de hierro

$\checkmark$ Una hacha de partir leña

$\checkmark$ Un aparador viejo de cocina

$\checkmark \quad$ Una arca vieja quebrada para pan

$\checkmark$ Un mortero de mármol

$\checkmark$ Una tapadera de cobre de / olla pequeña

$\checkmark$ Quatro candiles

$\checkmark \quad$ Una paleta de hierro de sacar carne

$\checkmark$ Una escarpia

$\checkmark$ Dos escaleretas pequeñas de pasos viejos

$\checkmark$ Un velador de madera

$\checkmark$ Dos arquillos de hierro viejos

$\checkmark$ Dos librillos de labar 
$\checkmark$ Una tinajuela pequeña

$\checkmark$ Dos cántaros viejos

$\checkmark$ Un arnero de cuero

$\checkmark \quad$ Una xaula grande de páxaros.

$\checkmark \quad$ Tres tablas y un madero como pedaço de palo

$\checkmark$ Otra tabla vieja

$\checkmark$ Una arca vieja para tener harina

$\checkmark$ Un tinajonçito

$\checkmark$ Un tablero

$\checkmark$ Dos librillos para amasar

$\checkmark$ Una artesa para masar

$\checkmark$ Quatro çedaços

$\checkmark$ Dos tablas con sus piel tendida para pan

$\checkmark$ Una mesa baxa con pies para masar

$\checkmark \quad$ Una horquilla de hierro para meter leña al horno

$\checkmark$ Un pala de horno y un barredero

$\checkmark$ Una tapadera de palo de horno

$\checkmark$ Un tablero para amasar pan

$\checkmark \quad$ Una polea pequeña

$\checkmark$ Dos bancos pequeños y un cañiço

$\checkmark$ Una cesta grande de berga

$\checkmark \quad$ Un gallo y dos gallinas con diez y ocho pollitos chiquitos.

$\checkmark$ Quatro tinajas de agua grandes y pequeñas

$\checkmark$ Otra gallina con nueve pollos

$\checkmark$ Una caldereta con una cadenilla de hierro delgadita

$\checkmark$ Una canasta grande

$\checkmark$ Otra tinajuela de agua llovediça

$\checkmark \quad$ Un azetre con su carrillo de pozo

$\checkmark$ Dos mesas pequeñas de labar viejas

$\checkmark$ Un escaño con su caxón y cerradura

$\checkmark$ Una mesa con sus bancos y cadena

$\checkmark$ Otra mesa con dos pies de madera sueltos

$\checkmark \quad$ Tres barriles de madera para vino y vinagre.

$\checkmark$ Dos tinajuelas de azeyte la una llena y la otra con alguno

$\checkmark$ Una canasta blanca con colgadero de hierro

$\checkmark$ Unas guarniçiones de mula viejas con sus estrivos

$\checkmark \quad$ Un pico de albañil

$\checkmark$ Una orca blanca de barro pequeña

$\checkmark$ Quatro banquillos de pipas

$\checkmark$ Unos hierros de colgar carne de hierro

$\checkmark$ Una pala de hierro

$\checkmark$ Un rodabillo de hierro

$\checkmark$ Una baçinerilla con tres limetas y una taça de vidro

$\checkmark$ Una banca vieja de madera

$\checkmark \quad$ Un pesebre de palo viejo y un sillero viejo pequeño

$\checkmark \quad$ Una mula negra con dos pares de guarniçiones negras.

$\checkmark \quad$ Un gualdrapa de paño negro.

$\checkmark$ Una esclava negra de hedad de hasta diez y seis o diez y siete años la qual se llama esperança

$\checkmark$ Yten lo que paresçiere que deven los señores mayordomos de la mesa capitular al dicho alonso mudarra de su prebenda 
$\checkmark$ Yten con un talego de lienço en que avía mill y ochoçientos y ochenta y ocho reales y a parte en un cofresico mil y quinientos reales.

$\checkmark \quad$ Una caxa de madera blanca vieja que tenía en la yglesia con dos sobrepellizes capa de coro de trama

$\checkmark$ Un papagayo en su xaula.

$\checkmark \quad$ Una xaula con un pajaro canario.

$\checkmark$ Otra xaula con otro pajaro xamarin.

El qual dicho canónigo Ramos dixo que jurava y juró por las ordenes sagradas que resçibió como sacerdote puestas las manos en su pecho que el dicho ynbentario es cierto y verdadero e que al presente nos ve de más bienes que del dicho señor canónigo alonso mudarra ayan quedado [...] que dellos supiere / o a su noticia $[\ldots]$ 


\section{ANEXO XI}

\section{Almoneda del CANónigo MudarRa}

Sevilla, 14 de abril de 1580

AHPSe, Oficio 19, de Gaspar de León Garabito, Libro $3^{\circ}$ de 1580, Signatura 12459, ff. 728-740.

Almoneda del canónigo mudarra. En la muy noble e muy leal çiudad de sevilla jueves catorze días del mes de abrill de myl e quinientos y ochenta y uno ante my gaspar de león garavitos escribano público de sevilla e testigos yusoescriptos de pedymiento del señor canónigo fernando mohedano de saavedra canónigo en la santa yglesia de la çiudad de sevilla gaspar sánchez pregonero del conçejo desta çiudad de sevilla remito ciertos bienes que dixo aver quedado del señor alonso mudarra canónigo que fue de la dicha santa yglesia difunto y los bienes que ansí remató y los precios y personas en quien se remataron y en los días que ansí se remataron es esto que se sigue

$\checkmark$ Primeramente un tosino que tubo quinze libras y media en el señor canónigo antonio gonzález a precio de cinquenta y seis maravedís libra que monta veynte y çinco reales y medio

$\checkmark \quad$ Iten otro tosino que tubo catorze libras en el señor raçionero pedro pablo cinquenta y seis maravedís libra que monta veynte y tres reales y dos maravedís

$\checkmark$ Yten otro tosino que que pesó doze libras y media en fernán ramírez de beger a cinquenta y seis maravedías libra que monta setecientos y setenta y dos maravedís

$\checkmark$ Yten un papagayo en su jaula en el señor licenciado raçionero diego alonso gasco en setenta reales.

$\checkmark$ Yten dos pájaros uno xamaris y otro canario en sus jaulas en francisco de iza [cortado]

$$
\text { [f. } 728 \mathrm{v}]
$$

$\checkmark$ Yten una Romana de hierro pequeña en el señor canónigo antonio gonzález en diez reales.

$\checkmark$ Tres lienços en sus bastidores de figuras el uno quando apareçió dios en la sarsa a moyzén y el otro de batalla y el otro de Jacó quando llegó a la fuente y alçó la piedra del pozo en francisco de chaves a veintidos reales

$\checkmark$ Una madalena en un retablo con un cristo en la mano en el señor raçionero francisco perez tamayo en treynta y ocho reales.

$\checkmark$ Yten un lienço de la oraçión del huerto con su bastidor en el señor raçionero pedro de la rrosa en ocho reales

$\checkmark$ Yten un retablo de nuestro señor crucificado y los dos ladrones a los lados en madera en el señor raçionero pedro mexía en seis reales

$\checkmark$ Yten un lienço de san sebastián en un bastidor en francisco de alcalá en quatro reales

$\checkmark$ Yten quatro retablitos pequeños de diferentes ystorias guarnesidas en el señor raçionero tamayo en ocho reales

$\checkmark$ Yten dos ymágenes forxadas de yeso una de nuestra señora de loreto y otra de nuestra señora y san José en el dicho señor raçionero tamayo en un real

$\checkmark \quad$ Yten nueve papeles de estanpas viejos en fernando de león clérigo en dos reales

$\checkmark$ Yten quatro guadamesíes dorados en el dicho señor raçionero tamayo en diez ducados

$\checkmark$ Yten seis guadamesíes colorados con sus cenefas verdes

$\checkmark$ En el dicho señor raçionero pedro mexía en doze ducados

$\checkmark$ Yten una sobremesa de guadamesí colorada en el dicho señor raçionero pedro mexía en ocho reales

$\checkmark$ Yten una alfombra pequeña en el señor canónigo antonio gonzález en treynta y tres reales

$\checkmark$ Yten otra alfombra pequeña verde y colorada en el señor don pedro vélez de guevara en veynte y çinco reales 
$\checkmark$ Yten una sobremesa de paño azul en diego alonso en catorze reales

$\checkmark$ Un ropa de pelo de camello aforrada en pellejos negros en el señor raçionero san miguel en cinquenta reales

$\checkmark$ Yten una ropa de paño morisco en antonio roque en quarenta y dos reales

$\checkmark$ Yten un manto de anascote en diego de figueroa en catorze reales

$\checkmark$ Yten un manto de burato en el señor raçionero gerónimo gonzález en sesenta y dos reales

$\checkmark$ Un manteo de rrafa en el señor raçionero san myguel en quarenta y siete reales

$\checkmark$ Yten un herrerillo de paño negro en el señor licenciado gasco en noventa reales

$\checkmark$ Yten una ropa de gorbarán negro aforrada de bayeta negra en Juan de herrera clérigo en veynte y dos reales

$\checkmark \quad$ Un pañezuelo y una sinta de tafetán en francisco gutiérrez en dos reales

$$
\text { [f. } 729 \mathrm{v} \text { ] }
$$

$\checkmark \quad$ Una ropilla de paño negro el señor doctor cristobal de mesa en veynte y siete reales

$\checkmark$ Yten una sotana de rraxa en francisco de alcalá en quarenta y ocho reales

$\checkmark$ Yten una sotana de burato vieja en francisco gutiérrez en doze reales Juan de herrera clérigo en doze reales

$\checkmark$ Yten una ropa de trama de seda en el señor raçionero jerónimo gomes en çinquenta reales

$\checkmark$ Yten una zamarra de carisea negra en antonio de arias en nueve reales

$\checkmark$ Yten unas medias de lana negra en Jusepe de betolaca en quinze reales

$\checkmark$ Yten un manteo de burato en el señor dotor mesa en treynta reales

$\checkmark$ Una carpeta aforrada en lienço blanco en el dicho raçionero pedro pablo en veynte y çinco reales

$\checkmark$ Yten unos griguiescos de paño aforrados en lienço en el dicho señor raçionero tamayo

$\checkmark$ Una manga de tamenete colorado y dos pedaços en Juan de alcalá en un real

$\checkmark$ Yten unas mangas de anascote en francisco de aguilar clérigo en dos reales

$\checkmark$ Yten unos griguiescos de paño negro en diego de figueroa en treze reales

$\checkmark$ Yten un garniel y un regalillo y quatro bonetillos de tafetán viejos y un sinidor de tafetán y otro senidor de seda y unas medias calças de estameña en diego de figueroa en ocho reales

$$
\text { [f. 730] }
$$

$\checkmark$ Yten un arca de madera ensayalada en el señor canónigo antonio gonzález en veynte y seis reales

$\checkmark$ Yten un cobertor colorado de valençia en el dicho señor dotor san miguel en çinquenta y seis reales

$\checkmark$ Yten una bigüela en el dicho canónigo antonio gonzález en treynta y seis reales.

$\checkmark$ Otra bigüela metida en una caxa en el señor raçionero cristobal de mesa en treyta y ocho reales.

$\checkmark$ Yten una ropilla de pelo de camello corta en el dicho señor raçionero tamayo en quinze reales

$\checkmark$ Yten dos candeleros de açofar en el dicho señor raçionero san myguel en doze reales

$\checkmark$ Yten dos pares de medias calças de lana unas cortas y otras largas en el dicho señor raçionero tamayo en diez y seis reales

$\checkmark$ Yten unos griguiescos de carisea viejos en en juan lópez en diez reales

$\checkmark$ Yten unos griguiescos de pelo de camello aforrados en lienço en el dicho señor dotor sant myguel en treze reales

$\checkmark$ Unas medias calças de paño colorado en francisco de alcalá en tres reales y medio

$\checkmark$ Yten otras medias de carisea negras en francisco lópez en quatro reales y medio alonso de arras en quatro reales y medio

$\checkmark$ Yten unas botas enseradas en jusepe de betolaca en doze reales

$\checkmark$ Yten unos borceguíes en jusepe de betolaca en tres reales

$$
\text { [f. 730v] }
$$

$\checkmark$ Yten un pedaço de olanda que tuvo diez varas y quarta en Juan de herrera clérigo a seis reales la vara que monta sesenta y dos reales

$\checkmark$ Yten una pieça de lienço Ruan que tuvo catorze varas en francisco de chaves a noventa y dos maravedís la vara que monta myll y doszientos y ochenta y ocho maravedís

$\checkmark$ Yten dos pedaços de lienço Ruan en el dicho señor raçionero pedro mexía en seis reales 
$\checkmark$ Yten una tabla de manteles alimaniscos en el dicho señor raçionero gerónimo gomes en honze reales

$\checkmark$ Yten otra tabla de manteles alimaniscos en el dicho señor raçionero alonso gasco en quinze reales

$\checkmark$ Yten un serrojo con su serradura y llave y armella en el dicho señor raçionero gerónimo gómes en siete reales

$\checkmark$ Yten ocho servilletas en el dicho señor dotor san myguel en quatorze reales

$\checkmark$ Yten una arca de madera en çinquenta y tres en el señor don antonio pimentel chantre

$\checkmark$ En viernes quinze días del dicho mes de abrill del dicho año el dicho pregonero remató los bienes siguientes

$\checkmark$ Primeramente una jaula con veinte pollitos y dos gallinas que los crían en el señor canónigo fernando mohedano de saavedra en quinze reales

$\checkmark$ Yten una tabla de manteles alimaniscos en el dotor fernán ramírez en siete reales

$$
\text { [f. 731] }
$$

$\checkmark$ Yten quatro pañuelos alimaniscos en el dicho hernán ramírez en çinco reales y medio

$\checkmark$ Yten una tabla de manteles bastos en que ay nueve pañuelos caseros en francisco de guido en quinze reales

$\checkmark$ Yten quatro pares de escarpines en el señor raçionero pernia en dos reales

$\checkmark$ Yten media fraçada blanca en señor raçionero pedro pablo en siete reales y medio

$\checkmark$ Yten un pedaço de lienço ruan en que uvo seis varas menos sesma en el señor raçionero real a tres reales la vara

$\checkmark$ Una pieça de presilla pelada en el señor raçionero Juan real a ochenta y dos maravedís la vara tuvo veynte y quatro varas

$\checkmark$ Yten un pedaço de presilla en que uvo vara y media en el señor raçionero pernia en tres reales

$\checkmark$ Yten un pedaço de lienço françés angosto que tuvo tres varas en jusepe de vetocala a veynte y seis maravedís la vara

$\checkmark$ Yten un cofre grande tunbado de flandes con dos llaves en el sochantre juan bauptista en treynta y ocho reales

$\checkmark$ Una colcha blanca de olanda en el señor raçionero tamayo en seys ducados

$\checkmark$ rellenos de un colchón de crea nuevo en el señor raçionero megía en dos ducados

$\checkmark$ Una baçía para hazer la barva con dos paños grandes y dos pequeños para los mesmo con una taleguita en que están estos paños al señor canónigo mohedano en veynte y çinco reales

$\checkmark$ Un pedaço de lienço ruan de tres varas y quarta a doze reales al señor canónigo mohedano

$\checkmark$ Tres camisas de olanda en diez y ocho reales en juan francisco sacristán

$\checkmark$ Un paño de rostro guarneçido de red mosca en catorze reales en el señor raçionero ysla

$\checkmark$ Dos pomas de vidrio de colores una grande y otra pequeña con sus pies de madera en diez reales en pedro bravo

$\checkmark$ Un como relicario en un vidrio con un calvario dentro en seys reales en pedro bravo

$\checkmark$ Una cama de red blanca labrada/ de quatro paños y fruçido en lorenço vasquez puntador en sesenta y un reales

$$
\text { [f. 731v] }
$$

$\checkmark$ Quatro remates o mançanas de madera pintadas y doradas en dos reales al señor hierónimo costilla de cuevas

$\checkmark$ Un bavadero colchado una almohada blanca y un coxinito blanco vazío y dos paños de rostro blancos en quatro reales y medio en francisco de guido

$\checkmark$ Seys pares de escarpines y quatro bonetillos de lienço y çinco calçetas de lienço y un paño de manos / y una almilla de punto de seda blanca/ en el mesmo en çinco reales

$\checkmark \quad$ Un cofre de flandes tumbado con dos llaves el señor Raçionero tamayo en tres ducados

$\checkmark$ Doss sábanas de olanda el señor canónigo don ýñigo de villalobos en treynta reales

$\checkmark$ Doss sávanas de lienço de presilla en / diez y siete reales al señor canónigo mohedano

$\checkmark$ Otras dos sávanas de presilla en barrios en veynte y quatro reales

$\checkmark$ Una sávana basta y un coxinico lleno de lana con su vanda blanca de hilo en honze reales al señor raçionero ysla 
$\checkmark$ Una almohada de lienço vaçía labrada de grana en nueve reales y medio al señor canónigo ýñigo de villalobos

$\checkmark \quad$ Una tabla de manteles caseros al mesmo señor don ýñigo en honze reales

$\checkmark$ Otra tabla de manteles caseros en el mesmo señor don ýñigo en en honze reales y medio

$\checkmark$ Otra tabla de manteles caseros al dicho señor canónigo don ýñigo en doze reales

$\checkmark$ Otros manteles alimaniscos en honze reales al señor raçionero Ysla

$\checkmark$ Una camisa de ruan en diego de figueroa / en siete reales y medio

$\checkmark$ Una tabla de manteles caseros en doze reales al señor raçionero Ysla

$\checkmark$ Quatro pañuelos de mesa / y dos escofietas de lienço al señor doctor mesa en quatro reales

$\checkmark \quad$ Una caxa de madera vieja en madalena esclava del señor canónigo mudarra en tres reales

$\checkmark$ Dos camisas de olanda nuevas quarenta y dos reales al señor doctor sant miguel

$\checkmark$ Una camisa de olanda en veynte y dos reales en el señor doctor mesa

$\checkmark$ Otra colcha de olanda el señor raçionero juan real en honze ducados

$\checkmark$ Un paño de rostro con su guarniçión de red ancha en el señor hierónimo costilla en veynte y un reales

$\checkmark$ Otro paño de rostro de la mesma guarniçión en el señor canónigo mohedano / en diez y siete reales

\section{[f. 732]}

$\checkmark$ Un paño de rostro / [...] labrado de azul en el señor canónigo antonio del corro en doze reales

$\checkmark$ Un paño de rostro con guarniçión ancha de red en honze reales en el señor canónigo costilla

$\checkmark$ Dos almohadas pequeñas syn lana de lienço con su guarniçión de red en el señor canónigo armijo en treze reales

$\checkmark$ Un coxinyco labrado de grana lleno de lana el señor don myguel de villalobos en çinco reales

$\checkmark$ Dos coxinycos de lienço vazíos / uno labrado de azul / y otro labrado de grana /en el señor raçionero tamayo en seys reales

$\checkmark$ Dos sávanas de crea grandes en el raçionero tamayo en quarenta y ocho reales

$\checkmark$ Dos pares de calcetas de lienço / y un bonetillo de lienço colchado en hierónimo de chaves en quatro reales

$\checkmark$ Una caxa de madera con guarnyçiones de herro en el señor dotor don pedro veles de guevara en / noventa reales

$\checkmark$ Una antepuerta aforrada de lienço basto vieja en siete reales en el señor canónigo costilla

$\checkmark$ Un sonbrero con sus cordones de seda y aforrada la copa de tafetán en diez reales y medio en antonio ramos

$\checkmark$ Un colete de cuero / en el señor canónigo costilla en dos reales

$\checkmark$ Unos manteles pequeños alimaniscos en doze reales en el señor don ýñigo de villalobos

$\checkmark \quad$ Un cuxín de tripa azul lleno de lana / en guydo en tres reales

$\checkmark$ Un sayto de paño azul de muchacho en ocho reales en el señor raçionero marín

$\checkmark$ Dos candadillos de cubo con dos armellas / en çinco reales en el canónigo raçionero ysla

$\checkmark$ Un escaño que tanbién sirve de arca/ con su çerradura en quarenta y seys reales en el señor doctor sanct miguel

$\checkmark$ Un paño de rostro casero basto y unos pañetes de lienço y tres escofietas en çinco reales en el señor pedro mexía

$\checkmark \quad$ Çinco pedazuelos de paño negro y otro pedaço de paño azul y otro de verde en luys lópez en dos reales y medio

$\checkmark$ Un cordón de seda dorada en sesenta maravedías en el señor canónigo costilla

$\checkmark$ Un bavadero colchado y dos cañones de lienço y un coxinito de lienço vazío y unos guantes cortadas las puntas y una sevilla colorada / en betolaça / en real y medio

$\checkmark$ Una sobrepelliz guarneçida de seda digo labrada de seda en sesenta reales en el señor canónigo hernando peres

$\checkmark$ Otra sobrepelliz llana de anabasa en treynta y seys reales en el señor canónigo pedro de espinosa

$\checkmark$ Una beca de tafetán vieja en nueve reales en el señor canónigo costalla

$\checkmark$ Dos pares de guantes en dos reales en betolaça

$\checkmark$ Una arquilla de cedro con su cerradura y su llave en honze reales en el señor raçionero tamayo 
$\checkmark$ Una caxa de madera con su zelozía para tener vidrios/ en treynta y un reales en el señor raçionero gasco

$\checkmark$ Un aparador con una gaveta / de puerta caýda en el señor canónigo antonio del corro en nueve reales

$\checkmark$ Un escritorio pequeño labrado por dedentro con sus caxones de ataraçea en el señor raçionero gerónimo gómez en quarenta y seis reales

$\checkmark$ Una caxa de cuchillos uno grande con cabo blanco y dos cuchillos medianos con caxas negras y un tenedor en el señor licenciado gasco en doze reales

$\checkmark \quad$ En martes diez y nueve días del dicho mes de abril del dicho año de mil y quinientos y ochenta años el dicho gáspar sanches pregonero del dicho pedimiento remató una esclava negra nonbrada por nombre esperança en noventa y dos ducados en el señor juan de villán contador en la santa iglesia de sevilla

$\checkmark$ Yten una mula negra con su gualdrapa y guarniçiones de paño y otras guarniçiones de cuero y con su manta y cadena silla y freno en ochenta y dos ducados y medio en el jurado alonso de vilacarrera

$\checkmark$ En miércoles veynte días del dicho mes de abril y del dicho año el pregonero remató los bienes siguientes

$\checkmark \quad$ Primeramente un pesebre y cavallejo de madera para poner una silla de mula viejos y hechos pedaços en el señor canónigo fernando mohedano de saavedra en dos reales

$\checkmark$ Yten siete papeles de siete virtudes en bernardino de santa maría en nueve reales

$\checkmark$ Yten un pichel de barro y un tenedor de hierro en tres reales menos un quartillo en el licenciado andrés de saavedra

$\checkmark$ Yten tres platos y un albarnis y un jarro de varro labrados de colores en quatro reales en rodrigo de çavallos

$\checkmark$ Yten un glovo pequeño con su pie de madera en el señor doctor don pedro veles en tres reales

$\checkmark$ Yten una caxa de oja de milán para tener fruta con su tapadera en dos reales y medio en diego sanches

$\checkmark$ Yten un reloxito de arena en su caxa de madera en el señor canónigo hernando mohedano en quatro reales y medio

$\checkmark$ Yten dos bonetes de burato aforrados en tafetán uno viejo y otro nuevo en tres reales en el señor antonio ramos

$\checkmark \quad$ Yten un tintero de vidrio en hernán ramírez en quarenta y ocho maravedís

$\checkmark$ Yten tres tinteros de vidrio y dos salvaderas en el señor raçionero pedro pablo en tres reales

$\checkmark$ Yten unas tenasas y unos alicates de hierro en cincuenta y nueve maravedís en el señor canónigo hernando mohedano

$\checkmark$ Yten un estuche con unas tixeras y otras tres herramienta de hierro en dos reales y medio en el señor canónigo hernando mohedano

$\checkmark$ Yten una caja de cuchillos con dos cuchillos y un tenedor en el señor dotor don pedro veles en dos reales y medio

$\checkmark \quad Y$ ten unate $[\ldots]$ y unbotesice

$\checkmark$ Yten un escritorio que sirve de escritorio y mesa con sus visagras y una gaveta en el señor raçionero jacomar en veinte reales

$\checkmark$ Yten una mesa con su banco y cadena en el señor dotor mesa en siete reales

$\checkmark$ Yten un bufete en el señor dotor don pedro veles en treynta y quatro reales

$\checkmark$ Yten un aparador de madera en el señor raçionero lucas gonçales de miedes en quarenta reales

$\checkmark$ Yten dos lienços uno de la storia del rico avariento y grande y un pequeño de los quatro evangelistas en el señor licenciado gasco raçionero en nueve reales y medio

$\checkmark$ Yten un papel de mapamundi aforrado en lienço en el señor dotor san miguel en nueve reales

$\checkmark$ Yten una media de medir trigo con su raedero en el señor canónigo antonio gonçales en siete reales

$\checkmark$ Yten otra media sin raedero en el señor don ýñigo de villalobos en dos reales

$\checkmark$ Yten una escrivanía de madera con salvadera / con tintero y dos cuchillos y unas tijeras y un punçón y dos pares de antojos en ocho reales en francisco de chaves

$\checkmark$ Yten otro tintero escrivanía de madera con su salvadera en el señor raçionero bartolomé ruiz en un real

$\checkmark$ Yten un candil de açofar de tres lunbres en el señor dotor don pedro de veles de guevara en siete reales

$\checkmark$ Yten una mesa redonda de pie pintada en francisco de chaves en tres reales y medio

$\checkmark$ Yten un cántaro de cobre pequeño en el señor canónigo antonio gonçales en honze reales 
$\checkmark$ Yten otro cántaro de cobre mayor en diego sanches en diez y nueve reales

$\checkmark$ Yten un alfanje con un cuchillo y un punsón con su vayna vaya en hernán ramírez de vejer en treynta y quatro reales

$\checkmark$ Yten una caxa de madera guarneçida para un serviçio en el señor don ýñigo de villalobos en dos reales

$\checkmark$ Yten una copa de cobre con pie de madera y sus tenazas en el señor raçionero ysla en honze reales

$$
\text { [f. 733v] }
$$

$\checkmark$ Yten una caldera grande de cobre en el señor raçionero gasco en diez y seis reales y medio

$\checkmark$ Yten una caldera mediana de cobre en el señor canónigo mohedano en çinco reales y medio

$\checkmark$ Yten otra caldera pequeña de cobre en el señor raçionero jacomar en catorze reales

$\checkmark$ Yten otra caldera mediana de cobre en treze reales en el señor canónigo antonio gonçales

$\checkmark$ Yten un açetre de cobre en el señor raçionero ysla en tres reales

$\checkmark$ Yten una calderetilla de açofar y un perol para hazer conservas de açofar en el señor canónigo hernando mohedano en diez y siete reales

$\checkmark$ Yten una vazía de açofar grande en el señor canónigo don ýñigo de villalobos en veinte y seis reales

$\checkmark$ Yten otra vazía de açofar mediana en el señor licenciado alonso gasco en ocho reales y medio

$\checkmark$ Yten un caso grande con su asta de hierro y otro pequeño con su cabo de hierro en el señor canónigo don ýñigo de villalobos en tres reales

$\checkmark$ Yten dos sartenes de hierro con sus cabos y una cuchara tanbién de hierro en siete reales y medio en el señor raçionero ysla

$\checkmark$ Yten unas parrillas y un badil y una paleta de hierro en el señor raçionero ysla e dos reales y medio

$\checkmark$ Yten unas trévedes y unas tenazas de hierro en el señor raçionero juan real en quatro reales y medio

$\checkmark$ Yten un mortero de marmol y su mano de madera en el señor dotor san miguel en dos reales y un quartillo

$\checkmark$ Yten una geringa de açofar en francisco de herrera clérigo en diez reales

$\checkmark$ Yten un hornillo de cobre con su cobertera en el señor raçionero bartolomé ruiz en ocho reales

$\checkmark$ Yten dos picheles pequeños de estaño uno con cobertera y otro sin ella en el señor raçionero armijo en tres reales y medio

$\checkmark$ Yten nuebe platos grandes y pequeños de peltre en el señor don ýñigo de villalobos en diez reales

$\checkmark$ Yten un calentador de cobre con su asta de hierro en el señor raçionero bartolomé ruiz en nueve reales y medio

$\checkmark$ Yten un cobertor de olla de cobre en el señor raçionero bartolomé ruiz en dos reales y medio

$\checkmark$ Yten dos candeleros de açofar en el señor dotor don pedro veles de guevara en dos reales

$\checkmark$ Yten otro candelero de açofar y una fuentesilla de oja de milán en el señor canónigo mohedano en quatro reales

\section{[f. 734]}

$\checkmark$ Yten tres morillos de hierro en nueve reales en juan de herrera clérigo

$\checkmark$ Quatro açadores de hierro el uno con tres puntas en el dicho juan de herrera en ocho reales

$\checkmark$ Yten una vallesta con su aljava y tiros y gafas en el señor canónigo sauzedo en doze reales

$\checkmark$ Yten otra vallesta de bodoques con sus gafas en siete reales en el señor raçionero ysla

$\checkmark$ Yten una sera con pasas en siete reales y medio en el señor canónigo andrés de sauzedo

$\checkmark$ Yten una porselana grande de talavera labrada de pintura en el señor canónigo andrés de sauzedo en çinco reales y medio

$\checkmark$ Yten una caxa de madera de yndias pintada y dorada con su tapadera en el señor doctor pedro veles de guevara en tres reales y medio

$\checkmark$ Yten un tirasol de bocasín verde con su madera en quatro reales en el señor licenciado alonso gasco

$\checkmark$ Yten dos papeles de mapamundi chiquitos viejos y dos amoscadores todo viejo y roto en un real en cristóval álvarez

$\checkmark$ Yten una plancha de hierro para chimenea en siete reales en el señor canónigo andrés de sauzedo

$\checkmark$ Yten tres jaulas de hierro en ocho reales en el señor raçionero pedro pablo

$\checkmark$ Yten una lança y una rodela en nueve reales en el señor canónigo ýñigo de villalobos

$\checkmark$ Yten un dardo en quarenta maravedís en el señor dotor leandro de san miguel

$\checkmark$ Yten tres cordones de madera de yndias en dos reales en el señor dotor san miguel 
Yten una prensa de bonetes de madera y unos fuelles para el fuego en çinco reales y medio en el señor raçionero pedro pablo

$\checkmark$ Yten un atrilico de madera con su pie en quatro reales en el señor dotor don pedro veles de guevara

$\checkmark$ Yten un atrilico de madera de gonçel en dos reales en el señor raçionero ysla

$\checkmark$ Yten otro atrilico pequeño de gosnes en tres reales en el señor canónigo mohedano

$\checkmark$ Yten una tinaja de lavar con un maçetón devaxo verde en tres reales en baltasar de varrio

$\checkmark \quad$ En jueves veinte y un días del dicho mes de abrill del dicho año el dicho pregonero remató los bienes siguientes

$\checkmark$ Primeramente un anafre de hierro en el señor raçionero ysla en siete reales y medio

$\checkmark$ Yten una hacha de partir leña en gonçalo gomez en dos reales

$$
\text { [f. 734v] }
$$

$\checkmark$ Yten quatro sedaços y una arteza y una mesa con sus bancos para debaxo del arteza y pala y jurgonero de hierro y una tabla de llevar pan y un barredero de horno en el señor raçionero bartolomé ruiz en nueve reales

$\checkmark$ Yten una cama de biento de madera y lienço en el señor raçionero consognexo en treynta y çinco reales

$\checkmark$ Yten una caxa de madera vieja en seis reales en betolaca

$\checkmark$ Yten una mesa de pies para lavar vieja en el señor dotor san miguel en tres reales

$\checkmark$ Yten un almires de bronze con su mano en el señor raçionero juan real en treze reales y medio

$\checkmark$ Yten una linterna de vidrio que llaman faro en el señor raçionero montoya en quatro reales

$\checkmark$ Yten un aparador de madera viejo en el señor raçionero san miguel en syete reales

$\checkmark$ Yten ocho platos de peltre grandes y medianos y pequeños en el señor raçionero alonso marín en treze reales y medio

$\checkmark$ Yten una caxa de madera vieja en el señor raçionero tamayo en siete reales

$\checkmark$ Yten ocho platos de talavera pintados en nueve reales en el señor raçionero montoya

$\checkmark$ Yten seis porselanas grandes y pequeñas de talavera las çinco pintadas y una blanca en diez reales en el señor raçionero marín

$\checkmark$ Yten un vaso como escudilla de varro de la yndia por de dentro labrado de azul y por defuera dorado en el señor dotor don pedro veles de guevara en seis reales

$\checkmark$ Yten tres escudillas de talavera blancas con una pintura azul por dedentro en el señor licenciado alonso gasco en dos reales y medio

$\checkmark \quad$ Yten un jarro y un salero y una salserica de talavera pintado de azul y una jícara en dos reales en el señor raçionero marín

$\checkmark$ Yten dos jarros de talavera uno de pico y otro redondo en quatro reales en el señor raçionero juan real

$\checkmark$ Yten dos jarros de varro de portugal colorado en treynta y seis maravedís en el señor raçionero montoya

$\checkmark \quad$ Yten un caracol para beber en el señor dotor san miguel en medio real

$\checkmark$ Yten dos jarros de vidro con sus tapaderos en el señor raçionero pernia en quatro reales

$\checkmark$ Yten un jarro y dos taças de vidro en quatro reales y medio en el raçionero pernia

$\checkmark \quad$ Yten dos jarros de vidro con sus coberteras en quatro reales en el señor canónigo don ýñigo

$\checkmark$ Yten dos vasos de vidro el uno con su cobertor y a partes dorados en siete reales en el señor don ýñigo

$\checkmark$ Yten dos copas de vidrio en quatro reales menos un quartillo en el señor don ýñigo

$\checkmark$ Yten otras dos copas de vidrio en un real en el señor ra-

$$
\text { [f. 735] }
$$

cionero pernia

$\checkmark$ Yten otras dos copas de vidrio en sesenta maravedís en el señor canónigo mohedano

$\checkmark$ Yten un jarro de pico de vidrio elado y una limeta para enfriar vidrio en real y medio en juan bauptista sochantre

$\checkmark$ Yten otros dos copas de vidrio en un real en el señor raçionero tamayo

$\checkmark$ Yten dos taças de vidrio en quatro reales en el señor dotor hurtado

$\checkmark$ Yten otras dos taças de vidrio verde en dos reales en el señor dotor de pedro vello

$\checkmark$ Yten dos vasos de vidrio en dos reales en el señor dotor hurtado 
$\checkmark$ Yten dos vasos de vidrio el uno con su cobertor y labrado de verde en real y medio en el señor raçionero pernia

$\checkmark$ Yten dos tasitas de vidrio y un brinquiño blanco y un aguamanil azul dorado en real y medio en el señor raçionero tamayo

$\checkmark$ Yten un jarro y dos cubiletes de vidrio en medio real en el señor raçionero armijo

$\checkmark$ Yten dos bazos de vidrio uno largo y otro como limeta en veynte maravedís en el señor raçionero tamayo

$\checkmark$ Yten dos limetas grandes de vidrio y un bote de lo mesmo en real y medio y un quartillo en el señor licenciado gasco

$\checkmark$ Yten tres redomas de vidrio con sus baseras en dos reales en el señor raçionero tamayo

$\checkmark$ Yten un jarro amarillo lleno de miel en seis reales en el señor raçionero pernia

$\checkmark$ Yten una vedriera en un bastidor de la ystoria de tovías en diez y seis reales en el señor raçionero gasco

$\checkmark$ Yten dos jubones uno de lienço y otro de estamenete en ocho reales en francisco de guido

$\checkmark$ Yten dos cortinas de lienço para corredores con sus cordeles en veinte reales en el señor licenciado gasco

$\checkmark$ Yten una vela de patio de lienço en veynte reales en el señor raçionero espinosa

$\checkmark$ Yten un pedaço de lienço basto en siete reales menos un quartillo en francisco de guido

$\checkmark$ Yten dos costales uno nuevo y otro viejo en çinco reales en el señor don ýñigo

$\checkmark$ Yten una silla de mula en diez y seis reales y medio en el señor raçionero bartolomé ruiz

$\checkmark$ Yten la madera de una cama de campo con tornillos y una llave en veinte y siete reales en francisco de chaves

$\checkmark$ Yten dos pies de caxas de hierro que son ellas de madera en quarenta maravedís en el señor raçionero armijo

$\checkmark$ Yten un maçetón de varro verde y dos cantaricos de varro blancos y un jarro vedriado en tres reales en el señor raçionero tamayo

$\checkmark \quad$ Yten un maçetón y tres cántaros de varro y un frasco de vidrio en dos reales y medio en el señor dotor san miguel

$\checkmark$ Yten una canasta de colar grande en tres reales y quartillo en alexandre de la çerna

$\checkmark$ Yten una çesta de mymbre blanca en un real en el señor raçionero pernia

$\checkmark$ Yten un carrilo y un escarpia en sesenta maravedís en el señor raçionero ysla

$\checkmark$ dos harneros y un medio almud y un quartillo en quatro reales y medio en el señor dotor san miguel

$\checkmark$ Yten una caxa de madera en seis reales en juan bautista sochantre

$\checkmark$ Yten una palanca de hierro fornida y gruesa se remató en la fabrica en tres reales

$\checkmark$ Yten una caxa con un san sevastián de bulto en veynte y dos reales en el señor raçionero jacomar

$\checkmark$ Yten un retablico pequeño de la salutación de nuestra señora guarneçido en siete reales en el señor licenciado gasco

$\checkmark$ Yten otro retablo pequeño con nuestro señor con la cruz a cuestas e con su guarniçión en seis reales en el señor dotor san miguel

$\checkmark$ Yten un retablo grande con tres retablos dentro guarneçidos el uno de nuestra señora con el niño jesu en braços y el otro de la mujer adúltera y otro de quando la madalena derramó de ynguentos a los pies del señor en treynta y seis reales en el señor dotor mesa

$\checkmark$ Yten un cofre pequeño de flandes con su llave en seis reales en francisco de guido

$\checkmark$ Yten un crucifijo con su cruz y pie de évano en quatro reales y medio en el señor raçionero ysla

$\checkmark$ Yten un bonete de paño aforrado en escarlatín en tres reales en antonio ramos

$\checkmark$ Yten un brebiario de media cámara con sus registros de los nuevos en treynta reales en el señor raçionero pedro pablo

$\checkmark$ Yten un candelero de açofar con tres lumbres en siete reales y un quartillo en antonio ramos

$\checkmark$ Yten un libro yntitulado platino en real y medio en el señor dotor mesa

$\checkmark$ Yten un diurno romano de los nuevos con sus registros en çinco reales en señor dotor san miguel

$\checkmark$ Yten la ystoria ymperial de pero mexía en diez reales en el señor dotor hurtado

$\checkmark$ Yten un libro purificador de la conçiençia en dos reales e un quartillo en el señor dotor san miguel

$\checkmark$ Yten otro libro dionisio cartuxano en dos reales y medio en señor dotor hurtado digo tres reales 
$\checkmark \quad$ Yten otro libro el tratado de supersiçiones de martín harnes en tres reales en el señor dotor san miguel

$\checkmark$ Yten otro libro vocabulario eclesiástico en juan sanches portero del cabildo en tres reales

$\checkmark$ Yten otro libro de los ynventores del arte de marear en veynte maravedís en el señor dotor san miguel

$\checkmark$ Yten otro libro catasismo del consilio en quatro reales en el señor canónigo mohedano

$\checkmark$ Yten otro libro manual de confesores de nabarro en nueve reales en el señor raçionero pedro pablo

$\checkmark$ Yten otro libro dionisio cartuxano todos los salmos en siete reales en señor dotor mesa

$\checkmark$ Yten otro libro aviso de privados en dos en dos [sic] reales en el señor dotor san miguel

$\checkmark$ Yten otro libro de epístolas familiares de don antonio de guevara ques la primera parte y otro libro es la segunda parte en seis reales menos quartillo en el señor dotor san miguel

$\checkmark$ Yten otro libro de equio contra lutero en un real en el señor dotor san miguel

$\checkmark$ Yten otro libro titelman sobre salmos en dos reales y medio en el señor don ýñigo de villalobos

$\checkmark$ Yten otro libro menospreçio de corte y alabança de haldea en dos reales en francisco de guido

$\checkmark$ Yten otro libro de fero sobre dos salmos en un real en el señor dotor don pedro veles

$\checkmark$ Yten otro libro manual de la oraçión de navarro en tres reales y medio en el señor dotor san miguel

$\checkmark$ Yten otro libro guía de pecadores de frai luis de granada en tres reales y medio y un quartillo en el sochantre juan bautista

$\checkmark \quad$ En viernes veynte y dos días del mes de abril del dicho año de myl y quinientos y ochenta años el dicho pregonero remató los bienes siguientes

$\checkmark$ Primeramente un colchón de lana en el señor raçionero ysla en treynta reales

$\checkmark$ Yten otro colchón lleno de lana en pedro hernandes clérigo para el señor chantre en veynte y tres reales

$\checkmark$ Yten otro colchón lleno de lana en treynta y seis reales en el señor raçionero ysla

$\checkmark$ Yten otro colchón lleno de lana en veynte y ocho reales en pedro hernandes clérigo para el señor chantre

$\checkmark$ Yten una mesa con dos bancos de pie levadisos en honze reales en juan de herrera clérigo

$\checkmark$ Yten una sávana de lienço en honze reales en francisco de guido

$$
\text { [f. 736v] }
$$

$\checkmark$ Yen otra sávana bretona en diez reales en el señor raçionero ysla

$\checkmark$ Yten otra sávana en seis reales en juan sanches portero del cabildo

$\checkmark$ Yten una freçada en catorze reales y medio en el dicho uan sanches portero del cabildo

$\checkmark$ Yten una fraçadilla vieja y rota en real y medio en betolaca

$\checkmark$ Yten otra freçada vieja en tres reales en francisco de guido

$\checkmark$ Yten otra freçada en gonçalo gómez en ocho reales

$\checkmark$ Yten otra freçada vieja en real y medio en betolaca

$\checkmark$ Yten un cofre de hierro en el señor raçionero miedes en veinte ducados

$\checkmark$ Yten una freçada vieja e rota en siete reales en gonçalo gomes

$\checkmark$ Yten una sávana vieja e rota en quatro reales y medio en francisco de guido

$\checkmark$ Yten una mesa de cadena con su banco en nueve reales en martín gómez

$\checkmark$ Yten un misal romano de los nuevos pequeño con sus registros en veynte y çinco reales en el señor raçionero miedes

$\checkmark$ Yten dos libros de primera y segunda parte de pontifical en treynta y siete reales en juan de herrera clérigo

$\checkmark$ Yten un libro sermones de cartuxano en tres reales en el señor raçionero mosén roquen

$\checkmark$ Yten otro libro la ystoria eclesiástica en romanse en tres reales y medio en juan de herrera clérigo

$\checkmark$ Yten otro libro castro contra las eregías en seis reales en el señor raçionero bartolomé ruiz

$\checkmark$ Yten otro libro titelman sobre los salmos en seis reales y medio en el señor raçionero juan real

$\checkmark$ Yten otro libro orden de selebrar en un real en juan francisco

$\checkmark$ Yten otro libro guiguillermo parisiençis de sacramentis en un real en el señor raçionero mosén roque

$\checkmark$ Yten otro libro don alexo piamontés en un real en el señor raçionero mosén roque

$\checkmark$ Yten otro libro pandecta del evangelio en un real en el señor canónigo mohedano

$\checkmark$ Yten otro libro de bocabulario eclesiástico en dos reales en juan francisco

$\checkmark$ Yten otro libro de leyenda de los santos en un real en juan sanches 
$\checkmark$ Yten libro raçionale divinorun en seis reales en pedro hernandes clérigo para el señor chantre

$\checkmark$ Yten otro libro ynchiridion cristiano en quatro reales en el señor raçionero gasco

$\checkmark$ Yten otro libro suma de consilio suma de consilio [sic] en çinco reales en martín gómez

$\checkmark$ Yten otro libro calendario romano en dos reales en el señor raçionero mosén roque

$\checkmark$ Yten otro libro ofiçio de la semana santa en quatro reales en el señor don ýñigo de villalobos

$\checkmark$ Yten otro libro grabiel biel sobre el canon de la misa en dos reales en gonçalo de cabrera clérigo

$\checkmark$ Yten un peso con su marco entero de pesar oro metido todo en una caxa en nueve reales en el señor raçionero antonio marín

$\checkmark$ Yten una caxa de cuchillos de monte con un cuchillo grande y otro pequeño con su punsón en honze reales y medio en el señor don ýñigo

$\checkmark$ Yten un garniel de terçiopelo negro en quatro reales en el señor raçionero bartolomé ruiz

$\checkmark$ Yten tres tinajas para agua con sus cobertores y un a caldereta de cobre con una cadenica de hierro en veinte y çinco reales en pedro hernandes clérigo para el señor chantre

$\checkmark$ Yten una caxa de cuchillos con dos cuchillos y un tenedor en real y medio en juan francisco

$\checkmark$ Yten dos pañuelos de narizes labrados con seda blanca en seis reales en francisco de chaves

$\checkmark$ Yten unos guantes adobados en seis reales y medio en el señor dotor don pedro veles de guevara

$\checkmark$ Yten un señidor de colonia y çinco cordones de seda negros en dos reales en juan francisco

$\checkmark$ Yten un pañuelo de narizes largo labrado de seda azul en dos reales en el señor raçionero miedes

$\checkmark$ Yten una caxita de flandes pintada con dos rosarios negros pequeños y otro de cuentas gruesas leonadas en dos reales y medio en el señor raçionero miedes

$\checkmark$ Yten la hechura de una cruz de madera de la cama en un real en el señor raçionero bartolomé ruiz

$\checkmark$ Yten dos caxitas de madera de flandes coloradas y dos escofietas de lienço colchadas en un real en gaspar sanches pregonero

$\checkmark$ Yten dos medallas una de bronze y otra de madera con la figura del sumo pontífiçe pio quinto en dos reales en el señor raçionero bartolomé ruiz

$\checkmark$ Yten tres cañutillos de lacre en quarenta maravedís en alonso martín

$\checkmark \quad$ Yten la blibia [sic] en çinco cuerpos en diez y siete reales en señor dotor san miguel

$\checkmark$ Yten una caxa de cuchillos con dos cuchillos y otro cuchillo suelto en seis reales y medio en el señor dotor juan hurtado

$\checkmark$ Yten un compás de hierro y dos formones dos reloxitos y una pauta en dos reales y medio en el señor dotor hurtado

$\checkmark$ Yten dos pares de antojos de camino puestos en su cuero en tres reales en el señor canónigo mohedano

$\checkmark$ Yten una caxita de madera verde con su cobertor y dos rosarios de cuentas dentro en real y medio en francisco de guido

$\checkmark$ Yten dos caxas de antojos y otros quatro pares de antojos sueltos y otro antojo guarneçido de madera en quarenta maravedís en el señor raçionero pedro pablo

$\checkmark$ Yten un anillo y dos piedras de sangre en çinco reales reales [sic] y medio en el señor dotor juan hurtado

$\checkmark$ Yten unas cuentas de ánbar menudas en dos reales en gonçalo de cabrera clérigo

$\checkmark$ Yten una dozena de çintas de hiladillo en un real en el señor canónigo mohedano

$\checkmark$ Yten un escritorio de alto y vaxo en diez y seis ducados y un real en el señor raçionero miedes

$\checkmark$ Yten un sendal en medio real en gonçalo de cabrera clérigo

$\checkmark$ En sábado veinte y tres días del dicho mes de abril y del dicho año el dicho pregonero remató los bienes siguientes

$\checkmark \quad$ Primeramente tres pares de bancos de cama viejos y dos cañizos en quatro reales en francisco de chaves

$\checkmark$ Yten quatro lebrillos grandes en çinco reales en el dicho francisco de chaves

$\checkmark$ Yten una mesa para labar mediana en tres reales y medio en el dicho francisco de chaves

$\checkmark$ Yten otra mesa para labar grande y otra mediana en tres reales en el dicho francisco de chaves

$\checkmark$ Yten una vasinexa de tener cosas en diez y seis reales y medio en el dicho francisco de chaves

$\checkmark$ Yten una escalera pequeña en el señor raçionero pedro pablo en dos reales y medio

$\checkmark$ Yten una escalera mayor en el dicho francisco de chaves en quatro reales

$\checkmark$ Yten un pipote con sus bancos en alexander de laserna en çinco reales y un quartillo 
$\checkmark$ Yten otro pipote con sus bancos en doze reales y medie el señor dotor hurtado en treze reales

$\checkmark$ Yten un jarro grande bidriado de verde en el señor canónigo mohedano en tres reales y medio

$\checkmark$ Yten un madero en un real en el dicho francisco de chaves

$\checkmark$ Yten unas tijeras de platero en dos reales y un quartillo en en señor canónigo mohedano

$\checkmark$ Yten un pipote en dos reales en el dicho francisco de chaves

$\checkmark$ Yten tres tinajas pequeñas en tres reales en el dicho francisco de chaves

$\checkmark \quad$ Un pico de alvañil para la fábrica en un real

$\checkmark$ Yten unas tinajas y una charreta con azeitunas en çinco reales en el dicho francisco de chaves

$\checkmark$ Yten una puerta con un un herrojo y aldavilla en tres reales en el señor raçionero ysla

$\checkmark$ Yten una silla de descanso en treze reales y medio en pedro garçía clérigo

$\checkmark$ Yten dos bastidores en quatro reales en el dicho francisco de chaves

$\checkmark$ Yten una pala y un rodadillo de hierro y otra de palo en seis reales y medio para la fábrica

$\checkmark$ Yten una tabla para llevar pan al horno y una ratonera en dos reales en el dicho francisco de chaves

$\checkmark$ dos garavatos de hierro y dos poleas de madera en quatro reales en el dicho francisco de chaves

$\checkmark$ Yten un plato grande de barro en medio real en el dicho francisco de chaves

$\checkmark$ Yten un cuchillo grande de cortar carne en un real en el señor raçionero pedro pablo

$\checkmark$ Yten unas tenazas y una sierra pequeña en quatro reales en el señor raçionero Gerónimo Brizeño

$\checkmark$ Yten un martillo de hierro pequeño en real y medio en el dicho francisco de chaves

$\checkmark$ Yten unos grillos y una cadena larga de hierro y otra cadena pequeña en siete reales en el señor raçionero brizeño

$\checkmark$ Yten un hierro para cojer un antepuerta y unas tijeras de despavilar en el señor raçionero ysla en dos reales

$\checkmark$ Yten un esportón con una bota de cuero y un escardadero de hierro y dos cuchillos de cusina y dos espuelas y unos hierros de carrillo y dos serrojuelos de hierro y un aldava y una tabla para que no desiendan los ratones y un bastidorsillo de ventana en seis reales en el señor raçionero brizeño

$\checkmark$ Yten una cortina de tripa azul con su hierro y presillas en veinte reales y medio en el dicho francisco de chaves

$\checkmark$ Yten un cajón de madera con dos estribos y un argolla de hierro y dos platelillos de peltre viejos y otras menudençias y unas espuelas y una hoz en quatro reales y un quartillo en francisco de guido

$\checkmark$ Yten un candilito de oja de milán en real y medio en el señor raçionero brizeño

$\checkmark$ Yten una lanternilla de oja de milán en un real en fernán ramírez

$\checkmark$ Yten una canasta con dos guarniçiones de mula y quatro frenos y otras menudençias en quatro reales en francisco de guido

$\checkmark$ Una sesta de brinbe [sic] para pan y un tarro de varro blanco y una bolsa de cuero grande y una puerta de ventana y unas tablas delgadas en çinco reales y medio en el señor raçionero pedro pablo

$\checkmark$ Yten una tinajita y dos enbudos y tres limetas de bidrio y una tasa de bidrio y dos caños de varro verde en tres reales en el dicho francisco de chaves

$$
\text { [f. 738v] }
$$

$\checkmark$ Yten una hacha de çera amarilla y una candela de sera blanca pintada y labrada en quinze reales en el señor raçionero brizeño

$\checkmark$ Yten una alabarda en doze reales en el señor dotor hurtado

$\checkmark$ Yten un colchón lleno de lana en veinte y siete reales en el dicho francisco de chaves

$\checkmark$ Yten otro colchón lleno de lana en treynta y un reales en el dicho francisco de chaves

$\checkmark$ Yten dos almohadas medianas una labrada de grana y otra de azul en diez y ocho reales en el señor raçionero armijo

$\checkmark$ Yten una freçada en veinte reales en el señor raçionero ysla

$\checkmark$ Yten dos sávanas en veinte reales en el señor alonso álvarez de córdova

$\checkmark$ Yten un candado con su llave en diez reales y medio en el señor dotor hurtado

$\checkmark$ Yten una cama de paño colorada con un cobertor de lo mismo y su madera en treynta y tres ducados en el señor raçionero brizeño

$\checkmark$ Yten quatro candiles y un candelero de palo en seys reales en el dicho francisco de chaves 
$\checkmark$ Yten nueve esteras desparto en diez y nueve reales en el señor raçionero pedro pablo

$\checkmark$ Tres harneros uno de cuero y dos de esparto y dos bancos en seis reales y medio en el señor raçionero pedro pablo

$\checkmark$ Yten en antonio de arias se remataron dos tinajas con azeite Yten dos tinajas con azeite en el señor dotor juan hurtado las tinajas en quatro reales y el azeite en nueve reales la arroba que son que son onze arrobas y media de azeite

$\checkmark$ Yten un candado con su llave en el dicho francisco de chaves en nueve reales

$\checkmark$ Yten un misal de los romanos antiguos en dos reales en el señor raçionero armijo

$\checkmark$ Yten un brebiario sevillano en el señor raçionero pedro pablo en un real

$\checkmark \quad$ Yten otro brebiario de los antiguos en un real en señor dotor hurtado

$\checkmark$ Yten dos libros de las quatroçientas preguntas y respuestas del almirante en diez reales y medio en el señor dotor hurtado

$\checkmark$ Yten otro libro de los propberbios de don ýñigo de mendoca en tres reales menos un quartillo en el señor dotor hurtado

$\checkmark$ Yten otro libro de los secretos de piamonte en dos reales y medio en el señor dotor hurtado

$$
\text { [f. 739] }
$$

$\checkmark$ Yten otros libros que son el brebiario nuevo en siete reales en el señor raçionero pedro pablo

$\checkmark$ Yten un libro ystoria natural de la propiedad de las cosas en honze reales y medio en el señor dotor hurtado

$\checkmark$ Yten otro libro officio de la semana santa en un real en cristóval méndez

$\checkmark$ Yten otro libro brebiario romano de los viejos en treynta y ocho maravedís en el dicho francisco de chaves

$\checkmark$ Yten otro libro romansero en dos reales en el señor raçionero ysla

$\checkmark$ Yten otro libro calendario perpetuo del resado romano nuevo en diez reales y medio en el señor raçionero pedro pablo

$\checkmark$ Yten un diurnal romano de los viejos en medio real en juan francisco

$\checkmark$ Yten otro libro de yndulgençias de roma en un real en el señor dotor hurtado

$\checkmark$ Yten otro libro ychidion de los tiempos en dos reales y medio en cristóval méndez

$\checkmark$ Yten una escrivanía de metal con un cuchillo en dos reales y medio en el señor dotor hurtado

$\checkmark$ Yten otro libro armas de cargos de conçiençia en dos reales en cristóval méndez

$\checkmark$ Yten suma de cargos de conçiençia por un fraile franciscano en quatro reales y medio en el señor dotor hurtado

$\checkmark$ Suma de dotrina cristiana por frai domingo de soto en medio real en cristóval méndez

$\checkmark$ Yten otro libro remedio contra la pestilençia por el dotor siruelo en real y medio en el señor dotor hurtado

$\checkmark$ Yten otro libro valerio máximo en dos reales y un quartillo en bartolomé serafín sacristán del altar mayor

$\checkmark$ Otro libro ystoria de guerras subçedidas contra cristianos y ynfieles por pedro de salazar en ocho reales en el señor raçionero pedro pablo

$\checkmark$ Yten otro libro de trezientas preguntas de cosas naturales en dos reales en el dotor herrera

$\checkmark$ Yten otro libro de tratado de canbios de frai luis de alcalá en dos reales en el señor dotor hurtado

$\checkmark$ Ystoria de los turcos en siete reales en el señor dotor hurtado

$\checkmark$ Yten otro libro ystoria de las cosas de tiopa en quatro reales en el señor canónigo mohedano

$\checkmark$ Yten otro libro bocabulario de antonio de lebrija en nueve reales en fernán ramírez

$\checkmark$ Yten otro libro de agricultura de grabiel alonso en çinco reales en gonçalo de cabrera rematose en el señor dotor hurtado en seis reales

$$
\text { [f. 739v] }
$$

$\checkmark$ Yten otro libro primera segunda y terçera parte de la ystoria midiçinal del dotor monardes en dos reales en el señor liçençiado herrera

$\checkmark$ Yten otro libro de ynos y oraçiones con comento de antonio de lebrija en tres reales en el señor dotor hurtado

$\checkmark$ Yten otro libro catálogo de los libros proyvidos en el liçençiado herrera en veinte y quatro maravedís 
$\checkmark$ Yten otro libro hechos de emperador por fray tomás de espinosa en quatro reales en gerónimo de herrera

$\checkmark$ Yten otro libro tratado de como se ha de gastar los frutos eclesiásticos en un real en el liçençiado herrera

$\checkmark$ Yten otro libro de la vanidad del mundo de diego de san cristoval en dos reales y medio en el señor raçionero pedro pablo

$\checkmark$ Yten otro libro regimiento curatibo del dotor andrés de çamudio en seis maravedís en vetolaça

$\checkmark$ Yten otro libro de sermonario de patavino de sermones de cuaresma en un real en el señor dotor hurtado

$\checkmark$ Yten otro libro de varia lesión de pedro mexía en seis reales y medio en el licenciado herrera

$\checkmark$ Yten otro libro jardín de flores en dos reales y medio en cristóval méndez

$\checkmark$ Yten otro libro declaraçion de la tierra santa en dos reales y medio en el señor dotor hurtado

$\checkmark$ Yten otro libro sumo de filosofía natural de alonso de fuentes en tres reales en el señor raçionero bartolomé ruiz

$\checkmark$ Yten otro libro carlos de famoso por don luis çapata en quinze reales en el señor canónigo mohedano

$\checkmark$ Yten otro libro sensura general contra herrores en un real en el señor raçionero bartolomé ruiz

$\checkmark$ Yten otro libro de memorial de la byda cristiana por frai luis de granada en seis reales y medio en gonçalo de cabrera

$\checkmark$ Yten otro libro del sínodo de la diósesis de sevilla en un real en gonçalo de cabrera

$\checkmark$ Yten otro libro documentos por el ilustrísimo arçobispo de sevilla en el señor canónigo mohedano en real y medio

$\checkmark \quad$ Yten otro libro tratado de yndulgençias en fernán ramírez en medio real

$\checkmark$ Yten otro libro de los dose libros de la eneyda de virgilio en dos reales en el liçençiado herrera

$\checkmark$ Yten otro libro josefo de velo judaico en tres reales en el señor bartolomé ruiz raçionero

$\checkmark$ Un libro hordenaças en romanse en quatro reales en el liçençiado herrera

$$
\text { [f. 740] }
$$

$\checkmark$ Yten otro libro medina de penitençias en seis reales en el señor raçionero bartolomé ruiz

$\checkmark$ Yten dos libros uno de la conquista de nápoles y otro del discurso de la navegaçion de portugueses y otro de ysopo en tres reales menos un quartillo en el señor raçionero pedro pablo

$\checkmark$ Yten otro libro prosisionario de sevilla en seis reales y medio en el señor dotor hurtado

$\checkmark$ Yten otro libro floresta española por melchor de santa cruz en tres reales y medio en pedro de carrión

$\checkmark$ Yten un misal sevillano de los viejos en dos tres reales en el señor dotor hurtado

$\checkmark$ Yten un libro de la torre de david en un real en el señor dotor hurtado

$\checkmark$ Yten quatro diurnos romanos viejos real y medio en juan perez

$\checkmark \quad$ Yten un libro de la ystoria del pirú y un librito de memorias en el señor raçionero bartolomé ruiz en tres reales

$\checkmark$ En veynte y seis días del dicho mes de abrill y del dihco año el dicho pregonero remató los bienes siguientes

$\checkmark$ Primeramente tres sillas de cadera en juan de herrera para el señor chantre en veinte reales

$\checkmark$ Yten dos sillas de descanso en el jurado andrés de molina en veinte y siete reales

$\checkmark$ Yten una silla de caderas y dos medias sillas de cadera y una silla de madera de yndias en el señor raçionero diego vejarano en diez y seis reales

$\checkmark$ Yten tres escavellos y una sillita rasa pequeña en catorze reales en juan real

$\checkmark$ Yten una mesa de cadena con su banco en doze reales en pedro de carrión

$\checkmark$ Yten un paño de corte que tuvo veinte y quatro $₹$ anas a siete reales el ana en pedro de palaçios procurador que monta çiento y sesenta y ocho reales

$\checkmark$ Yten quatro paños de corte que tuvieron sesenta y seis anas

$\checkmark \quad$ En veinte y siete de abrill del dicho año el dicho pregonero remató los bienes siguientes

$$
\text { [f. } 740 v]
$$

$\checkmark$ Primeramente quatro paños de corte biejos que tienen setenta e seys anas a çinco reales el ana en juan barba 
$\checkmark$ Yten otros dos paños de corte biejos que tienen quarenta y ocho anas en el dicho juan barba a quatro reales e quartillo el ana

$\checkmark$ Yten un cofreçico de flandes amarillo en el señor antonio ramos en quatro reales

Es de todo esto en como paso yo el dicho [...] çivdad de sevilla los dichos días mes y año susodichos [...] alonso de valladares y juan de velasco [...] de sevilla y [...] raçionero san myguel seis mill en don ýñigo diez y nueve y 


\section{ANEXO XII \\ Recibo de Miguel de Abrego, Criado de Alonso Mudarra}

Sevilla, 9 de mayo de 1580

AHPSe, Oficio 19, de Gaspar de León Garabito, Libro 3º de 1580, Signatura 12459, f. 285.

[f. 285]

Sepan quantos esta carta vieren como yo miguel de abrego criado que fue del señor alonso mudarra canónigo que fue en la santa yglesia desta ciudad de Sevilla difunto que sea en gloria vecino que yo soy desta ciudad de Sevilla en la collación de san Martín otorgo e conozco que he rrecebido e rrecebí del señor antonio rramos clérigo presbítero vecino desta dicha ciudad de Sevilla en la collación de Santa cruz que está ausente ocho ducados y dos rreales los quales son que me da e paga como albaçea del dicho señor alonso mudarra y en virtud de un mandamiento del ilustre señor licenciado martín de acosta juez y vicario general deste arçobispado de Sevilla su thenor del qual es este que se sigue:

Yo el licenciado martín de acosta juez oficial y vicario general en esta ciudad de Sevilla y arçobispado de Sevilla mando en virtud de santa obediencia y so pena de descomunión mayor al señor antonio ramos clérigo presbítero y albacea del canónigo Alonso Mudarra difunto que dé y pague a miguel de abrigo criado que fue del dicho canónigo seis ducados que por su testamento le mandó y otros veinte y quatro rreales de dos meses de serviçio que le sirvió al dicho canónigo Mudarra e dentro de tres días primeros siguientes que vos doy y asino por tres canónicas muniçiones plazo y término parezcáis ante mí a dar razón por qué no lo debéis cumplir que yo os diré y haré justicia so la dicha pena de descomunión maior que promulgaré contra los amonestados y reveldes so la qual mando a qualquier clérigo escribano e notario bos lo notifique e dé fee dello fecha en Sevilla a veinte e ocho días del mes de abril de mil e quinientos y ochenta años el licenciado martín de acosta fernando de cervantes notario.

[f. 285]

Los quales dichos maravedíes recibí en dineros de contado de que me doy por contento a mi boluntad sobre que renuncio [...] Fecha la carta en Sevilla lunes nuebe días del mes de mayo de myll e quinientos e ochenta años $[\ldots]$ 


\section{ANEXO XIII}

\section{Reparto y Venta de Cebada de Alonso MudarRa}

Sevilla, 18 de mayo de 1580

AHPSe, Oficio 19, de Gaspar de León Garabito, Libro $3^{\circ}$ de 1580, Signatura 12459, f. 386.

\section{[f. 386]}

En la muy noble y muy leal ciudad de Sevilla miércoles diez y ocho días del mes de mayo de myll quinientos e ochenta años ante mí gaspar de león garavito escribano público de Sevilla e testigos yusoscriptos pareçió el señor hernando mohedano de saavedra canónigo en la santa yglesia desta ciudad de Sevilla al qual yo el dicho escribano público doy fee que que conozco e dixo que por quanto el señor Alonso mudarra canónigo que fue de la dicha santa yglesia difunto que dios aya mandó que todos los bienes que dél quedaren a la fábrica de la dicha santa yglesia y que demás de otros bienes que dél quedaron y quél ha hecho vender resçibió y cobró del señor Antonio Ramos clérigo presvítero albaçea que quedó del dicho señor señor canónigo quarenta y dos fanegas y media de trigo y veynte fanegas y honze almudes de çevada de las quales se daba y dio por carta de a su voluntad sobre que renunçió la excepción de los dos años e de la pecunia como en ella se contiene quel declarava y declaró que avía vendido e vendió el dicho trigo y çevada por mandado de los muy ilustres señores deán y cabildo de la dicha santa yglesia como administradores perpetuos de la dicha fábrica a las personas y prescios siguientes:

Primeramente seis fanegas de çevada en el señor deán don alonso de rrevenga a çinco reales y medio la fanega.

Yten seis fanegas de çevada al señor raçionero pedro mexía a çinco reales y medio la fanega.

Yten dos fanegas de çevada al señor raçionero gonçalo de solís a çinco reales y medio la fanega.

Yten dos fanegas de çevada

[f. 386v]

al señor raçionero gerónimo gómez a çinco reales y medio la fanega.

Yten dos fanegas de çevada al señor raçionero christóbal leandro de san miguel a çinco reales y medio la fanega.

Y las dos fanegas de çevada y honze almudes restantes al señor canónigo dotor Juan hurtado al dicho preçio.

Y las dichas quarenta y dos fanegas y media de trigo que vendió a honze reales la fanega a las hermanas y sobrinas del dicho señor canónigo alonso mudarra de las quales se dieron dos fanegas dellas al [...] dicho precio.

E que juraba e juró por las sacras hórdenes que resçibió puesta la mano en su pecho que lo susodicho es ansý la verdad y que no ay en ello fraude ni engaño alguno y lo pidió por testimonio y lo firmó de su nombre [...] 


\section{BIBLIOGRAFÍA}

\section{FUENTES Y EDICIONES MUSICALES}

ABOndante, Julio [Giulio]. Intabolatura di lautto libro secondo. Madrigale a cinque \& a quatro. Canzoni Franzese a cinque \&o a quator. Motetti a cinque \&o a quatro. Recercari di fantasia... Venecia, Hieronimo Scotto, 1548. (HMB 1548 1 )

Ediciones facsimilares:

- Ginebra, Minkoff Reprint, 1982.

BAENA, Gonzalo de. Arte novamente inventada pera aprender a tanger. Lisboa, German Galharde, 1540. [Único ejemplar en la Biblioteca del Palacio Real de Madrid, VIII-1816]

Ediciones modernas:

- $\quad$ FORST, Bruno (ed.). Madrid, Dairea, 2012.

BAL Y GAY, Jesús. Romances y villancicos del siglo XVI. Dispuestos en edición moderna para canto y piano. México, La Casa de España en México, 1939.

BArberiIs, Melchiore de. Opera intitolata Contina. Intabolatura di lauto di Fantasie, Motetti, Canzoni, discordate a varii modi, Fantasía per sonar uno solo con uno Lauto, \& farsi tenore \& soprano: Madrigali per sonar a dui Lauti: Fantasie per fonar a dui Lauti: Fantasie per sonar sopra la Chitarra da sette corde. Venecia, G Scotto, 1549. (HMB 15492)

Bermudo, Fray Juan. Comiença el libro primero de la declaración de instrumentos. Osuna, Juan de León, 1549.

- Reproducción digital en la Biblioteca Digital Hispánica de la BNE.

Bermudo, Fray Juan. Arte Tripharia. Osuna, Juan de León, 1550.

- Reproducción digital en la Biblioteca Digital Hispánica de la BNE.

Bermudo, Fray Juan. Declaración de instrumentos musicales. Osuna, Juan de León, 1555. (=Bermudo. Declaración)

Ediciones facsimilares:

- $\quad$ Kassel, Bärenreiter, 1957.

- Madrid, Arte Tripharia, 1982.

- Valladolid, Maxtor, 2009.

- Reproducción digital en la Biblioteca Digital Hispánica de la BNE.

CABEZÓn, Hernando de. Obras de música para tecla, arpa y vibuela, de Antonio de Cabecón, Músico de la cámara y capilla del rey Don Philippe nuestro Señor. Madrid, Francisco Sánchez, 1578. (=CABEZÓN. Obras)

Ediciones facsimilares:

- Puebla, Benemérita Universidad Autónoma de Puebla, Escuela de Artes, 2008.

- Reproducción digital en la Biblioteca Digital Hispánica de la BNE.

Ediciones modernas:

- Antonio de Cabezón. Obras de música para tecla, harpa y vihuela...recopiladas y puestas en cifra por Hernando de Cabezón su bijo (Madrid, 1578). Ed. Felipe Pedrell, revisada por Higinio Anglés. MME 27-29, 3 vols. Barcelona, CSIC, Instituto Español de Musicología, 1966. 
- Antonio de Cabezón (*1510c; +1566) Obras de música para tecla, arpa y vibuela. Nueva edición crítica completa. Javier Artigas Pina; Gustavo Delgado Parra; Antonio Ezquerro Esteban; Luis Antonio González Marín; José Luis González Uriol; José Vicente González Valle (eds.). 4 vols. Zaragoza, Institución «Fernando el Católico»), Sección de Música Antigua, Excma. Diputación Provincial, 2010.

- Ester Sala, Maria Asunción (ed.). Antonio de Cabezón, Glosados. Unión Musical Española, Madrid, 1980.

Cançoner de Barcelona. Biblioteca de Catalunya, M 454. Reproducción digital en Memòria Digital de Catalunya, <http://mdc.cbuc.cat/cdm/ref/collection/partiturBC/id/9385> [consulta 3-7-2015]

Cancionero de París. París, Bibliothèque École Nationale Supérieure des Beaux-Arts, MS Jean Masson 56

Ediciones modernas:

- Morais, Manuel (ed.): Vilancetes, cantigas e romances do século XVI. Transcripción de Manuel Morais. Portugaliae Musica; XLVII. Lisboa, Fundaçao Calouste Gulbenkian, 1986. (Parcial)

Cancionero musical de la Casa de Medinaceli (Siglo XVI) I. Polifonía profana. Transcripción y estudio por Miguel Querol Gavaldá. MME 8-9, 2 vols. Barcelona, CSIC, Instituto Español de Musicología, 1949.

Cancionero musical de Palacio. Biblioteca del Palacio Real de Madrid, nº 11/1335. (=CMP)

Ediciones modernas:

- Anglés, Higinio (ed.). La Música en la Corte de los Reyes Católicos. Polifonía profana. Cancionero Musical de Palacio (Siglos XV-XVI). MME 5 y 10, 2 vols. Barcelona, CSIC, Instituto Español de Musicología, 1947-1951.

Caroso, Fabritio. Il ballarino. Venecia, Francesco Ziletti, 1581.

Casteliono, G. Antonio. Intabolatura de leuto de diversi autori novamente stampata... Milán, Casteliono, 1536. (HMB 1536,

Ediciones facsimilares:

- $\quad$ Florencia, Studio Per Edizioni Scelte, 1979.

Correa de Arauxo, Francisco. Libro de Tientos y Discursos de Música práctica y Theórica de órgano, intitulado Facultad orgánica. Alcalá de Henares, Antonio Arnao, 1626.

Ediciones facsimilares:

- Ginebra, Minkoff Reprint, 1981.

Ediciones modernas:

- Francisco Correa de Arauxo: Libro de tientos y discursos de musica practica, y theorica de organo intitulado Facultad Orgánica (Alcalá, 1626). 2 vols. Transcripción y estudio por Santiago Kastner. MME 6 y 12, 2 vols. Barcelona, CSIC, Instituto Español de Musicología, 1948-1952.

- Bernal Ripoll, Miguel (ed.). Francisco Correa de Arauxo (1584-1654). Libro de Tientos y Discursos de Música práctica y Theórica de órgano, intitulado Facultad orgánica. 3 vols. $2^{\mathrm{a}}$ edición $\left(1^{\mathrm{a}}\right.$ edición, 2005). Madrid, SEdeM, 2013.

DALZA, Joan Ambrosio. Intabulatura de Lauto. Libro Quarto. Venecia, Petrucci, 1508.

Ediciones facsimilares:

- Ginebra, Minkoff Reprint, 1980.

DAZA, Esteban. Libro de Música en cifras para vihuela, intitulado el Parnasso. Valladolid, Diego Fernández de Córdova, 1576. (=DAZA. El Parnaso) 
Ediciones facsimilares:

- Ginebra, Minkoff Reprint, 1979.

- Arriaga, Gerardo; GonzÁlez, Carlos; Somoza, Javier (eds.). Libros de música para vibuela, 1536-1576. Madrid, Música Prima, Ópera Tres, 2003. CD-ROM.

- $\quad$ Valladolid, Maxtor, 2010.

- Reproducción digital en la Biblioteca Digital Hispánica de la BNE.

Ediciones facsimilares con transcripción moderna:

- Zayas, Rodrigo de (ed.). Los vihuelistas: Esteban Daşa. Colección Opera Omnia. Madrid, Alpuerto, 1983.

Ediciones modernas:

- Griffiths, John (ed.). Esteban Daza: The Fantasias for vibuela. Recent Researches in Music of the Renaissance, 54. Madison, A-R Editions, 1982. (Parcial)

FÉvIN, Antoine de:

- Liber quindecim missarum electarum quae per excellentissimos musicos compositae fuerunt. Roma, Andrea Antico, 1516 (RISM B/1 15161).

- Missa de Ave Maria

Fuenllana, Miguel de. Libro de música para vihuela intitulado Orphénica lyra. Sevilla, Martín de Montesdoca, 1554. (=FuENLLANA. Orphénica lyra)

Ediciones facsimilares:

- Ginebra, Minkoff Reprint, 1981.

- Arriaga, Gerardo; GonzÁlez, Carlos; Somoza, Javier (eds.). Libros de música para vibuela, 1536-1576. Madrid, Música Prima, Ópera Tres, 2003. CD-ROM.

- Reproducción digital de los 4 ejemplares de la BNE en la Biblioteca Digital Hispánica de la BNE.

Ediciones modernas:

- JACOBS, Charles (ed.). Fuenllana, Orphénica Lyra. Oxford, Oxford University Press, 1978.

Guerrero, Francisco. Sacrae Cantiones, vulgo moteta. Sevilla, Martín de Montesdoca, 1555.

Hofhaimer, Paul y Senfl, Ludwig. Poeticae Pauli Hofbeimeri, niri equestri dignitate insigni, ac Musici excellentis, quales sub ipsam mortem cecinit, qualesq[ue] ante hac nunquàm uisae..., Nuremberg, Johan Petreium, 1539.

JOSQUIN:

- Liber primus Missarum Josquin. Fossombrone, Ottaviano Petrucci, 1502 (RISM A/I J 666).

- Missa La. Sol. Fa. Re. Mi

- Missarum Josquin liber tertius. Fossombrone, Ottaviano Petrucci, 1514 (RISM A/I J 673).

- Missa Faisans regres

- Missa de beata virgine

- Liber quindecim missarum electarum quae per excellentissimos musicos compositae fuerunt. Roma, Andrea Antico, 1516 (RISM B/1 151612).

- Missa de Beata virgine

- Missa faisant Regretz.

- Missae tredecim quatuor vocum a praestantis: artificib: compositae. Nuremberg, Grapheus, 1539. (RISM B/1 15392).

- Missa Pangue lingua

- Trente sixiesme livre contenant XXX chansons tres musicales, à quatre, cinq \& six parties, en cinq livres, dont le cinquiesme livre contient les cinquiesmes \& sixiesmes parties. París, Pierre Attaingnant, 1549. (RISM A/1 J 681).

- Je ne me puis tenir d'aimer

Ediciones modernas: 
- $\quad$ SMijers, Albert (ed.). Werken van Josquin des Prez:

- Je ne me puis tenir d'aimer. Vol 8, Wereldlijke werken III. Leipzig, Kistner \& Siegel, 1925.

- Missa La sol fa re mi. Vol. 11, Missen II. Amsterdam, G. Alsbach \& Co., 1926.

- Missa Faisant Regretz. Vol 27, Missen XIII. Amsterdam, G. Alsbach \& Co., 1951.

- Blume, Friedrich (ed.).

- Josquin des Prés. Missa Pangue lingua. Das Chorwerk 1, Wolfenbüttel y Zurich, Möseler Verlag, 1929.

- Josquin des Prés. Missa de Beata virgine. Das Chorwerk 42, Wolfenbüttel, Möseler Verlag, 1936.

- $\quad$ ELDERS, Willem (ed.).

- New Josquin Edition.

MiLÁn, Luys. Libro de música de vihuela de mano intitulado «El maestro». Valencia, Francisco Díaz Romano, 1536. (=MiLÁN. El maestro)

Ediciones facsimilares:

- Ginebra, Minkoff Reprint, 1975.

- $\quad$ RoA, Francisco (ed.). Madrid, Sociedad de la Vihuela, 2008.

- Arriaga, Gerardo; GonzÁlez, Carlos; Somoza, Javier (eds.). Libros de música para vihuela, 1536-1576. Madrid, Música Prima, Ópera Tres, 2003. CD-ROM.

- Reproducción facsimilar del ejemplar de Leipzig, Städtische Bibliotheken, Musikbibliothek, signatura II.2.54, en doble soporte: papel, en blanco y negro, y en CD-ROM, en color. Introducción de Hopkinson Smith. [Lübeck], Tree Edition, 2007.

- Reproducción digital en la Biblioteca Digital Hispánica de la BNE.

Ediciones modernas:

- Schrade, Leo (ed.). Libro de Música de Vibuela de mano intitulado "El Maestro", compuesto por Luis Milán. Publikationen Älterer Musik, 2. Leipzig, 1927 (reimp. Hildesheim, Georg Olms, 1967).

- Chiesa, Ruggiero (ed.). Luys Milan. El Maestro, opere complete per vihuela. Milán, Edizioni SuviniZerboni, 1965 [para guitarra].

- Jacobs, Charles (ed.). Milán, Luis de. El Maestro. University Park y Londres, Pennsylvania State University Press, 1971.

MORLAYE, Guillaume.

- Le Premier livre de Chansons, Gaillardes, Pavannes, Bransles, Almandes, Fantaisies, reduictz en tabulature de Guiterne par Maistre Guillaume Morlaye ioueur de Lut. París, Robert GranJon \& Michel Fezandat, 1552. (HMB 15525).

- Le Second livre de Chansons, Gaillardes, Paduanes, Bransles, Almandes, Fantasies, reduictr en tabulature de Guiterne, par Maistre Guillaume Morlaye ioueur de Leut. París, Michel Fezandat, 1553. (HMB 15534).

- Quatriesme livre contenant plusieurs Fantasies, Chansons, Gaillardes, Paduanes, Bransles, reduictes en Tabulature de Guyterne \&o au ien de la Cistre, par Maistre Guillaume Morlaye \& autres bons autheurs. París, Michel Fezandat, 1552. (HMB 15526).

Ediciones facsimilares:

- Tyler, James (ed.). Simon Gorlier \& Guillaume Morlaye. Four Guitar Books (1551-1553). Complete facsimile edition with an introduction by James Tyler. Mónaco, Chanterelle, 1980.

MORPHY, Guillaume. Les Luthistes espagnoles du XVI siècle. Die spanischen Lautenmeister des 16 Jabrhunderts. Leipzig, Breitkopf \& Härtel, 1902, 2 vols.

Mudarra, Alonso. Tres libros de música en cifras para vibuela. Sevilla, Juan de León, 1546. (=MudARRA. Tres libros de música)

Ediciones facsimilares:

- Tyler, James (ed.). Complete facsimile edition with an introduction by James Tyler. Mónaco, Chanterelle, 1980. 
- $\quad$ Arriaga, Gerardo; González, Carlos; Somoza, Javier (eds.). Libros de música para vihuela, 15361576. Madrid, Música Prima, Ópera Tres, 2003. CD-ROM.

- Reproducción digital de BNE: R/14630 en la Biblioteca Digital Hispánica de la BNE.

Ediciones modernas:

- $\quad$ Pujol, Emilio (ed.). Alonso Mudarra. Tres libros de música en cifra para vihuela. (Sevilla 1546). MME 7, Barcelona, CSIC, Instituto Español de Musicología, 1949, reed. 1984. (=PUjOL. Mudarra)

- TArragó, Graciano (ed.). Tres libros de música en cifra para vihuela; Sevilla, 1546. Alonso de Mudarra. Transcripción para guitarra. Madrid, Unión Musical Española, 1972.

- Baldissera, Florindo y Fontana, Melita (eds.) Trascrizione in notazione moderna per Chitarra. Bolonia, Ut Orpheus, 2002.

NARvÁEZ, Luys de. Los seys libros del Delphín de música de cifra para tañer Vihuela. Valladolid, Diego Fernández de Córdova, 1538. (=NARVÁEZ. El delphín)

Ediciones facsimilares:

- Ginebra, Minkoff Reprint, 1980.

- Arriaga, Gerardo; GonzÁlez, Carlos; SomozA, Javier (eds.). Libros de música para vibuela, 1536-1576. Madrid, Música Prima, Ópera Tres, 2003. CD-ROM.

Ediciones facsimilares con transcripción moderna:

- Zayas, Rodrigo de (ed.). Los vihuelistas: Luys de Narváez. Colección Opera Omnia. Madrid, Alpuerto, 1981.

Ediciones modernas:

- Martínez Torner, Eduardo (ed.). Colección de vibuelistas españoles del siglo XVT. Narváez. El Delphin de Música. 1538. Madrid, Orfeo Tracio, 1923.

- $\quad$ Pujol, Emilio (ed). Luys de Narváez. Los seys libros del Delphin de música de cifra para tañer vihuela. Valladolid, 1538. MME 3, Barcelona, CSIC, Instituto Español de Musicología, 1945, reed. 1971.

PEDRELl, Felipe. Cancionero musical popular español. Valls, Eduardo Castells, 1917-1922, 4 vols.

PHALÈSE, Pierre.

- Carminum pro Testudine Liber IIII in quo continentur excellentissima carmina, dicta Paduana \& Galiarda, composita per Franciscum Mediolanensem \& Petrum Paulum Mediolanensem, ac alios artifices in hac arte praestantissimos. Lovaina, P. Phalèse y Jacobus Batius, 1546. (HMB 1546 20 )

- Hortus Musarum in quo tanquam flosculi quidam selectissimorum carminum collecti sunt ex optimis quibusque autoribus. Lovaina, P. Phalèse, 1552. (HMB 155211)

PISADOR, Diego. Libro de Música de Vibuela. Salamanca, 1552. (=PISADOR. Libro de música de vibuela)

Ediciones facsimilares:

- Ginebra, Minkoff Reprint, 1973.

- Madrid, Pygmalión, 2002.

- Arriaga, Gerardo; GonzÁlez, Carlos; Somoza, Javier (eds.). Libros de música para vihuela, 1536-1576. Madrid, Música Prima, Ópera Tres, 2003. CD-ROM.

- Reproducción digital en la Biblioteca Digital Hispánica de la BNE.

Ediciones facsimilares con transcripción moderna:

- RoA, Francisco y GÉRtrudix, Felipe (eds.). El libro de música de vihuela de Diego Pisador (1552). Madrid, Editorial Pygmalión, 2002. (Parcial)

Ramillete de flores.

- REY, Juan José (ed.). Ramillete de flores: colección inédita de piezas para vibuela (1593). Madrid, Alpuerto, 1982 ( $2^{\mathrm{a}}$ ed.)

SAlinAs, Francisco. De Musica libri Septem. Salamanca, Mathias Gastius, 1577. 
Ediciones facsimilares:

- Al cuidado de Amaya García Pérez y Bernardo García-Bernalt Alonso. Salamanca: Ediciones de la Universidad de Salamanca, 2013.

- Reproducción digital en la Biblioteca Digital Hispánica de la BNE.

Ediciones modernas:

- Fernández de la Cuesta, Ismael (ed.). Francisco Salinas. Siete libros sobre la música. Primera versión castellana por Ismael Fernández de la Cuesta. Madrid, Alpuerto, 1983.

Santa María, Fray Tomás de. Libro llamado Arte de tañer fantasía. Valladolid, Francisco Fernández de Córdova, 1565.

Ediciones facsimilares:

- Gregg International Publisher, 1972.

- Madrid, Arte Tripharia, 1982.

- Barcelona, CSIC-Milà i Fontanals, 2007.

- Valladolid, Maxtor, 2009.

- Reproducción digital en la Biblioteca Digital Hispánica de la BNE.

Tarazona, ms. 2. [Manuscrito de la catedral de Tarazona]

Ediciones modernas:

- Calahorra, Pedro (ed.). Autores hispanos de los siglos XV-XVI de los ms. 2 y 5 de la catedral de Tarazona. Polifonía aragonesa, IX. Zaragoza, Institución «Fernando el Católico», Sección de Música Antigua, Excma. Diputación Provincial, 1995.

- ESCOBAR, Pedro de. Clamabat autem mulier.

TORres, Melchior de. Arte ingeniosa de música, con nueva manera de avisos breves y compendiosos sobre toda la facultad della. Alcalá, Pedro de Robles y Juan de Villanueva, 1566. Copia digital de Zfm: An $75^{\text {a }}$ 13(2) en <http://zaguan.unizar.es/documents/fondos/AN_7_5_13B.djvu> [consulta 11-8-2015]

Valderrábano, Enríquez de. Libro de Música de Vibuela, intitulado Silva de Sirenas. Valladolid, Francisco Fernández de Córdova, 1547. (=VALDERRÁBANO. Silva de sirenas)

Ediciones facsimilares:

- Ginebra, Minkoff Reprint, 1981.

- Arriaga, Gerardo; GonzÁlez, Carlos; Somoza, Javier (eds.). Libros de música para vibuela, 1536-1576. Madrid, Música Prima, Ópera Tres, 2003. CD-ROM.

- Reproducción digital en la Biblioteca Digital Hispánica de la BNE.

Ediciones modernas:

- Pujol, Emilio (ed.). Enríquez de Valderrábano: Libro de Música de Vihuela, intitulado Silva de Sirenas, (Valladolid, 1547). MME 22-23, vol. I y II, Barcelona, CSIC, Instituto Español de Musicología, 1965. (Parcial)

VÁZQUEZ, Juan. Villancicos i canciones de Iuan Vasqueza a tres y a cuatro. Osuna, Juan de León, 1551.

Ediciones modernas:

- $\quad$ Russell, Eleanor (ed.). Juan Vásquez. Villancicos i canciones. Madison, A-R Editions, 1995.

VÁzQueZ, Juan. Agenda defunctorum. Sevilla, Martín de Montesdoca, 1556.

VÁZQUEZ, Juan. Recopilación de sonetos y villancicos a quatro y a cinco. Sevilla, Juan Gutiérrez, 1560.

Ediciones modernas:

- ANGLÉS, Higinio (ed.). Juan Vásquez «Recopilación de Sonetos y Villancicos a quatro y a cinco» (Sevilla, 1560). MME 4, Barcelona, CSIC, Instituto Español de Musicología, 1946. 
Venegas De Henestrosa, Luys. Libro de cifra nueva para tecla, harpa y vihuela. Alcalá de Henares, Joan de Brocar, 1557.

Ediciones facsimilares:

- Reproducción digital en la Biblioteca Digital Hispánica de la BNE.

Ediciones modernas:

- Anglés, Higinio (ed.). La Música en la Corte de Carlos V, con la transcripción del «Libro de cifra nueva, para tecla arpa y vibuela» de Luys Venegas de Henestrosa (Alcalá de Henares, 1557). MME 2, vol. II. Barcelona, CSIC, Instituto Español de Musicología, 1944, reed. 1984.

Willaert, Adrian de

- Primus liber cum quatuor vocibus. "Motteti del fiore". Lyon, Jacques Moderne, 1532. [RISM 153210]

- Liber secundus quatuor et viginti musicales quatuor vocum motetos. París, Pierre Attaingnant, 1534. [RISM 15344]

- Ave Maria a4

- Musicorum Sex vocum, que vulgo Motecta dicuntur...Liber primus. Venecia, Antonio Gardano, 1542. [RISM 1542a-W1112]

- Ave Maria a6

Ediciones modernas:

- Zenck, H.-Gerstemberg, W. (ed). Adriani Willaert. Opera Omnia. II: Motteta IV vocum, Liber secundus 1539 et 1545. CMM: Corpus Mensurabilis Musicae 3, Roma, American Institute of Musicology, 1950. 


\section{Fuentes TEXTUALES}

Alfonso X Las siete partidas del Rey Don Alfonso el Sabio: cotejadas con varios códices antiguos por la Real Academia de la Historia. Madrid, Real Academia de la Historia, 1807. Reproducción digital en www.cervantes.virtual.

Breviarium secundum consuetudinem sanctae ecclesiae Toletanae nuper et auctum et emendatum. Lyon, Barthélemy Freny, 1551 (=Breviarium Toletanae)

Cancionero general Agora nuevamente añadido. Otra vezympresso con adición de muchas y muy escogidas obras. Las quales quien más presto querrá ver vaya a la tabla: y todas aquellas que terná esta señal * son las nuevamente añadidas. Toledo, Ramón de Petras, 1527.

Cancionero sevillano de Toledo. Manuscrito 506 (fondo Borbón-Lorenzana) Biblioteca de Castilla-La Mancha. LABRADOR Herraiz, José L.; DiFranco, Ralph A.; MOnTERo, Juan (eds.). Sevilla, Universidad de Sevilla, 2006.

Constituciones de la iglesia de Sevilla. Biblioteca de la Universidad de Valladolid. Signatura Rms 73. Copia digital en <http://uvadoc.uva.es/handle/10324/231> [consulta 16-6-15]. (=Estatutos Valdés)

Boscán, Juan. Las obras de Boscán y algunas de Garcilasso de la vega repartidas en quatro libros. Barcelona, Carles Amoros, 1543

Covarrubias, Sebastián de. Tesoro de la lengua castellana o española. Madrid, 1611 (Reed. Madrid, Castalia, 1994).

Crónica de los Reyes de Castilla. 3 Tomos. Biblioteca de Autores Españoles, Tomos 68, 68 y 70. Madrid, M. Rivadeneyra, , 1875, 1877 y 1878.

ENCINA, Juan del. Obras completas. II. Poemas jocosos y cultos. Tragedia trovada a la dolorosa muerte del príncipe don Juan. Otros poemas a la muerte. Viaje a Jerusalén. RAmBALDO, Ana M. (ed.). Madrid, Espasa Calpe, 1978.

ENCINA, Juan del. Cancionero de las obras de Juan del Enzina. Salamanca, 1496. (ed. facsímil Madrid, Real Academia Española, 1989).

ESPINOSA, Juan de. Tractado de principios de música práctica y teórica sin dejar ninguna cosa atrás. Toledo, Guillem de Brocar, 1520. (ed. facsímil Viejos Libros de Música, 13, Madrid, Joyas Bibliográficas, 1978).

EsPinOSA, Juan de. Tratado Breve de principios de canto llano. c1520. (ed. facsímil Viejos Libros de Música, 10, Madrid, Joyas Bibliográficas, 1978).

Estatutos y Constituciones de la Santa Iglesia de Sevilla. [s. d.]. Fondo Antiguo de la Universidad de Sevilla, Signatura A Res. 74/2/05 Copia digital en <http://fondosdigitales.us.es/fondos/libros/ 1322/8/estatutos-y-constituciones-de-la-santa-iglesia-de-seuilla/> [consulta 16-6-15].

(=Estatutos Manrique)

FERnÁndeZ De Oviedo, Gonzalo. Libro de la Cámara Real del principe don Juan, oficios de su casa y servicio ordinario. FABregat Barrios, Santiago (ed.). Valencia, Publicacions de la Universitat de València, 2006.

Garcilaso de La vega. Poesias castellanas completas. Rivers, Elías L. (ed.). Madrid, Castalia, 2003, $3^{a}$ ed.

Hermosilla, Diego de. Diálogo de los pajes. Rodríguez Villa, A. (ed.). Madrid, Imprenta de la Revista Española, 1901. 
Jorge ManriQue. Obra completa. Cortina, Augusto (ed.). Madrid, Espasa Calpe, 1979.

Jorge De Montemayor. Segundo Cancionero espiritual. Amberes, 1558.

Lalaing, Antoine. «Voyage de Philippe le Beau en Espagne, en 1501», Collection des voyages des souverains des Pays-Bas. GACHARD, M. (ed.). Bruselas, Hayez, 1876, vol. I, pp. 121- 340.

López De MendozA, Íñigo. Memorial de cosas notables, compuesto por Don Ýñigo López de Mendoça, Duque quarto del Infantado. Guadalajara, el autor, 1564.

Marqués de Santillana. Poesías completas. Kerkhof, Maxim P A. M y Gómez Moreno, Ángel (eds.). Madrid, Castalia, 2003.

Marineo Sículo, Lucio. De las cosas memorables de España. Alcalá de Henares, Juan de Brocar, 1539.

Martínez de Bizcargui, Gonzalo. Arte de canto llano y contrapunto y canto de órgano con proporciones y modos. Burgos, Fadrique Alemán de Basilea, 1511. (ed. facsímil Viejos Libros de Música 8, Madrid, Joyas Bibliográficas, 1976).

Mata Carriazo, Juan de. Hechos del Condestable don Miguel Lucas de Iranzo (Crónica del siglo XV). Madrid, Espasa-Calpe, 1940 (Edición facsímil con estudio preliminar de Michel García, Granada, Universidad de Granada-Marcial Pons, 2009).

MÜNZER, Jerónimo. «Viaje por España y Portugal en los años 1494 y 1495», (Versión del latín por Julio Puyol). Boletín de la Real Academia de la Historia, 84 (1924), pp. 197-279.

NAvagero, Andrea. «Viaje por España del magnífico Micer Andres Navagero, Embajador de Venecia al Emperador Cárlos V», FABIÉ, Antonio Maria. Viajes por España de Jorge de Einghen, del Barón León de Rosmithal de Blatna, de Francisco Guicciardini y de Andrés Navajero. Madrid, Librería de los Bibliófilos, 1879, pp. 231-352.

NAVAgero, Andrea. «Cartas de Micer Andrés Navajero, gentil-hombre veneciano, á M. Juan Bautista Raumusio», FABIÉ, Antonio Maria. Viajes por España de Jorge de Einghen, del Barón León de Rosmithal de Blatna, de Francisco Guicciardini y de Andrés Navajero. Madrid, Librería de los Bibliófilos, 1879, pp. 353-413.

NúÑEZ DE CASTRO, Alonso. Historia eclesiástica y seglar de la muy noble ciudad de Guadalajara. Madrid, Pablo de Val, 1653.

Ovidio. Heroidas. MOYA CORTINES, Francisca (ed. bilingüe). Madrid, CSIC, 1986.

PedrazA, Cristóbal. «Relación de Honduras é Higueras por el obispo D. Cristobal Pedraza», Relaciones de Yucatán. Colección de Documentos Inéditos de Ultramar, Tomo 11, Madrid, Sucesores de Rivadeneyra, 1898.

Petrarca, Francesco. Cancionero. Cortines, Jacobo (ed. bilingüe). (Texto italiano establecido por

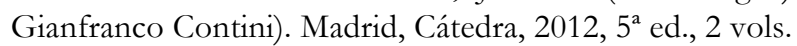

Pulgar, Hernando del. Los claros varones de España. Sevilla, Stanislao Polono, 1500 (ed. facsímil, Buenos Aires, Barcelona, Salvat, 1970).

Romeu Figueras, José (ed.). La Música en la Corte de los Reyes Católicos. Cancionero Musical de Palacio (Siglos XVXVI). Edición crítica de los textos. MME 14-2, Barcelona, CSIC, Instituto Español de Musicología, 1965. 
SAnNAZARo, Jacopo. Le rime di M. Giacobo Sannazaro Nobile Napolitano. Venecia, Nicolo d'Aristotile detto Zoppino, 1532.

SannaZArO, Iacopo. Opere Volgari. Mauro, Alfredo (ed.). Bari, Laterza, 1961.

Sannazaro, Jacopo. Arcadia. Tateo, Francesco (ed.) (Traducción de Julio Martínez Mesanza). Madrid, Cátedra, 1993.

VÉLEZ De Guevara, Luis. Si el caballo vos han muerto, y blasón de los Mendozas [c. 1625-30]. Edición crítica y anotada de William R. Manson y C. George Peale. Estudios introductorios de Javier J. González y Valerie L. Endres. Newark (Delaware), Juan de la Cuesta-Hispanic Monographs, 2007.

VIRGILIO. Eneida. (Introducción y traducción de Rafael Fontán Barreiro). Madrid, Alianza, 1990.

ZúÑIGA, Don Francés. Crónica burlesca del emperador Carlos V. (Edición, introducción y notas de José Antonio Sánchez Paso). Salamanca, Universidad de Salamanca, 1989. 


\section{EsTUdios}

Aguirre RinCón, Soterraña. «Torres, Alonso de (I)», DMEH, vol. 10, p. 398.

Alatorre, Antonio. «Fama española de un soneto de Sannazaro», Nueva Revista de Filología Hispánica, 36/2 (1988), pp. 955-973.

Alegre CARVAjal, Esther. «La configuración de la ciudad nobiliaria en el Renacimiento como proyecto ideológico de una élite de poder», Tiempos modernos: Revista Electrónica de Historia Moderna, 6/16 (2008), pp. 1-19.

Alegre Carvajal, Esther (ed.) Damas de la Casa de Mendoza. Historias, leyendas y olvidos. Madrid, Ediciones Polifemo, 2014.

Alonso Cortés, Narciso. Los cofrades de Santa María de Esgueva. Miscelánea Vallisoletana, $6^{a}$ serie. Valladolid, Librería Santarén, 194?

Alonso Yllana, Jesús. Contribución de la arqueología subacuática al conocimiento de la evolución de la guitarra. Tesis Doctoral, Universidad Complutense de Madrid, 2014.

Álvarez Álvarez, César y Cavero Domínguez, Gregoria. «La encomienda hospitalaria de Puente de Órbigo en La Edad Media (1184-1494)», Lógos hellenikós: homenaje al profesor Gaspar Morocho Gayo, J. María Nieto Ibáñez (coord.), vol. 2, 2003, pp. 749-762.

Álvarez, Rosario y Siemens, Lothar. La música en la sociedad canaria a través de la historia. I - Desde el periodo aborigen hasta 1600. [s. 1.], Proyecto RALS de Canarias, El Museo Canario y Cosimte, 2005.

ANDrÉs, Alfonso. «Don Pedro González de Mendoza el de Aljubarrota (1340-1385). Ensayo biográfico», Boletín de la Real Academia de la Historia, 78/3,4,5,6 (1921), pp. 255-273, 353-376, 415-436, 496504 y 79/1-2 (1921) pp. 29-42, 144-187.

ANDRÉs, Ramón. Diccionario de instrumentos musicales. De Pindaro a Bach. Barcelona, Bibliograf, 1995.

ANGLÉs, Higinio. La Música en la Corte de Carlos V, con la transcripción del «Libro de cifra nueva, para tecla arpa y vihuela» de Luys Venegas de Henestrosa (Alcalá de Henares, 1557). MME 2, 2 vols. Barcelona, CSIC, Instituto Español de Musicología, 1944, reed. 1984.

ANglés, Higinio y Romeu Figueras, José. La Música en la Corte de los Reyes Católicos. MME 1, 5, 10 y 14, 5 vols. Barcelona, CSIC, Instituto Español de Musicología, 1941-1965.

ANGLÉs, Higinio y SuBIRÁ, José. Catálogo Musical de la Biblioteca Nacional de Madrid. III Impresos: Música práctica. Barcelona, CSIC, Instituto Español de Musicología, 1951.

Antolínez de Burgos, Juan. Historia de Valladolid. Editada y anotada por Juan Ortega Rubio, Valladolid, Hijos de Rodríguez, 1887.

ArriagA, Gerardo. «La Guitarra de cuatro órdenes en el siglo XVI. Conveniencia de su inclusión en los programas actuales de los Conservatorios», Música y Educación, 1/2 (1988), pp. 369-406.

ARriagA, Gerardo. «La obra vocal de Luis Milán», Roseta, 1 (2008), pp. 6-43.

ArriagA, Gerardo. «La obra instrumental de Luis Milán», Roseta, 4 (2010), pp. 6-45.

Arteaga y Falguera, Cristina de. La casa del Infantado. Cabeza de los Mendoza. 2 vols. Madrid, El duque del Infantado, 1940. 
ASEnjo GonZÁLEZ, María. «Acerca de los linajes urbanos y su conflictividad en las ciudades castellanas a fines de la Edad Media», Clio \& Crimen, 6 (2009), pp. 52-84.

ATIEnZa HernándeZ, Ignacio. Aristocracia, poder y riqueza en la España Moderna: La casa de Osuna siglos XVXIX. Madrid, Siglo XX de España, 1987.

Atienza HernándeZ, Ignacio y Simón López, Mina. «Patronazgo real, rentas, patrimonio y nobleza en los siglos XVI y XVII: Algunas notas para un análisis político y socioeconómico», Revista internacional de sociología, 45/1 (Enero-Marzo 1987), pp. 25-75.

ATLAS, Allan W. La música del Renacimiento. La música en la Europa occidental, 1400-1600. (Traducción de Juan González-Castelao). Madrid, Akal, 2002. Ed. castellana de Renaissance Music. Music in Western Europe, 1400-1600. Nueva York, Norton \& Company, 1998.

Barrio GoZalo, Maximiliano. «El sistema beneficial en la España del siglo XVIII. Pervivencias y cambios», Cuadernos Dieciochistas, 2 (2001), pp. 73-107.

Barroso Castro, José y SÁnChez de Bustos, Joaquín. «Propuestas de transcripción para textos del XV y Siglos de Oro», Estado actual de los estudios sobre el Siglo de Oro: actas del II Congreso Internacional de Hispanistas del Siglo de Oro. García MARTín, Manuel (coord.), vol I, 1993, pp. 161-178.

BATAILlON, Marcel. Erasmo y España. Estudios sobre la historia espiritual del siglo XVI. (Traducción de Antonio Alatorre.). México, Buenos Aires, Fondo de Cultura Económica, 1966. Ed. castellana de Érasme et l'Espagne. Recherches sur l'bistoire spirituelle du XVIe siècle. París, Librairie Droz, 1937.

Bejarano PelliCER, Clara. «Juventud y formación de los ministriles de Sevilla entre los siglos XVI y XVII», Revista de Musicología, 36/1-2 (2013), pp. 57-91.

Bejarano Pellicer, Clara. El mercado de la música en la Sevilla del Siglo de Oro. Sevilla, Universidad de SevillaFundación Focus-Abengoa, 2013.

BELMONTE FERnÁNDEZ, Diego. «Borradores, originales, copias y recopilaciones: los Libros de Estatutos del cabildo catedralicio sevillano», Historia. Instituciones. Documentos, 41 (2014), pp. 45-74.

Bennassar, Bartolomé. Los españoles. Actitudes y mentalidad. (Traducción de Ignacio Gaos). Barcelona, Argos, 1978. Ed. castellana de L'Homme Espagnol, Attitudes et mentalités XVI'-XIX's, París, Hachette, 1975.

BENNASSAR, Bartolomé. «Los inventarios post-mortem y la historia de las mentalidades», La documentación notarial y la Historia: Actas del II Coloquio de Metodología Histórica Aplicada. Santiago de Compostela, 1984, vol. II, pp. 139-146.

BenNAsSAR, Bartolomé. Valladolid en el Siglo de Oro. Una ciudad de Castilla y su entorno agrario en el siglo XVI. (Traducción de Francisca Aramburu et alii). Valladolid, Ámbito, 1989. Ed. castellana de Valladolid au siècle d'or. Une ville de Castille et sa campagne au XVIe. siècle. París, La Haya Mouton, 1967.

Bergua Cavero, Jorge. La música de los clásicos. Versiones de la poesía antigua de la Edad Media al Renacimiento. Valencia, Pre-textos, 2012.

Berlanga FERnÁNDEZ, Miguel Ángel. «El bajo Guárdame las vacas y las músicas tradicionales en el sureste español», Revista de Musicología, 28/1 (2005), pp. 501-513.

BERmúdEZ, Egberto. «Sobre la identidad de Ludovico», Nassarre: Revista aragonesa de musicología, 10/1 (1994), pp. $9-16$. 
BERNIS, Carmen. Indumentaria española en tiempos de Carlos V. Madrid, Instituto Diego Velázquez (CSIC), 1962.

BLACKBURN, Bonnie J. «Josquin's Chansons: Ignored and Lost Sources», Journal of the American Musicological Society, 29/1 (Spring, 1976), pp. 30-76.

BlecuA, José Manuel. «Mudarra y la poesía del Renacimiento: una lección sencilla», Studia Hispanica in bonorem R. Lapesa, I. Madrid, Cátedra Seminario Menéndez Pidal - Gredos, 1972, pp. 173-179.

Bombi, Andrea; Carreras, Juan José; Marín, Miguel Ángel (eds.). Música y cultura urbana en la edad moderna.Valencia, Universitat de València, 2005.

Bonilla Almendros, Víctor. El monasterio de San Francisco en Guadalajara. Guadalajara, Ayuntamiento de Guadalajara, 1999.

BORDAS, Cristina. «The double harp in Spain from the 16th to the 18th centuries», Early Music, 15/2 (1987), pp. $148-163$.

Borren, Charles Van den. «Publications musicologiques espagnoles», Revue Belge de Musicologie/Belgisch Tijdschrift voor Muiiekwetenschap, 7/2-4 (1953), pp. 146-164.

BROwn, Howard Mayer. Instrumental music printed before 1600. A Bibliography. Cambridge Massachusetts, Harvard University Press, 1979.

BROWN, Kennneth y GARCíA-SAN ROMÁN, Gemma. «Un cuaderno de versos manuscritos en español de ca. 1550 en el Archivo Histórico de Protocolos de Barcelona», Studia Aurea, 8 (2014), pp. 477 608.

Cabeza Rodríguez, Antonio. Clérigos y señores. Política y Religión en Palencia en el Siglo de Oro. Palencia, Diputación Provincial, 1996.

CabeZA, Antonio. La vida en una catedral del Antiguo Régimen. Palencia, Junta de Castilla y León: Consejería de Educación y Cultura, 1997.

Calderón Ortega, José Manuel. El ducado de Alba. La evolución histórica, el Gobierno y la Hacienda de un Estado señorial (siglos XIV-XVI). Madrid, Dykinson, 2005.

Calderón Ortega, José Manuel. Felipe el Hermoso. Madrid, Espasa Calpe, 2001.

CaÑas GÁlveZ, Francisco de Paula. «La música en la corte de Juan II de Castilla (1406-1454). Nuevas fuentes para su estudio», Revista de Musicología, 23/2 (2000), pp. 367-394.

CARAnde, Ramón. Carlos V y sus banqueros. Barcelona, Crítica, 2000. Reedición de la edición abreviada de 1977.

CARRASCO, Adolfo. El poder de la sangre. Los duques del Infantado (1601-1841). Madrid, Actas, 2010.

CARRERAS, Juan José. «Música y ciudad: de la historia local a la historia cultural», Música y cultura urbana en la edad moderna. BOMBI, A.; CARreras, J. J. ; MArín, M. A. (eds.). Valencia, Universitat de València, 2005, pp. 17-51.

CAStañeda, Paulino. «El proceso inquisitorial», GIL, Juan (ed.) Los conversos y la Inquisición. Sevilla, Fundación El Monte, 2000, pp. 199-222. 
CASTRo SÁnCHEZ, Álvaro. Las noches oscuras de María de Cazalla. Mujer, herejía y gobierno en el siglo ХVI. Madrid, La Linterna Sorda, 2011.

CEA Galán, Andrés. La cifra hispana: música, tañedores e instrumentos (siglos XVI-XVIII). Tesis Doctoral, Universidad Complutense de Madrid, 2014.

CERro Bex, Victoriano del. «Itinerario seguido por Felipe el Hermoso en sus dos viajes a España», Chronica nova. Revista de historia moderna de la Universidad de Granada, 8 (1973), pp. 59-80.

Chailley, Jacques. L'imbroglio des modes. París, Alphonse Leduc, 1977.

ChilesotTi, Oscar. «Il Pater noster di Adriano Willaert», Sammelbände der Internationalen Musikgesellschaft, 3 (1902), pp. 468-472.

Clare, Lucien. «Le connétable, la musique et le pouvoir (d'après Los hechos del Condestable Miguel Lucas de Iranzo)», Bulletin Hispanique, 90/1-2 (1988), pp. 27-57.

Corona-AlCAlde, Antonio. «A vihuela manuscript in the archivo de Simancas», The Lute, 26/1 (1986), pp. 3-20. Traducción castellana de Juan Carlos Ayala en: «Un manuscrito de vihuela en el Archivo de Simancas», Hispanica Lyra, 1 (2005), pp 20-26, con reproducción facsímil. Incluye transcripción diplomática a cargo de Francisco Valdivia.

CORTÉS LÓPEZ, José Luis. La esclavitud negra en la España peninsular del siglo XVI. Salamanca, Universidad de Salamanca, 1989.

CORTÉS RUIZ, Mª Elena. Articulación jurisdiccional y estructura socioeconómica en la comarca de Molina de Aragón a lo largo de la baja edad media. Tesis Doctoral, Universidad Complutense de Madrid, 2000.

CrAig-MCFeELy, Julia. English Lute Manuscripts and Scribes, 1530-1630. An examination of the place of the lute in 16th-and 17th-century English Society through a study of the English Lute Manuscripts of the so-called "Golden Age", including a detailed catalogue of the sources. Oxford, 2000. Publicación electrónica en: <http://www.ramesescats.co.uk/thesis/> [consulta 28-10-14]

Dabrio GonzÁlez, María Teresa. «La capilla musical de don Cristóbal de Rojas en la Catedral de Córdoba», Laboratorio de Arte, 4 (1991), pp. 101-118.

Diago HernándeZ, Máximo.. «Las corporaciones de caballeros hidalgos en las ciudades castellanas a fines de la Edad Media. Su participación en el ejercicio del poder local», Anuario de Estudios Medievales, 36/2 (2006), pp. 803-838.

DíAz RodrígueZ, Antonio J. «El precio del nepotismo. Coadjutoría y resigna en las catedrales andaluzas (SS. XVI-XVIII)», Chronica nova. Revista de historia moderna de la Universidad de Granada, 35 (2009), pp. 287-309.

DMEH= Diccionario de la música española e hispanoamericana, 10 vols. Casares Rodicio, Emilio; López-Calo, José; Fernández de la Cuesta, Ismael (eds.). Madrid, Sociedad General de Autores y Editores (SGAE), 1999-2002.

Doctor De Toledo. Cronicón de Valladolid. 1539. Publicado en Colección de documentos inéditos para la historia de España. Madrid, Imprenta de la Viuda de Calero, 1842-1896, Tomo XIII, 1848.

Domínguez Casas, Rafael. Arte y etiqueta de los Reyes Católico. Artistas, residencias, jardines y bosques. Madrid, Alpuerto, 1993.

Domínguez OrTIZ, Antonio. «Un informe sobre el estado de la sede hispalense en 1581», Hispania Sacra, 6/1 (1953), pp. 181-195. 
Domínguez OrTiz, Antonio. La clase social de los conversos en Castilla en la Edad Moderna. Madrid, Instituto Balmes de Sociología, [1955?].

Domínguez Ortiz, Antonio. Orto y ocaso de Sevilla. Sevilla, Secretariado de Publicaciones de la Universidad de Sevilla, 1981, $3^{\text {a }}$ edición (1ª edición 1946).

Domínguez ORTIZ, Antonio. La esclavitud en Castilla en la Edad Moderna y otros estudios de marginados. Granada, Comares, 2003.

Domínguez Ortiz, Antonio. Las clases privilegiadas en el Antiguo Régimen. Madrid, Akal, 2012 (1ª edición 1973).

Dugot, Joël. «La vihuela del Musée Jacquemart-André», Aux origines de la guitare: La vihuela de mano. París, Cité de la musique, Musée de la musique, 2004, pp. 50-61.

DumanoIR, Virginie. «Melodía y texto. El caso de los romances viejos», Música y literatura en la España de la Edad Media y del Renacimiento. Madrid, Casa de Velázquez, 2003, pp. 107-116.

Elliot, John H. La España imperial 1469-1716. (Traducción de J. Marfany.). Barcelona, RBA, 2006. Ed. castellana de Imperial Spain 1469-1716. Londres, Edward Arnold Publisher, 1963.

EnRIQUe y CaGnOlO, Hugo Abel. Bibliografía de las obras para Canto y Vibuela del Siglo XVI. Madrid, H. A. Enrique, 1988.

Escudero y Perosso, Francisco. Tipografía hispalense. Anales bibliográficos de la ciudad de Sevilla desde el establecimiento de la imprenta hasta finales del siglo XVII. Madrid, Sucesores de Rivadeneyra, 1894.

EsTER-SAlA, María A. «El mecenazgo de la nobleza en la música del siglo XVI», Nassarre:: Revista aragonesa de musicología, 4/1-2 (1988), pp. 37-58.

FABIÉ, Antonio María. Viajes por España de Jorge de Einghen, del Baroón León de Rosmithal de Blatna, de Francisco Guicciardini y de Andrés Navajero. Madrid, Librería de los Bibliófilos, 1879.

FERNÁNDEZ-CORTÉs, Juan Pablo. La música en las Casas de Osuna y Benavente (1733-1882). Un estudio sobre el mecenazgo musical de la alta nobleza española. Madrid, SEdeM, 2007.

FERnÁndez de Córdova Miralles, Álvaro. La Corte de Isabel I. Ritos y ceremonias de una reina (1474-1504). Madrid, Dykinson, 2002.

FERNÁNDEZ MARTín, Luis. «Francisco Mudarra, difamador y protegido de San Ignacio 1538-1555», Archivum historicum Societatis Iesu, 62 (1993), pp. 161-173.

FERNÁNDEZ MARTín, Luis. «Don Alonso Enríquez, un abad valisoletano de la época imperial (1497-1577)», Hispania Sacra, 50/102 (1998), pp. 407-446.

FiorentinO, Giuseppe. «La pavana ternaria de Luis Milán», Roseta, 0 (2007), pp. 36-43.

Fiorentino, Giuseppe. Música española del Renacimiento entre tradición oral y transmisión escrita: el esquema de folia en procesos de composición e improvisación. Tesis Doctoral, Universidad de Granada, 2009.

Francisco Olmos, José María de. «La evolución de los cambios monetarios en el reinado de Isabel la Católica según las cuentas del tesorero Gonzalo de Baeza (1477-1504)», En la España Medieval, 21 (1998), pp. 115-142. 
Franco Silva, Alfonso. La esclavitud en Sevilla y su tierra a fines de la Edad Media. Sevilla, Diputación Provincial, 1979.

FrANCO SiLVA, Alfonso. «La herencia patrimonial del gran cardenal de España D. Pedro González de Mendoza», Historia. Instituciones. Documentos, 9 (1982), pp. 453-491.

Franco Silva, Alfonso. La esclavitud en Andalucía 1450-1550. Granada, Universidad de Granada, 1992.

FRANCO Silva, Alfonso. «La cámara del Cardenal Mendoza. Lujo, riqueza y poder de un príncipe de la iglesia hispana del siglo XV», Historia. Instituciones. Documentos, 39 (2012), pp. 65-127.

FREIS, Wolfgang. «Becoming a theorist: The growth of the Bermudo's Declaración de instrumentos musicales», Revista de Musicología, 18/1-2 (1995), pp. 27-112.

FrENK, Margit. «Sobre los textos poéticos en Juan Vásquez, Mudarra y Narváez», Estudios sobre la lirica antigua. Madrid, Castalia, 1978, pp. 175-203. Anteriormente publicado en Nueva Revista de Filología Hispánica, 6 (1952), pp. 35-56.

Frenk, Margit. «Glosas de tipo popular en la antigua lírica», Poesía popular bispánica. 44 estudios. México, Fondo de Cultura Económica, 2006, pp. 413-447. Anteriormente publicado en Nueva Revista de Filología Hispánica, 12 (1958), pp. 301-334.

FrenK, Margit. «Los romances-villancico», Poesía popular hispánica. 44 estudios. México, Fondo de Cultura Económica, 2006, pp. 621-631. Anteriormente publicado en ABIADA y BERNASOCCHI. De los romances-villancico a la poesía de Claudio Rodríguez. Madrid, José Esteban, 1984, pp. 141-156.

FrenK, Margit. «El cancionero oral en el Siglo de Oro», Poesía popular hispánica. 44 estudios. México, Fondo de Cultura Económica, 2006, pp. 159-175.

FrenK, Margit. Nuevo Corpus de la Antigua Lírica Popular Hispánica (siglos XV a XVII). 2 vols., México, D. F., Facultad de Filosofía y Letras UNAM, El Colegio de México, Fondo de Cultura Económica, 2003. (=FrENK. Nuevo Corpus)

FREUND SCHWARTZ, Roberta. En busca de liberalidad: music and musicians in the courts of the Spanish nobility, 14701640. Tesis Doctoral, University of Illinois at Urbana-Champaign, 2001.

GACHARD, E. (ed.) Collection des voyages des souverains des Pays-Bas. Bruselas, Hayez, 1876, vol. I.

García de PAZ, José Luis. «Las mujeres de los Mendoza», Los Mendoza y el mundo renacentista. Foro Castellano, ANABAD, Universidad de Castilla la Mancha, 2011, pp. 35-49.

García Garcimartín, Hugo. Articulación jurisdiccional y dinámica socioeconómica de un espacio natural: la cuenca del Alberche (siglos XII - XV). Tesis Doctoral, Universidad Complutense de Madrid, 2002.

GARCía HeRnÁN, David. La nobleza en la España moderna. Madrid, Ediciones Istmo, 1992.

García PÉreZ, Noelia. Mencía de Mendoza. (1508-1554). Madrid, Ediciones del Orto, 2004.

GÁsser, Luis. Luis Milán on Sixteenth-Century Performance Practice. Bloomington \& Indianapolis, Indiana University Press, 1996.

GuENTNER, Francis J. «Dulces exuviae in Sixteenth Century Music», The Classical Journal 68/1 (1972), pp. 6267.

Gerbert, Marie Claude. La nobleza en la Corona de Castilla. Sus estructuras sociales en Extremadura (1454-1516). Cáceres, Institución cultural «El Brocense», 1989. 
GIL, Juan. «Un español ante la Inquisición romana: Francisco Mudarra», Scripturus vitam. Festgabe für Walter Berschin zum 65. Geburtstag, Heidelberg, Mattes Verlag, 2002, pp. 617-625.

Giordano, María Laura. María de Cazalla (1487-?). Madrid, Ediciones del Orto, 1998.

Gómez Lorente, Manuel. El marquesado del Cenete (1490-1523). Tesis Doctoral, Universidad de Granada, 1990.

Gómez MunTANÉ, Maricarmen. «San Miguel de los Reyes y la capilla musical de don Fernando de Aragón, duque de Calabria (1488-1550)», San Miguel de los Reyes: De Biblioteca Real a Biblioteca Valenciana, Valencia, Generalitat, 2000, pp. 91-111.

GÓMEZ, Maricarmen (ed.). Historia de la música en España e Hispanoamérica. Vol. 2. De los Reyes Católicos a Felipe II. Madrid, Fondo de Cultura Económica, 2012.

GÓMEZ, Maricarmen. «El renacer del repertorio lírico español», GÓMEZ, Maricarmen (ed.). Historia de la música en España e Hispanoamérica. Vol. 2. De los Reyes Católicos a Felipe II. Madrid, Fondo de Cultura Económica, 2012, pp. 21-161.

GómeZ-Salvago SÁncheZ, Mónica. Fastos de una boda real en la Sevilla del Quinientos (Estudio y documentos). Sevilla, Universidad de Sevilla, 1998.

GONZÁLEZ, Carlos (ed.). Estudios sobre la vihuela. Madrid, Sociedad de la Vihuela, 2007.

GonzÁlez BARrionuevo, Herminio. Francisco Guerrero (1528-1599) Vida y obra. La música en la catedral de Sevilla a finales del siglo XVI. Sevilla, Cabildo Metropolitano de la Catedral de Sevilla, 2000.

GONZALEZ CRESPO, Esther. «Organización de la cancillería castellana en la primera mitad del siglo XIV», En la España Medieval. 8 (1986), pp. 447-470.

GonzÁlez Marrero, María del Cristo. La Casa de Isabel la Católica. Espacios domésticos y vida cotidiana. Ávila, Institución «Gran Duque de Alba» de la Diputación Provincial de Ávila, 2005.

GonzÁlez RAmos, Roberto. «Imágenes, libros y armas. Tipología y significado de los bienes de Diego Hurtado de Mendoza, conde de Saldaña y marqués del Cenete (1520-1560)», Anuario del Departamento de Historia y Teoría del Arte, 21 (2009), pp. 31-46.

GONZÁLEZ RAMOS, Roberto. «Evolución cultural y contraste generacional. Tres generaciones de la casa del Infantado y cuatro categorías de sus bienes (1531-1566)», Tiempos modernos: Revista Electrónica de Historia Moderna, 7/20 (2010), pp. 1-38.

Gonzalo SÁNChez-Molero, José Luis. La "Librería rica" de Felipe II. Estudio histórico y catalogación. San Lorenzo de El Escorial, Estudios Superiores del Escorial, 1998.

GonZALO SÁNCHEZ-MOLERO, José Luis. El aprendizaje cortesano de Felipe II (1527-1546). La formación de un principe del Renacimiento. Madrid, Sociedad Estatal para la Conmemoración de los Centenarios de Felipe II y Carlos V, 1999.

GrIER, James. The Critical Editing of Music. History, Method, and Practice. Cambridge, Cambridge University Press, 1996.

GrIFFITHS, John. The Vibuela Fantasia: A comparative study of forms and styles. Tesis doctoral, Monash University, 1983. 
GRIFFITHS, John. «La «Fantasía que contrahaze la Harpa» de Alonso Mudarra; estudio histórico analítico», Revista de Musicología, 9 (1986), pp. 29-40.

GRIFFITHS, John. «Mudarra, Alonso», DMEH, vol. 7, pp. 855-858.

GRIFFITHS, John. «Mudarra, Diego», DMEH, vol. 7, p. 858.

GRIFFITHS, John. «Pavana», DMEH, vol. 8, pp. 523-524.

GRIFFITHS, John. «Pavanilla», DMEH, vol. 8, p. 524.

Griffiths, John. Tañer vibuela según Juan Bermudo. Polifonía Vocal y Tablaturas Instrumentales. Zaragoza, Institución «Fernando el Católico» (CSIC), Sección de Música Antigua, Excma. Diputación Provincial, 2003.

GRIFFITHS, John. «Luis Milán, Alonso Mudarra y la canción acompañada», Edad de Oro, 22 (2003), pp. 7-28.

GRIFFITHS, John. «La vihuela en la época de Felipe II», SuÁREZ-PAJARES, Javier y GRIFFITHS, John (eds.). Políticas y prácticas musicales en el mundo de Felipe II. Madrid, ICCMU, 2004, pp. 415-448.

GRIFFITHS, John. «Los dos renacimientos de la vihuela», Goldberg, 33 (Abril 2005), pp. 35-43.

GRIFFITHS, John. «Spinacino's Twelve-tone Experiment», Journal of the Lute Society of America, 40 (2011), pp. 47-76.

GRIFFITHS, John. «Arquitectural en Rethoric in Music of the Age of Victoria», SUÁREZ-PAJARES, Javier y Sol, Manuel del (eds.). Tomás Luis de Victoria: Estudios, Studies., Madrid, ICCMU, 2013, pp. 231 245.

Gutiérrez Coronel, Diego. Historia genealógica de la casa de Mendoza donde se refieren su Origen Sucesión y Armas. [Manuscrito], [Diego Gutiérrez Coronel], [1777?]. Reproducción digital en <http://bvpb.mcu.es/es/consulta/registro.cmd?id=415764> [consulta 15-6-2014]

Hamilton, Alastair. El proceso de Rodrigo de Bivar (1539). Madrid, Fundación Universitaria Española, 1979.

Hamilton, Earl J. El tesoro americano y la revolución de los precios en España, 1501-1650. (Traducción de Ángel Abad). Barcelona, Crítica, 2000. Ed. castellana de American Treasure and the Price Revolution in Spain, 1501-1650. Nueva York, Octagon, 1934.

HAZAÑAS, Joaquín. Algunas consideraciones sobre la casa sevillana. Sevilla, Padilla Libros, 1989.

Heartz, Daniel. «Parisian Music Publishing under Henry II: A Propos of Four Recentry Discovered Guitar Books», The Musical Quarterly, 46/4 (1960), pp. 448-467.

HernándeZ Borreguero, José Julián. La Catedral de Sevilla. Economía y Esplendor. (Siglos XVI y XVII). Sevilla, Ayuntamiento de Sevilla-ICAS, 2010.

Hernández Franco, Juan. Cultura y limpieza de sangre en la España moderna: puritate sanguinis. Murcia, Universidad de Murcia, 1996.

Herradón FigueroA, María Antonia. «Cera y devoción. Los agnusdei en la colección del Museo Nacional de Antropología», Revista de Dialectología y Tradiciones Populares, 54/1 (1999), pp. 207-237.

Herrera CaSAdo, Antonio. El marqués de Santillana. Marco, ruta y significados vitales. Guadalajara, Ayuntamiento de Guadalajara, 1998. 
Herrera Casado, Antonio. El palacio del Infantado en Guadalajara. Guadalajara, Aache, 2001.

Herrera Casado, Antonio. «El Legado arquitectónico de Don Pedro González de Mendoza, Cardenal de España, en la tierra de Guadalajara», Los Mendoza y el mundo renacentista. Foro Castellano, ANABAD, Universidad de Castilla la Mancha, 2011, pp. 187-201.

Hidalgo OgÁyar, Juana. «Mencía de Mendoza, marquesa del Zenete, condesa de Nassau y duquesa de Calabria», Alegre Carvajal, Esther (ed.) Damas de la Casa de Mendoza. Historias, leyendas y olvidos. Madrid, Ediciones Polifemo, 2014, pp. 461-482.

Hudson, Richard. «The Folia, Fedele and Falsobordone», The Musical Quarterly, 58 (1972), pp. 398-411.

JACOBS, Charles. Tempo Notation in Renaissance Spain. Musicological Studies, 8. Brooklyn Nueva York, Institute of Medieaeval Music, 1964.

KIRKENDALE, Warren. «Ciceronians versus Aristotelians on the Ricercar as Exordium, from Bembo to Bach», Journal of the American Musicological Society, 32/1 (Spring 1979), pp. 1-44.

KNighton, Tess. «La música en la casa y capilla del Príncipe Felipe (1543-1556): modelos y contextos», Aspectos de la cultura musical en la Corte de Felipe II. Madrid, Alpuerto, Fundación Caja Madrid, 2000, pp. 35-97.

Knighton, Tess. Música y músicos en la corte de Fernando el Católico, 1474-1516. Zaragoza, Institución «Fernando el Católico» (C.S.I.C.), Sección de Música Antigua, Excma. Diputación Provincial, 2001. Versión española de Luis Gago.

Knighton, Tess. «Una confluencia de capillas. El caso de Toledo, 1502», La Capilla Real de los Austrias. Música y ritual de corte en la Europa moderna. Madrid, Fundación Carlos de Amberes, 2001, pp. 127-149.

Knighton, Tess. «Escobar, Pedro de [Pedro del Puerto, Pedro do Oporto]», DMEH, vol. 4, pp. 721-724.

KNighton, Tess. «Peñalosa, Francisco de», DMEH, vol. 8, pp. 586-589.

KREITNER, Kenneth. «The repertory of the Spanish cathedral bands», Early Music, 37/2 (2009), pp. 267-286.

Ladero QuesadA, Miguel Ángel. «Corona y ciudades en la Castilla del siglo XV», En la España Medieval, 8 (1986), pp. 551-574.

LAdero QuesadA, Miguel Ángel. «El modo de vida noble y su entorno social y cultural en Andalucía a fines de la Edad Media: Guzmanes y Ponces», II Congreso de Academias Iberoamericanas de la Historia. Factores de diferenciación e instancias integradoras en la experiencia del mundo iberoamericano. Madrid, Real Academia de la Historia, 1994, pp. 291-318.

LAdero QuesAdA, Miguel Ángel. «La Casa Real en la Baja Edad Media», Historia, instituciones, documentos, 25 (1998), pp. 327-350.

LAdero Quesada, Miguel Ángel. «La población de reinos y ciudades en la baja Edad Media española (De finales del siglo XIII a comienzos del XVI)», Boletín de la Real academia de la Historia, 211/1 (Enero-Abril 2014), pp. 37-78.

LAMPÉREZ Y RomeA, Vicente. Los Mendoza del siglo XV y el castillo del Real de Manzanares. Madrid, Real Academia de la Historia, 1916.

LAWRENCE, Deborah. «Mudarra's Instrumental Glosas: Imitation and Homage in a Spanish Style», Encomium Musicae. Essays in Honor of Robert J. Snow. David Crawford, G. Grayson Wagstaff (eds.), Festschrift Series no 17, Hillsdale, Nueva York, Pendragon Press, 2002, pp. 305-319. 
LAWrenCE, Deborah. «Spain's “Conde Claros”: From Popular Song to Harmonic Formula», Journal of Musicological Research, 30 (2011), pp. 46-65.

LAYNA SERranO, Francisco. Historia de Guadalajara y sus Mendozas en los siglos XV y XVI. Guadalajara, Aache, 1993, 4 vols. (reedición de Madrid, Aldus, 1942).

LAYNa SERrano, Francisco. El Palacio del Infantado en Guadalajara. Guadalajara, Aache, 1997. (reedición de Madrid, 1941).

LEÓN DE LA VEGA, Manuel de. Los protestantes y la espiritualidad evangélica en la España del siglo XVI. 2 vols., El autor, 2011.

Lleó Canal, Vicente. Nueva Roma. Mitología y bumanismo en el Renacimiento sevillano. Madrid, Centro de Estudios Europa Hispánica, 2012.

LOP OTÍN, María José. El cabildo catedralicio de Toledo en el siglo XV: aspectos institucionales y sociológicos. Tesis Doctoral, Universidad Complutense de Madrid, 2002.

LÓPEZ CALO, José. La música en la Catedral de Granada en el siglo XVI. Granada, Fundación Rodríguez-Acosta, 1963, 2 vols.

LóPEZ-CALO, José. «Peraza [Pedraza]», DMEH, vol. 8, pp. 603-605.

LóPez De Meneses, Amada. «Una Prima gitana de Miguel de Cervantes», Estudis Romànics, 14 (1969), pp. 247-250.

López DíEz, María. «Juan Guas en la catedral de Segovia», Archivo Español de Arte, 315 (Julio-Septiembre 2006), pp. 299-306.

Llamazares RodrígueZ, Fernando. «Mecenazgo artístico del Cardenal Mendoza en Toledo», Los Mendoza y el mundo renacentista. Foro Castellano, ANABAD, Universidad de Castilla la Mancha, 2011, pp. 133-159.

Llorens Cisteró, José María. Francisco Guerrero. Opera Omnia. Tomo X. Magnificats per Omnes Tonos. MME 56. Barcelona, CSIC, Instituto Español de Musicología, 1999.

MALDONADO FERnÁndeZ, Manuel. «Don Luis Zapata, consejero real, letrado de las Cortes y fundador del mayorazgo y señorío de Çehel de las Alpujarras», Actas de la II Jornada de Historia de Llerena. Llerena, Junta de Extremadura, Consejería de Educación, Ciencia y Tecnología, Dirección General de Ordenación, Renovación y Centros, 2001, pp. 95-116.

Maldonado FernándeZ, Manuel. «Don Luis Zapata de Chaves, III Señor del Estado de Çehel de las Alpujarras y de las Villas de Jubrecelada (Llerena), Ulela y Ulula», Revista de Estudios Extremeños, 58/3 (2002), pp. 991-1029.

Mañueco Villalobos, Manuel y Zurita Nieto José. Documentos de la Iglesia Colegial de Santa María la Mayor (hoy Metropolitana) de Valladolid. Siglo XIII. Valladolid, Imprenta Castellana, 1920.

Marías Franco, Fernando. «Los Mendoza y la introducción del Renacimiento en España», Nobleza, coleccionismo y mecenazgo. Sevilla, Real Maestranza de Caballería, 1998, pp. 29-44.

MÁrQueZ, Antonio. Los alumbrados. Origenes y filosofía (1525-1559). Madrid, Taurus, 1980 (2a ed. corregida y aumentada). 
MÁrquez Villanueva, Francisco. «Conversos y cargos concejiles en el siglo XV», Revista de Archivos, Bibliotecas y Museos, 63/2 (1957), pp. 503-540.

MARTín ABAD, Julián. La imprenta en Alcalá de Henares (1502-1600). Madrid, Arco Libros, 1991, 3 vols.

MARTín GaLÁn, Jesús. «Espinosa, Juan de«. DMEH, vol. 4, pp. 781-782.

Martín Moreno, Antonio. Historia de la música andaluza. Sevilla, Editoriales Andaluzas Unidas, 1985.

Martínez Millán, José (dir.). La Corte de Carlos V. 5 vols. Madrid, Sociedad Estatal para la Conmemoración de los Centenarios de Felipe II y Carlos V, 2000.

MARTínez Millán, José y EzQUerra Revilla, Ignacio Javier. «La integración de las élites sociales en las monarquías dinásticas: los continos», Espacios de poder: cortes, ciudades y villas (S. XVI-XVIII), 1 (2002), pp. 339-380.

MARTínez Millán, José y Fernández Conti, Santiago (coords.). La monarquía de Felipe II: la Casa del Rey. 2 vols. Madrid, Fundación Mapfre Tavera, 2005.

Martínez Ruiz, Enrique (dir.). Diccionario de Historia Moderna de España. I. La Iglesia. Madrid, Istmo, 1998.

Mazuela-Anguita, Ascensión. «Mujeres músicas y documentos de la Inquisición en el mundo ibérico del siglo XVI: Isabel de Plazaola y la IV Duquesa del Infantado», Revista de Musicología, 36/1-2 (2013), pp. 15-55.

Medianero Hernández, José María. Nuesta Señora de la Antigua. La Virgen «decana» de Sevilla. Sevilla, Diputación de Sevilla, 2008.

MEDINA, Ángel. Los atributos del capón. Imagen histórica de los cantores castrados en España. Madrid, ICCMU, 2011 ( $3^{\circ}$ ed. aumentada).

MenÉndez Pidal, Ramón. Poesía juglaresca y orígenes de las literaturas románicas. Madrid, Instituto de Estudios Políticos, 1957, $6^{a}$ ed.

Mold, Jaime. «Músicos en la Corte del Cardenal Juan Tavera (1523-1545): Luis Venegas de Henestrosa», Anuario Musical, 6 (1951), pp. 155-178.

Moll, Jaime. «Documentos para la historia de la música de la catedral de Toledo», Anuario musical, 13 (1958), pp. 159-166.

MolL, Jaime. «Notas para la historia musical de la corte del Duque de Calabria», Anuario Musical, 18 (1963), pp. 123-135.

MOLL, Jaime. «Gaspar Zapata, impresor sevillano condenado por la Inquisición en 1562», Pliegos de Bibliofilia, 7 (1999), pp. 5-10.

Montaner Frutos, Alberto. Prontuario de bibliografía. Pautas para la realización de descripciones, citas y repertorios. Gijón, Ediciones Trea, 1999.

Morales Padrón, Francisco. Historia de Sevilla. La ciudad del Quinientos. Sevilla, Universidad de Sevilla, 1989.

Mотте, Diether de la. Contrapunto. (Traducción de Miguel Ángel Centenero Gallego). Madrid, Labor, 1991. Ed. castellana de Kontrapunkt. Kassel-Bassel-London-New York, Bärenreiter-Verlag, 1981.

MOXÓ, Salvador de. «De la nobleza vieja a la nobleza nueva. La transformación nobiliaria castellana en la Baja Edad Media» Feudalismo, señorío y nobleza en la Castilla medieval. Madrid, Real Academia de 
la Historia, 2000, pp. 311-370. Reproducción parcial del publicado en Cuadernos de Historia. Anexos de la revista Hispania, 3 (1969), pp. 1-210.

MuÑoz, Ferrán. Mencía de Mendoza y la Viuda de Mateo Flecha. Valencia, Institució Alfons el Magnànim, Diputació de València, 2001.

NAder, Helen. Los Mendoza y el Renacimiento español. (Traducción de Jesús Valiente Malla). Guadalajara, Institución Provincial de Cultura «Marqués de Santillana», 1986. Ed. castellana de The Mendoza Family in the Spanish Renaissance. New Brunswids, New Jersey, Rutgers University Press, 1979.

Navarro Sainz, José María. «Aproximación a los gastos señoriales de la Casa de los duques de Medina Sidonia a principios del siglo XVI», Huelva en su Historia, 3 (1990), pp. 175-194.

NiETO Soria, José Manuel y SANZ SANCHO, Iluminado. Historia de España. La época medieval: Iglesia y cultura. Madrid, Istmo, 2011.

NOONE, Michael. «Los ministriles en la catedral de Toledo en la segunda mitad del siglo XVI», Los instrumentos musicales en el siglo XVI. Ávila, Fundación cultural Sta. Teresa, 1993, pp. 125-133.

OHLSEN V., Oscar. Aspectos Técnicos Esenciales en la Ejecución del Laúd. Madrid. Ópera tres, 1992.

Ollero PINA, José Antonio. «Clérigos, universitarios y herejes. La Universidad de Sevilla y la formación académica del cabildo eclesiástico», Universidades hispánicas. Modelos territoriales en la Edad Moderna (I). Coord. por Luis Enrique Rodríguez San Pedro Bezares, Juan Luis Polo Rodríguez, vol. 2, 2007 (Valencia, Valladolid, Oñate, Oviedo y Granada), pp. 107-196.

OTAOlA, Paloma. «Los romances para vihuela del siglo XVI», Actas del XIV Congreso de ll Asociación International de Hispanistas. LeRNer, Isaías, Nival, Robert y AlOnSO, Alejandro (eds.). Newark (Delaware), Juan de la Cuesta, 2004, vol. II, pp. 435-446.

OtAola, Paloma. «Aspectos iconográficos en los libros de música para vihuela», Hispanica Lyra, 4 (2006), pp 12-19.

PECHA, Hernando. Historia de las vidas de los Ex[celentísi]mos Señores Duques del Ynfantado y su progenitores desde el Infante Donzuria primer Señor de Vizcaya hasta la Excelentísima señora Duquesa Doña Ana y su Hija Doña Luysa Condesa de Saldaña. 1635. Manuscrito, Biblioteca Provincial de Guadalajara, Ms 57.

PECHA, Hernando. Historia de Guadalaxara y cómo la Religión de San Gerónimo en España fué fundada y restaurada por sus ciudadanos, (BN. Mss. 1756). Edición Guadalajara, Diputación Provincial, 1977.

Perales de la Cal, Ramón. Papeles Barbieri. Madrid, Alpuerto, 1985.

Perea Rodríguez. Óscar. «Mencía de Mendoza, condesa de Haro», Alegre Carvajal, Esther (ed.) Damas de la Casa de Mendoza. Historias, leyendas y olvidos. Madrid, Ediciones Polifemo, 2014, pp. 97-132.

PÉREZ, Joseph. Los Comuneros. Madrid, Historia 16, 1997.

PÉreZ GuTiÉRreZ, Mariano. «Chacón, F.», DMEH, vol. 3, p. 523.

PÉREZ PASTOR, Cristóbal. «Escrituras de concierto para imprimir libros», Revista de Archivos, Bibliotecas y Museos, 26 (1897), pp. 363-371. 
PIKE, Ruth. Aristócratas y comerciantes. La sociedad sevillana en el siglo XVI. (Traducción de Barbara MacShane y Javier Alfaya). Barcelona, Ariel, 1978. Ed. castellana de Aristocrats and traders. Sevillian society in the sixteenth century. Ithaca y Londres, Cornell University Press, 1972.

Pino Rebolledo, Fernando. El primer libro de actas del ayuntamiento de Valladolid. Valladolid, Archivo Municipal de Valladolid, 1990.

Ponce CÁRdenAs, Jesús. «El epitafio hispánico en el Renacimiento: textos y contextos», La mort des grands; arts, textes et rites (XIe-XVIIIe siècle). e-Spania, 17 (2014). Revista electrónica en <http://espania.revues.org $>$ [consulta 10-6-2015]

Pope, Isabel. «Notas sobre la melodía del Conde Claros», Nueva Revista de Filología Hispánica, 7 (1953), pp. 395402.

Pope, Isabel. «La vihuela y su música en el ambiente humanístico», Nueva Revista de Filología Hispánica, 12 (1961), pp. 364-376.

Preciado, Dionisio. «Las esclavas del canónigo vihuelista Alonso Mudarra (†1580)», Revista de Musicología, 2 (1979), pp. 132-135.

Quintanilla Raso, María Concepción. «Haciendas señoriales nobiliarias en el Reino de Castilla a finales de la Edad Media», Historia de la Hacienda española (épocas antigua y medieval). Homenaje al Profesor García de Valdeavellano. Instituto de Estudios Fiscales, 1982, pp. 767-798.

RÁbade Obradó, María del Pilar. «Cristianos nuevos», El mundo social de Isabel la Católica. Madrid, Miguel Ángel Ladero Quesada (coord.) Dykinson, 2004, pp. 275-292.

RAmíreZ RUIZ, Victoria. Las tapicerías en las colecciones de la nobleza española del siglo XVII. Tesis Doctoral, Universidad Complutense de Madrid, 2013.

REY, Juan José. Danzas cantadas en el Renacimiento español. SEdeM, 1978.

Rey, Pepe. Músicas para Felipe II. Programa de mano del Ciclo celebrado en el Auditorio Municipal de Logroño, Febrero 1998.

REY, Pepe. «Guillermo Morphy: el redescubrimiento de la vihuela en el siglo XIX. I. París, 1868-1870», Roseta, 3 (2009), pp. 26-45.

REY, Pepe. «Guillermo Morphy: el redescubrimiento de la vihuela en el siglo XIX. I. Madrid, 1875-1899», Roseta, 4 (2010), pp. 46-61.

REYNAud, François. La polyphonie tolédane et son milieu. Des premiers témoignages aux environs de 1600. París y Turnhout, CNRS y Brepols, 1996.

REYNAUD, François. «Música y músicos toledanos: grupos e individuos fuera de la catedral», Políticas y prácticas musicales en el mundo de Felipe II. Madrid, ICCMU, 2004, pp. 241-252.

RIVERS, Elías L. Boscán y Garcilaso: su amistad y el Renacimiento en España. Sevilla, Sibilina-Fundación BBVA, 2010.

RoA Alonso, Francisco Javier. «Tecla, arpa y vihuela: aspectos de la cultura material en la época de Cabezón», Revista de Musicología, 34/2 (2011), pp. 109-132.

Robledo Estaire, Luis. «La música en la corte madrileña de los Austrias. Antecedentes: las casas reales hasta 1556», Revista de Musicología, 10/3 (1987), pp. 753-796. 
Robledo Estaire, Luis. «La música en el pensamiento humanista español», Revista de Musicología, 21/2, (1998), pp. 385-429.

Robledo Estaire, Luis et alii. Aspectos de la cultura musical en la Corte de Felipe II. Madrid, Alpuerto, 2000.

Robledo Estaire, Luis. «La música en la Casa del Rey», Aspectos de la cultura musical en la Corte de Felipe II. Madrid, Alpuerto, Fundación Caja Madrid, 2000, pp. 99-193.

Robledo EstAire, Luis. «La música en la Casa de la Reina, Príncipe e Infantas», Aspectos de la cultura musical en la Corte de Felipe II. Madrid, Alpuerto, Fundación Caja Madrid, 2000, pp. 195-212.

Rodríguez Bernis, Sofía. Diccionario de mobiliario. Madrid, Ministerio de Cultura, 2006. Publicación electrónica en: <http://www.mcu.es/museos/MC/Tesauros/Mobiliario/Capitulos.html> [consulta 16-8-2015]

RODRíguez CACHÓN, Irene. El «Libro de cetrería» (1583) de Luis de Zapata: estudio y edición crítica. Tesis Doctoral, Universidad de Valladolid, 2013.

Rodríguez Posilio, Montserrat. «Brianda de Mendoza y Luna», Alegre CARvajal, Esther (ed.) Damas de la Casa de Mendoza. Historias, leyendas y olvidos. Madrid, Ediciones Polifemo, 2014, pp. 219-241.

Rodríguez Rebollo, Ángel. «El Palacio de don Antonio de Mendoza en Guadalajara. Aspectos decorativos y formales», Archivo Español de Arte. 75/299 (2002), pp. 269-281.

Rodríguez VÁzQueZ, Antonio L. Ricos y pobres. Propiedad y vida privada en la Sevilla del siglo XVI. Sevilla, Servicio de Publicaciones del Ayuntamiento de Sevilla, 1995.

Roig-Francolí, Miguel A. «Dos tientos de Cabezón basados en tonos de Magnificat», Revista de Musicología, $21 / 2$ (1998), pp. 477-495.

Rojo VegA, Anastasio. «Libros y bibliotecas en Valladolid», Bulletin Hispanique, 99/1 (1997), pp. 193-210.

Romanillos Vega, José Luis y Harris Winspear, Marian. The vihuela de mano and the Spanish Guitar. A dictionary of the makers of plucked and bowed musical instruments of Spain (1200-2002). Guijosa, The Sanguino Press, 2002.

Romero MedinA, Raúl. «La arquitectura en época de los Reyes Católicos. Lorenzo Vázquez de Segovia introductor del Renacimiento en Castilla (c.1450-1515)», Comunicación del Conocimiento. Anuario cientifico de la Universidad Isabel I, 1 (2012), pp. 479-498.

Romeu Figueras, José. «Mateo Flecha el Viejo, la corte literariomusical del duque de Calabria y el Cancionero llamado de Upsala», Anuario Musical, 13 (1958), pp. 25-101.

Ros FÁbregas, Emilio. «Libros de música en bibliotecas españolas en el siglo XVI (y III)», Pliegos de bibliofilia, 17 (2002), pp. 17-54.

Rubio Fuentes, Manuel. «Evolución demográfica de Guadalajara durante los siglos XVI y XVII», Wad-alayara, 25 (1998). Guadalajara, Institución provincial de cultura «Marqués de Santillana», pp. 91-115.

RuCQuOI, Adeline. I: Valladolid en la Edad Media. Génesis de un poder (1085-1367). II El mundo abreviado (13671474). 2 vols. Valladolid, Junta de Castilla y León, Consejería de Educación y Cultura, 1997.

RuCQuOI, Adeline. «"Por la nasción de España": Castilla en el concierto europeo del siglo XV», ALONSO Ruiz, Begoña y Villaseñor Sebastián, Fernando (eds.), Arquitectura tardogótica en la Corona 
de Castilla. Trayectorias e intercambios, Universidad de Sevilla - Universidad de Cantabria, Sevilla - Santander, 2014, pp. 13-32.

Rueda SABATER, Mercedes. «El florín: un «dolar» bajomedieval», En la España Medieval, 5 (1984), pp. 865874.

Ruiz-JimÉnEZ, Juan. «La dinastía de los Peraza. Nuevos datos para la biografía de Jerónimo Peraza II», Cuadernos de Arte, 46 (1995), Universidad de Granada, pp. 53-63.

RUIZ-JIMÉNEZ, Juan. «Ministriles y extravagantes en la celebración religiosa», Políticas y prácticas musicales en el mundo de Felipe II. Madrid, ICCMU, 2004, pp. 199-239.

RUIZ-JIMÉNEZ, Juan. «Power and musical exchange: the Dukes of Medina Sidonia in Renaissance Seville», Early Music, $37 / 3$ (2009), pp. 401-415.

RuIZ-JimÉNEZ, Juan. «Música sacra el esplendor de la tradición», GÓMEZ, Maricarmen (ed.). Historia de la música en España e Hispanoamérica. Vol. 2. De los Reyes Católicos a Felipe II. Madrid, Fondo de Cultura Económica, 2012, pp. 291-395.

Ruiz Somavilla, María José. "El cuerpo limpio". Análisis de las prácticas higiénicas en la España del mundo moderno. Málaga, Universidad de Málaga, 1993.

Russell, Eleanor. «Music in the House of the Third Duke of Béjar: ca. 1520-1544», Encomium Musicae. Essays in Honor of Robert J. Snow. Crawford, David y WAGSTAFF, G. Grayson (eds.), Festschrift Series no 17, Hillsdale, Nueva York, Pendragon Press, 2002, pp. 285-303.

SALAZAR Y ACHA, Jaime de. Génesis y evolución histórica del apellido en España. Discurso leído el día 26 de mayo de 1991. Madrid, Real Academia Matritense de Heráldica y Genealogía, 1991.

Salazar de Mendoza, Pedro. Crónica de el Gran Cardenal de España, don Pedro Gonçalez de Mendoça. Toledo, Imprenta de doña María Ortiz de Saravia, 1625, p. 414. Copia digital en:

<http://bibliotecadigital.jcyl.es/i18n/consulta/registro.cmd?id=13377> [consulta 11-4-15]

SÁNCHEZ SAUS, Rafael. «Los patriciados urbanos», El mundo social de Isabel la Católica. Miguel Ángel Ladero Quesada (coord.). Madrid, Dykinson, 2004, pp. 143-155.

SÁnCHeZ Prieto, Ana Belén. La Casa de Mendoza hasta el tercer Duque del Infantado (1350-1531). El ejercicio y alcance del poder señorial en la Castilla bajomedieval. Madrid, Palafox \& Pezuela, 2001.

SAndoval, Prudencio de. Historia del emperador Carlos V, rey de España. Madrid, Madoz y Sagasti, 1846.

SAnHuesa FonseCA, María. «Torres, Melchor de», DMEH, vol. 10, p. 405.

SAn Román, Francisco de Borja. «Las obras y los arquitectos del Cardenal Mendoza», Archivo Español de Arte y Arqueología, 7/20 (1931), pp. 153-161.

Santa Cruz de Dueñas, Melchor. Floresta española. Buenos Aires, México, Espasa Calpe, 1947.

SANTIAGo FERnÁndeZ, Javier de y Francisco Olmos, Jose María de. «La inscripción de la fachada del palacio del Infantado en Guadalajara», Documenta \& Instrumenta, 4 (2006), pp. 131-150.

SANZ SANCHO, Iluminado. «El cabildo catedralicio de Córdoba en la Edad Media», En la España Medieval, 23 (2000), pp. 189-264.

SCHIFF, Mario. La Bibliothèque du marquis de Santillane. París, Libraire Émile Bouillon, 1905. 
SCHNEIDER, Marius. «Un villancico de Alonso de Mudarra procedente de la música popular granadina», Anuario Musical, 10 (1955), pp. 79-83.

SELKE DE SÁNCHEZ, Ángela. «Algunos datos nuevos sobre los primeros alumbrados. El Edicto de 1525 y su relación con el proceso de Alcaraz», Bulletin Hispanique, 54/2 (1952), pp. 125-152.

SELKE DE SÁNCHEZ, Ángela. «Vida y muerte de Juan López de Celain, alumbrado vizcaíno», Bulletin Hispanique, 62/2 (1960), pp. 136-162.

Serrano y SANZ, Manuel. «El licenciado Juan de Cervantes y don Íñigo López de Mendoza, cuarto duque del Infantado», Boletín de la Real Academia Española, 13/41 (1926), pp. 18-43.

SOBRADO CORREA, Hortensio. «Los inventarios post-mortem como fuente privilegiada para el estudio de la historia de la cultura material en la Edad Moderna», Hispania: Revista española de historia, 63/215 (2003), pp. 825-862.

SOla CASTAÑo, Emilio. Los Reyes Católicos: los reyes que sufragaron la mayor quimera de la historia. Madrid, Anaya, 1988.

SORIA MESA, Enrique. «Los estudios sobre las oligarquías municipales en la Castilla moderna. Un balance en claroscuro», Manuscrits, 18 (2000), pp. 185-197.

Sousa Congosto, Francisco de. Introducción a la historia de la indumentaria en España. Madrid, Istmo, 2007.

Stevenson, Robert. «Escobar, Pedro de [Pedro del Puerto; Pedro do Porto]», The New Grove Dictionary of music and musicians, vol. 6, Londres, Macmillan, 1980, pp. 243-244.

STEVEnSOn, Robert. «Mudarra Alonso», The New Grove Dictionary of music and musicians, vol. 12, Londres, Macmillan, 1980, pp. 757-758.

STEVEnSOn, Robert. La Música en la Catedral de Sevilla. 1478-1606. Documentos para su estudio. Madrid, SEdeM, 1985.

STEVEnSON, Robert. La música en las catedrales españolas del Siglo de Oro. (Traducción de María Dolores Cebrián de Miguel y Amalia Correa Liró). Madrid, Alianza, 1993. Ed. castellana de Spanish Cathedral Music in the Golden Age. Berkeley, California, 1961.

SubirÁ, José. La Música en la Casa de Alba. Estudios Históricos y Biográficos. Madrid, Sucesores de Rivadeneira, 1927.

SuÁrez de Arcos, Fernando y Herrera Casado, Antonio. «Tapicerías en la Casa de Mendoza», Wad-alayara, 14 (1987). Guadalajara, Institución provincial de cultura «Marqués de Santillana», pp 213-247.

SuÁREZ FERNÁNDEZ, Luis. Nobleza y Monarquia. Entendimiento y rivalidad. El proceso de construcción de la Corona española. Madrid, RBA, 2007.

SuÁReZ MARTos, Juan María. El rito de la Salve en la catedral de Sevilla durante el siglo XVI. Estudio del repertorio musical contenido en los manuscritos 5-5-20 de la Biblioteca Colombina y el Libro de Polifonía $n^{o} 1$ de la catedral de Sevilla. Granada, Centro de Documentación Musical de Andalucía, Junta de Andalucía, 2010.

SuÁREZ-PAJARES, Javier. «La música instrumental: vihuelas, arpa y tecla», GómEZ, Maricarmen (ed.). Historia de la música en España e Hispanoamérica. Vol. 2. De los Reyes Católicos a Felipe II. Madrid, Fondo de Cultura Económica, 2012, pp. 215-290. 
TELLECHEA IDÍGORAS, J. Ignacio. «Biblias publicadas fuera de España secuestradas por la Inquisición de Sevilla en 1552», Bulletin Hispanique, 64/3-4 (1962), pp. 236-247.

TORre, Antonio de la. La Casa de Isabel la Católica. Madrid, CSIC, 1954.

TOrre, Antonio de la y TORre, E. A. de la. Cuentas de Gonzalo de Baeza tesorero de Isabel la Católica. 2 vols. Madrid, CSIC, 1956.

TORRE, Esteban. «La traducción del epodo II de Horacio (Beatus ille)», Hermēneus. Revista de Traducción e Interpretación, 1 (1999), pp. 1-14.

TORRES SANZ, David. La administración central castellana en la Baja Edad Media. Valladolid, Secretariado de Publicaciones, Universidad de Valladolid, 1982.

Trallero Sanz, Antonio Miguel. «El modelo constructivo del patio del palacio de Antonio Mendoza», Actas del Primer Congreso Nacional de Historia de la Construcción. A. de las Casas, S. Huerta, E. Rabasa (eds.), Madrid, Juan de Herrera, 1996, pp. 499-506.

Trend, John Brande. Luis Milan and the Vihuelistas. Oxford, Oxford University Press, Humphrey Milford, 1925 (Hispanic Notes and Monographs. Essays, Studies, and Brief Biographies Issued by The Hispanic Society of America, XI).

TYLER, James. «The renaissance guitar 1500-1650», Early Music, 3 (1975), pp. 341-347.

TYLER, James. The early guitar. A History and Handbook. Londres, Oxford University Press, 1980.

TYler, James y Sparks, Paul. The Guitar and its Music from the Renaissance to the Classical Era. Nueva York, Oxford University Press, 2007.

URREA FernándeZ, Jesús. «Caballeros de la Orden de San Juan de Malta de Valladolid», Boletín del Seminario de Estudios de Arte. 75/2 (2009), pp. 157-168.

VAcCARO, Jean-Michel. La musique de luth en France au XVI siècle. París, Centre National de la Recherche Scientifique, 1981.

VAnder Straeten, Edmond. La musique aux Pays-Bas avant le XIX siècle. 8 vols. Bruselas, G.-A. van Trigt, 1867-1888.

VegA, María José. Poética y música en el Renacimiento. La invención del paradigma clásico. Madrid, Caronte, 2011.

Vicente Delgado, Alfonso de. Los cargos musicales y las capillas de música en los monasterios de la orden de san Jerónimo (siglos XVI-XIV). Tesis Doctoral, Universidad Complutense de Madrid, 2010.

Villalba Ruiz De Toledo, F. Javier. «Colección diplomática del cardenal Mendoza (1454-1503)», Cuadernos de Historia Medieval, Sección Colecciones Documentales, 1 (1999).

Villalba Ruiz De Toledo, F. Javier. El cardenal Mendoza (1428-1495). Madrid, Rialp, 1988.

Villanueva SerRano, Francesc. «La identificación de Pedro de Escobar con Pedro de Porto: una revisión definitiva a la luz de nuevos datos», Revista de Musicología, 34/1 (2011), pp. 37-58.

WAGNER, Klaus. «¿Qué costaron los estudios universitarios en Salamanca a principios del siglo XVI?», Archivo Hispalense, 59/180 (1976), pp. 149-151.

WAGNER; Klaus. «Lecturas y otras aficiones del inquisidor Andrés Gasco (†1566)», Boletín de la Real academia de la Historia, 171/1 (1979), pp. 149-181. 
WAgner, Klaus. Martín de Montesdoca y su prensa. Contribución al estudio de la imprenta y de la bibliografía sevillanas del siglo XVI. Sevilla, Universidad de Sevilla, 1982.

WAGNER, Klaus. «Los libros del canónigo y vihuelista Alonso Mudarra», Bulletin Hispanique, 92/1 (1990), pp. 655-675.

WARD, John. «The Editorial Methods of Venegas de Henestrosa», Musica Disciplina, 6 (1952), pp. 105-113.

WARD, John. «The Use of Borrowed Material in 16th-Century Instrumental Music», Journal of the American Musicological Society, 5/2, (Summer 1952), pp. 88-98.

WARD, John. The «Vihuela de mano» and its music (1536-1576). Tesis doctoral, New York University, 1953,2 vols.

Whitwell, David. The Renaissance Wind Band and Wind Ensemble. The History and Literature of the Wind Band and Wind Ensemble, volume 2. Austin, Texas, Whitwell Books, 2011, (2 ed.).

WIERING, Frans. The Language of the Modes. Studies in the History of Polyphonic Music. Nueva York y Londres, Routledge, 2001. 


UNIVERSIDAD COMPLUTENSE DE MADRID

FACULTAD DE GEOGRAFÍA E HISTORIA

Departamento de Musicología
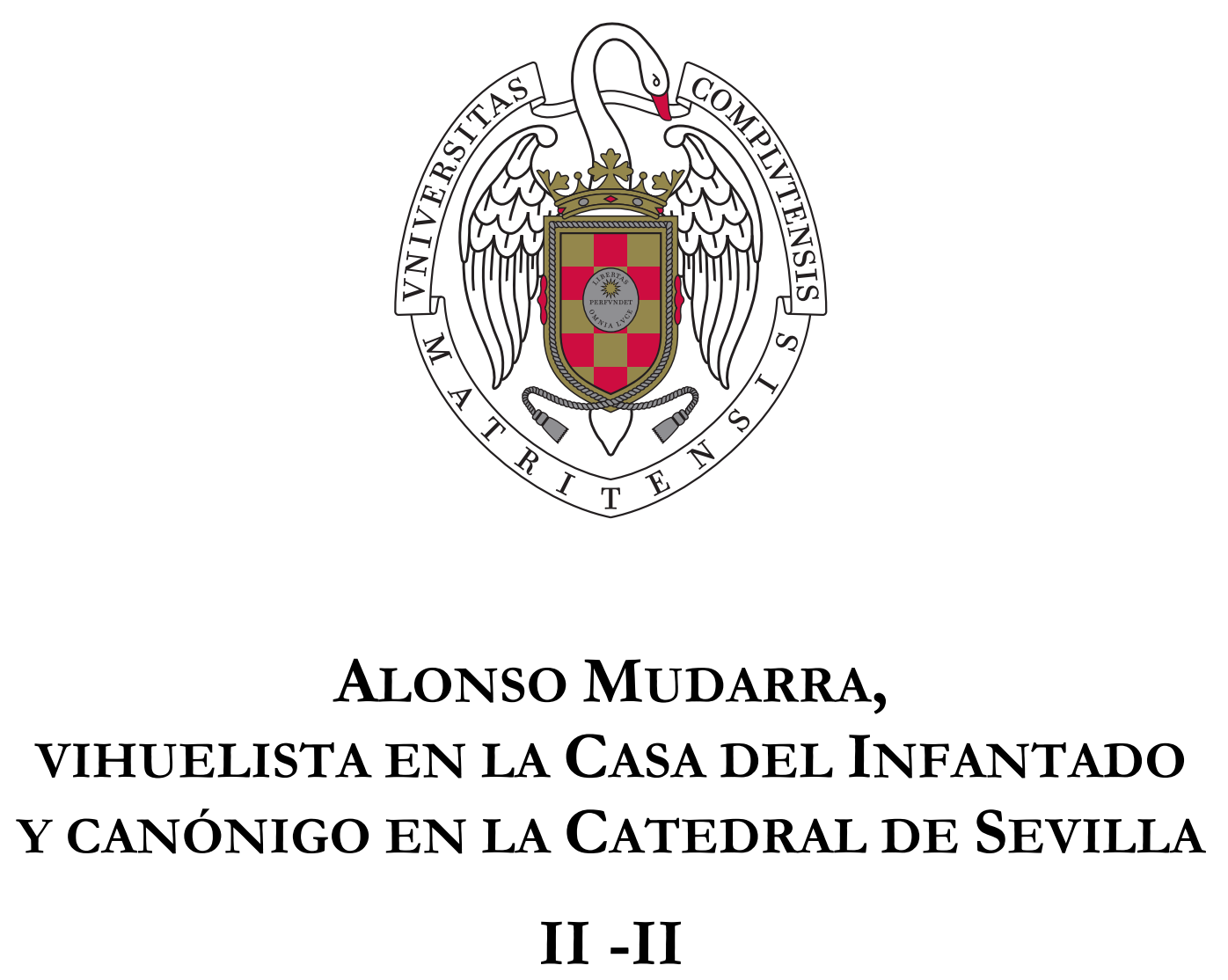

TESIS DOCTORAL PRESENTADA POR:

Francisco Javier Roa Alonso

DIRECTOR:

Dr. Gerardo Arriaga Moreno

Madrid, 2015 



\section{Alonso Mudarra, VIHUELISTA EN LA CASA DEL INFANTADO Y CANÓNIGO EN LA CATEDRAL DE SEVILLA}

VOLUMEN 2 

PARTe 3

\section{TRANSCRIPCIONES}




\section{ÍNDICE TRANSCRIPCIONES}

\section{LIBRO I}

1- Fantasía 1

2- Fantasía 2

3- Fantasía 3

4- Fantasía 4

5- Fantasía 5

6- Fantasía 6

7- Fantasía 7

8- Fantasía 8

9- Fantasía 9

10- Qui tollis

11- Pleni

12- Fantasía 10

13- Conde Claros

14- Romanesca. Guárdame las vacas 1

15- Pavana 1

16- Pavana de Alexandre

17- Gallarda

18- Fantasía 11

19- Fantasía 12

20- Fantasía 13

21- Fantasía 14

22- Pavana 3

23- Romanesca. Guárdame las vacas 2

\section{LIBRO II}

24- Tiento 1

25- Fantasía 15

26- Kyrie 1

27- Fantasía 16

28- Tiento 2

29- Fantasía 17

30- Fantasía 18

31- Tiento 3

32- Fantasía 19

33- Kyrie 2

34- Tiento 4 
38- Fantasía $21 \quad 120$

39- Fantasía $22 \quad 123$

40- Tiento $6 \quad 128$

41- Fantasía $23 \quad 130$

42- Kyrie $3 \quad 133$

43- Tiento $7 \quad 139$

44- Fantasía $24 \quad 141$

45- Cum sancto spiritu 145

46- Tiento $8 \quad 151$

47- Fantasía 25

48- Fantasía $26 \quad 156$

49- Fantasía $27 \quad 160$

\section{LIBRO III}

50- Pater noster 163

51- Respice in me, Deus 179

52- Clamabat autem mulier. Motete de la cananea 190

53- Durmiendo yva el Señor 201

54- Triste estava el rey David 206

55- Israel, mira tus montes 209

56- Sin dudar. Canción al milagro de la Encarnación 213

57- Recuerde el alma dormida 223

58- Claros y frescos ríos 226

59- ¿Qué llantos son aquestos? 230

60- Si por amar el hombre $\quad 235$

61- Por ásperos caminos 241

62- Regia qui mesto 246

63- Dulces exuviae 250

64- Beatus ille 256

65- Hanc tua Penelope 257

66- La vita fugge 259

67- Lassato a il Tago 265

68- O gelosia d'amanti 270

69- Itene a l' ombra 275

70- Dime adó tienes las mientes 277

71- Si me llaman 282

72- Gentil cavallero 288

73- Ysabel, perdiste la tu faxa $\quad 295$

74- Si viesse e me levasse 300

75- Nisi Dominus 302

76- Exurge, quare obdormis 304

77- Tiento $9 \quad 307$ 


\section{sฯ1 - Fantasía 16ะ}

Fantasía de pasos largos para desembolver las manos

[Libro I, f. I]
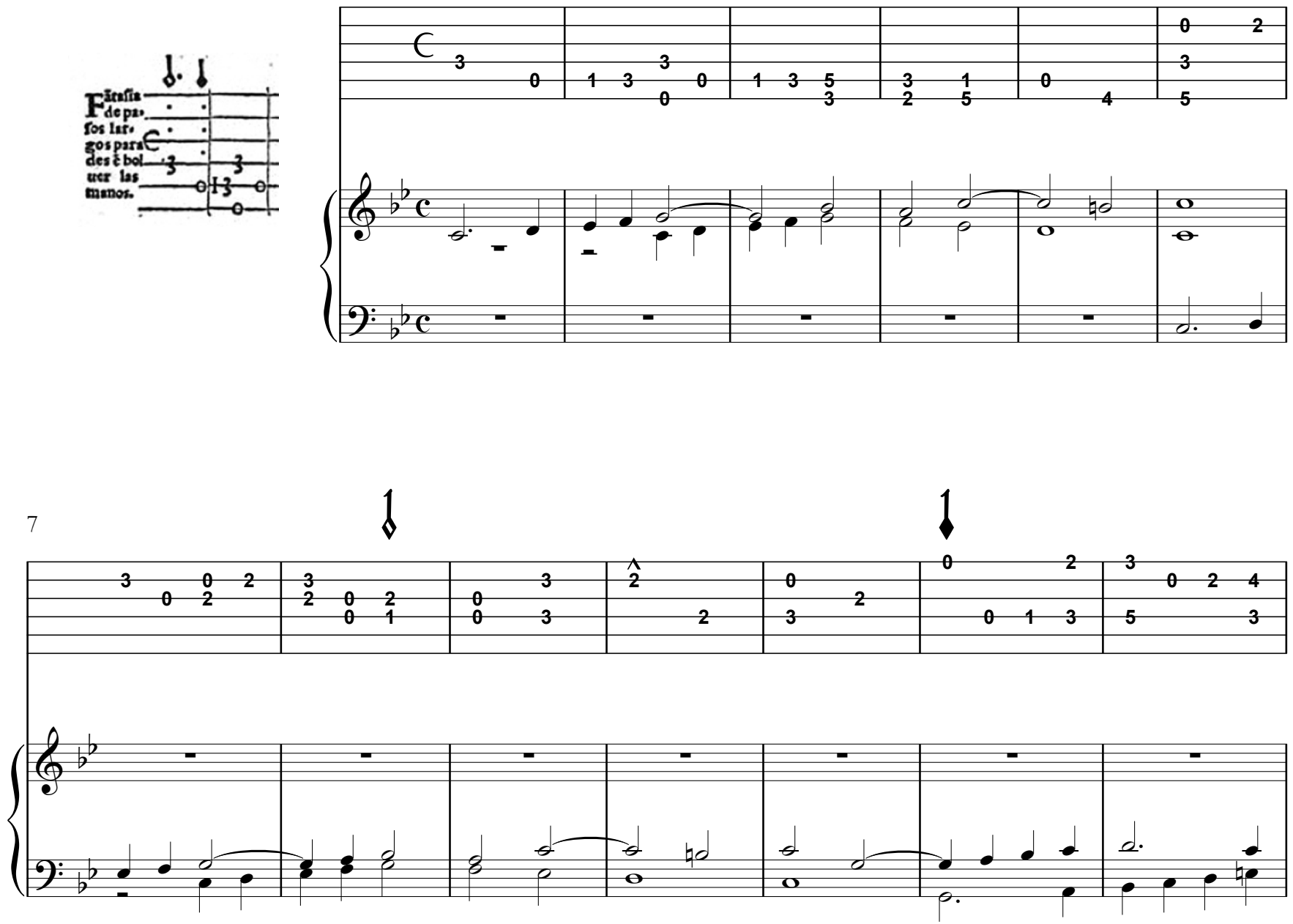

$14 \quad 1 \quad 1$

1

$\uparrow$

$1 \quad 1$

\begin{tabular}{|c|c|c|c|c|c|c|}
\hline & $N$ & & & 320 & & \\
\hline $\begin{array}{lll}0 & 2 & 4 \\
& & 2\end{array}$ & 22 & 1 & $2=0$ & & & 2 \\
\hline & & 0 & & & $\begin{array}{lllllll}3 & 1 & 0 & 0 & 1 & 3\end{array}$ & 1 \\
\hline
\end{tabular}

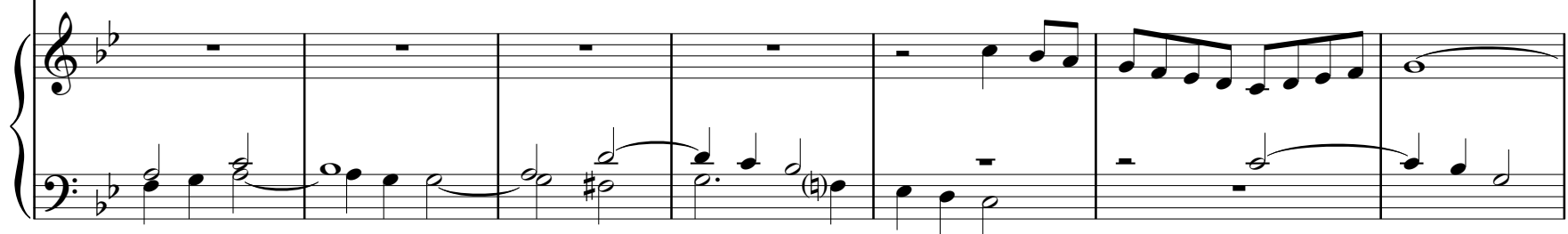



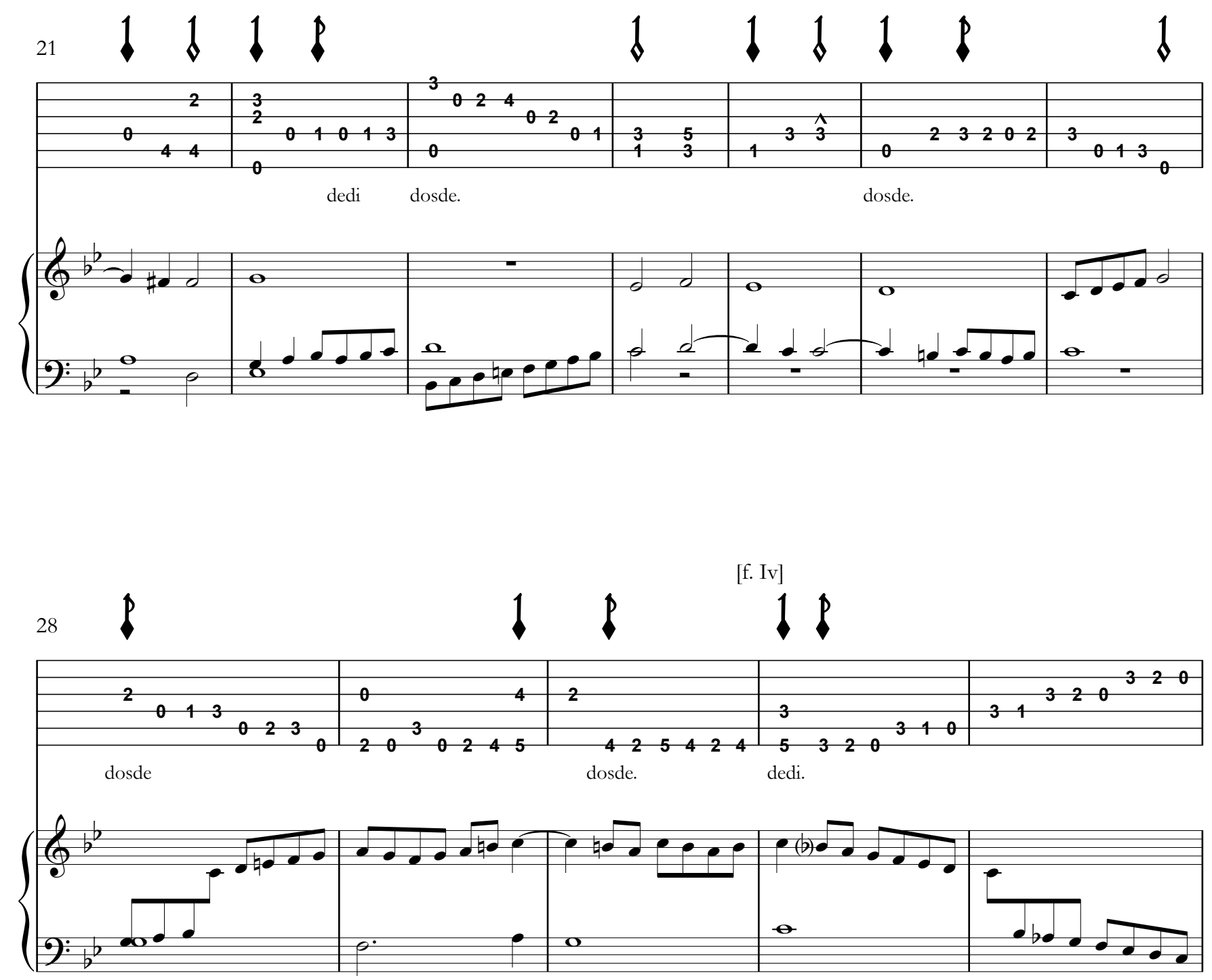

33

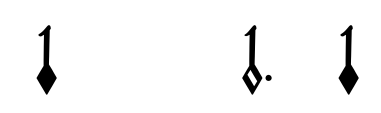

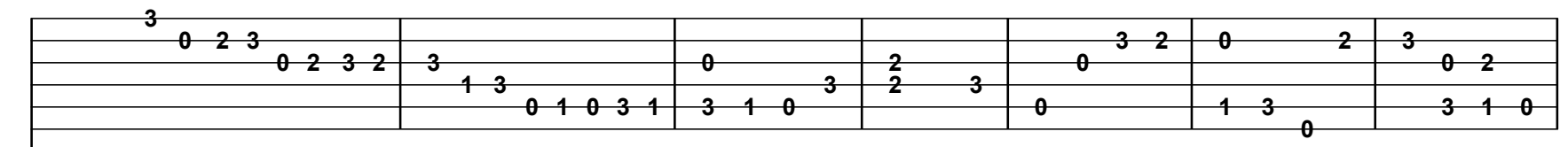

dosde,

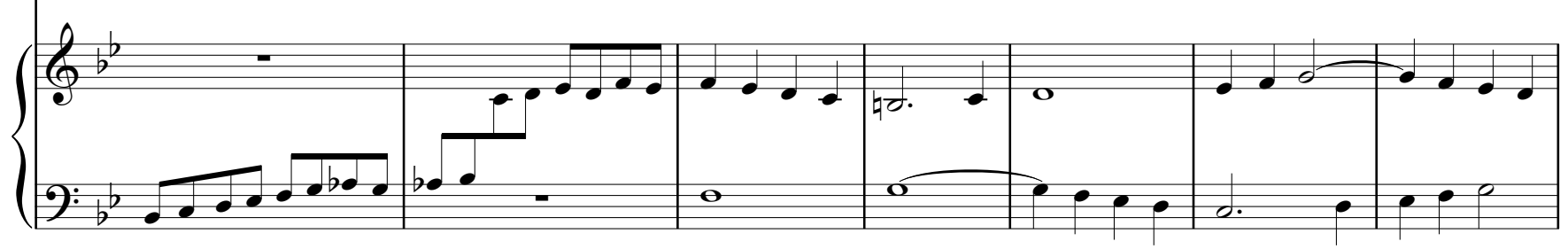



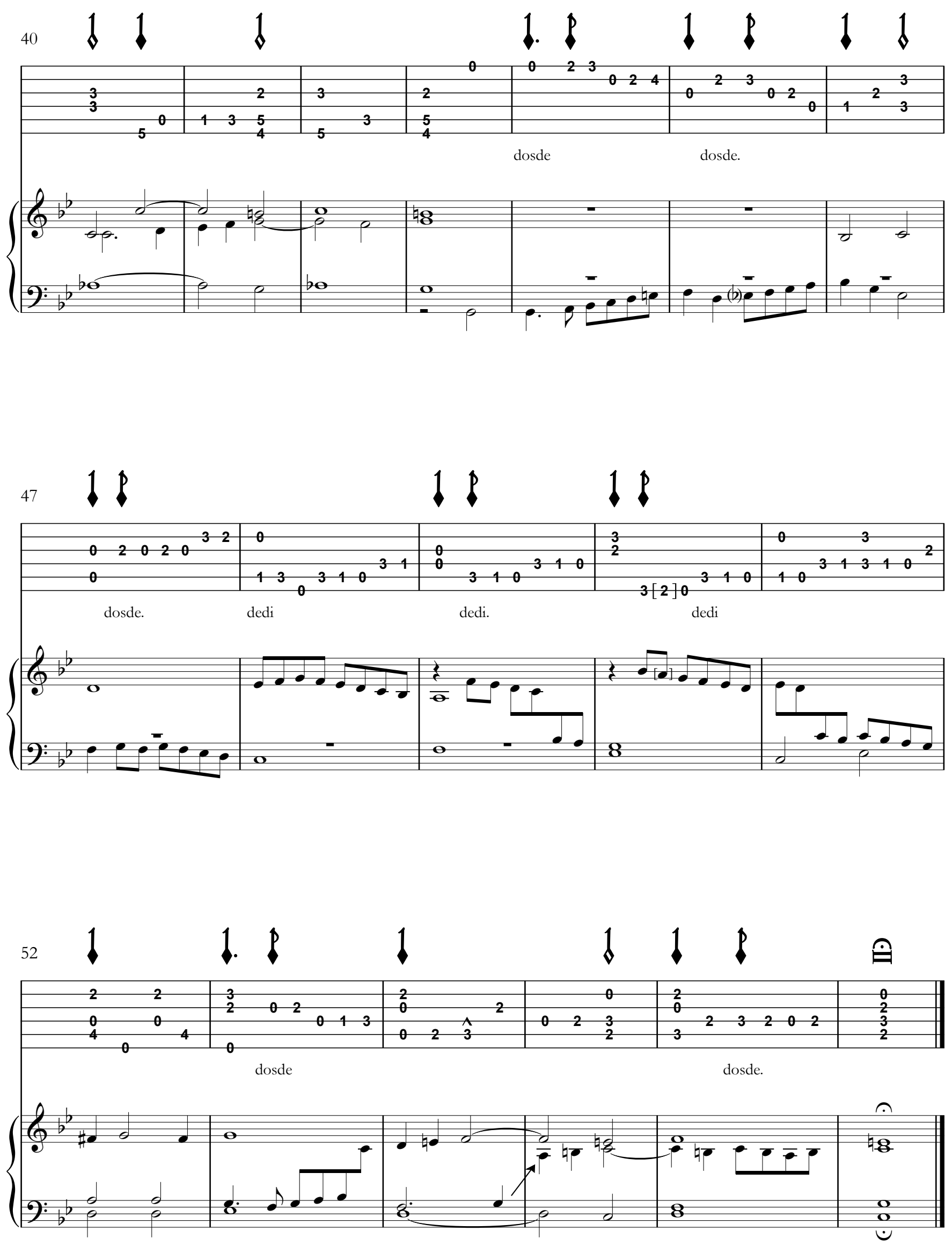


\section{se 2 - Fantasía 2}

Fantasía para desembolver las manos [Libro I, f. II]
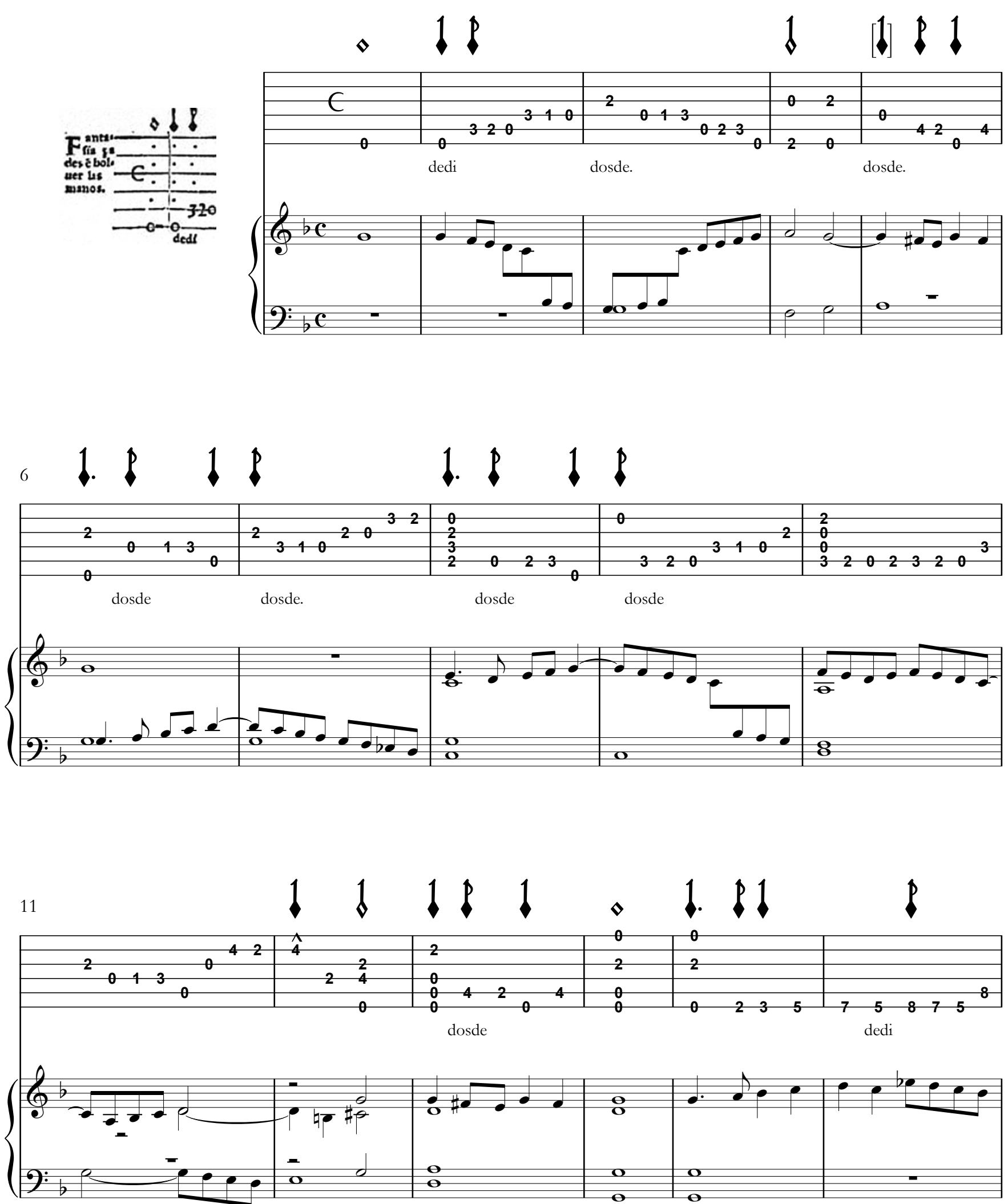


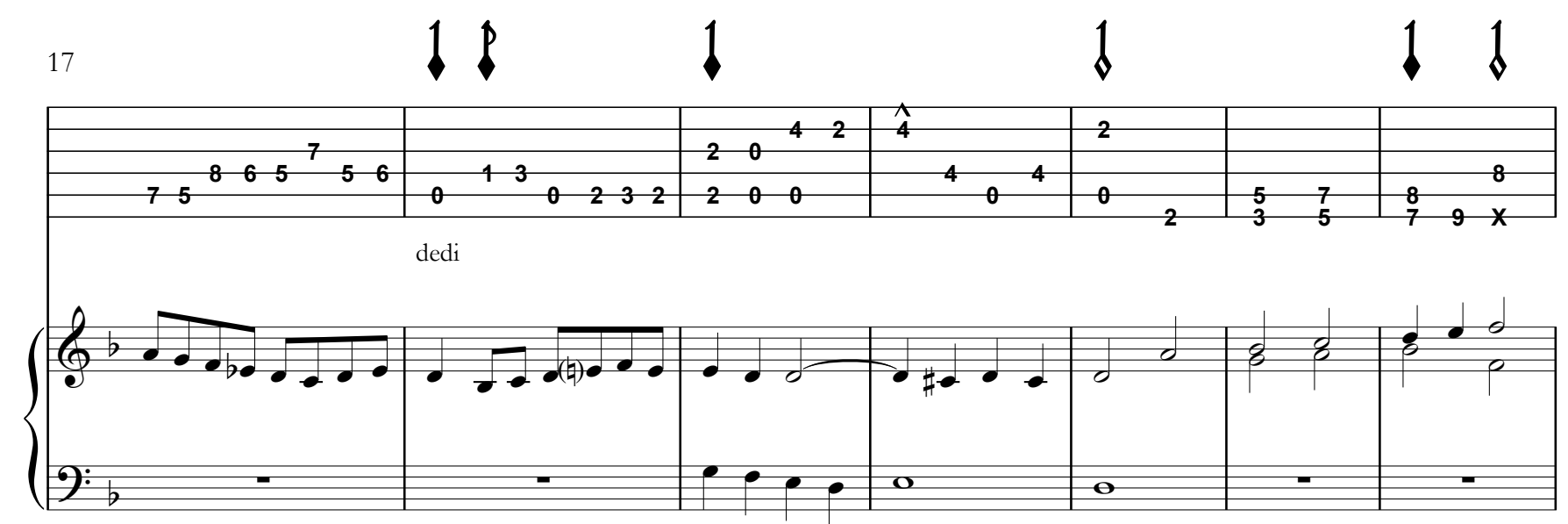

[f. IIv]
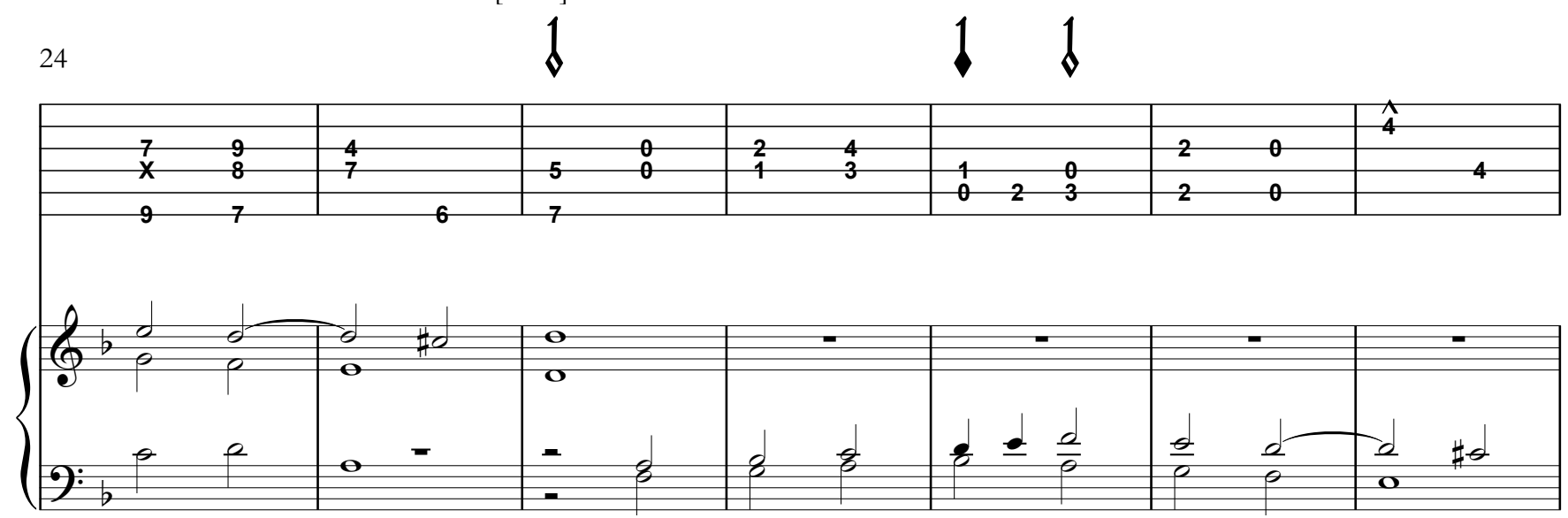

31
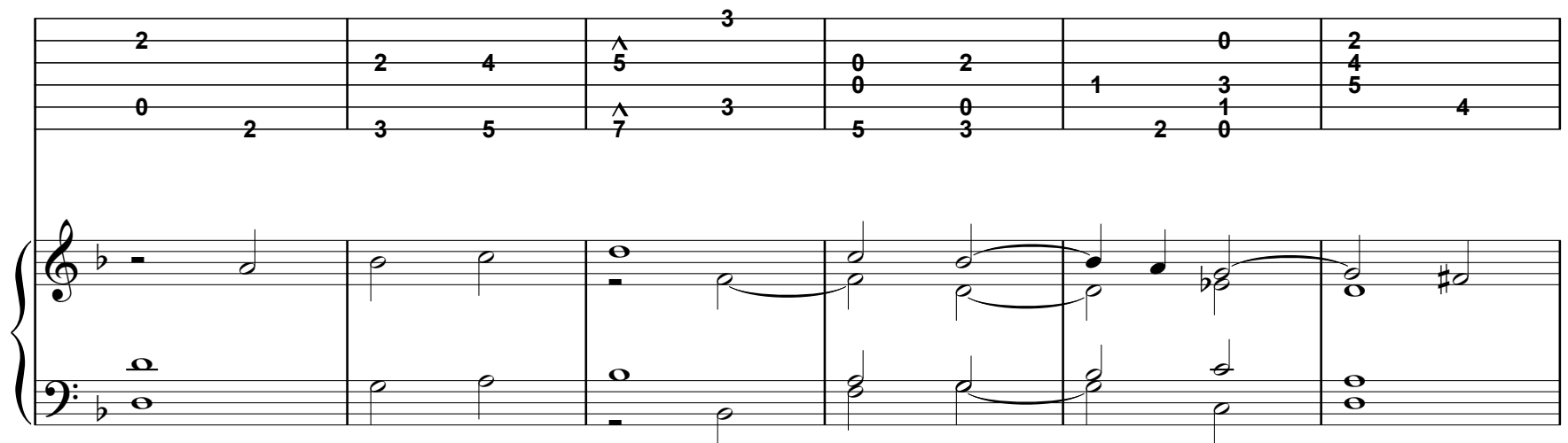

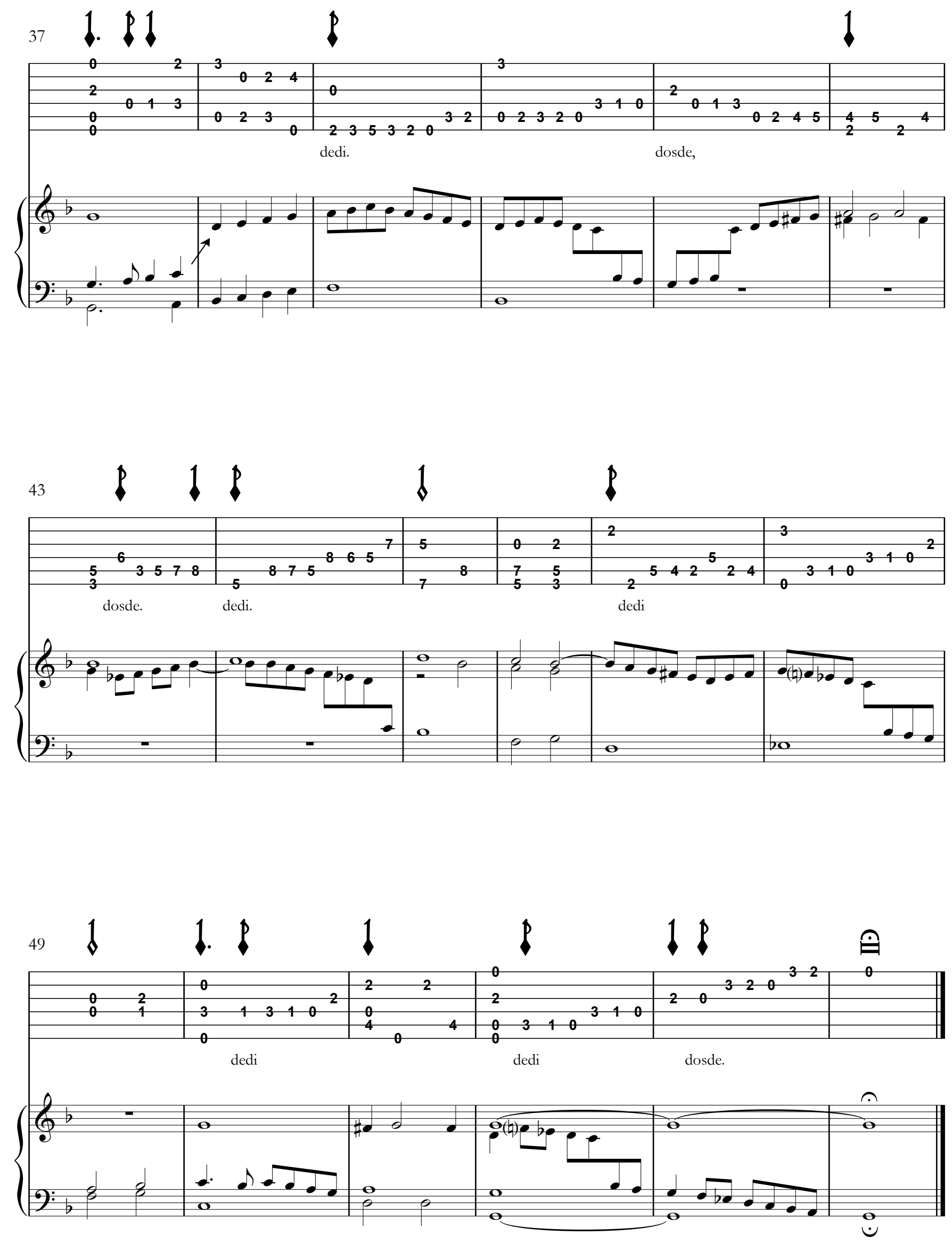


\section{s\&3 - Fantasía 3}

Fantasía de pasos para desembolber las manos

[Libro I, f. III]
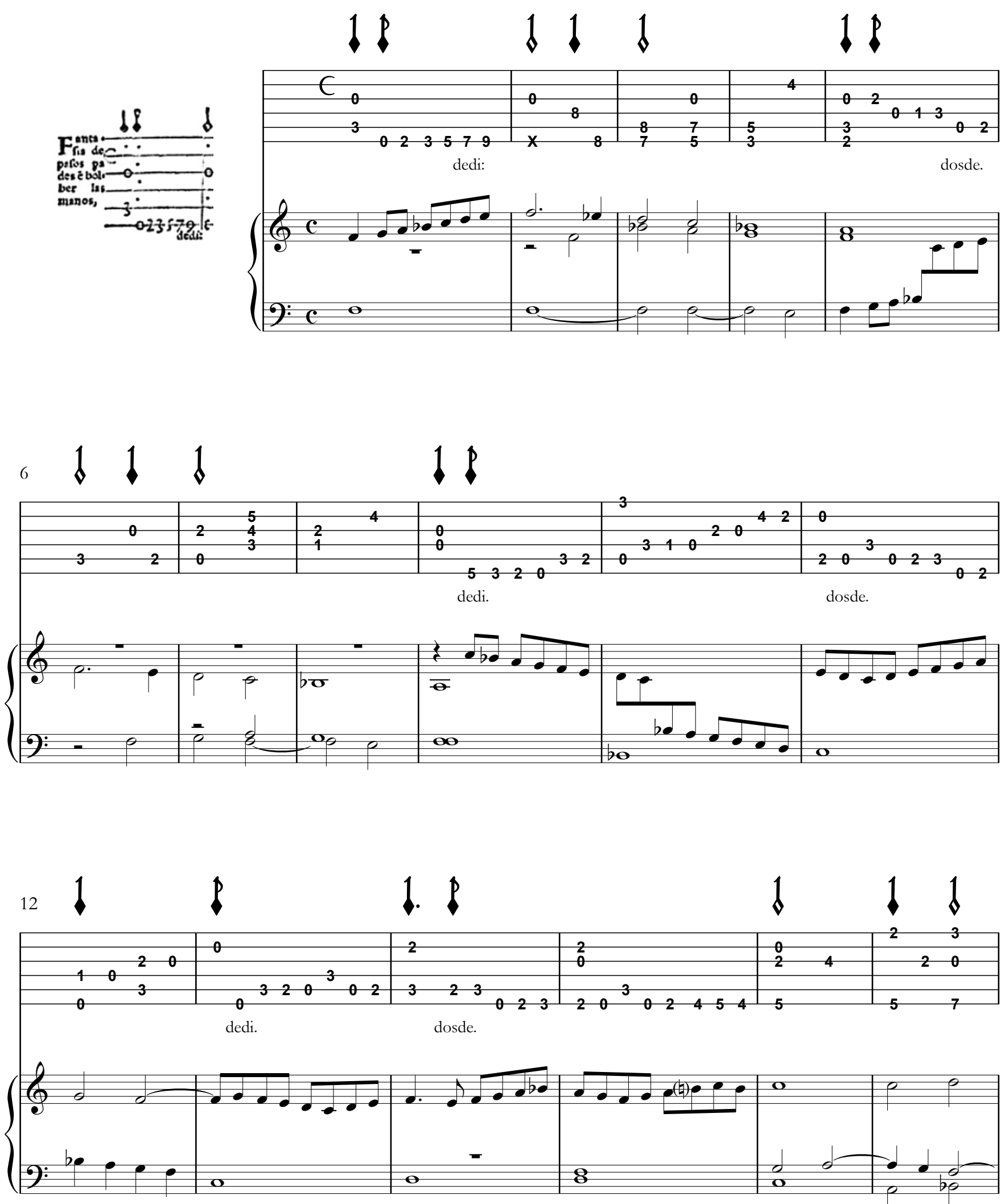

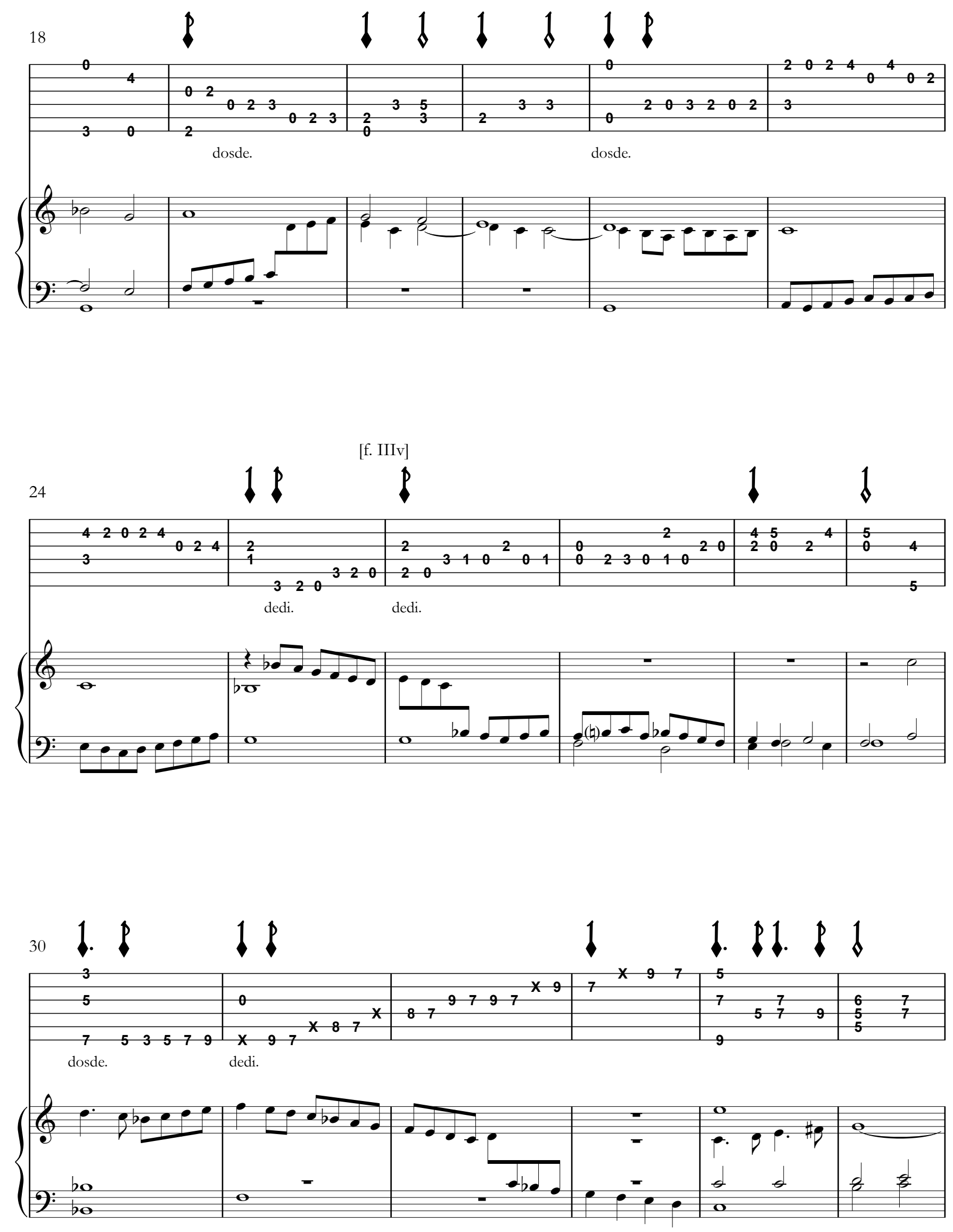

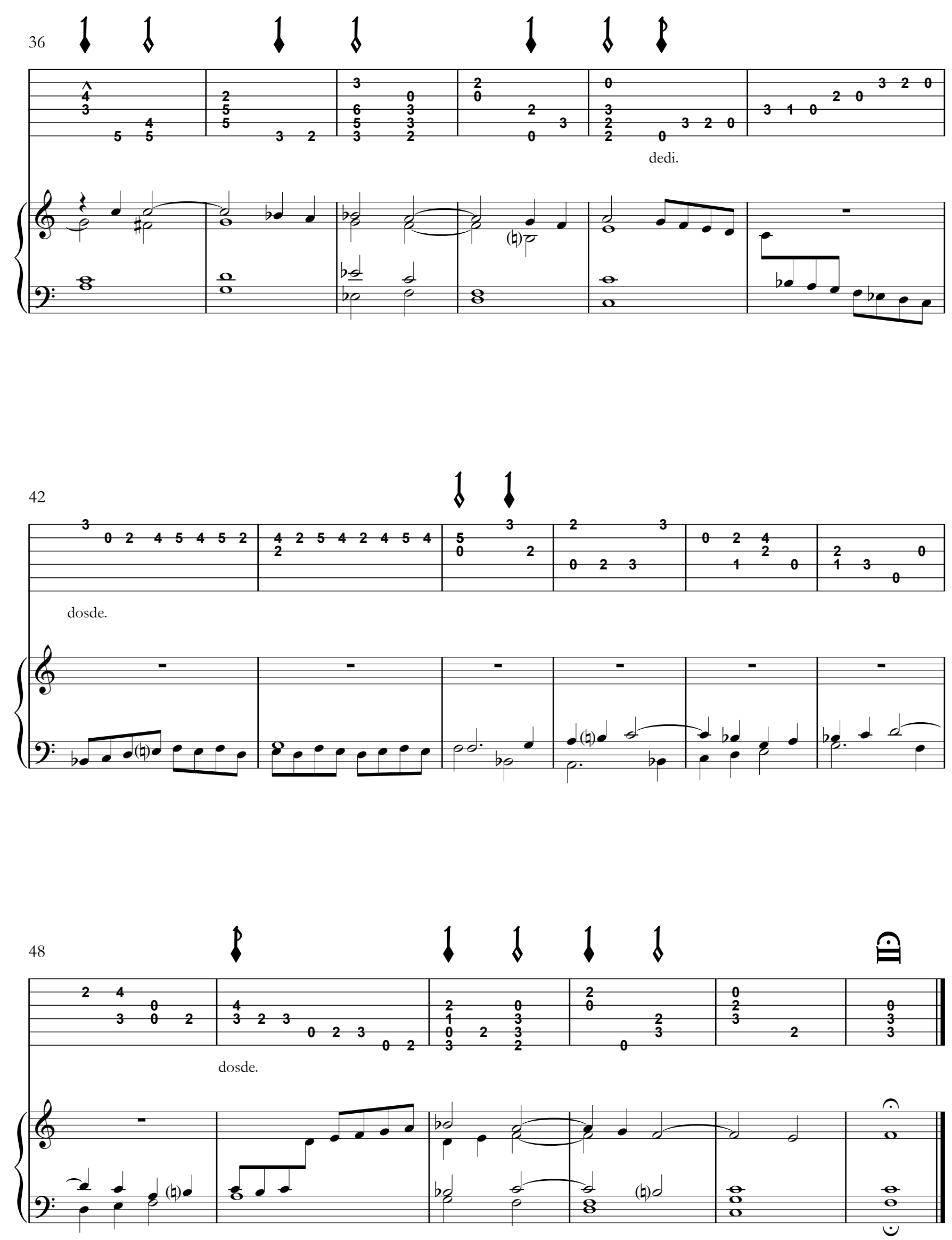


\section{sø4 - Fantasía 4}

Fantasía de pasos de contado. Á de yr el compás muy apriesa

[Libro I, f. IV]
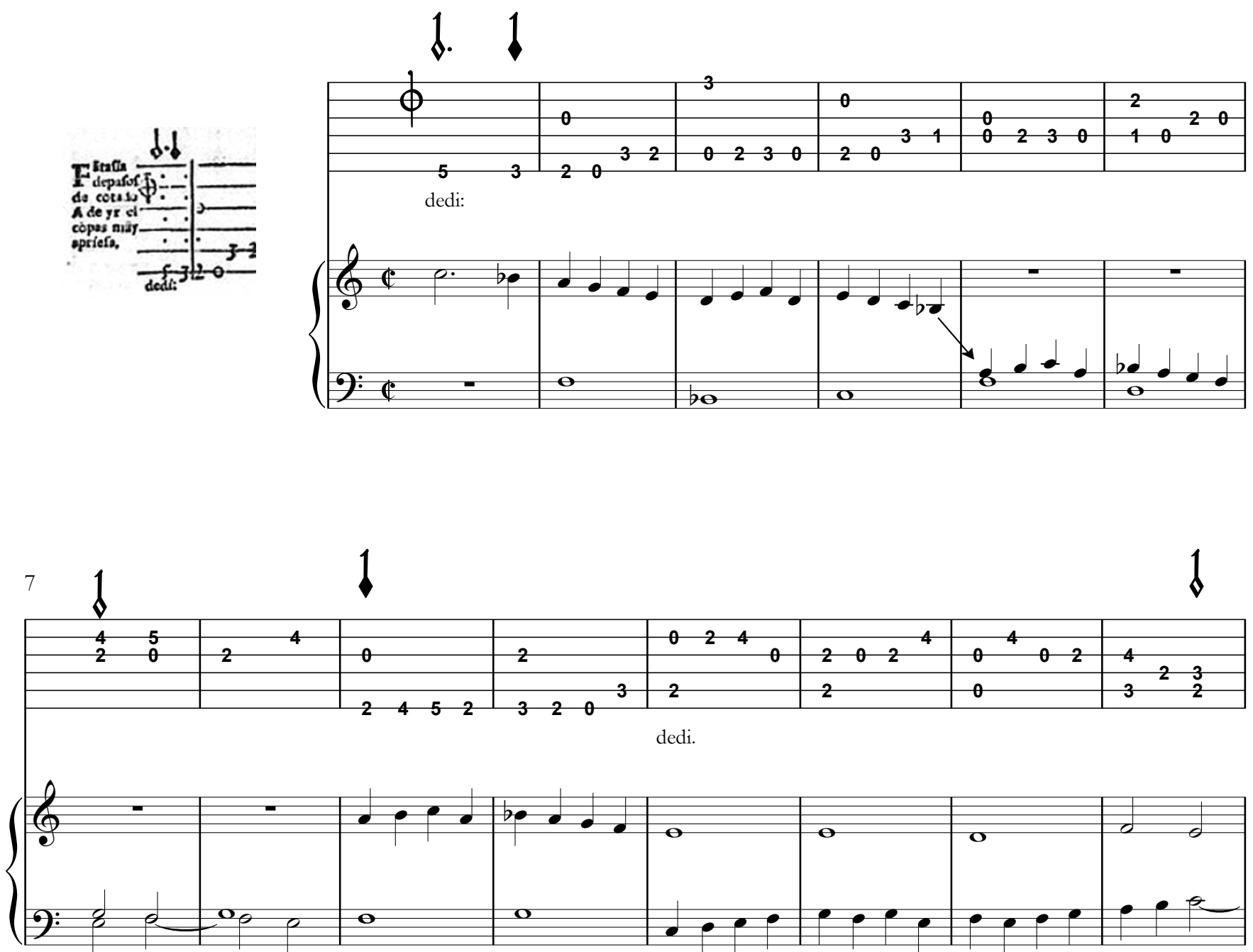

15

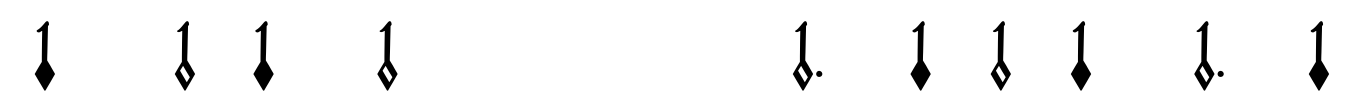

\begin{tabular}{|c|c|c|c|c|c|c|c|}
\hline & & & & & & & $\begin{array}{ll}0 & 2\end{array}$ \\
\hline ? & 3 & & & & $\begin{array}{ll}0 & 2\end{array}$ & 0 & 3 \\
\hline 0 & 0 & $2 \quad 3$ & 53 & 2 & 3 & 3 & 2 \\
\hline
\end{tabular}

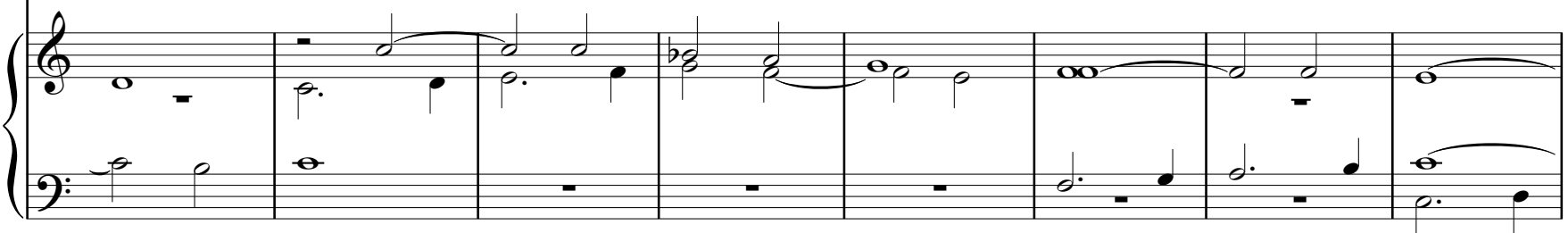




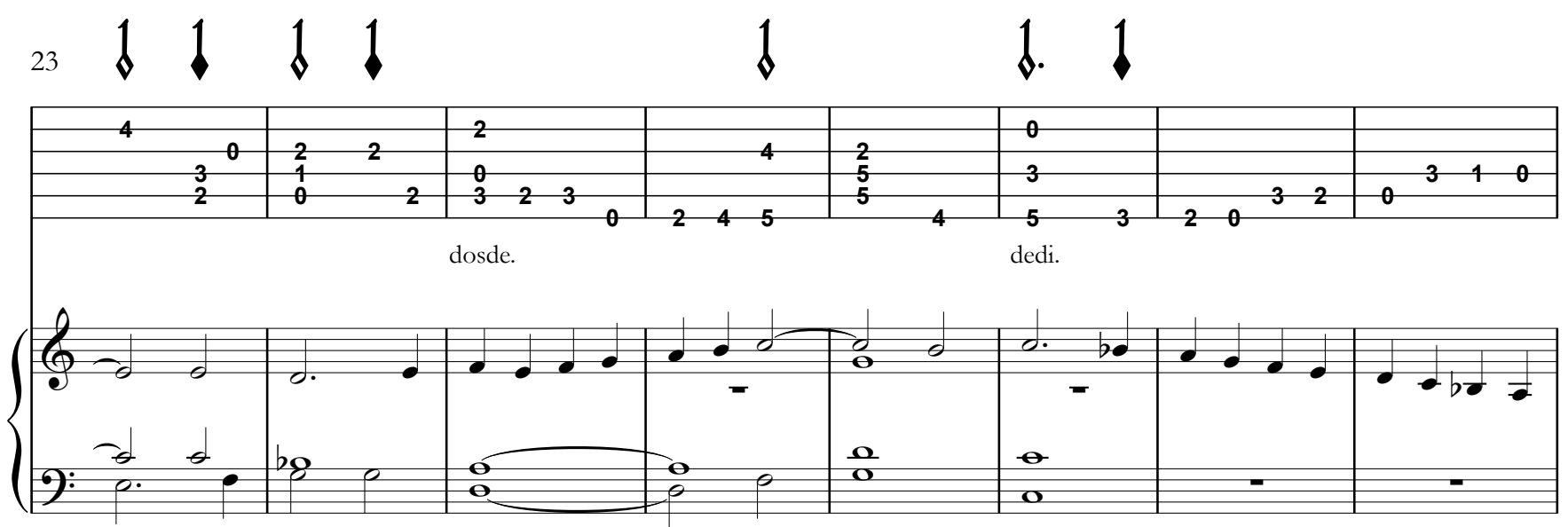

[f. IVv]

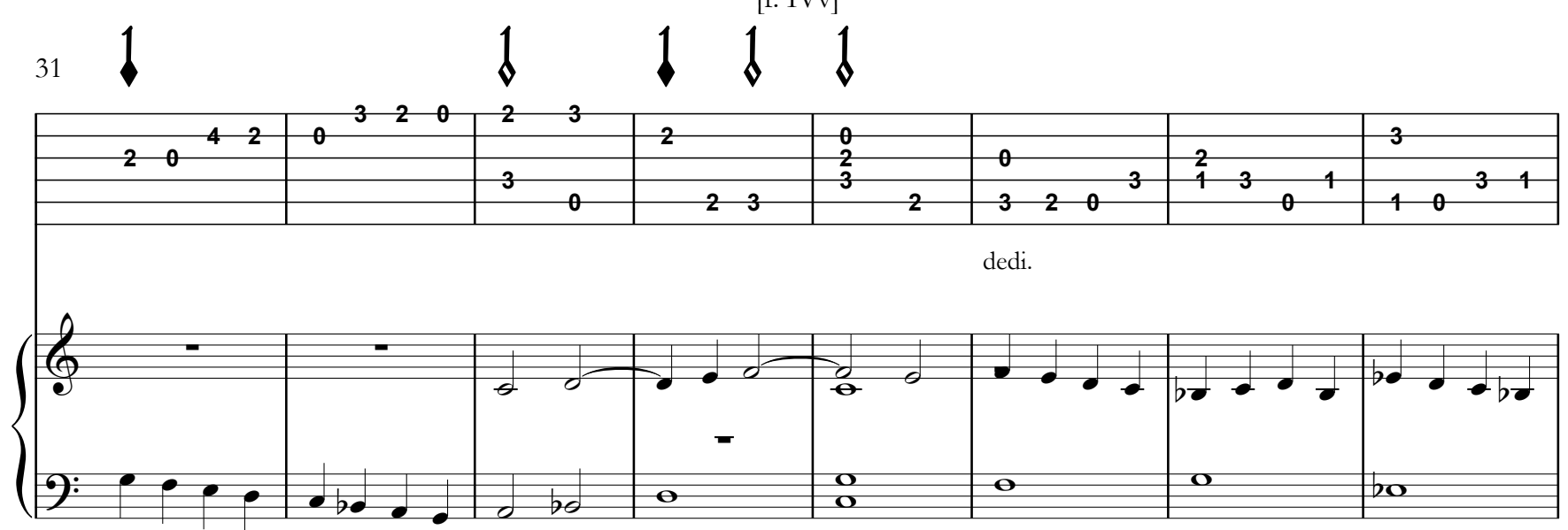

39
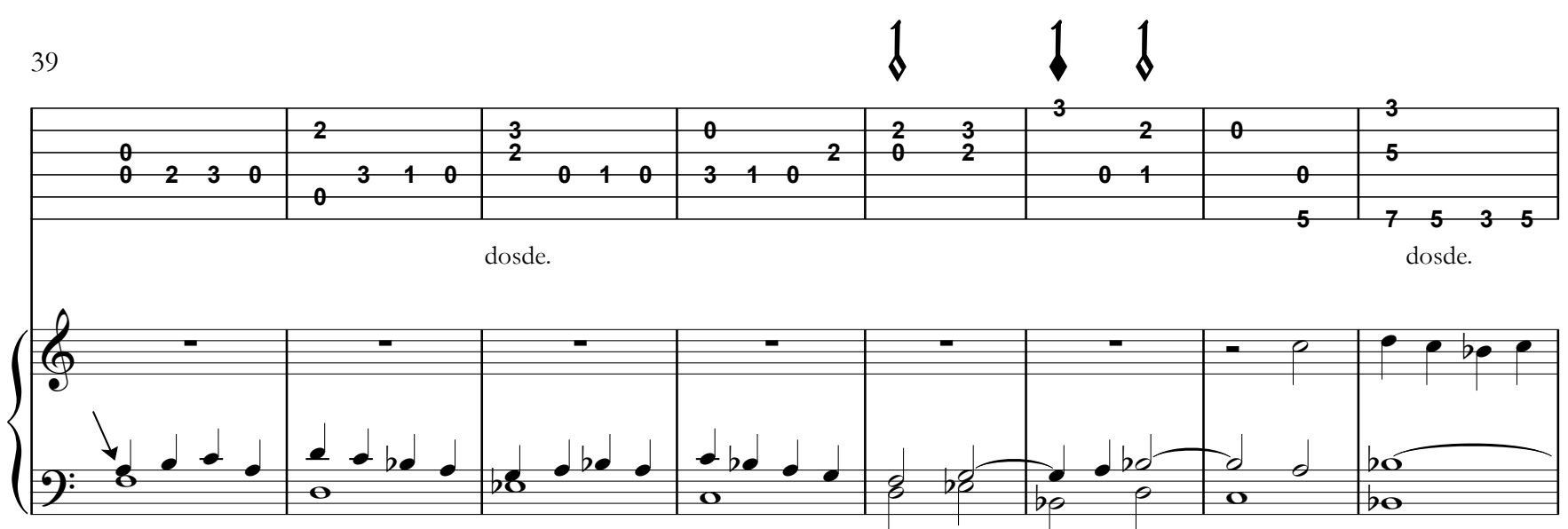
$47 \quad 1 \quad 1$

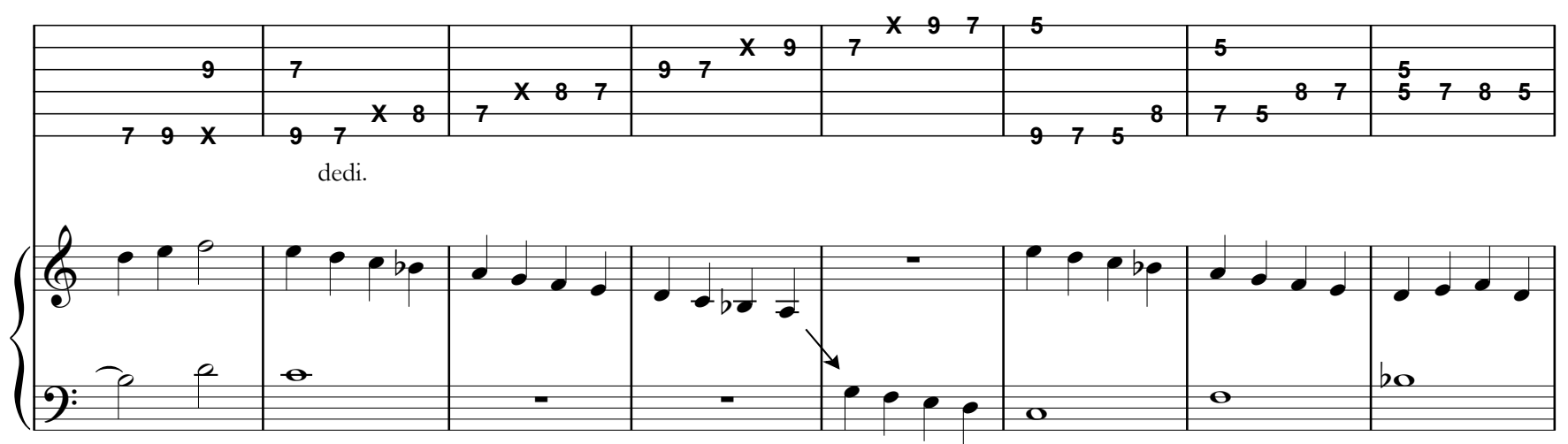

55

1 d 1

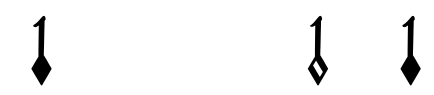

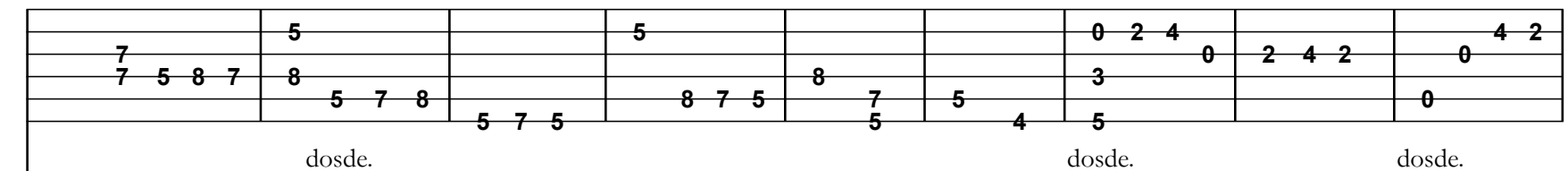
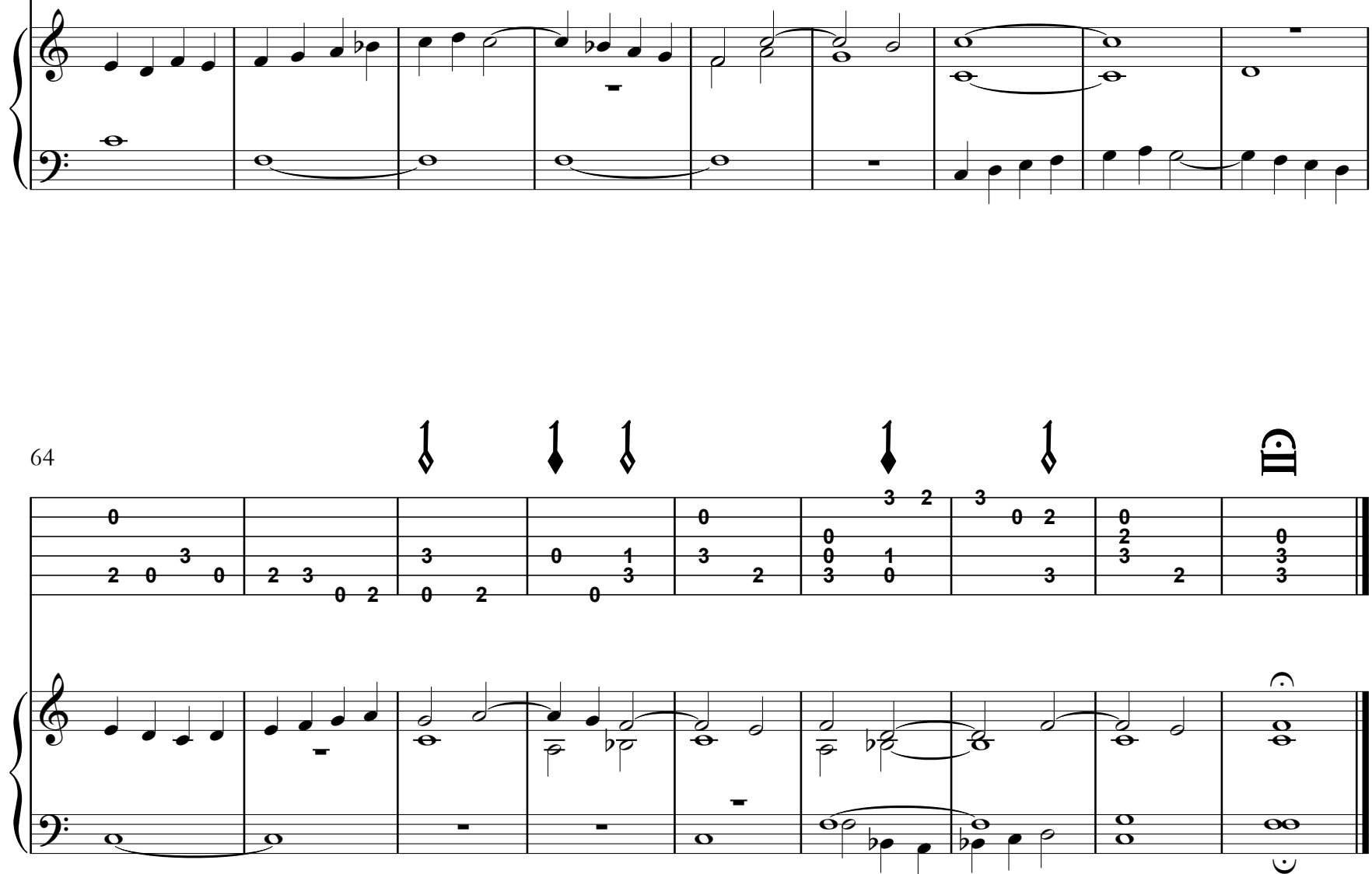


\title{
so 5 - Fantasía 5
}

\author{
Fantasía fácil
}

[Libro I, f. V]
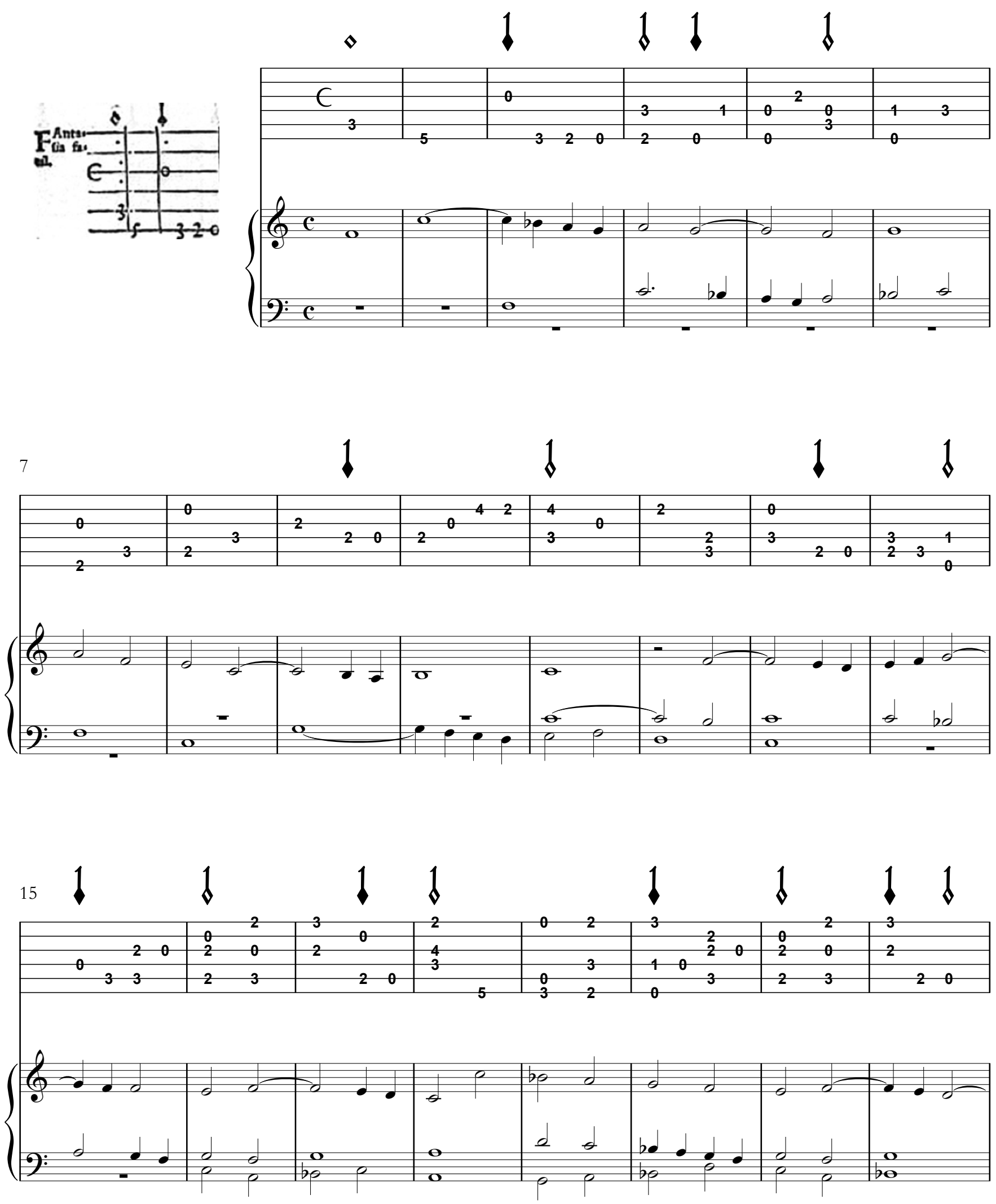
23

\section{$16 \quad 1 \quad 1 \quad 1 \quad 1 \quad 1$}
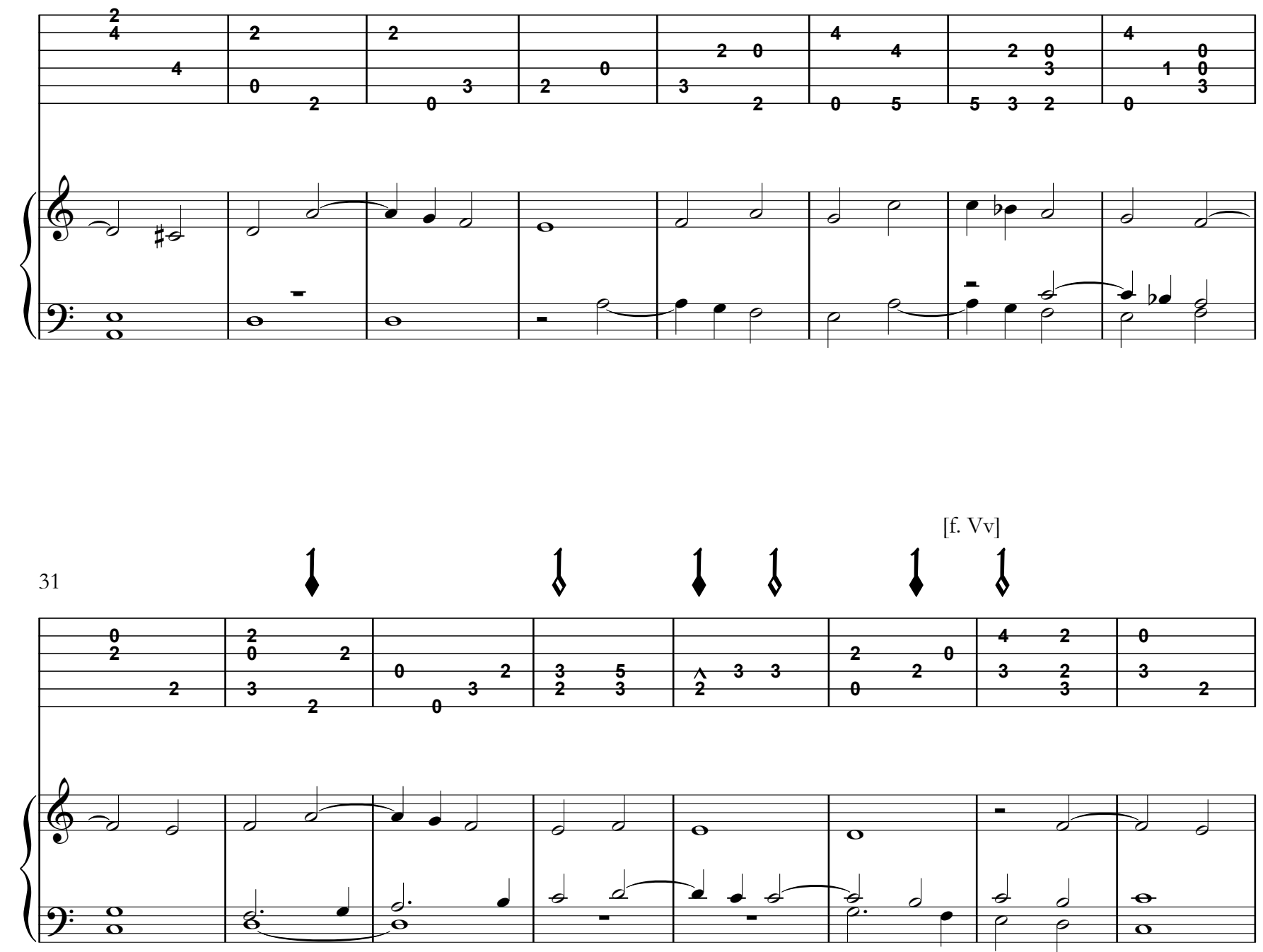

39

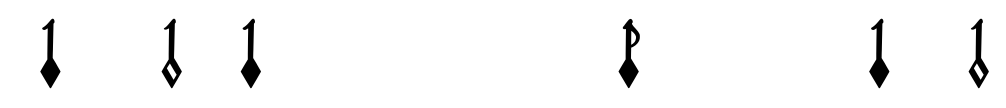

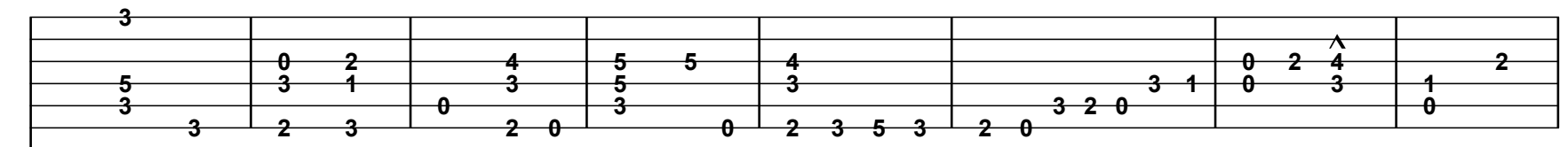

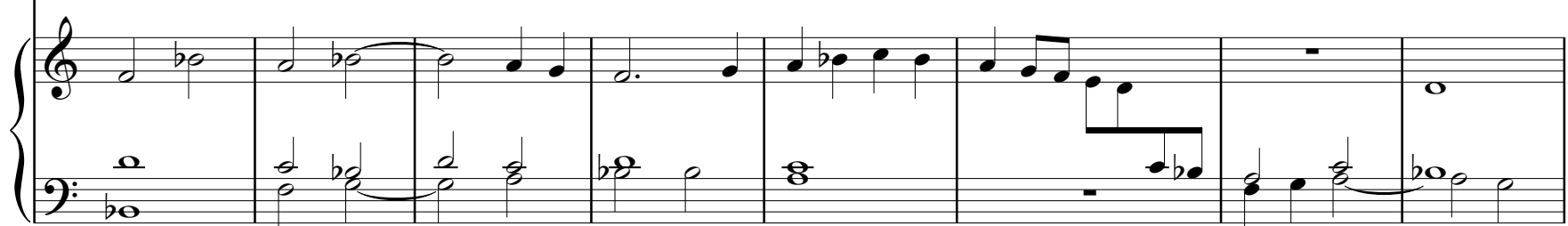



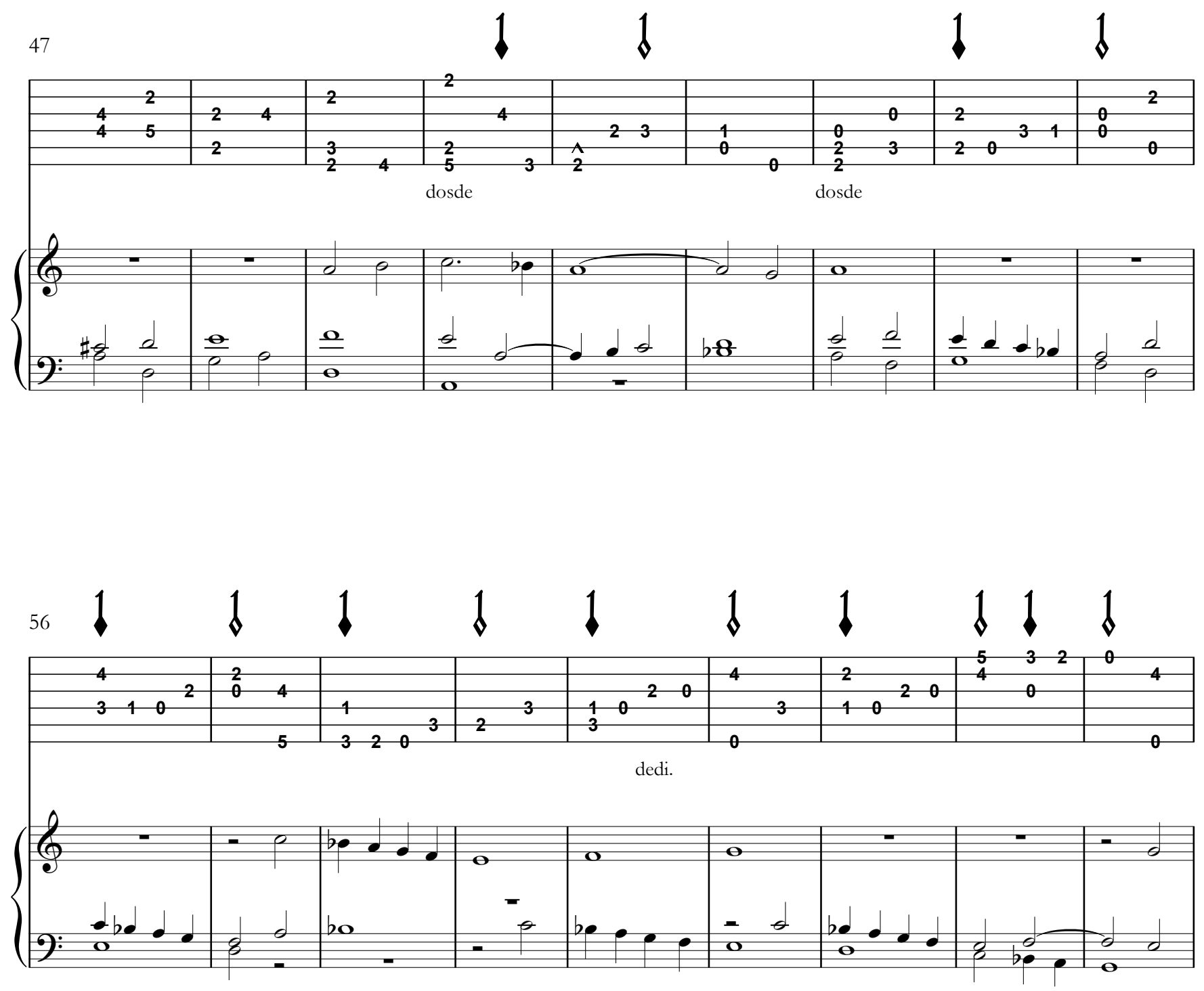

65
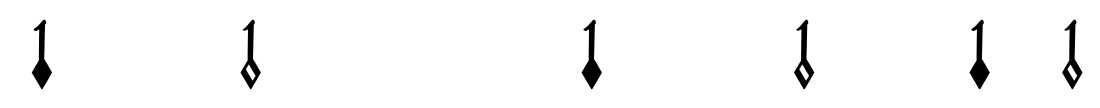

@
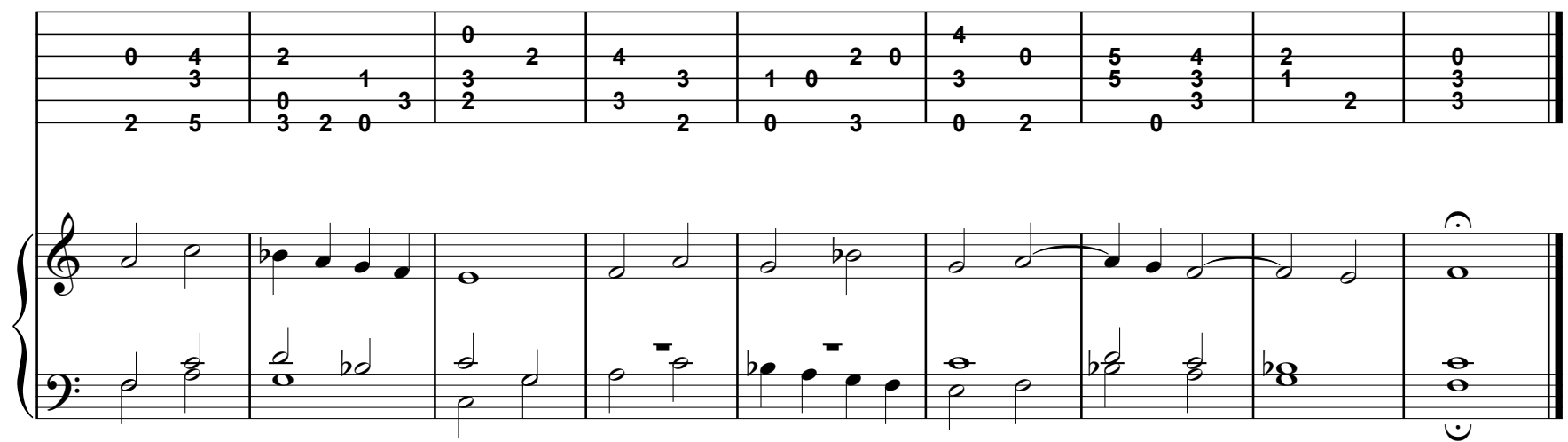


\title{
sov 6 - Fantasía 6
}

\author{
Fantasía fácil
}

[Libro I, f. VI]
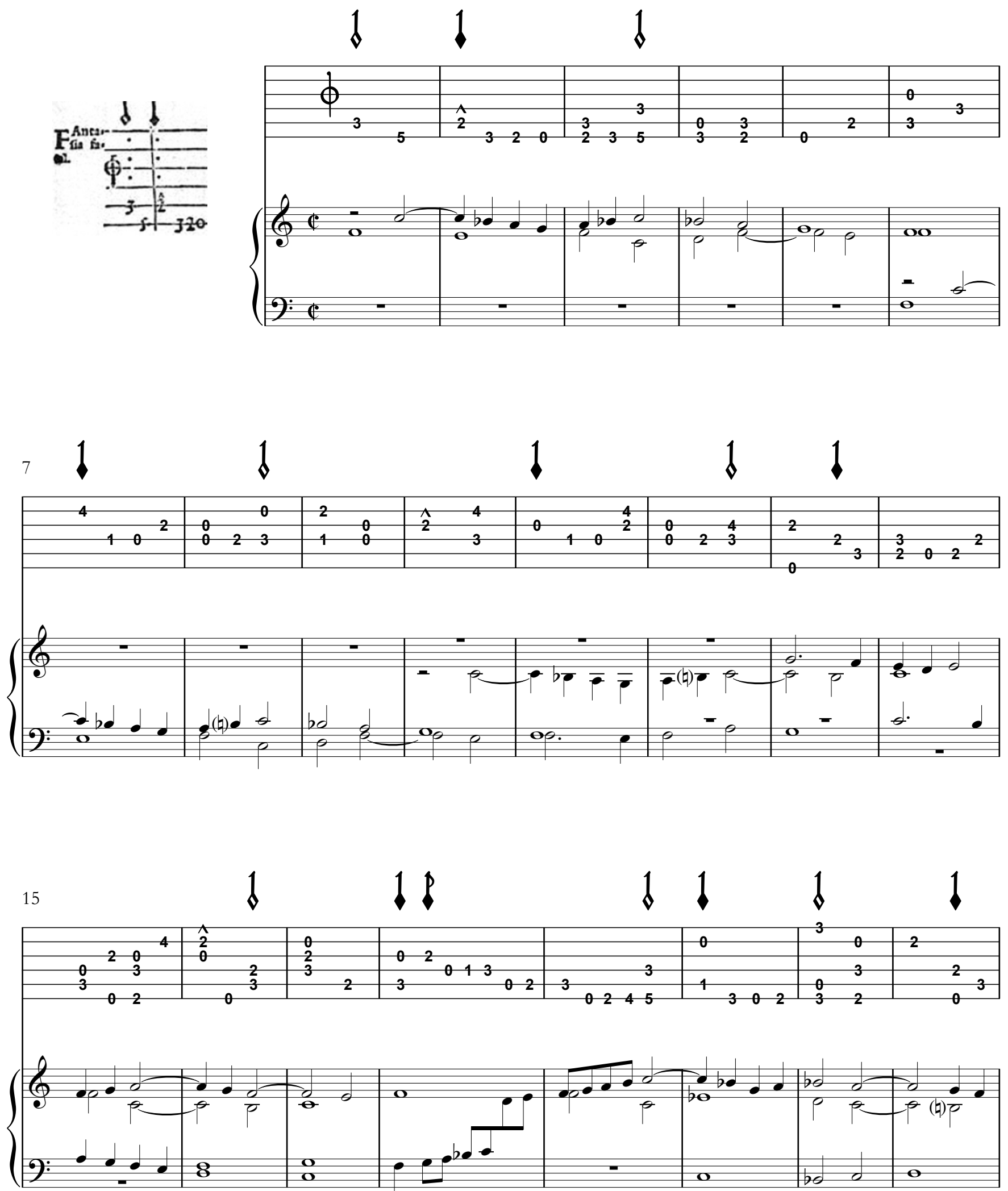

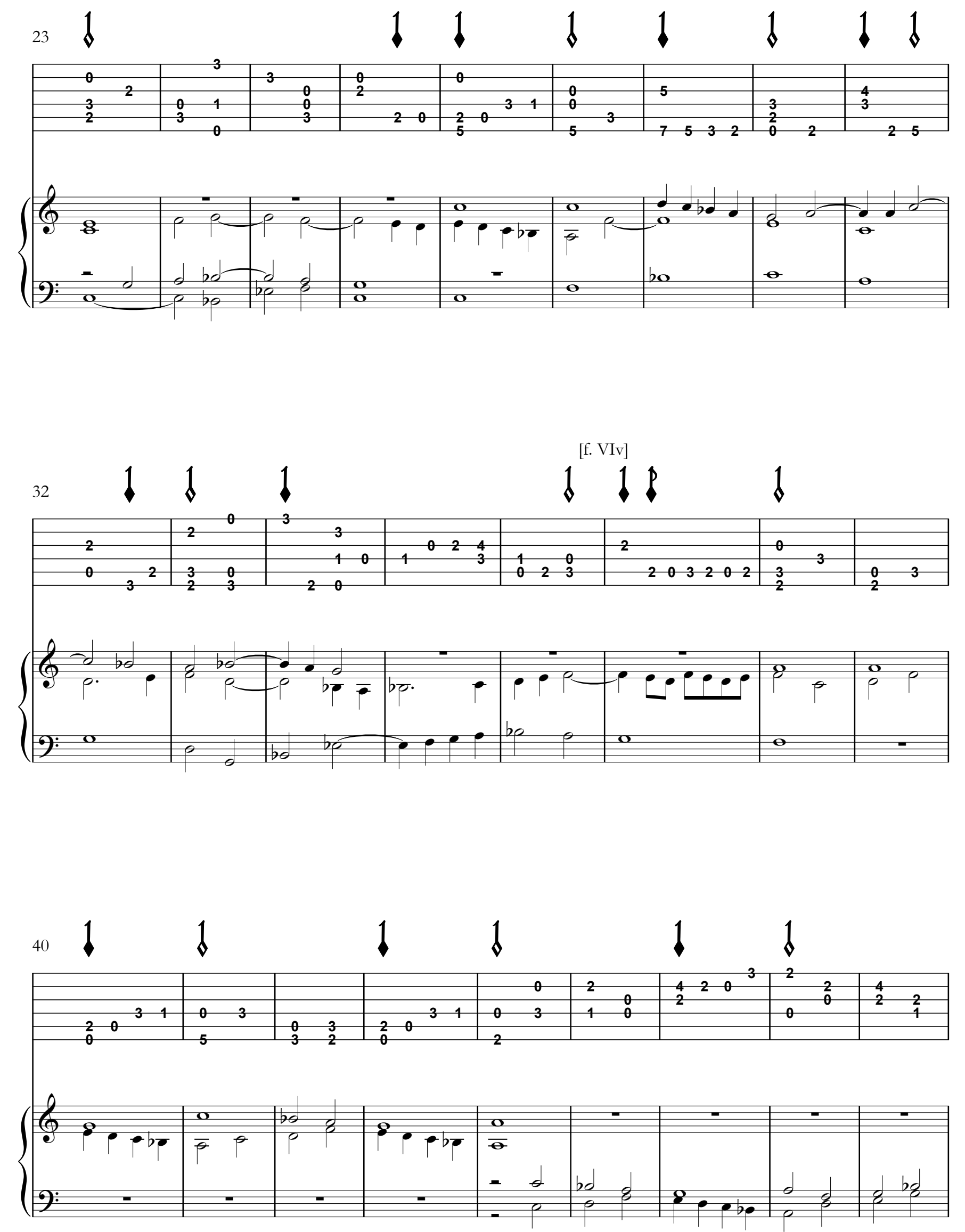

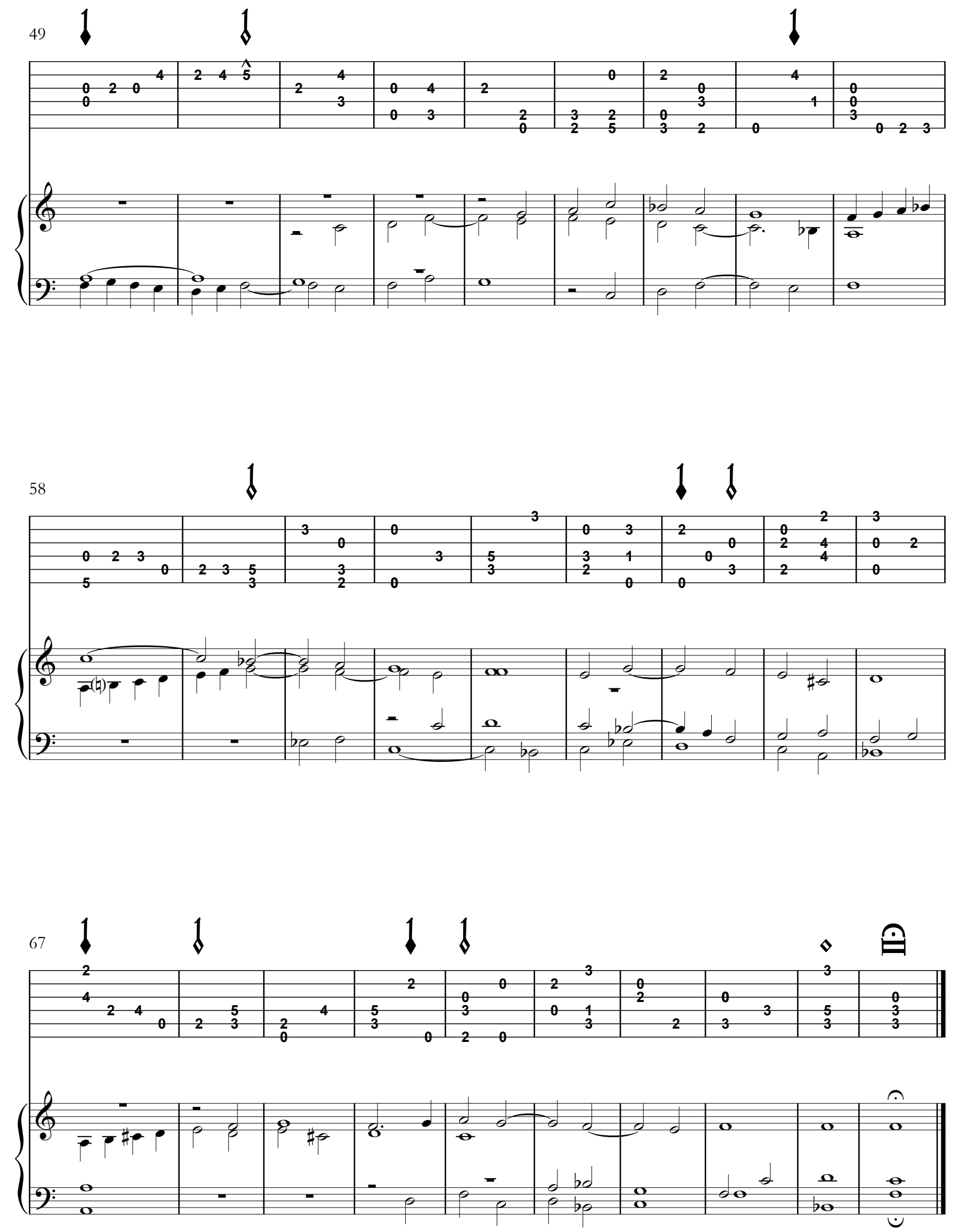


\title{
sov 7 - Fantasía 7
}

\author{
Fantasía fáci
}

[Libro I, ff. VII-VIII]

1. 11
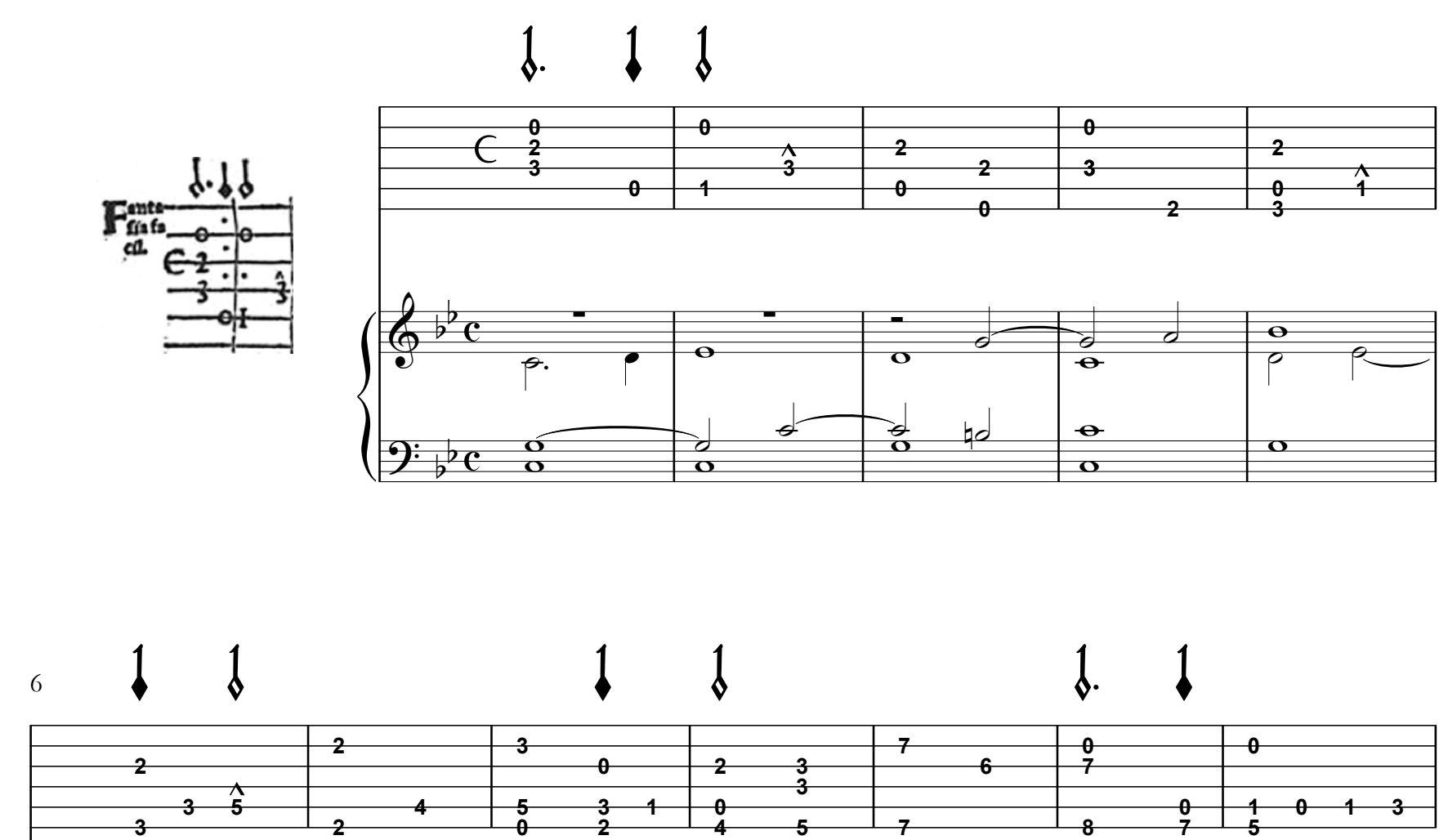

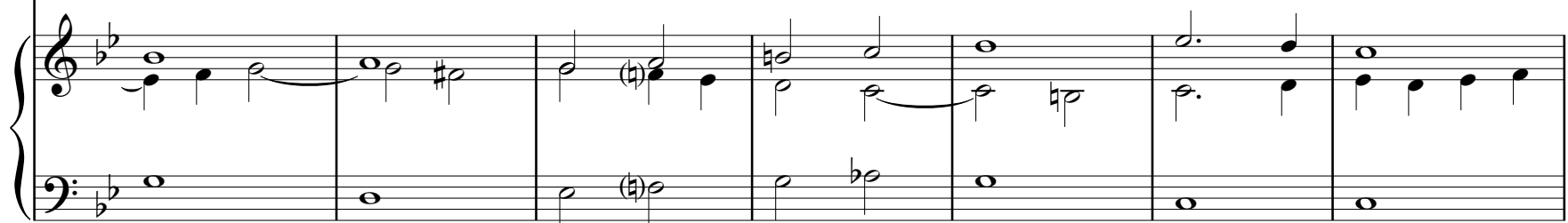
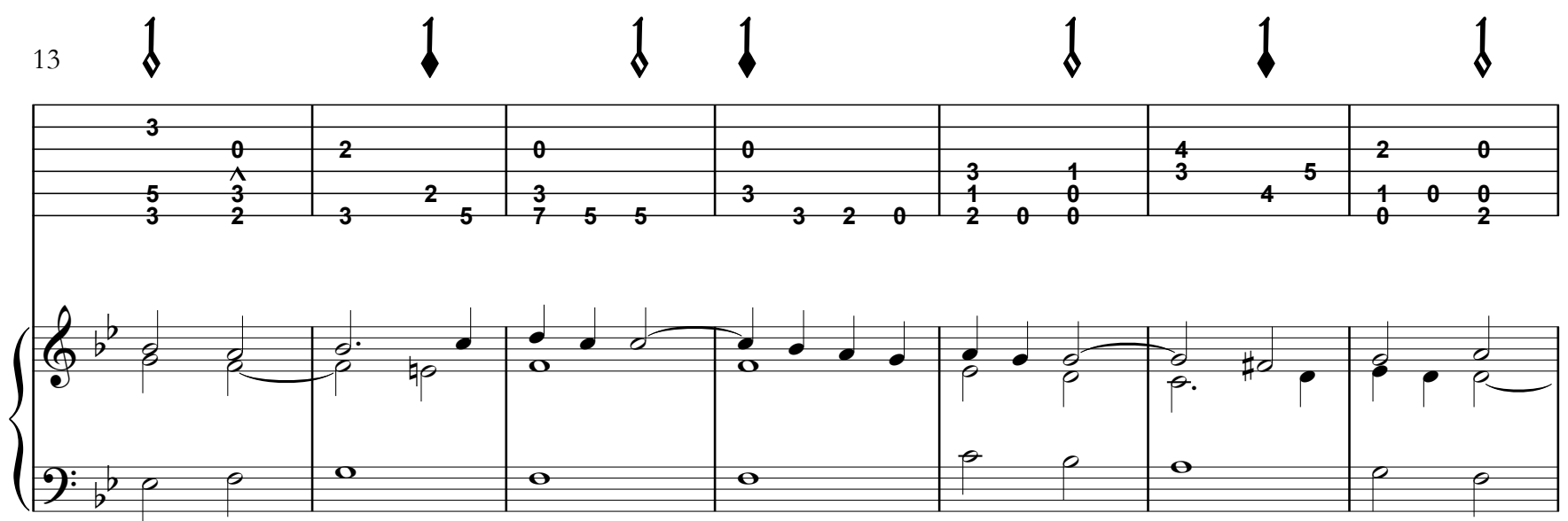

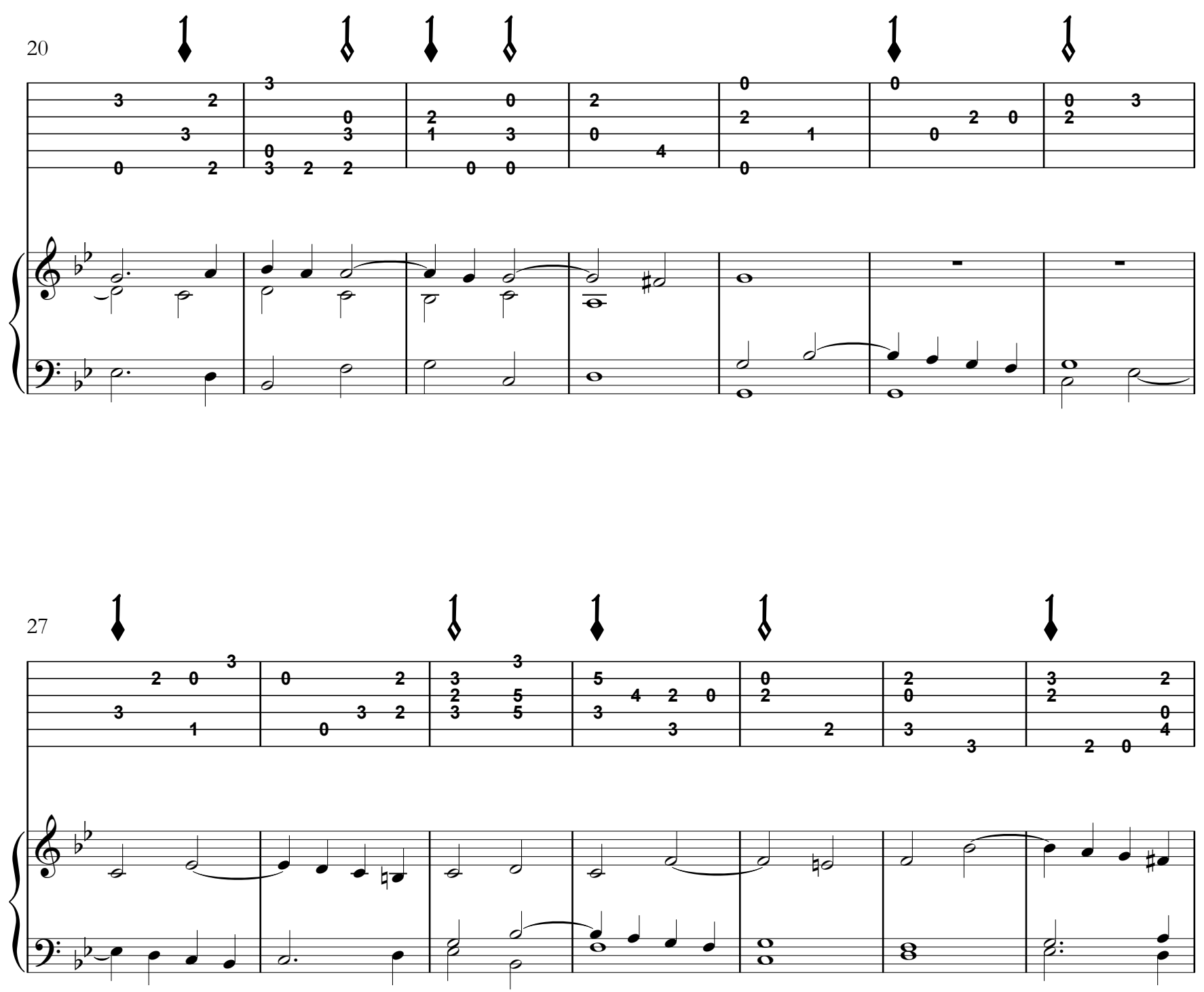

34
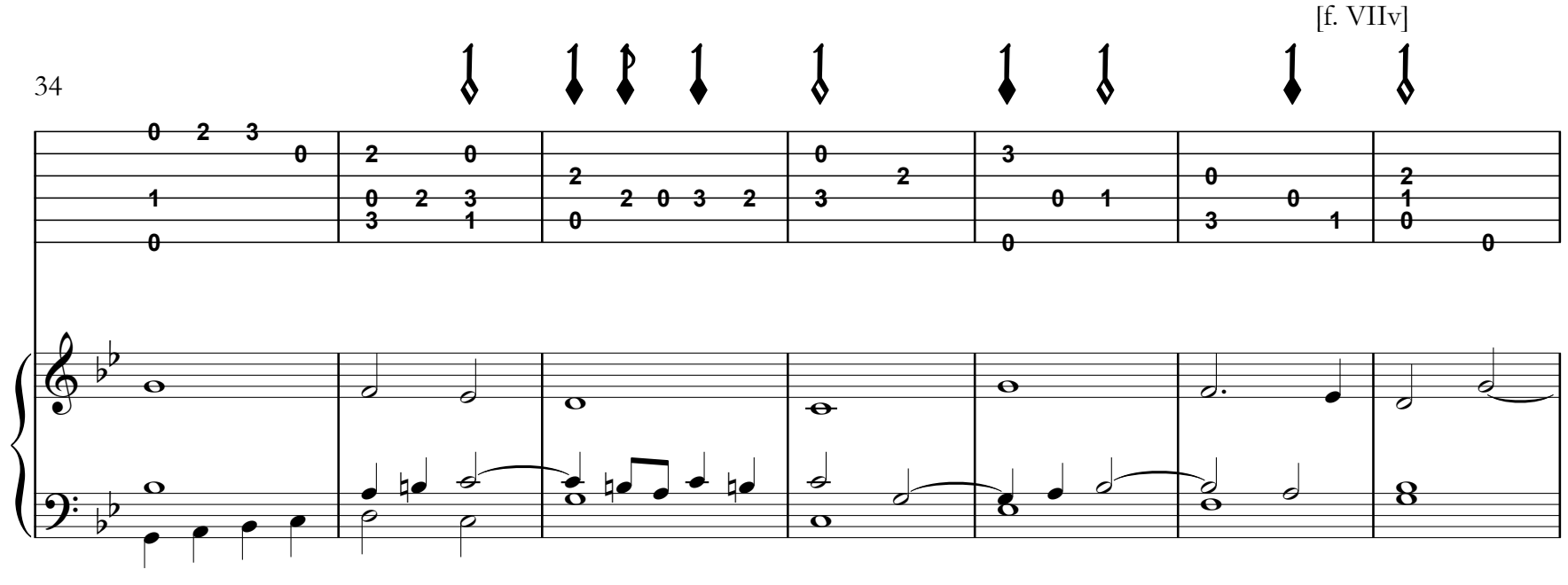

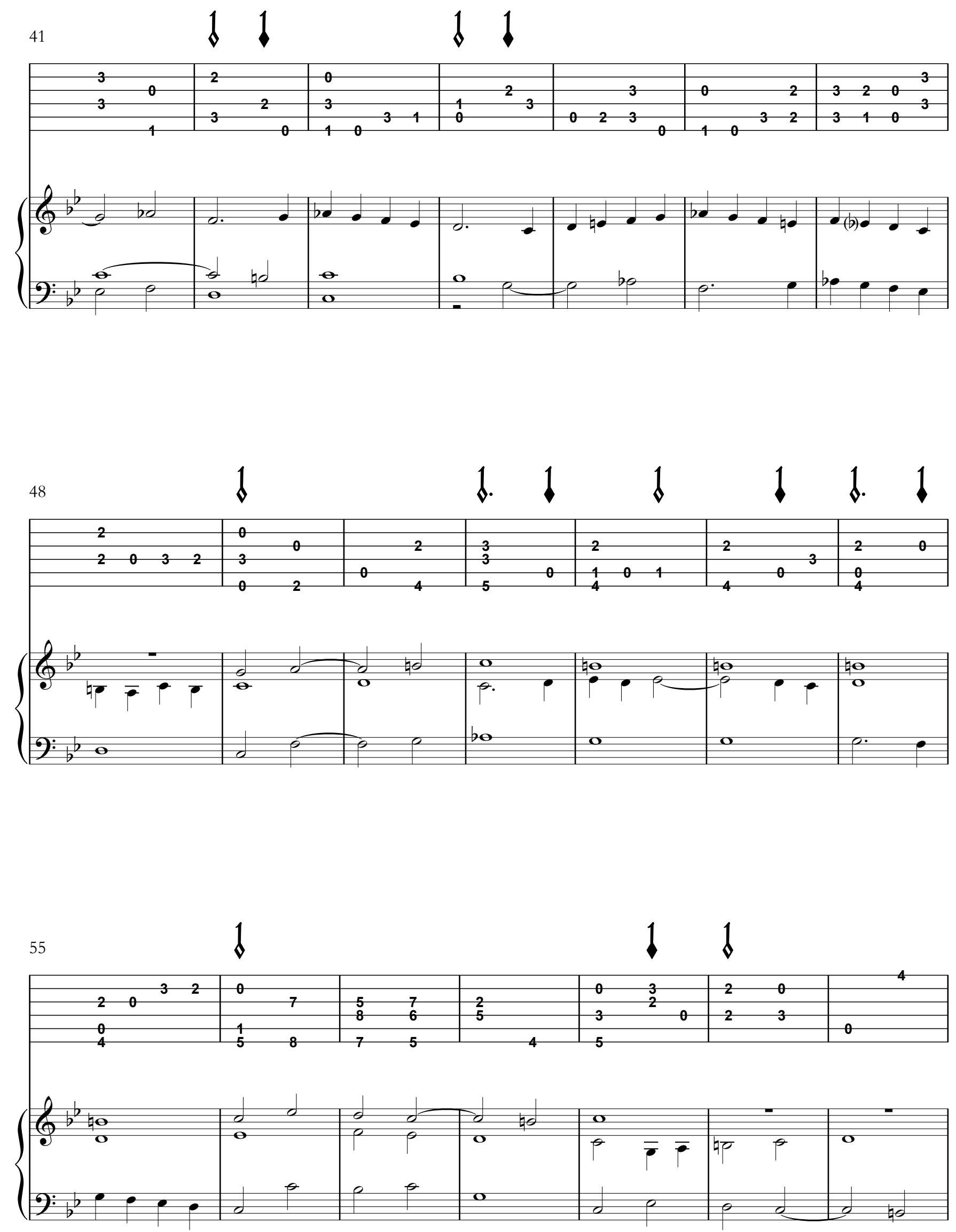


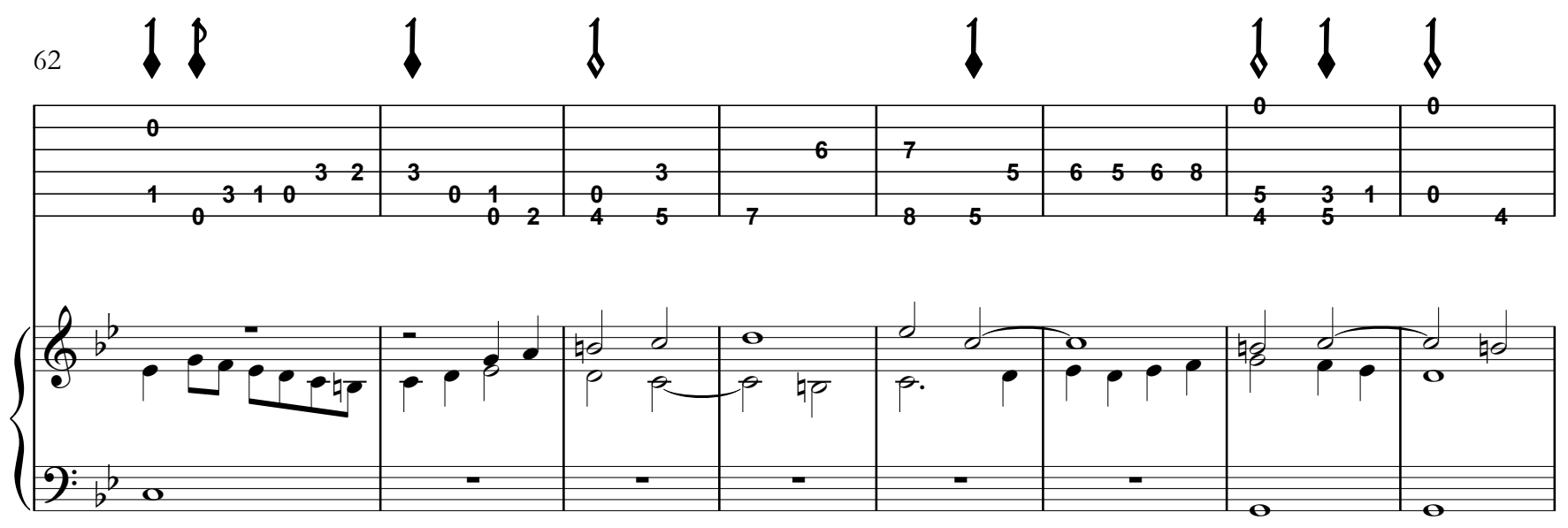

[f. VIII]
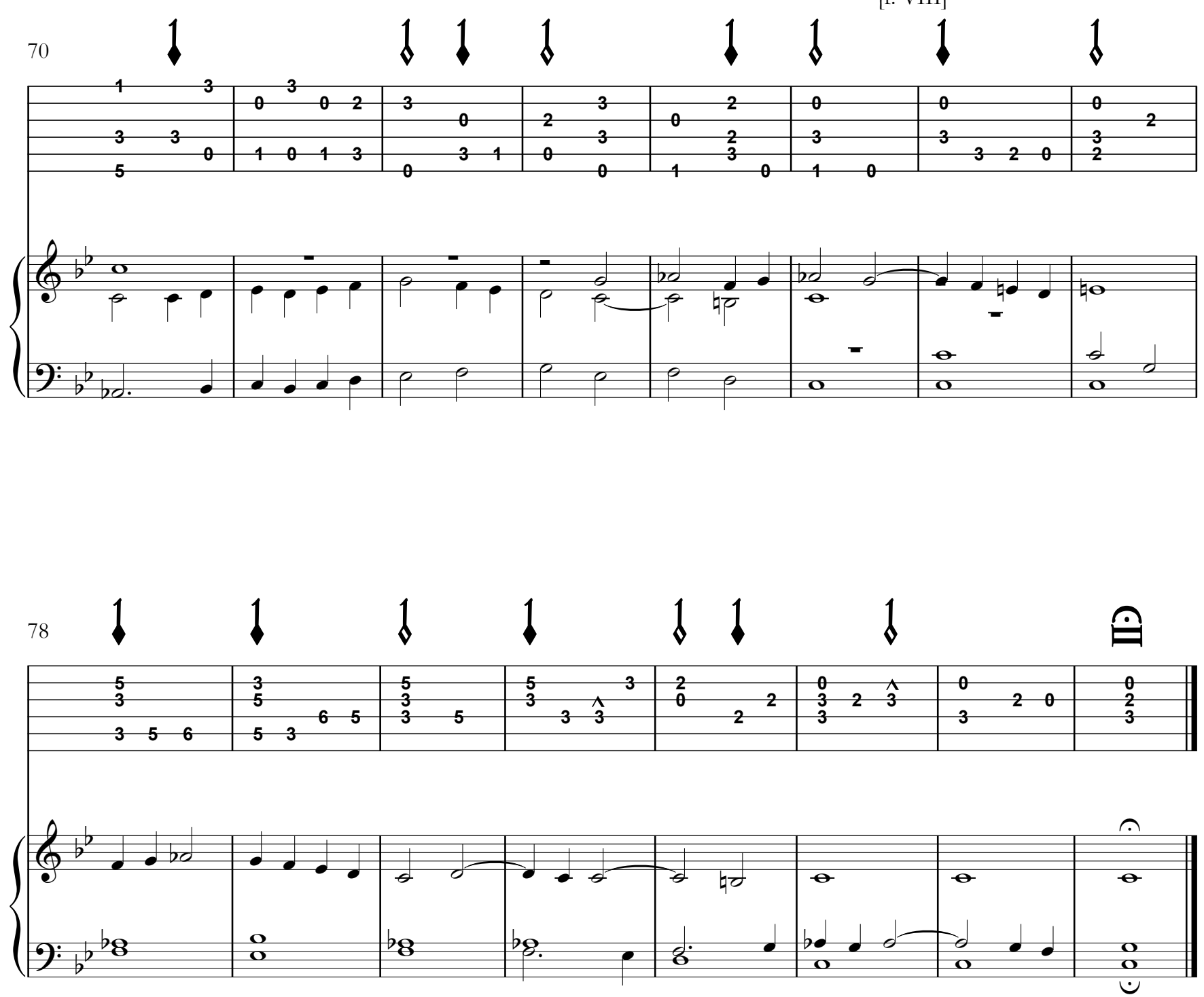


\section{sฯ8 - Fantasía 84}

[Libro I, ff. VIII-IX]
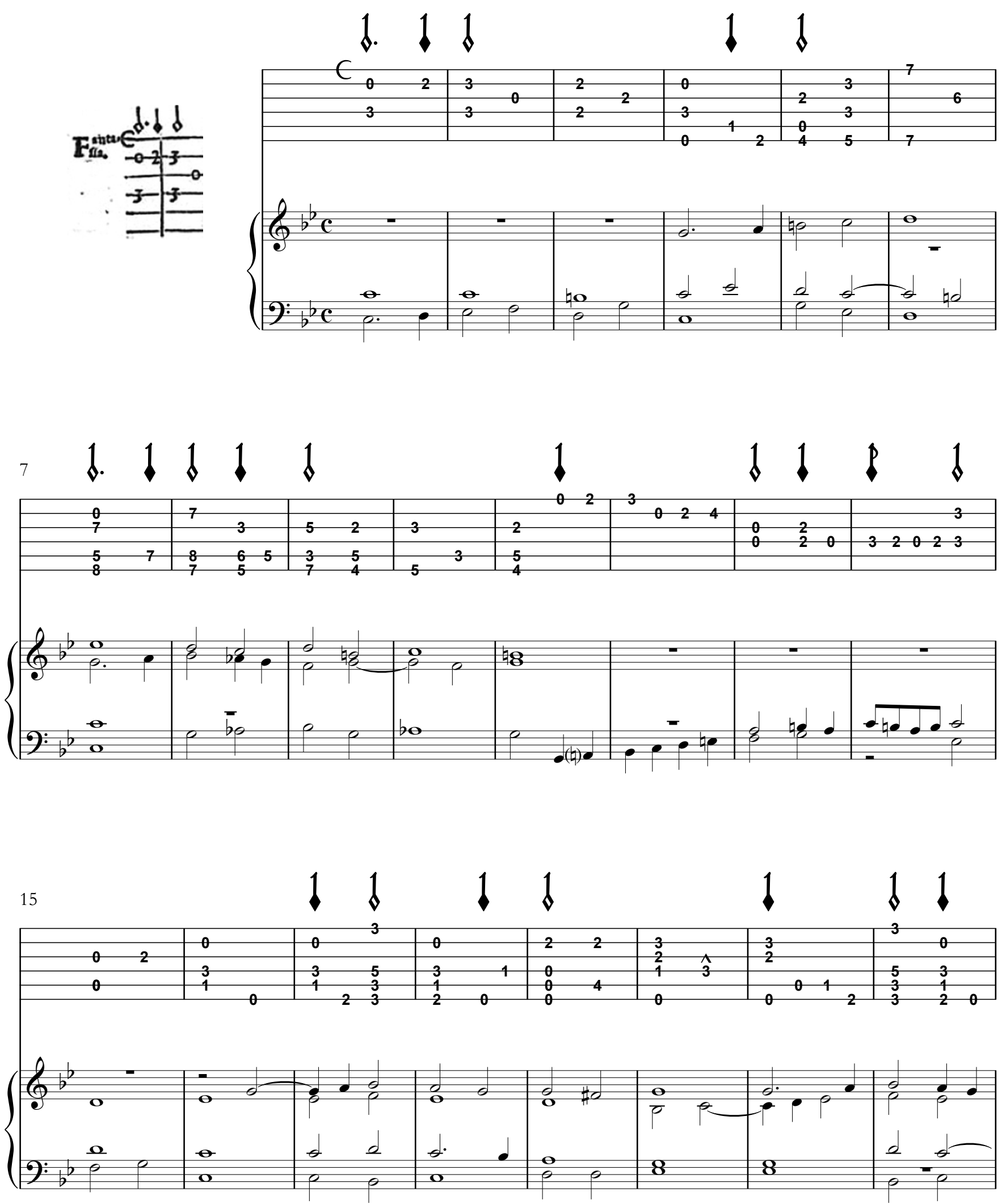
[f. VIIIv]

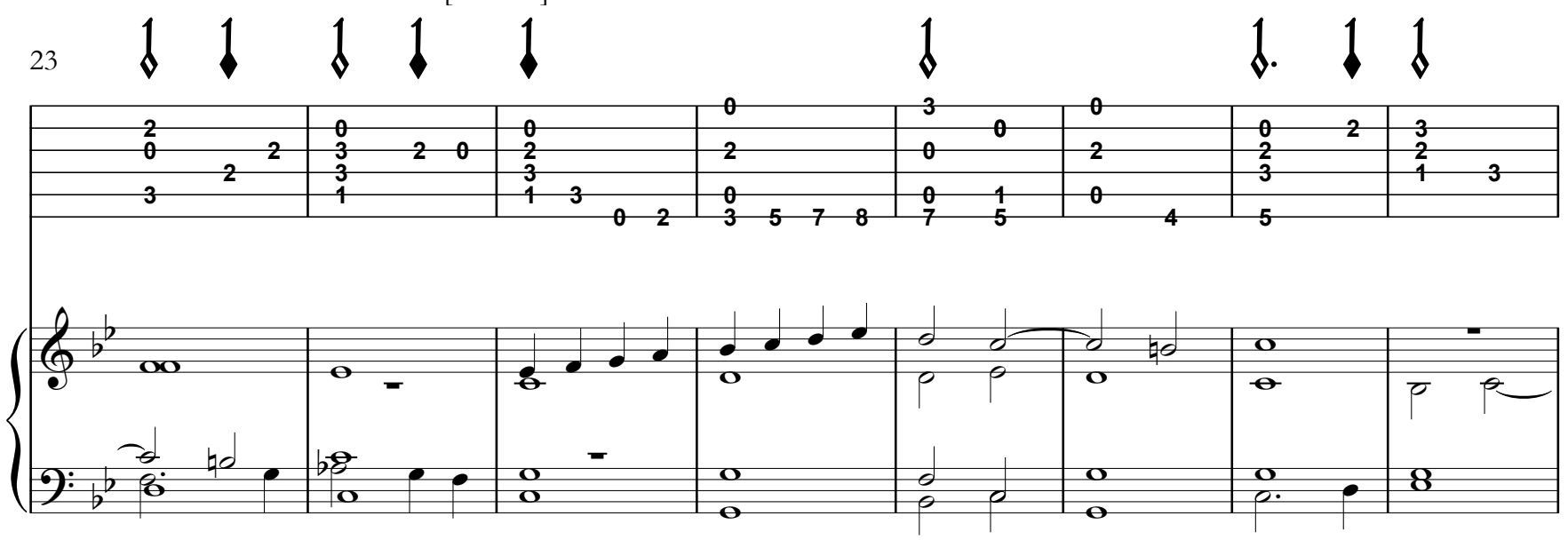
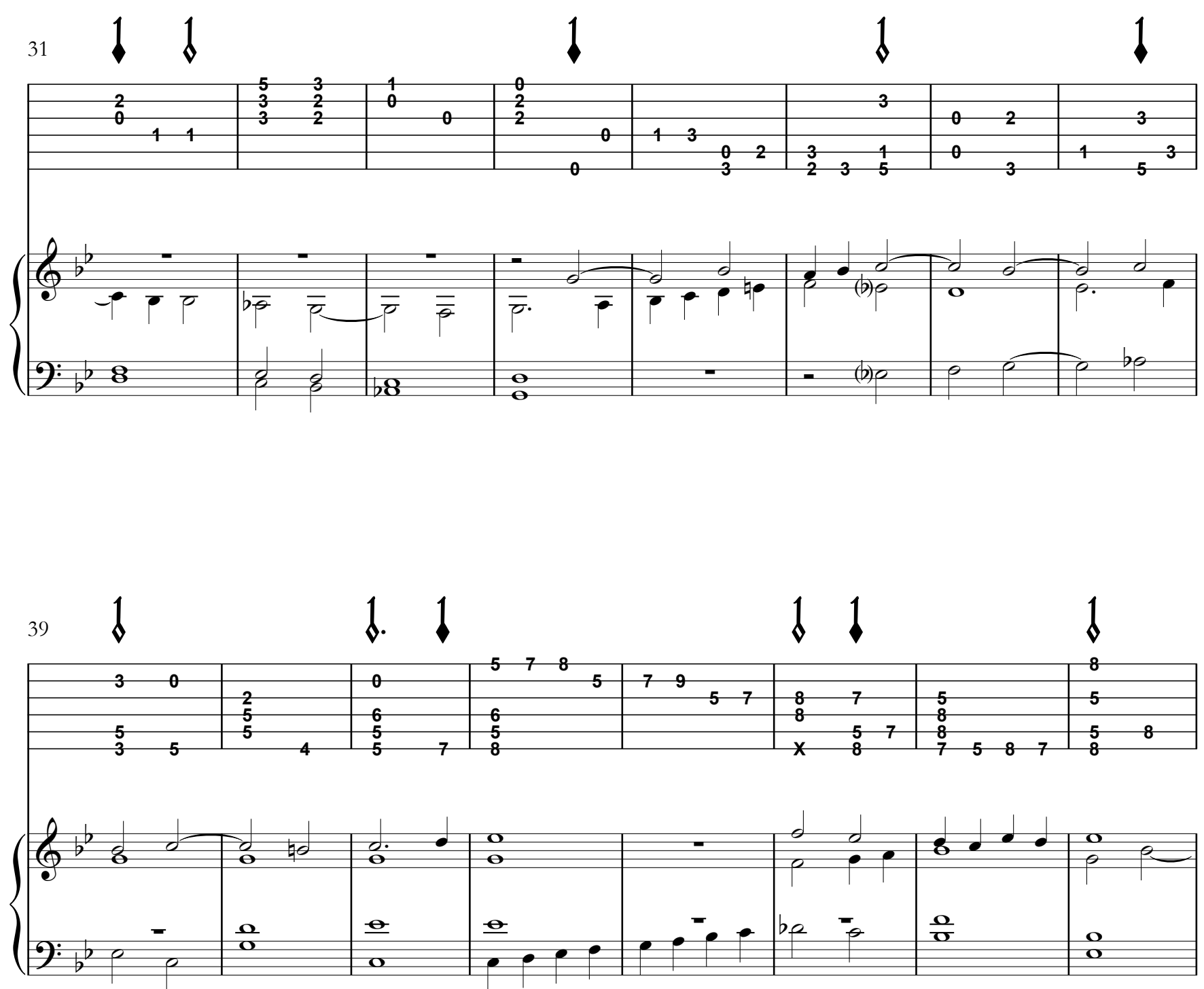


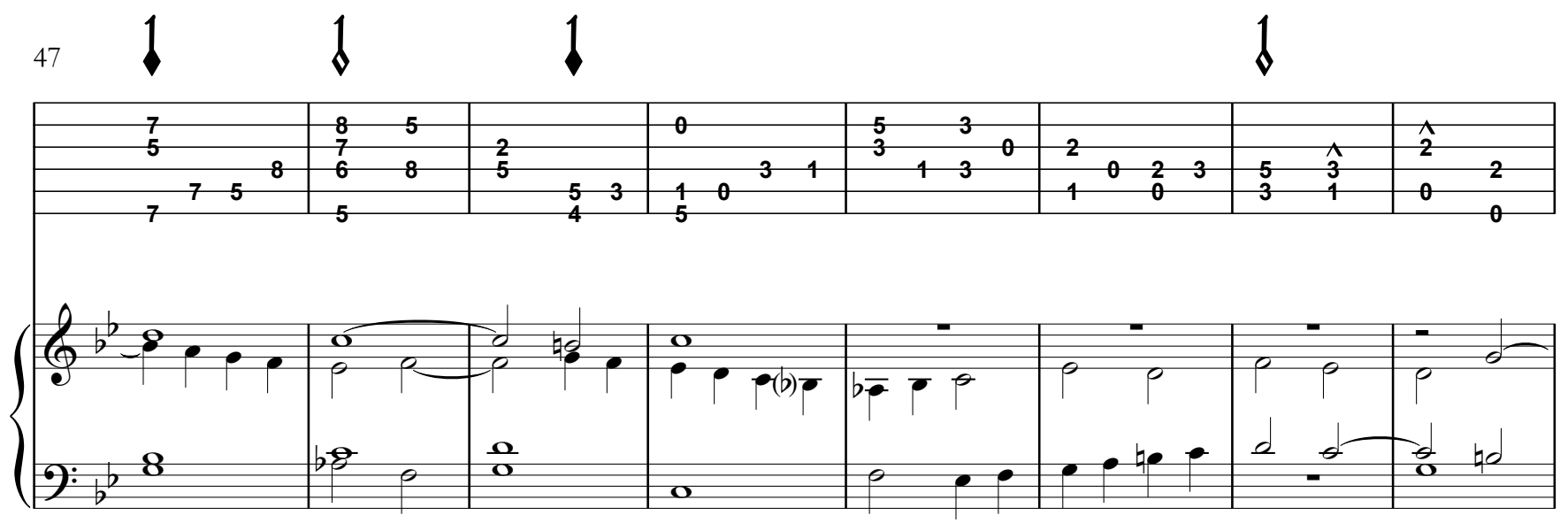

[f. IX]
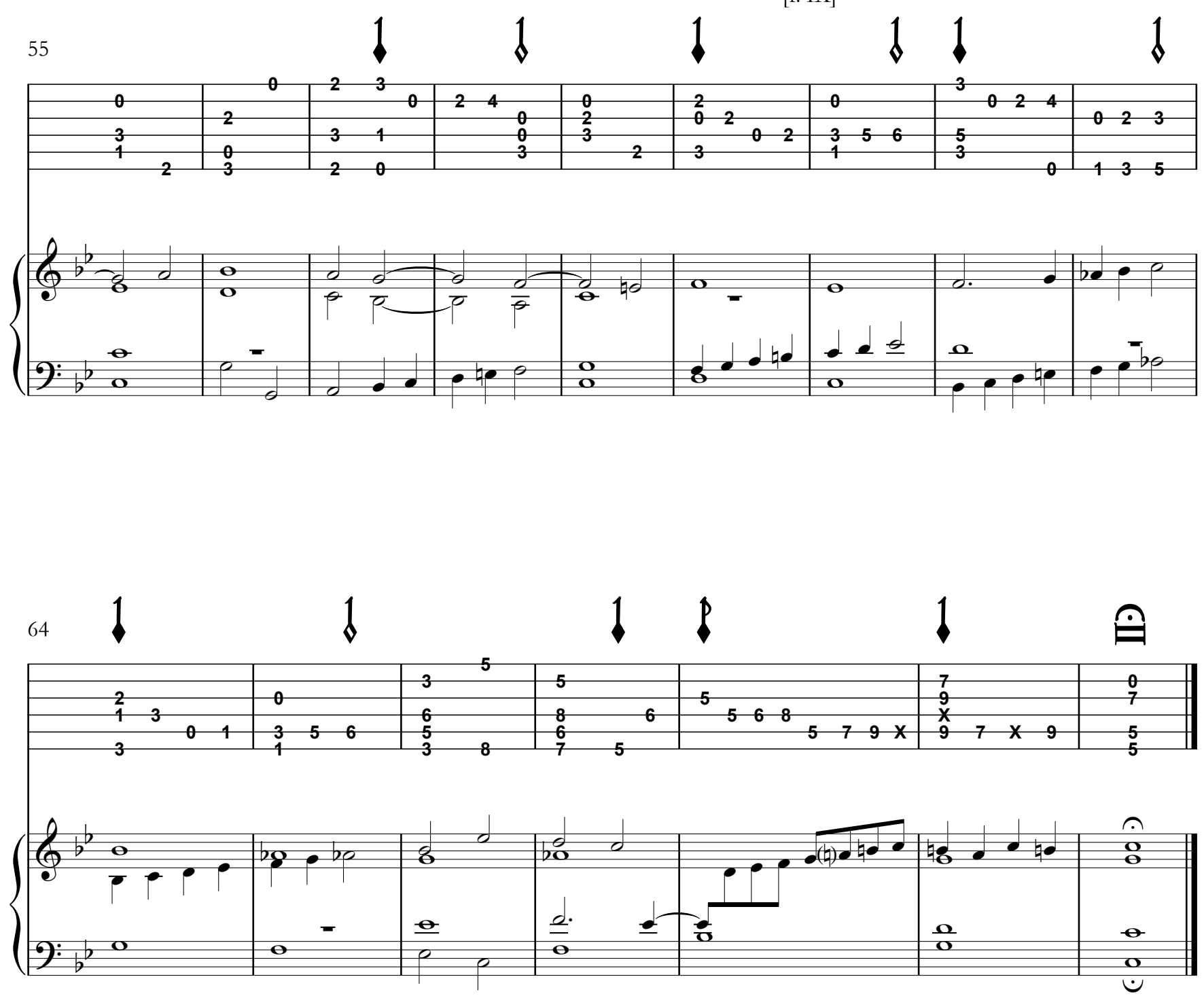


\section{so9 - Fantasía 9es}

\section{Fantasía}

[Libro I, ff. IX-X]
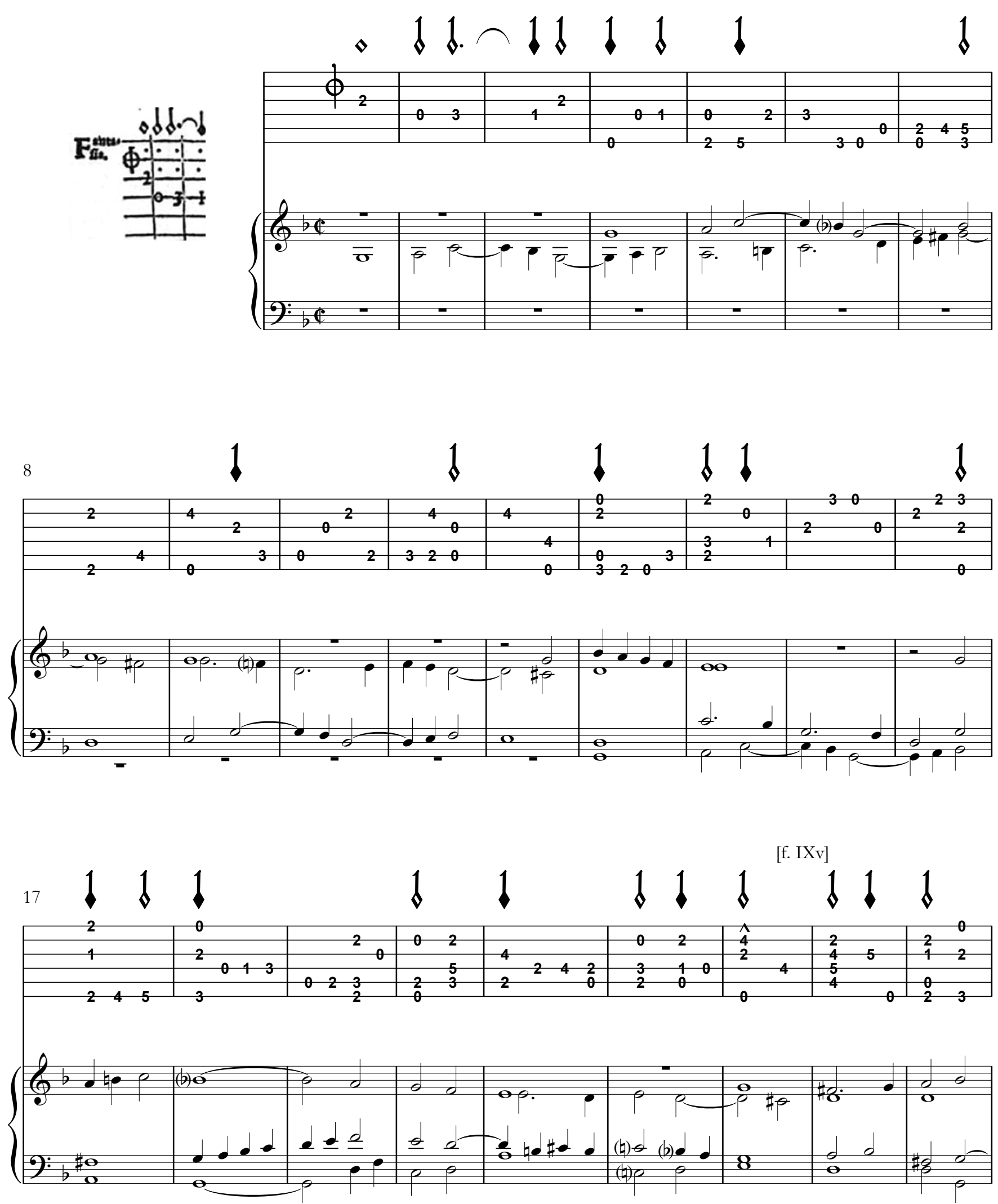

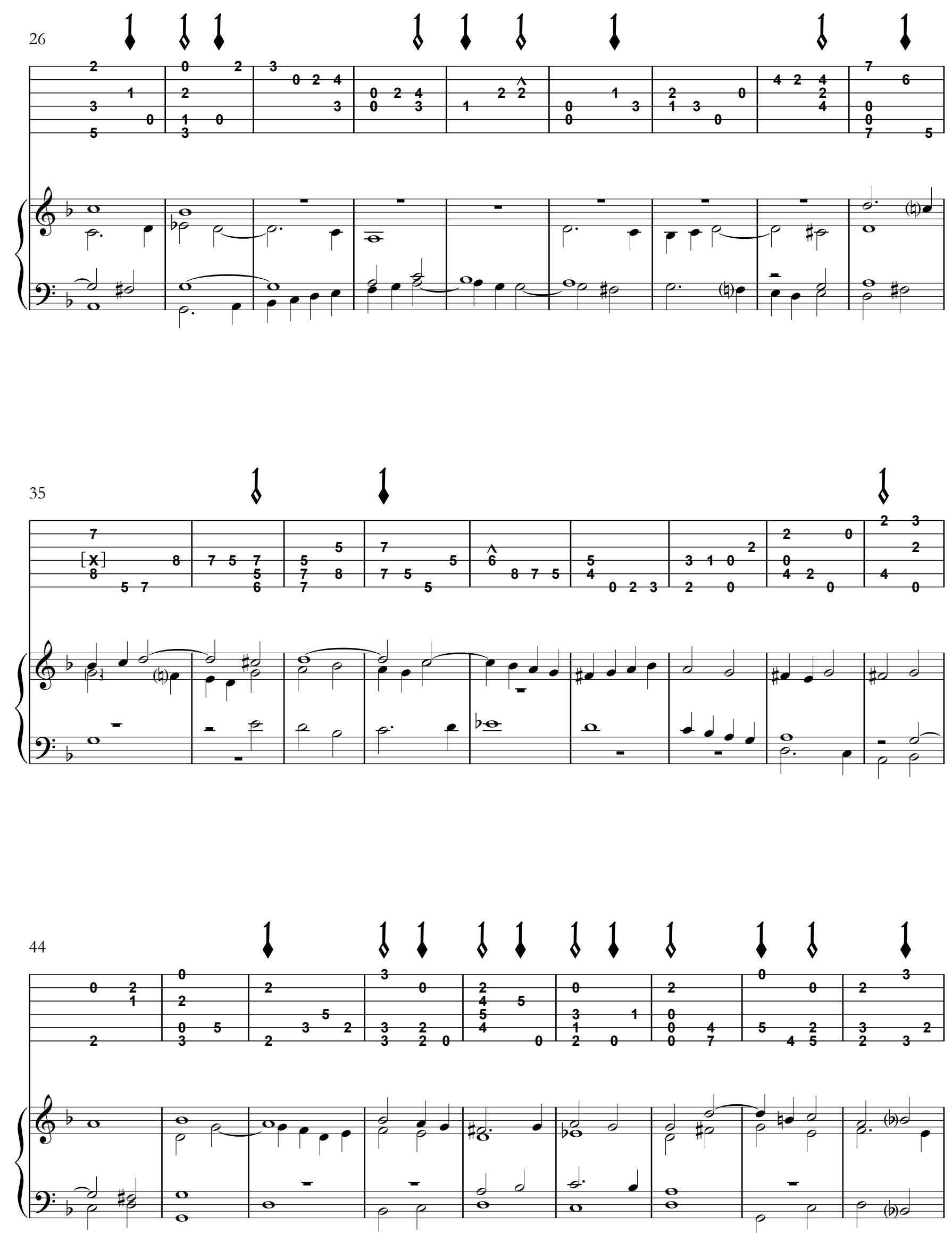

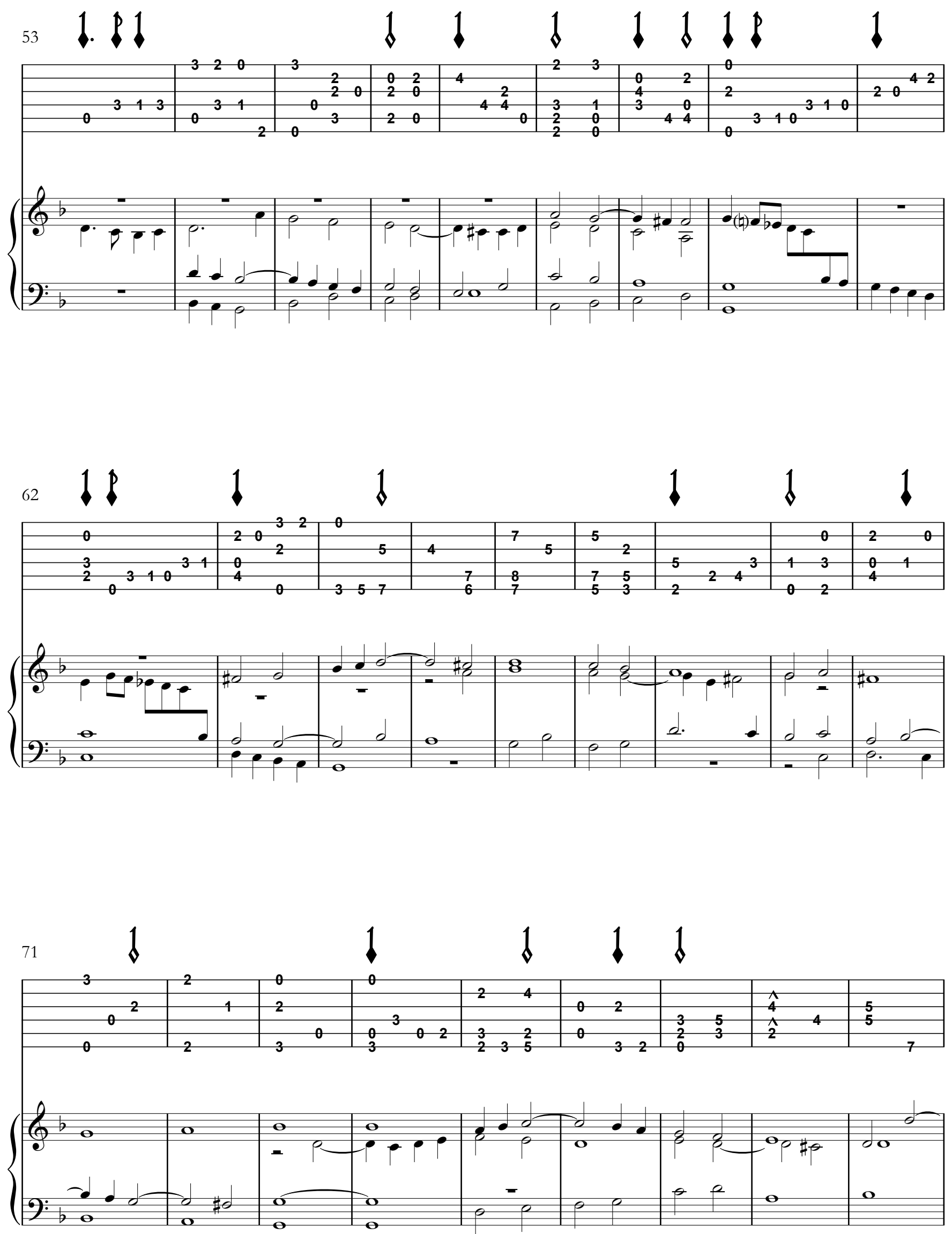


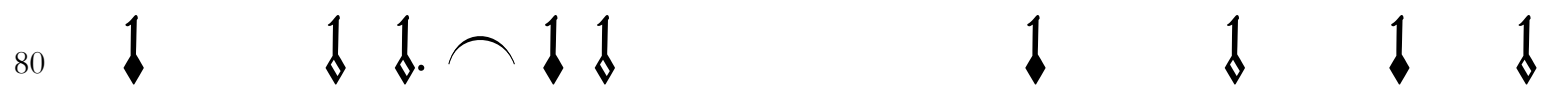

\begin{tabular}{|c|c|c|c|c|c|c|c|c|}
\hline & & & & 2 & {$\left[\begin{array}{lll}0 & 2 & 4 \\
\end{array}\right.$} & 4 & 22 & 4 \\
\hline 7 & $0 \quad 7$ & 9 & 4 & & {$[0] 2-7$} & 0 & 0 & 2 \\
\hline & $7 \quad x$ & 8 & 7 & 50 & 1 & 0 & & \\
\hline $\begin{array}{llll} & 5 & 7 & 9\end{array}$ & $\begin{array}{l}x \\
x\end{array}$ & 77 & 6 & 17 & & & & \\
\hline
\end{tabular}
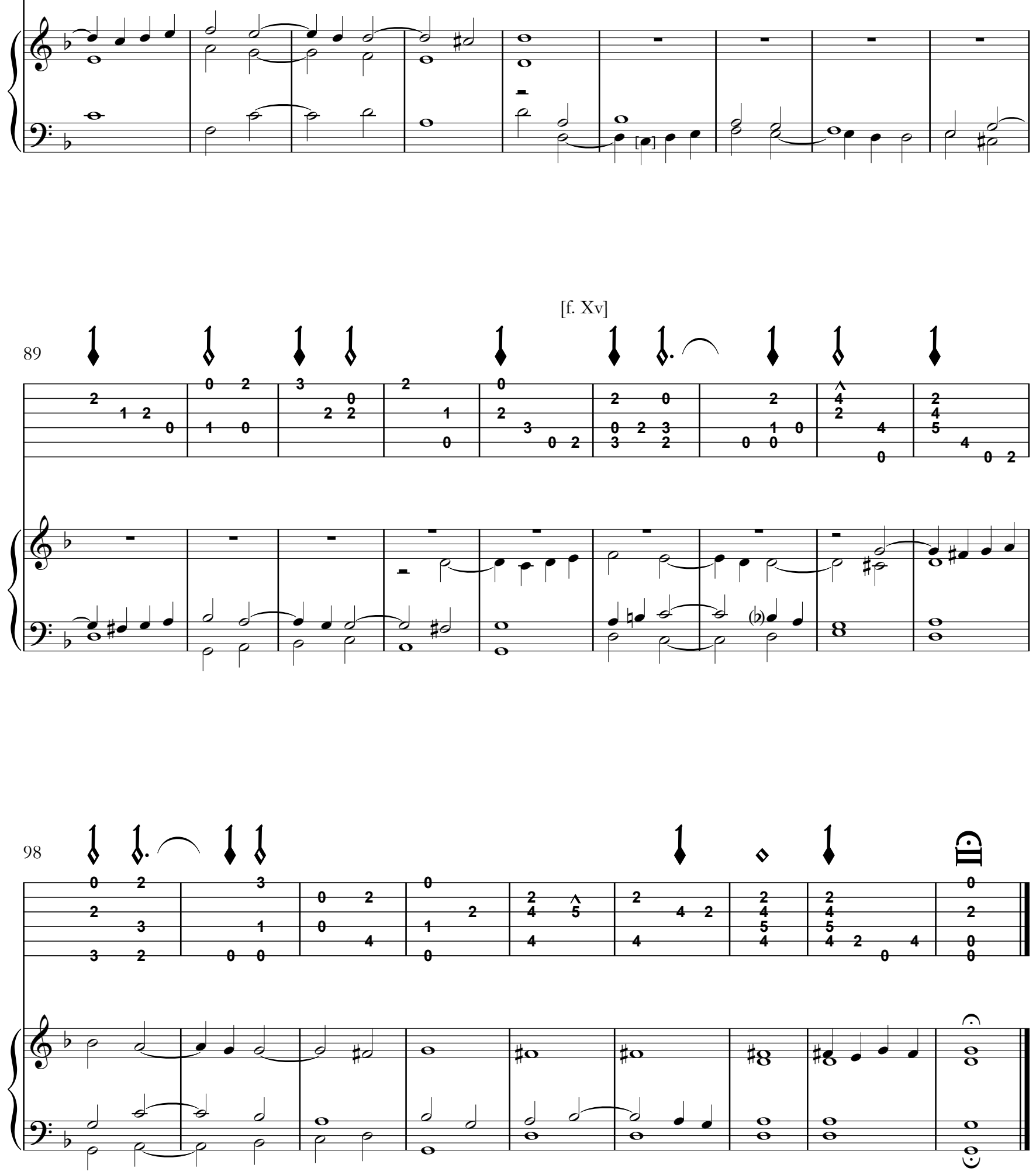


\section{s\&10 - Qui tollis}

La segunda parte de la gloria de la misa de faysan regres de Iosquin [Libro I, ff. Xv-XII]

Josquin/Mudarra
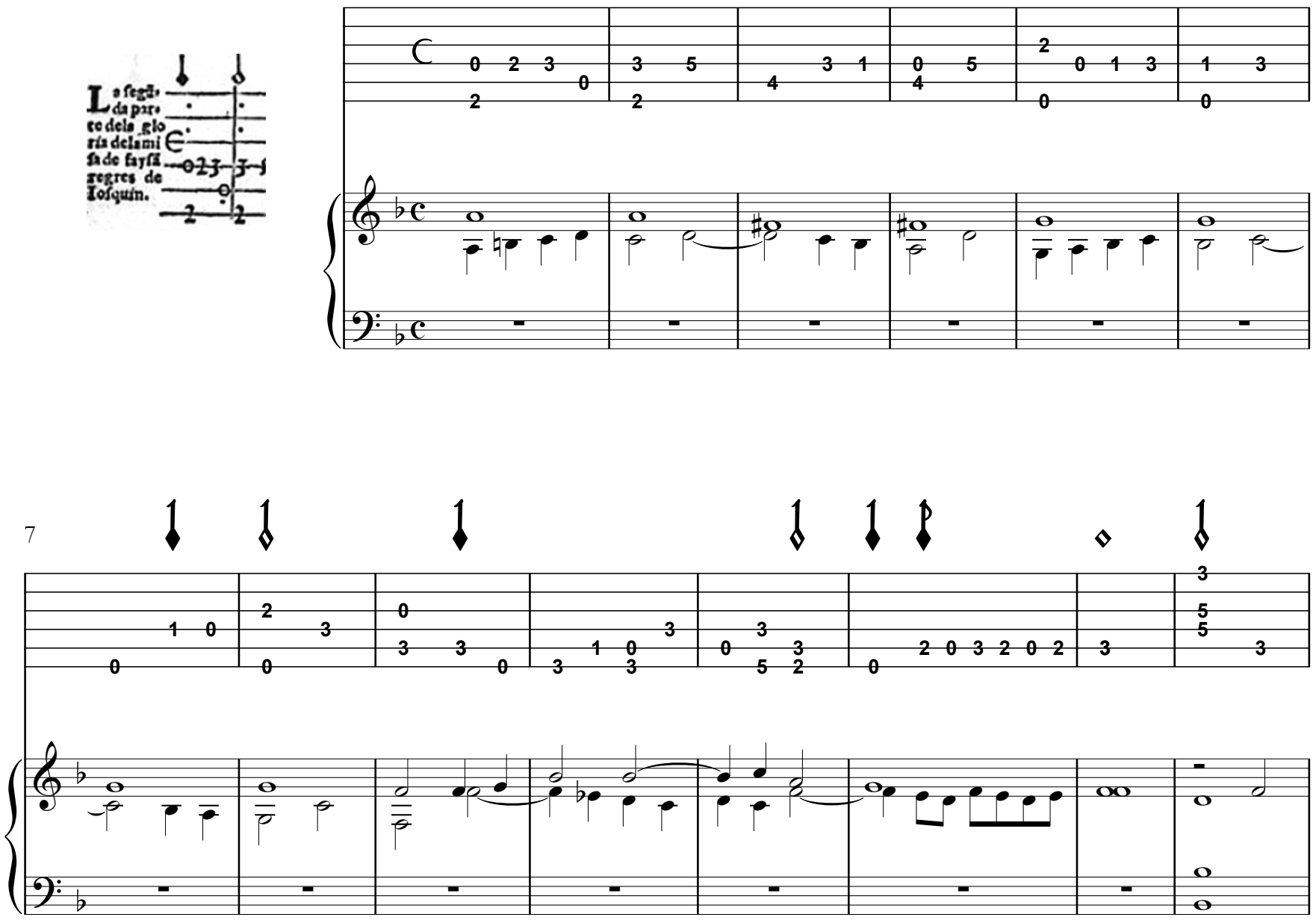

$15 \diamond$

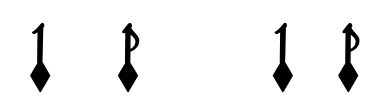

[f. XI]
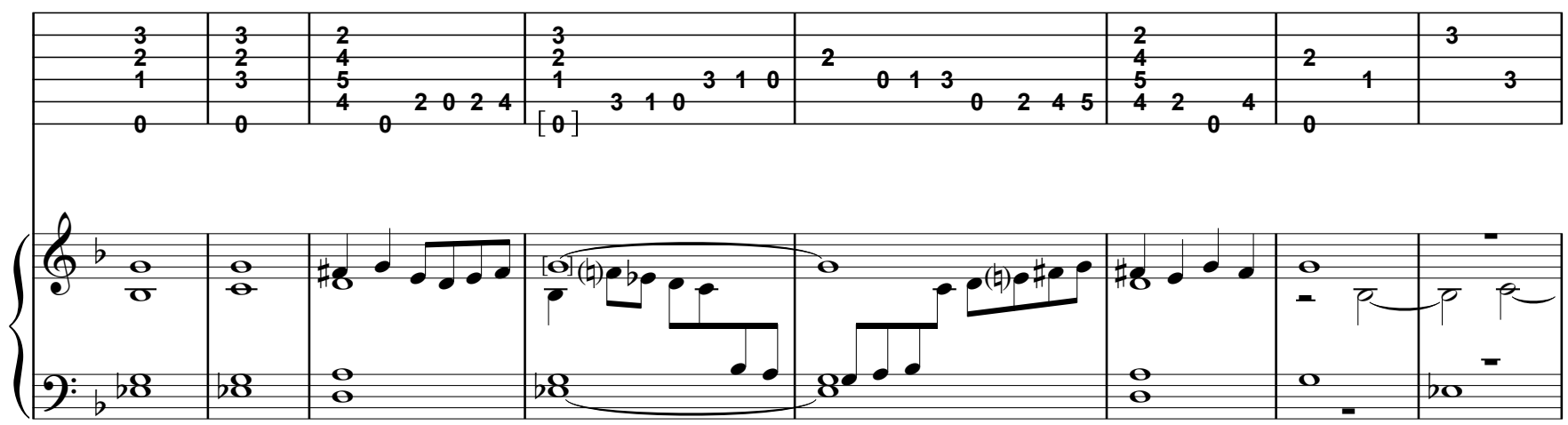
$23 \quad 1 \quad 1 \quad 1 \quad 1 \quad 1 \quad 1 \quad 1$

\begin{tabular}{|c|c|c|c|c|c|c|c|}
\hline 0 & 2 & 2 & 2 & $\begin{array}{lll}0 & 2 & 3\end{array}$ & & 320 & 2 \\
\hline $\begin{array}{lll}0 & 0 \\
& & 0\end{array}$ & $\begin{array}{ll}0 & 1 \\
& 1\end{array}$ & 0 & $\begin{array}{lll}2 & 0 & 2 \\
& & 0\end{array}$ & 3 & $\begin{array}{lll}2 & 3 & 0 \\
& 3\end{array}$ & 33 & $\begin{array}{lll}2 & 3 & 2\end{array}$ \\
\hline & & & & & 0 & 0 & \\
\hline
\end{tabular}

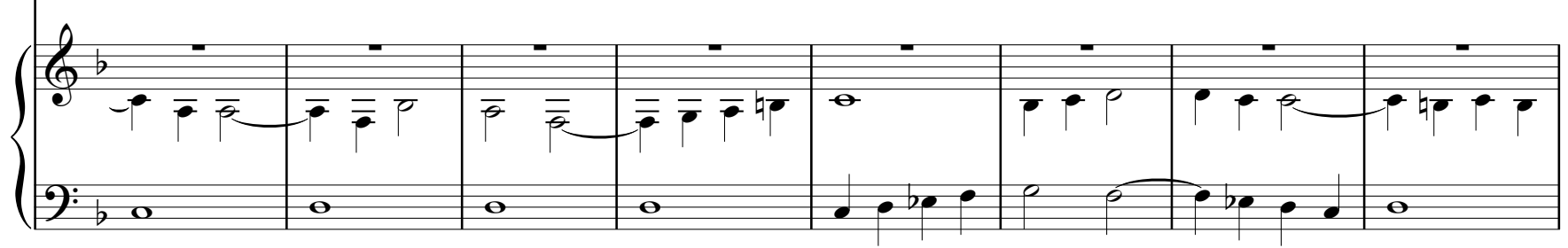
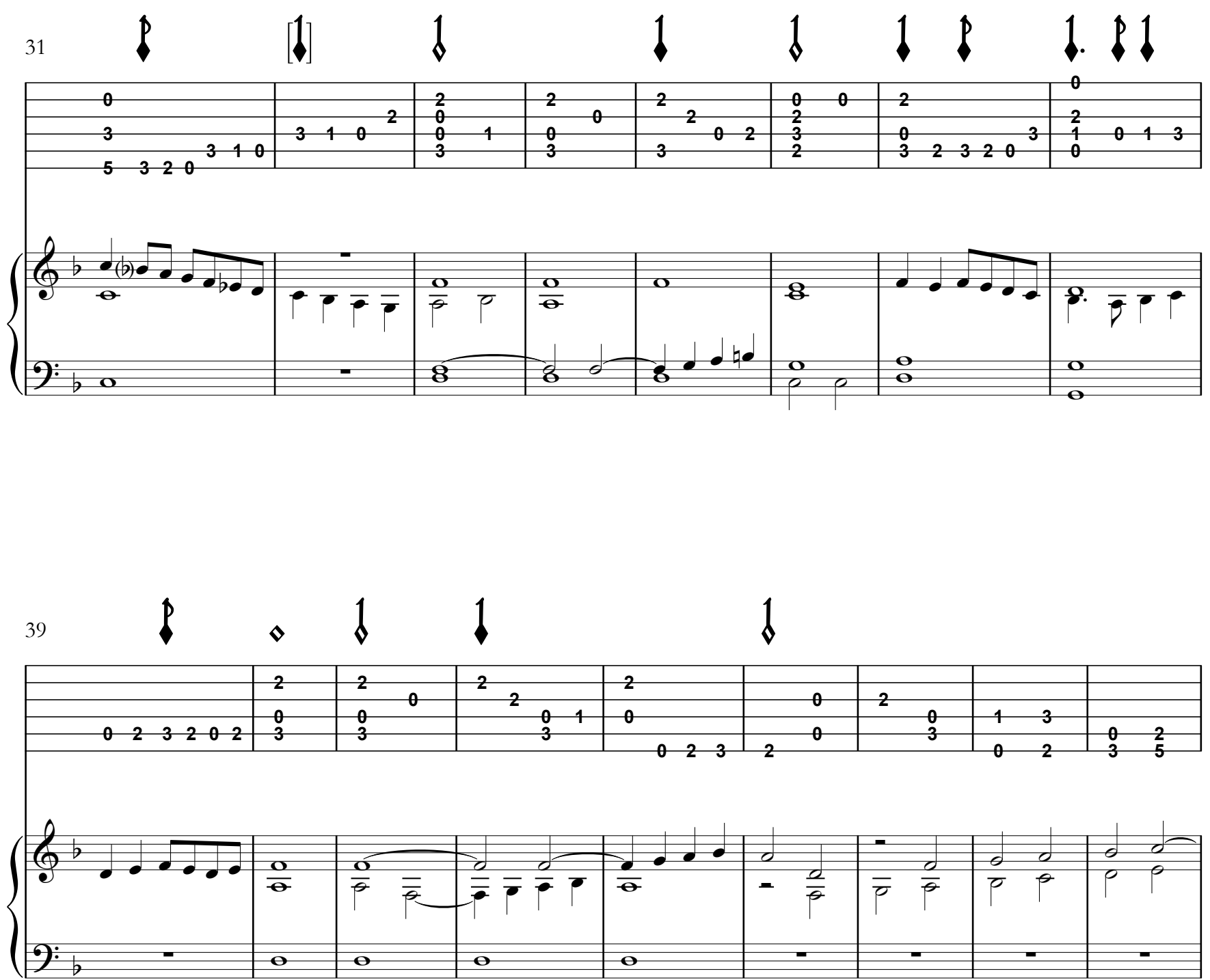


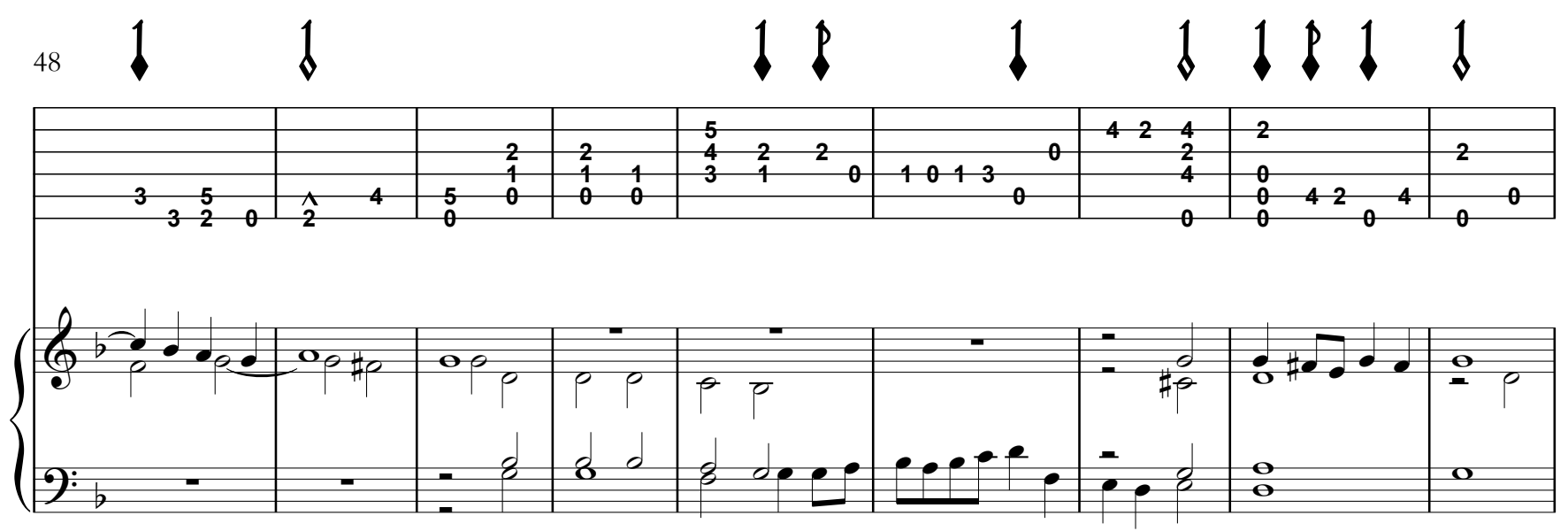

[f. XIv]

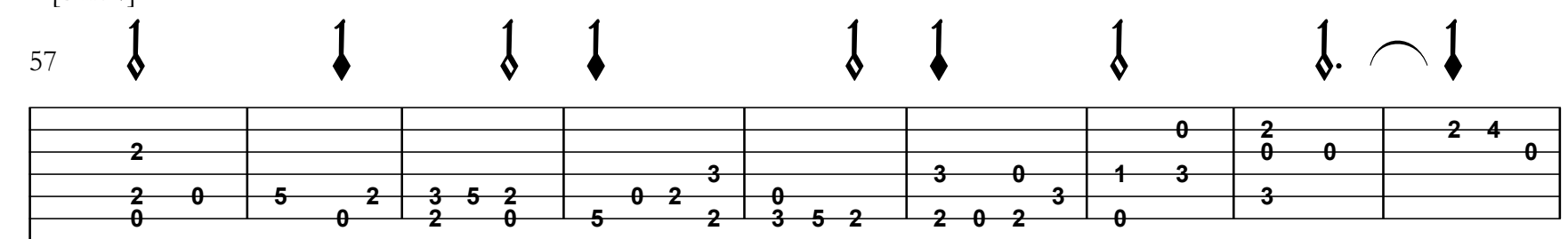

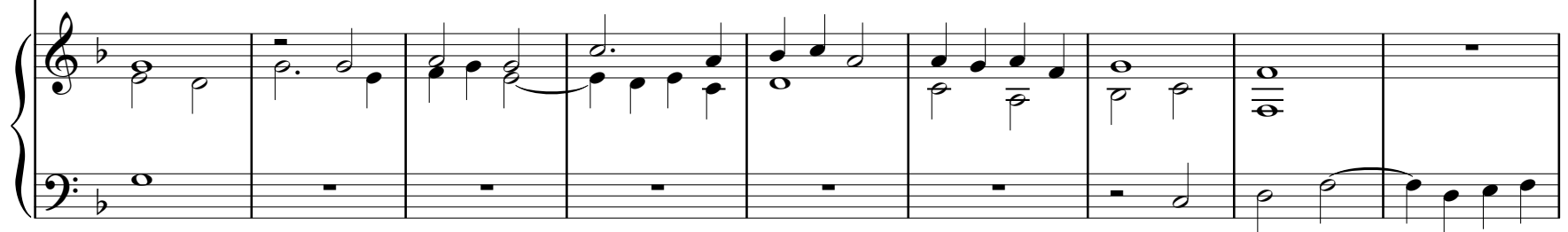

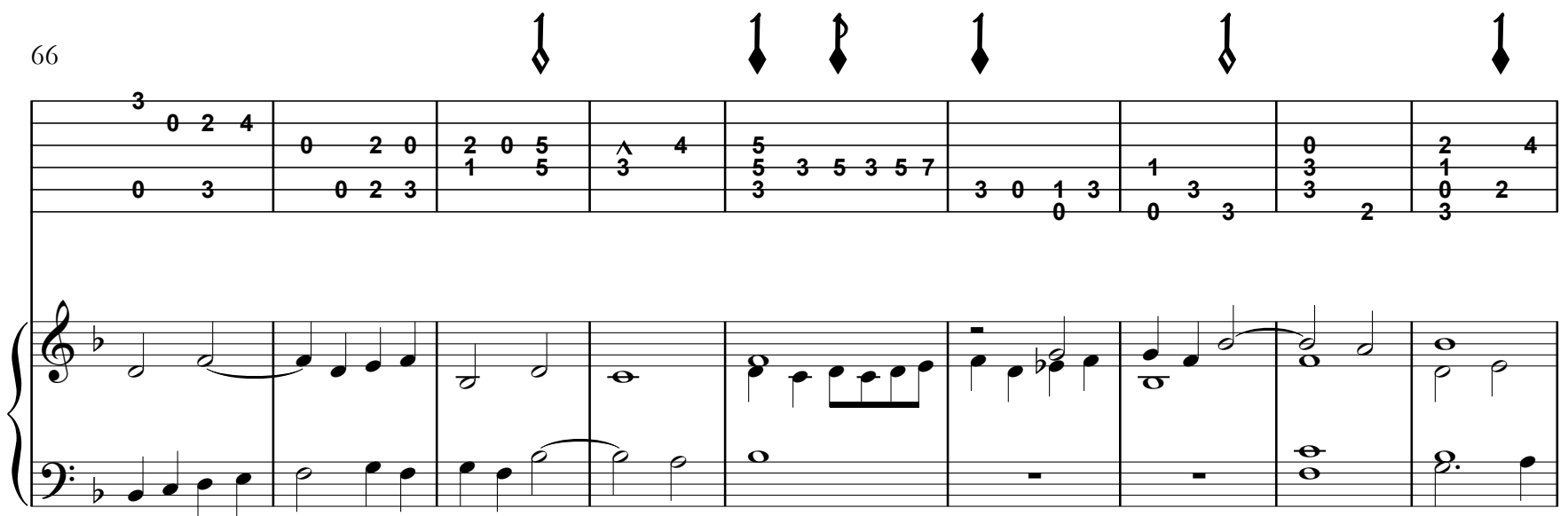


${ }_{75} 11+1016$

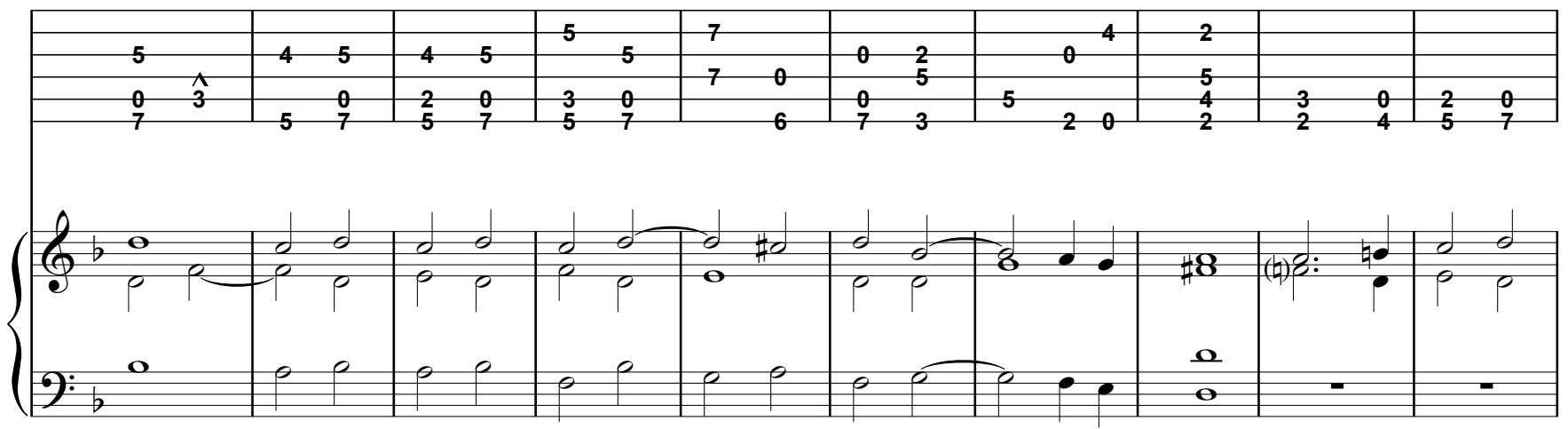

85 1. 1 3!

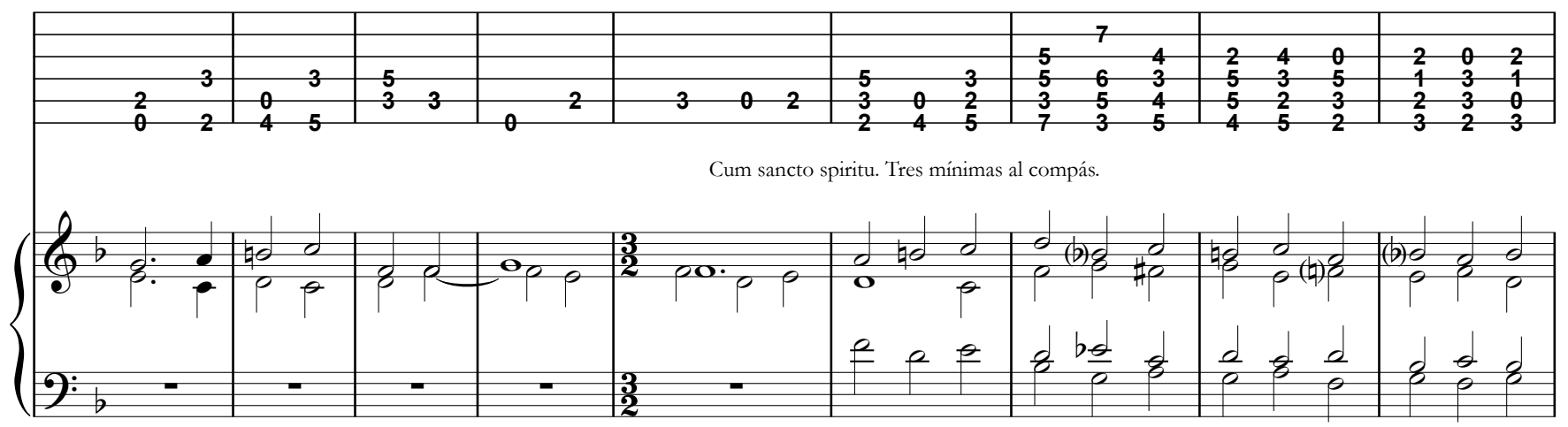

[f. XII]

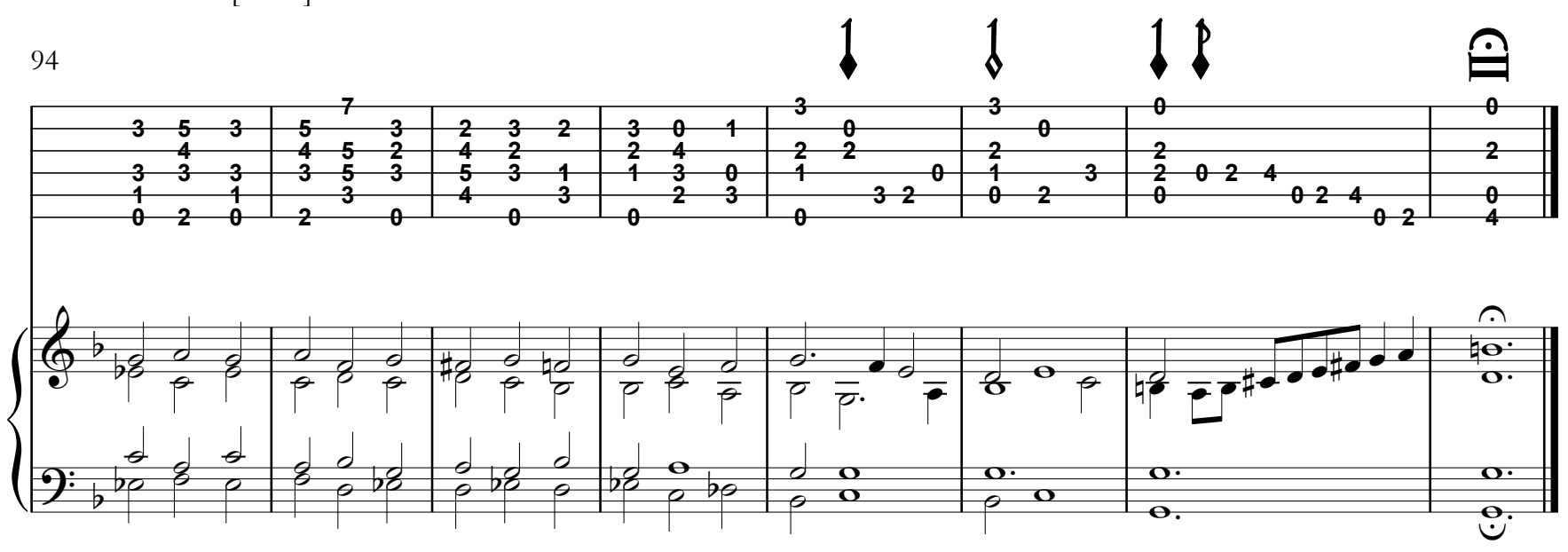




\section{sol11 - Plenies}

Pleni de la missa de faysan regres de Iosquin

[Libro I, ff. XII-XIII]

Josquin/Mudarra
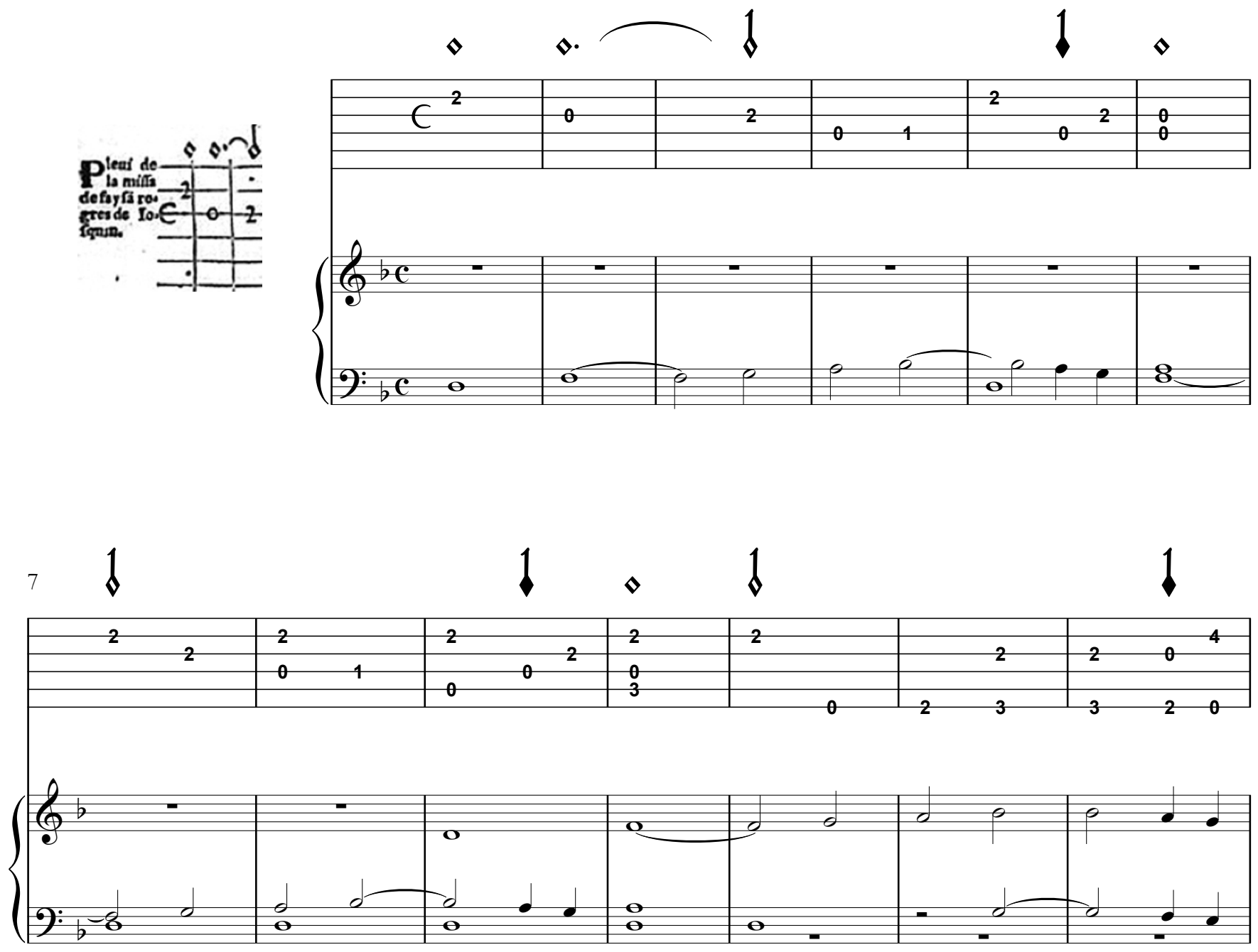

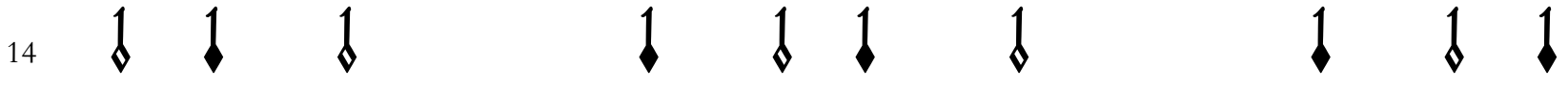

\begin{tabular}{|c|c|c|c|c|c|c|}
\hline & ( & . & 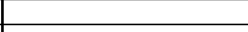 & & & 2 \\
\hline 0 & 2 & & 0 & & & 4 \\
\hline 0 & 1 & 10 & 0 & 1 & $1 \quad 3 \quad 1$ & 3 \\
\hline & [U] & & & 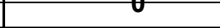 & & \\
\hline
\end{tabular}

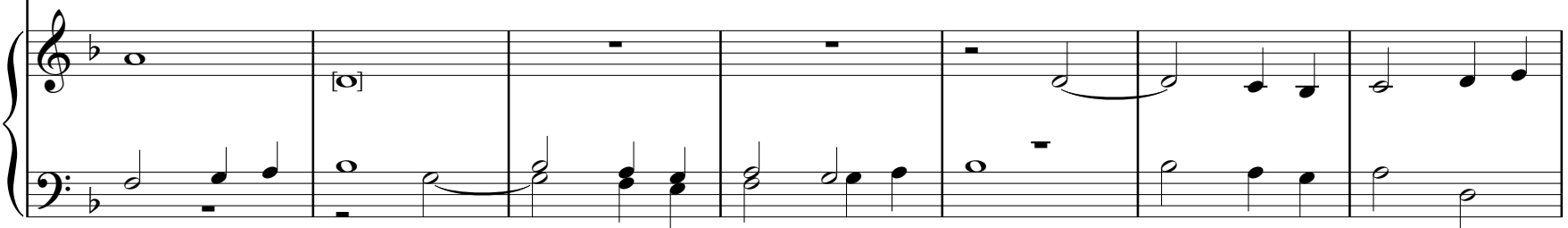




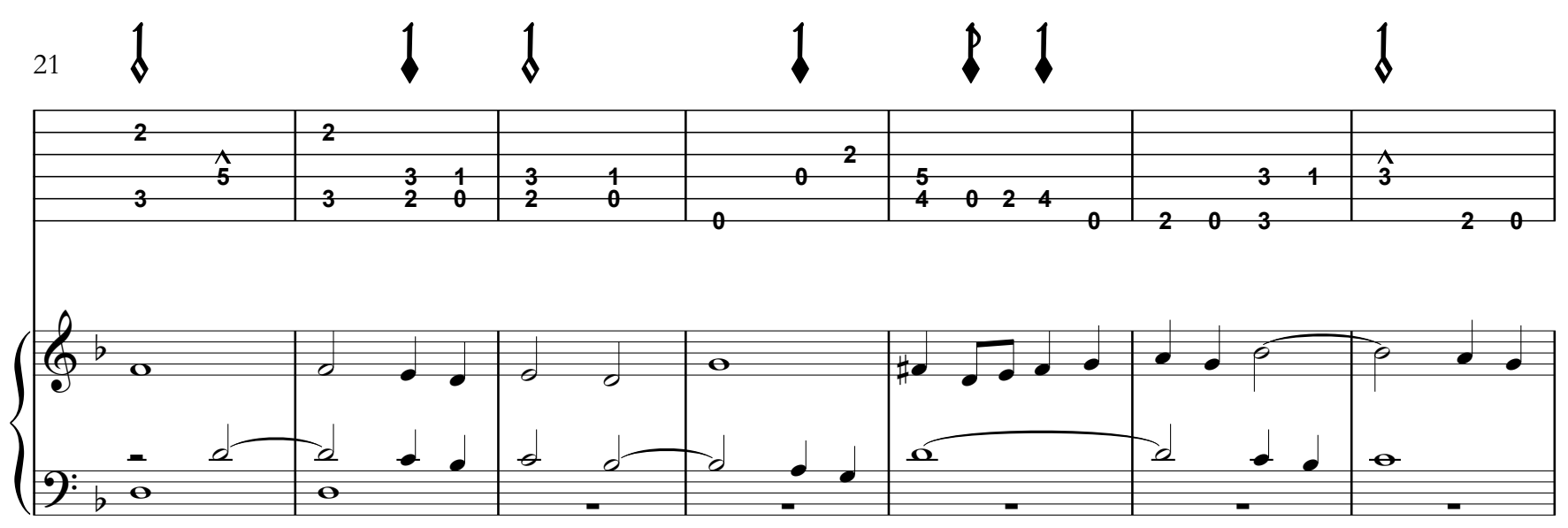

[f. XIIv]

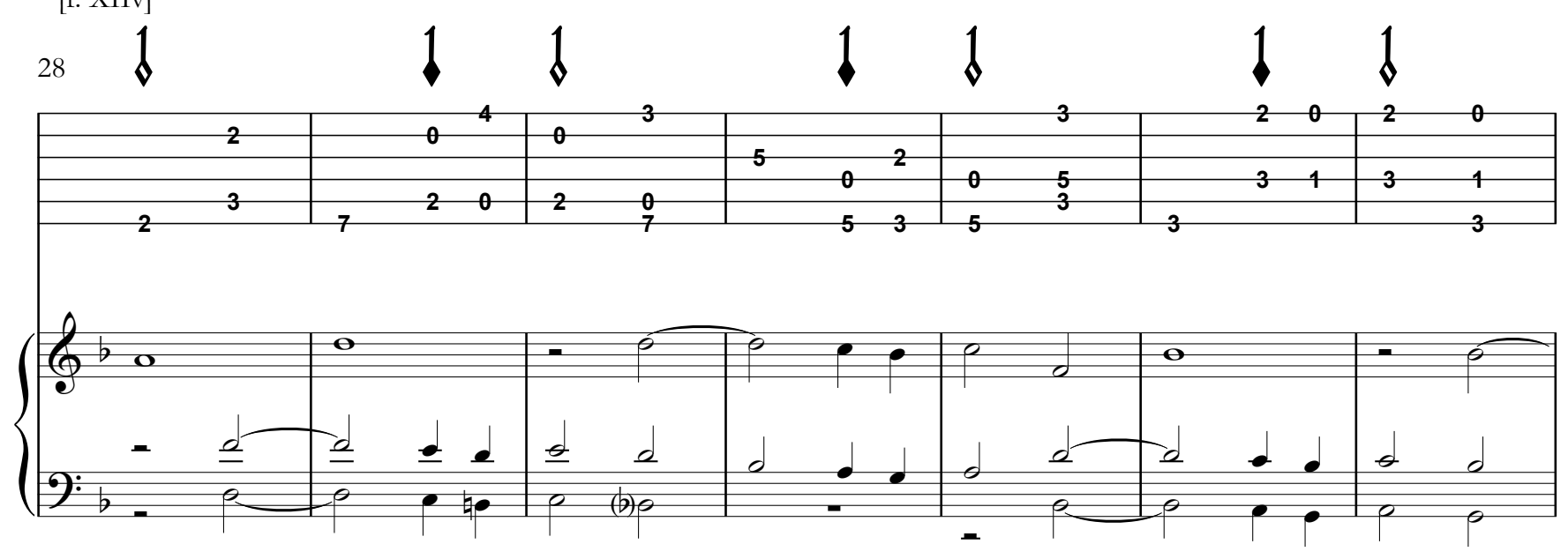

$\begin{array}{lllllll}35 & 1 & 1 & 1 & 1 & 1 & 1\end{array}$
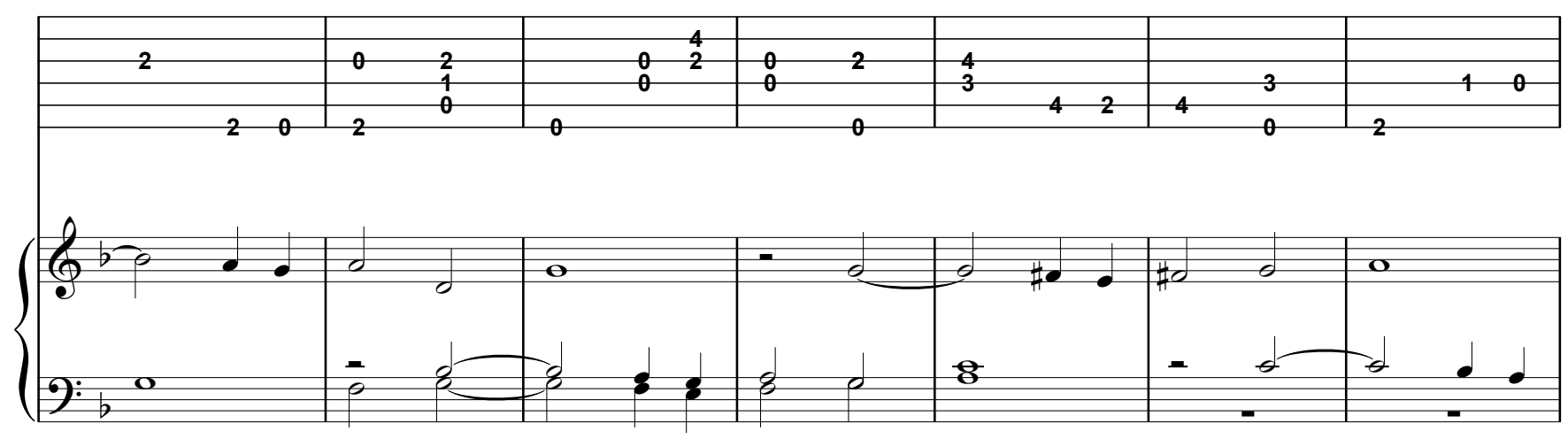

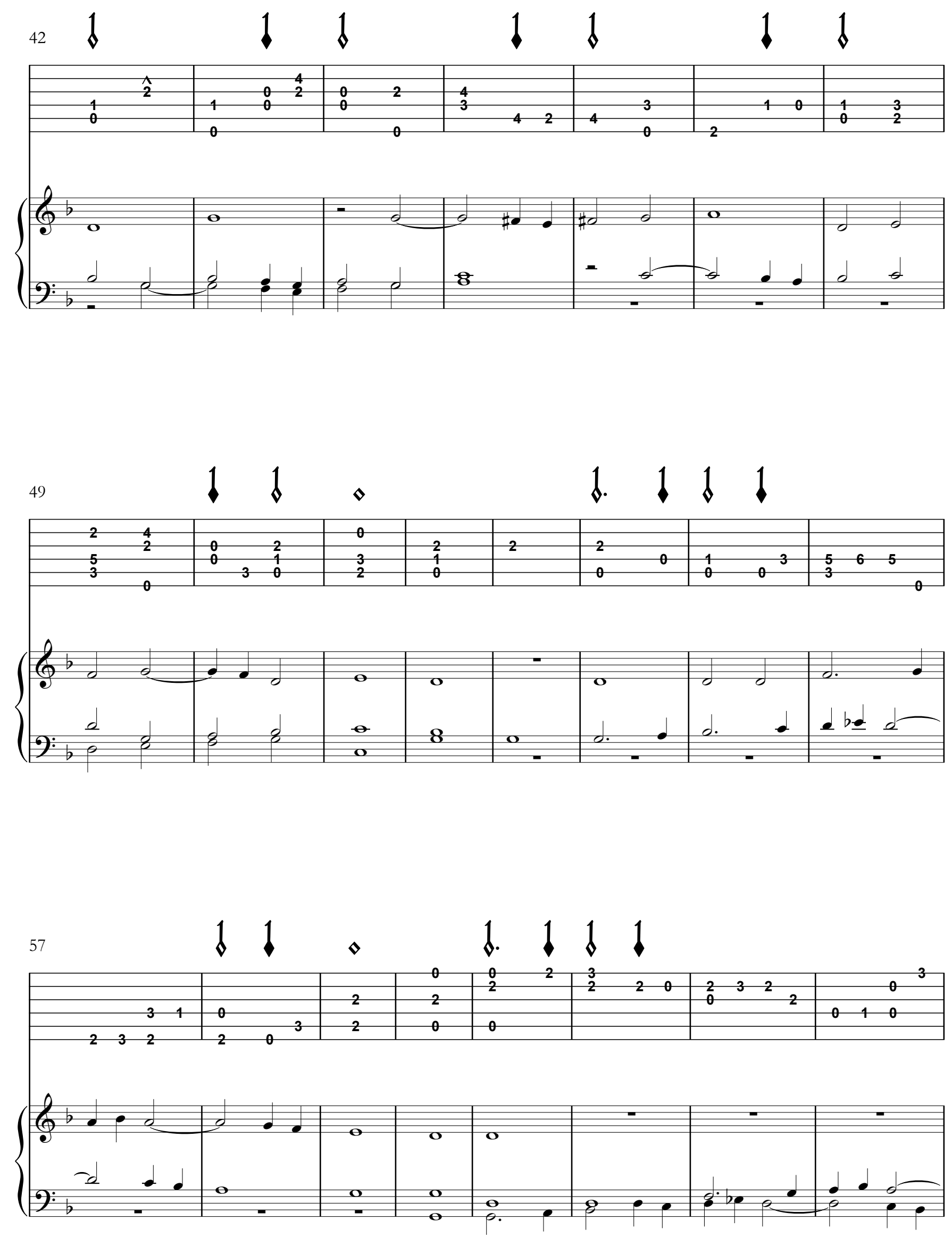
[f. XIII]
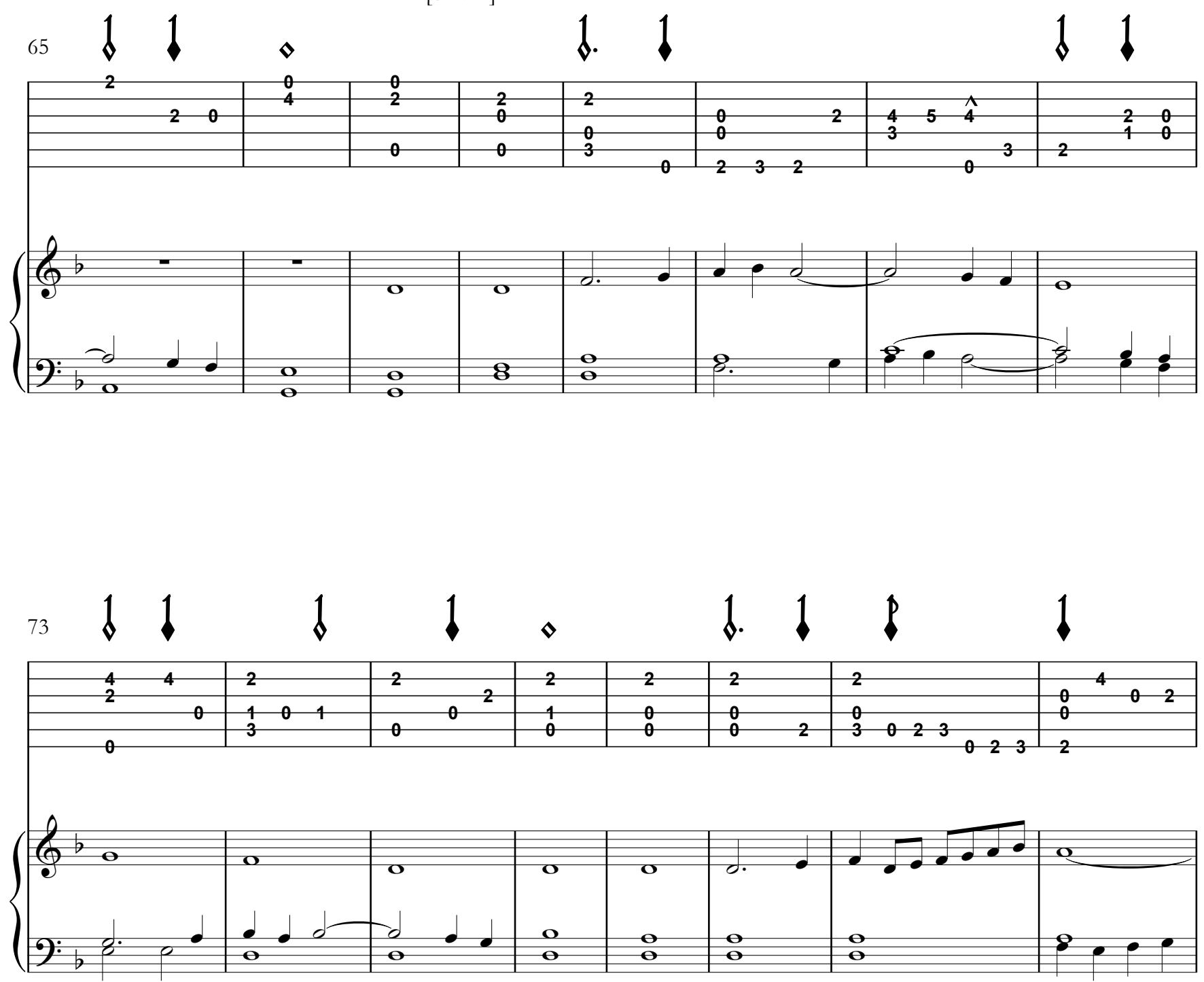

$\left.\begin{array}{lllllllll}81 & \$ & 1 & \$ & 1 & 1 & 1 & 1\end{array}\right]$

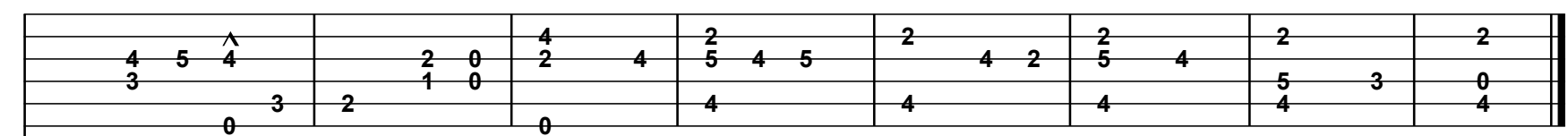

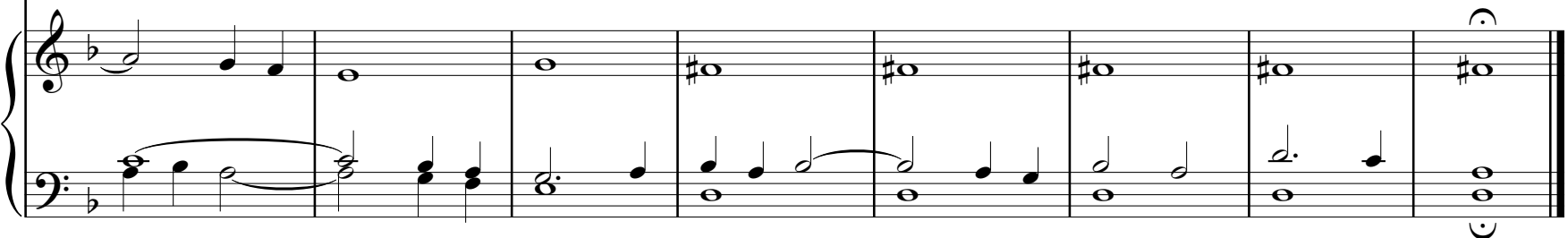




\section{sะ12 - Fantasía 10}

Fantasía que contrahaze la harpa en la manera de luduvico. es diffícil hasta ser entendida [Libro I, ff. XIII-XV]

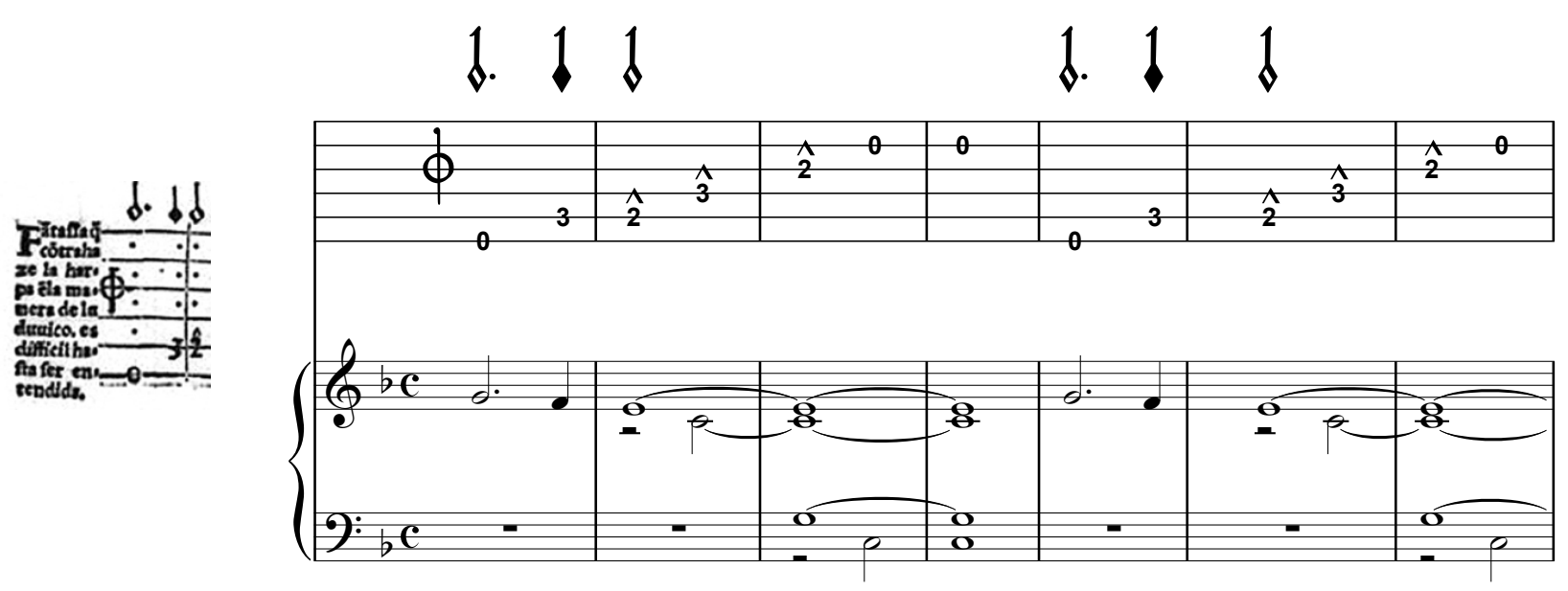

[f. XIIIv]
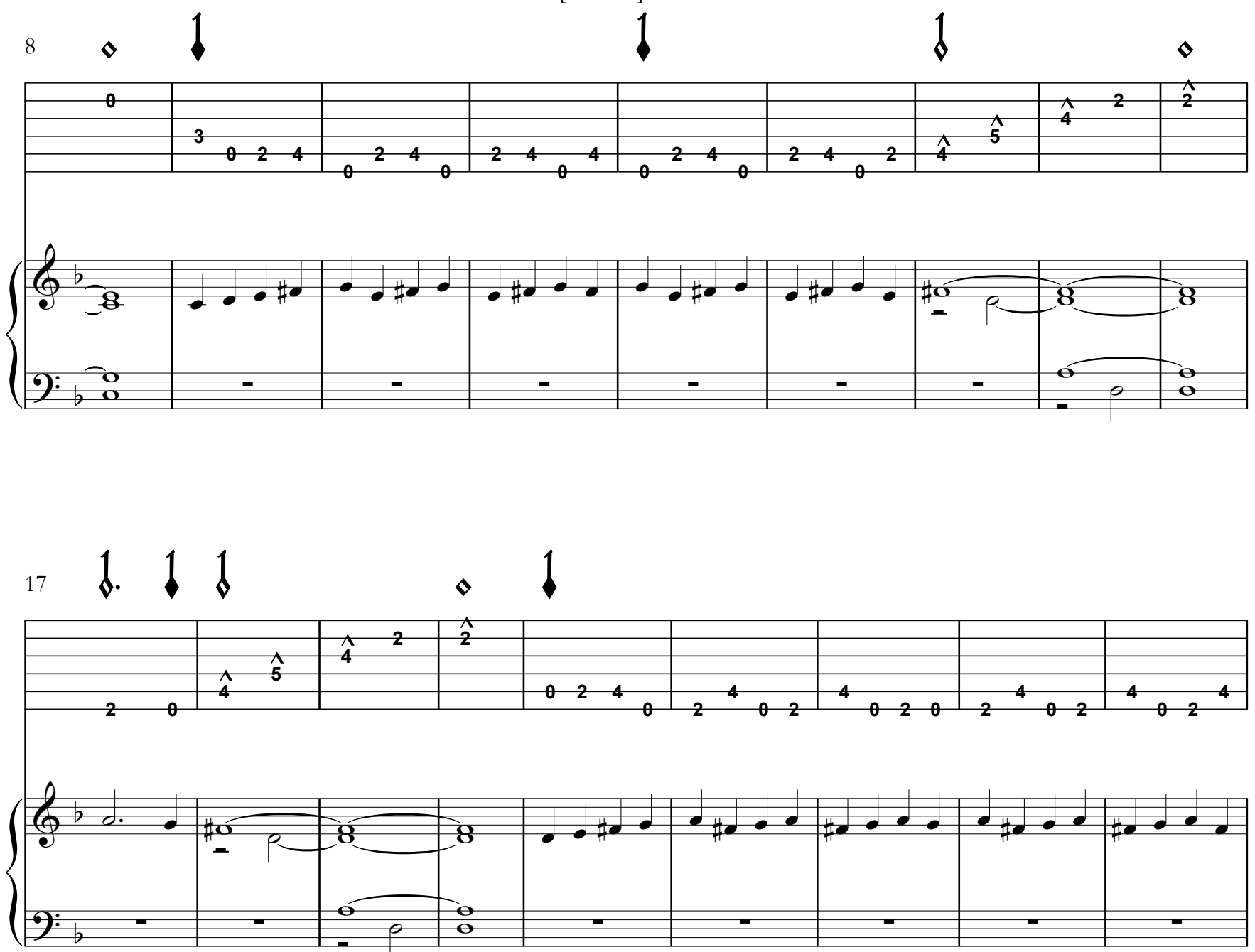


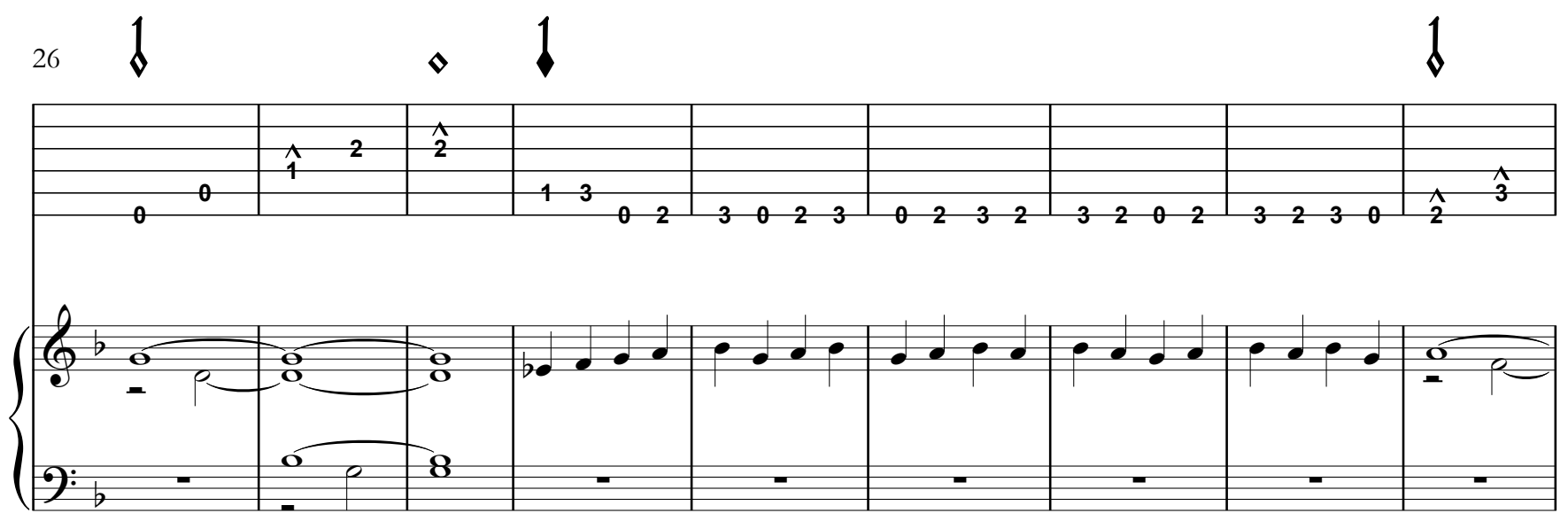

35
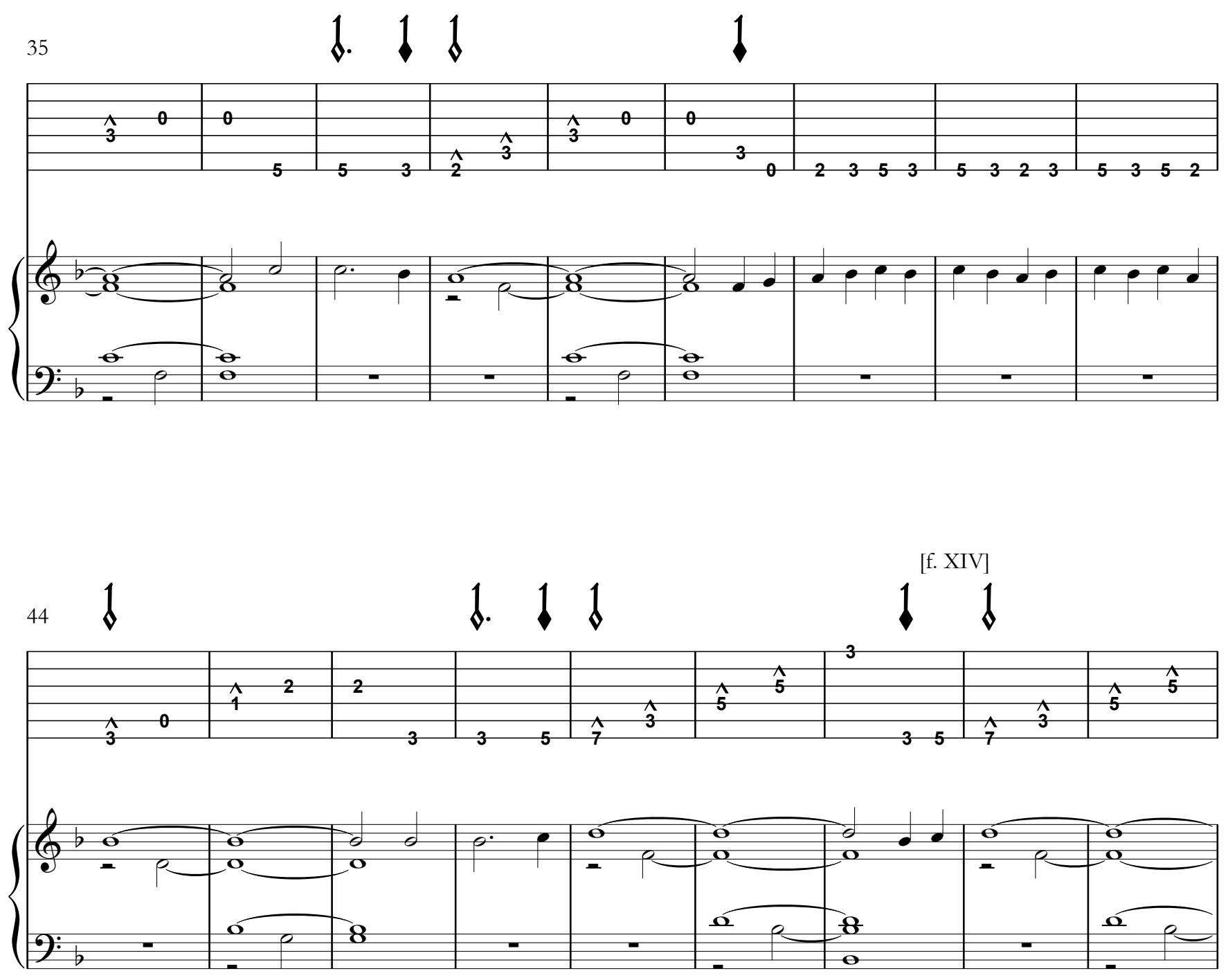
53
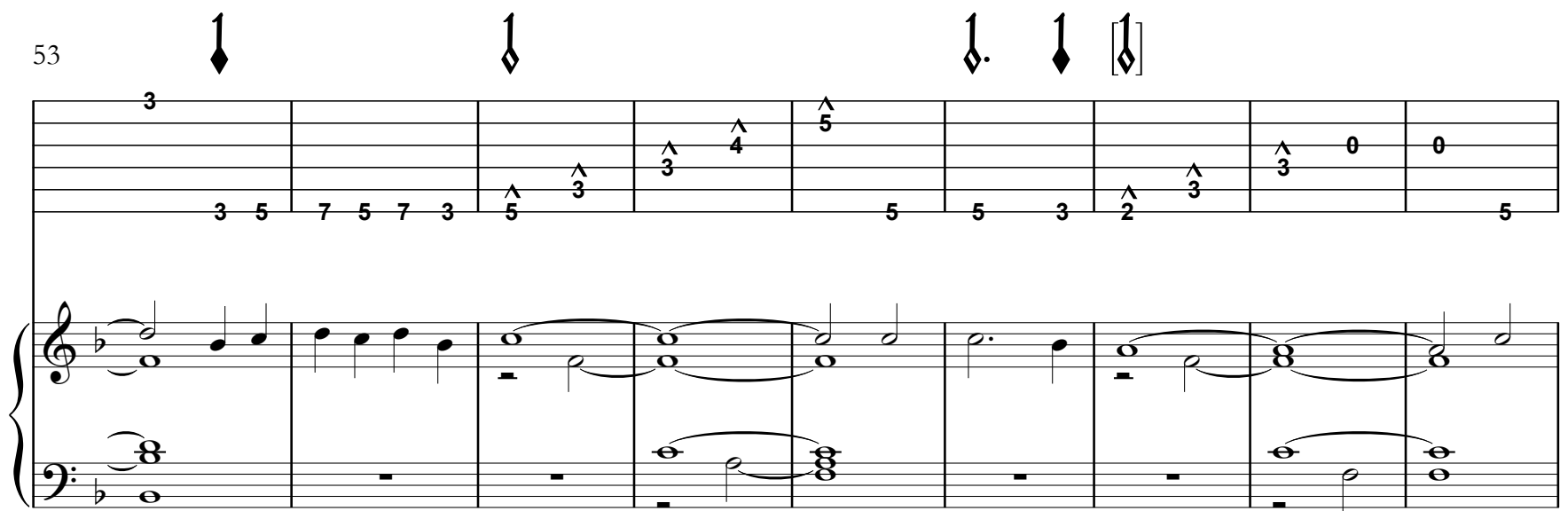

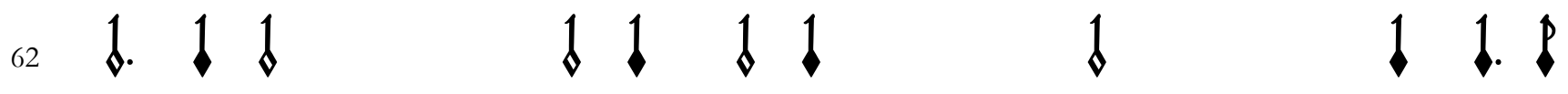

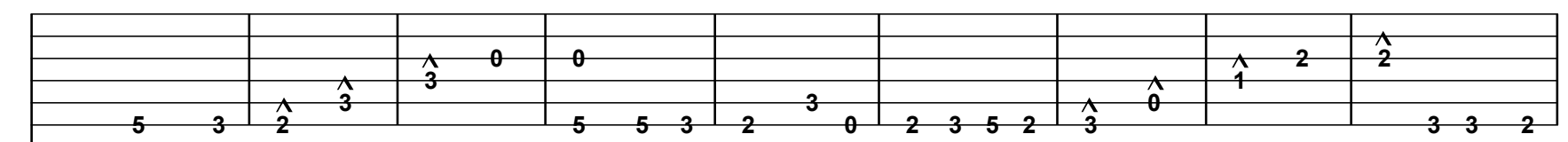

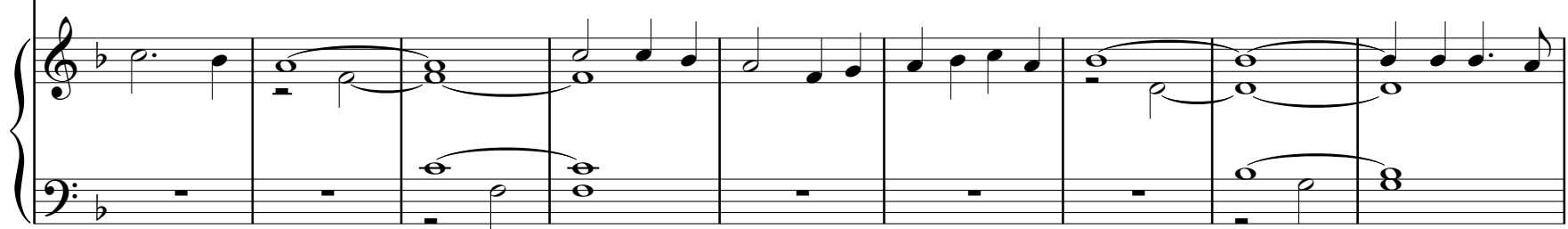

710101.161

\begin{tabular}{|c|c|c|c|c|c|c|c|c|}
\hline & . & & & & & & & 2 \\
\hline & 12 & 2 & & & 2 & & & $\hat{4}$ \\
\hline & 12 & & & 310 & $\begin{array}{llll}2 & 0 & 1 & 3\end{array}$ & & 5 & \\
\hline \begin{tabular}{|l}
0 \\
0
\end{tabular} & & 020 & 31 & 0 & & $\begin{array}{llll}0 & 2 & 4 & 5\end{array}$ & 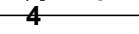 & \\
\hline
\end{tabular}

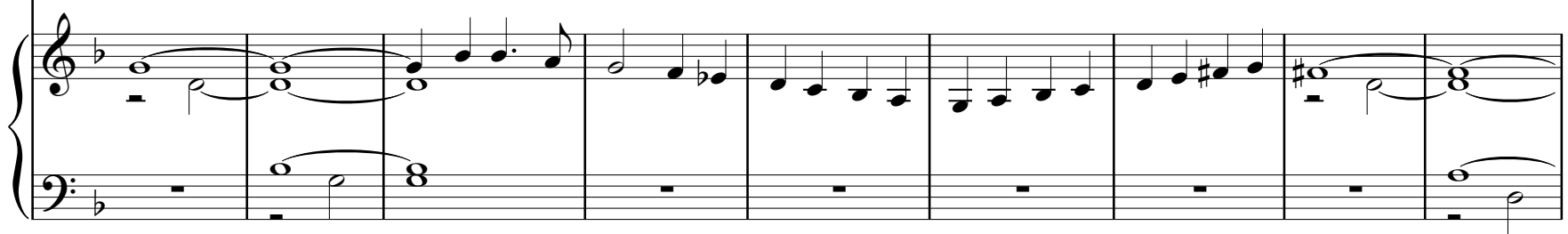


80
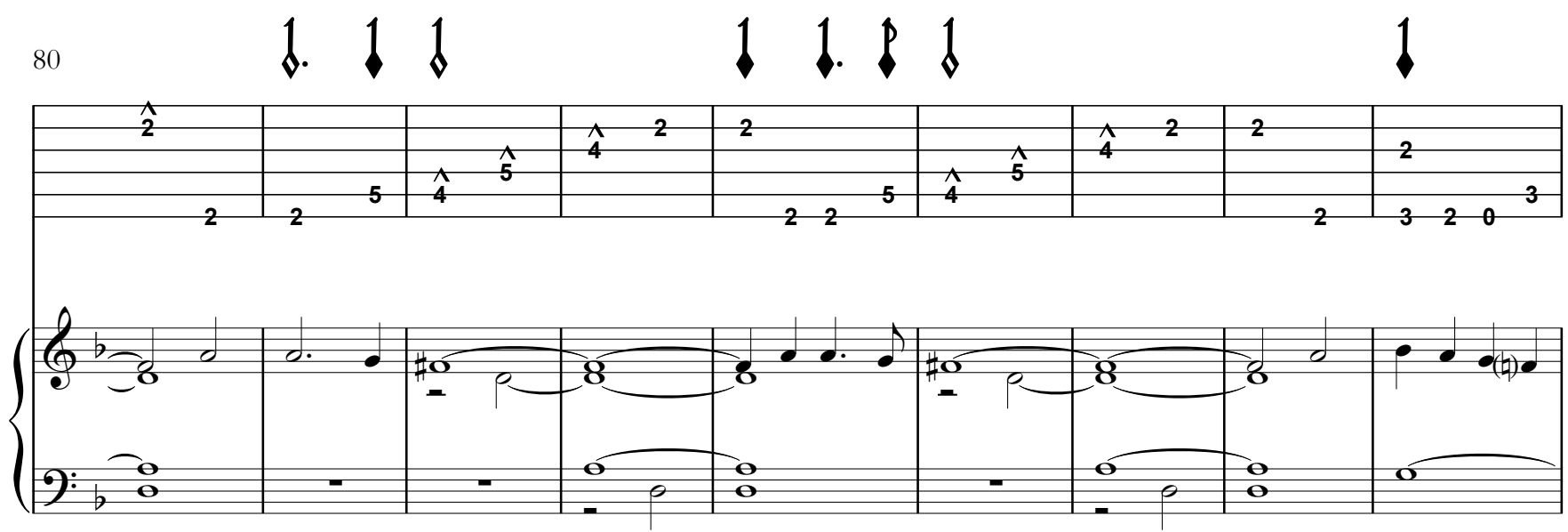

89
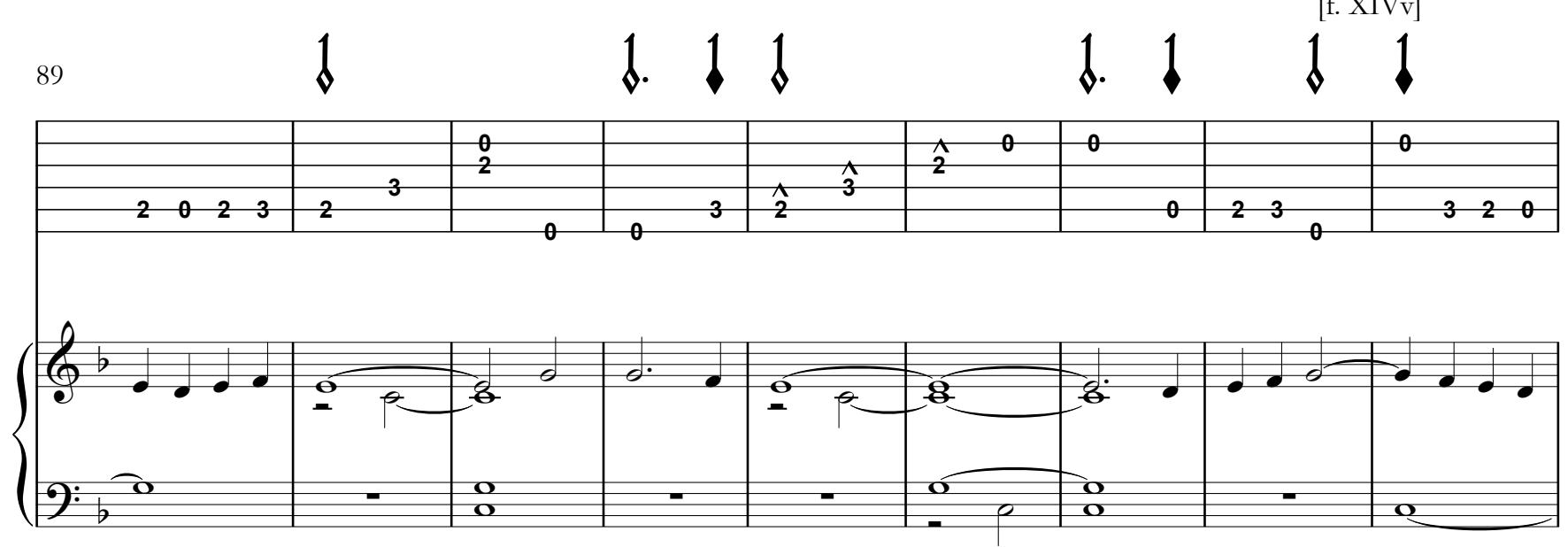

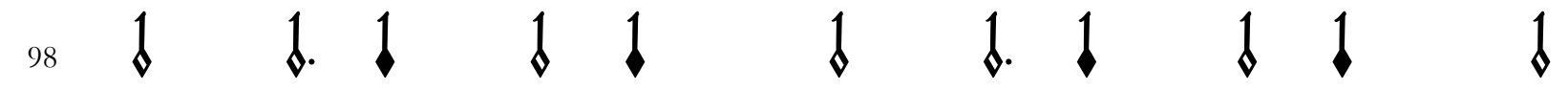

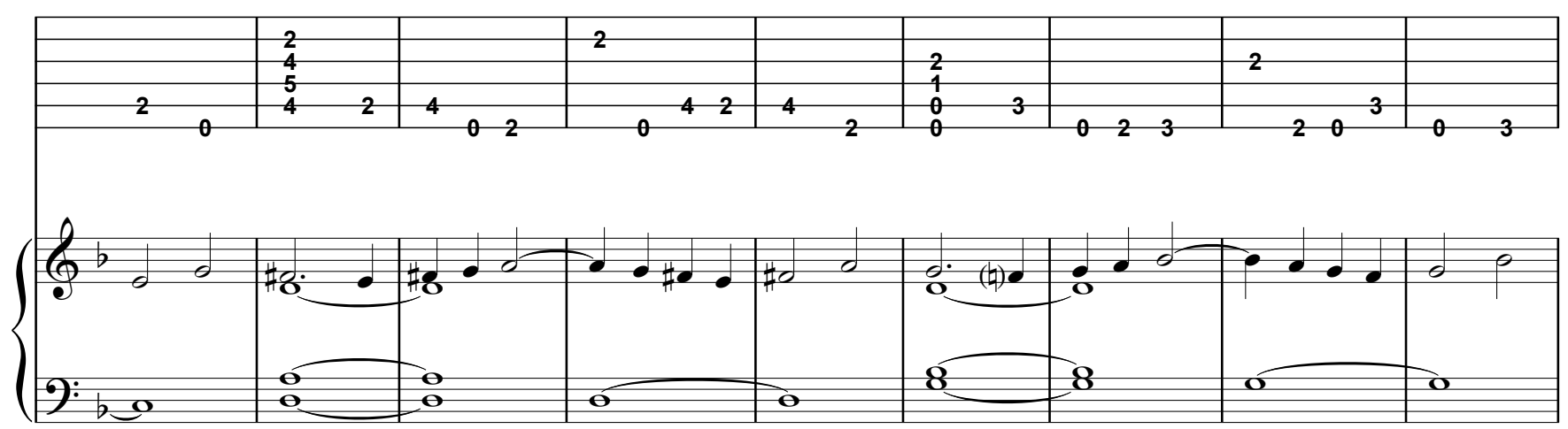


${ }_{107}$ \&. \& \& \& ।

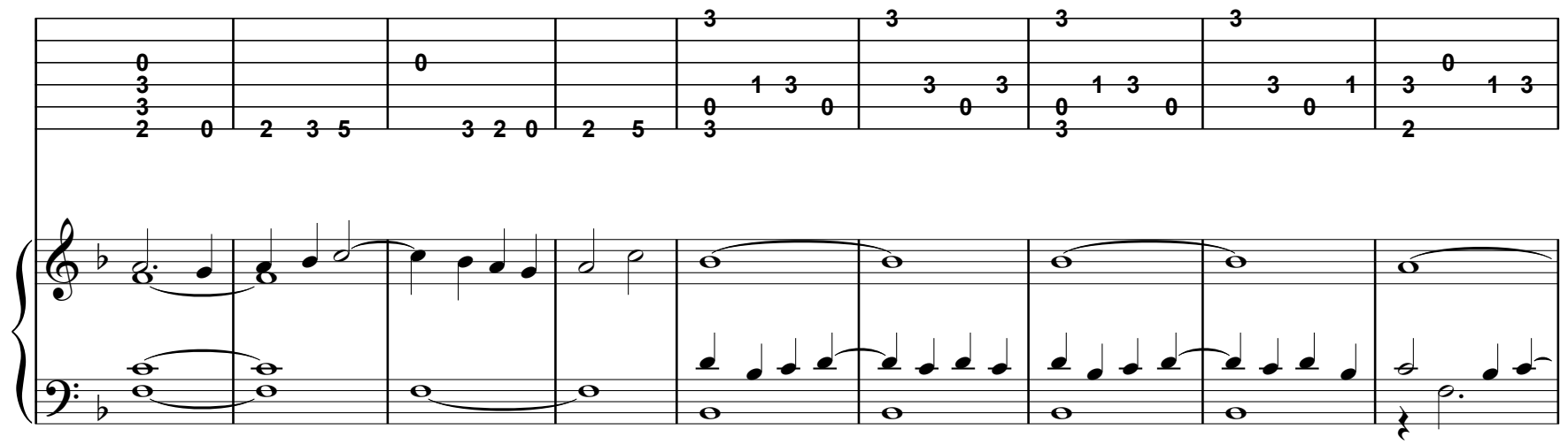

116

1. 1

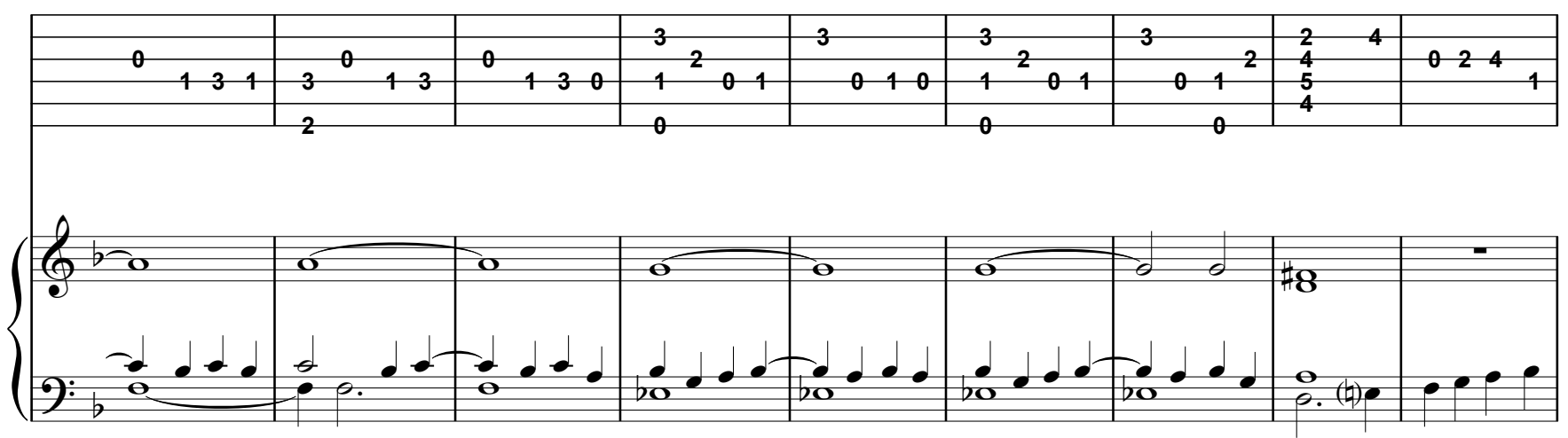

[f. XV]

125

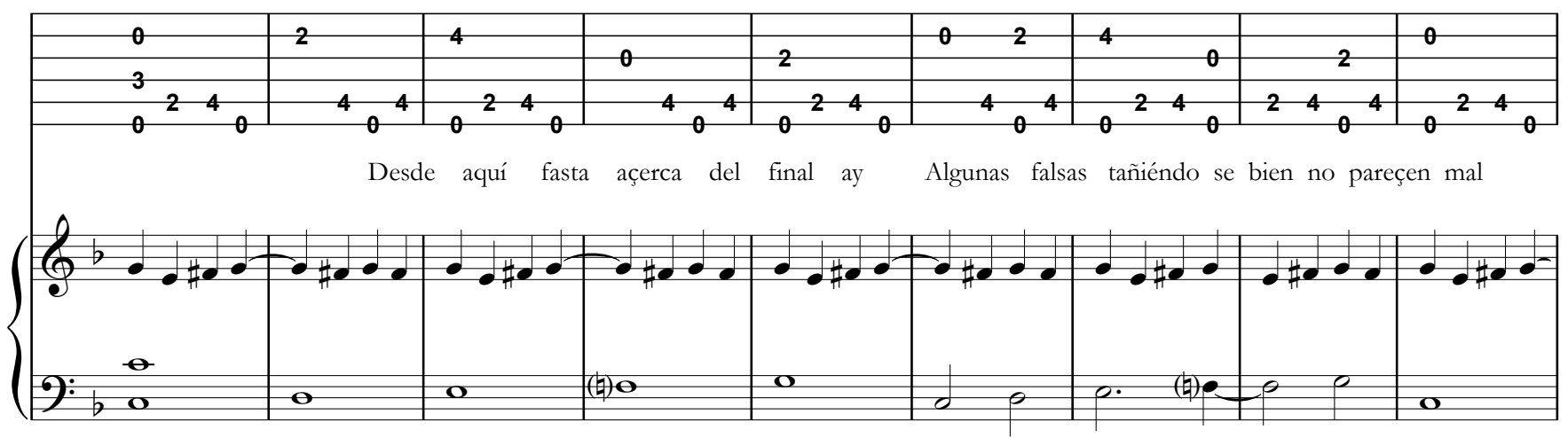



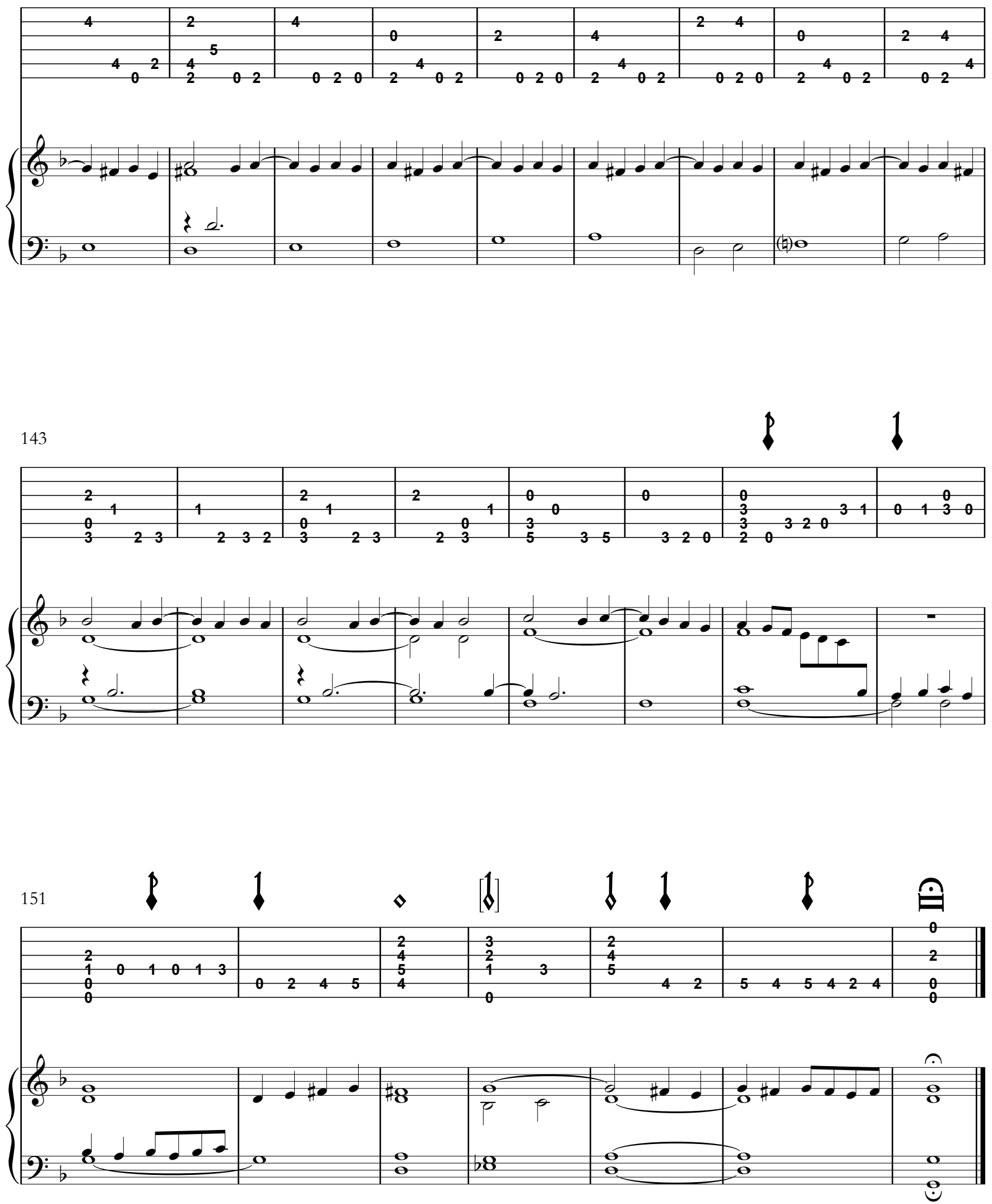


\title{
so 13 - Conde Claros
}

\author{
Conde claros
}

[Libro I, ff. XVv-XVIv]
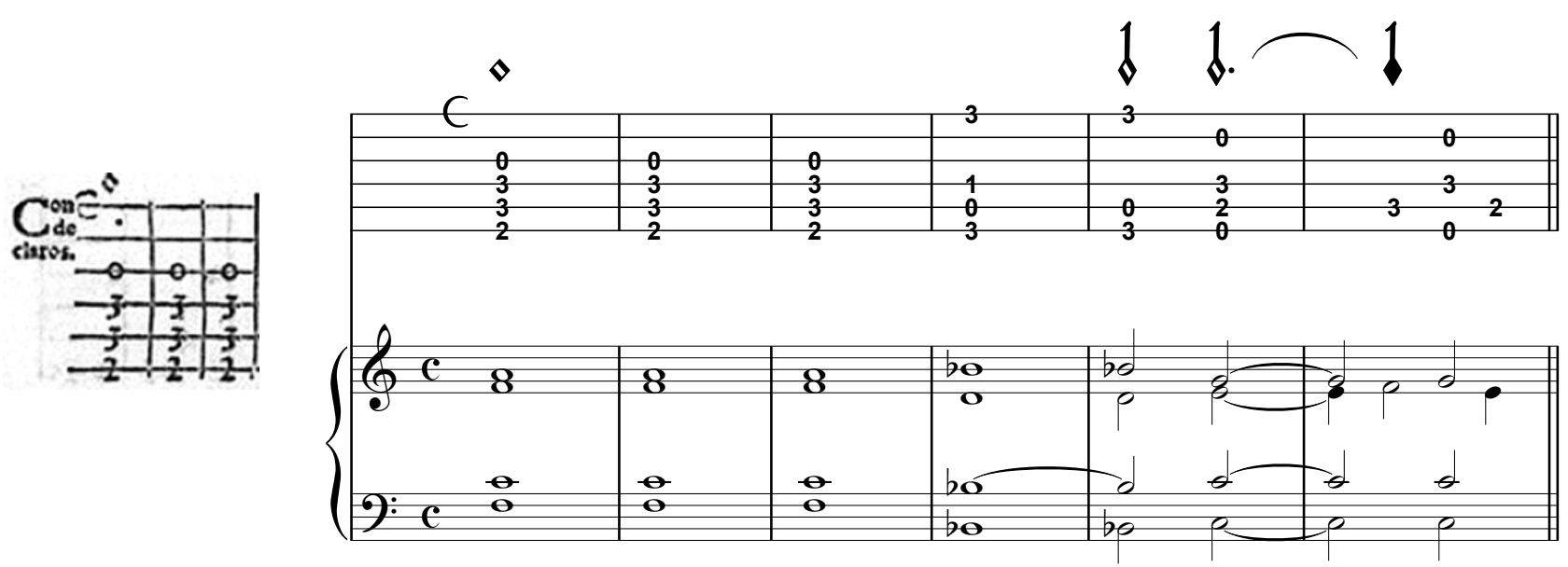

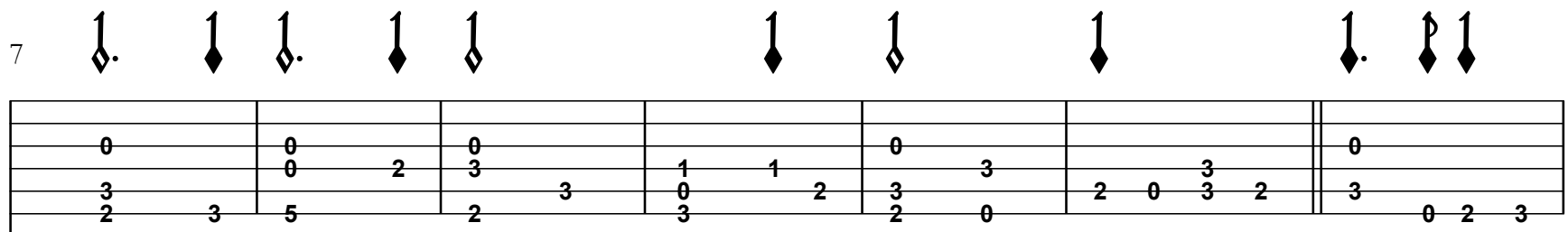
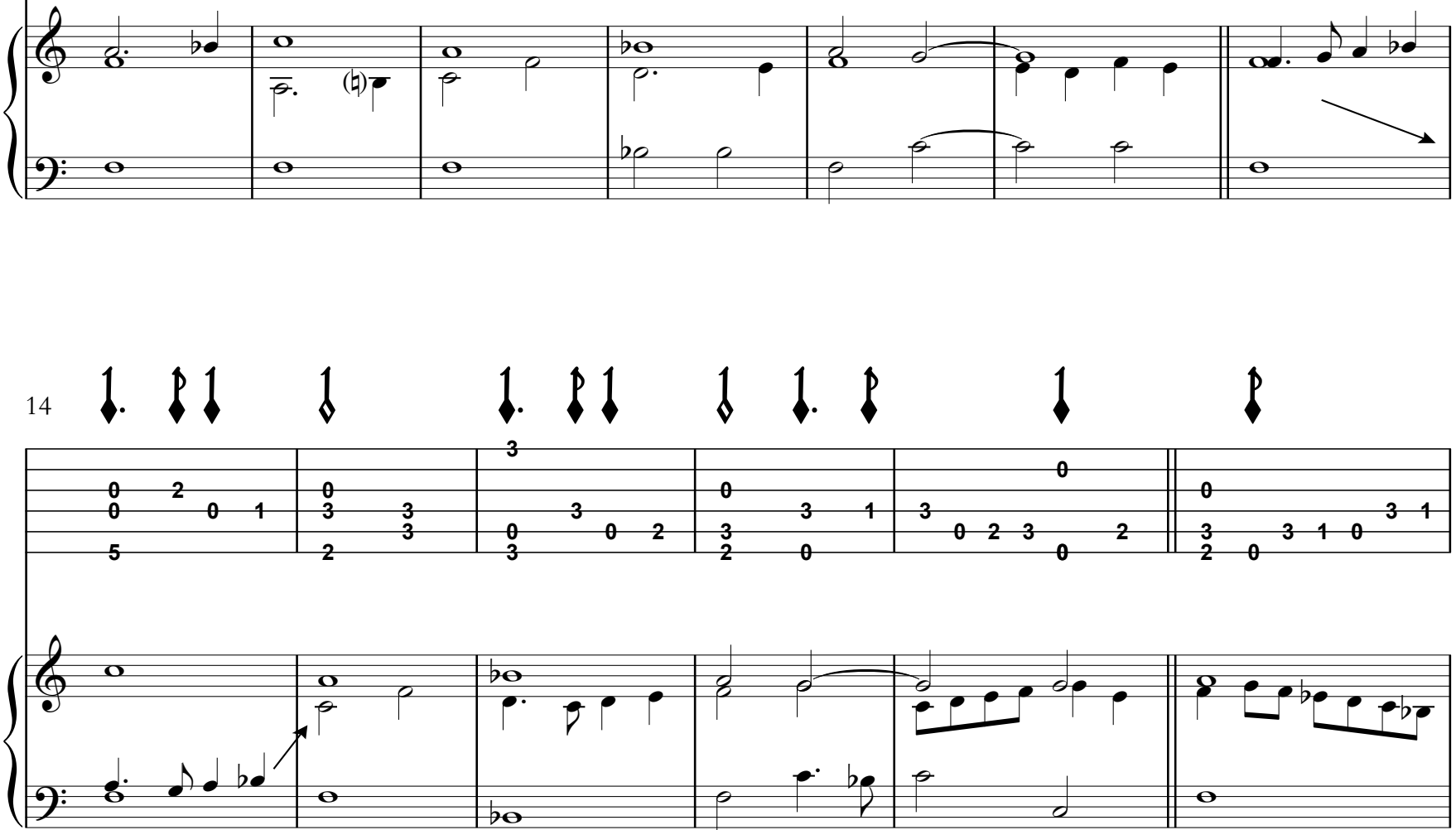

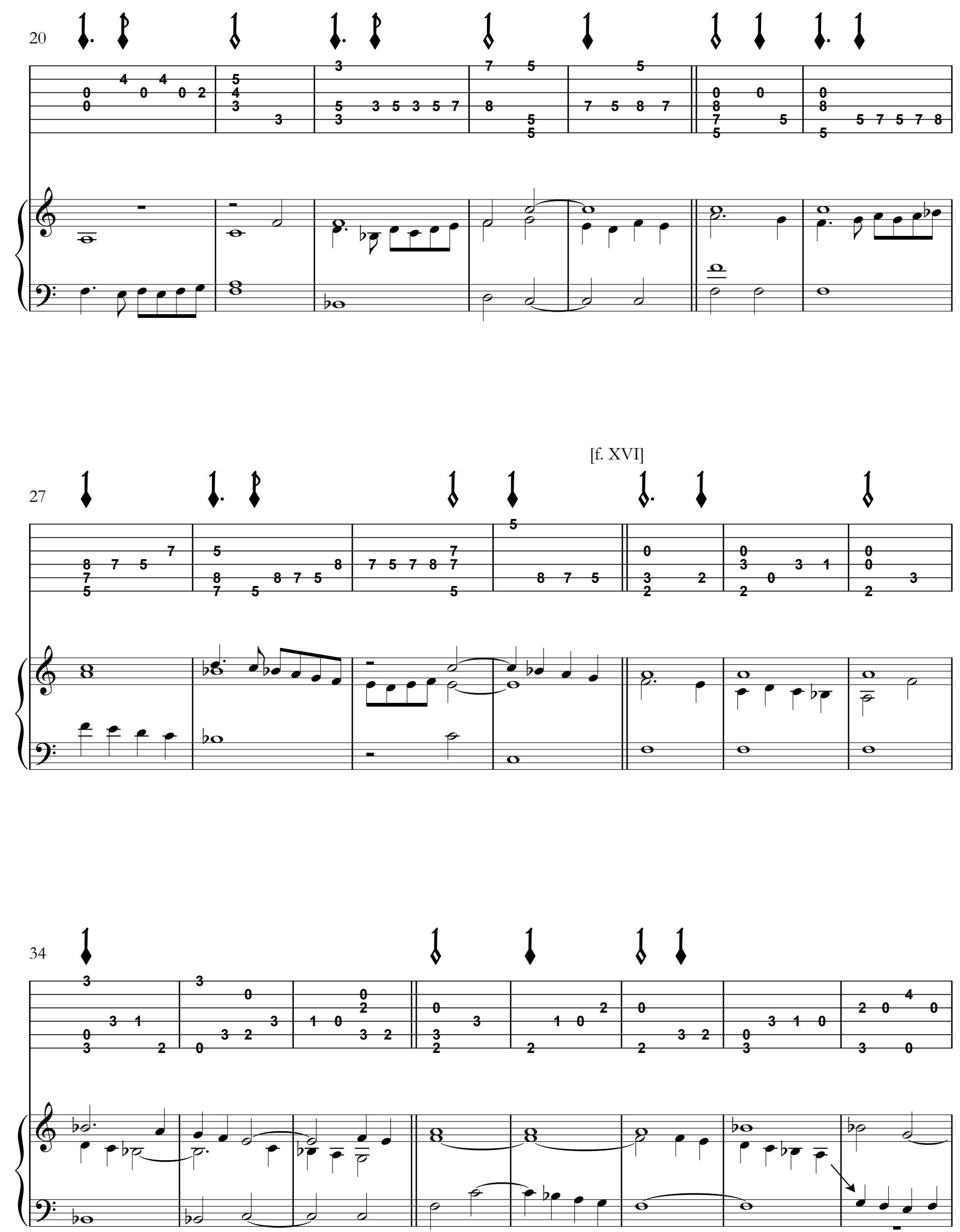

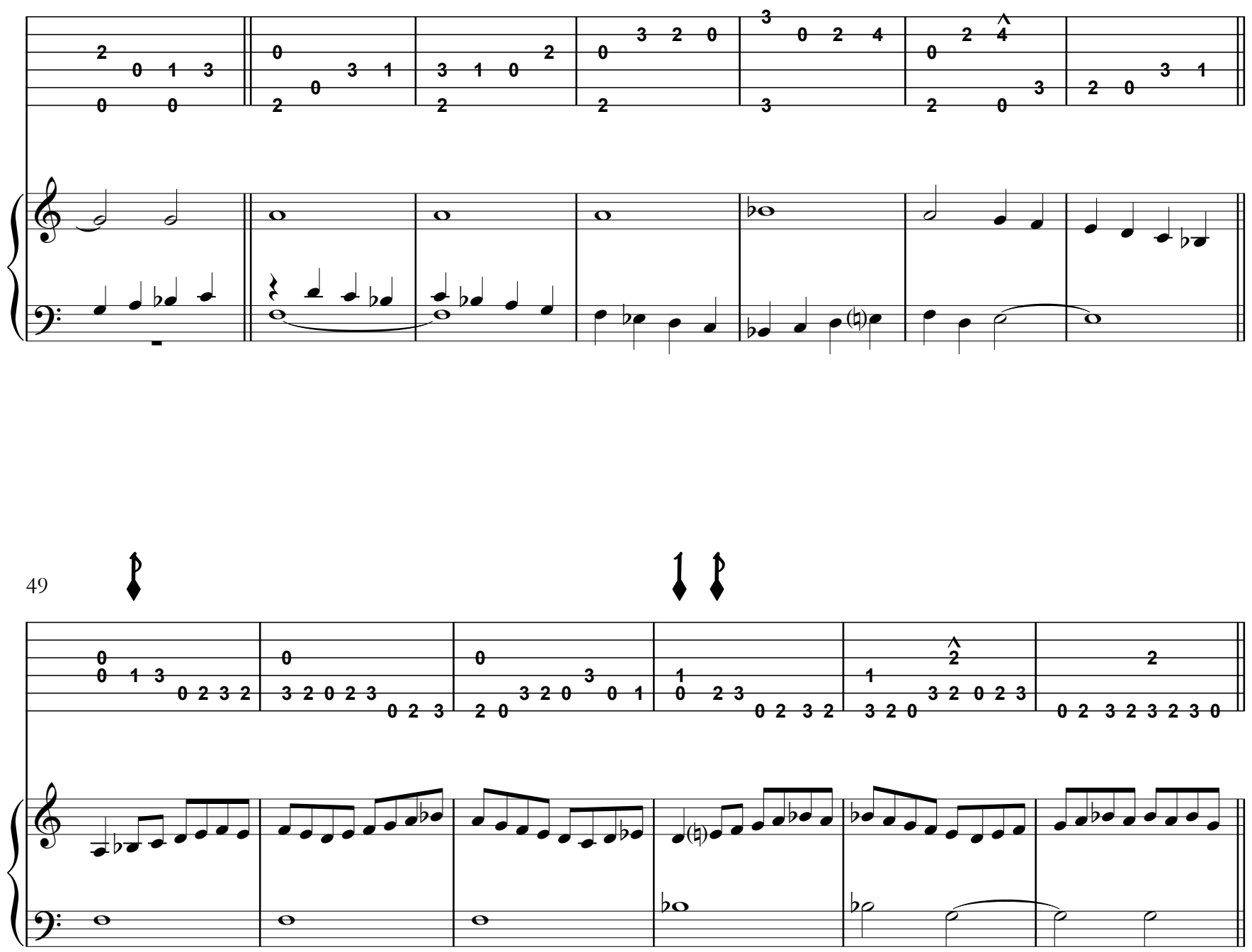

[f. XVIv]

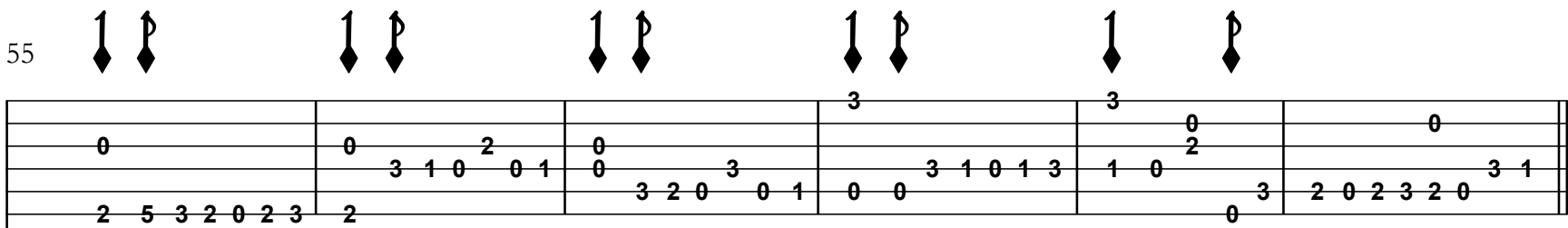

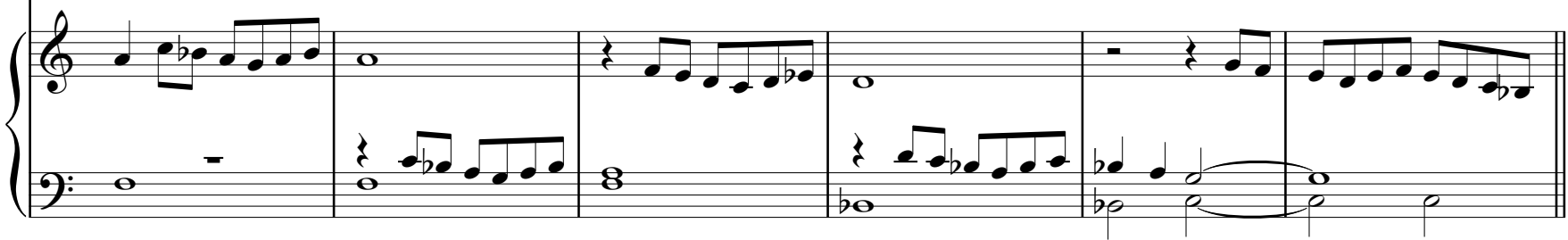



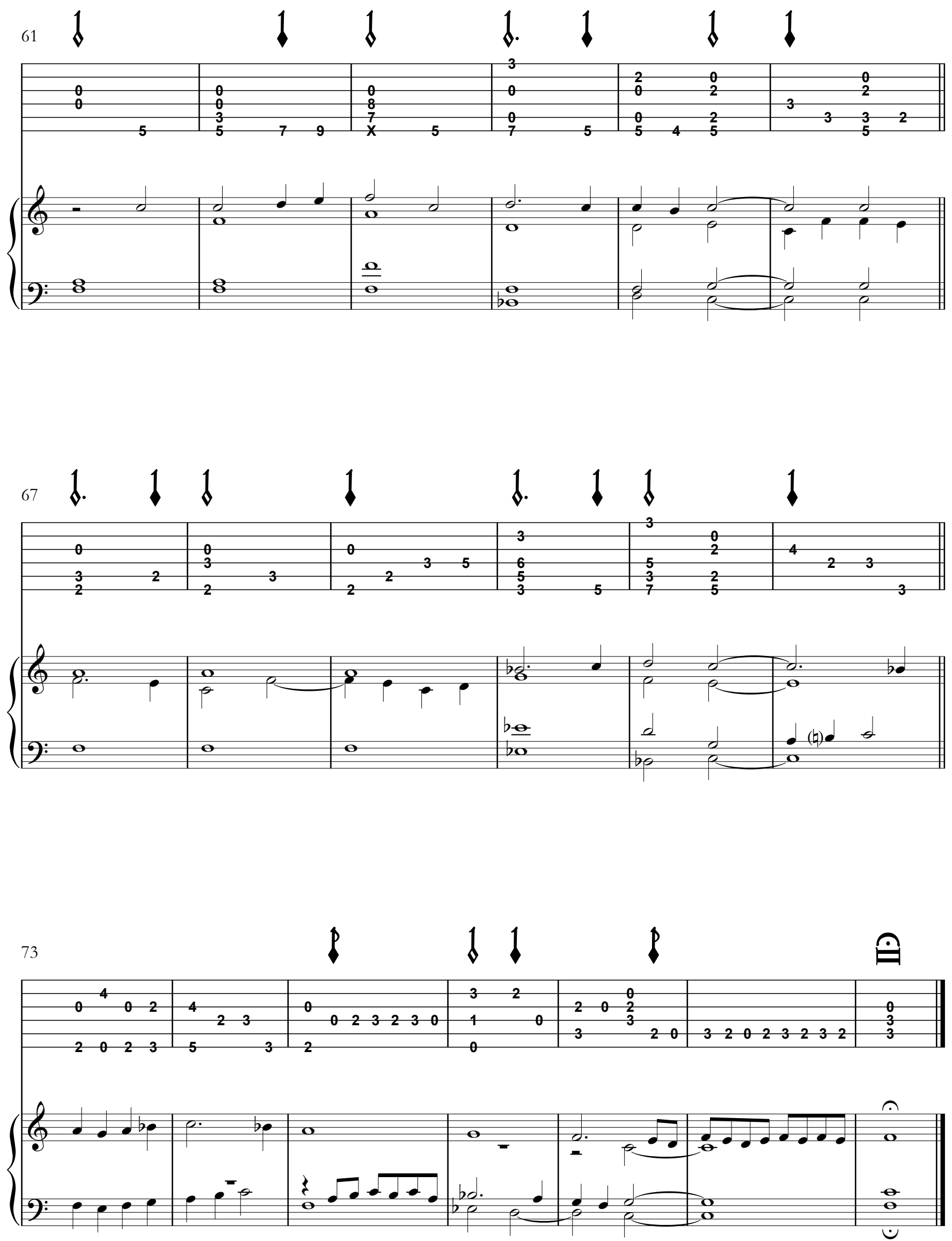


\section{\&\&14 - Romanesca. Guárdame las vacas 1 \&\&}

Romanesca: o guárdame las vacas. Proporción tres semibreves al conpás

[Libro I, ff. XVII-XVIII]
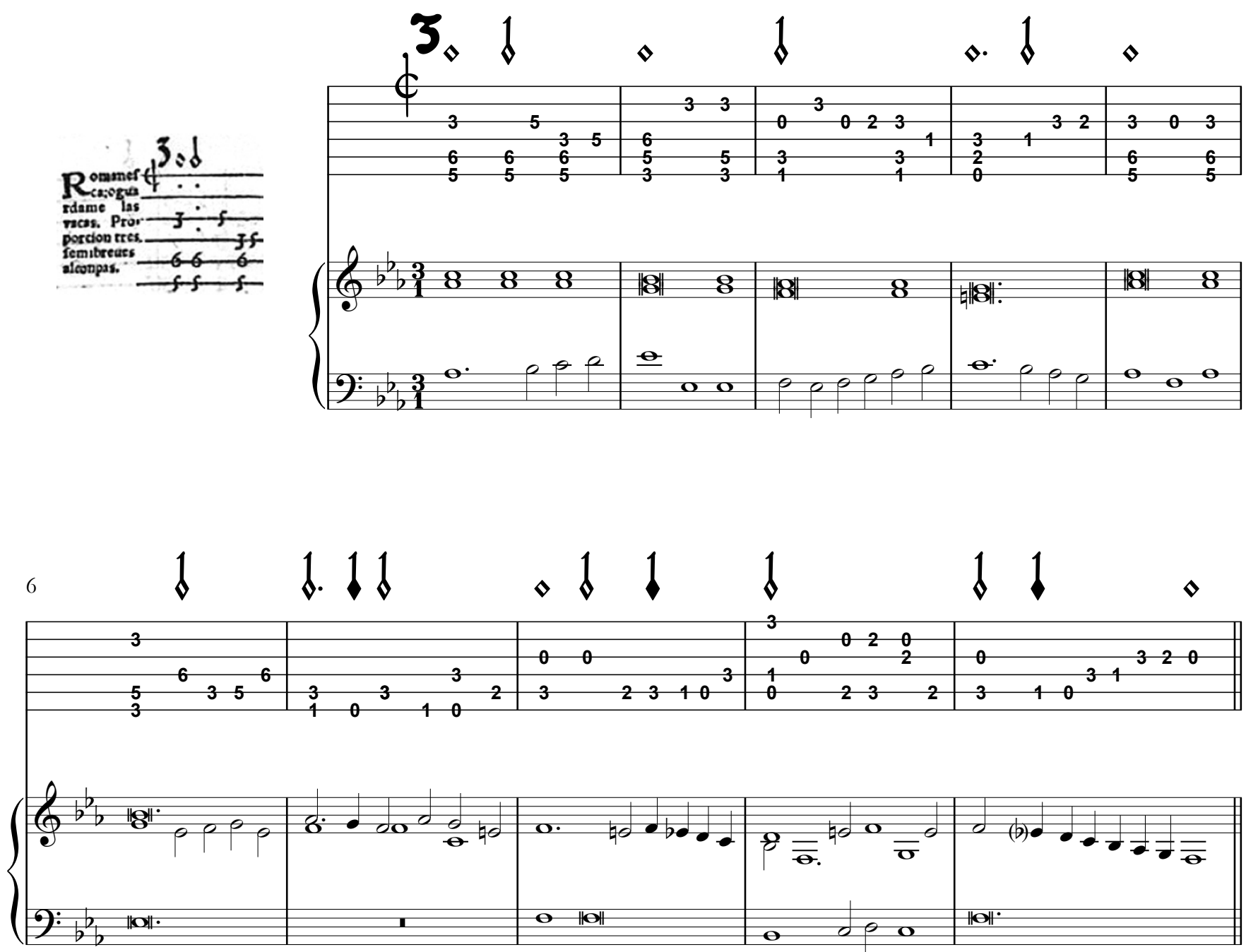

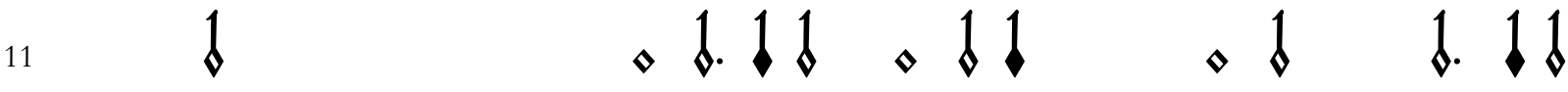

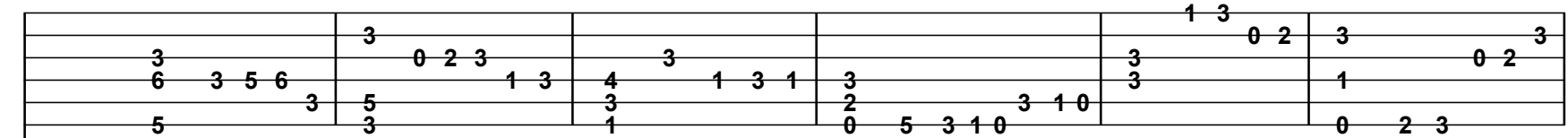

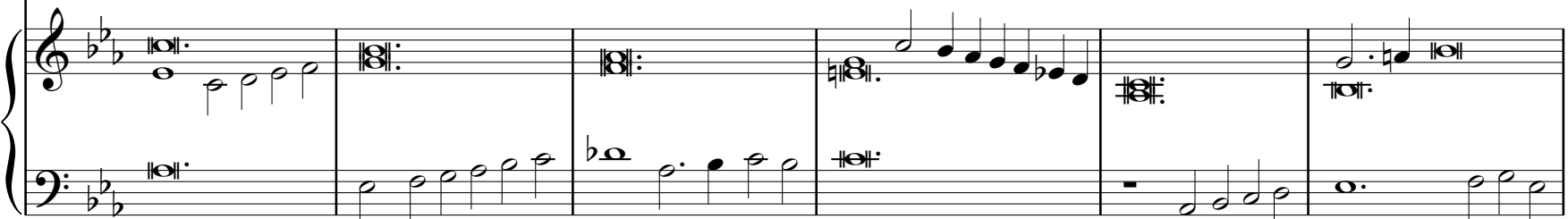



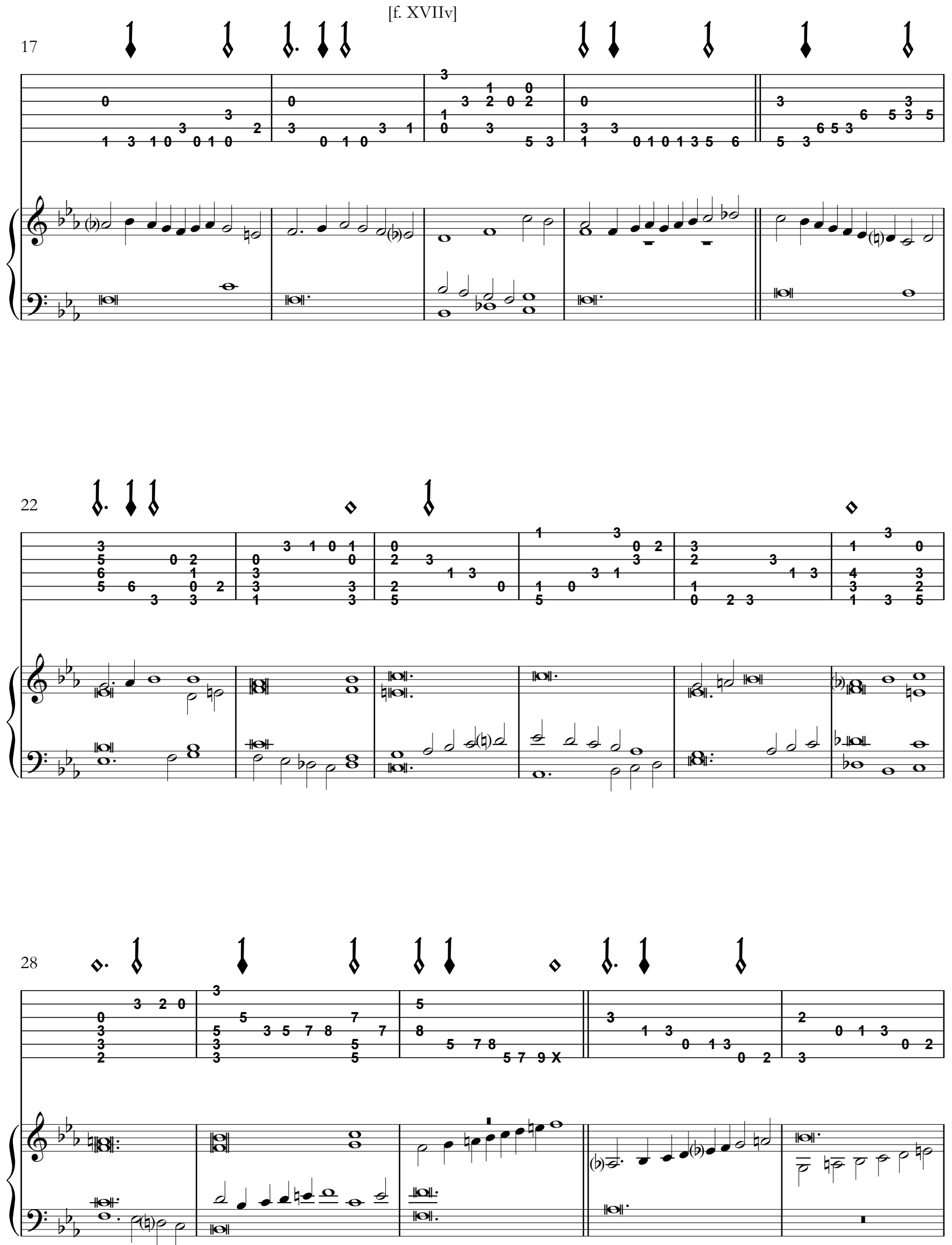
33

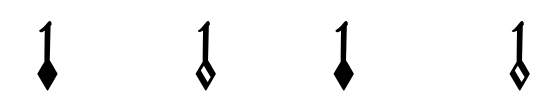

$1 \quad 1.1 \quad \downarrow$

จ. 1

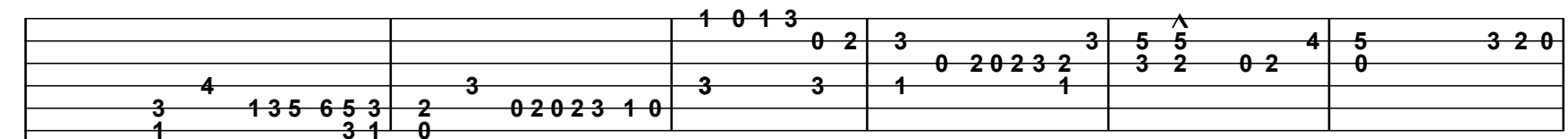
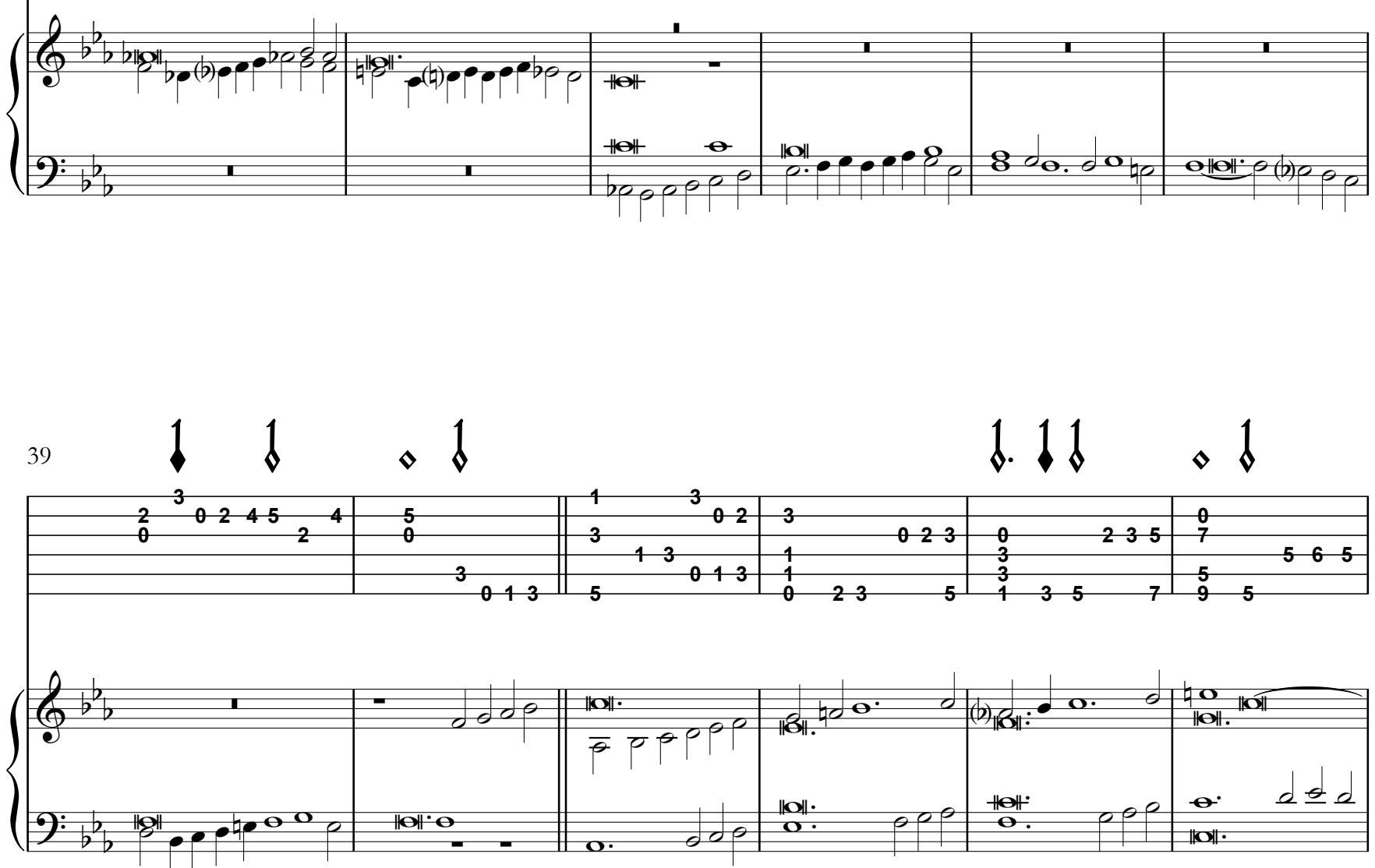

45

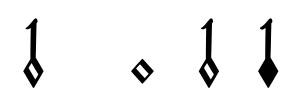

1

$\checkmark 1$

อ
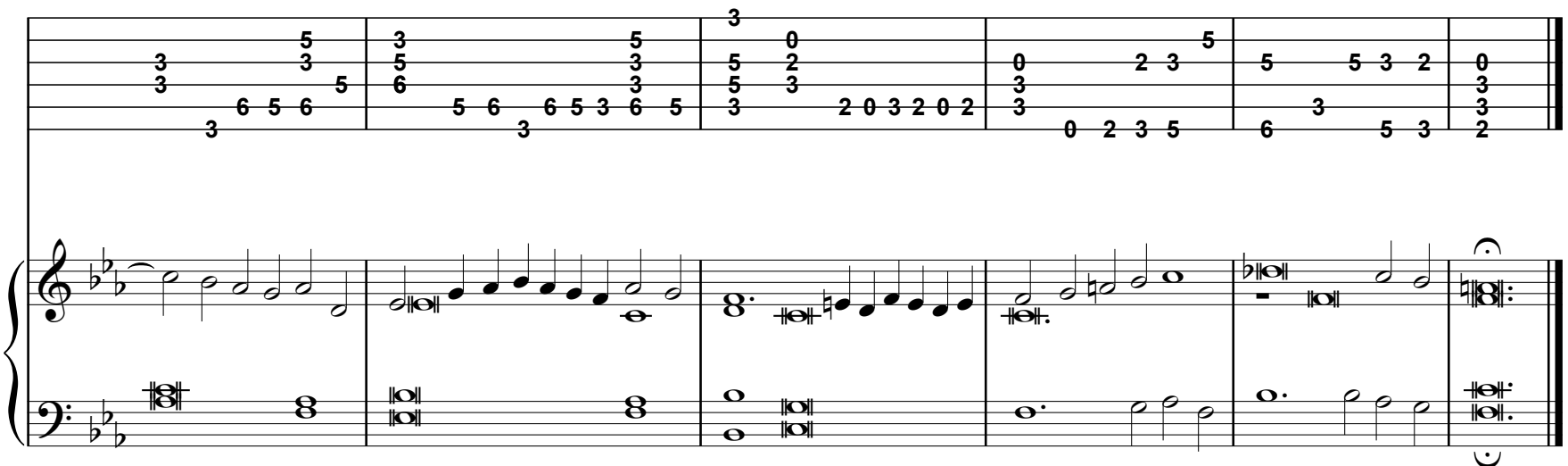


\title{
so15 - Pavana 1es
}

\author{
Pavana
}

[Libro I, ff. XVIII-XX]
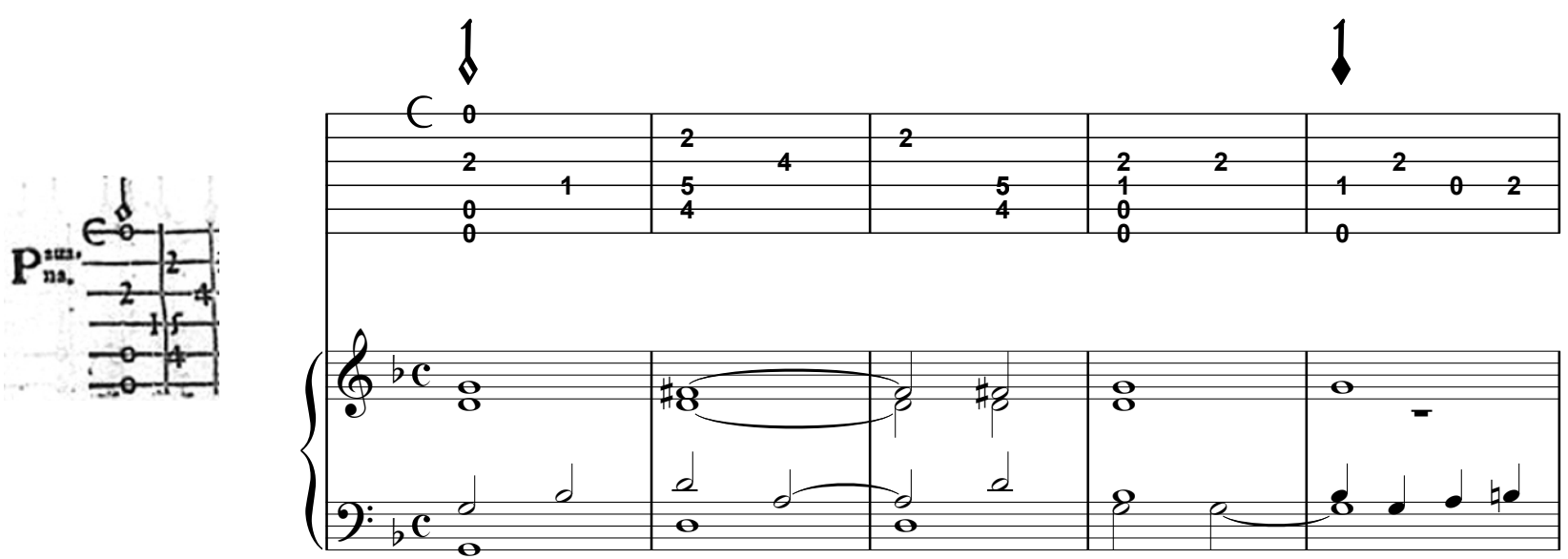

[f. XVIIIv]
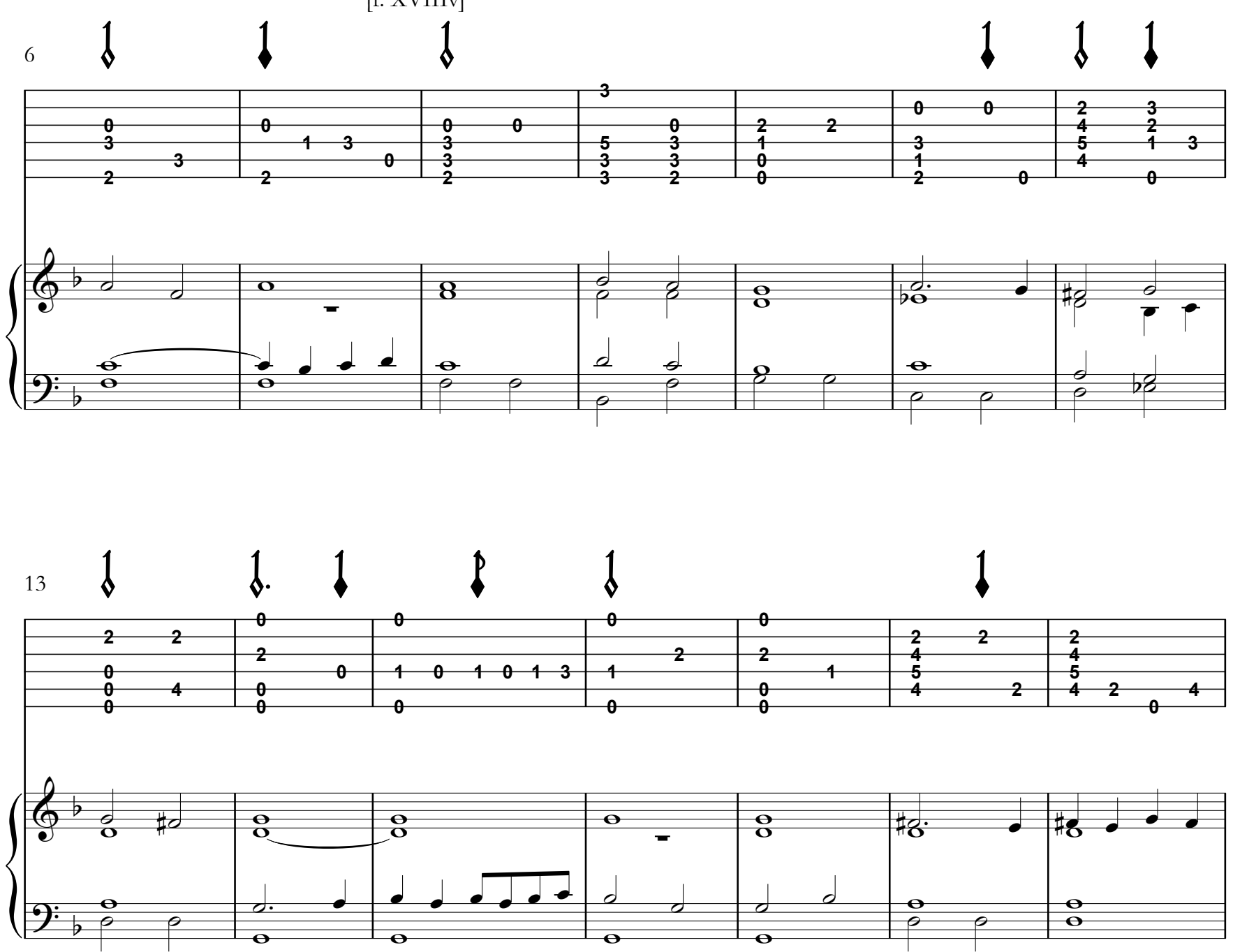


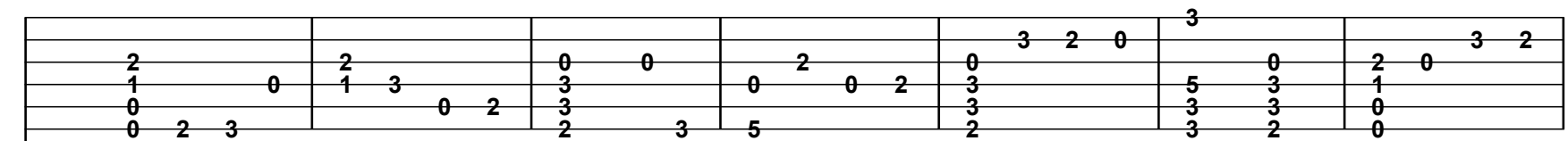
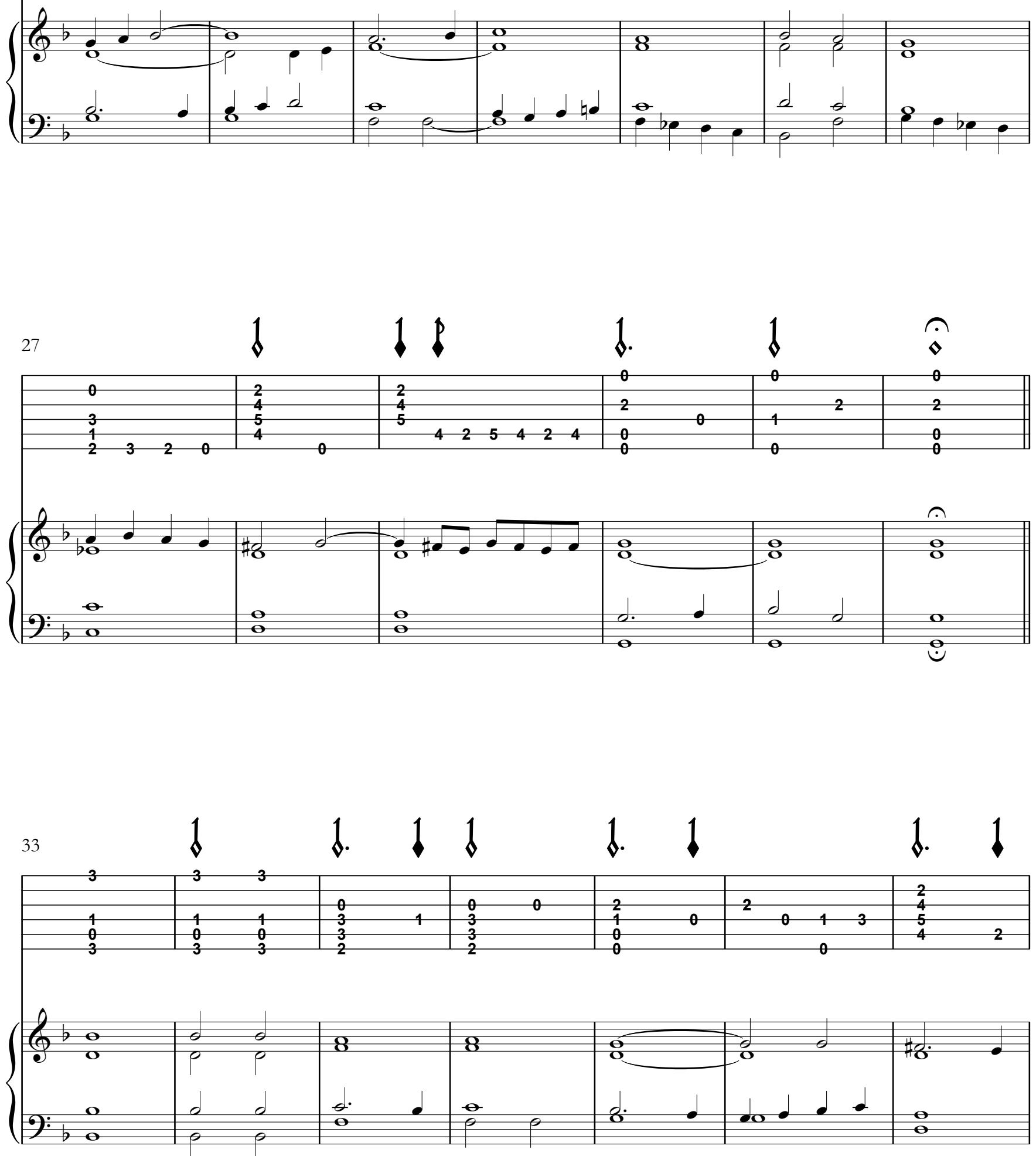

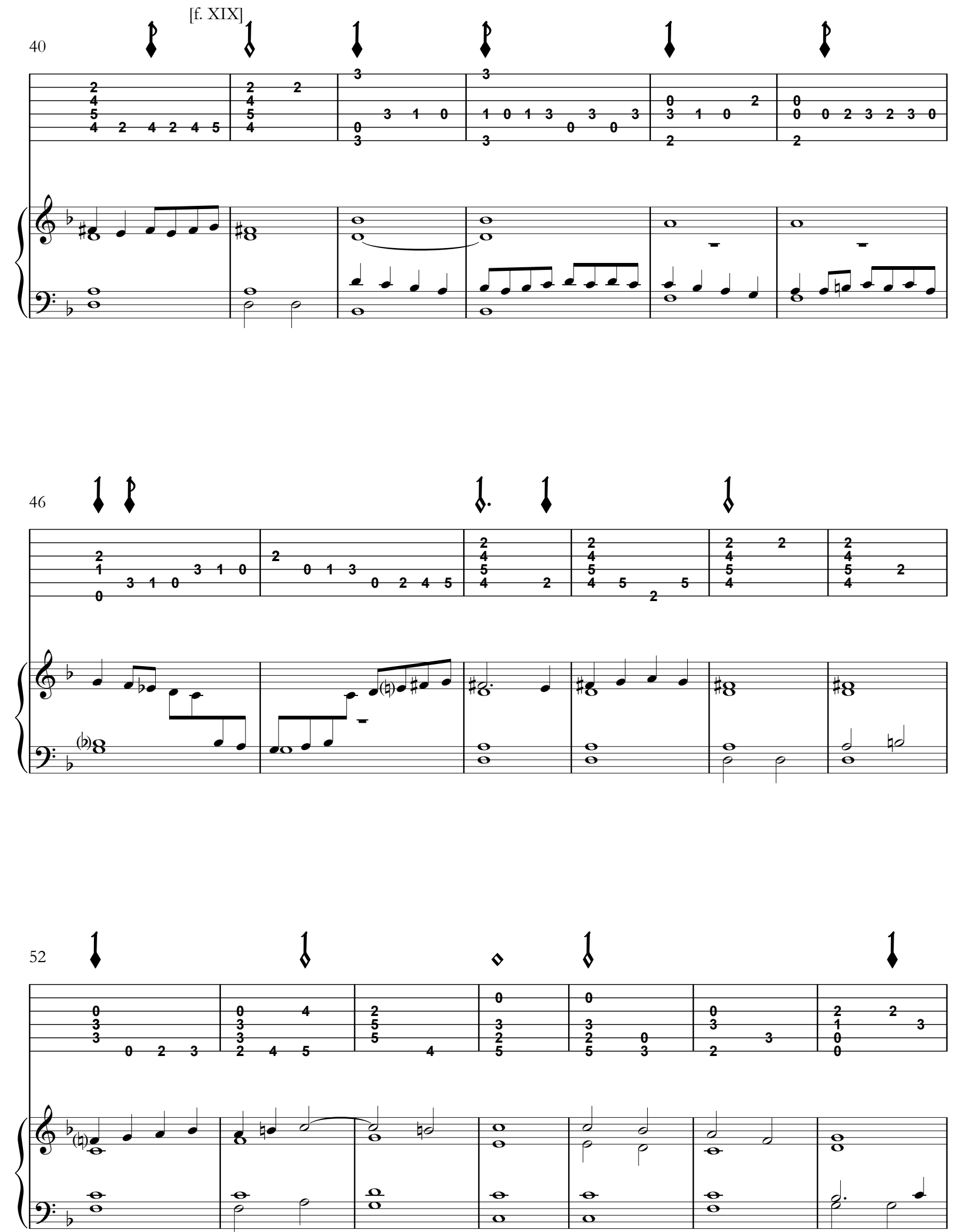
1

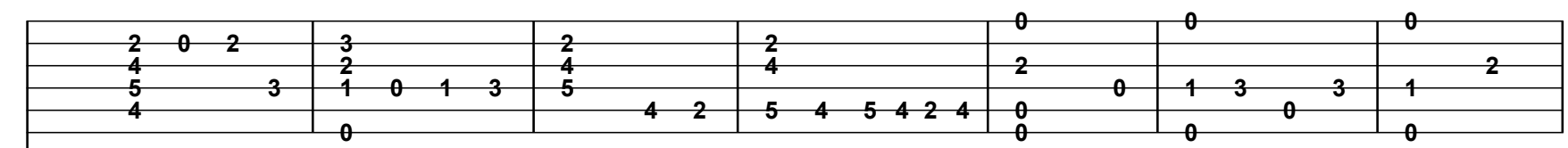
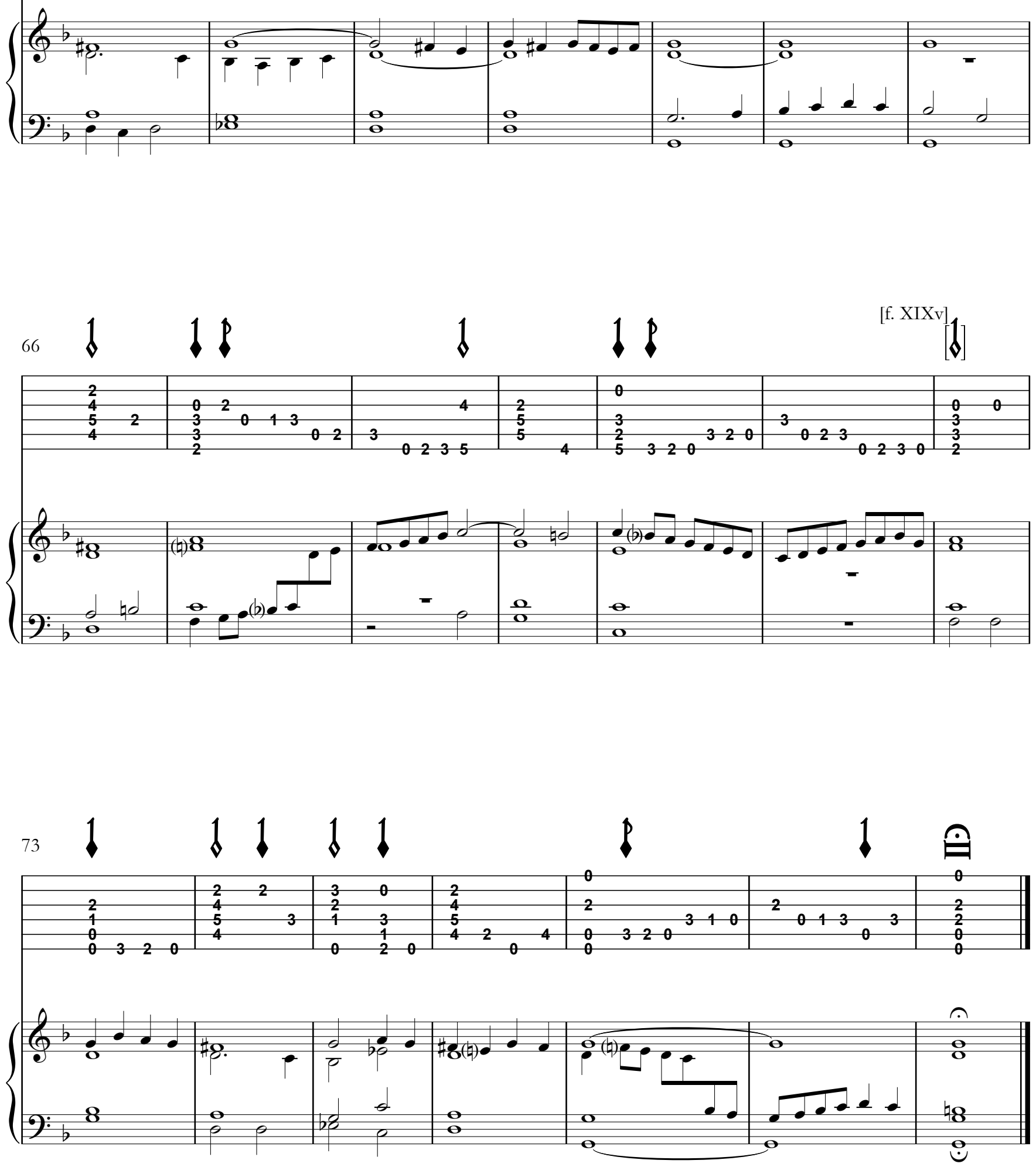


\section{s\&16 - Pavana de Alexandre}

Pavana de alxandre [sic]

[Libro I, ff. XIXv-XX]
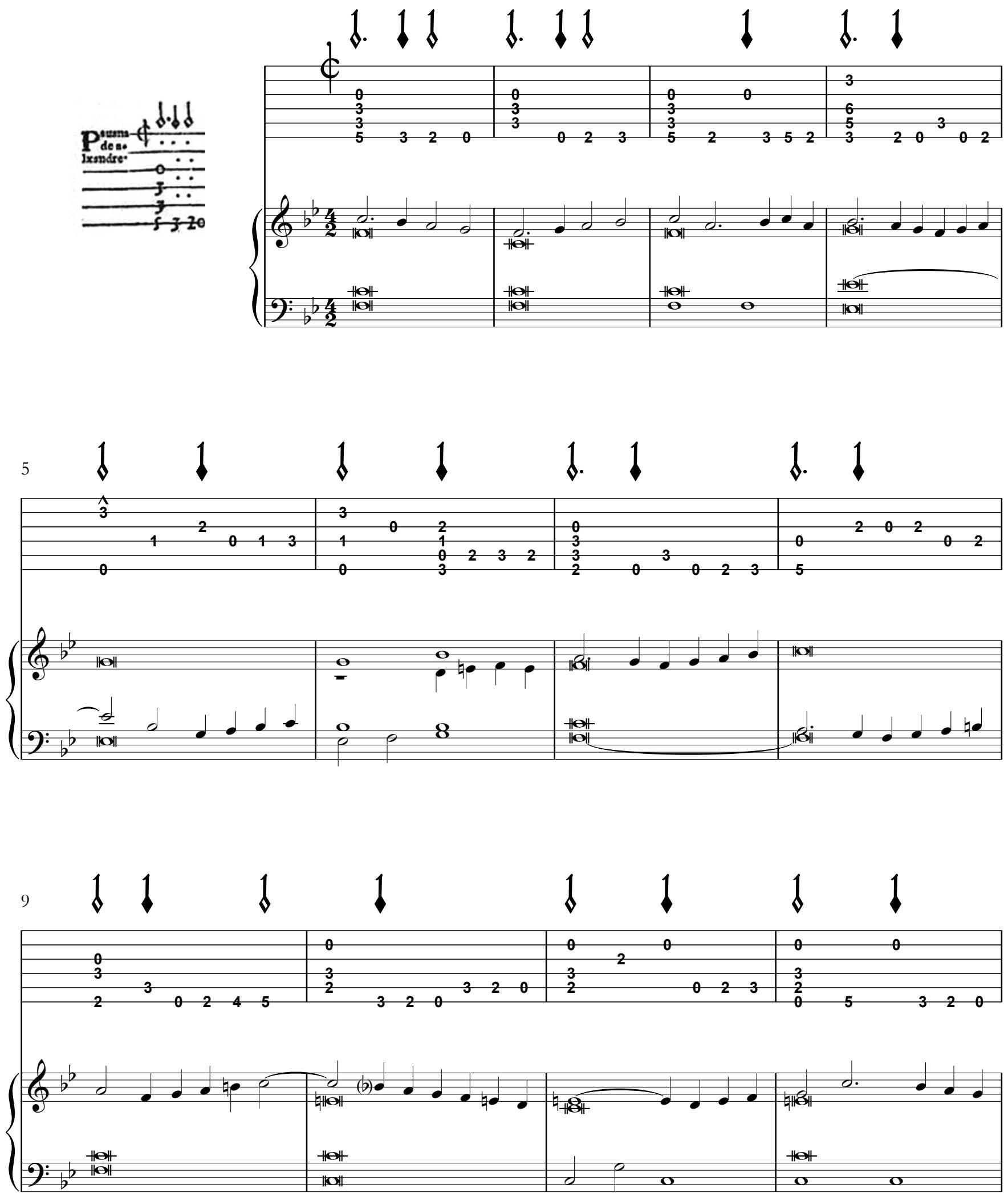
[f. XX]

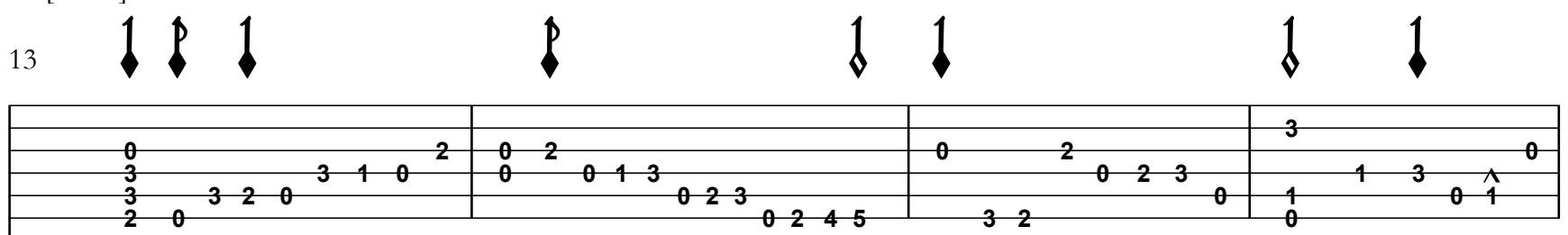

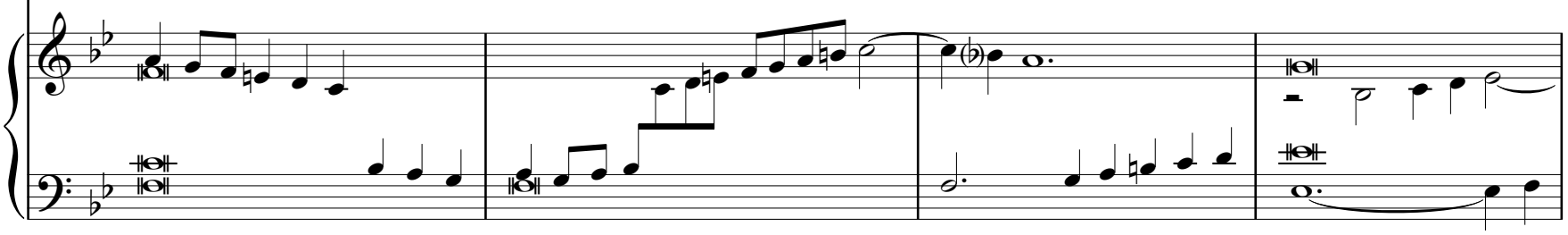
$17 \$ 1$
111
1

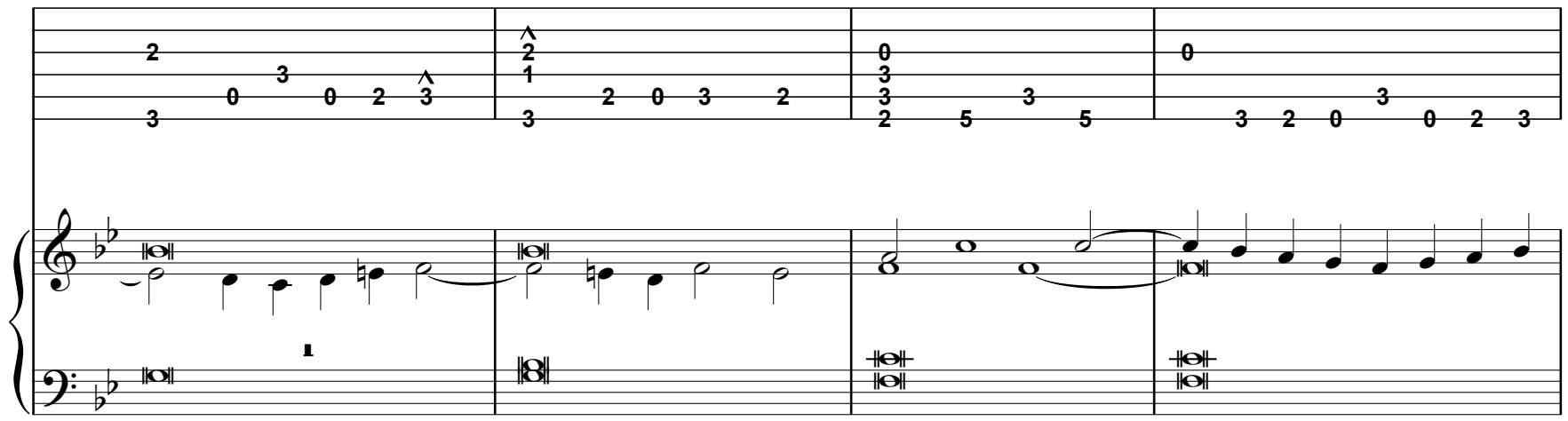

21

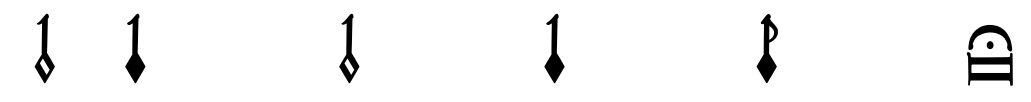

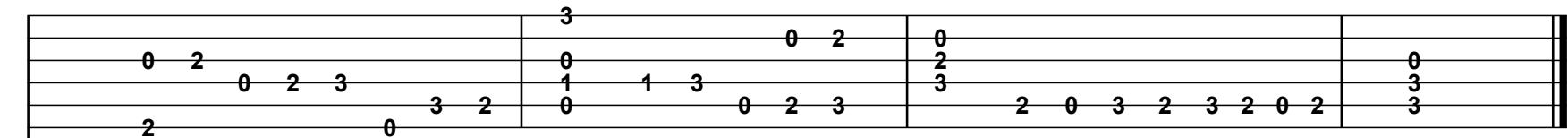

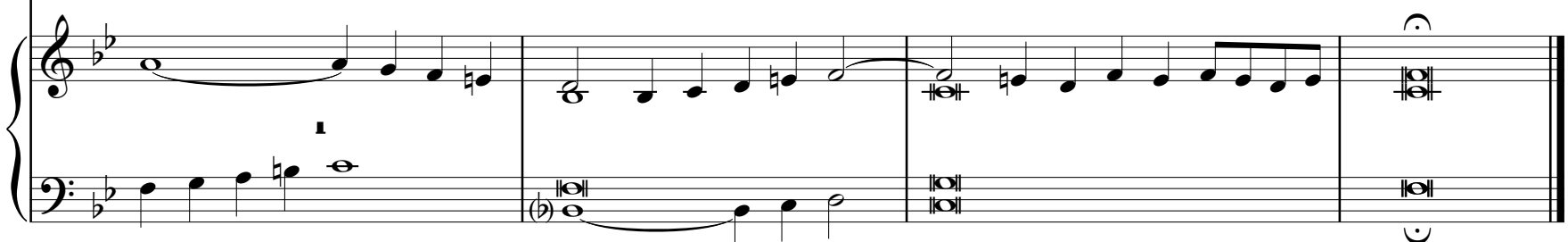




\section{sey 17 - Gallardaves}

Gallarpa [sic]

[Libro I, f. XX]
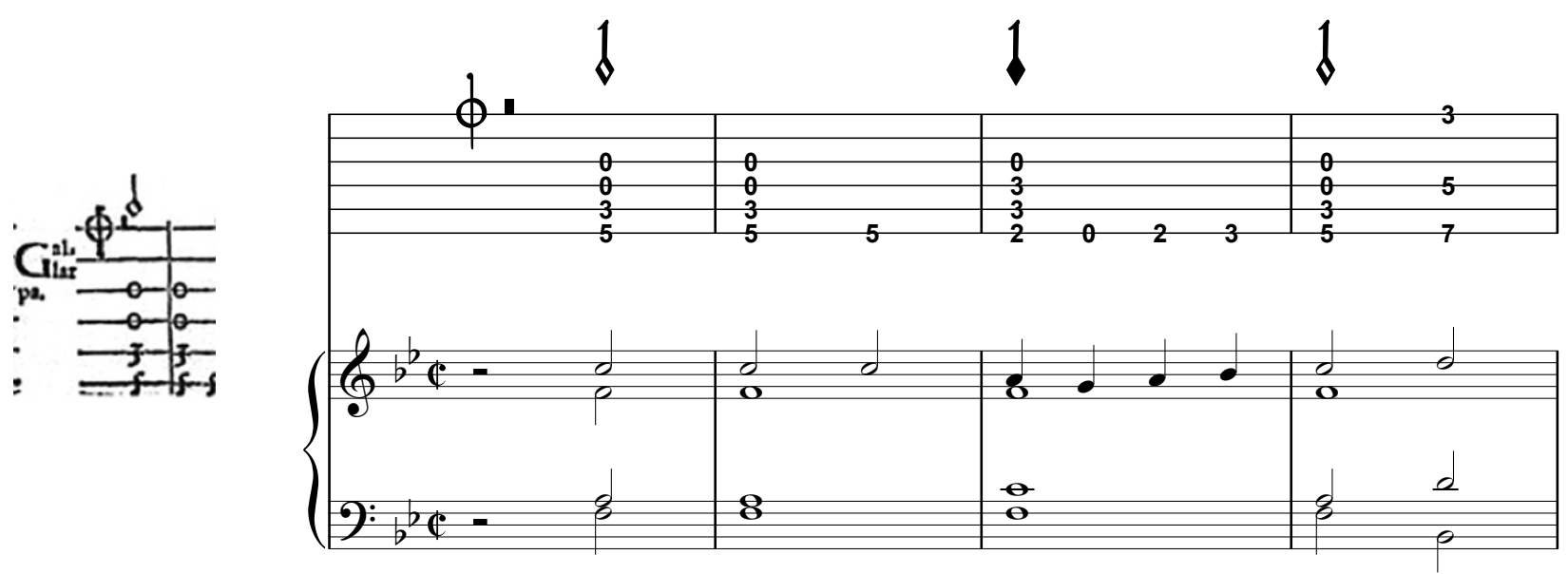

[f. XXv]

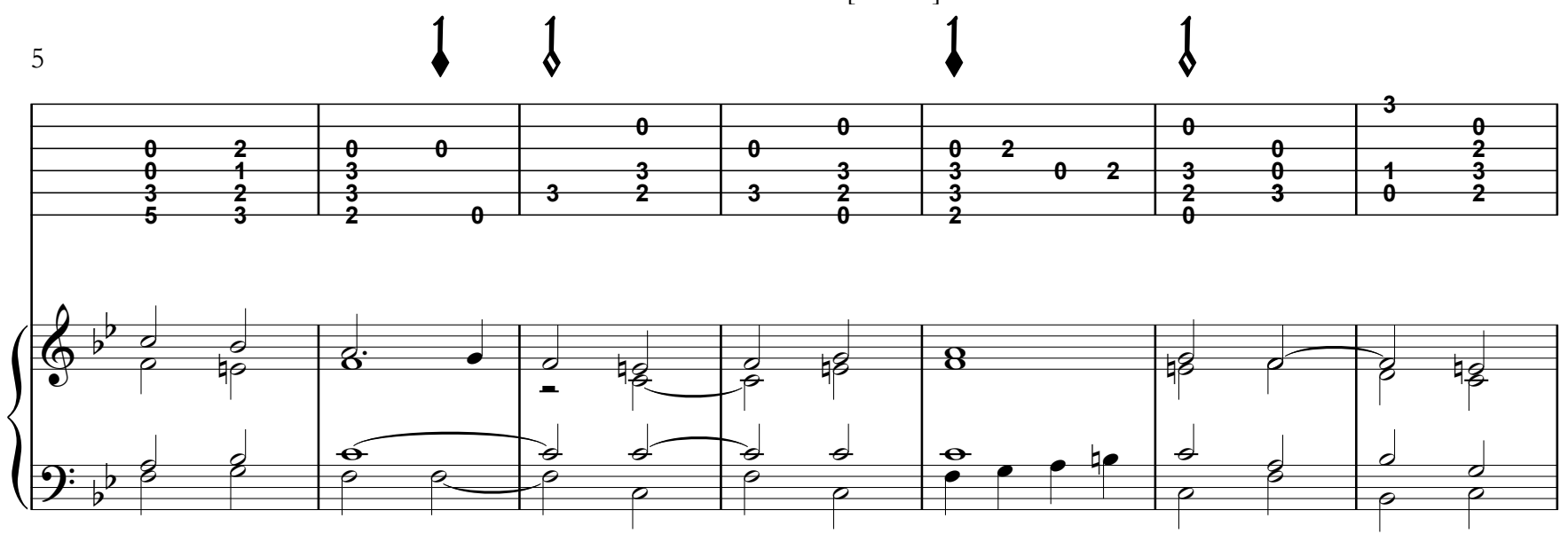

$\begin{array}{lllllllllllll}12 & 1 & 1 & 1 & 1 & 1 & 1 & 1 & 8\end{array}$

\begin{tabular}{|c|c|c|c|c|c|c|}
\hline & 0 & 0 & & $3 \quad 2$ & & \\
\hline $\begin{array}{ll}0 & 2\end{array}$ & 0 & 0 & & 2 & & 0 \\
\hline $320^{3} 10$ & 3 & 3 & $\begin{array}{llllll}3 & 1 & 0 & 2 & 3 & 0\end{array}$ & 10 & 3 & 3 \\
\hline & & & & & 2 & \\
\hline
\end{tabular}

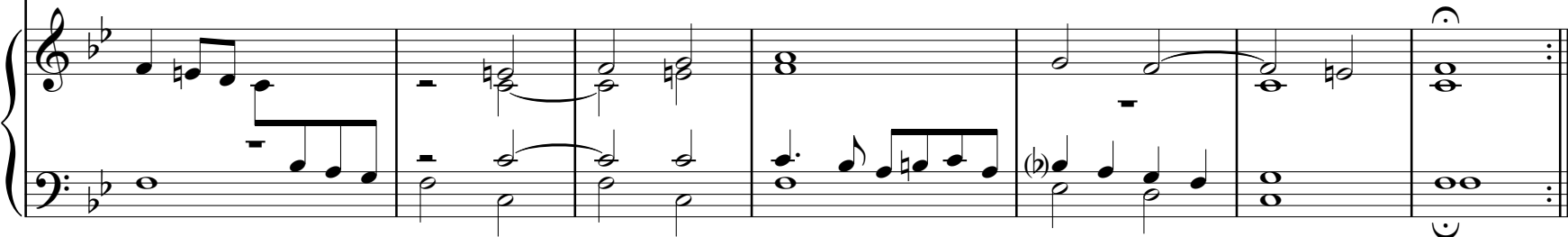



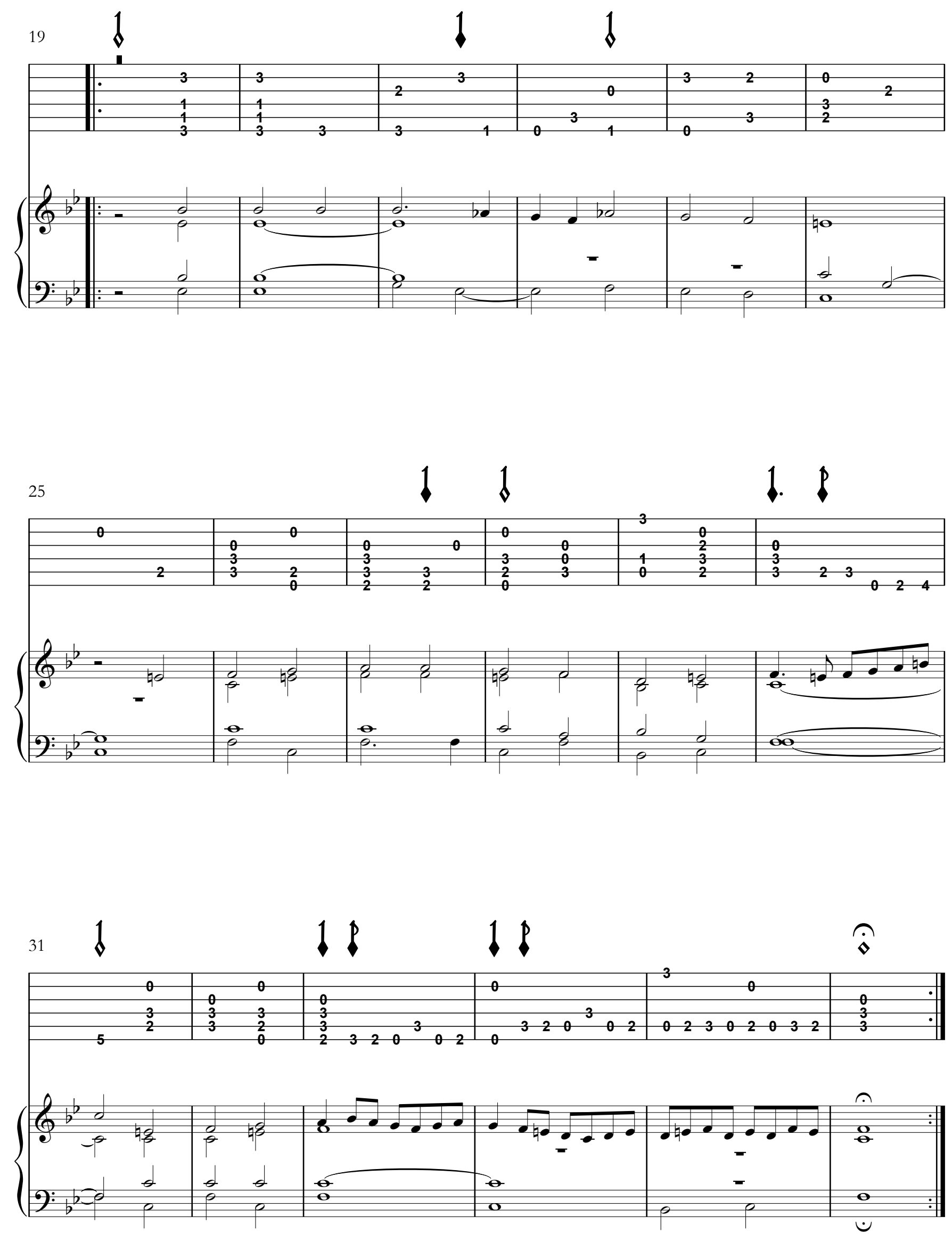


\section{s\&18 - Fantasía 11}

[Guitarra al temple viejo]

Fantasía del primer tono

[Libro I, f. XXI]
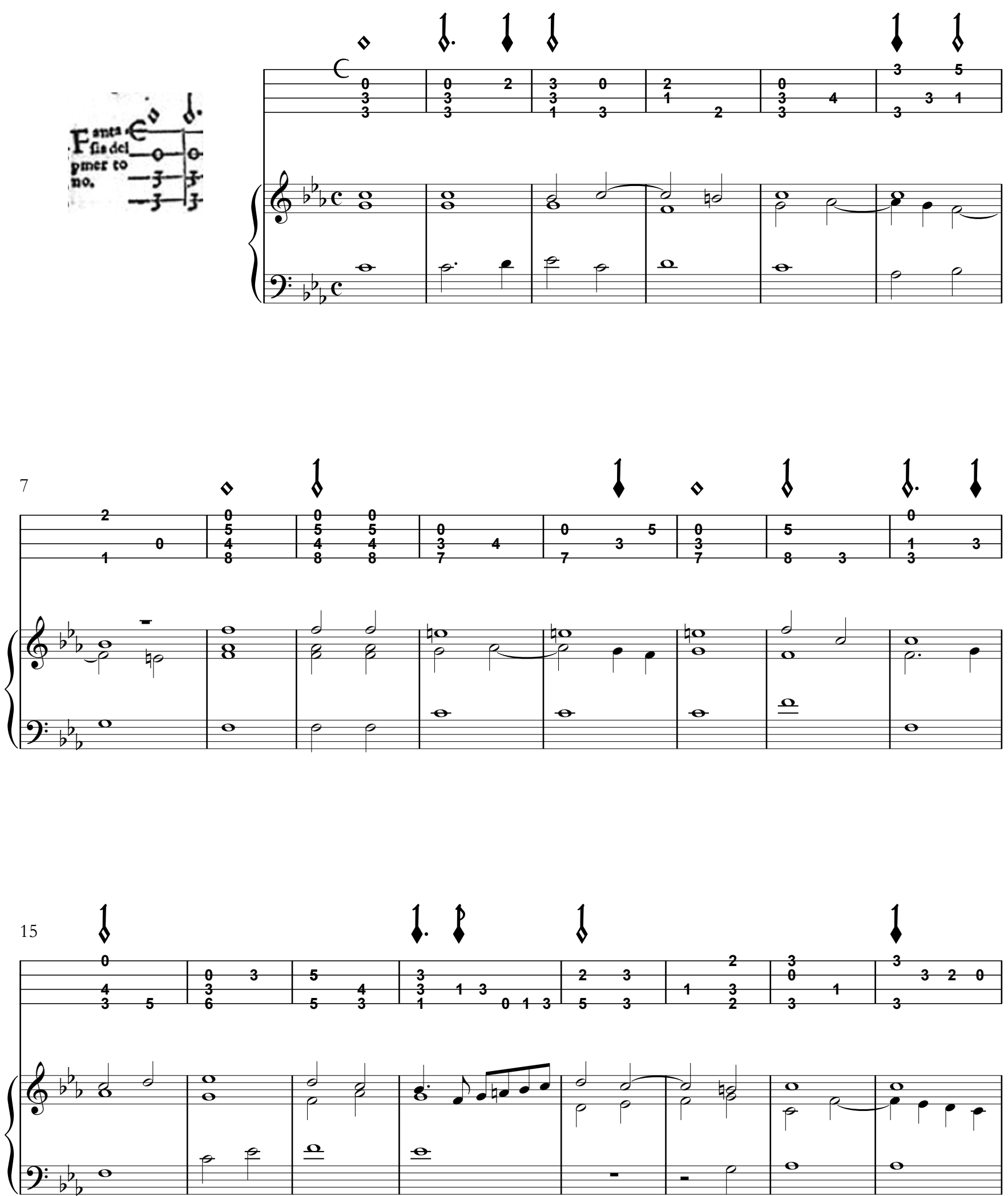

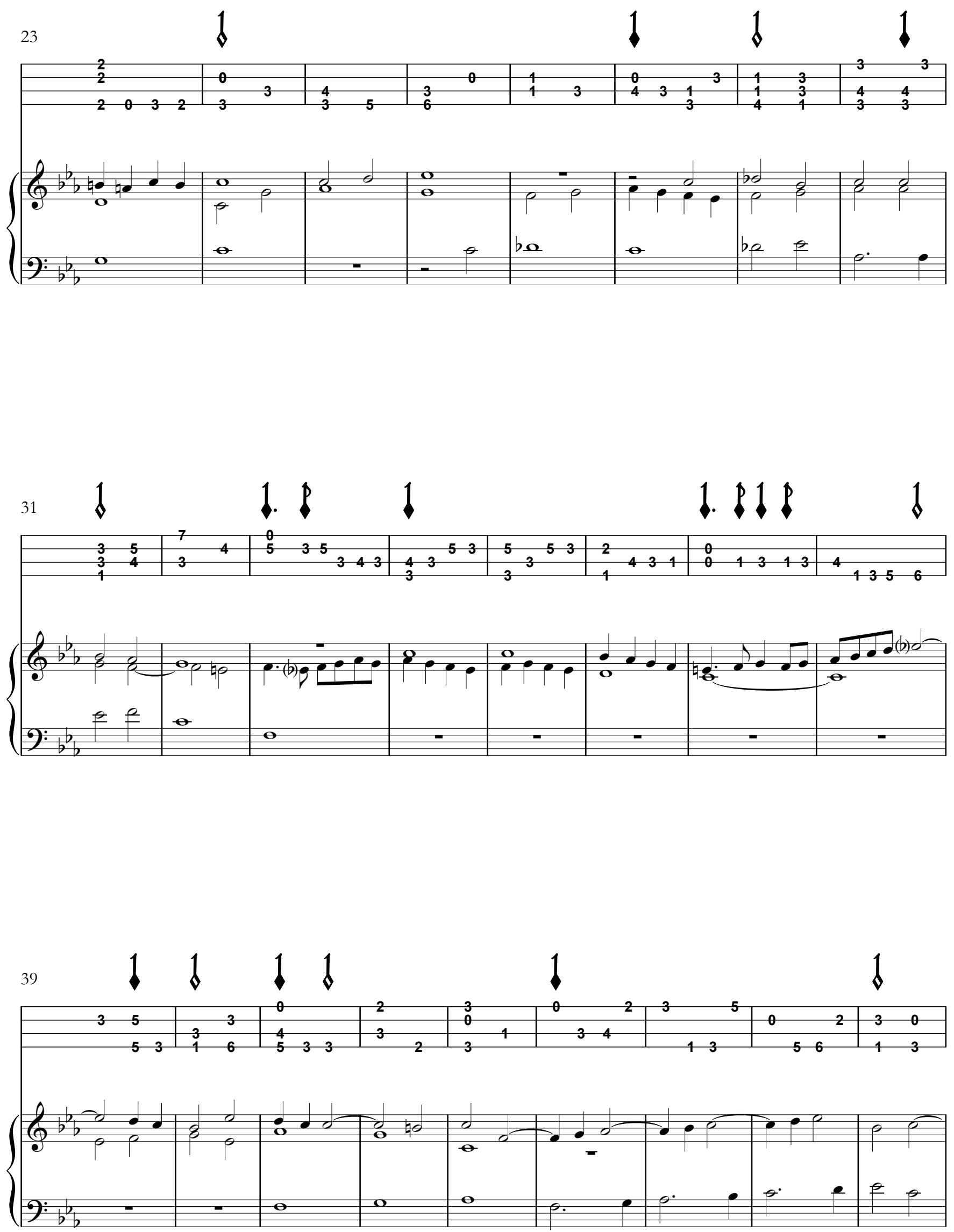

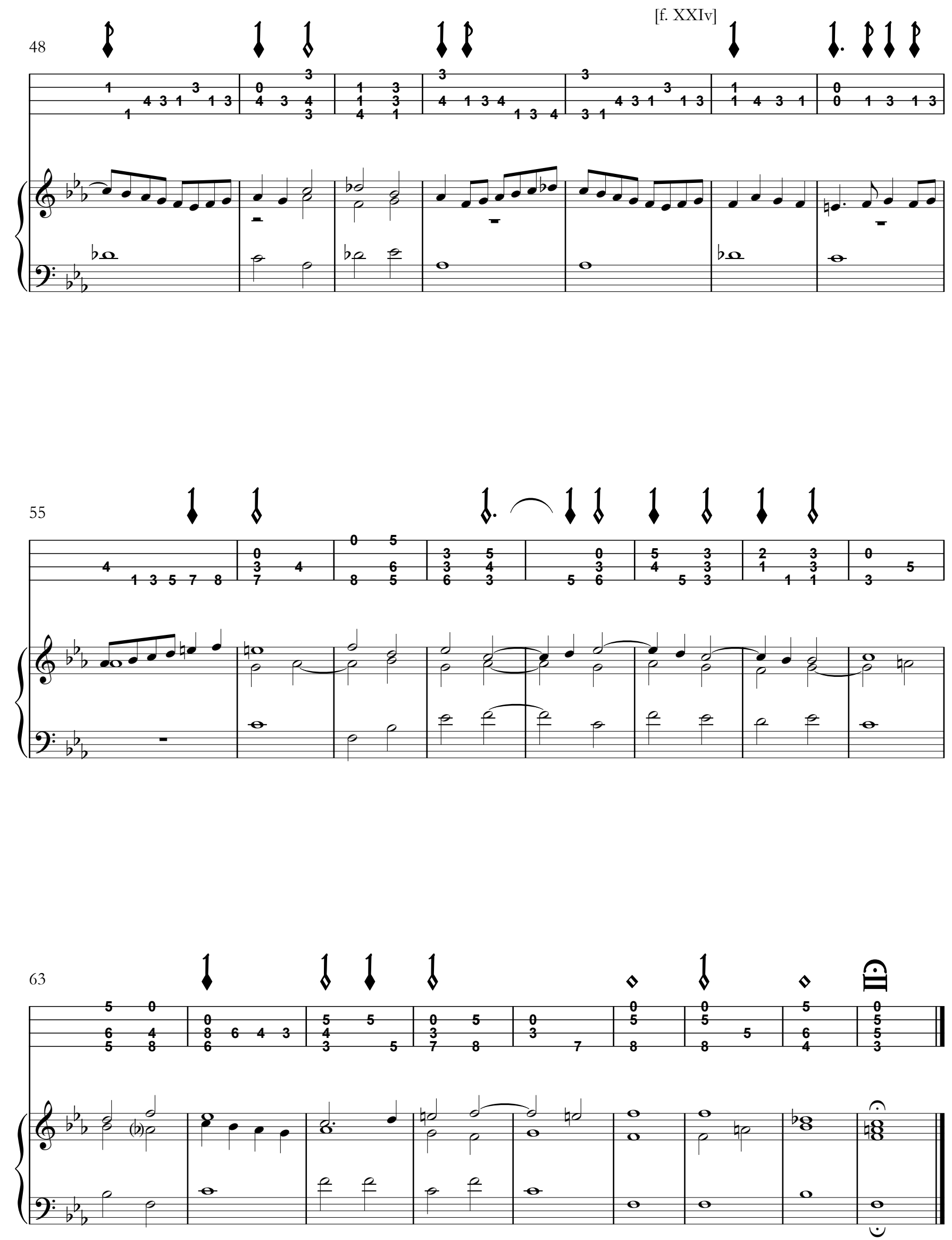


\section{\&ะ19 - Fantasía 12}

Fantasía del quarto tono

[Libro I, ff. XXIv-XXII]
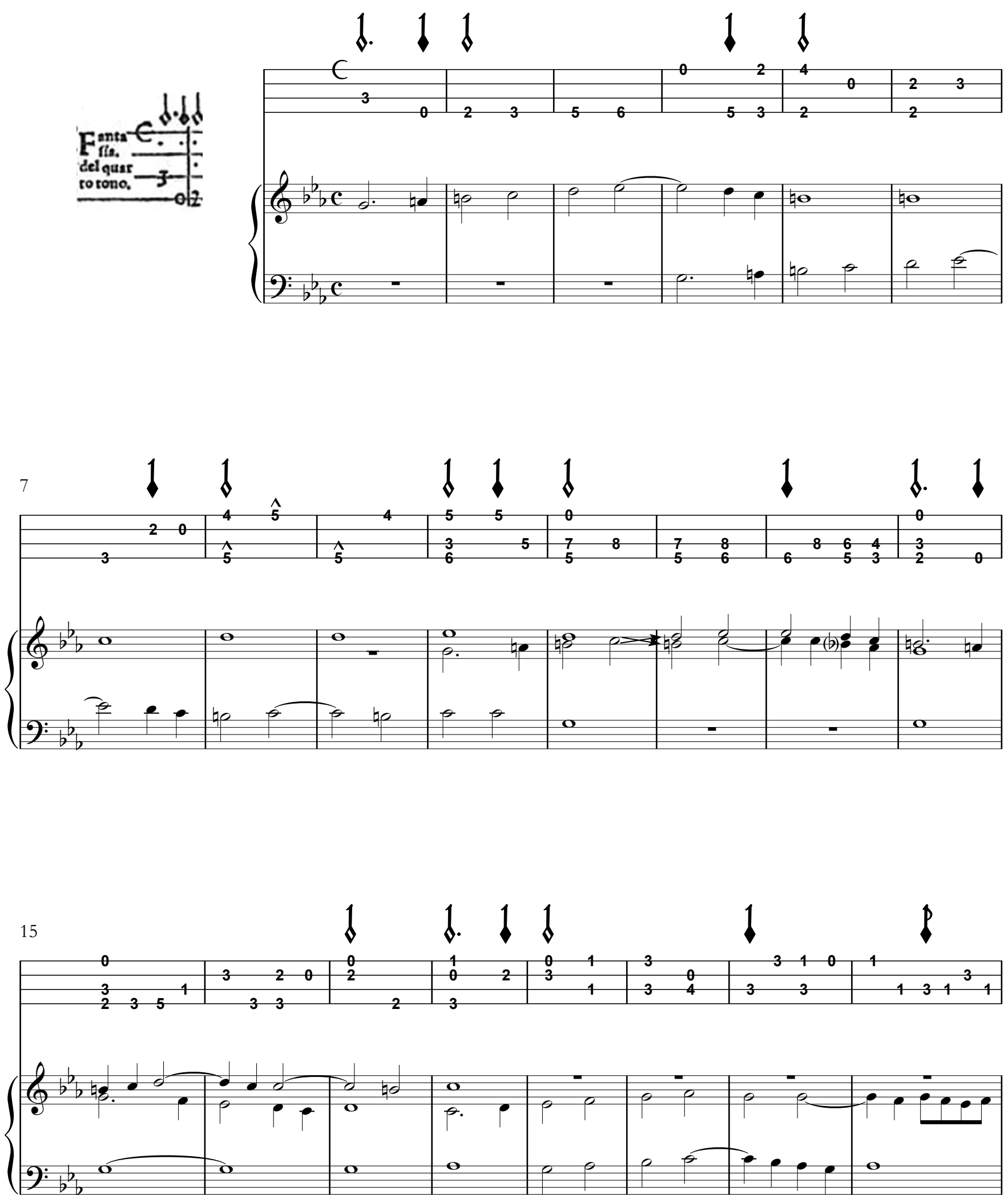

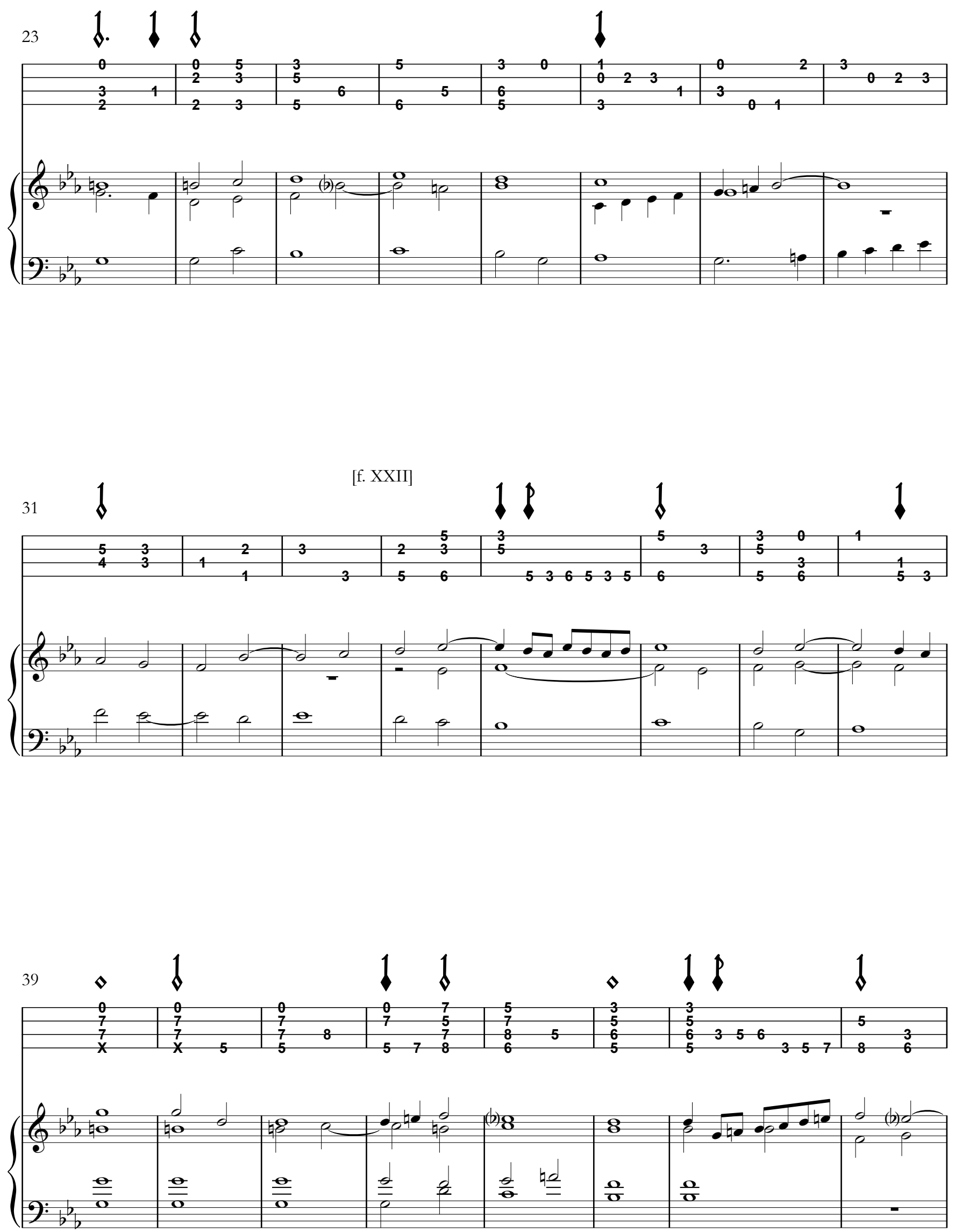

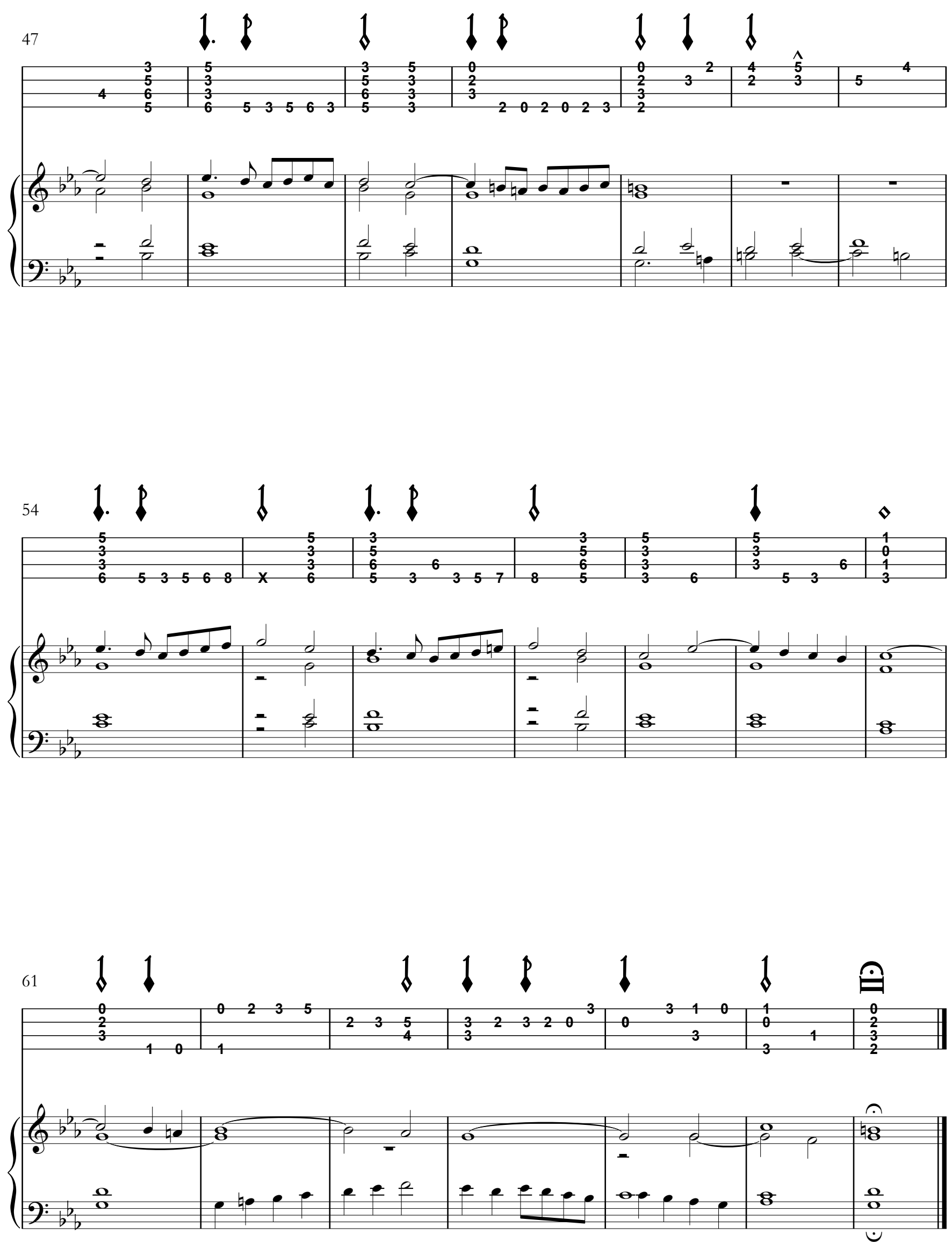


\section{sะ20 - Fantasía 13}

Fantasía del quinto tono

[Libro I, f. XXII]
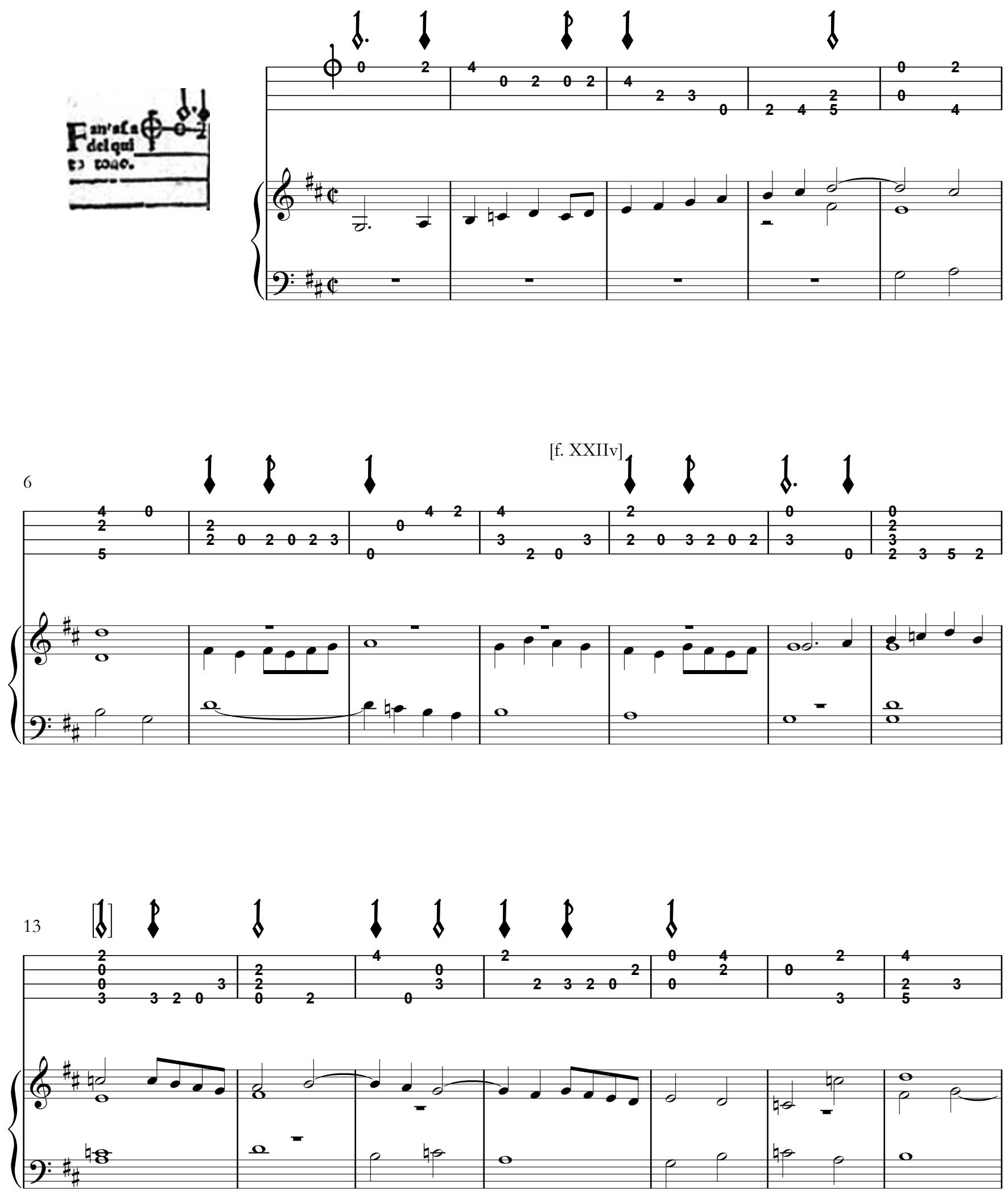

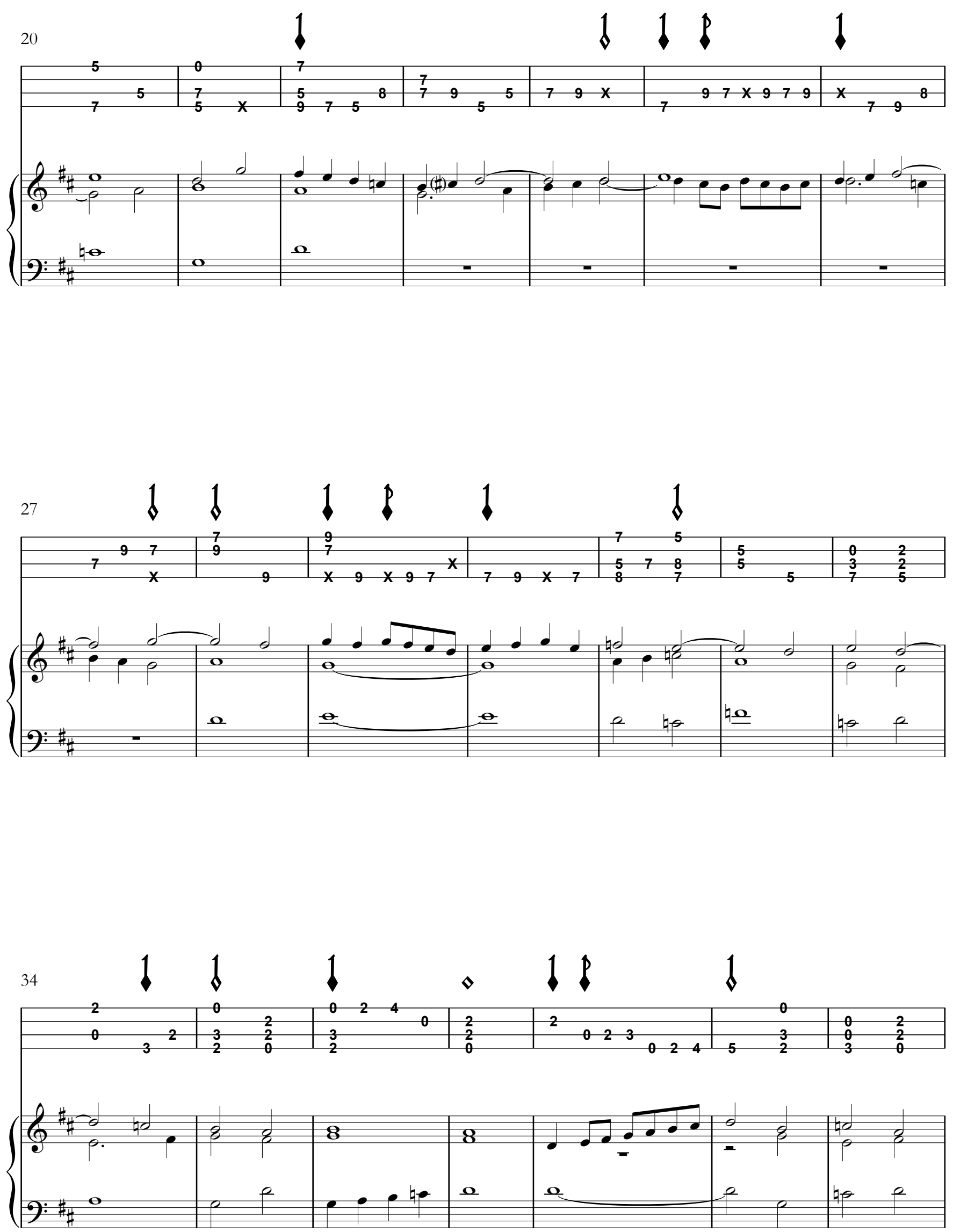

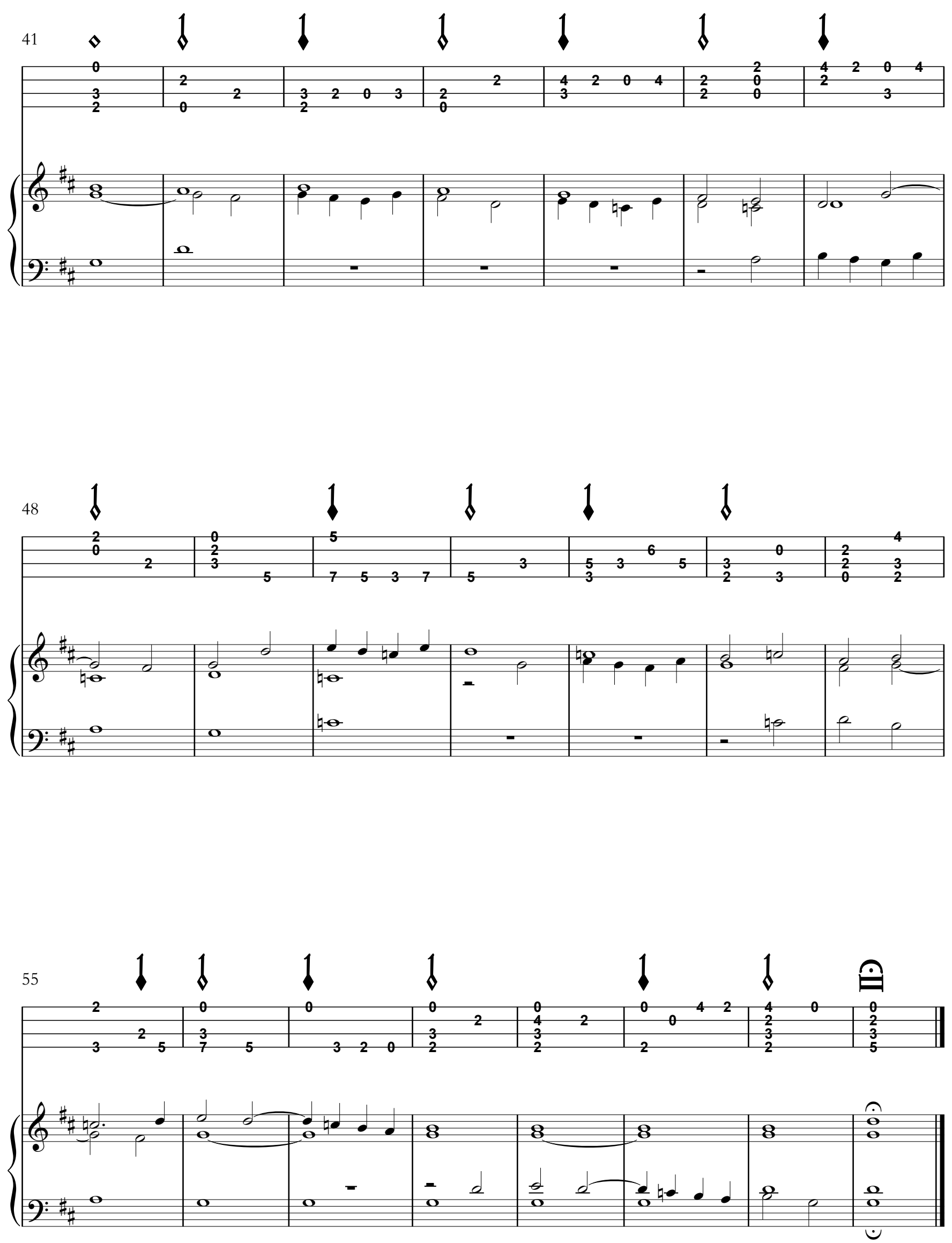


\section{ระ21 - Fantasía 14}

Fantasía del primer tono

[Libro I, f. XXIII]
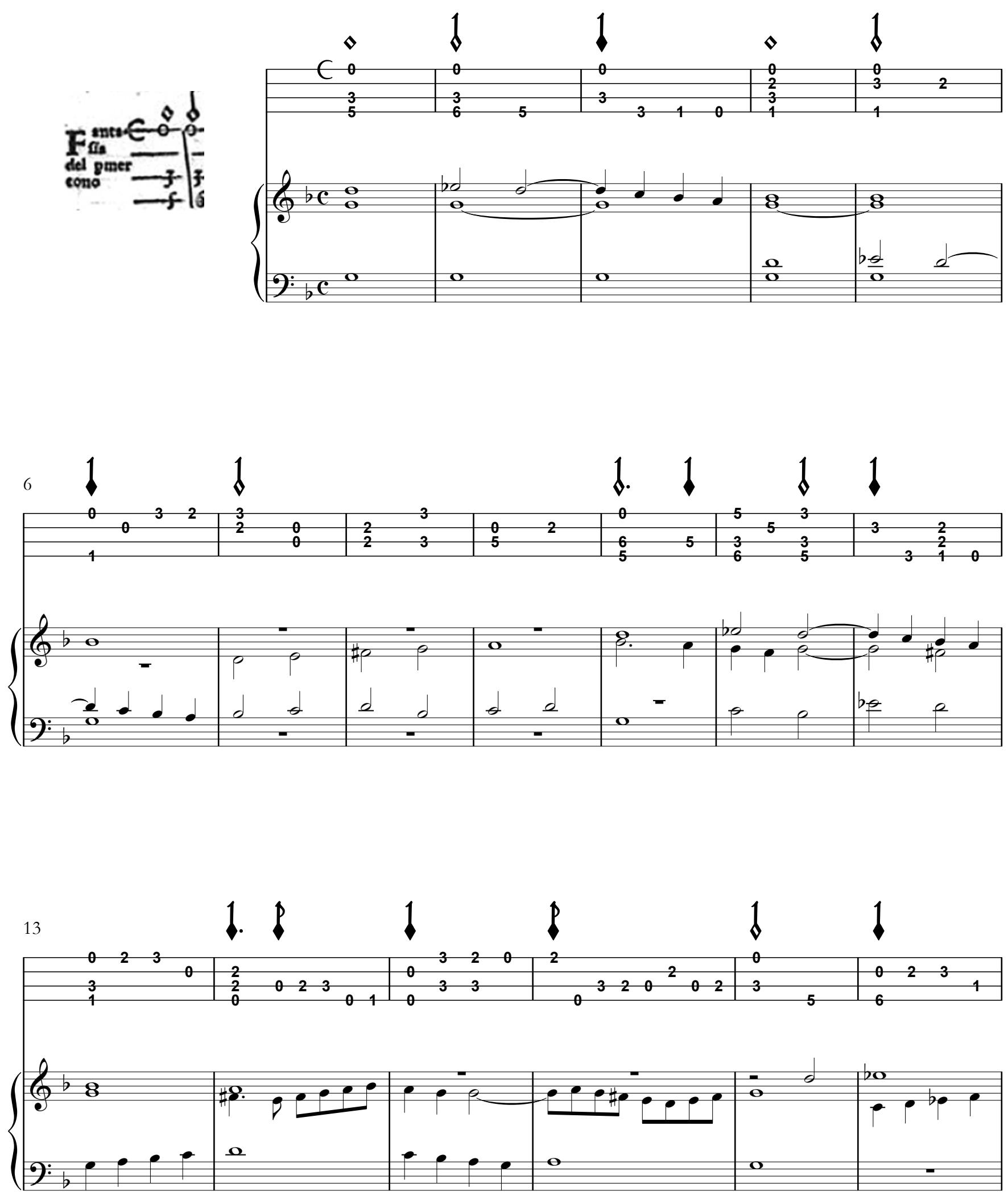

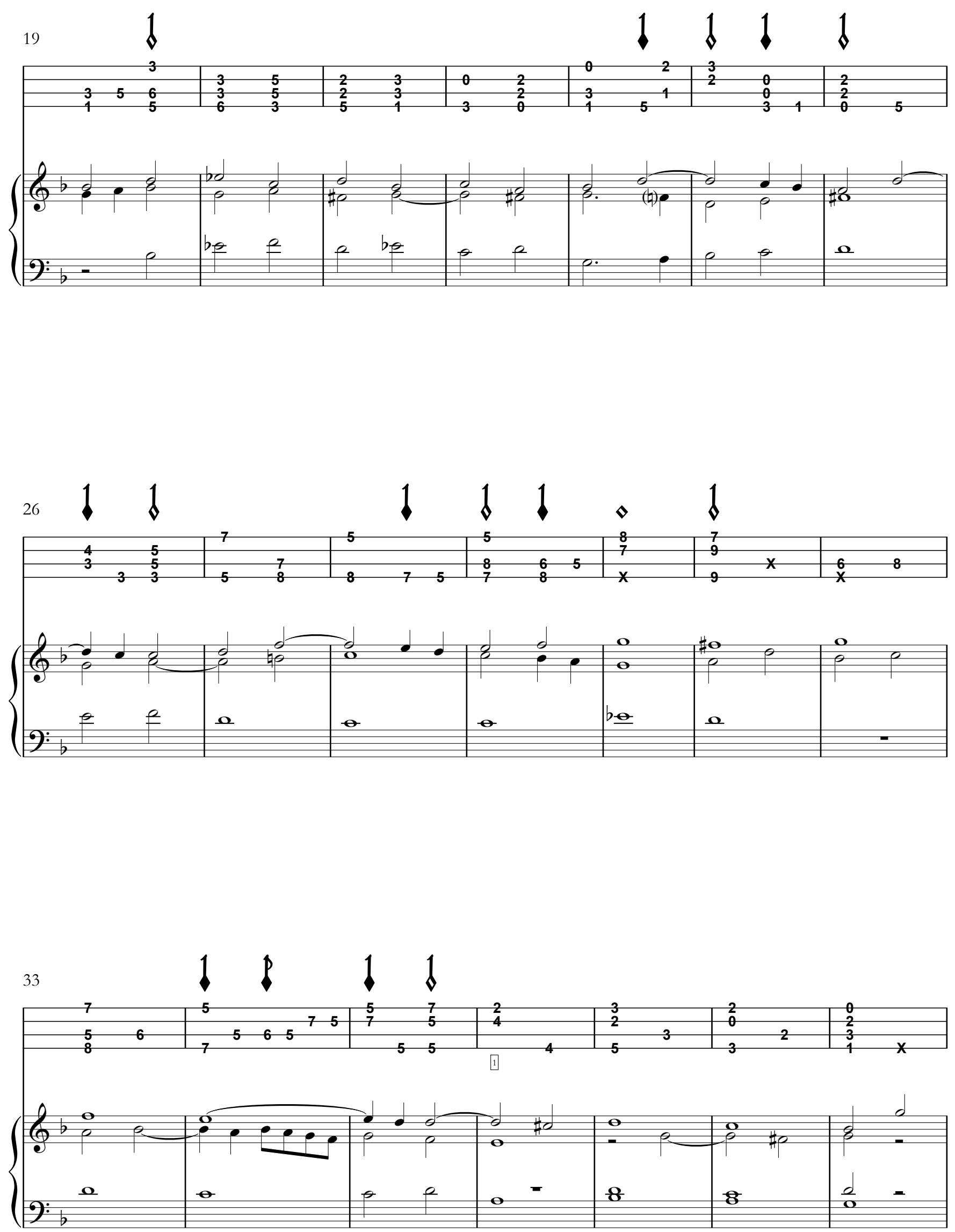

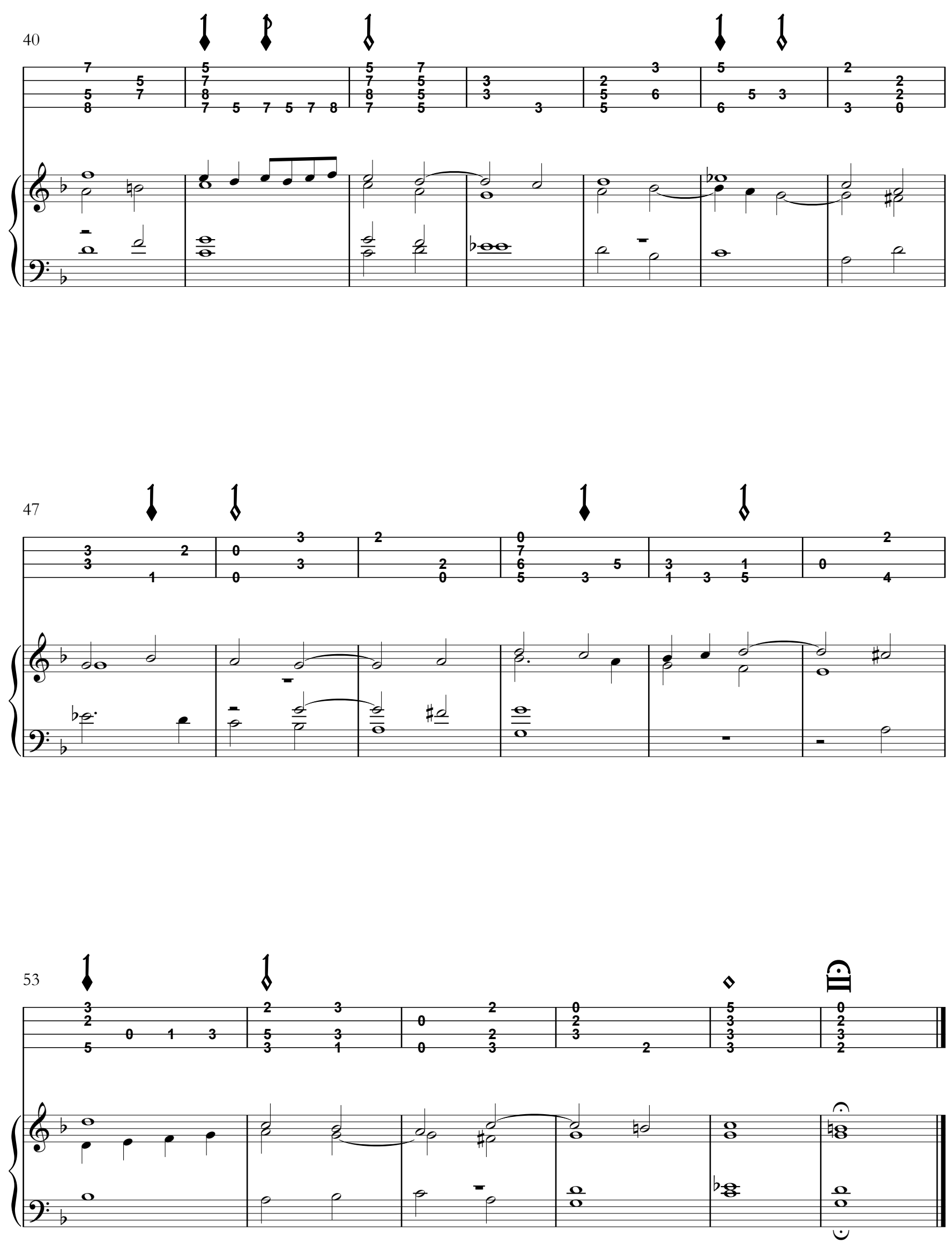


\section{s*22 - Pavana 3}

[Libro I, f. XXIIIv]
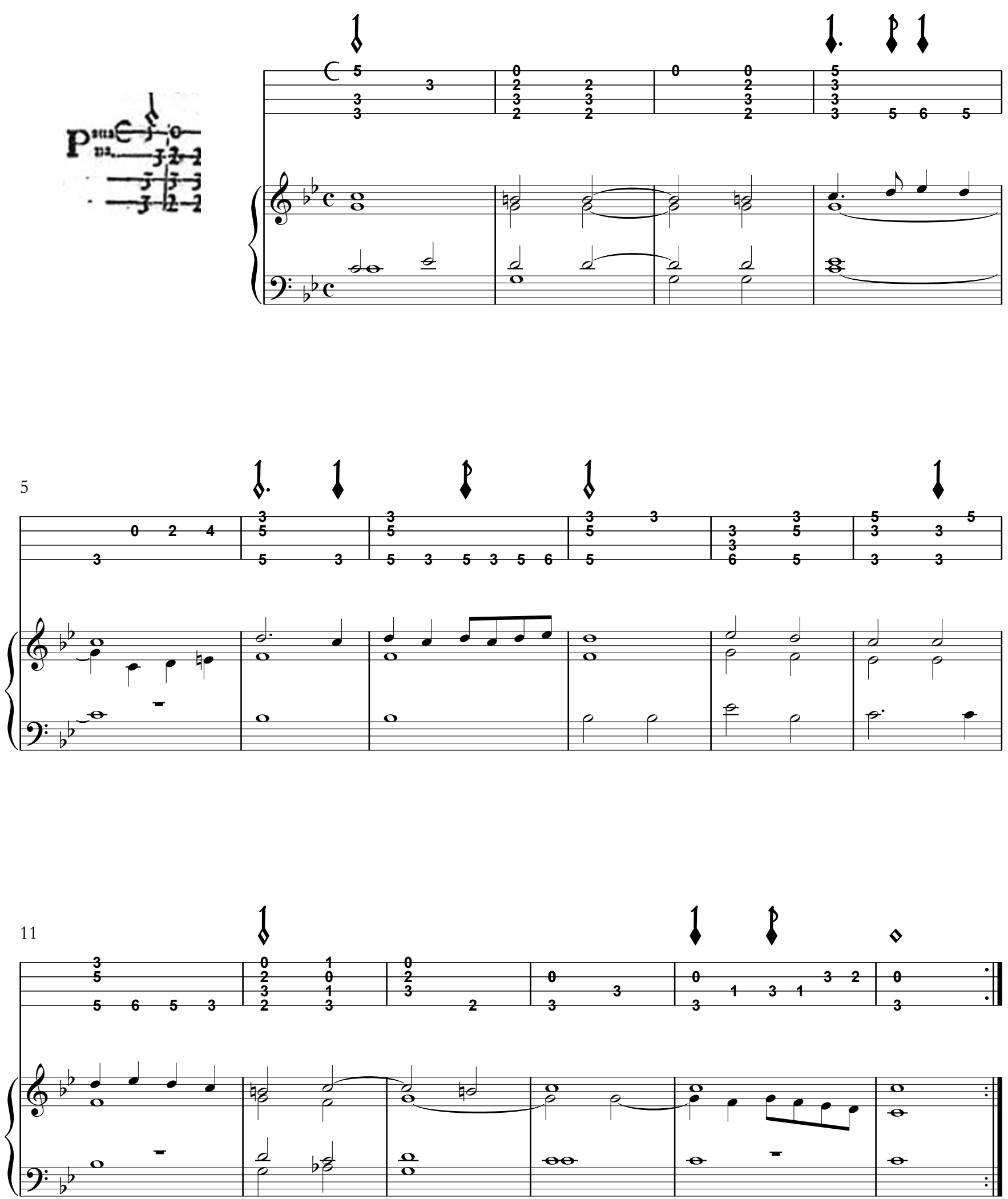

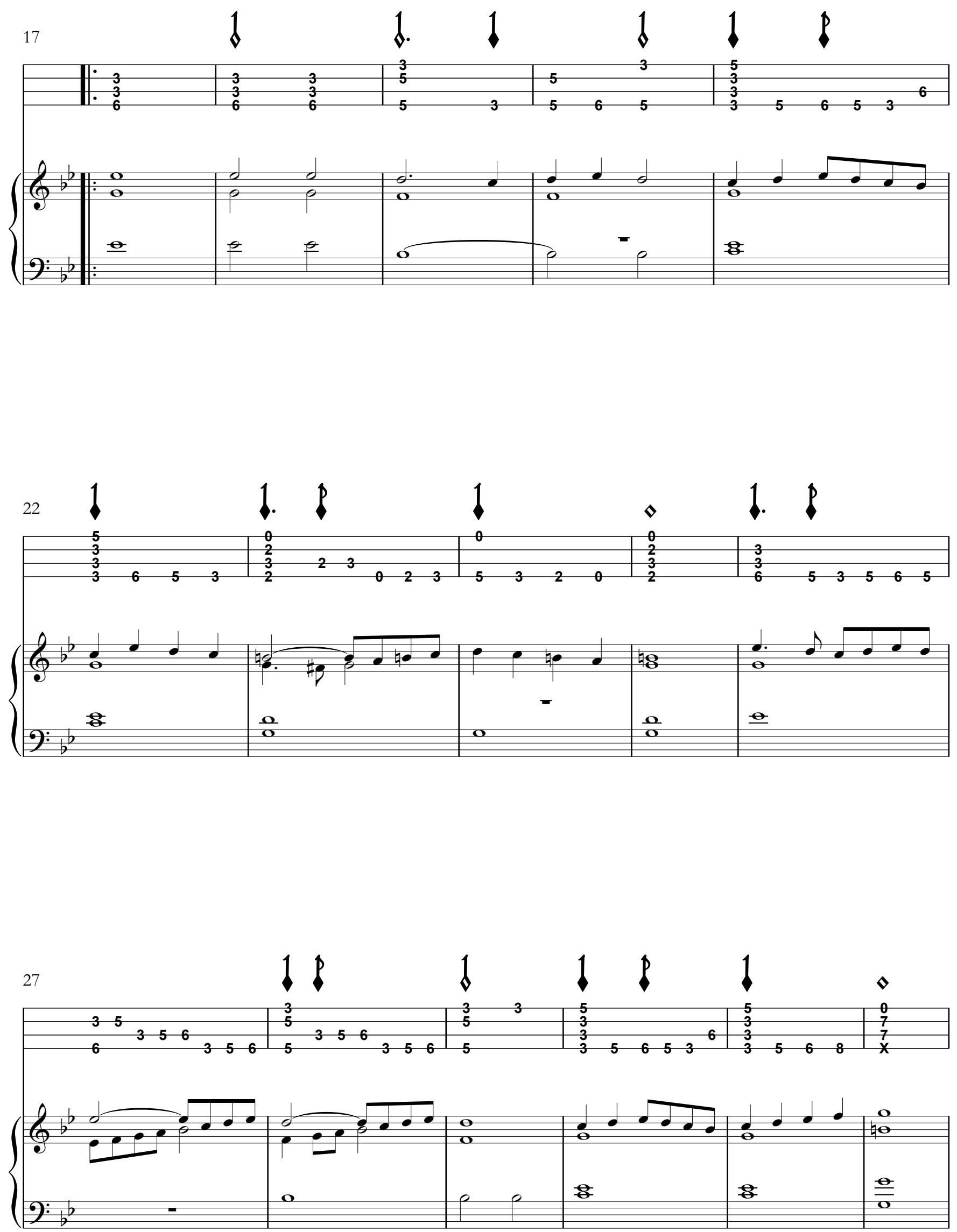

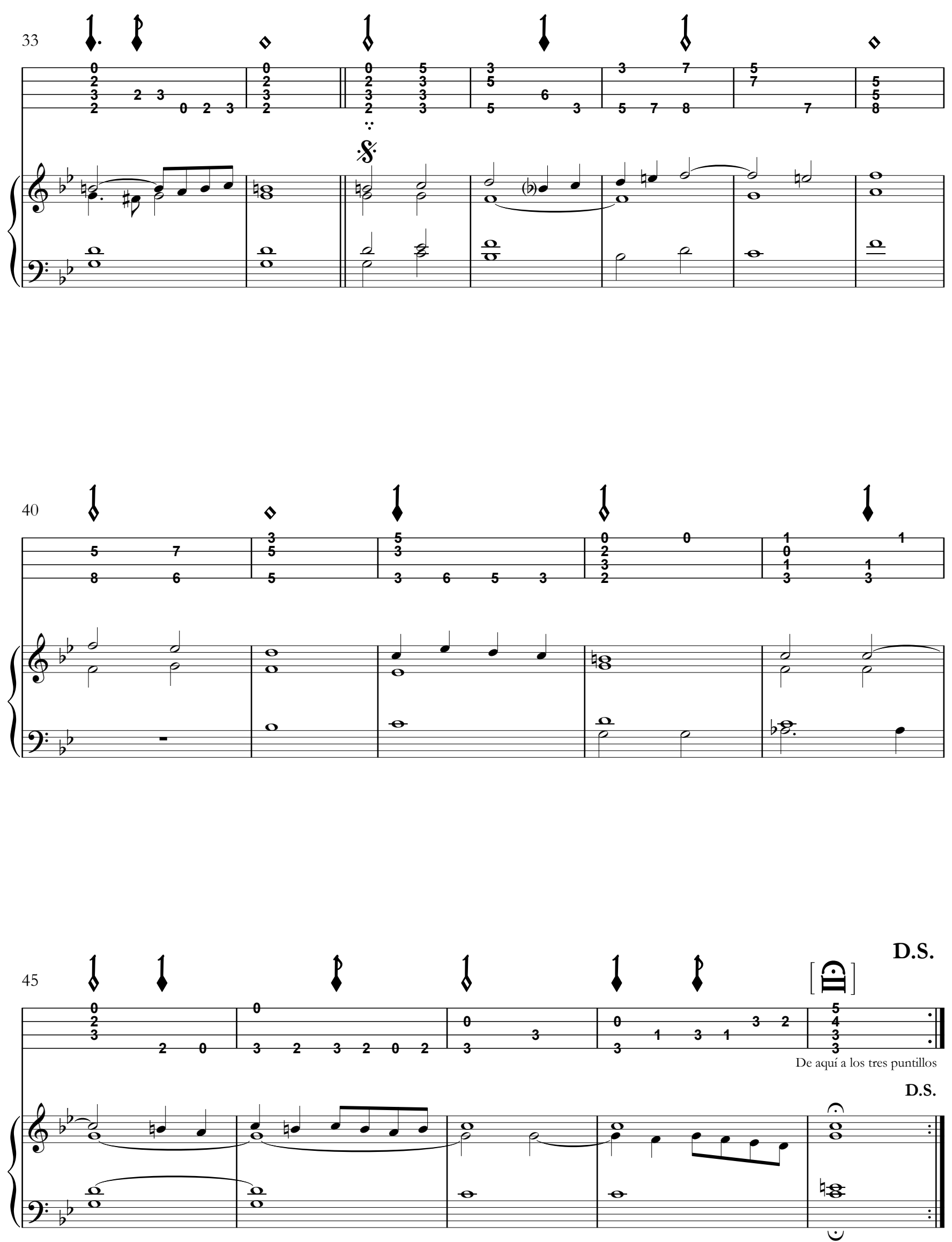


\section{\&ะ23 - Romanesca. Guárdame las vacas 2 \&}

Romanesca o guárdame las vacas. Proporción tres semibreues al conpás

[Libro I, f. XXIV]
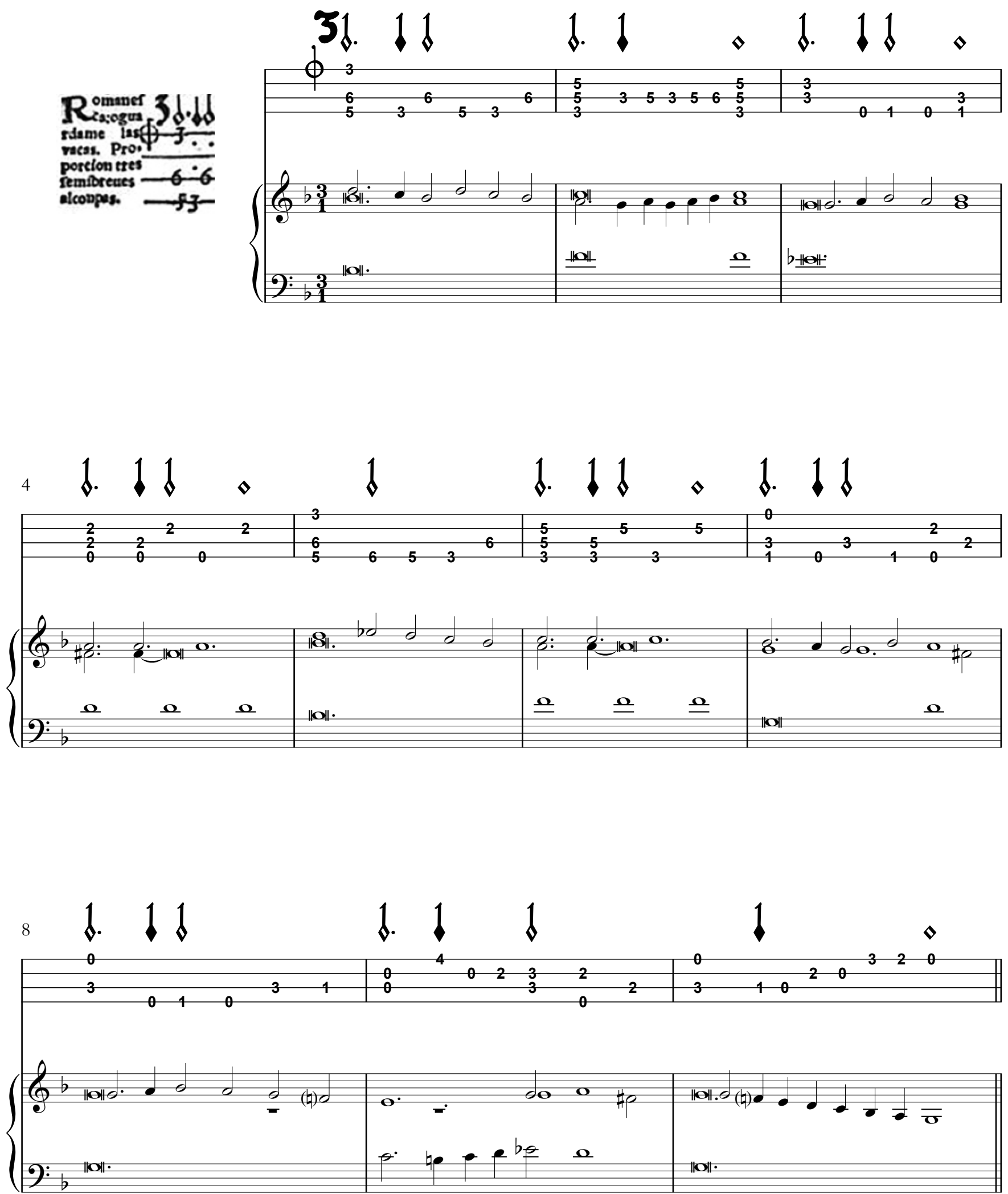

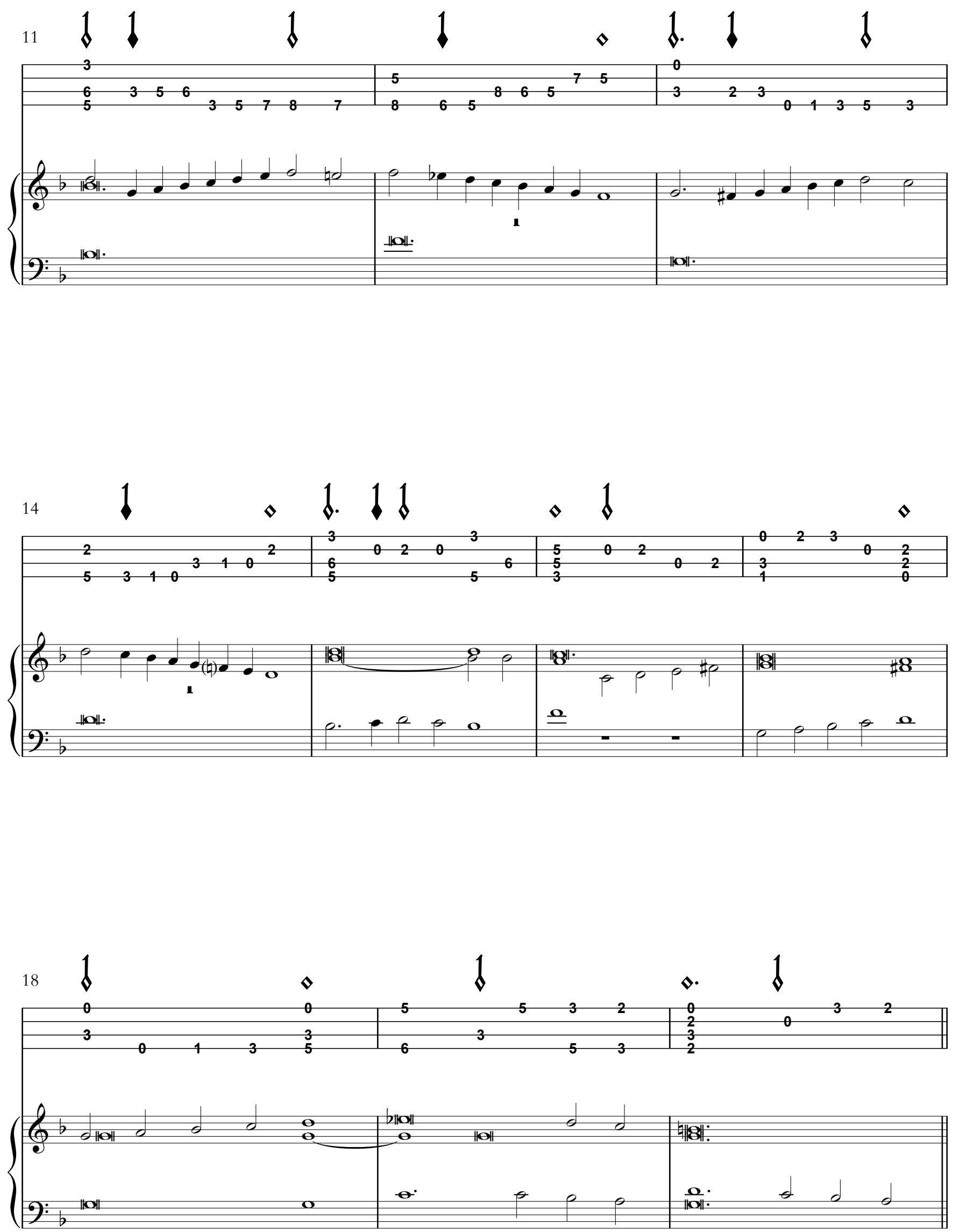

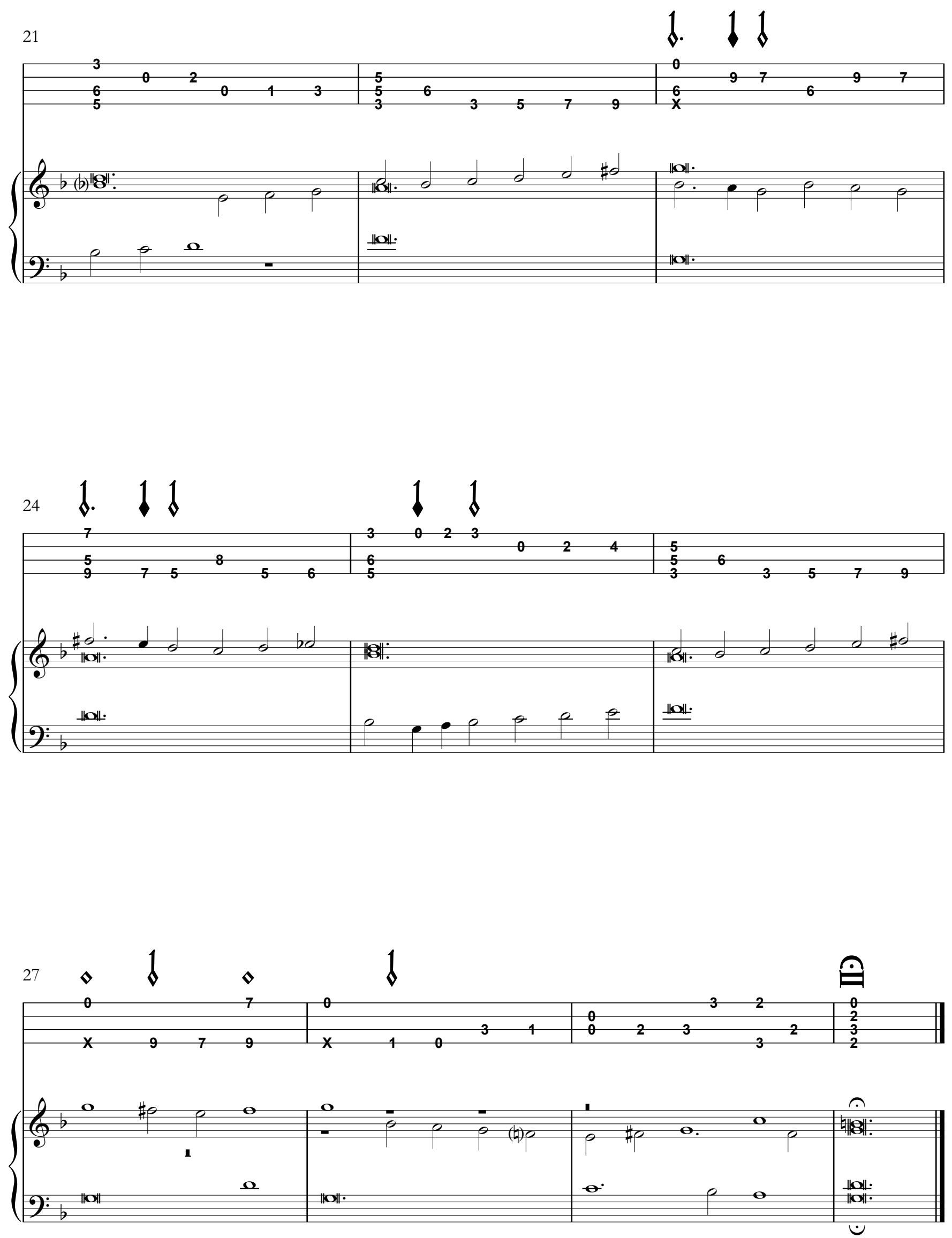
s\& 24 - Tiento 1 ed

Tiento

I Tono

[Libro II, f. I]
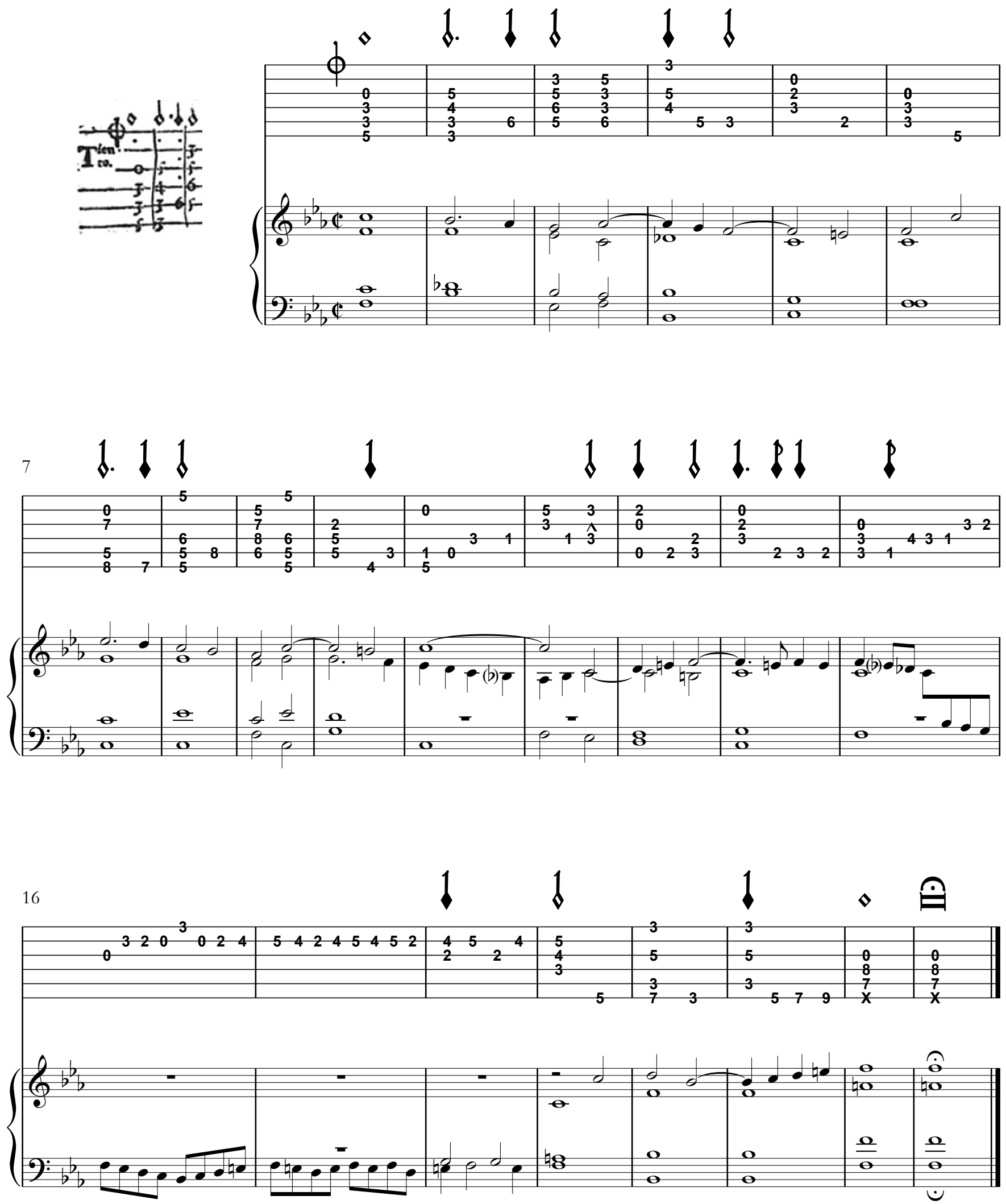
so 25 - Fantasía 15

Fantasía

I Tono

[Libro II, ff. I-II]
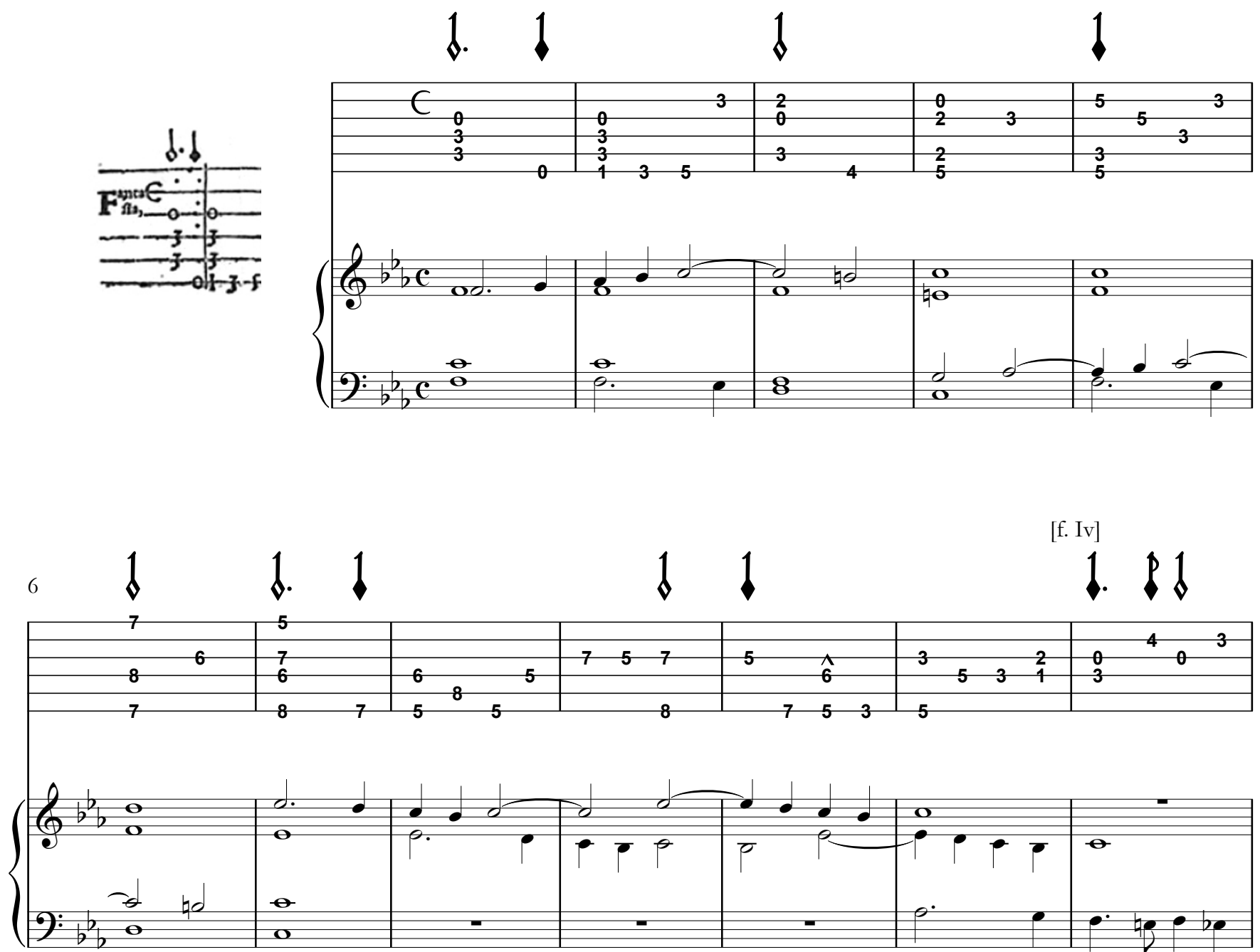

13

1. 11

1

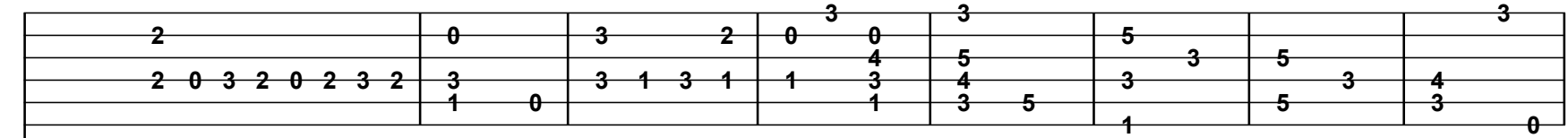

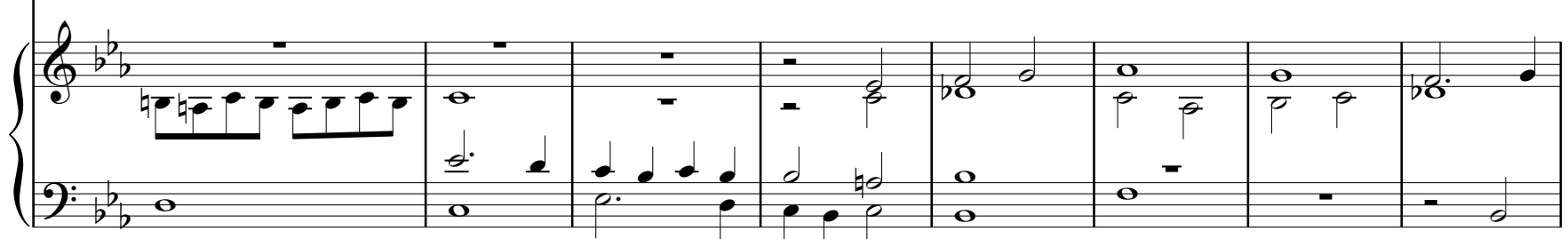



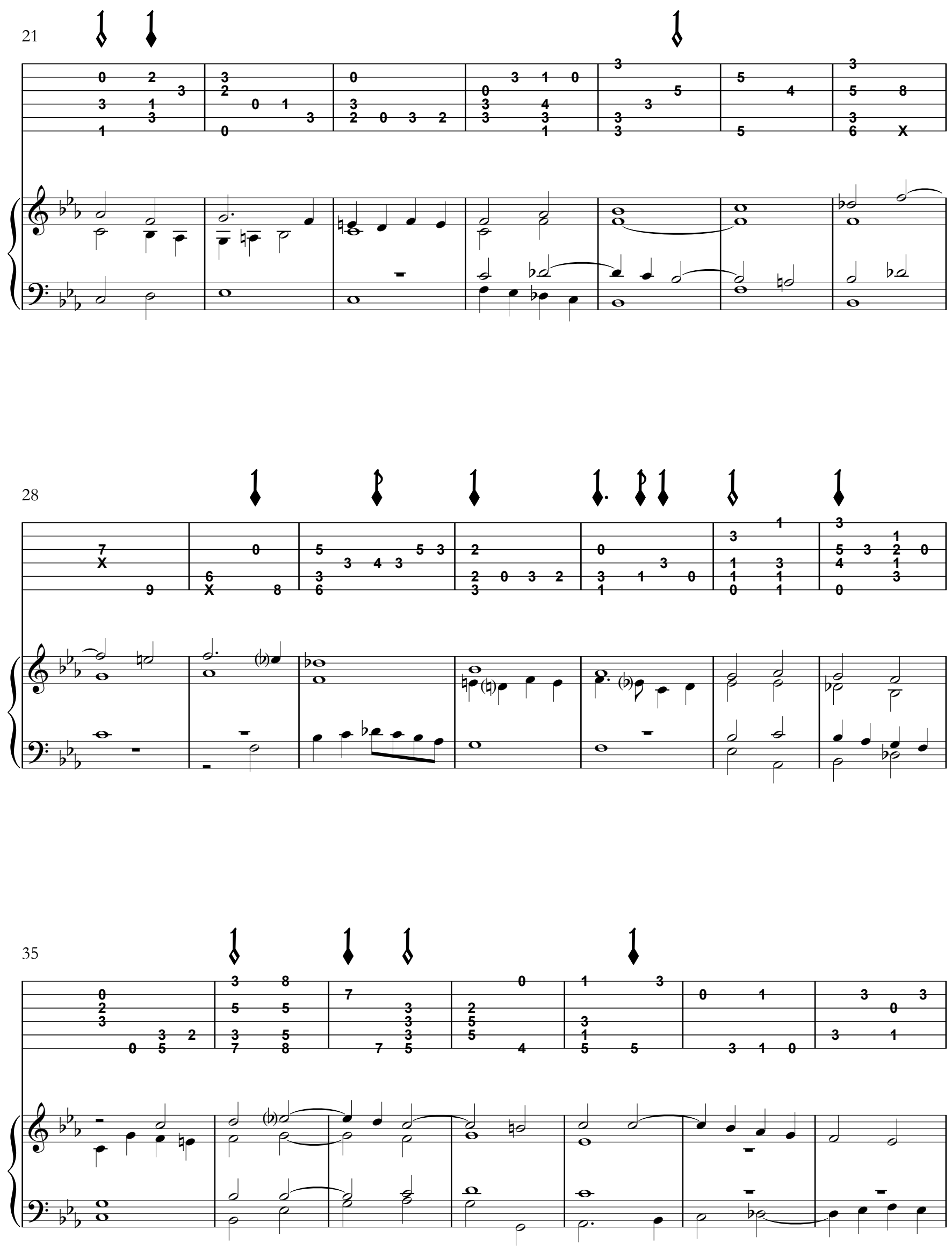

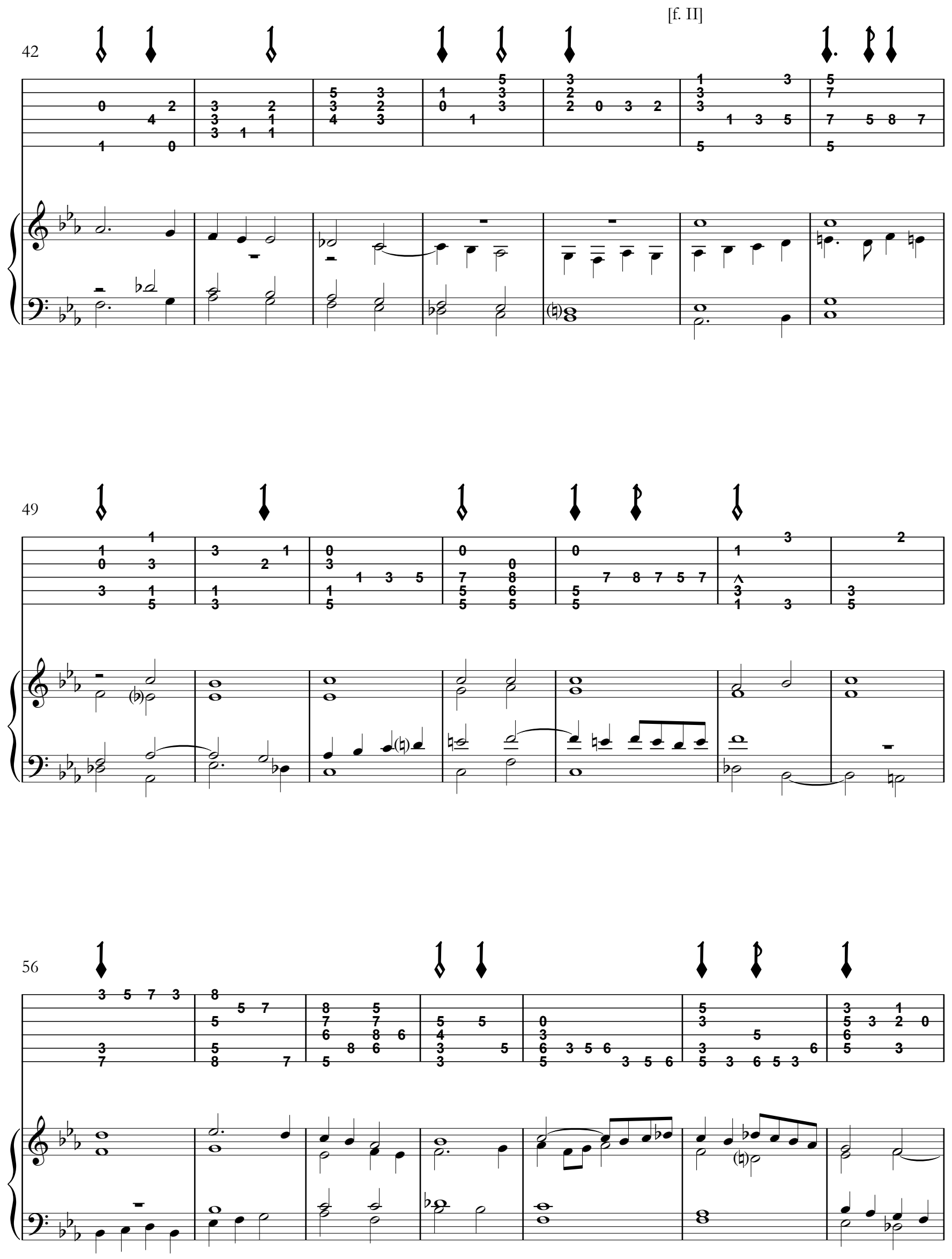

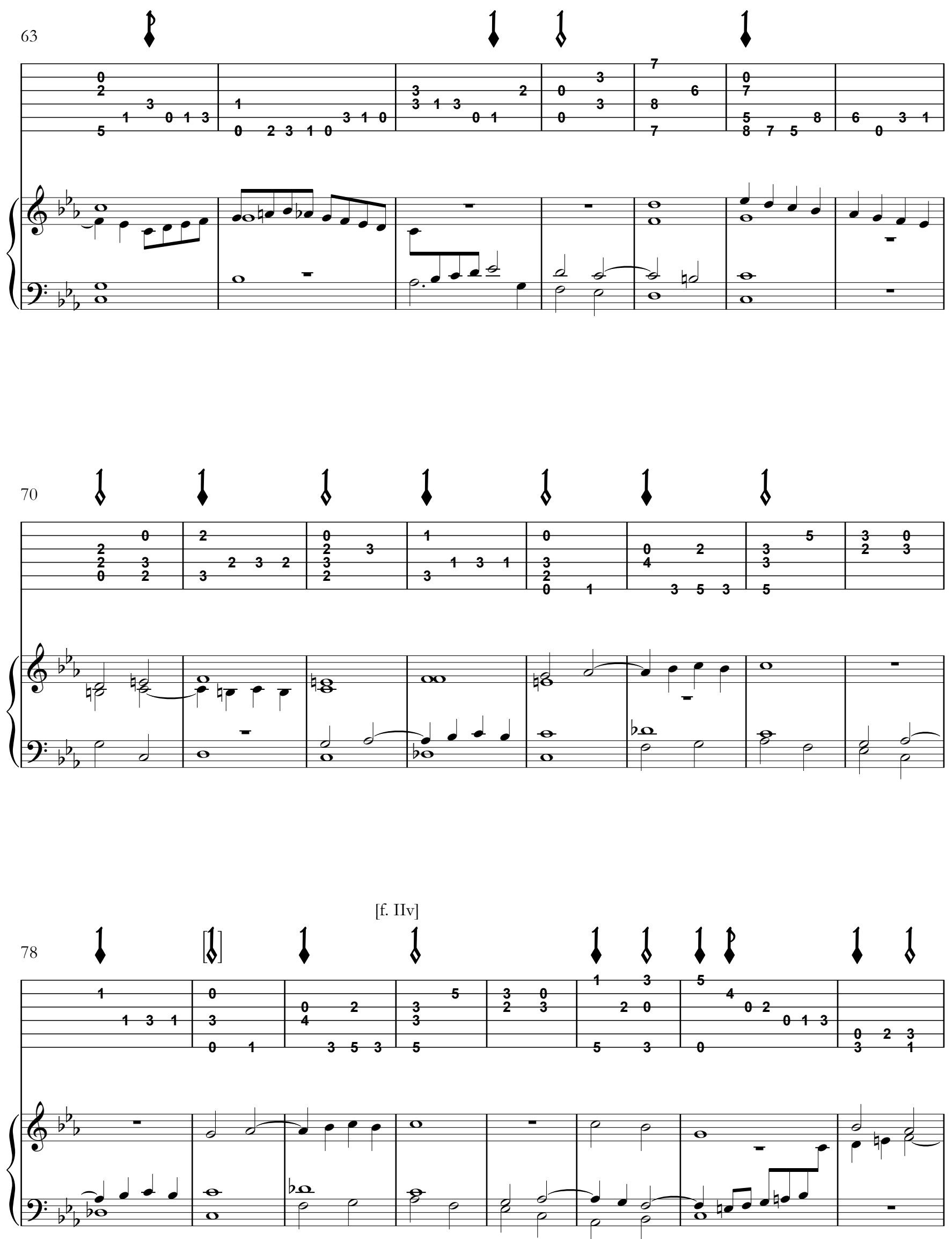

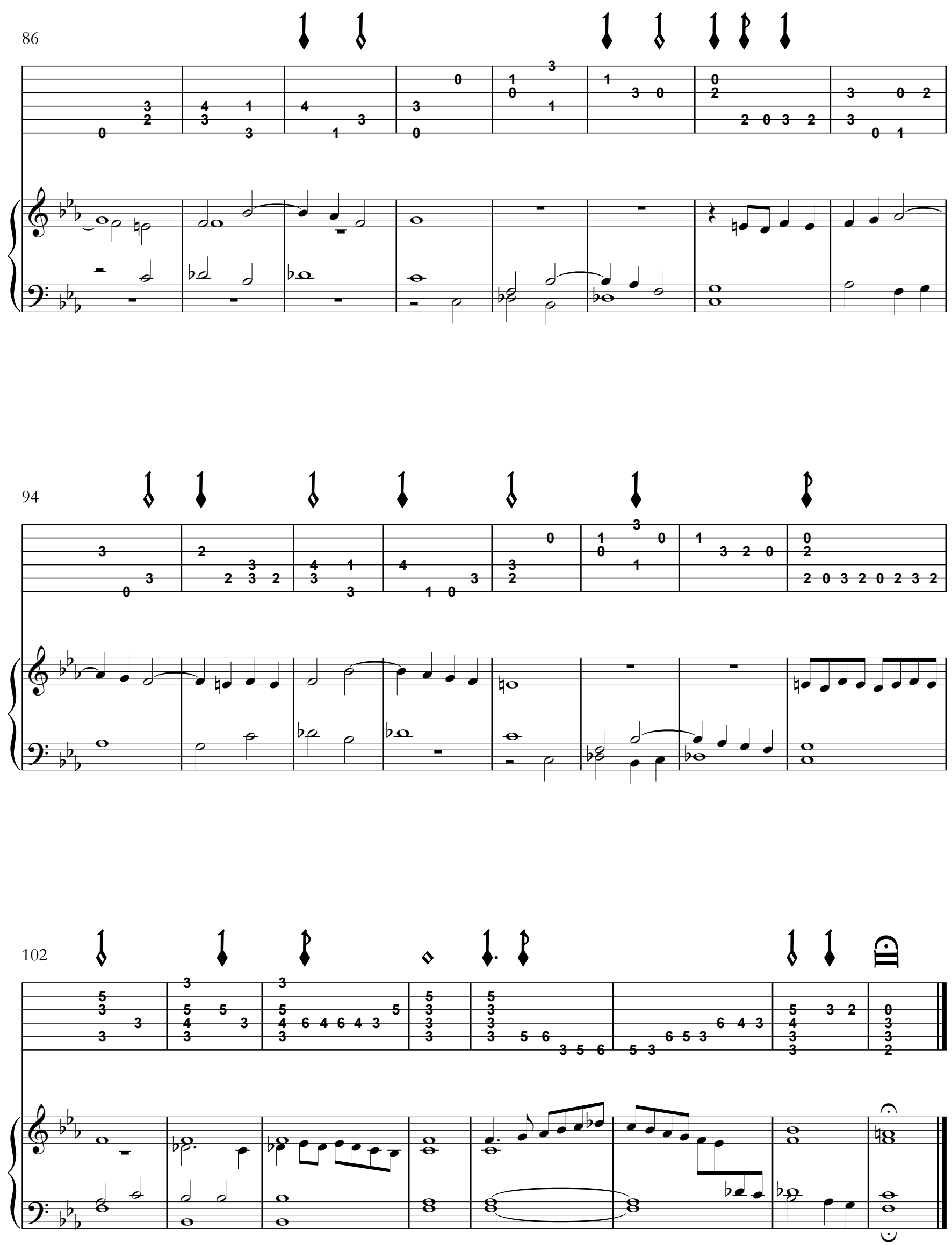


\section{so26 - Kyrie 108}

Kyrie primero de la missa de beata virgine de iosqui glosado

[Libro II, ff. III-IV]

Josquin/Mudarra
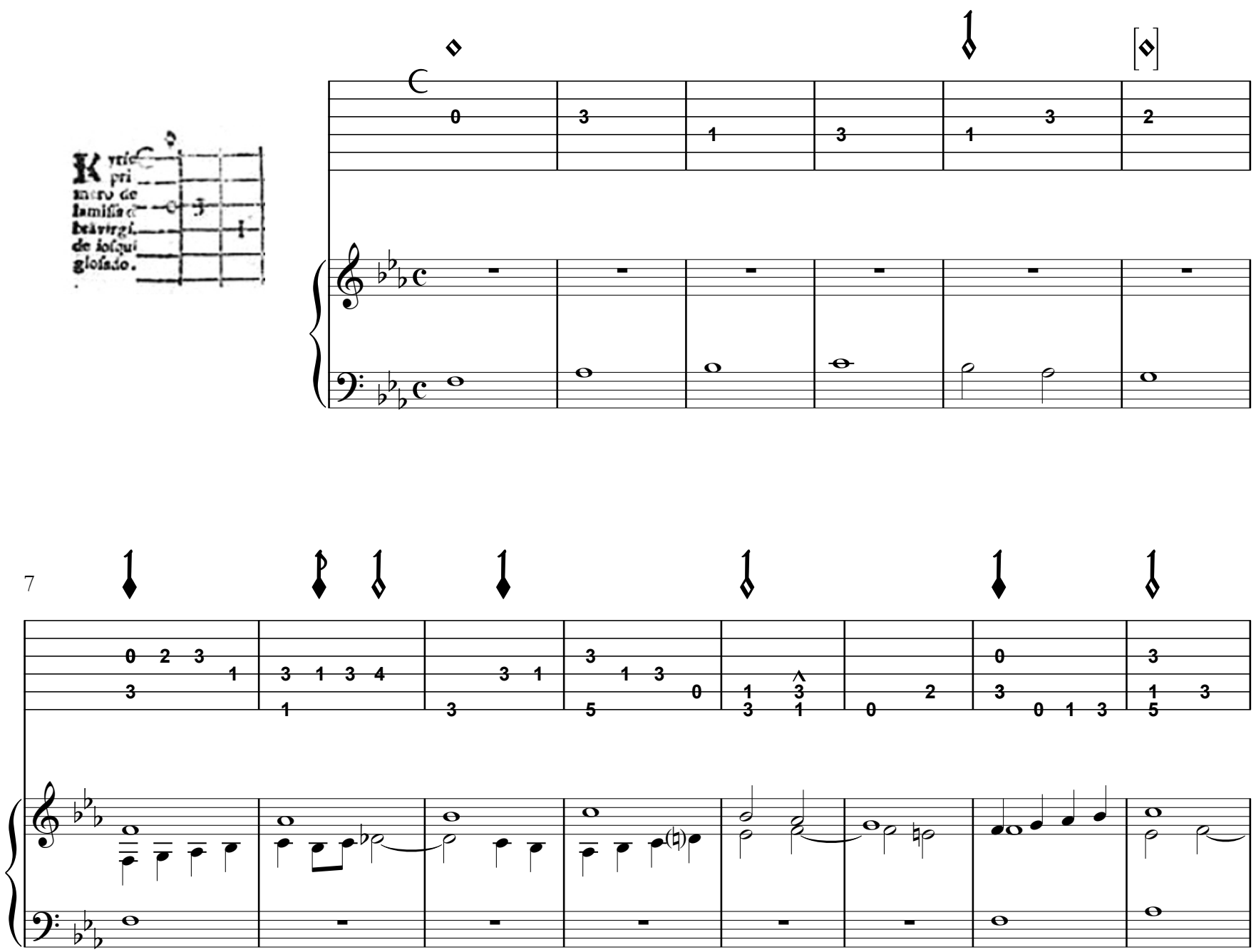

$\begin{array}{lllll}15 & 1 & 1 & 1 & 1\end{array}$
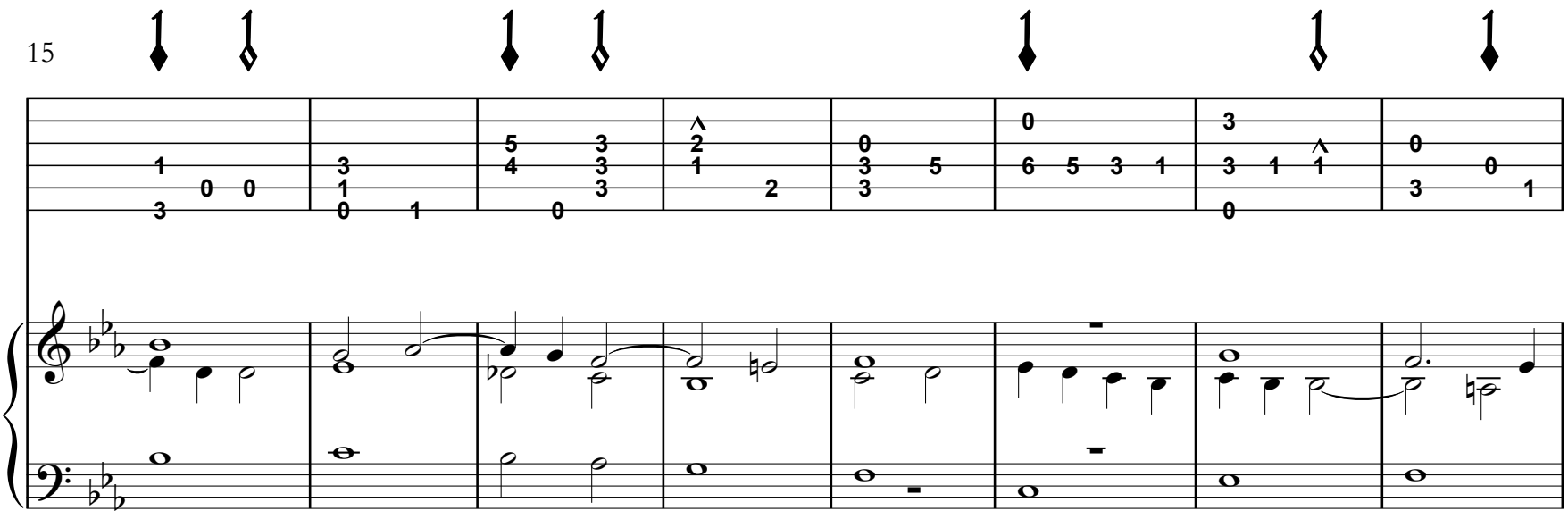

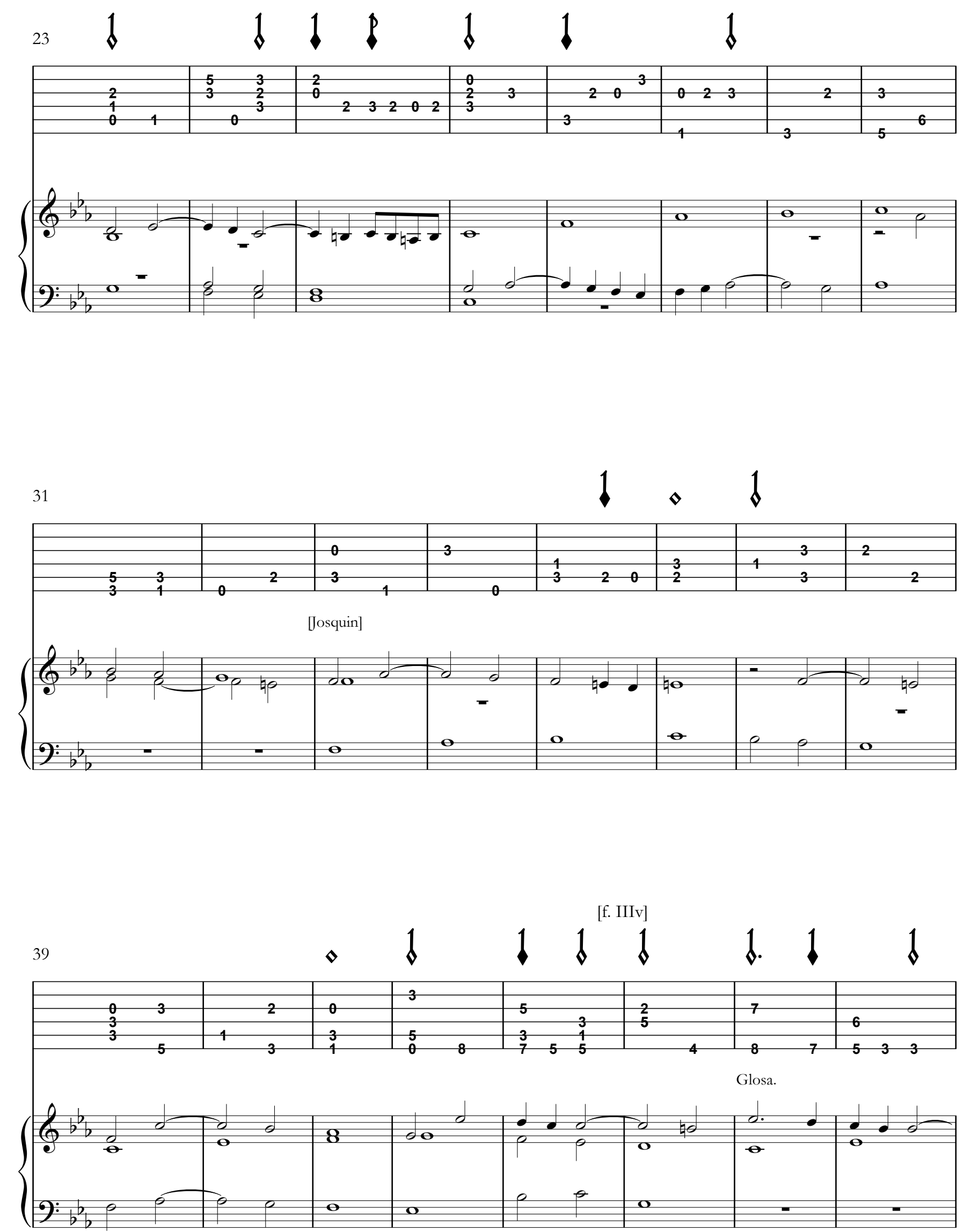

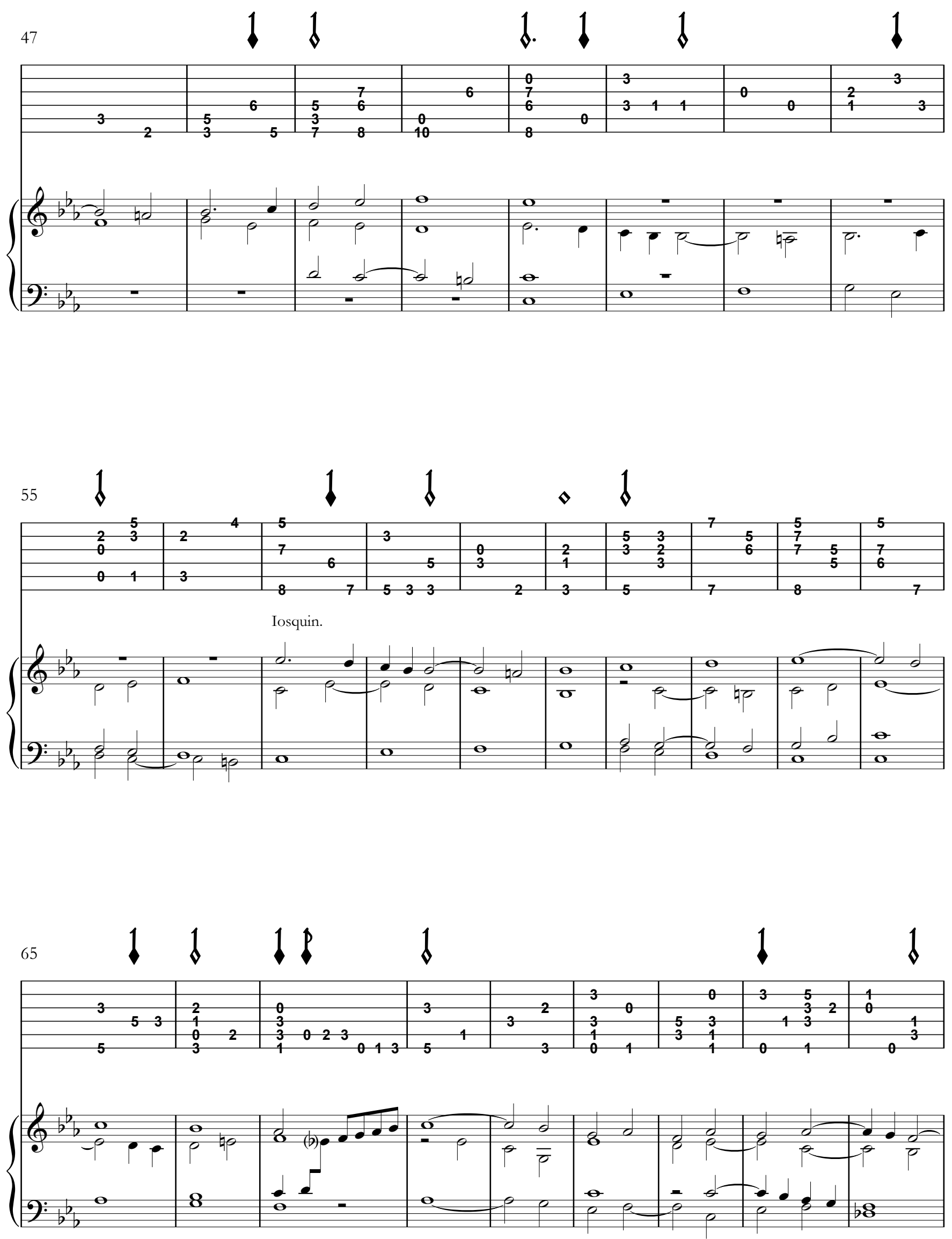

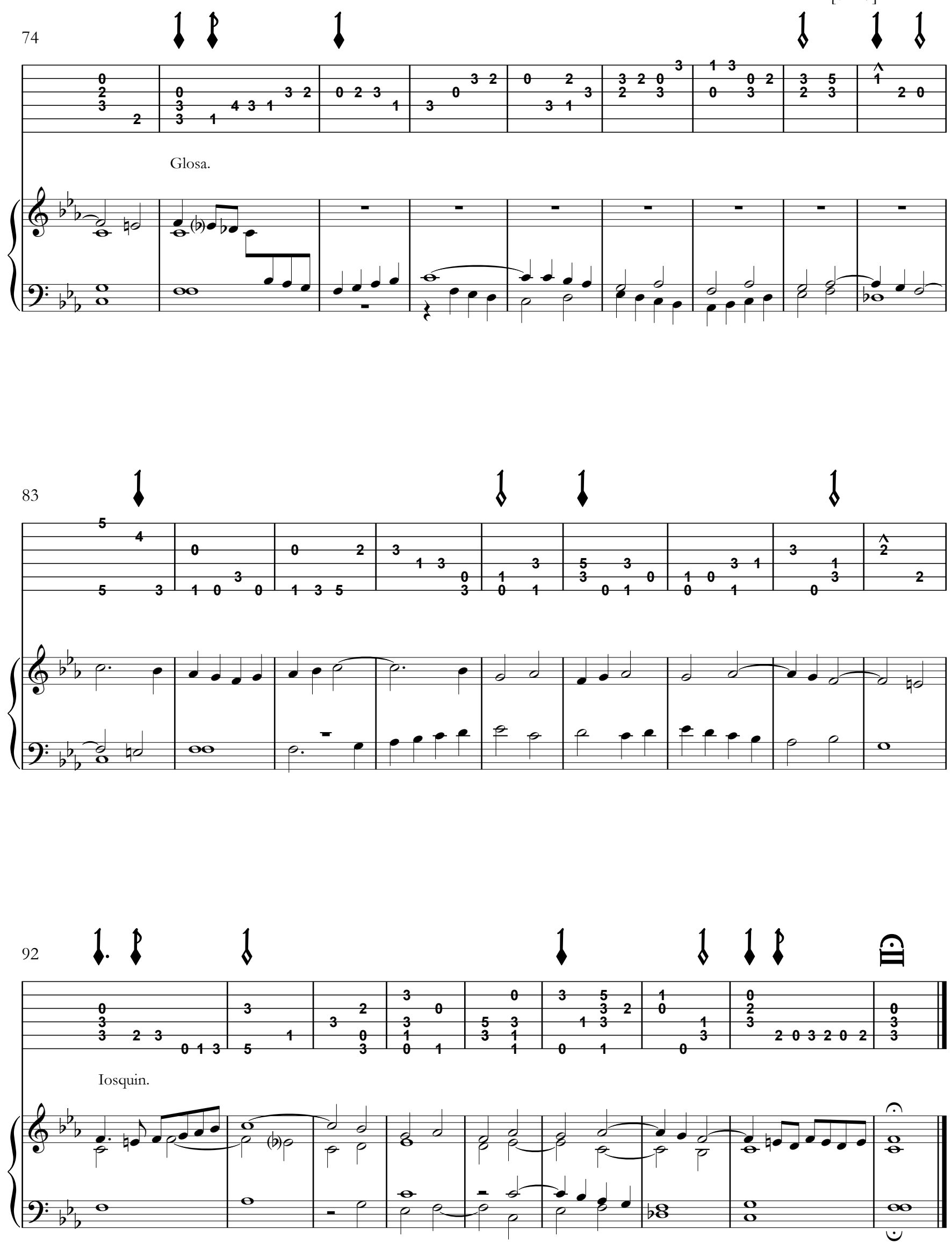
se 27 - Fantasía 16

Fantasía

[Libro II, ff. IV-V]
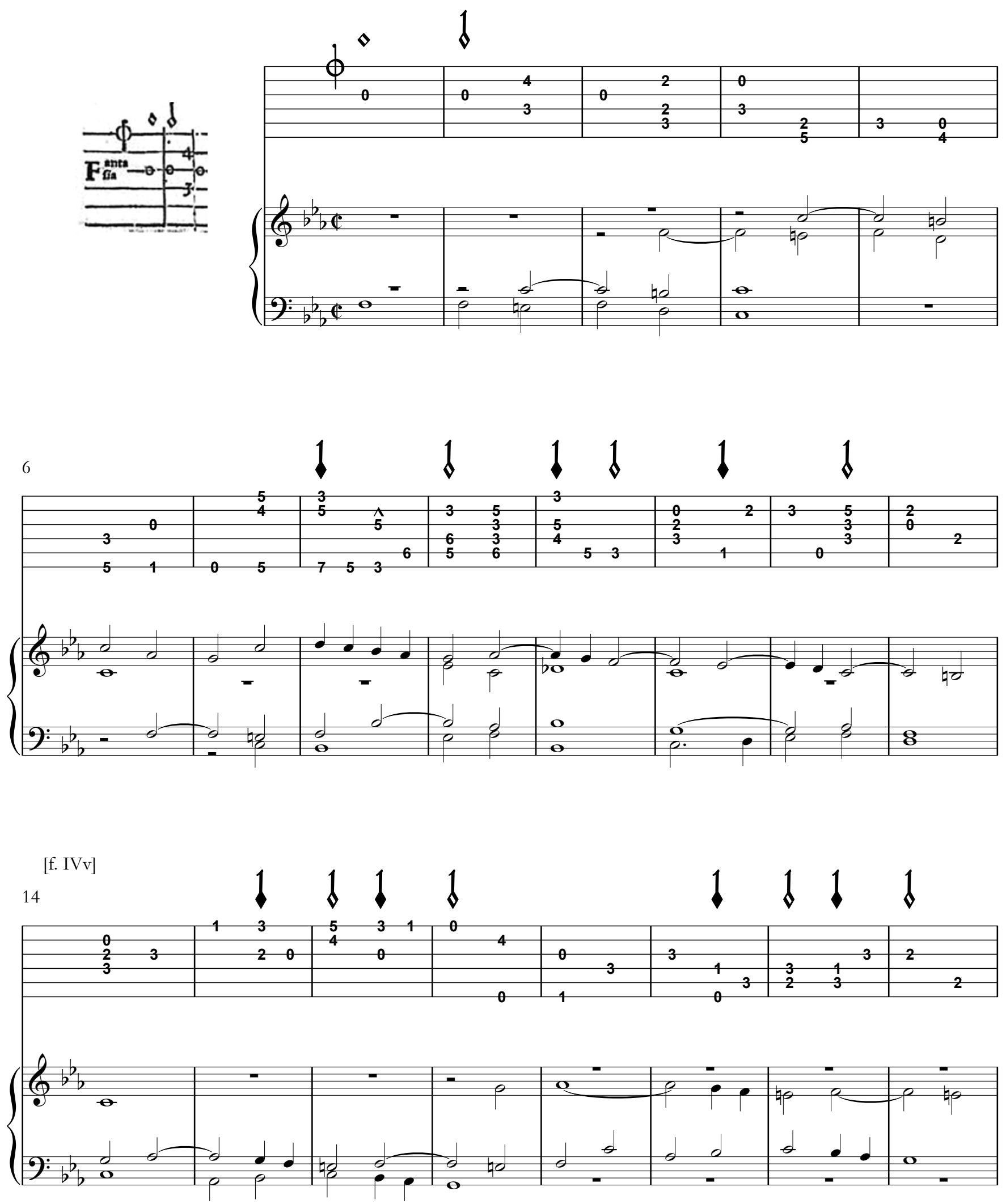


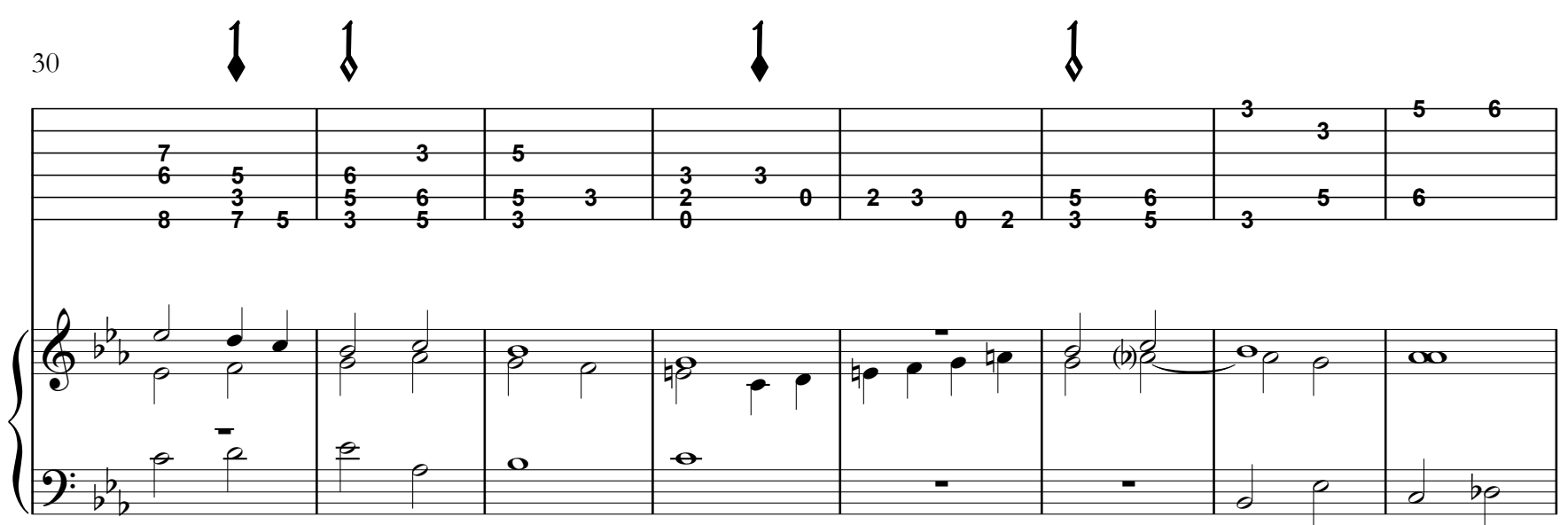

38

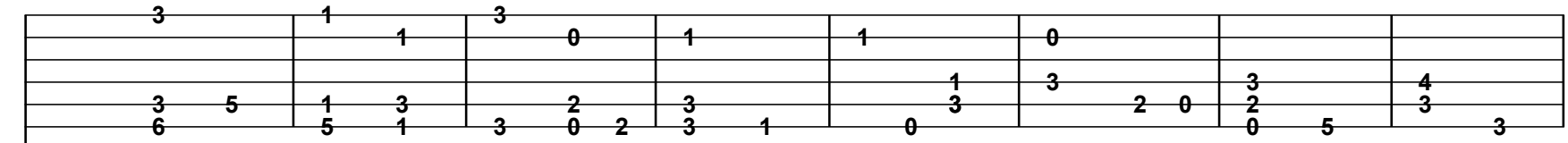

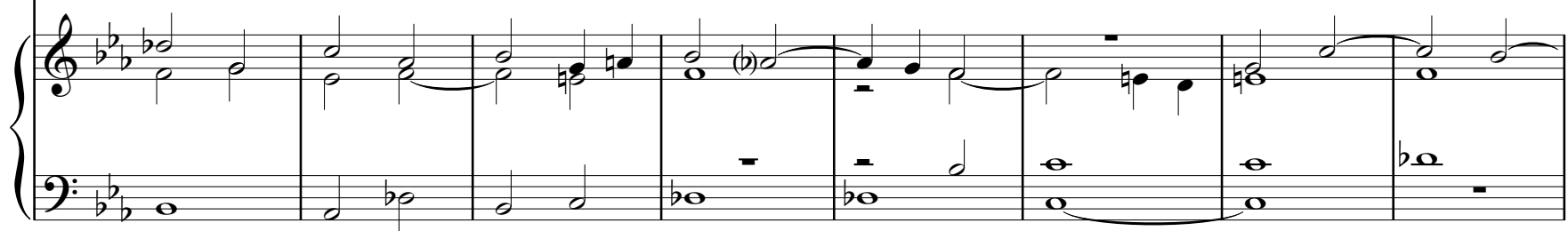



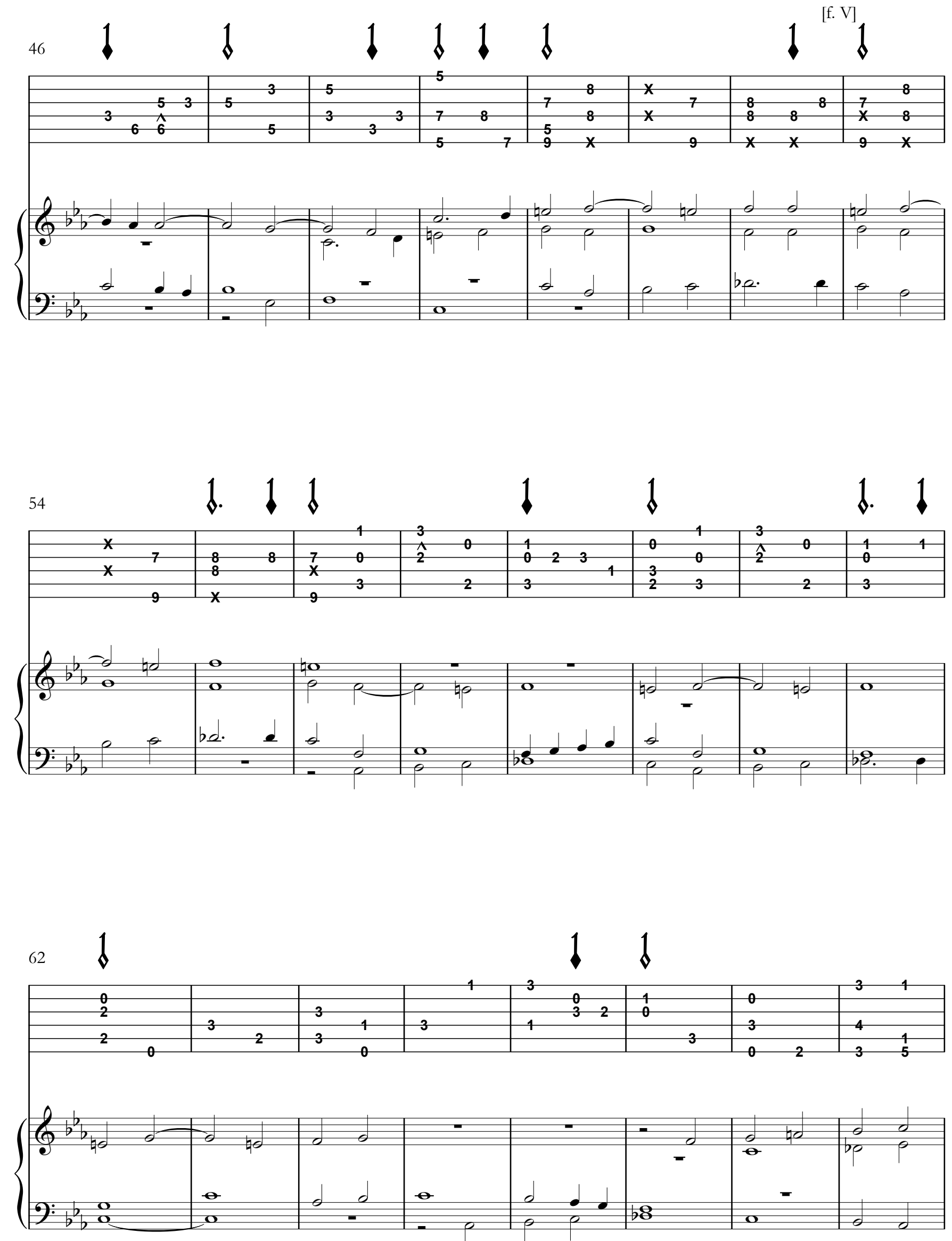

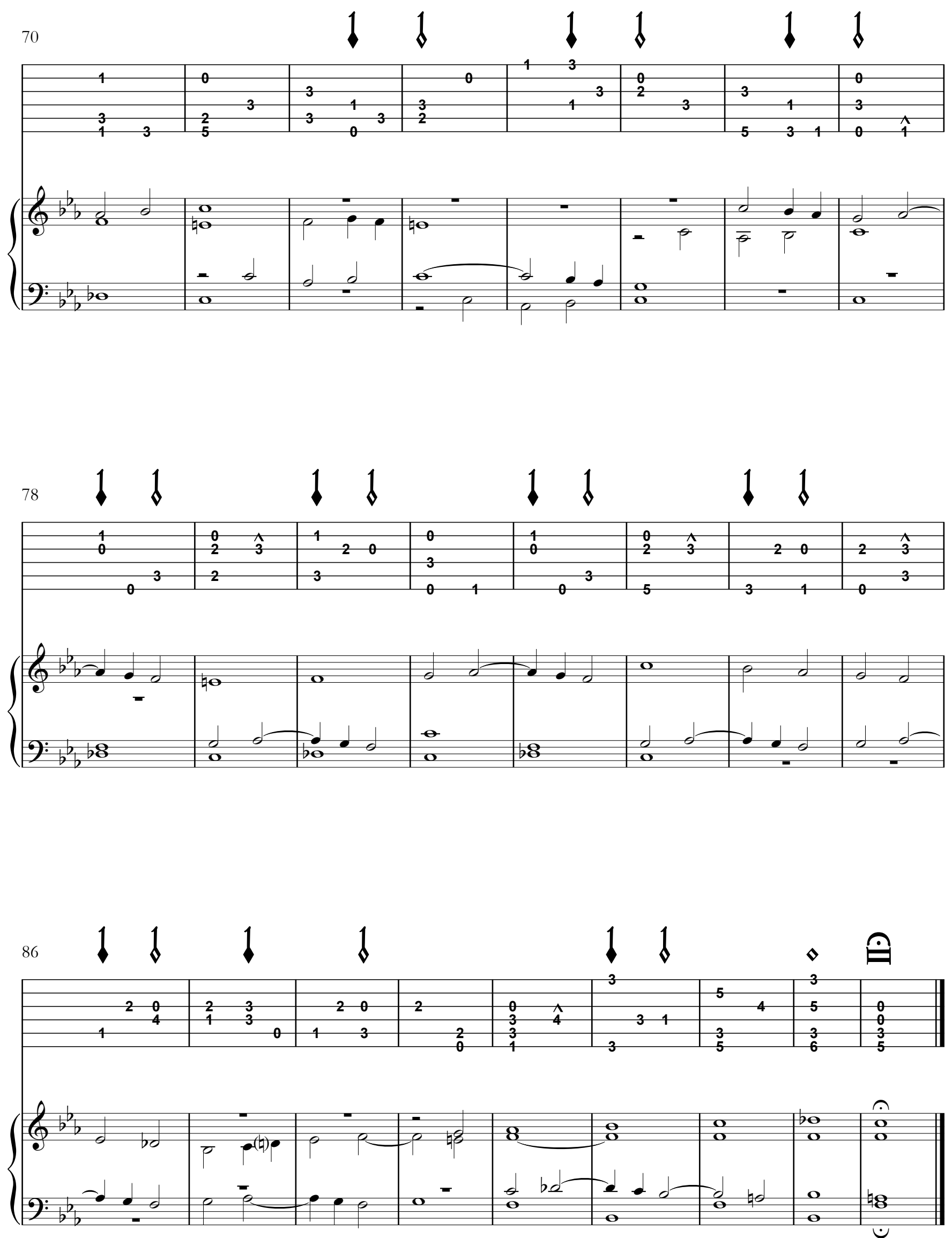


\section{so 28 - Tiento 2 ex}

Tiento

II Tono

[Libro II, f. VIv]
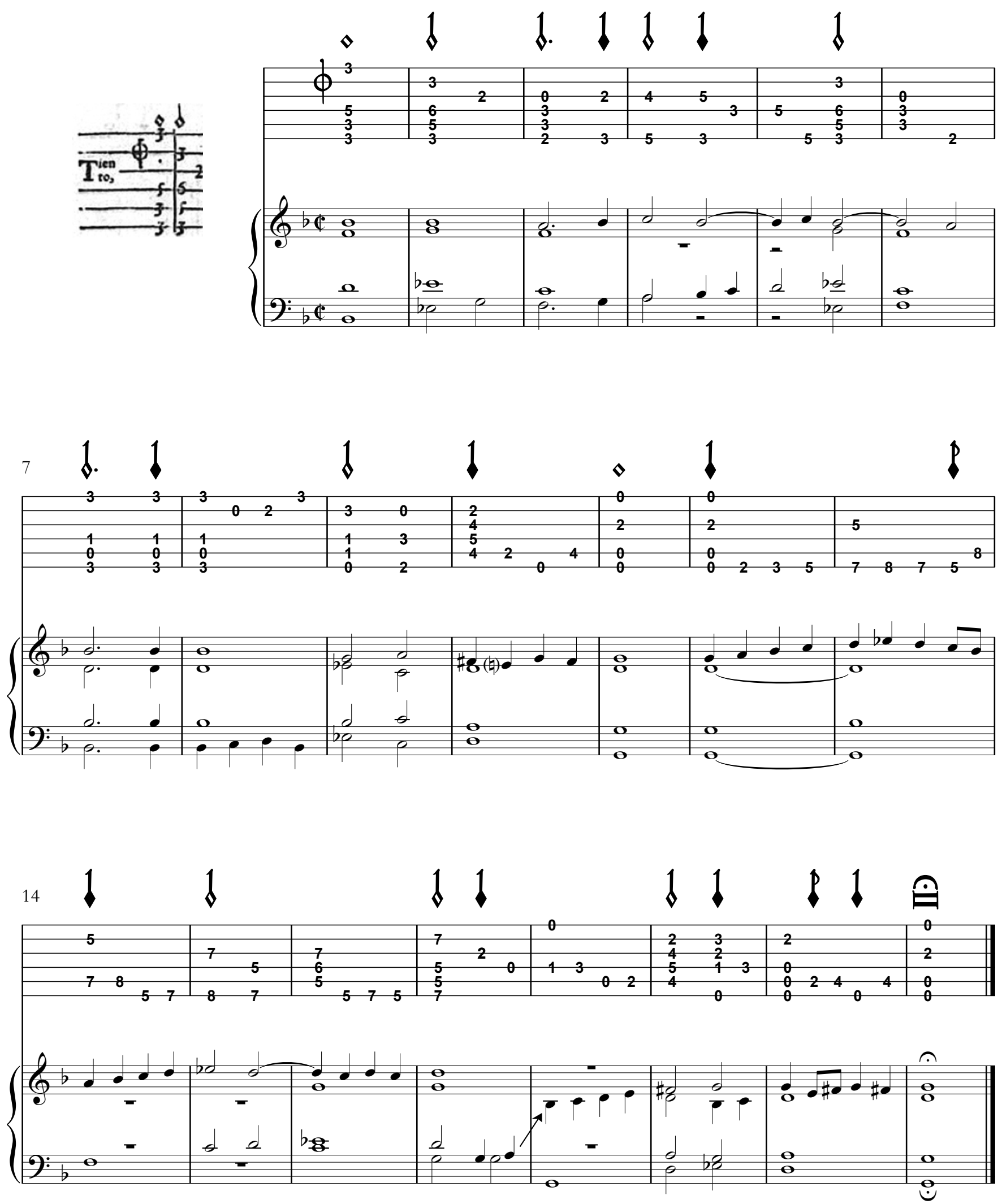


\author{
[Libro II, ff. Vv-VI]
}
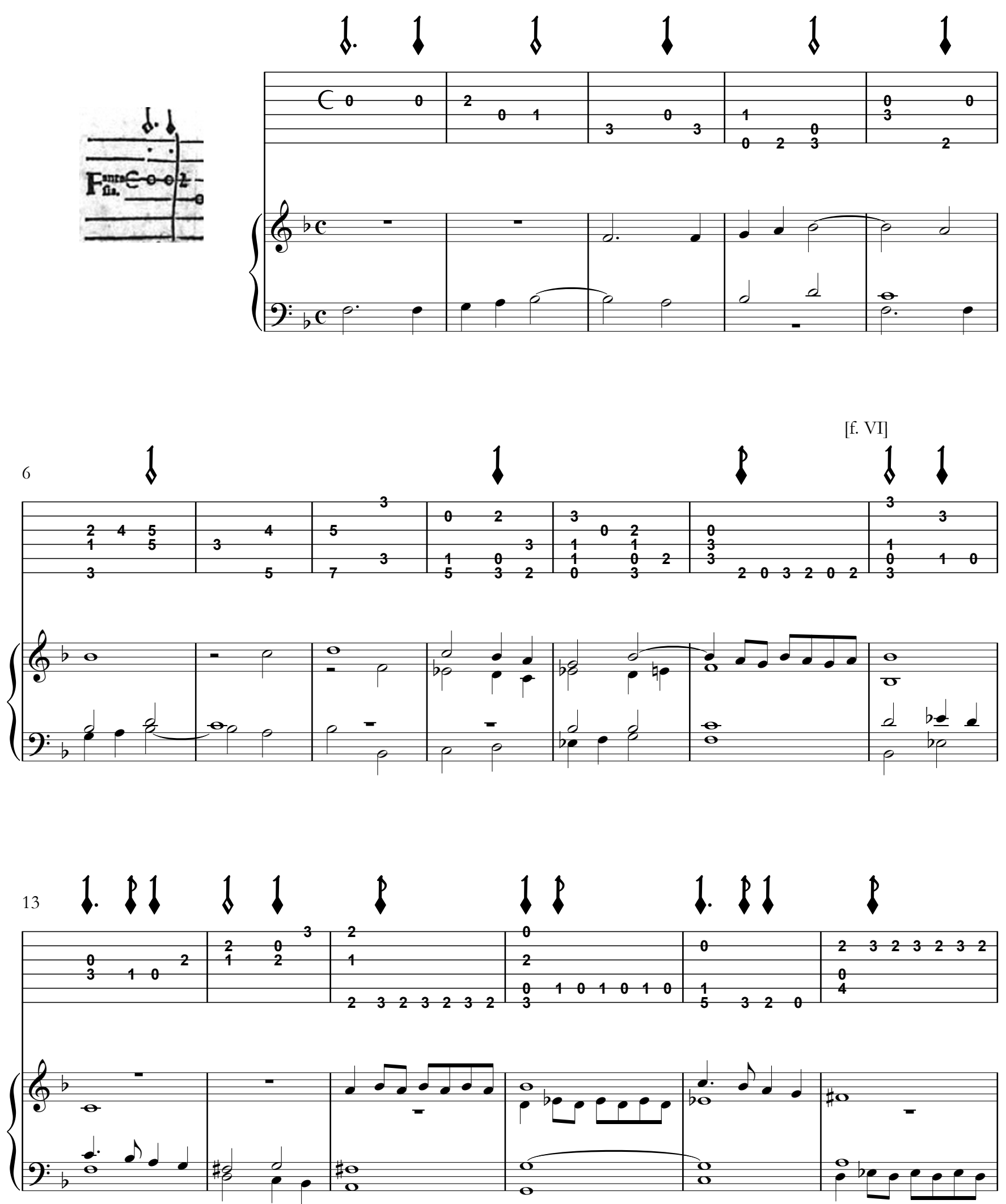

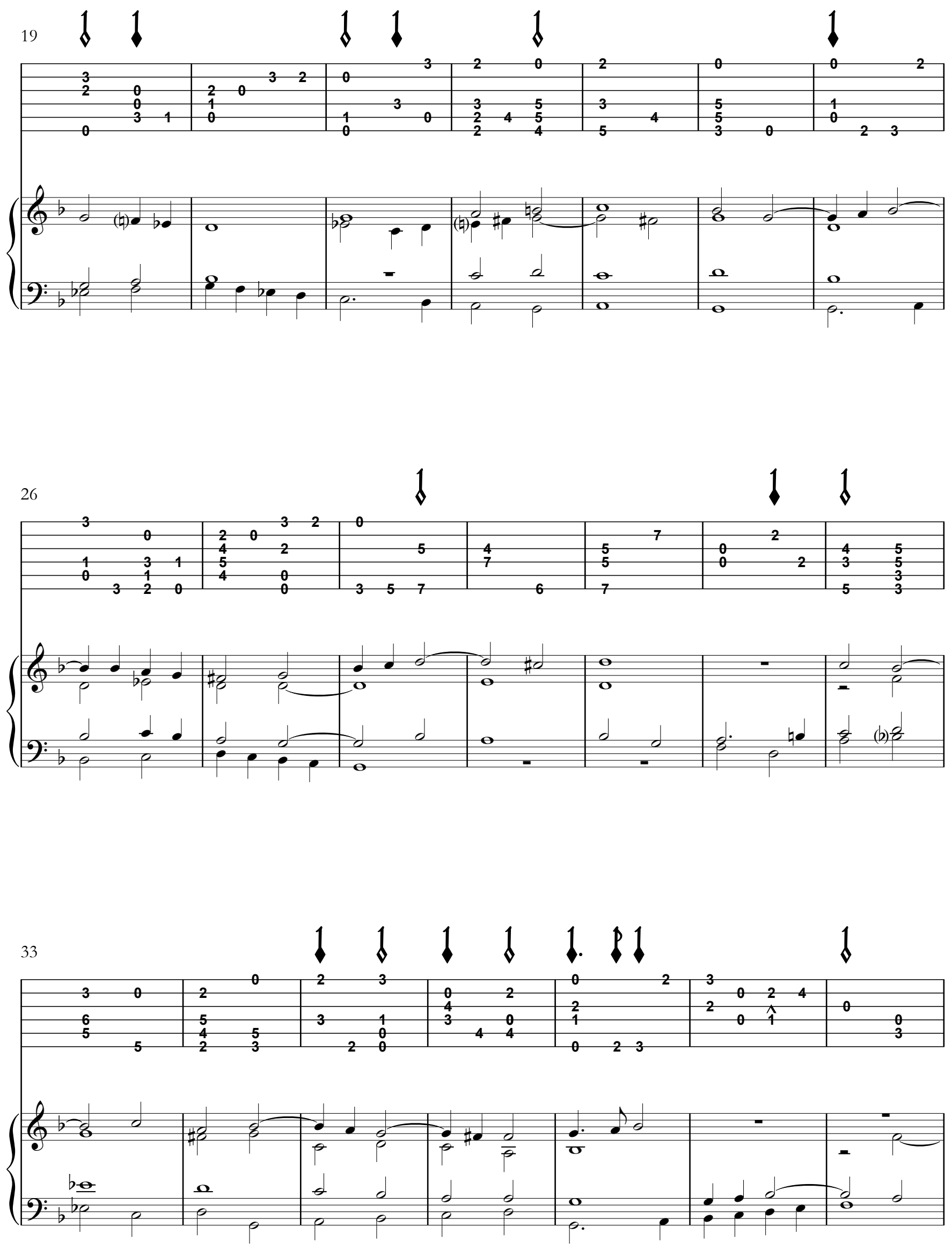
Fantasía 17
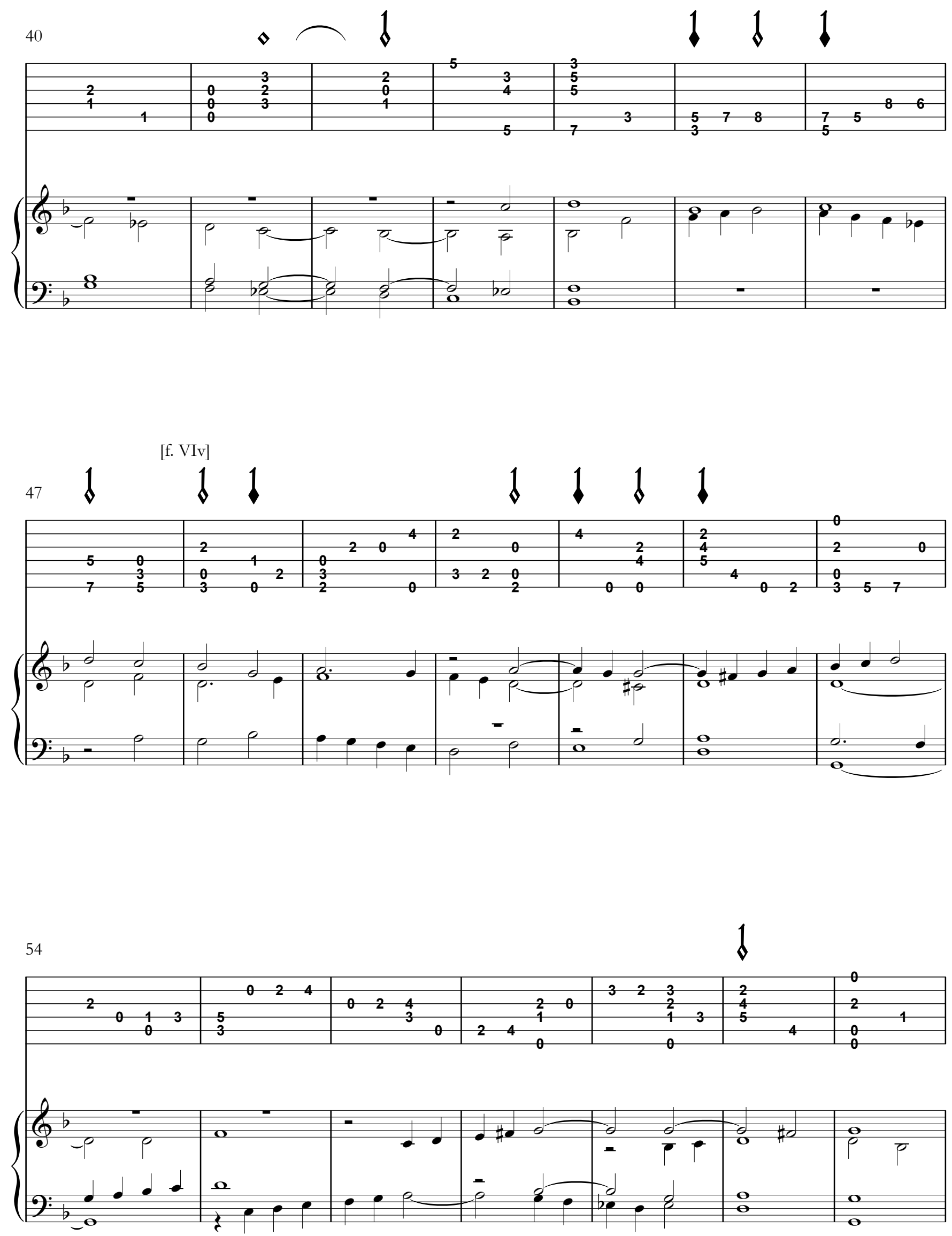

94 

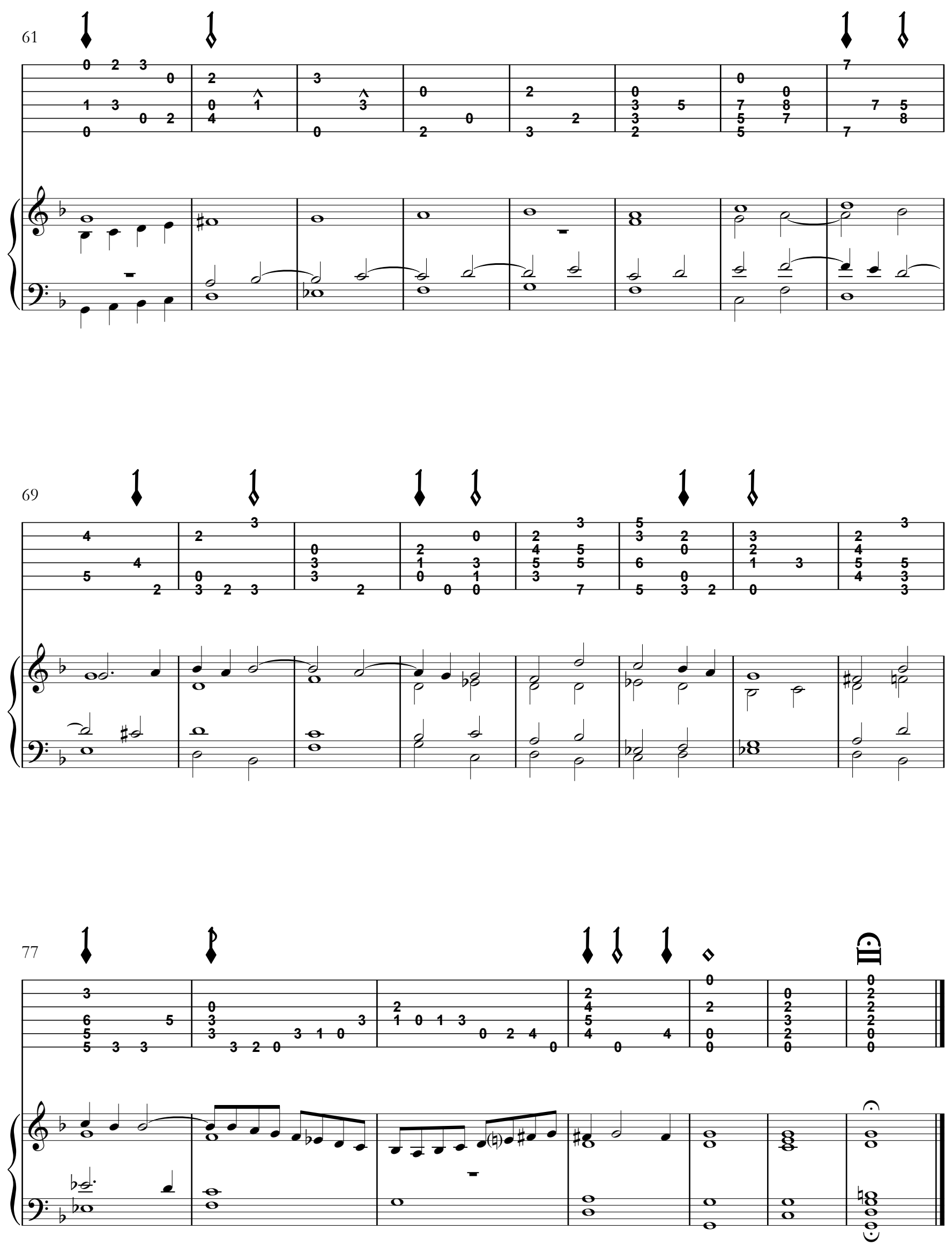


\section{sะ30 - Fantasía 18}

Fantasía de sobre fa mi.ut.re

[Libro II, f. VII]
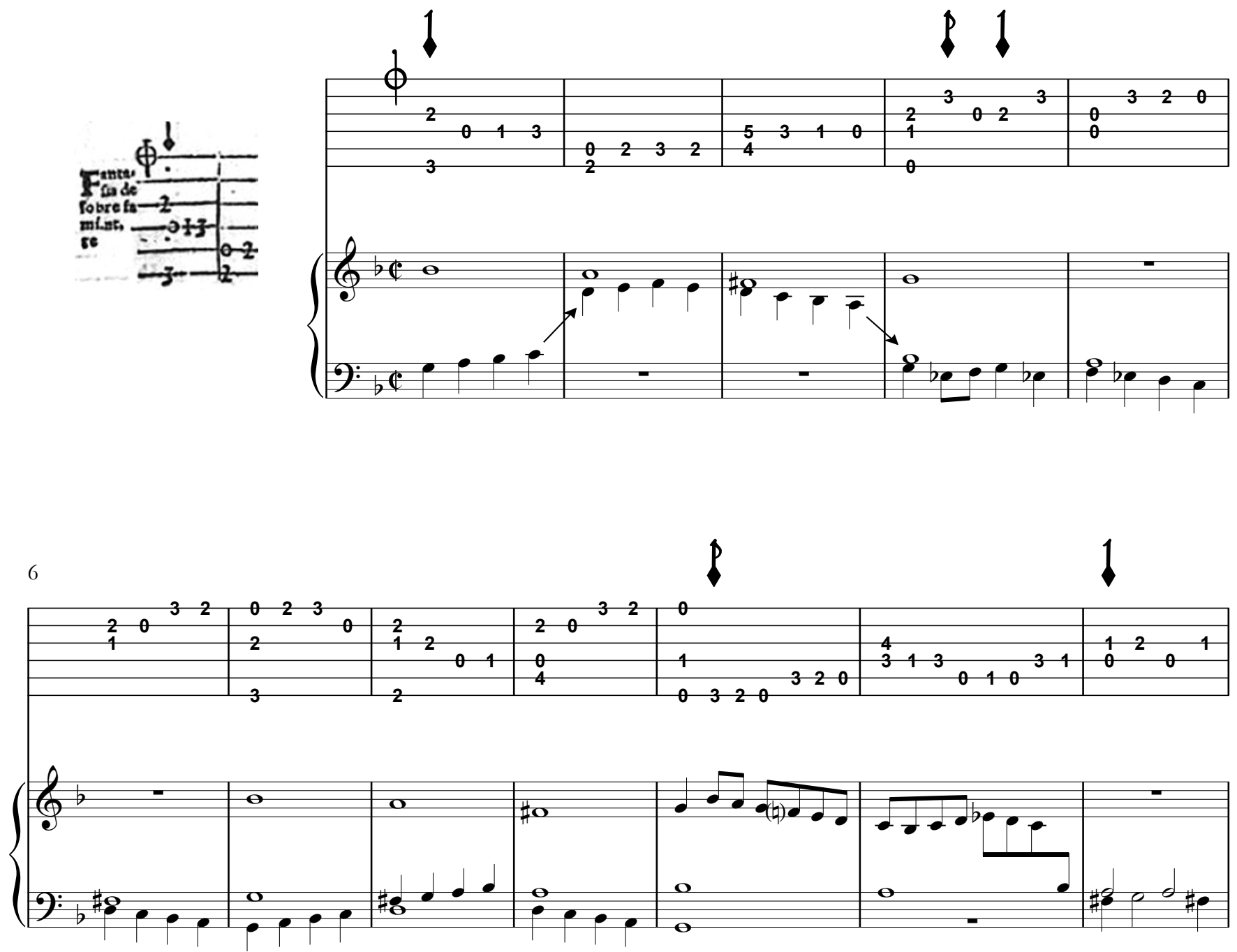

13

16

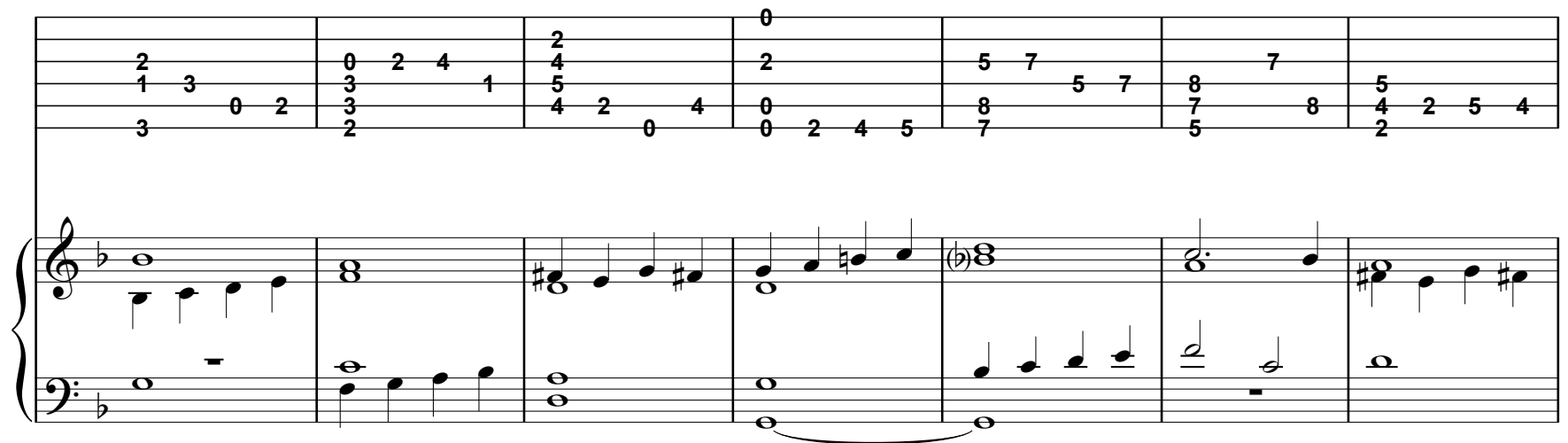




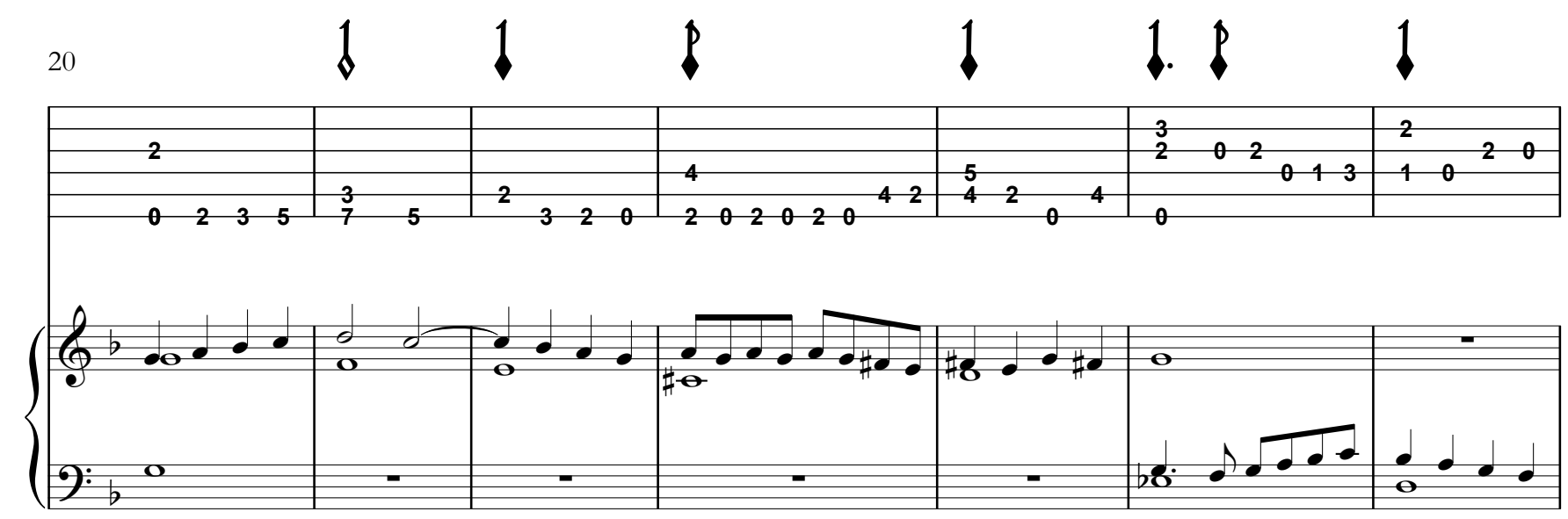

[f. VIIv]
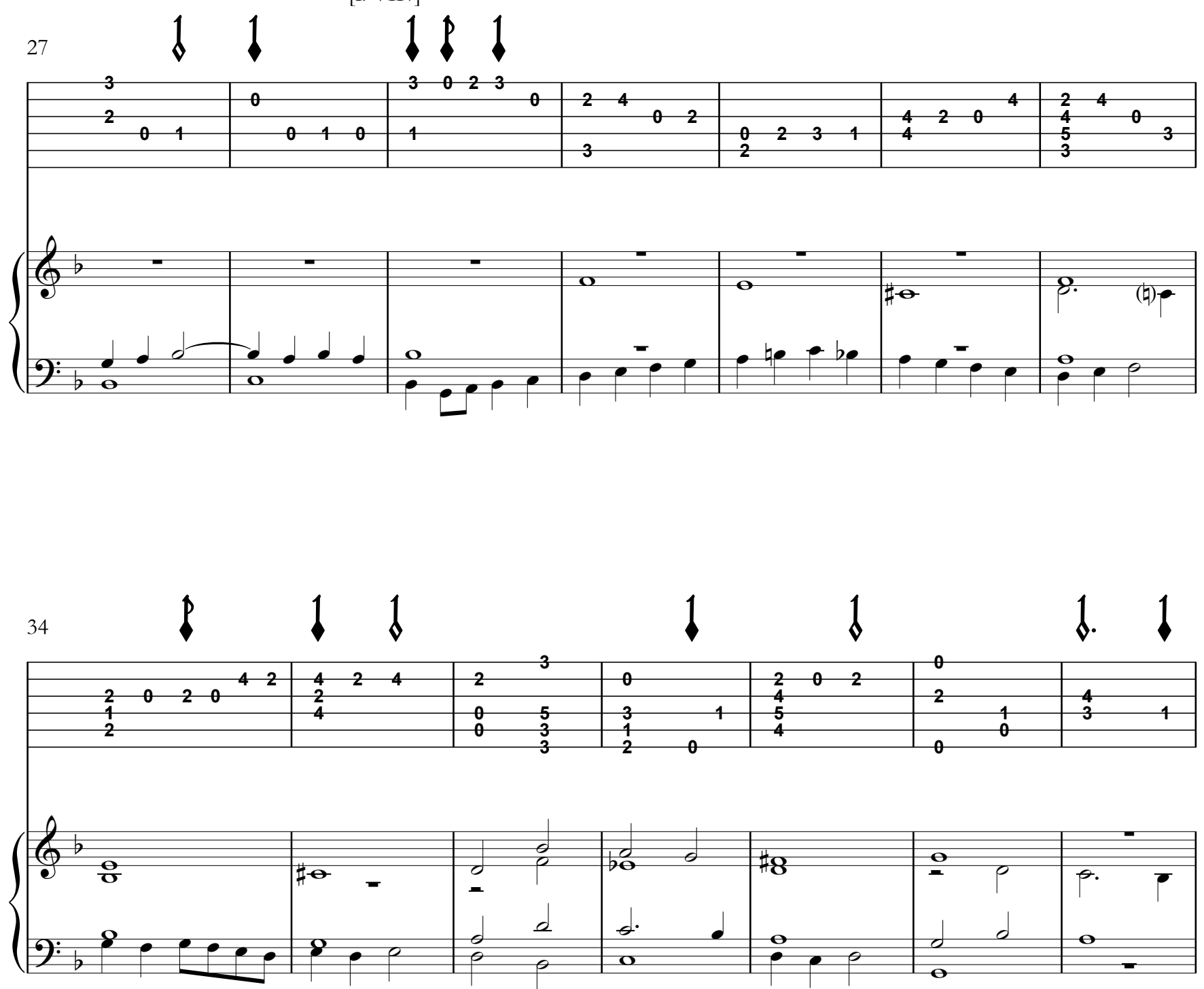

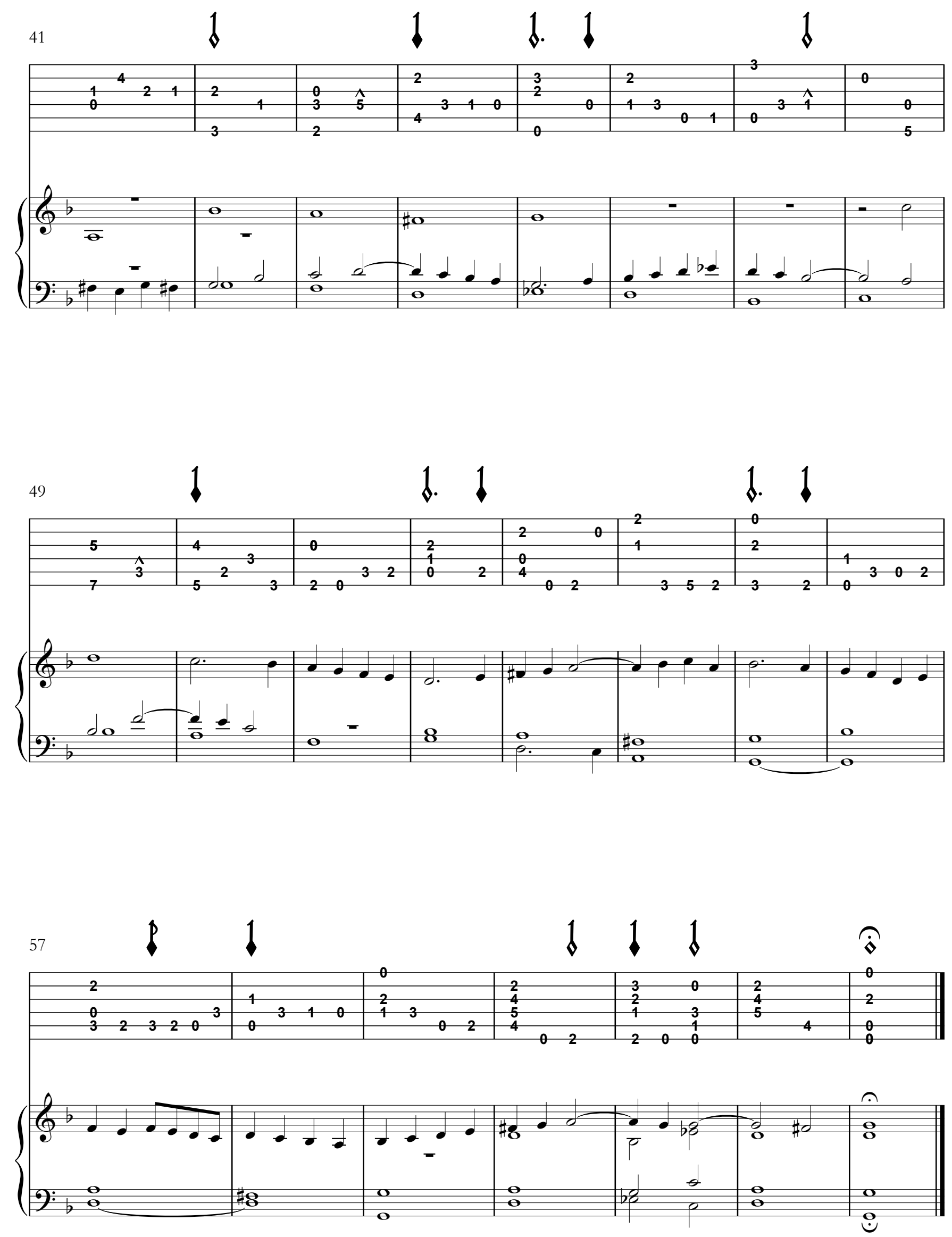


\title{
so 31 - Tiento 3 es
}

\author{
Tiento
}

III Tono

[Libro II, f. VIII]
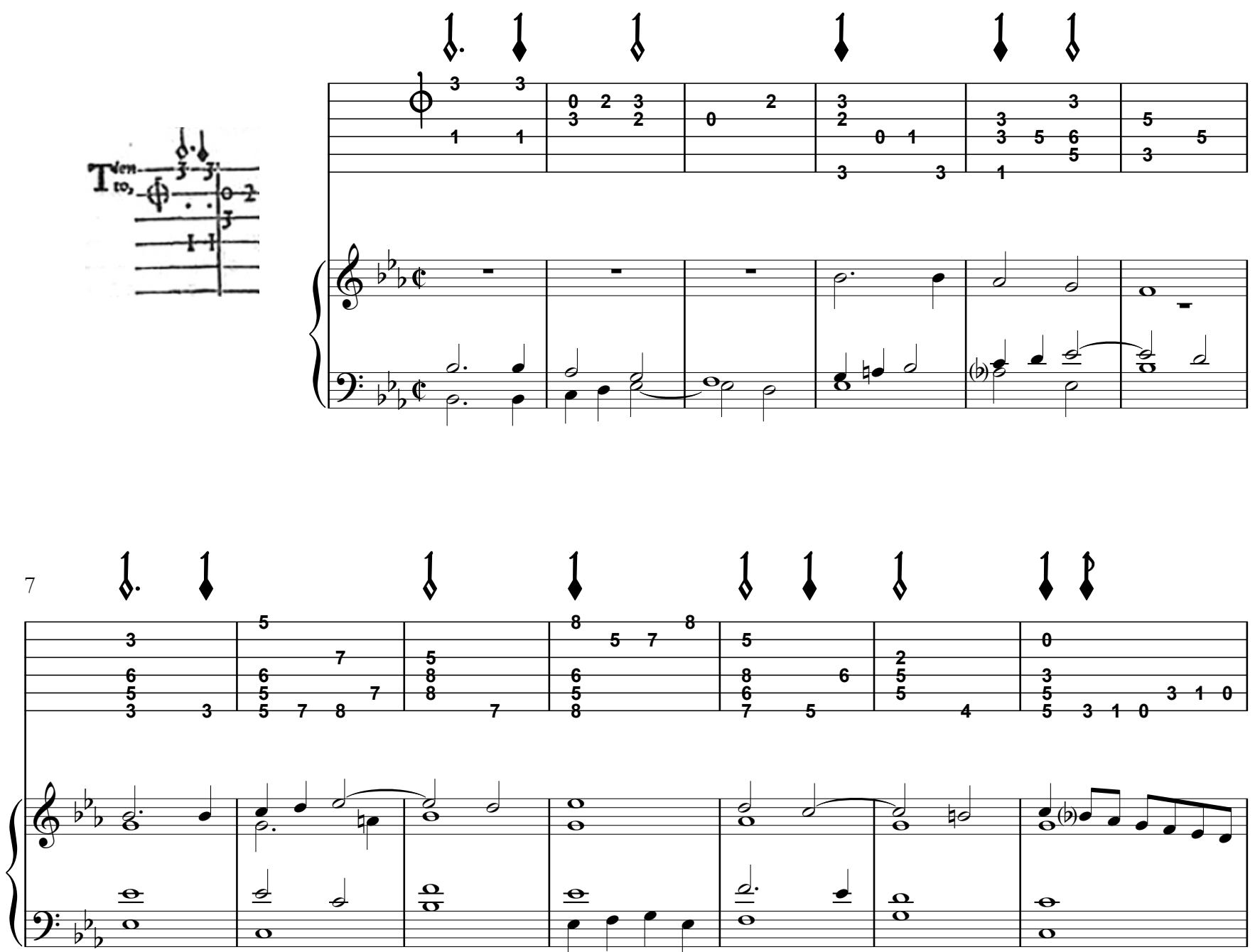

14

$111+10$

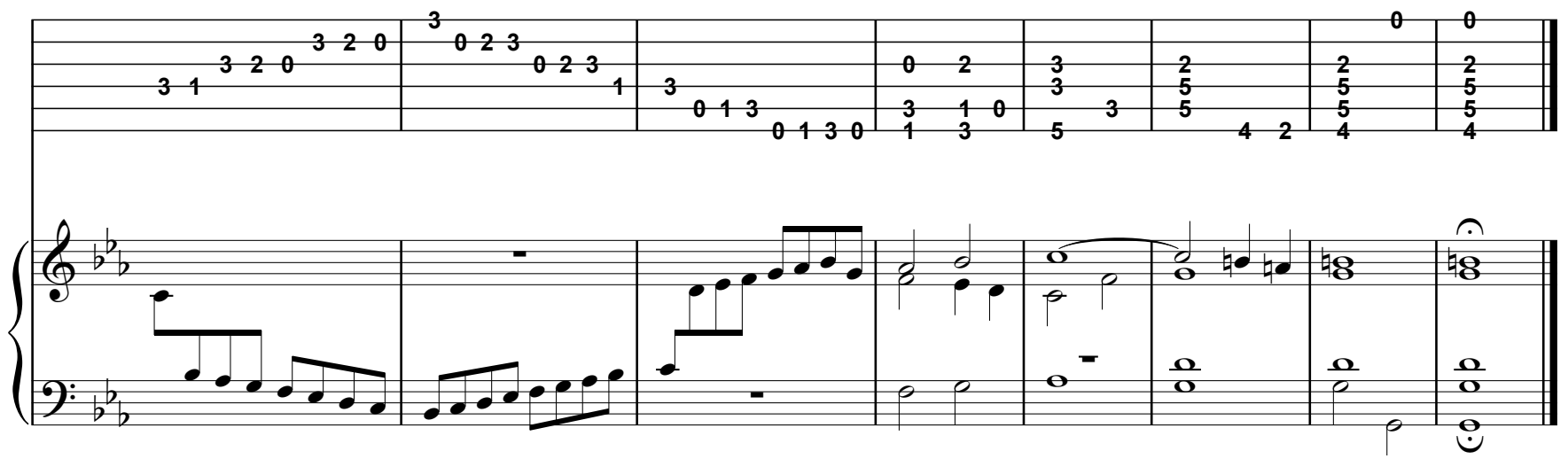


so 32 - Fantasía 19us

Fantasía

[Libro II, ff. VIII-IX]
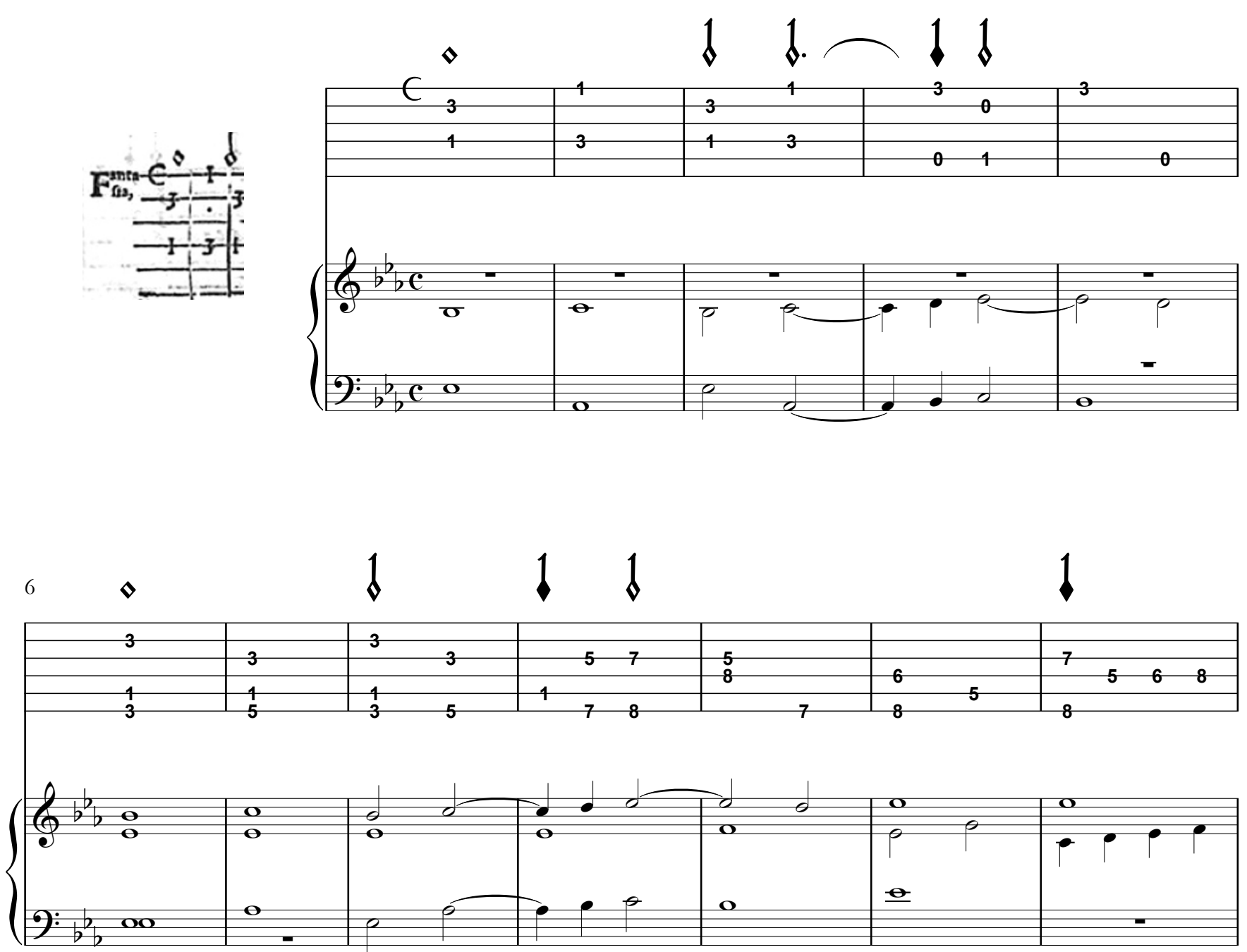

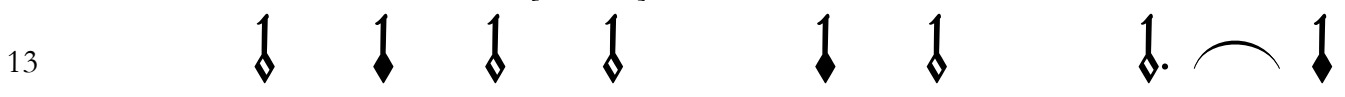

\begin{tabular}{|c|c|c|c|c|c|c|}
\hline & & & 3 & & 320 & 2 \\
\hline & 7 & 2 & 3 & $2 \quad 0$ & $5 \quad 6$ & $z$ \\
\hline $\begin{array}{lll} & 6 & 8\end{array}$ & 6 & 5 & 3 & $1 \quad 0$ & 33 & $\begin{array}{llll}2 & 0 & 3 & 2\end{array}$ \\
\hline 5 & 5 & 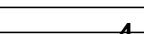 & 5 & $1 \quad 0$ & & \\
\hline
\end{tabular}

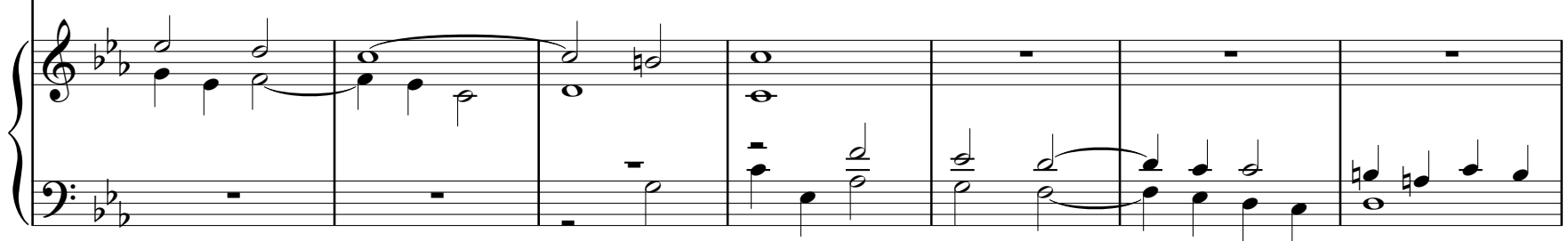



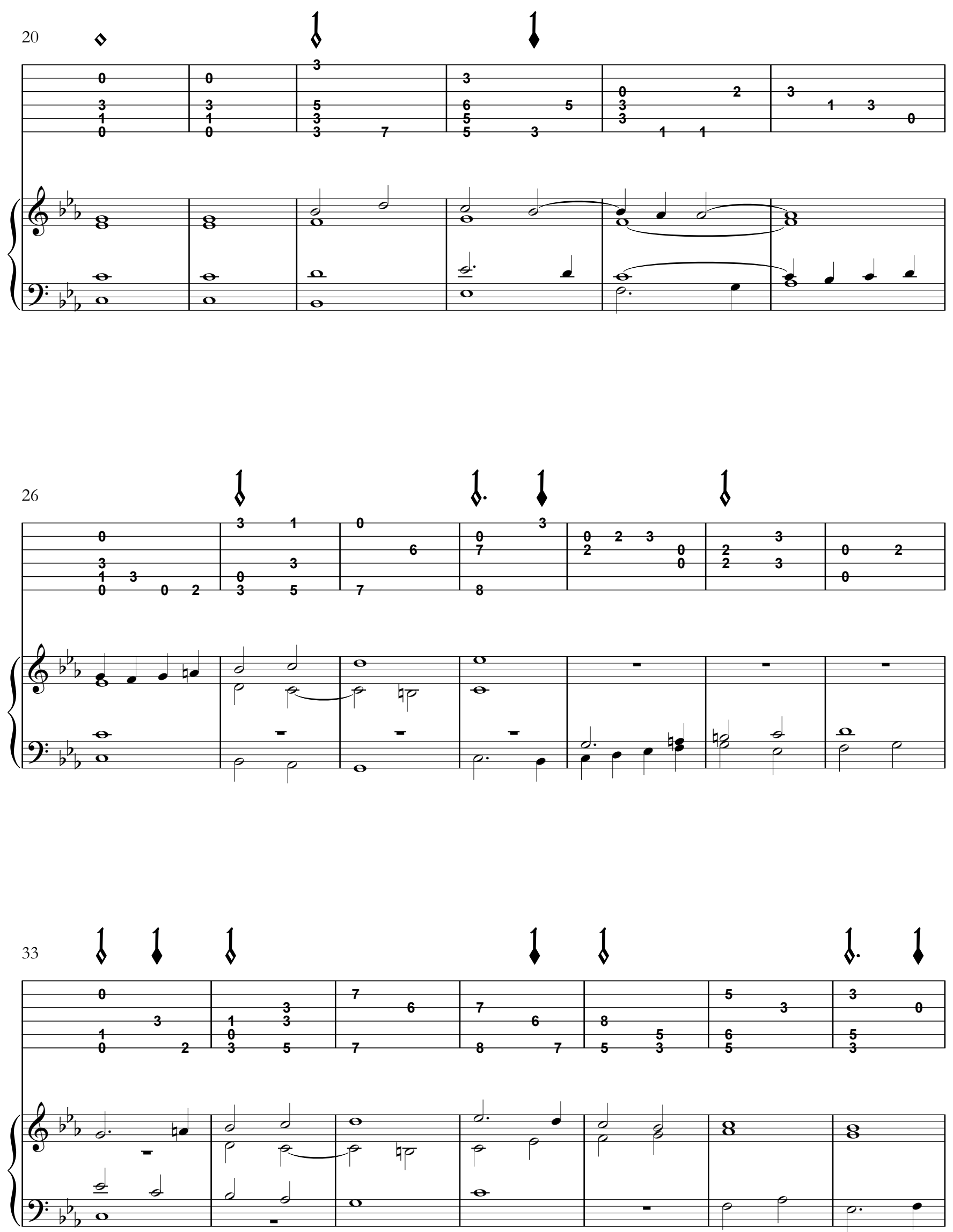

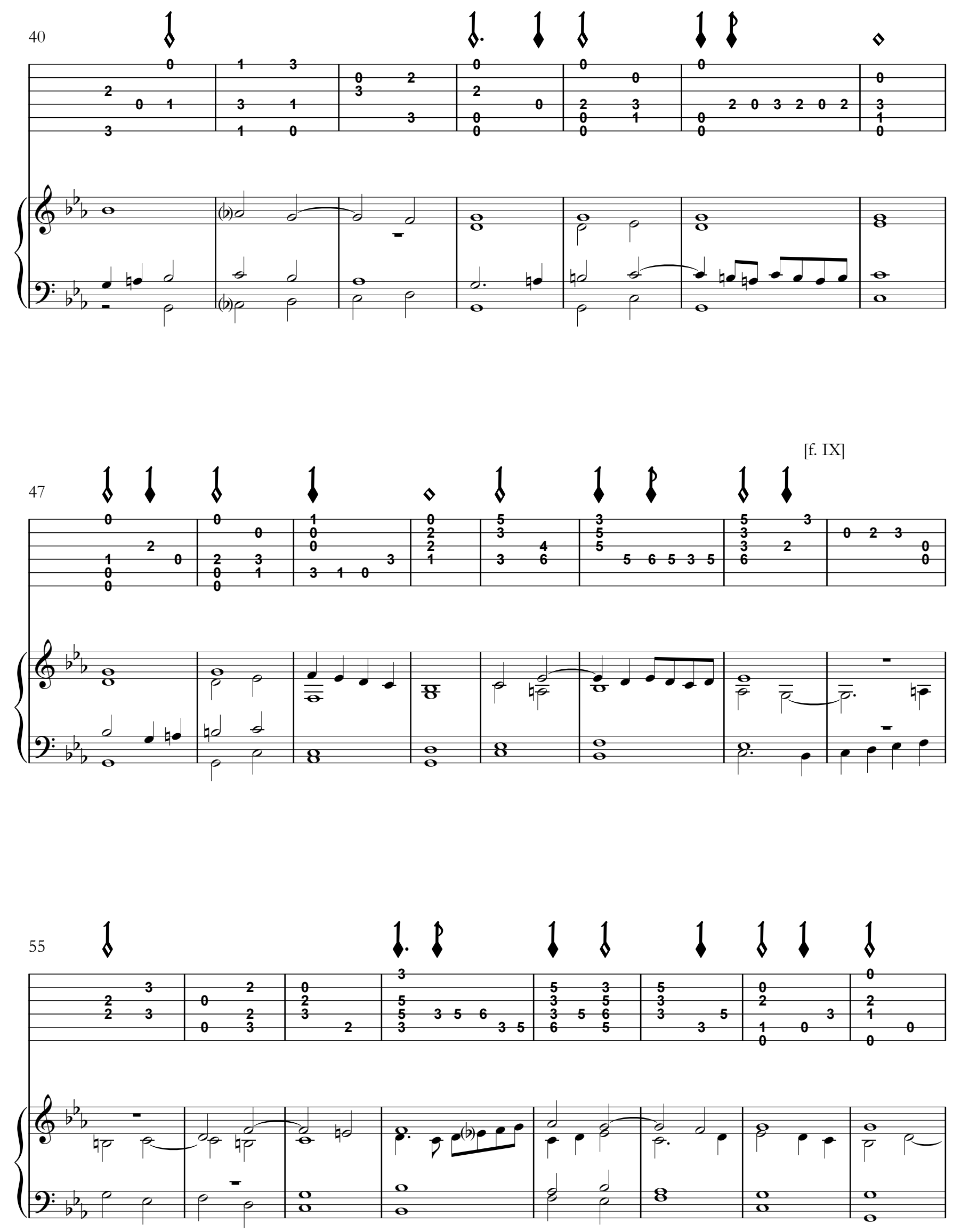

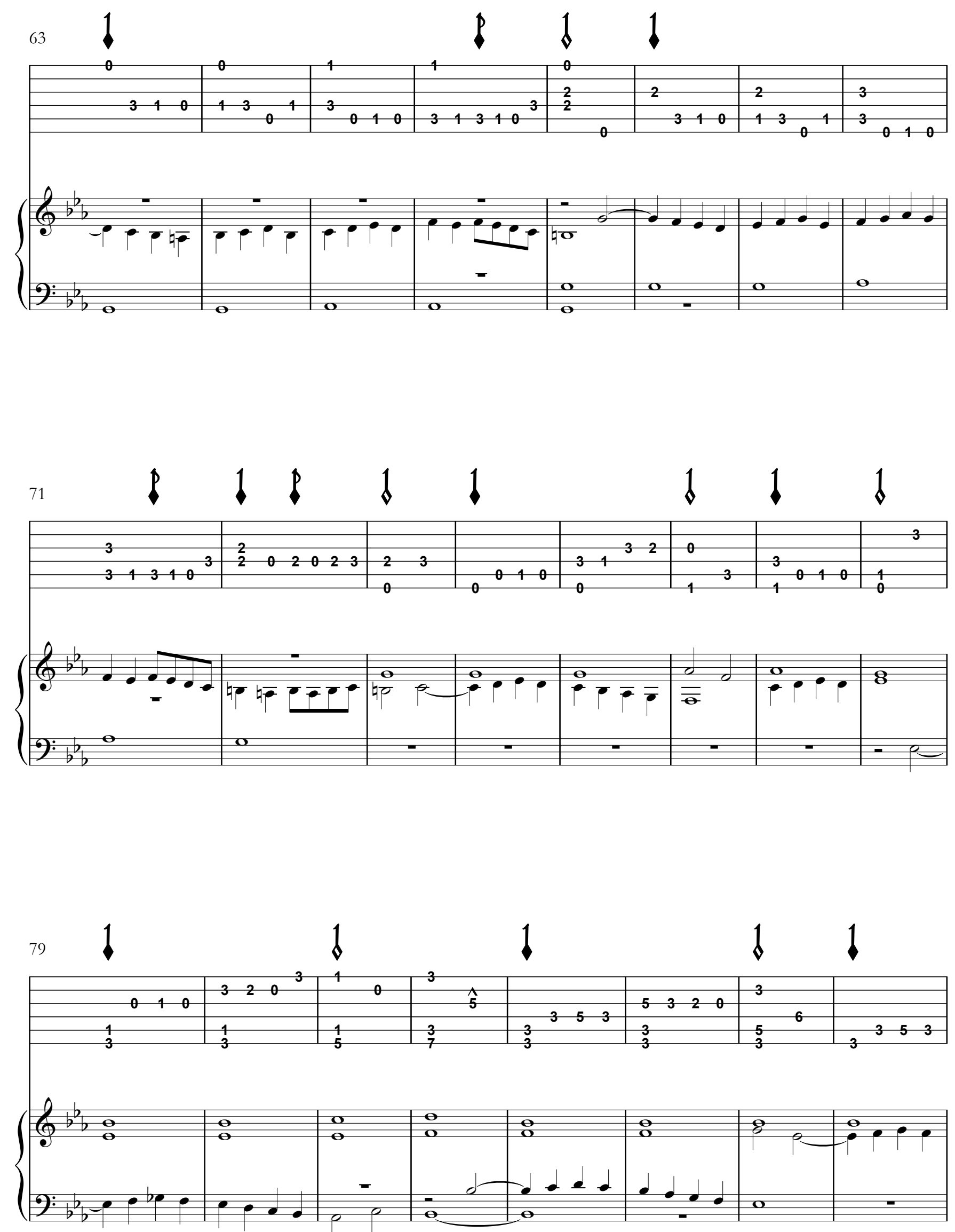
[f. IXv]

87

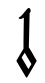

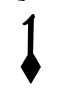

$\$ \quad 1$

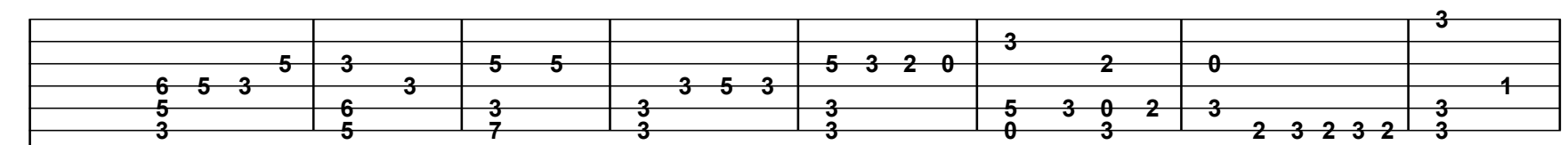
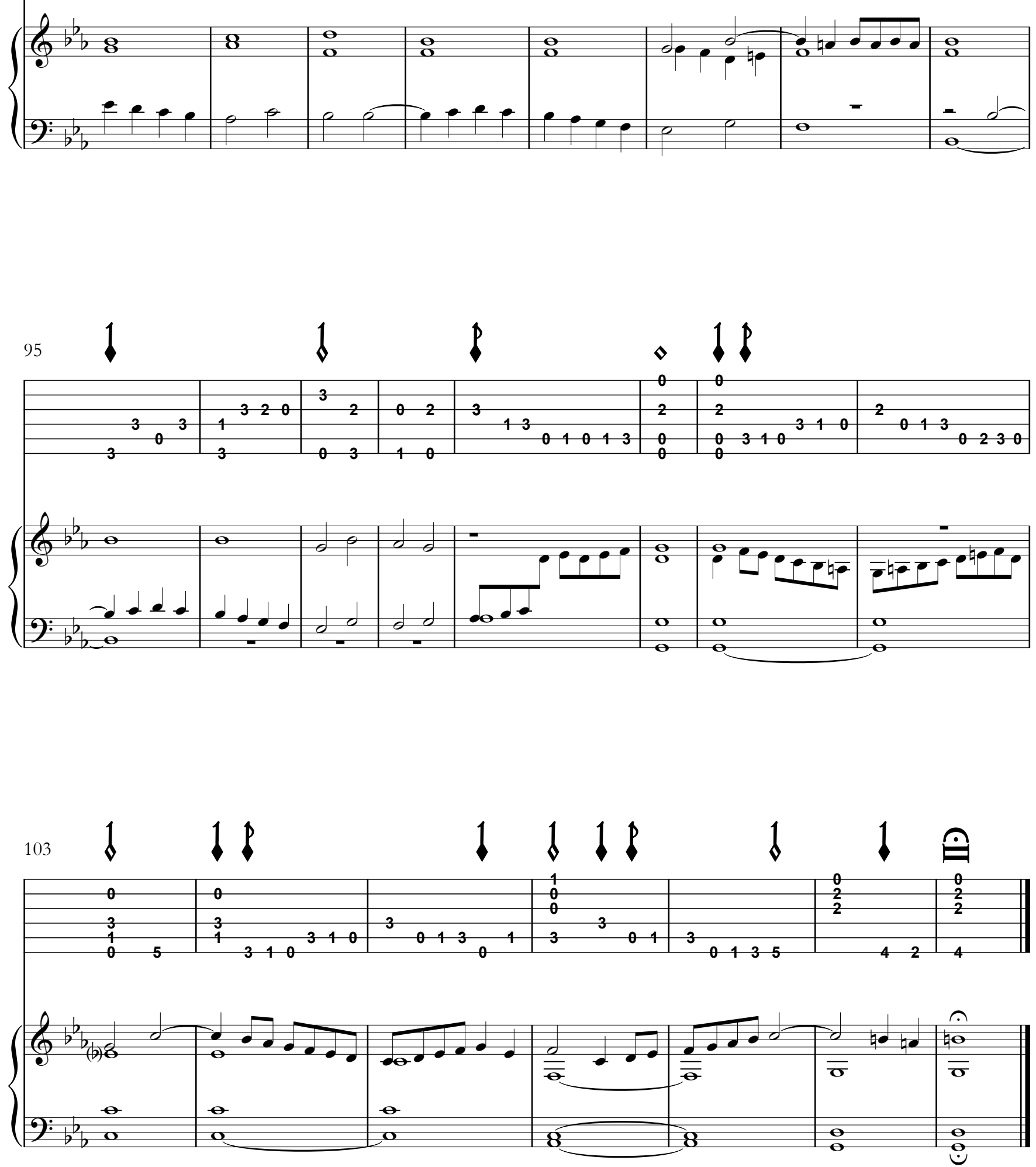


\section{so 33 - Kyrie 2}

Glosa sobre un Kyrie postrero de una misa de iosquin que va sobre pange lingua [Libro II, ff. IXv-XI]
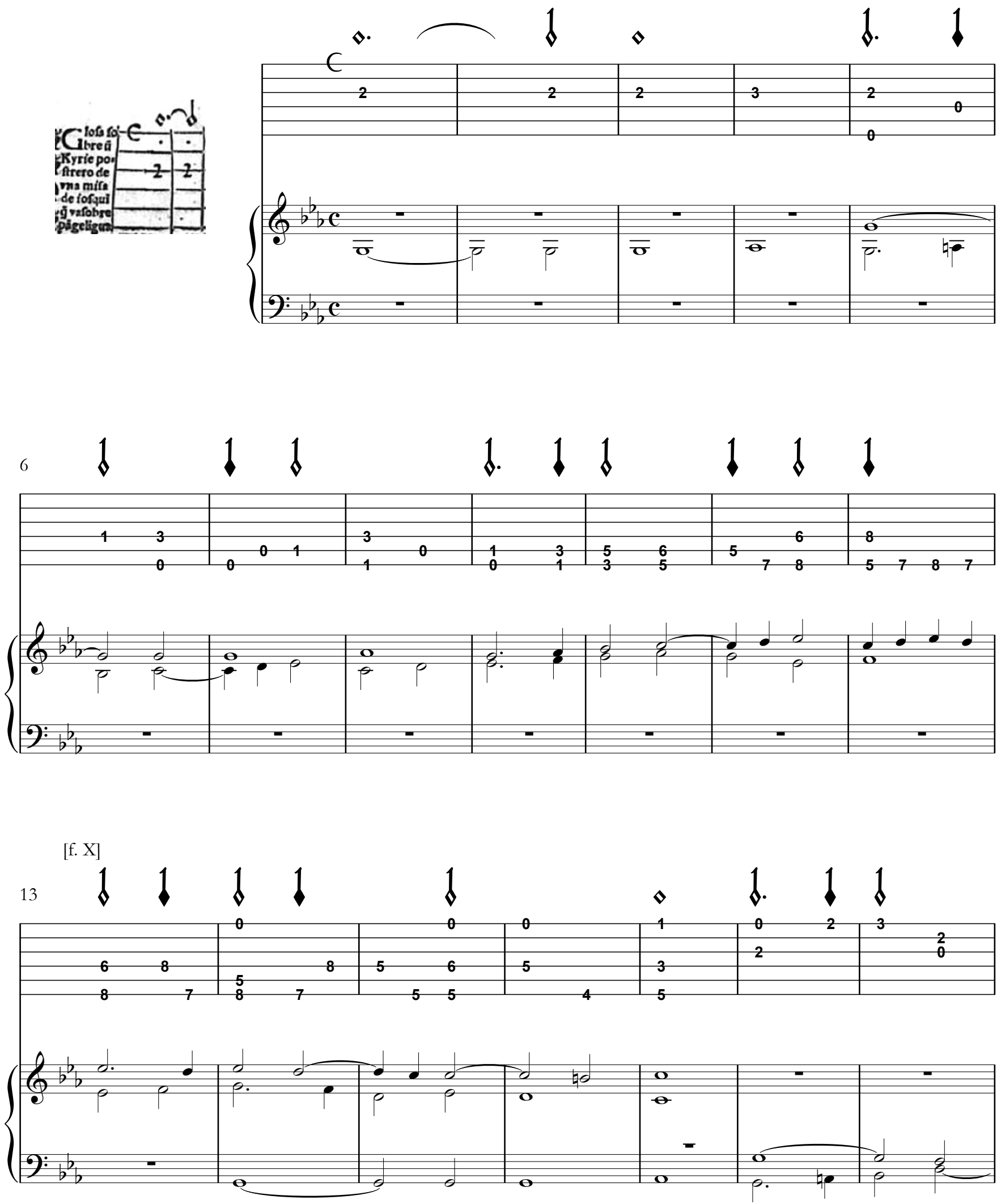
$20 \quad 1 \quad 1 \quad 1.81 \quad 1.81 \quad 1 \quad 1 \quad 1 \quad 1.81$

\begin{tabular}{|c|c|c|c|c|c|c|}
\hline 23 & $\begin{array}{llll}0 & 2 & 3 & 2\end{array}$ & 3 & & 3 & & 3 \\
\hline 2 & $3-2$ & $\begin{array}{llll}2 & & & \\
2 & 0 & 1\end{array}$ & $\begin{array}{ll}2 & 3 \\
1 & 3\end{array}$ & 2 & 0 & $\begin{array}{lll}0 & 2 & \\
& 0\end{array}$ \\
\hline & & & & 0 & $\begin{array}{llll}1 & 0 & 1 & 0\end{array}$ & 1 \\
\hline
\end{tabular}
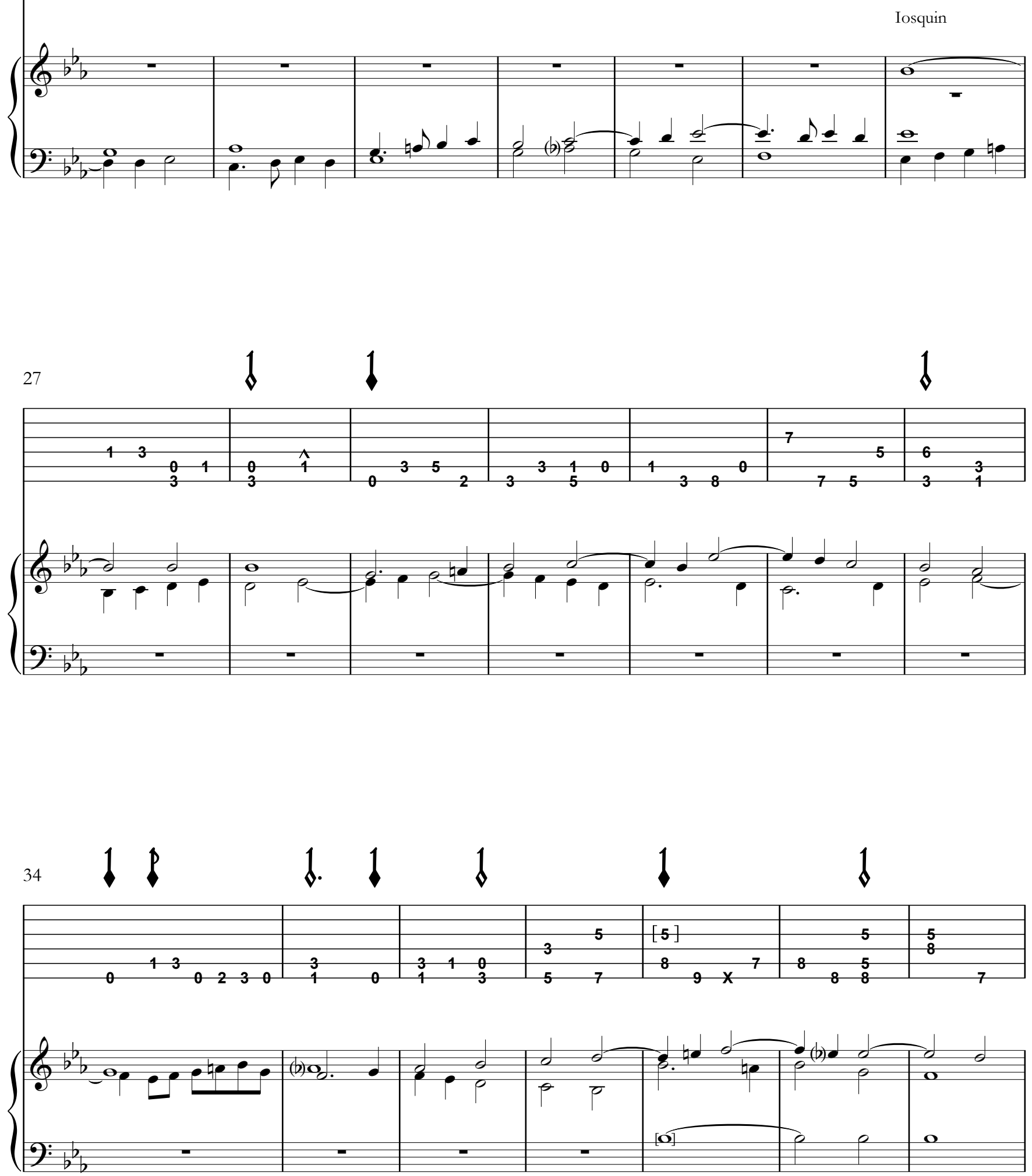


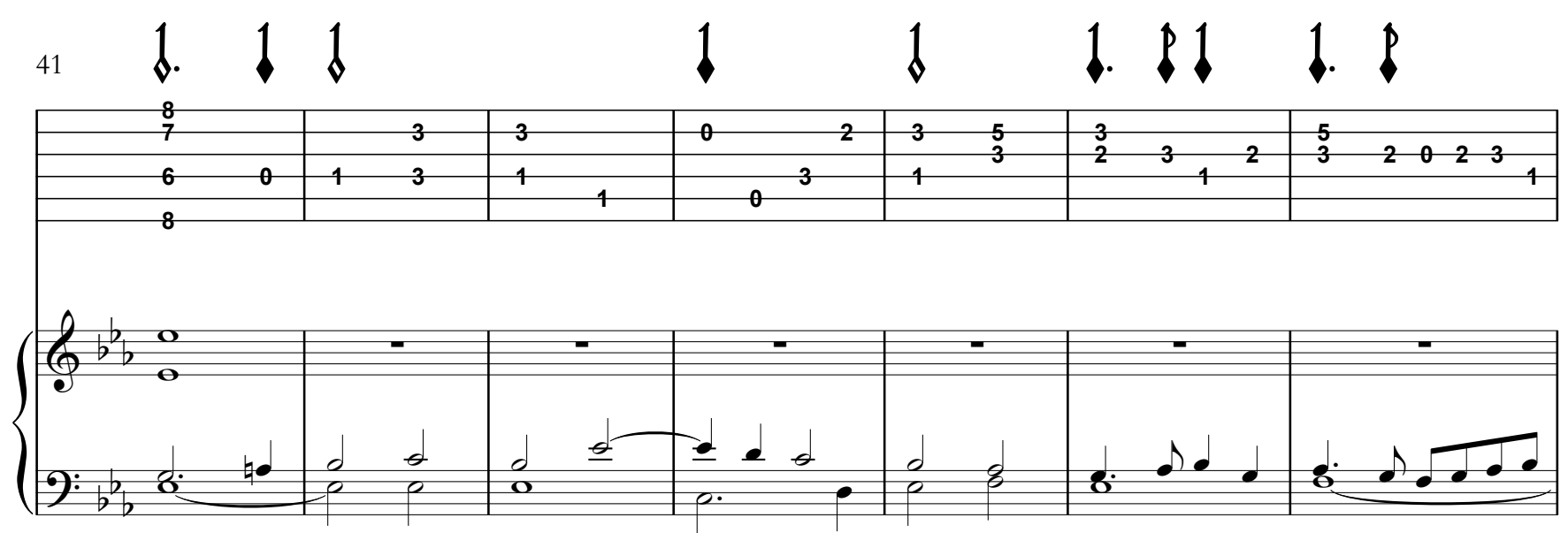

[f. Xv]

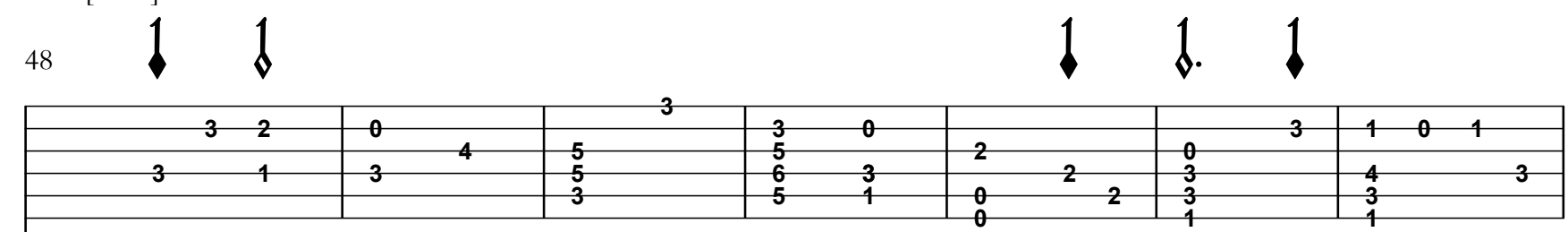

glosa
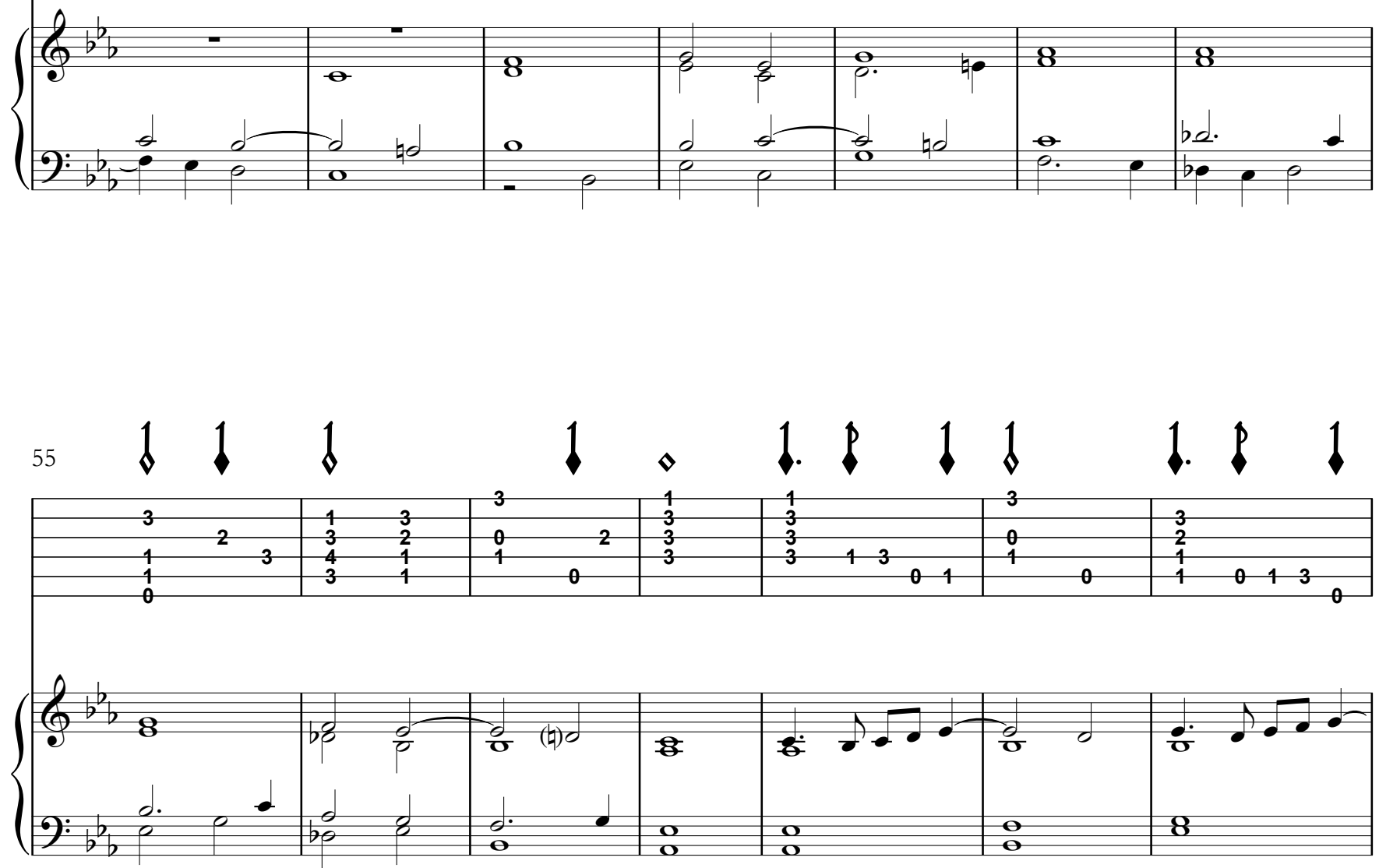

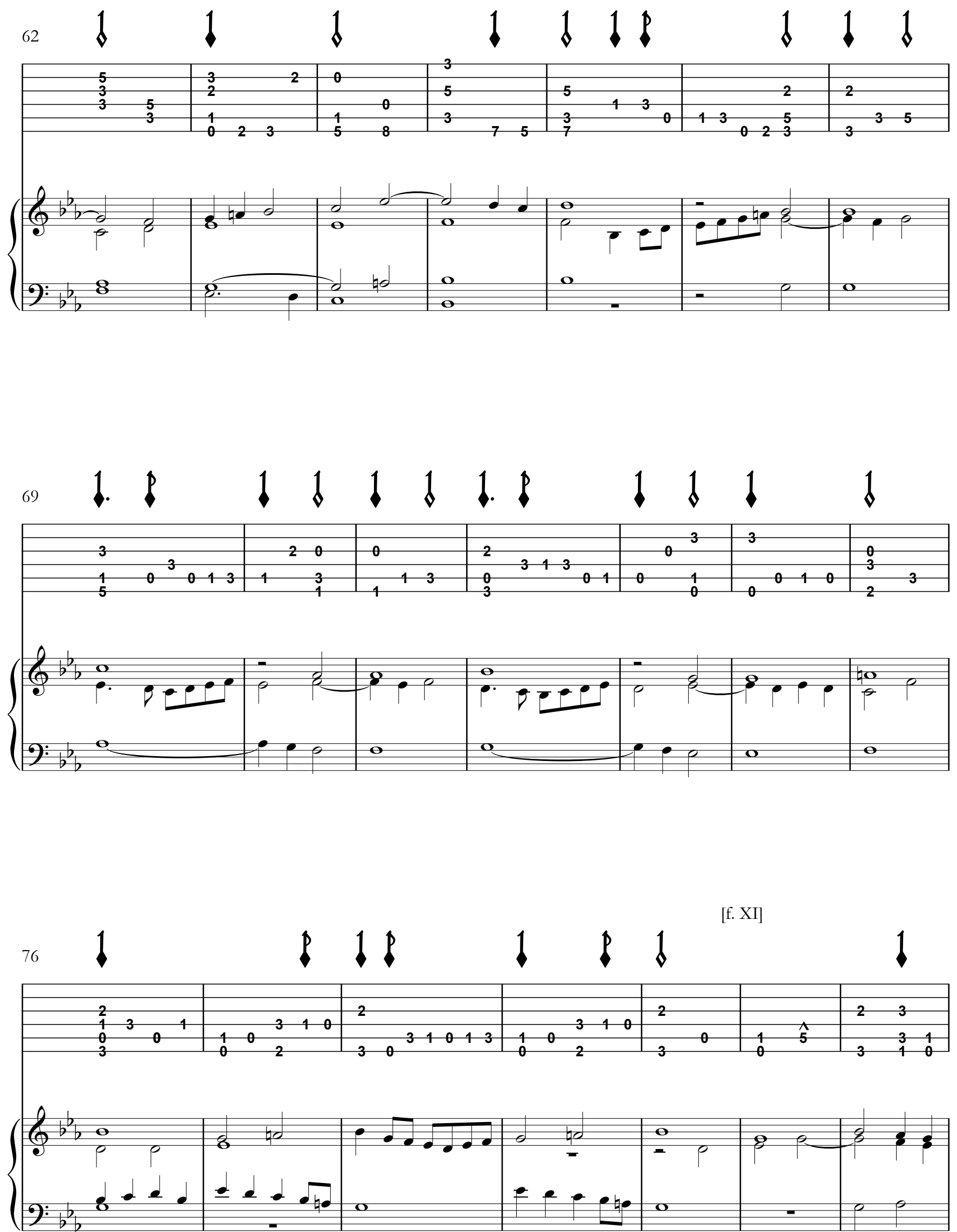


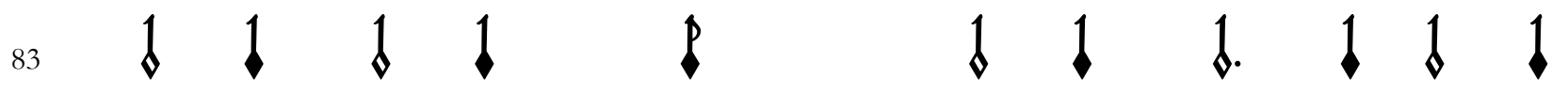

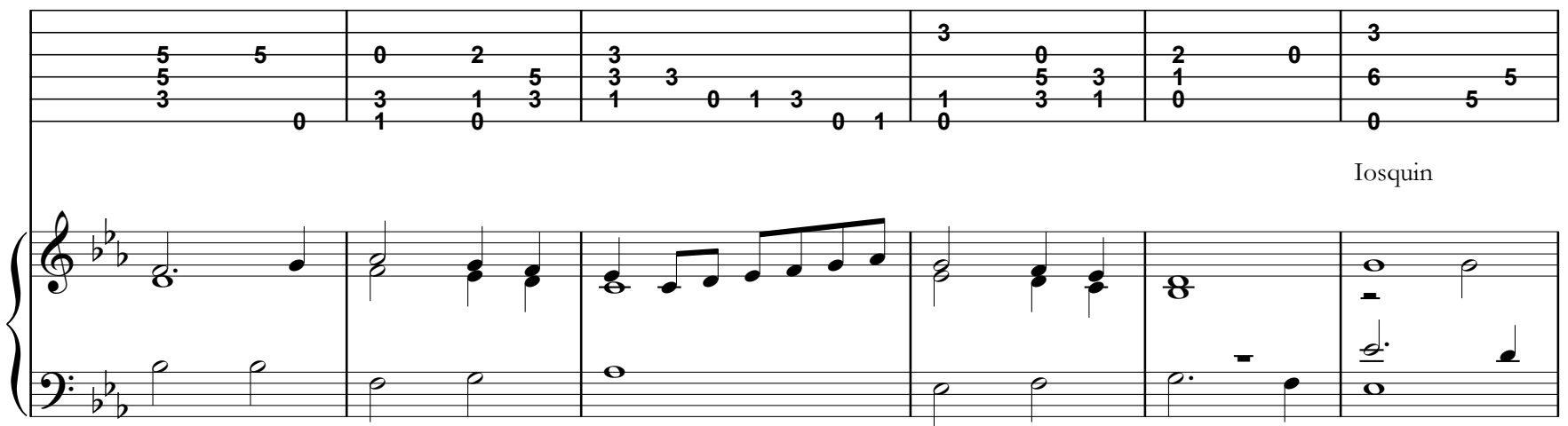

$89+1 \quad 1 \quad 1$
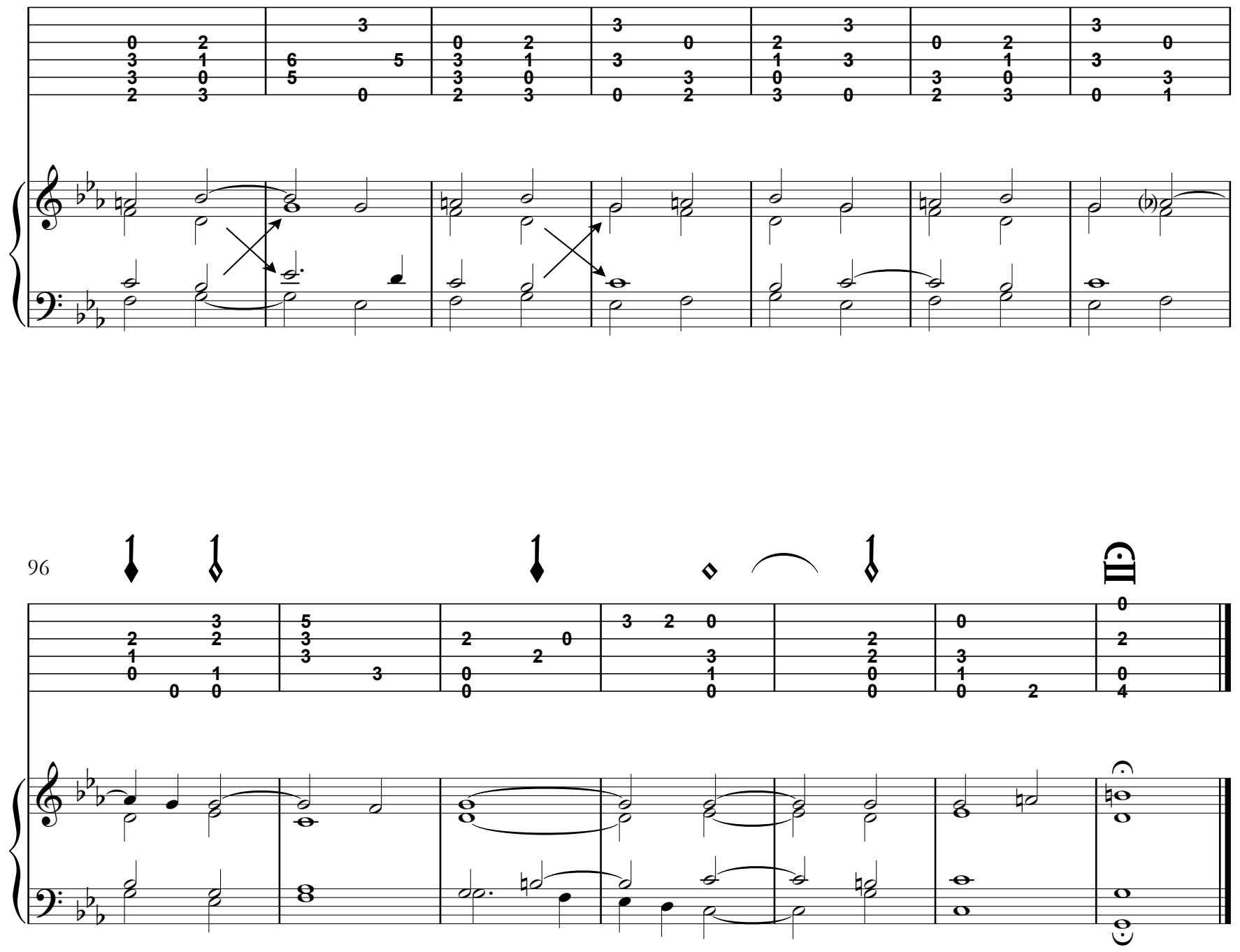


\section{sะ34 - Tiento 4 es}

Tiento

IV Tono

[Libro II, f. XI]

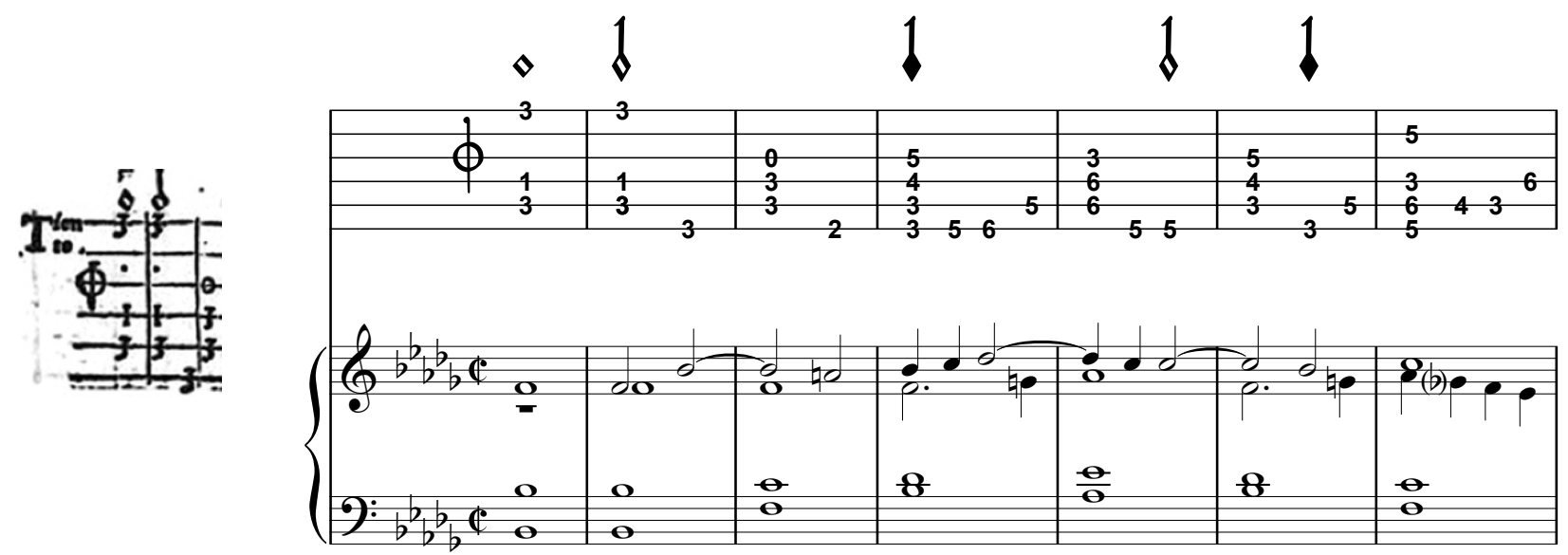

111

[f. XIv]

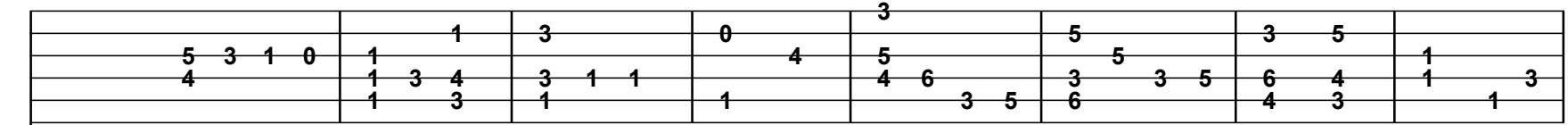

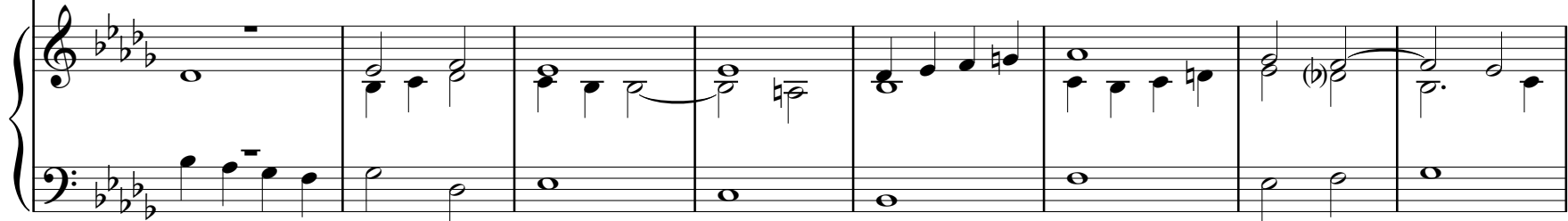

16

1

1.

(b) 1

ค

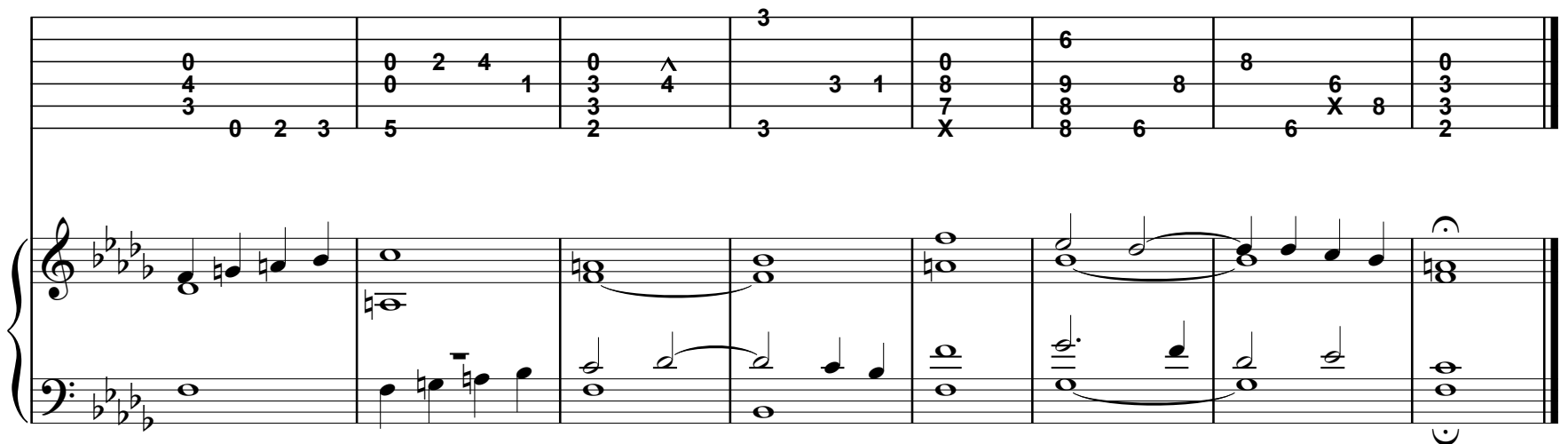


so 35 - Fantasía 20

Fantasía
[Libro II, ff. XIv-XII]
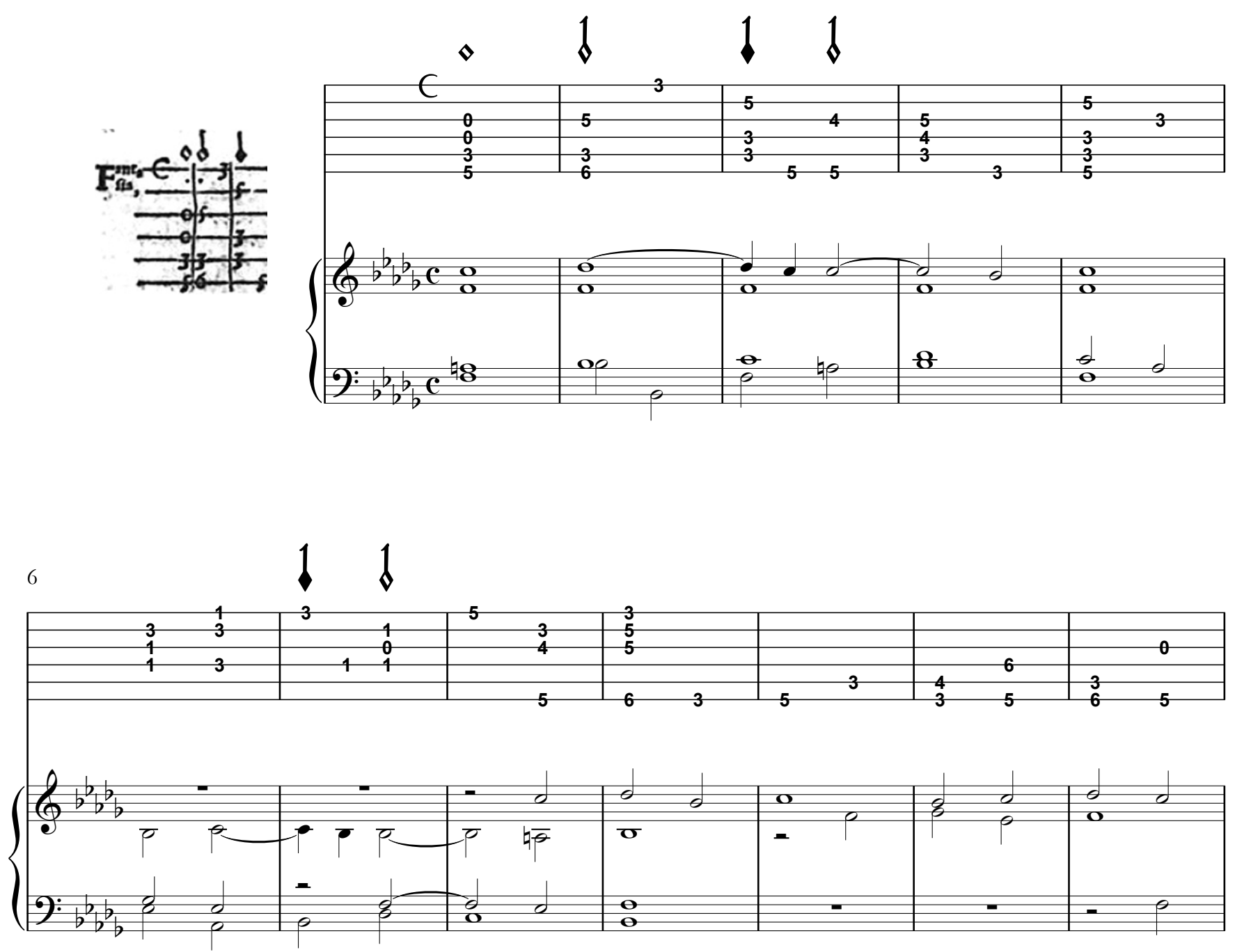

13
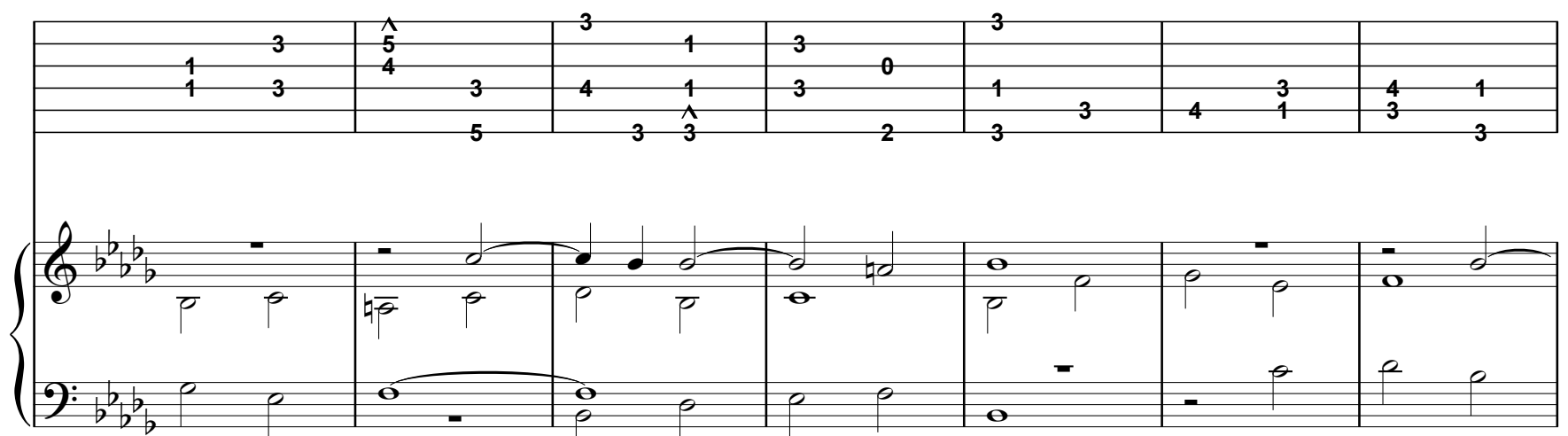

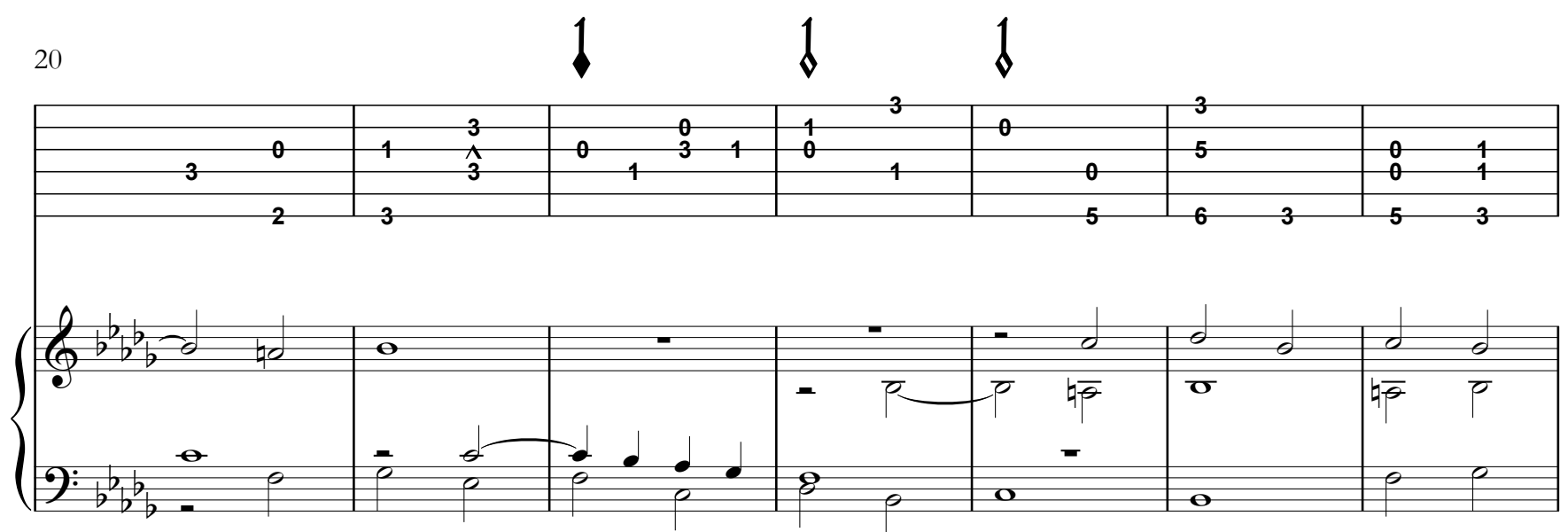

27

[f. XII]

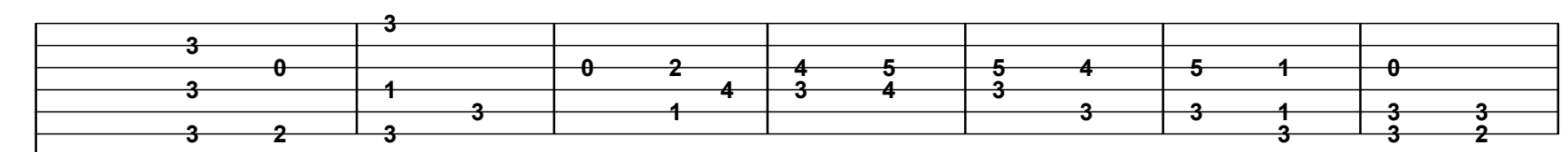

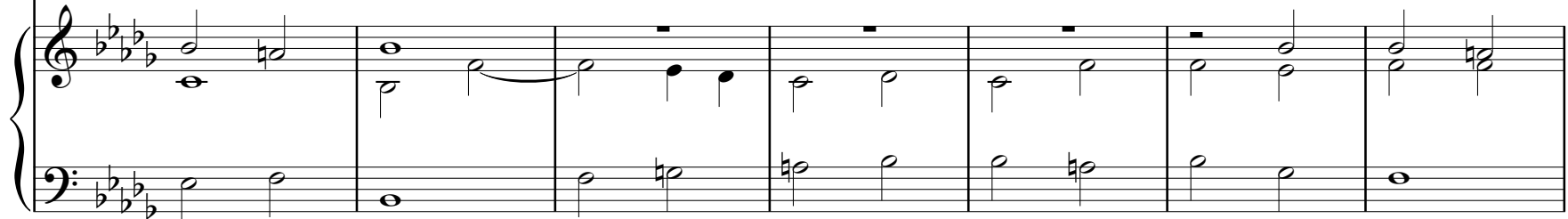

34

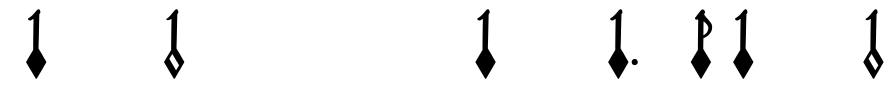

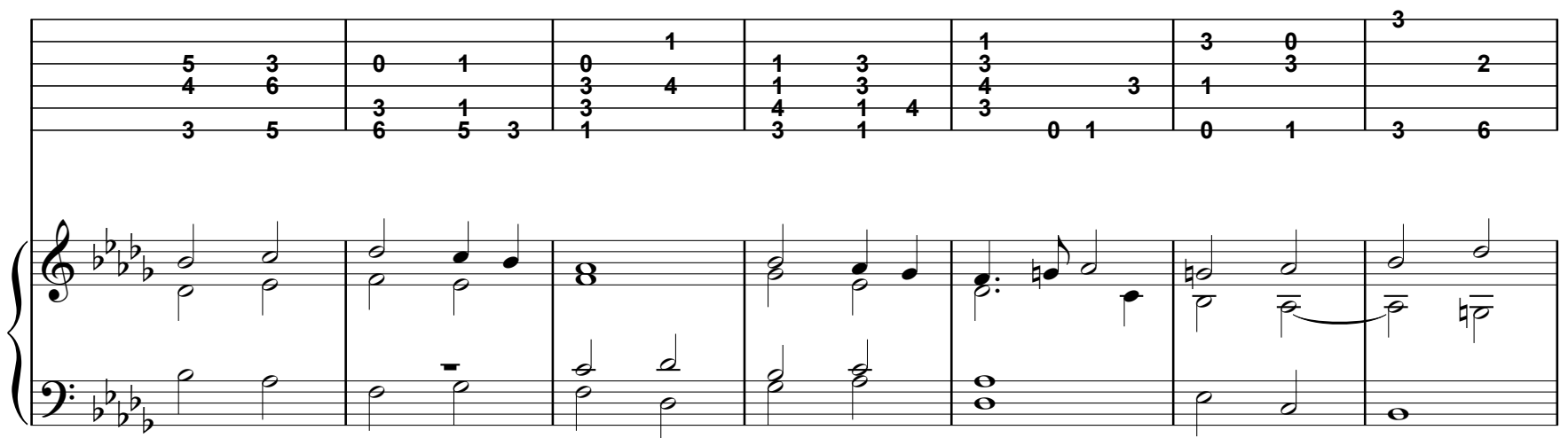



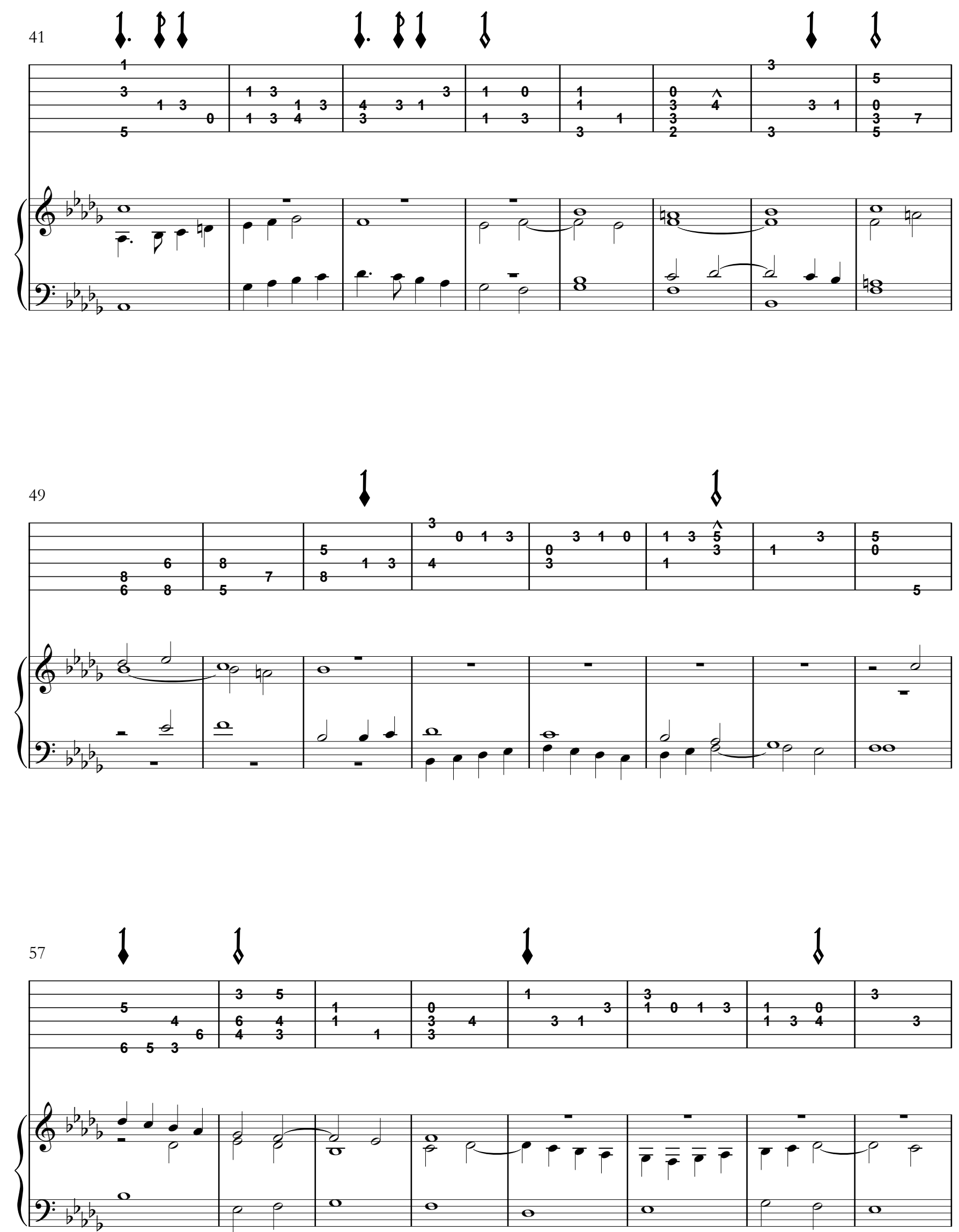


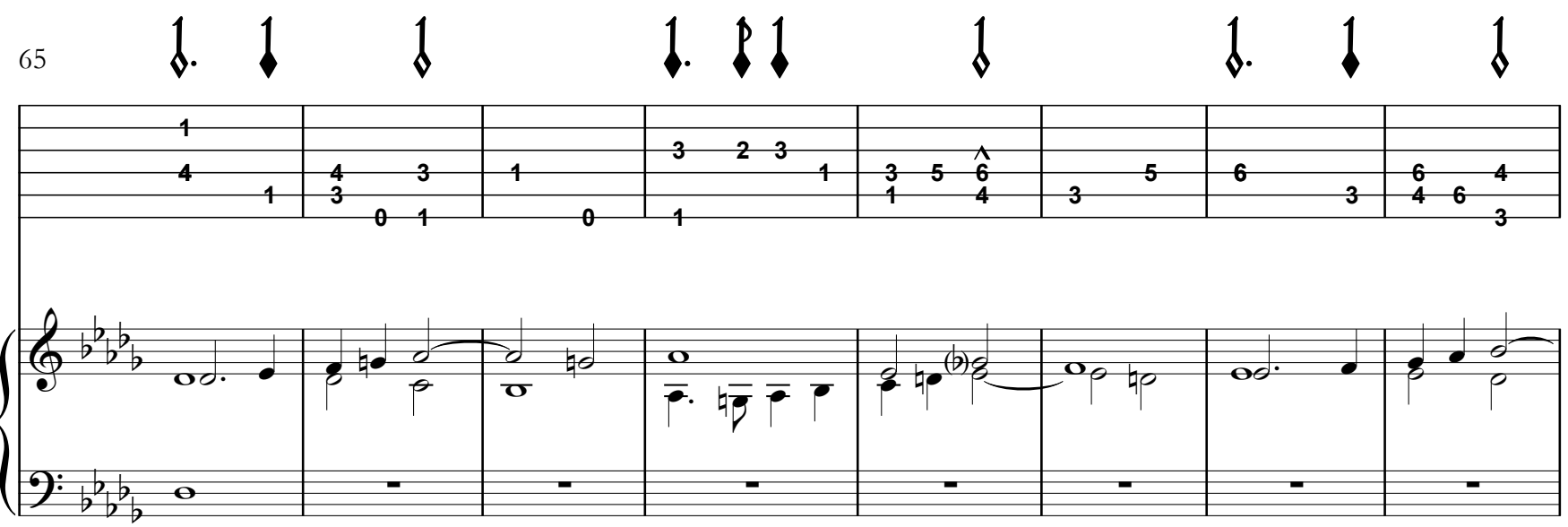

[f. XIIv]
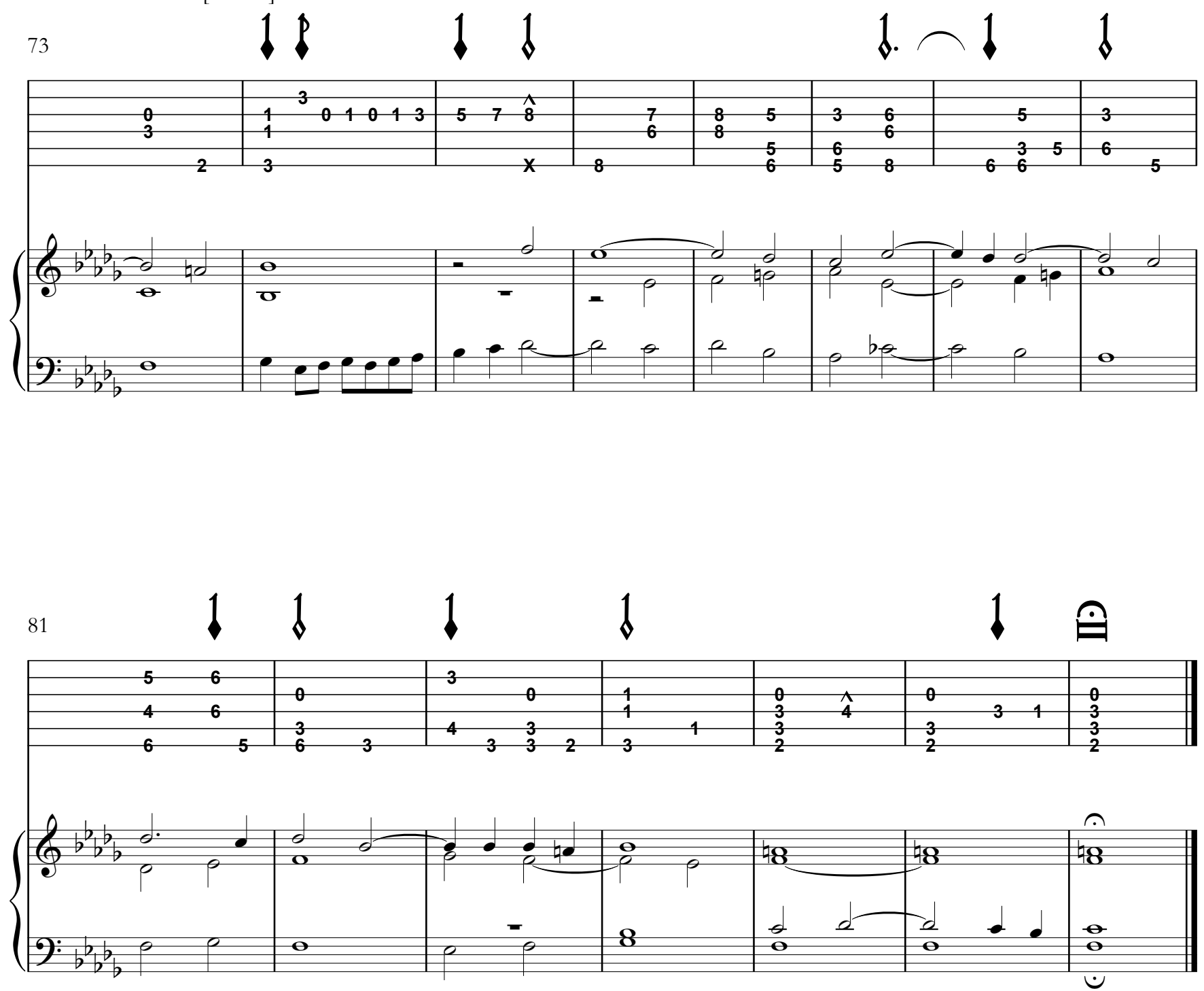


\section{s\& 36 - Benedictus}

Glosa sobre un beneditus [sic] de una missa de iosquin que va sobre la, sol, fa, re, mi

[Libro II, ff. XIIv-XIII]

Josquin/Mudarra
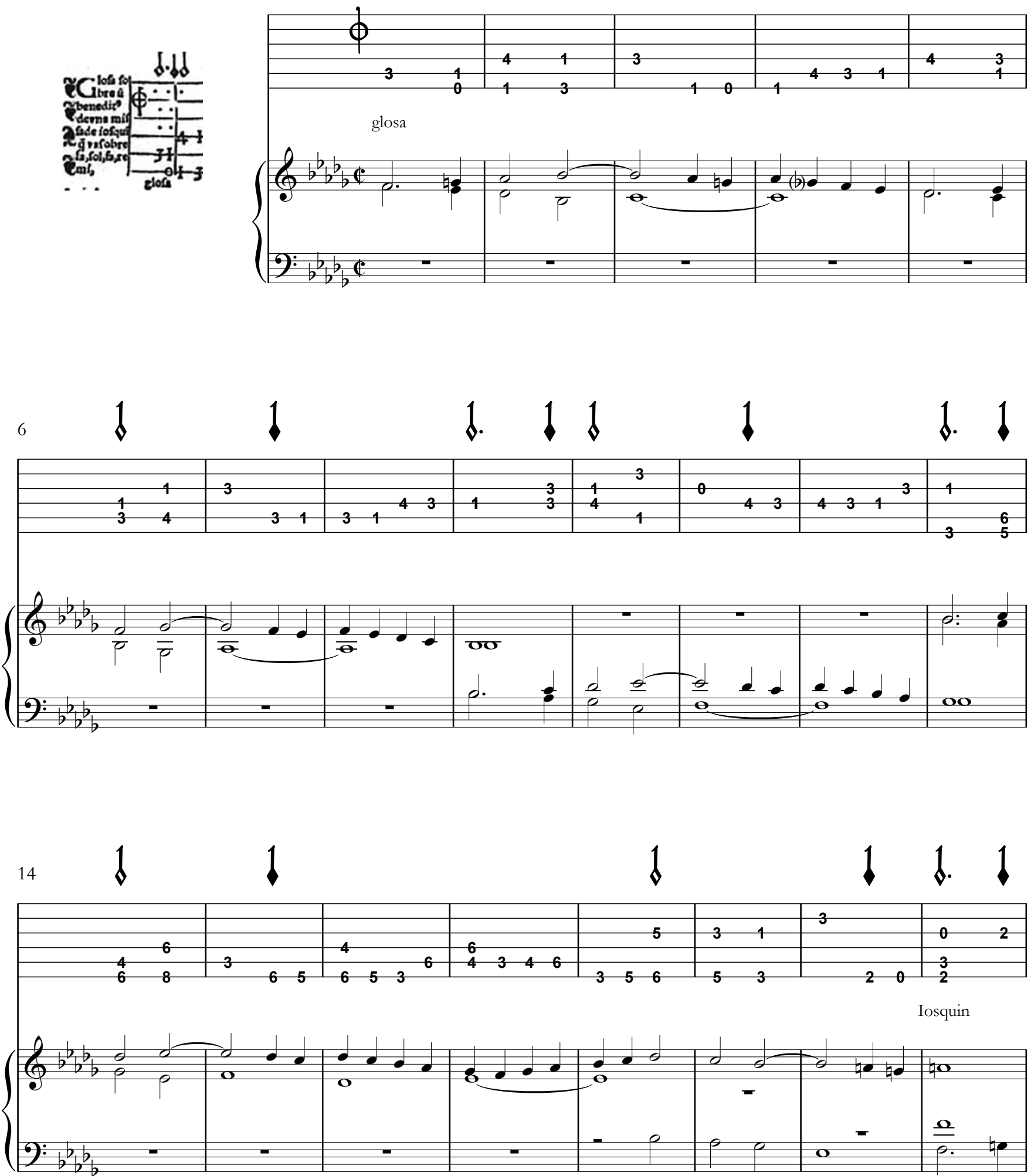


\section{[f. XIII]}
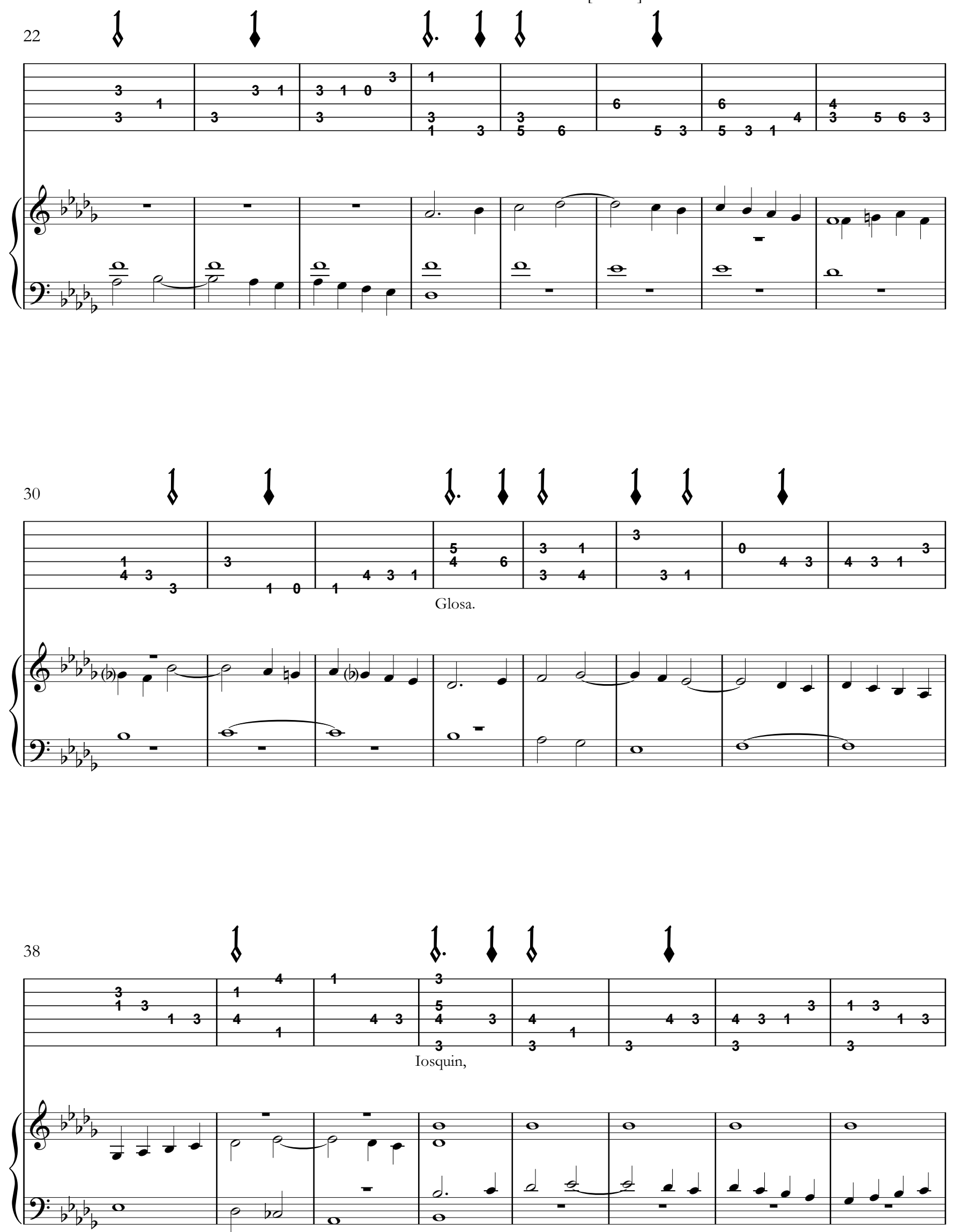

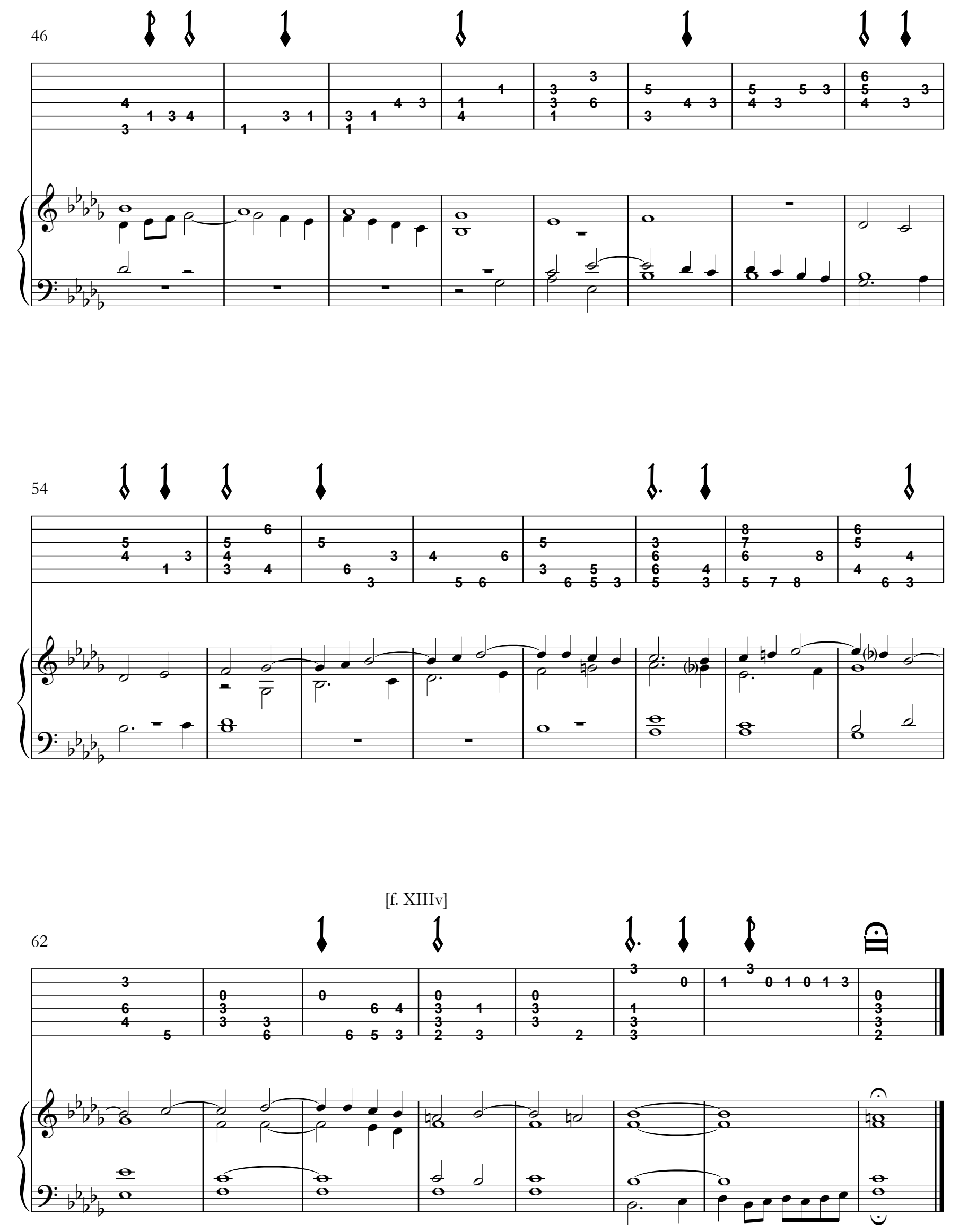


\section{se 37 - Tiento 5 ed}

Tiento

V Tono

[Libro II, ff. XIIIv-XIV]
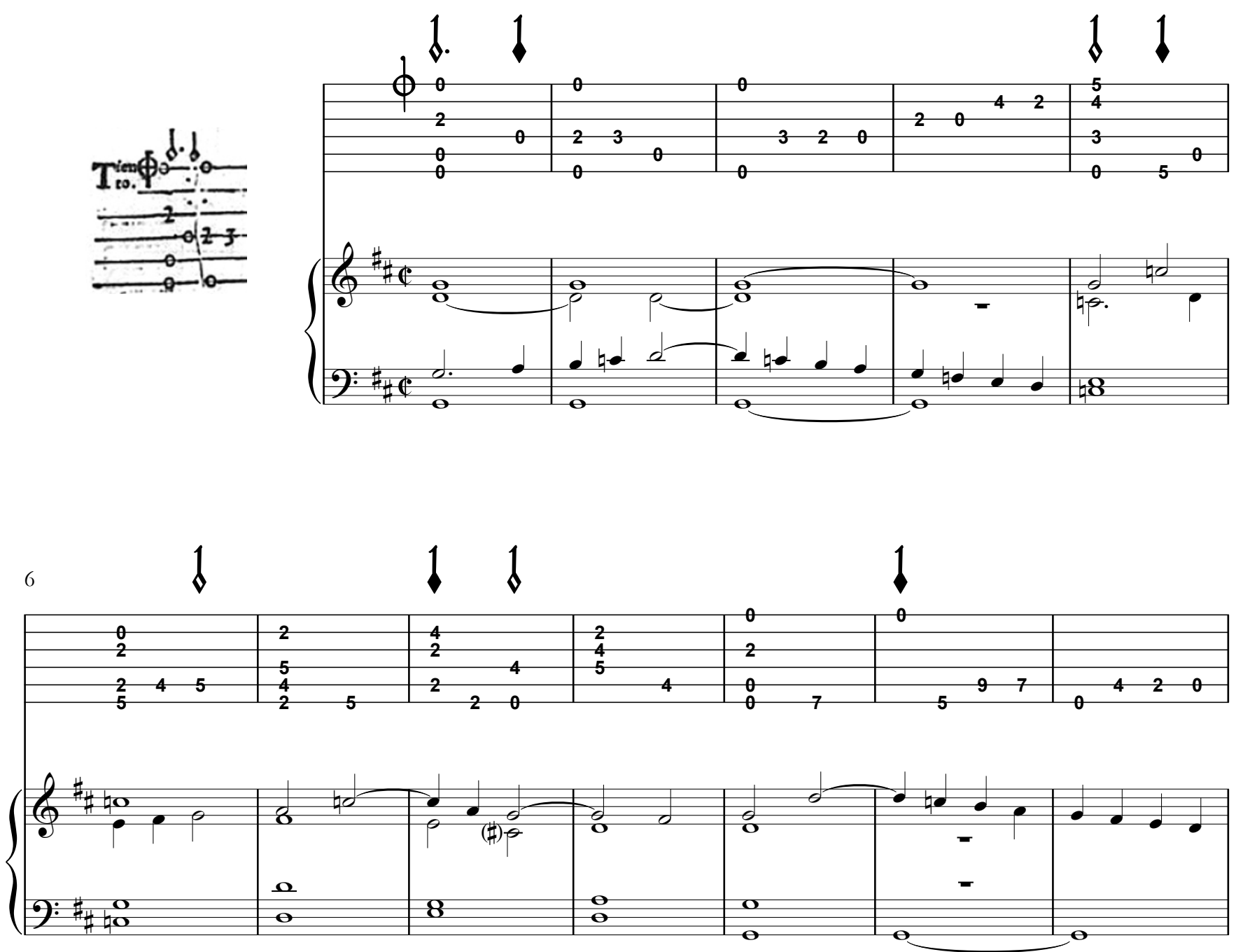

$13 \quad 1 \quad 1 \quad 1101$

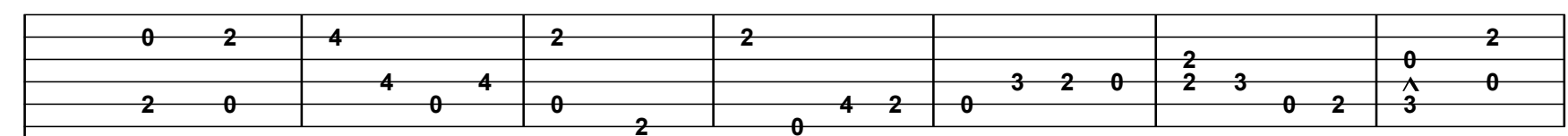

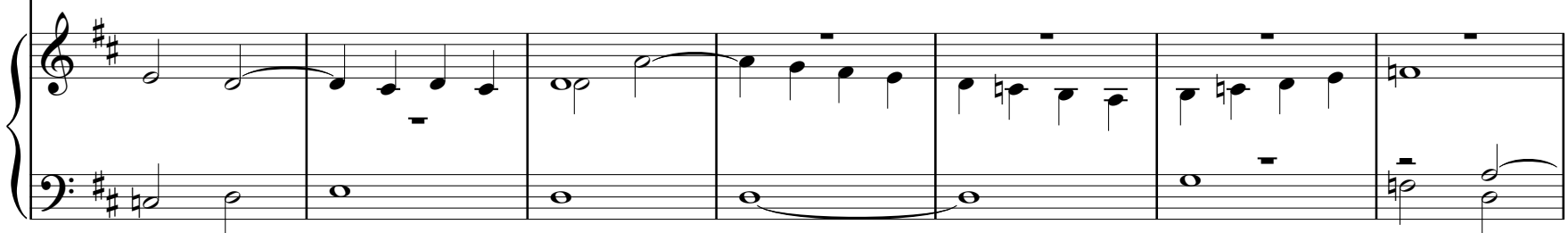


[f. XIV]

20

1

1 1

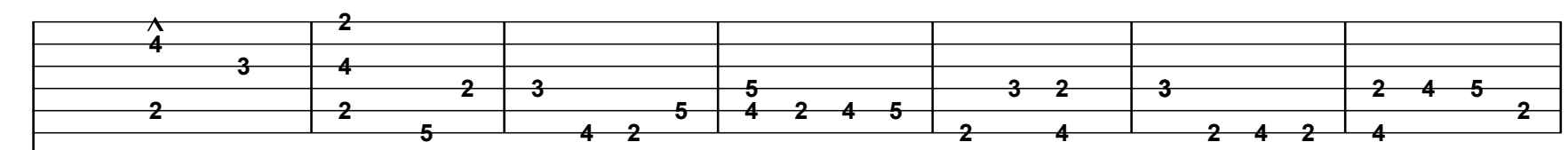

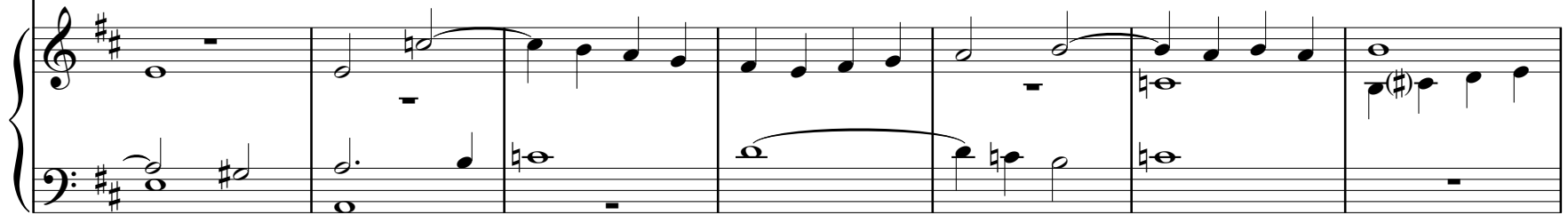

${ }_{27}+1<1.1$
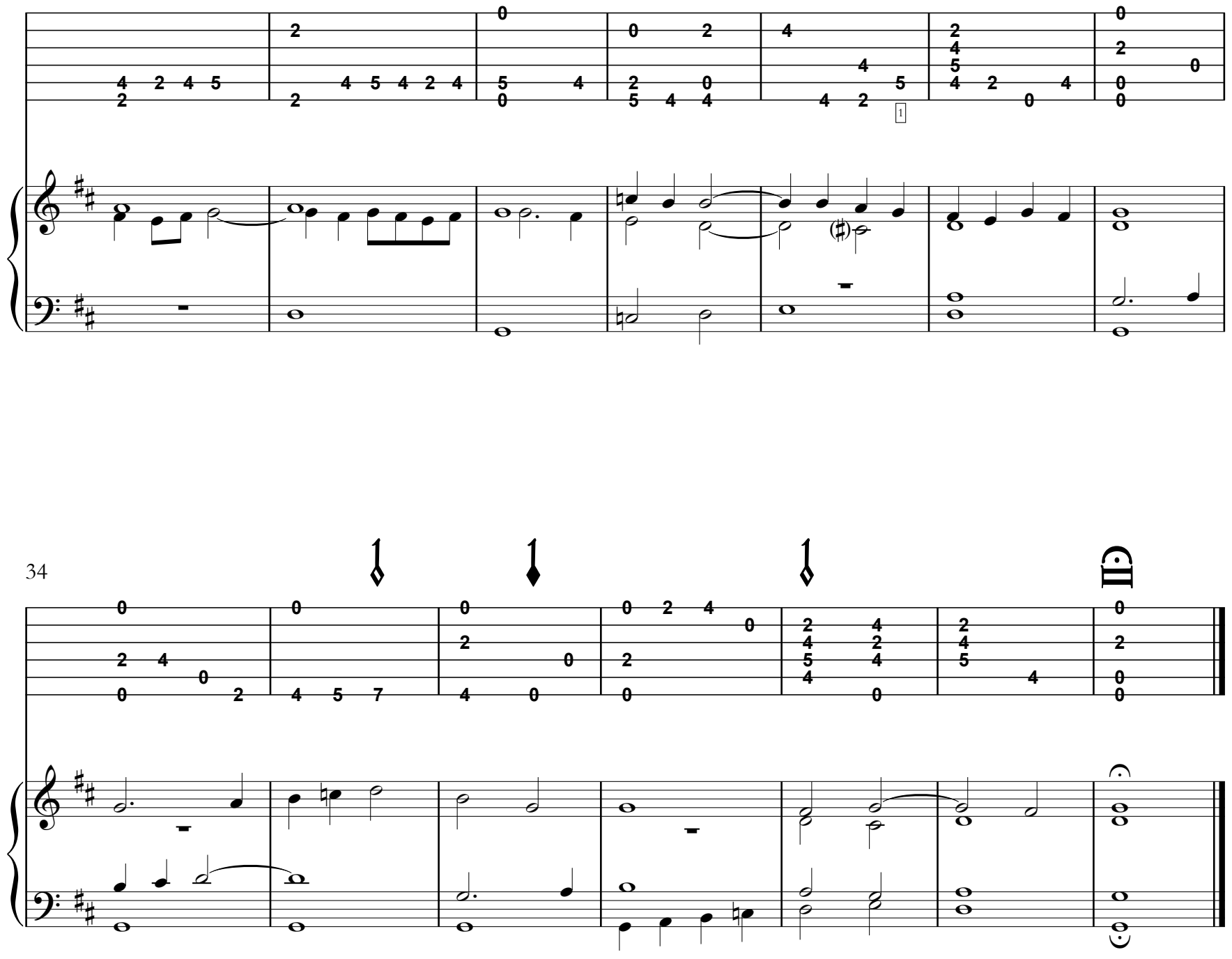
sะ38 - Fantasía 21

\author{
[Libro II, ff. XIV-XV]
}
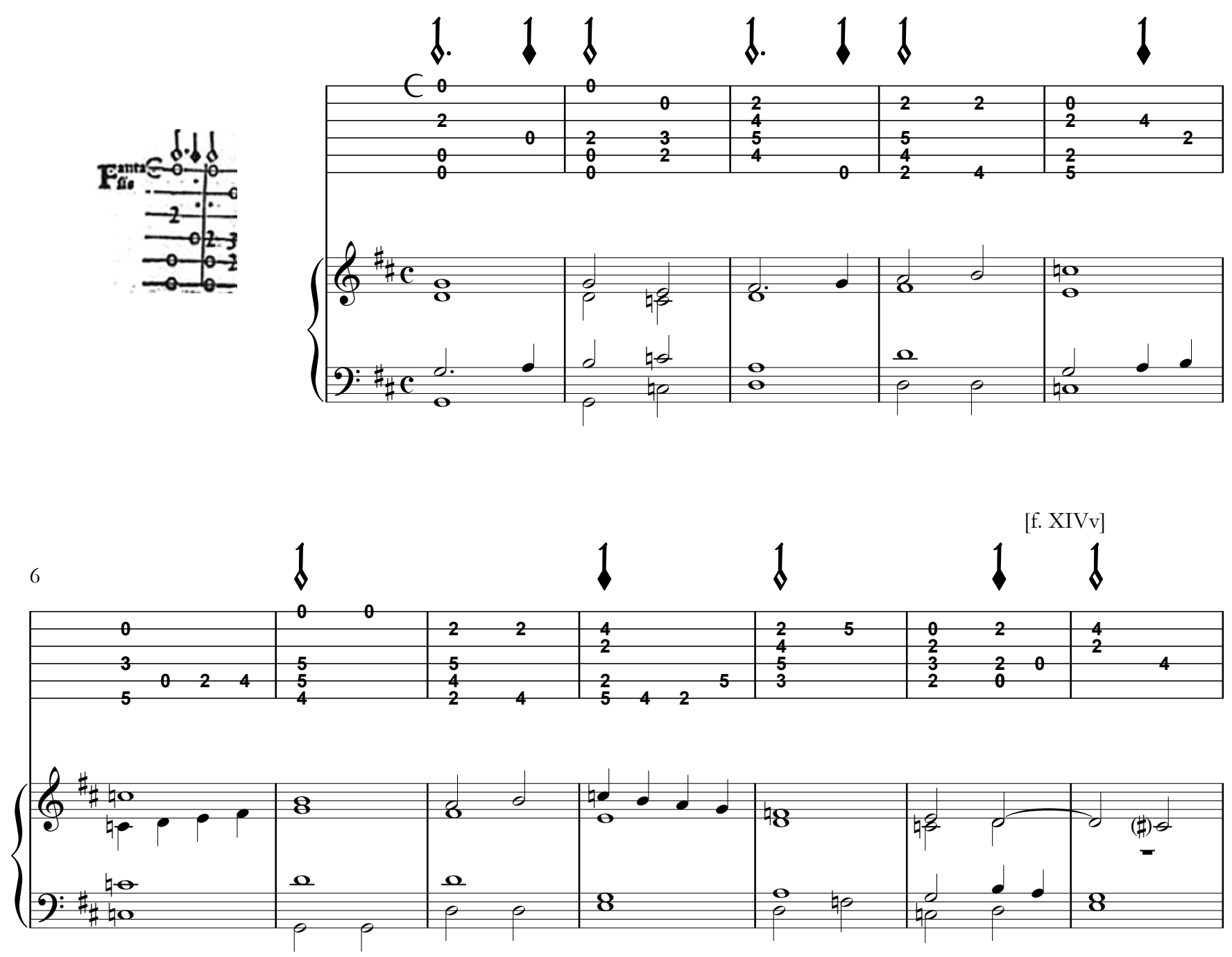

13
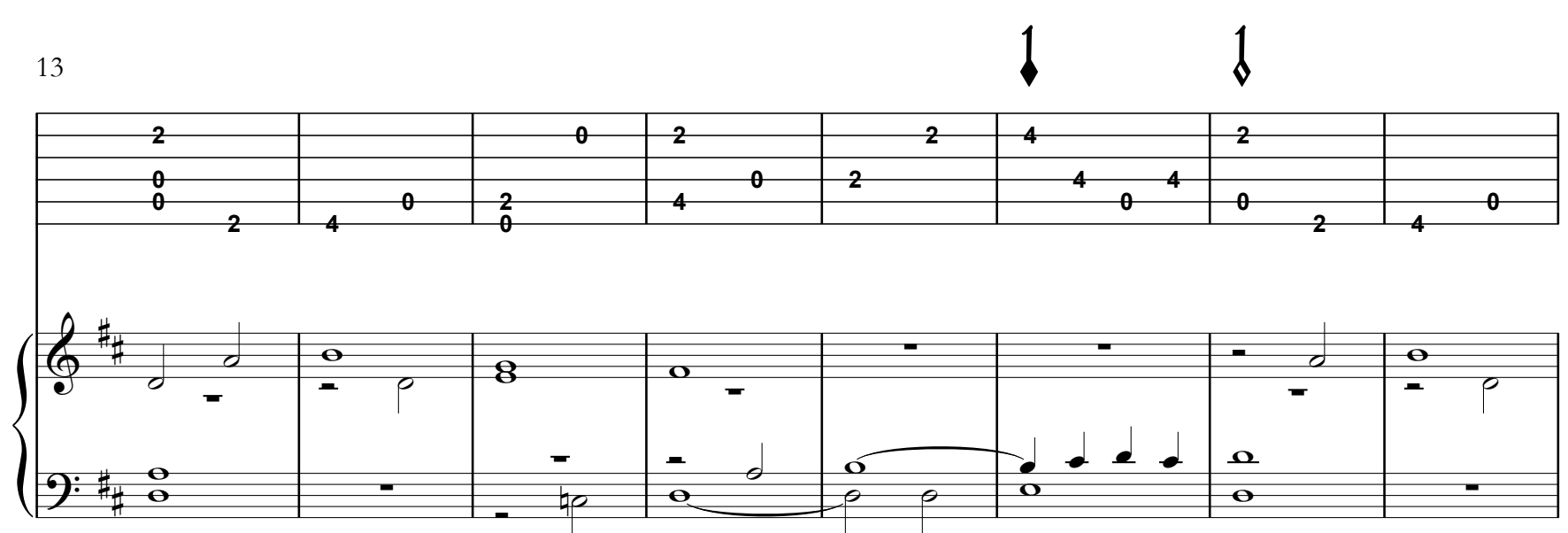
Fantasía 21

21
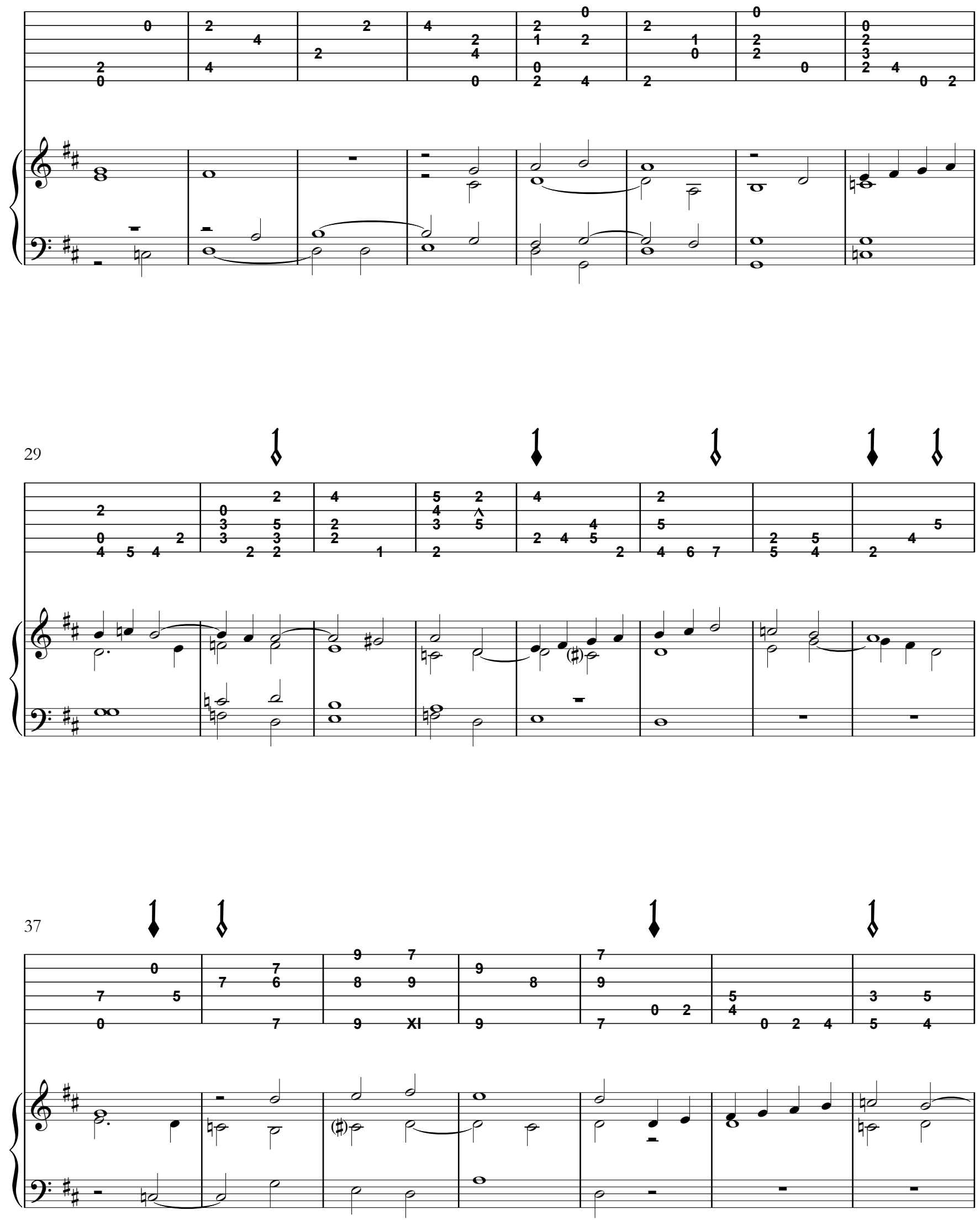

121 

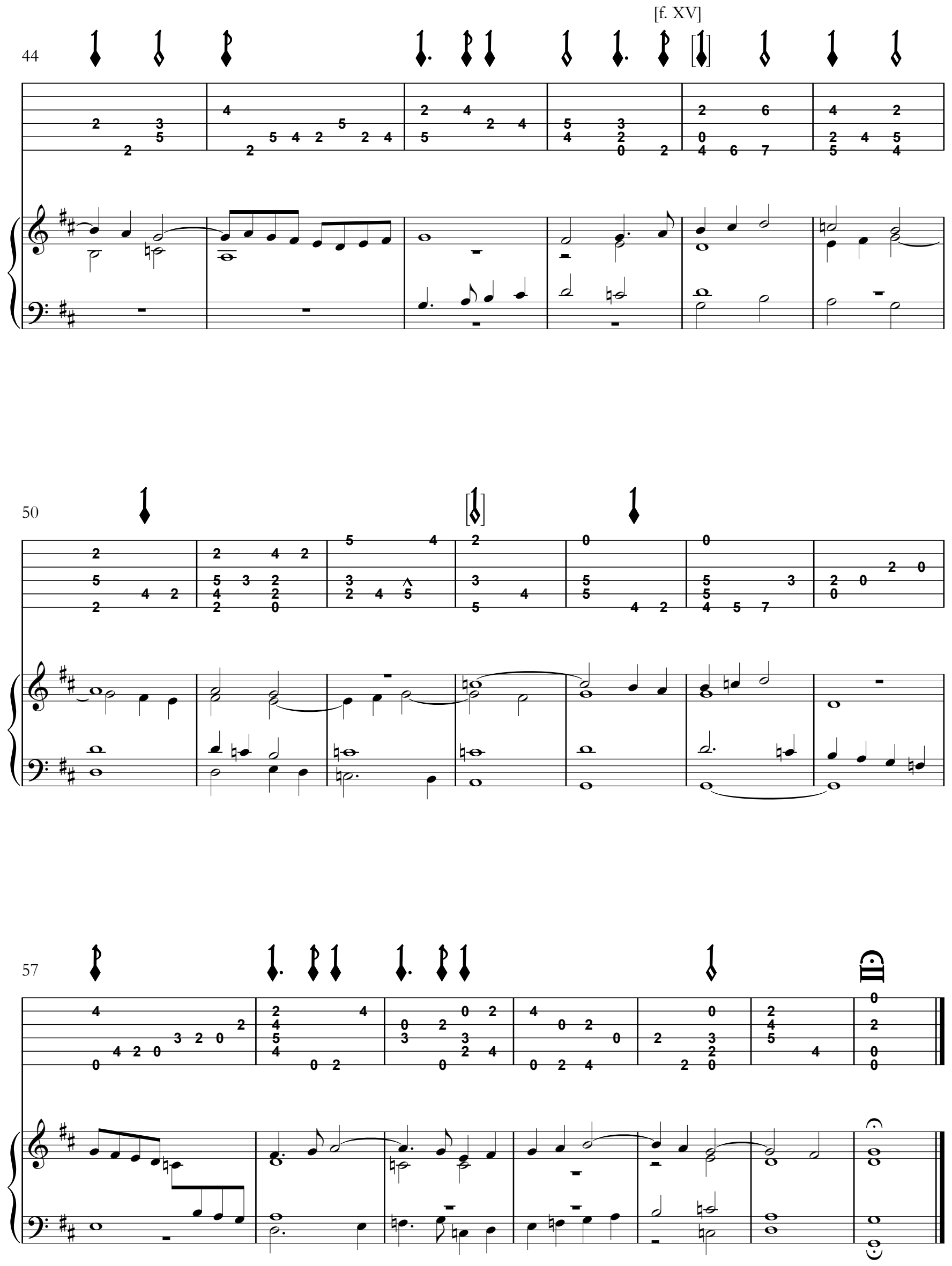


\section{\&439 - Fantasía 22}

[Libro II, ff. XV-XVIv]
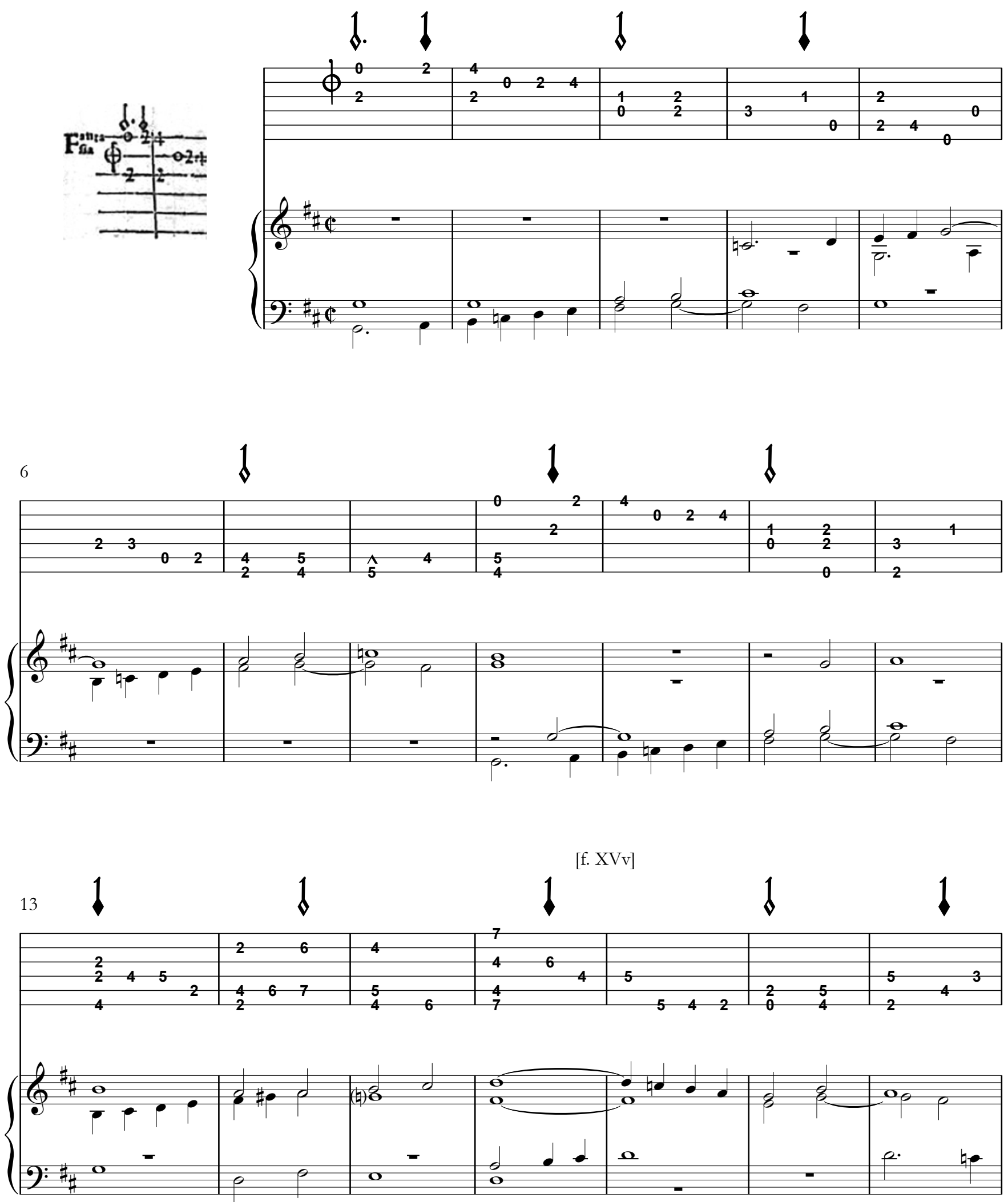

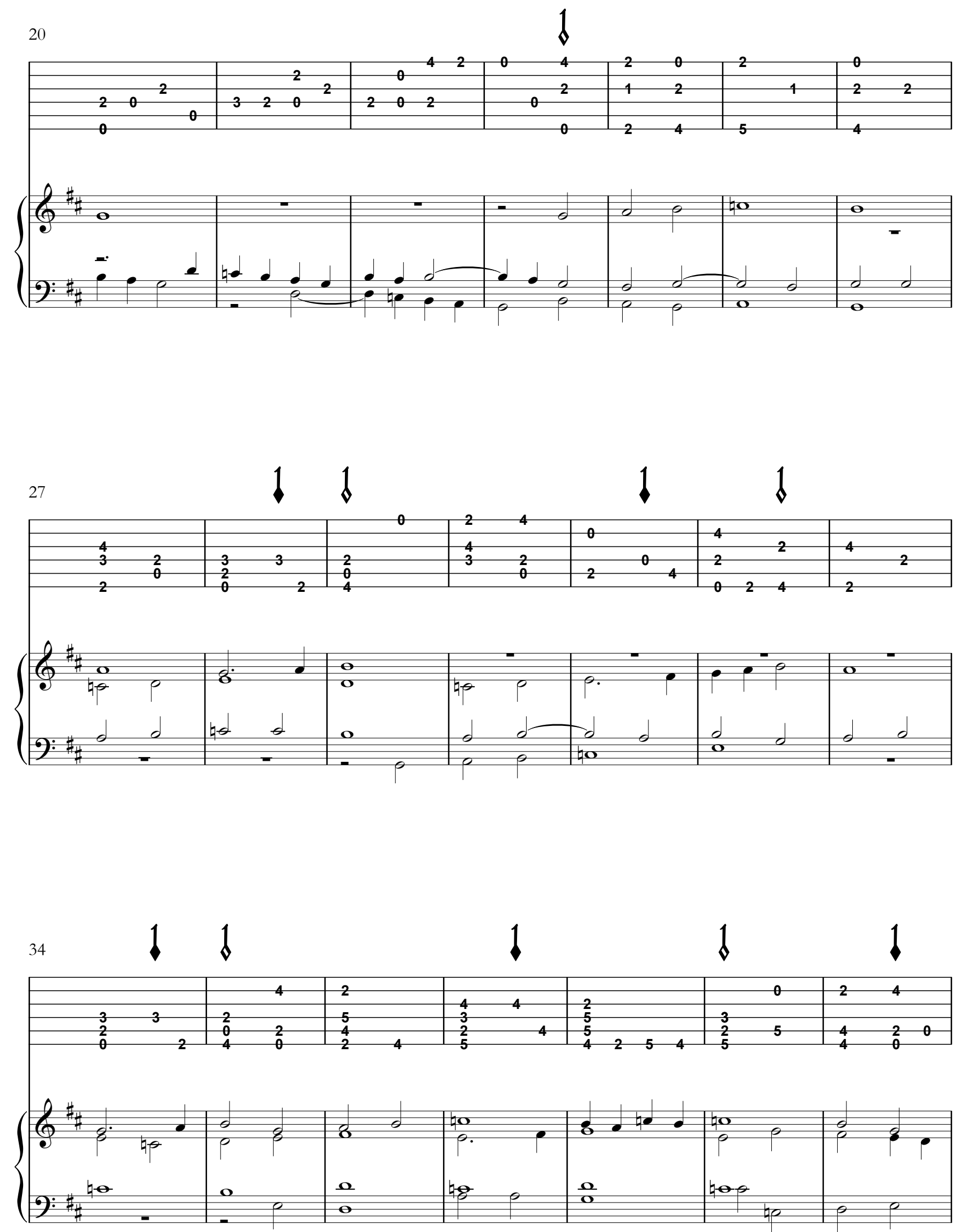

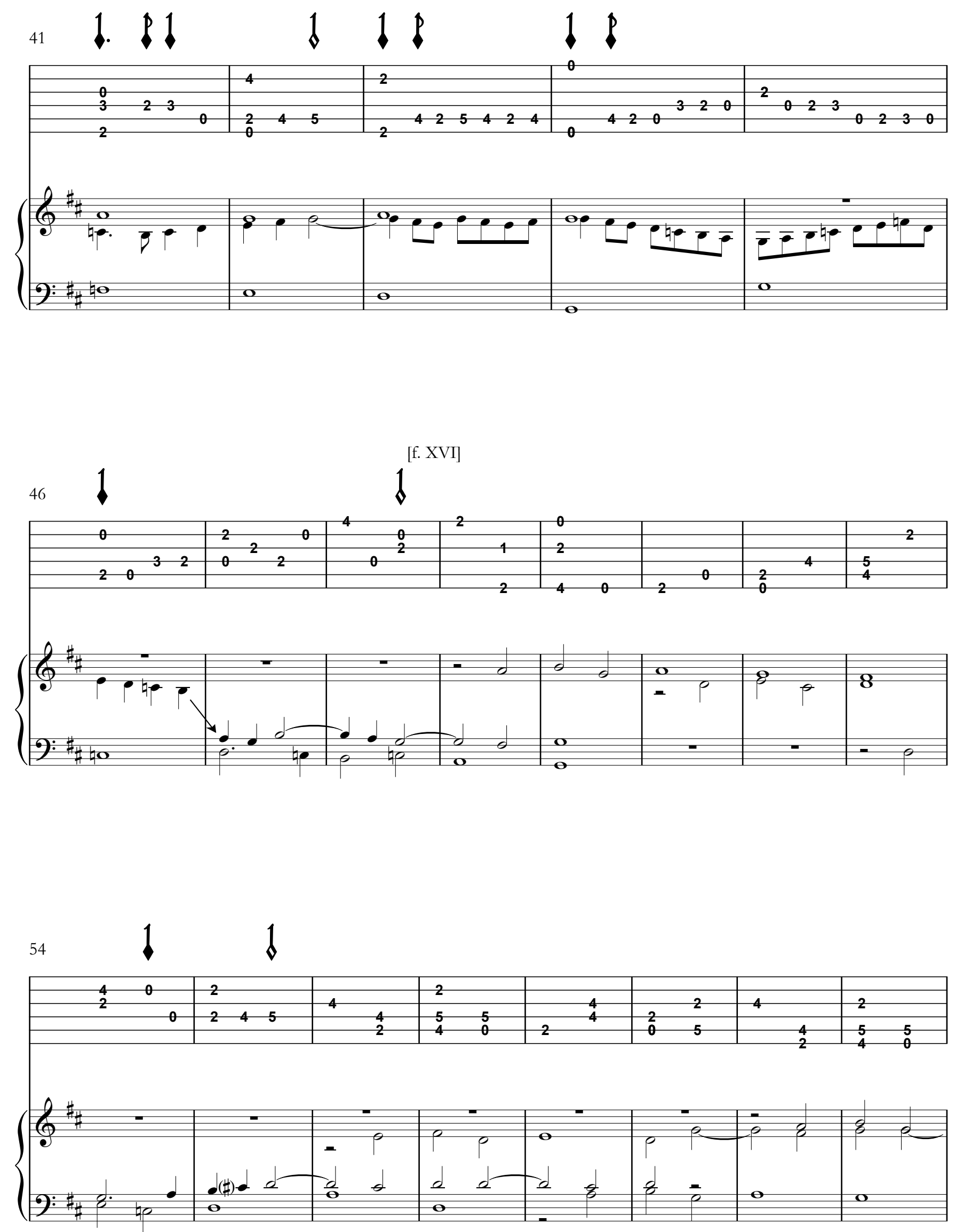


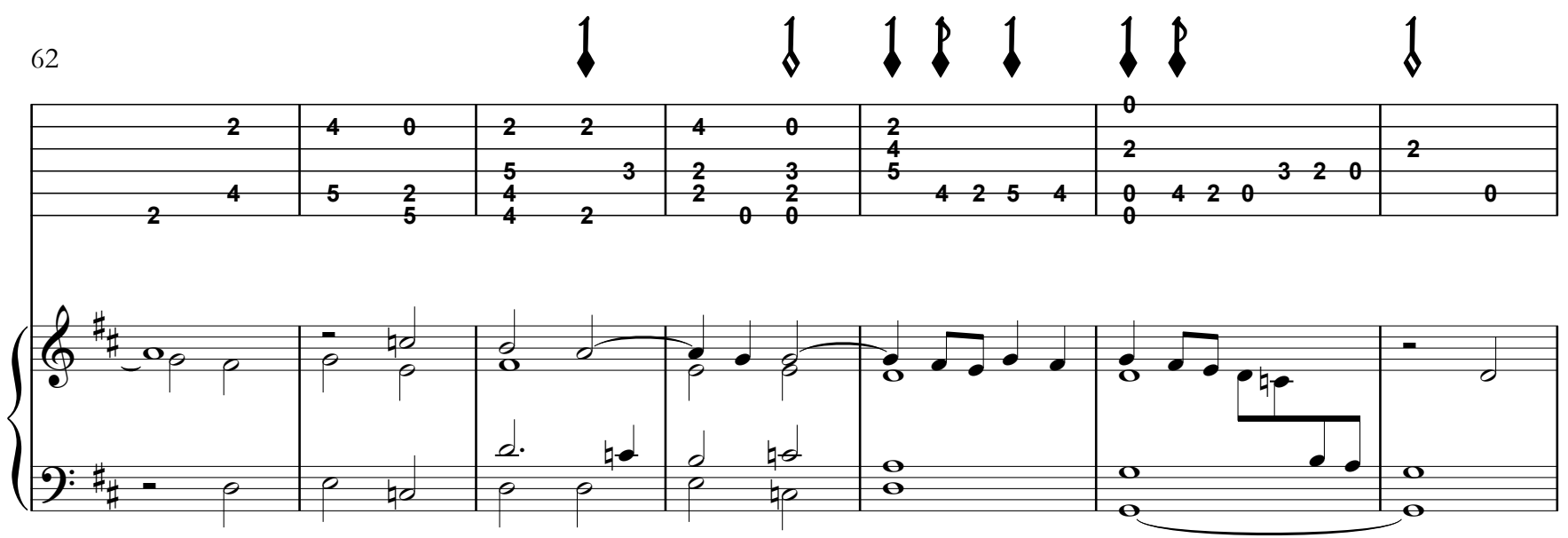

69
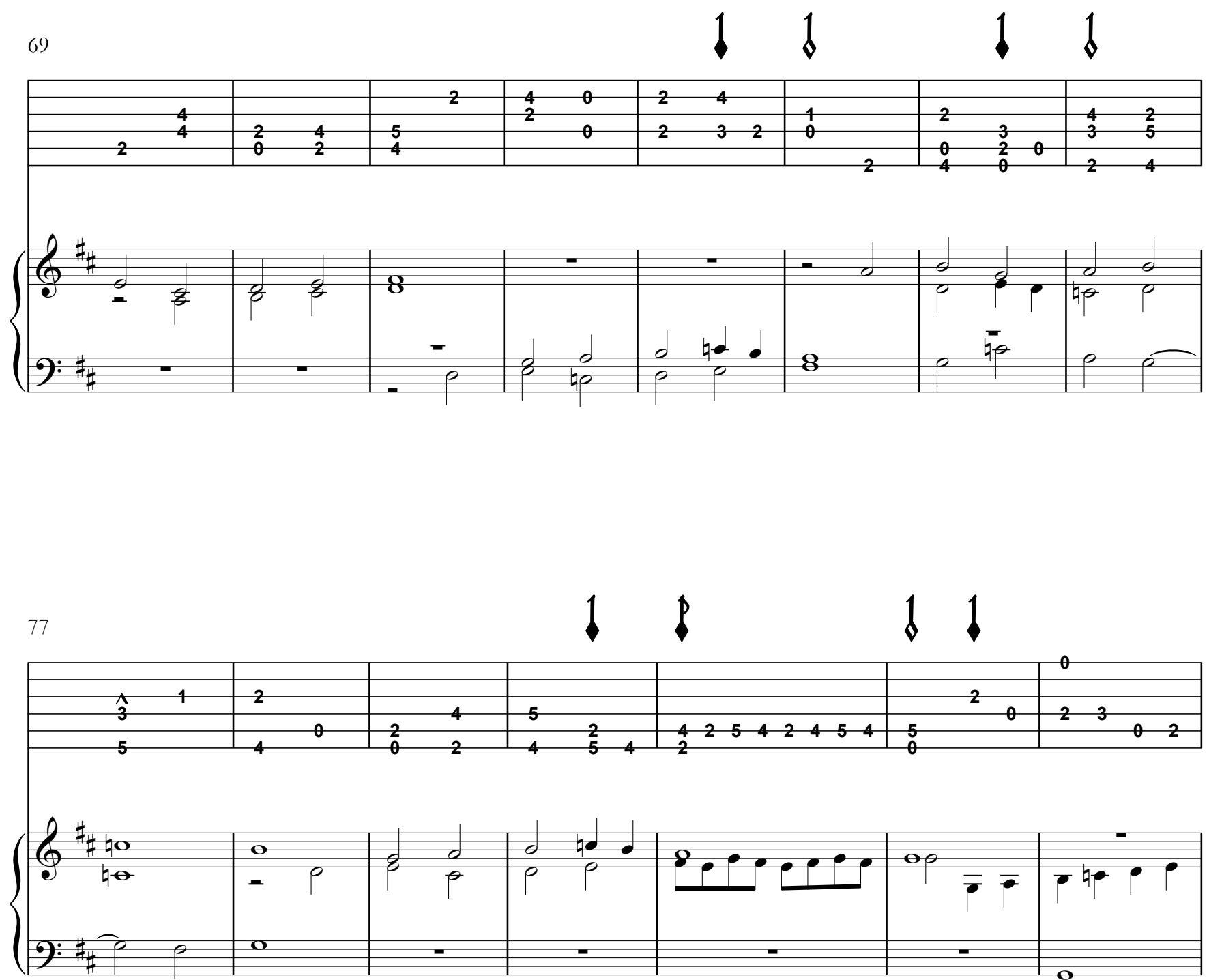
[f. XVIv]

84

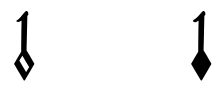

11

\begin{tabular}{|c|c|c|c|c|c|c|c|}
\hline 0240 & $\begin{array}{llll}2 & 4 & 2 & 4\end{array}$ & & & 42 & -4 & 2 & \\
\hline & 2 & $\begin{array}{ll}1 & 2 \\
0 & 2\end{array}$ & $\begin{array}{ll}4 & 2 \\
3 & \end{array}$ & 0 & 4 & 5 & 5 \\
\hline 0 & & & $\begin{array}{ll}0 & 2\end{array}$ & $\begin{array}{ll}0 & 0\end{array}$ & & 02 & 4 \\
\hline
\end{tabular}
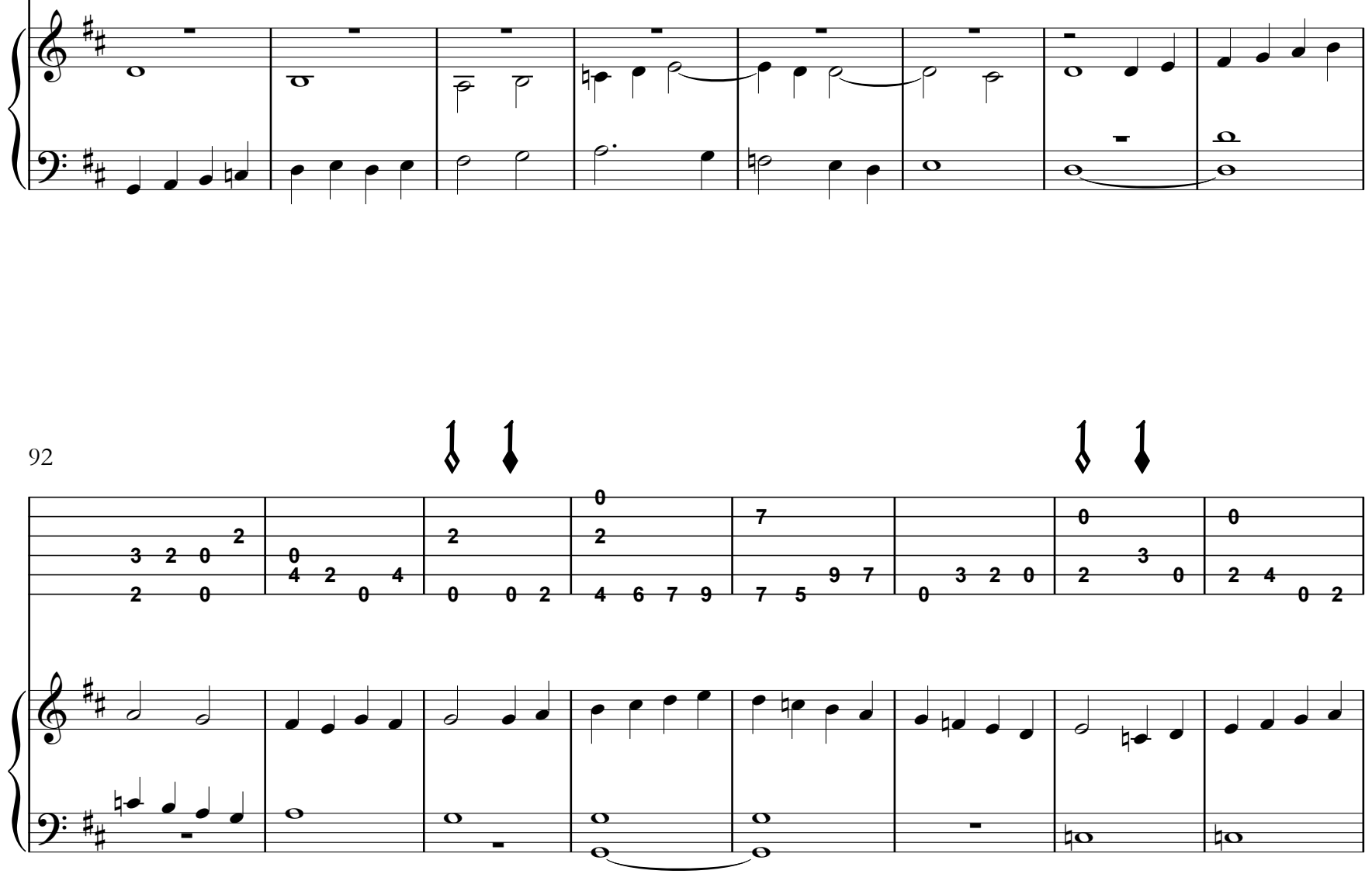

100

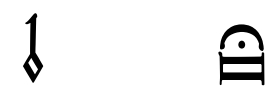

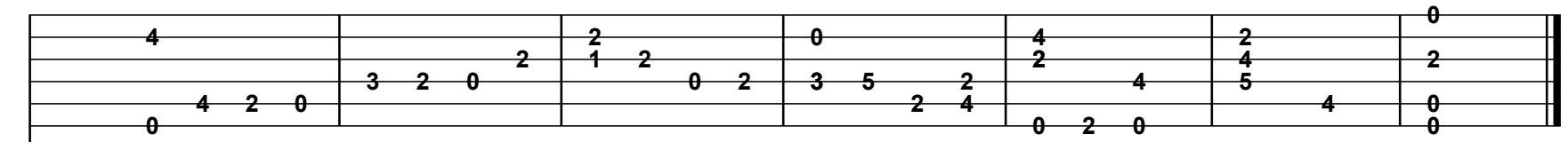

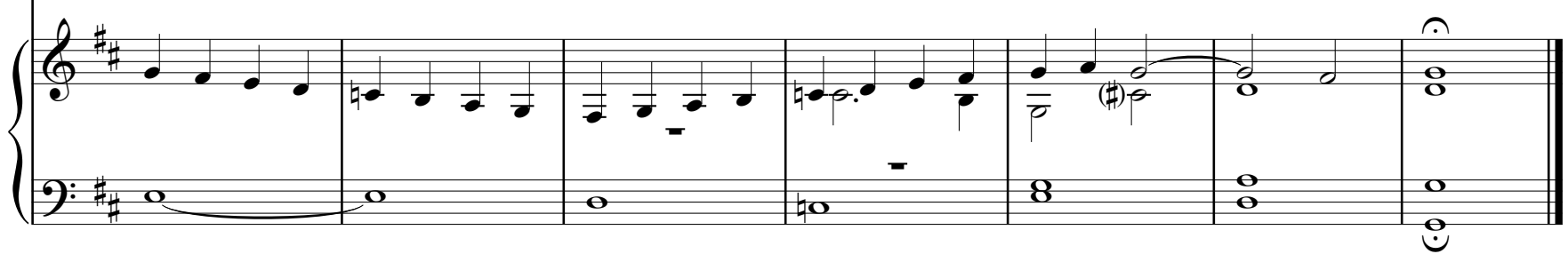




\title{
so 40 - Tiento 6 ed
}

\author{
Tiento
}

VI Tono

[Libro II, ff. XVIv-XVII]
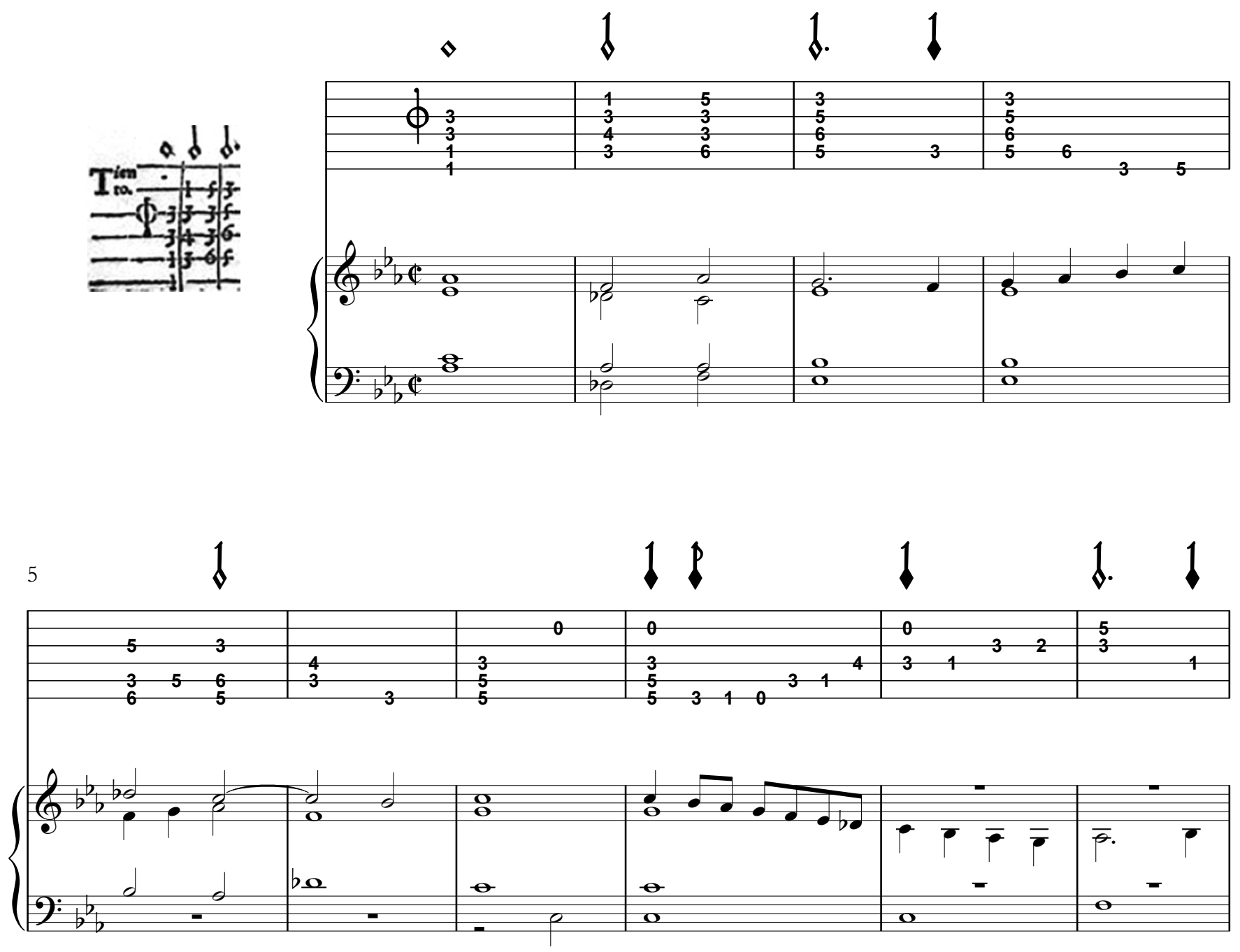

[f. XVII]

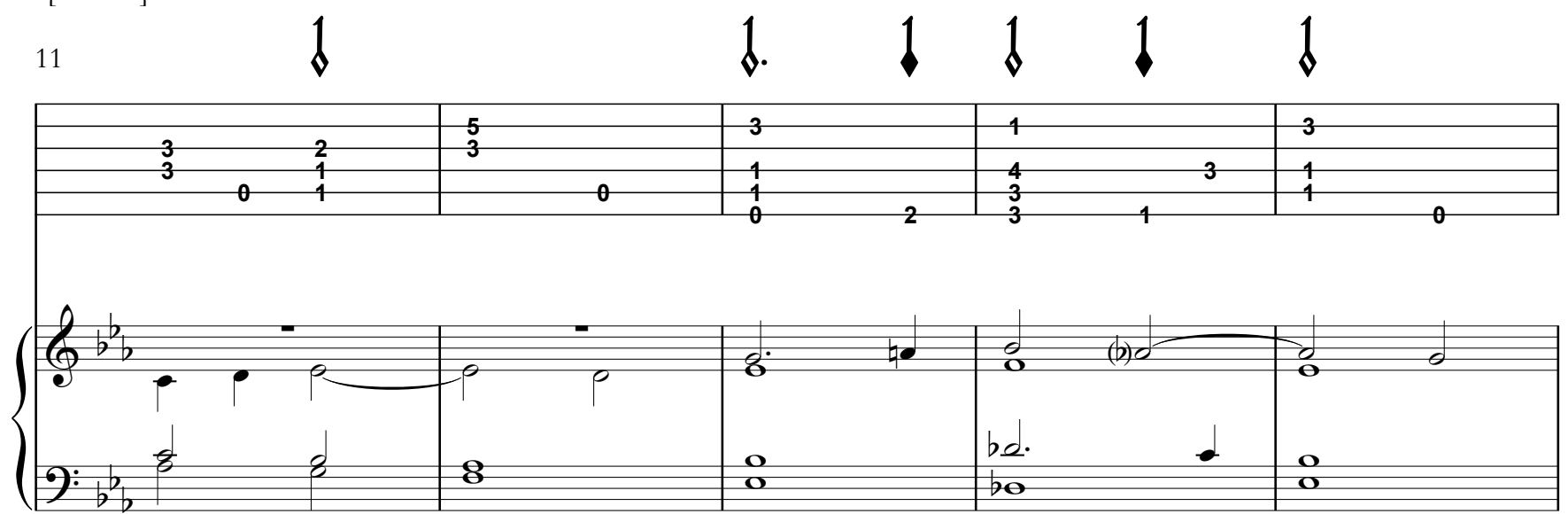



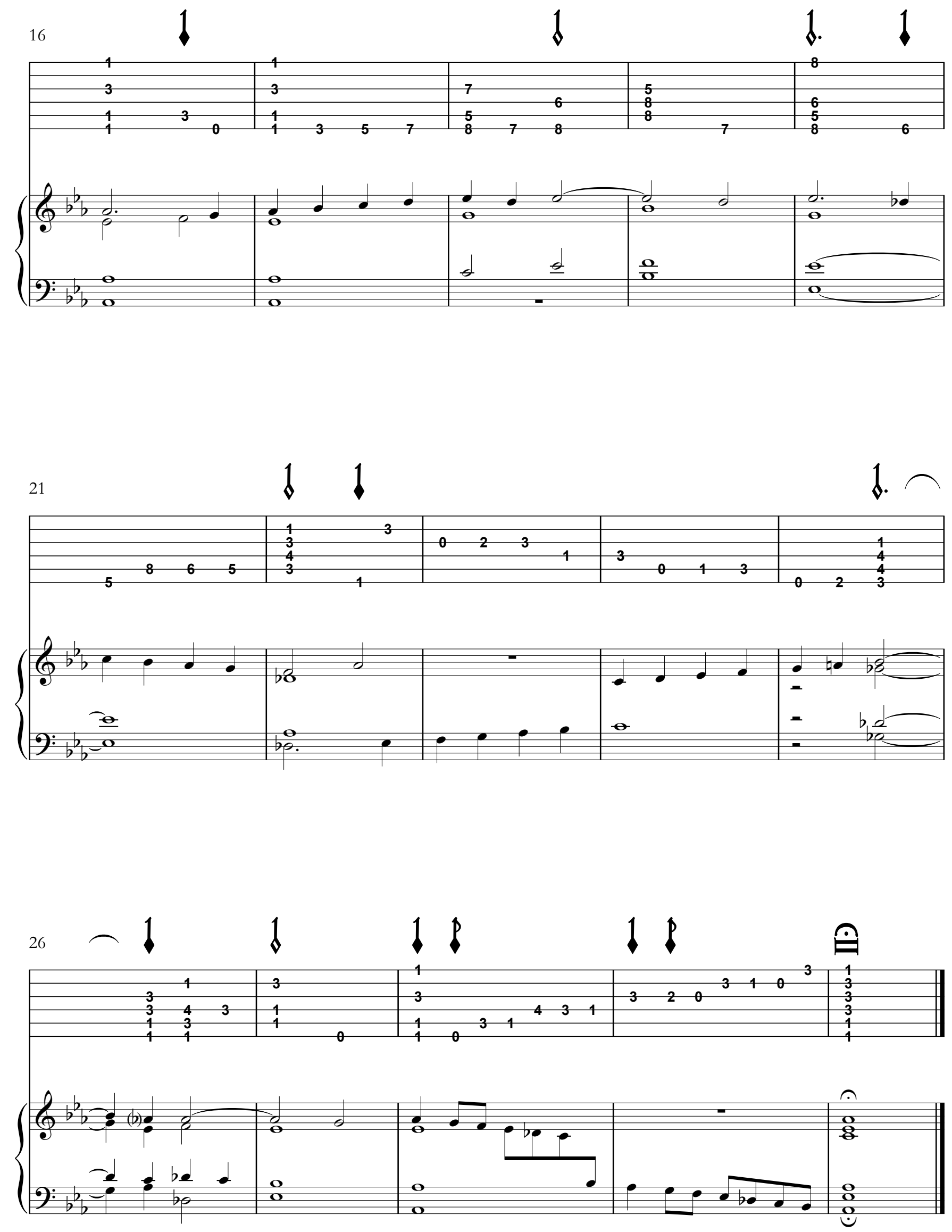

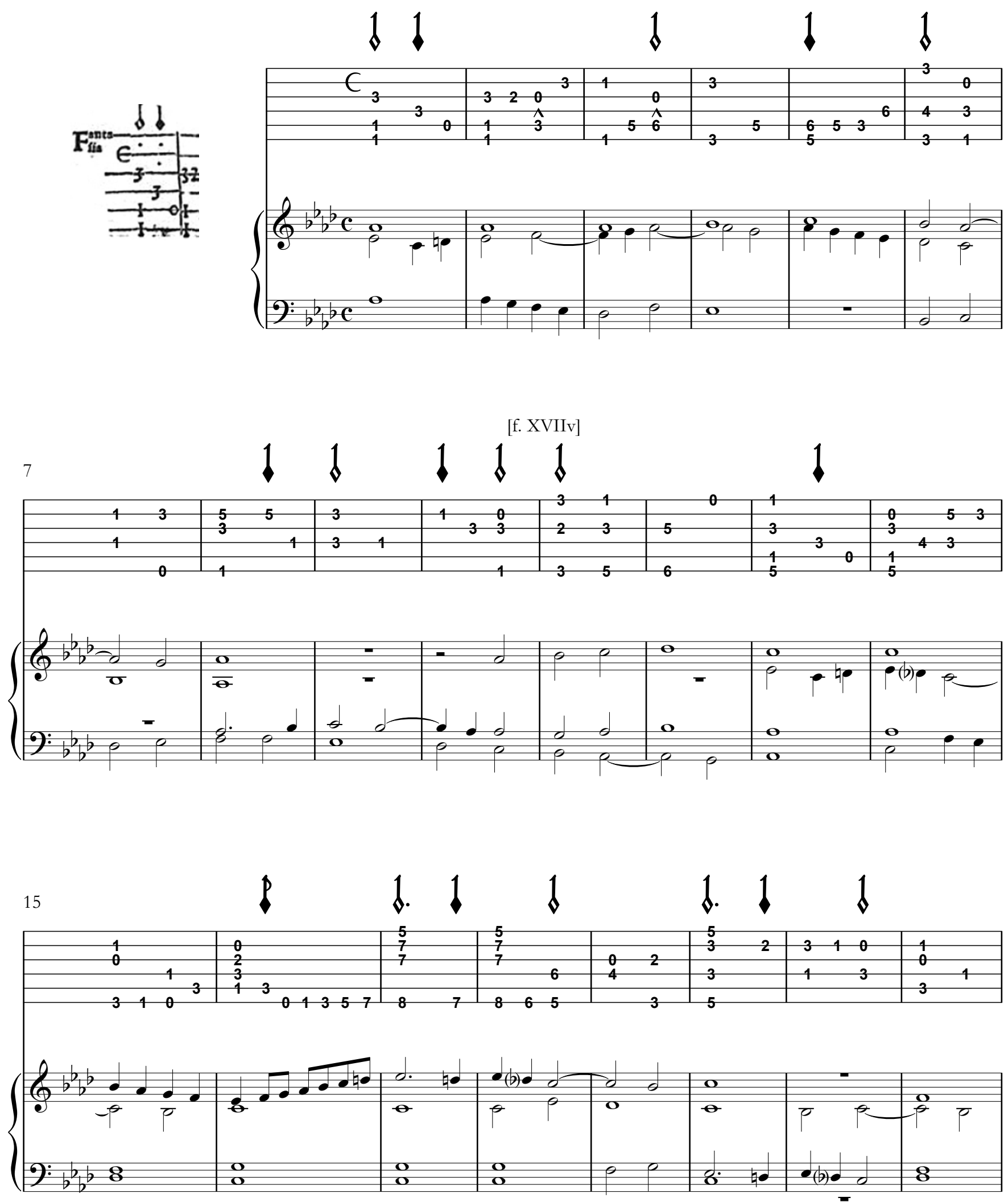

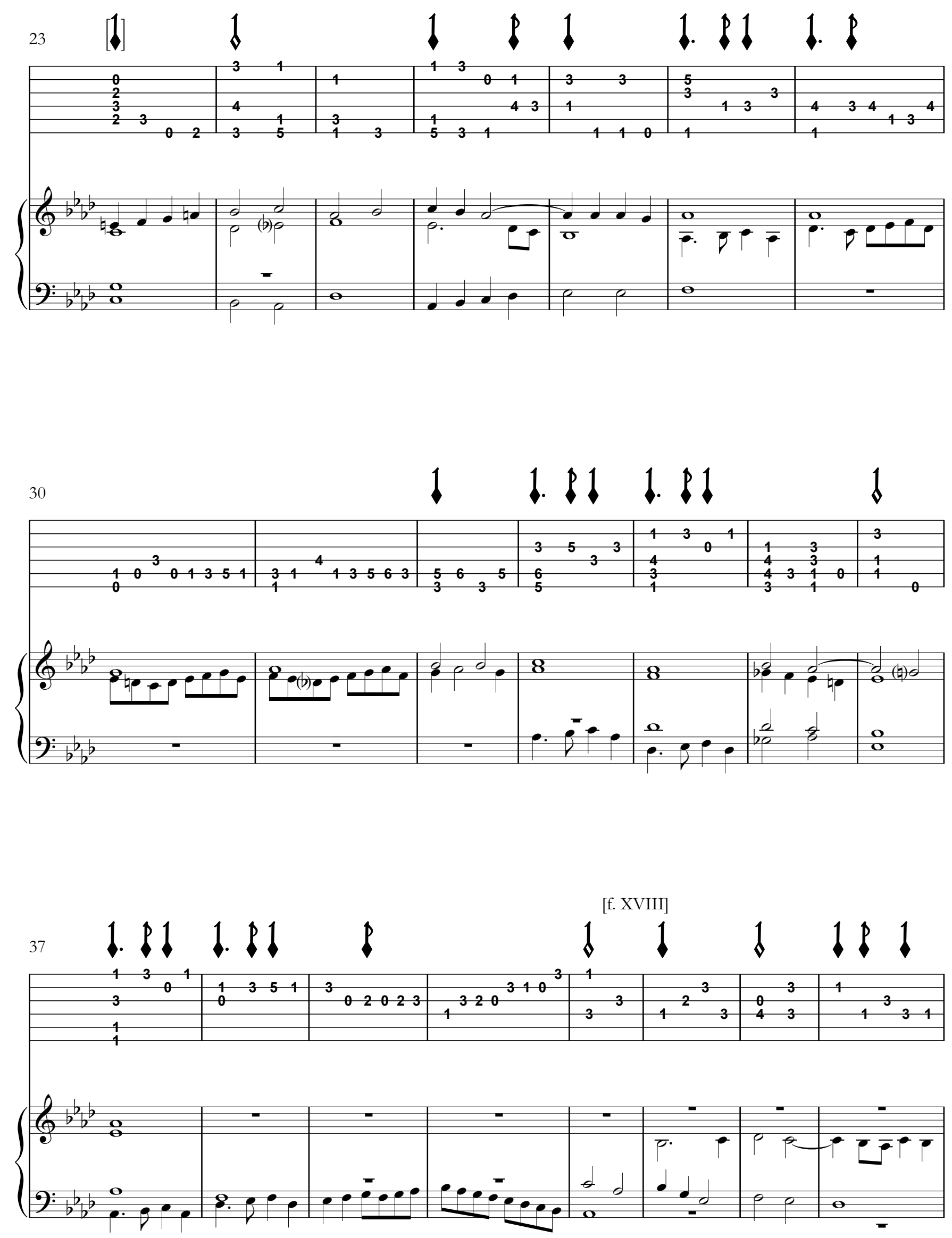

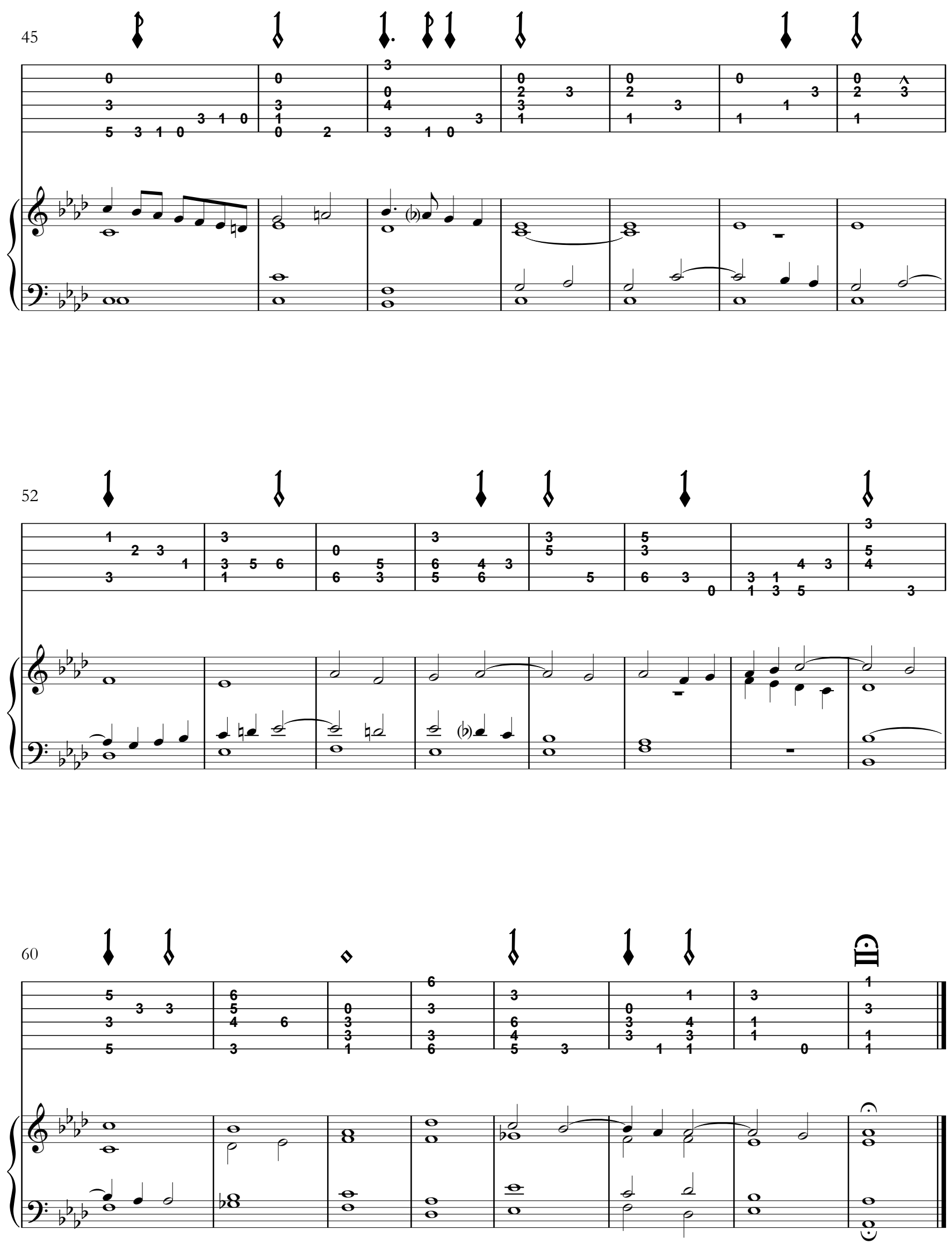


\section{sov 42 - Kyrie 3 es}

Glosa sobre el primer Kyrie de una missa

de févin que va sobre avemaría

[Libro II, ff. XVIII-XX]

Févin/Mudarra
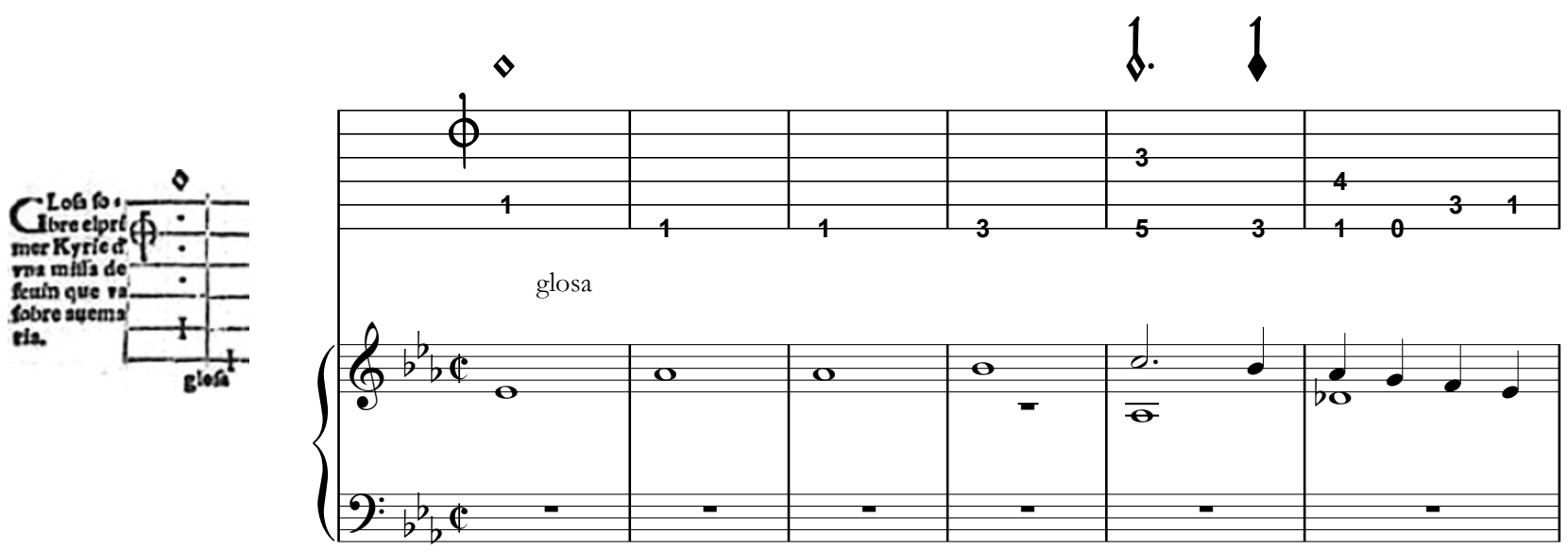

[f. XVIIIv]
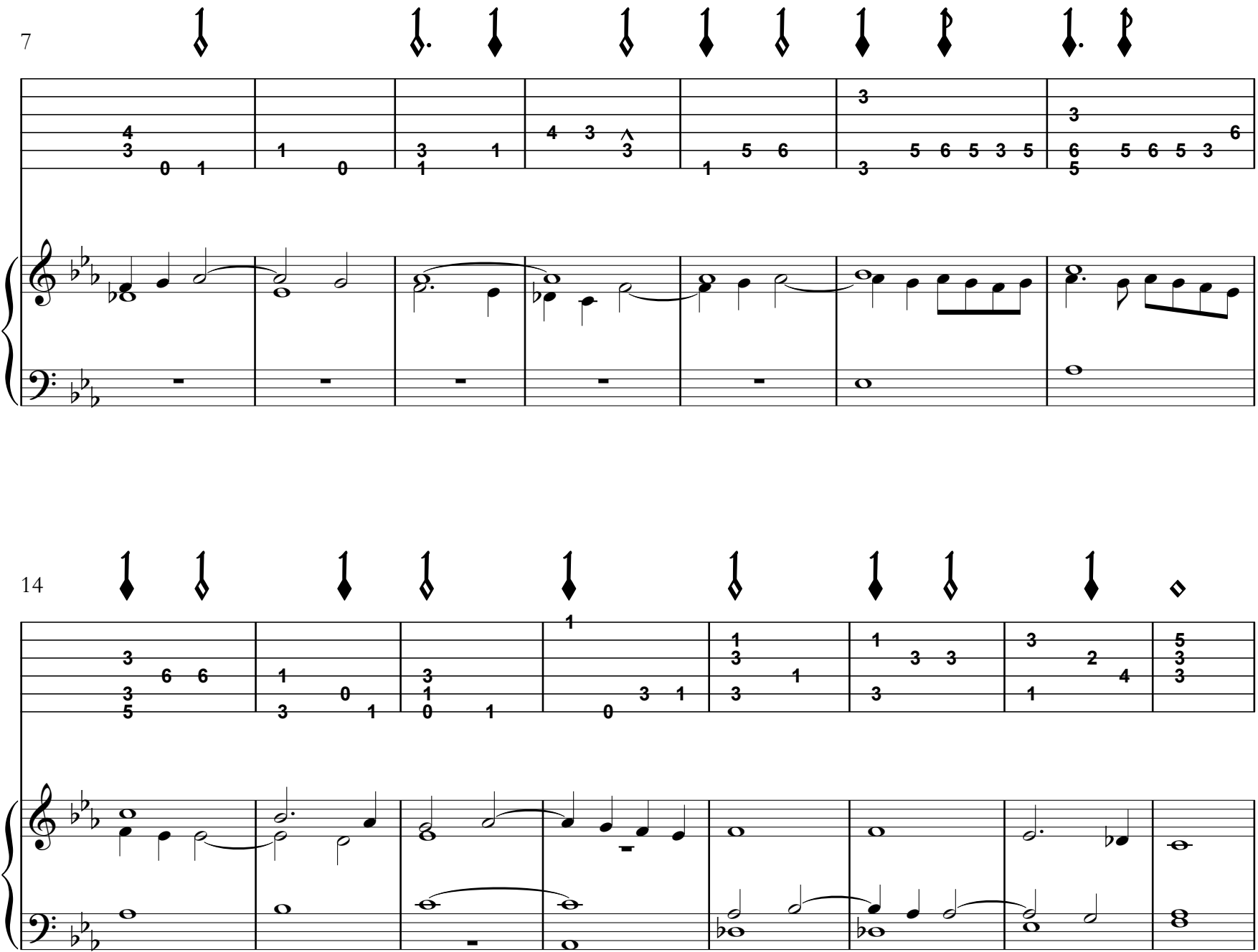

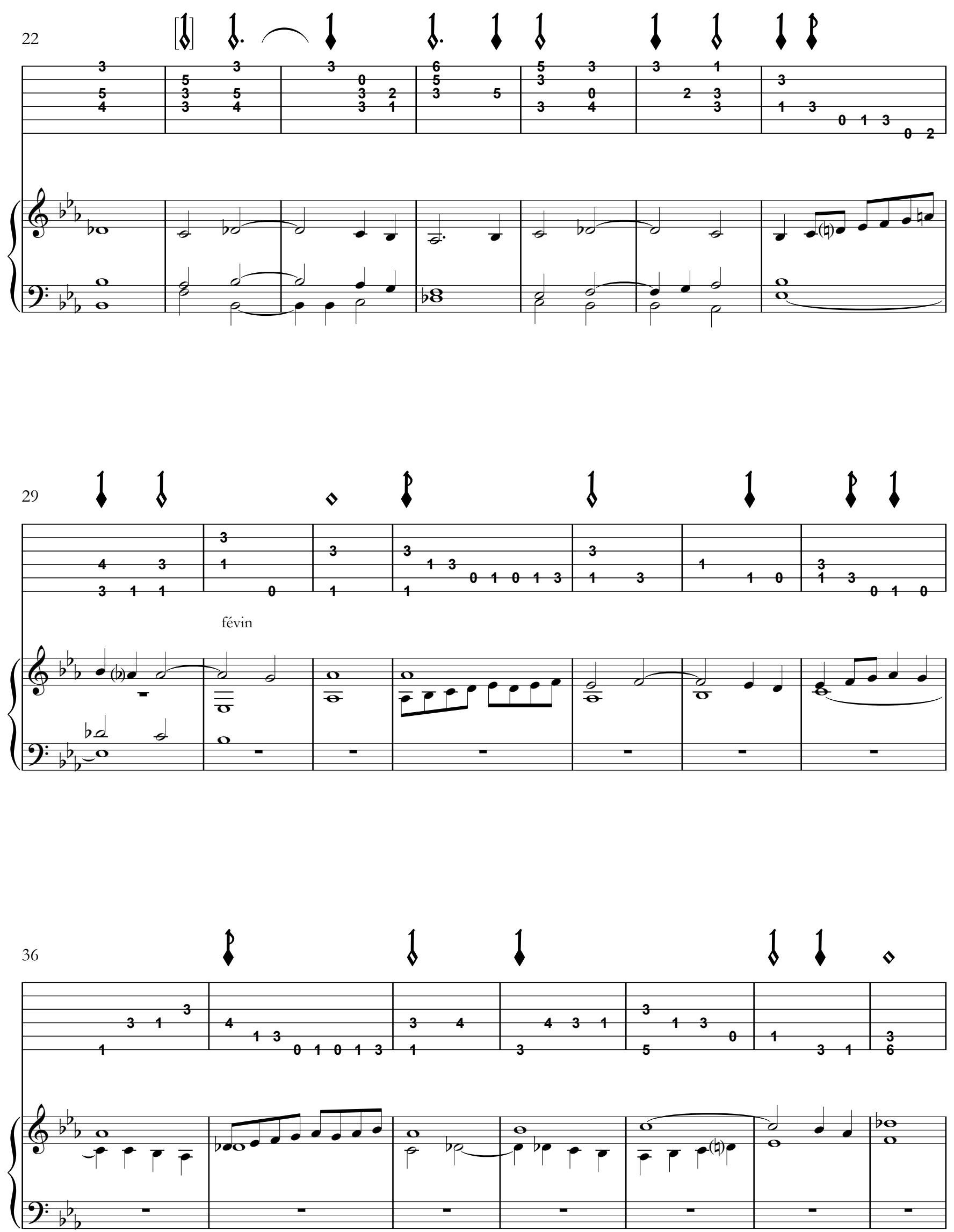

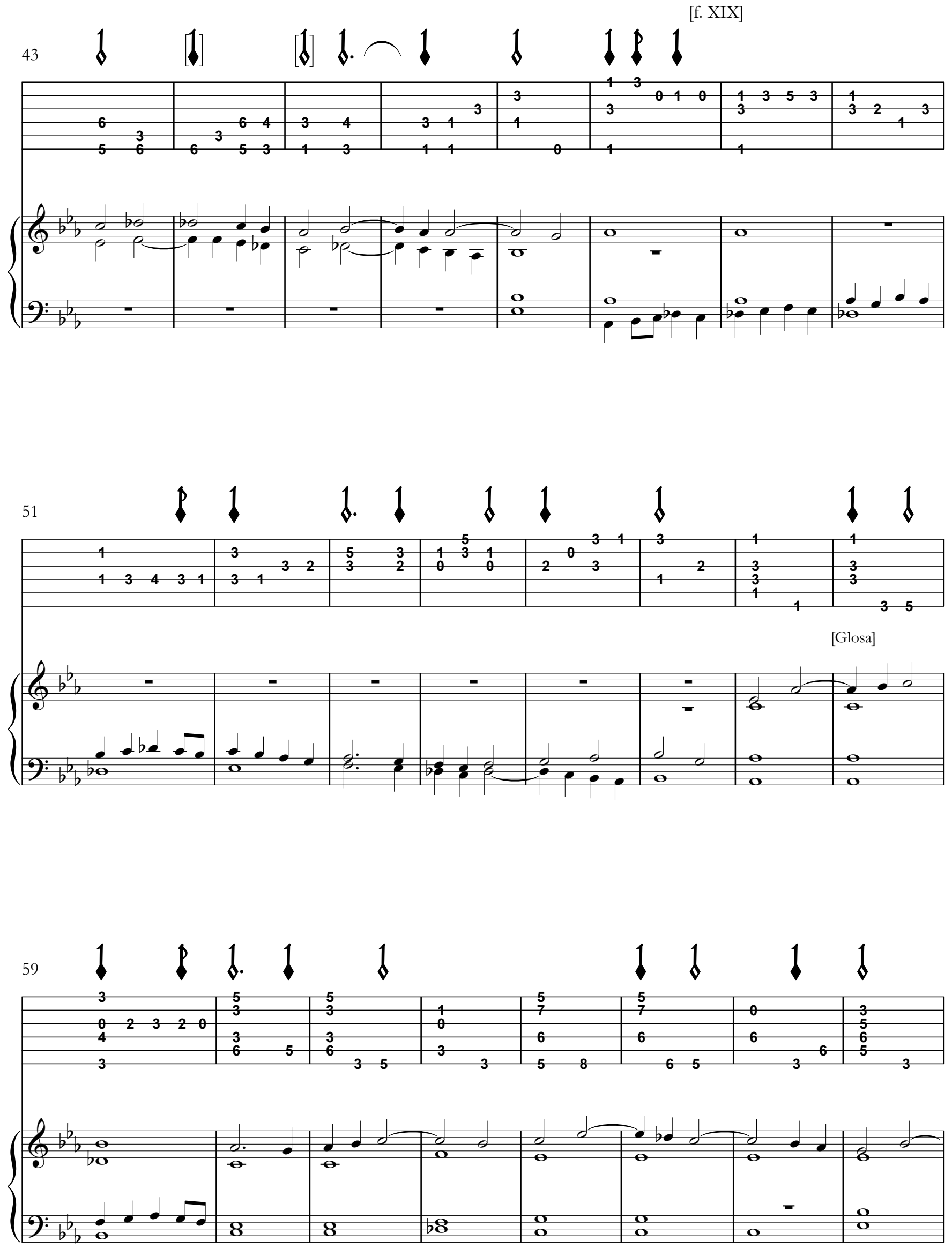

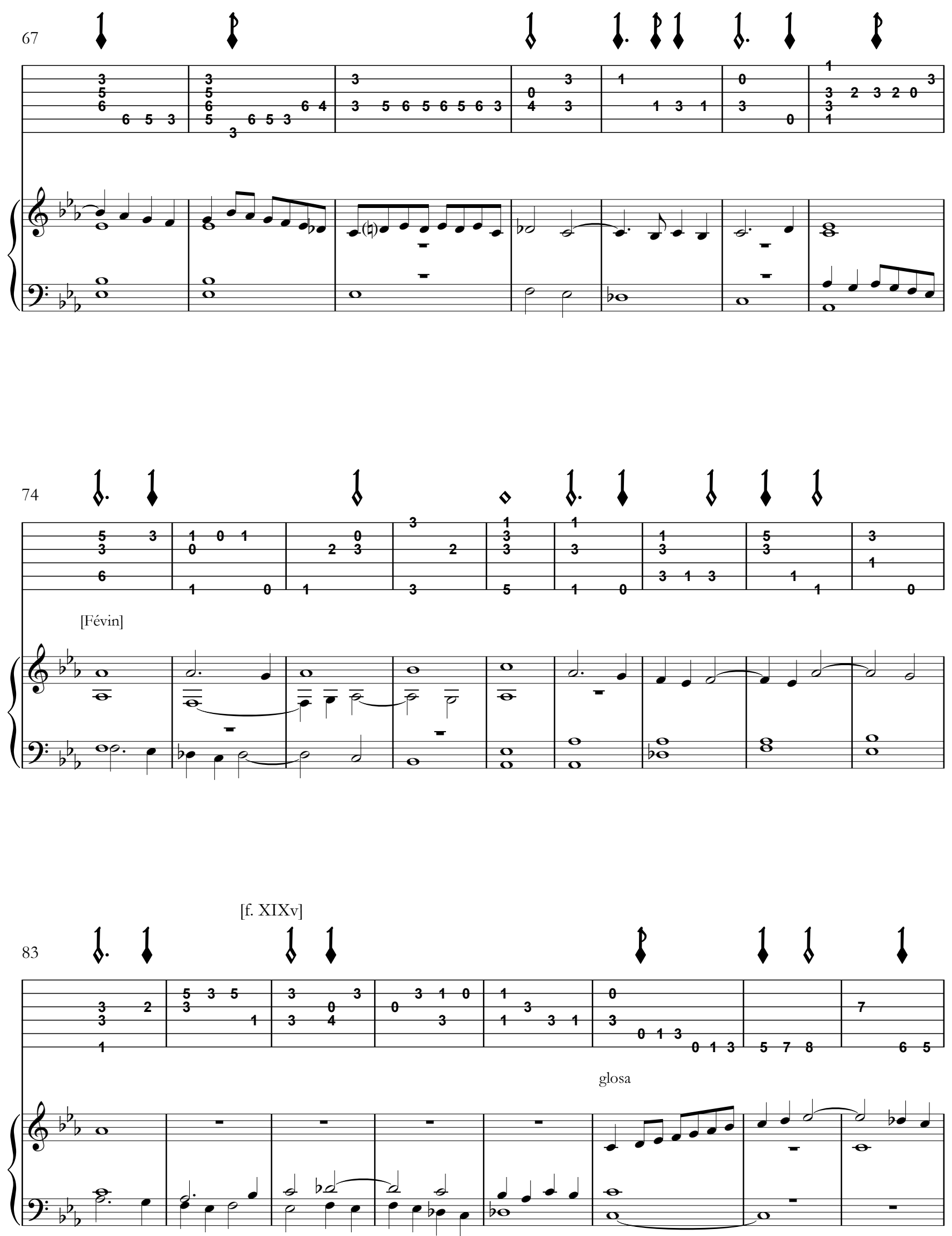

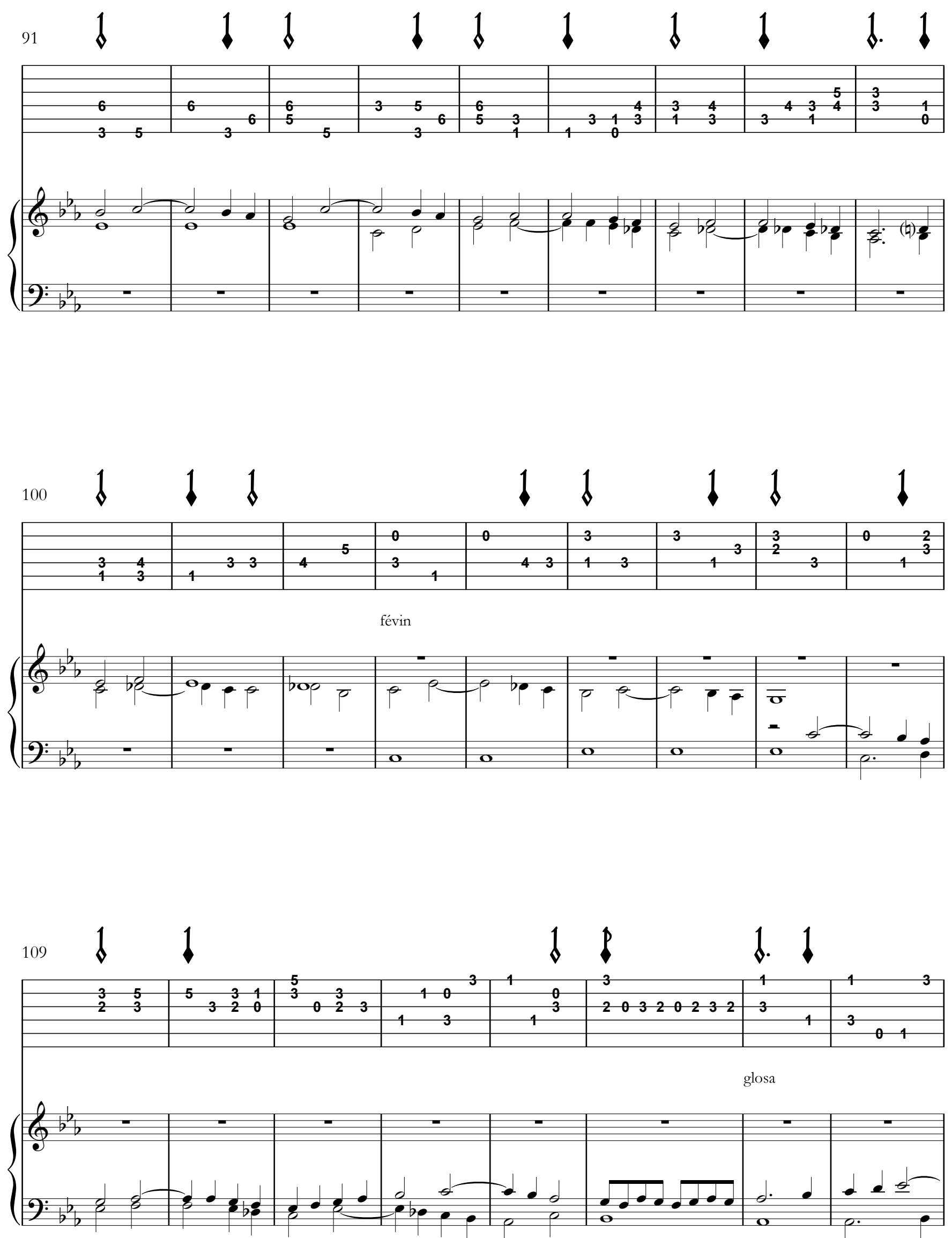
[f. XX]

117

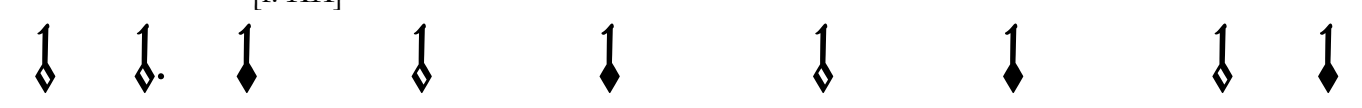

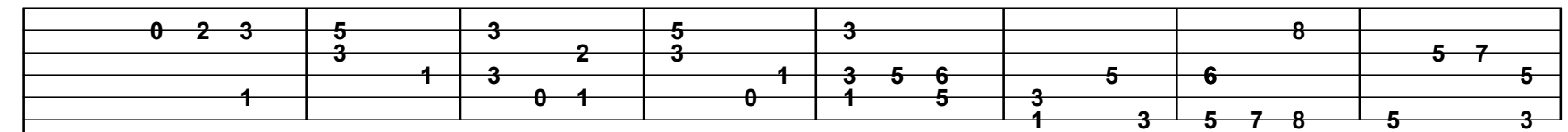

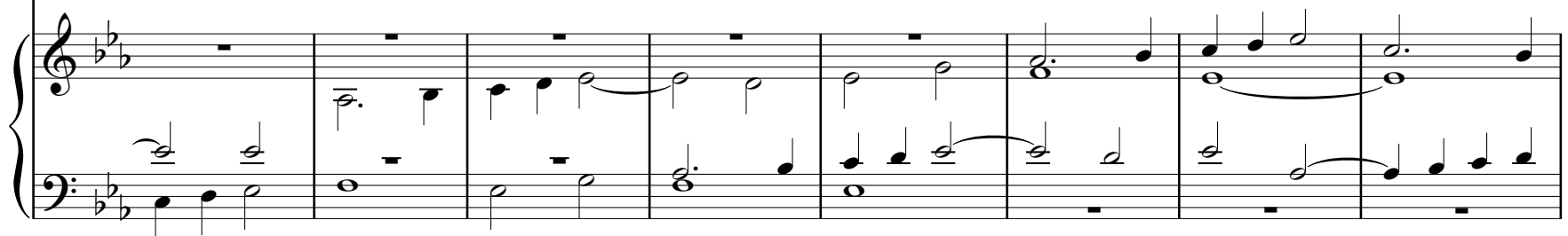

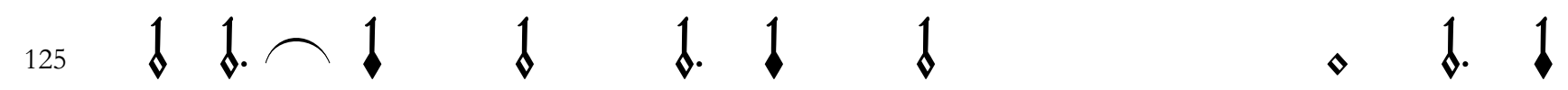

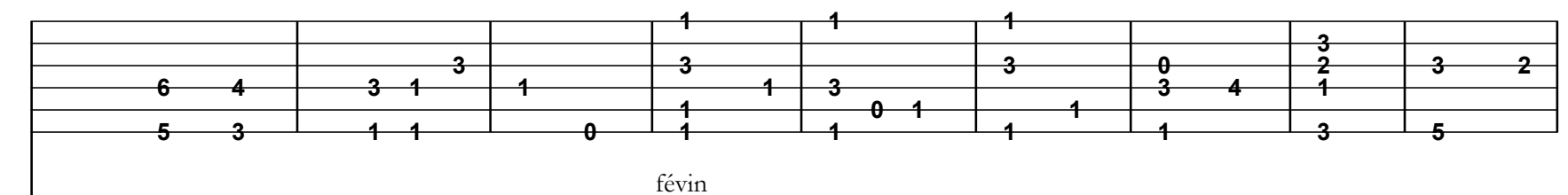

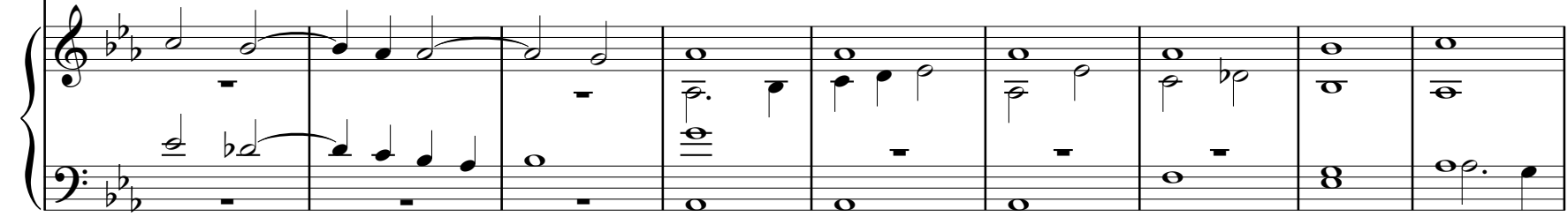

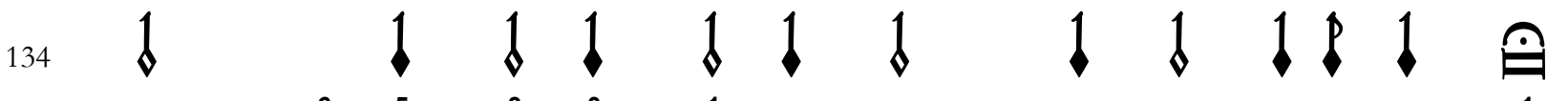

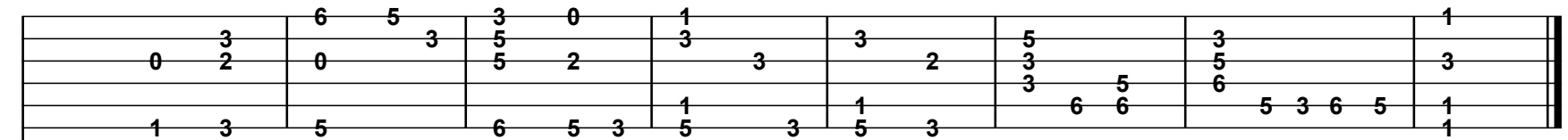

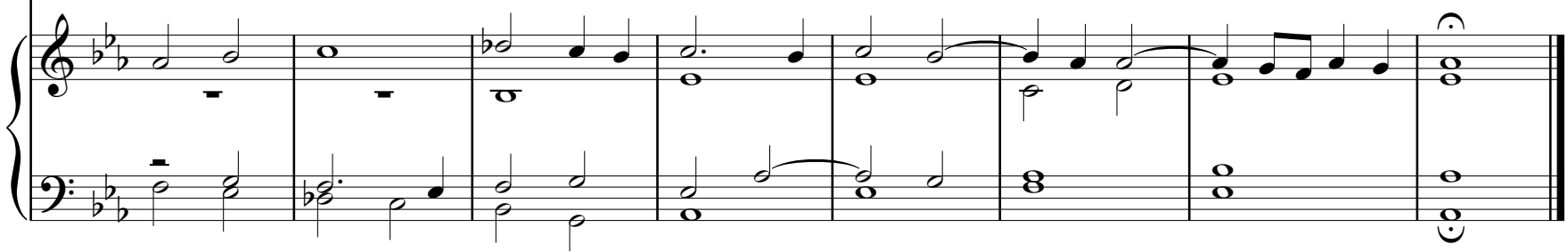


so 43 - Tiento 7 ?

Tiento

VII Tono

[Libro II, f. XX]
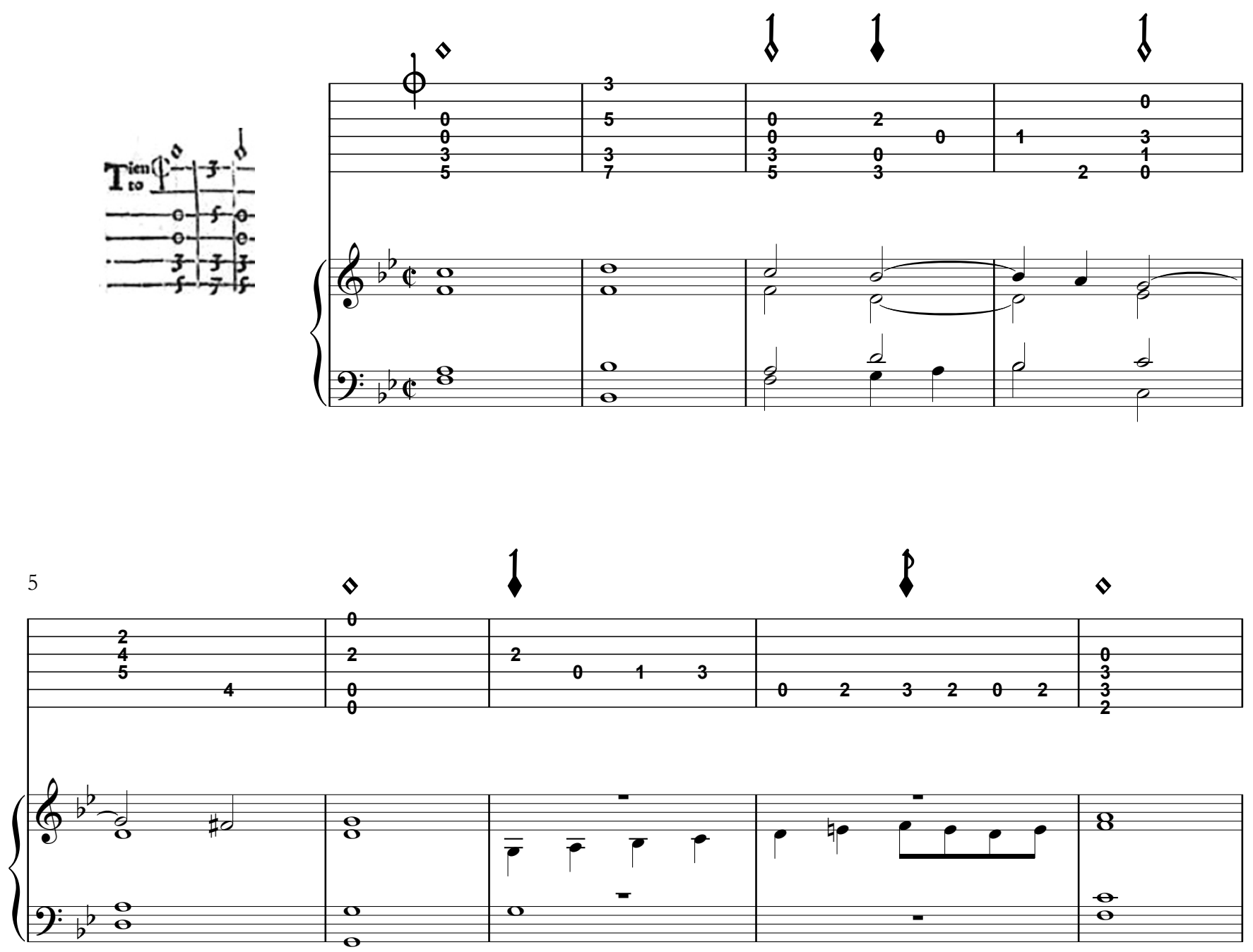

[f. XXv]

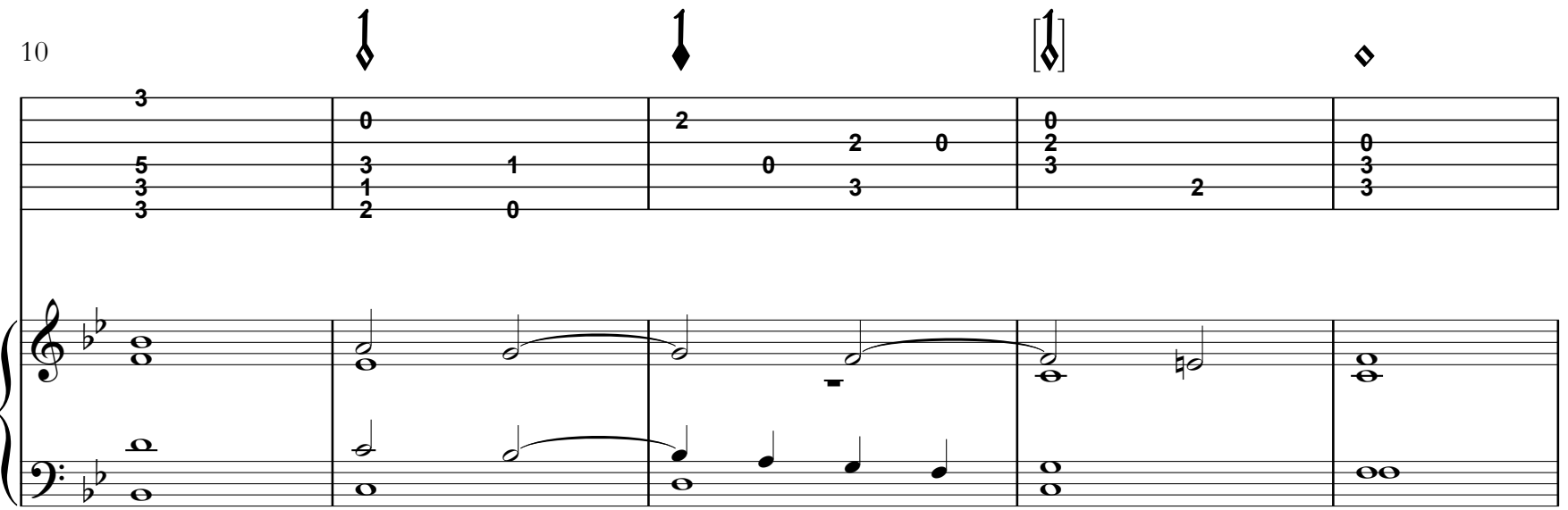



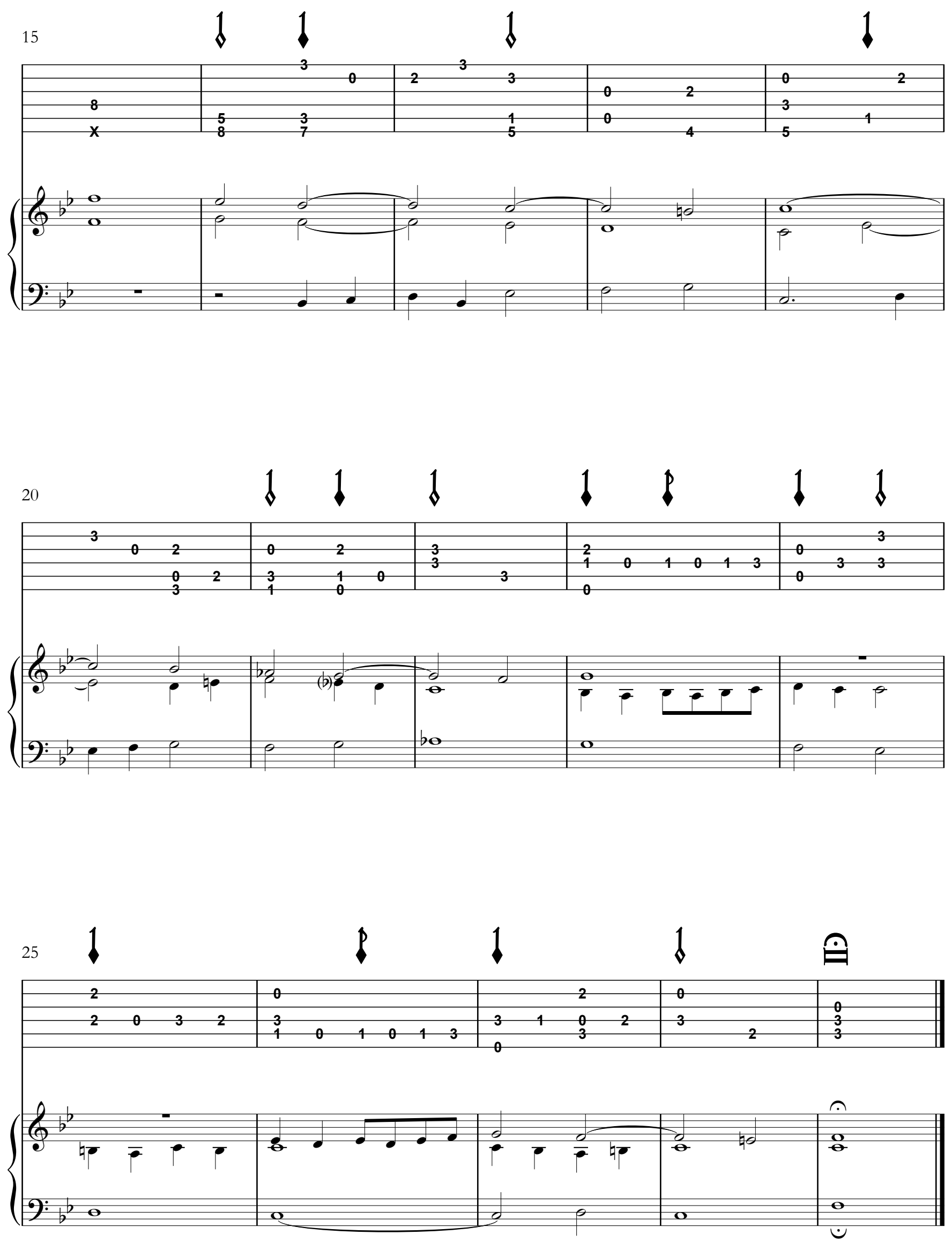
sov44 - Fantasía 24

\author{
[Libro II, ff. XXv-XXI]
}
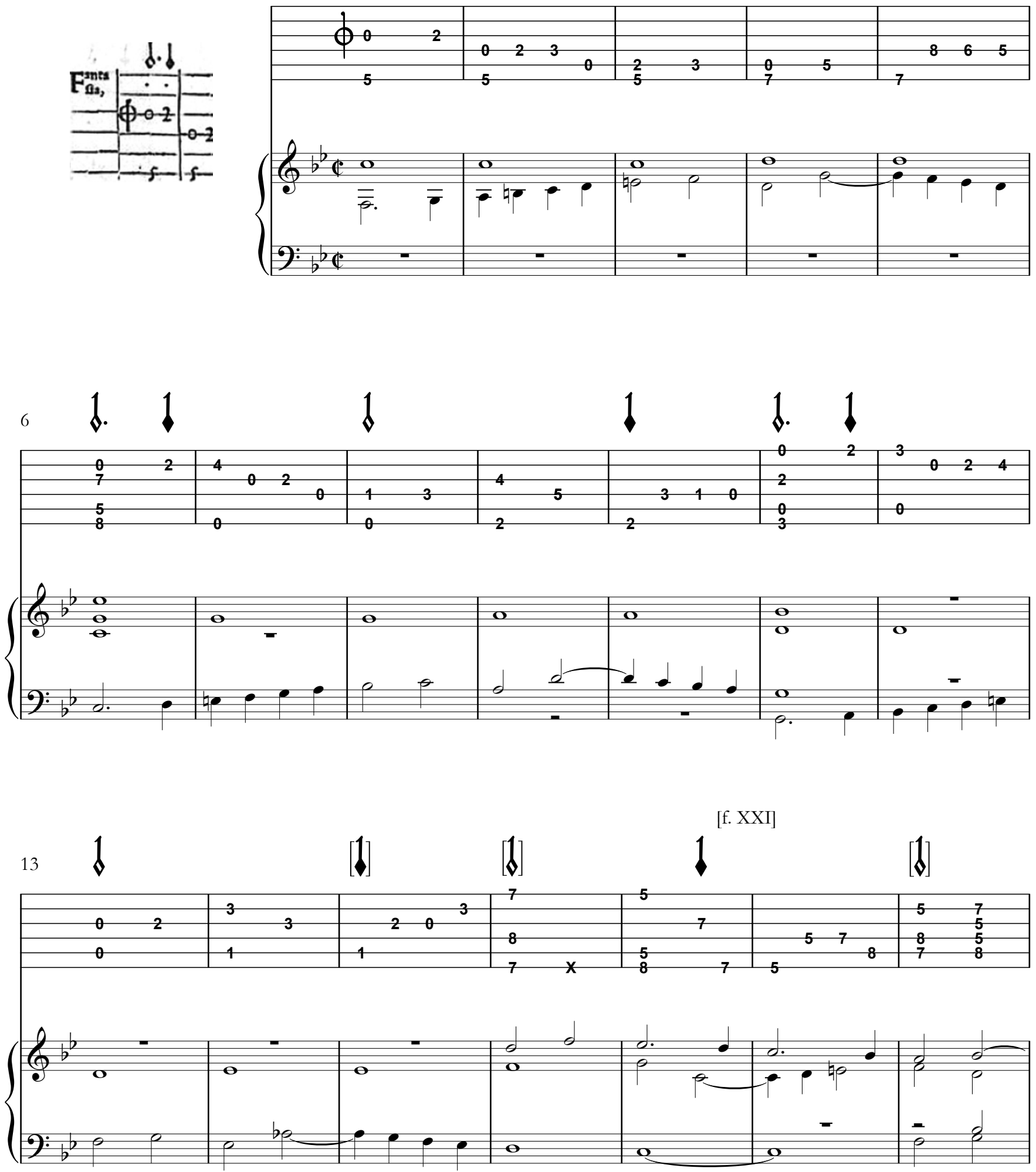

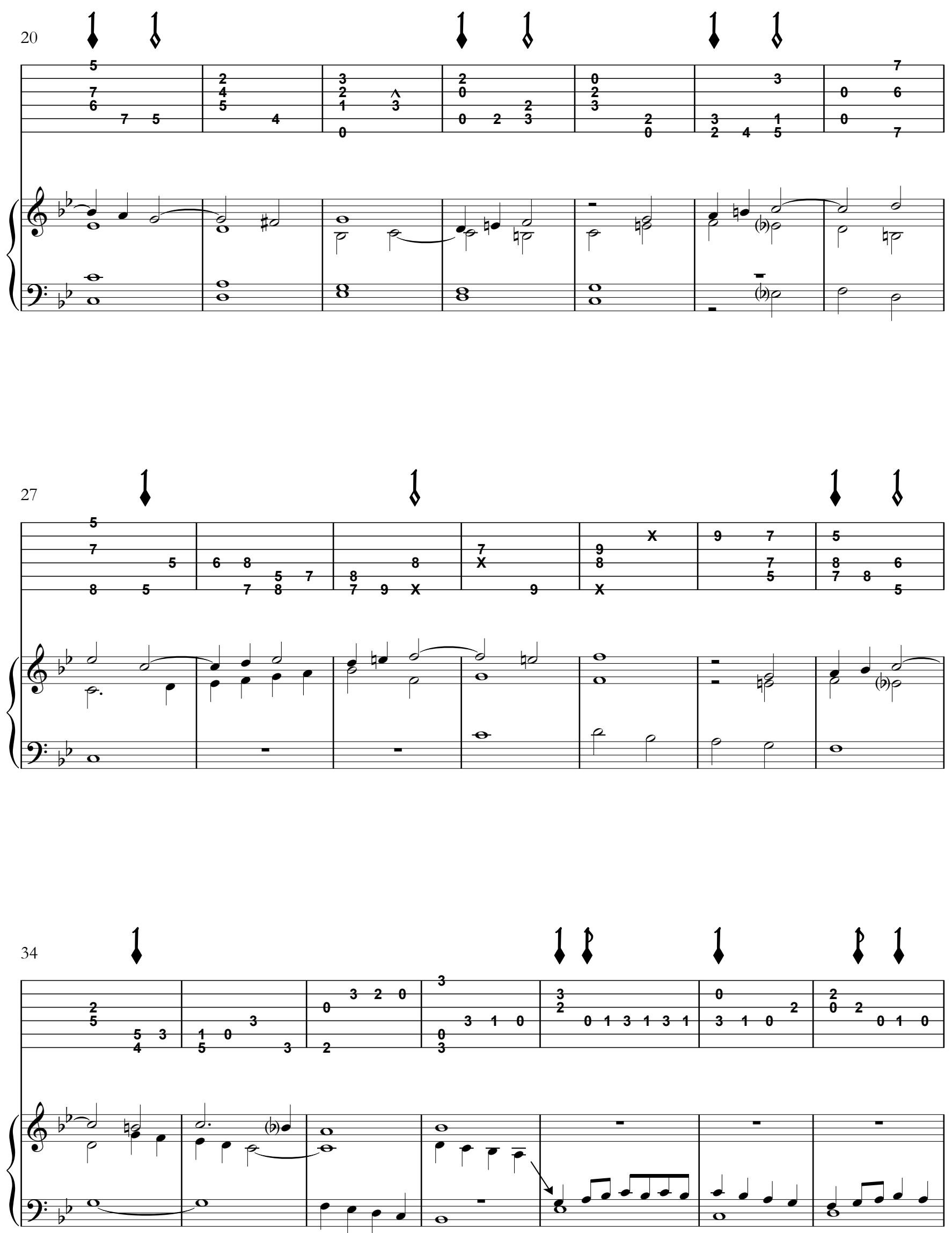


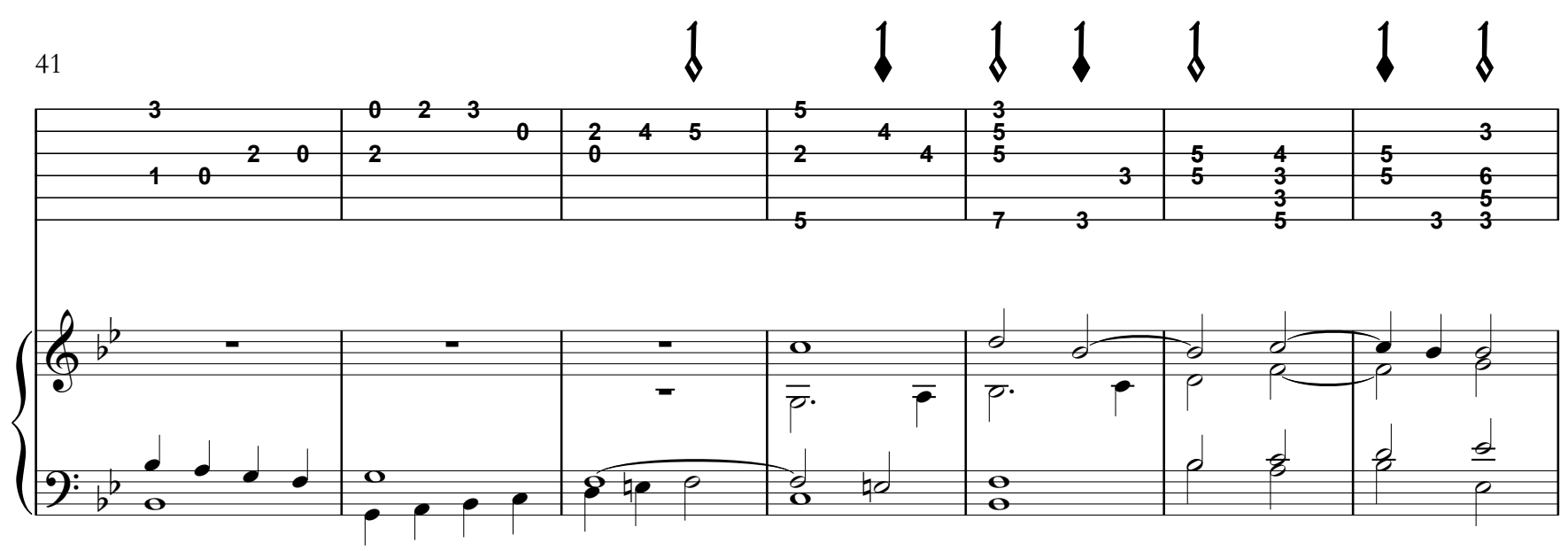

[f. XXIv]
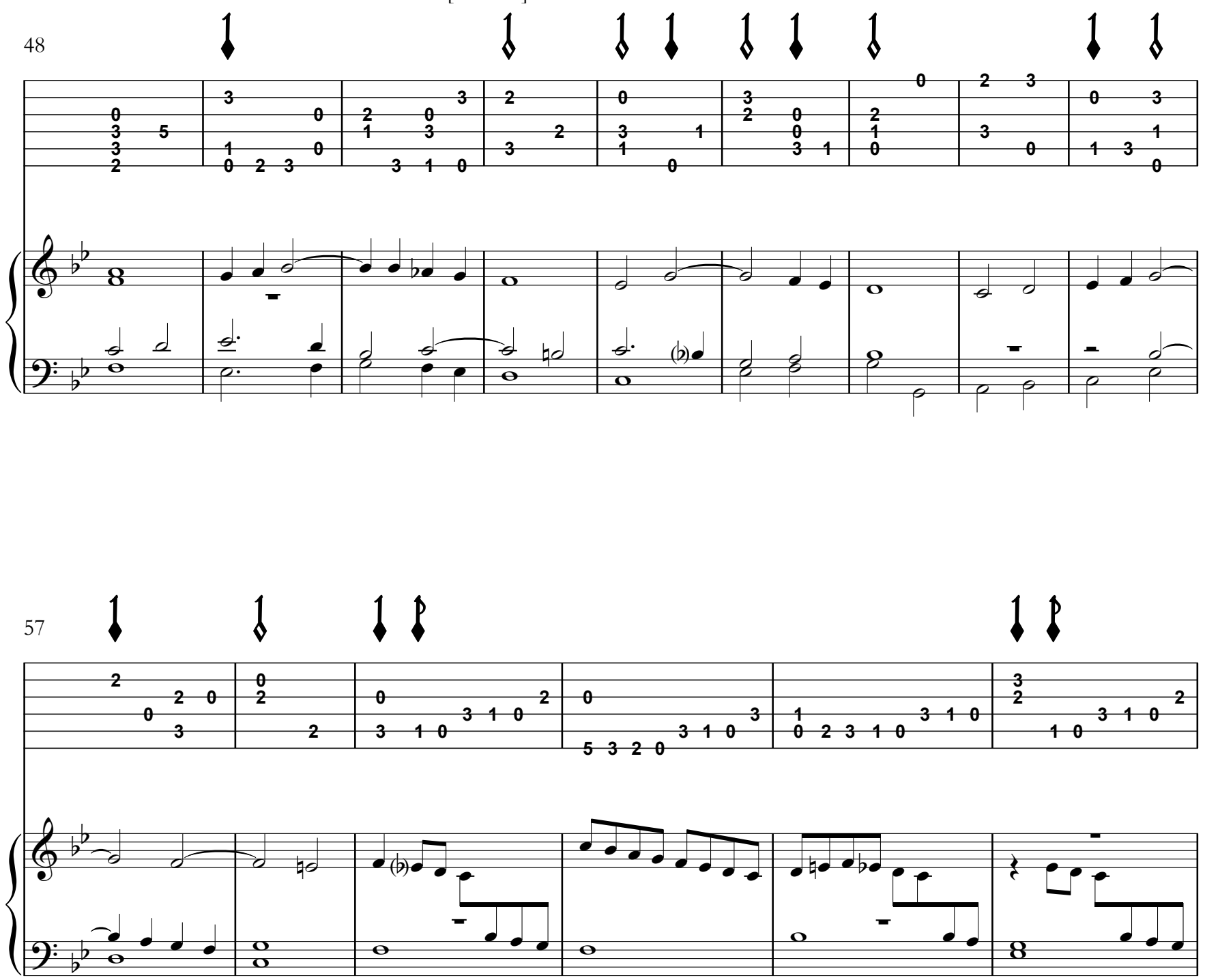

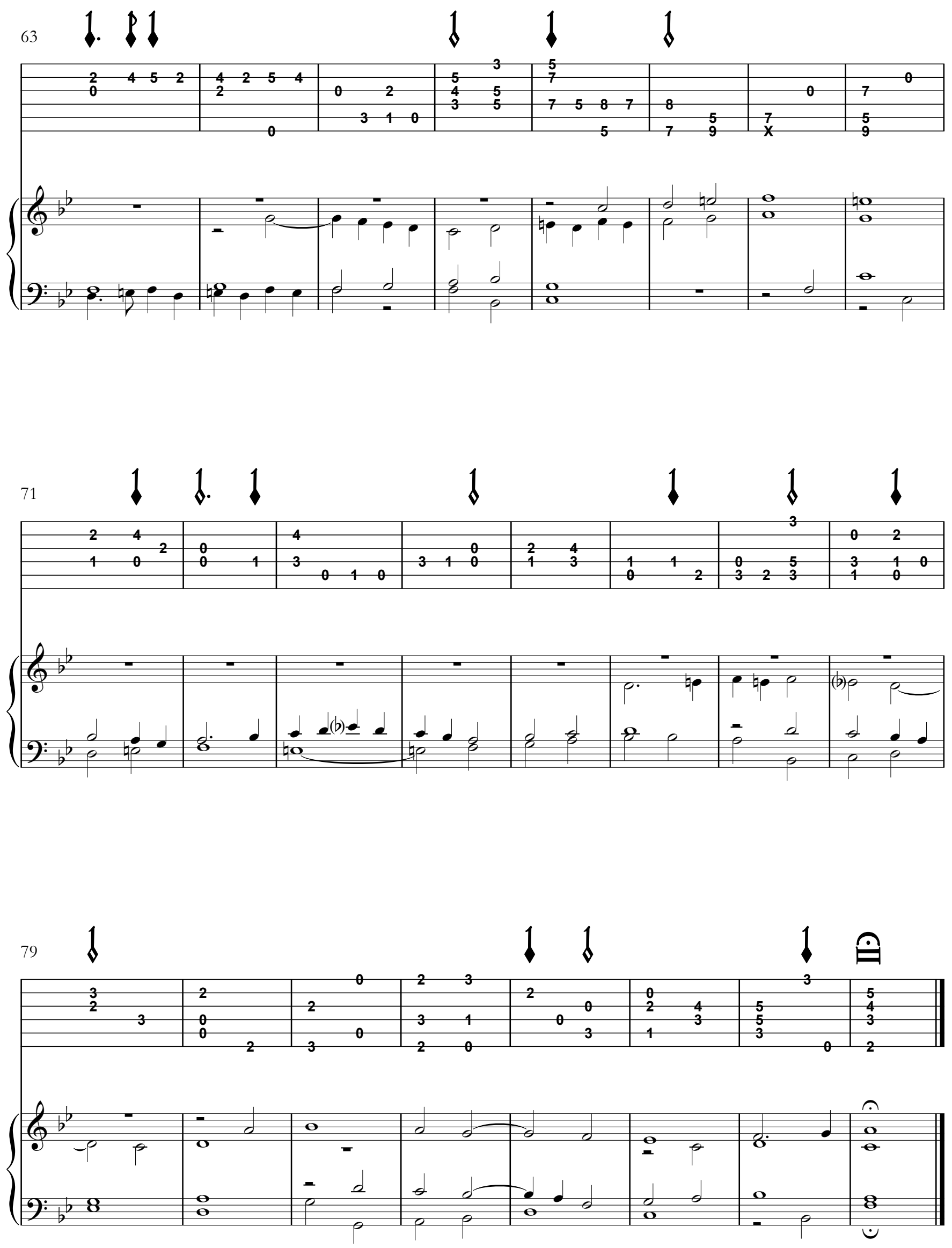


\section{so 45 - Cum sancto spiritu}

Glosa sobre el cum sancto spiritu de la missa de beata virgine de iosquin [Libro II, ff. XXII-XXIII]
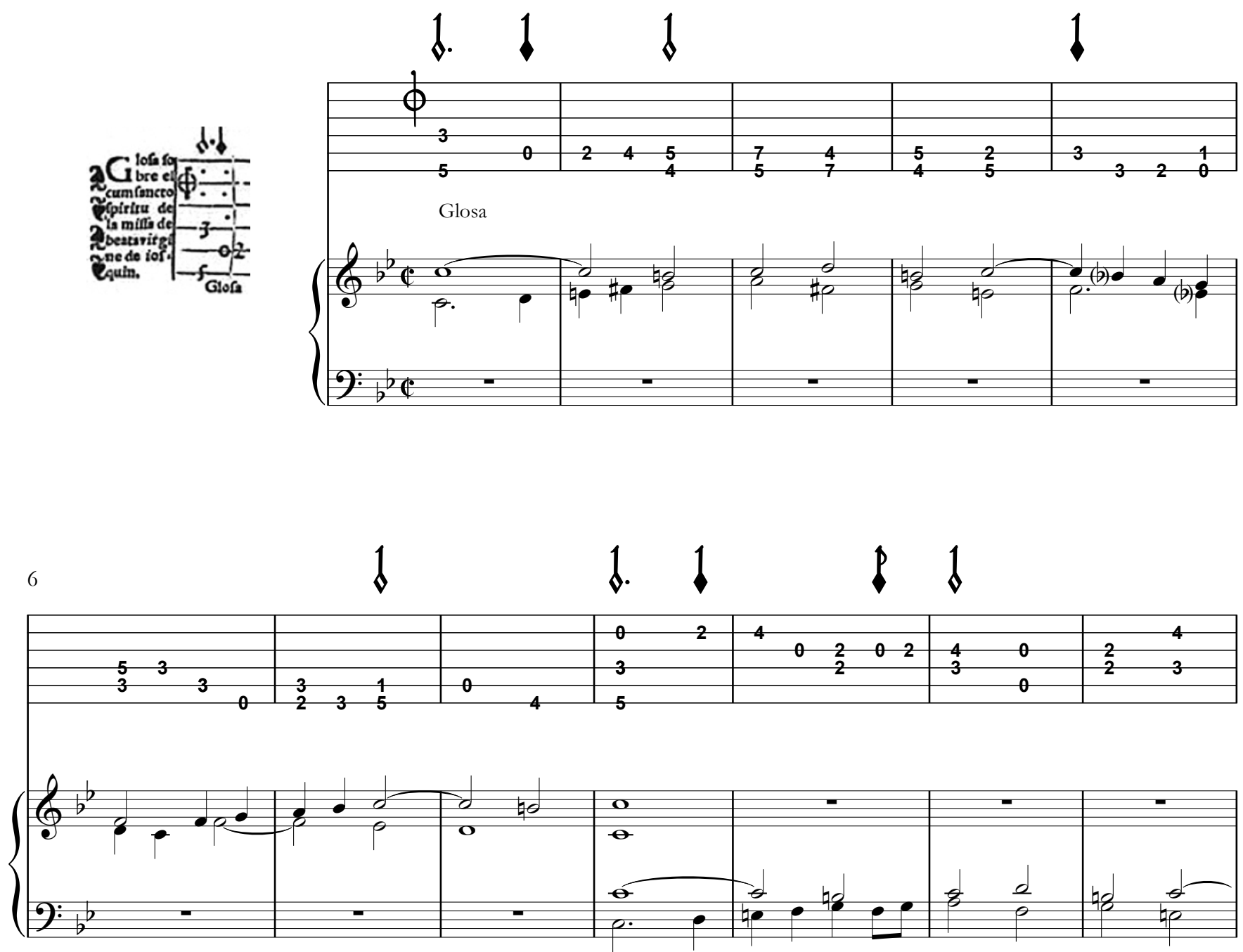

$13 \div \quad 1 \quad 1 \% 18$

\begin{tabular}{|c|c|c|c|c|c|c|}
\hline 3 & $\begin{array}{lll}2 & 0 & 5\end{array}$ & 3 & 2 & 0 & & 5 \\
\hline $0,10^{2}$ & 02 & 423 & 20,3 & 3 & 1 & 3 \\
\hline & & & $320 \times 2$ & $\begin{array}{lllll}2 & 3 & 2 & 0 & 2\end{array}$ & 3 & 2 \\
\hline
\end{tabular}

Iosquin

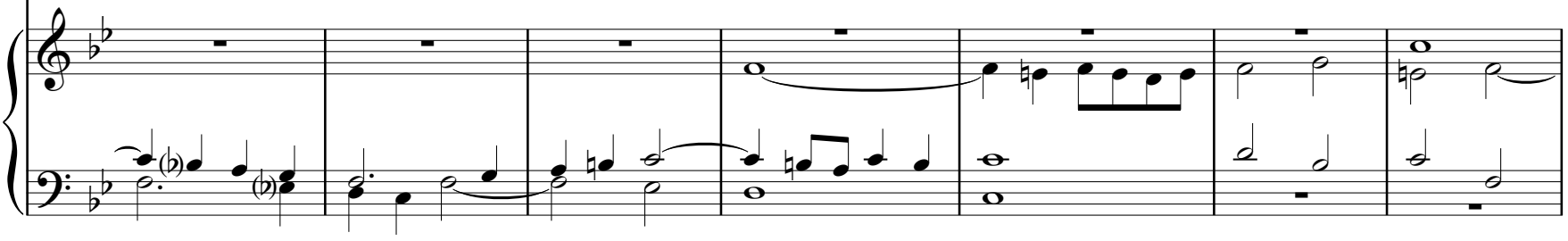



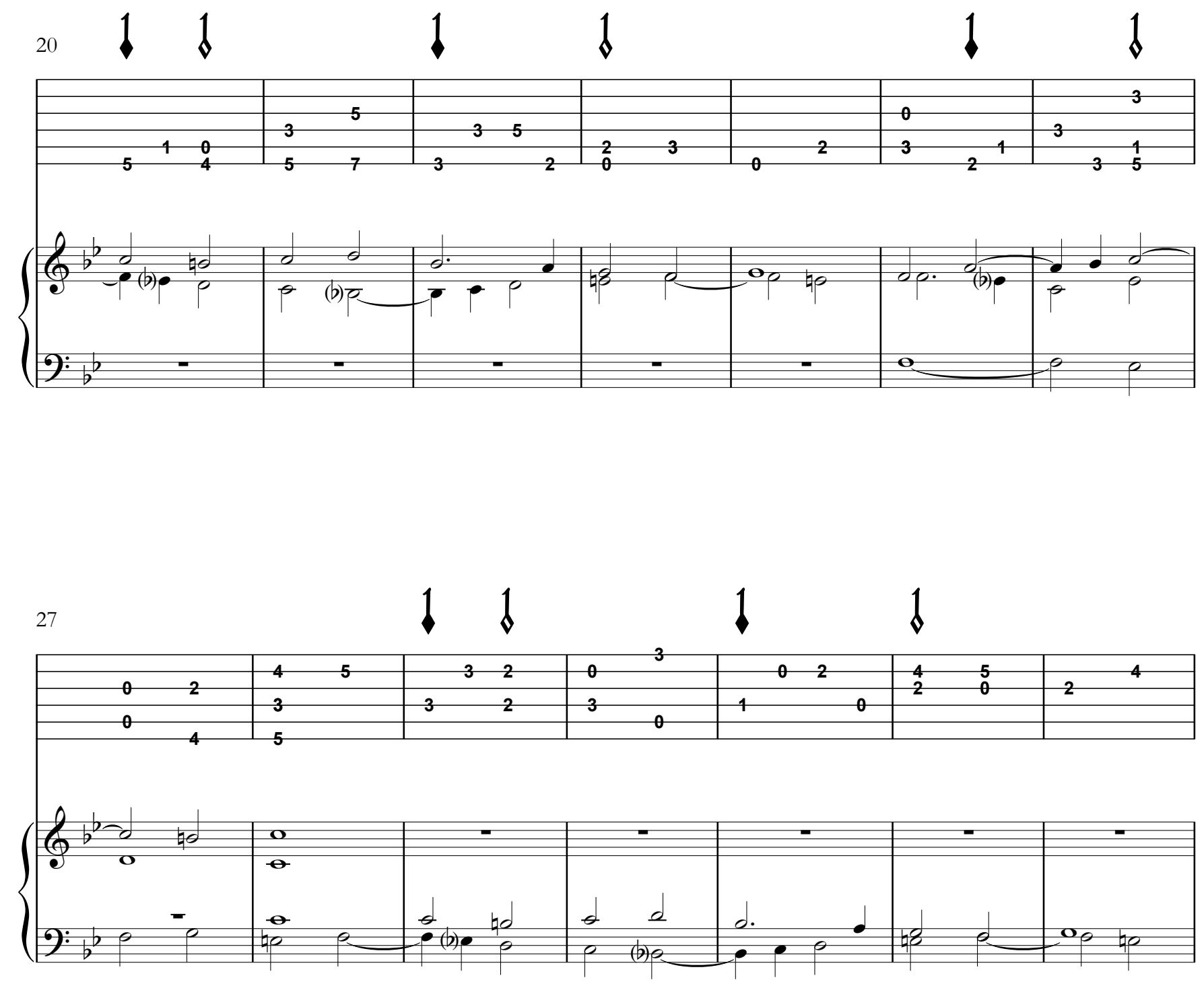

[f. XXIIv]

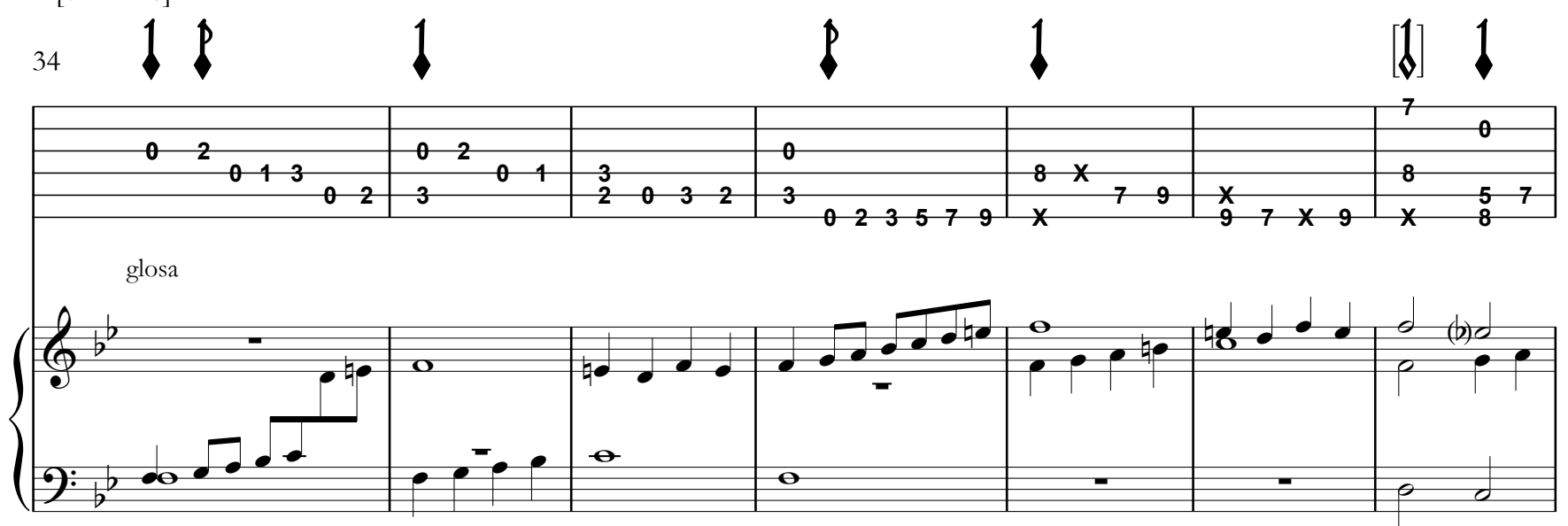



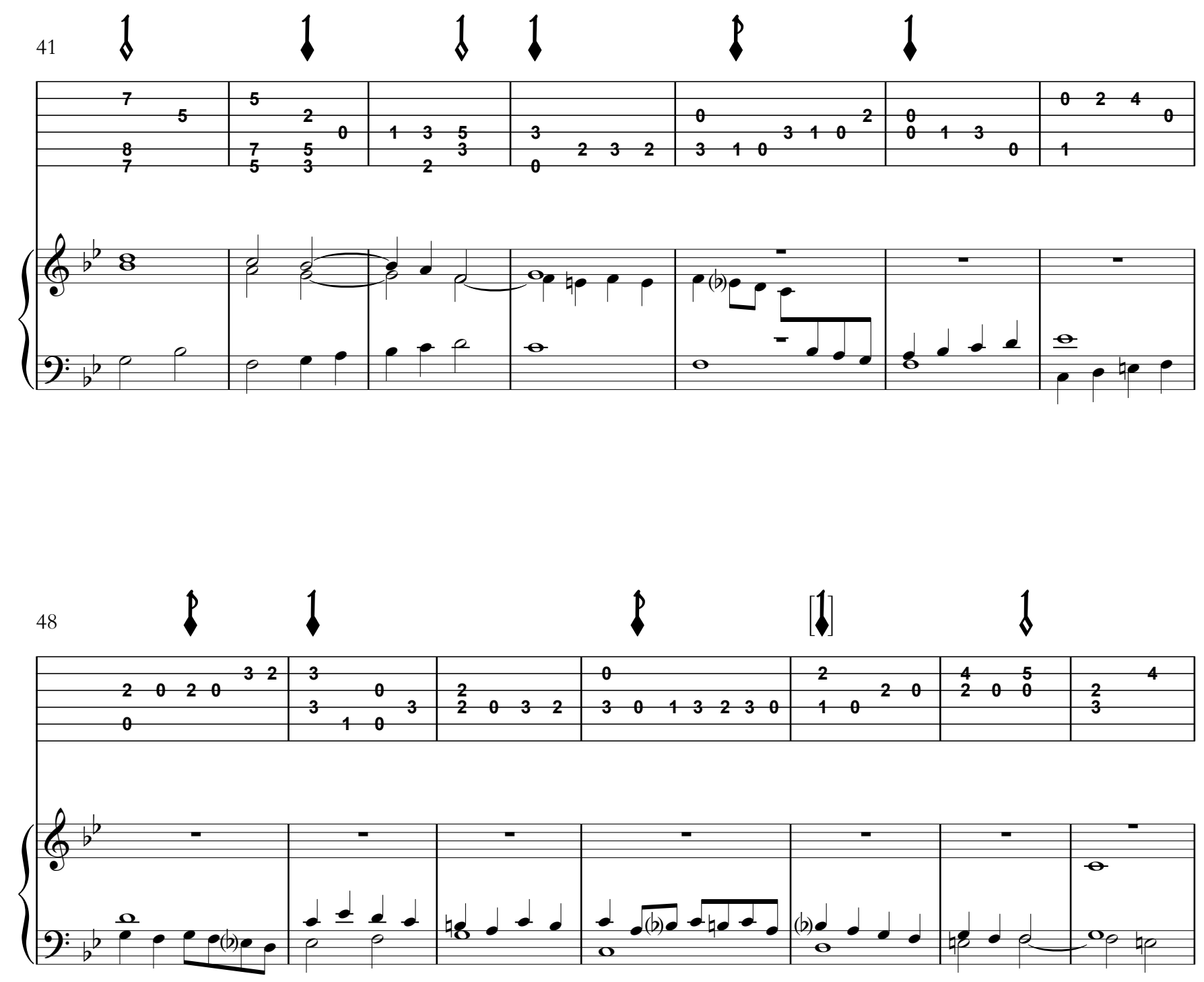

55

- 1

\begin{tabular}{|c|c|c|c|c|c|c|}
\hline & & & & 9 & $x$ & \\
\hline 0 & 0 & & 0 & $>9$ & 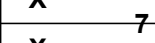 & 0 \\
\hline 3 & 15 & $1 \quad 3$ & 3 & & $x$ & 8 \\
\hline
\end{tabular}
Iosquin

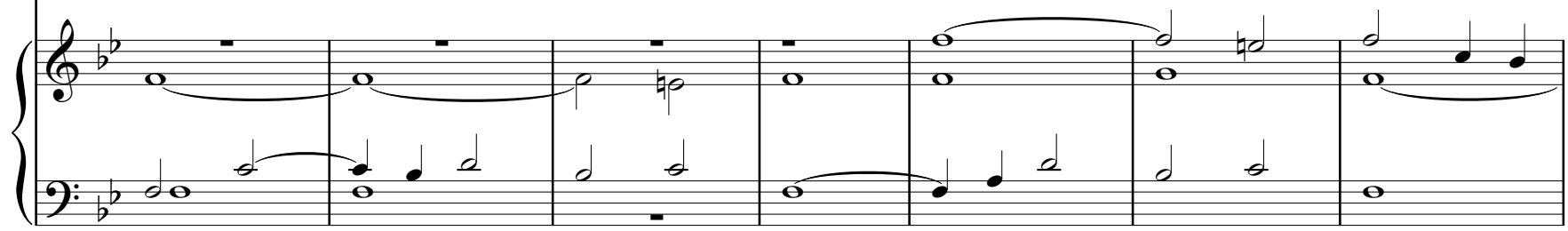


[f. XXIII]

62

181

! 1

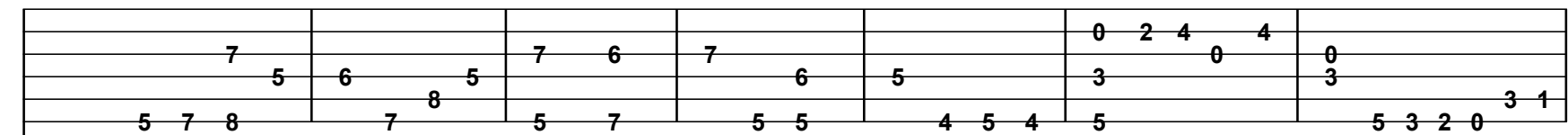

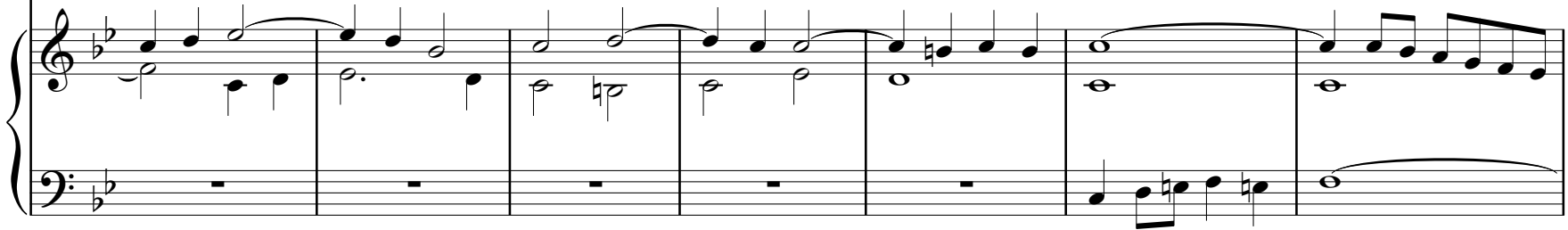

69 $1 \quad p \quad 1 \quad 1$

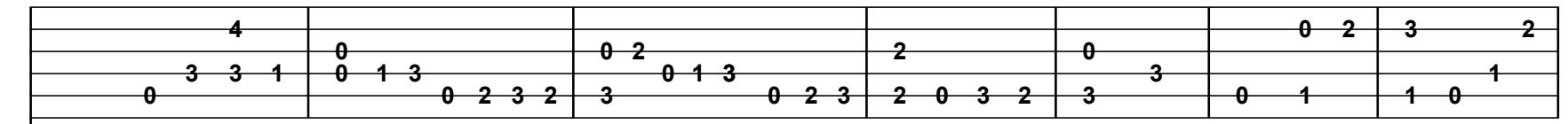

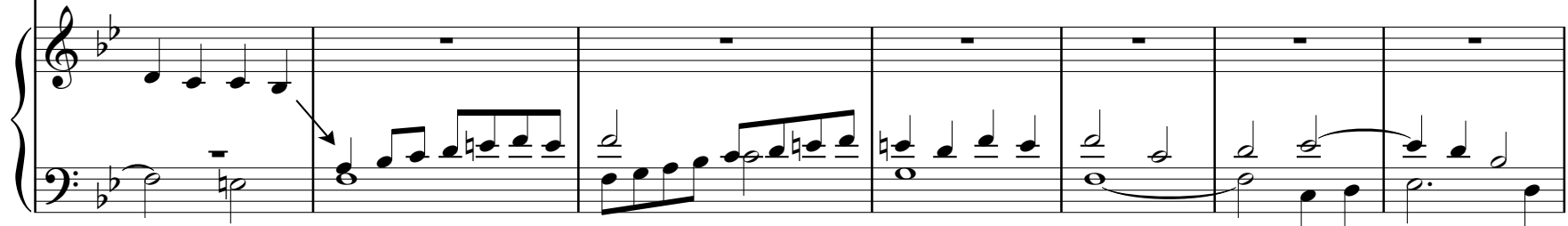

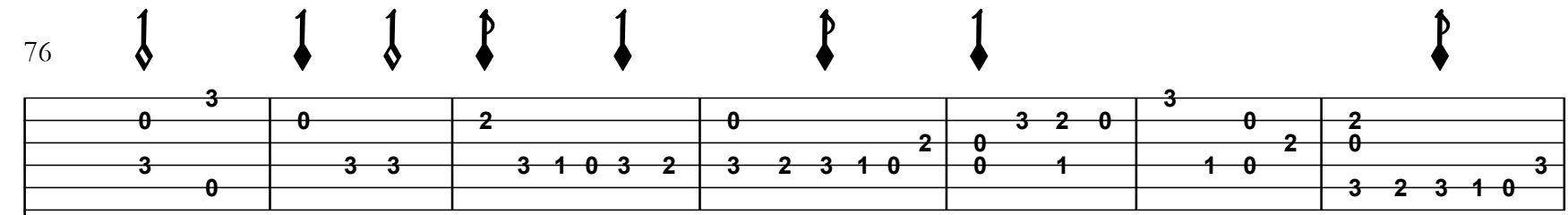

glosa

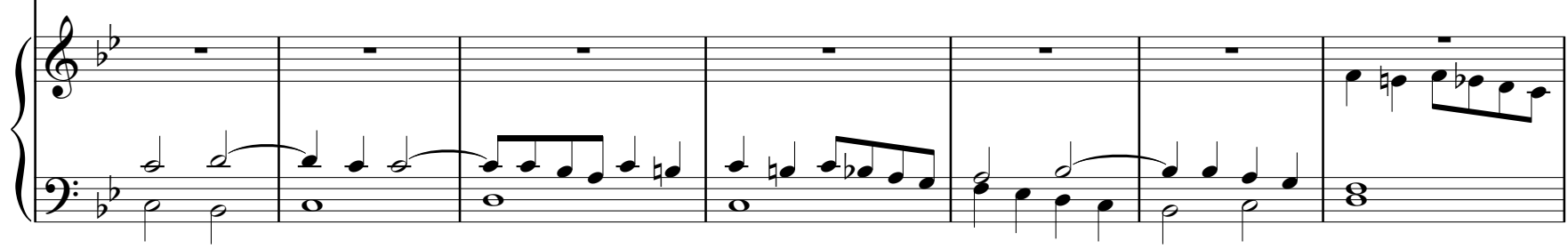




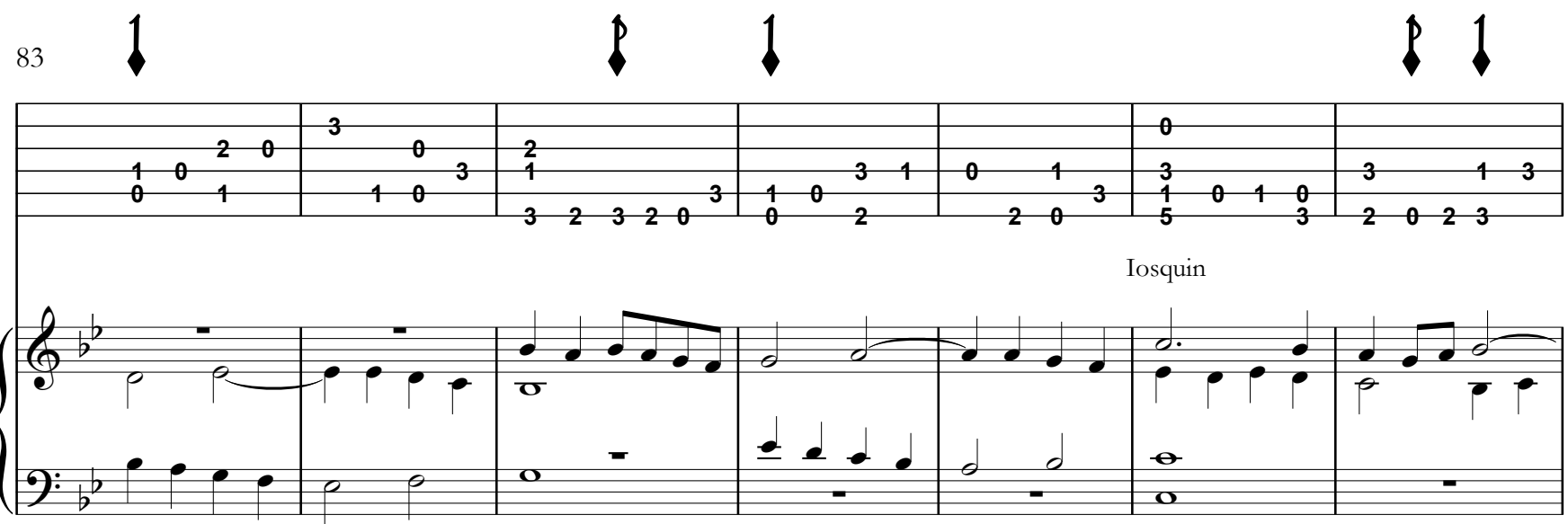

[f. XXIIv]
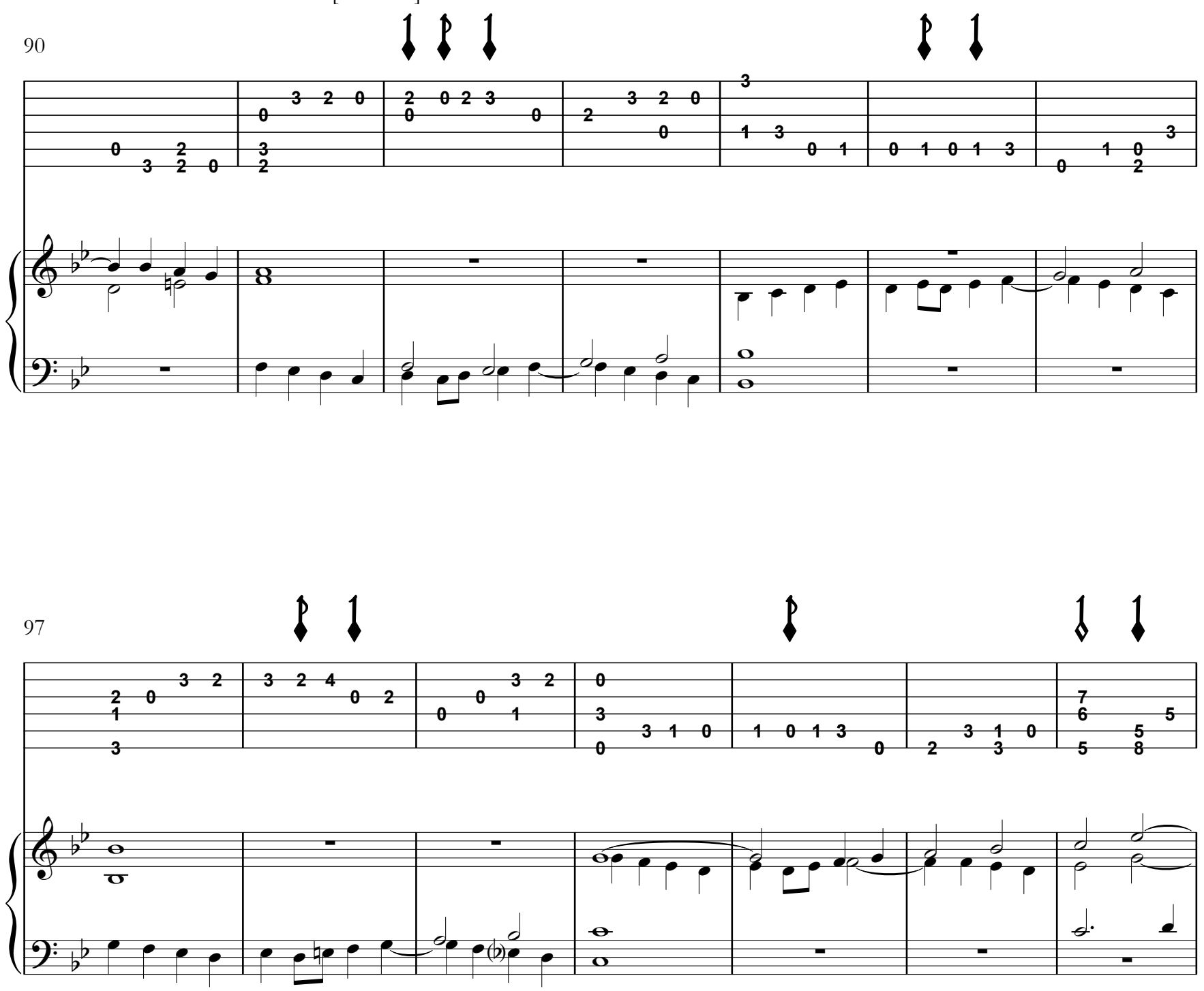
$\begin{array}{lllll}104 & 1 & 1 & 1 & 1\end{array}$

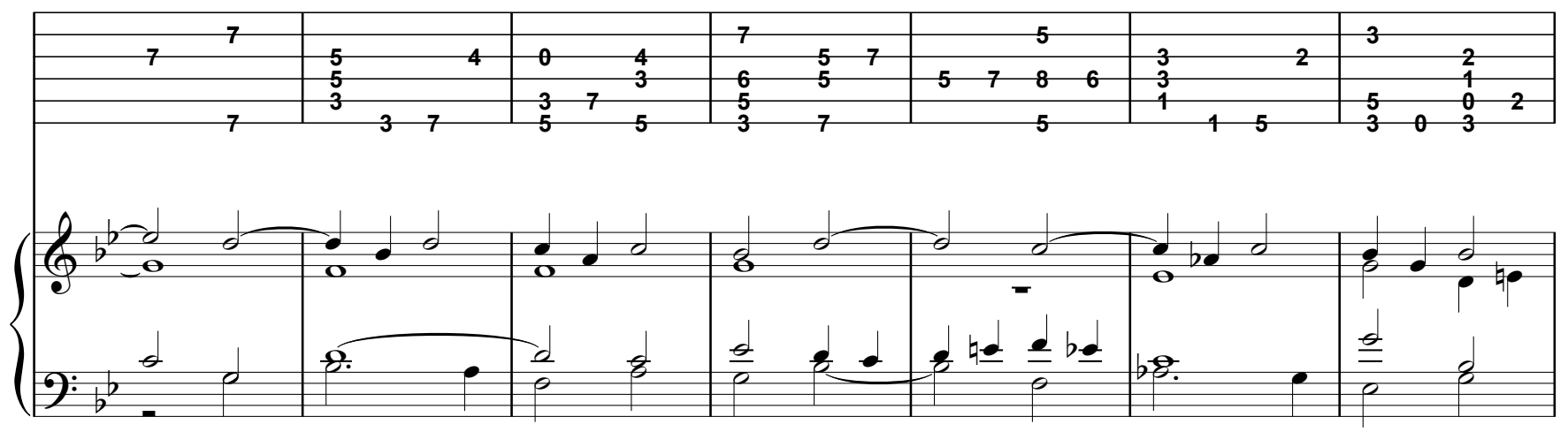

$111+1$

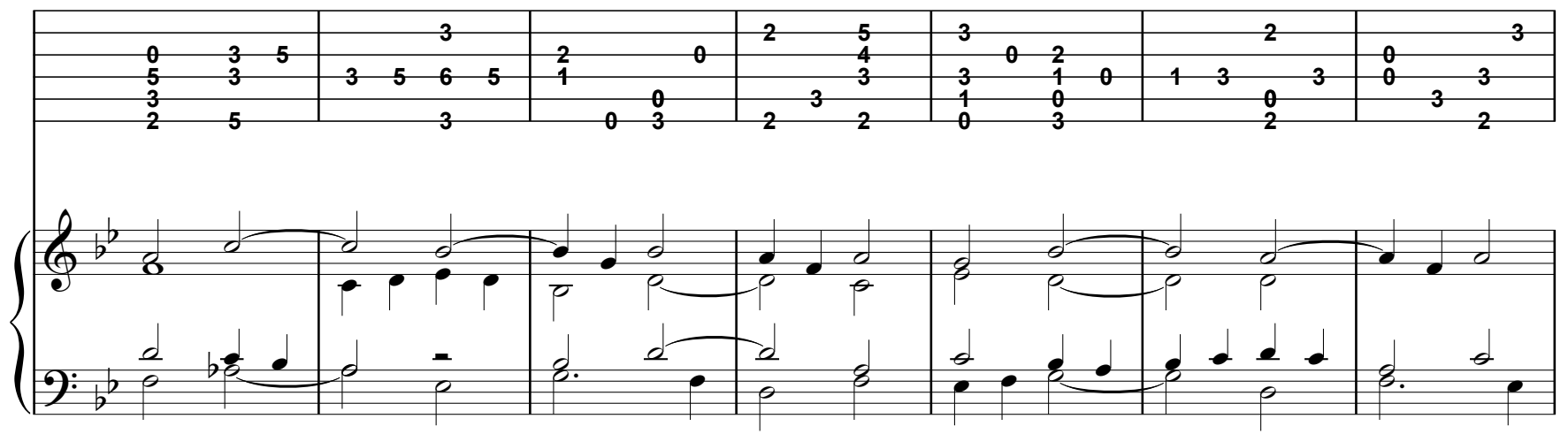

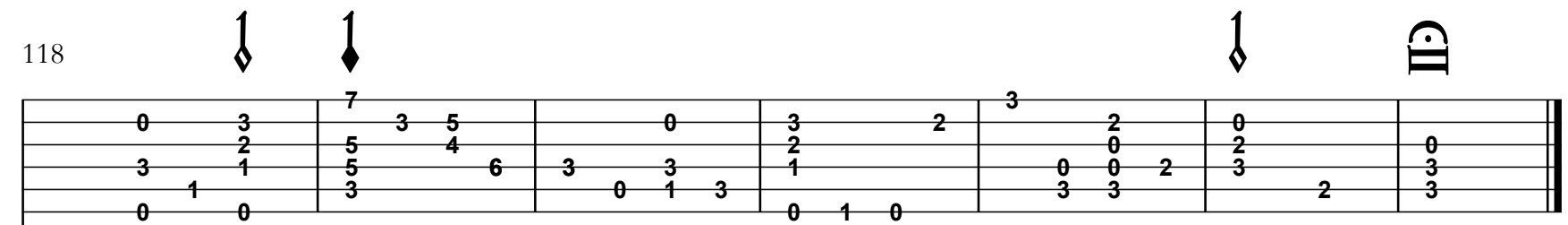

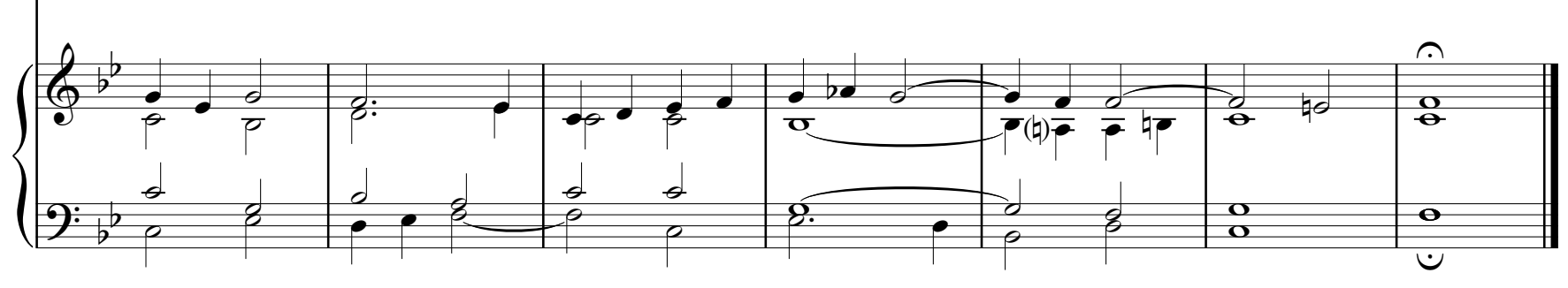




\title{
sey 46 - Tiento 8 ex
}

\author{
Tiento
}

VIII Tono

[Libro II, f. XXIV]
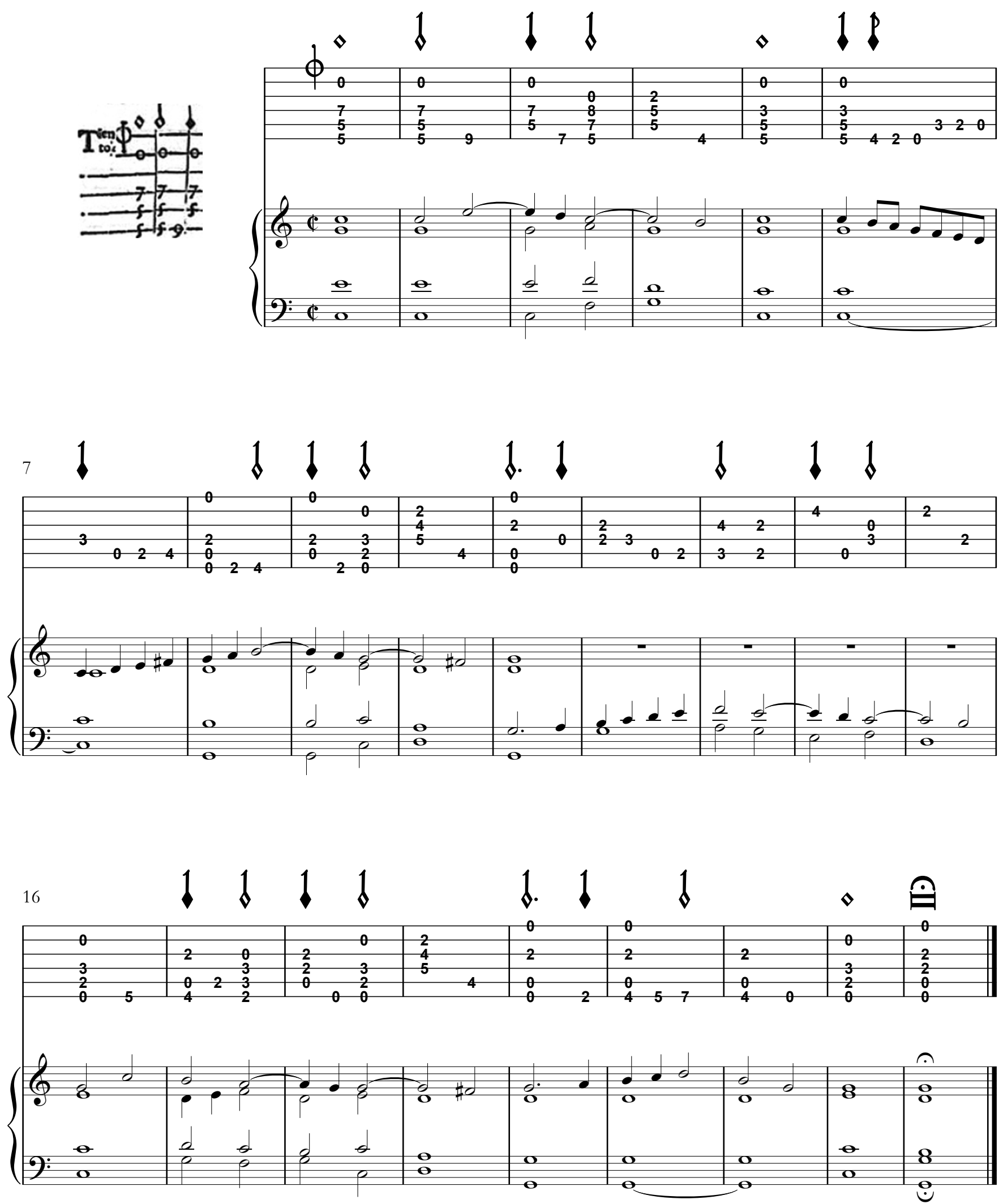


\section{se47 - Fantasía 25}

[Libro II, ff. XXIV-XXV]
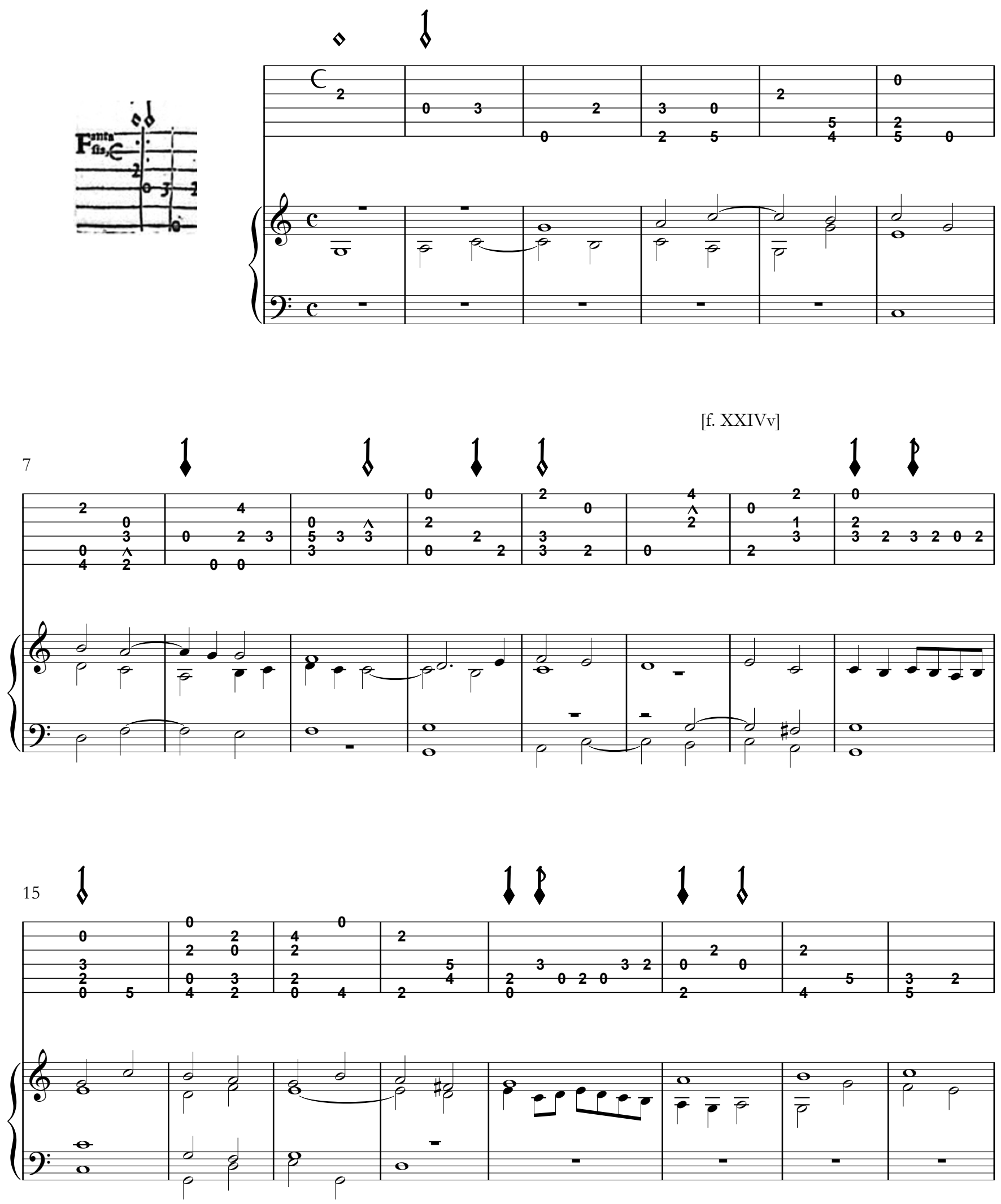


\begin{tabular}{|c|c|c|c|c|c|c|c|}
\hline & $\mathbf{0}$ & 2 & & & & & \\
\hline & $7 \quad 0$ & 240 & 2 & & & & \\
\hline & & & $\begin{array}{llll}2 & 0 & 2 & 3\end{array}$ & $5 \quad 0$ & 23 & 2 & 3 \\
\hline $\begin{array}{ll}0 & 5 \\
7\end{array}$ & & 2 & 0 & 3 & 2 & 0 & $\begin{array}{|llll|}5 & 0 & 2 & 4 \\
\end{array}$ \\
\hline
\end{tabular}
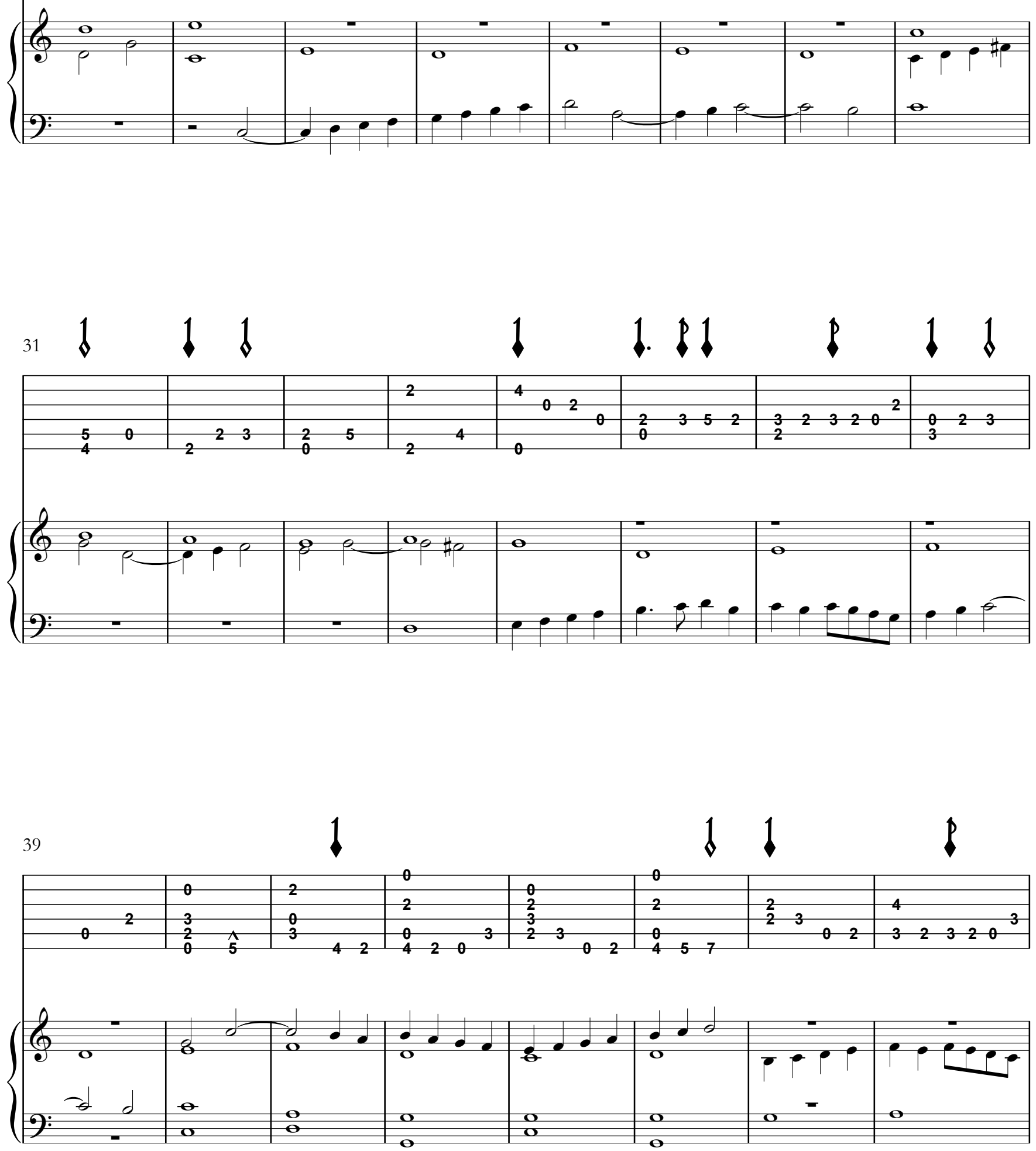

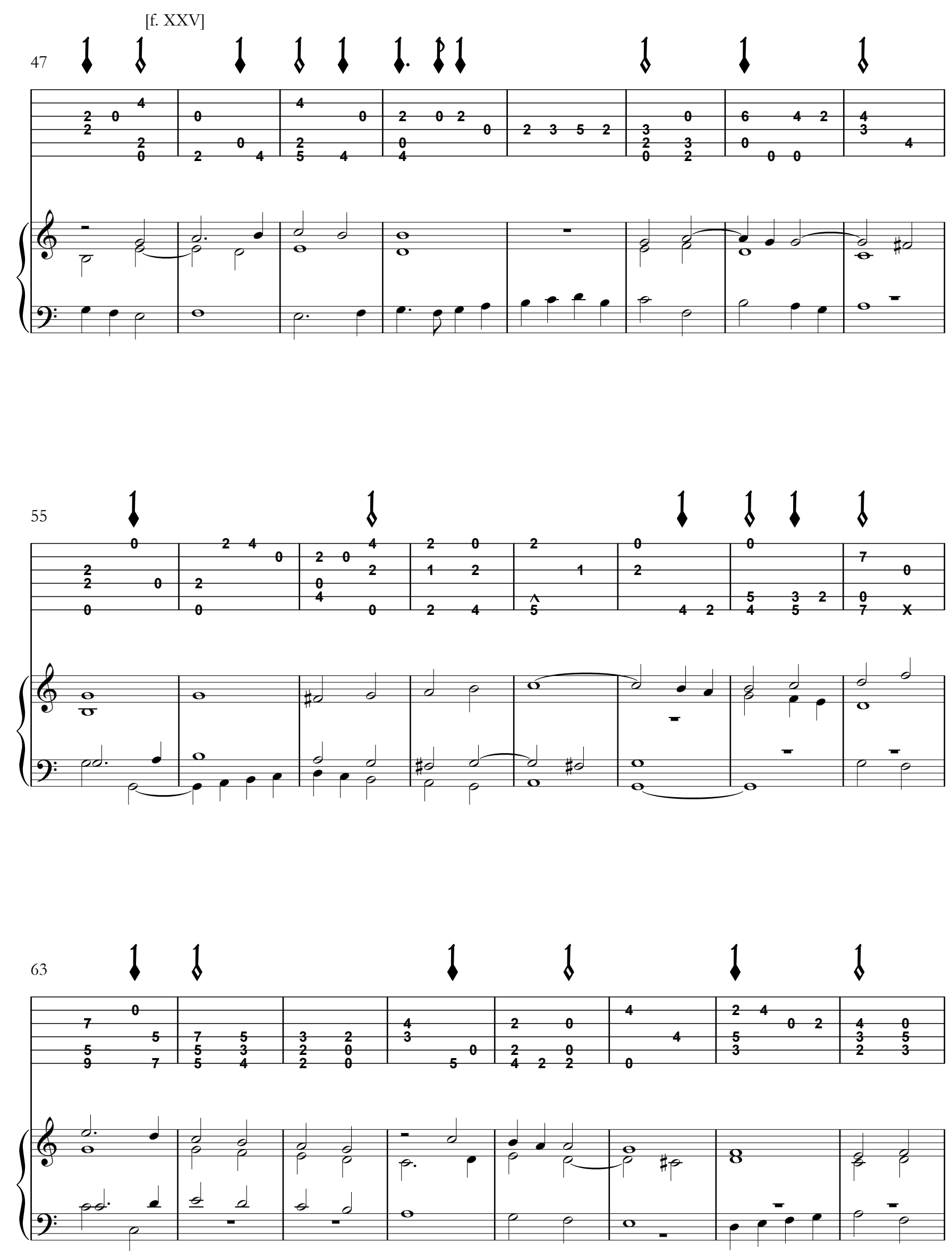

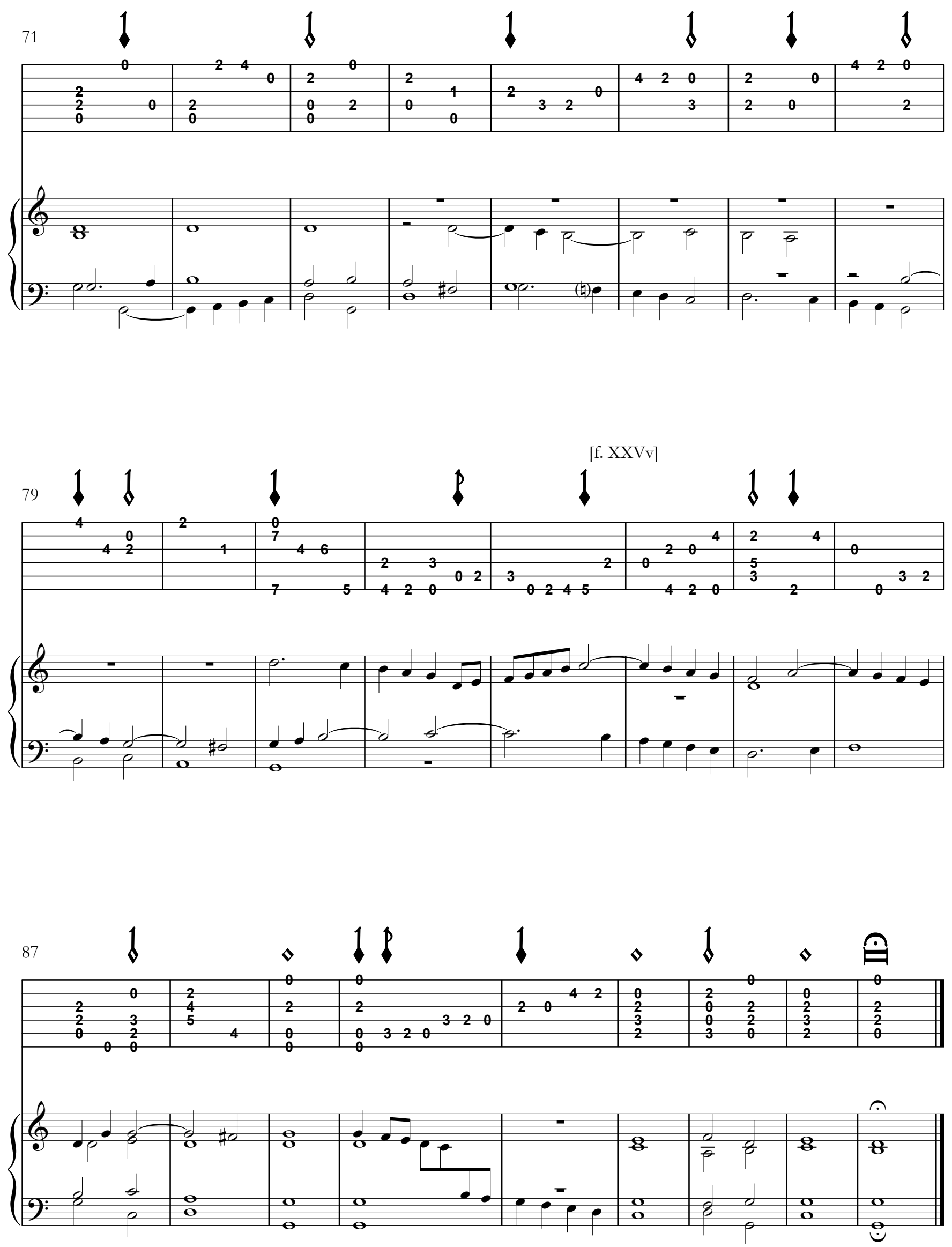


\title{
sะ48 - Fantasía 26ø
}

\author{
Fantasía
}

[Libro II, ff. XXVv-XXVIv]
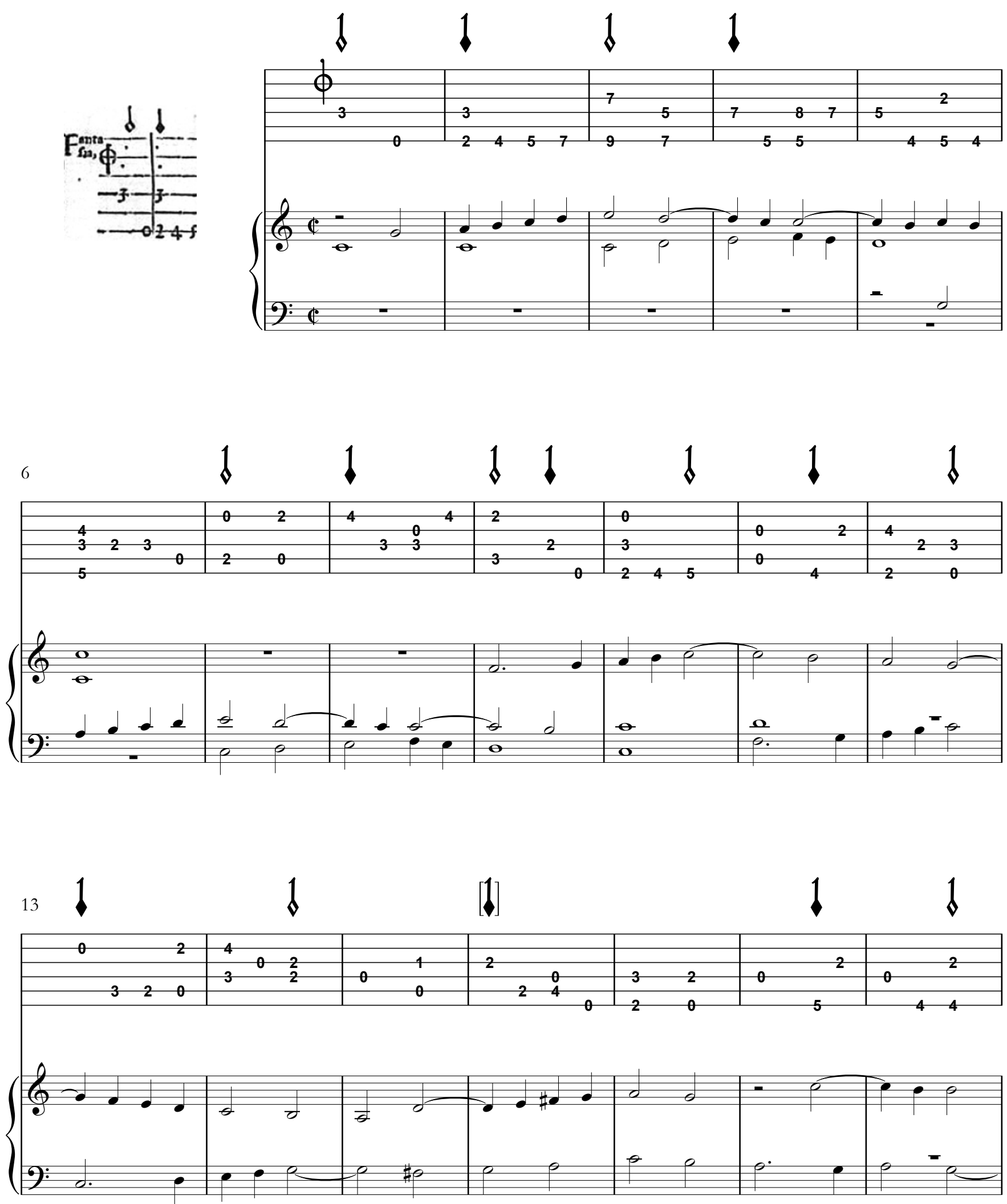
Fantasía 26
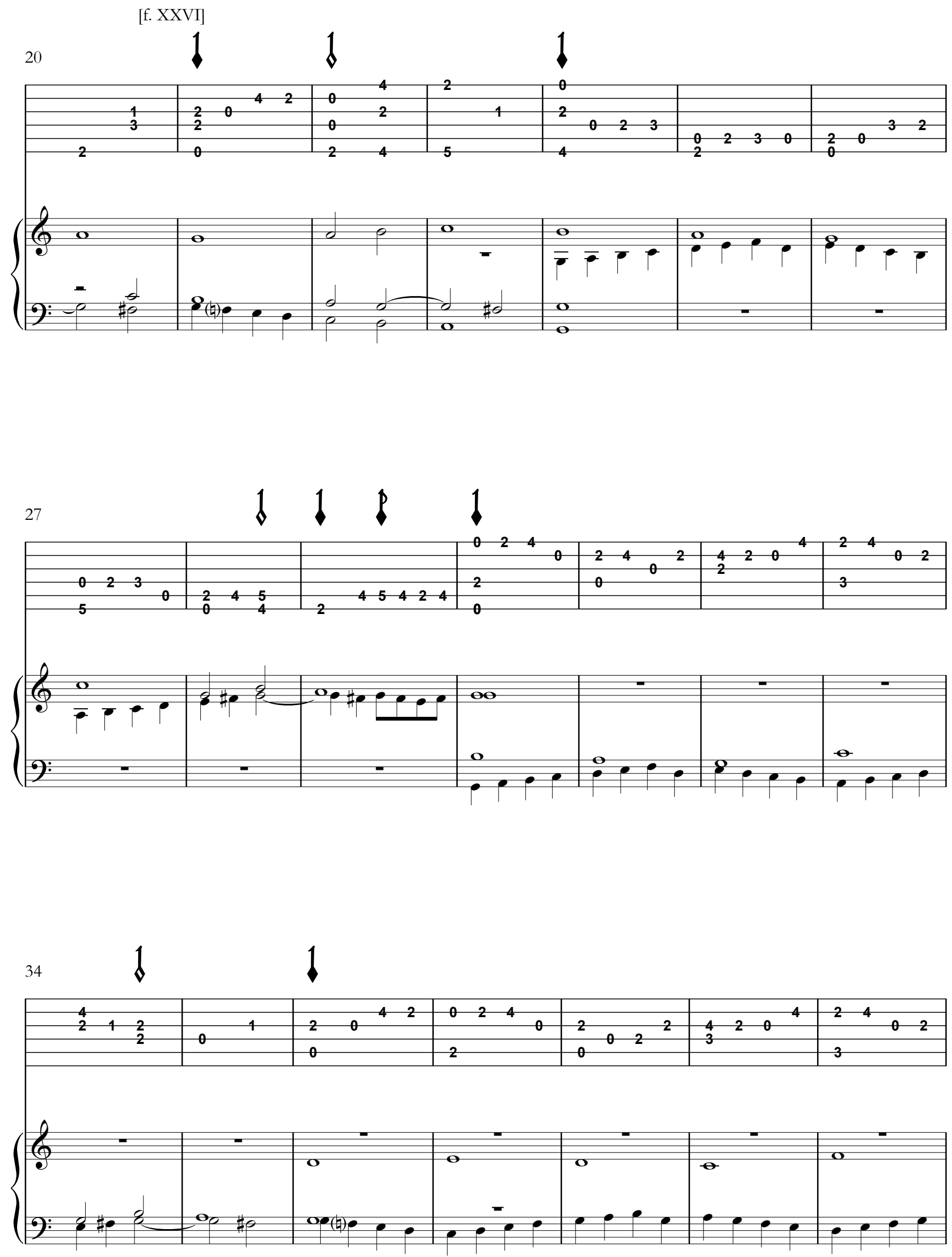

157 


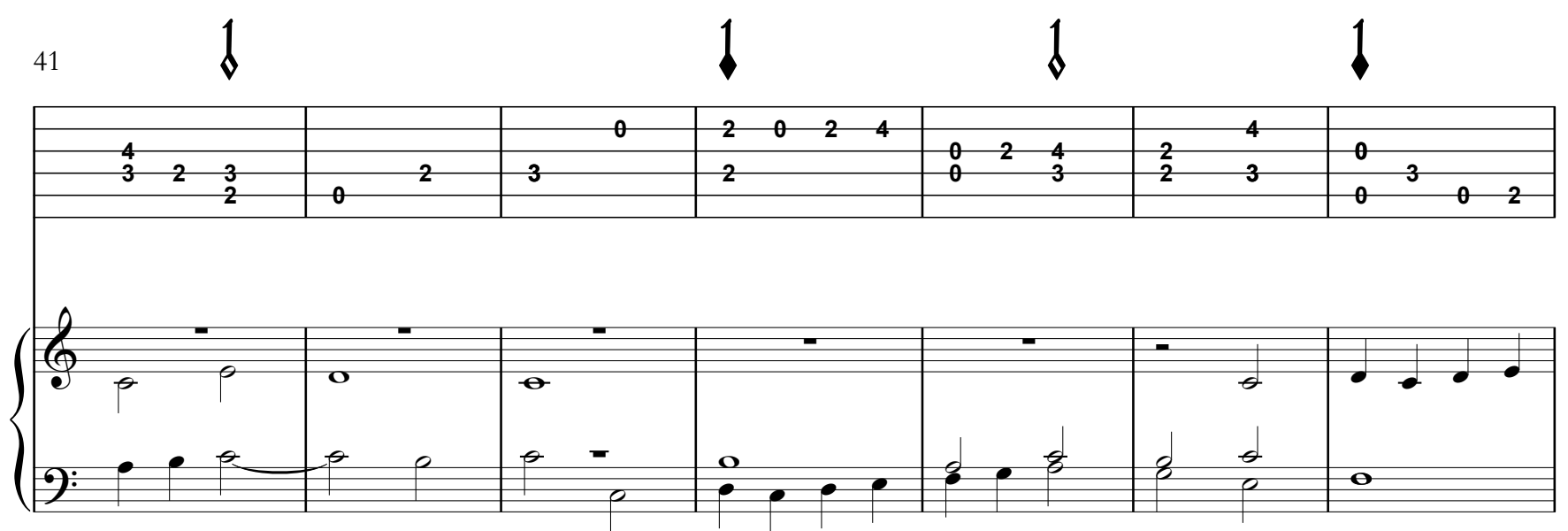

[f. XXVIv]
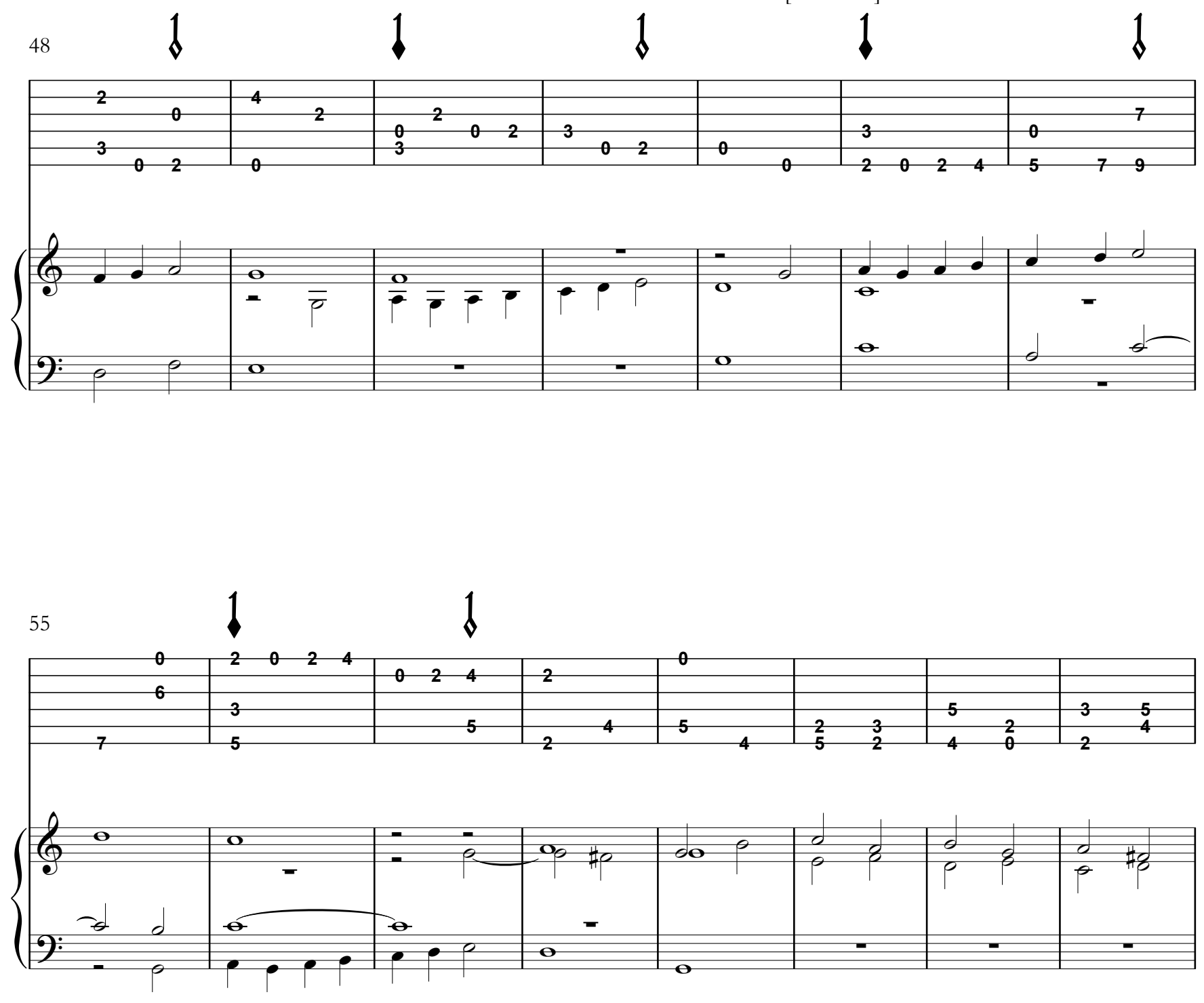
63

\begin{tabular}{|l|ll|ll|ll|l|l|l|l|l|}
\hline & 0 & 2 & 4 & 0 & & & & & 2 & 4 & 0 \\
\hline & & & & 2 & 4 & 0 & 2 & & 4 & 2 & 2 \\
\hline
\end{tabular}
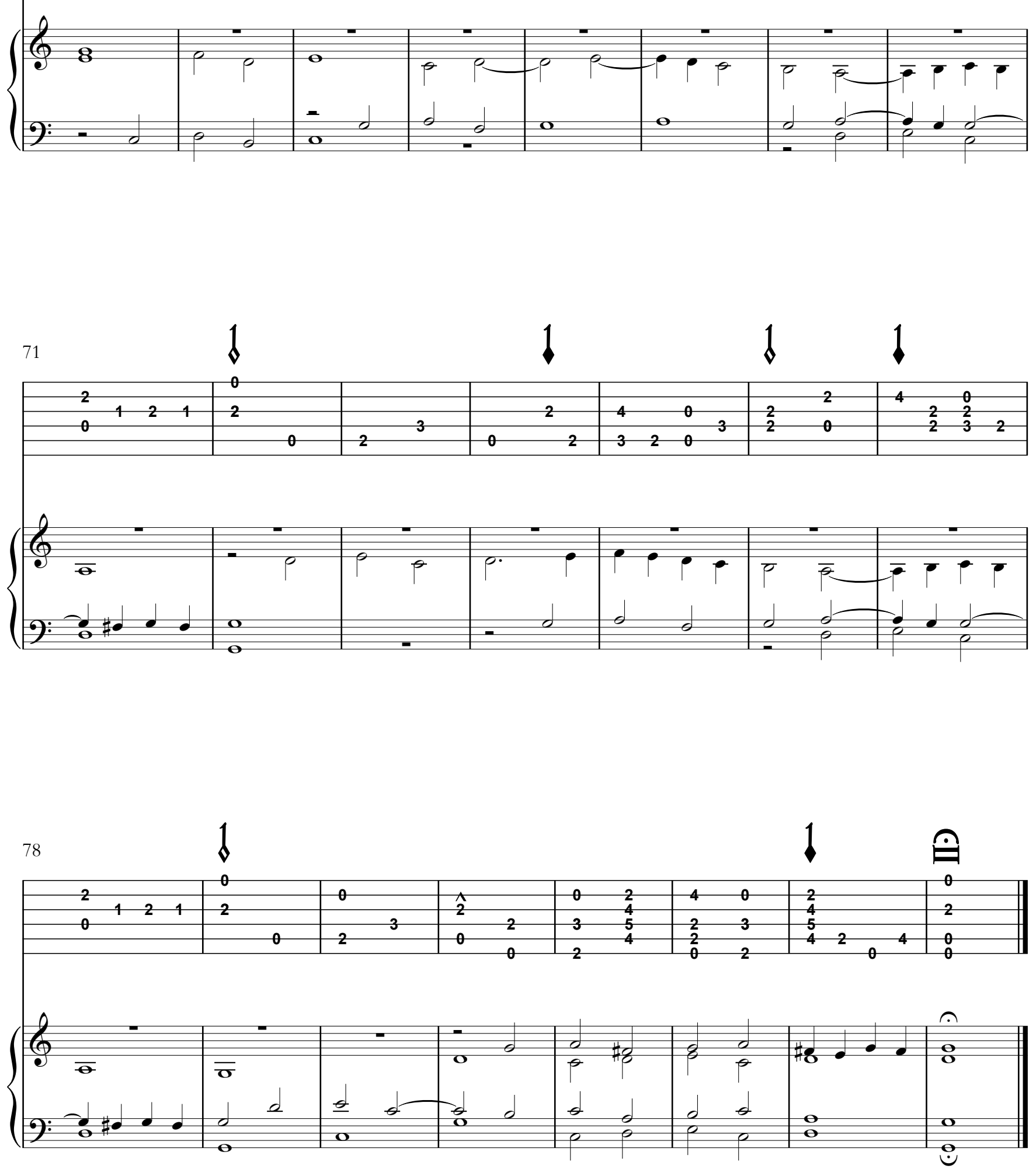


\section{s\&49 - Fantasía 27}

Fantasía va sobre fa mi fa, re ut, sol fa sol mi re

[Libro II, f. XXVII]
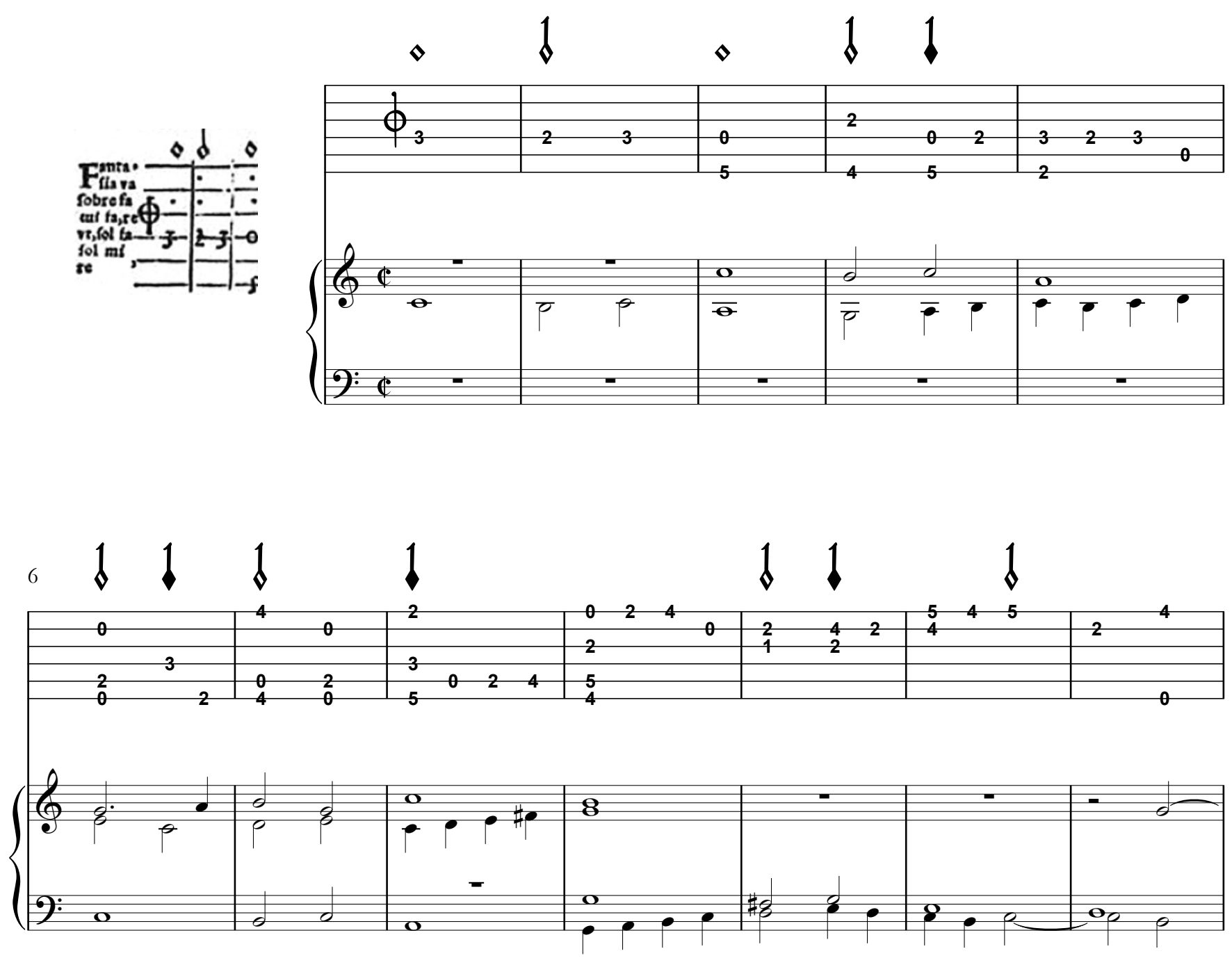

13

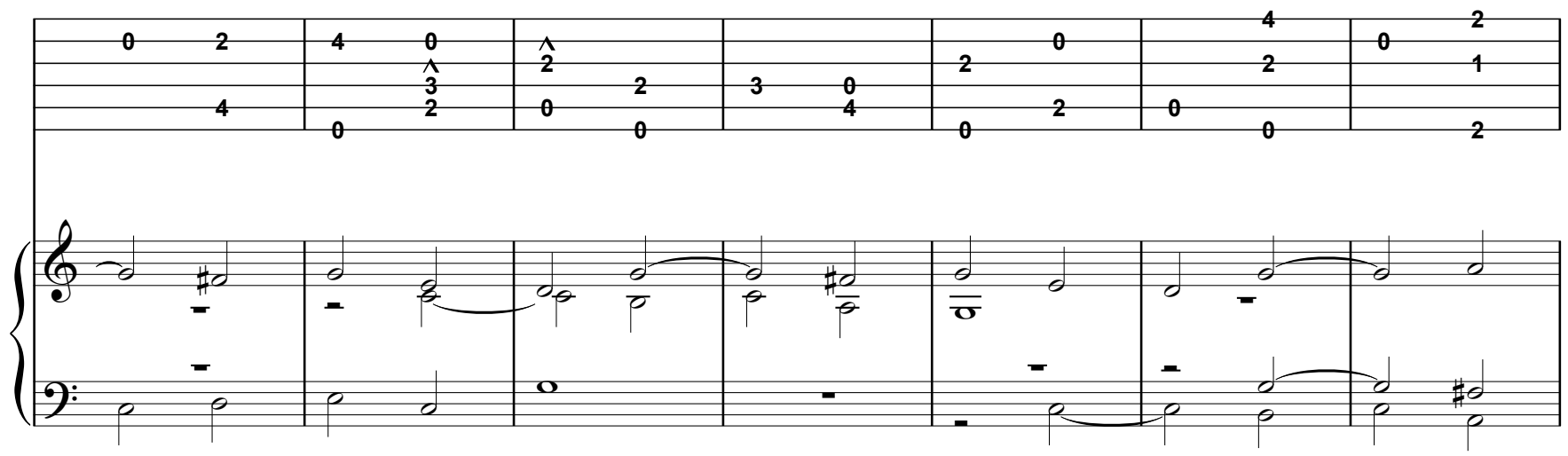




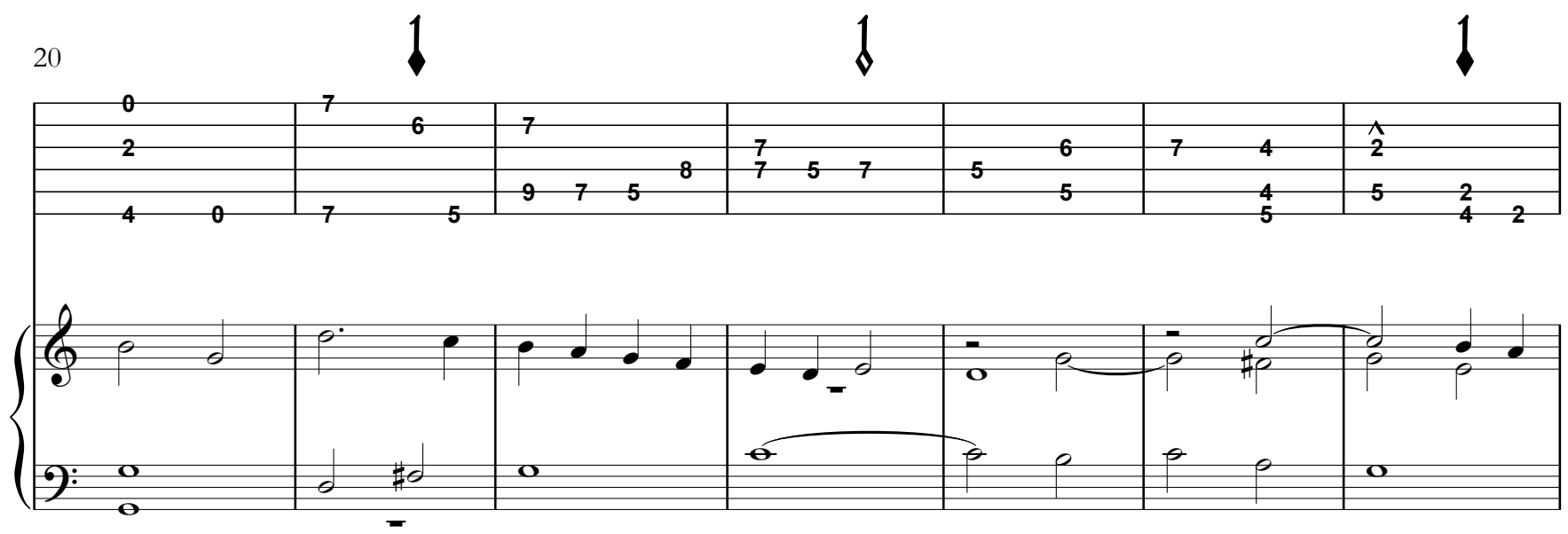

[f. XXVIIv]
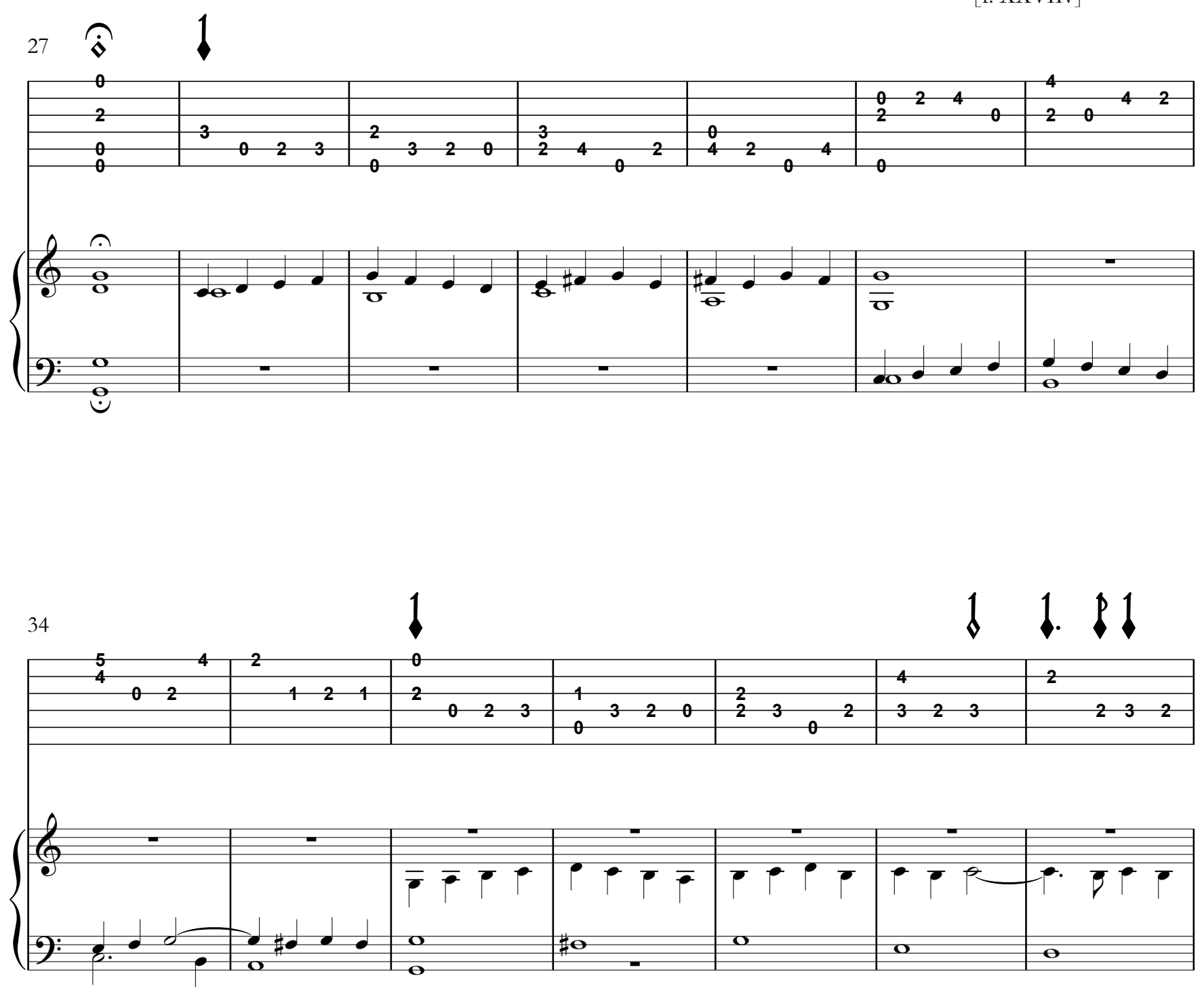

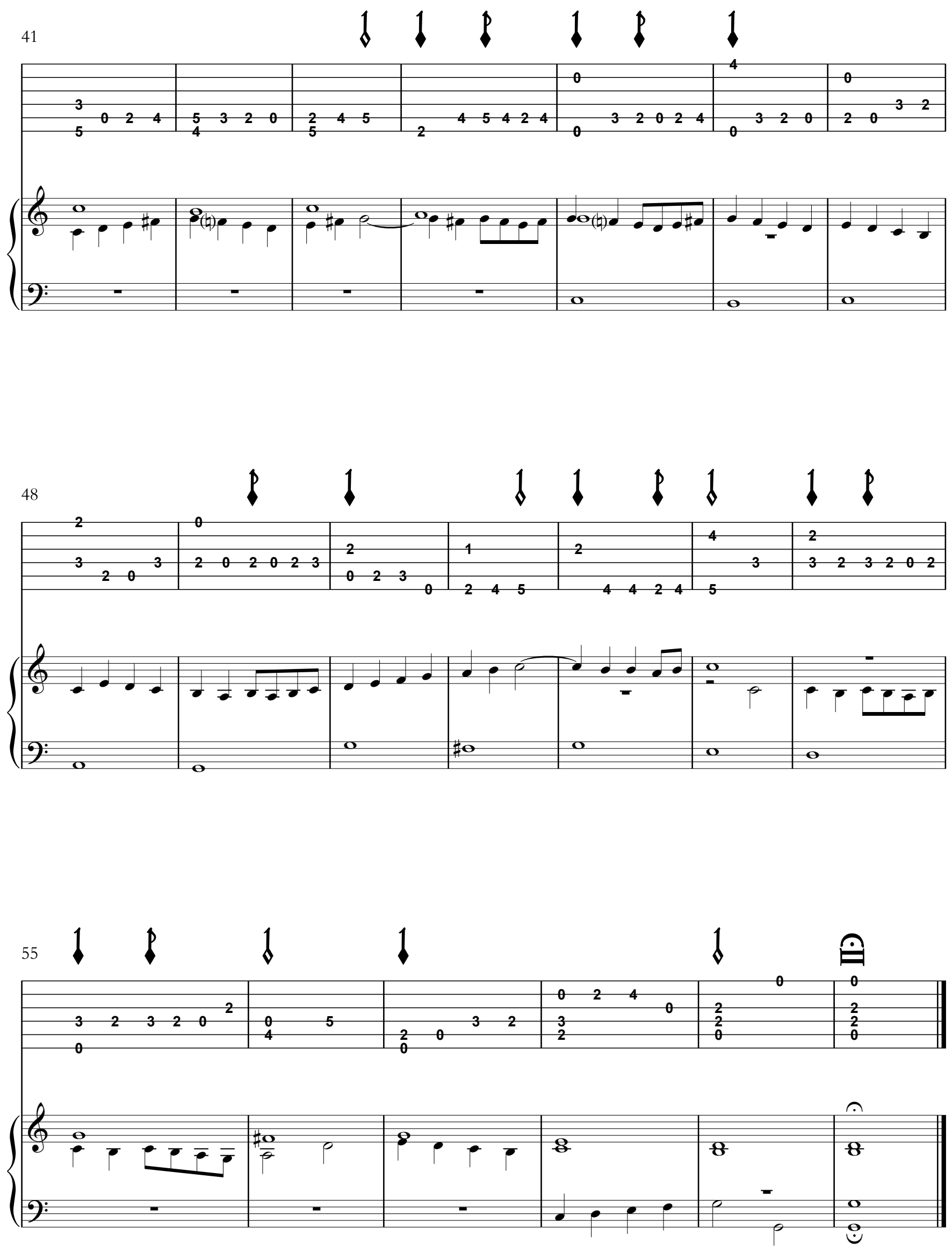


\title{
s\& 50 - Pater noster
}

\author{
[Motete I]
}

Pater noster a quatro de Adrian Vuillart [sic]

[Libro III, I]
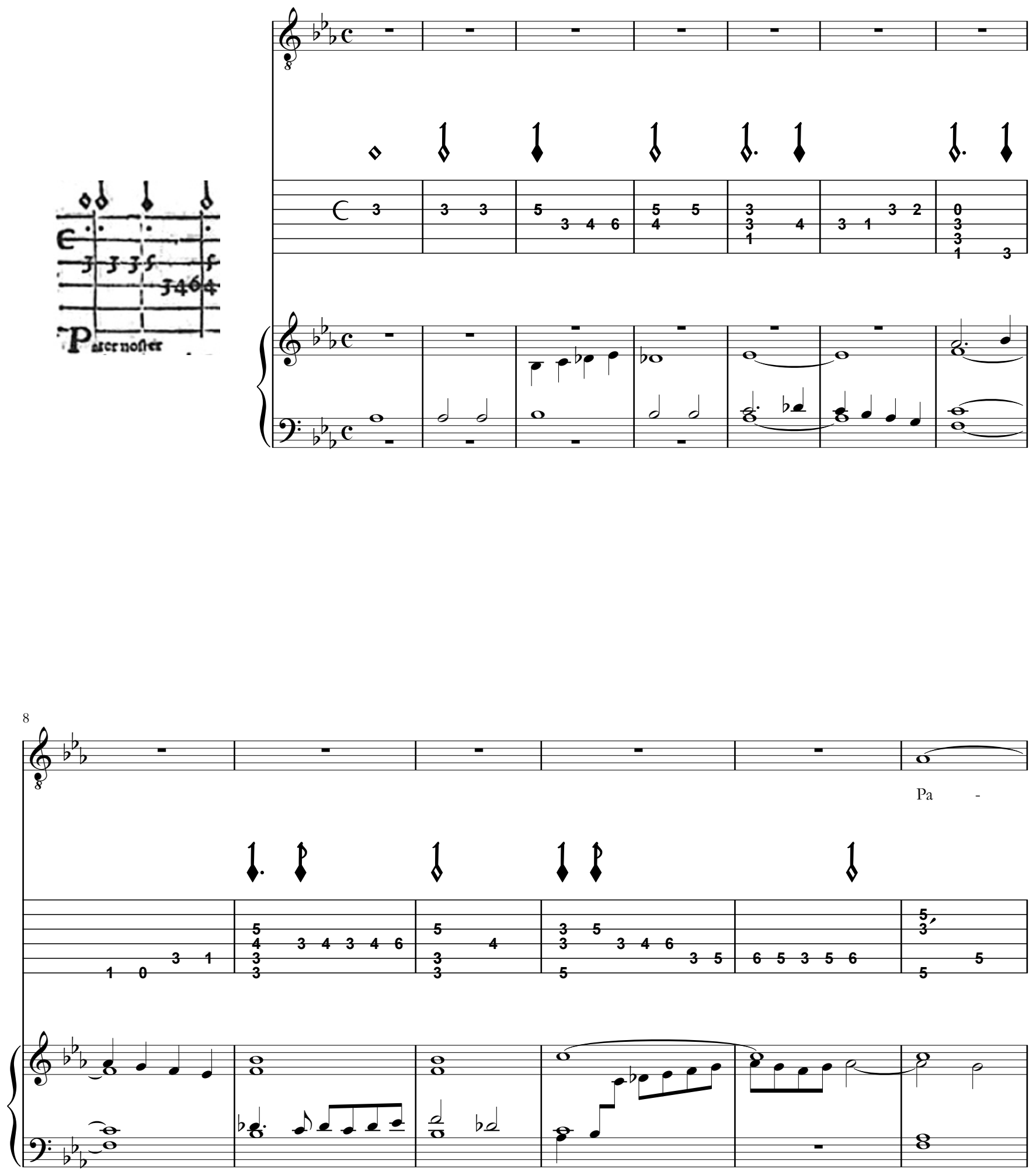

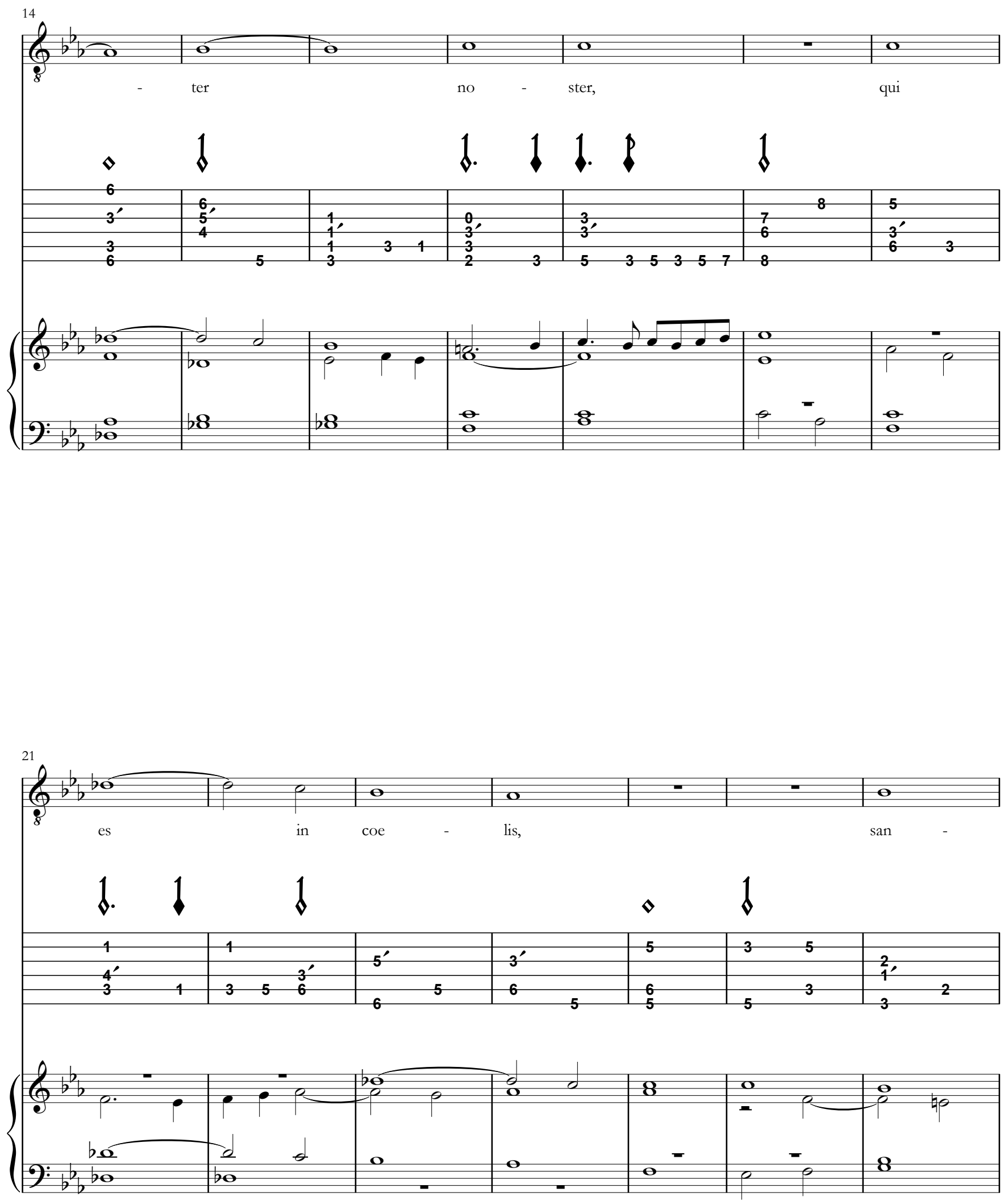

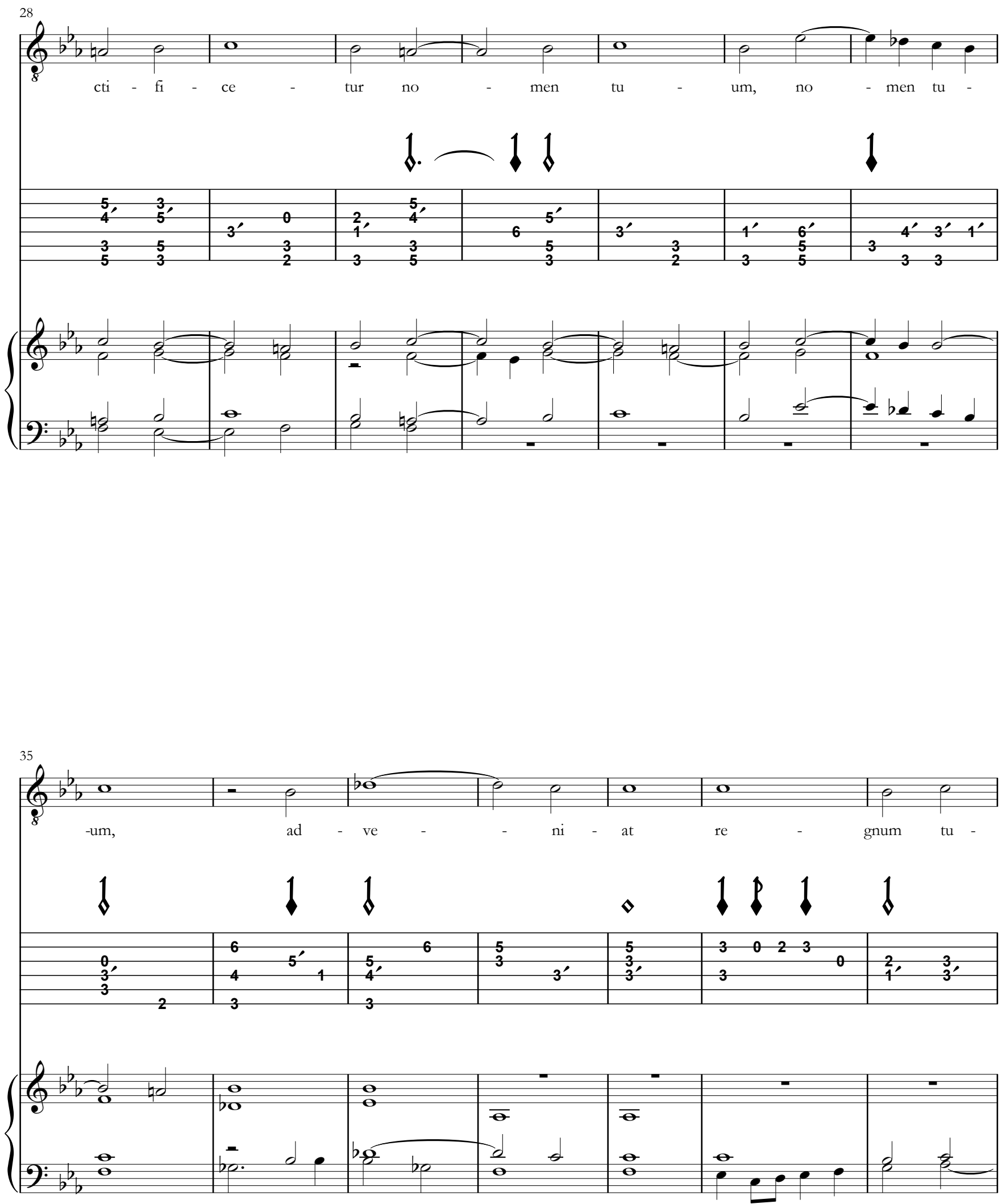

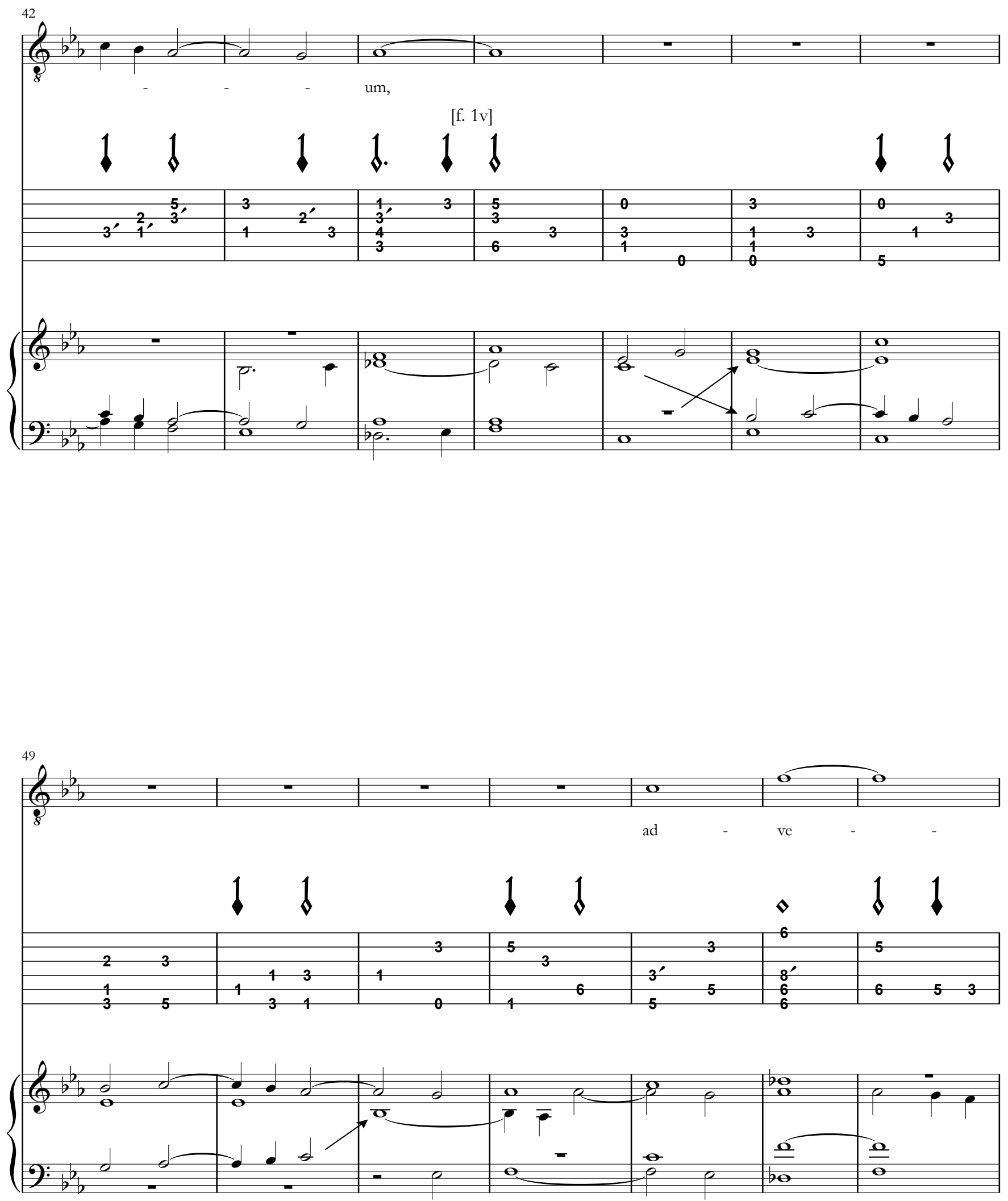

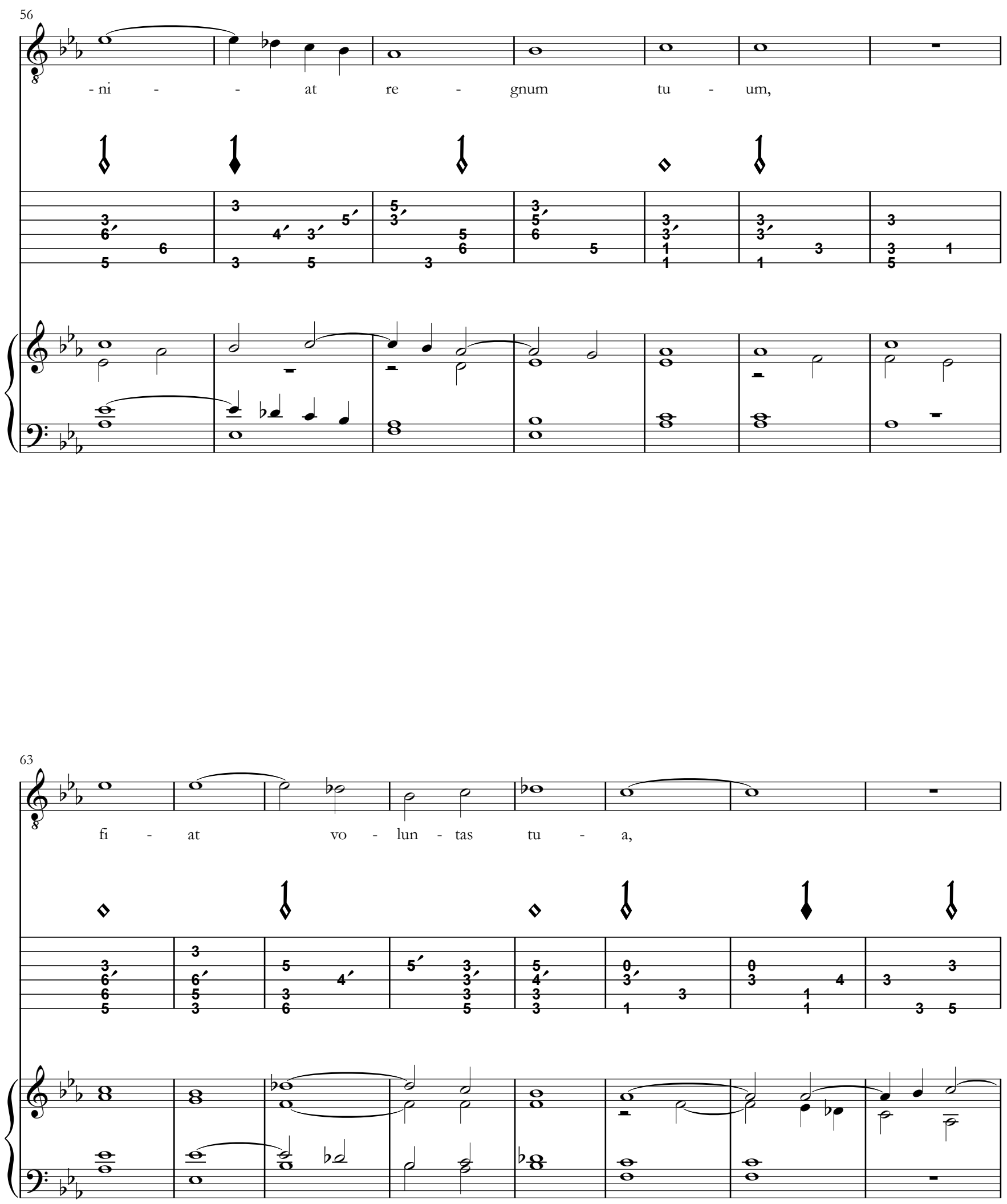

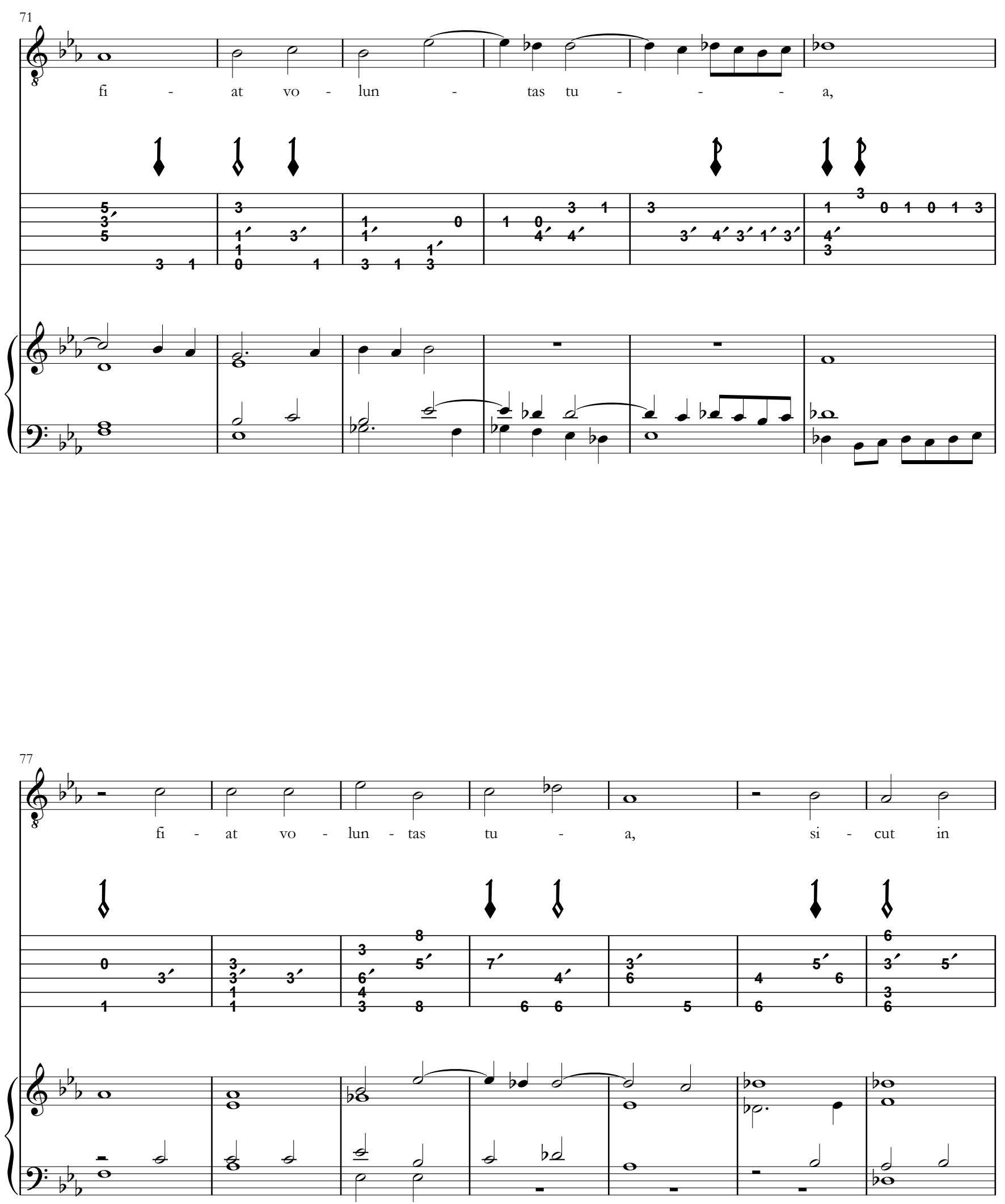

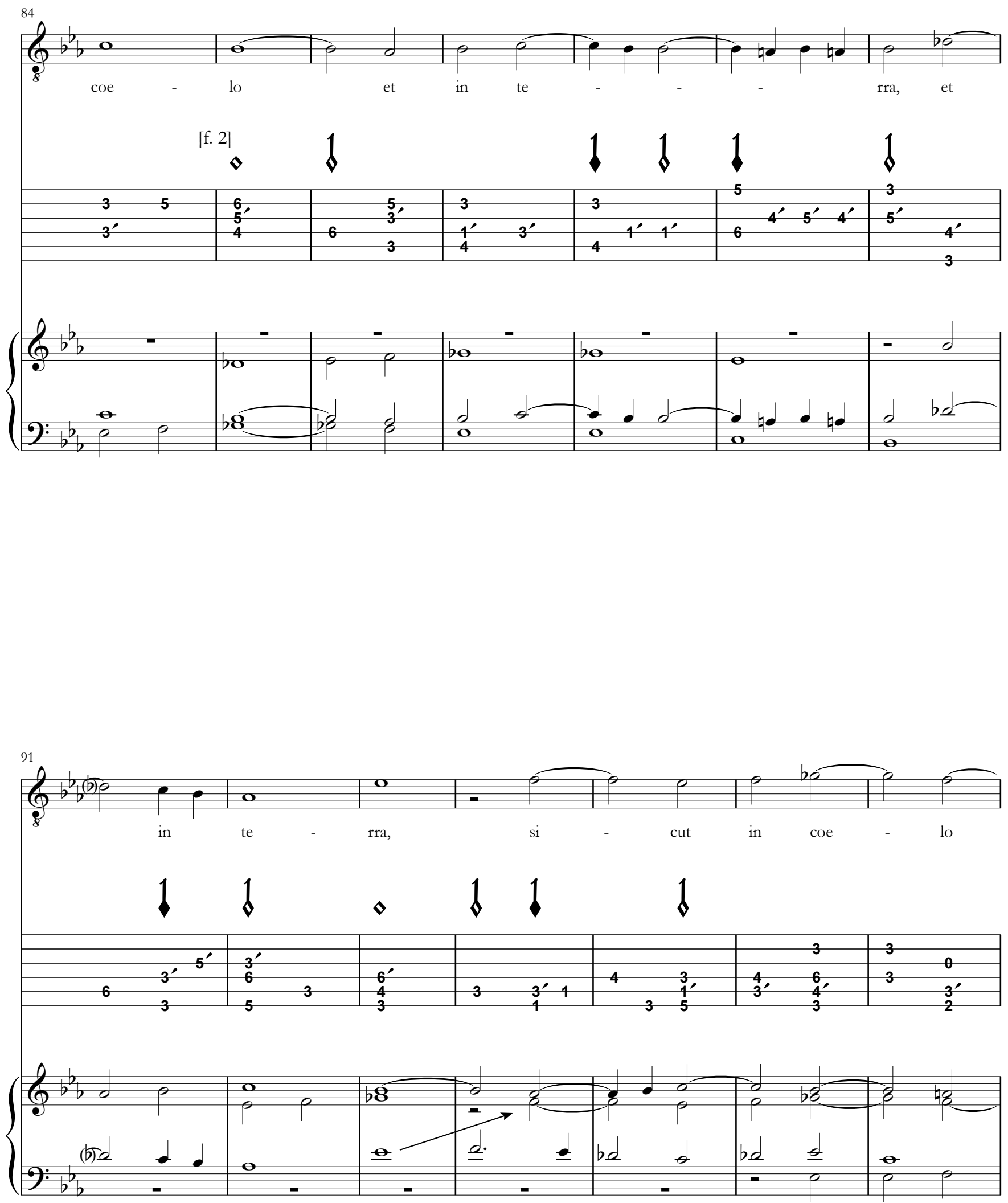

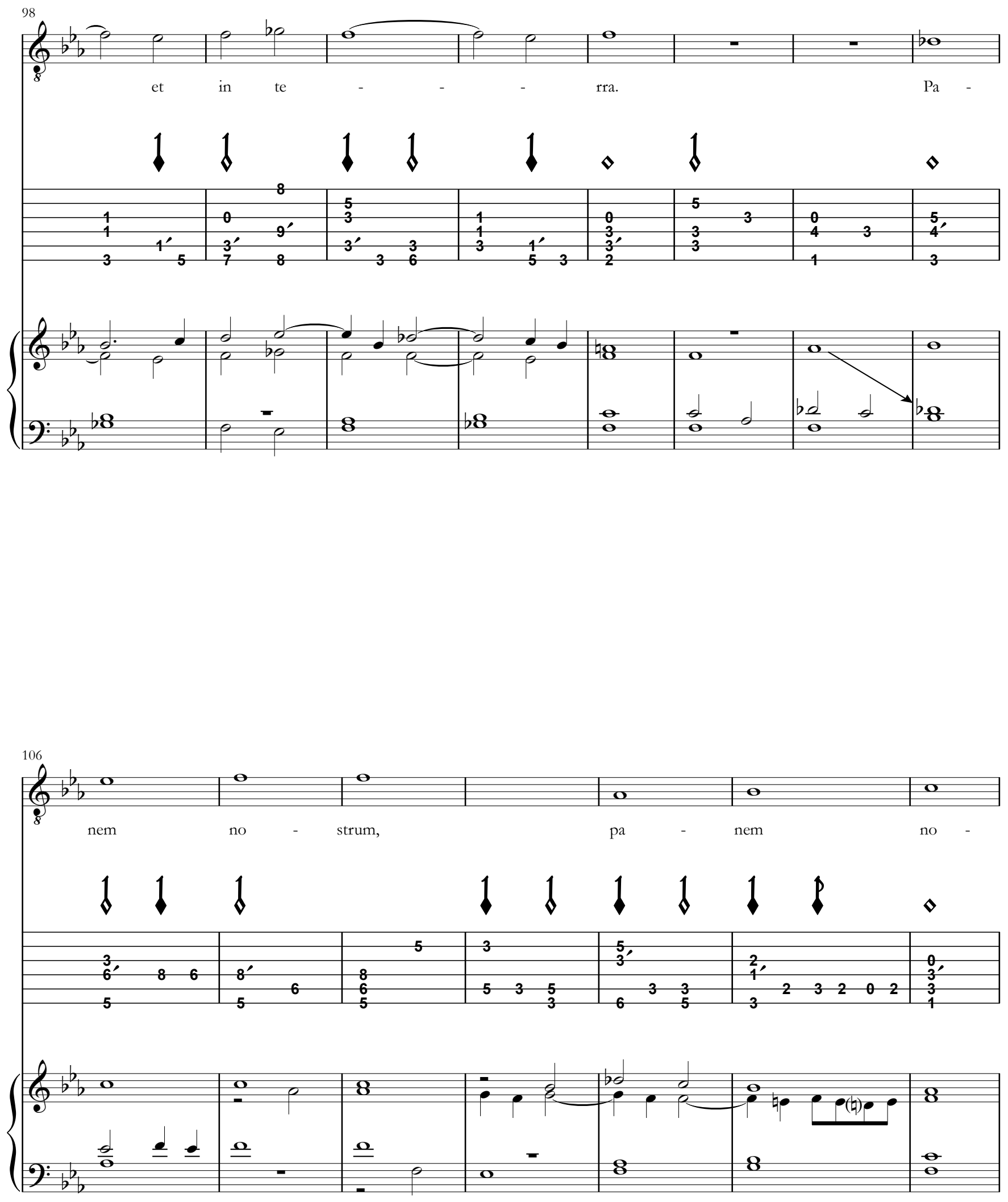

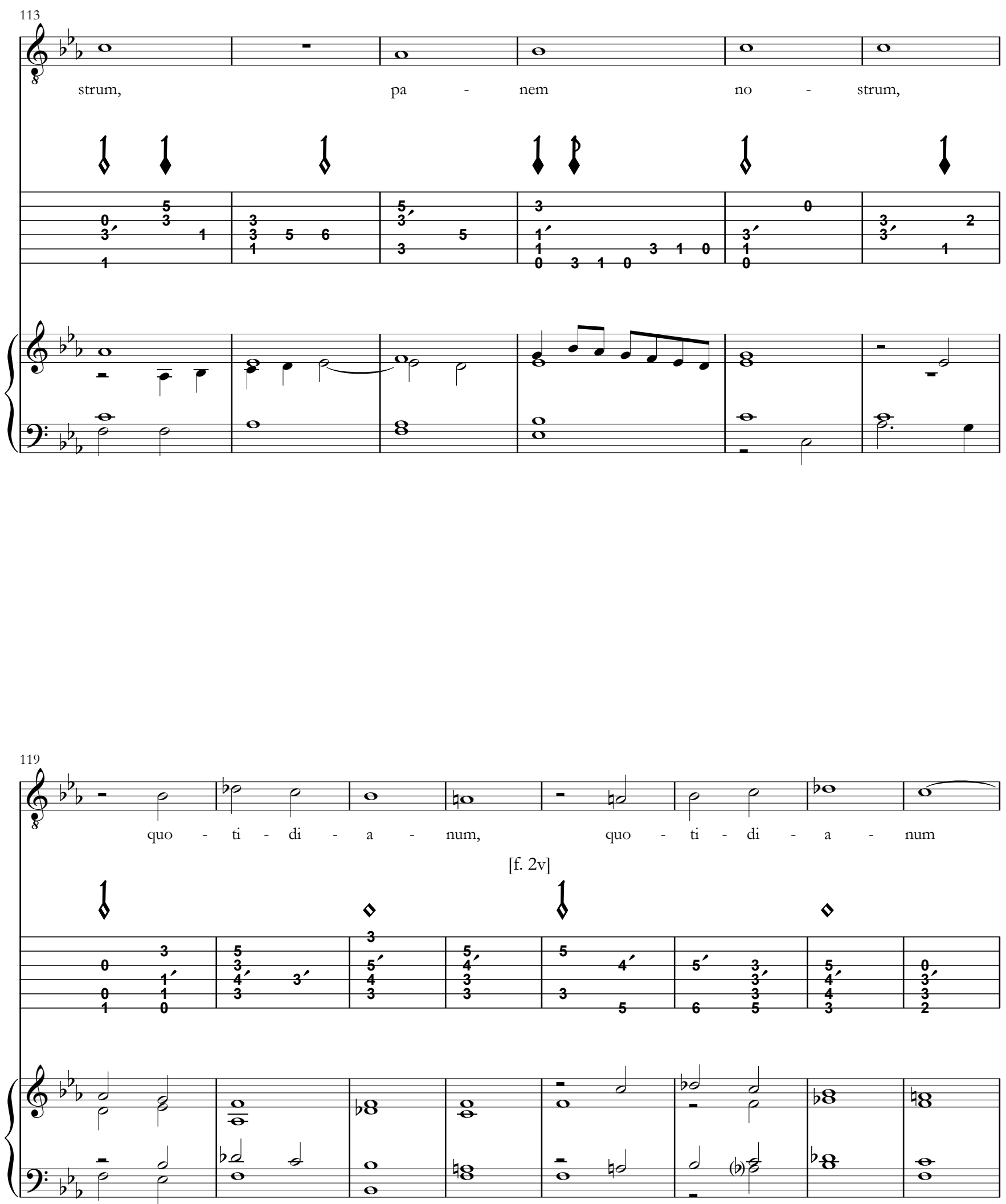

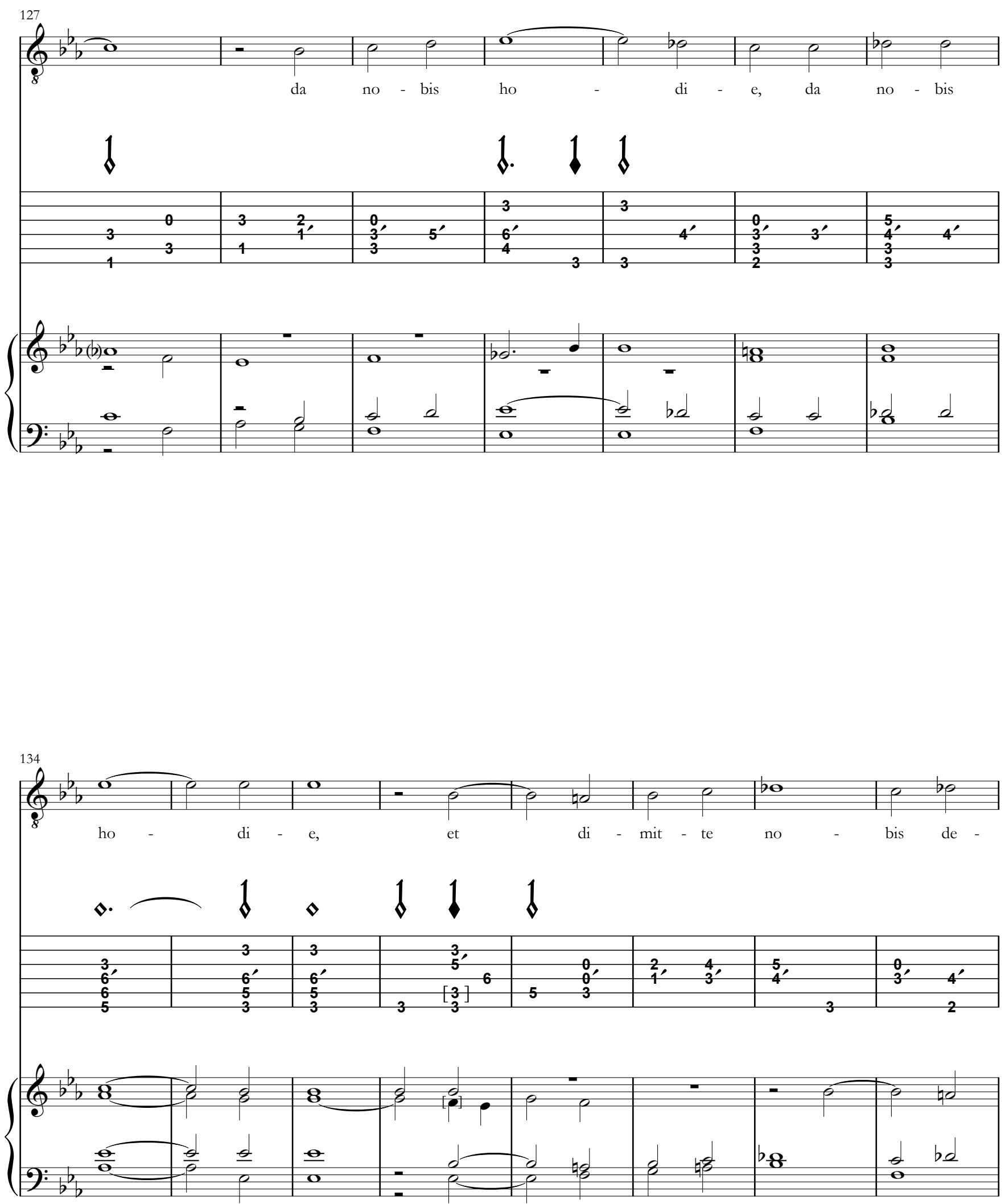

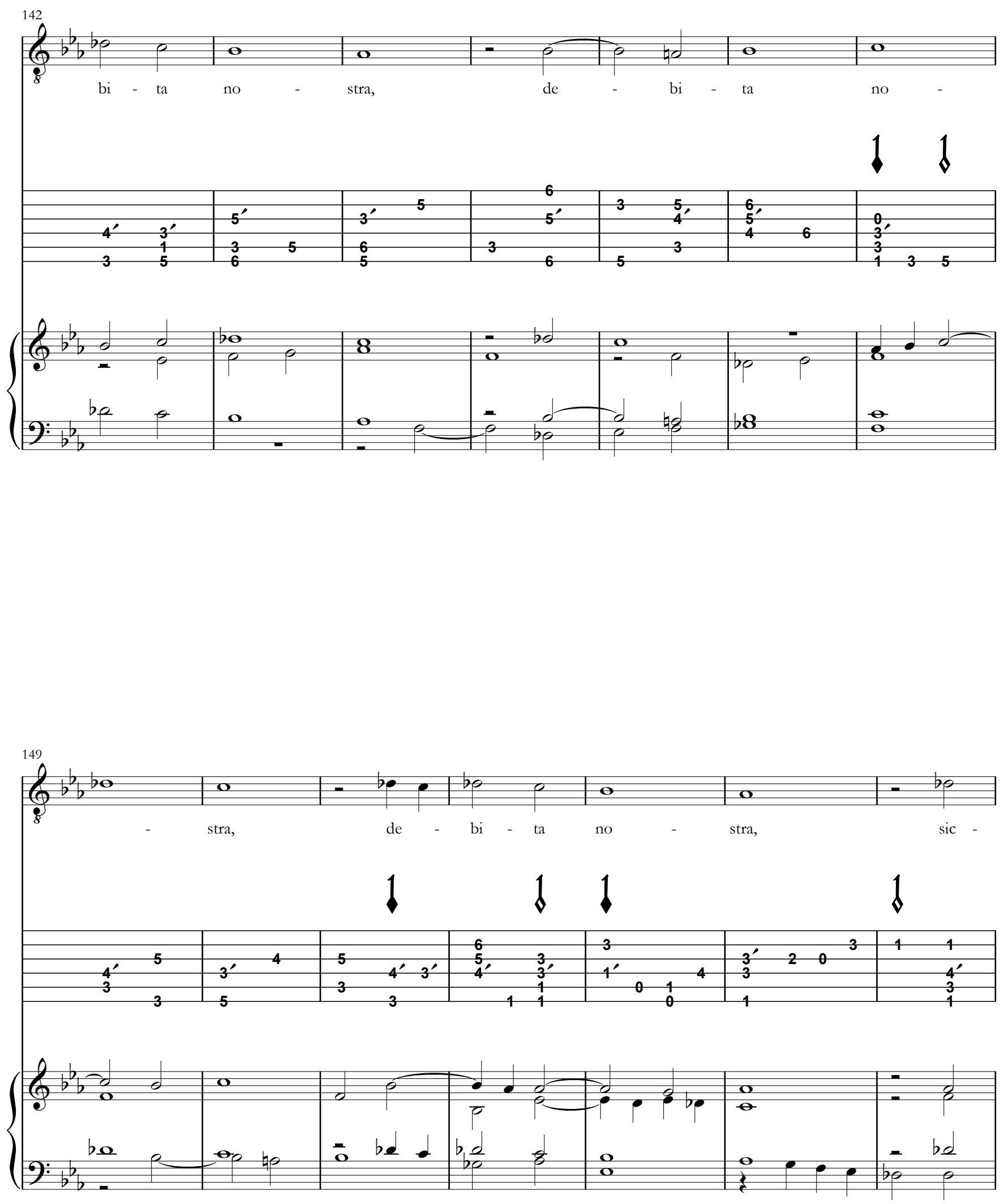

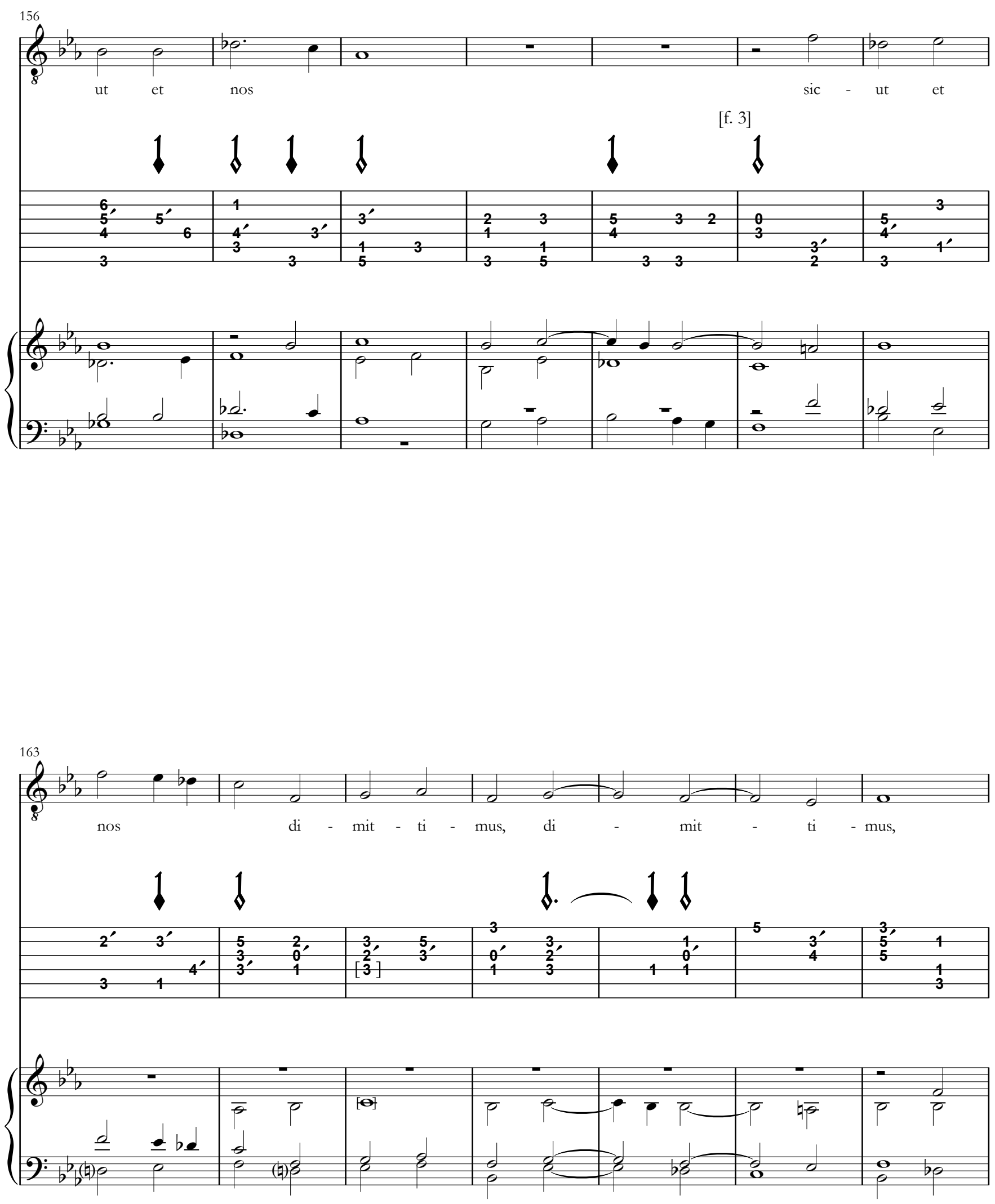

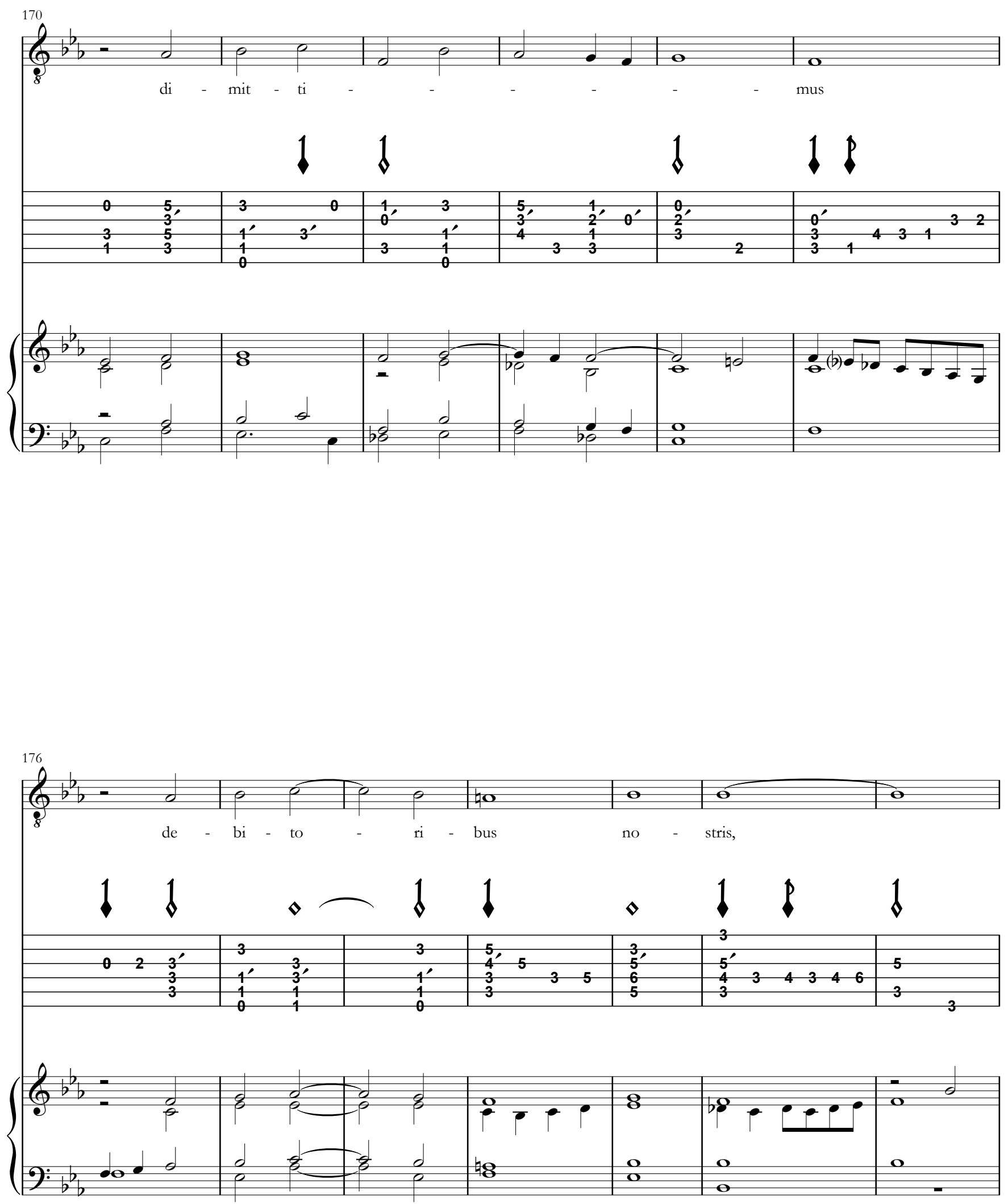

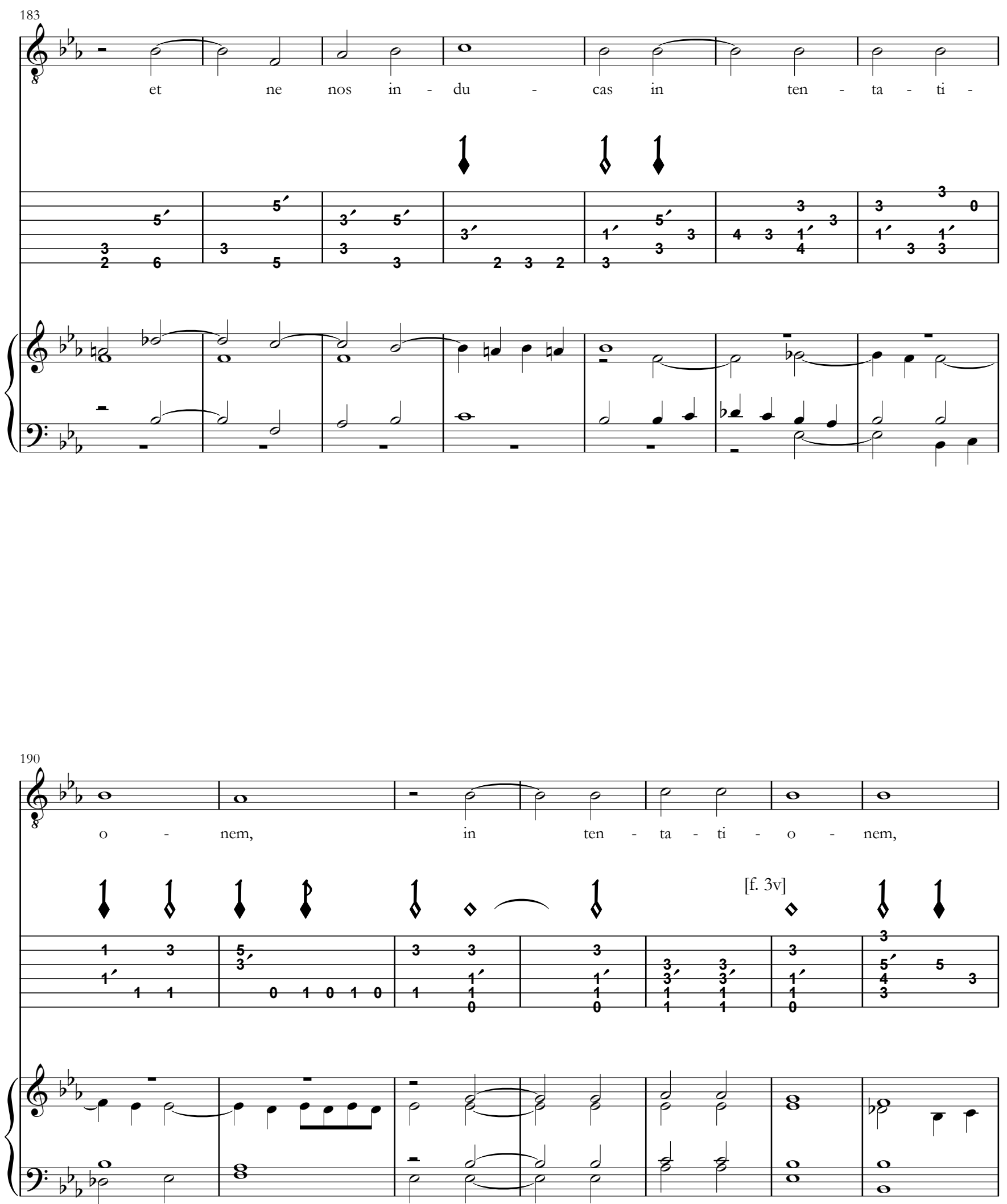

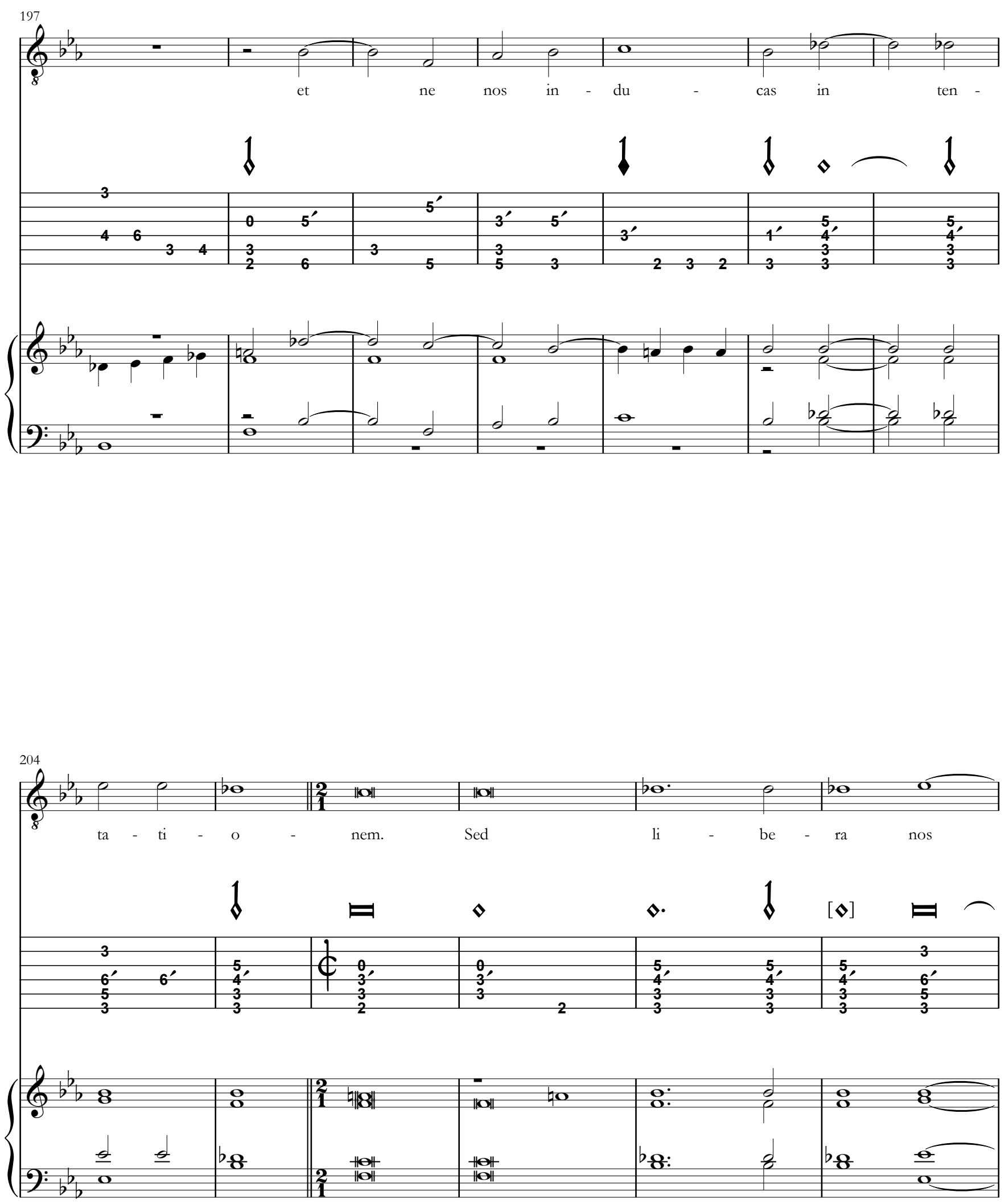

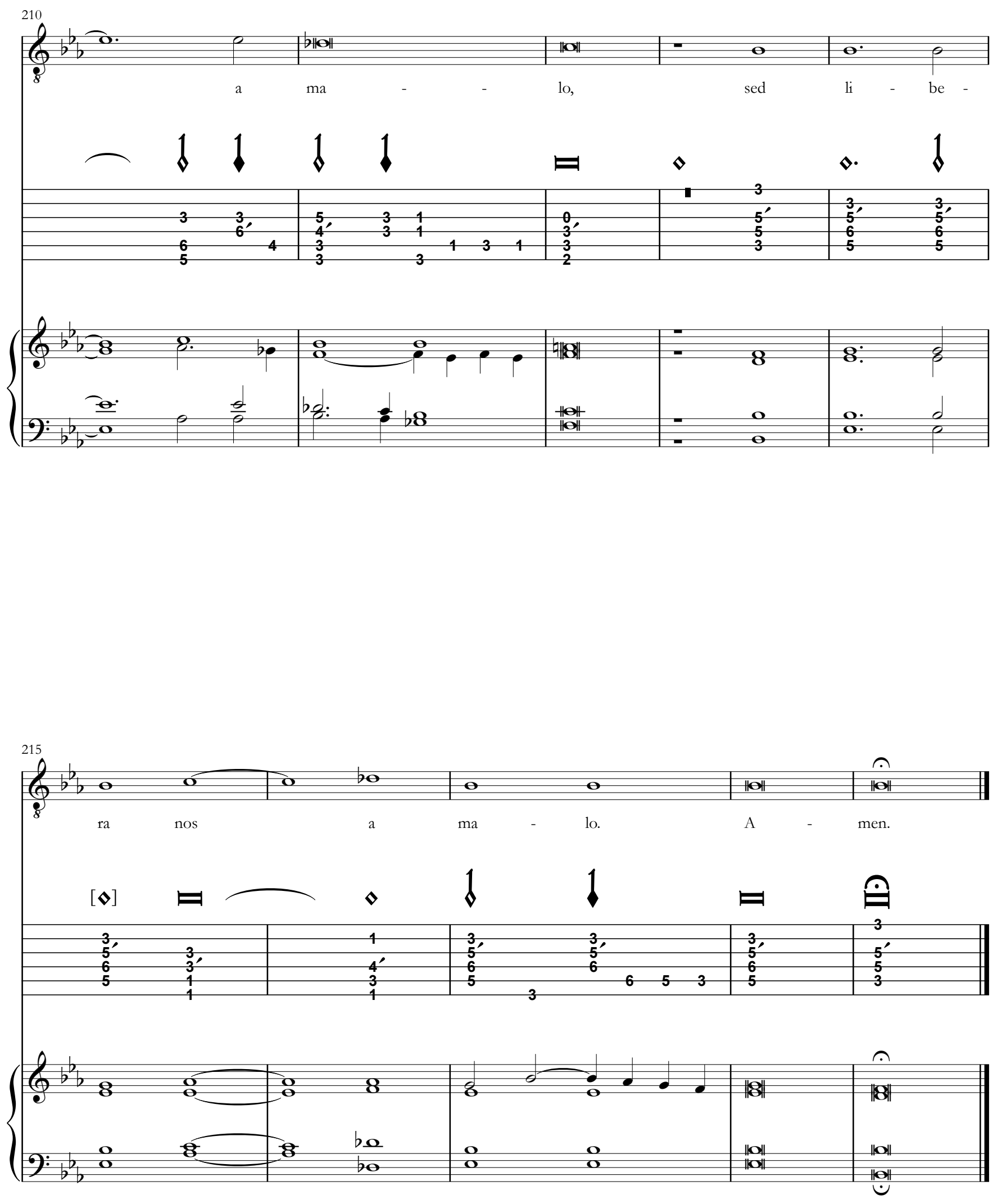


\section{so 51 - Respice in me, Deus}

[Motete II]

Respice in me deus de Gomberth [sic]

[Libro III, II]
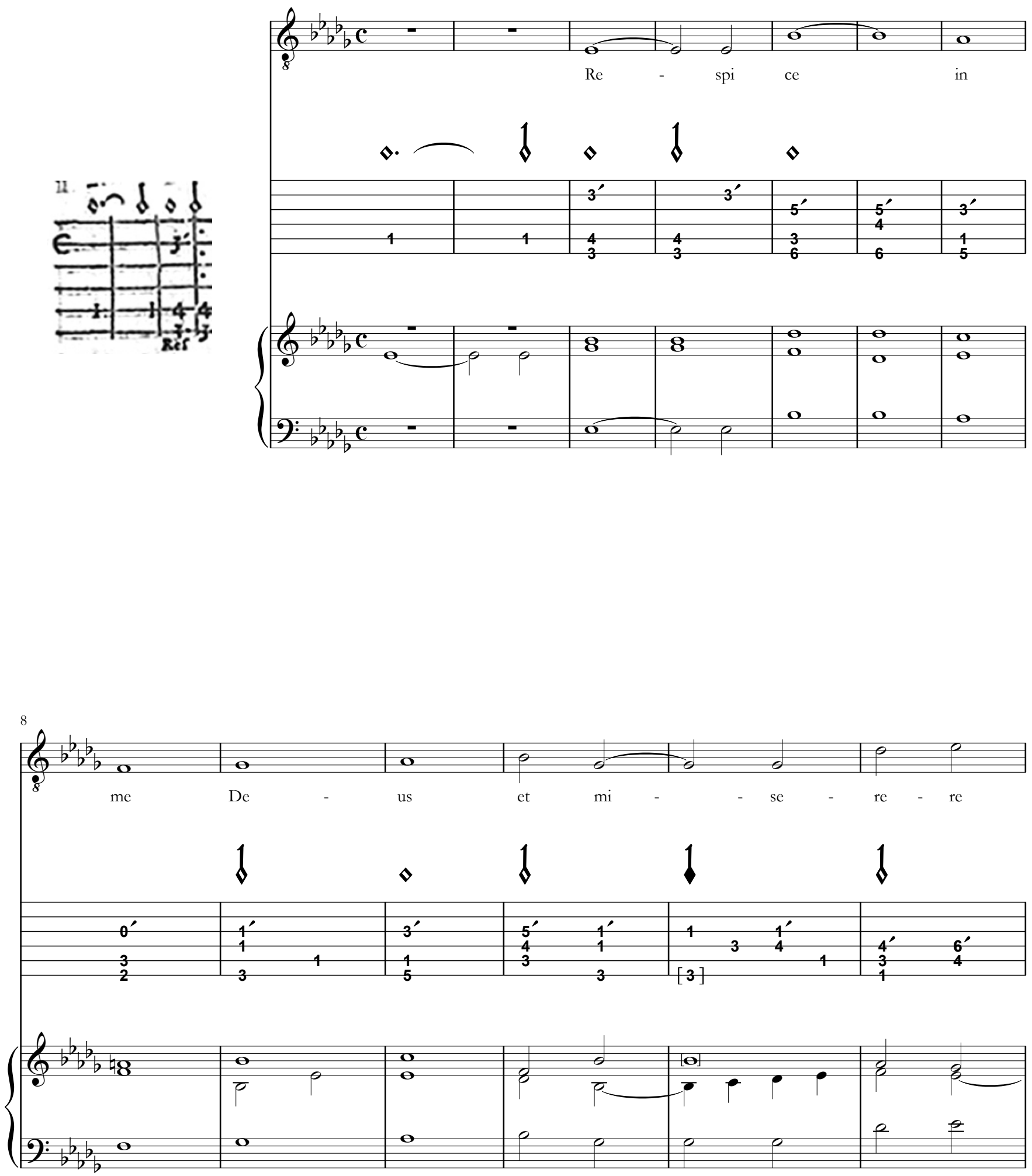

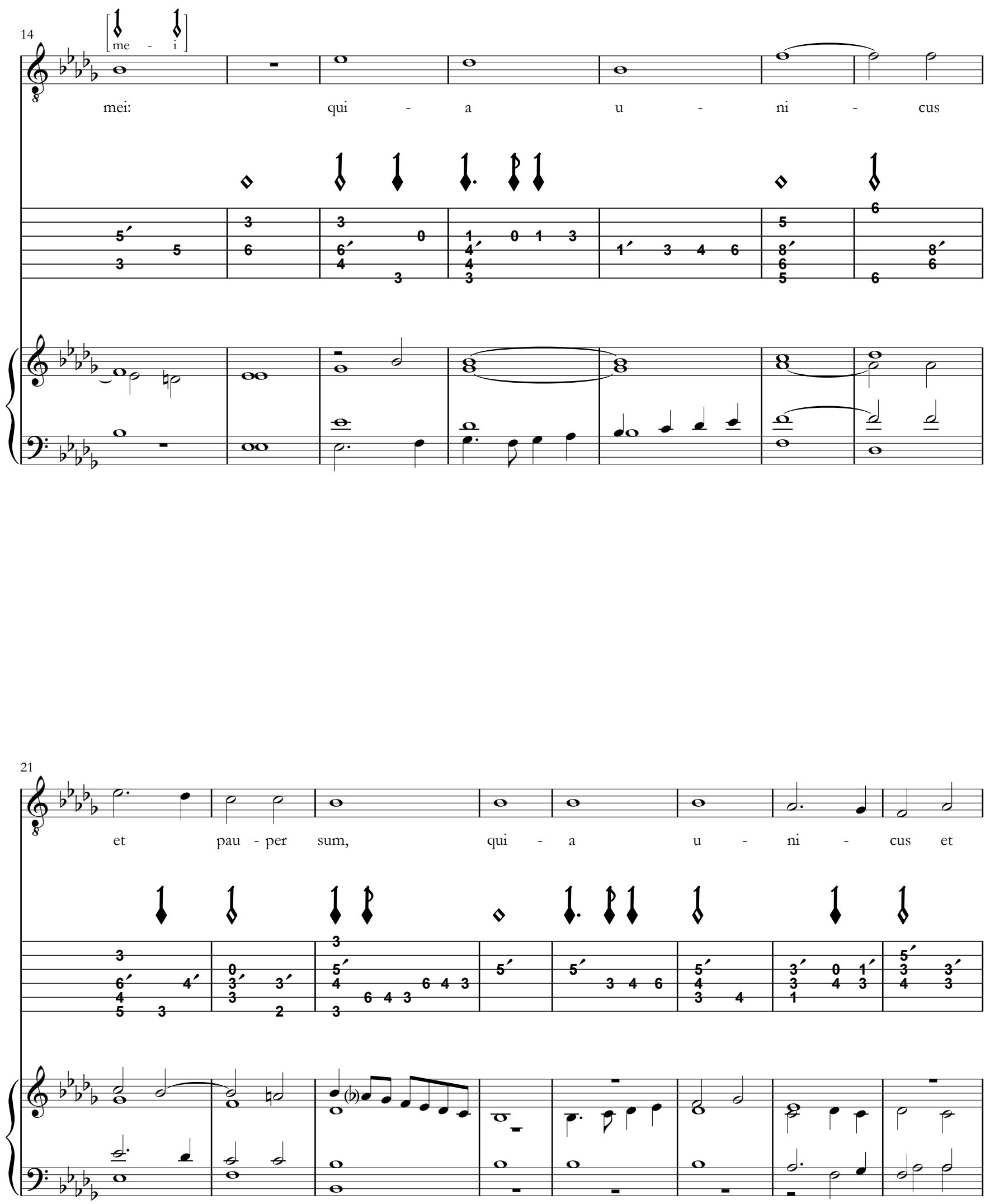

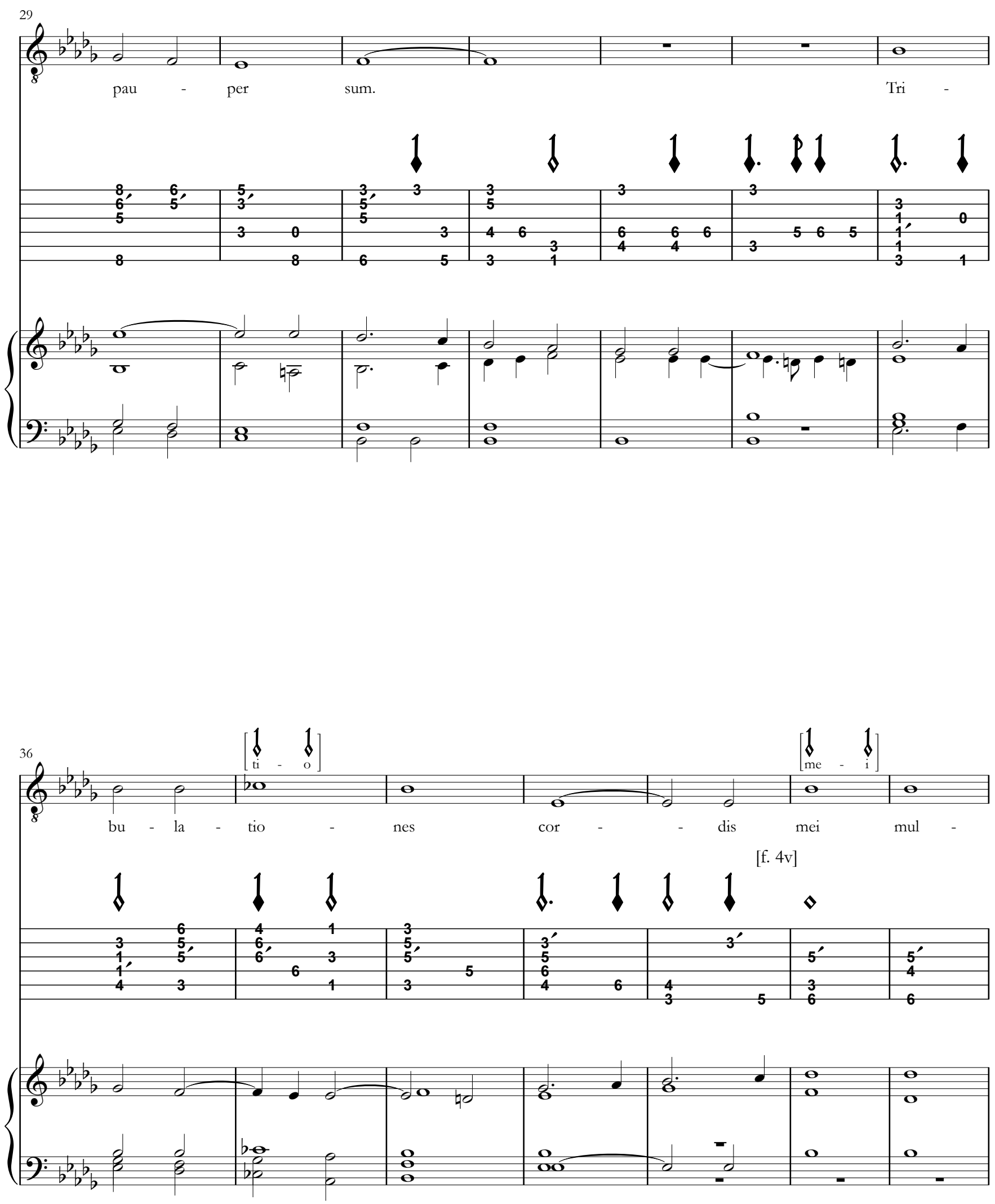

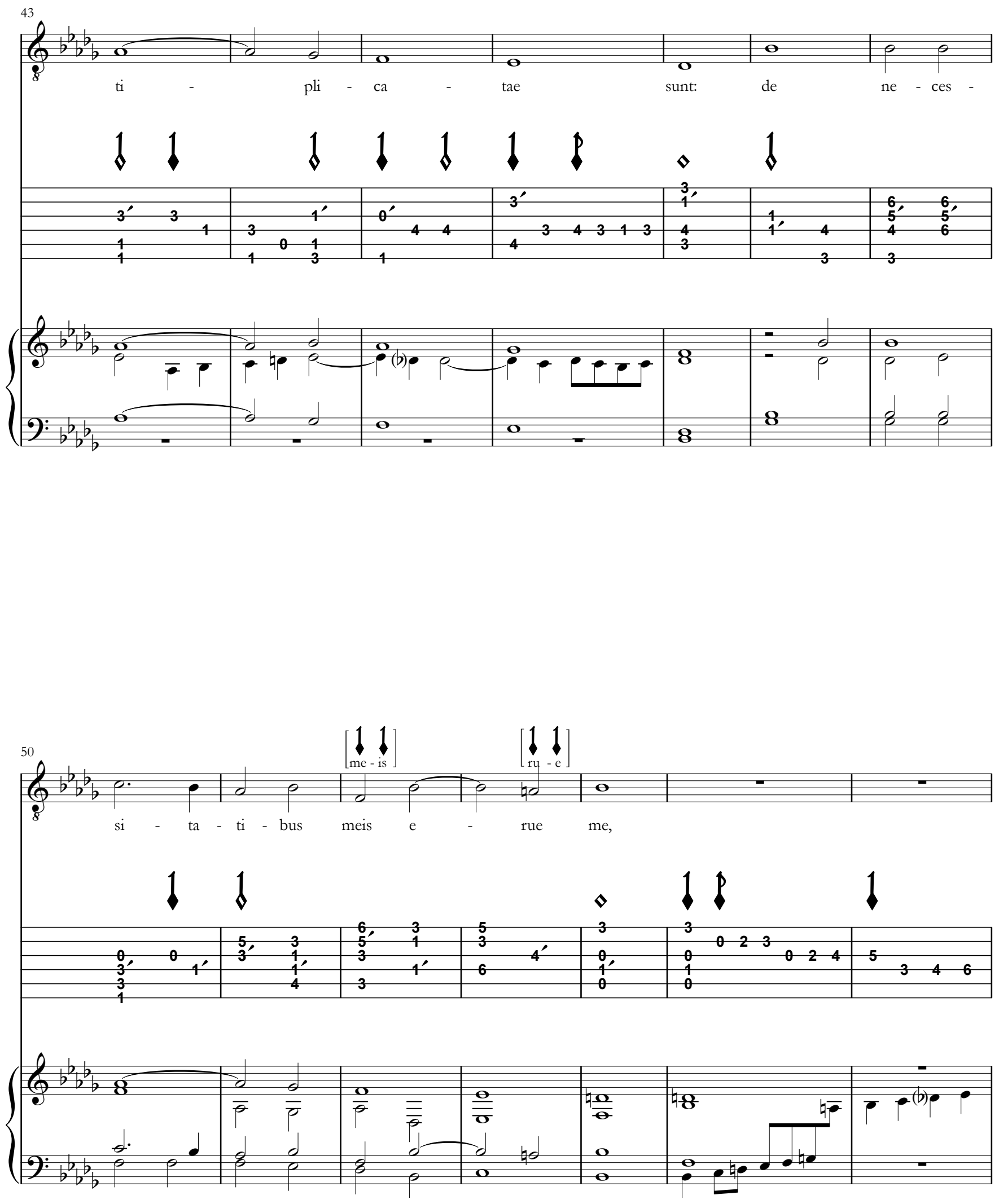

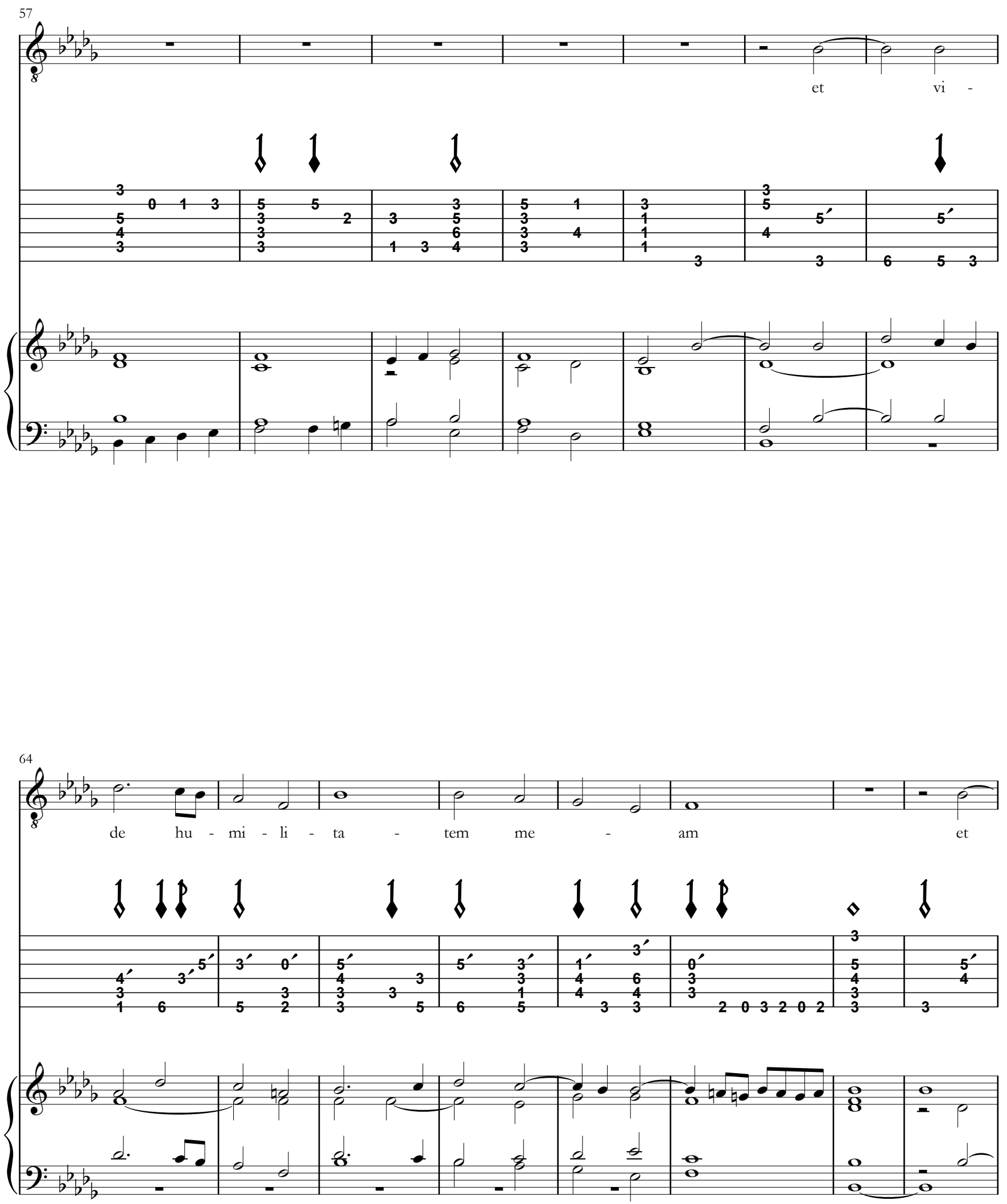

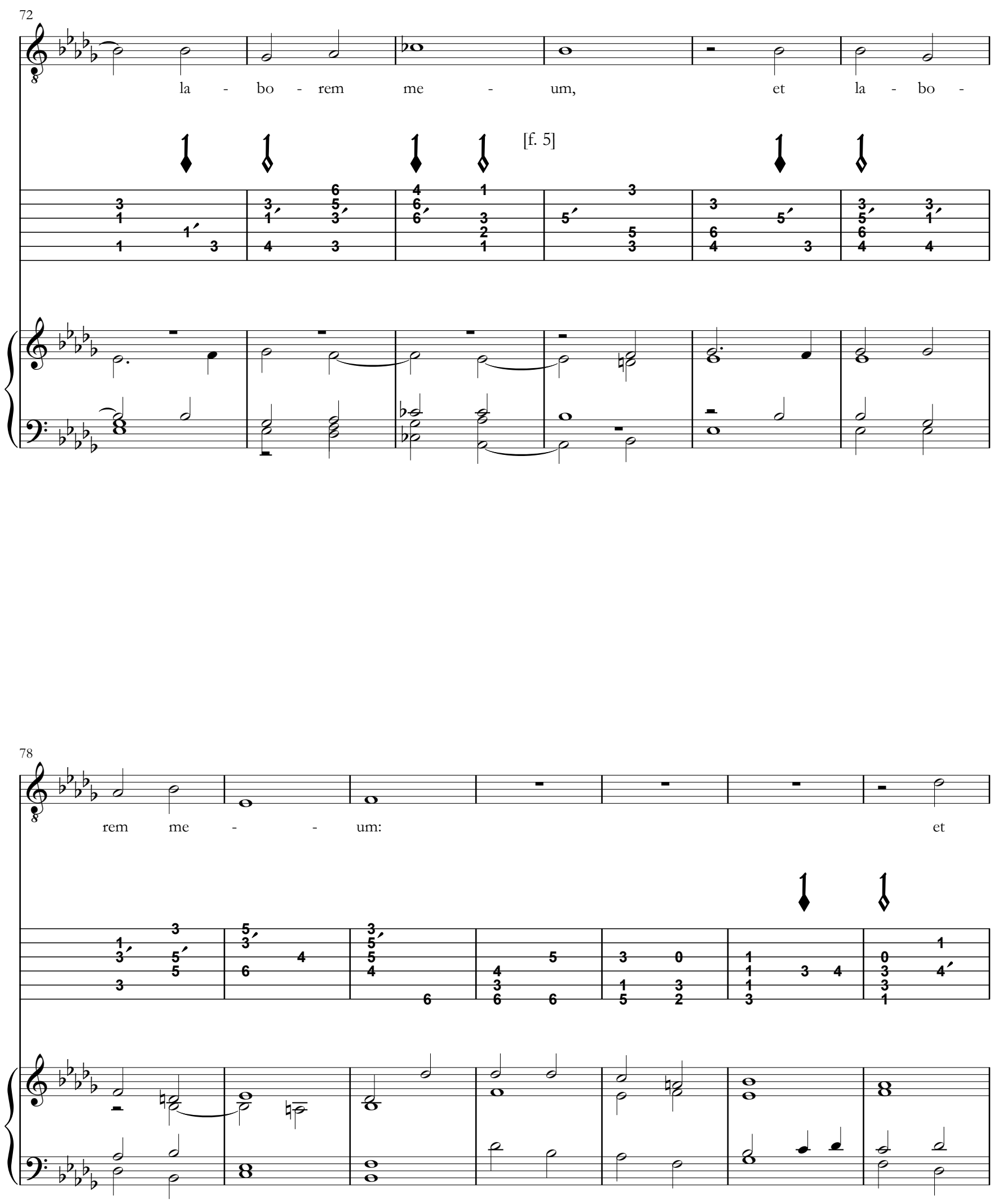

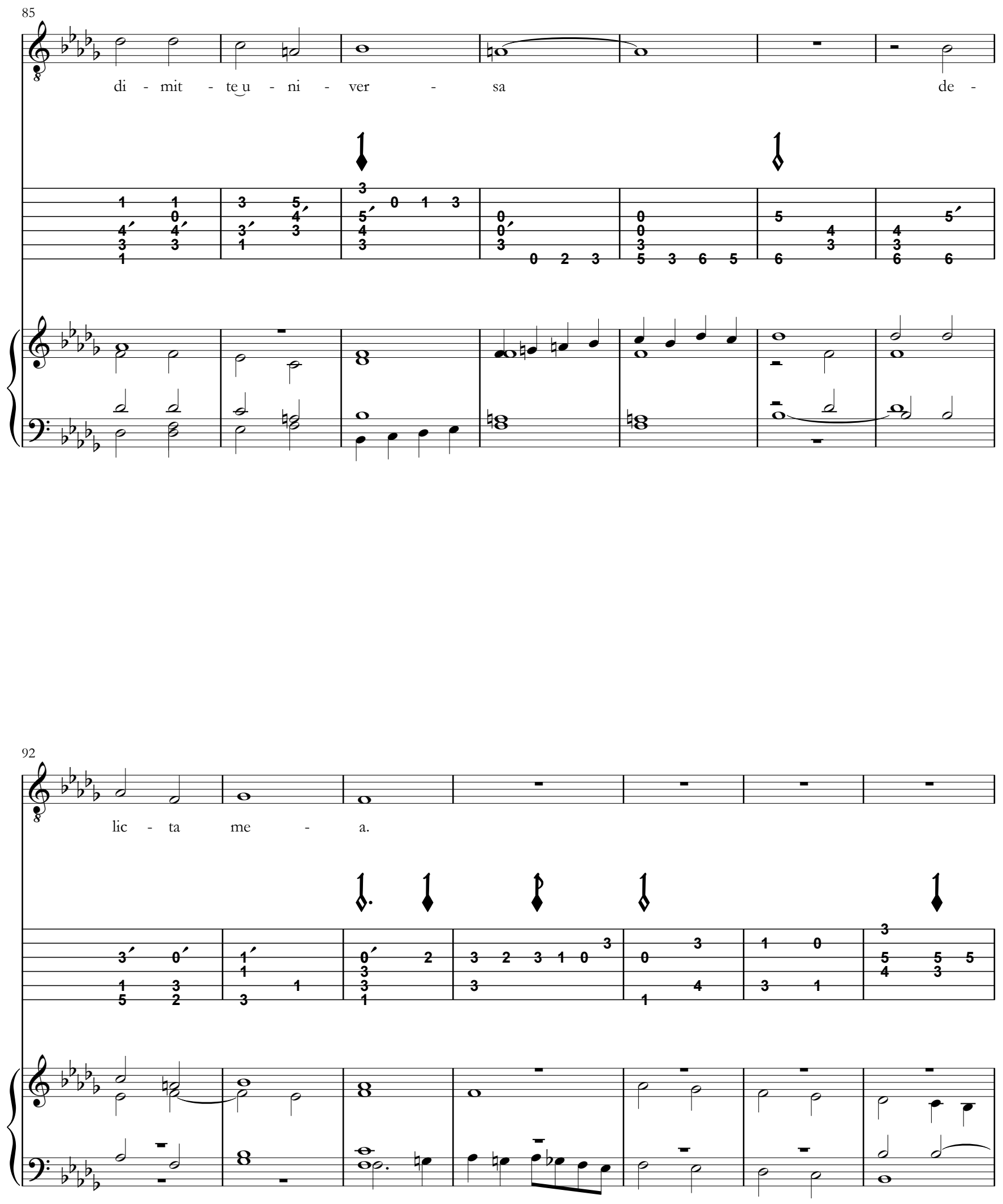

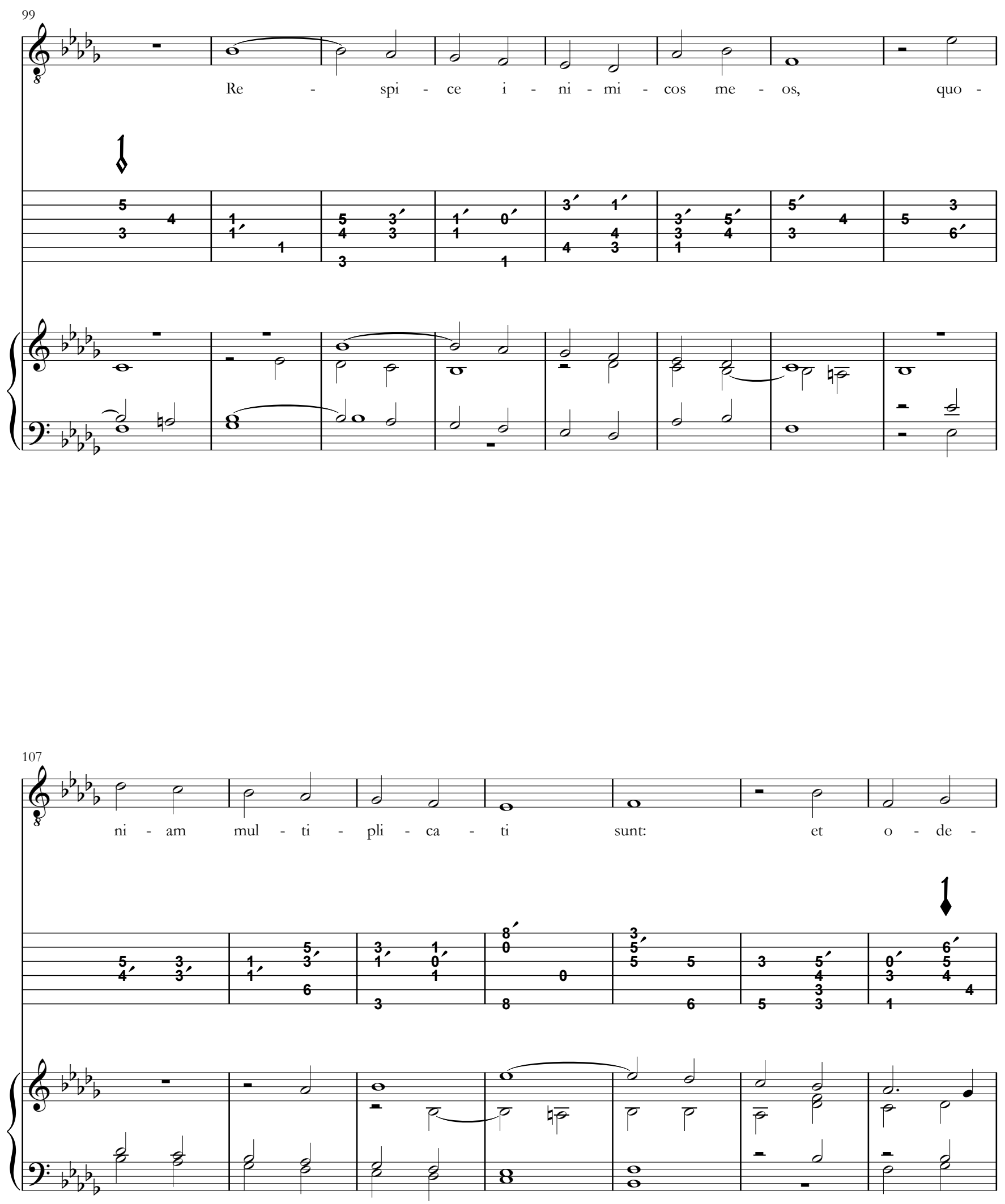

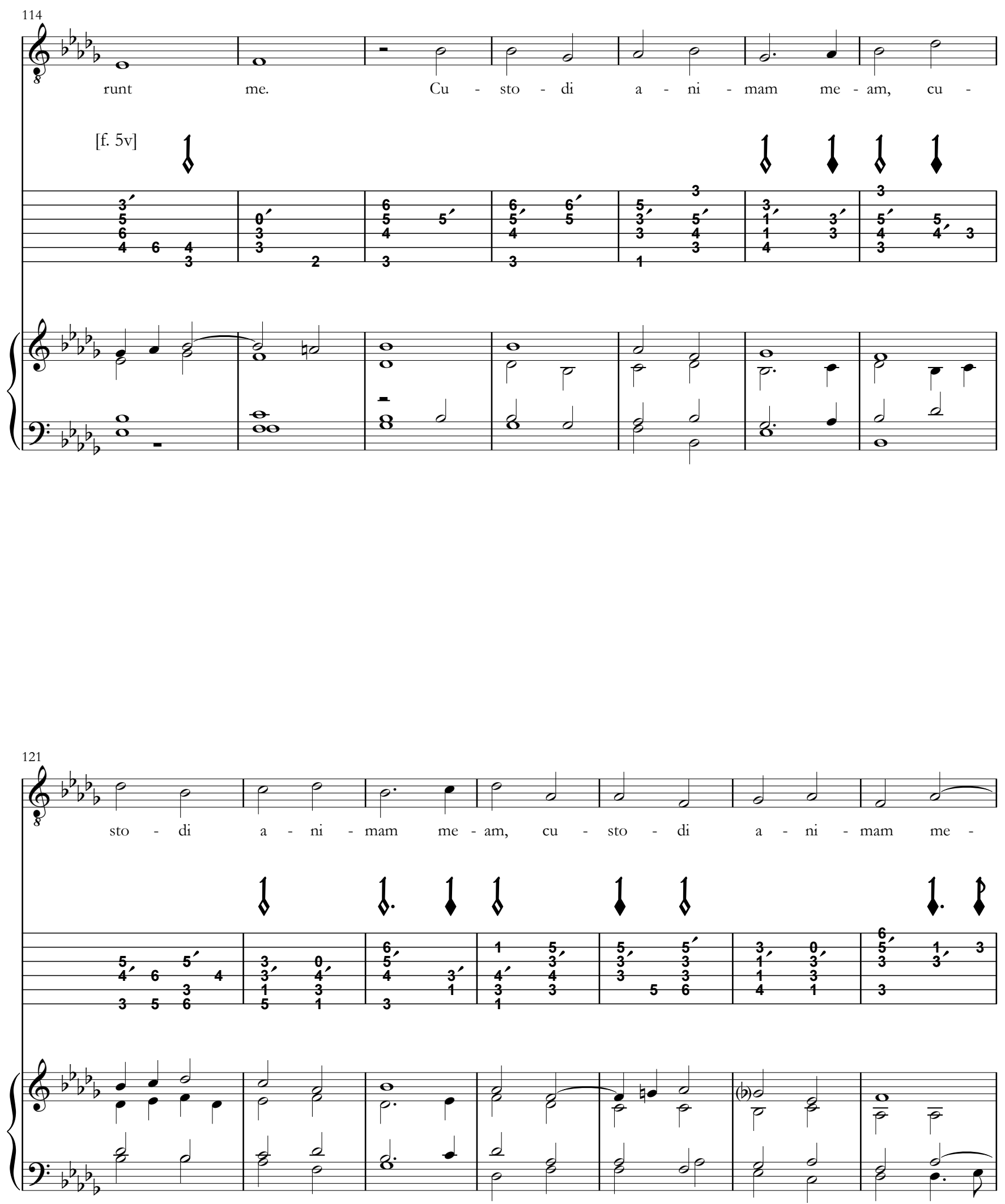

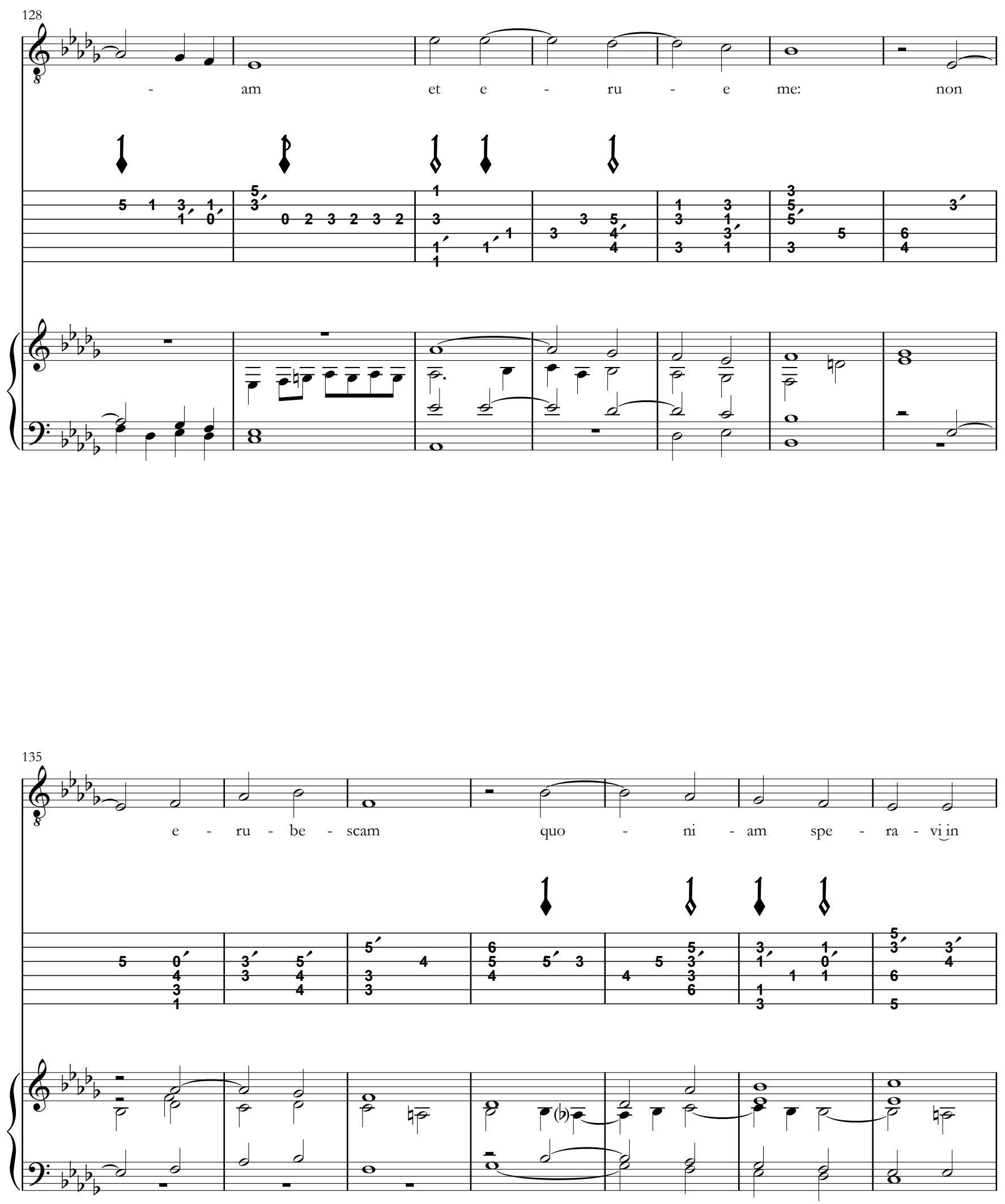

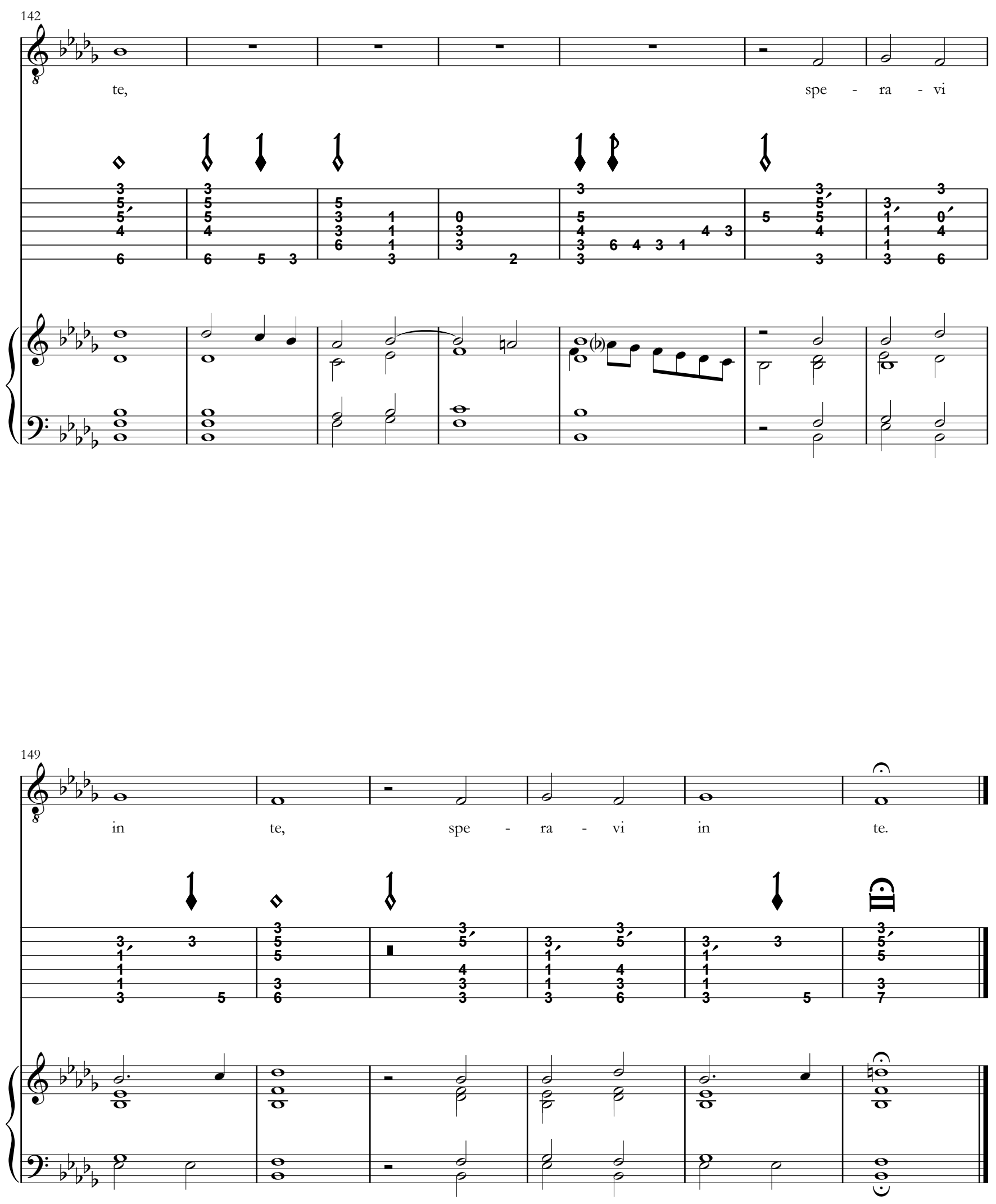
so 52 - Clamabat autem mulier. Motete de la cananea

[Motete III]

Entónase la boz en la tercera al tercero traste

[Libro III, III]

Pedro de Escobar/Mudarra
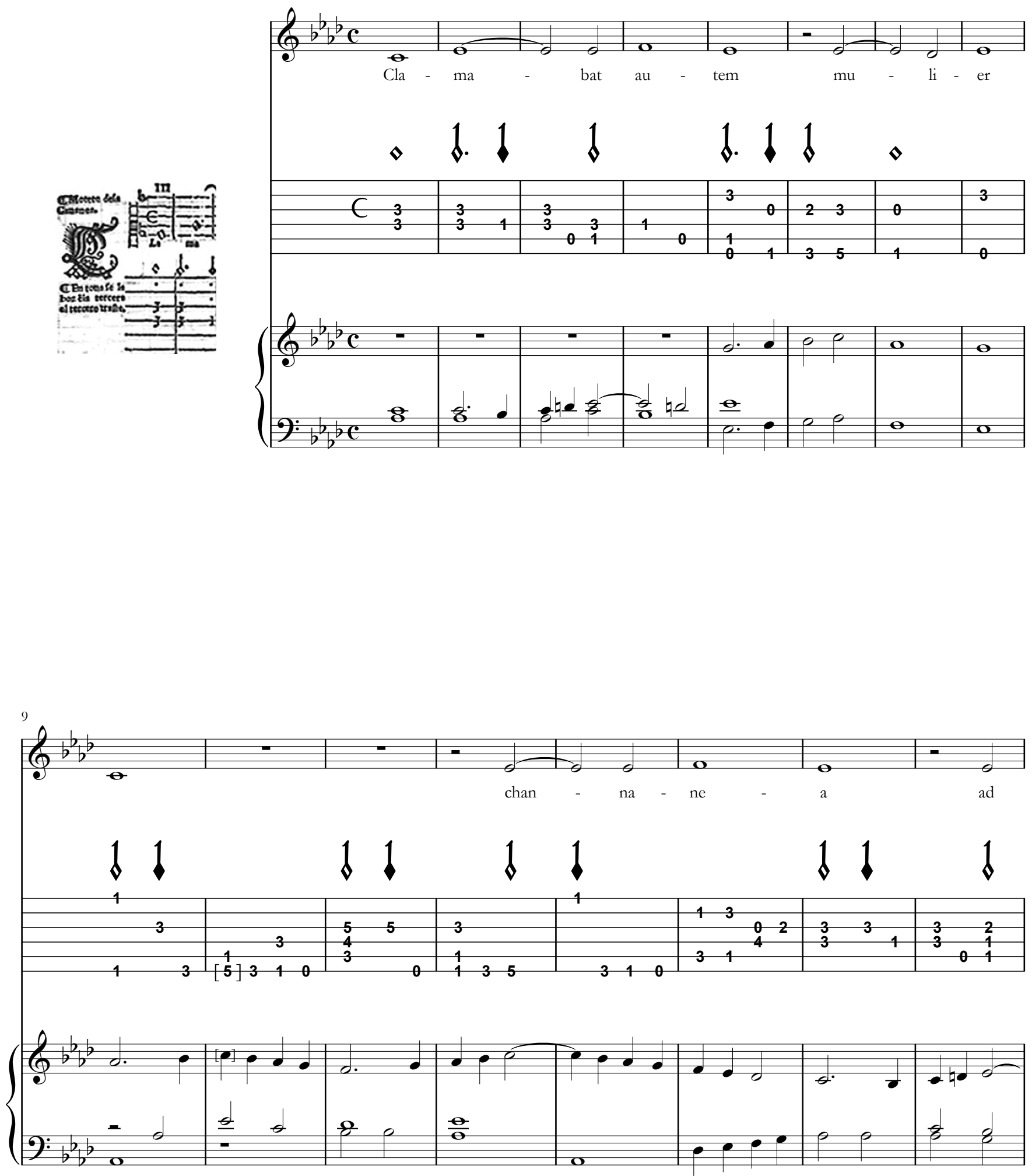

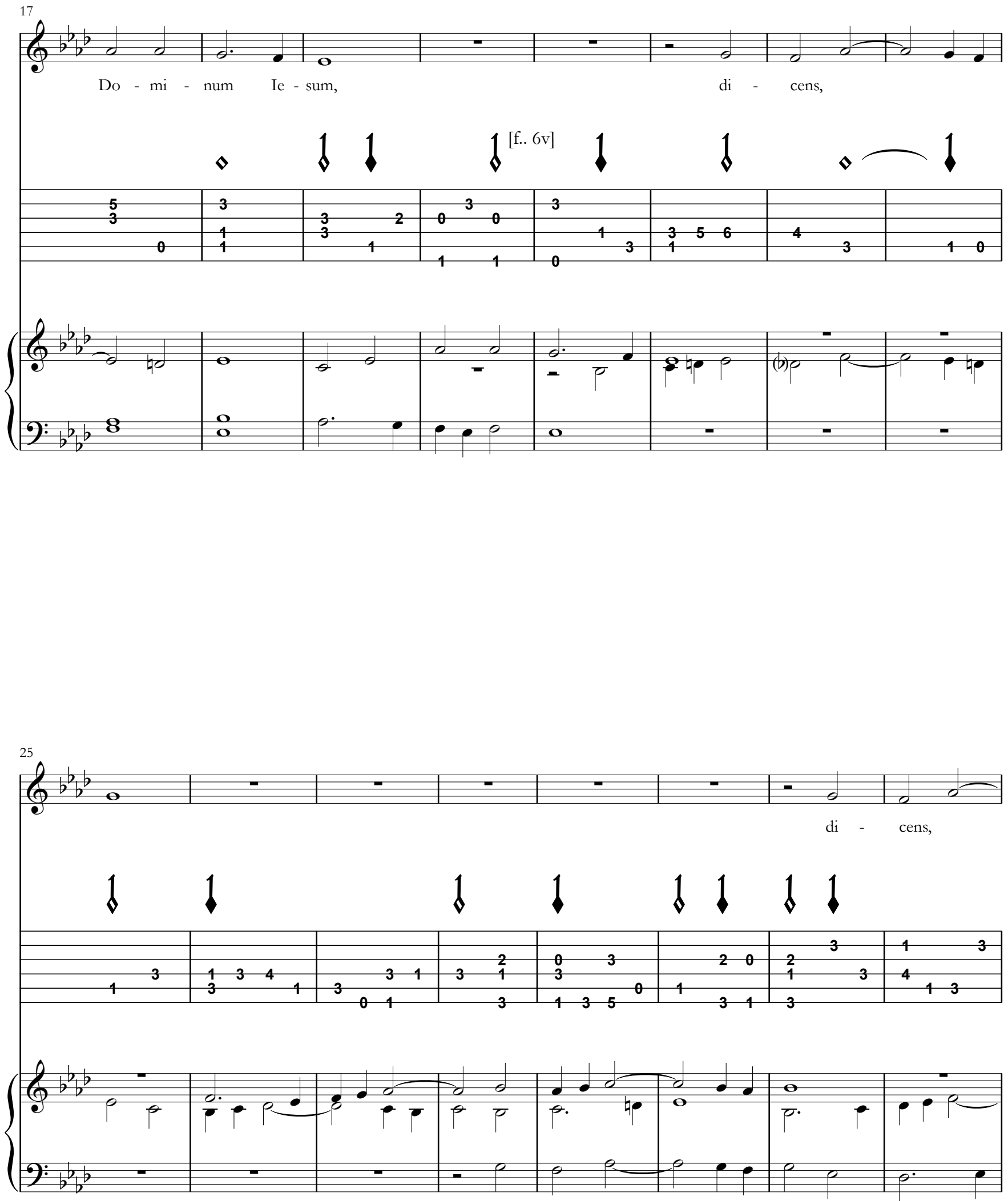

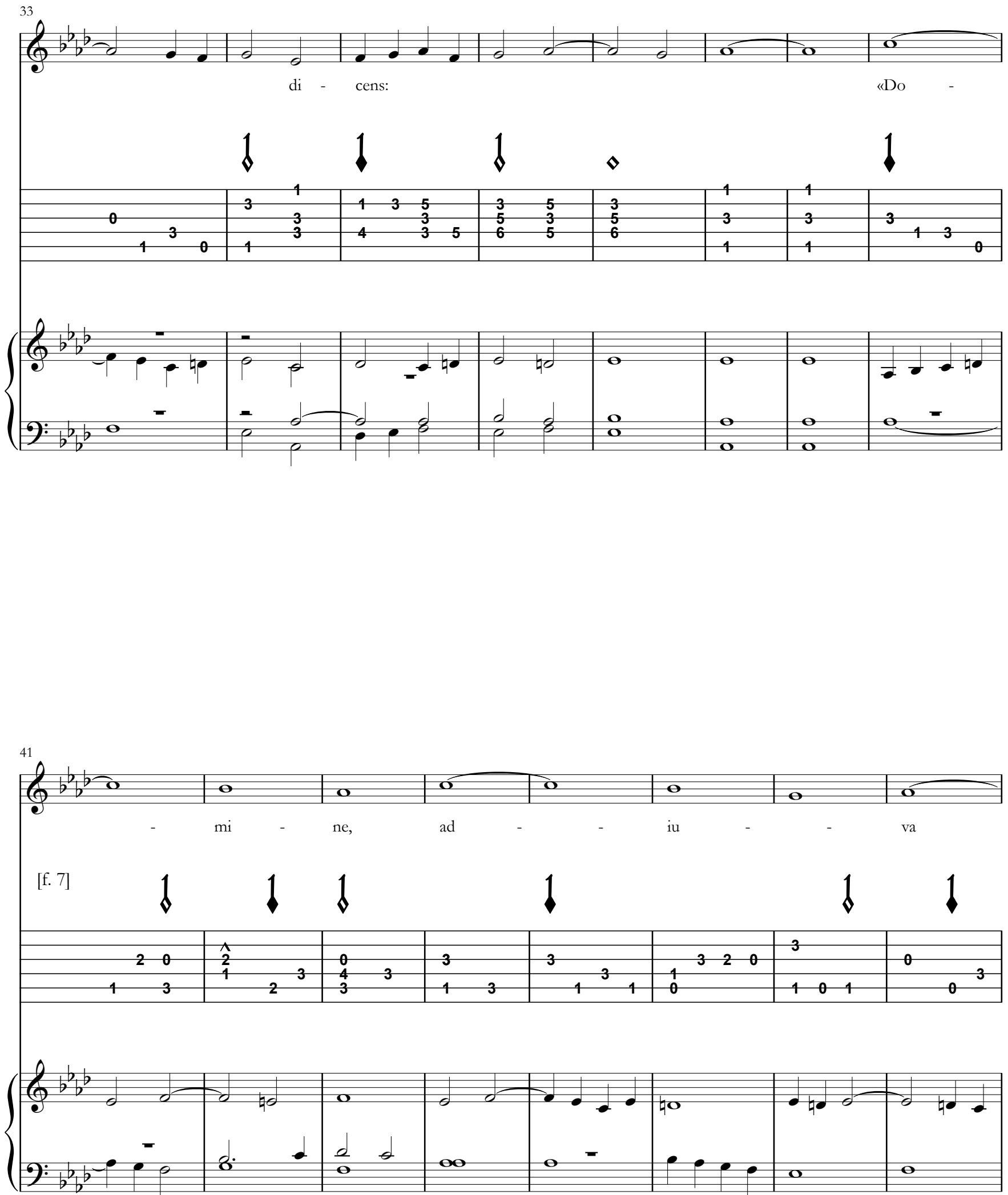

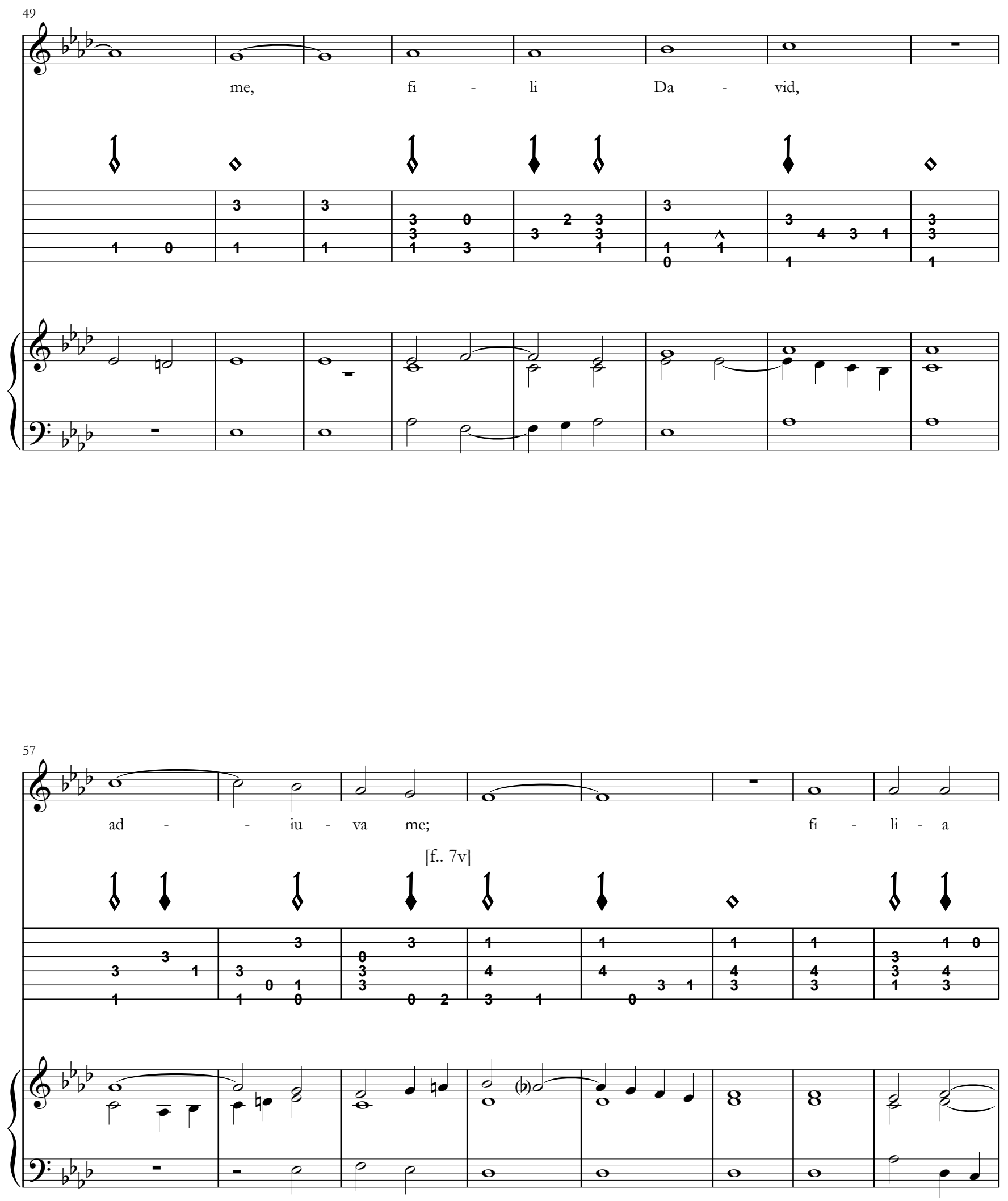

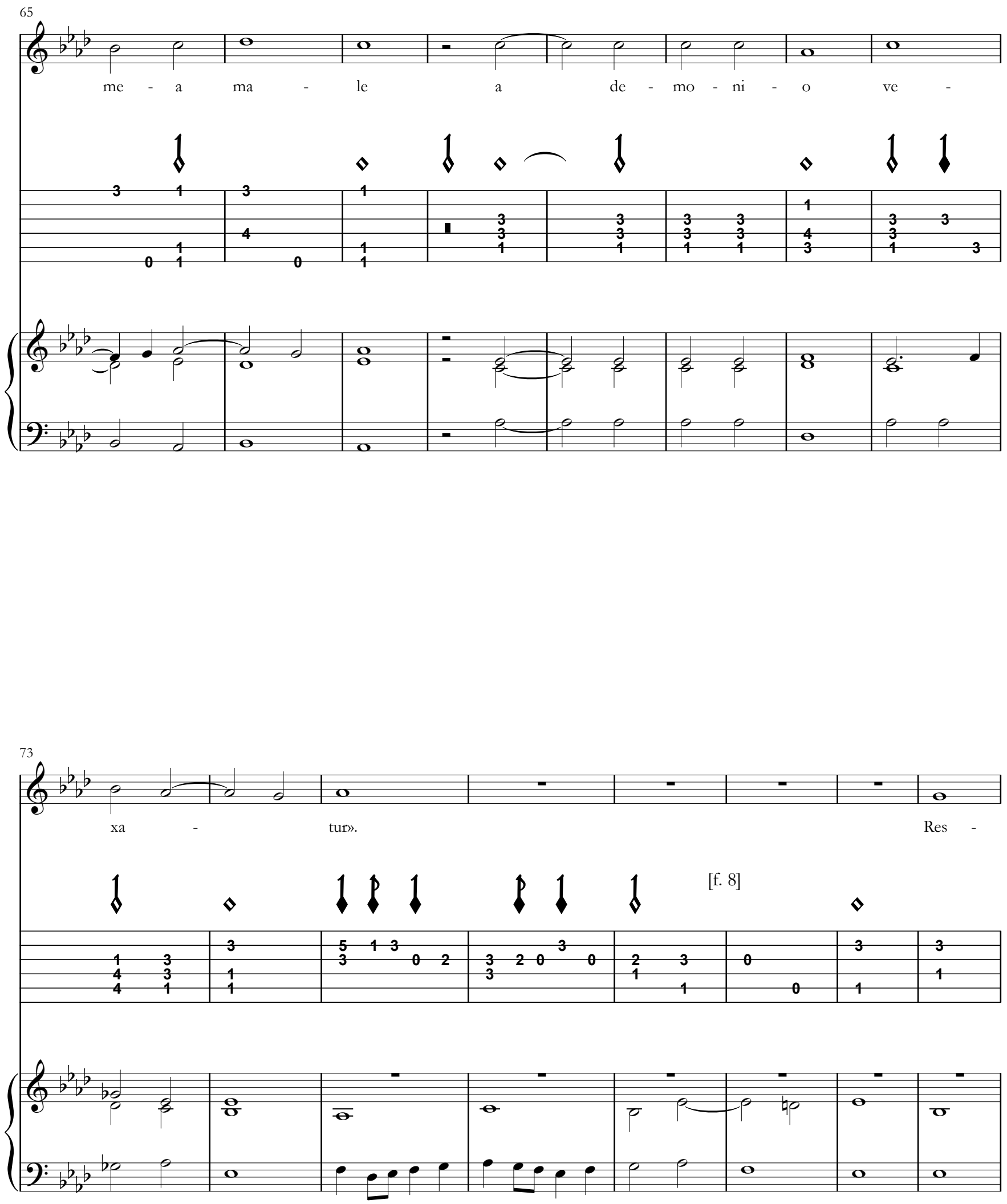

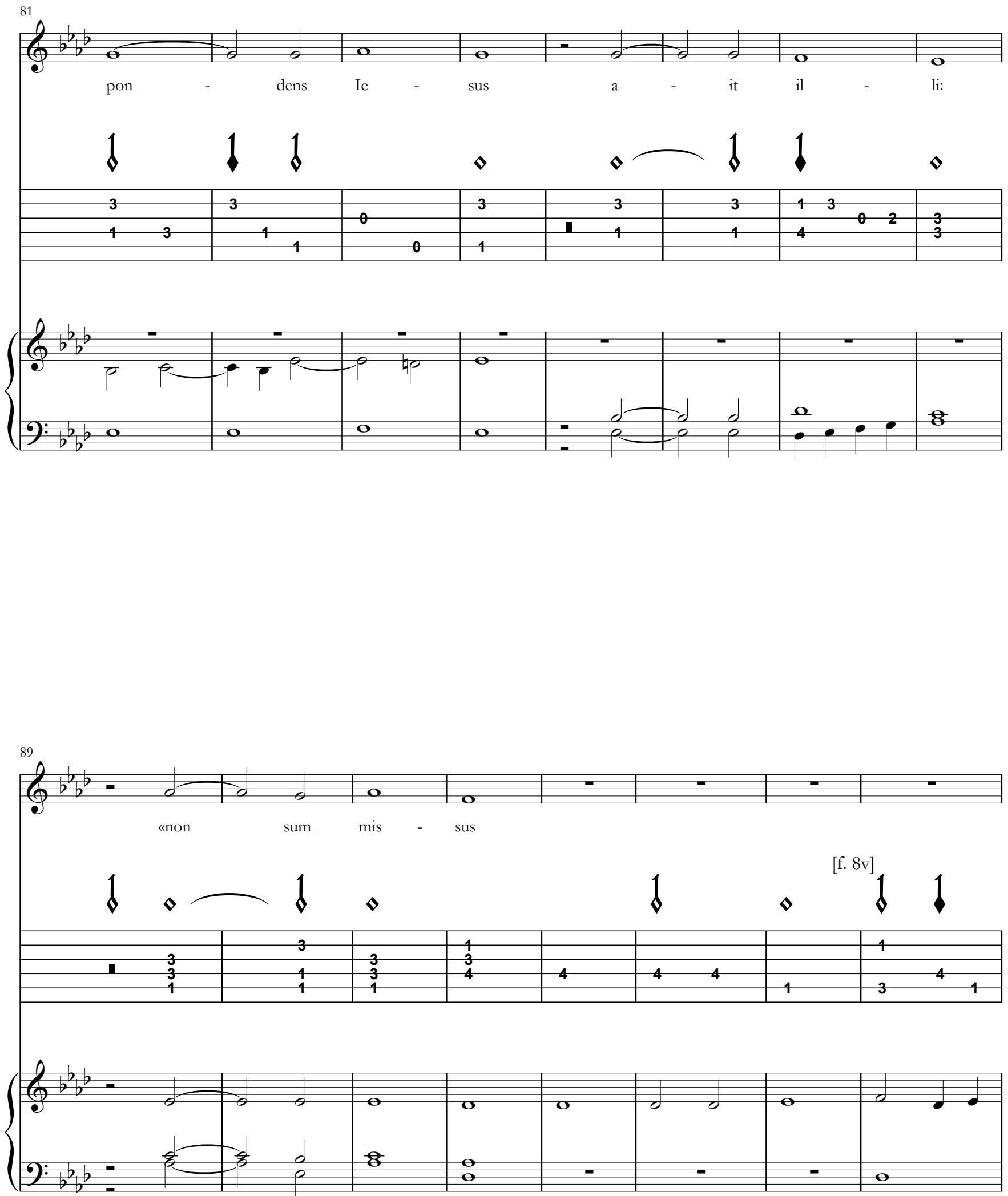

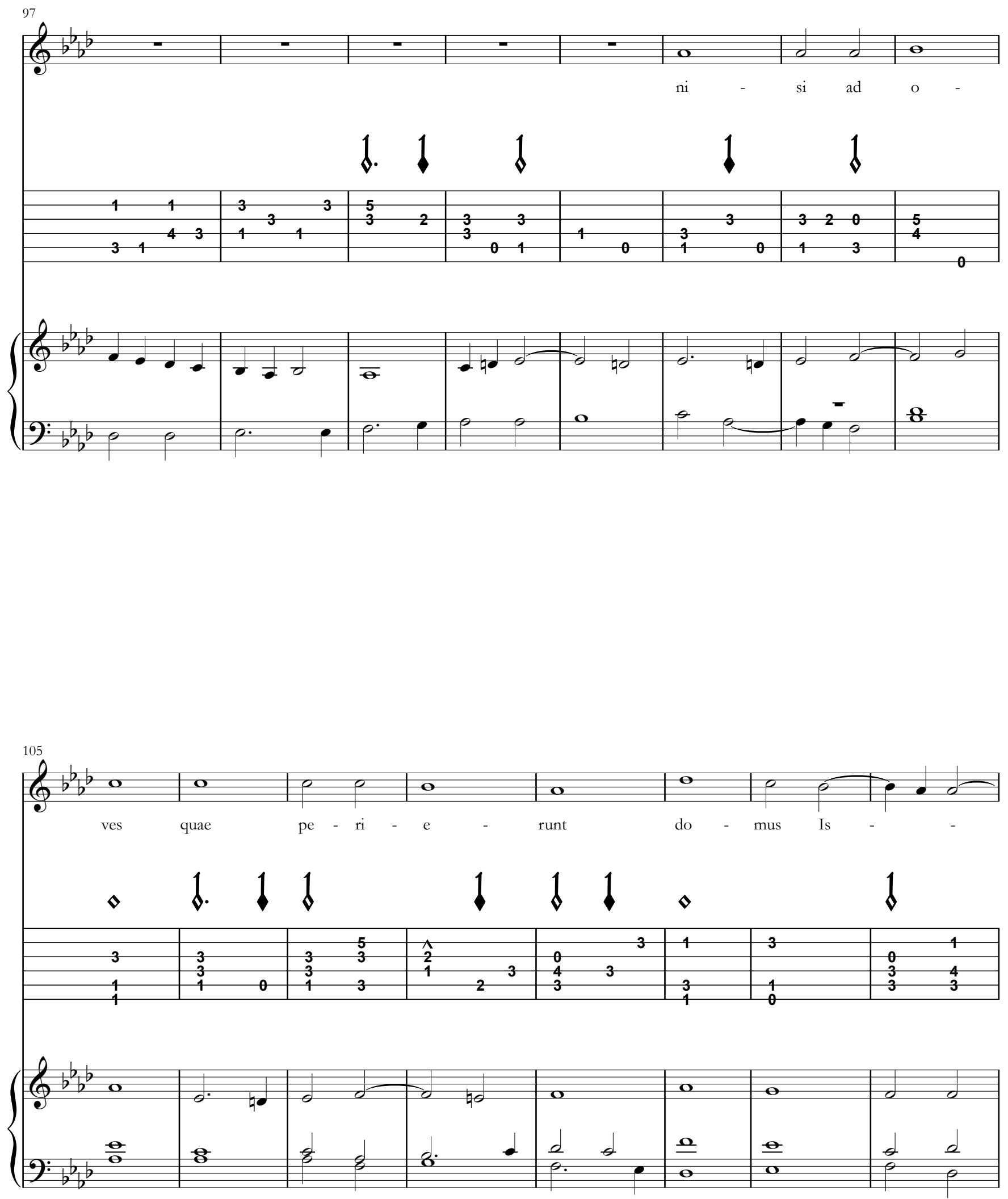

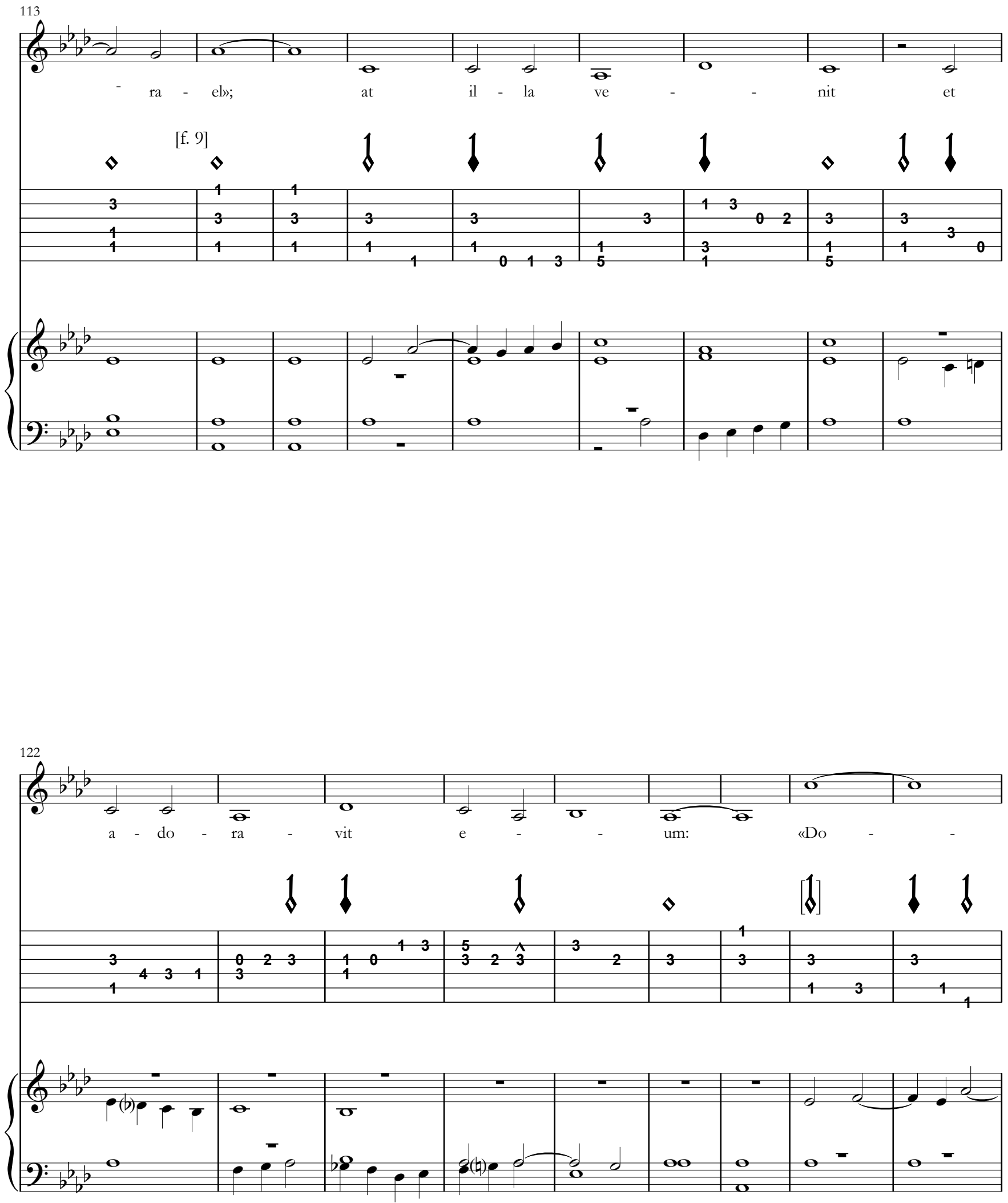

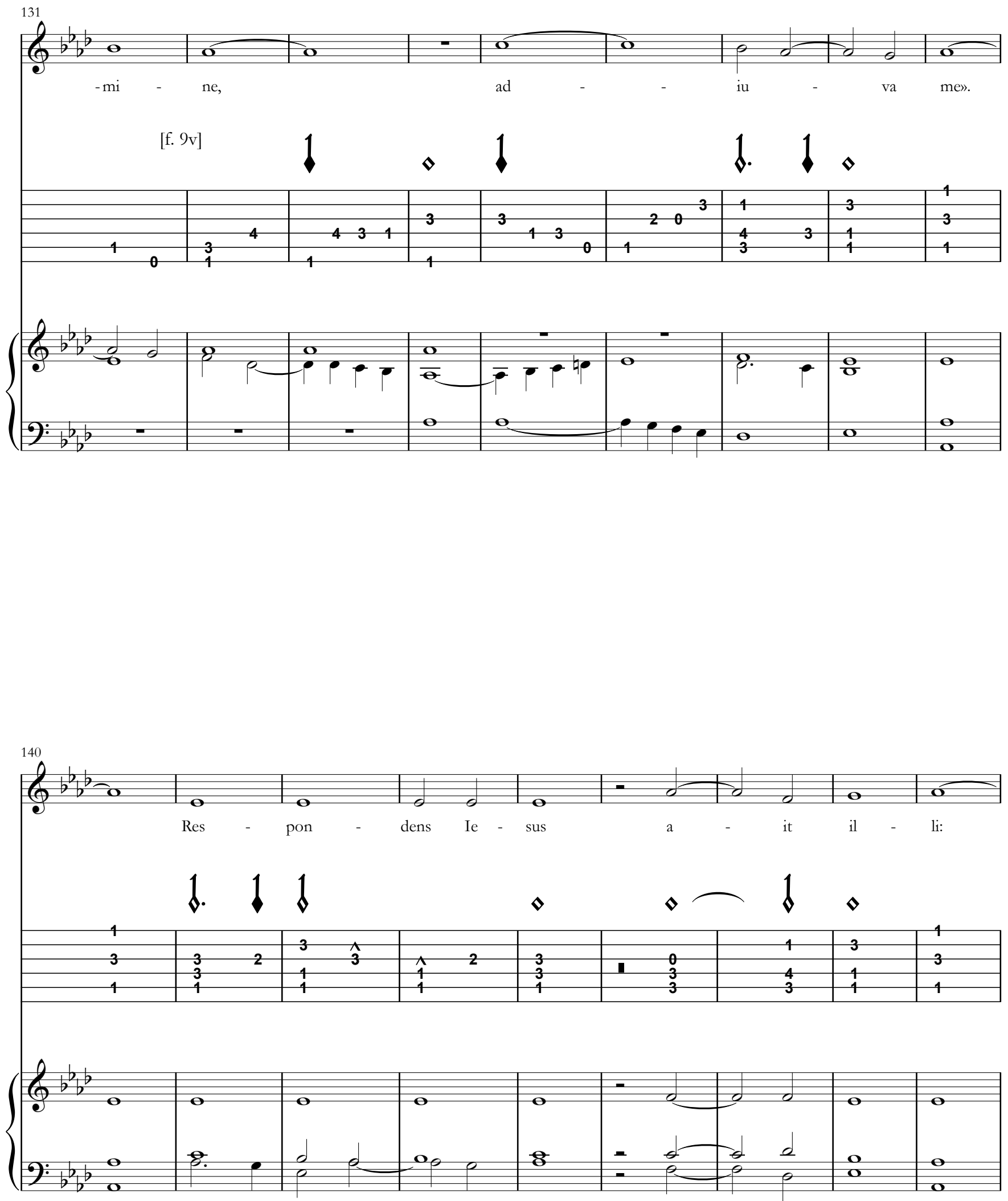

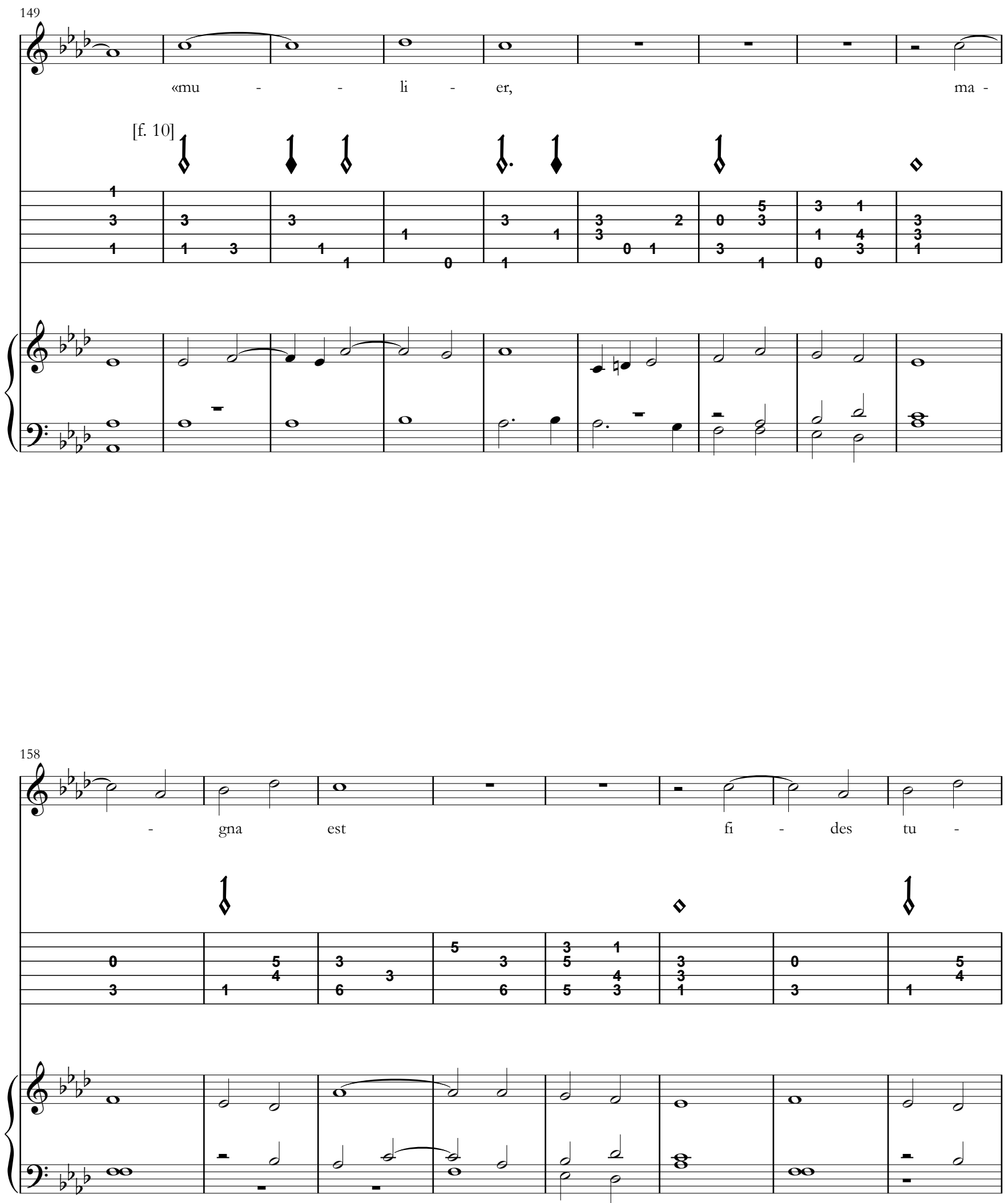

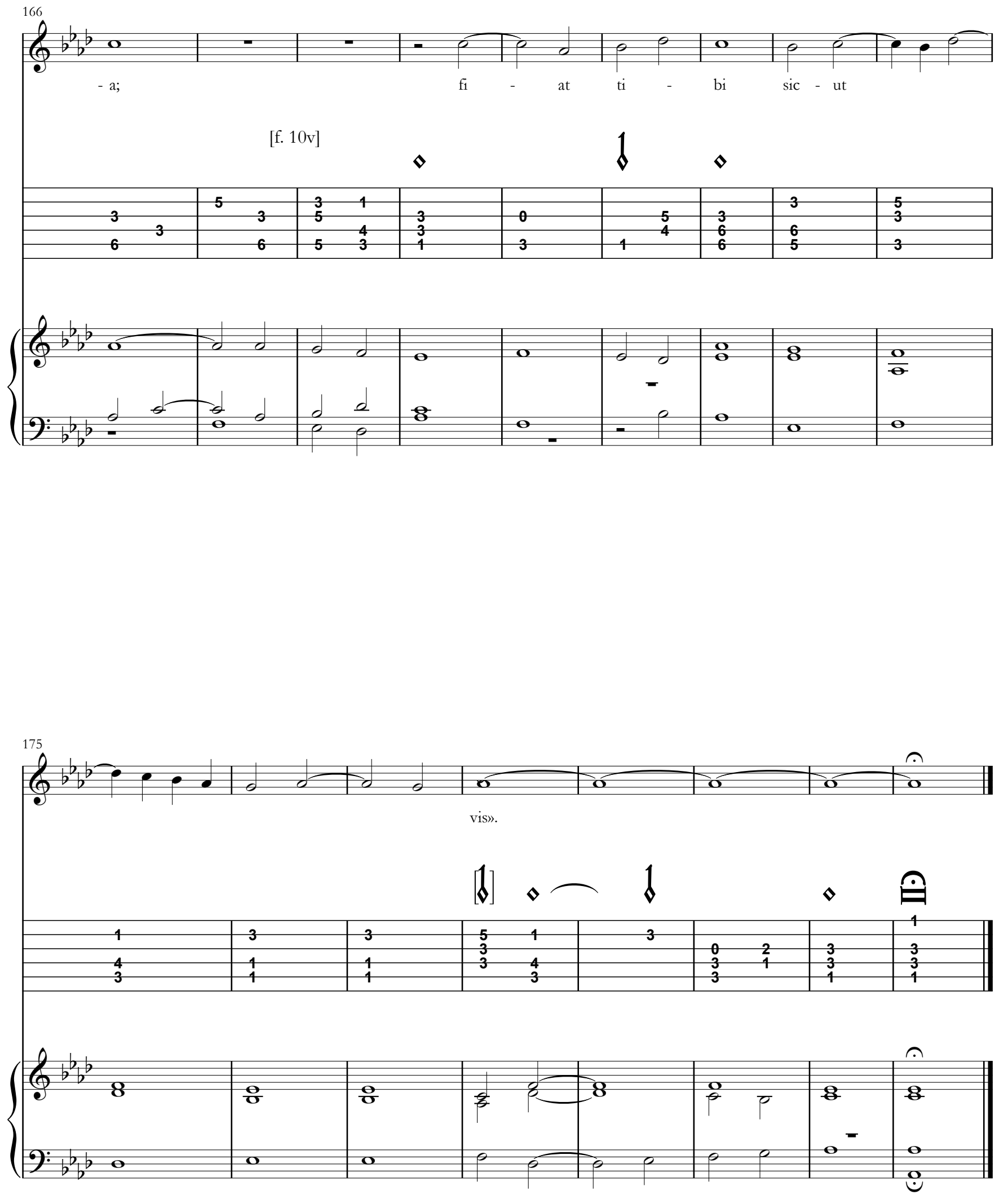
sะ 53 - Durmiendo yva el Señor

[Romance I]

Entónase la boz en la tercera al tercero traste

[Libro III, IV]
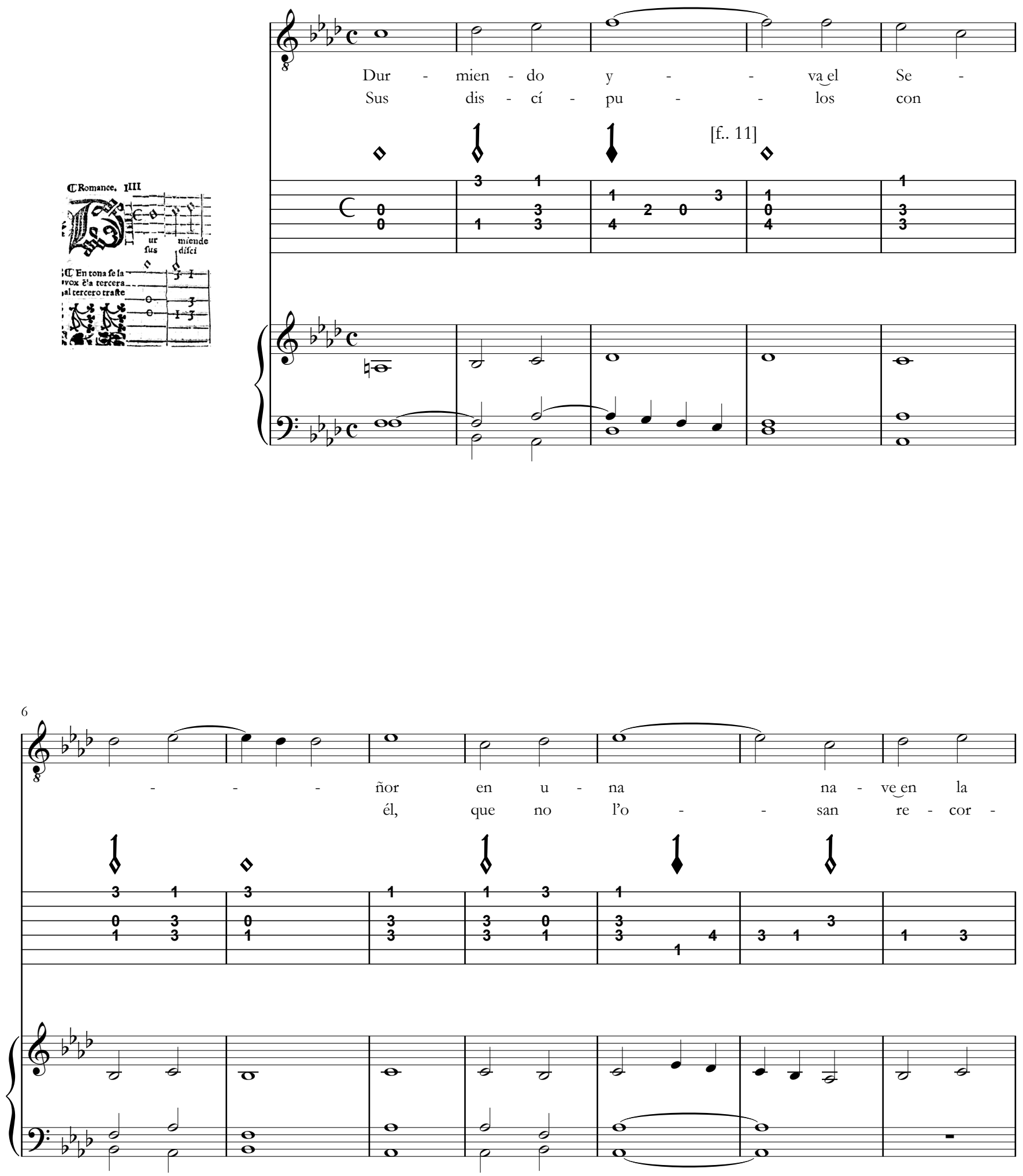

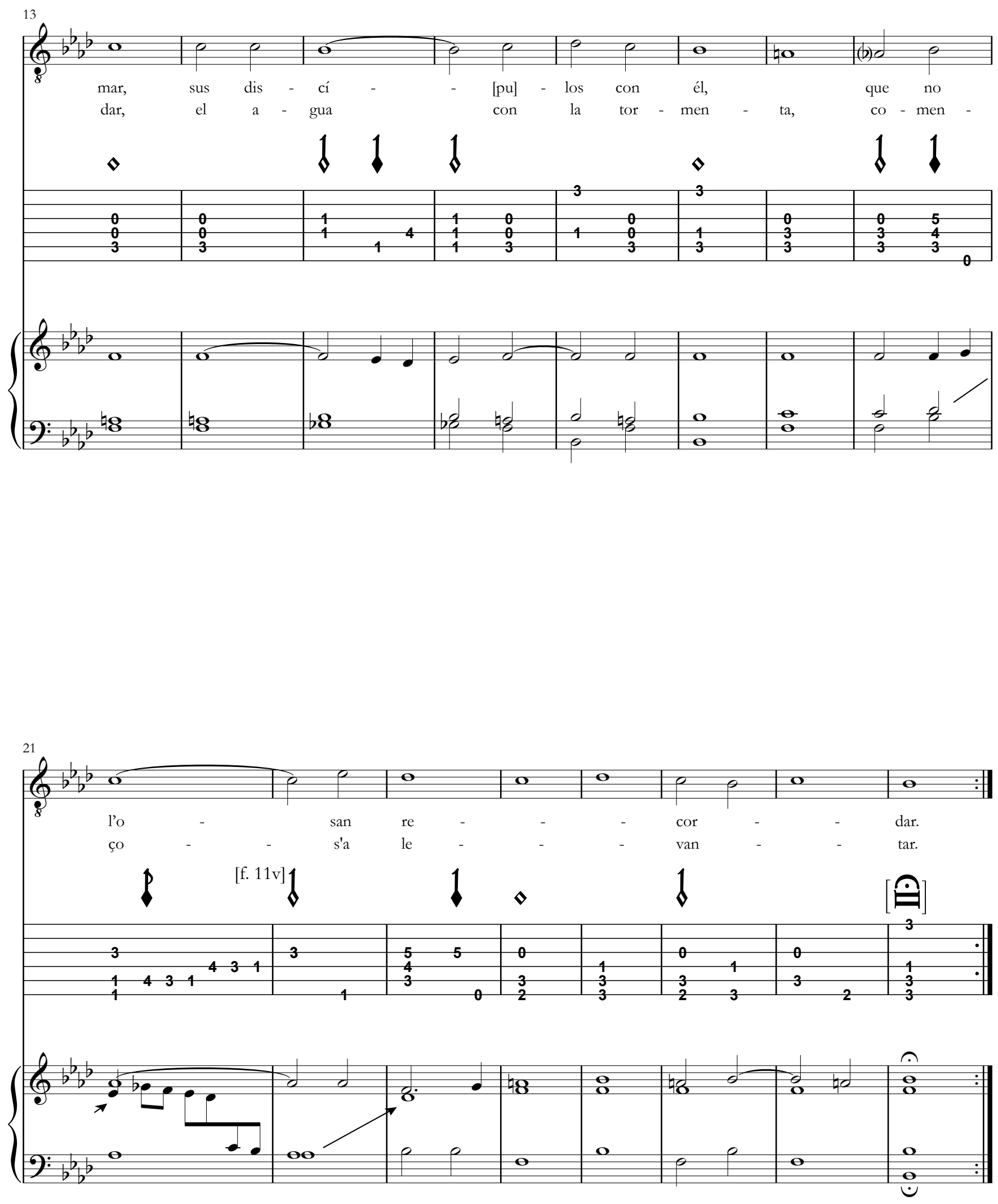

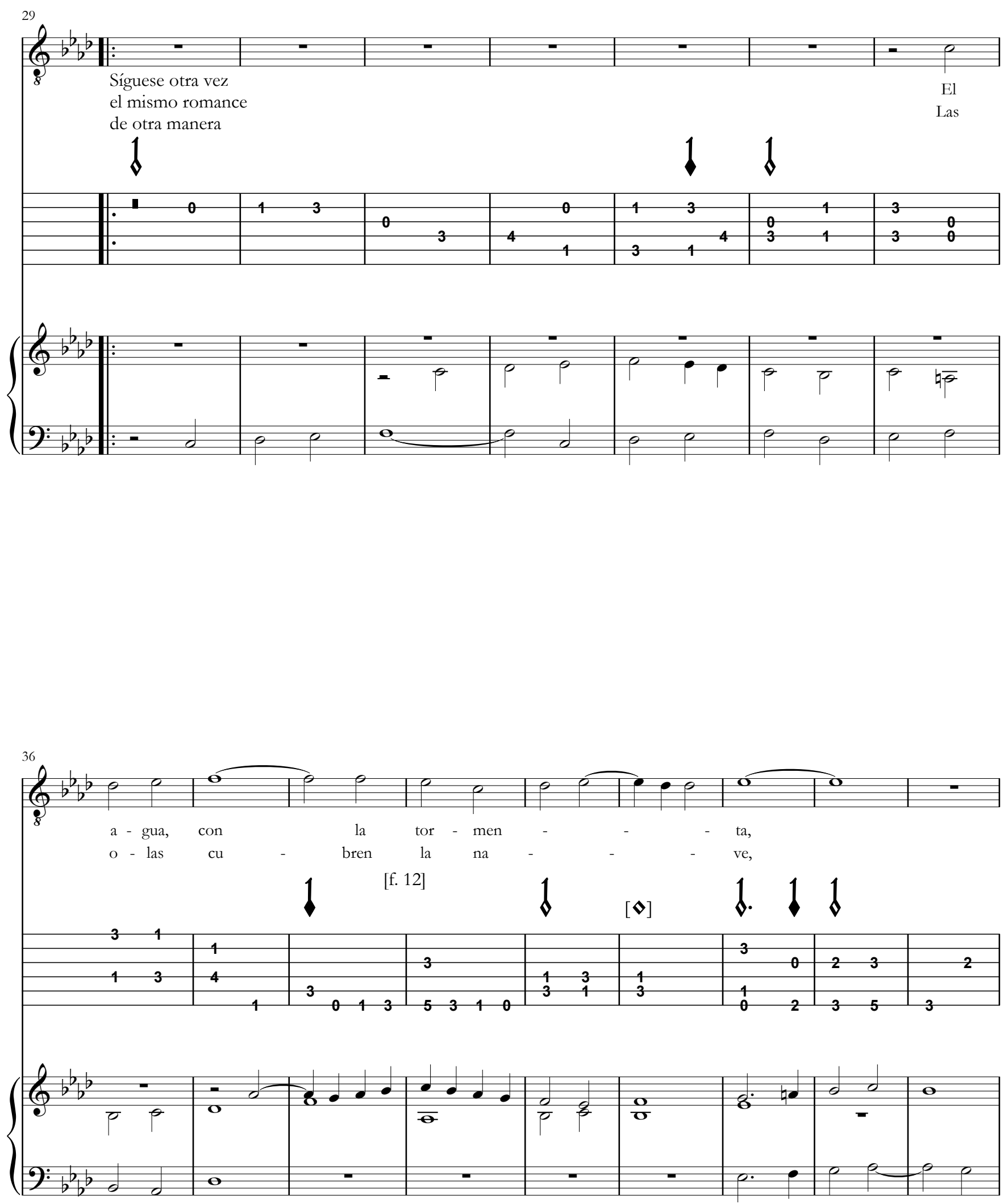

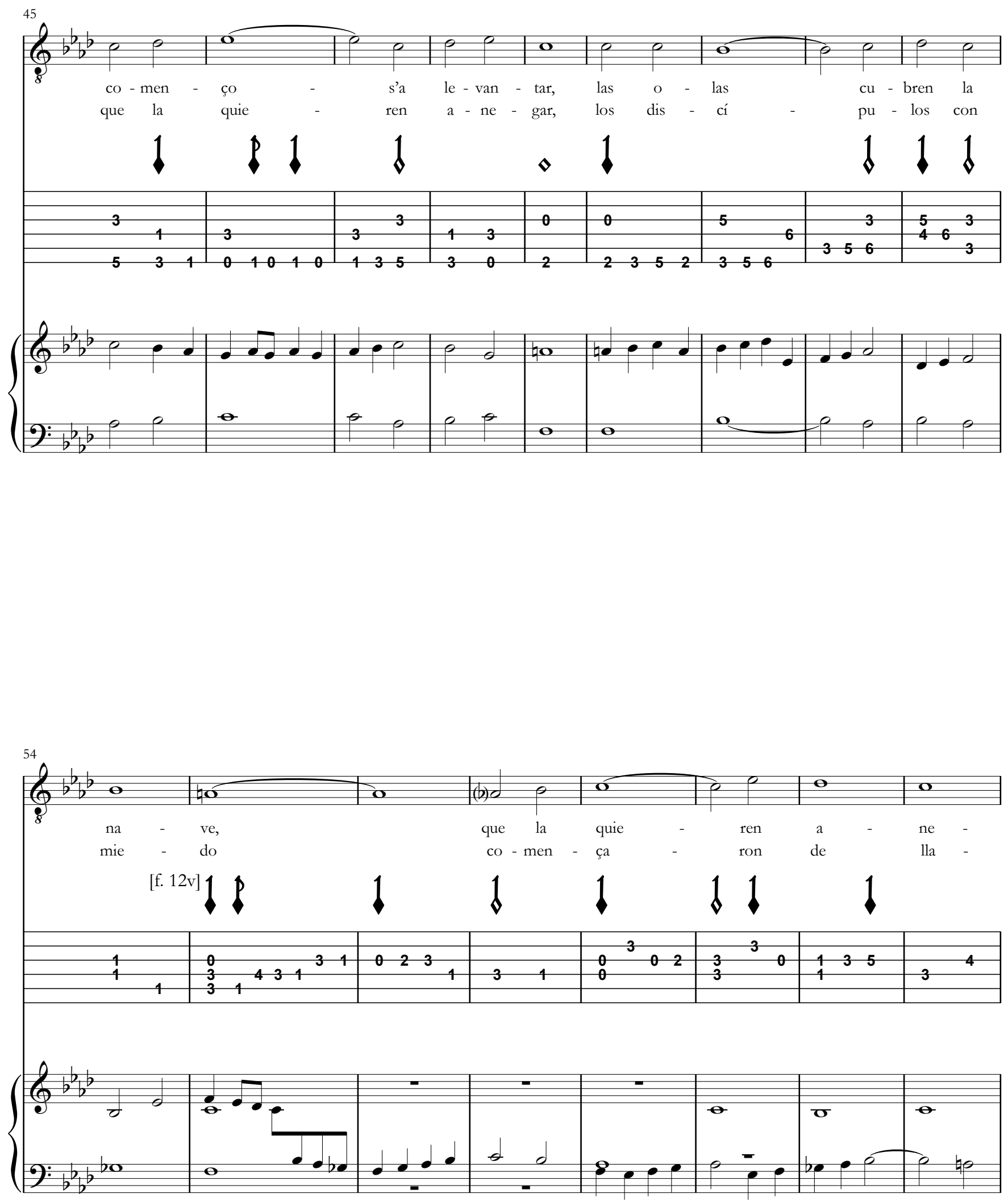


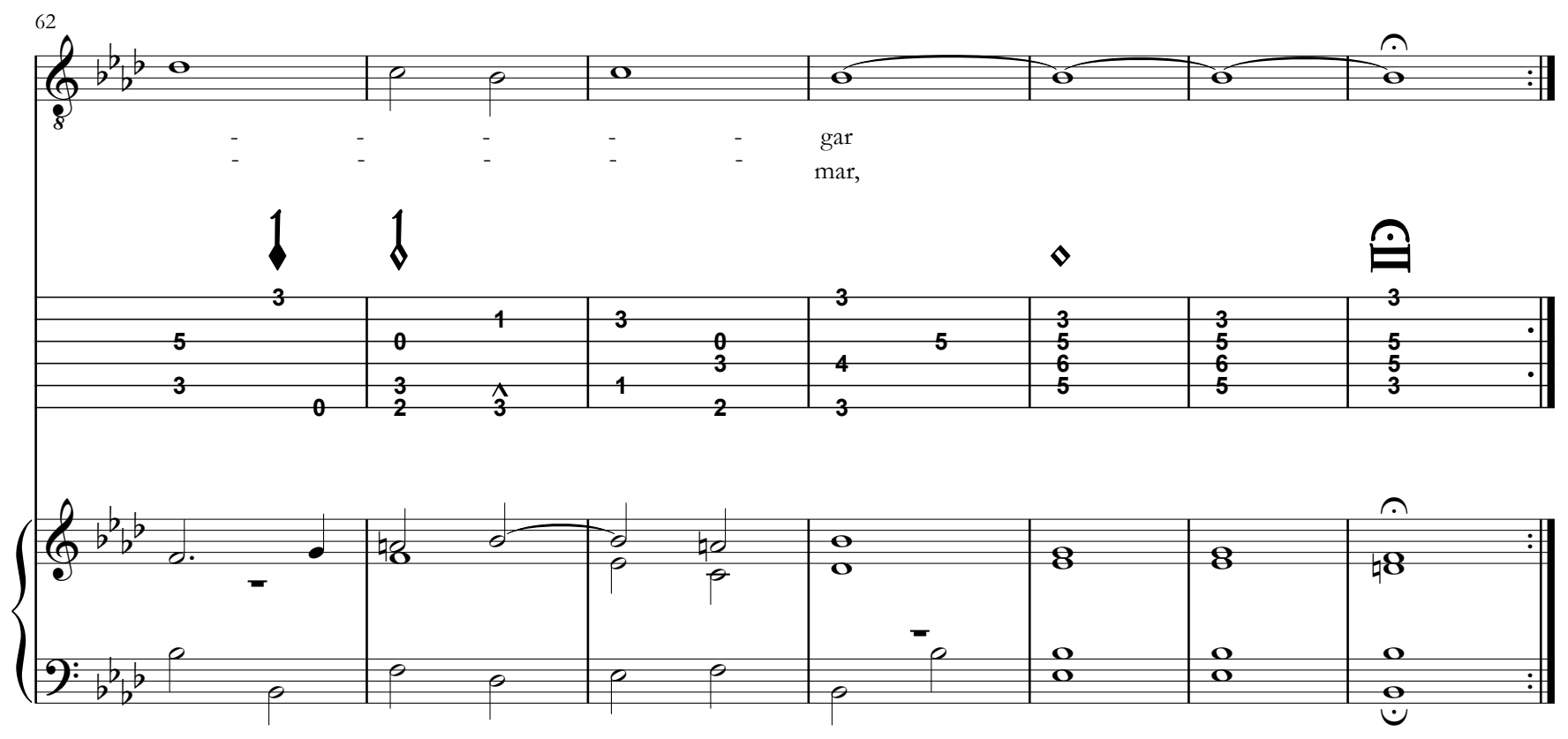

diziendo: «Señor, Señor, quiérasnos presto librar». Y despierto el buen Jesú, començoles de hablar. 


\section{s\& 54 - Triste estava el rey David}

[Romance II]

Entónase la boz en la segunda al tercero traste

[Libro III, V]
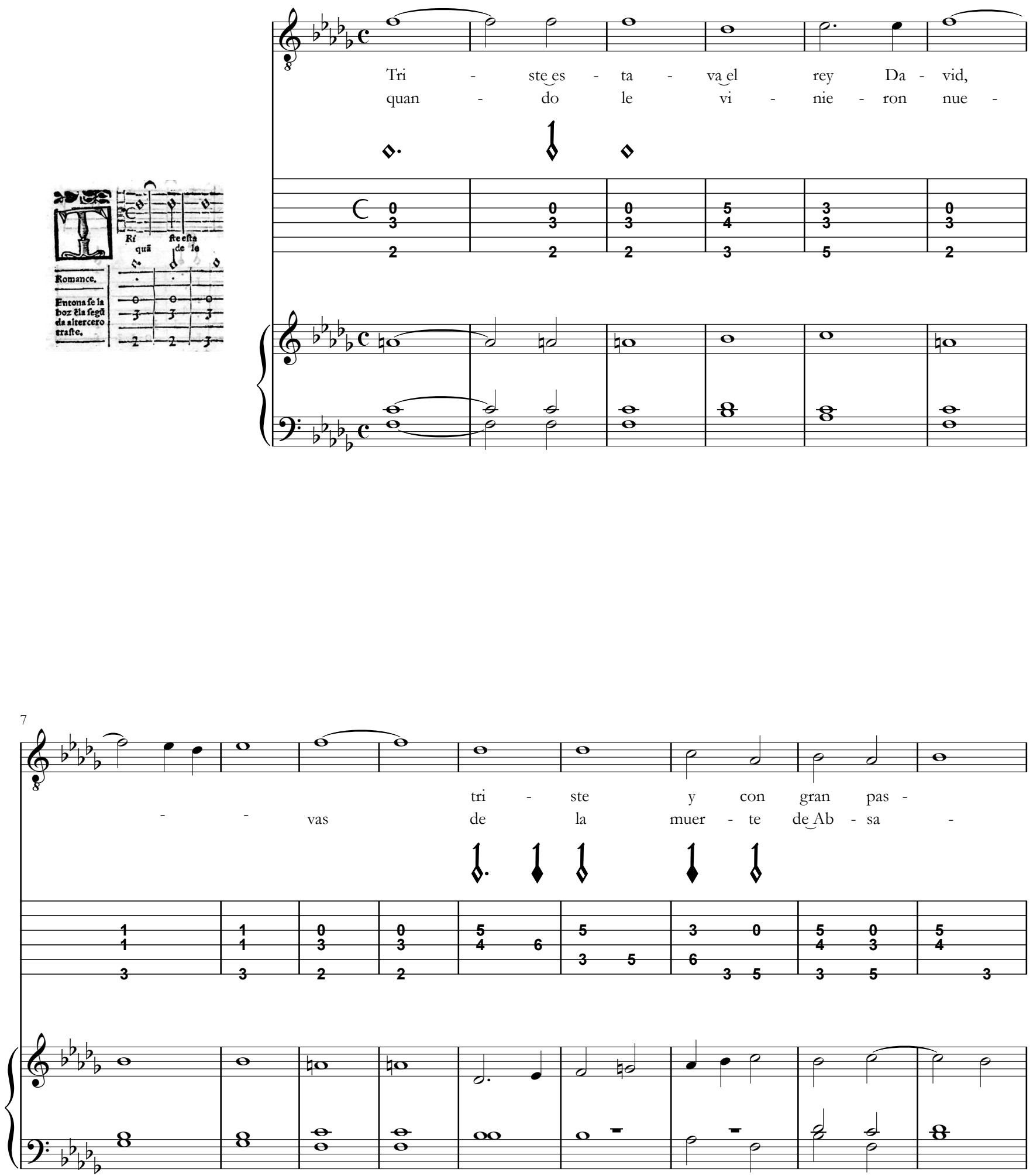

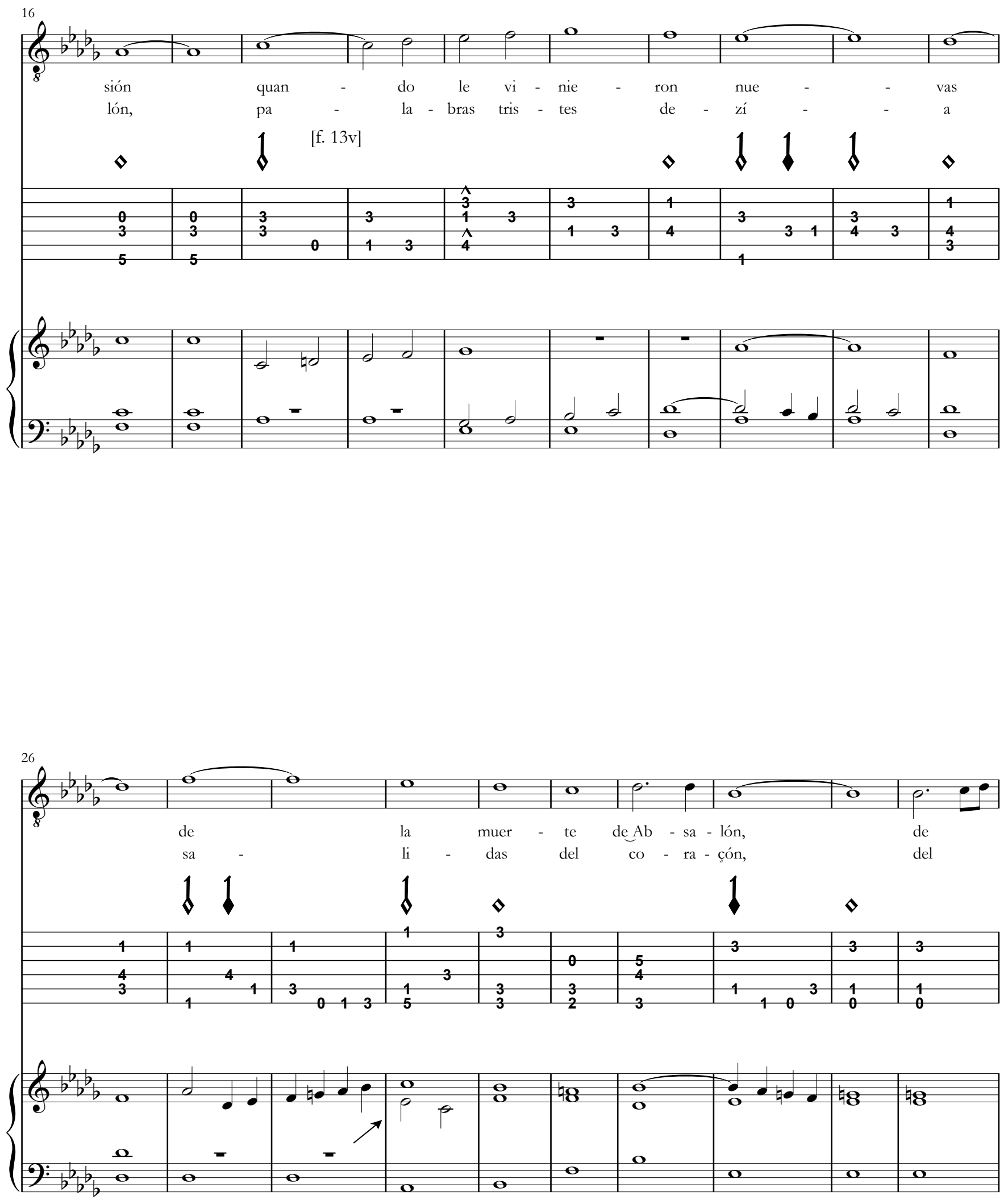


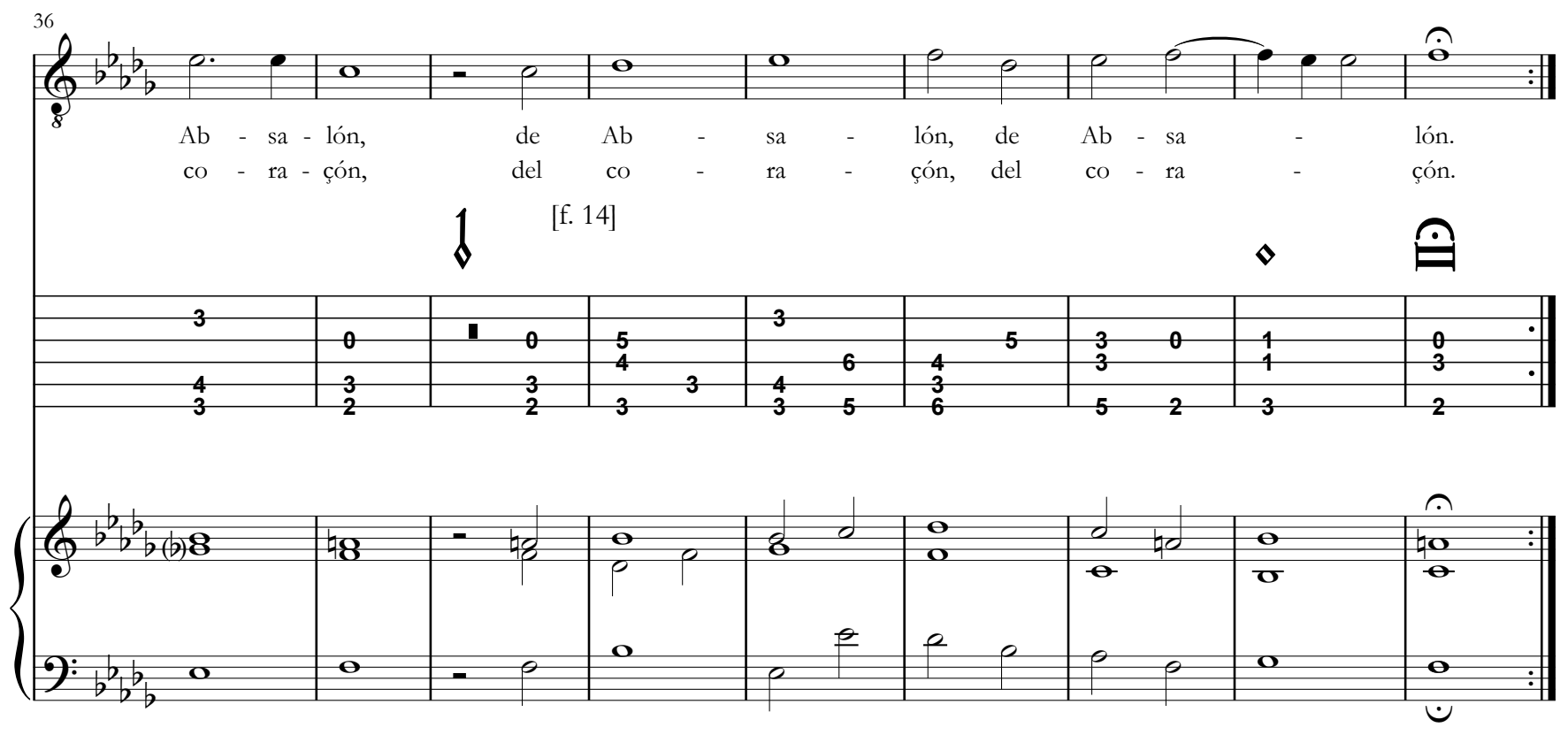

«Ellos mesmos fueron causa, de tu muerte y mi passión, no te quisiera ver muerto, sino vivo en mi prisión.

que aunque me eras desobediente, yo te otorgara perdón».

Fili mi. 
so 55 - Israel, mira tus montes

[Romance III]

Entónase al boz en la segunda al segundo traste

[Libro III, VI]
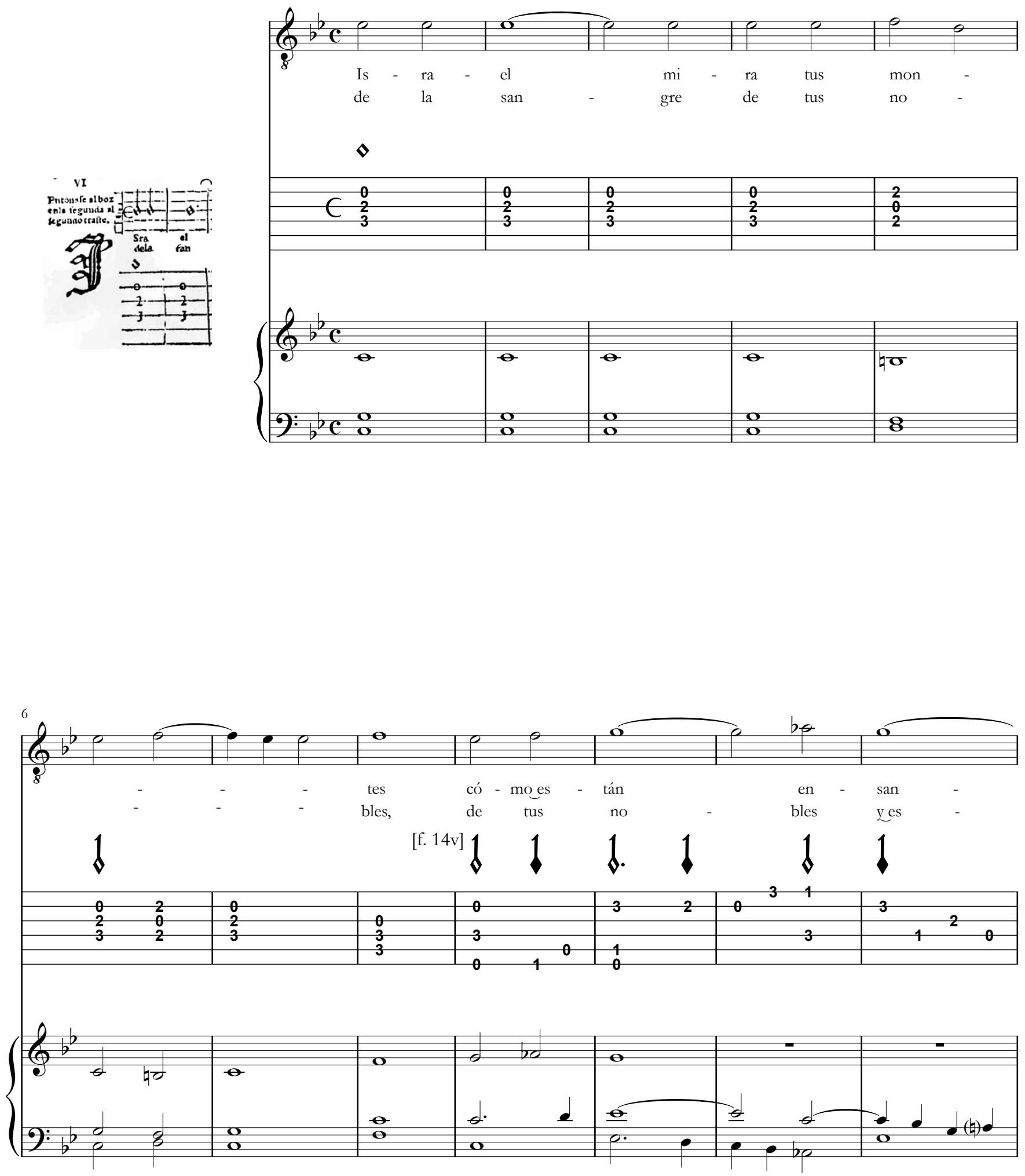

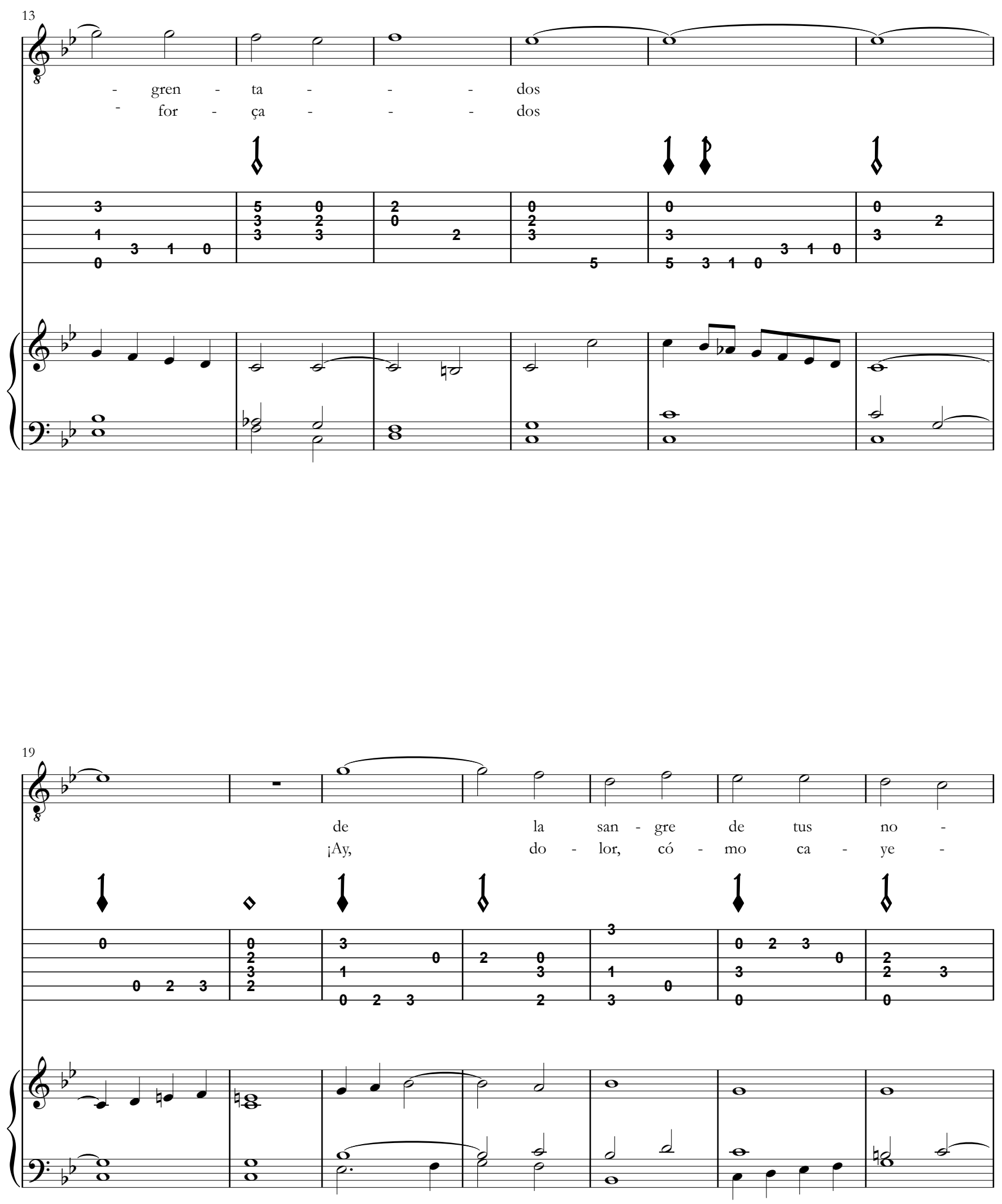

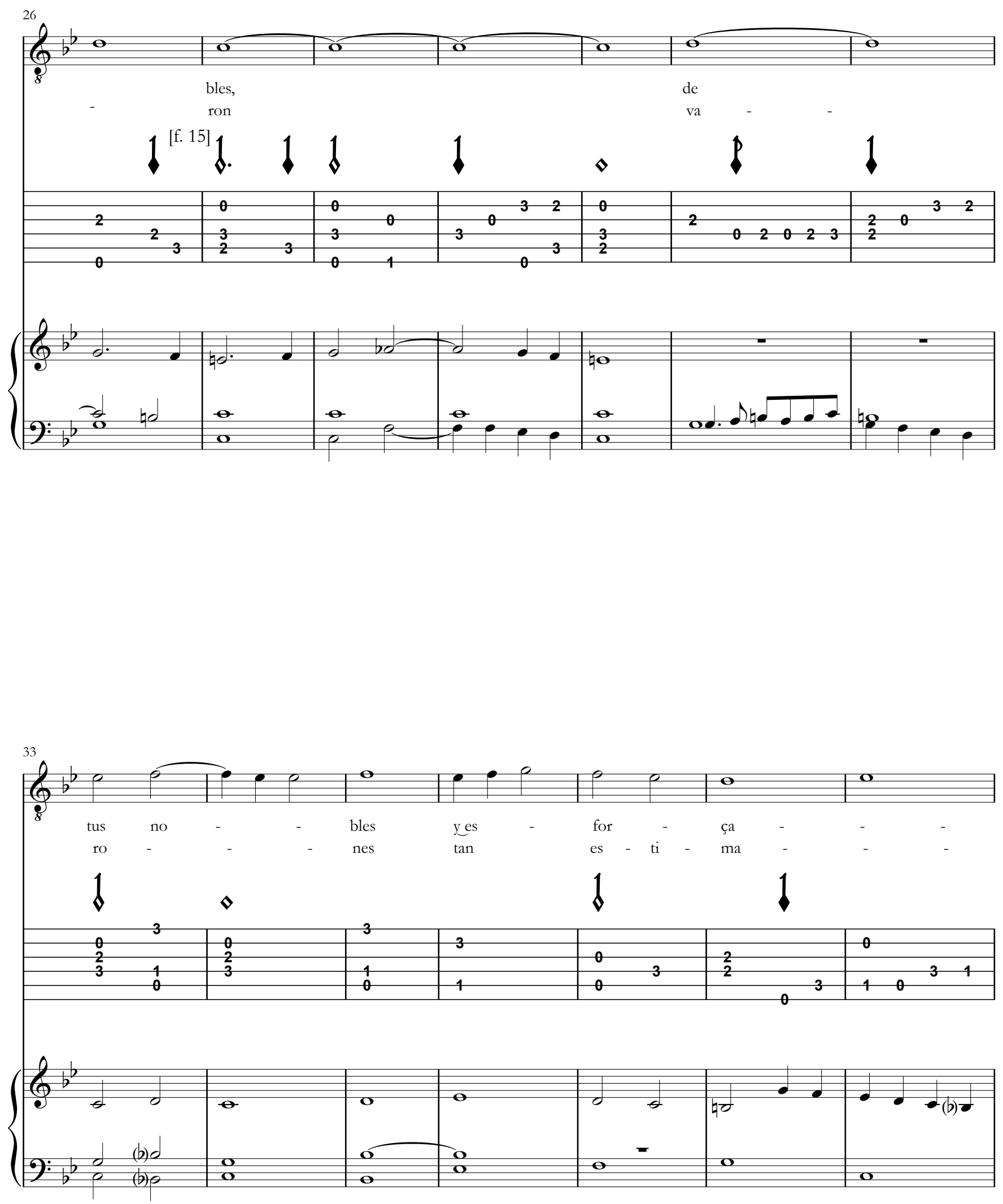

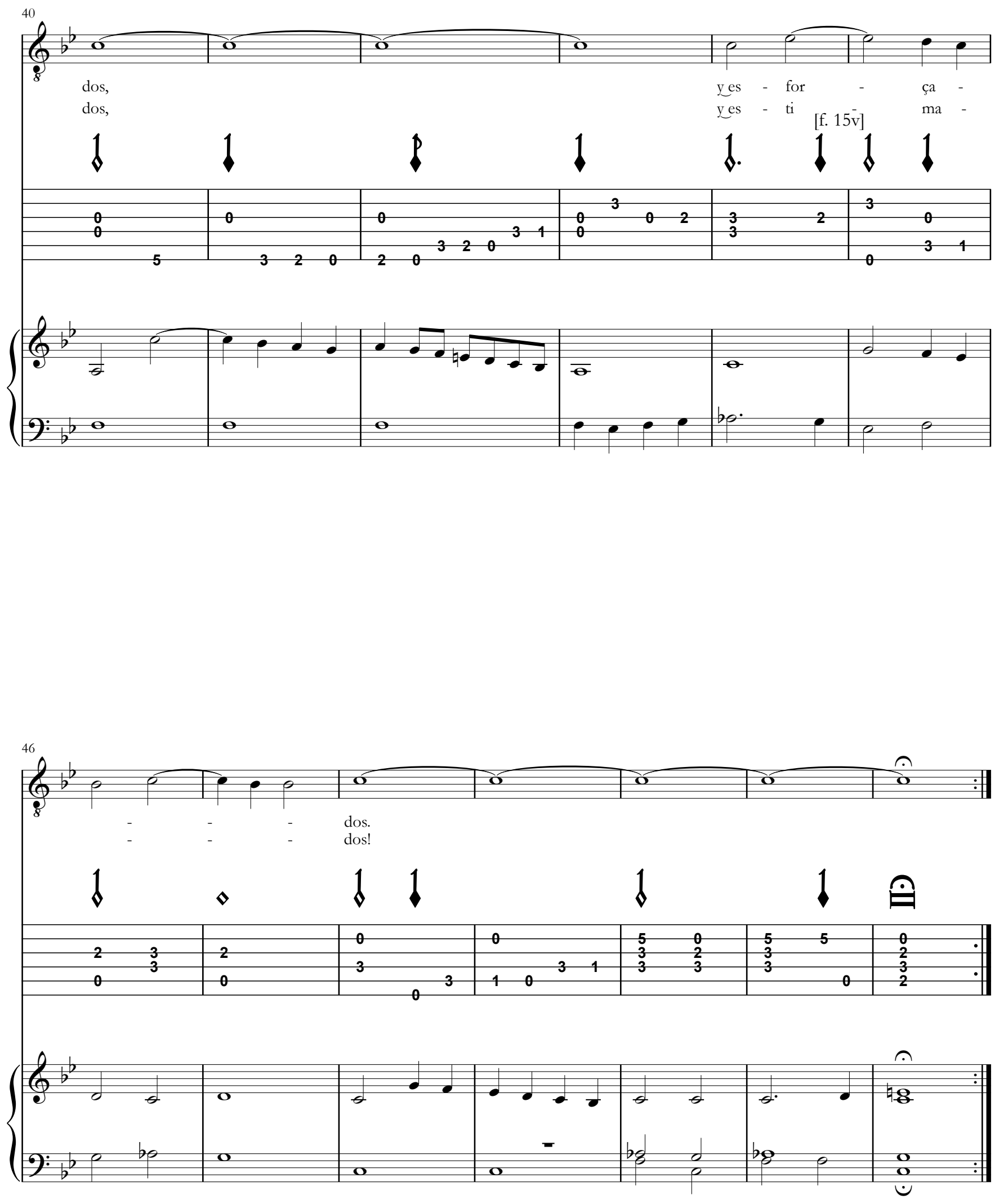
sฯ 56 - Sin dudar. Canción al milagro de la Encarnación [Canción I]

Entónase la vox en la segunda al segundo traste, va tañida esta vox [Libro III, VII]
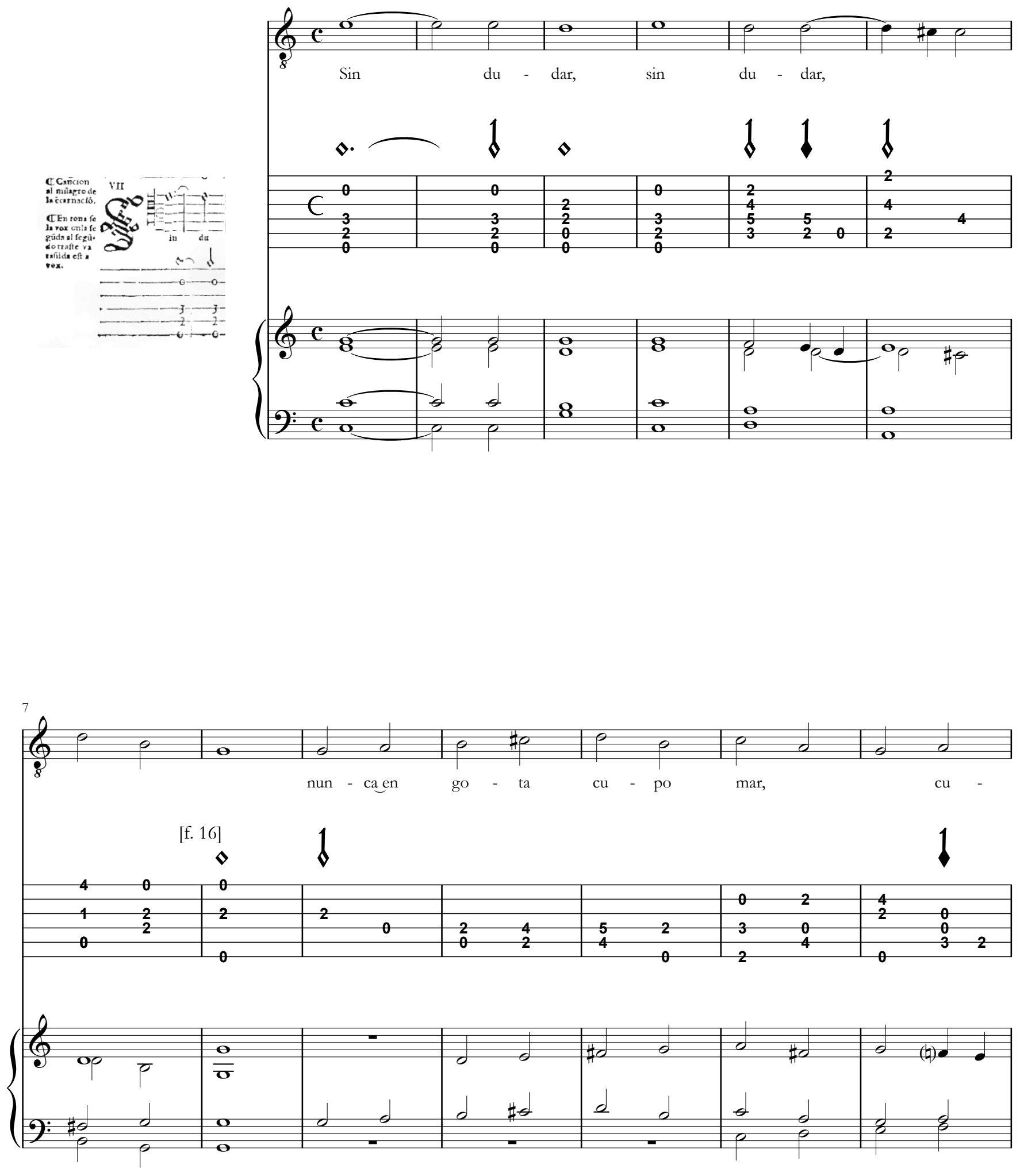

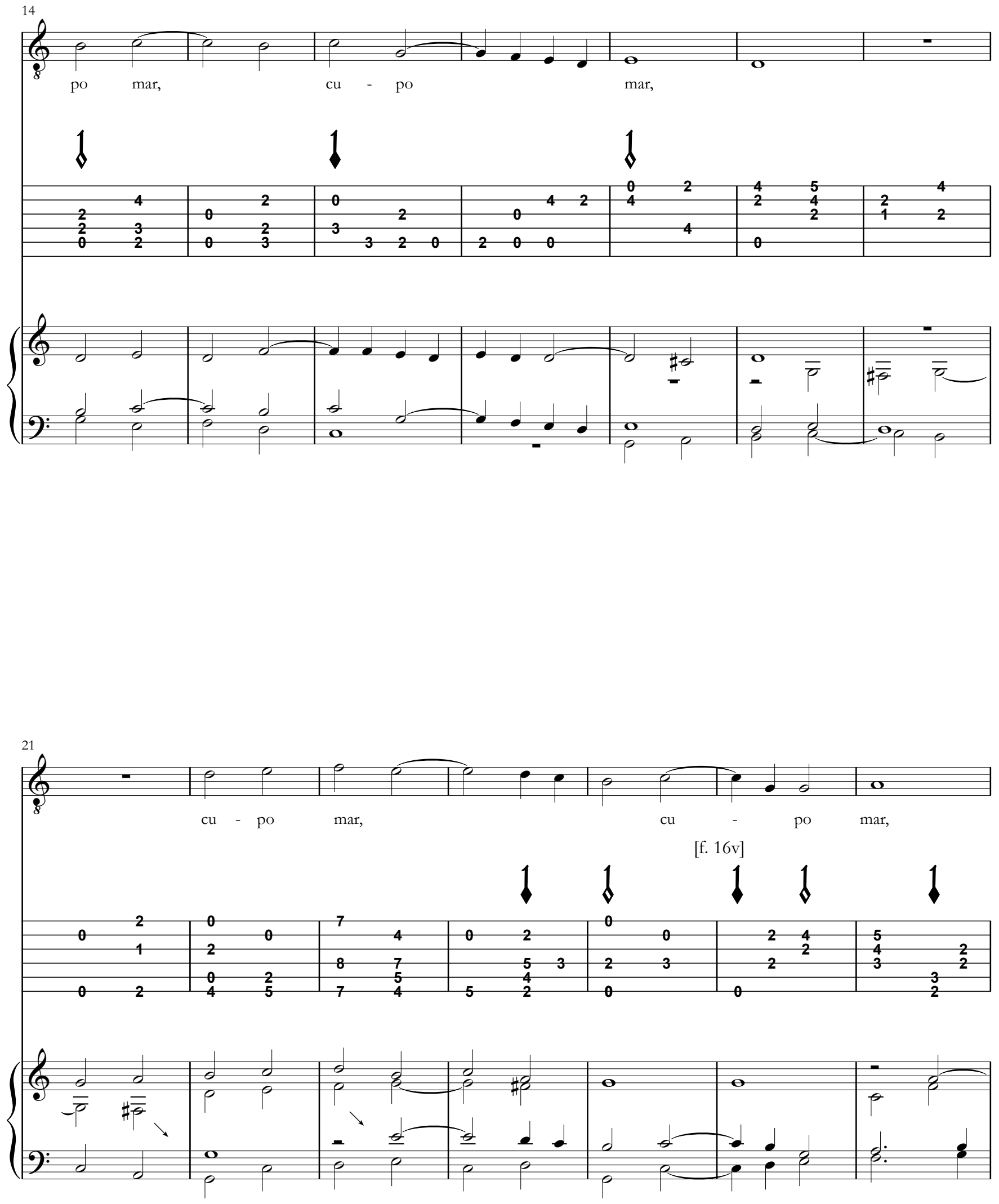

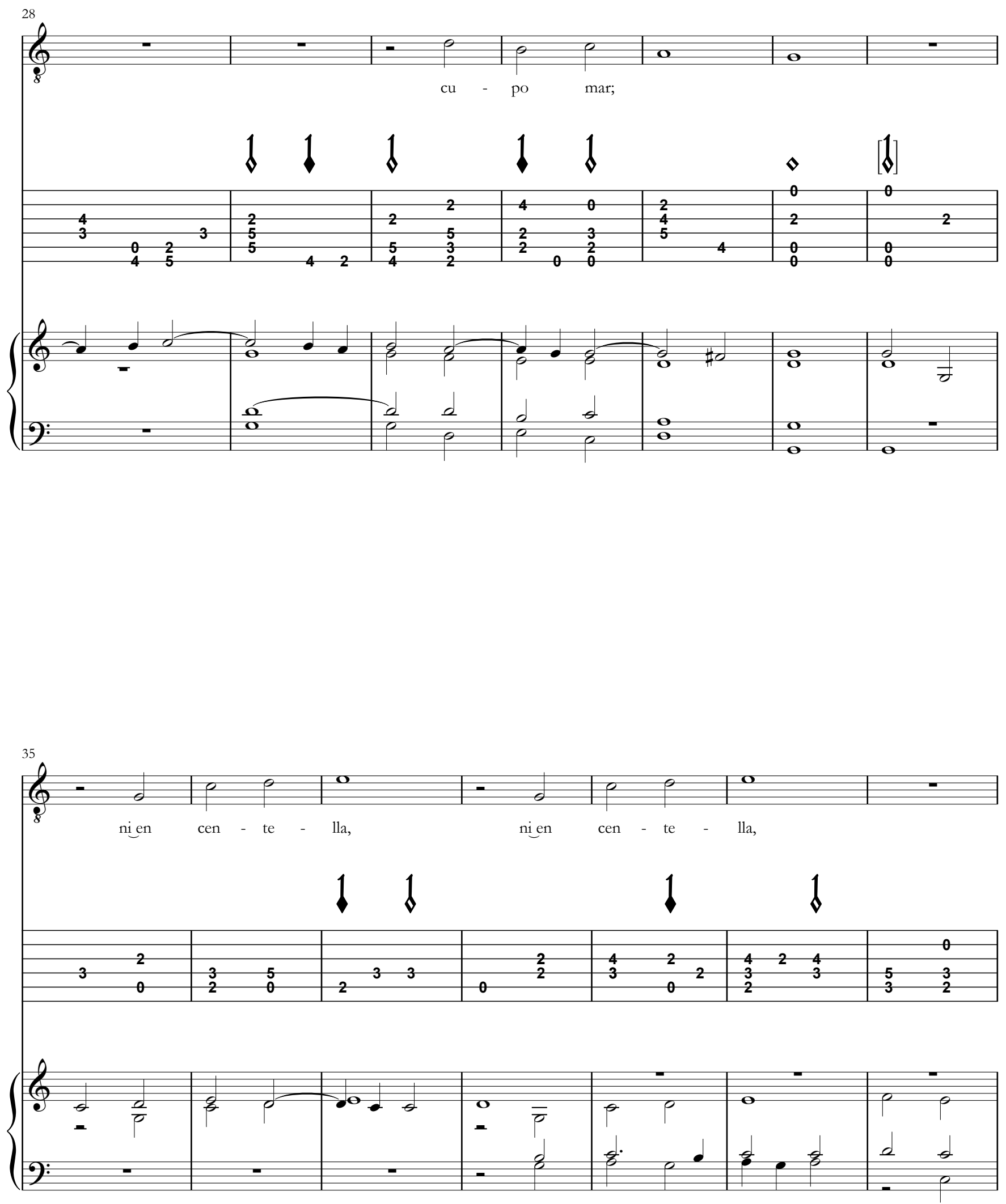

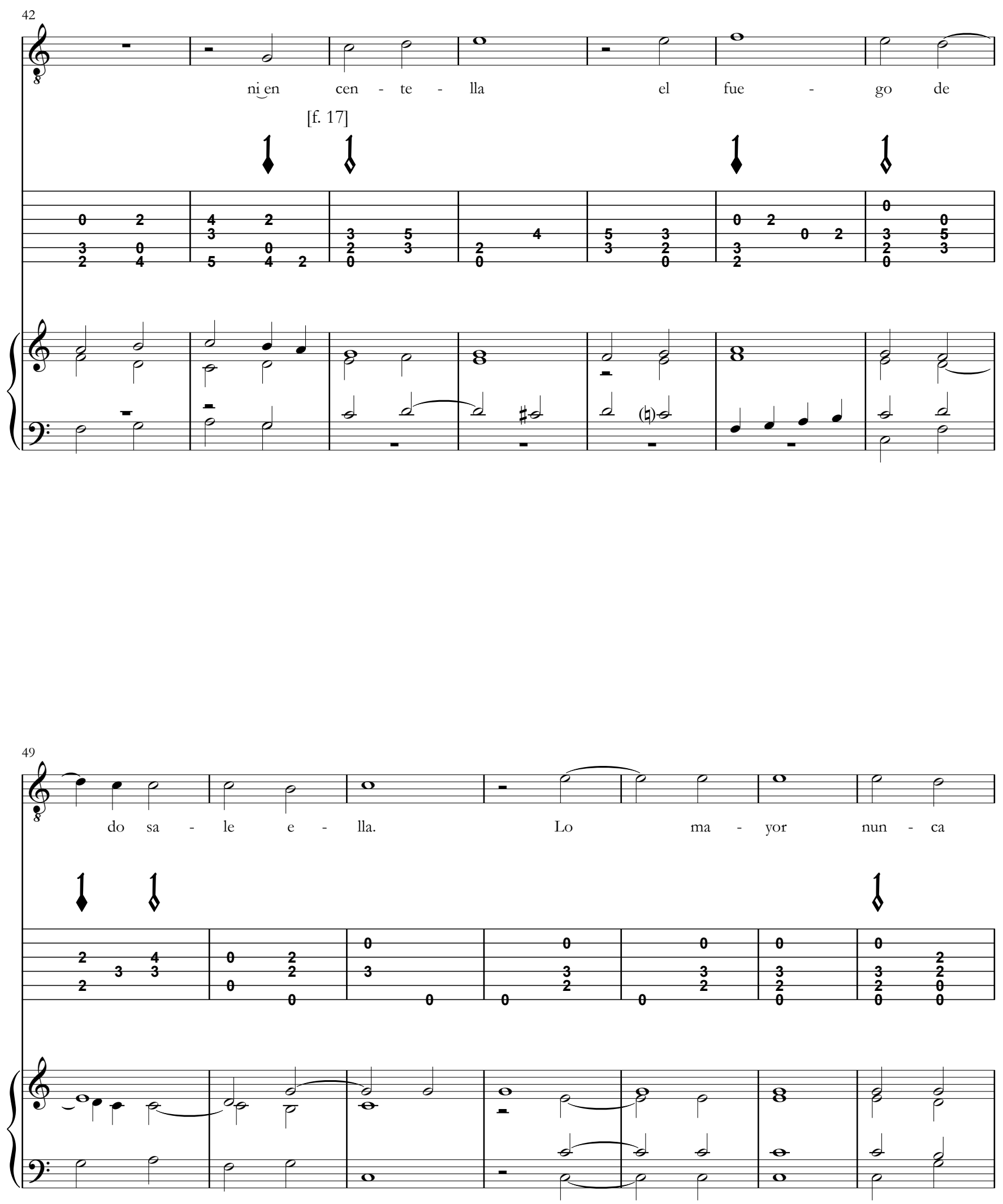

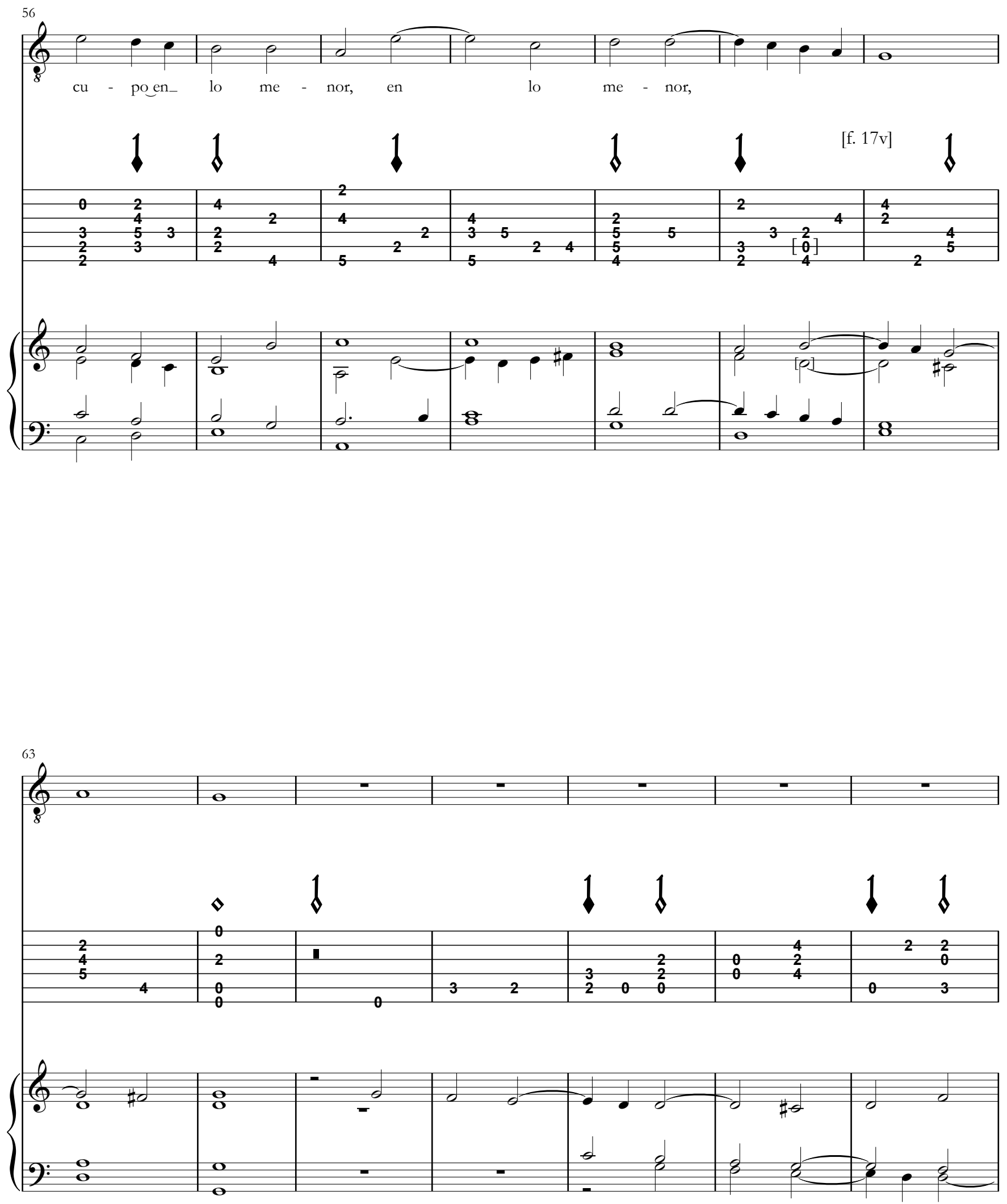

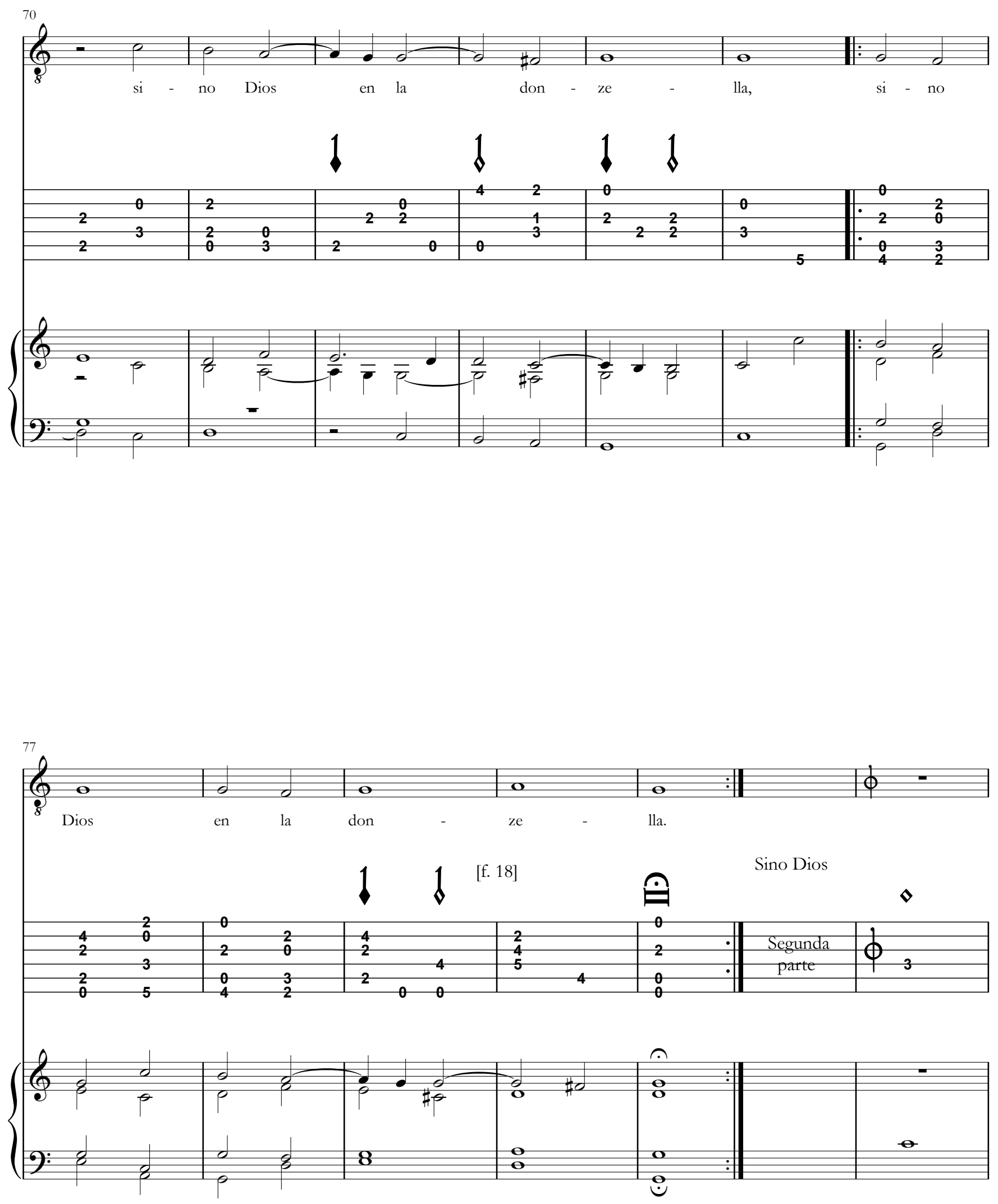

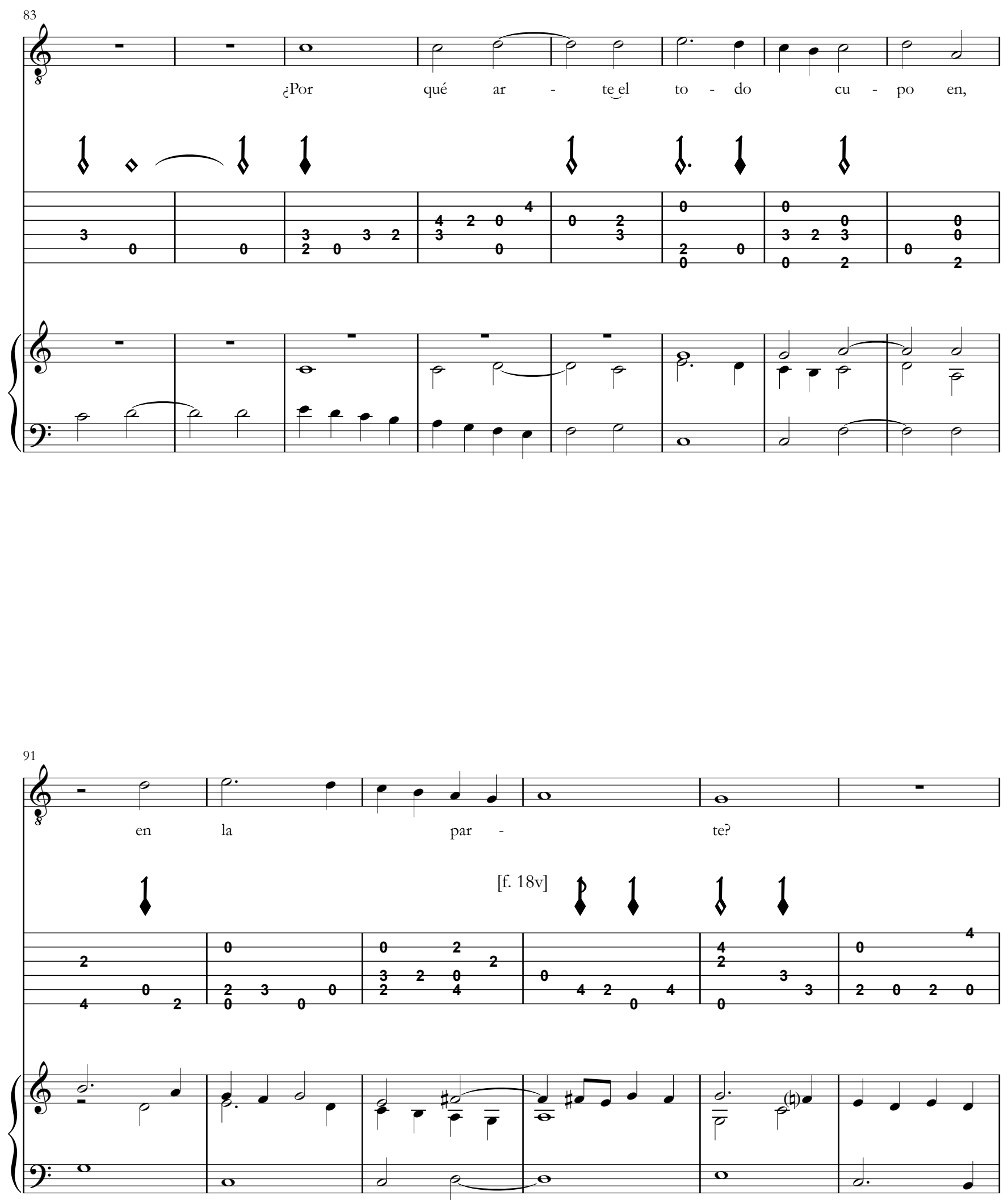

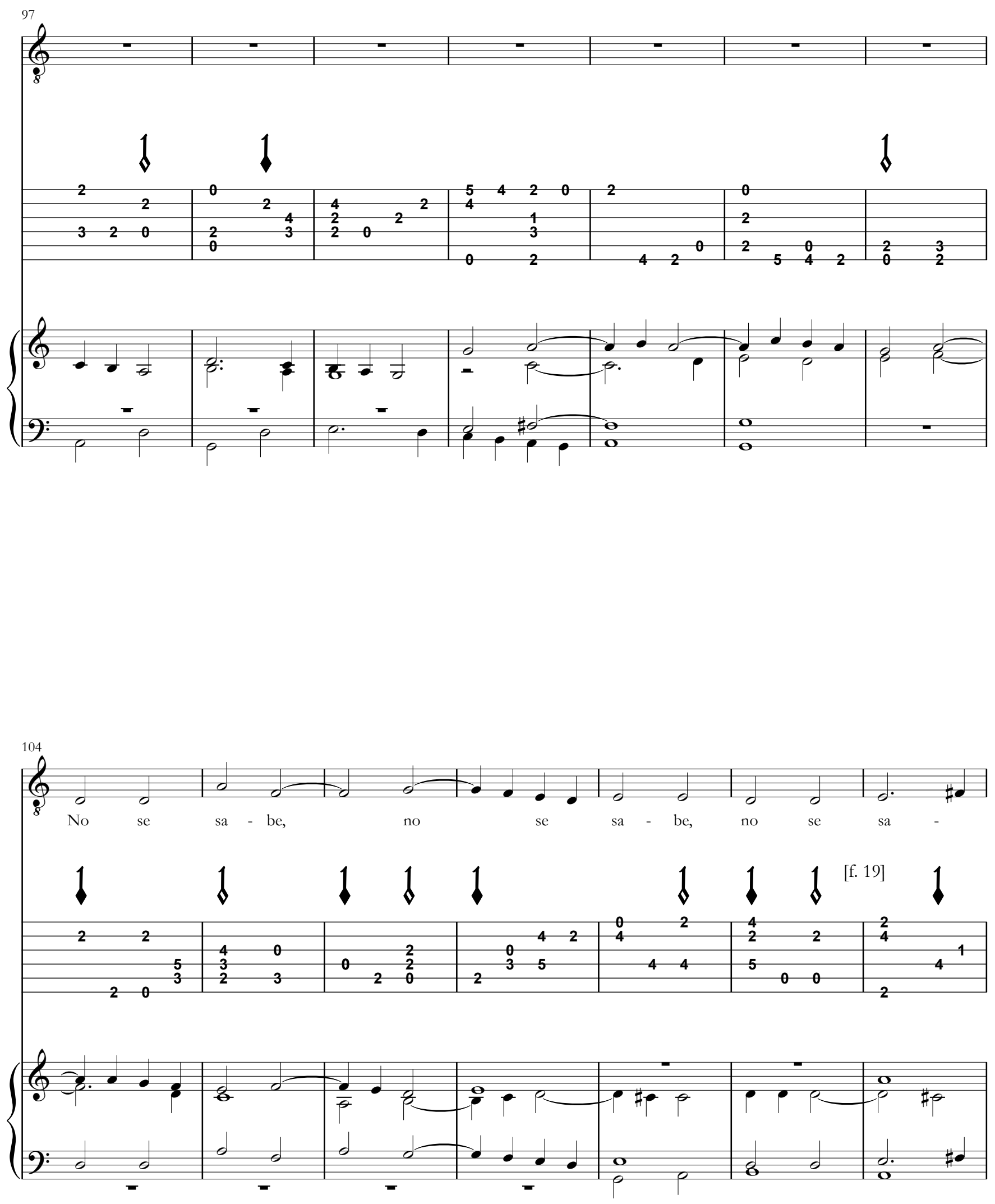

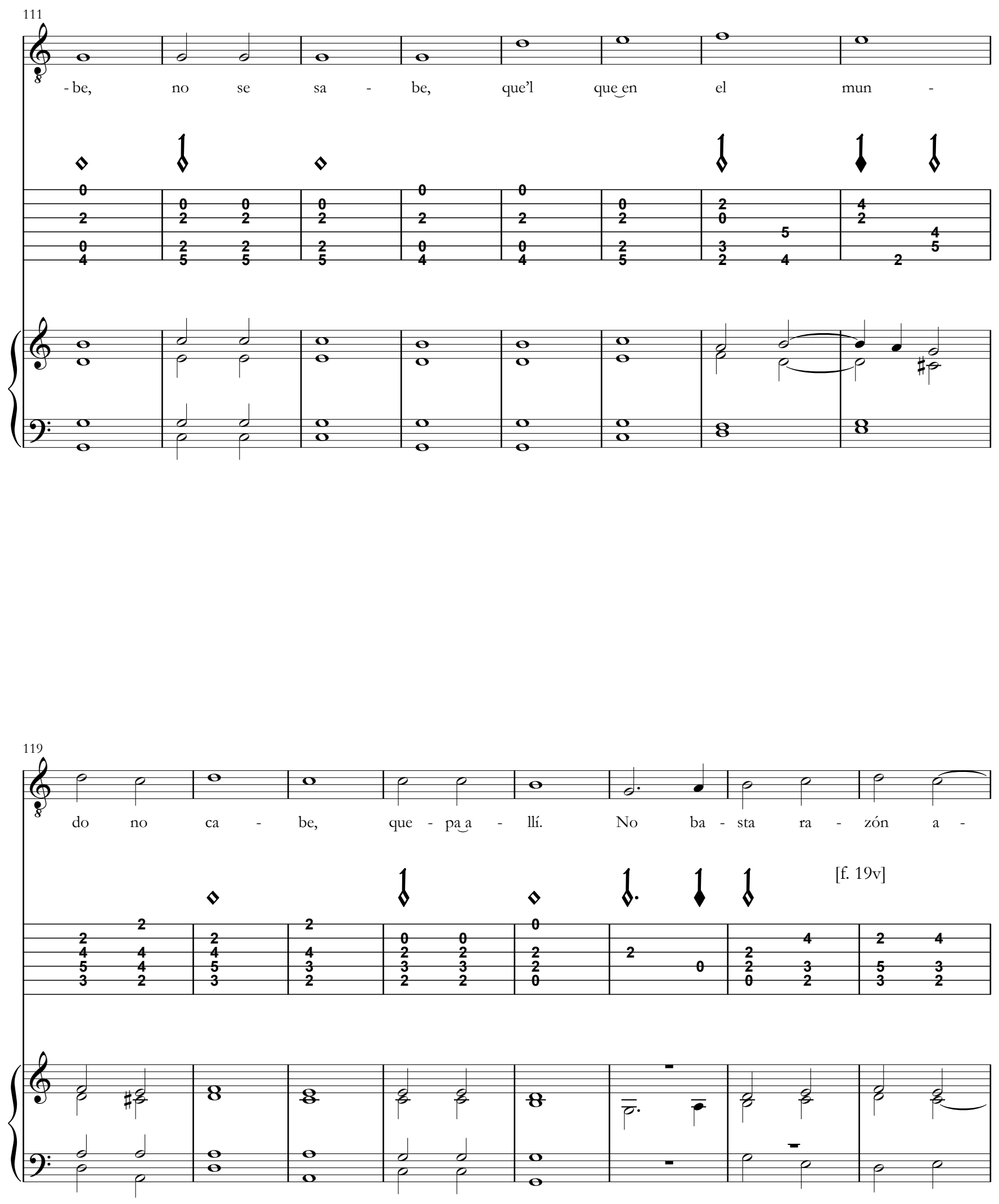

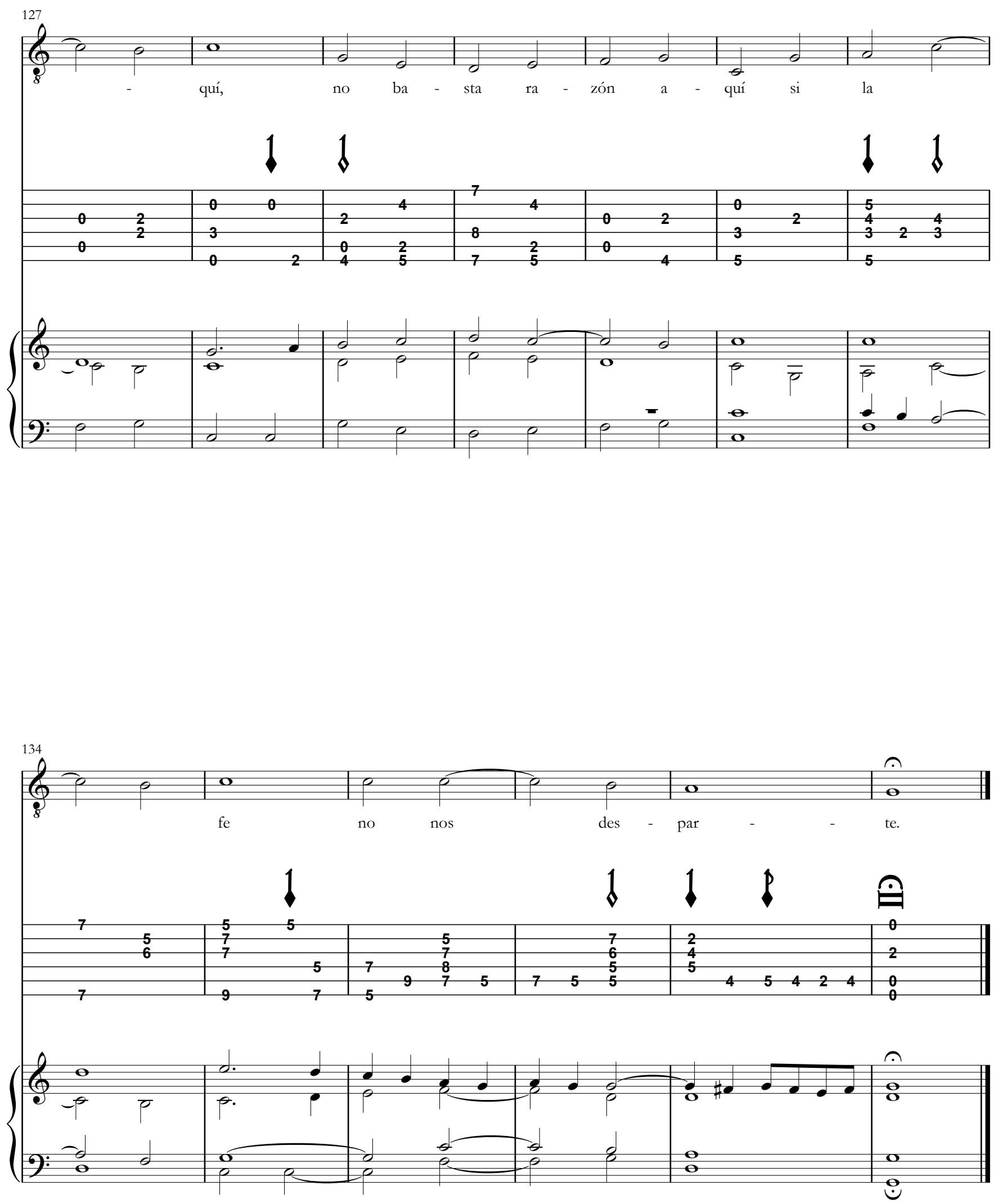


\section{so 57 - Recuerde el alma dormida}

[Canción II]

Entónase la vox en la segunda al tercero traste

[Libro III, VII]

[Texto: Jorge Manrique]
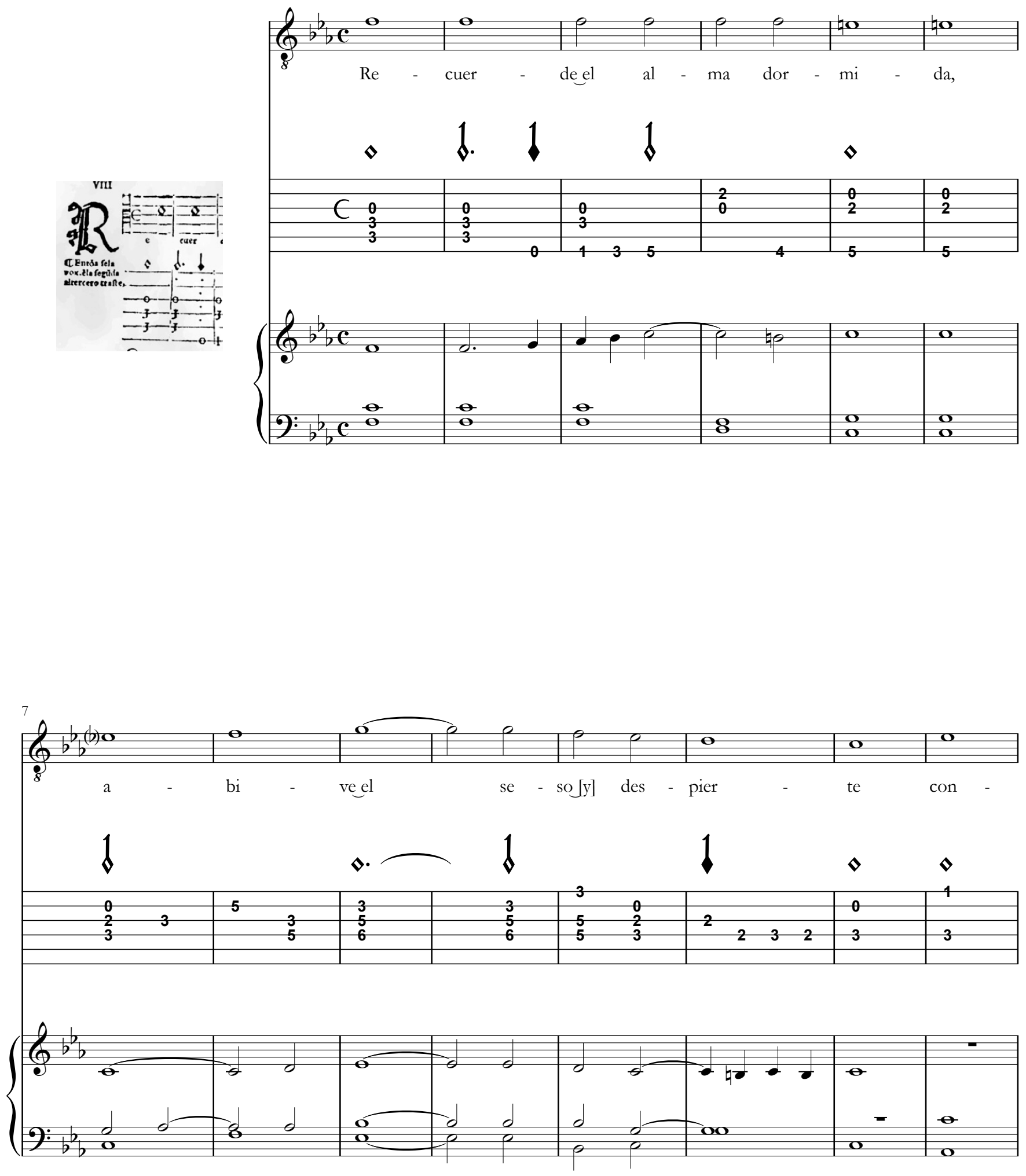

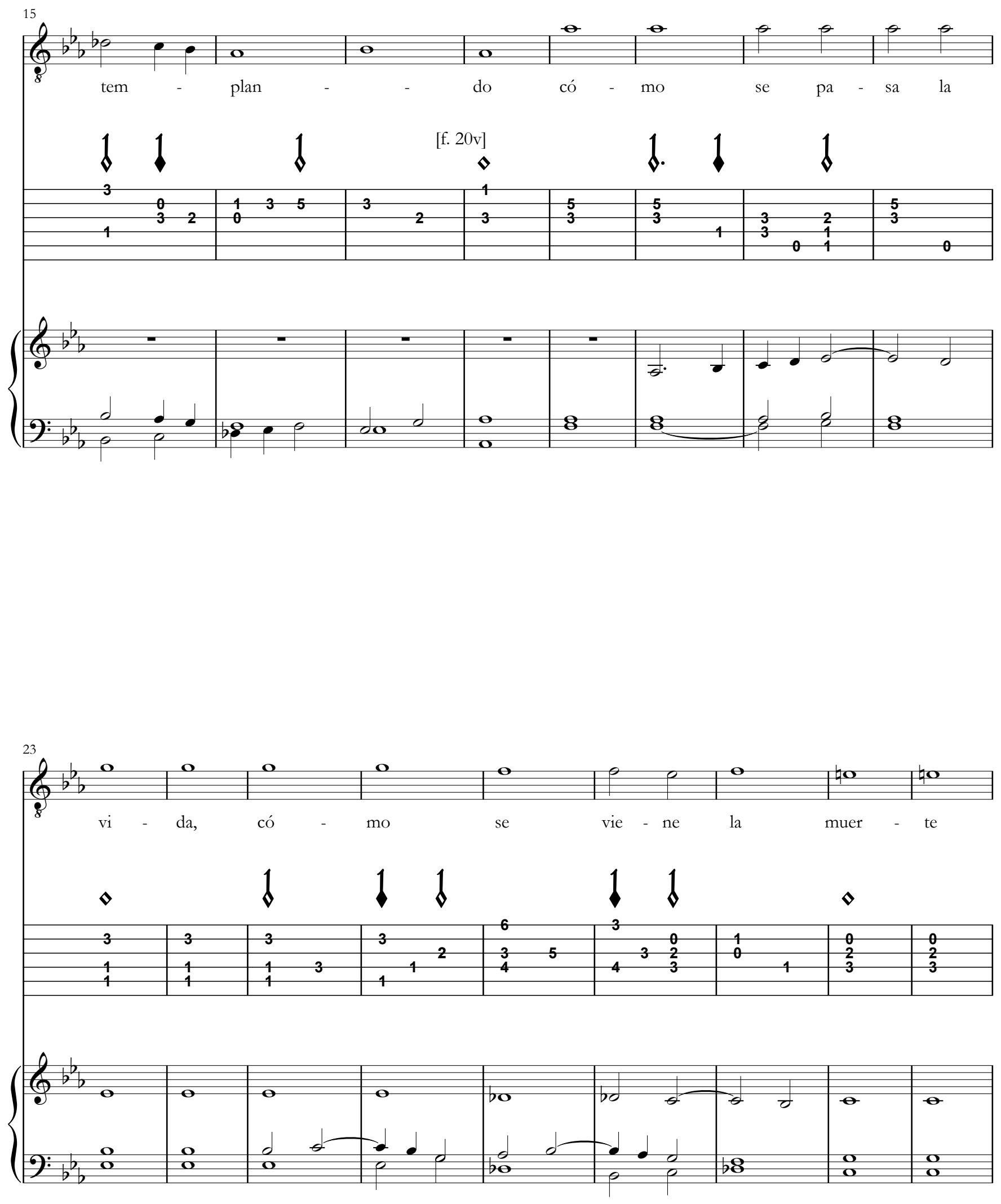


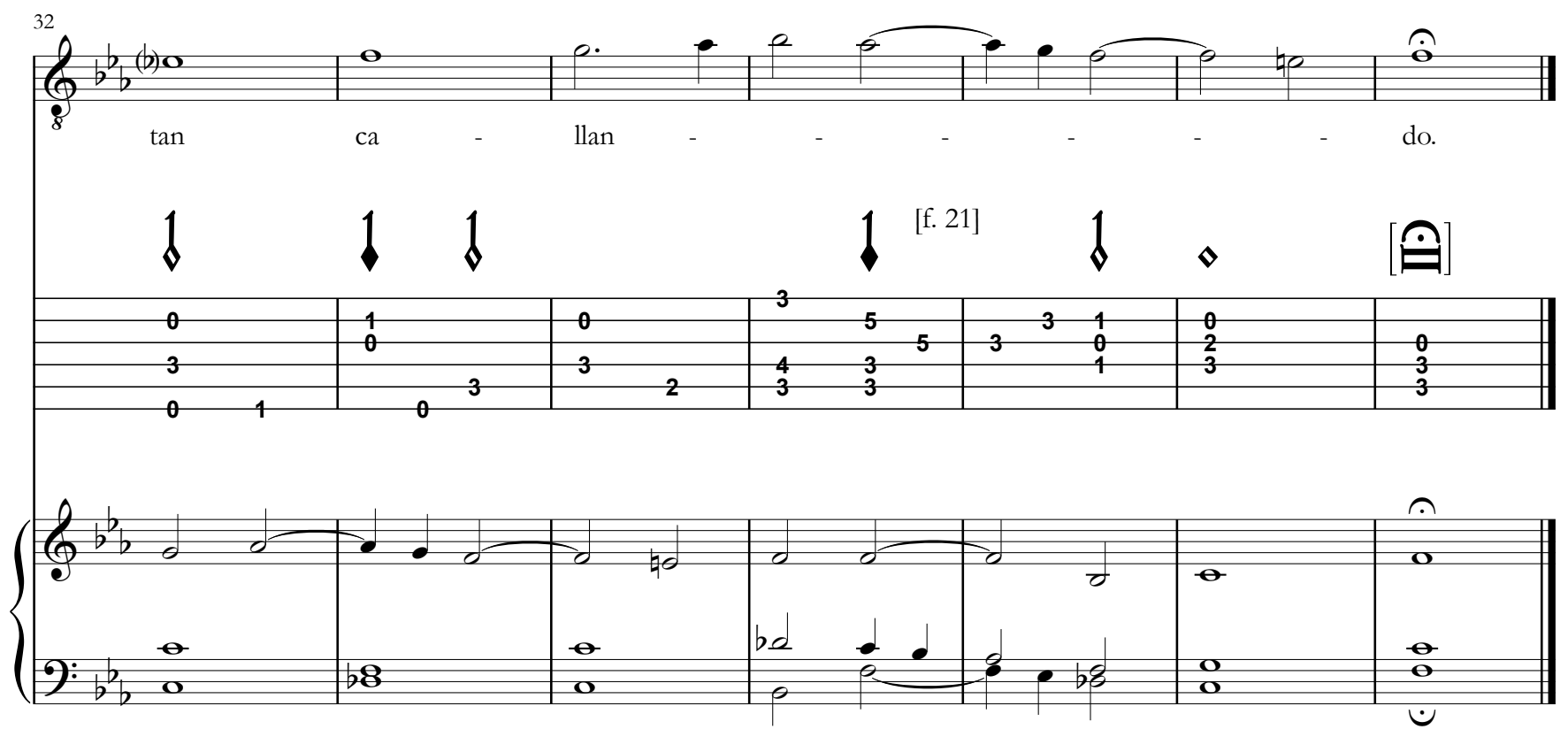

Quán presto se va [el] plazer, cómo después de pasado da dolor, cómo a nuestro parescer qualquier[a] tiempo pasado fue mejor. 
sะ 58 -Claros y frescos ríos

[Canción III]

Entónase la boz en la prima en vazío

[Libro III, IX]

[Texto: Juan Boscán]
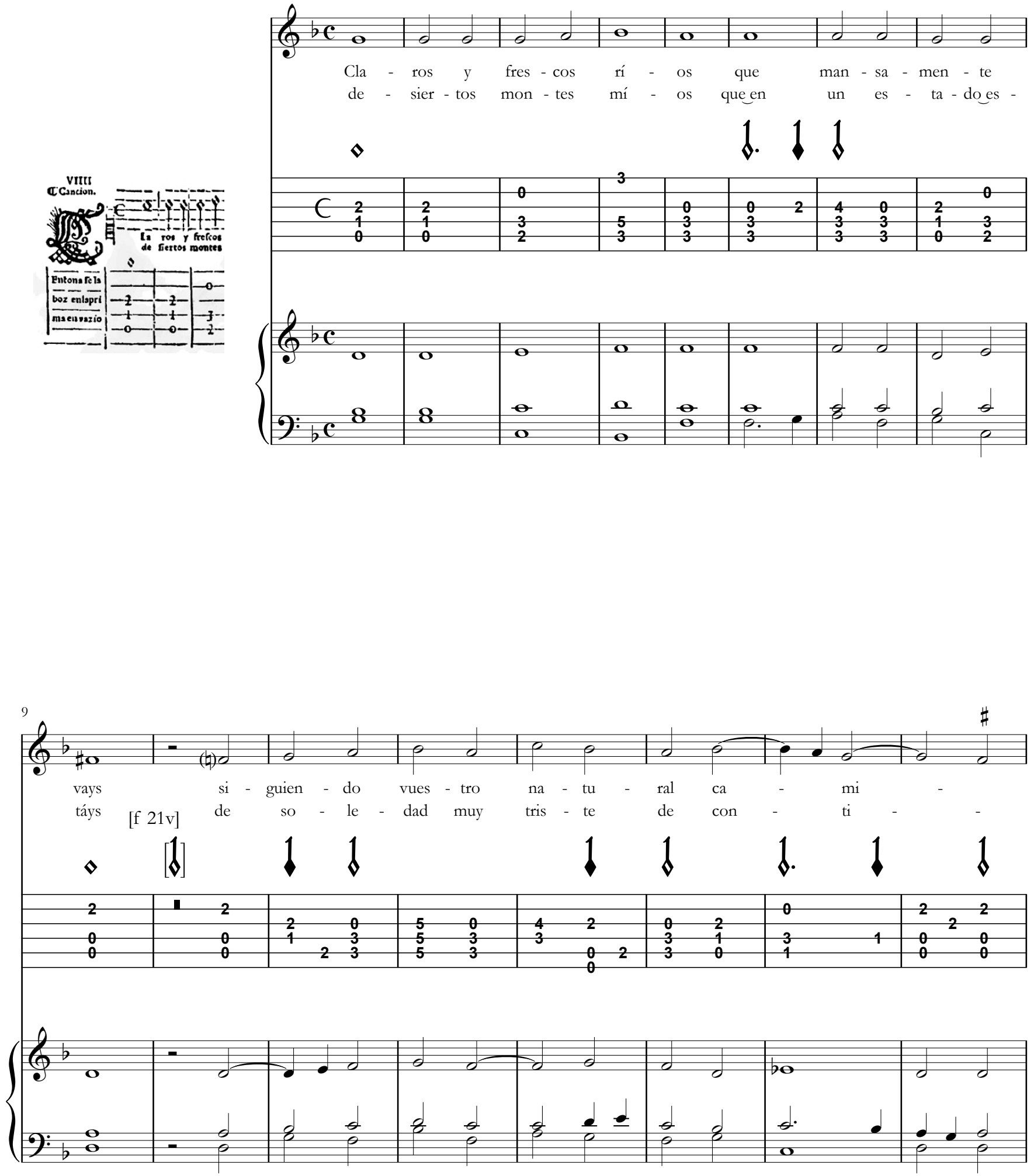

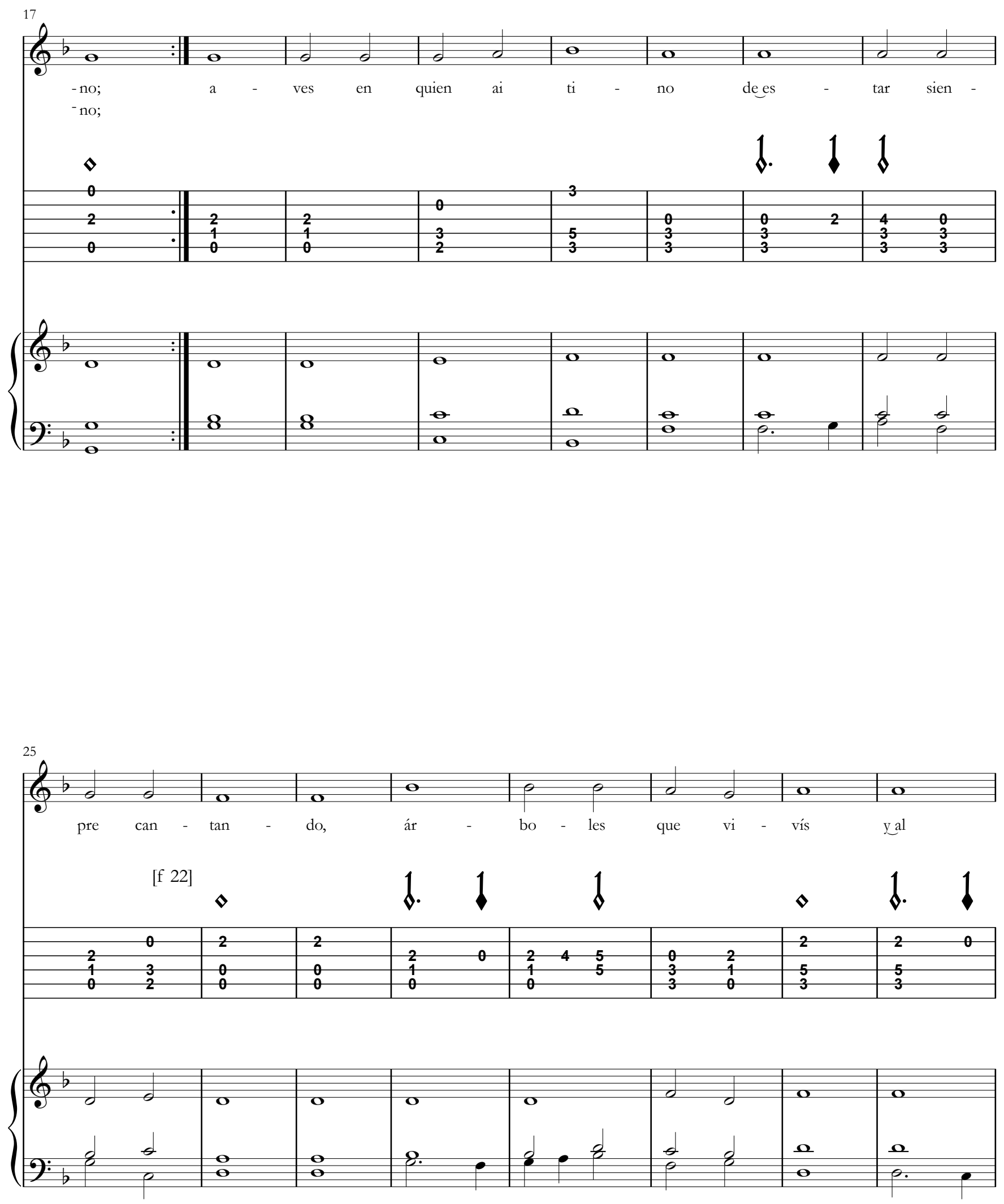

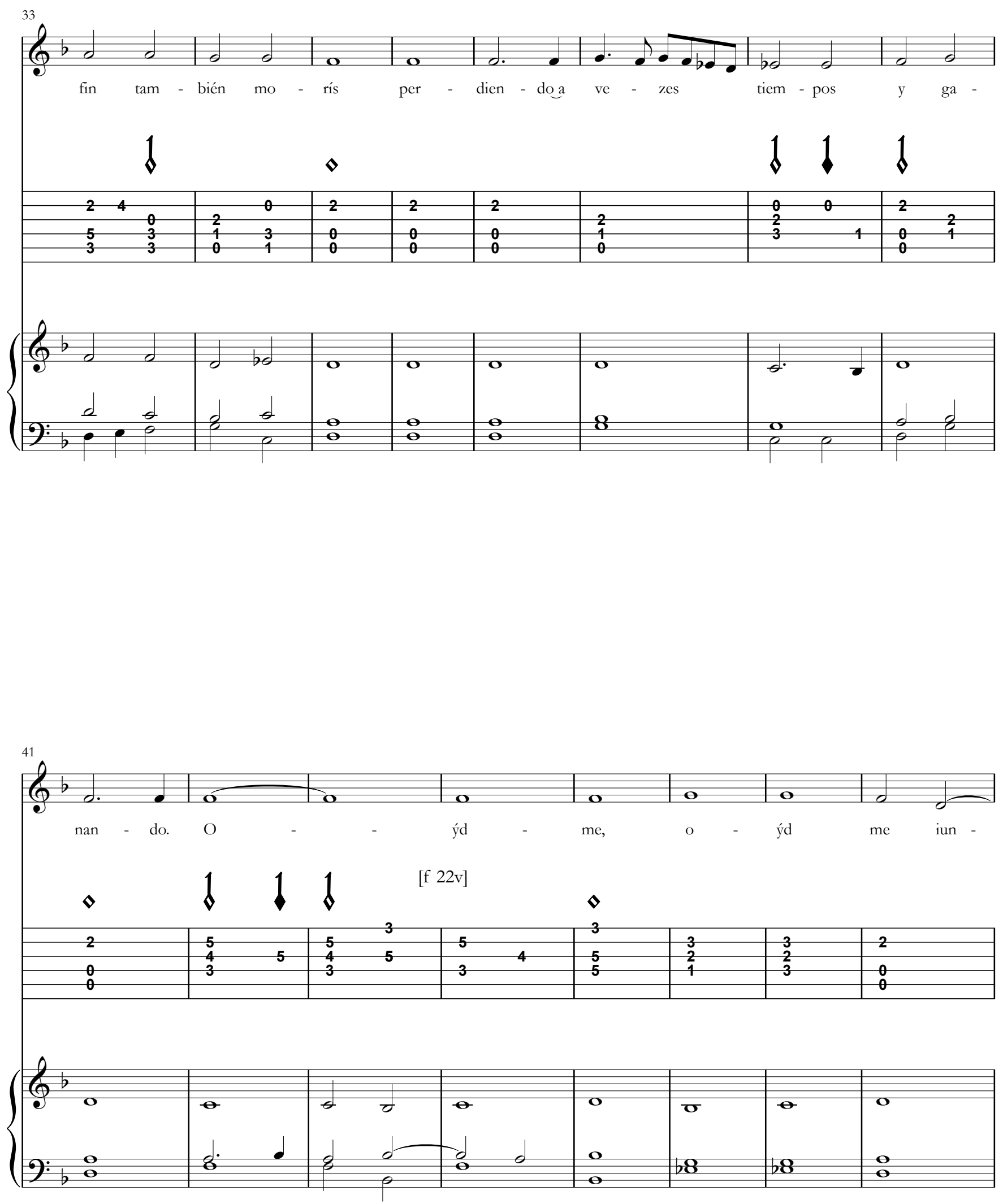

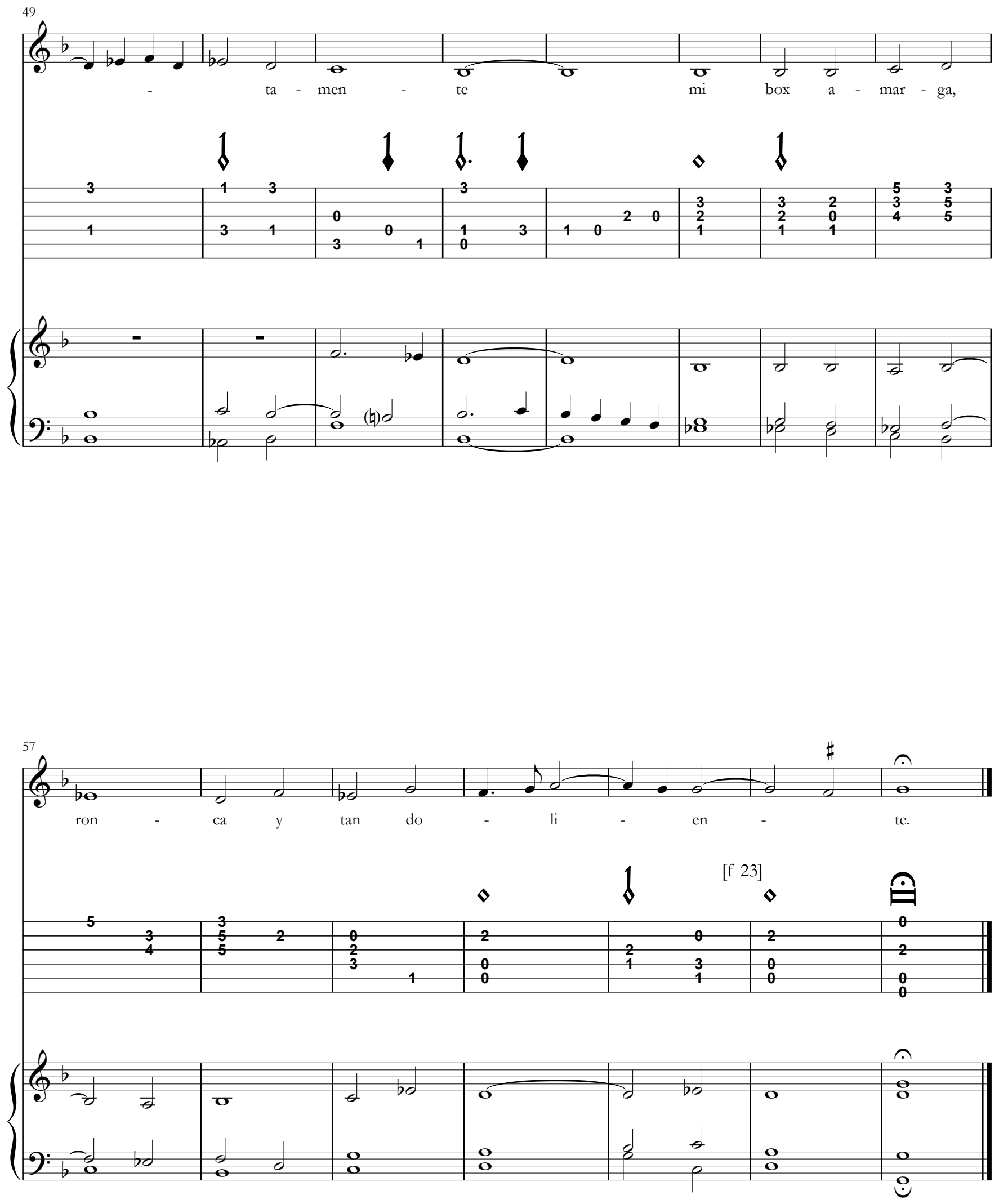


\title{
\&459- ¿Qué llantos son aquestos?
}

\author{
[Soneto I en castellano]
}

Sonetto a la muerte de la serenissima princesa

doña maría nuestra señora, va a manera de diálogo.

Entónase la box en la segunda al tercero traste

[Libro III, X]
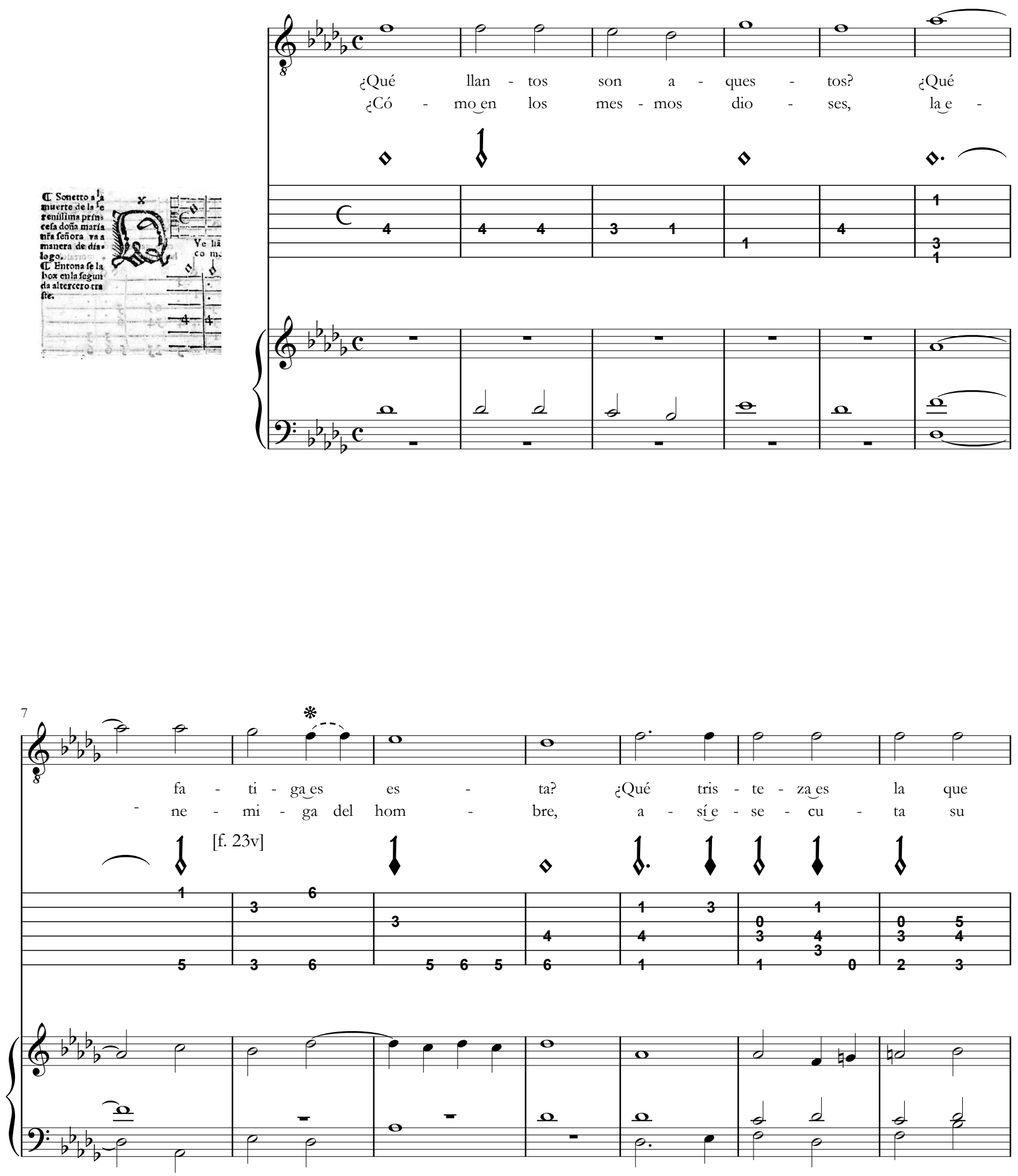

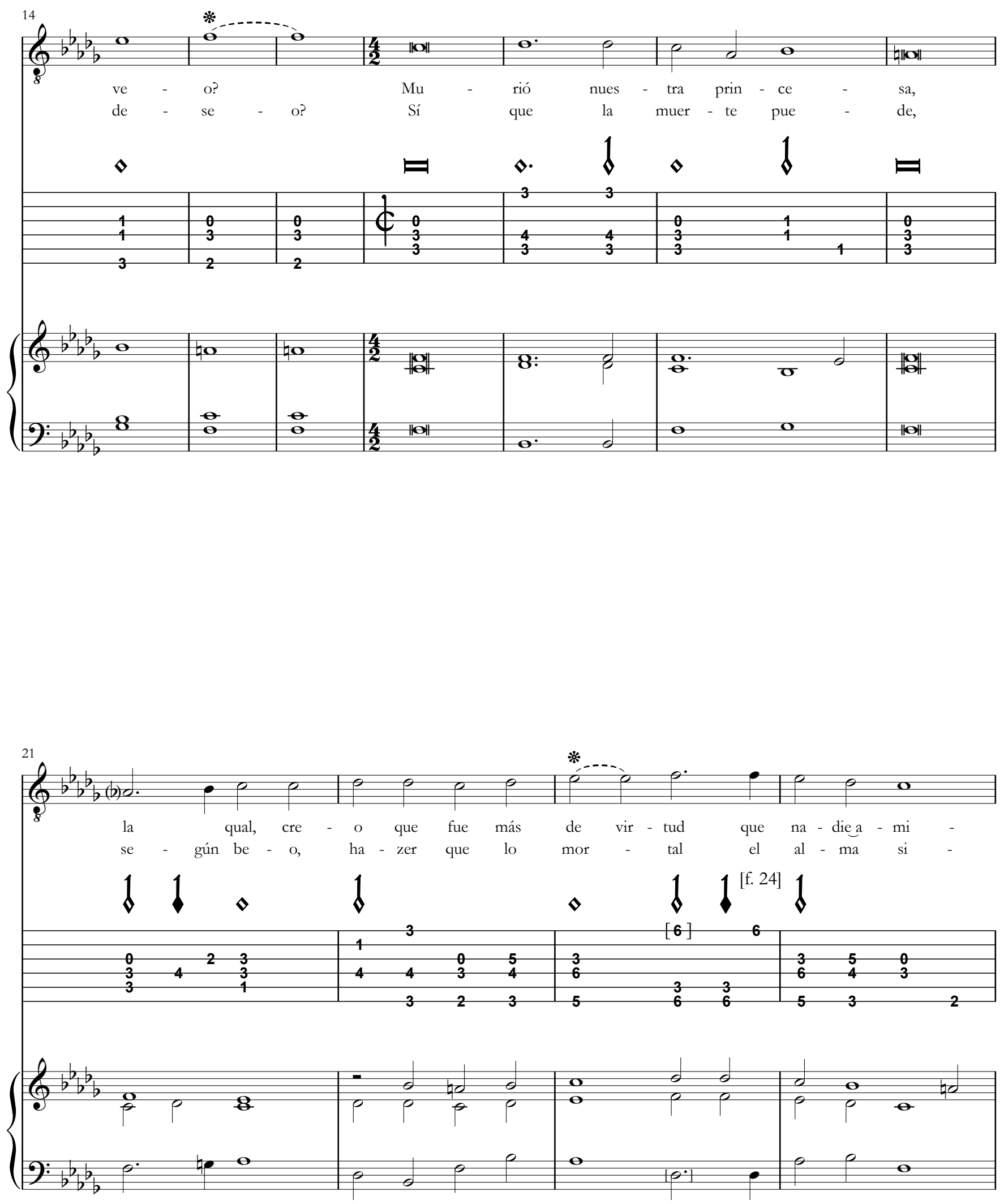

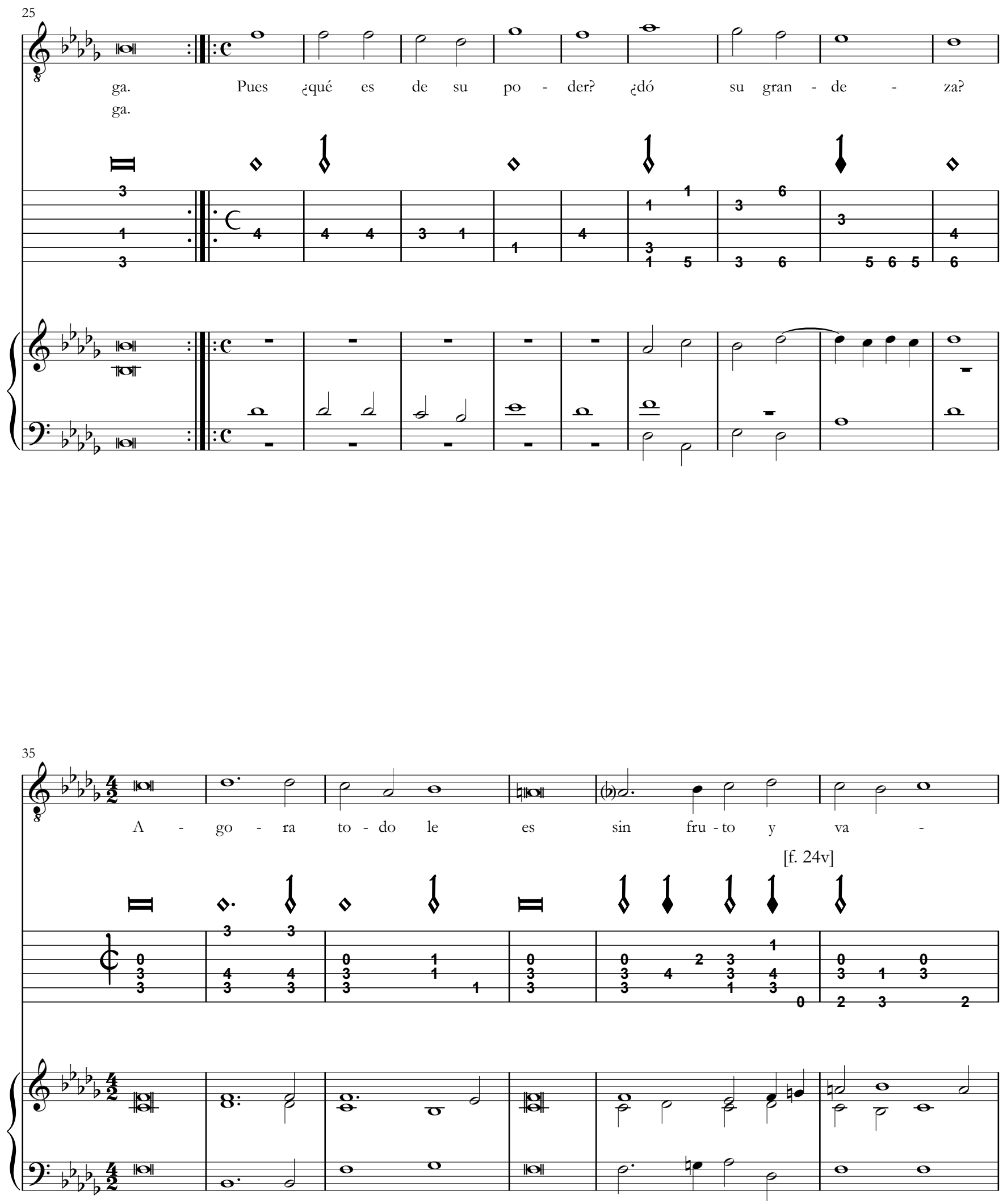

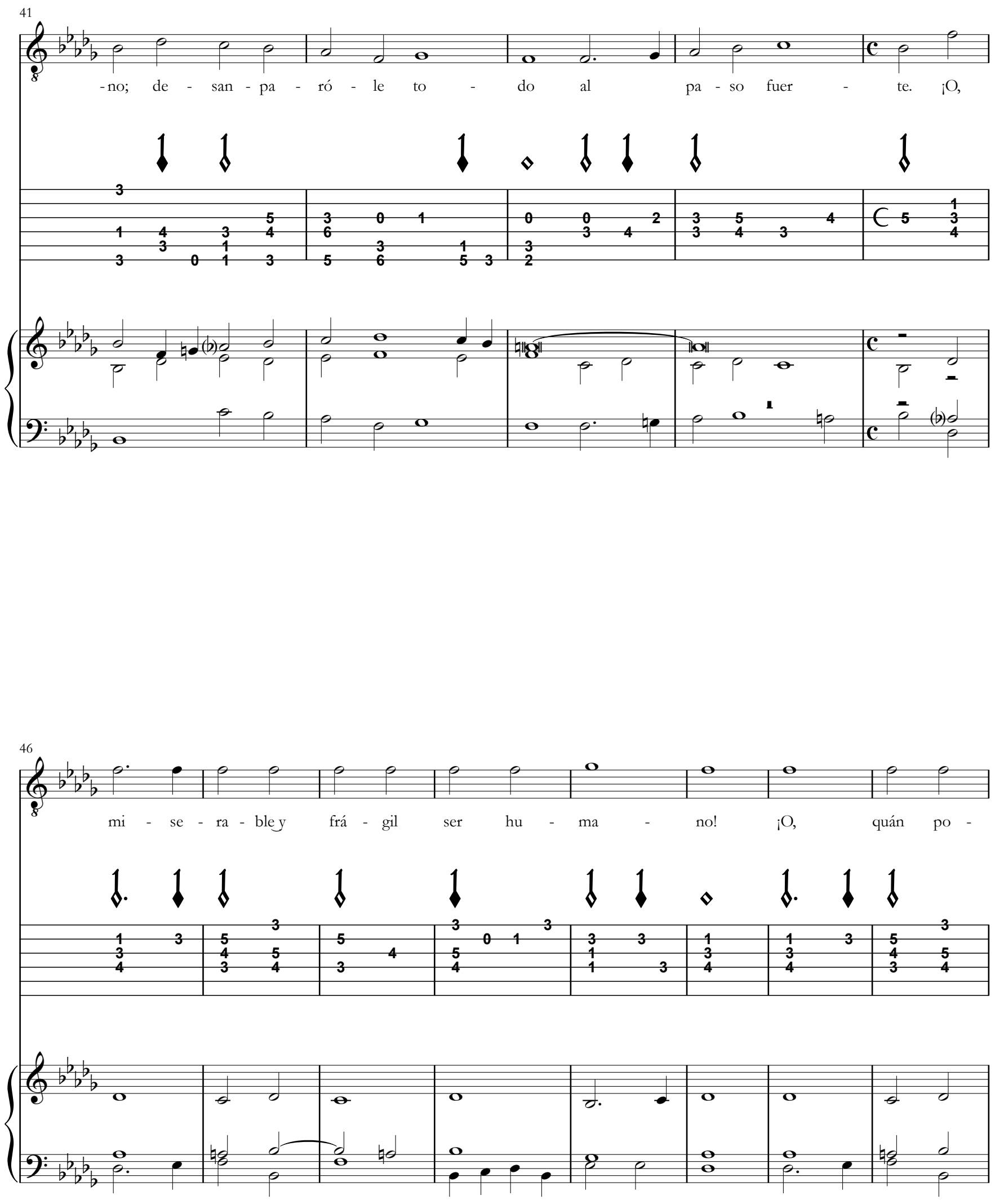

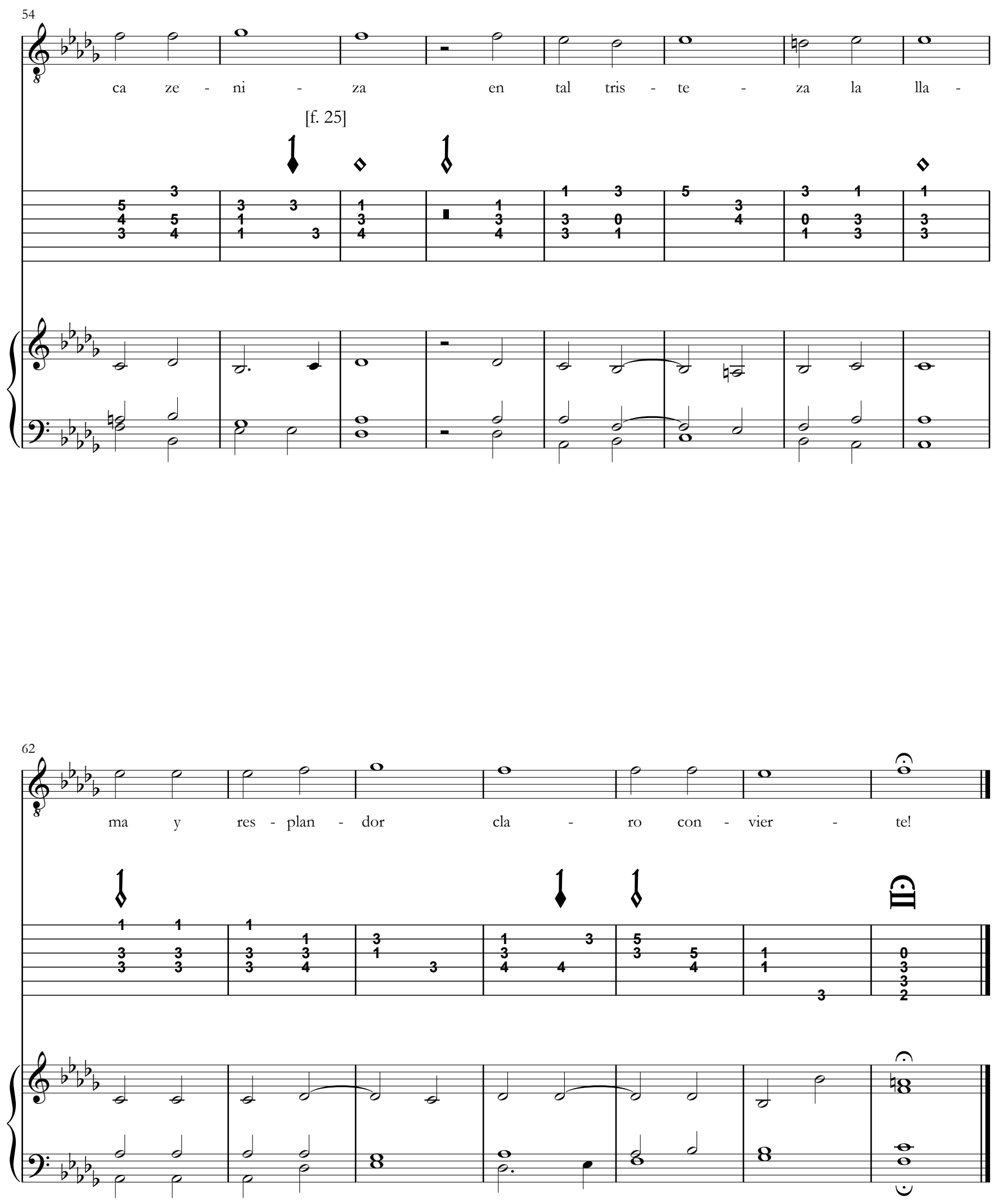


\section{se 60 - Si por amar el hombre}

[Soneto II en castellano]

Entónase la boz en la prima en vazío

[Libro III, XI]
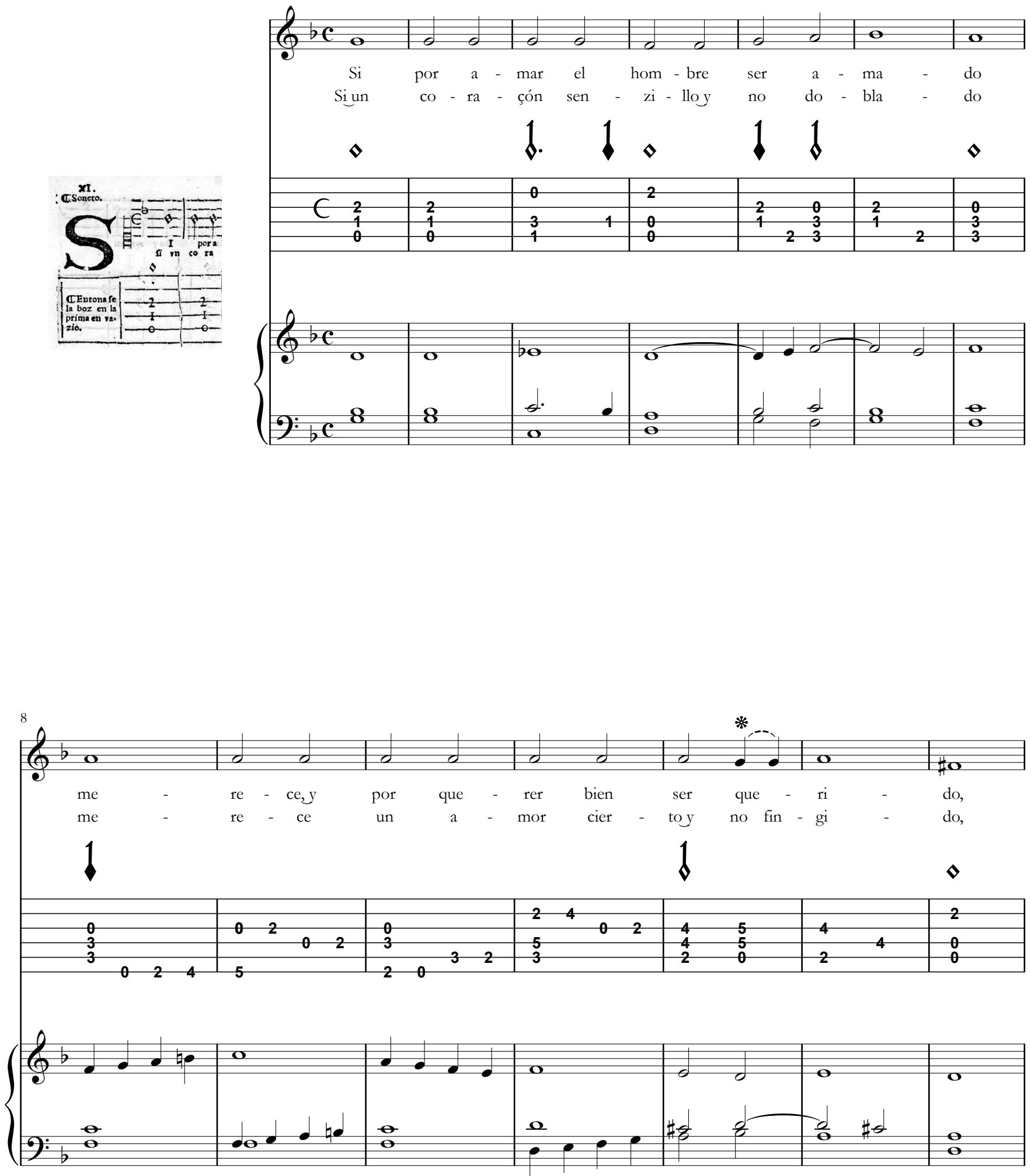

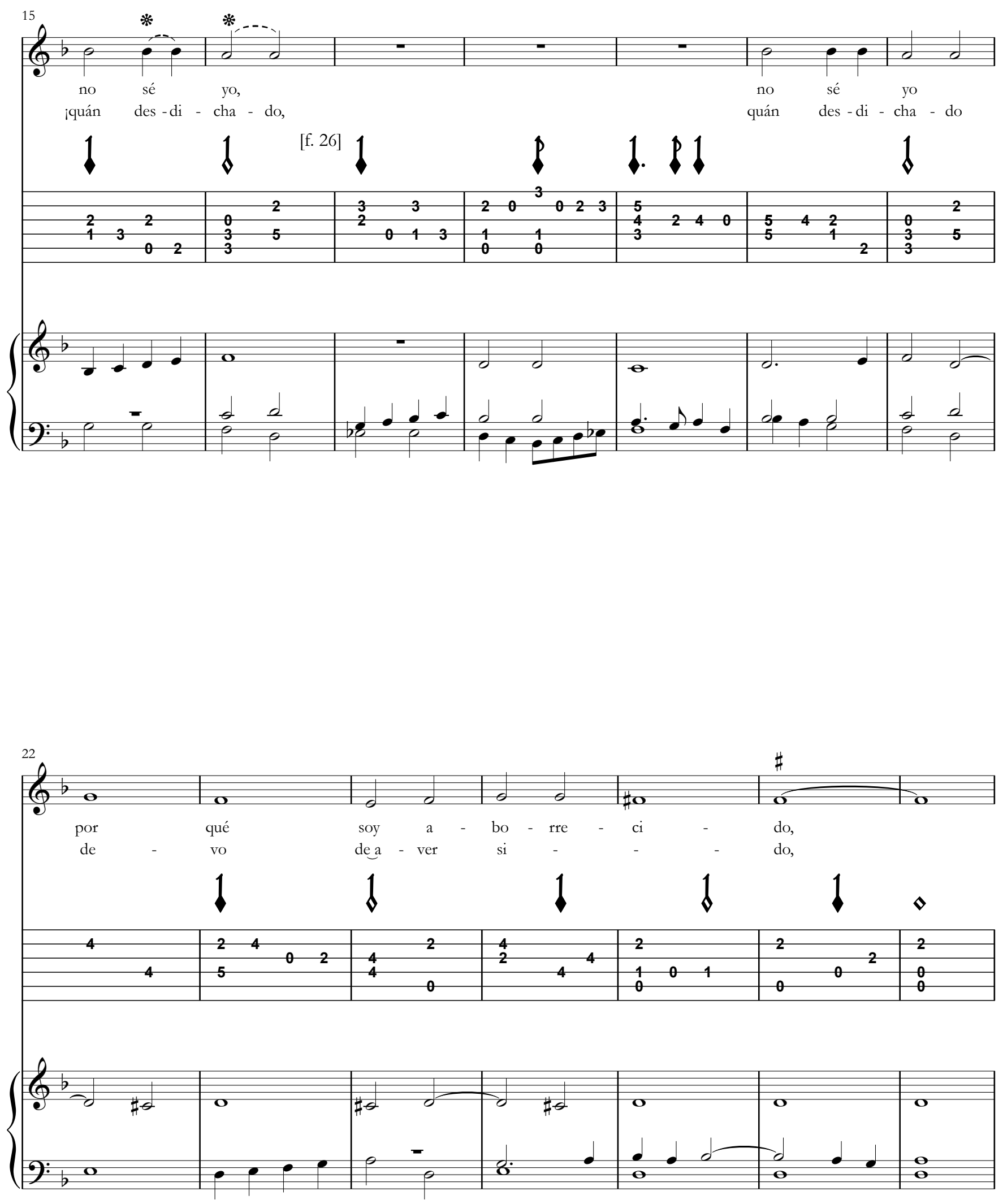

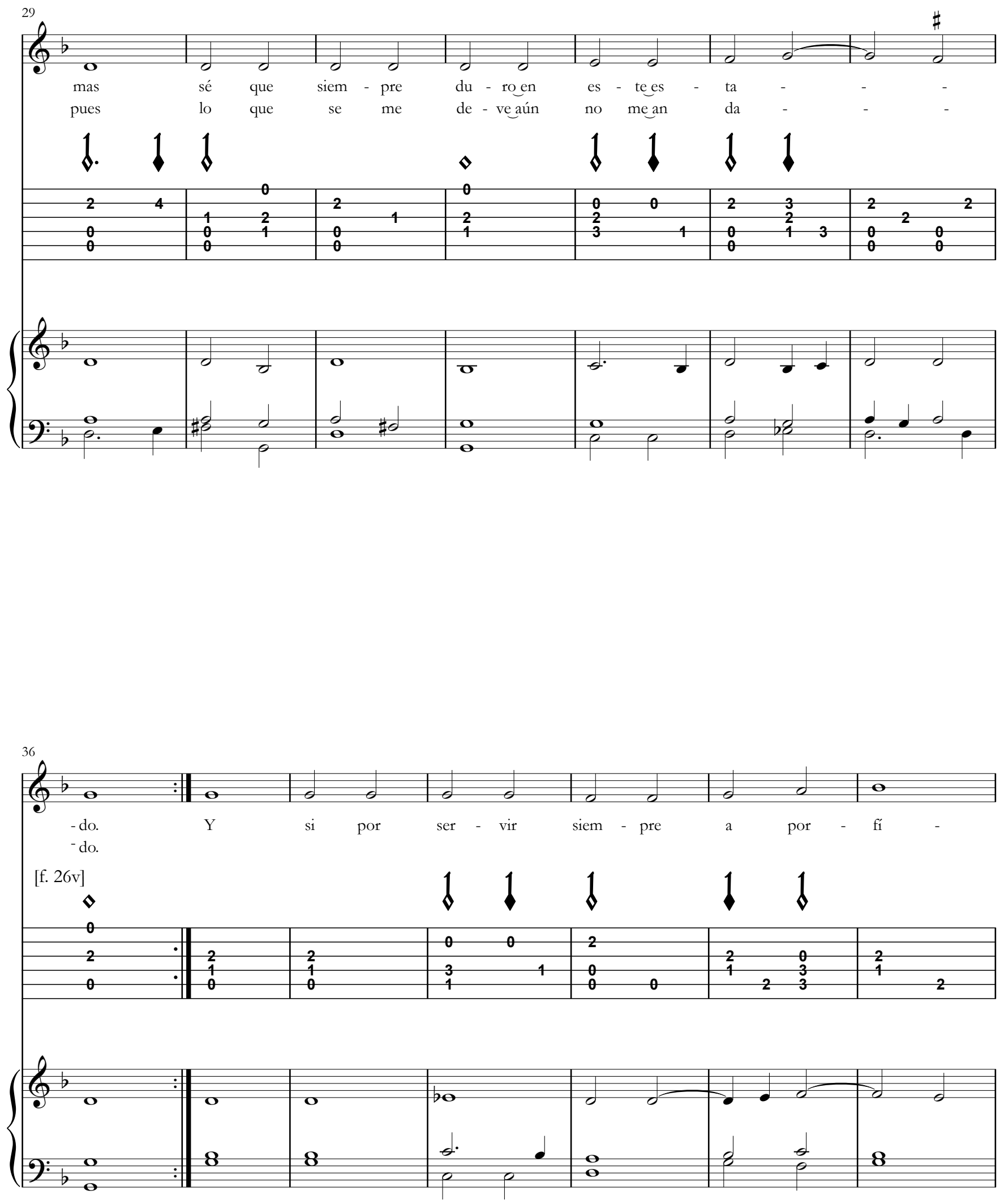

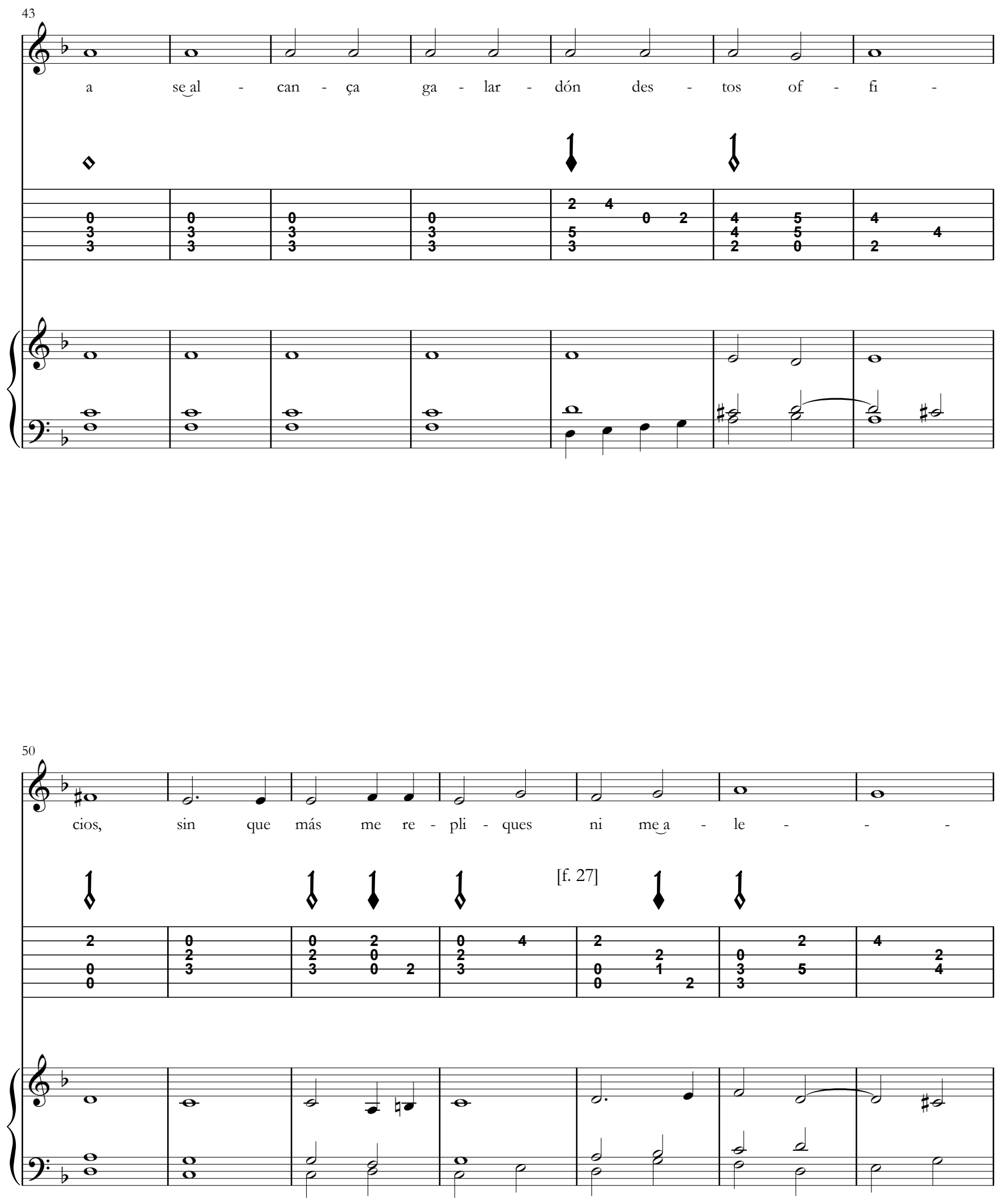

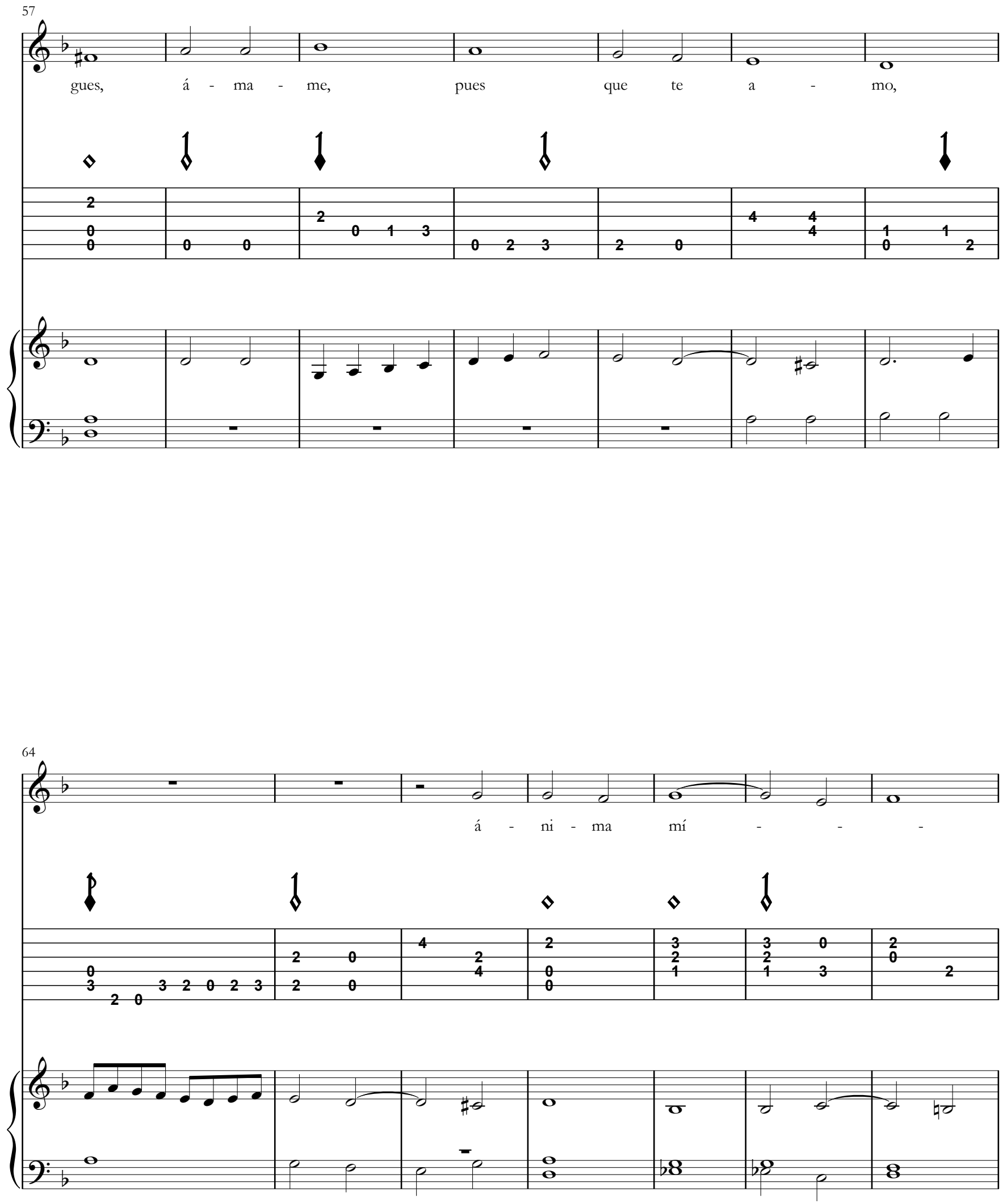

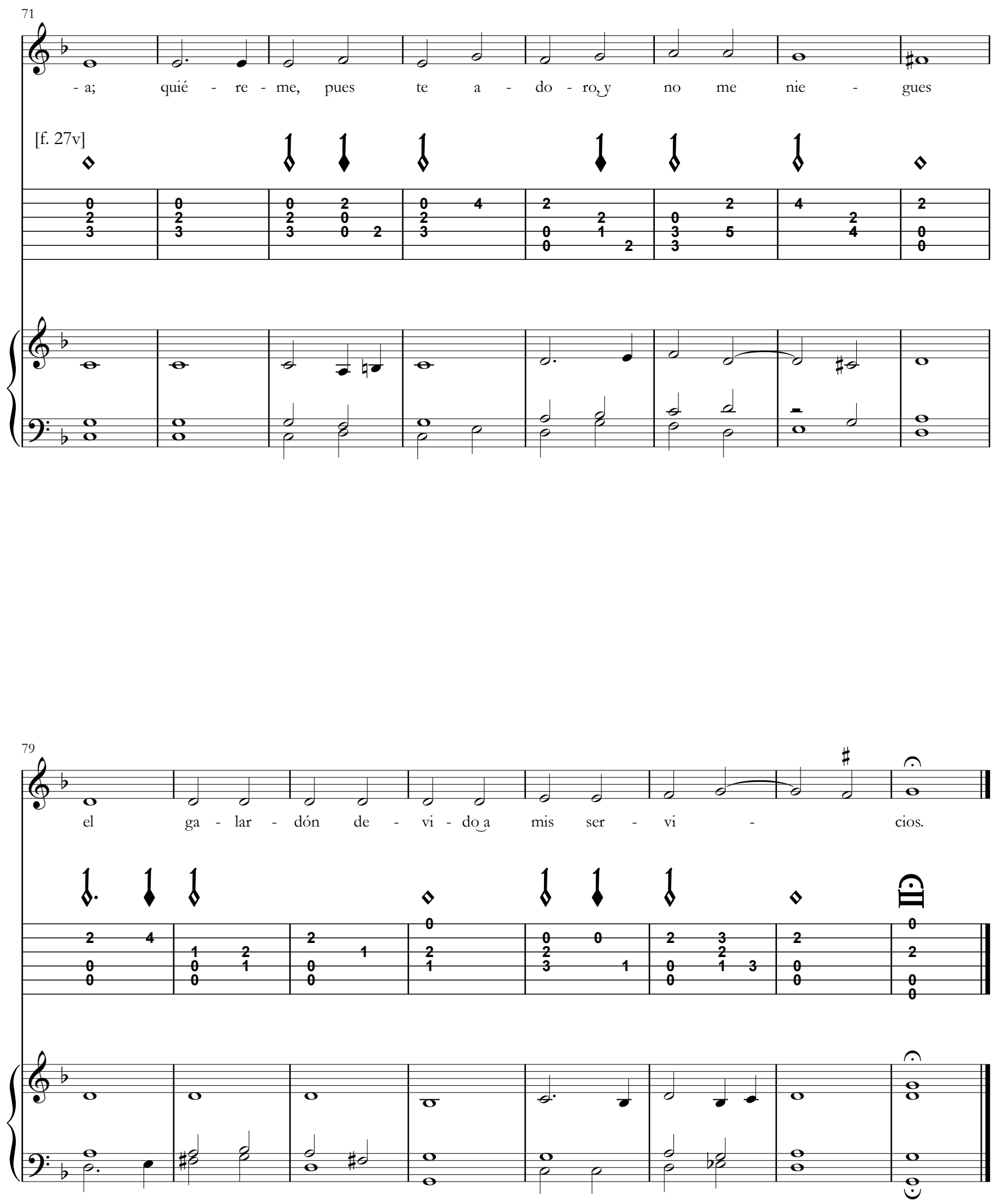


\section{s\&61 - Por ásperos caminos}

[Soneto III en castellano]

Entónase la boz en la prima en segundo traste

[Libro III, XII]

[Texto: Garcilaso de la Vega]
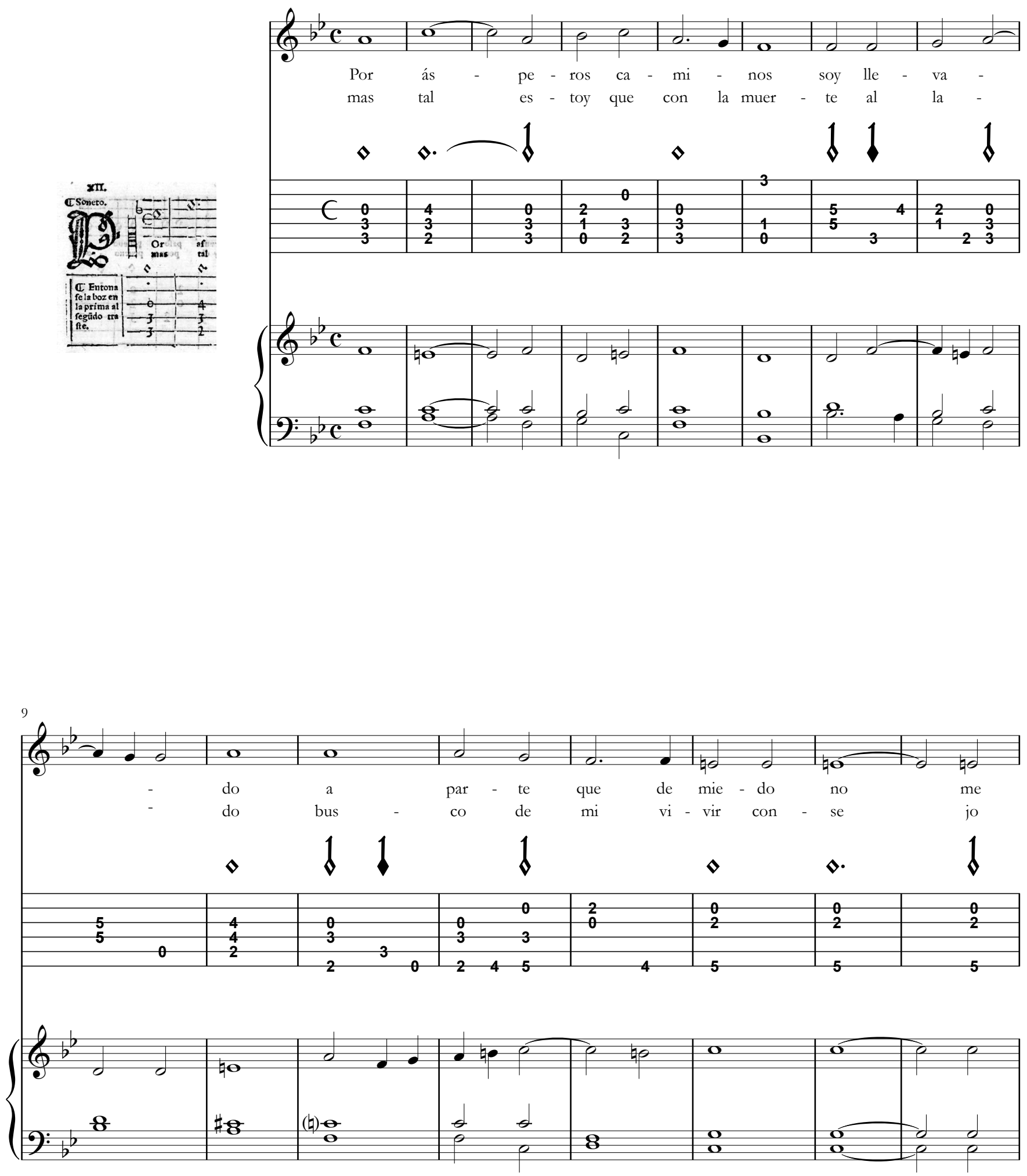

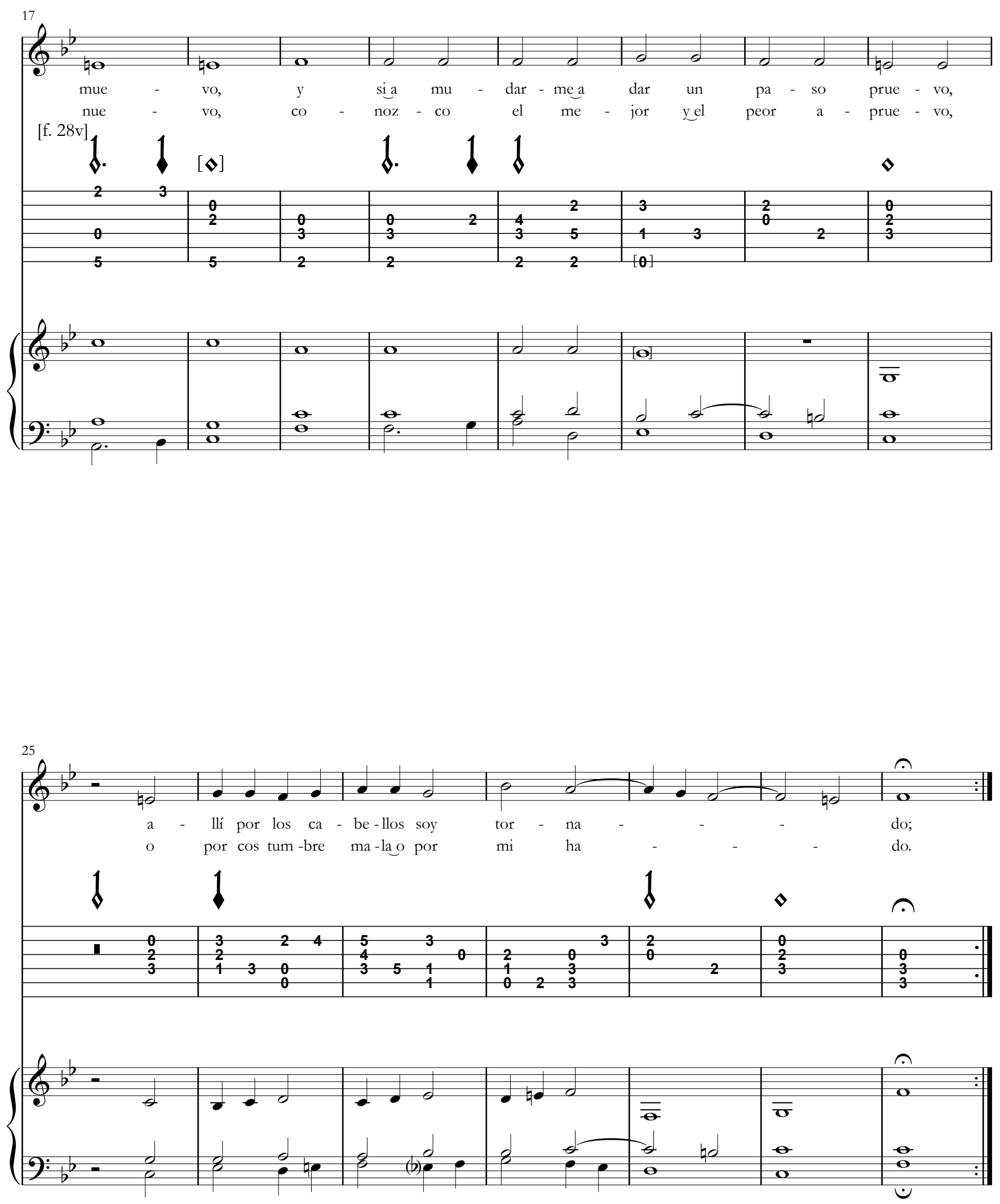

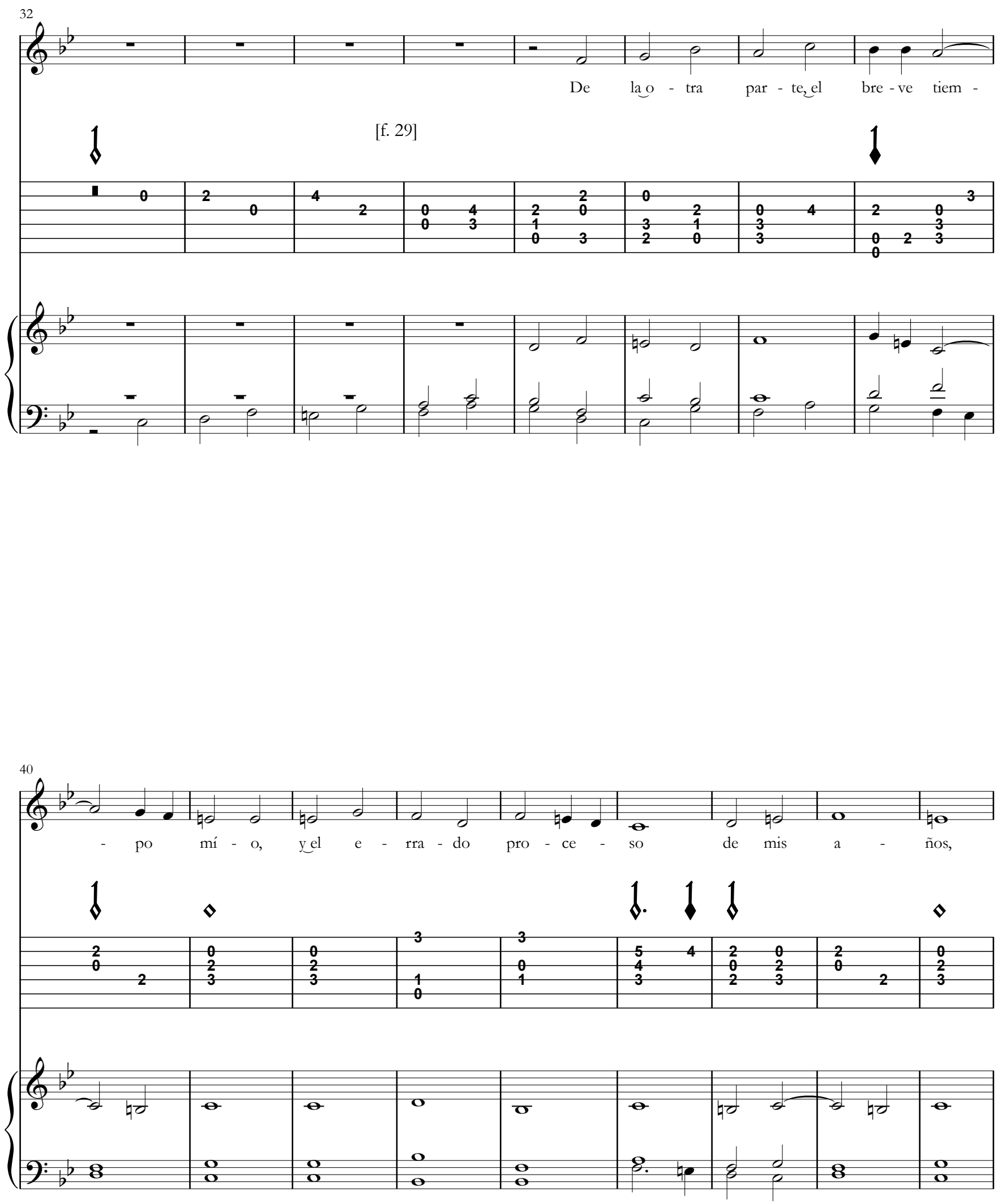

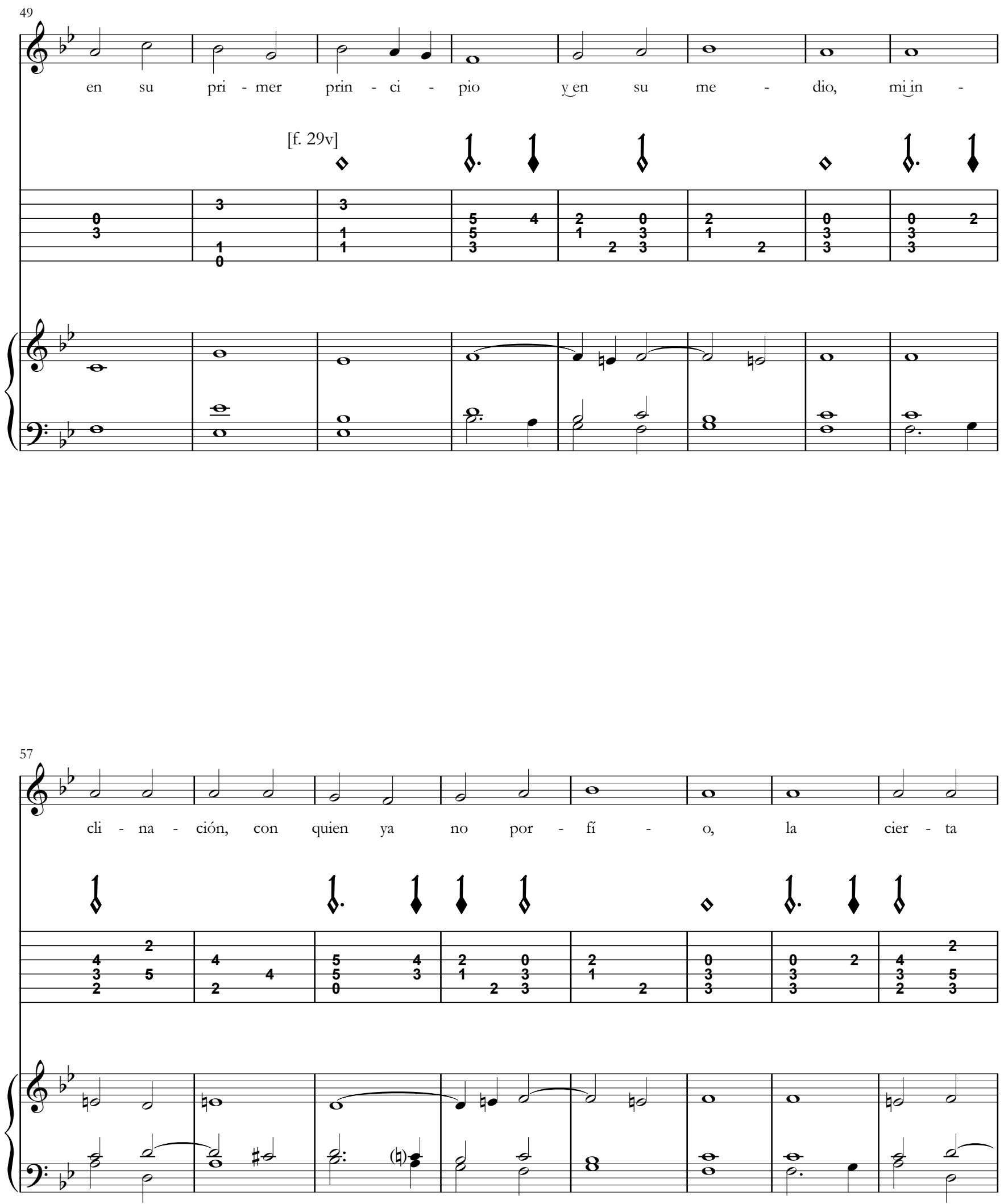

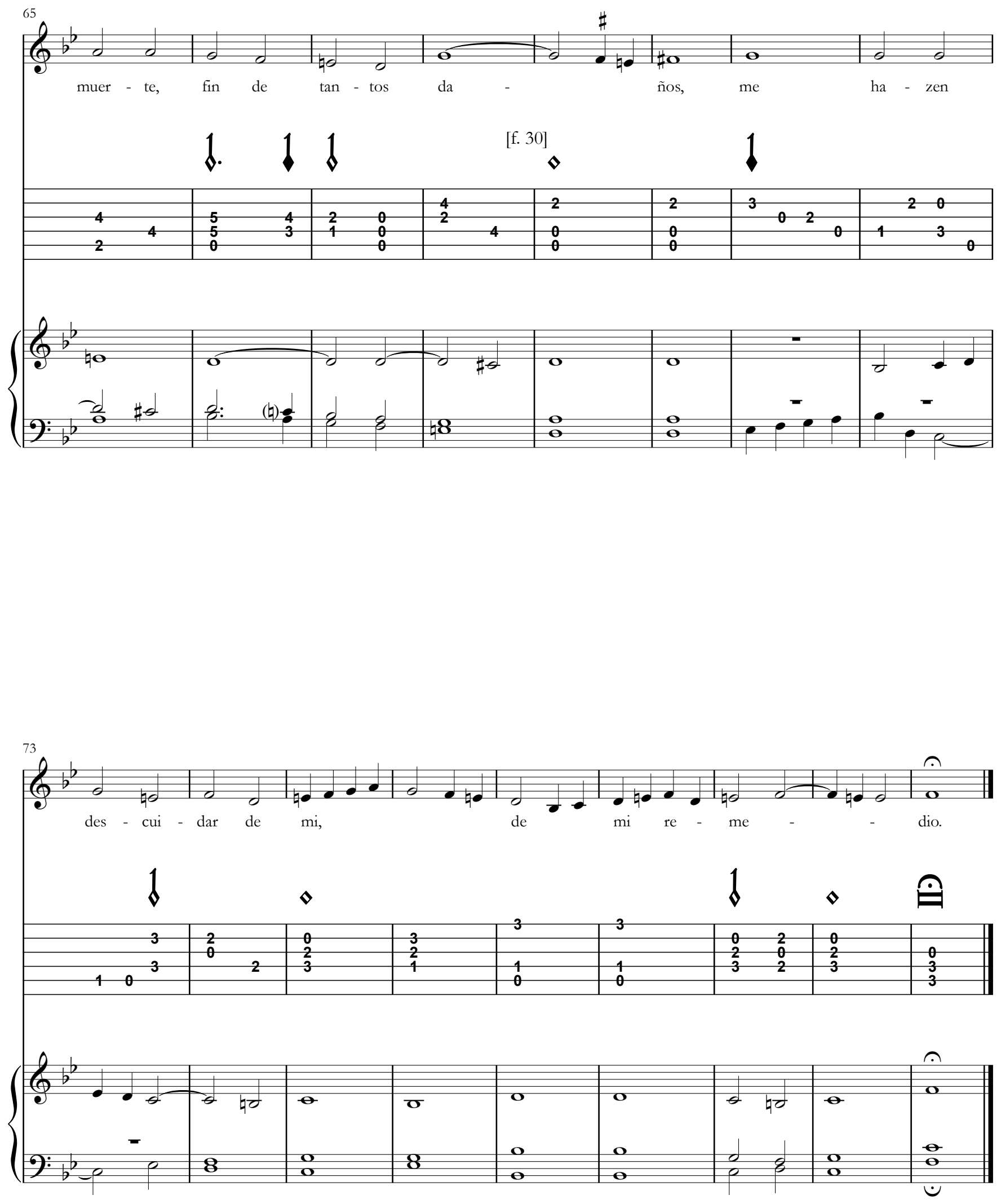


\section{so 62 - Regia qui mestow}

[Versos en latín I]

Versos a la muerte de la sereníssima princesa doña maría nuestra señora.

Entónase la box en la segunda al tercero traste

[Libro III, XIII]
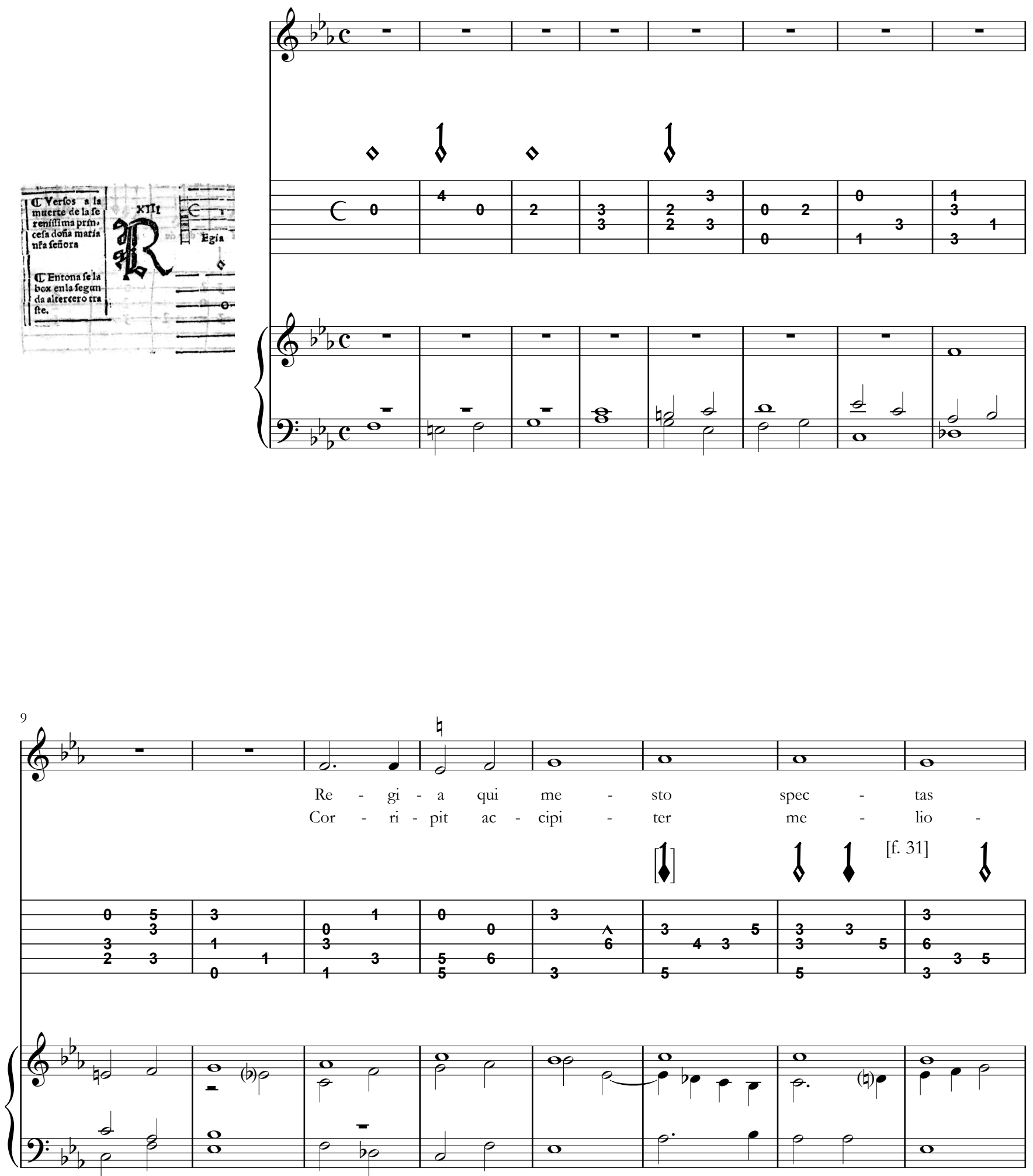

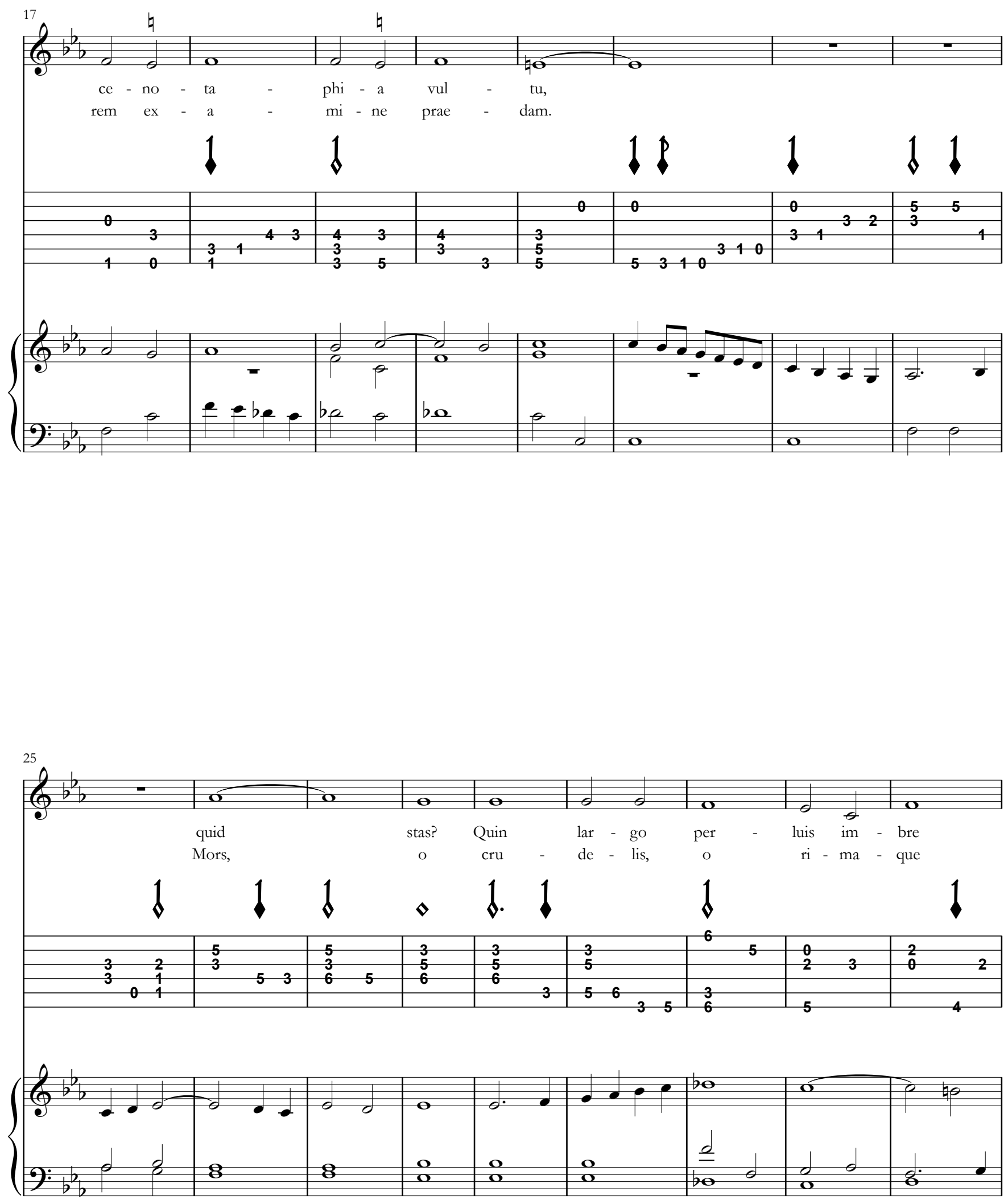

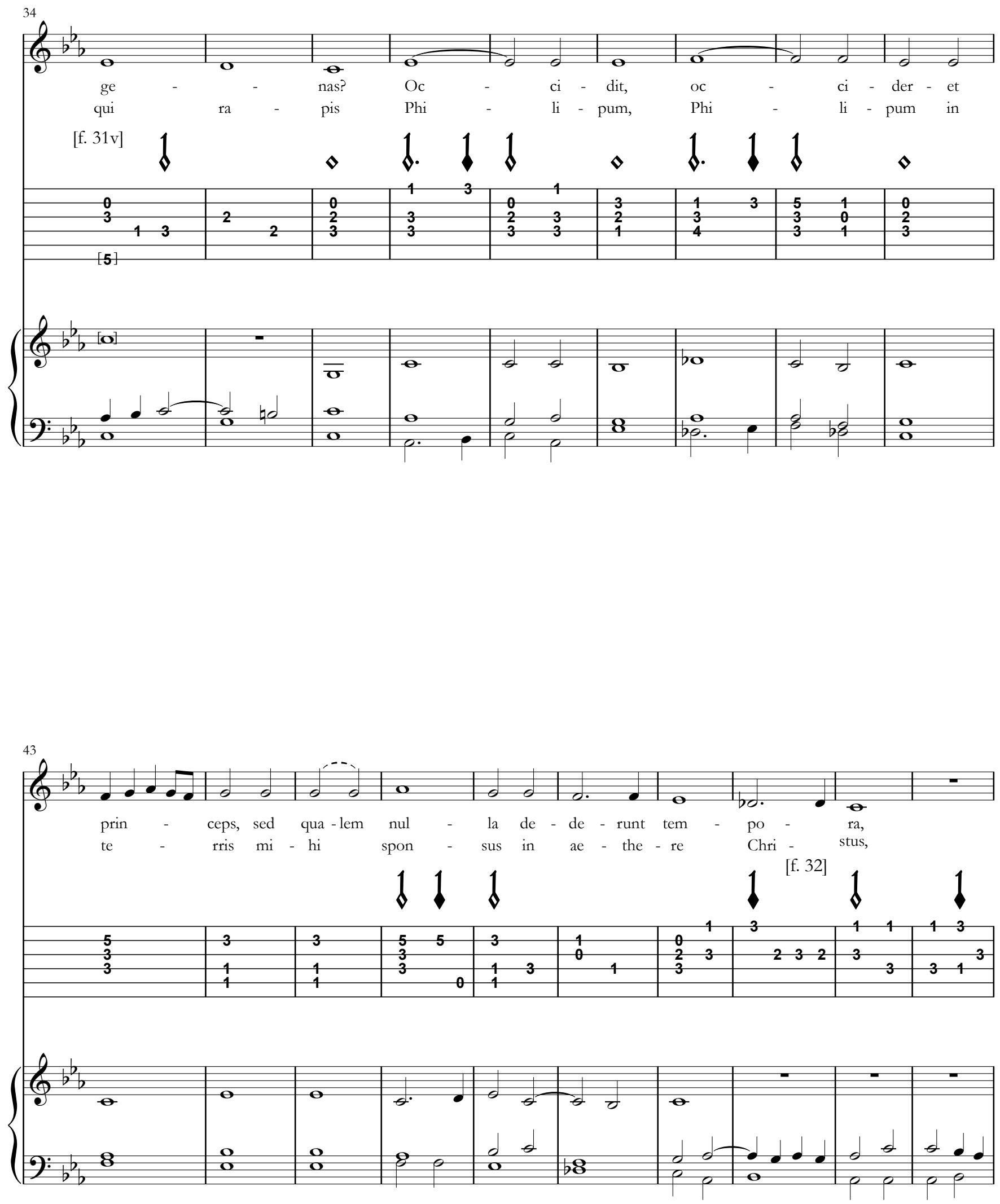


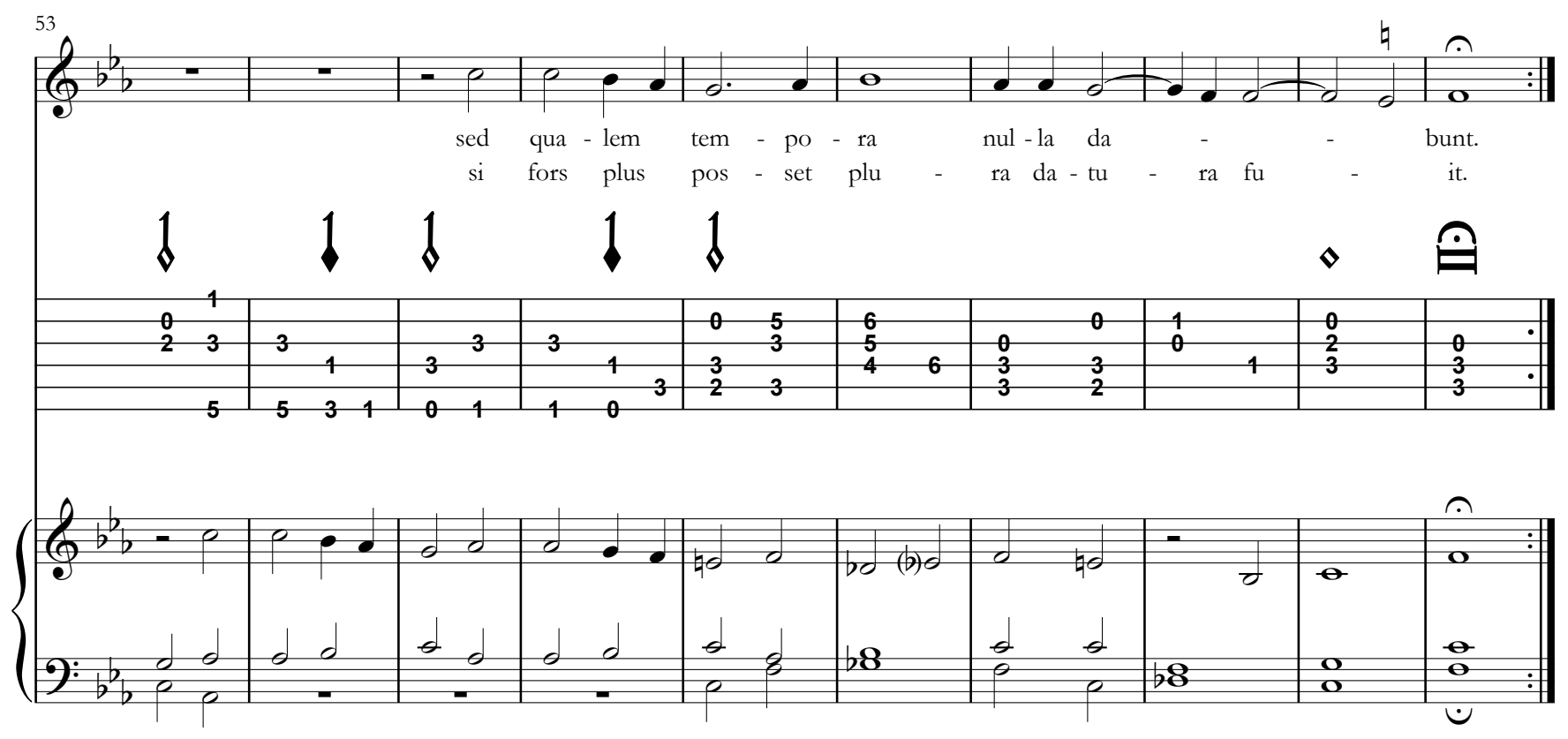

Nil mihi vobiscum, iam mors et vita.

Valete nam vivo felix, non moritura deo.

Haec mihi sit vita, haec requies aeterna laborum.

Cetera nam semper sors violenta rapit. 
so 63 - Dulces exuviae

[Versos en latín II]

Versos del quarto de vergilio.

Entónase la box en la segunda al quarto traste

[Libro III, XIV]
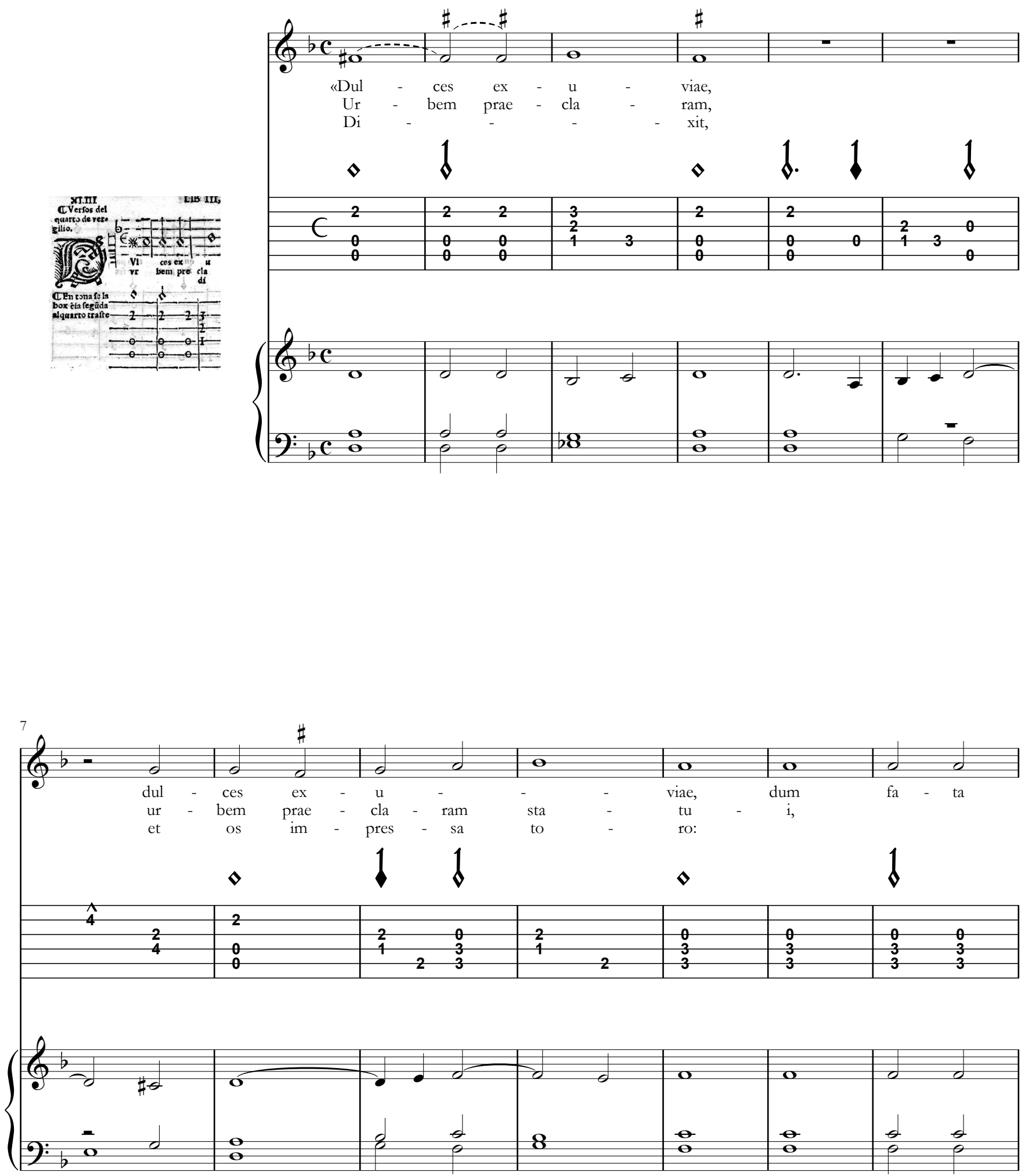

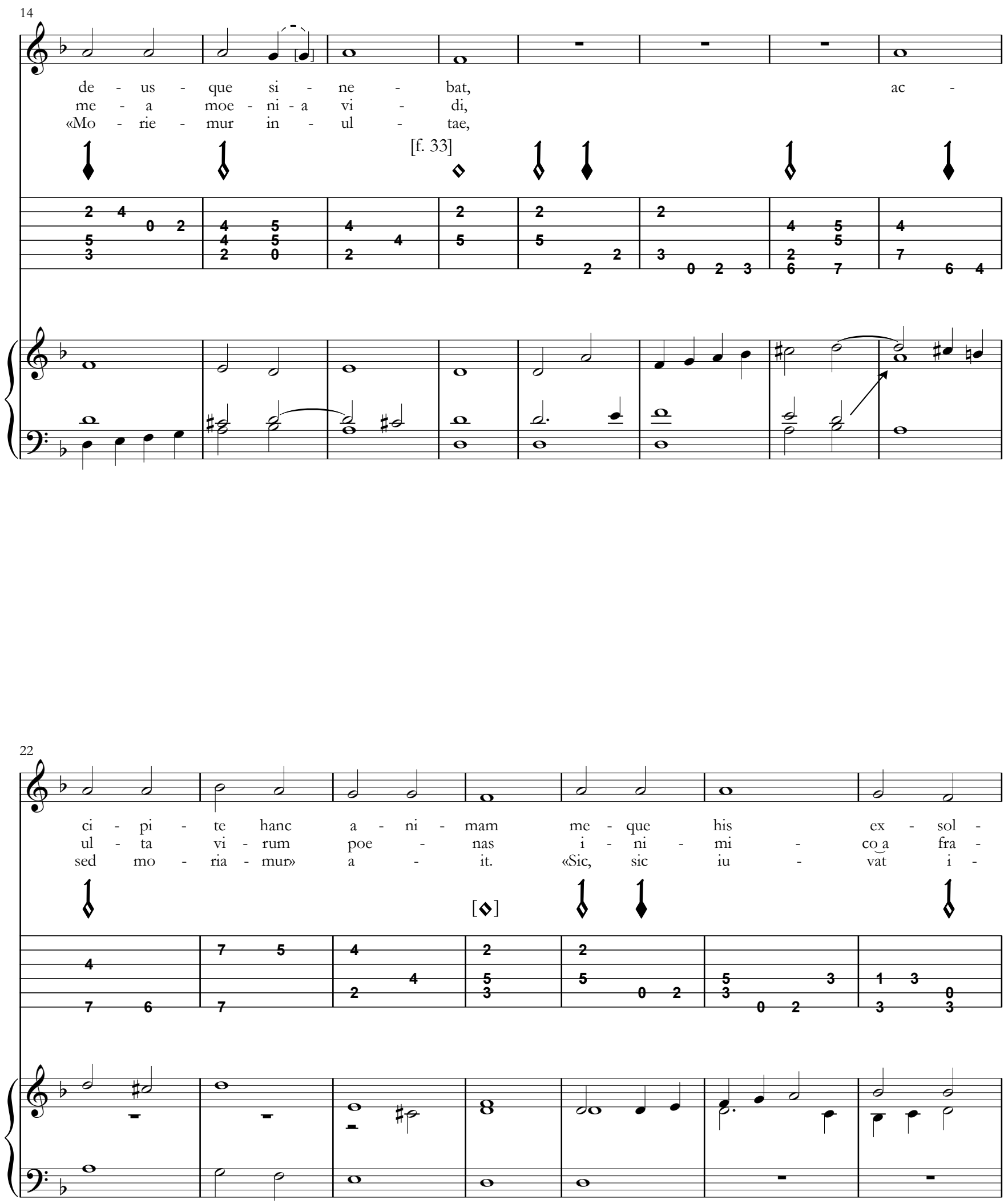

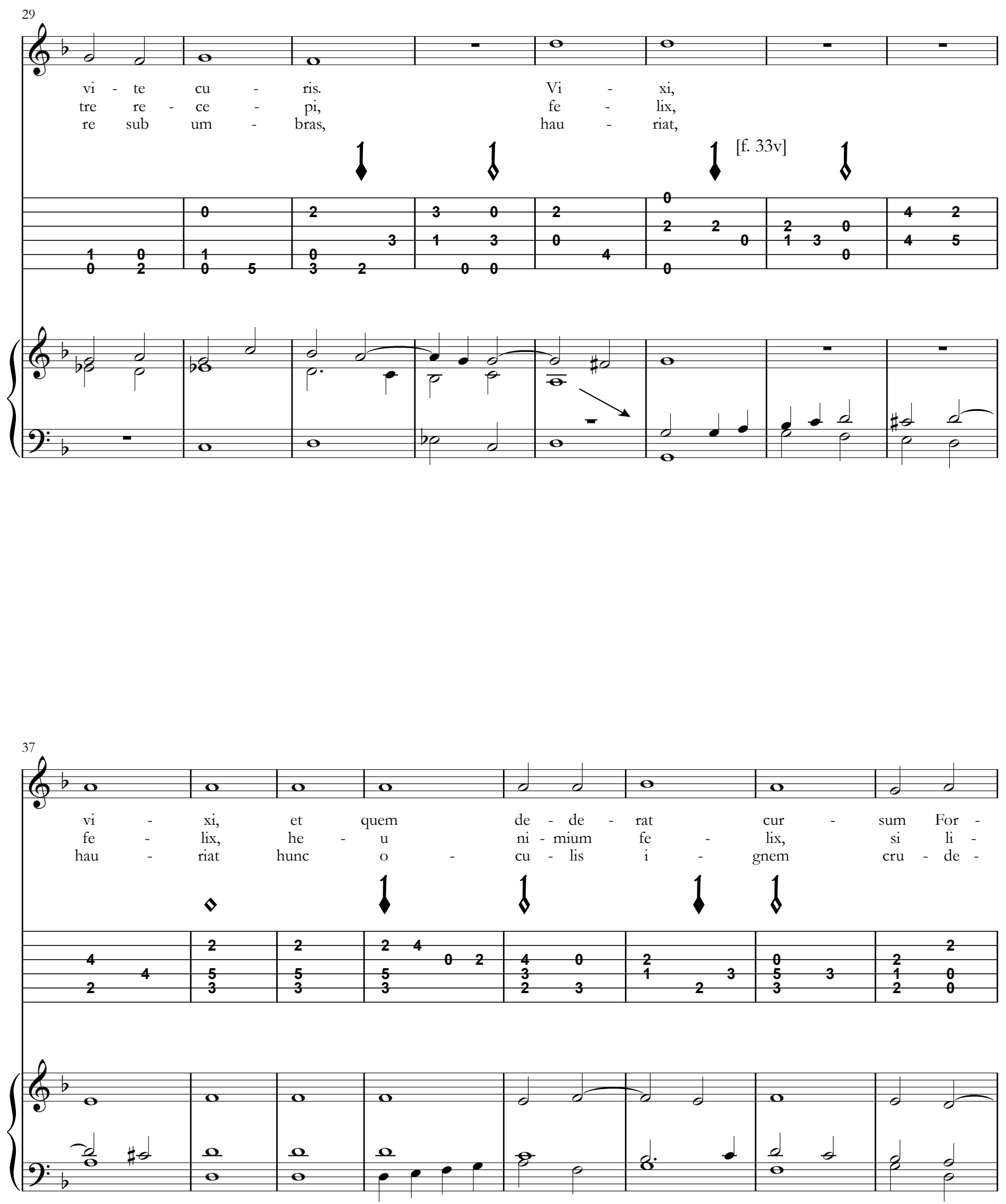

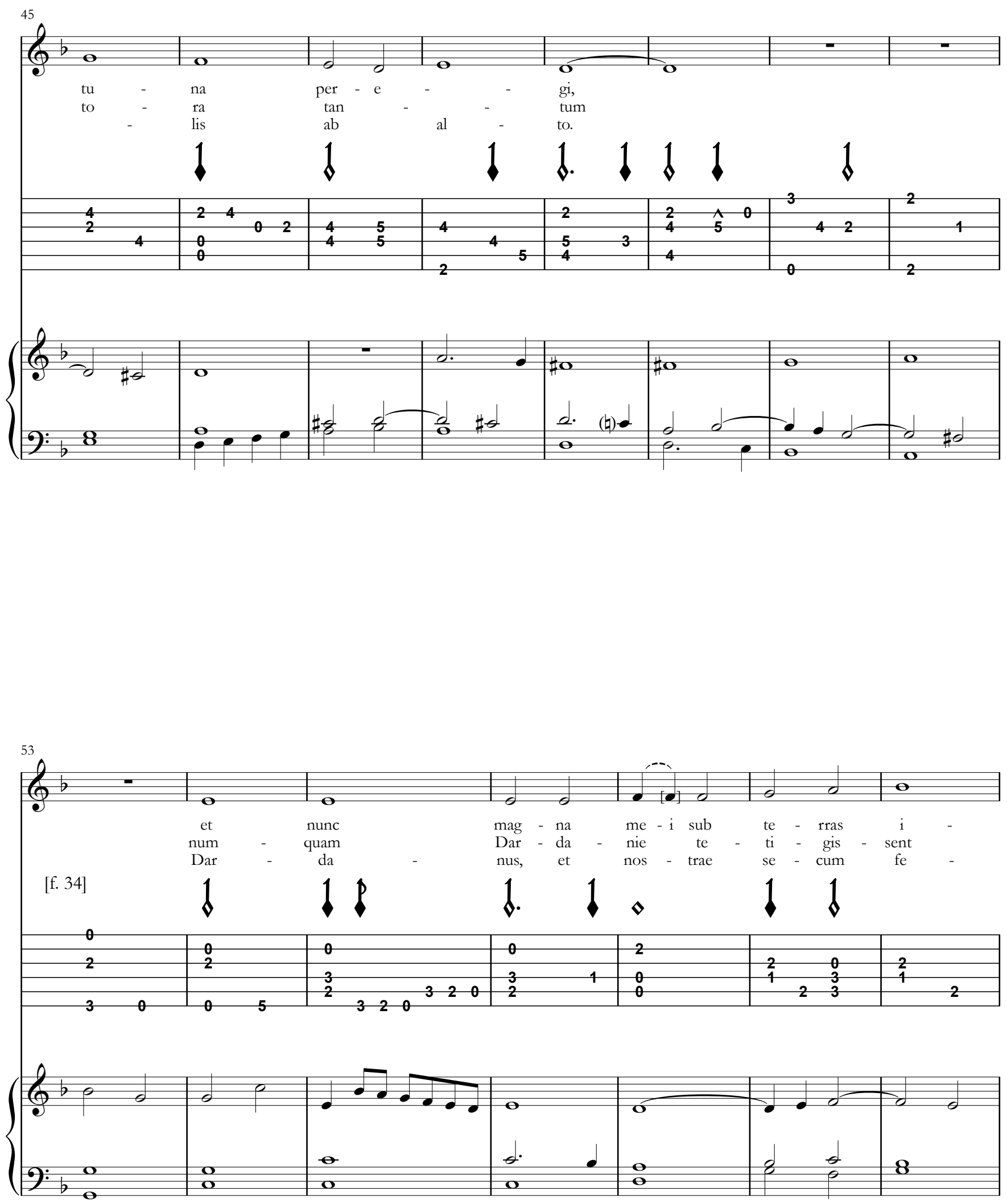

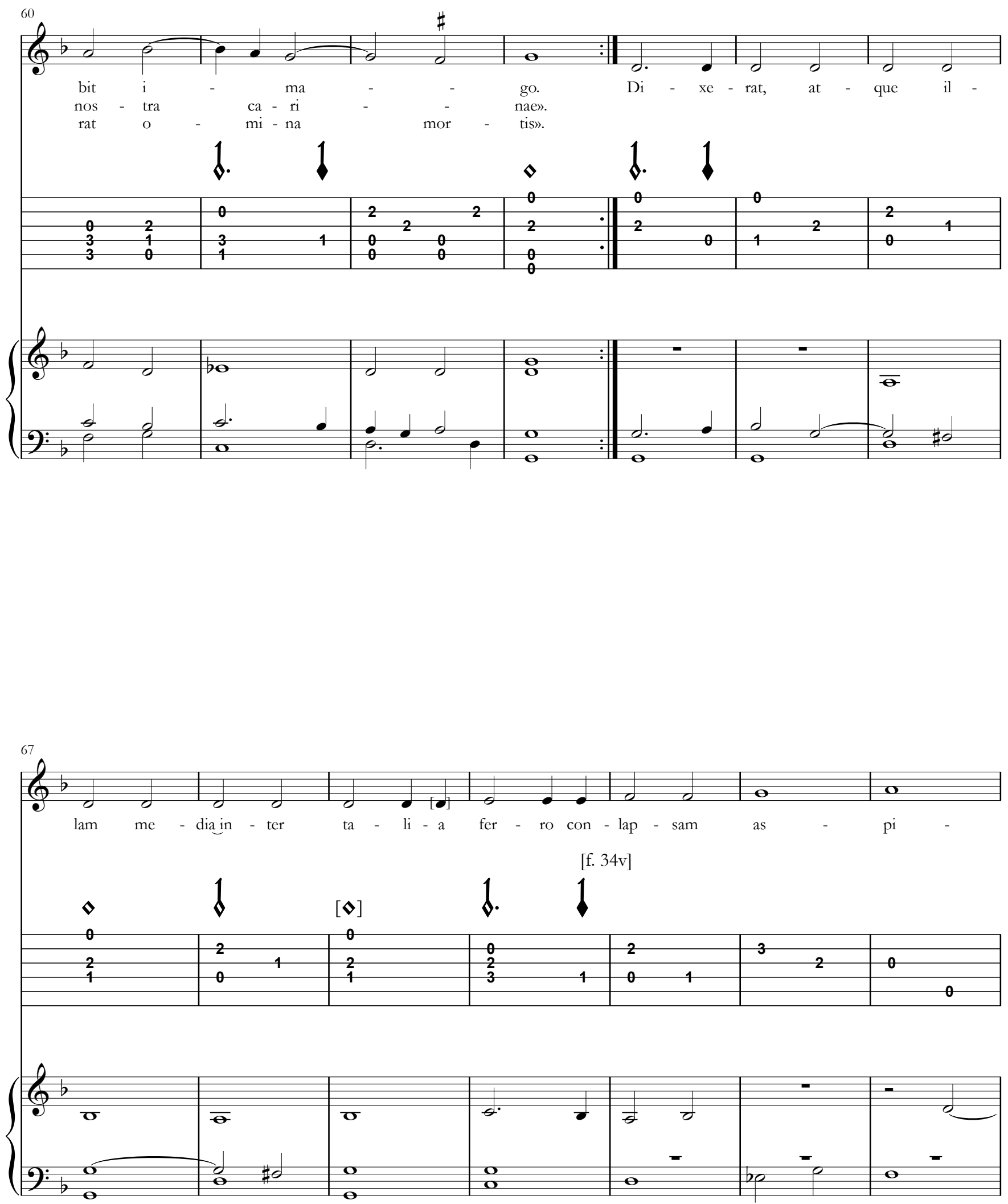

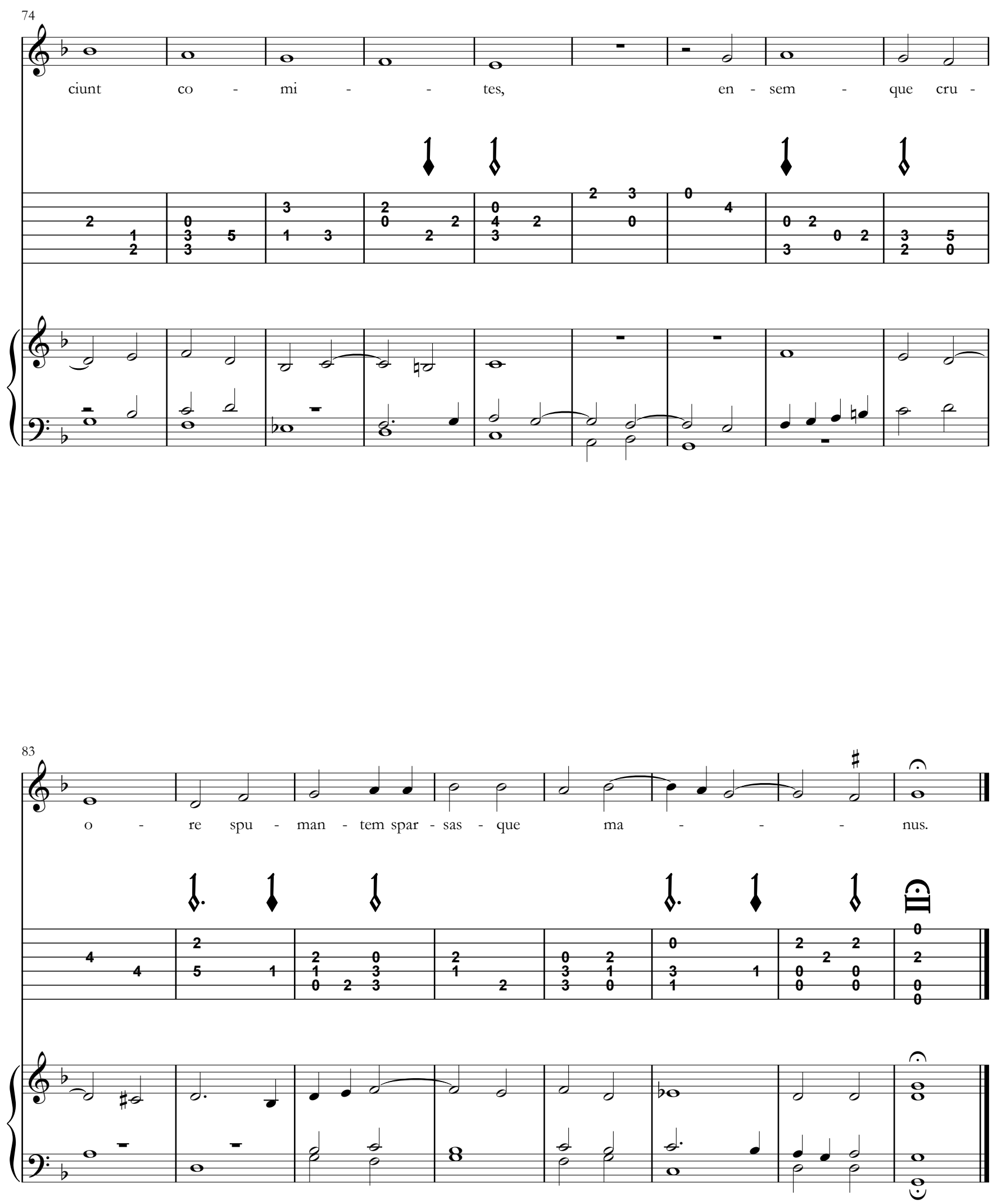


\section{sov64 - Beatus ille}

[Versos en latín III]

Entónase la boz en la segunda al tercero traste

[Libro III, XV]

[Texto: Horacio]
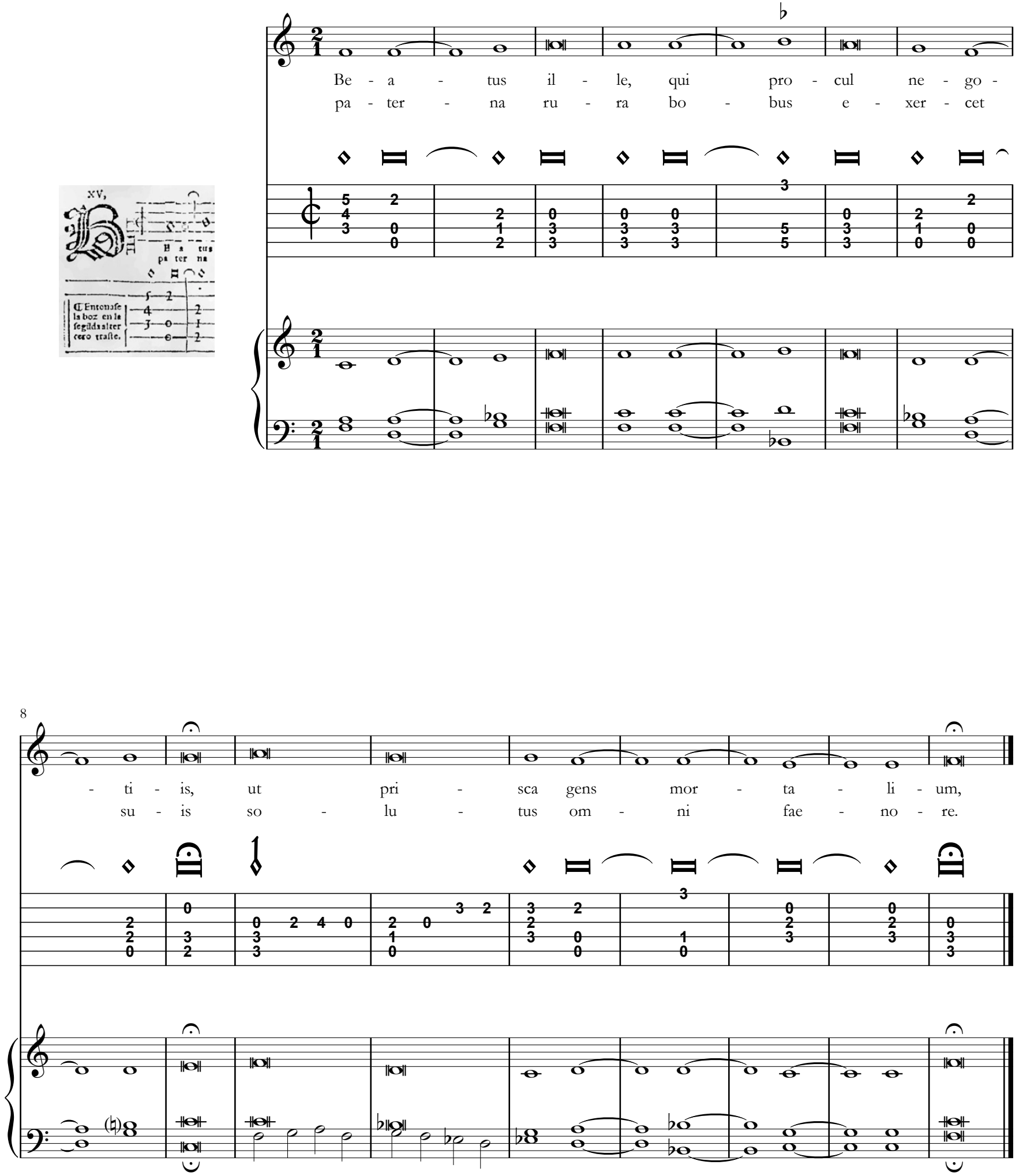
so 65 -Hanc tua Penelope

[Versos en latín IV]

Entónase la boz en la prima al segundo traste

[Libro III, XVI]

[Texto: Ovidio]
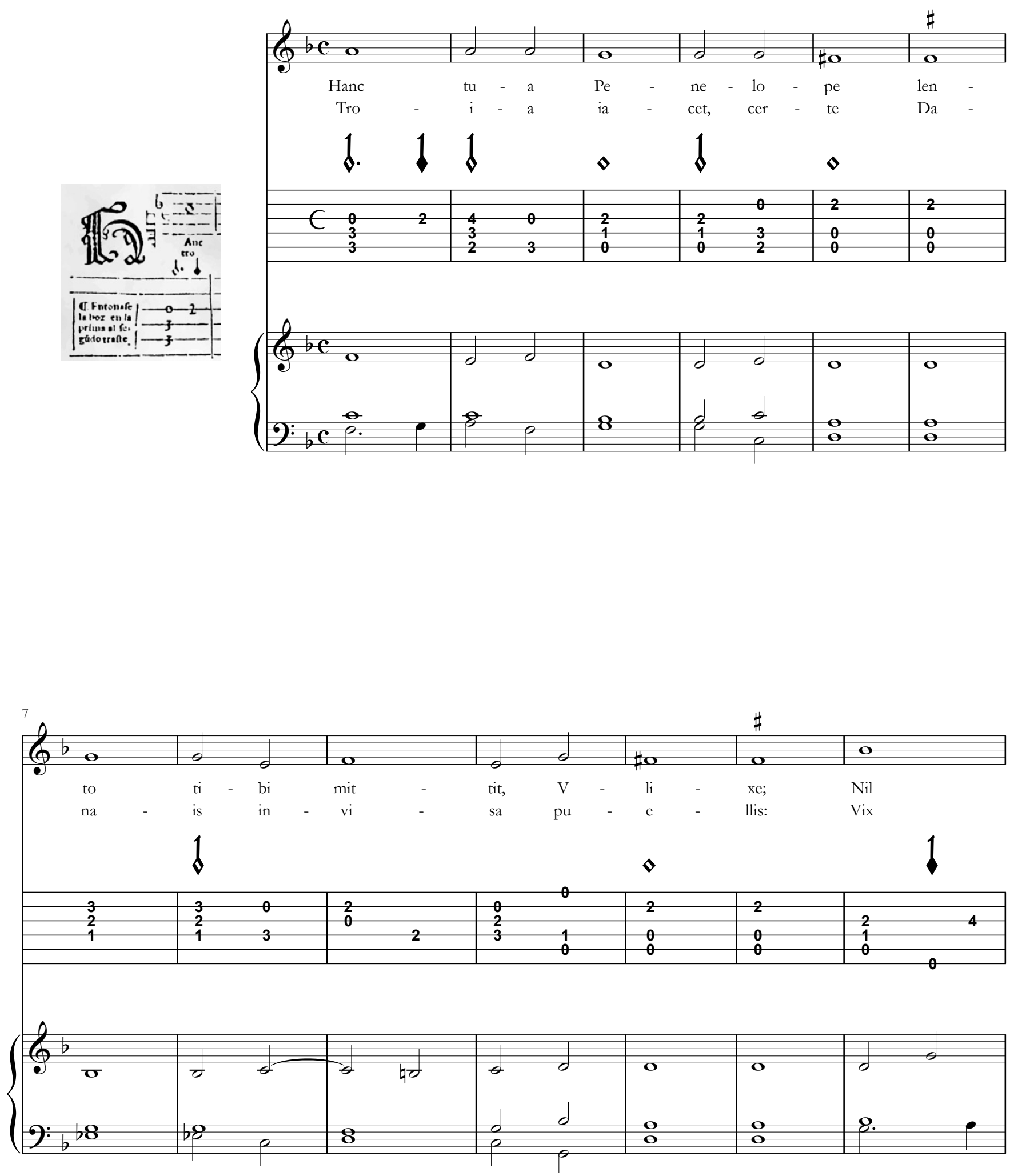

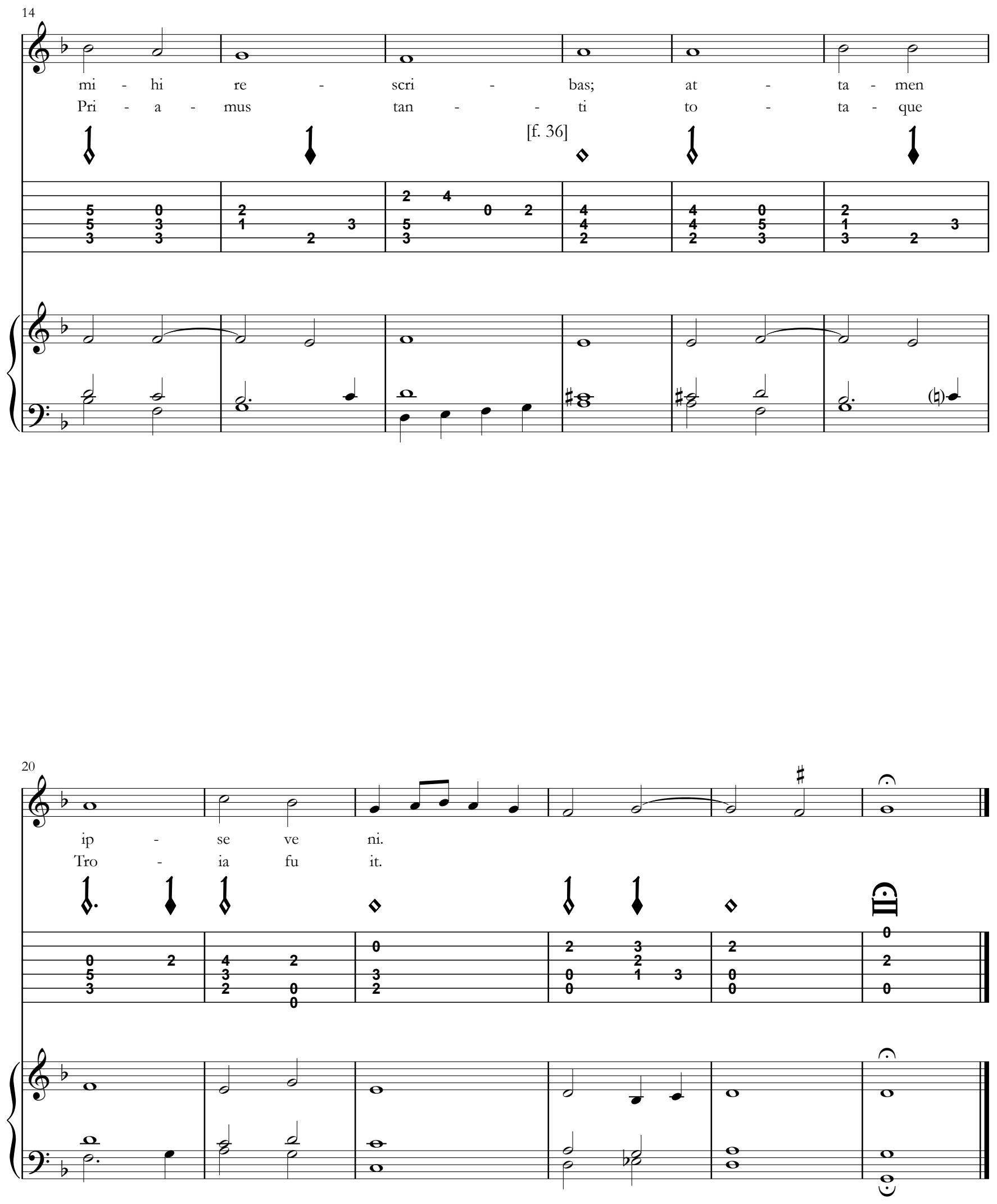


\section{se 66 - La vita fugge}

[Soneto I en italiano]

Entónase la boz en la prima al quinto traste

[Libro III, XVII]

[Texto: Petrarca]
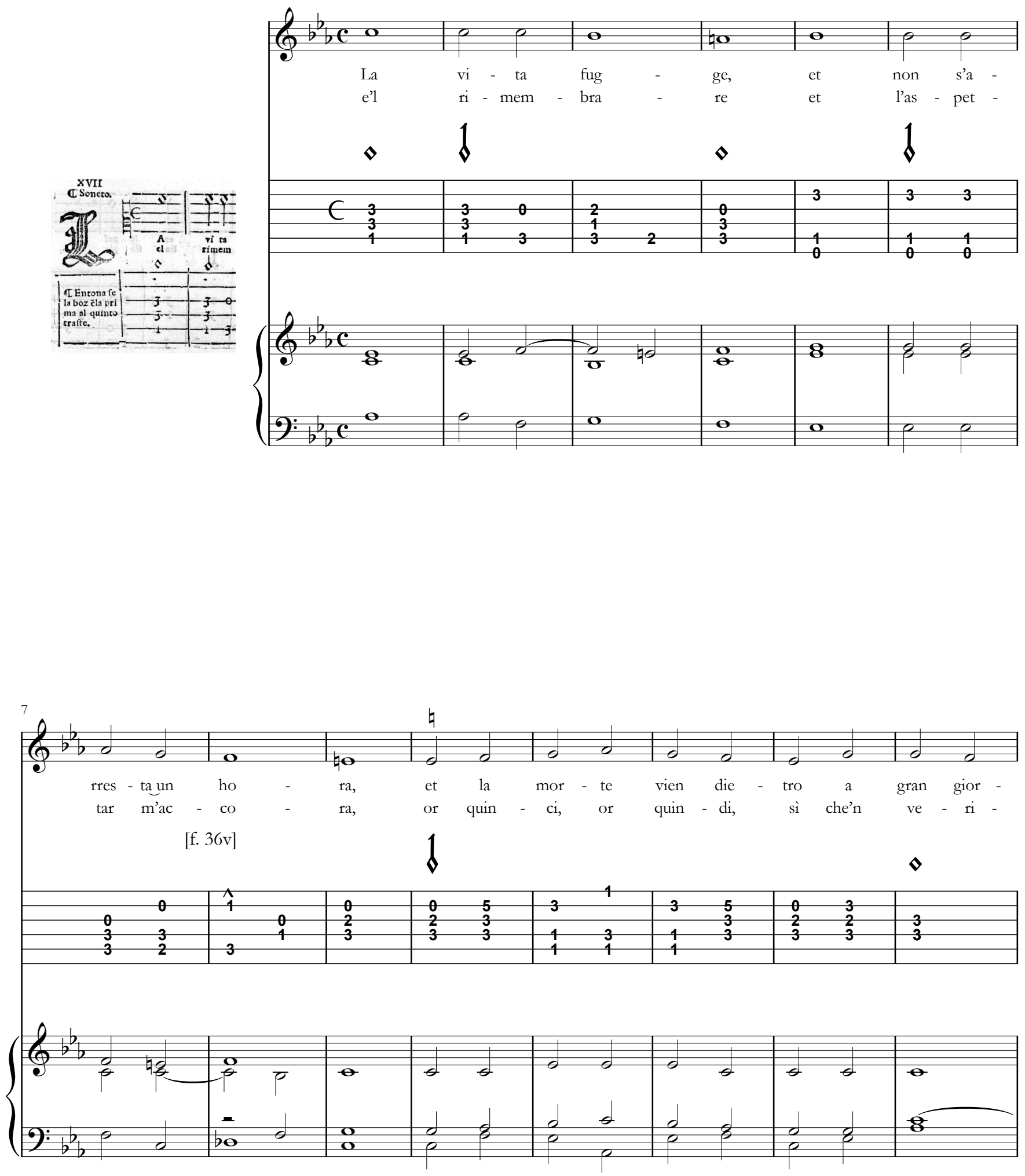

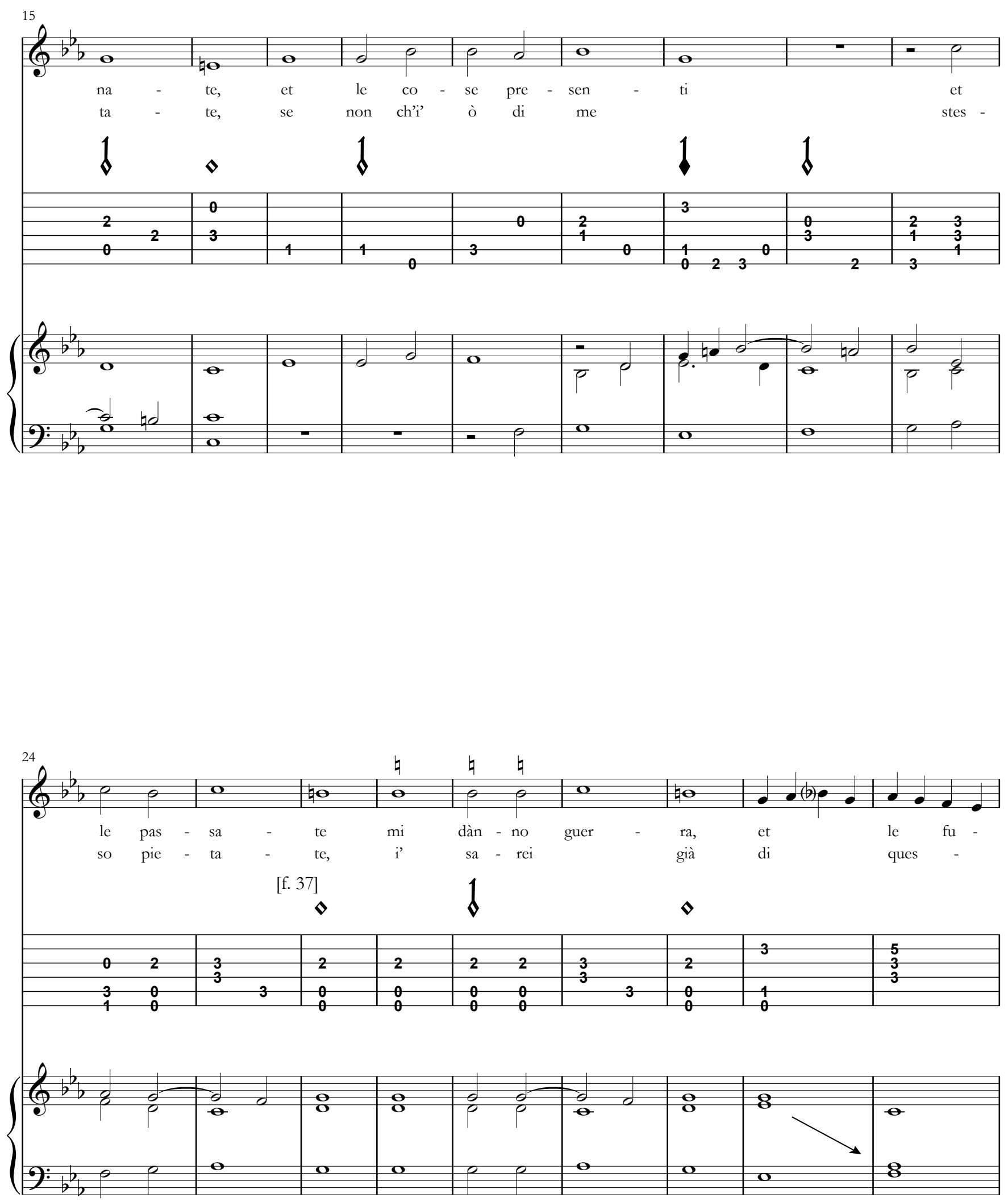

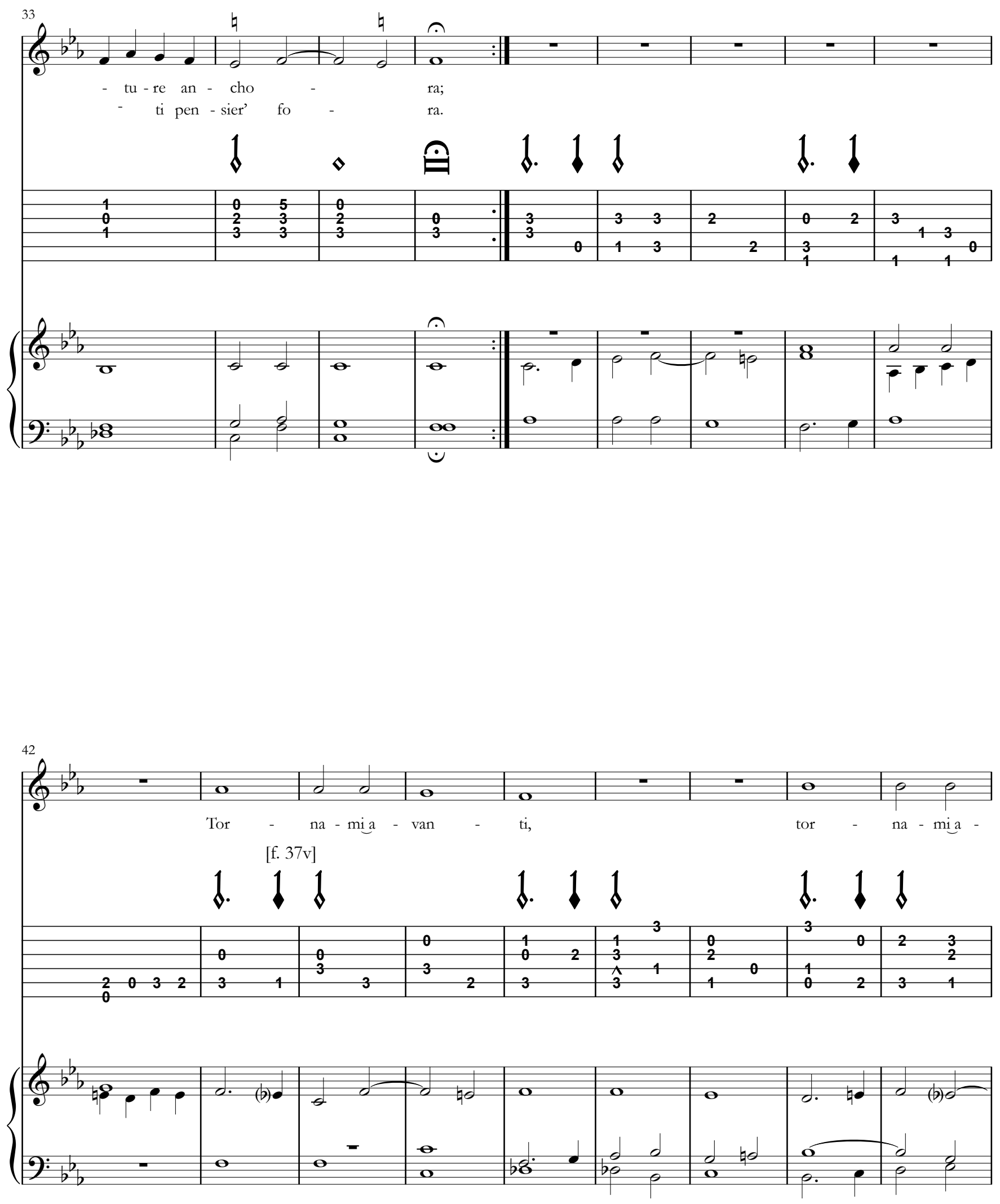

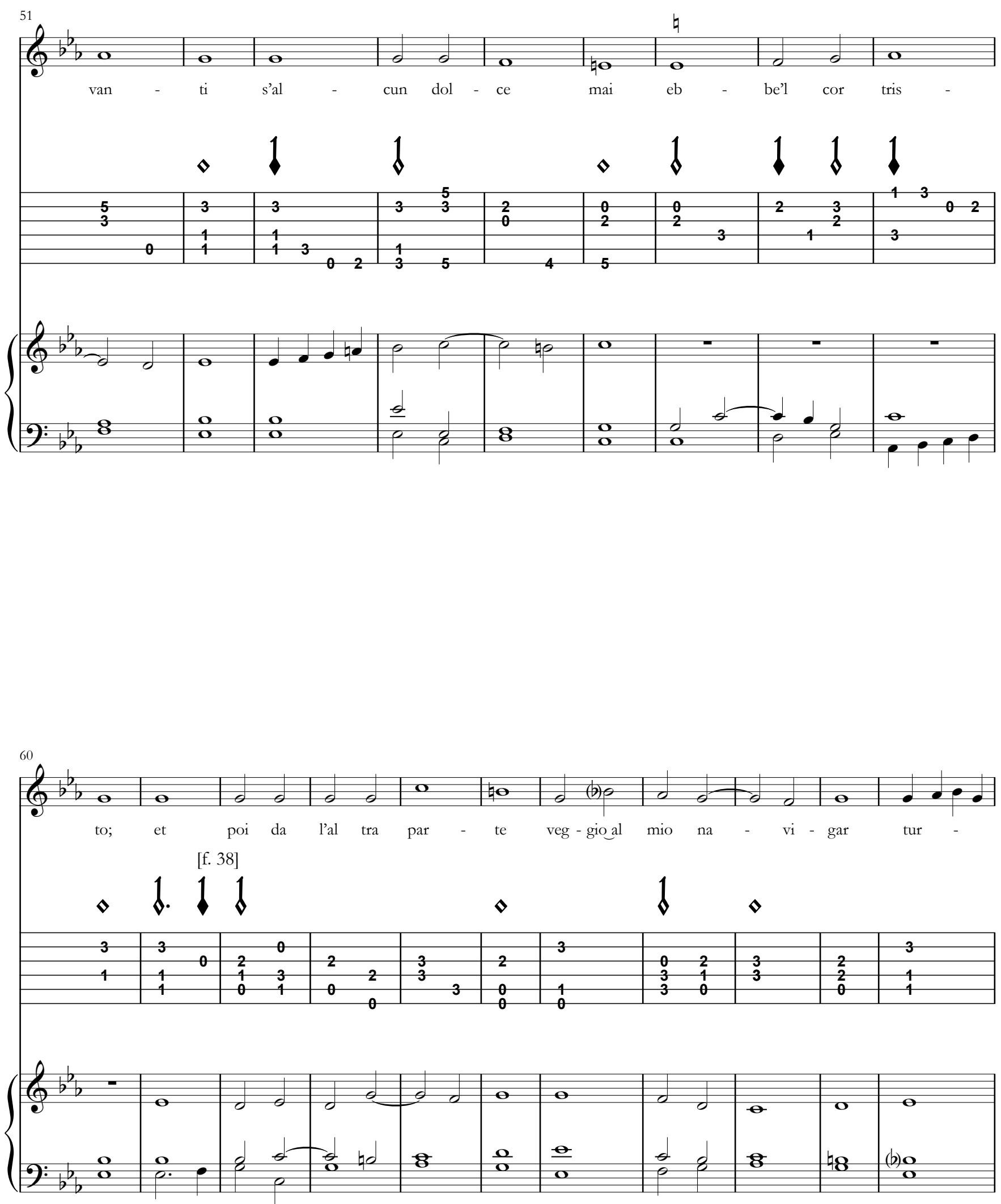

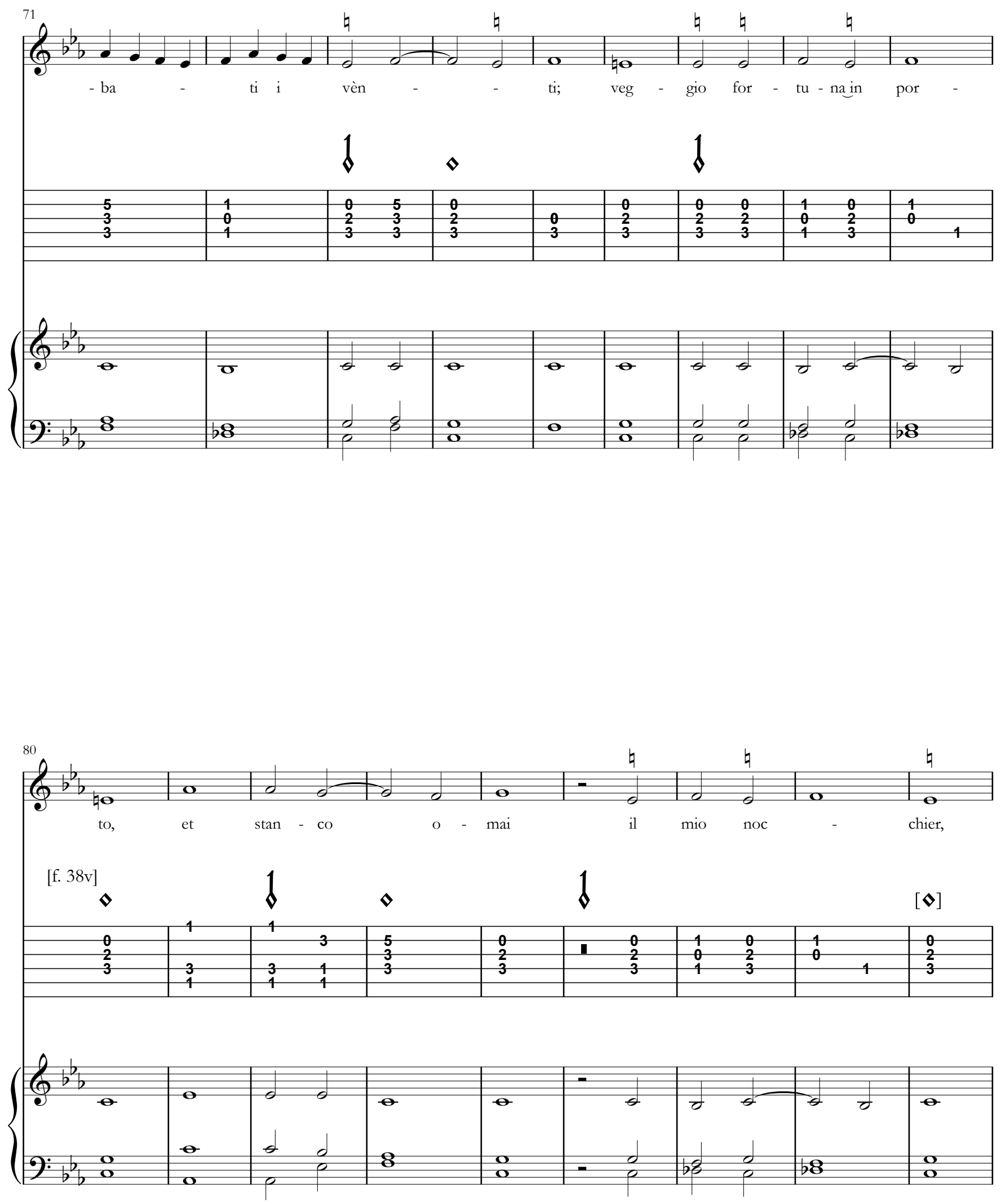

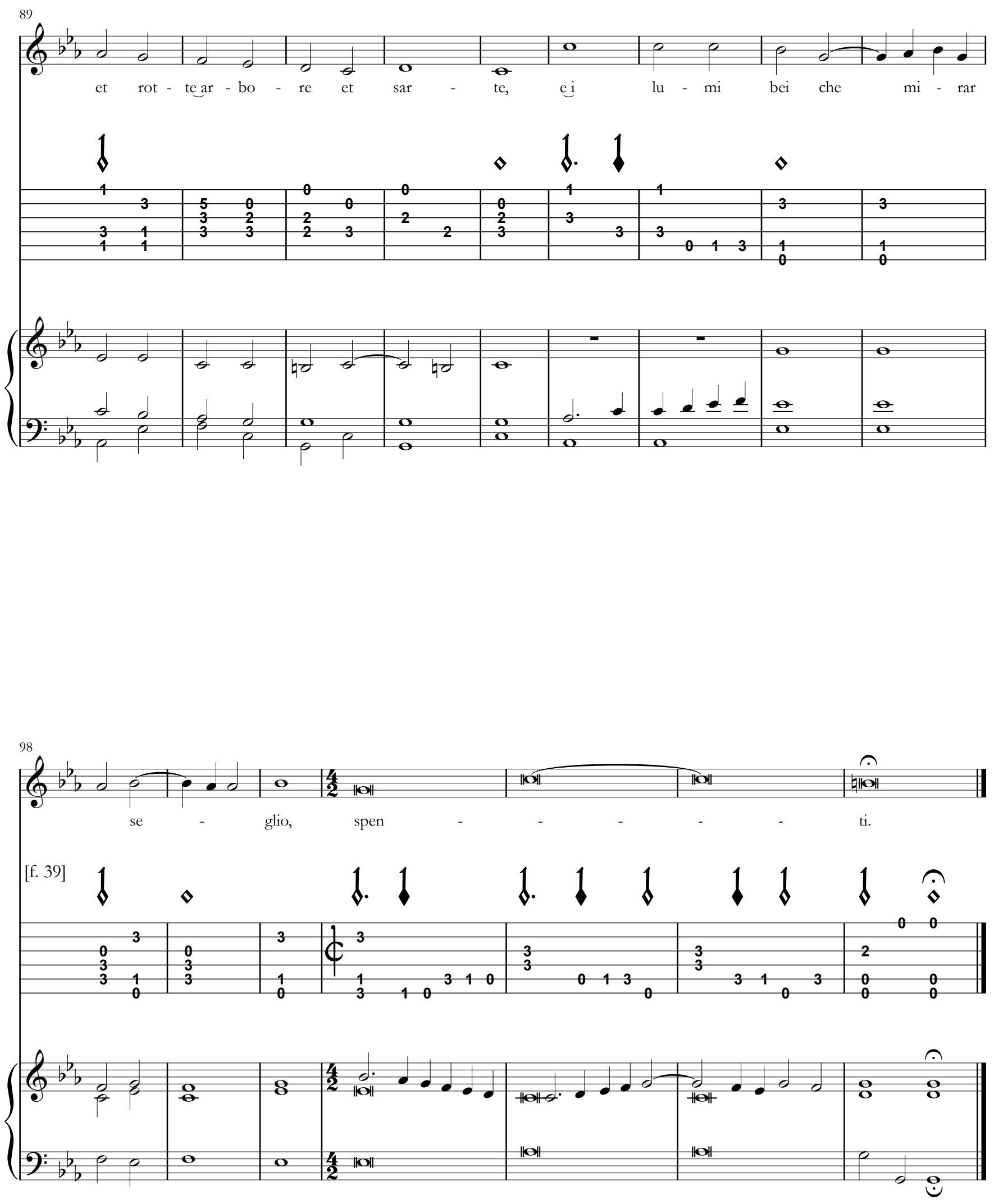
sø67 - Lassato a il Tago

[Soneto II en italiano]

Entónase la box en la tercera al quarto traste

[Libro III, XVIII]
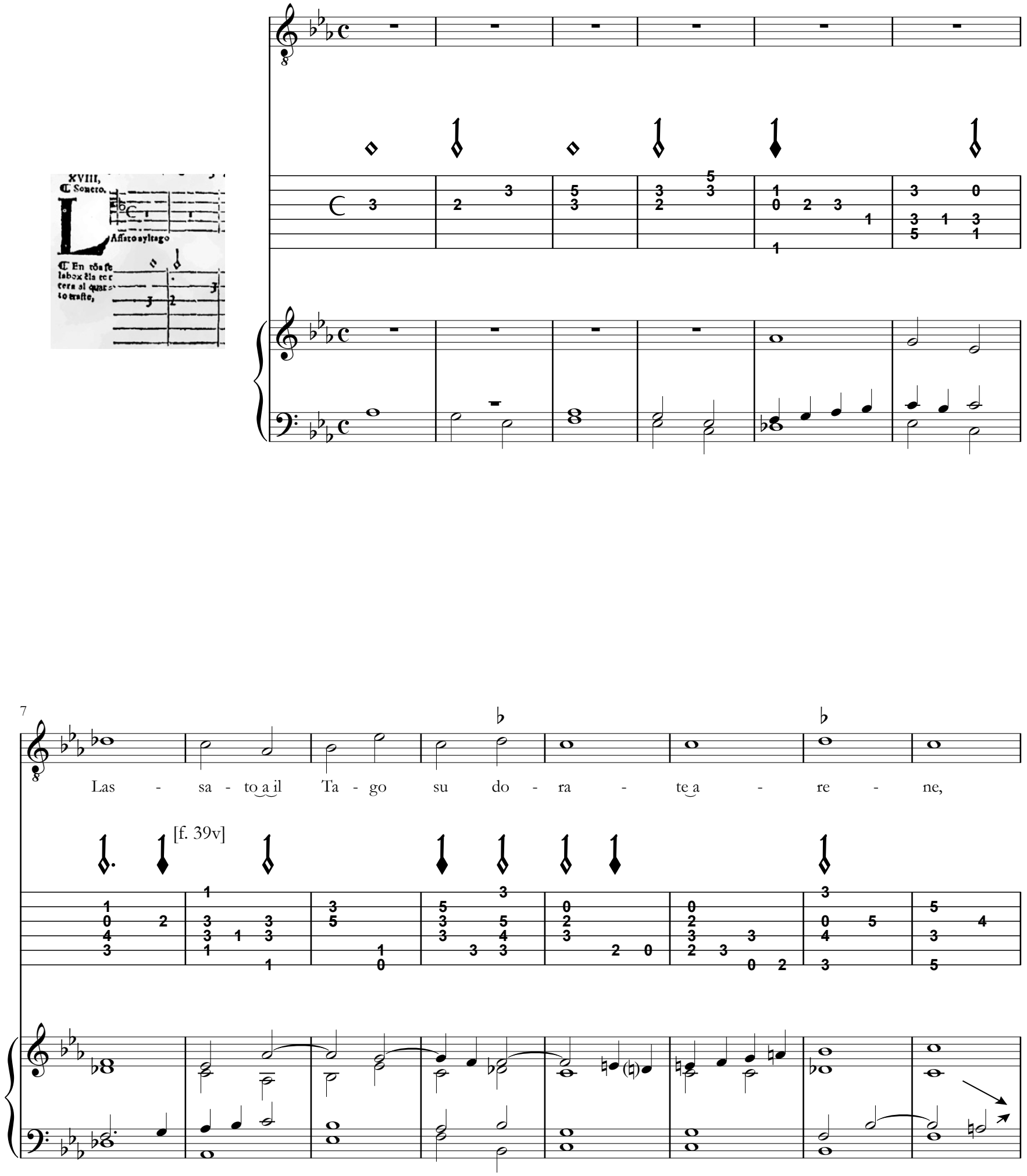

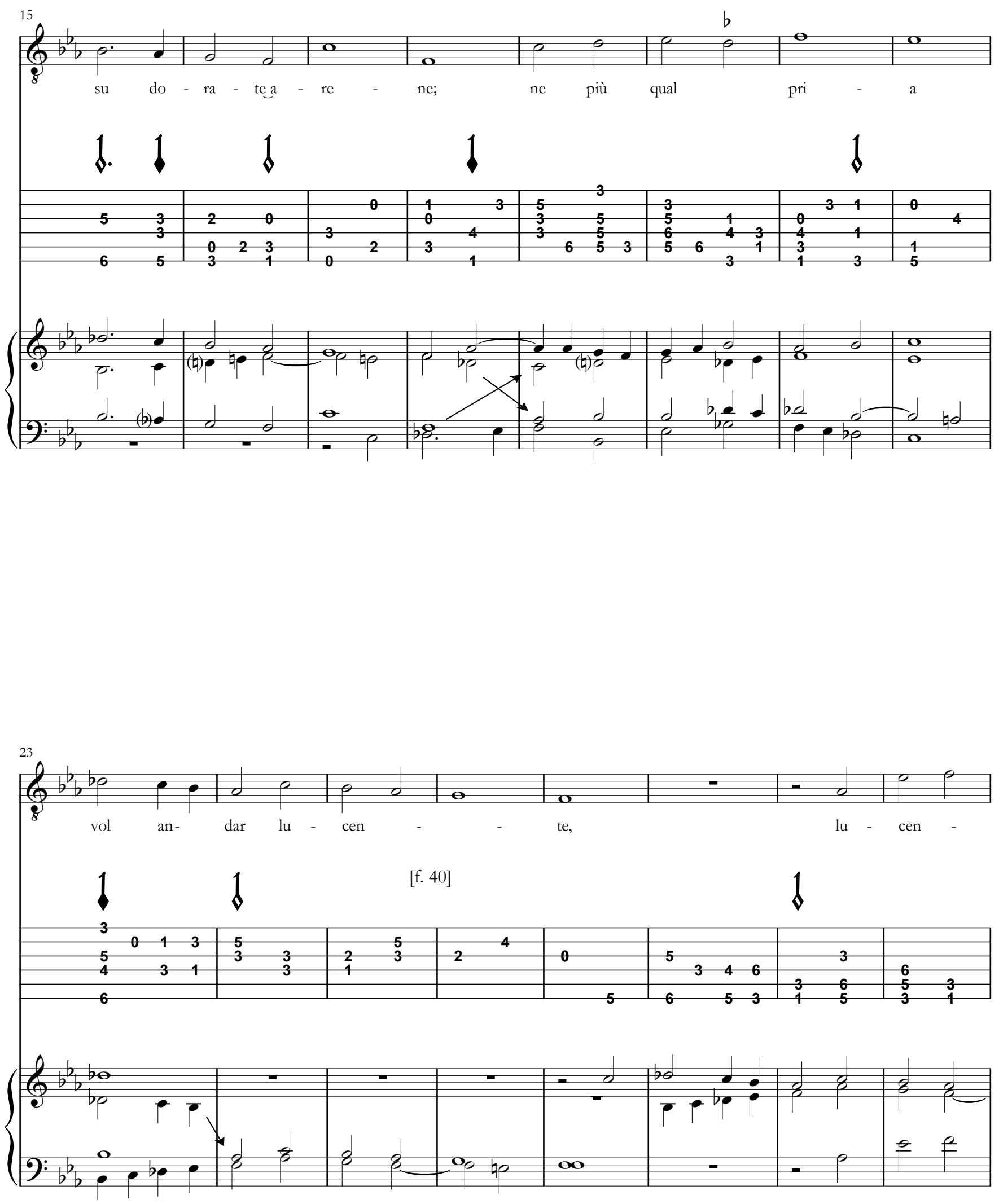

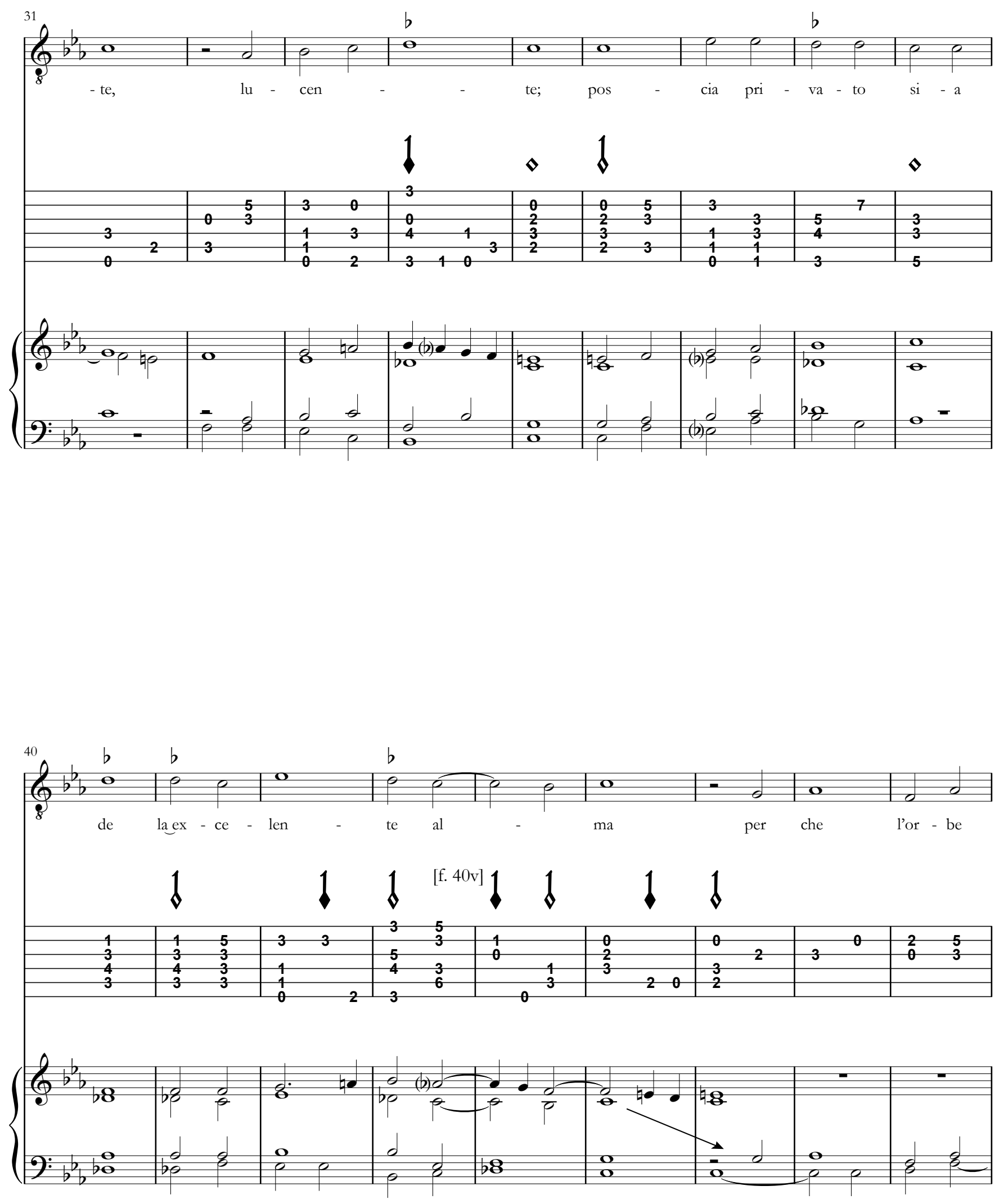

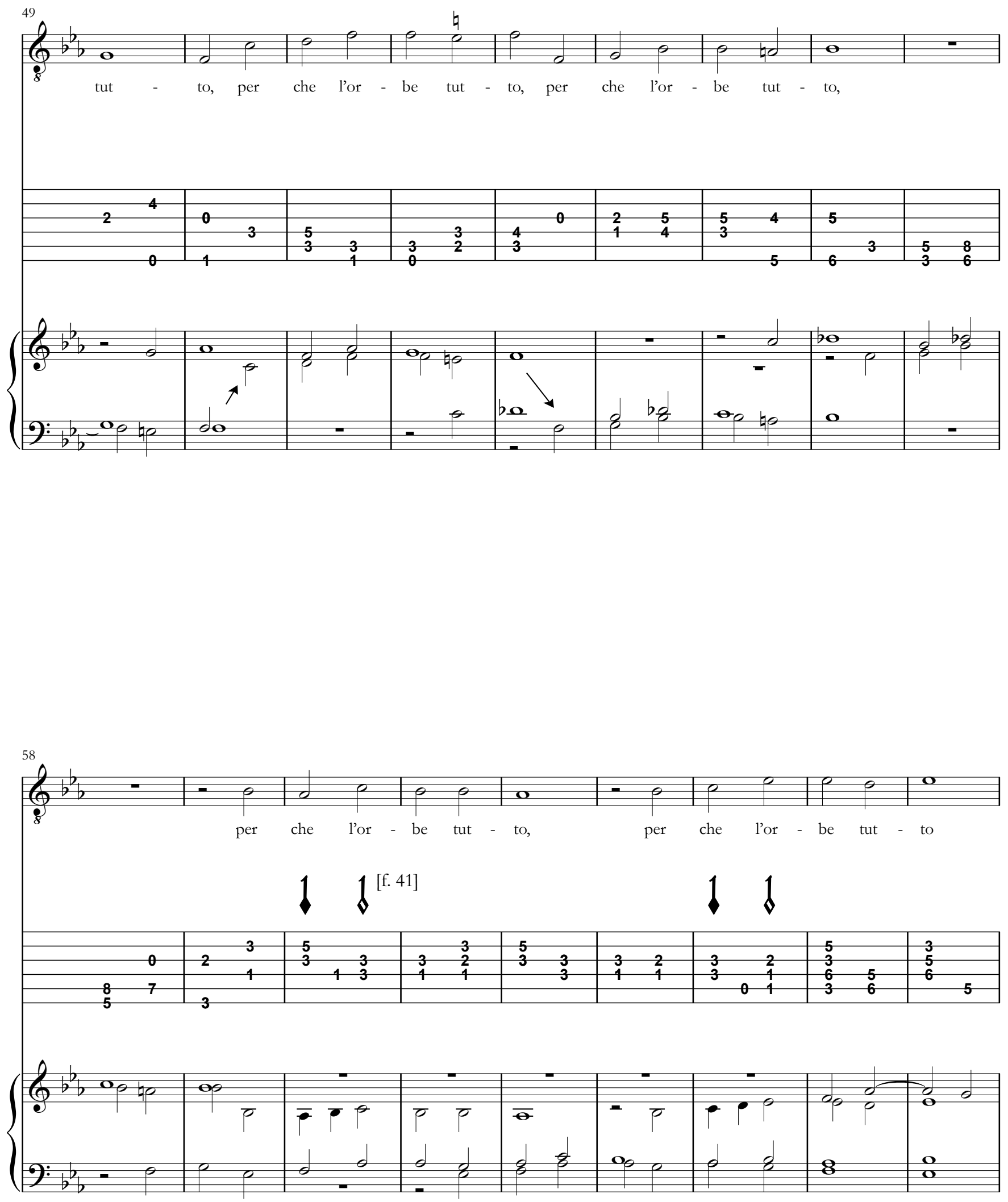

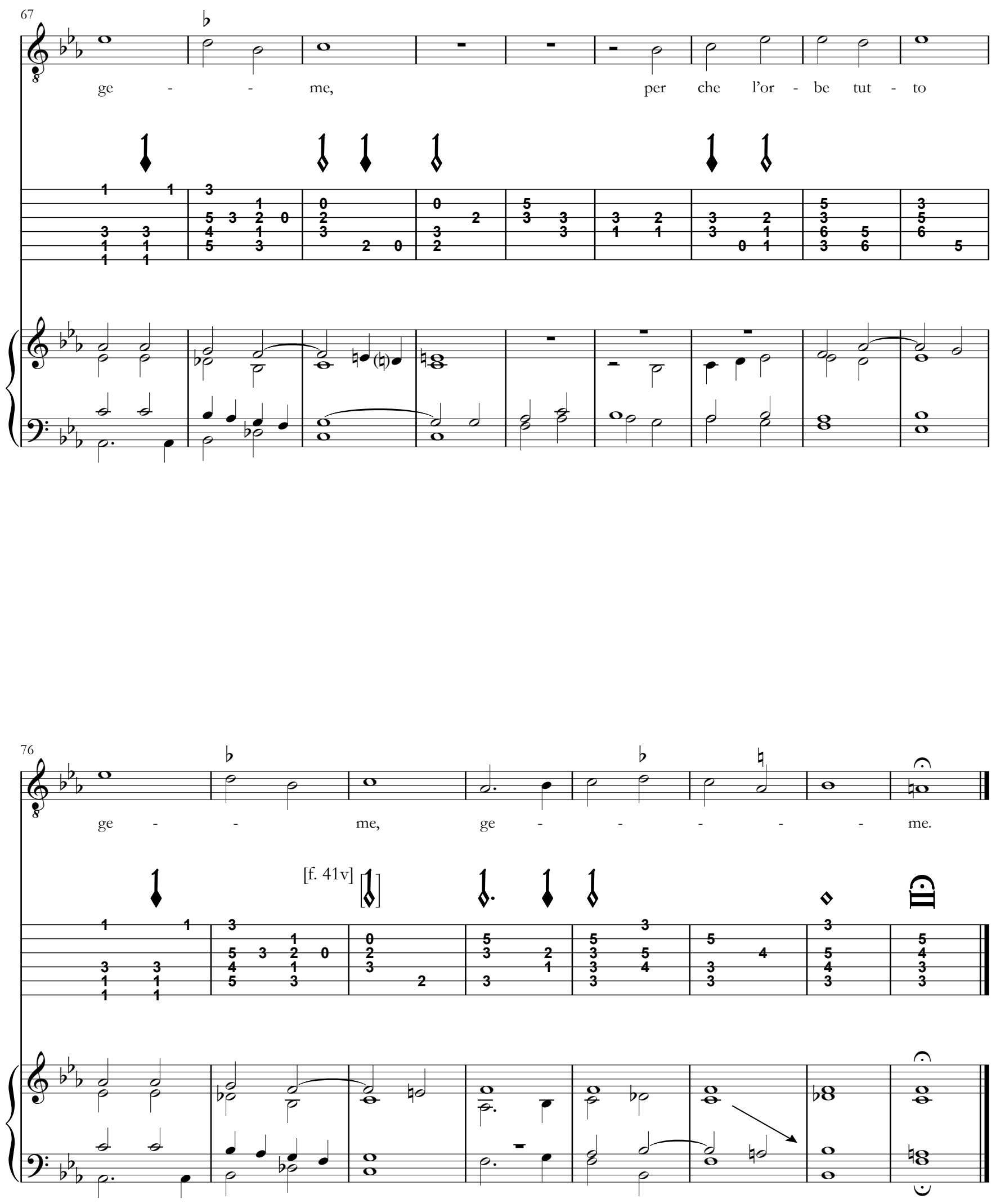


\section{sะ68 - O gelosia d'amanties}

[Soneto III en italiano]

Entónase la box en la prima en vazío

[Libro III, XIX]

[Texto: Sannazaro]
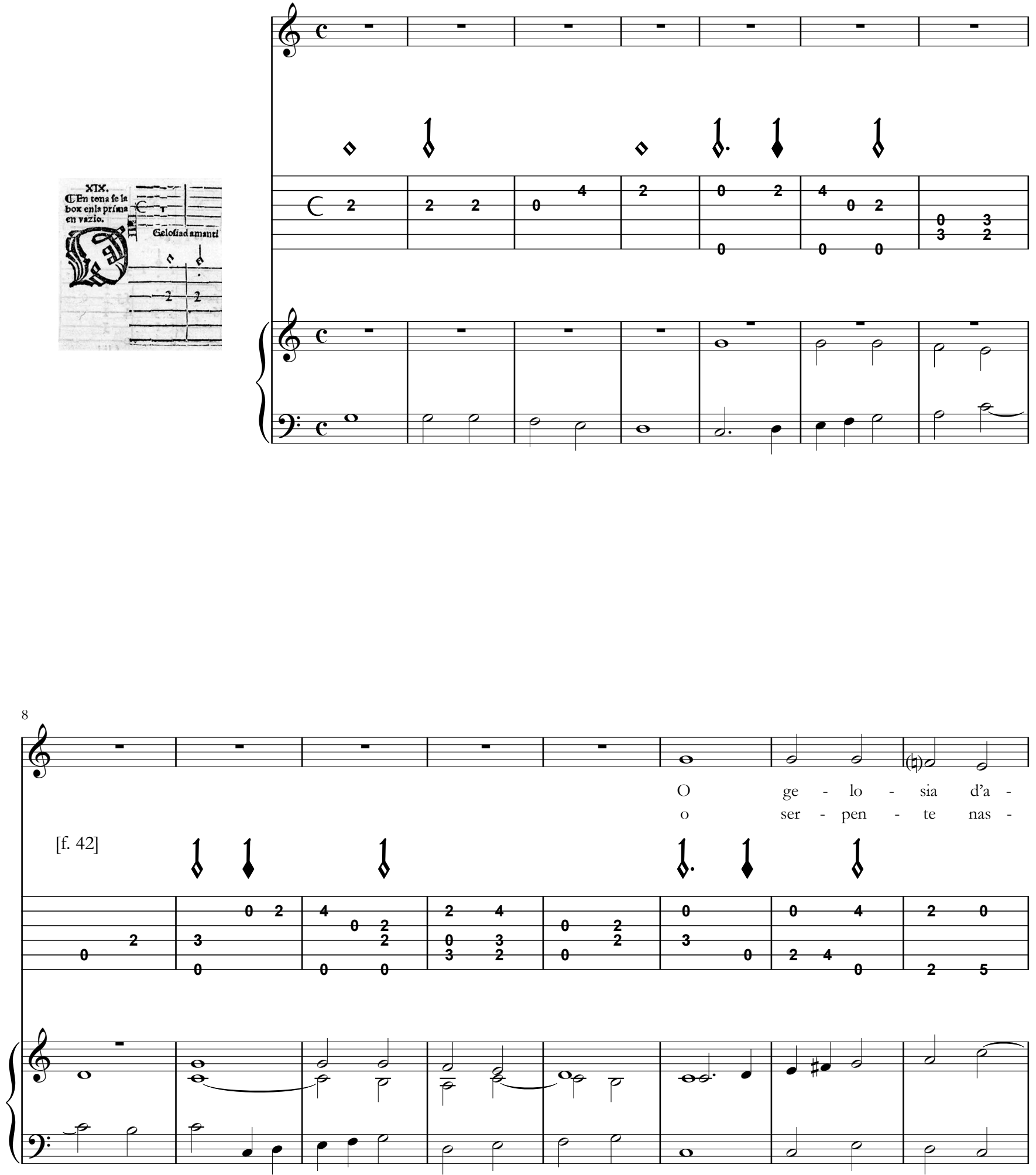

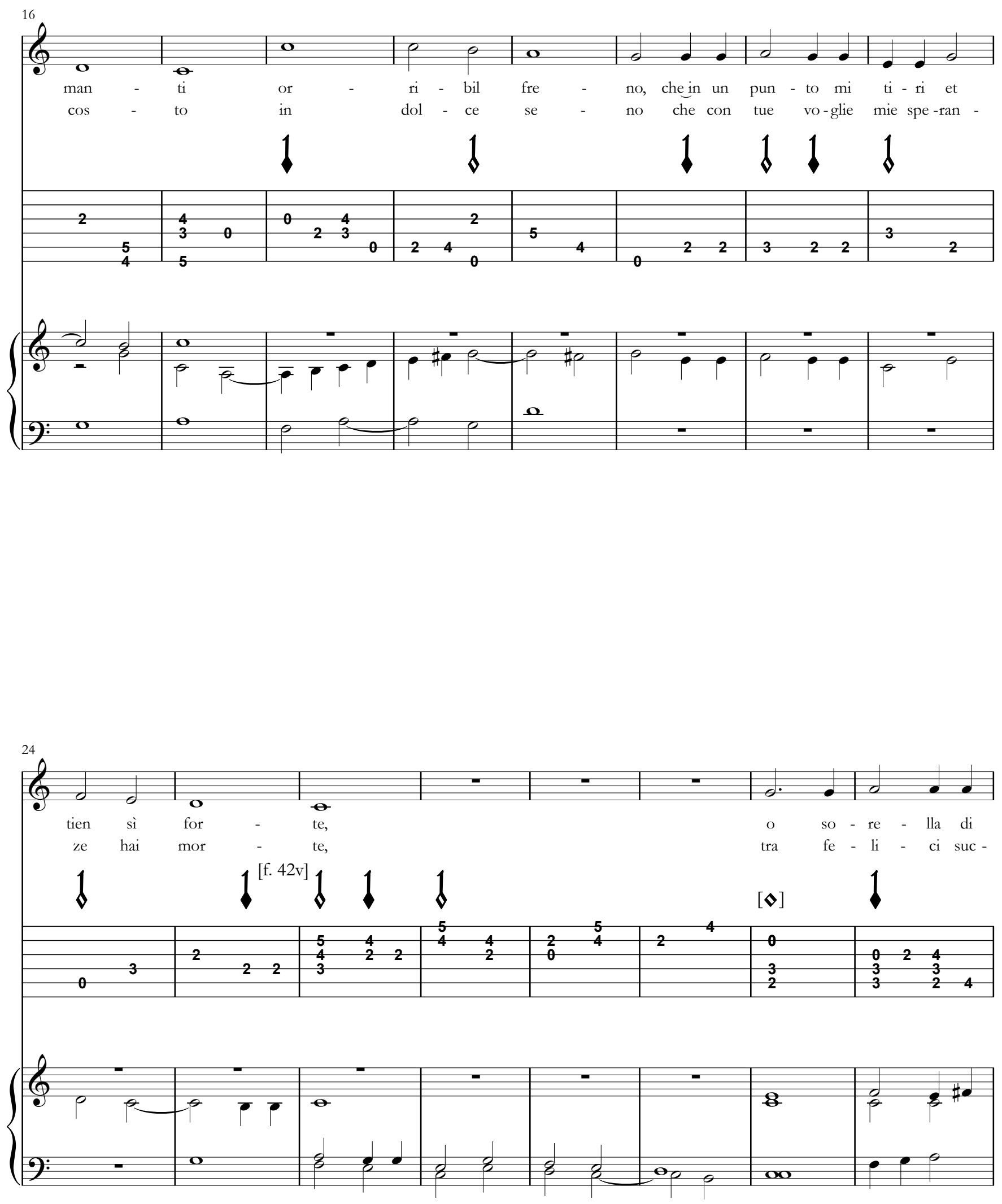

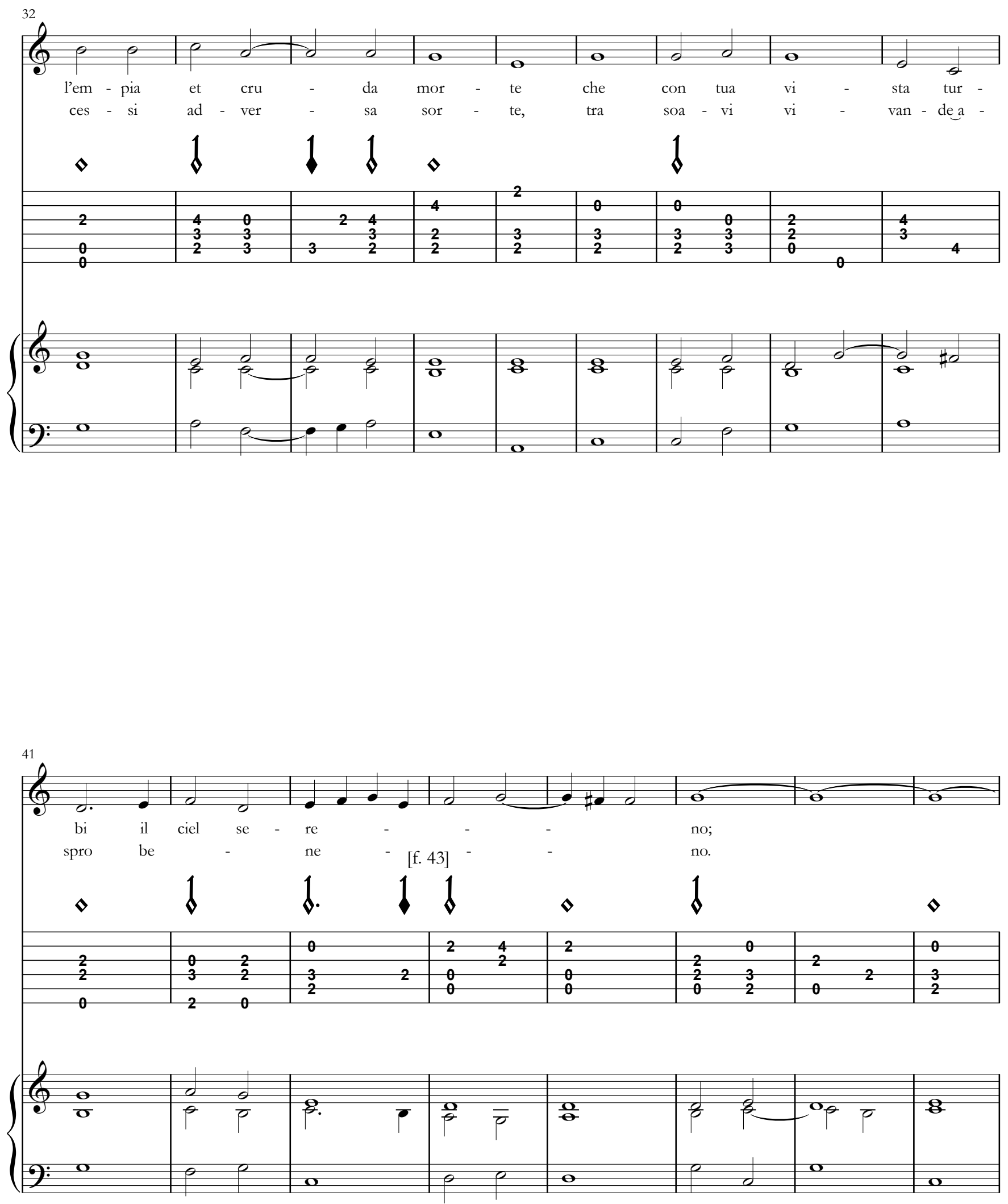

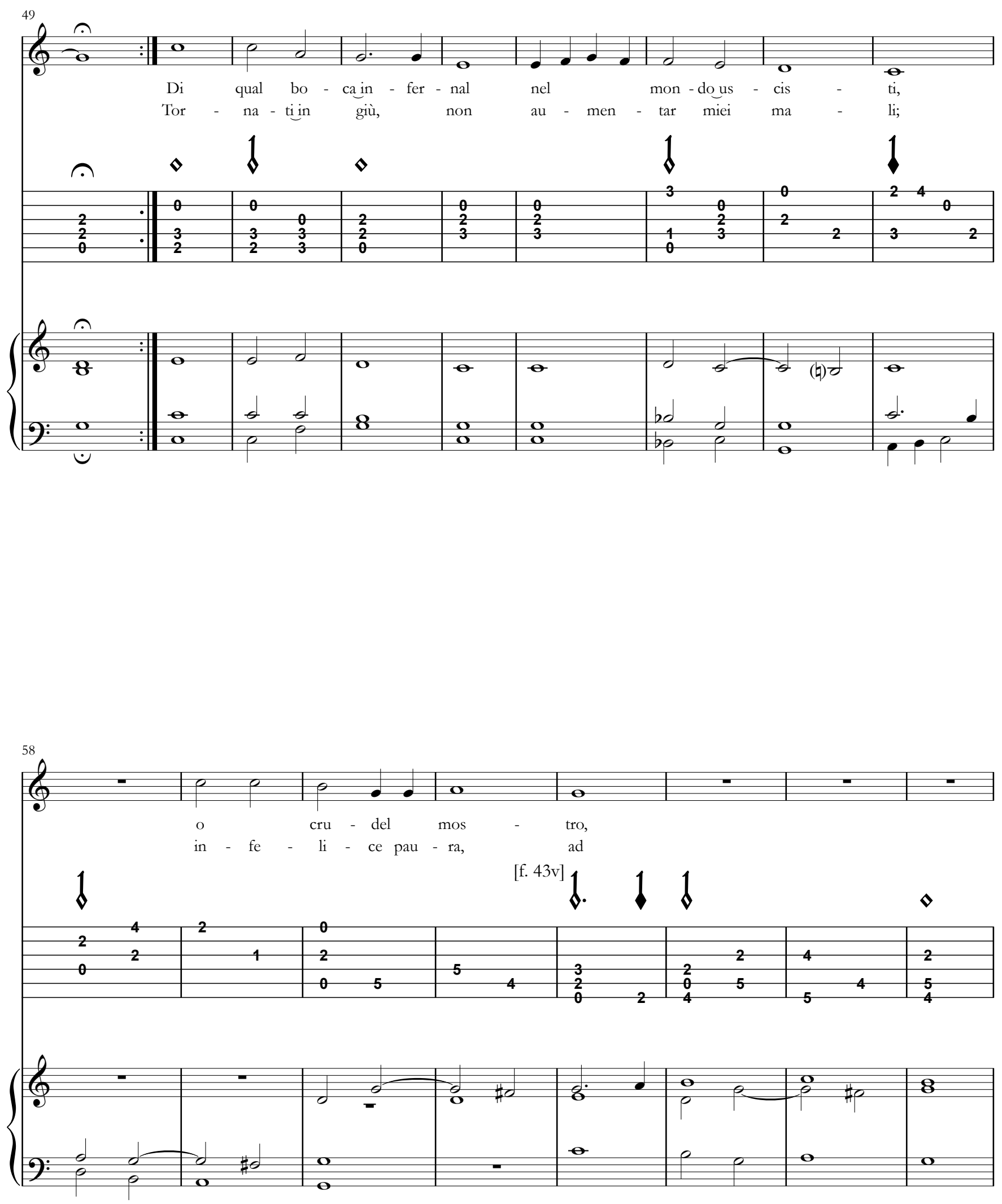

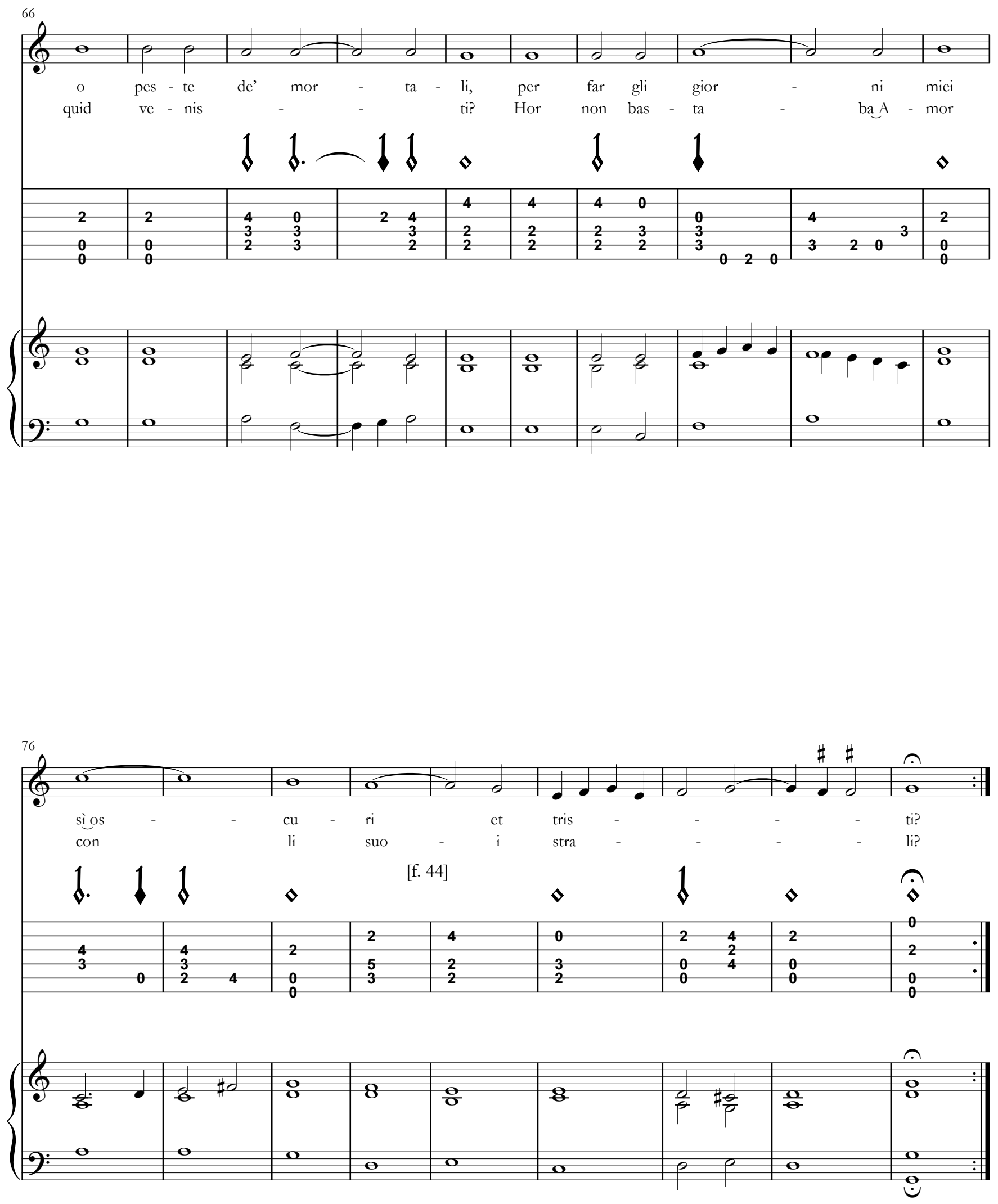


\section{so69 - Itene a l'ombra}

[Soneto IV en italiano]

Entónase la boz en la segunda [en] el primer traste

[Libro III, XX]

[Texto: Sannazaro]
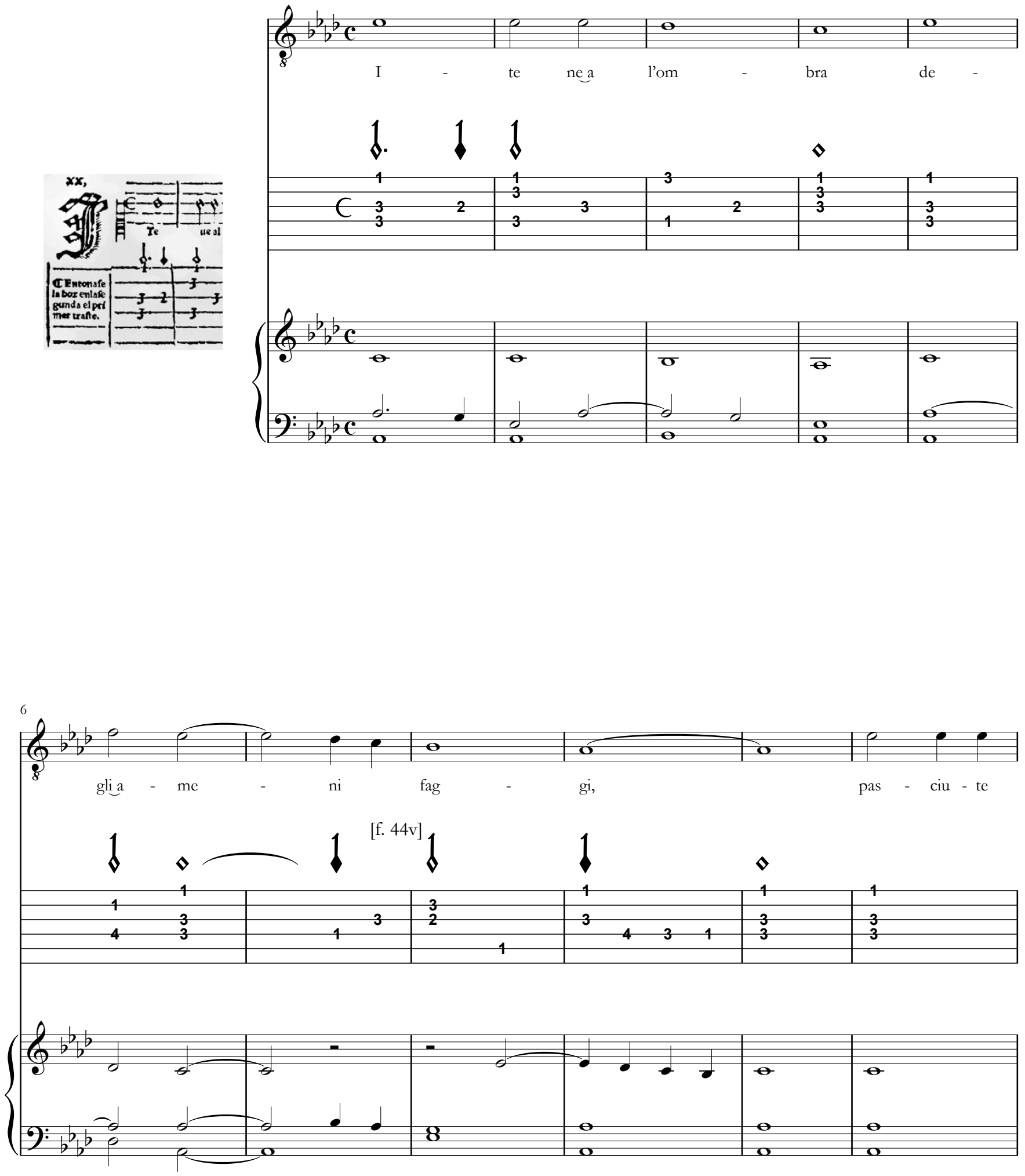

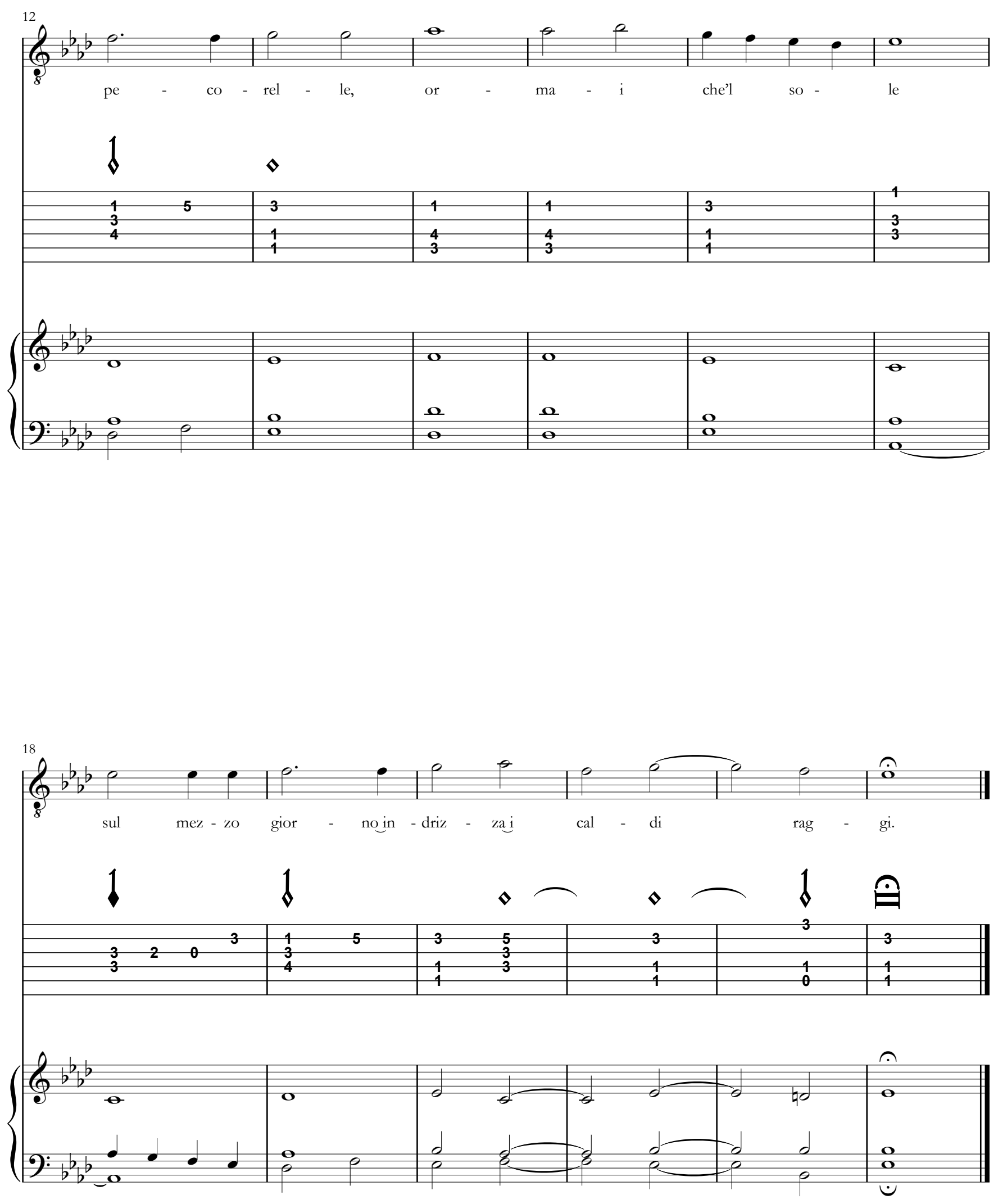


\section{s\&70 - Dime adó tienes las mientes}

[Villancico I]

Entónase la boz en la segunda al tercero traste

[Libro III, XXI]
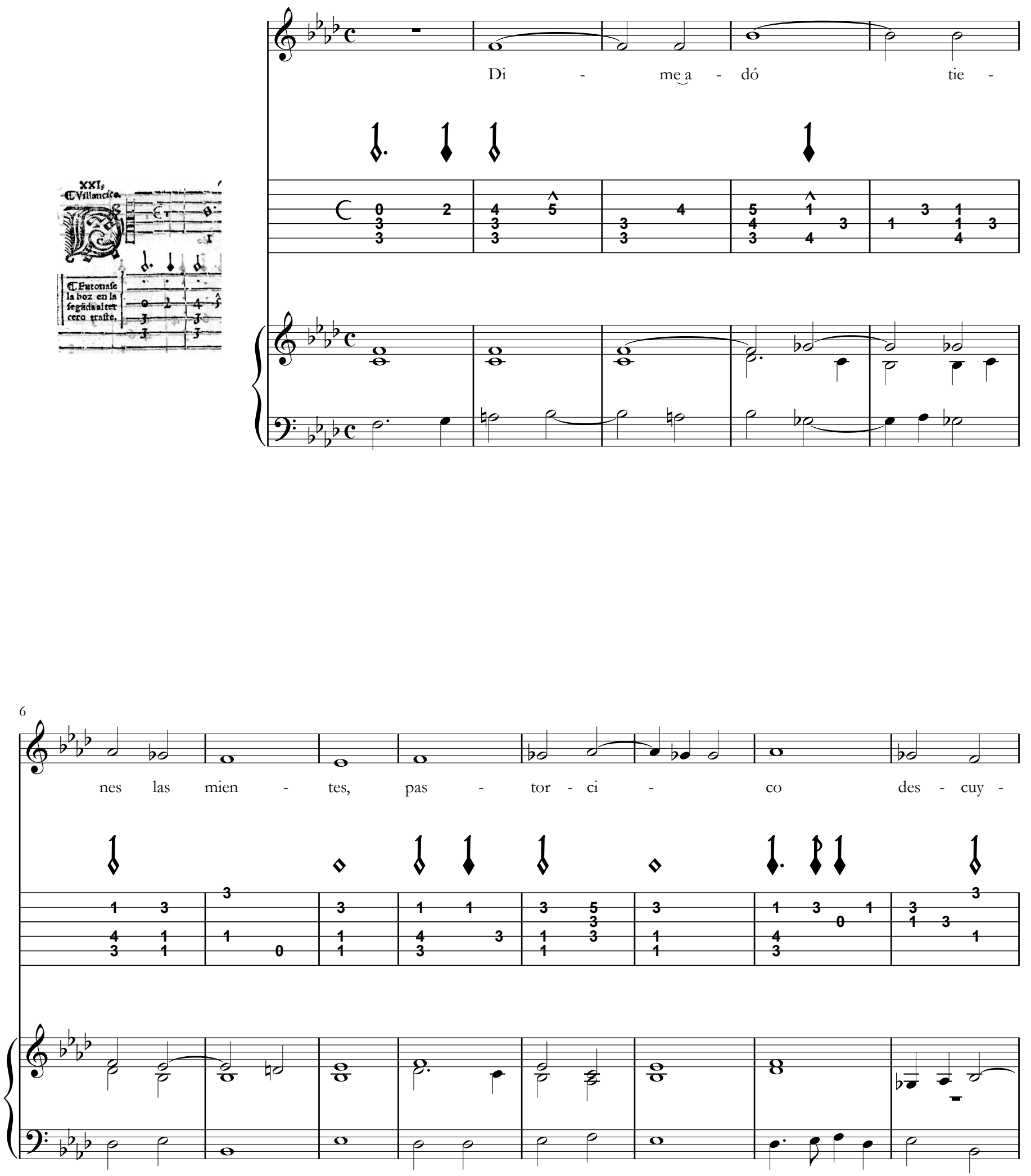

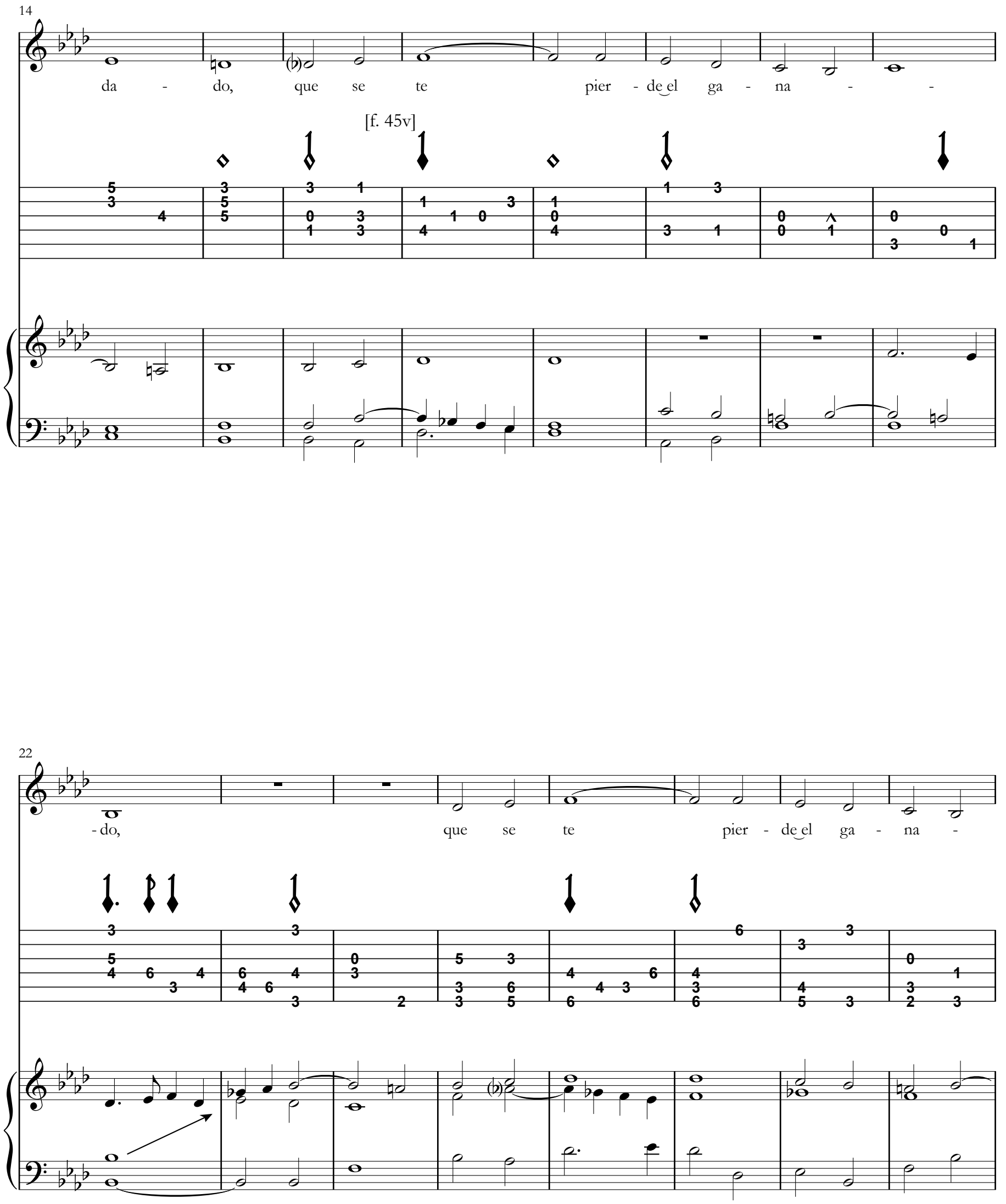

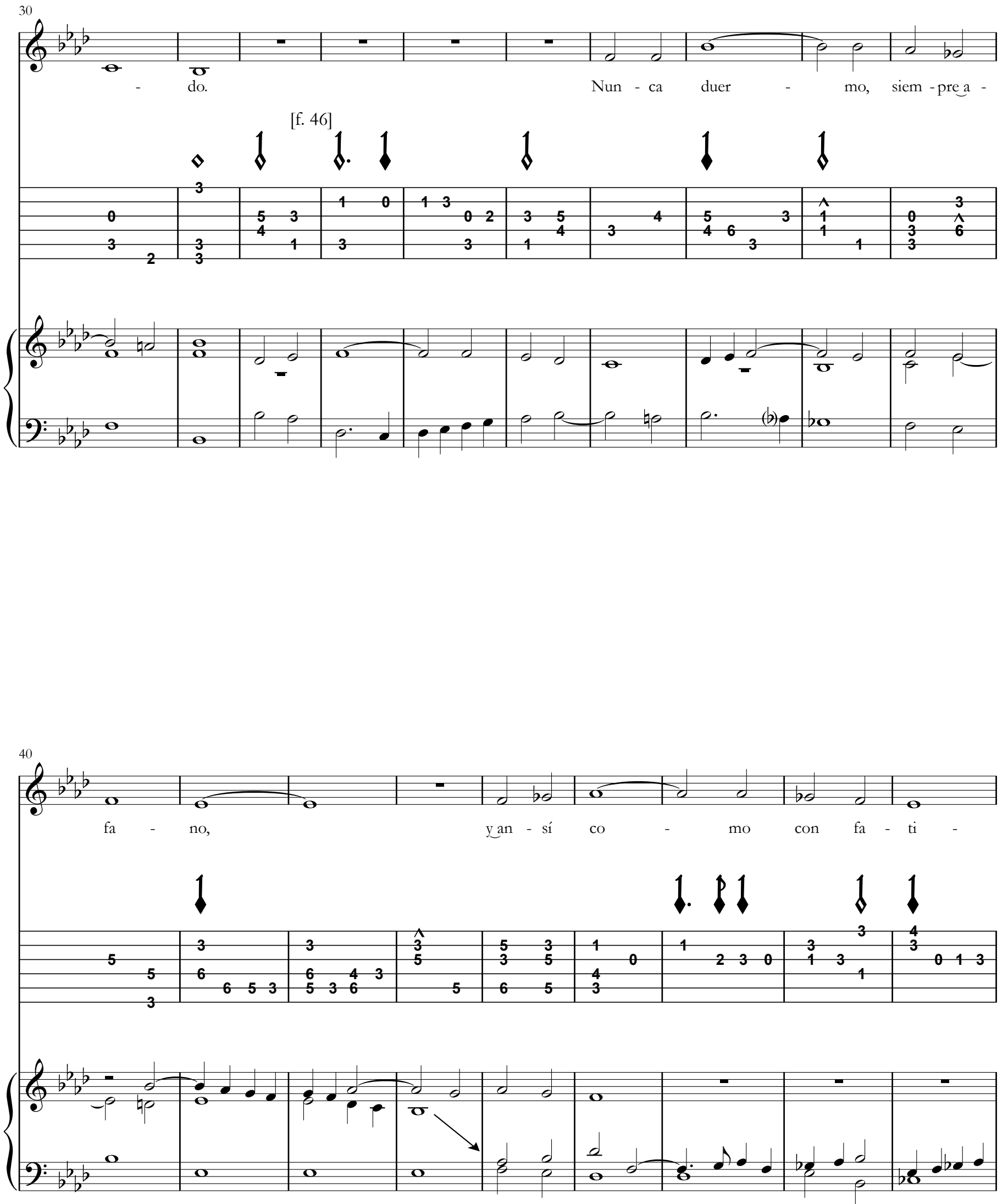

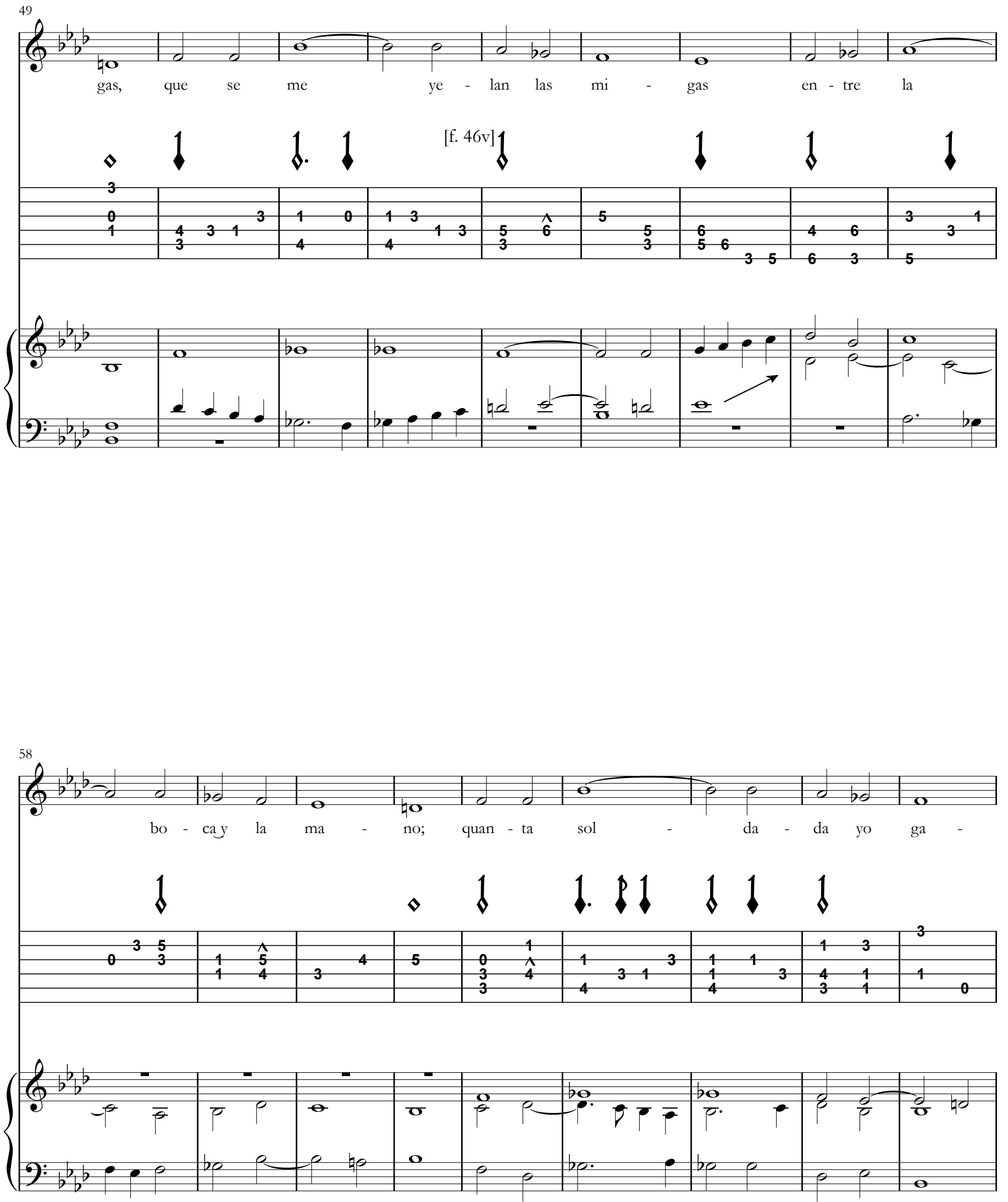

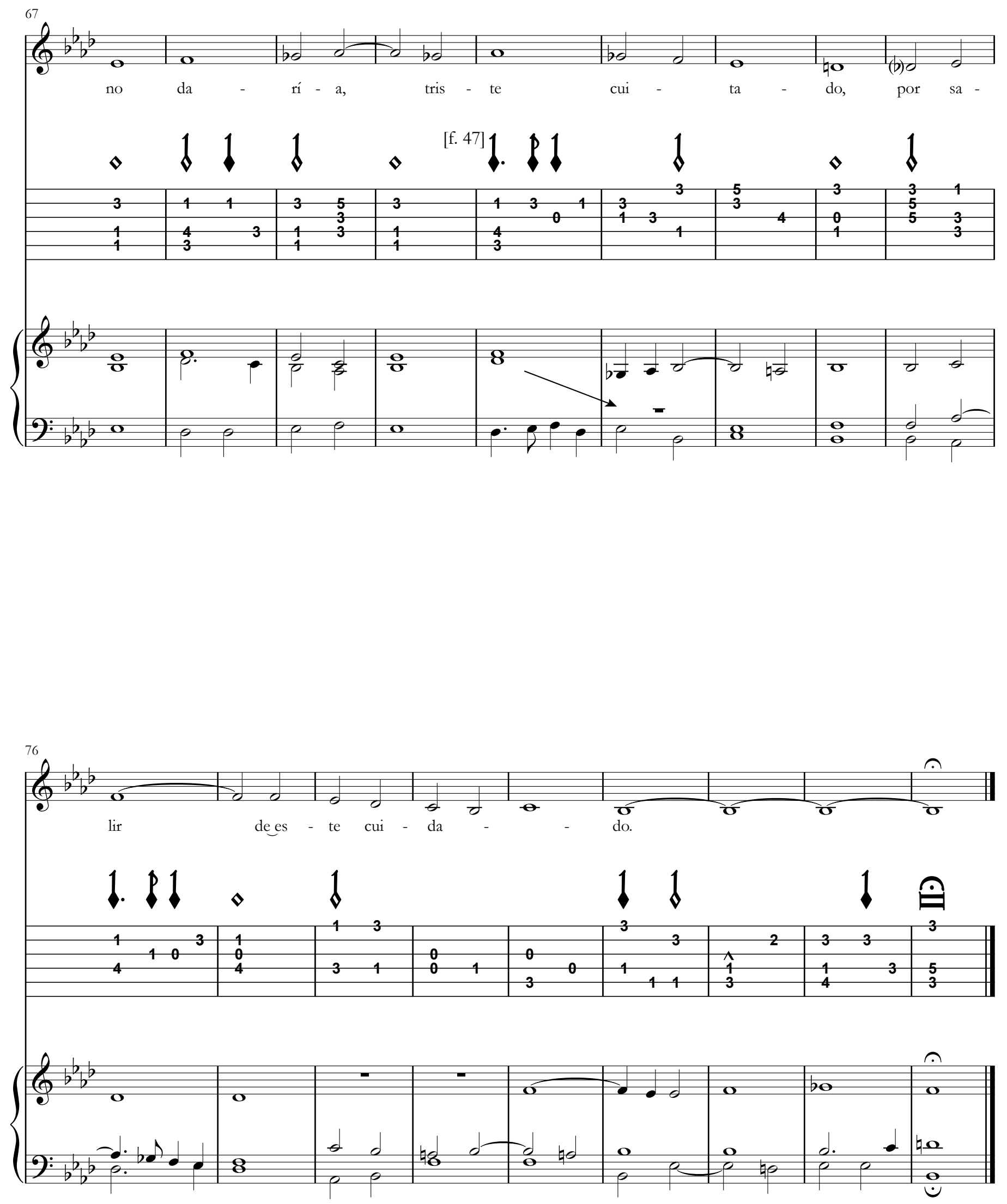
so 71 - Si me llamanes

[Villancico II]

Entónase box en la prima en vazío

[Libro III, XXII]
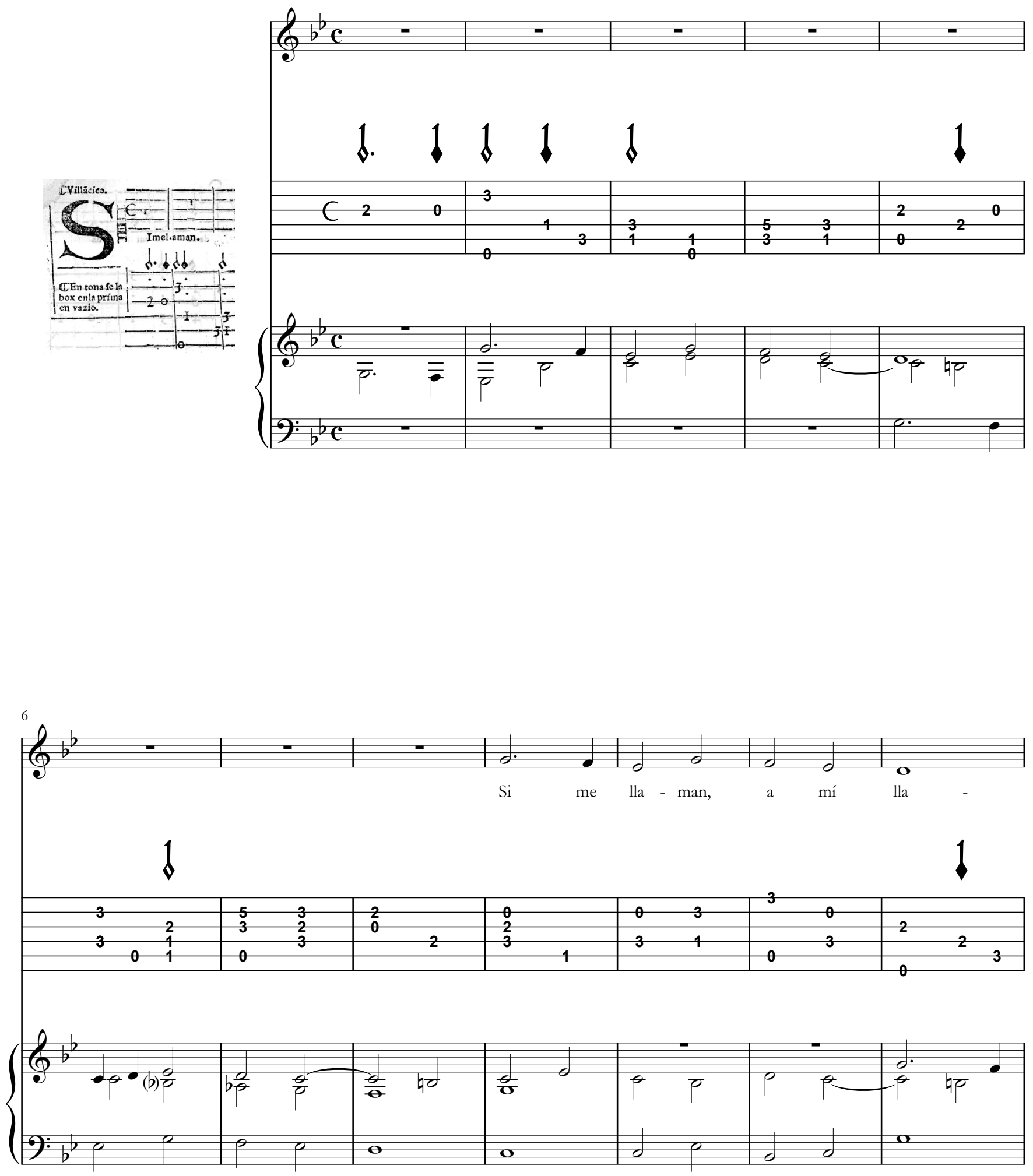

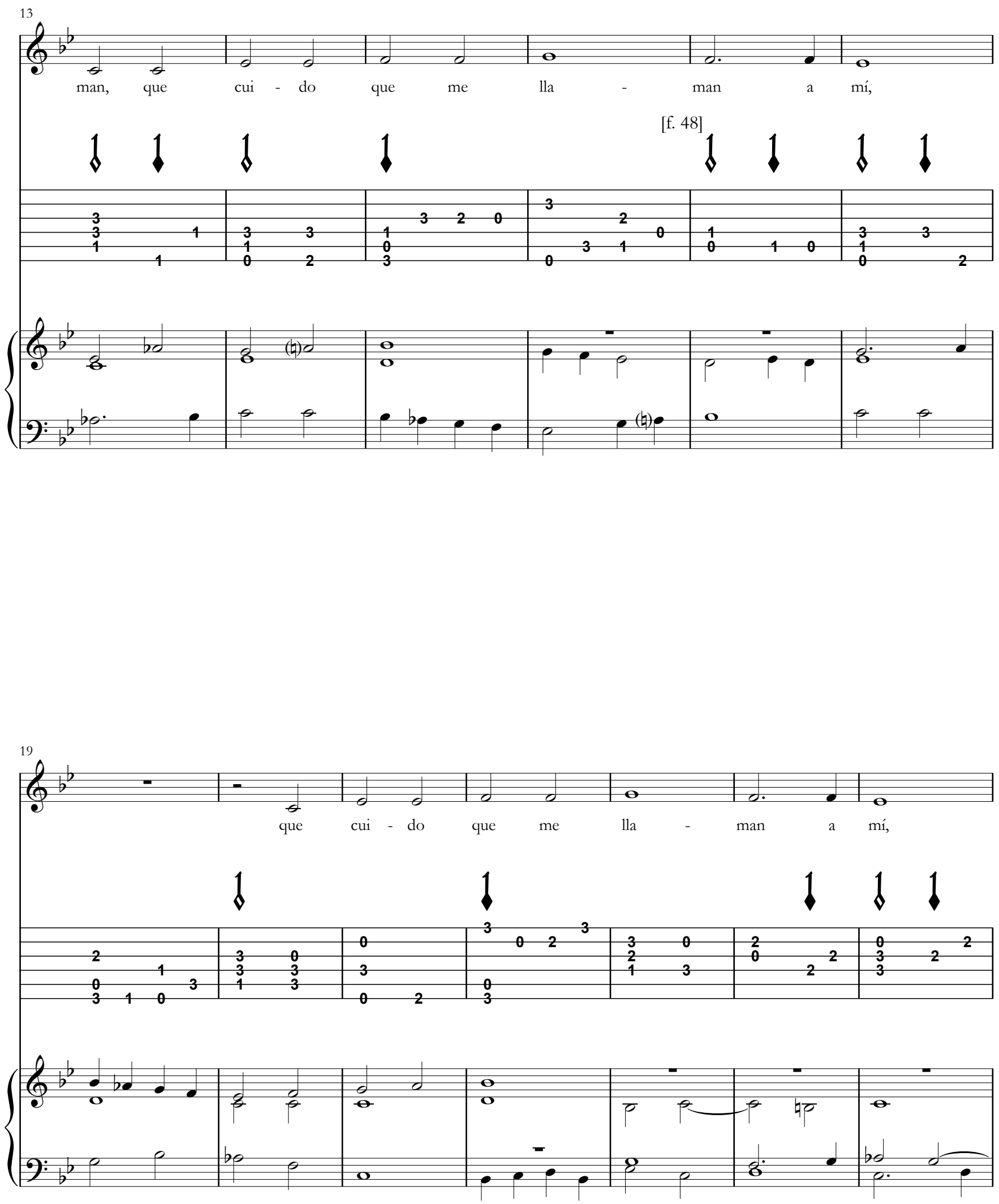

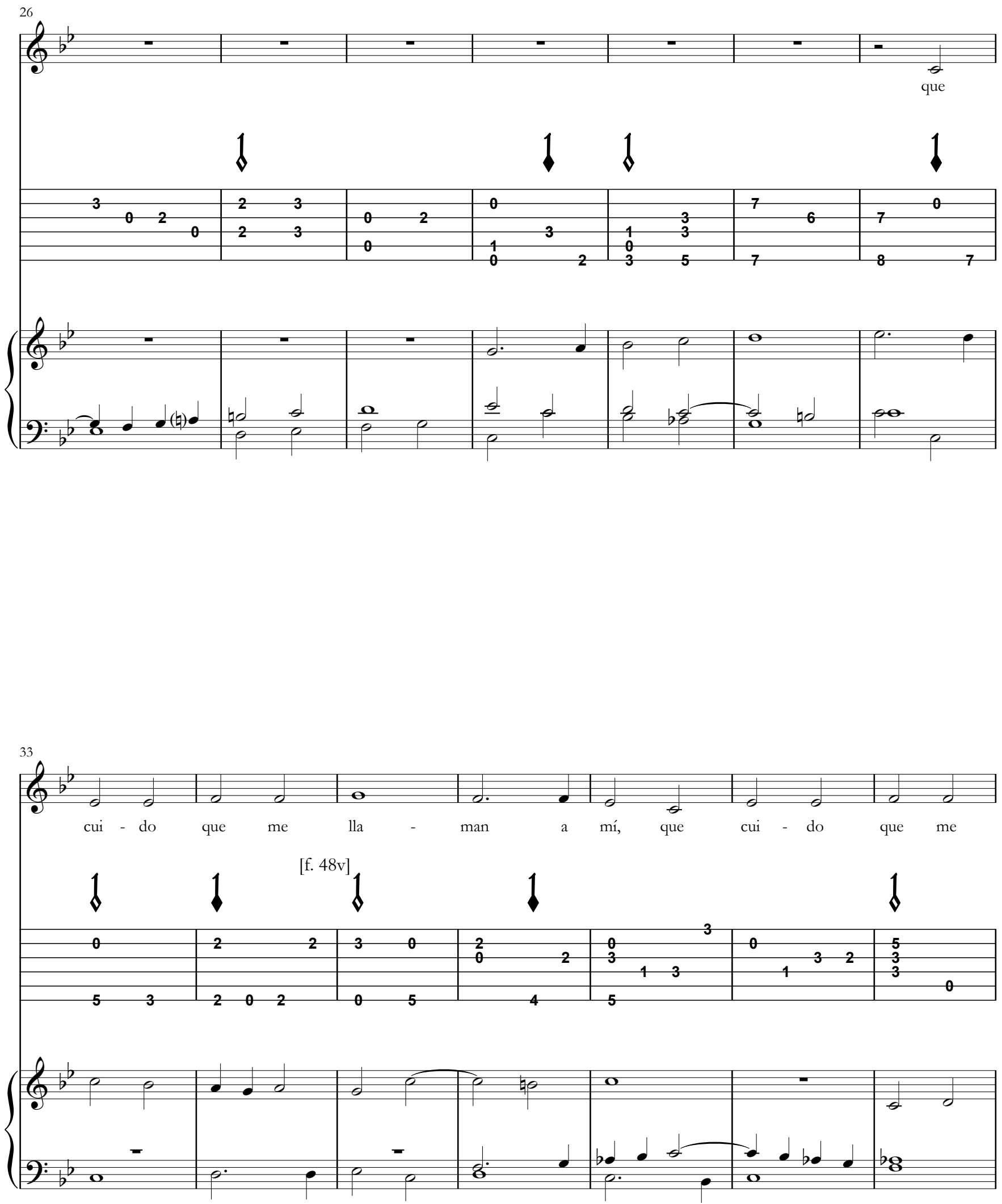

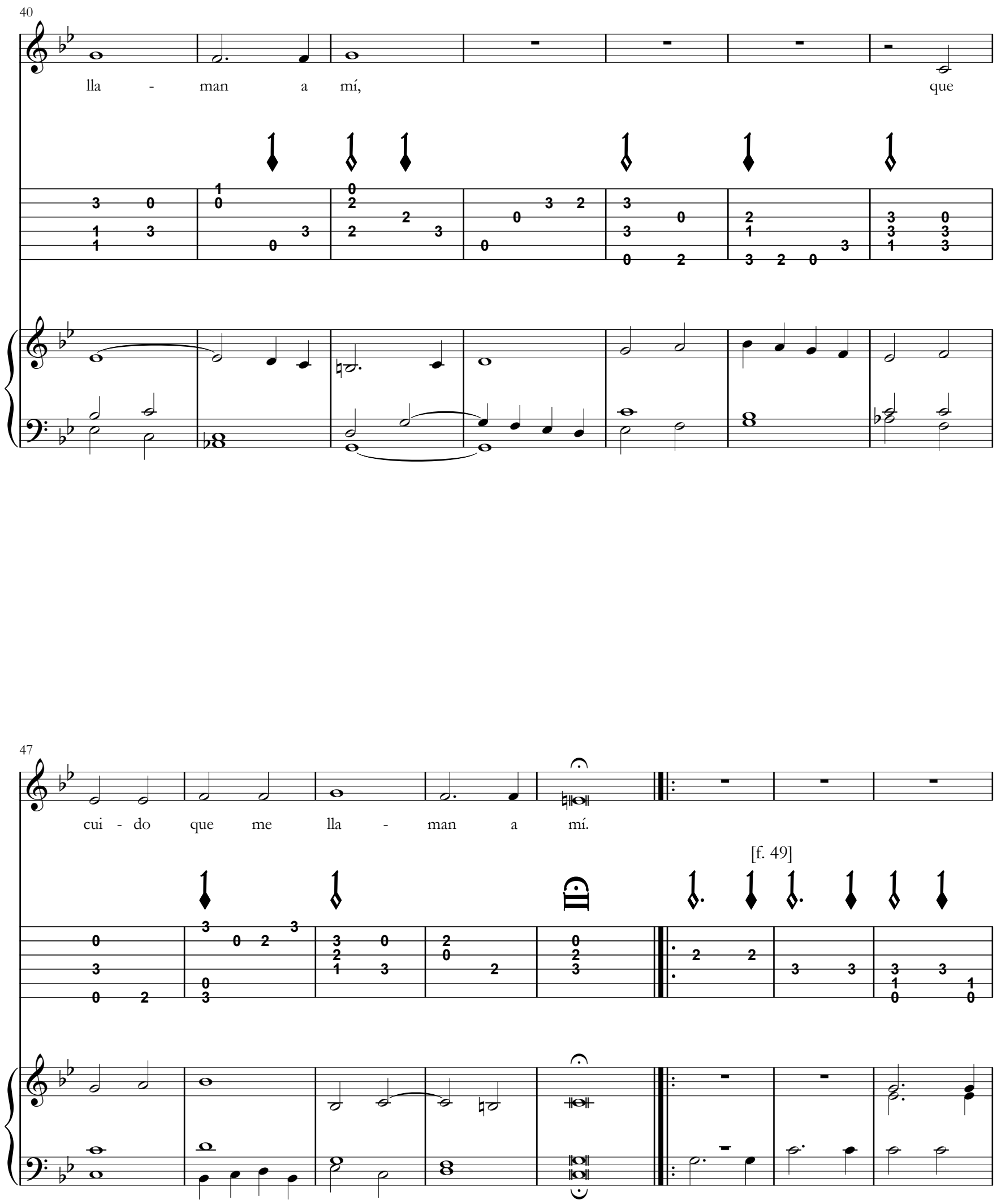

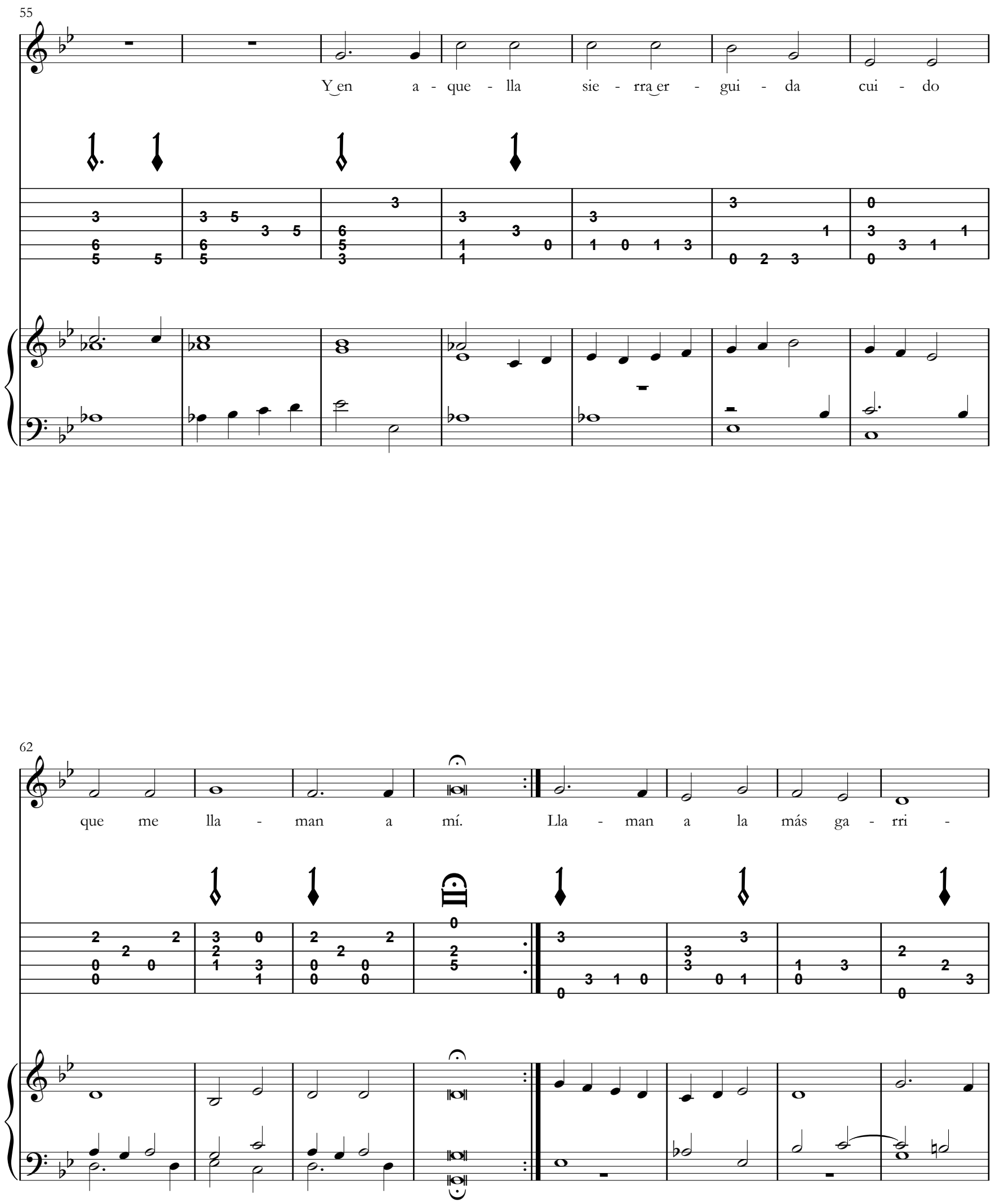

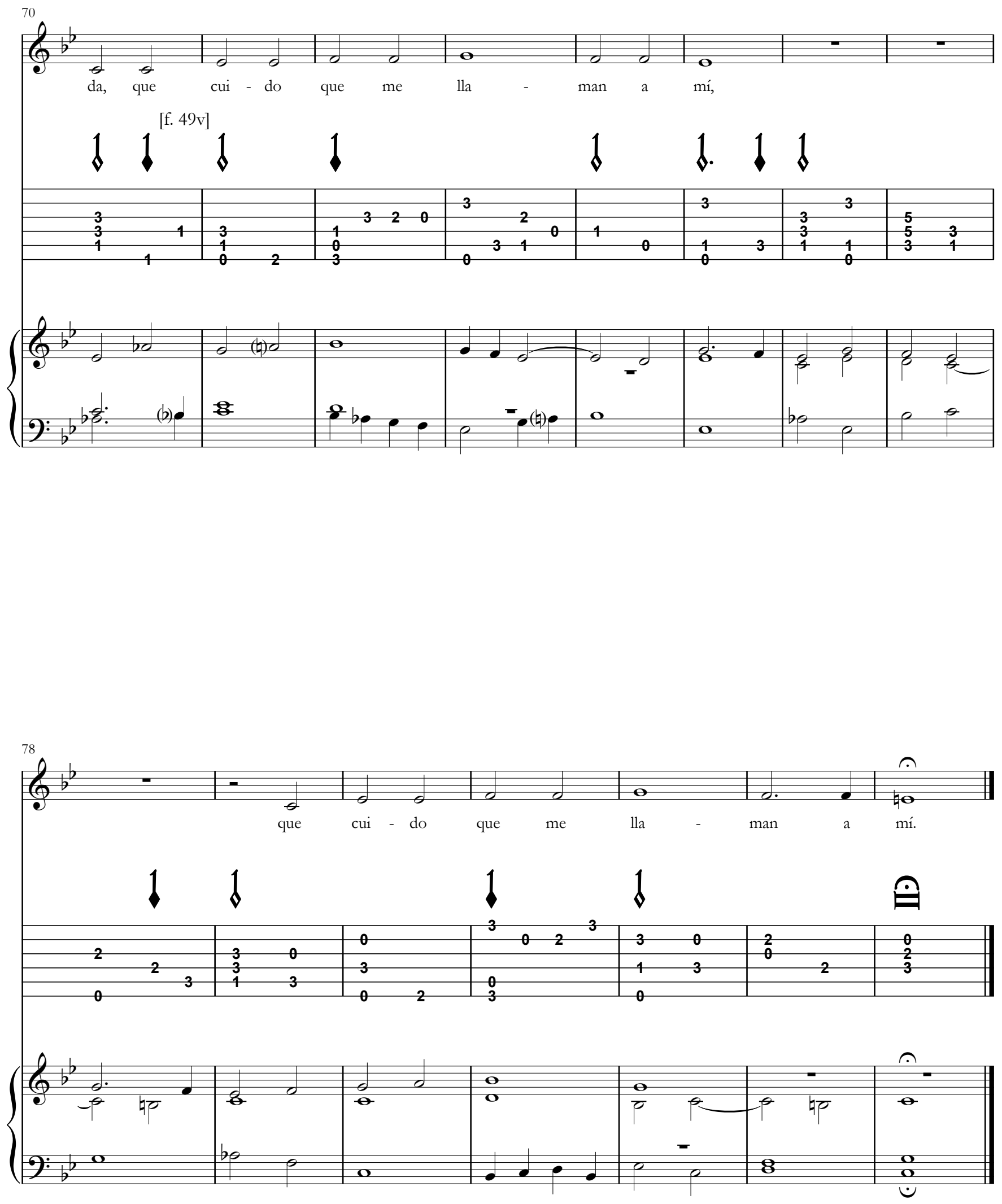
so 72 - Gentil cavallerow

[Villancico III]

Entónase la boz en la tercera al tercero traste

[Libro III, XXIII]
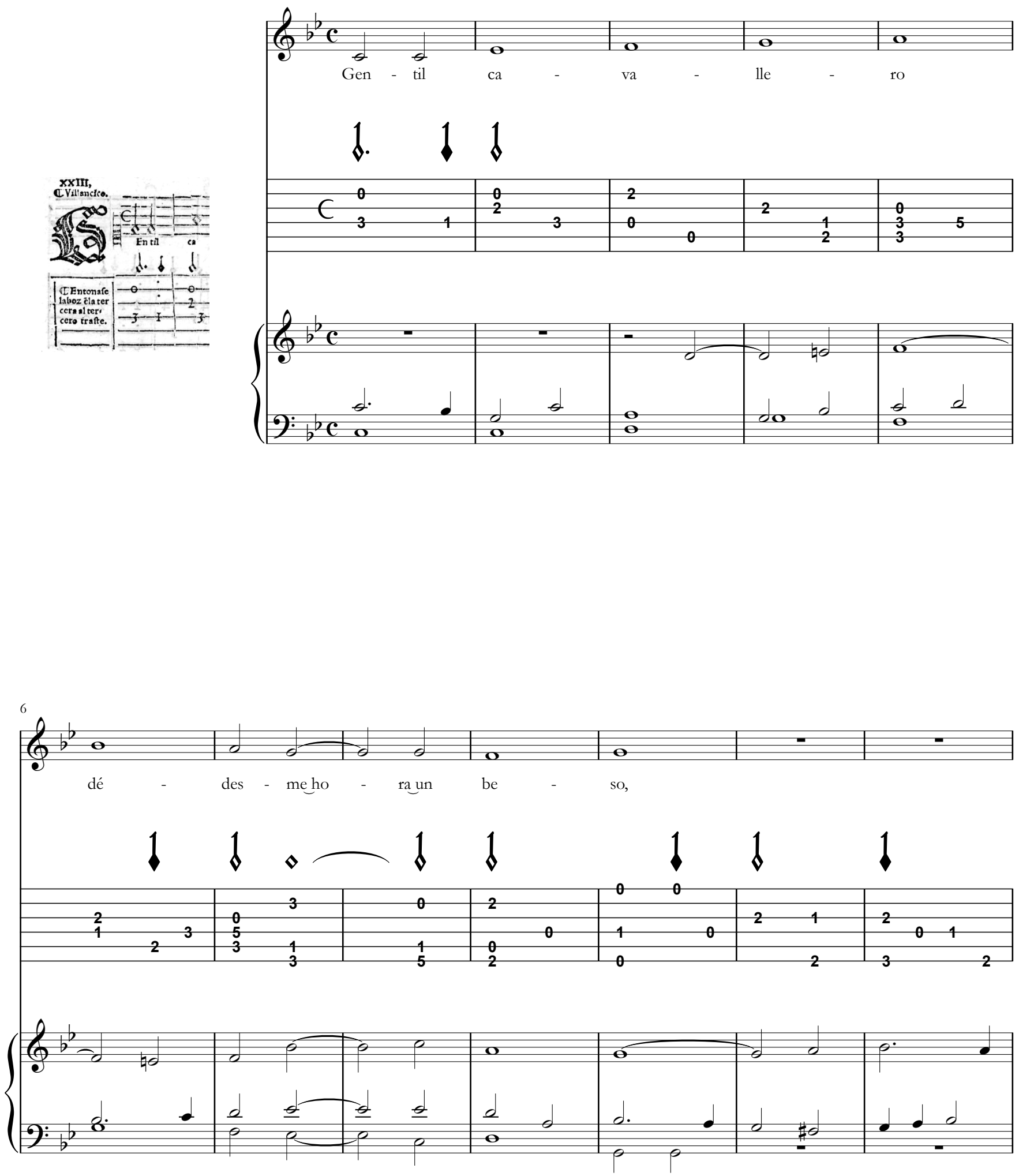

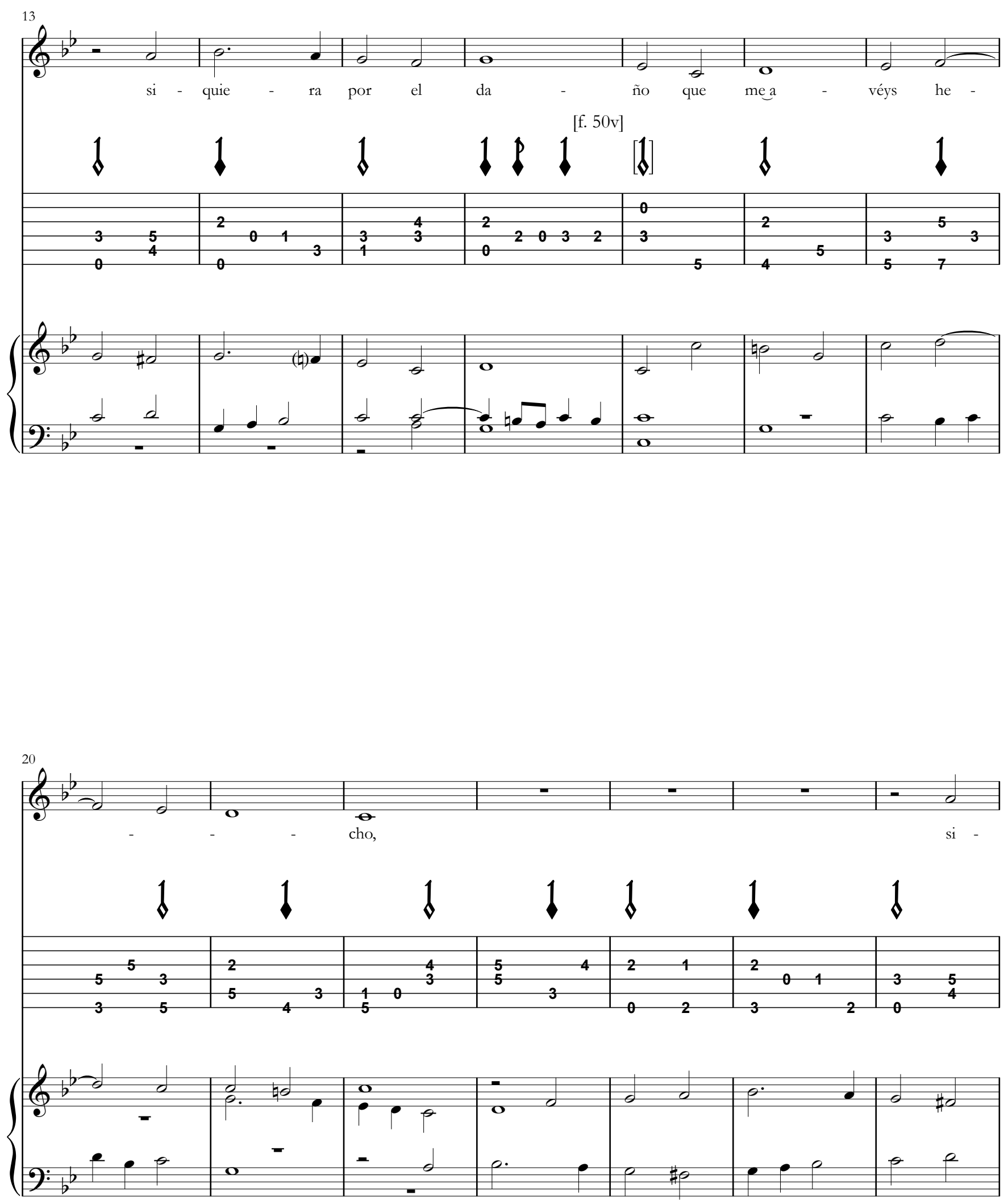

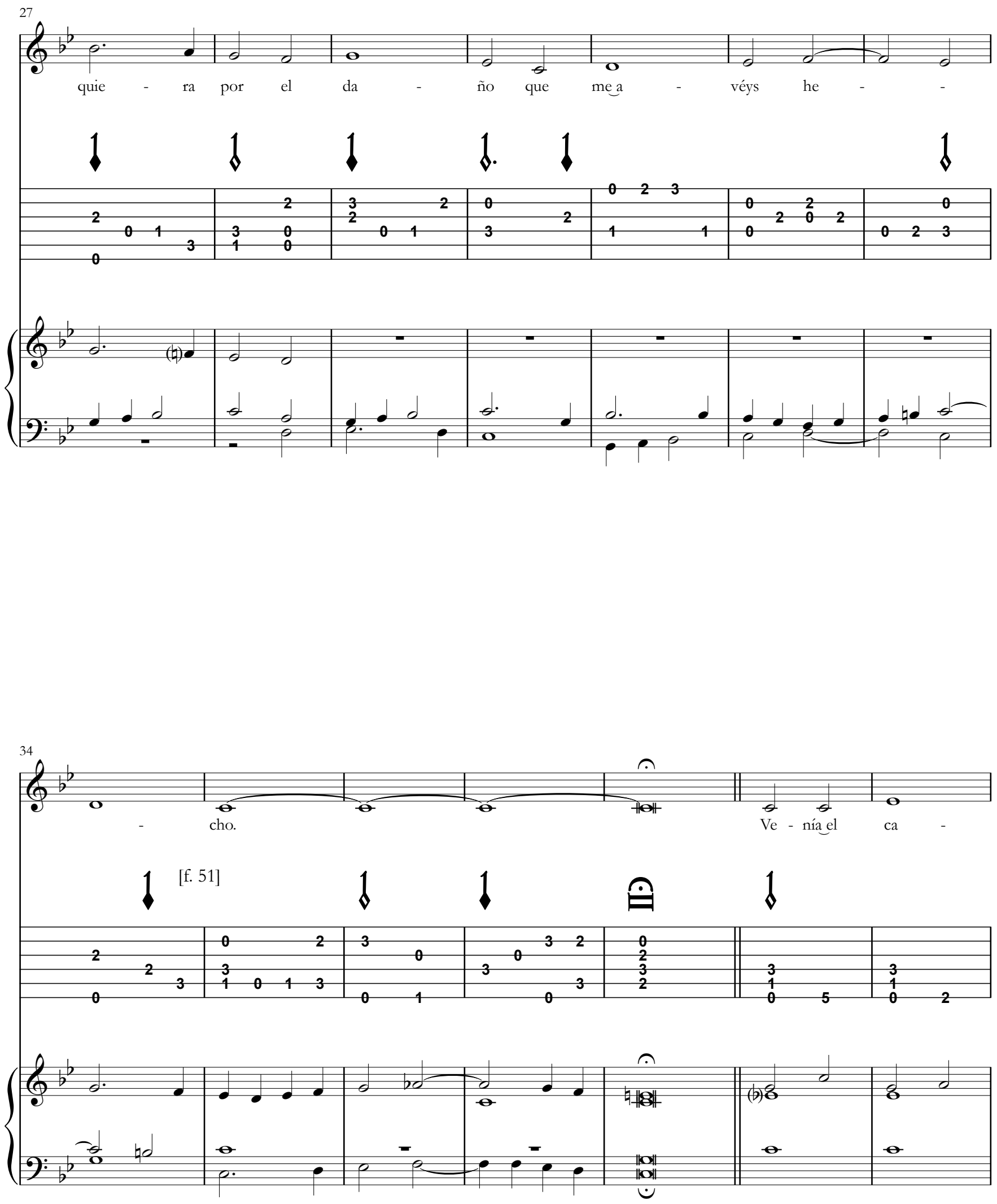

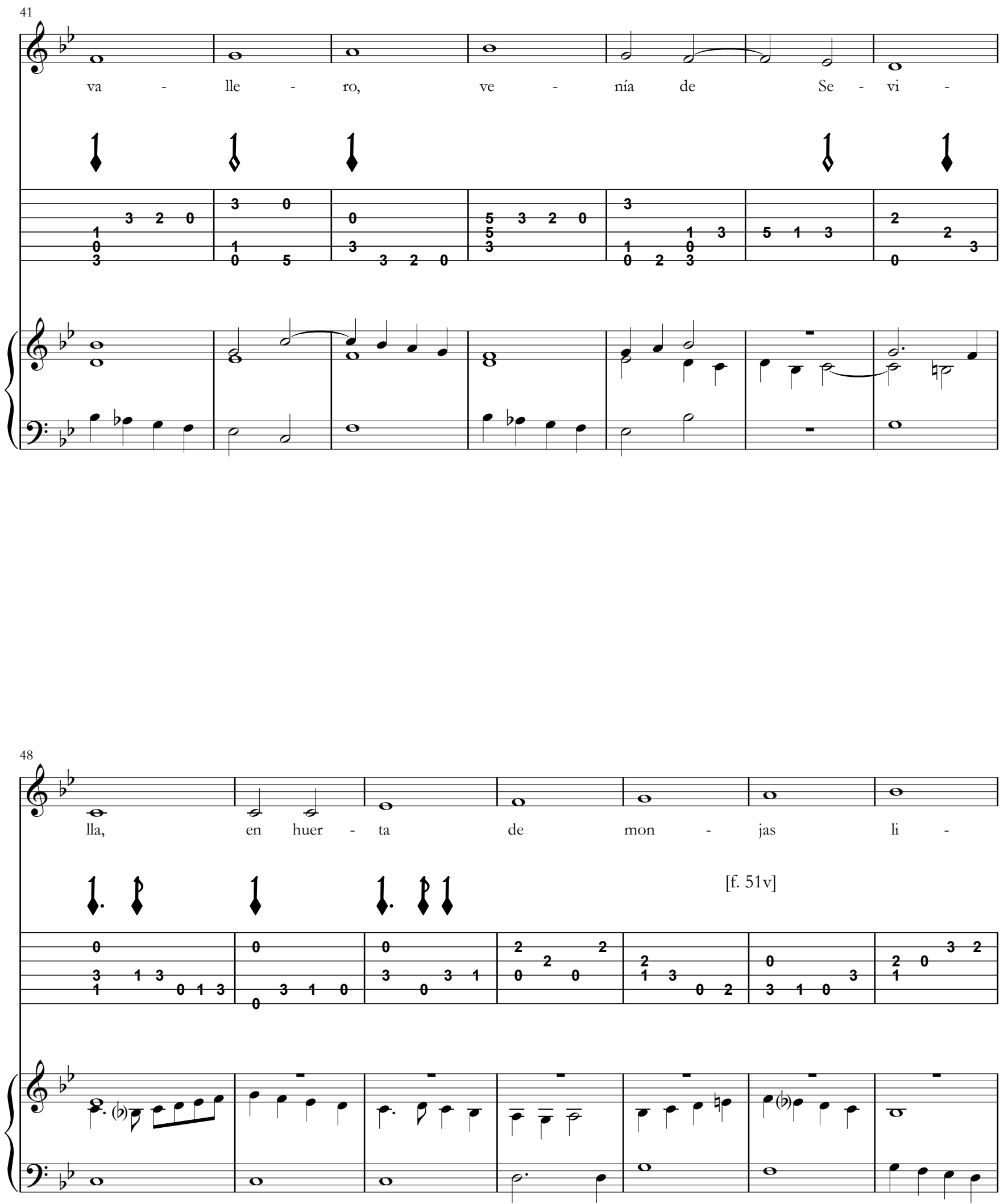

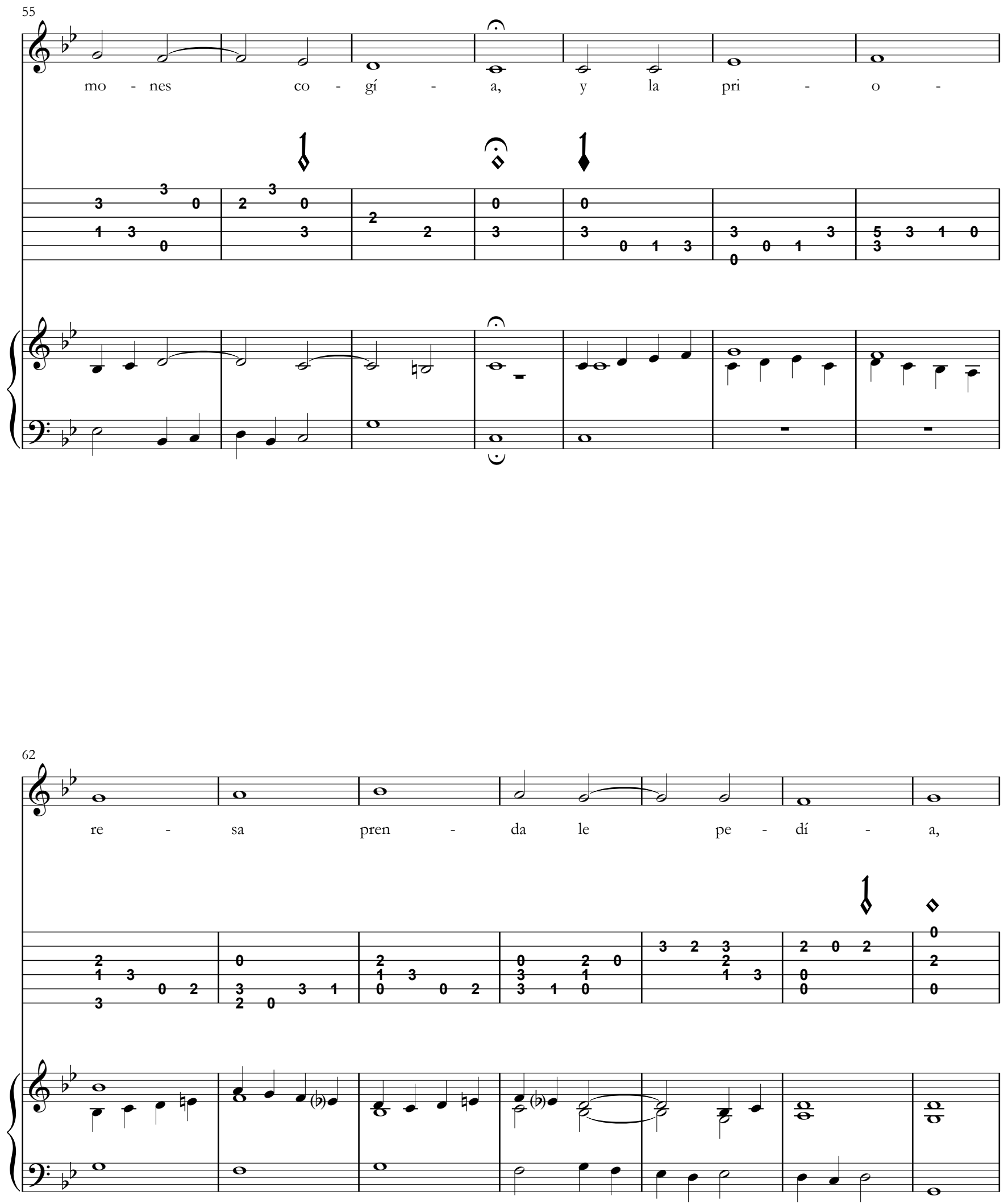

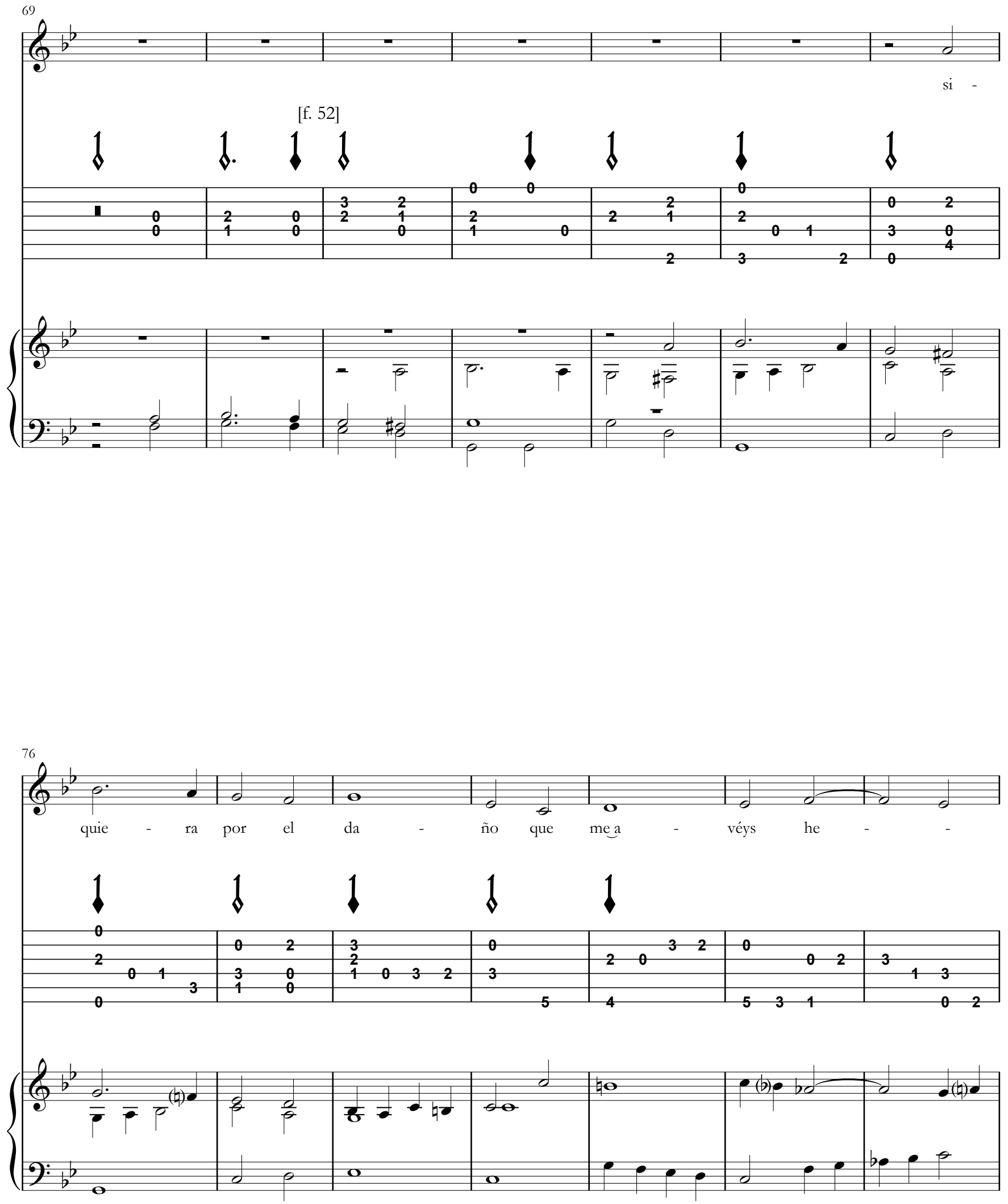

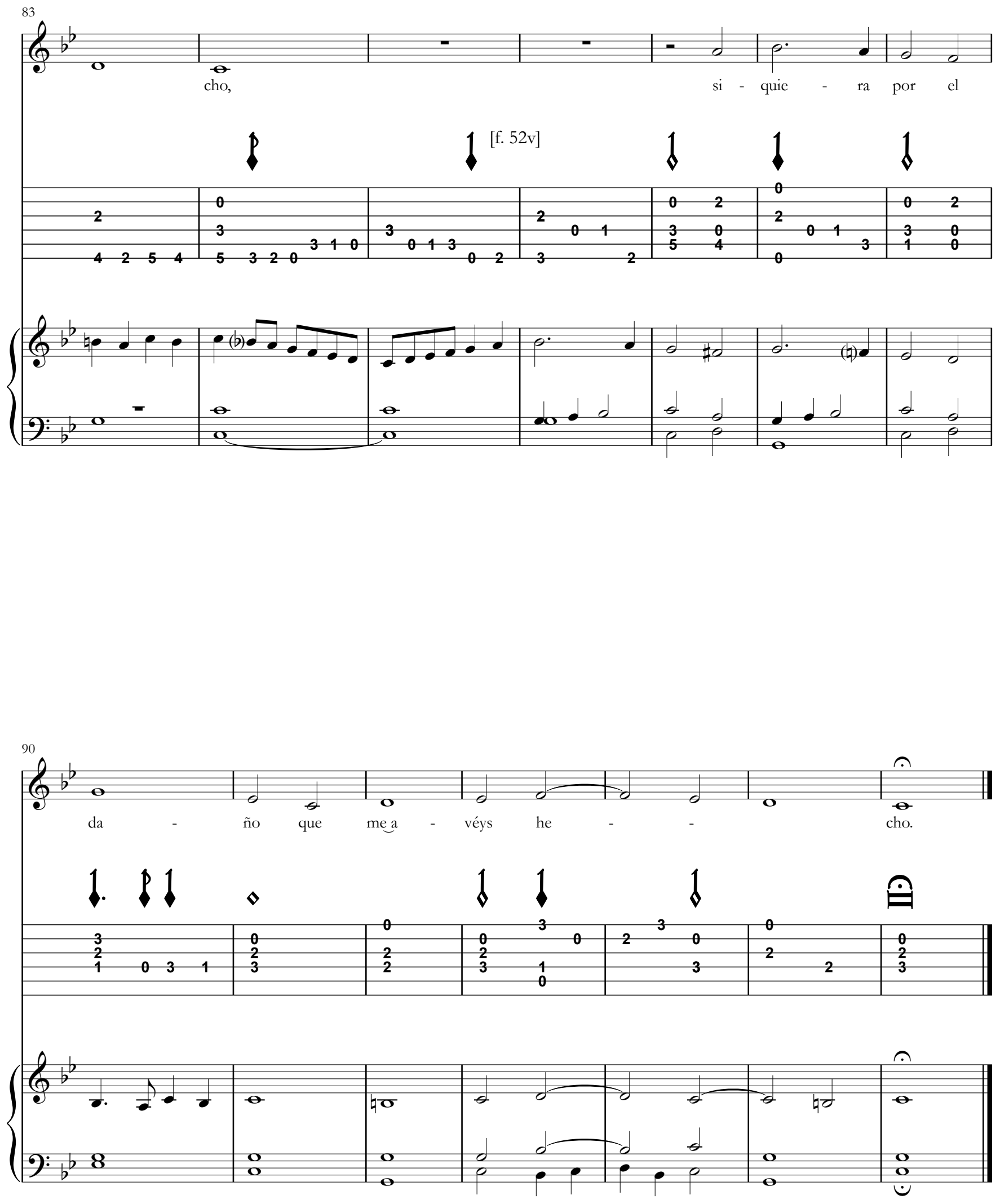


\title{
s\& 73 - Ysabel, perdiste la tu faxa
}

\author{
[Villancico IV]
}

Entónase la boz en la tercera al primer traste, y puédese también cantar octava arriba, entonándose en la prima al tercero traste

[Libro III, XXIV]
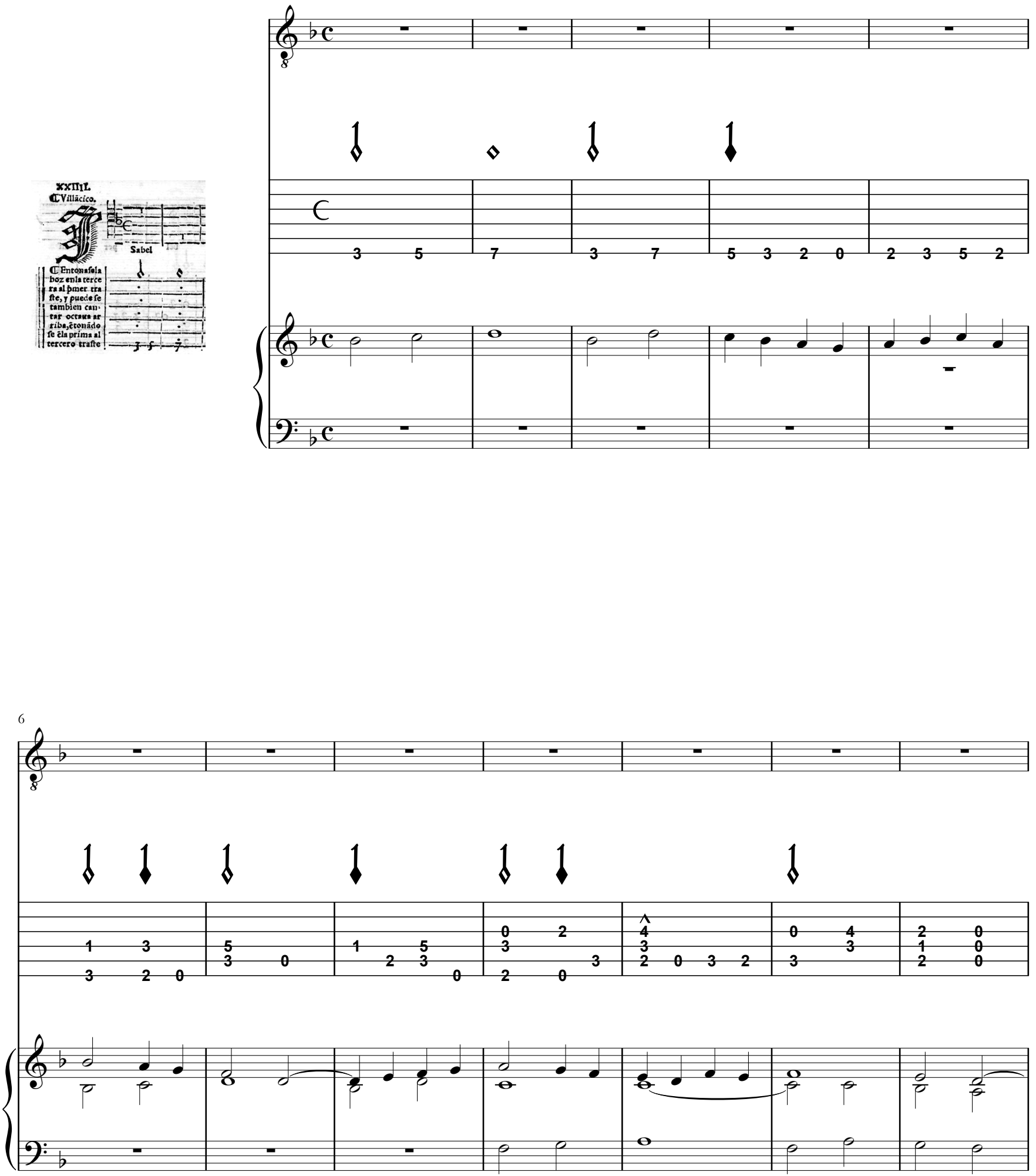

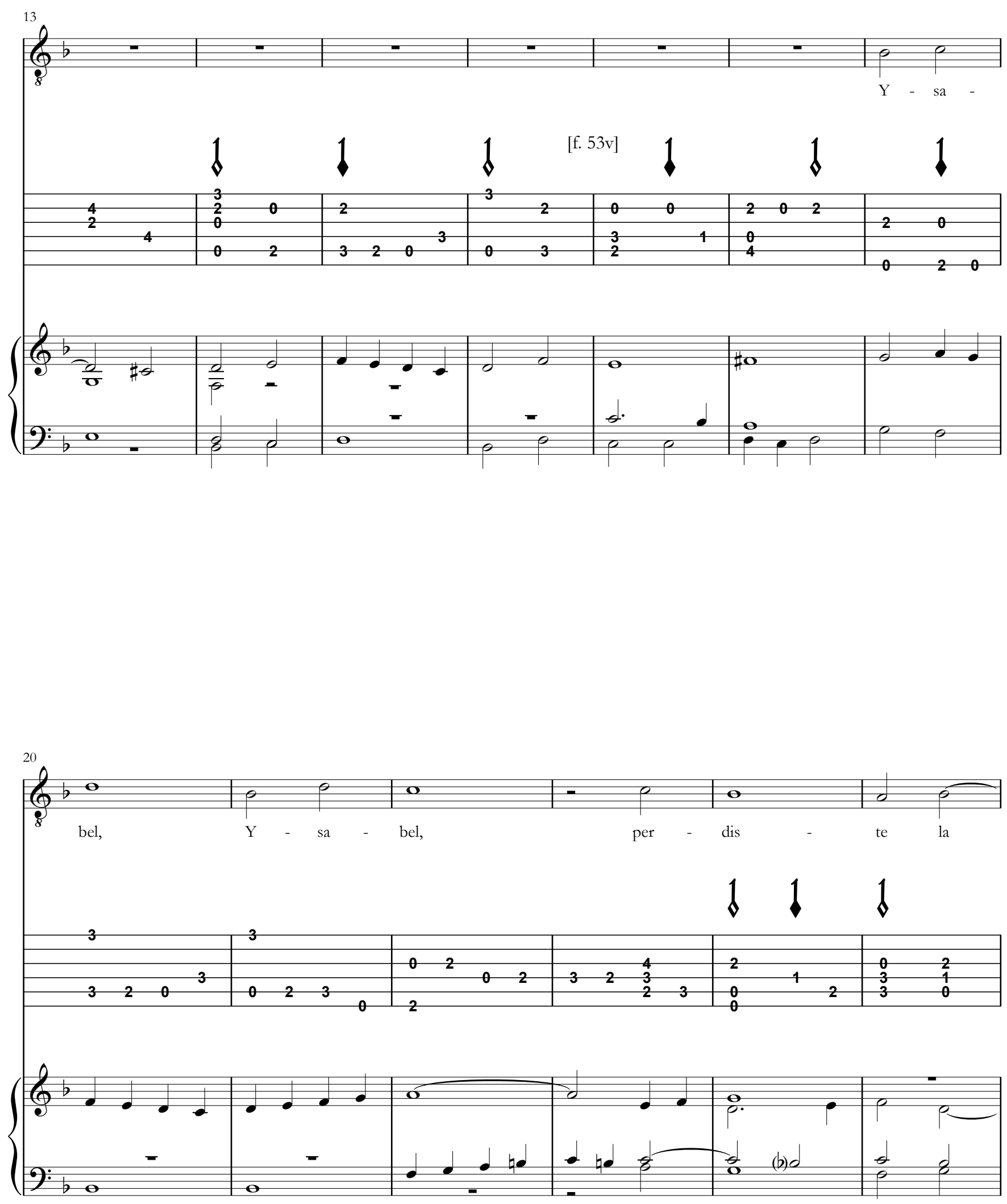

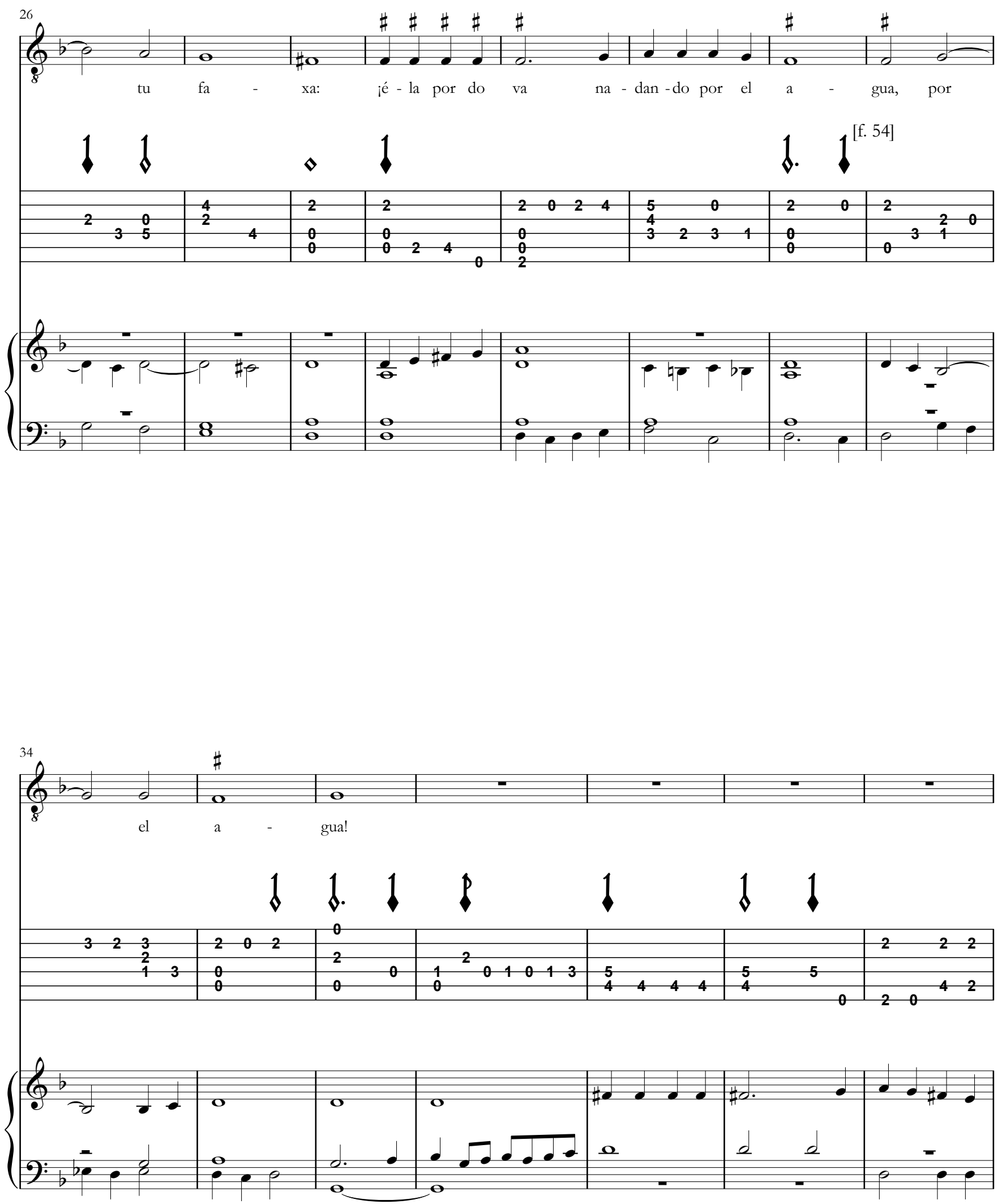

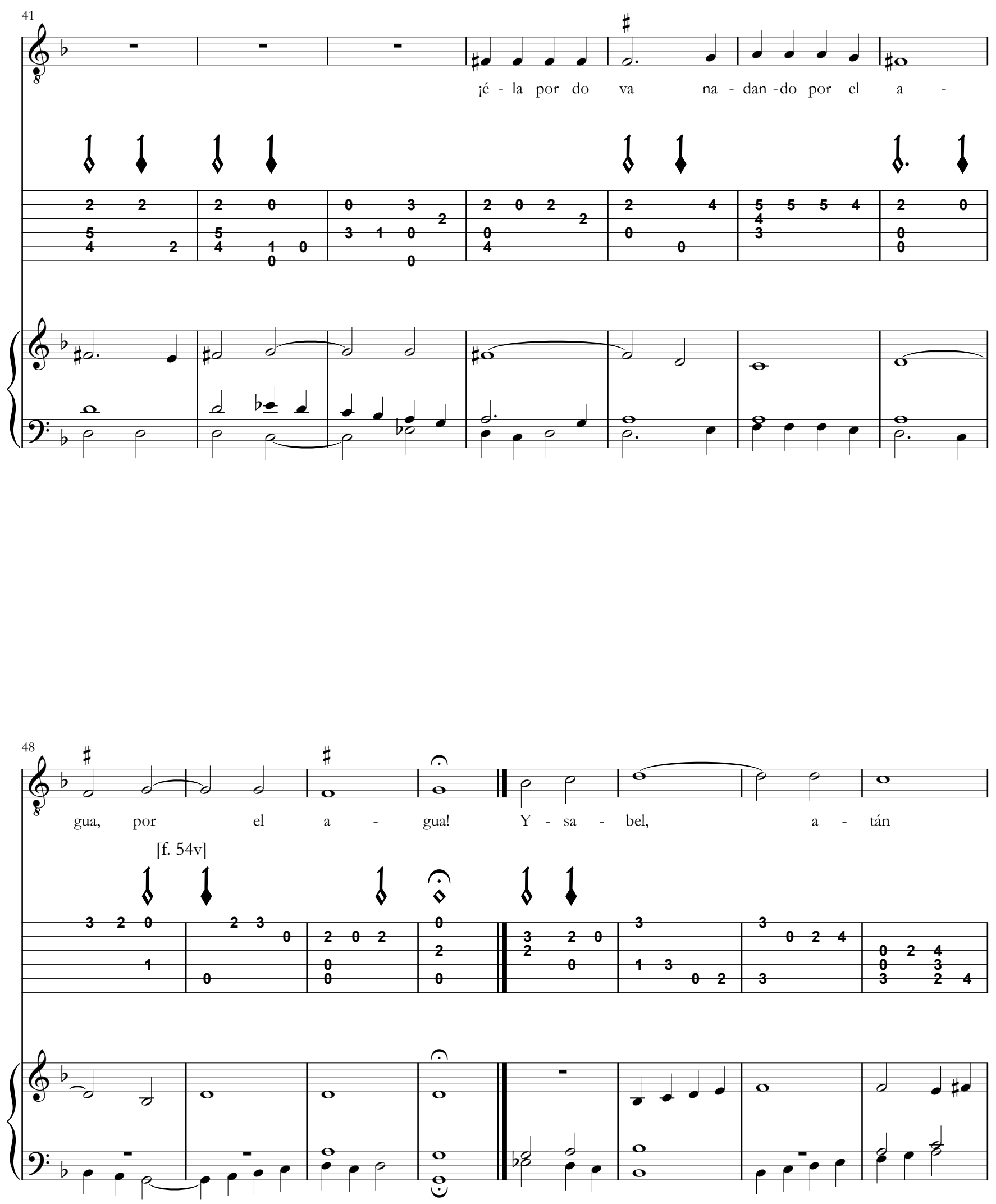

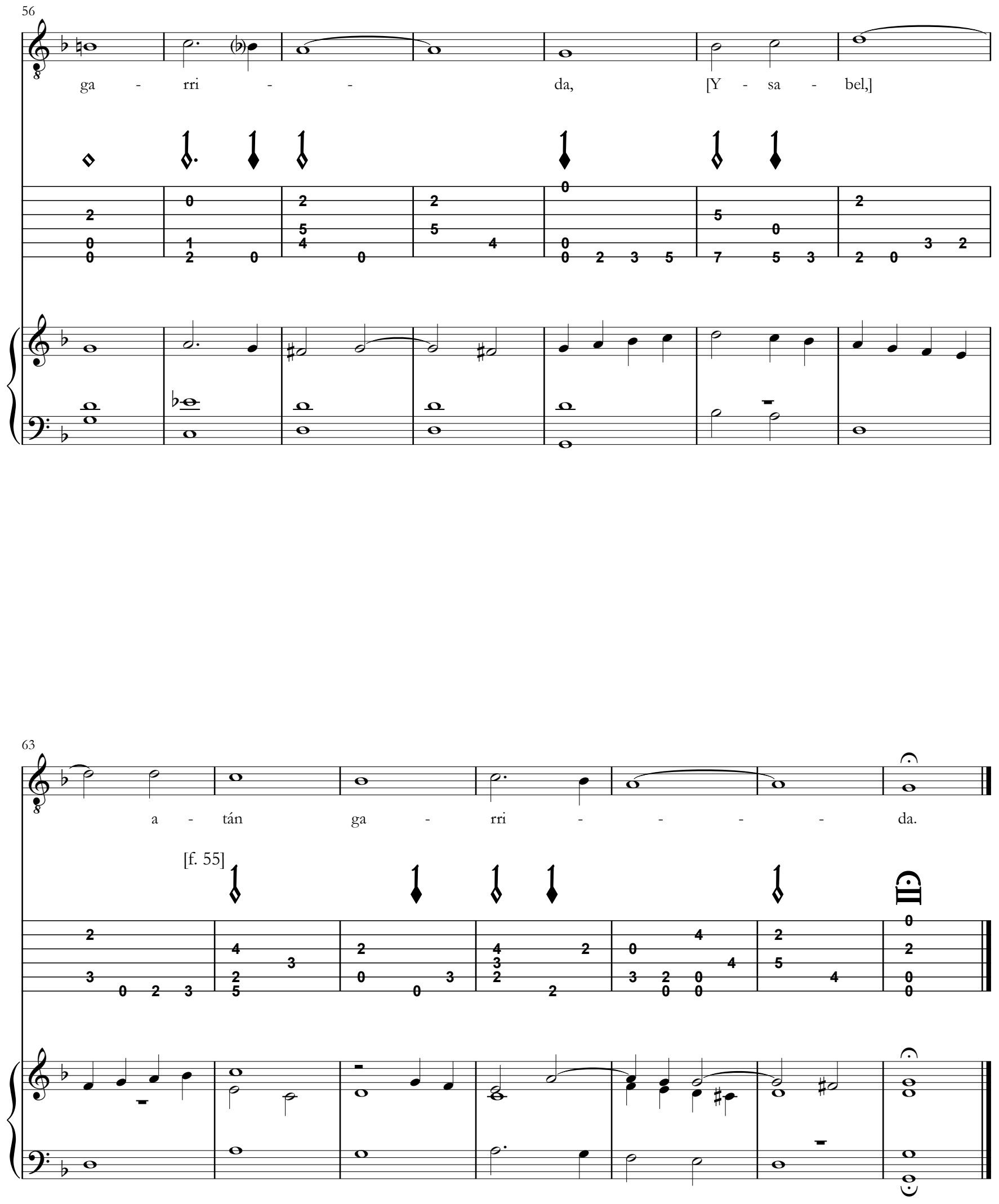
so 74 - Si viesse e me levasse

[Villancico V]

Entónase la boz en la tercera en tercero traste

[Libro III, XXV]
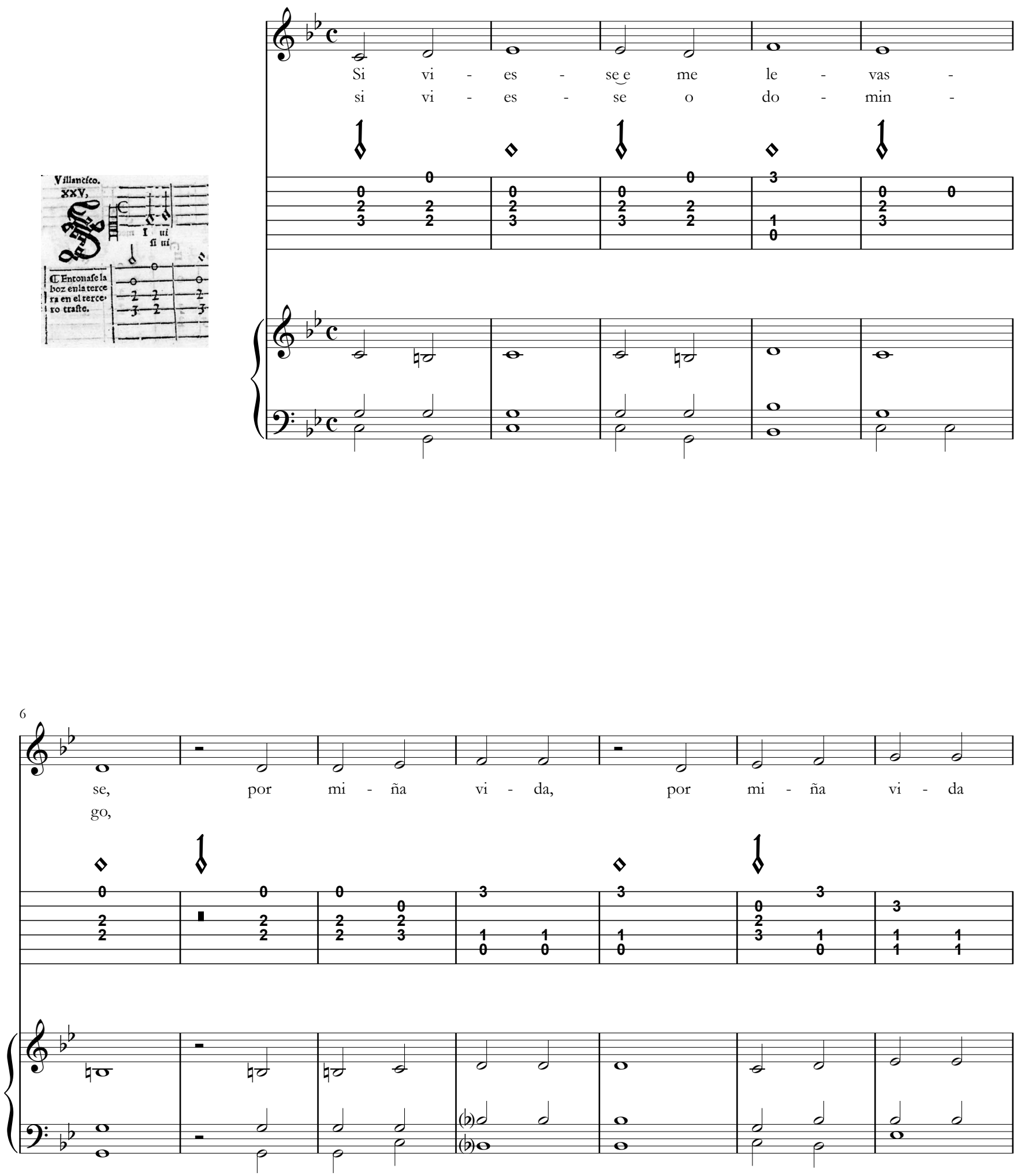


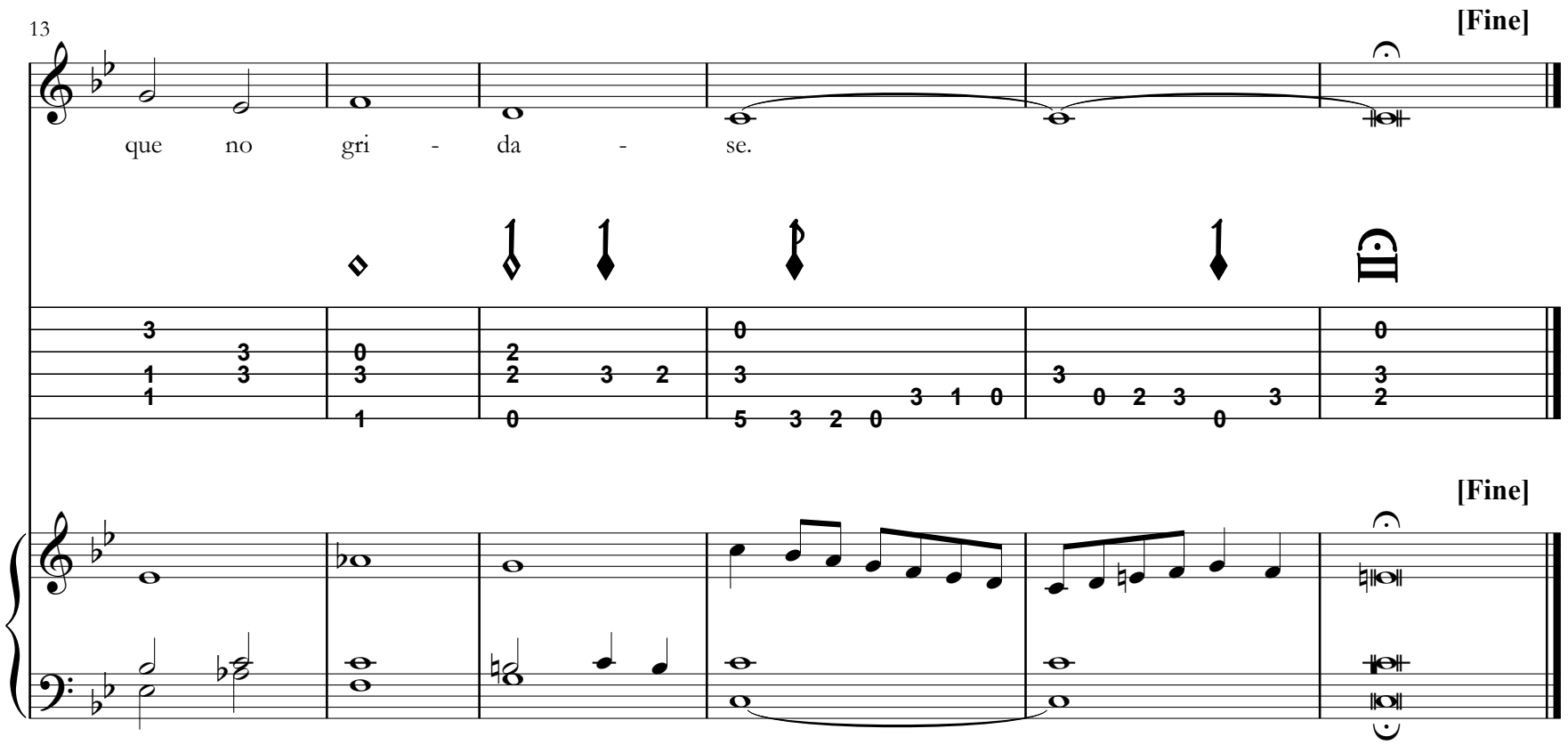

[D.C. al Fine]

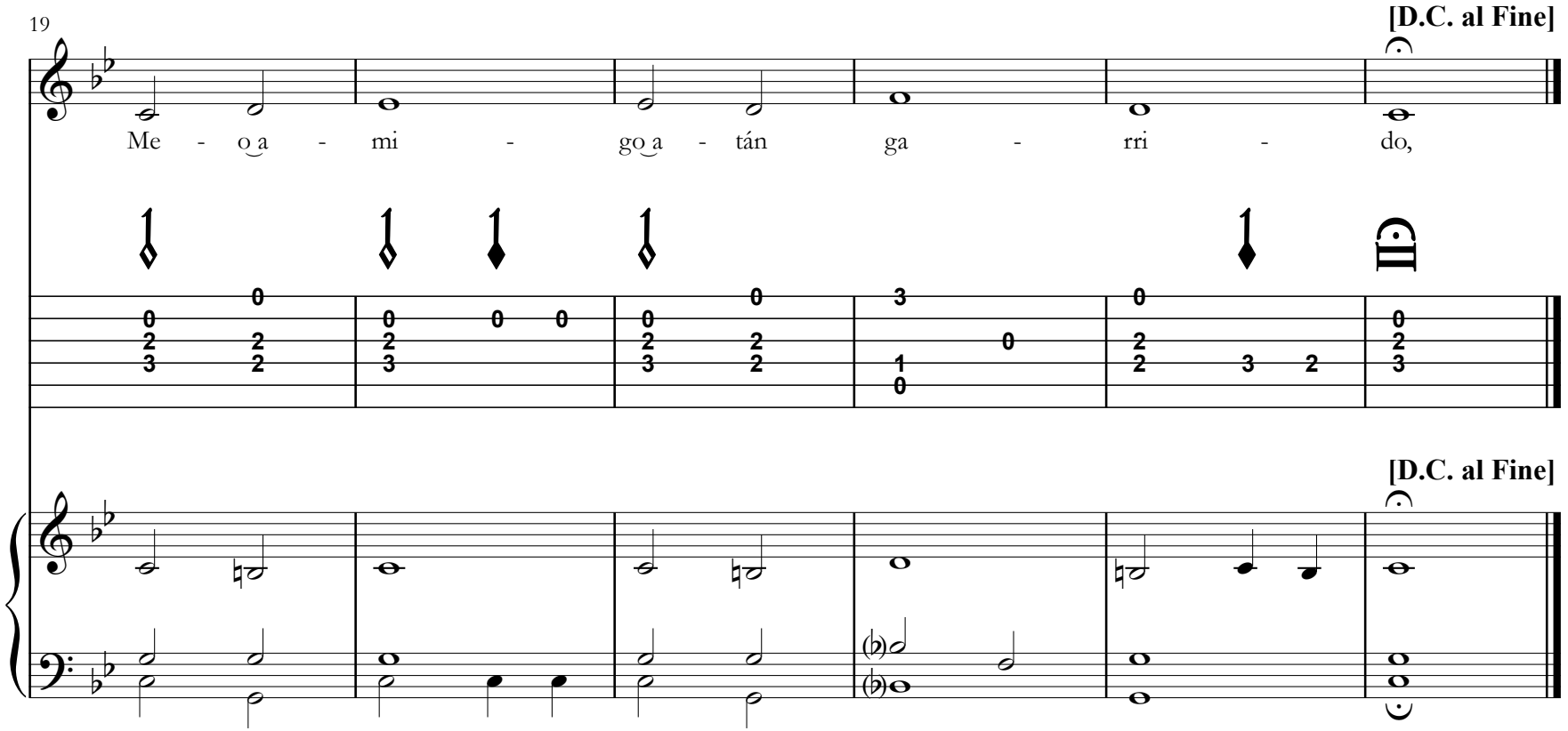


se75 - Nisi Dominus

[Salmo I]

Psalmo por el séptimo tono.

Entónase la boz en la tercera al tercero traste

[Libro III, XXVI]
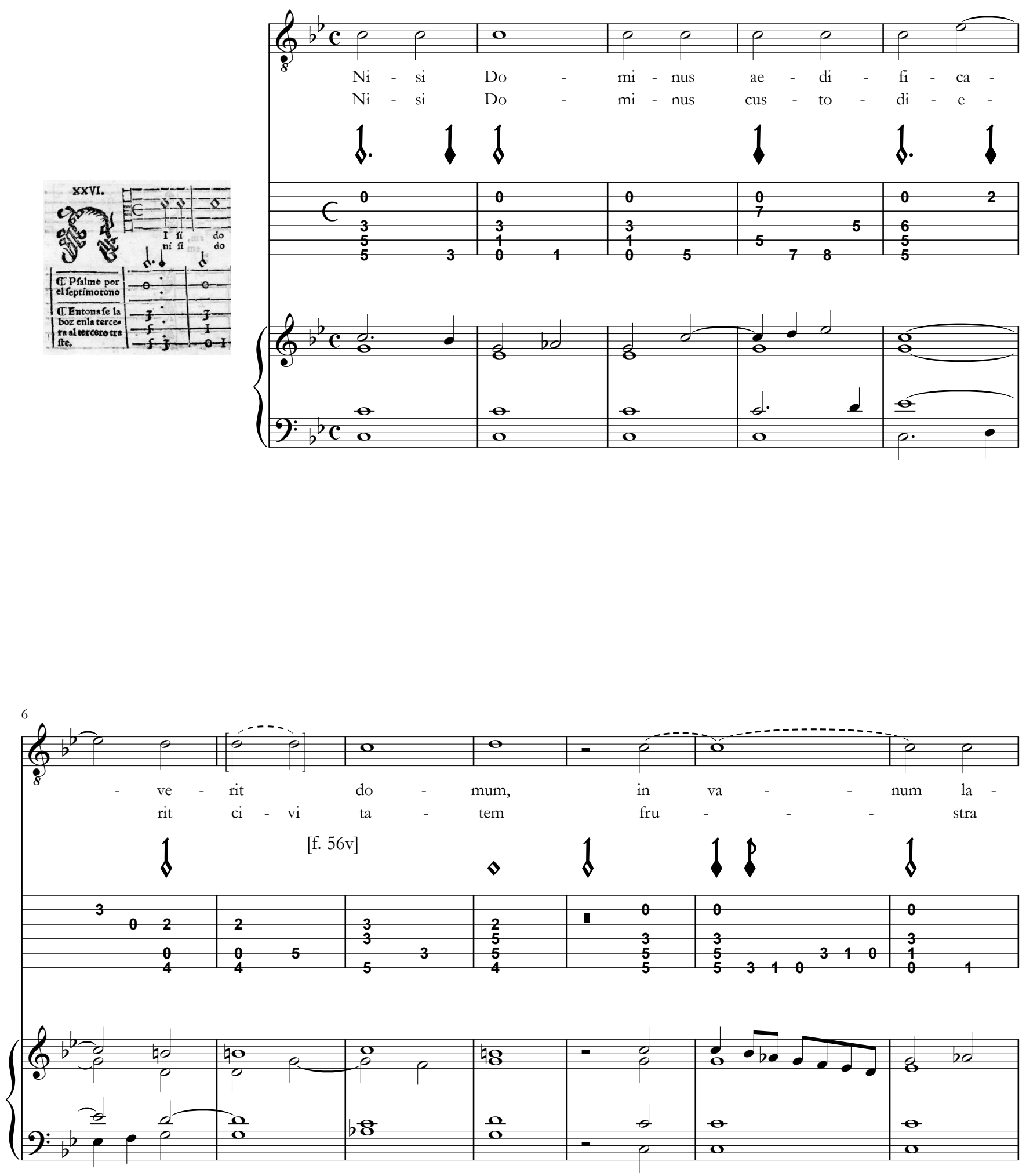


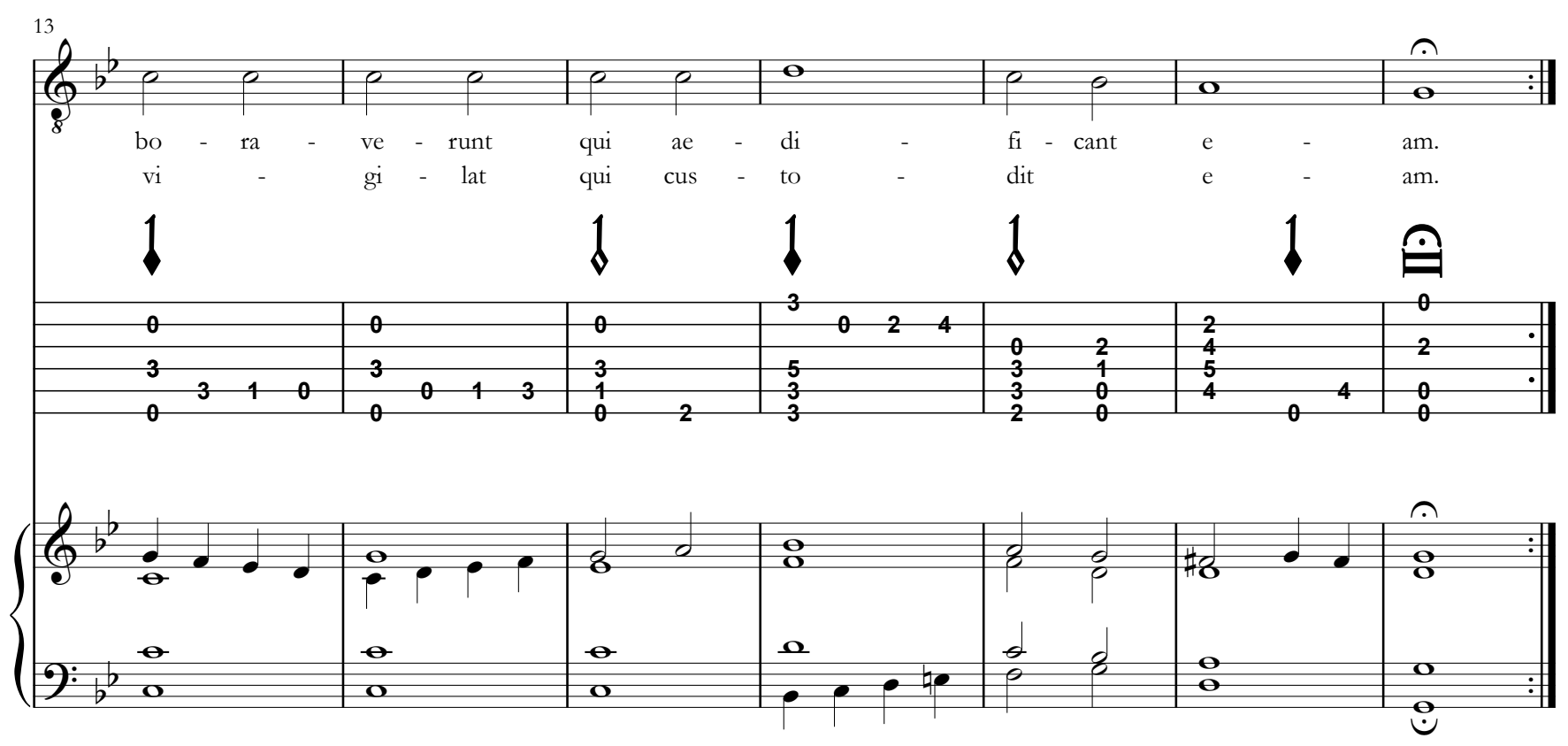




\section{se 76 - Exurge, quare obdormis}

[Salmo II]

Psalmo por el primer tono.

Entónase la boz en la prima al quinto traste, puédese cantar octaua baxo

[Libro III, XXVII]
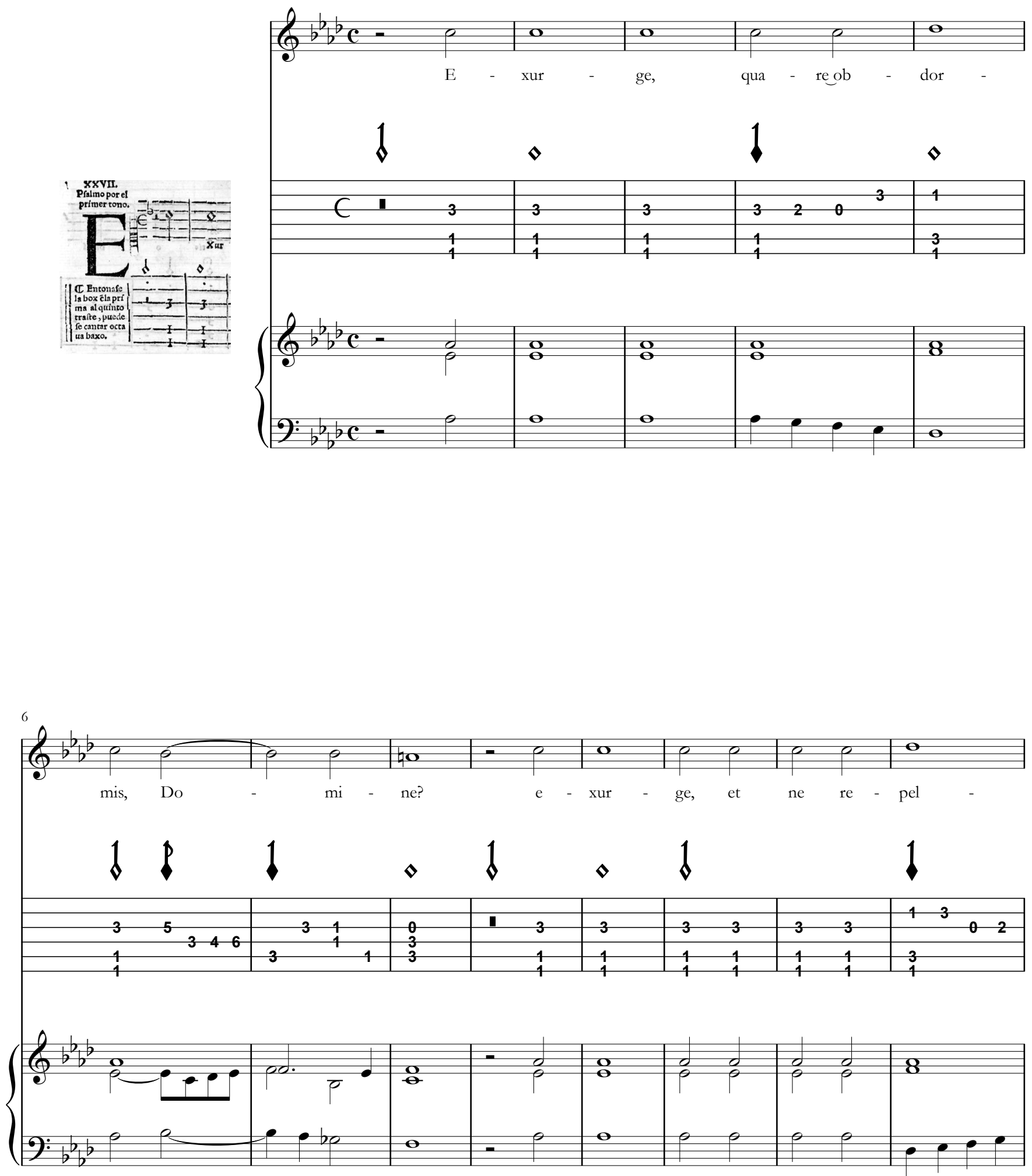

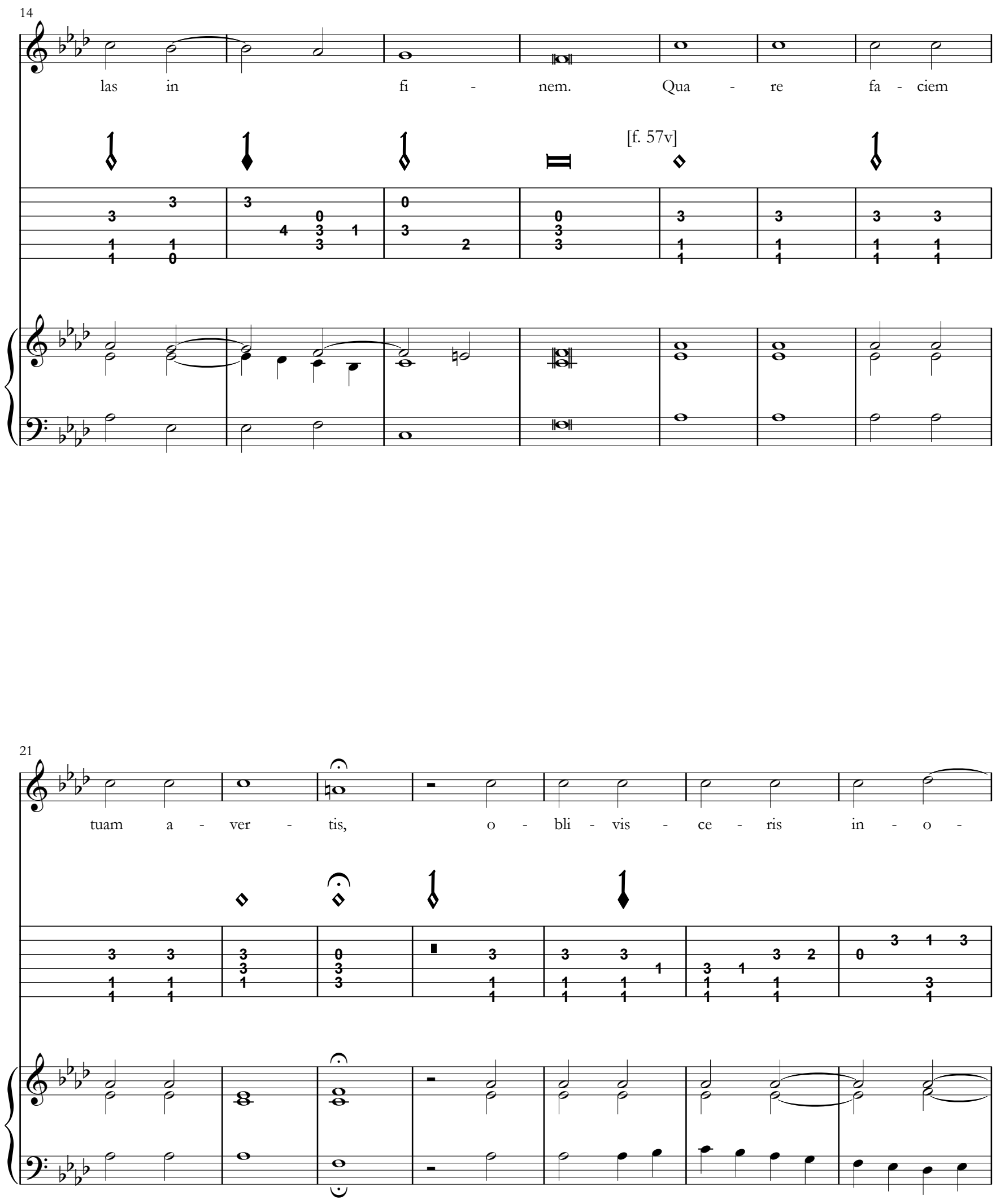

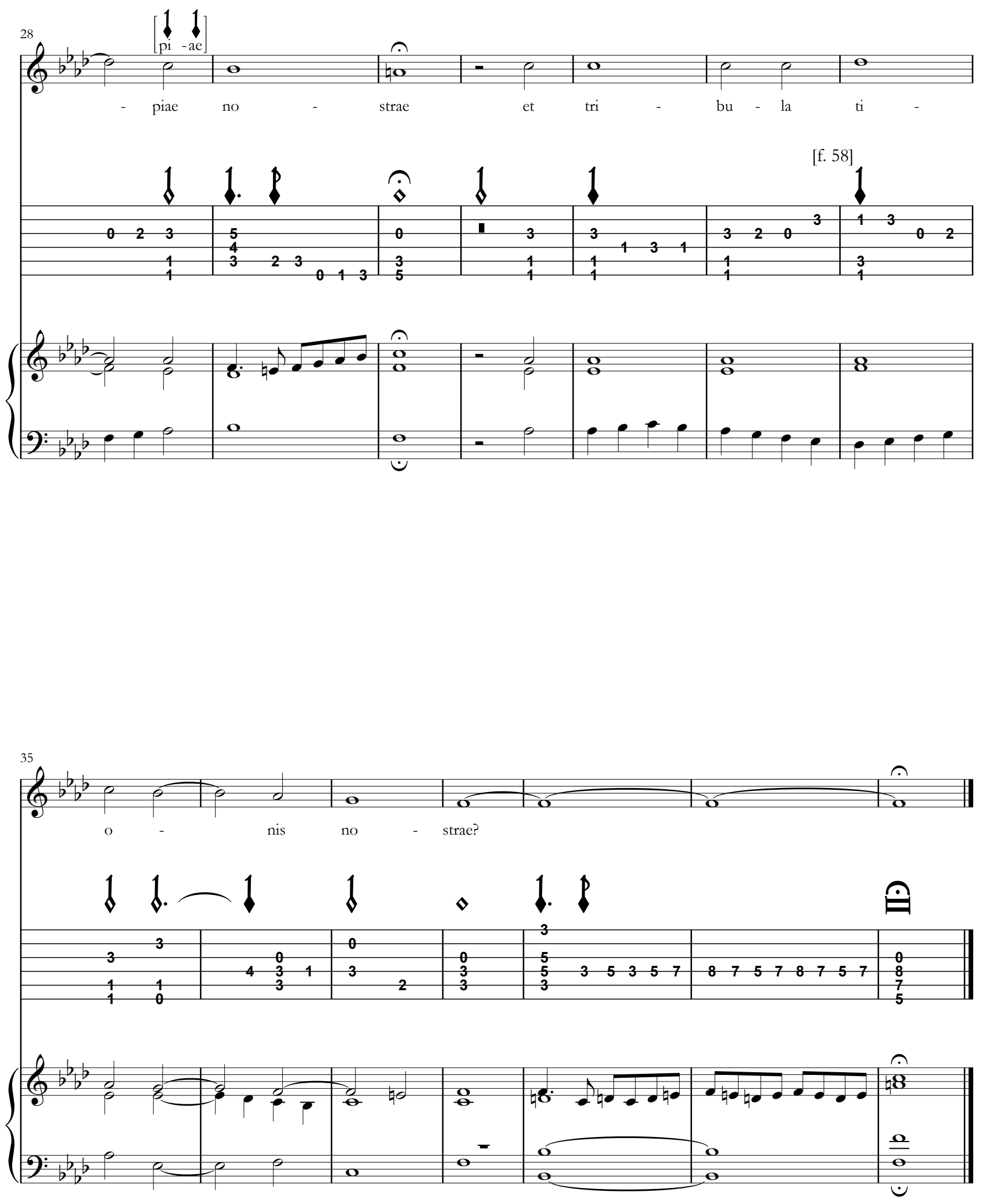


\section{so477 - Tiento 948}

Tiento para harpa y órgano

[Libro III]
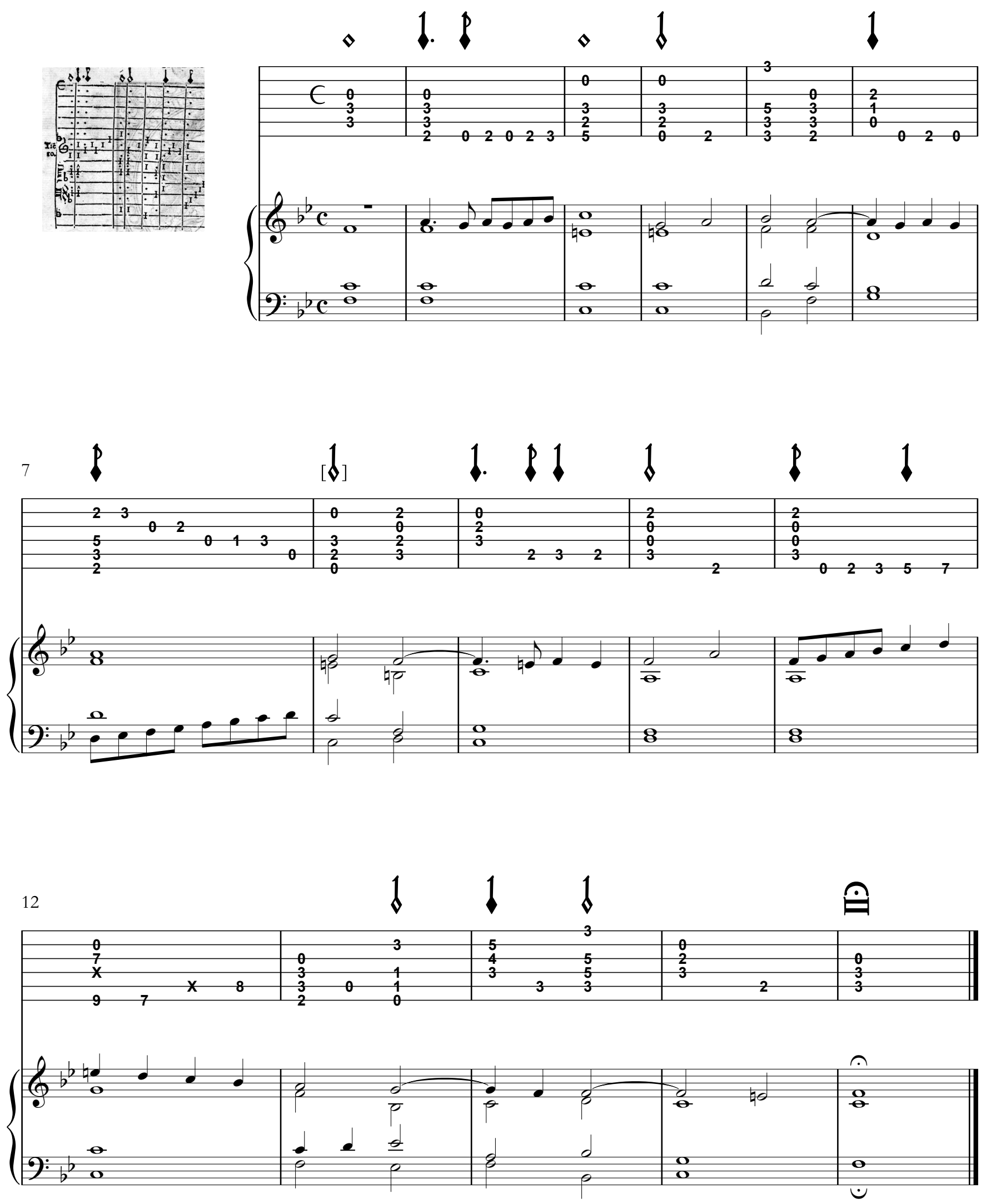
